UNIVERSIDADE DE SÃO PAULO

FACULDADE DE ECONOMIA, ADMINISTRAÇÃO E CONTABILIDADE DEPARTAMENTO DE ADMINISTRAÇÃO PROGRAMA DE PÓS-GRADUAÇÃO EM ADMINISTRAÇÃO

ANÁLISE COMPARATIVA DE MODELOS PARA DETERMINAÇÃO DO CUSTO DE CAPITAL PRÓPRIO: CAPM, TRÊS FATORES DE FAMA E FRENCH (1993) E QUATRO FATORES DE CARHART (1997)

Luciana Julio Rizzi

Orientador: Prof. Dr. José Roberto Securato

SÃO PAULO 
Prof. Dr. João Grandino Rodas

Reitor da Universidade de São Paulo

Prof. Dr. Reinaldo Guerreiro

Diretor da Faculdade de Economia, Administração e Contabilidade

Prof. Dr. Adalberto Américo Fischmann

Chefe do Departamento de Administração

Prof. Dr. Lindolfo Galvão de Albuquerque Coordenador do Programa de Pós-Graduação em Administração 


\title{
ANÁliSE COMPARATIVA DE MODELOS PARA DETERMINAÇÃO DO CUSTO DE CAPITAL PRÓPRIO: CAPM, TRÊS FATORES DE FAMA E FRENCH (1993) E QUATRO FATORES DE CARHART (1997)
}

\begin{abstract}
Dissertação apresentada ao Programa de PósGraduação em Administração da Faculdade de Economia, Administração e Contabilidade da Universidade de São Paulo, para a obtenção do título de Mestre em Ciências.
\end{abstract}

Orientador: Prof. Dr. José Roberto Securato

(Versão Corrigida)

\section{SÃO PAULO}




\section{FICHA CATALOGRÁFICA}

Elaborada pela Seção de Processamento Técnico do SBD/FEA/USP

Rizzi, Luciana Julio

Análise comparativa de modelos para determinação do custo de capital próprio: CAPM, três fatores de Fama e French (1993) e quatro fatores de Carhart (1997) / Luciana Julio Rizzi. -- São Paulo, 2012. $212 \mathrm{p}$.

Dissertação (Mestrado) - Universidade de São Paulo, 2012.

Orientador: José Roberto Securato.

1. Custo de capital 2. Investimentos 3. Ações I. Universidade de São Paulo. Faculdade de Economia, Administração e Contabilidade. II. Título.

CDD - 332.041 
Dedico este trabalho a minha família e meus amigos, que sempre me apoiaram. 


\section{Agradecimentos}

Ao Prof. Dr. José Roberto Securato, por todos os ensinamentos, técnicos e sobre a vida, ao longo deste processo inesquecível do mestrado, que contribuíram muito para meu amadurecimento, pelas oportunidades que me concedeu e pela confiança depositada em mim.

Ao Prof. Dr. Flávio Málaga, por todos os conselhos, sugestões e ocasiões de aprendizado ao longo do curso de Mestrado e por toda a atenção no exame de qualificação.

À Profa. Dra. Rosana Tavares, por todas as oportunidades, momentos de aconselhamento e sugestões durante estes dois anos, especialmente em relação a esta dissertação.

Aos autores Pablo Rogers e Adriano Mussa, por todas as discussões e apoio nos momentos de dúvida.

Aos Prof. José Roberto Savoia, Keyler Rocha, Eduardo Kayo e Alessandra Montini, com quem tive a oportunidade de me desenvolver.

Aos meus pais, Rafael e Telma, e aos meus irmãos, pelo apoio incondicional ao longo de toda a minha vida.

Ao Alexandre, pelo apoio diário e por entender os momentos difíceis por que passamos.

Aos amigos da FEA-USP: Thiago Rocha, Roberto Nardi, Mariana Lorenzi, Alcides Araújo, Fábio Zugman, Ana Carolina Shinoda, Bruna Pereira, Marina Begalli, entre outros.

Aos amigos da FIA.

A toda a equipe da Secretaria de Pós-Graduação e da Biblioteca da FEA-USP.

Às minhas amigas, Priscilla, Maria Marta e Lia G., que sempre me apoiaram.

E um agradecimento especial a Edison Simoni, Eduardo Contani, Bruno Cals, Helena Julio Rizzi e Lia Carrari Rodrigues. 
"A mente que se abre a uma nova ideia nunca mais volta ao seu tamanho original." Albert Einstein 


\section{Resumo}

Esta dissertação procurou comparar os modelos CAPM, três fatores de Fama e French (1993) e quatro fatores de Carhart (1997) com o objetivo de verificar qual possui o maior poder de explicação das variações dos retornos dos ativos no mercado brasileiro.

O estudo considerou 512 ações listadas na Bolsa de Valores de São Paulo no período de 1995-2011. Utilizou-se metodologia preditiva, que aplica regressão em dois estágios série temporal e corte transversal - com erro padrão calculado de acordo com técnica desenvolvida por Fama e Macbeth (1973). Foram calculados os retornos mensais das ações, que foram agrupadas em carteiras e utilizadas como variável dependente nas regressões. Já foram utilizadas como variáveis independentes os fatores carteira de mercado, tamanho, índice book-to-market e momento.

Os resultados observados indicaram que, apesar de o modelo de três fatores de Fama e French (1993) ter apresentado maior poder preditivo em relação ao de quatro fatores de Carhart (1997) e ao CAPM, nenhum dos modelos foi suficiente para explicar as variações dos retornos das carteiras formadas.

Os fatores tamanho e momento não foram estatisticamente significantes, o que indicou que não foi possível observar no mercado brasileiro os mesmos efeitos documentados por Fama e French (1993) e Carhart (1997). Já o fator mercado foi significante somente nos modelos com intercepto, e o fator índice $\mathrm{B} / \mathrm{M}$ foi significante somente nos modelos sem intercepto. $\mathrm{O}$ intercepto foi fortemente significante nos modelos de três e quatro fatores, o que sinaliza, juntamente com o baixo poder de explicação dos modelos, que outros fatores não incluídos nos modelos, seriam capazes de explicar as variações dos retornos dos ativos.

Palavras-chave: custo de capital, investimentos, ações. 


\section{Abstract}

This dissertation seeks to compare the CAPM model, three factor model of Fama and French (1993) and four factor model of Carhart (1997). Its goal is to verify the one that has the best capability to explain the stock return variations in the Brazilian market.

This study considered 512 stocks listed in São Paulo Stock Exchange (BOVESPA) along the period 1995-2011. Predictive methodology, which applies a two stage regression (time series and cross-sectional), was used. The standard error was calculated in accordance to the technique developed by Fama and Macbeth (1973). Stocks monthly returns were calculated and grouped in portfolios that were employed afterwards as dependent variable in the regressions. The market portfolio factor, the size factor, the book-to-market index factor and the momentum factor were used as independent variables.

The observed results indicated that, despite the tree factor model of Fama and French (1993) had showed a better predictability over the four factor model of Carhart (1997) and CAPM, none of these models were enough to explain the return variation of the formed portfolios.

The size and momentum effects weren't statistically significant, which indicates that it was not observed, in the Brazilian market, the same effects documented by Fama and French (1993) and Carhart (1997). The market factor was significant only in the models with the intercept, and the B/M index factor was significant only in the models without the intercept. The intercept itself was strongly significant in the tree and four factor models, which, combined with the poor power of explaining the models, signalizes that other factors not included in the models would be able to explain the stock return variations.

Keywords: cost of capital, investments, stocks. 


\section{SUMÁRIO}

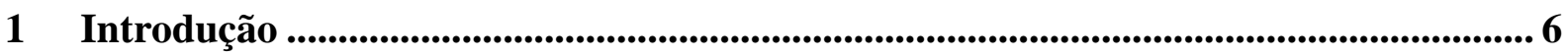

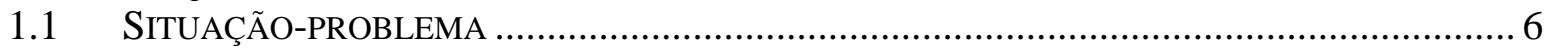

1.2 OBJETIVO GERAL E OBJETIVOS ESPECÍFICOS ......................................................... 9

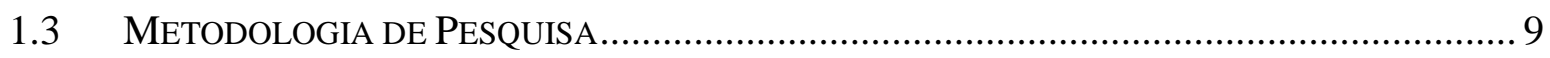

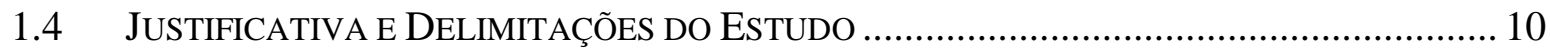

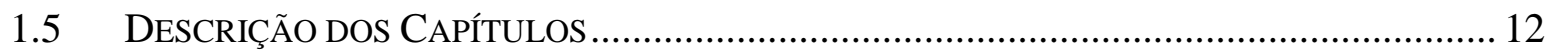

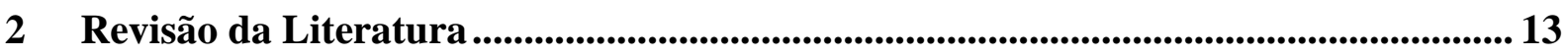

2.1 Teoria de Carteiras e Modelos de AvaliaÇão de Ativos .................................. 13

2.1.1 Decisões em Condição de Incerteza e a Fronteira Eficiente ..................................... 13

2.1.2 Ativo Livre de Risco e Carteira de Mercado ………………………....................... 23

2.1.3 Linha de Mercado de Capitais e o Capital Asset Pricing Theory (CAPM) ……... 25

2.1.4 Principais Estudos Sobre CAPM ……………………......................................... 31

2.1.5 Principais Estudos Sobre CAPM no Brasil............................................................. 34

2.1.6 Principais Limitações da Aplicação do CAPM no Brasil .......................................... 36

2.2 HIPÓTESE DE EFICIÊNCIA DE MERCADO …………….............................................. 37

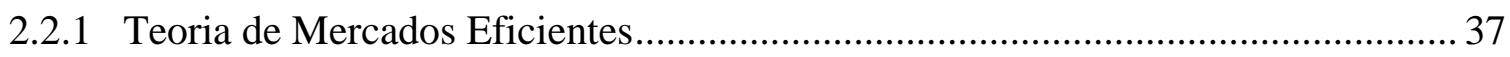

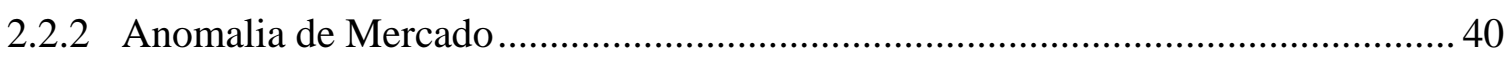

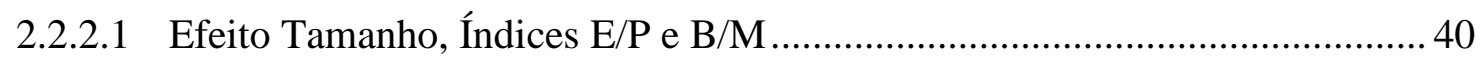

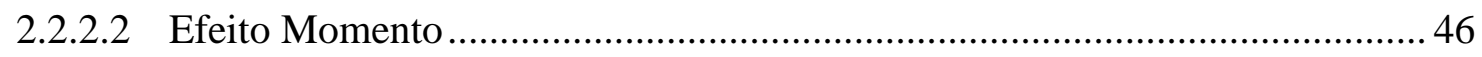

2.2.3 Estudos sobre Anomalias no Brasil ..................................................................... 49

2.3 ARBITRAGE PRICING THEORY (APT) ………………...................................... 53

2.4 MODELO DE TRÊS FATORES PARA O APREÇAMENTO DE ATIVOS .................................57

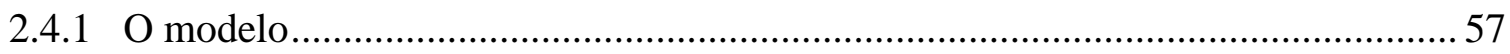

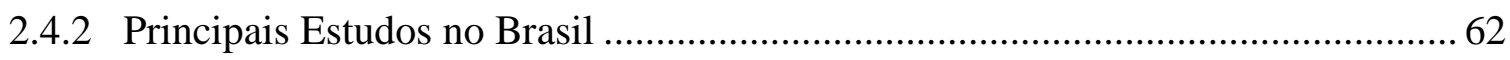

2.5 Modelo de Quatro Fatores PARA O APREÇAMENTO de Ativos ............................ 63

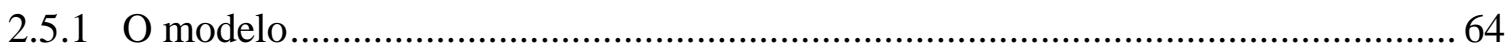

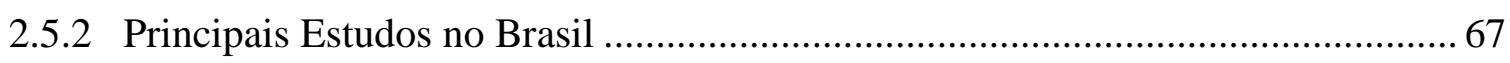

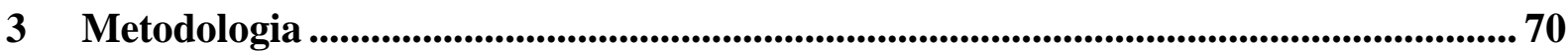

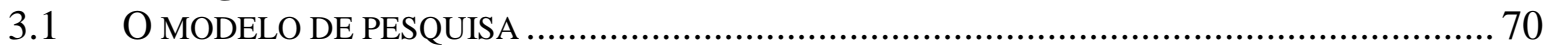

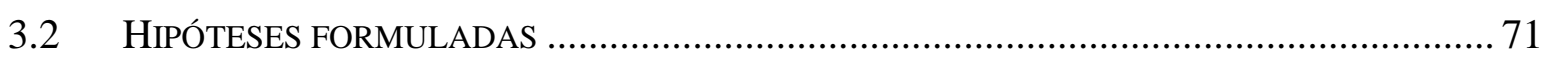

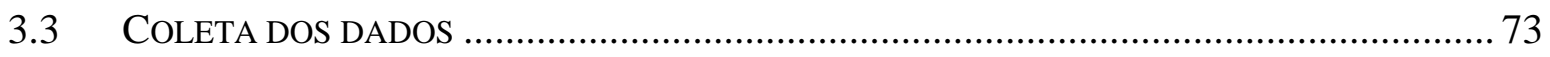

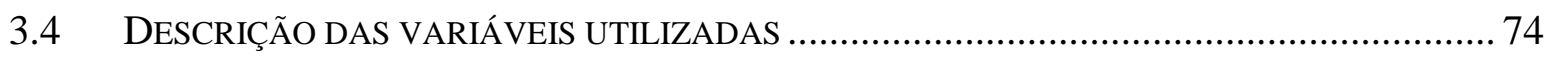

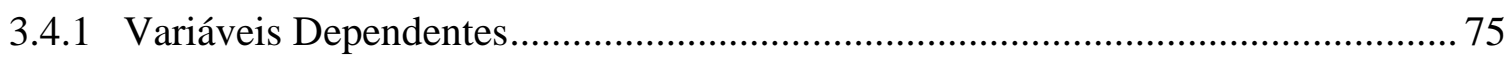

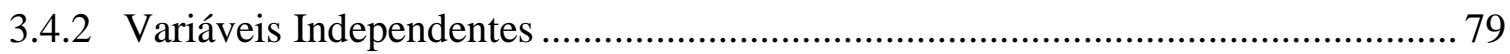

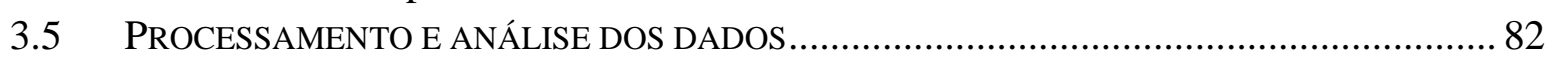

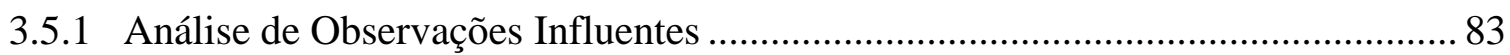

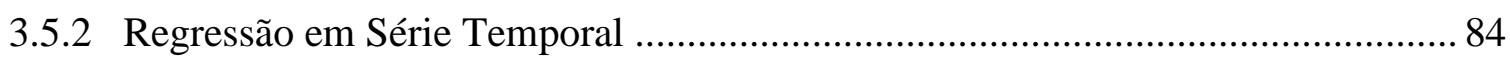

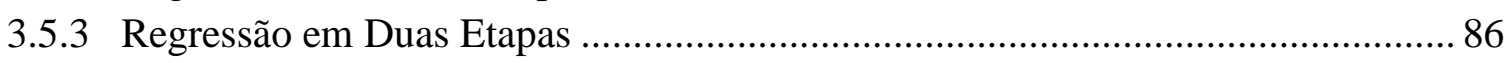

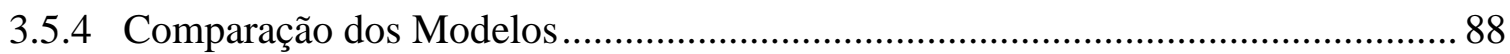

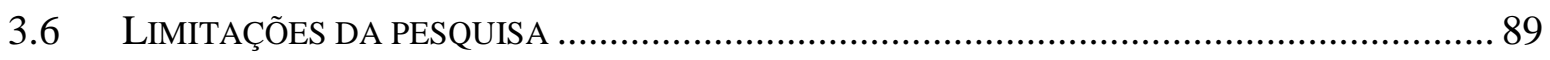

4 Análise dos Dados ............................................................................................................ 91

4.1 ESTATÍSTICA DESCRITIVA DAS CARTEIRAS ……………………….................... 91 
4.2 ANÁlISE DOS MODELOS POR REGRESSÃO EM SÉRIE TEMPORAL …............................ 97

4.3 ANÁliSE dOS MODELOS POR REGRESSÃO EM DOIS ESTÁGIOS ................................. 102

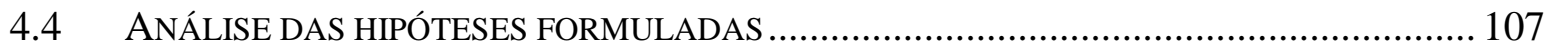

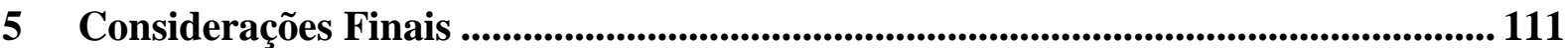

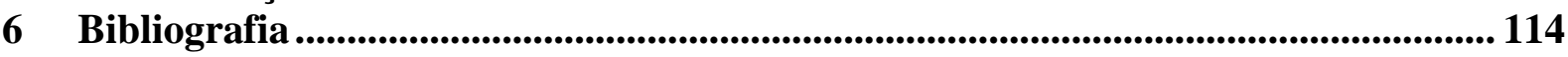

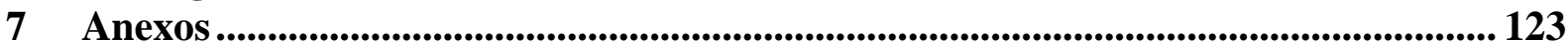


Lista de Figuras

Figura 1 - Processo de Construção das Carteiras ................................................................... 78

Figura 2 - Intervalo de Confiança e Região de Rejeição da Hipótese Nula Bilateral ............. 85

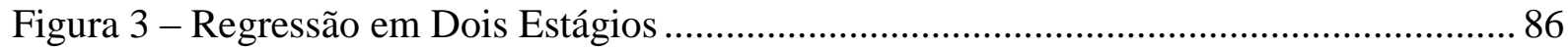


Lista de Gráficos

Gráfico 1 - Risco-Retorno Esperado de Ativos ..................................................................... 16

Gráfico 2 - Relação entre Risco e Retorno quando a correlação é 1, 0 e -1 …....................... 19

Gráfico 3 - Curva de Oportunidade formada por $\mathrm{N}$ ativos com risco .................................... 22

Gráfico 4 - Combinação do ativo livre de risco e da carteira de ativos com risco .................. 24

Gráfico 5 - Linha de Mercado de Capitais (LMC) ................................................................. 27

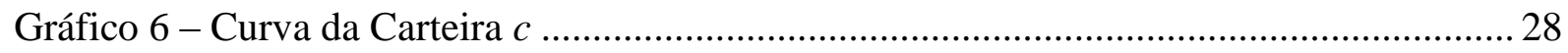

Gráfico 7 - Linha de Mercado de Títulos ................................................................................. 31

Gráfico 8 - Distância de Cook das carteiras Big|High|Loser e Small|Medium|Winner........... 92 
Sumário de Tabelas

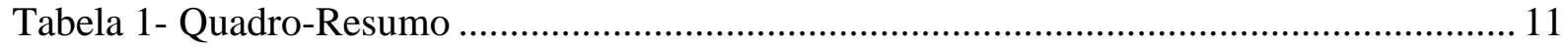

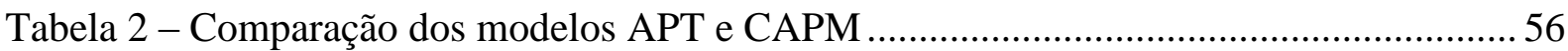

Tabela 3 - Carteiras formadas a partir dos fatores tamanho, índice B/M e momento, utilizadas

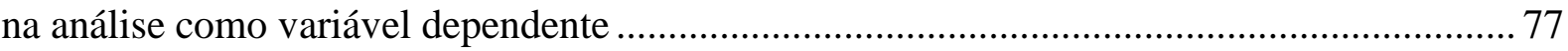

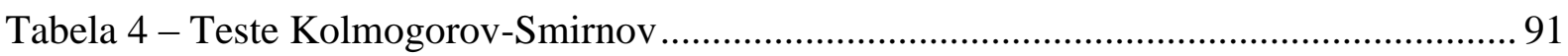

Tabela 5 - Teste Kolmogorov-Smirnov sem pontos influentes ............................................ 93

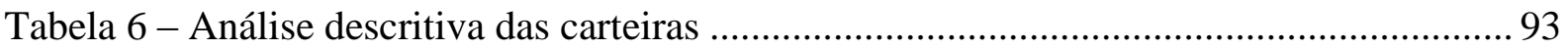

Tabela 7 - Prêmio e Desvio Padrão Médio das Carteiras .......................................................... 95

Tabela 8 - Estatística Descritiva dos Fatores de Risco dos Modelos ..................................... 96

Tabela 9 - Regressão Temporal dos modelos CAPM com e sem intercepto para o período de

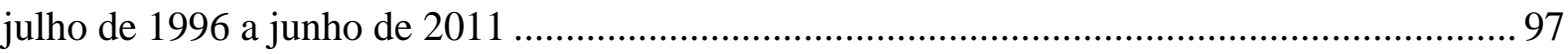

Tabela 10 - Regressão Temporal do modelo de 3 Fatores de Fama e French (1993) com e sem intercepto para o período de julho de 1996 a junho de 2011 ................................................ 99

Tabela 11 - Regressão Temporal do modelo de 4 Fatores de Carhart (1997) com e sem intercepto para o período de julho de 1996 a junho de 2011 .............................................. 101

Tabela 12 - Regressão em Corte Transversal do período Out-of-Sample (jan/2004 a jun/2011)

Tabela 13 - Regressão em Corte Transversal: Análise de Períodos ..................................... 106

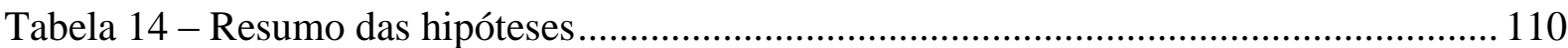




\section{Introdução}

\subsection{Situação-problema}

Um marco importante para o reconhecimento da melhora na estabilidade econômica do Brasil foi a elevação a Grau de Investimento, inicialmente pela agência Standard \& Poor's em abril de 2008, seguida pelas agências Fitch em maio de 2008 e Moody's em setembro de 2009. A classificação de risco de crédito sinaliza a saúde financeira da instituição ou do país, e o termo Grau de Investimento sugere que determinado país ou empresa possui baixa probabilidade de dar default em sua dívida, ou seja, acredita-se que o risco econômico do país ou empresa é baixo.

O processo de redução do risco econômico brasileiro e o consequente aumento da confiança no país resultaram, entre outros, no desenvolvimento do mercado de capitais, permitindo que mais empresas tivessem acesso à captação de recursos nos mercados de ações e de dívida.

No mercado interno de dívida, as emissões de debêntures evoluíram de $\mathrm{R} \$ 6,8$ bilhões em 1995 para R\$ 52,3 bilhões no ano de 2010. Já o volume captado em ofertas públicas de ações, considerando ofertas iniciais e secundárias, que foi de R \$ 1,9 bilhão em 1995, passou para o recorde de R\$ 75 bilhões no ano de 2007. Em 2010, atingiu os R 30 bilhões, desconsiderando a emissão secundária realizada pela Petrobras, que, sozinha, foi responsável por captar R \$ 120 bilhões.

Se consideradas somente as operações de abertura de capital, o volume de captações atingiu o valor de R \$ 55,6 bilhões no ano de 2007, número dez vezes maior que o volume captado em 2004. Em 2010, o volume captado foi de R\$ 11,2 bilhões. Por fim, o volume médio diário negociado na Bolsa de Valores de São Paulo (BOVESPA), no ano de 2011, estava em torno de $\mathrm{R}$ \$ 6 bilhões, ante o R \$ 1 bilhão negociado no ano de 2004.

Além disso, o relatório Anbima (2011) informou que houve 143 operações de fusões e aquisições, ofertas públicas de aquisição de ações (OPA) e reestruturações societárias no ano de 2010 que movimentaram um volume de R\$ 184,4 bilhões, maior número desde 2006, considerando a atual metodologia de cálculo. Este montante é $55 \%$ superior ao registrado em 2009 e $35 \%$ superior ao registrado em 2007, antigo recorde.

Esse processo de crescimento foi desacelerado pela crise de crédito nos sistemas bancários norte-americano e europeu, que teve início no mercado imobiliário e culminou numa crise de confiança em meados de 2008. Diversos bancos tiveram perdas significantes 
com o aumento da inadimplência e com a desvalorização dos ativos lastreados em crédito imobiliário, o que provocou uma redução patrimonial destas instituições. Como o crédito que uma instituição pode oferecer ao sistema depende do seu valor patrimonial, essa queda do valor patrimonial de diversos bancos causou uma drástica redução da oferta de crédito no sistema.

O Brasil foi um dos países que menos sofreram com esta redução da oferta de crédito. No entanto, medidas foram adotadas pelo governo para evitar que bancos e empresas tivessem problemas para renovar suas dívidas. Entre tais medidas, é possível citar a redução da taxa básica de juros e a isenção de impostos para alguns setores.

Neste cenário de desenvolvimento do mercado de capitais brasileiro e incerteza em relação aos desdobramentos da crise, a análise da taxa de retorno esperada em um investimento se mostra, cada vez mais relevante. A metodologia mais utilizada para estimar esta taxa, de acordo com Raifur (2008, p. 135), é o CAPM - Capital Asset Pricing Model, desenvolvido por Sharpe (1964), Lintner (1965) e Mossin (1966) a partir do trabalho realizado por Markowitz (1952) sobre a teoria de carteiras e por Tobin (1958) sobre a teoria de separação.

O CAPM é um modelo de equilíbrio que assume algumas premissas em relação ao comportamento dos agentes e ao funcionamento do mercado. Define que o retorno de qualquer ativo pode ser explicado pelo retorno do ativo livre de risco adicionado ao prêmio da carteira de mercado multiplicado pelo fator beta, que indica a sensibilidade do ativo em relação a essa carteira de mercado. Esta medida de sensibilidade também é chamada de medida de risco sistemático: quanto maior o beta de um determinado ativo, maior deveria ser o retorno esperado pelos investidores.

O modelo CAPM auxiliou no desenvolvimento da teoria de finanças, por mostrar matematicamente esta relação linear entre o retorno do ativo e o retorno do mercado, em uma situação de equilíbrio. Em virtude de sua importância, ele passou a ser largamente estudado e testado.

Trabalhos iniciais evidenciaram que o CAPM explicava boa parte dos retornos observados (BLACK et al., 1972; FAMA e MACBETH, 1973). No entanto, outros estudos indicaram que o CAPM era incompleto e que determinadas características da empresa, como tamanho, índice de valor contábil do patrimônio líquido sobre preço de mercado, crescimento das vendas, entre outros, poderiam ser utilizadas para explicar os retornos observados (BASU, 1977; BANZ, 1981; FAMA e FRENCH, 1992). 
Porque estes padrões nos retornos médios, aparentemente, não são explicados pelo CAPM, eles são chamados de anomalias. (FAMA e FRENCH, 1996, p. 55)

Na tentativa de melhorar o modelo desenvolvido por Sharpe (1964), Fama e French (1993) sugeriram a inclusão de dois fatores ao modelo do CAPM: o tamanho da empresa e o índice de valor contábil do patrimônio líquido sobre preço de mercado (índice Book-toMarket ou B/M). Estes fatores foram selecionados a partir dos estudos de anomalias de mercado, constituindo, assim, um modelo multifatorial que ficou conhecido como o modelo de três fatores de Fama e French (1993). De acordo com os autores, os retornos das ações poderiam ser explicados pelo retorno do mercado, conforme definido no CAPM, pelo tamanho da empresa e pelo índice Book-to-Market.

Jegadeesh e Titman (1993) evidenciaram que estratégias de momento, que significam a compra de ações de melhor desempenho e a venda de ações de pior desempenho nos doze meses anteriores, apresentavam retornos anormais positivos. Fama e French (1996) encontraram evidências de que o modelo de três fatores não era capaz de explicar este efeito. A partir destas evidências, Carhart (1997) propôs a adição do fator momento ao modelo de três fatores de Fama e French (1993) e encontra evidências da superioridade do modelo de quatro fatores em relação ao modelo de três fatores para explicar os retornos dos ativos.

Para o mercado brasileiro, Málaga e Securato (2004) encontraram evidências da superioridade do modelo de três fatores de Fama e French (1993) em relação ao modelo CAPM, utilizando regressão em série de tempo. Mussa, Santos e Fama (2007) testaram o modelo de quatro fatores de Carhart (1997) no mercado acionário brasileiro e identificaram sua superioridade em relação ao modelo de três fatores e ao CAPM, utilizando também regressão em série de tempo.

No entanto, em trabalho mais recente, Mussa, Rogers e Securato (2009) testaram os modelos CAPM, três e quatro fatores, utilizando um modelo de teste preditivo, e encontraram evidências contrárias às anteriormente observadas: apesar de os resultados indicarem a superioridade do modelo de quatro fatores sobre o de três fatores, e este em relação ao CAPM, nenhum dos três modelos foi capaz de explicar de forma satisfatória as variações dos retornos das ações no mercado brasileiro. Além disso, foram encontradas evidências de que os fatores tamanho e momento não estavam presentes no mercado de capitais brasileiro.

Nesse contexto, levando em conta o mercado de capitais brasileiro mais desenvolvido e considerando as divergências encontradas nos resultados apontados, o presente trabalho objetiva responder a seguinte questão: 
Entre os modelos CAPM, três fatores de Fama e French (1993) e quatro fatores de Carhart (1997), qual apresenta maior poder de explicação das variações dos retornos dos ativos no mercado brasileiro?

\subsection{Objetivo Geral e Objetivos Específicos}

O principal objetivo deste estudo é comparar os modelos CAPM, três fatores de Fama e French (1993) e quatro fatores de Carhart (1997) a partir de metodologia de teste preditivo, que aplica regressão em dois estágios - série temporal e corte transversal -, com erro padrão calculado a partir de técnica desenvolvida por Fama e Macbeth (1973). A análise compreende o período entre julho de 1995 e junho de 2011.

Para alcançar o principal objetivo deste trabalho foram estabelecidos os seguintes objetivos específicos:

- detalhar o arcabouço teórico sobre os principais aspectos dos modelos CAPM, três fatores de Fama e French (1993) e quatro fatores de Carhart (1997);

- testar empiricamente os três modelos no mercado brasileiro;

- comparar os resultados alcançados pelos três modelos, de forma a identificar qual deles apresentaria maior poder preditivo das variações dos retornos dos ativos.

\subsection{Metodologia de Pesquisa}

A metodologia utilizada nesta dissertação é a positivista, em que se busca descrever as características de determinada população ou evento, além de estabelecer relações entre os fatos e as variáveis, conforme Martins (1994, p. 60). Ainda de acordo com o autor, o tratamento dos dados é feito por meio de técnica estatística, que seria mais adequada para responder a pergunta-problema do trabalho, e a análise dos resultados obtidos é realizada a partir dos níveis de significância estatística. Estuda-se a relação entre variáveis dependentes e independentes a fim de estabelecer uma relação de causalidade que deve se manter no futuro.

Para se alcançar os objetivos propostos, empregou-se nesta dissertação a pesquisa quantitativa, cujo principal objetivo é testar uma hipótese formulada a partir da observação de uma característica da população ou de um evento.

A pesquisa quantitativa utiliza basicamente técnicas estatísticas para tratar os dados. 
Neste sentido, Andrade (2008) comenta que, como o estudo quantitativo está baseado em uma ferramenta estruturada, suas conclusões apresentam grande probabilidade de serem verdadeiras e não se baseiam em interpretações dos autores. A autora ainda comenta o seguinte:

A manipulação estatística permite comprovar as relações dos fenômenos entre si, e obter generalizações sobre sua natureza, ocorrência ou significado. (ANDRADE, 2008, p. 14)

A metodologia de pesquisa se baseia em uma revisão teórica do modelo CAPM de Sharpe (1964), Lintner (1965) e Mossin (1966), bem como dos modelos baseados em anomalias de mercado que se desenvolveram a partir dele: o modelo de três fatores de Fama e French (1993) e o modelo de quatro fatores de Carhart (1997). Tais modelos utilizam os efeitos tamanho, índice Book-to-Market e momento (quarto fator) para explicar o retorno dos ativos no mercado.

A metodologia estatística escolhida para testar estes modelos no mercado de capitais brasileiro foi a de Fama e Macbeth (1973), sendo necessárias algumas adaptações, devido a peculiaridades do próprio mercado brasileiro.

\subsection{Justificativa e Delimitações do Estudo}

Entender a aplicabilidade de modelos de análise dos retornos dos ativos é fundamental para evitar uma análise inadequada que pode sobre ou subavaliar o retorno esperado para determinado ativo, o que poderia impactar decisões de financiamento e investimento, conforme anteriormente citado.

Esta dissertação visa: 1) contribuir para discussões acerca do modelo CAPM e seus derivados; 2) auxiliar na análise do poder preditivo dos modelos CAPM, três fatores de Fama e French (1993) e quatro fatores de Carhart (1997), assim como na relevância de seus fatores para a explicação dos retornos dos ativos e 3) elucidar evidências acerca do tema para melhor compreensão da aplicação dos modelos no mercado brasileiro. A tabela 1 mostra um resumo dos objetivos e a metodologia empregada. 
Tabela 1- Quadro-Resumo

\begin{tabular}{|c|c|c|}
\hline Pergunta-problema & Objetivo do Trabalho & Metodologia \\
\hline \multirow{3}{*}{$\begin{array}{l}\text { Entre os modelos } \\
\text { CAPM, três fatores } \\
\text { de Fama e French } \\
\text { (1993) e quatro } \\
\text { fatores de Carhart } \\
\text { (1997), qual } \\
\text { apresenta maior } \\
\text { poder de } \\
\text { explicação das } \\
\text { variações dos } \\
\text { retornos dos ativos } \\
\text { no mercado } \\
\text { brasileiro? }\end{array}$} & $\begin{array}{l}\text { Discutir os principais } \\
\text { aspectos dos modelos } \\
\text { CAPM, três fatores de } \\
\text { Fama e French (1993) e } \\
\text { quatro fatores de Carhart } \\
\text { (1997). }\end{array}$ & $\begin{array}{l}\text { Levantamento bibliográfico sobre } \\
\text { os modelos CAPM, três fatores de } \\
\text { Fama e French (1993) e quatro } \\
\text { fatores de Carhart (1997) }\end{array}$ \\
\hline & $\begin{array}{l}\text { Testar empiricamente os } \\
\text { modelos CAPM, três } \\
\text { fatores de Fama e French } \\
\text { (1993) e quatro fatores de } \\
\text { Carhart (1997) no mercado } \\
\text { brasileiro. }\end{array}$ & $\begin{array}{l}\text { A) Geração de carteiras conforme } \\
\text { Mussa, Rogers e Securato } \\
\text { (2009) } \\
\text { B) Teste dos modelos a partir de } \\
\text { regressões em série de tempo } \\
\text { C) Aplicação de metodologia de } \\
\text { teste preditivo de regressão em } \\
\text { dois estágios - série temporal } \\
\text { e corte transversal - com erro } \\
\text { padrão calculado a partir de } \\
\text { técnica desenvolvida por Fama } \\
\text { e Macbeth (1973) }\end{array}$ \\
\hline & $\begin{array}{l}\text { Comparar o poder de } \\
\text { explicação dos três } \\
\text { modelos, de forma a } \\
\text { identificar qual deles } \\
\text { apresenta maior poder } \\
\text { preditivo das variações dos } \\
\text { retornos dos ativos. }\end{array}$ & $\begin{array}{l}\text { A) Comparação entre os } \\
\text { coeficientes das regressões e } \\
\text { os coeficientes de } \\
\text { determinação ajustados } \\
\text { gerados pelas regressões }\end{array}$ \\
\hline
\end{tabular}




\subsection{Descrição dos Capítulos}

Este trabalho foi estruturado em cinco capítulos: Introdução, Revisão da Literatura, Metodologia, Análise dos Dados e Considerações Finais.

O capítulo inicial contextualizou as mudanças ocorridas no mercado de capitais brasileiro, apresentou os objetivos do trabalho, justificou a escolha do tema e trouxe uma breve descrição da metodologia empregada.

O segundo capítulo expõe a Moderna Teoria de Carteiras e alguns dos principais modelos de apreçamento de ativos no mercado financeiro, além de apresentar os principais trabalhos empíricos que testaram o modelo CAPM e os modelos dele derivados.

O terceiro capítulo descreve de forma detalhada os procedimentos empregados para aplicação e análise dos modelos CAPM, três e quatro fatores no mercado brasileiro.

O quarto capítulo detalha a análise dos dados e dos testes de hipótese apresentados na descrição da metodologia, além de relacionar os resultados obtidos neste trabalho com as evidências já encontradas no mercado brasileiro em trabalhos anteriores.

Finalmente, o quinto e último capítulo apresenta as considerações finais em relação ao trabalho realizado. 


\section{Revisão da Literatura}

Neste capítulo serão abordadas as principais referências teóricas utilizadas neste trabalho.

\subsection{Teoria de Carteiras e Modelos de Avaliação de Ativos}

Para entender os modelos apresentados e comparados na presente dissertação, é necessário entender como eles foram desenvolvidos, bem como compreender os testes já realizados tanto no mercado internacional como no brasileiro. Dessa maneira, as diferentes abordagens são detalhadas e discutidas a seguir.

\subsubsection{Decisões em Condição de Incerteza e a Fronteira Eficiente}

Pode-se avaliar um cenário com as seguintes características: não há incertezas em relação ao fluxo de caixa a ser recebido, só há uma opção de investimento com remuneração a uma taxa pré-definida, não há custos de transação e as decisões de investimento são realizadas para um período. Neste caso, os investidores se deparam com um único problema: decidir quanto consumir hoje versus quanto irão poupar para consumir no futuro. E o que determina esta escolha é a disposição do indivíduo ao consumo e a sua satisfação em relação a essa disposição. Esta relação é conhecida como função de utilidade ou curva de indiferença.

O exemplo acima é uma forma simplista de retratar a realidade da tomada de decisão em investimentos. No entanto, sabe-se que estas características não são observáveis no mercado e que a grande maioria das decisões de investimento, sejam elas referentes a empresas ou a indivíduos, envolvem incertezas ou variabilidades que devem ser consideradas na análise do problema.

Além da incerteza associada ao investimento e da falta de conhecimento, pelos investidores, de suas curvas de indiferença, é possível encontrar diversas opções de investimento que podem influenciar o conjunto de oportunidades do investidor e, por consequência, a proporção ótima entre investimento e consumo.

Segundo Securato (2007, p. 20), o conceito de incerteza surgiu da tentativa de prever o que aconteceria no futuro e, nesta tentativa, estimativas são feitas a respeito dos eventos futuros. O conceito de risco surgiu da possibilidade de perda ou de acontecer no futuro algo diferente do que foi estimado ou previsto. O risco de um evento estaria associado à 
variabilidade em relação aos seus possíveis resultados. Segundo Securato (2007, p. 25), “o grau de incerteza, ou seja, o risco estará intimamente ligado à probabilidade de ocorrência dos eventos em estudo".

Incerteza pode ser definida como:

\begin{abstract}
Incerteza é uma característica saliente dos investimentos em ativos. As forças econômicas não são compreendidas suficientemente bem para que as previsões estejam livres de qualquer dúvida ou erros. Mesmo que as consequências das condições econômicas sejam entendidas perfeitamente, há ainda influências não econômicas que podem mudar o rumo da prosperidade geral, o nível do mercado ou o sucesso de um ativo em particular. (MARKOWITZ, 1959, p. 4)
\end{abstract}

De acordo com Rubinstein (2006, p. 102), Markowitz (1952) foi o primeiro a introduzir o conceito de tomada de decisão em finanças a partir de uma relação de riscoretorno e a ideia de diversificação para as finanças, partindo de algumas premissas sobre o comportamento do investidor. Primeiramente, todos os investidores desejariam retornos altos e estáveis, não sujeitos a variações. Ou seja, os investidores prefeririam mais retorno a menos retorno e menos risco a mais risco. Estas preferências os levariam a selecionar a carteira de menor risco e maior retorno (MARKOWITZ, 1959, p. 5).

Já na seleção dos ativos que compõem estas carteiras, os investidores tomariam suas decisões de investimento comparando as alternativas de retorno esperado e risco a partir das respectivas distribuições de probabilidade, que representariam os possíveis resultados de cada alternativa com a respectiva probabilidade de ocorrência. As medidas mais apropriadas de retorno esperado e risco são, segundo Markowitz (1959, p. 55), a média e o desvio padrão dos retornos.

Ainda de acordo com o autor, a média seria a medida mais conveniente de retorno esperado por dois aspectos: nenhuma distribuição tem mais de uma média, e a relação entre a média dos ativos e a média da carteira é mais simples do que a relação correspondente para moda e mediana (outras medidas de tendência central consideradas pelo autor em seu trabalho). A média poderia ser entendida também como medida de valor esperado, uma vez que o retorno futuro esperado se localizaria no centro de todos os possíveis eventos futuros, ponderados pela respectiva probabilidade de ocorrência.

Para calcular a média, atribui-se uma probabilidade de ocorrência para cada resultado esperado, conforme equação 2.1 .

$$
E\left(\widetilde{R}_{i}\right)=\bar{R}_{i}=\sum_{j=1}^{N} P_{i j} R_{i j}
$$


em que

$E\left(\tilde{R}_{i}\right)$ e $\bar{R}_{i}=$ retorno esperado do ativo $i$;

$P_{i j}=$ probabilidade de ocorrência do retorno $j$ no ativo $i$;

$R_{i j}=\operatorname{retorno} j$ no ativo $i$.

Já a variância ou o desvio padrão representa a distância média dos pontos em relação ao seu valor esperado, ou seja, mede o grau de incerteza associado ao evento futuro (MARKOWITZ, 1959, p. 76).

$$
\sigma^{2}\left(\widetilde{R}_{i}\right)=\sigma_{i}^{2}=\sum_{j=1}^{N} P_{i j}\left[\left(R_{i j}-\bar{R}_{i}\right)^{2}\right]
$$

em que

$\sigma^{2}\left(\widetilde{R}_{i}\right)$ e $\sigma_{i}^{2}=$ variância do ativo $i$;

$P_{i j}=$ probabilidade de ocorrência do retorno $j$ no ativo $i$;

$R_{i j}=$ retorno $j$ no ativo $i$;

$\bar{R}_{i}=$ retorno esperado do ativo $i$.

Sendo que $\sum_{j=1}^{N} P_{i j}=1$ e que $\sigma\left(\tilde{R}_{i}\right)=\sigma_{i}=\sqrt{\sigma_{i}^{2}}$.

A teoria de carteiras assume que cada investidor estima as distribuições de probabilidades e os possíveis resultados dos eventos, além de tomar suas decisões com base na média - ou valor esperado - e na variância destas distribuições. Portanto, seria possível representar a relação risco-retorno de três ativos em um gráfico (vide Gráfico 1). O desvio padrão é a raiz quadrada da variância dos retornos e está representado na abscissa, e o retorno esperado ou média está representado na ordenada. 


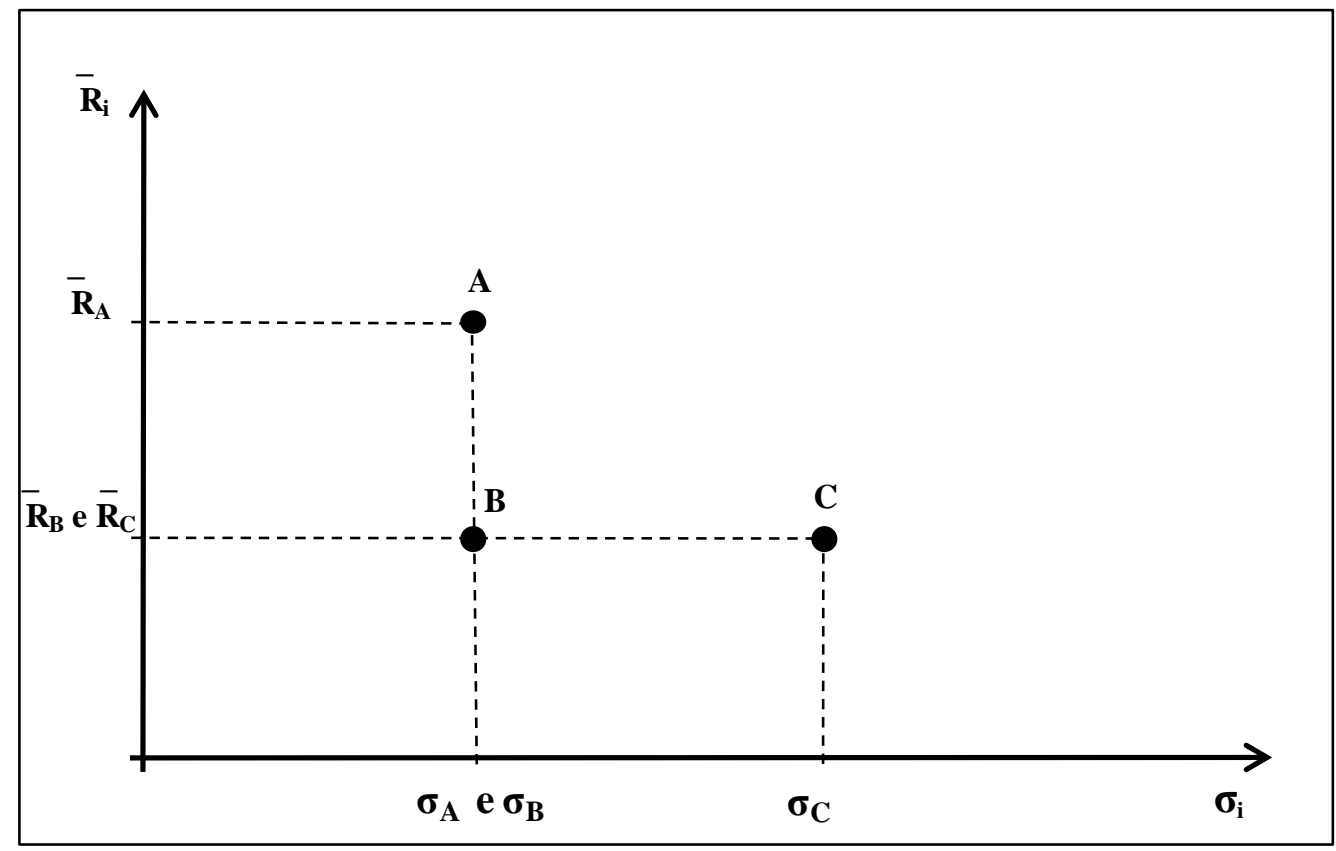

Gráfico 1 - Risco-Retorno Esperado de Ativos

Fonte: Adaptado de Elton e Gruber (1995, p. 54)

De acordo com a teoria de carteiras, as seguintes premissas seriam aplicadas a todos os investidores na tomada de decisão de investimento:

a) se dois ativos tiverem o mesmo retorno esperado (caso dos ativos $\mathrm{B}$ e C), o ativo que possuir o menor risco seria preferível. No Gráfico 1, o ativo B é preferível ao ativo C;

b) se dois ativos tiverem o mesmo risco, medido pelo desvio padrão, o ativo que possuir o maior retorno esperado seria preferível. No Gráfico 1, o ativo A é preferível ao ativo $\mathrm{B}$;

c) se um ativo tiver menor risco e maior retorno esperado, ele seria preferível. No Gráfico 1, o ativo A é preferível ao ativo C.

Deve-se salientar a diferença entre a análise de risco-retorno de um ativo individualmente e a análise do risco-retorno de uma carteira. A análise de ativos é baseada em condições e perspectivas sobre a economia e sobre o mercado, na estrutura da empresa, na posição da empresa em relação a seus concorrentes, entre outros aspectos. Tais aspectos serão utilizados para determinar a perspectiva futura desse ativo. Essa perspectiva futura apresenta incerteza e, em função disso, serão atribuídas probabilidades a cada possível cenário, formando, assim, a distribuição de probabilidades e seus respectivos valores futuros. Esta distribuição é utilizada para analisar a relação risco-retorno de uma carteira. "Uma análise de carteiras começa onde a análise de ativos termina" (MARKOWITZ, 1959, p. 28). 
A construção de uma carteira de investimentos tem como elemento principal o efeito da diversificação, observado na variância da carteira. Segundo o autor, os ativos tendem a se movimentar de forma conjunta, porém em intensidades ou direções distintas. Estes movimentos são chamados de covariância ou correlação. Este fato pode ser definido da seguinte forma: "O fato de que os retornos dos ativos são altamente correlacionados, mas não perfeitamente correlacionados, implica que a diversificação pode reduzir o risco, mas não eliminá-lo" (MARKOWITZ, 1959, p. 5).

Considerando uma carteira $p$ formada por dois ativos, A e B, nas proporções $x_{A}$ e $x_{B}, \mathrm{o}$ retorno esperado da carteira $p$ seria uma ponderação entre os retornos esperados dos dois ativos.

$$
\boldsymbol{E}\left(\widetilde{\boldsymbol{R}}_{\boldsymbol{p}}\right)=\overline{\boldsymbol{R}}_{\boldsymbol{p}}=\boldsymbol{x}_{\boldsymbol{A}} * \overline{\boldsymbol{R}}_{\boldsymbol{A}}+\boldsymbol{x}_{\boldsymbol{B}} * \overline{\boldsymbol{R}}_{\boldsymbol{B}}
$$

em que

$E\left(\tilde{R}_{p}\right)$ e $\bar{R}_{p}=$ retorno esperado da carteira $p$, formada pelos ativos $\mathrm{A}$ e $\mathrm{B}$;

$\bar{R}_{A}$ e $\bar{R}_{B}=$ retornos esperados dos ativos $\mathrm{A}$ e $\mathrm{B}$;

$x_{A}$ e $x_{B}=$ proporção da riqueza total investida em cada ativo.

Considerando que o investidor aplicaria, no máximo, todo o seu patrimônio, a proporção investida em A somada à proporção investida em B deve ser igual a $100 \%$ do patrimônio, ou seja, $x_{A}+x_{B}=1$.

Já a variância da carteira $p$ não é uma simples ponderação dos riscos de cada um dos ativos que a compõem, uma vez que é necessário considerar a interrelação dos retornos dos dois ativos $\mathrm{A}$ e $\mathrm{B}$.

$\sigma^{2}\left(\tilde{R}_{p}\right)=\sigma_{p}^{2}=E\left\{\left[x_{A} R_{A j}+x_{B} R_{B j}\right]-\left[x_{A} \bar{R}_{A}+x_{B} \bar{R}_{B}\right]\right\}^{2}$

ou

$$
\sigma_{p}^{2}=E\left\{x_{A}\left[R_{A j}-\bar{R}_{A}\right]+x_{B}\left[R_{B j}-\bar{R}_{B}\right]\right\}^{2}
$$

Ao aplicar a propriedade distributiva, tem-se: 


$$
\sigma_{p}^{2}=E\left\{x_{A}^{2}\left[R_{A j}-\bar{R}_{A}\right]^{2}+x_{B}^{2}\left[R_{B j}-\bar{R}_{B}\right]^{2}+2 x_{A} x_{B}\left[R_{A j}-\bar{R}_{A}\right]\left[R_{B j}-\bar{R}_{B}\right]\right\}
$$

em que

$x_{A}$ e $x_{B}=$ proporção da riqueza total investida em cada ativo;

$R_{A j}$ e $R_{B j}=$ são os retornos dos ativos A e B no momento j;

$\bar{R}_{A}$ e $\bar{R}_{B}=$ retornos esperados dos ativos $\mathrm{A}$ e $\mathrm{B}$;

$\left[R_{A j}-\bar{R}_{A}\right]\left[R_{B j}-\bar{R}_{B}\right]=$ coeficiente de interrelação entre os ativos A e B.

O coeficiente $\left[R_{A j}-\bar{R}_{A}\right]\left[R_{B j}-\bar{R}_{B}\right]$ é definido como a covariância entre os retornos de $\mathrm{A}$ e de $\mathrm{B}$, expresso pelo símbolo $\sigma_{A, B}$, e indica como os desvios dos retornos do ativo $\mathrm{A}$ em relação ao seu valor esperado variam relativamente aos desvios dos retornos do ativo $\mathrm{B}$ em relação ao seu valor esperado. A covariância entre os retornos dos ativos A e B pode ser determinada pela multiplicação do coeficiente de correlação pelo desvio padrão dos retornos de cada um dos ativos.

$$
\sigma_{A, B}=\rho_{A, B} \sigma_{A} \sigma_{B}
$$

em que

$\sigma_{A, B}=$ covariância entre os retornos dos ativos A e B;

$\rho_{A, B}=$ correlação entre os retornos dos ativos A e B;

$\sigma_{A}$ e $\sigma_{B}=$ desvio padrão dos ativos $\mathrm{A}$ e $\mathrm{B}$, respectivamente.

Assim, é possível estabelecer a seguinte relação:

$$
\sigma_{p}^{2}=E\left\{x_{A}^{2} \sigma_{A}^{2}+x_{B}^{2} \sigma_{B}^{2}+2 x_{A} x_{B} \sigma_{A} \sigma_{B} \rho_{A, B}\right\}
$$

em que

$x_{A}$ e $x_{B}=$ proporção da riqueza total investida nos ativos A e B;

$\sigma_{A}$ e $\sigma_{B}=$ são os desvios padrão dos ativos A e B;

$\sigma_{A, B}=$ covariância entre os retornos dos ativos A e B;

$\rho_{A, B}=$ correlação entre os retornos dos ativos A e B;

$\sigma_{A}$ e $\sigma_{B}=$ desvio padrão dos ativos $\mathrm{A}$ e $\mathrm{B}$, respectivamente. 
A identificação desta inter-relação, ou da existência de correlação entre os retornos dos ativos, é uma das principais contribuições da teoria de carteiras. É esta propriedade que permitiu observar e quantificar os benefícios da diversificação dos investimentos para a gestão de riscos. (MÁLAGA, 2003, p. 13)

O coeficiente de correlação é uma medida padronizada da interrelação dos ativos e assume valores entre -1 e +1 . Quanto menor a correlação entre os ativos, menor é a variância da carteira e maior é o benefício da diversificação.

O Gráfico 2 ilustra a relação entre o retorno esperado e o desvio padrão da carteira para diferentes índices de correlação. Cada curva foi construída alterando-se os pesos alocados em cada ativo para um dado coeficiente de correlação, assim, estas curvas representam todas as carteiras que podem ser formadas pelos ativos A e B para diferentes coeficientes de correlação. Estas curvas são chamadas de Curvas de Oportunidade, pois representam todas as combinações possíveis e viáveis em proporções diferentes entre os ativos A e B.

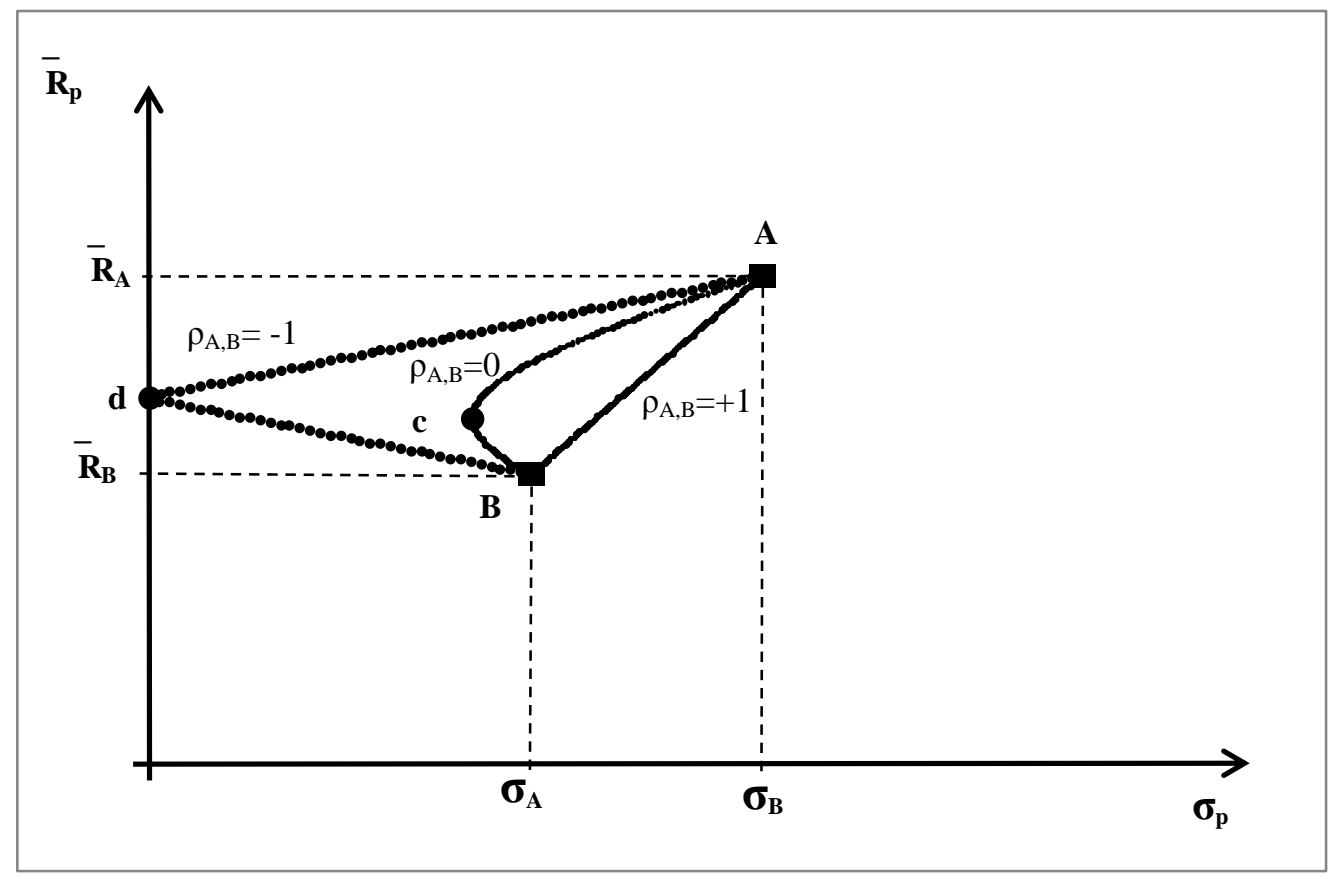

Gráfico 2 - Relação entre Risco e Retorno quando a correlação é 1, 0 e -1 Fonte: Adaptado de Elton e Gruber (1995, p. 79)

Se a correlação entre os retornos dos ativos da carteira for positiva e perfeita, o coeficiente de correlação é igual a 1 e não há efeito de diversificação, pois os ativos se movimentarão na mesma intensidade e na mesma direção. Neste caso, o risco da carteira é uma média ponderada do risco dos ativos e aumenta ou diminui linearmente em função 
somente das proporções investidas em cada ativo, bem como do risco de cada ativo, conforme Gráfico 2, reta $\mathrm{AB}$.

$\sigma_{P}^{2}=\left[x_{A} \sigma_{A}+x_{B} \sigma_{B}\right]^{2}$

(2.8) $\sigma_{P}=x_{A} \sigma_{A}+x_{B} \sigma_{B}$

Quando a correlação é inferior a 1, o risco da carteira não é mais linear em relação ao risco dos ativos e a proporção investida em cada um deles. No caso em que não há correlação entre os ativos, o coeficiente de correlação é zero e seria possível observar o efeito da diversificação na diminuição do risco da carteira, conforme curva AcB. Um risco da carteira igual ou próximo a zero seria atingido na situação extrema em que a correlação entre os ativos é perfeita e negativa, com coeficiente de correlação igual a -1 . Neste caso, os ativos se movimentariam na mesma intensidade, mas em direções opostas, conforme curva AdB.

É possível notar que as carteiras formadas entre os pontos $c A$ e $d A$ são preferíveis àquelas situadas entre $c B$ e $d B$, pois oferecem um retorno superior para um mesmo nível de risco. Por este motivo, estas curvas são chamadas de "conjunto eficiente" ou fronteira eficiente (ROSS, WESTERFIELD e JAFFE, 2007, p. 217).

Ressalta-se que as três curvas apresentadas no Gráfico 2 não existem simultaneamente para os mesmos dois ativos, considerando a mesma distribuição de retornos.

Ao considerar uma carteira formada por $N$ ativos, a média ou o valor esperado para a carteira é:

$$
E\left(\widetilde{R}_{p}\right)=\bar{R}_{p}=\sum_{i=1}^{N} x_{i} \bar{R}_{i}
$$

em que

$x_{i}=$ proporção da carteira $p$ investida em cada ativo $i$;

$\bar{R}_{i}=$ retorno esperado de cada ativo $i$;

$\sum_{i=1}^{N} x_{i}=1$

E a variância da carteira formada por $\mathrm{N}$ ativos é: 
$\sigma^{2}\left(\tilde{R}_{p}\right)=\sigma_{p}^{2}=\sum_{i=1}^{N} x_{i}^{2} \sigma_{i}^{2}+\sum_{i=1}^{N} \sum_{\substack{j=1 \\ j \neq i}}^{N} x_{i} x_{j} \sigma_{i, j}$

ou

(2.10) $\sigma_{p}^{2}=\sum_{i=1}^{N} x_{i}^{2} \sigma_{i}^{2}+\sum_{i=1}^{N} \sum_{\substack{j=1 \\ j \neq i}}^{N} x_{i} x_{j} \sigma_{i} \sigma_{j} \rho_{i, j}$

em que

$x_{i}$ e $x_{j}=$ proporções da carteira $p$ investida em cada ativo $i$ e $j$;

$\sigma_{i}$ e $\sigma_{j}=$ desvio padrão de cada ativo $i$ e $j$, respectivamente;

$\rho_{i, j}=$ coeficiente de correlação entre o retorno esperado dos ativos $i$ e $j$;

$\sigma_{i, j}=$ covariância entre o retorno esperado dos ativos $i$ e $j$.

A Curva de Oportunidade formada por $N$ ativos com risco tem a mesma forma da curva com dois ativos, contudo é a fronteira de uma área compacta formada por diversas carteiras. De acordo com Ross, Westerfield e Jaffe (2007, p. 218), “esta área corresponde a todas as combinações possíveis de retorno esperado e desvio padrão para uma carteira".

O conjunto eficiente é formado pelas carteiras que se situam entre o ponto de mínima variância $c$ e a carteira de máximo retorno esperado $b$, conforme é possível observar no Gráfico 3, e estas carteiras podem ser constituídas com mais ativos, como podem ser constituídas de ativos individuais que são eficientes em sua média-variância por si só. Além disso, deve-se considerar que "qualquer ponto abaixo do conjunto eficiente produziria retorno esperado menor e teria o mesmo desvio padrão de um ponto situado no conjunto eficiente" (ROSS, WESTERFIELD e JAFFE, 2007, p. 219). Portanto, nenhum investidor selecionaria uma carteira dentro da área compacta, pois há uma carteira na Fronteira Eficiente que oferece um retorno superior para um mesmo nível de risco.

Segundo Ross, Westerfield e Jaffe (2007, p. 216), nenhum investidor iria aplicar em uma carteira que oferecesse um retorno inferior ao retorno da carteira de mínima variância, pois uma carteira com retorno inferior ofereceria menor retorno para um nível maior de risco. Portanto, todos os investidores escolhem carteiras que se situem na curva $c b$, pois preferem sempre mais retorno a menos retorno para um dado nível de risco.

A decisão sobre qual carteira escolher dentro das opções disponíveis na fronteira eficiente é feita com base nas necessidades e preferências individuais a respeito de risco e 
retorno que maximizem sua curva de utilidade, segundo Markowitz (1959, p. 23). A carteira exata para cada pessoa é determinada pela tangência da curva de indiferença com a fronteira eficiente.

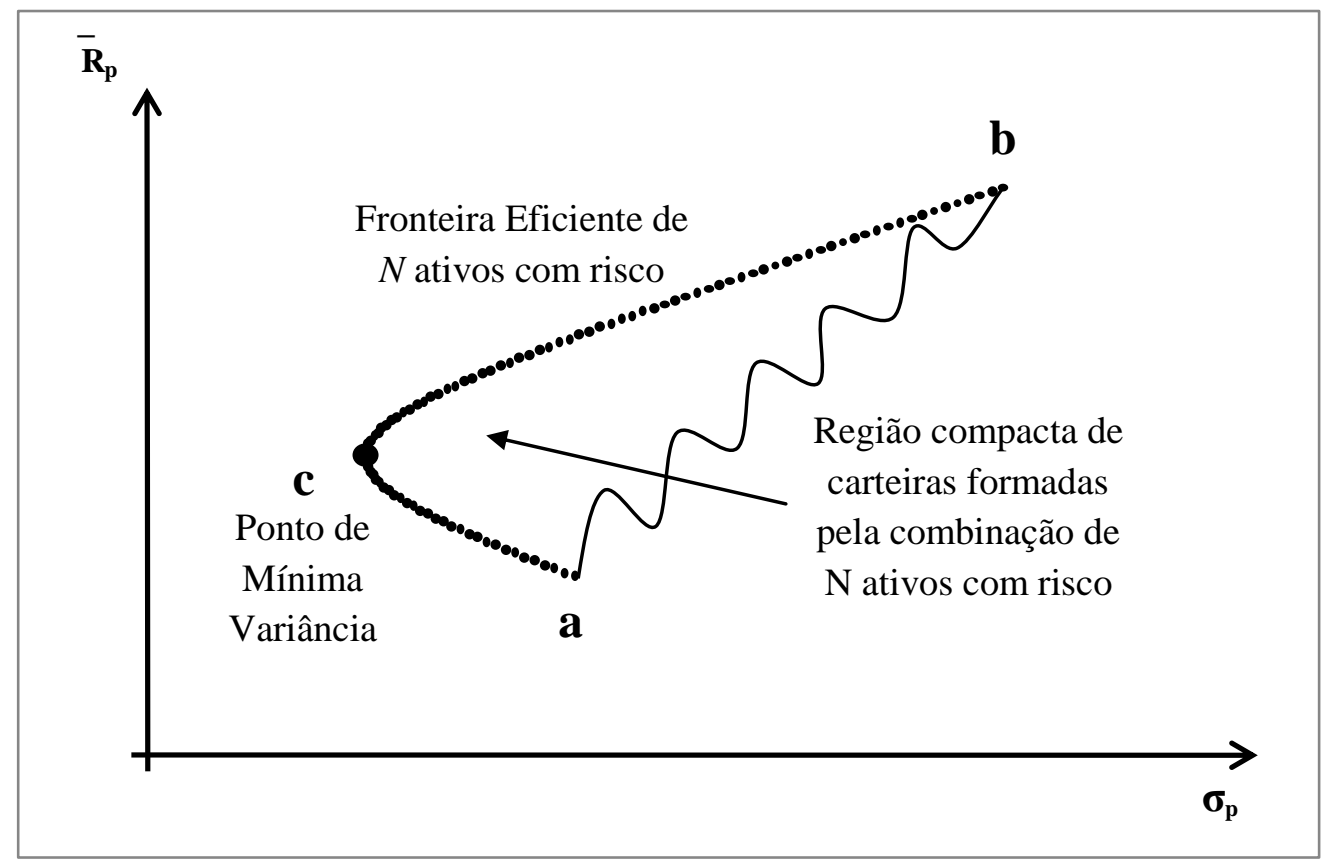

Gráfico 3 - Curva de Oportunidade formada por $\mathrm{N}$ ativos com risco Fonte: Adaptado de Galeno (2010, p. 24) e Elton e Gruber (1995, p. 87)

À medida que muitos ativos são incluídos na carteira, o peso de cada ativo individualmente diminui e o retorno esperado da carteira se aproxima de uma média. A inserção de um ativo de alto retorno individualmente não influencia significantemente o da carteira, pois o retorno desse ativo é diluído pelo seu baixo peso.

Já em relação à medida de variância da carteira, a inclusão de muitos ativos faz com que o risco da carteira seja mais influenciado pela covariância entre os retornos dos ativos do que pelo risco individual de cada ativo. Isso porque o número de variâncias na carteira é igual ao número de ativos $N$, e o número de covariâncias na carteira é igual a $\left(N^{2}-N\right)$ ou $N(N-1)$. Portanto, à medida que se têm diversos ativos na carteira, a covariância se torna mais relevante. Supondo uma carteira ponderada igualmente entre os ativos

$$
\sigma_{p}^{2}=\frac{1}{N^{2}} \sum_{i=1}^{N} \sigma_{i i}+\frac{1}{N^{2}} \sum_{i=1}^{N} \sum_{\substack{j=1 \\ j \neq i}}^{N} \sigma_{i j}
$$


tem-se que

(2.11) $\sigma_{p}^{2}=\frac{N \sigma_{i i}}{N^{2}}+\frac{\left(N^{2}-N\right) \sigma_{i j}}{N^{2}}=\frac{\sigma_{i i}}{N}+\frac{(N-1) \sigma_{i j}}{N}$

Assim é possível observar que a covariância da carteira passa a ser determinada praticamente pelas covariâncias entre os ativos.

\subsubsection{Ativo Livre de Risco e Carteira de Mercado}

Tobin (1958), tomando como base o trabalho desenvolvido por Markowitz (1952; 1959), definiu que, na existência de um ativo livre de risco na economia, os investidores poderiam captar ou emprestar recursos à taxa livre de risco e as decisões de investimento ficariam limitadas à combinação deste ativo livre de risco e de uma carteira de ativos com risco, conforme indicado no Gráfico 4 pela linha $\bar{R}_{L R} g h$. Este trabalho recebeu o nome de Teorema da Separação e implica que só existe um único preço de equilíbrio para o risco determinado pelo mercado.

À medida que o coeficiente angular é maximizado, chega-se ao ponto em que esta reta tangencia a fronteira eficiente, ponto $g$, e esta carteira do ponto de tangência oferece o maior retorno e, consequentemente, a melhor combinação entre o ativo livre de risco e uma carteira de ativos com risco. Esta carteira foi chamada por Sharpe (1970, p. 69) de ótima combinação de ativos com risco. Segundo o autor, qualquer combinação da carteira ótima e do ativo livre de risco, representado pela reta $\bar{R}_{L R} g h$ no Gráfico 4, é preferível em relação a qualquer outra combinação de ativos. É possível observar, no Gráfico 4, que existem outras combinações entre o ativo livre de risco e as carteiras que se encontram na fronteira eficiente, como $\bar{R}_{L R} c$. Contudo, esta combinação não é eficiente, uma vez que é possível obter um retorno superior em outra combinação, para o mesmo nível de risco.

Assim, resta ao investidor apenas compor carteiras com o ativo livre de risco e com a carteira $g$ que melhor corresponde aos seus objetivos de risco e retorno, maximizando assim sua função utilidade. O ponto $g$ da reta $\bar{R}_{L R} g h$ indica que $100 \%$ do total de recursos disponíveis estão investidos na carteira $g$. Qualquer ponto à esquerda dele indica uma menor proporção dos recursos disponíveis investidos na carteira $g$ e maior proporção dos recursos investidos no ativo livre de risco $\bar{R}_{L R}$. Já os pontos à direita da carteira $g$ indicam que mais de 
$100 \%$ dos recursos estão investidos na carteira de ativos com risco, ou seja, recursos são captados à taxa livre de risco e investidos na carteira $g$.

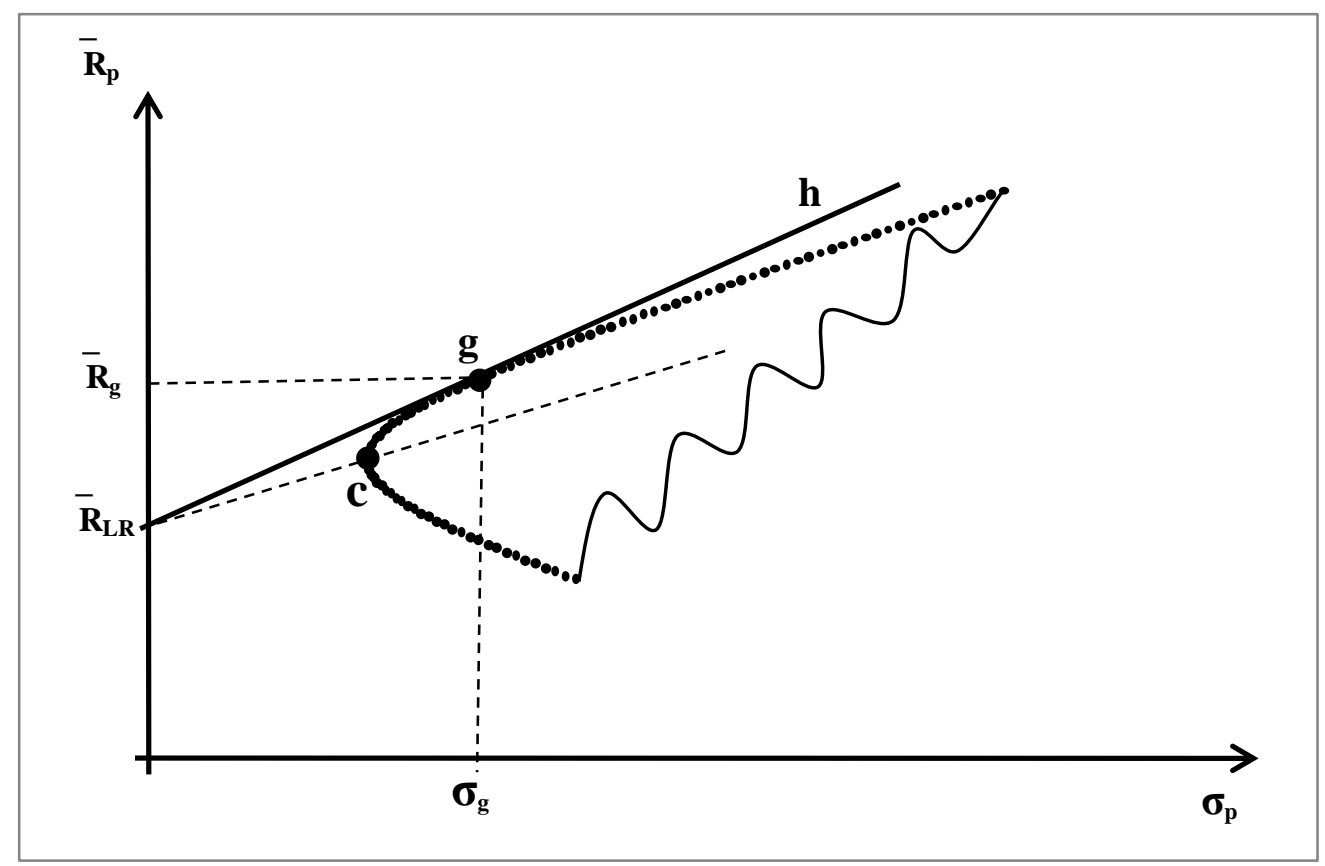

Gráfico 4 - Combinação do ativo livre de risco e da carteira de ativos com risco Fonte: Adaptado de Copeland, Weston e Shastri (2005, p. 133)

Copeland, Weston e Shastri (2005, p. 135) comentam o seguinte:

Cada investidor terá uma carteira que maximize sua função utilidade formada pela combinação do ativo livre de risco e da carteira (ou fundo) de ativos com risco que é determinada pela linha desenhada a partir da tangente do ativo livre de risco e da fronteira eficiente de ativos com risco.

Sendo (1-x) o montante aplicado no ativo livre de risco e $x$ o montante aplicado na carteira $g$, o retorno desta combinação é dado por:

$$
\bar{R}_{C}=(1-x) R_{L R}+x \bar{R}_{g}
$$

em que

$\bar{R}_{C}=$ retorno da combinação do ativo livre de risco com a carteira de ativos com risco;

$(1-x)$ e $x=$ pesos atribuídos ao ativo livre de risco e a carteira de ativos com risco, sendo que $(1-x)+x=1$

$R_{L R}$ e $\bar{R}_{g}=$ retorno do ativo livre de risco e da carteira de ativos com risco, respectivamente. 
O risco da combinação do ativo livre de risco com a carteira de ativos com risco é:

$$
\sigma_{C}=E\left\{(1-x)^{2} \sigma_{L R}^{2}+x^{2} \sigma_{g}^{2}+2(1-x) x \sigma_{L R} \sigma_{g} \rho_{L R, g}\right\}^{\frac{1}{2}}
$$

Como $\sigma_{L R}$ é zero, a correlação entre os retornos do ativo livre de risco e os retornos da carteira de ativos com risco é zero também. Portanto, o primeiro e o terceiro termos da equação são zero. O risco da combinação é:

$$
\sigma_{C}=E\left(x^{2} \sigma_{g}^{2}\right)^{\frac{1}{2}}=x \sigma_{g}
$$

A partir da equação 2.14, é possível observar uma relação de linearidade entre o risco da carteira $c$ e o risco da carteira $g$ : o risco da carteira $c$ depende somente do montante aplicado na carteira $g$. Assim, é possível desenvolver a seguinte relação:

$$
\text { (2.15) } x=\frac{\sigma_{C}}{\sigma_{g}}
$$

Substituindo na equação do retorno da carteira $c$ :

(2.16) $\overline{\boldsymbol{R}}_{C}=\left(1-\frac{\sigma_{C}}{\sigma_{g}}\right) \boldsymbol{R}_{L R}+\frac{\sigma_{C}}{\sigma_{g}} \overline{\boldsymbol{R}}_{g}=\boldsymbol{R}_{L R}+\left(\frac{\overline{\boldsymbol{R}}_{g}-\boldsymbol{R}_{L R}}{\sigma_{g}}\right) \sigma_{C}$

Todas as combinações de empréstimo e investimento entre o ativo livre de risco e a carteira $g$ se encontram na reta $\sigma_{L R} g h$, em que o intercepto é a taxa livre de risco e a inclinação é $\left(\frac{\overline{\mathrm{R}}_{\mathrm{g}}-\mathrm{R}_{\mathrm{LR}}}{\sigma_{\mathrm{g}}}\right)$.

De acordo com Sharpe (1970, p. 70), a combinação do ativo livre de risco e da carteira de ativos com risco simplifica muito o processo de constituição de uma carteira.

\subsubsection{Linha de Mercado de Capitais e o Capital Asset Pricing Theory (CAPM)}

Baseados no trabalho desenvolvido por Markowitz (1952, 1959), Sharpe (1963, 1964, 1970), Lintner (1965) e Mossin (1966) introduziram conceitos que deram início à Moderna 
Teoria de Carteiras, que considera o comportamento conjunto dos investidores na formação dos preços dos ativos na economia. Esta teoria possibilitou o desenvolvimento do modelo CAPM - Capital Asset Pricing Theory.

Os autores adicionaram premissas às anteriormente impostas por Markowitz, para formular o modelo:

1) os investidores possuem expectativas homogêneas em relação a retorno, risco e correlação entre os ativos, e a distribuição dos retornos dos ativos segue uma distribuição normal;

2) os investidores selecionam carteiras diversificadas a partir do retorno esperado, do desvio padrão e da correlação entre o retorno dos ativos;

3) os investidores apresentariam aversão ao risco, portanto preferem menos risco a mais risco;

4) entre duas carteiras com mesmo risco, os investidores sempre preferem a de maior retorno esperado;

5) todos os investidores tomam suas decisões no mesmo horizonte de tempo de um período;

6) o mercado está em equilíbrio e não há pressões para mudanças no preço de equilíbrio;

7) há uma taxa livre de risco na economia, igual para todos os investidores, com a qual podem emprestar e pedir empréstimo na quantia que desejarem;

8) as mesmas informações estão disponíveis a todos os investidores, sem custo adicional;

9) não há custo de transação, legislações, impostos, restrição à venda a descoberto, ou qualquer outra imperfeição de mercado.

A partir dessas premissas, todos os investidores teriam as mesmas estimativas a respeito do risco, do retorno e da correlação dos ativos. Portanto, teriam a mesma carteira de ativos com risco (LINTNER, 1965, p. 77) e escolheriam carteiras ao longo da reta $\bar{R}_{L R} M Z$, conforme apresentado no Gráfico 5. Segundo Sharpe (1964, p. 434; 1970, p. 83), investidores mais conservadores iriam preferir combinações entre os pontos $\bar{R}_{L R} M$, enquanto investidores menos conservadores iriam preferir combinações que envolvem uma proporção superior ao investimento inicial na carteira de mercado (combinações entre os pontos $M Z$ ). Contudo, todos os investidores estariam em algum ponto da reta $\bar{R}_{L R} M Z$ ou Linha de Mercado de Capitais (LMC).

Sharpe (1970, p. 82) afirmou que, em equilíbrio, a combinação ótima de ativos com risco deveria conter todos os ativos disponíveis na economia, incluindo ativos financeiros e de capital, sendo que o peso de cada ativo nessa carteira deveria ser proporcional à relação entre o valor desse ativo e o valor da carteira de mercado. Dadas estas condições, a carteira ótima, M, seria a Carteira de Mercado. 


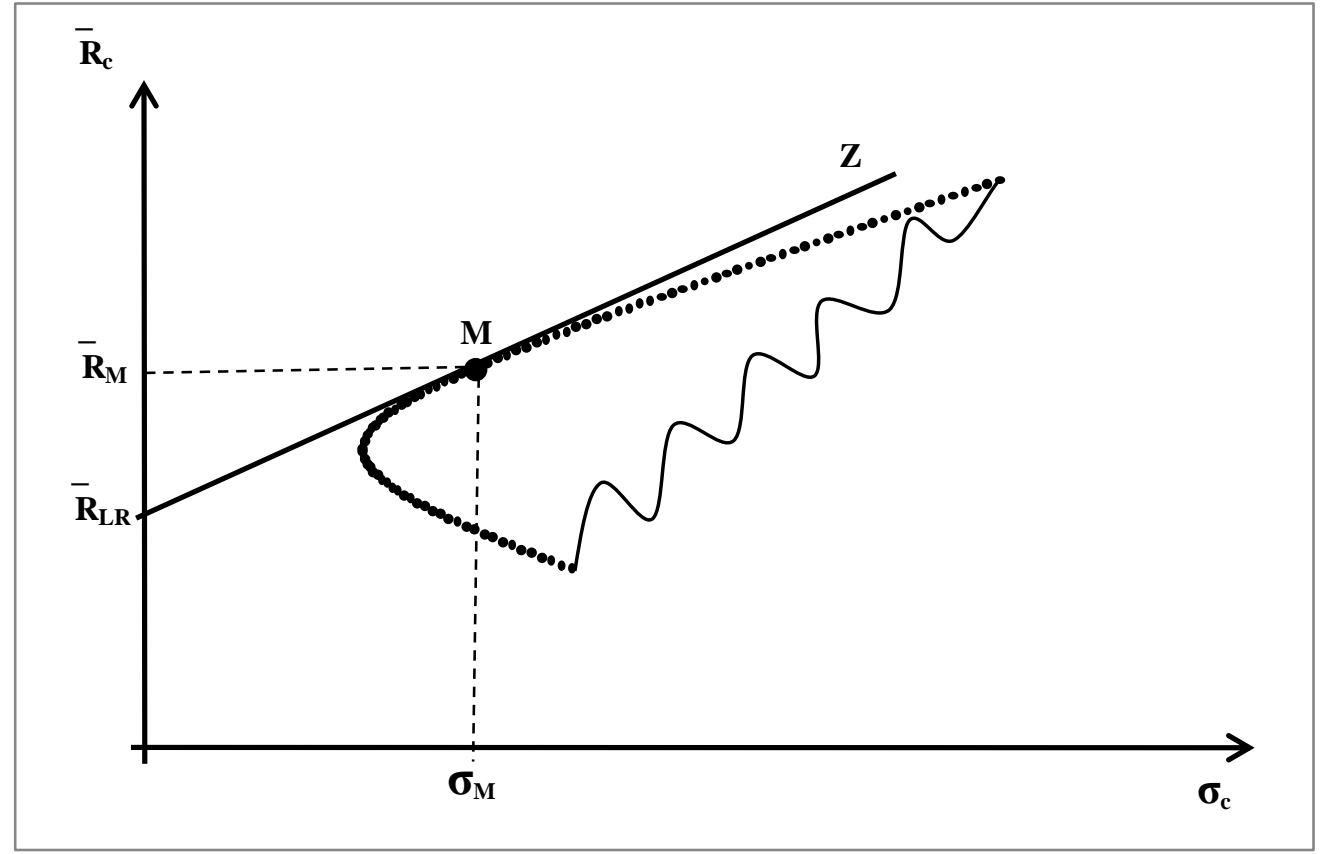

Gráfico 5 - Linha de Mercado de Capitais (LMC)

Fonte: Adaptado de Sharpe (1970, p. 83)

A partir da Linha de Mercado de Capitais, é estabelecida uma relação linear entre o risco e o retorno esperado para carteiras eficientes. A inclinação desta reta indica qual o retorno esperado para uma unidade adicional de risco (SHARPE, 1970, p. 84). A equação da Linha de Mercado de Capitais é a mesma apresentada por Tobin (1958):

(2.17) $\bar{R}_{L M C}=R_{L R}+\left(\frac{\bar{R}_{M}-R_{L R}}{\sigma_{M}}\right) \sigma_{L M C}$

em que $\left(\frac{\bar{R}_{M}-R_{L R}}{\sigma_{M}}\right)$ é a inclinação desta reta.

Conforme descrito anteriormente, a proporção de cada ativo na carteira de mercado é:

(2.18) $x_{i}=\frac{\text { Valor de mercado do ativo } i}{\text { Valor de mercado da carteira de mercado }}$

em que

$\mathrm{x}_{\mathrm{i}}=$ proporção do ativo $i$ na carteira de mercado em condições de equilíbrio.

A partir das premissas assumidas sobre o comportamento dos investidores, a 
composição de uma carteira $c$, formada por um ativo $i$ na proporção $x$ e a carteira de mercado na proporção (1-x), teria o seguinte retorno esperado e o seguinte desvio padrão:

(2.19) $E\left(\widetilde{\boldsymbol{R}}_{c}\right)=\overline{\boldsymbol{R}}_{c}=x \overline{\boldsymbol{R}}_{i}+(\mathbf{1}-\boldsymbol{x}) \overline{\boldsymbol{R}}_{M}$

(2.20) $\sigma_{C}=E\left\{x^{2} \sigma_{i}^{2}+(1-x)^{2} \sigma_{M}^{2}+2 x(1-x) \sigma_{i} \sigma_{M} \rho_{i, M}\right\}^{\frac{1}{2}}$

em que

$\bar{R}_{i}$ e $\bar{R}_{M}=$ retorno esperado do ativo $i$ e da carteira de mercado, respectivamente;

$\sigma_{i}^{2}$ e $\sigma_{M}^{2}=$ variância do retorno esperado do ativo $i$ e da carteira de mercado, respectivamente; $\rho_{i, M}=$ correlação entre o retorno do ativo $i$ e a carteira de mercado.

A partir da variação do peso $(x)$ atribuído a cada ativo na carteira formada, seria possível obter a relação desse ativo $i$ em relação à carteira de mercado, de acordo com o Gráfico 6. A partir da definição de Sharpe (1970) a respeito da carteira de mercado e em condição de equilíbrio, o ativo $i$ já está contido na carteira de mercado na proporção do seu valor de mercado, e o excesso de demanda por este ativo deve ser zero (COPELAND, WESTON e SHASTRI, 2005, p. 150).

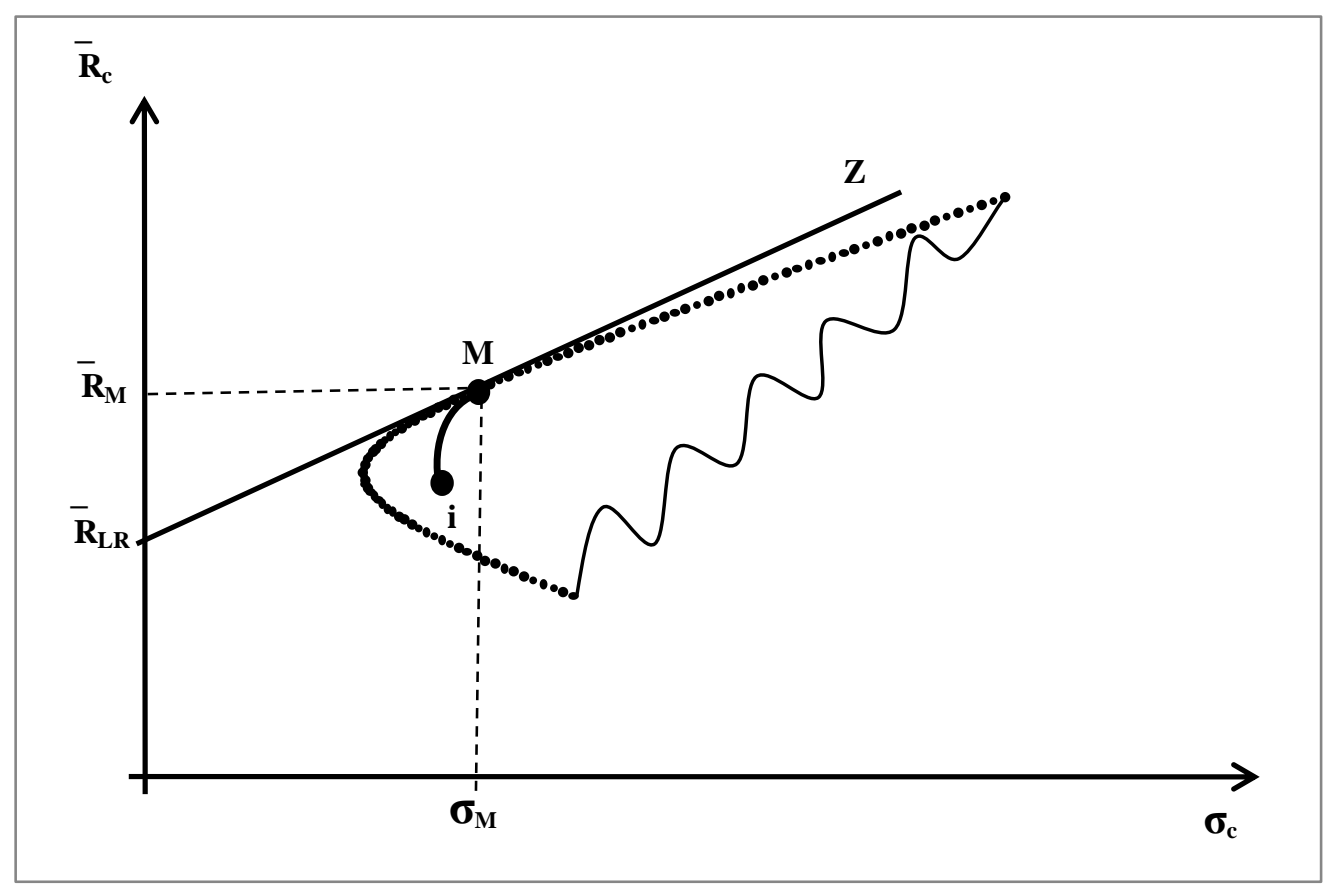

Gráfico 6 - Curva da Carteira $c$

Fonte: Adaptado de Sharpe (1970, p. 88) 
Assim, a variação da média e do desvio padrão da carteira $c$ em relação à $x$ quando $x=0$, ou seja, a primeira derivada deve ser:

$$
\begin{aligned}
& \left.\frac{\partial \bar{R}_{c}}{\partial x}\right|_{x=0}=\bar{R}_{i}-\bar{R}_{M} \\
& \frac{\partial \sigma_{c}}{\partial x} \mid=\frac{1}{2} * \frac{\left(2 x \sigma_{i}^{2}-2 \sigma_{M}^{2}+2 x \sigma_{M}^{2}+2 \sigma_{i M}-4 x \sigma_{i M}\right)}{\sqrt{x^{2} \sigma_{i}^{2}+(1-x)^{2} \sigma_{M}^{2}+2 x(1-x) \sigma_{i M}}}=\frac{x\left(\sigma_{i}^{2}+\sigma_{M}^{2}-2 \sigma_{i M}\right)+\sigma_{i M}-\sigma_{M}^{2}}{\sigma_{c}} \\
& \text { (2.21) }\left.\frac{\partial \sigma_{c}}{\partial x}\right|_{x=\mathbf{0}}=\frac{\sigma_{i M}-\sigma_{M}^{2}}{\sigma_{M}}
\end{aligned}
$$

Sendo que $\sigma_{c}=\sigma_{M}$ no ponto $\mathrm{M}$.

Assim, a inclinação da reta tangente à curva formada pela combinação do ativo $i$ e da carteira de mercado em equilíbrio seria:

$$
\left.\frac{\partial \bar{R}_{c} / \partial x}{\partial \sigma_{c} / \partial x}\right|_{x=0}=\frac{\bar{R}_{i}-\bar{R}_{M}}{\frac{\sigma_{i M}-\sigma_{M}^{2}}{\sigma_{M}}}=\frac{\left(\bar{R}_{i}-\bar{R}_{M}\right) \sigma_{M}}{\sigma_{i M}-\sigma_{M}^{2}}
$$

A condição de tangência indica que a variação da carteira composta pelo ativo $i$ e a carteira de mercado deve ser igual à variação da Linha de Mercado de Capitais no ponto M, ou seja:

$\frac{\left(\bar{R}_{i}-\bar{R}_{M}\right) \sigma_{M}}{\sigma_{i M}-\sigma_{M}^{2}}=\left(\frac{\bar{R}_{M}-R_{L R}}{\sigma_{M}}\right)$

Rearranjando a equação, tem-se:

(2.22) $\overline{\boldsymbol{R}}_{i}=\boldsymbol{R}_{L R}+\left(\overline{\boldsymbol{R}}_{M}-\boldsymbol{R}_{L R}\right) \frac{\sigma_{i M}}{\sigma_{M}^{2}}$

em que

$\bar{R}_{i}=$ retorno esperado do ativo $i$;

$R_{L R}=$ retorno do ativo livre de risco; 
$\bar{R}_{M}=$ retorno esperado do ativo da carteira de mercado;

$\sigma_{i M}=$ covariância entre o retorno do ativo $i$ e a carteira de mercado;

$\sigma_{M}^{2}=$ variância da carteira de mercado.

A equação 2.23 é a equação do Capital Asset Pricing Model ou CAPM, em que o retorno do ativo $i$ corresponde à taxa livre de risco adicionada do prêmio pelo risco da carteira de mercado, que multiplica a divisão da covariância entre os retornos do ativo $i$ e da carteira de mercado pela variância da carteira de mercado, também chamada de Beta $(\beta)$.

$O$ beta $(\beta)$ mede a sensibilidade dos retornos do ativo em relação às variações nos retornos da carteira de mercado, ou "mede a volatilidade da taxa de retorno do ativo em relação a mudanças na taxa de retorno do mercado" (SHARPE, 1970, p. 93).

De acordo com Sharpe (1964, p. 439), o beta é o componente do risco do ativo que pode ser chamado de risco sistemático. Seus preços são ajustados pela sensibilidade dos retornos do ativo a variações nos retornos da carteira de mercado, ou seja, ativos mais sensíveis a variações positivas de mercado terão retornos esperados maiores. Dessa forma, o beta é a parte do risco do ativo que não pode ser diversificada quando o ativo é adicionado na carteira.

Cada ativo tem uma relação linear em função do ativo livre de risco e do prêmio pelo risco, ou seja, cada ativo apresenta um beta e, consequentemente, uma Linha de Mercado de Títulos, como indicado no Gráfico 7.

Sharpe (1964, p. 441) concluiu que a diversificação era capaz de minimizar todos os riscos de um ativo menos o risco advindo da atividade econômica, o chamado risco sistêmico, que se mantinha mesmo em combinações eficientes de ativos. E como todos os demais riscos poderiam ser evitados através da diversificação, não haveria porque remunerar um risco que poderia ser evitado. Assim, apenas a sensibilidade dos retornos de determinado ativo em relação à atividade econômica seria considerada na avaliação de risco deste ativo. 


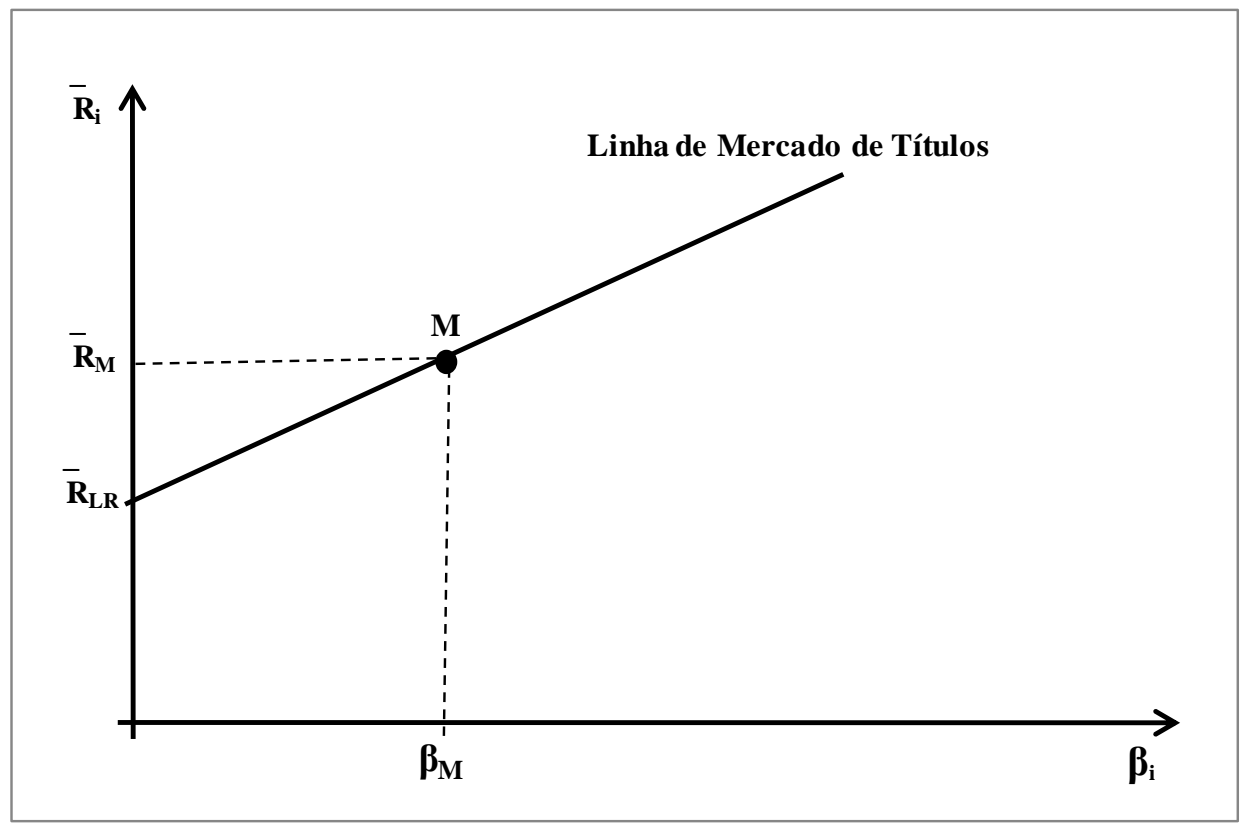

Gráfico 7 - Linha de Mercado de Títulos Fonte: Adaptado de Sharpe (1964, p. 440)

A partir de sua formulação, diversos autores passaram a utilizar o modelo CAPM na análise dos retornos esperados dos ativos e seus trabalhos são descritos a seguir.

\subsubsection{Principais Estudos Sobre CAPM}

Douglas (1969) foi um dos primeiros autores a analisar o modelo CAPM empiricamente. Utilizando o período de 1947 a 1963, o autor testou se outros fatores de risco, além do beta, contribuiriam para a explicação dos retornos das ações. A partir dos retornos médios anuais e trimestrais e utilizando regressão múltipla, analisou se o desvio padrão e a variância dos retornos das ações eram capazes de explicar os retornos dos ativos. Os resultados levaram à rejeição da hipótese de que os investidores formavam carteiras eficientes e que só pagavam prêmios por risco que contribuíssem para o risco da carteira.

Friend e Blume (1970) analisaram a relação risco-retorno proposta pela teoria de mercado de capitais. Montaram 200 carteiras de forma aleatória, a partir das 788 ações listadas na NYSE (New York Stock Exchange - Bolsa de Nova York), no período de janeiro de 1960 a junho de 1968. A partir de então testaram se as medidas de desempenho - derivadas do modelo CAPM - dessas carteiras poderiam ser explicadas pela medida de risco correspondente (o beta ou o desvio padrão). Os resultados encontrados indicaram que as medidas de desempenho pareciam produzir estimativas enviesadas, sendo a magnitude do viés 
relacionada à medida de risco utilizada (FRIEND e BLUME, 1970, p. 574).

Black et al. (1972) testaram a validade da linha de mercado de títulos utilizando ações listadas na NYSE entre 1926 e 1965. Os autores agruparam as empresas em carteiras, com o objetivo de diminuir os erros apresentados por pesquisas anteriores. Assim, calcularam os betas dos ativos com os primeiros cinco anos de dados e estes betas foram, então, ordenados e divididos em dez decis iguais. Cada decil correspondia a uma carteira.

Para testar o CAPM, Black et al. (1972) utilizaram, a princípio, regressões em série de tempo utilizando todos os retornos mensais disponíveis para as dez carteiras. As carteiras de betas altos apresentaram interceptos negativos, enquanto as carteiras de betas baixos apresentaram interceptos altos e positivos.

Para testar o intercepto (taxa livre de risco) e o prêmio pelo risco de mercado, os autores primeiramente calcularam o beta a partir de regressão em série de tempo e, com estes betas, calcularam o intercepto $\left(\gamma_{0}\right)$ e o prêmio pelo risco de mercado $\left(\gamma_{1}\right)$. Os resultados indicaram que a relação entre o retorno da carteira e o beta era linear, e que o modelo CAPM era capaz de explicar os retornos dos ativos.

Fama e Macbeth (1973) utilizaram retornos mensais das ações da NYSE no período de janeiro de 1926 a junho de 1968 para testar as seguintes hipóteses: a relação risco-retorno proposta pelo modelo CAPM é linear $\left(\gamma_{2 t}=0\right)$, o beta é uma medida completa de risco e capta todo o efeito dos retornos dos ativos $\left(\gamma_{3 t}=0\right)$, maiores riscos estão associados a maiores retornos $\left(\gamma_{1 \mathrm{t}}>0\right)$.

Para analisar as hipóteses, os autores agruparam os ativos em carteiras a partir dos betas ordenados, com o objetivo de diminuir o viés do beta estimado para o teste. Assim, os betas das ações foram calculados utilizando os primeiros quatro anos do período e ordenados, formando 20 carteiras.

Os autores utilizaram metodologia preditiva em duas etapas, para testar as hipóteses: na primeira etapa, calcularam-se os betas das carteiras com regressão em série de tempo e, na segunda, estimaram-se o intercepto e os coeficientes, com regressões em corte transversal.

Assim, na primeira etapa, utilizando os retornos mensais, calcularam-se os betas das ações em relação à carteira de mercado por meio de regressão em série de tempo para os cinco anos subsequentes ao período de formação das carteiras. A partir da média simples dos betas das ações pertencentes à carteira, obtiveram-se os betas de cada carteira. Os betas das ações foram recalculados anualmente, incorporando o respectivo ano, e os betas das carteiras foram então ajustados.

Na segunda etapa, as regressões em corte transversal foram calculadas para cada mês 
dos quatro anos seguintes aos da primeira etapa.

A equação utilizada consistiu nos retornos das carteiras calculados pela média simples dos retornos dos ativos como variável dependente e as variáveis beta da carteira de mercado, beta da carteira de mercado ao quadrado e desvio padrão médio dos resíduos da equação utilizada para gerar os betas na primeira etapa como variáveis independentes. Com isso, foi possível analisar se os coeficientes médios resultantes destas regressões eram diferentes de zero (significantes) e se eram próximos à variável de mercado (para o prêmio pelo risco de mercado e para a taxa livre de risco). A carteira de mercado correspondeu à média ponderada simples de todas as ações utilizadas na análise.

Os resultados obtidos por Fama e Macbeth (1973) indicaram que, dado que a proxy da carteira de mercado era eficiente, não foi possível rejeitar a hipótese de que os retornos médios das ações da NYSE refletiam a aversão ao risco do investidor em montar carteiras eficientes (FAMA e MACBETH, 1973, p. 633). Não foi possível rejeitar as hipóteses de que a relação entre risco e retorno era linear e positiva e de que nenhuma outra medida de risco, além da carteira de mercado, afetou sistematicamente o retorno médio dos ativos. Apesar de serem identificados efeitos não lineares entre os períodos, seus efeitos foram, na média, nulos e imprevisíveis. Além disso, os coeficientes da regressão eram consistentes com a hipótese de mercados eficientes, ou seja, um mercado em que os preços refletem completamente a informação disponível.

Blume e Friend (1973) também formaram carteiras para analisar empiricamente a validade da linha de mercado de capitais. Foram estimados os betas de cada ação listada na NYSE a partir dos retornos mensais de janeiro de 1950 a dezembro de 1954. Estas ações foram alocadas em doze carteiras com aproximadamente oitenta ações cada.

A partir das carteiras montadas, calcularam os retornos mensais das doze carteiras para o período seguinte, de janeiro de 1955 a dezembro de 1959, de duas formas: com pesos iguais para todos os ativos e ponderando-os pelo seu valor de mercado de dezembro de $t$ - 1 . Os retornos das carteiras foram regredidos em relação ao índice de mercado para gerar os betas das carteiras. Após a estimativa dos betas, o retorno das carteiras foi regredido em relação ao beta na forma linear e quadrática para o mesmo período (janeiro de 1955 a dezembro de 1959). Este procedimento foi repetido para os períodos de janeiro de 1960 a dezembro de 1964 e janeiro de 1965 a dezembro de 1968.

Os resultados obtidos por Blume e Friend (1973, p. 26) confirmaram a relação de linearidade entre o retorno dos ativos e o retorno da carteira de mercado, porém lançaram dúvidas sobre a validade da teoria de precificação de ativos, uma vez que os autores 
encontraram evidências de que não era possível prever o retorno dos ativos em virtude da impossibilidade de venda a descoberto dos ativos, uma das premissas da teoria.

Roll (1977) questionou os trabalhos e os resultados obtidos por alguns artigos que testavam o modelo CAPM, como os artigos de Black et al. (1972) e Fama e Macbeth (1973). De acordo com o autor, estes trabalhos testaram simultaneamente duas variáveis: a carteira de mercado e a relação de linearidade entre o retorno da carteira de mercado e o retorno dos ativos, sendo que a linearidade dependia da eficiência da carteira de mercado, e esta relação comprometia a independência dos testes.

$\mathrm{O}$ autor reforçou que o modelo CAPM somente poderia ser testado se a exata composição da carteira de mercado fosse conhecida, ou seja, se todos os ativos na economia fossem conhecidos e pudessem ser incluídos na amostra. A utilização de uma carteira de mercado aproximada impõe, segundo Roll (1977), duas dificuldades: a carteira aproximada poderia ser eficiente, mesmo não sendo a carteira de mercado, e a carteira aproximada provavelmente apresentaria alta correlação com a carteira de mercado, o que levantaria dúvidas a respeito da relevância da carteira exata de mercado.

O trabalho de Roll (1977) trouxe muitos questionamentos a respeito dos testes realizados até então, motivando diversos outros autores a analisar fatores que invalidassem o modelo CAPM e questionassem o beta na explicação dos retornos.

No Brasil, alguns trabalhos também testaram o modelo CAPM. Estes trabalhos são detalhados no próximo tópico.

\subsubsection{Principais Estudos Sobre CAPM no Brasil}

Lintz e Renyi (1998) compararam o modelo de Sharpe e o de Markowitz para o cálculo do risco da carteira e analisaram se os erros de análise do modelo de Sharpe eram significantes para carteiras compostas pelas ações mais líquidas da BOVESPA no período de setembro de 1996 a agosto de 1997.

Os autores levantaram a questão das possíveis distorções na mensuração de risco a partir do modelo de Sharpe, em função de duas simplificações: 1) o modelo de Sharpe calcula as variâncias e covariâncias dos ativos em relação à carteira de mercado, que não é conhecida, conforme trabalho de Roll (1977) e 2) o modelo de Sharpe considera que a covariância residual dos retornos dos ativos é zero, o que influenciaria as medidas de variância e covariância utilizadas para cálculo do risco da carteira. 
Para o teste, foram criadas combinações aleatórias dos ativos, para diversos tamanhos (de 1 a 50 ativos), gerando, assim, um total de 50.000 simulações. Os resultados indicaram que o risco total da carteira tende a um patamar definido pelo risco não diversificável em ambas as metodologias, à medida que o número de ativos aumenta na carteira. Este patamar foi atingido com 13 ativos para o modelo de Markowitz e com 11 para o modelo de Sharpe.

No teste de hipótese de igualdade de variância, encontraram-se evidências de que carteiras formadas por mais de 15 ativos apresentam variâncias estatisticamente diferentes. De acordo com Lintz e Renyi (1998), o percentual de erro da análise chega a 14\% entre os dois métodos para carteiras formadas por 50 ativos.

Já o trabalho de Araújo, Fajardo e Tavani (2006) analisou o modelo CAPM, utilizando como proxy da carteira de mercado a metodologia proposta por Hou (2002) e comparou seus resultados se utilizado o Ibovespa como proxy da carteira de mercado para o período de 1991 a 2002. A metodologia de Hou propõe a construção de uma carteira agregada que pague o Produto Interno Bruto (PIB) como dividendo.

Os autores encontraram evidências de que o retorno do Ibovespa apresentou melhor desempenho ao explicar os retornos das carteiras setoriais do que a metodologia de Hou, especialmente para a amostra inteira. Assim, concluíram que o Ibovespa é uma proxy mais razoável para o mercado brasileiro, apesar da superioridade conceitual e dos bons resultados encontrados por Hou no mercado norte-americano.

Bergmann (2006) testou a validade do modelo CAPM a partir de Método de Momento Generalizado no período de 1995 a 2004. O autor justificou a utilização desta metodologia para teste do modelo em virtude dos retornos das ações individuais e da carteira de mercado (Ibovespa) não serem independentes e identicamente distribuídos (IID) e não seguirem uma distribuição normal.

Para testar o modelo CAPM, o autor montou carteiras setoriais de Siderurgia, Bancos, Papel e Celulose, Elétrico, Petroquímico e Telecomunicações. Estes setores agrupavam as ações de maior liquidez diária na BOVESPA. Como proxy da carteira de mercado foi utilizado o Ibovespa e como ativo livre de risco foram utilizadas as taxas mensais da SELIC e CDI.

Os resultados obtidos por Bergmann (2006) indicaram uma maior eficiência, em termos de risco-retorno, do modelo CAPM não-condicional zero-beta em relação ao CAPM. Além disso, o autor ressaltou que não houve diferença significativa nos resultados do modelo CAPM ao se utilizar a SELIC ou o CDI.

Mais recentemente, Bellizia (2009) comparou quatro metodologias diferentes de 
cálculo do CAPM para o mercado brasileiro: o CAPM Local, o CAPM Global, o Modelo Goldman e o modelo proposto por Solnik (2000) a partir de metodologia preditiva de Fama e Macbeth (1973), no período de janeiro de 1998 a dezembro de 2007.

A autora encontrou evidências de que existiam outros fatores não especificados no modelo CAPM que possuíam poder explanatório sobre o prêmio pelo risco das carteiras e que a relação entre o retorno das carteiras e o retorno da carteira de mercado era linear e positiva. De acordo com os resultados encontrados, ao excluir os interceptos das regressões, que representavam os fatores não especificados, os betas dos modelos foram capazes de explicar quase a totalidade dos prêmios pelo risco das careiras.

\subsubsection{Principais Limitações da Aplicação do CAPM no Brasil}

As principais limitações da aplicação do CAPM no Brasil são:

- conforme anteriormente discutido, o modelo CAPM é um modelo de equilíbrio que tem como base uma série de premissas, como ausência de custo de transação e impostos. No entanto, o mercado brasileiro possui algumas características, como, por exemplo, a alta concentração do volume negociado em poucas ações, que adicionam “imperfeições” ao preço. Neste exemplo, os investidores iriam esperar um prêmio por liquidez como consequência do baixo volume negociado em alguns ativos. Sabe-se que, na prática, estes fatores podem influenciar o processo de tomada de decisão dos agentes;

- a alta concentração do mercado acionário brasileiro e a pouca liquidez observada em algumas ações aumentam a dificuldade de construir uma carteira que represente a economia brasileira, conforme proposto por Sharpe (1964);

- no modelo CAPM, assume-se que a relação entre o retorno do ativo e a carteira de mercado é linear, sendo esta a premissa básica do modelo. Porém, como foi observado por Mussa, Rogers e Securato (2009), há evidências de que esta relação não era linear.

Vale ressaltar que, apesar destas limitações, o modelo é válido como uma ferramenta de análise do retorno esperado de um investimento e auxilia no processo de tomada de decisão dos agentes. 


\subsection{Hipótese de Eficiência de Mercado}

O conceito de eficiência do mercado de capitais tem sido amplamente discutido na literatura acadêmica desde 1960, de acordo com Elton e Gruber (1995, p. 406), e é um tema relevante, uma vez que a Hipótese de Eficiência de Mercado é uma das premissas do modelo CAPM.

\subsubsection{Teoria de Mercados Eficientes}

De acordo com Fama (1970, p. 383), "Um mercado em que os preços 'refletem completamente' a informação disponível é chamado de 'eficiente"”.

De acordo com Rubinstein (2006), Working (1958) foi o primeiro a comentar a interpretação do que ficou conhecido como caminho aleatório e culminou no conceito de eficiência de mercado. Fama (1970) comentou sobre o trabalho de Roberts (1959), que analisou o modelo aleatório e discutiu sua interpretação.

Elton e Gruber (1995, p. 406) comentaram que uma condição necessária para que os ativos sejam negociados até que reflitam toda a informação disponível é que o custo marginal da informação seja menor do que seu benefício marginal.

Copeland, Weston e Shastri (2005, p. 354) fizeram uma comparação interessante entre o mercado perfeito, hipótese considerada no modelo CAPM, e a eficiência de mercado. De acordo com os autores, o mercado perfeito possui pressuposições muito mais rígidas que as do mercado eficiente. O mercado eficiente permite fricções de mercado, taxas de corretagem, informação com custo e os ativos não são divisíveis. Além disso, considera a competição imperfeita, o monopólio e a alocação ineficiente de recursos, desde que todas estas informações estejam refletidas no preço dos ativos de forma instantânea.

Fama (1970) inicialmente dividiu a HEM em três categorias que lidavam com tipos diferentes de informação: Forma Fraca diz respeito a testes que analisam se todas as informações disponíveis nos preços históricos estão refletidas nos preços atuais, Forma Semiforte pressupõe que toda a informação pública disponível estará incorporada nos preços e Forma Forte pressupõe que todas as informações, incluindo as não públicas, serão incorporadas aos preços.

Em sua mais recente revisão da literatura sobre eficiência de mercado, Fama (1991) sugeriu alterar a definição da primeira categoria, Forma Fraca, para Teste de Previsibilidade dos Retornos, que considera a previsibilidade dos retornos a partir de outras variáveis, como 
dividend yield e taxa de juros. Esta categoria passou a incorporar a análise dos modelos de avaliação de preço e as anomalias, uma vez que não é possível separar o conceito de eficiência de mercado e o modelo de equilíbrio de preço. Para as demais categorias, o autor propôs a seguinte alteração: de Forma Semiforte para Teste de Evento, que analisa como os preços se ajustam à divulgação pública de informação; e de Forma Forte para Teste de Informação Privada, em que se testa se determinados investidores possuem informações não divulgadas publicamente no mercado.

Em sua primeira análise, Fama (1970) concluiu que o mercado era eficiente na forma semiforte. A análise de trabalhos mais recentes indicou que o mercado não era eficiente a partir dos Testes de Previsibilidade dos Retornos, e em estudo mais recente o autor ressaltou que estes testes, conforme propostos pelas novas categorias, possuem um problema de hipótese conjunta: se o mercado é ineficiente ou o modelo não é capaz de explicar o retorno dos ativos ao longo do tempo (FAMA, 1991, p. 1577).

Elton e Gruber (1995, p. 407) comentaram que muitos testes de eficiência de mercado estavam, na verdade, analisando a velocidade com que a informação era incorporada ao preço dos ativos. Segundo os autores, "a hipótese de eficiência de mercado não nega a utilidade da informação. (...) A hipótese de eficiência de mercado está preocupada com as condições em que um investidor obtém excesso de retorno neste ativo" (ELTON e GRUBER, 1995, p. 407).

Fama (1970, p. 384) especificou com mais detalhes o processo de formação de preços, de forma que a hipótese de refletir completamente a informação disponível seja empiricamente testável. De acordo com o autor, havia três modelos que explicavam o comportamento dos preços ao longo do tempo. O primeiro definia o processo de formação do preço como sendo um jogo justo (fair game): não há como utilizar a informação disponível no momento $t$ para ganhar um retorno acima do normal.

$$
E\left(\widetilde{p}_{j, t+1} \mid \phi_{t}\right)=\left[1+E\left(\tilde{r}_{j, t+1} \mid \phi_{t}\right)\right] p_{j t}
$$

Ou seja, o preço esperado em $t+1$ do ativo $j$, dada a informação $\phi$ no momento $t$, é igual ao preço no momento $t$ somado à multiplicação do preço no momento $t$ pelo retorno esperado no ativo em um período, dada a nova informação.

Elton e Gruber (1995) explicam que, baseado na nova informação, o investidor fará uma estimativa de retorno para o ativo entre o período $t$ e $t+1$ e comparará esta estimativa com o retorno do modelo de equilíbrio. A comparação do valor estimado com o valor do 
modelo de equilíbrio não deve conter informação sobre o retorno futuro do ativo. Os autores ainda ressaltam que "se o conjunto de informações disponíveis para o investidor não está incorporado no preço, o modelo fair game não é válido para aquele conjunto de informações" (ELTON e GRUBER, 1995, p. 409).

Fama (1970) comentou que o modelo fair game somente define que o equilíbrio de mercado pode ser determinado a partir dos retornos dos ativos, mas não especificou o processo que gera tais retornos.

O segundo modelo é chamado submartingale. Nele o preço estimado a partir da informação $\phi$ no momento $t$ é igual ou maior que o preço corrente (FAMA, 1970, p. 386). De acordo com Copeland, Weston e Shastri (2005, p. 366), o submartingale é um fair game em que o preço de amanhã deve ser maior do que o preço de hoje, ou o retorno deve ser maior do que zero.

(2.24) $\boldsymbol{E}\left(\tilde{\boldsymbol{r}}_{\boldsymbol{j}, \boldsymbol{t}+\mathbf{1}} \mid \phi_{t}\right) \geq \mathbf{0}$

O terceiro modelo era o de caminho aleatório (random walk), que diz que a variação de preços deve ser independente e identicamente distribuída (FAMA, 1970, 386). O modelo define que as distribuições de probabilidade condicional e marginal de uma variável independente e aleatória são idênticas.

(2.25) $\boldsymbol{f}\left(\tilde{\boldsymbol{r}}_{j, t+1} \mid \phi_{t}\right)=\boldsymbol{f}\left(\tilde{\boldsymbol{r}}_{j, t+1}\right)$

Assim, a distribuição de retornos é independente da informação disponível em $t$.

Para os Testes de Previsibilidade dos Retornos, o conjunto de informações era definido pelo histórico de comportamento dos preços dos ativos, pelas características das empresas, pelas características do mercado e pela época do ano, entre outros. Nos Testes de Evento, o conjunto de informações é definido pelos anúncios de informações. Já nos Testes de Informação Privada, o conjunto de informações é qualquer informação, pública ou não, que está à disposição de um grupo seleto de investidores (ELTON e GRUBER, 1995, p. 409). 


\subsubsection{Anomalia de Mercado}

Esta seção apresenta alguns trabalhos empíricos de maior relevância que testaram o modelo CAPM e identificaram algumas anomalias. Há diversas anomalias identificadas, originadas de diferentes conceitos. No entanto, serão discutidas aquelas que motivaram o desenvolvimento do modelo de três fatores e o modelo de quatro fatores, foco deste trabalho.

Sobre o significado do conceito de anomalia de mercado, duas linhas principais definem anomalia em finanças, de acordo com Fama e French (2004, p. 37). A primeira linha, dos comportamentalistas, como DeBondt e Thaler (1987), Lakonishok, Shleifer e Vishny (1994), sugere que montar uma carteira de ativos a partir de padrões observados, como carteiras baseadas no índice de valor contábil em relação ao valor de mercado (book-tomarket), pode expor o investidor a reações de mercado, podendo gerar retornos anormais.

A segunda entende que anomalias são comportamentos que não são explicados pelo modelo de equilíbrio de preços CAPM (FAMA e FRENCH, 1996) e, assim, é necessário um modelo de precificação de ativos mais completo, com pressuposições menos rígidas.

O tema passou a ser debatido a partir de 1970, quando alguns autores apontaram para evidências de que a variação nos retornos esperados não estava relacionada à carteira de mercado, segundo Fama e French (2004, p. 35). As anomalias analisadas não possuiam base teórica, somente eram observadas. Diversos autores, como Banz (1981), Reinganum (1981a), Friend e Westerfield (1981), entre outros, comentaram que estes efeitos tanto poderiam decorrer de uma ineficiência de mercado como de uma evidência de má especificação do modelo.

\subsubsection{Efeito Tamanho, Índices E/P e B/M}

Blume e Husic (1973) foram os primeiros autores que evidenciaram o que mais tarde seria conhecido como efeito tamanho, de acordo com Rubinstein (2006, p. 230). Os autores montaram vinte e cinco carteiras a partir da interseção dos quintis do beta de mercado calculado com 60 meses e dos quintis do preço do fim do mês de cada ação, e os retornos destas carteiras foram então regredidos em relação aos preços do fim do mês e a carteira de mercado. Os resultados mostraram que os retornos das carteiras eram positivamente relacionados com a carteira de mercado e negativamente relacionados com o preço do fim do mês, o que sugeria um efeito preço: ações de preços baixos tendiam a ter retornos superiores 
em relação a ações de preços altos.

Em outro estudo, Banz (1981) especificou e testou o efeito tamanho da forma como é conhecido hoje. O autor examinou a relação entre valor de mercado total e o retorno das ações cotadas na NYSE no período de 1926 a 1975, a partir de 25 carteiras formadas da interseção dos quintis do valor de mercado das empresas ordenados e dos quintis do beta da carteira de mercado ordenados, calculados com retornos de cinco anos. Os resultados indicaram que empresas menores mostraram, na média, retornos ajustados a risco maiores que os apresentados pelas empresas maiores. $\mathrm{O}$ autor comentou, ainda, que não ficava claro o porquê desse efeito, sendo necessária cautela na sua interpretação.

Basu (1977) analisou a eficiência do mercado de capitais em relação aos índices de preço/lucro (do inglês price-earnings - P/E). De acordo com o autor, o índice poderia ser utilizado como indicador de desempenho futuro da empresa, ou seja, empresas com índice baixo tenderiam a ter desempenho superior a empresas com alto índice de P/E, possibilitando ganho acima da média. A partir do argumento apresentado, o autor analisou empiricamente se o desempenho das ações ordinárias estava relacionado com o índice de P/E.

Para isso, Basu (1977) ordenou e formou cinco carteiras com estes índices calculados com os dados de dezembro disponíveis no período de 1957 a 1971. Os resultados obtidos pelo autor indicaram que as carteiras com baixo índice P/E pareciam ter, na média, retornos absolutos e ajustados ao risco superiores aos apresentados por carteiras de alto índice P/E, o que indicava a violação das seguintes hipóteses: 1) o modelo de precificação de ativos possui validade descritiva e 2) o comportamento dos preços é consistente com a hipótese de eficiência de mercado. Assim, os resultados indicaram que a informação contida no índice P/E não estava completamente refletida no preço, o que resultava, segundo o autor, em uma ineficiência de mercado.

Reinganum (1981a) analisou o modelo CAPM em relação ao valor de mercado da empresa e ao índice E/P. O autor primeiro realizou a análise do modelo CAPM em relação a carteiras formadas a partir do índice E/P, utilizando dados trimestrais para o período de 1975 a 1977. Em seguida, analisou o modelo CAPM em relação ao índice E/P calculado com dados anuais para o período de 1962 a 1975. A terceira análise envolveu a relação entre o índice E/P e o valor de mercado da empresa, conforme analisado por Banz (1981).

Reinganum (1981a) encontrou evidências de que carteiras com alto índice E/P possuíam desempenho superior às carteiras com baixo índice E/P, mesmo após ajustá-las ao risco, o que corroborava os resultados encontrados por Basu (1977). De acordo com o autor, essa anomalia não era gerada por uma ineficiência de mercado, uma vez que persistiu por pelo 
menos dois anos. $\mathrm{Na}$ análise conjunta do índice $\mathrm{E} / \mathrm{P}$ e do efeito tamanho, empresas pequenas apresentaram retornos superiores às empresas grandes com beta equivalente para qualquer nível do índice E/P. Contudo, quando a amostra foi analisada por tamanho de empresa, não se observou o efeito E/P. Assim, o autor comentou que as duas anomalias pareciam estar relacionadas a um mesmo conjunto de fatores, os quais, por sua vez, pareciam estar mais relacionados ao tamanho da empresa do que ao índice E/P.

Em estudo posterior, Reinganum (1981b) analisou empiricamente se ativos com diferentes betas da carteira de mercado apresentavam retornos médios diferentes. A hipótese levantada pelo autor era a de que variações nos betas deveriam ser acompanhadas de variações nos retornos observados das ações. O autor analisou empresas listadas na NYSE e AMEX no período de 1964 a 1979 e utilizou três parâmetros diferentes como proxy da carteira de mercado: um índice formado por todas as ações listadas na base CRSP (The Center for Research in Security Prices), o índice proposto por Scholes e Williams (1977) e um índice de todas as ações listadas na NYSE e AMEX ponderadas pelo valor de mercado, conforme proposto por Dimson (1979).

O autor encontrou evidência de que não era possível relacionar o retorno das carteiras com o beta, independentemente da proxy utilizada para a carteira de mercado, uma vez que o retorno das carteiras com beta baixo foi, em muitos casos, superior ao retorno das carteiras com beta alto. De acordo com Reinganum (1981b), carteiras com betas diferentes possuíam retornos médios estatisticamente semelhantes. "Além disso, os betas estimados com base em índices de mercado de qualidade não parecem medir confiavelmente um 'risco que é apreçado no mercado"” (REINGANUM, 1981b, p. 439).

Friend e Westerfield (1981) ponderaram que a maior parte das análises realizadas utilizam como proxy da carteira de mercado um índice composto somente por ações, o que poderia trazer viés para a análise. Assim, tais autores propõem a utilização de um índice composto por ações, debêntures e títulos do governo americano para o período de 1952 a 1976. Os autores analisaram o excesso de retorno mensal das ações individuais e de carteiras em relação à carteira de mercado e ao desvio padrão dos retornos destas ações e das carteiras.

Os resultados indicaram que a sensibilidade dos retornos em relação à carteira de mercado não era nem mais nem menos significante do que o desvio padrão dos retornos, o que indicava, segundo Friend e Westerfield (1981), que outros fatores não sistêmicos seriam tão relevantes quanto a carteira de mercado.

Assim como Friend e Westerfield (1981), Lakonishok e Shapiro (1986) analisaram a relação entre os retornos das ações, o beta de mercado e o desvio padrão dos retornos dos 
ativos, adicionando o efeito tamanho na análise para o período de 1954 a 1981. Os autores testaram se o efeito tamanho poderia ser originado dos custos de transação, o que limitaria a diversificação do investidor, indicando que o modelo CAPM está mal especificado, uma vez que tem como premissa a completa diversificação. Mais especificamente, os autores testaram se a variância dos retornos afetava mais os retornos das empresas pequenas do que os retornos das empresas grandes, uma vez que estas não eram muito negociadas.

A partir da mesma metodologia de teste preditivo utilizada por Fama e Macbeth (1973), Lakonishok e Shapiro (1986) encontraram evidência de que a variável tamanho parecia ser a única significante, os demais coeficientes não eram estatisticamente significantes e eram muito sensíveis ao procedimento de formação das carteiras, ao tipo de regressão e aos dados utilizados. Assim, os autores rejeitaram a hipótese de que a variância dos retornos era mais importante para prever o retorno de ações de empresas pequenas do que para ações de empresas grandes. Além disso, os testes indicaram a rejeição do beta da carteira de mercado e da variância dos retornos.

Estendendo os trabalhos anteriormente realizados, Fama e French (1992) analisaram as variações dos retornos das ações em relação ao seguinte conjunto de variáveis: carteira de mercado, tamanho, índice lucro/preço (L/P ou E/P), alavancagem, índice B/M (Book-toMarket ou valor contábil/valor de mercado). Os autores utilizaram os dados das empresas não financeiras listadas na NYSE, AMEX e NASDAQ (National Association of Securities Dealers Automated Quotations) no período de 1963 a 1990.

Fama e French (1992) observaram, assim como Reinganum (1981b), Friend e Westerfield (1981) e Lakonishok e Shapiro (1986), que o beta de mercado era capaz de explicar muito pouco as variações dos retornos dos ativos no período. Contudo, observaram que, quando as variáveis tamanho, alavancagem, índice $\mathrm{E} / \mathrm{P}$, índice $\mathrm{B} / \mathrm{M}$ eram utilizadas de forma isolada para explicar o retorno dos ativos, os resultados eram favoráveis. Além disso, quando estas variáveis foram analisadas em conjunto, as variáveis tamanho e índice B/M pareciam absorver o efeito das variáveis alavancagem e índice E/P no período. Assim, as variáveis beta, tamanho e índice B/M pareciam explicar de forma satisfatória os retornos médios das ações no período.

Após os resultados obtidos neste estudo, Fama e French (1992) passaram a questionar a utilidade do beta de mercado. Black (1993) criticou os autores que proclamaram a morte do beta. Este movimento gerou grande discussão no meio acadêmico.

De acordo com Black (1993), Fama e French (1992) se equivocaram na análise dos dados, e muitas de suas conclusões resultaram do processo de data mining ou seleção dos 
dados. De acordo com o autor, data mining ocorre quando o pesquisador tenta de diversas formas realizar seus estudos, incluindo várias combinações de variáveis em diversos períodos no tempo, utilizando diferentes modelos e testes até obter um resultado que suporte suas hipóteses e conclusões.

Para justificar as suas críticas, Black (1993) analisou todas as ações listadas no Center for Research in Security Prices (CRSP) no período de 1926 a 1991, a partir das 20 carteiras formadas com os betas ordenados, conforme Black et al. (1972). O autor observou o mesmo comportamento que Fama e French (1992): ações com betas menores apresentavam um retorno superior em relação ao estimado pelo modelo CAPM, e ações com beta maior apresentavam retornos inferiores ao estimado pelo CAPM. No entanto, Black (1993) comentou que este resultado indicava que as carteiras não eram diversificadas e que os investidores poderiam utilizar este efeito como uma oportunidade de investimento.

Chan \& Lakonishok (1993) discutiram os resultados contraditórios encontrados pelos primeiros trabalhos de Fama e Macbeth (1973), Black et al. (1972), Reinganum (1981b) e Lakonishok e Shapiro (1986), entre outros, além da utilidade do beta de mercado. De acordo com os autores, "mesmo que não houvesse uma compensação para o risco do beta [de mercado], isso não significa que ele não tem uso para a tomada de decisão em investimento" (CHAN e LAKONISHOK, 1993, p. 52). O beta é uma medida estável de exposição aos movimentos de mercado e deve ser considerado pelos investidores. Os autores ainda levantaram uma explicação para a dificuldade de detectar a relação entre risco e retorno: fatores comportamentais e institucionais não relacionados ao risco poderiam estar afetando esta relação, como a tendência do investidor para sobrerreagir a eventos no longo prazo ou a existência do efeito momento no curto prazo.

Para analisar a explicação levantada, Chan \& Lakonishok (1993) estudaram um fator institucional específico: se um aumento da demanda por ações que compõem o índice S\&P 500 poderia resultar em aumento do retorno destas ações, fato este não relacionado ao risco. Os autores encontraram evidências de que o excesso de retorno, mesmo após o controle para o fator tamanho e B/M, era de 2,19\% ao ano e estatisticamente significante, o que indicou que outros fatores não associados a risco poderiam influenciar no retorno dos ativos.

Chan \& Lakonishok (1993) testaram ainda se carteiras de betas altos apresentavam retornos superiores aos verificados em carteiras de betas baixos e se o prêmio pelo beta era igual ao prêmio real de mercado. Para isso utilizaram a metodologia de Fama e Macbeth (1973), com dados da CRSP no período de 1926 a 1991. Os autores constataram que, no período de 1926 a 1982, a relação entre o beta e o retorno das ações era positiva e linear, 
validando o CAPM; porém, no período de 1982 a 1991, esta relação não se manteve, o que indicou invalidade do CAPM.

Grinold (1993), assim como Black (1993) e Chan \& Lakonishok (1993), reafirmou a utilidade do beta, independentemente das controvérsias que cercavam o modelo CAPM. De acordo com o autor, o beta poderia ser definido como a inclinação de uma linha de regressão ou como a sensibilidade projetada de uma carteira em relação a um benchmark. Além disso, poderia ser utilizado como medida de risco e como parâmetro na estimativa de retorno esperado. Estas aplicações não eram controversas, somente a utilização do beta no modelo CAPM era questionada, o que indicava que o beta era uma ferramenta útil.

Fama e French (1993, p. 4) continuaram seu trabalho de análise das anomalias, apesar das críticas, e expandiram os testes realizados no artigo anterior em três pontos: 1) passaram a considerar o retorno não só das ações, mas também dos títulos de dívida das empresas e do governo norte-americano; 2) utilizaram, além do tamanho e do índice B/M como variáveis explicativas, variáveis do mercado de títulos: o spread entre títulos de dívida do governo norte-americano em prazos diferentes e o spread entre títulos de dívida das empresas e do governo norte-americano, que os autores chamaram de prêmio por tempo e prêmio por default, respectivamente; e 3) utilizaram regressões em série de tempo, em vez das regressões mensais em corte transversal, uma vez que isso possibilitaria observar a sensibilidade dos retornos a cada fator.

Os autores montaram fatores a partir das variáveis tamanho e $\mathrm{B} / \mathrm{M}$, além dos dois fatores do mercado de títulos e o beta de mercado, e analisaram se estes fatores eram capazes de explicar a variação dos retornos dos ativos. Os resultados indicaram que, para o mercado de ações, o modelo contendo o excesso do retorno de mercado e os dois fatores construídos para imitar o efeito tamanho e B/M pareciam explicar de forma satisfatória os retornos dos ativos, apresentando um intercepto estatisticamente próximo a zero. Já para os bonds, ambos os fatores do mercado de títulos capturavam a maior parte das variações nos retornos das carteiras, exceto para os low-grade corporate bonds. Assim, Fama e French (1993) desenvolveram o modelo de três fatores para o mercado acionário, que além do beta de mercado contava com mais dois fatores, o tamanho e o índice B/M. O modelo é detalhado mais adiante.

MacKinlay (1995, p. 11) comentou que o modelo desenvolvido por Fama e French (1993) parecia um progresso genuíno na tentativa de identificar o modelo "correto" de apreçamento de ativos, porém o autor reforçou que o sucesso deste modelo veio do processo de data mining, que gerou viés nos dados, sendo, portanto, inapropriado, não possuindo uma 
razão teórica.

Kim (1997) investigou o poder de explicação das variáveis beta, tamanho da empresa, índice B/M e E/P em relação ao retorno médio das ações, corrigindo dois vieses: viés de seleção na base COMPUSTAT e viés de erro nas variáveis (errors-in-variables - EIV). O viés de seleção na base COMPUSTAT advinha do procedimento de back-filling-in, que consiste na prática de preencher dados ausentes de períodos anteriores. Empresas que, por exemplo, não apresentaram demonstrações financeiras devido a pouca negociação ou dificuldades financeiras, mas que se recuperaram, podem divulgar as demonstrações financeiras anteriores. Isso induziria a inclusão de empresas de alto índice B/M, de acordo com o autor.

Já o problema de erro nas variáveis se originava da utilização de betas estimados no lugar dos betas reais não observáveis e, segundo Kim (1997), faria com que o coeficiente beta fosse subestimado e os coeficientes das demais variáveis fossem superestimados. Para corrigir o problema, Kim (1997, p. 477) substituiu o beta real de mercado não observável por sua estimativa, defasada em um mês, calculada a partir de regressões em série de tempo.

Para verificar o viés de seleção na base COMPUSTAT, o autor utilizou ações de empresas não financeiras listadas na NYSE e AMEX no período de 1958 a 1993, e as agrupou de acordo com o método de carteiras de Fama e Macbeth (1973). Kim (1997) encontrou evidências do viés de seleção após 1970, período em que a prática de back-filling-in se tornou mais comum. Utilizando também a metodologia de Fama e Macbeth (1973) para verificar o problema de erro nas variáveis, os resultados indicaram que o beta passava a ter significância econômica e estatística na explicação dos retornos médios das ações, e o intercepto passava a ser estatisticamente igual a zero (KIM, 1997, p. 479). No entanto, a variável tamanho se mostrou pouco significante quando considerados os retornos mensais e insignificante quando considerados retornos trimestrais. Já a variável B/M ainda apresentou significância estatística após a correção de viés da amostra e erro nas variáveis.

\subsubsection{Efeito Momento}

DeBondt e Thaler (1985) analisaram as chamadas estratégias contrárias. A hipótese levantada pelos autores era de que, se um movimento de alta dos preços, por exemplo, fosse uma sobrerreação dos investidores a alguma informação, era de se esperar uma reversão ou queda nos preços para um nível de equilíbrio. Uma vez que o mercado sistematicamente sobrerreage, estes movimentos deveriam ser previsíveis a partir da análise dos retornos 
passados, sem que fosse necessário utilizar qualquer dado contábil. Assim, seria possível obter retornos anormais utilizando estratégia contrária, que envolve a compra de ações "perdedoras" e venda de ações "vencedoras".

Neste estudo, duas hipóteses foram levantadas: 1) movimentos extremos nos preços serão seguidos por movimentos na direção oposta (correção do movimento) e 2) o ajuste seria proporcional ao nível da sobrerreação, ou seja, movimentos de grandeza maior devem ser seguidos por ajustes ou correções maiores. Ambas as hipóteses implicavam a violação da Forma Fraca da HEM (DEBONDT e THALER, 1985, p. 795).

Para testar a sobrerreação, DeBondt e Thaler (1985) utilizaram retornos mensais das ações listadas na NYSE para o período de 1926 a 1982 e definiram ações "vencedoras" e "perdedoras" em função do excesso de retorno acumulado nos últimos cinco anos. Os autores encontraram evidência de que carteiras "perdedoras" apresentavam retornos superiores em relação a carteiras "vencedoras". Mesmo trinta e seis meses após a formação das carteiras, as ações "perdedoras" apresentavam retorno 25\% superior às ações "vencedoras". Além disso, no período de três a cinco anos, empresas que tiveram desempenho fraco nos três a cinco anos anteriores apresentavam retornos superiores a empresas que tiveram desempenho bom no mesmo período.

Em estudo posterior, DeBondt e Thaler (1987) encontraram evidências de que o efeito "vencedoras-perdedoras" não poderia ser atribuído ao efeito tamanho, contudo parecia estar associado ao efeito M/B (valor de mercado/valor contábil), uma vez que a ordenação das carteiras pelo retorno acumulado coincidia com a ordenação pelo índice M/B.

Os resultados apresentados por DeBondt e Thaler (1985; 1987) continuaram a ser debatidos. Zarowin (1990), por exemplo, argumentou que quando ações de empresas "perdedoras" eram comparadas com ações de empresas "vencedoras" do mesmo tamanho, havia pouca evidência de discrepâncias nos retornos. Além disso, em períodos em que ações "vencedoras" eram menores que ações "perdedoras", as ações "vencedoras" apresentavam retornos superiores às "perdedoras".

Apesar das estratégias contrárias terem recebido atenção, as estratégias de relative strength passaram a ser bastante estudadas também. As estratégias de relative strength são uma forma de capturar o efeito momentum e envolvem a análise conjunta de dois preços, que podem ser duas ações, uma carteira setorial ou um benchmark como o índice S\&P 500 (MURPHY, 1999, p. 240). Jegadeesh e Titman (1993) analisaram a estratégia de compra de ações que tiveram desempenho anterior bom e venda de ações que tiveram desempenho anterior ruim. De acordo com os autores, os traders que utilizaram as estratégias de relative 
strength baseavam suas seleções em movimentos nos preços no intervalo de três a doze meses.

Assim, Jegadeesh e Titman (1993) montaram estratégias utilizando os retornos acumulados para os períodos de três, seis, nove e doze meses como parâmetros de formação das carteiras e os mesmos períodos para sua manutenção. A combinação dos quatro períodos de formação das carteiras com os quatro períodos de manutenção totalizava dezesseis estratégias diferentes. Além destas, os autores analisaram mais dezesseis estratégias utilizando os mesmos prazos, mas defasando em uma semana a formação das carteiras e o período de manutenção. Com isso, pretendiam considerar evidências encontradas em relação a pressões nos preços, efeitos defasados nos preços e efeitos do spread nos preços de compra e venda documentados por Jegadeesh (1990) e Lehmann (1990).

As análises das ações negociadas na NYSE e AMEX no período de 1965 a 1989 mostraram evidências de retornos anormais significantes em todos os períodos de manutenção das carteiras. Adicionalmente, os retornos anormais não poderiam ser atribuídos ao risco sistemático e nem a reações tardias nos preços. De acordo com os autores, parte destes retornos anormais encontrados no período de manutenção não era permanente: os altos retornos obtidos no primeiro ano após a formação das carteiras já se dissipavam nos dois anos seguintes (JEGADEESH e TITMAN, 1993, p. 65). Além disso, quando a estratégia era considerada em relação ao tamanho das empresas, as maiores apresentaram retornos inferiores às de porte médio e pequeno.

Após o estudo de Jegadeesh e Titman (1993), outros autores passaram a testar o efeito momento e encontraram evidências de sua existência nos mercados mundiais.

Fama e French (1996) mostraram que muitas das anomalias que não eram capturadas pelo modelo CAPM poderiam ser explicadas com o modelo de três fatores, desenvolvido pelos autores. Para realizar o teste do modelo, utilizam as ações listadas na NYSE, AMEX e NASDAQ no período de 1963 a 1993. Os autores formam 25 carteiras a partir da interseção dos quintis do tamanho com os quintis do índice B/M em uma primeira análise, além de carteiras formadas dos decis da ordenação dos índices B/M, E/P, Fluxo de Caixa/Preço e crescimento das vendas. Os resultados indicaram que o modelo de três fatores era capaz de explicar o padrão dos retornos observados quando as carteiras eram formadas em relação aos índices E/P, Fluxo de Caixa/Preço e crescimento das vendas, assim como era capaz de capturar a reversão dos retornos de longo prazo documentado por DeBondt e Thaler (1985). Contudo, os autores destacaram que o modelo de três fatores não era capaz de explicar a persistência dos retornos de curto prazo documentada por Jegadeesh e Titman (1993). 
Rouwenhorst (1998) analisou carteiras baseadas na estratégia de relative strength, que envolvia a compra de ações que tiveram bom desempenho nos períodos de três a doze meses e a venda de ações que tiveram desempenho ruim no mesmo período, para doze países europeus, no período de 1978 a 1995. Os resultados encontrados pelo autor indicaram que esta estratégia gerou aproximadamente $1 \%$ de retorno ao mês, não era limitada a um mercado em particular e se manteve quando era considerado o tamanho das empresas, mas era mais proeminente em empresas pequenas. De acordo com o autor, os retornos anormais duraram por volta de um ano e não poderiam ser atribuídos a medidas convencionais de risco.

Em pesquisa posterior, Rouwenhorst (1999) estudou a estratégia de compra de ações "vencedoras" e venda de ações "perdedoras", considerando o prazo de seis meses para formação e seis meses de manutenção das carteiras para vinte países emergentes, dentre eles o Brasil, no período de 1982 a 1997. O autor utilizou a base de dados da Emerging Markets Database (EMDB) do International Finance Corporation (IFC), que apresentou dados para 87 empresas brasileiras.

Rouwenhorst (1999) constatou que o comportamento dos retornos nos mercados emergentes era qualitativamente semelhante ao encontrado nos mercados desenvolvidos. As ações apresentaram o efeito momento, ações de empresas pequenas apresentaram retornos superiores às ações de empresas grandes e empresas de baixo índice M/B apresentaram retornos maiores que empresas de alto índice M/B. Conforme o autor, não havia evidências de que empresas de beta alto oferecessem retornos superiores em relação a empresas de beta baixo. Para o Brasil, Rouwenhorst (1999) encontrou um efeito momento praticamente nulo, de $0,01 \%$ ao mês.

\subsubsection{Estudos sobre Anomalias no Brasil}

Bruni (1998) analisou o comportamento das ações de empresas não financeiras negociadas na BOVESPA no período de 1988 a 1996 em relação às seguintes variáveis: Índice BOVESPA como carteira de mercado, tamanho, endividamento, índice B/M, índice E/P, rentabilidade dos dividendos, liquidez corrente, índice fluxo de caixa sobre preço, crescimento anual das vendas, índice preço sobre vendas e variância individual.

O autor separou em suas análises as ações ordinárias das preferenciais, para considerar as diferenças entre ambos os tipos. Aplicou o modelo de regressão linear em corte transversal bivariada e multivariada, com ações individuais como variável dependente. $\mathrm{O}$ autor, além de 
analisar a amostra completa, subdividiu-a em dois períodos distintos: período 1, de 1988 a 1994, e período 2, de 1995 a 1996.

Bruni (1998) não identificou relação positiva e significativa entre o retorno das ações e a carteira de mercado para nenhum dos tipos de ação estudados, em nenhum dos períodos analisados.

A análise das ações preferenciais indicou significativa associação entre o retorno das ações e o índice B/M em todos os períodos de análise, sendo a variável mais significativa nas regressões. A variável endividamento se mostrou significativa e positiva, e a variável liquidez corrente se mostrou significativa e negativa no período 1 e na amostra completa. Já a relação preço sobre vendas indicou relação significativa e negativa no período 2 e amostra completa.

$\mathrm{Na}$ análise das ações ordinárias, a variável endividamento se mostrou a mais significativa para os três períodos analisados. $\mathrm{O}$ índice B/M se mostrou significativo também para os três períodos, em que ações com alto índice B/M apresentaram níveis de retorno mais elevados. Assim como na análise das ações preferenciais, a relação preço sobre vendas se mostrou negativa e significante para o período 1 e amostra completa.

Costa Jr. e Neves (2000) verificaram a influência das variáveis tamanho de mercado, índice preço/lucro e índice valor patrimonial da ação/preço, além do coeficiente da carteira de mercado na explicação dos retornos dos ativos negociados na BOVESPA no período de março de 1987 a fevereiro de 1996, a partir de método SUR (Seamingly Unrelated Regressions) para estimação dos coeficientes das regressões múltiplas.

Os autores utilizaram o método de carteiras para determinar as variáveis dependentes. Formaram oito carteiras da seguinte maneira: inicialmente, as ações foram ordenadas em função do índice P/L e divididas em dois grupos, em seguida, as ações de cada um destes grupos foram ordenadas em função do tamanho de mercado e divididas em outros dois grupos, formando assim quatro carteiras. Por fim, as ações de cada carteira foram ordenadas em função do índice valor patrimonial da ação/preço e divididas em outros dois grupos, formando assim oito carteiras. Este procedimento foi repetido no mês de março de cada ano.

Os resultados mostraram uma relação positiva e significativa entre o retorno das carteiras e a carteira de mercado, sendo esta a variável que mais se destacou na explicação da relação linear. Obtiveram um relacionamento negativo entre o retorno das carteiras e as variáveis valor de mercado e índice preço/lucro, além de uma relação positiva em relação ao índice valor patrimonial da ação/preço.

Nagano, Merlo e Silva (2003) analisaram quais variáveis, além da carteira de mercado, eram capazes de explicar os retornos dos ativos no mercado brasileiro, no período de maio de 
1995 a maio de 2000. Os autores utilizaram o índice ativo total/valor patrimonial, índice ativo total/valor de mercado, índice dividendo/preço, índice fluxo de caixa/preço, liquidez em bolsa, valor de mercado da empresa, índice B/M, índice lucro/preço e índice vendas preço.

A partir da análise dos resultados das regressões em corte transversal, os autores encontraram associação positiva entre os retornos das ações e algumas das variáveis incluídas na pesquisa, contradizendo assim a teoria do CAPM, que indicava que os retornos dos ativos estariam associados somente à carteira de mercado. O índice lucro/preço apresentou relação forte e positiva com os retornos dos ativos. O valor de mercado, juntamente com o índice lucro/preço, se mostrou uma das variáveis mais significativas no modelo e apresentou relação negativa com os retornos, o que indicava que empresas pequenas proporcionam rentabilidade superior em relação às empresas grandes.

A variável valor patrimonial/preço apresentou coeficiente bastante significativo e positivo, conforme os trabalhos anteriores, assim como o beta da carteira de mercado se mostrou positivo e significativo. A variável liquidez indicou que quanto menor a liquidez de uma ação, maior seria o retorno oferecido, uma vez que o coeficiente é negativo e significante. O índice vendas/preço apresentou coeficiente positivo, porém pouco significante, que só pôde ser aceito a um nível de significância de $10 \%$.

Rostagno, Kloeckner e Becker (2005) examinaram a previsibilidade dos retornos das ações brasileiras negociadas na BOVESPA, no período de janeiro de 1995 a dezembro de 1999, utilizando metodologia desenvolvida por Haugen e Baker (1996). Como variável dependente nas regressões, os autores utilizaram o retorno das ações e, como variáveis independentes, analisaram os seguintes fatores:

- Risco: beta de mercado, beta do APT (SELIC, mudança na produção industrial, taxa de inflação, diferença de retorno dos títulos privados e públicos), volatilidade do retorno total, variação residual, risco de rendimento, coeficiente de endividamento, tendência de endividamento, variabilidade de rendimento e variabilidade dos dividendos;

- Liquidez: capitalização de mercado, preço de mercado por ação, volume negociado/capitalização de mercado e tendência do volume de negociação;

- Nível de Preço: índice valor patrimonial por ação/preço, tendência valor patrimonial por ação/preço, índice lucro/preço, tendência lucro/preço, índice dividendo/preço, tendência dividendo/preço, fluxo de caixa/preço, tendência fluxo de caixa/preço, venda/preço e tendência venda/preço; 
- Rentabilidade: margem de lucro líquido, giro do ativo, tendência do giro do ativo, retorno sobre os ativos, tendência do retorno sobre os ativos, retorno sobre o patrimônio líquido, tendência do retorno sobre o patrimônio líquido e crescimento dos lucros;

- Histórico de Preços das Ações: diferença de retorno do Ibovespa em relação ao mês anterior, aos dois meses anteriores, aos três meses anteriores, aos seis meses anteriores, aos doze meses anteriores e aos vinte e quatro meses anteriores.

Foram realizadas regressões múltiplas mensais. Esta metodologia visou determinar quais variáveis deveriam ser utilizadas para prognosticar os retornos das ações e seguiu método proposto por Fama e Macbeth (1973).

Os resultados indicaram sete fatores capazes de explicar o retorno das ações: capitalização de mercado, tendência do volume de negociação, índice dividendo/preço, tendência de dividendo/preço, fluxo de caixa/preço, excesso de retorno do Ibovespa em relação aos três e doze meses anteriores. Surpreendentemente, de acordo com os autores, nenhum fator do grupo Risco se mostrou significativo.

Foi possível observar que os fatores selecionados eram capazes de formar carteiras que ofereciam ganhos acima da média. Outro resultado interessante apresentado na pesquisa sugeria que carteiras com retorno superior apresentaram desvio padrão inferior, o que indicava menor risco.

Mussa et al (2007) investigaram a existência do efeito momento no mercado acionário brasileiro, utilizando os retornos mensais de todas as ações listadas na BOVESPA no período de 1995 a 2006, a partir do método de carteiras e teste $t$ de Student, conforme realizado por Jegadeesh e Titman (1993).

Os autores encontraram evidências da possibilidade de ganhos anormais, se utilizada estratégia de momento em três das dezesseis analisadas. O maior retorno anormal médio observado ocorreu ao se montar a carteira com base no retorno acumulado dos últimos três meses e manter a carteira por seis meses $(3 \times 6)$. Foi observado que estratégias de $6 \times 9$ e 9x9 também geram retornos superiores aos investidores.

De acordo com Mussa et al (2007, p. 11), o total de estratégias vantajosas encontradas no mercado brasileiro era substancialmente menor do que o encontrado por Jegadeesh e Titman (1993). 


\subsection{Arbitrage Pricing Theory (APT)}

O Arbitrage Pricing Theory (APT), formulado por Ross (1976), é uma alternativa ao modelo de média-variância proposto por Sharpe (1964). O APT se baseia em uma lógica similar à do CAPM, porém utiliza premissas menos restritivas (ROSS, 1976). O modelo assume que o retorno do ativo é influenciado por duas fontes de risco: o risco sistemático, que são os riscos decorrentes de fatores macroeconômicos, externos à empresa, e o risco não sistemático, que são os advindos da própria empresa e do negócio no qual está inserida. Assim, de acordo com o APT, a taxa de retorno de um ativo $i$ seria linear em função de $k$ fatores macroeconômicos, que afetam todos os ativos em uma economia, além do fator específico da empresa:

$\tilde{R}_{i}=E\left(\tilde{R}_{i}\right)+b_{i 1} \tilde{F}_{1}+b_{i 2} \tilde{F}_{2}+\cdots+b_{i k} \tilde{F}_{k}+\tilde{\varepsilon}_{i}$

em que

$\tilde{R}_{i}=$ taxa aleatória de retorno do ativo $i$;

$E\left(\tilde{R}_{i}\right)=$ retorno esperado do ativo $i$ se todos os fatores forem zero;

$b_{i k}=$ sensibilidade do retorno do ativo $i$ em relação ao fator $k$;

$\tilde{F}_{k}=$ fator comum a todos os ativos da economia;

$\tilde{\varepsilon}_{i}=$ termo de incerteza do ativo $i$.

O modelo se baseia na lei de preço único, em que dois ativos iguais não poderiam apresentar preços diferentes (ELTON e GRUBER, 1995, p. 368). Em condição de equilíbrio de mercado, não seria possível arbitrar os preços, ou seja, não seria possível obter lucro sem incorrer em risco ou sem ter exposição financeira. O APT se baseia nas seguintes premissas: 1) o mercado é perfeitamente competitivo e não há pressões para mudanças no preço de equilíbrio; 2) os indivíduos possuem expectativas homogêneas sobre os fatores que influenciam os preços dos ativos; 3 ) o número de ativos é sempre maior do que o número de fatores; 4) o termo de incerteza, $e_{i}$, é o componente não sistemático para o ativo $i$ e é independente dos fatores e dos erros dos demais ativos (COPELAND, WESTON e SHASTRI, 2005, p. 177).

O modelo APT estaria pautado nas carteiras de arbitragem (arbitrage portfolios), as quais, em equilíbrio, deveriam ser construídas a partir da venda de alguns ativos da carteira 
inicial e, com os recursos da venda, comprar outros ativos, de forma que:

(2.26) $\sum_{i=1}^{n} w_{i}=0$

em que

$w_{i}=$ mudança na quantia investida no ativo $i$, em relação ao total investido, na tentativa de construção da carteira de arbitragem.

Desta forma, para $n$ ativos com risco na carteira de arbitragem, o retorno adicional é:

(2.27) $\widetilde{R}_{p}=\sum_{i=1}^{n} w_{i} \widetilde{R}_{i}=\sum_{i} w_{i} E\left(\widetilde{R}_{i}\right)+\sum_{i} w_{i} b_{i 1} \widetilde{F}_{1}+\cdots+\sum_{i} w_{i} b_{i k} \widetilde{F}_{k}+\sum_{i} w_{i} \tilde{e}_{i}$

Para se obter a carteira de arbitragem sem risco seria necessário eliminar o risco não sistemático e o sistemático, e isso poderia ser feito: 1) selecionando pequenas mudanças na quantia investida em cada ativo (wi); 2) diversificando-a em um grande número de ativos e 3) definindo mudanças na quantia investida, de forma que a soma ponderada das sensibilidades em relação a cada fator, $b_{i k}$, seja zero (ROSS, 1976, p. 342). Copeland, Weston e Shastri (2005, p. 177) mostraram matematicamente estas restrições:

$w_{i}=1 / n$

$n$ deve ser grande

$\sum_{i} w_{i} b_{i k}=0$ para cada fator

Como os termos de erro, $e_{i}$, são independentes, à medida que o número de ativos na carteira aumenta, sua média ponderada diminui, tendendo a zero. Além disso, os componentes de risco sistemático, ou fatores, são ponderados de forma a igualarem a zero. Portanto, ele seria eliminado também. Como resultado, o retorno na carteira de arbitragem seria uma constante e não mais uma variável aleatória, uma vez que a fonte de incerteza seria eliminada.

$$
R_{p}=\sum_{i} w_{i} E\left(\widetilde{R}_{i}\right)=\sum_{i} w_{i} \bar{R}_{i}
$$


E como a carteira de arbitragem deveria ser construída para não apresentar exposição financeira, o retorno deveria ser zero, caso contrário, existiria a possibilidade de obter retorno infinito sem a necessidade de capital e sem incorrer em risco; e esta oportunidade deveria ser impossível, se o mercado estivesse em equilíbrio.

$\mathrm{Na}$ existência de um ativo livre de risco na economia, a taxa de retorno da carteira de arbitragem deveria ser igual à taxa de retorno do ativo livre de risco, quando a sensibilidade dos retornos do ativo $i$ em relação ao fator $k$ for zero. A taxa de retorno da carteira e os fatores $k$ seriam expressos na forma de prêmio sobre o ativo livre de risco:

$$
E\left(R_{i}\right)-R_{L R}=b_{i 1}\left(\bar{\delta}_{1}-R_{L R}\right)+b_{i 2}\left(\bar{\delta}_{2}-R_{L R}\right)+\cdots+b_{i k}\left(\bar{\delta}_{k}-R_{L R}\right)
$$

em que

$\bar{\delta}_{k}-R_{L R}=$ prêmio dos $k$ fatores em relação ao ativo livre de risco;

$b_{i k}=$ sensibilidade dos retornos do ativo $i$ em relação ao prêmio dos fatores $k$.

A partir da equação 2.30, observa-se que cada ativo teria uma única sensibilidade a cada fator $k$, mas cada fator afetaria mais de um ativo. Caso contrário, deveria estar contido no resíduo e seria fonte de covariância entre os ativos (ELTON e GRUBER, 1995, p. 374).

Os coeficientes $b_{i k}$ poderiam ser interpretados da mesma forma como o beta no modelo CAPM, assumindo-se que os retornos possuem distribuição normal.

Se os retornos das ações pudessem ser explicados somente pelo prêmio do retorno da carteira de mercado, supondo que fosse possível identificá-la, então seria possível desenvolver o modelo APT, em que todo o risco sistêmico seria captado pela carteira de mercado. Assim, o modelo CAPM poderia ser entendido como um caso especial do modelo APT, segundo Copeland, Weston e Shastri (2005, p. 180).

É possível levantar algumas razões para a superioridade do modelo APT em relação ao CAPM, de acordo com a Tabela 2. 
Tabela 2 - Comparação dos modelos APT e CAPM

\begin{tabular}{|l|l|}
\hline \multicolumn{1}{|c|}{ APT } & \multicolumn{1}{|c|}{ CAPM } \\
\hline $\begin{array}{l}\text { Não faz pressuposição sobre a distribuição } \\
\text { dos retornos dos ativos. }\end{array}$ & $\begin{array}{l}\text { Pressupõe que o retorno dos ativos segue } \\
\text { uma distribuição normal. }\end{array}$ \\
\hline $\begin{array}{l}\text { Não faz pressuposição a respeito da } \\
\text { função utilidade dos indivíduos. }\end{array}$ & $\begin{array}{l}\text { Pressupõe que todos os indivíduos têm a } \\
\text { mesma função utilidade. }\end{array}$ \\
\hline $\begin{array}{l}\text { Permite que os retornos dos ativos sejam } \\
\text { dependentes em diversos fatores. }\end{array}$ & $\begin{array}{l}\text { O retorno dos ativos só é dependente do } \\
\text { retorno da carteira de mercado. }\end{array}$ \\
\hline $\begin{array}{l}\text { Não há uma carteira de mercado definida } \\
\text { para ser utilizada como um dos fatores no } \\
\text { modelo. }\end{array}$ & $\begin{array}{l}\text { Requer que a carteira de mercado seja } \\
\text { eficiente, pelo conceito definido por } \\
\text { Markowitz (1952). }\end{array}$ \\
\hline $\begin{array}{l}\text { O modelo é facilmente estendido para } \\
\text { diversos períodos. }\end{array}$ & $\begin{array}{l}\text { O modelo somente fornece resultado para } \\
\text { um período. }\end{array}$ \\
\hline
\end{tabular}

Fonte: Adaptado de Copeland, Weston e Shastri (2005, p. 180) e Ross (1976)

Ambos os modelos pressupõem mercados perfeitamente competitivos e sem pressões para mudanças no preço de equilíbrio, além da homogeneidade das expectativas.

Elton e Gruber (1995, p. 375) ressaltaram que, enquanto no CAPM o fator para estimar o retorno dos ativos era pré-definido como o retorno da carteira de mercado menos o retorno do ativo livre de risco, no modelo APT os fatores não eram definidos pela teoria e deveriam, portanto, ser definidos a partir de simulações. De acordo com os autores, havia três alternativas para estimar um modelo APT. A primeira era definir alguns atributos ou características que poderiam afetar os retornos e utilizar a Análise Fatorial para determinar fatores a partir destas características. A Análise Fatorial consiste em técnica estatística que representa em poucos fatores a estrutura ou dimensões inerentes comuns de um número maior de variáveis, assim a informação destas variáveis é condensada em um conjunto menor de fatores, com uma perda mínima da informação.

A segunda e a terceira alternativas envolviam a especificação de fatores, para então estimar a sensibilidade dos retornos do ativo em relação aos retornos dos prêmios por risco dos fatores. Na segunda alternativa, eram levantados fatores macroeconômicos que podiam afetar o retorno dos ativos, e na terceira eram montados fatores que imitavam características das empresas, como seu tamanho.

Roll e Ross (1980) aplicaram a técnica de análise fatorial para estudar a relação entre as variáveis. Os autores separaram as ações da New York Stock Exchange no período de 1962 
a 1972 em 42 grupos de ações por ordem alfabética, com 30 ações em cada, e, a partir destes 42 grupos, aplicaram a análise fatorial. Eles encontraram, na média, cinco fatores. Os testes que regrediram estes fatores em relação aos preços dos ativos indicaram pelo menos três fatores como necessários e quatro se mostraram suficientes.

Drhymes, Friend e Gultekin (1984) questionaram o trabalho de Roll e Ross (1980), apresentando resultados que indicavam que o número de fatores dependia da quantidade de ativos utilizados e da quantidade de carteiras formadas. Em seus testes, o número de fatores passou de três, para grupos com quinze ativos, para nove quando os grupos apresentavam noventa ativos. Roll e Ross (1984) criticam os comentários de Drhymes, Friend e Gultekin (1984), comentando que a diferença de resultados advém de diferentes metodologias e diferentes amostras, e que o artigo foi um primeiro passo para a análise do modelo APT.

Chen, Roll e Ross (1986) testaram o modelo APT a partir de variáveis macroeconômicas como fatores. Os autores utilizaram diferenças nas taxas de captação de curto e longo prazo, o efeito esperado e o efeito não esperado da taxa de inflação, produção industrial, preço do petróleo e a diferença das taxas de captação de títulos de dívida high e low grade. Os resultados indicaram que todos os fatores explicavam boa parte das variações dos retornos ao longo do tempo.

O modelo APT construído a partir de carteiras que imitavam determinadas características das empresas se difundiu no meio acadêmico a partir do trabalho desenvolvido por Fama e French (1993), que construíram fatores a partir do tamanho das empresas, do índice book-to-market e do prêmio pelo risco de mercado para o mercado de ações. Este modelo será comentado de forma mais detalhada.

\subsection{Modelo de Três Fatores para o Apreçamento de Ativos}

Neste capítulo é discutido o modelo de três fatores desenvolvido por Fama e French (1993) e alguns trabalhos já realizados utilizando este modelo.

\subsubsection{O modelo}

Diversos estudos analisaram o modelo CAPM após sua formulação e muitos deles identificaram que somente o risco de mercado, ou o fator beta, não era capaz de prever 
sozinho o retorno dos ativos. Baseados nas evidências e anomalias encontradas, Fama e French (1993) formularam um novo modelo de equilíbrio composto por três fatores: 1) o risco de mercado, ou beta, conforme definido no modelo CAPM; 2) o tamanho da empresa; e 3) o índice B/M (book-to-market) decorrente da divisão do valor contábil das ações pelo valor de mercado destas ações. Este modelo, segundo os autores, explicaria significativamente os retornos das ações.

Utilizando a metodologia de regressões em série de tempo desenvolvida por Black et al. (1972), os autores regrediram os retornos mensais das ações agrupadas em carteiras em relação à carteira de mercado e a carteiras que imitavam o efeito tamanho e o índice B/M. Os autores utilizaram todas as ações listadas na NYSE (New York Stock Exchange), AMEX (American Stock Exchange) para o período de 1963 a 1991 e NASDAQ (National Association of Security Dealers Automated Quotations), de 1973 a 1991.

Em junho de cada ano $t$, as empresas foram ordenadas a partir do tamanho de mercado, que corresponde ao preço de sua ação ordinária multiplicado pela quantidade de ações. A mediana das empresas negociadas na NYSE foi utilizada como divisor da amostra total, incluindo as três bolsas, gerando assim dois grupos: das empresas pequenas, chamado de $S$ e das empresas grandes, chamado de $B$ (Small e Big, respectivamente).

Também em junho de cada ano $t$ as empresas foram ordenadas de acordo com o seu índice book-to-market, calculado a partir da divisão do valor contábil do patrimônio líquido pelo valor de mercado do patrimônio líquido. Foram utilizados os dados do mês de dezembro do ano anterior ( $t$-1) para ambos os valores do patrimônio líquido. As ações foram ordenadas de acordo com o índice B/M e, então, separadas em três grupos: 30\% inferiores (Low), 40\% intermediarias (Medium), e 30\% superiores (High).

Foram excluídas da amostra empresas que apresentavam patrimônio líquido negativo em dezembro e foram consideradas somente empresas com ações ordinárias. Assim, em junho de cada ano $t$ são formados seis grupos, a partir da interseção da divisão da amostra feita em relação ao tamanho e ao índice B/M. Os grupos são:

- S/L (Small e Low): ações de empresas com valor de mercado e índice B/M baixos;

- $\mathrm{S} / \mathrm{M}$ (Small e Medium): ações de empresas com valor de mercado baixo e índice B/M intermediário;

- $\mathrm{S} / \mathrm{H}$ (Small e High): ações de empresas com valor de mercado baixo e índice B/M alto;

- B/L (Big e Low): ações de empresas com valor de mercado alto e índice B/M baixo; 
- B/M (Big e Medium): ações de empresas com valor de mercado alto e índice B/M intermediário;

- $\mathrm{B} / \mathrm{H}$ (Big e High): ações de empresas com valor de mercado e índice B/M alto.

De julho do ano $t$ a junho do ano $t+1$, foram calculados os retornos mensais de cada carteira ponderados para os seis grupos, sendo que o peso de cada ação correspondia ao valor de mercado da ação em relação ao valor de mercado da carteira. O processo de agrupamento foi repetido no mês de junho de cada ano.

O fator de risco tamanho, chamado SMB pelos autores (Small Minus Big), foi calculado mês a mês a partir da diferença da média aritmética dos retornos dos três grupos $S$ em relação à média aritmética dos retornos dos três grupos $B$.

$S M B=\left(\frac{S / L+S / M+S / H}{3}\right)-\left(\frac{B / L+B / M+B / H}{3}\right)$

Já o fator de risco do índice B/M, chamado HML (High Minus Low), foi calculado mensalmente a partir da diferença da média aritmética dos retornos dos dois grupos $H$ em relação à média aritmética dos retornos dos dois grupos $L$.

$H M L=\left(\frac{S / H+B / H}{2}\right)-\left(\frac{S / L+B / L}{2}\right)$

O fator de risco de mercado foi calculado para todos os meses a partir do retorno da carteira de mercado menos o retorno do ativo livre de risco. A carteira de mercado considerou o retorno de todas as ações ponderadas pelo seu valor de mercado e o ativo livre de risco consistiu na taxa de retorno do título do governo norte-americano (Treasury) para o período de um mês.

Os fatores de risco mercado, tamanho e índice B/M foram utilizados como variáveis independentes em regressões em série de tempo, conforme Black et al. (1972).

Em junho de cada ano $t$, as empresas foram ordenadas de acordo com o valor de mercado de junho e separadas em cinco quintis, que formaram cinco carteiras por consequência. Em junho de cada ano $t$, as ações foram ordenadas em função do índice B/M de dezembro de $t-1$ e separadas em cinco quintis. A interseção destas duas etapas formou as vinte e cinco carteiras. Os retornos destas vinte e cinco carteiras foram calculados ponderando-se os 
retornos dos ativos contidos em cada uma pelo valor de mercado. A cada ano o processo era repetido e as carteiras eram reformuladas. Utilizou-se o retorno das carteiras em excesso ao título do governo norte-americano de um mês como variável dependente nas regressões.

Assim, chegou-se à regressão utilizada no modelo:

$$
\boldsymbol{R}_{c(t)}-\boldsymbol{R} \boldsymbol{F}_{(t)}=a+b\left[R M_{(t)}-R F_{(t)}\right]+s\left[S M B_{(t)}\right]+h\left[H M L_{(t)}\right]+e_{(t)}
$$

em que

$R_{c(t)}-R F_{(t)}=$ retorno da carteira menos o ativo livre de risco para o mês $t$;

$R M_{(t)}-R F_{(t)}=$ retorno da carteira de mercado menos o ativo livre de risco para o mês $t$;

$S M B_{(t)}=$ fator tamanho - Small minus Big - para o mês $t$;

$H M L_{(t)}=$ fator índice B/M - High minus Low - para o mês $t$;

$e_{(t)}=$ resíduo do modelo.

Fama e French (1993) comentaram que a grande maioria das empresas listadas na AMEX e NASDAQ era menor do que as listadas na NYSE, o que faria com que a quantidade de empresas nos grupos e carteiras não fosse proporcional. Contudo, apesar da quantidade de empresas alocadas nas carteiras de menor valor de mercado ser alta, elas eram responsáveis por $0,70 \%$ em média do valor total do mercado, enquanto as empresas de maior tamanho correspondiam juntas a 74\% do valor total do mercado (FAMA e FRENCH, 1993, p. 12).

$\mathrm{Na}$ análise descritiva dos dados, os autores mostraram o excesso do retorno médio mensal e o desvio padrão das vinte e cinco carteiras, encontrando evidência de uma relação negativa entre tamanho e retorno médio da carteira, e de uma relação positiva entre o índice $\mathrm{B} / \mathrm{M}$ e o retorno médio, o que indicava que empresas menores e de índice $\mathrm{B} / \mathrm{M}$ alto apresentavam retornos superiores, confirmando os resultados encontrados em Fama e French (1992).

Fama e French (1993, p. 12) ainda comentaram que em todas as carteiras, com exceção da de menor índice B/M, o retorno médio tendia a diminuir das carteiras de menor para as de maior tamanho. Quanto ao índice B/M, a relação com o retorno médio das carteiras era ainda mais forte: se analisados em cada faixa de tamanho, os retornos médios das carteiras aumentavam à medida que o índice $\mathrm{B} / \mathrm{M}$ se tornava maior.

Os autores identificaram o prêmio médio de mercado para o período de 1963 a 1991 
de $0,43 \%$ ao mês. O prêmio médio do fator tamanho, que consiste na média do fator de risco, foi de $0,27 \%$ ao mês, e o prêmio médio do fator do índice B/M foi de $0,40 \%$ ao mês, ambos para o mesmo período.

Para verificar a validade do modelo, Fama e French (1993) primeiro testaram a influência de cada um dos fatores de risco sobre o retorno das carteiras isoladamente, para depois analisá-los em conjunto. Assim, foi testado primeiro o fator de mercado isoladamente. Em seguida, foram testados os fatores tamanho e índice $\mathrm{B} / \mathrm{M}$, e só no terceiro teste foram considerados os três fatores.

Na primeira análise, que considerou somente o fator de mercado, apenas uma das vinte e cinco carteiras apresentou $\mathrm{R}^{2}$ superior a 0,9. Empresas menores e de alto índice B/M apresentaram $\mathrm{R}^{2}$ entre 0,7 e 0,8 , o que indica que podem sofrer maior influência dos fatores SMB e HML.

$\mathrm{Na}$ segunda análise, os autores calcularam a regressão com os dois fatores SMB e HML. Na ausência do fator de risco de mercado, os dois fatores capturaram bem a variação dos retornos das carteiras, sendo que em oito, das vinte e cinco carteiras, os valores de $\mathrm{R}^{2}$ foram superiores a 0,5. Especialmente nas carteiras de maior tamanho, os fatores SMB e HML pareciam explicar uma menor proporção das variações dos retornos, deixando uma parcela maior desta explicação para o fator de mercado (FAMA e FRENCH, 1993, p. 21).

Somente na terceira análise Fama e French (1993, p. 21) testaram os três fatores conjuntamente. Os autores concluíram que o modelo de três fatores era o melhor dentre os três e captava a maior parte das variações dos retornos de todas as carteiras, uma vez que todos os $\mathrm{R}^{2}$ foram superiores a 0,83 . O fator de risco de mercado de todas as carteiras estava a pelo menos 38 erros padrão de zero. Outro ponto observado pelos autores foi que o coeficiente de mercado era estatisticamente igual a 1 nesta terceira análise, o que reforçou o poder dos demais fatores.

Com exceção de uma carteira, todas apresentaram estatísticas $t$ do coeficiente SMB acima de 4. Segundo Fama e French (1993, p. 21), o fator tamanho, ou SMB, claramente captava variações nos retornos que não eram captadas pelos demais fatores. Além disso, em cada quintil formado pelo índice B/M, o coeficiente do fator SMB decresceu dos quintis de menor para os de maior tamanho.

Já em relação aos coeficientes HML, em cada quintil de tamanho era possível observar que o coeficiente aumentava, indo de um valor fortemente negativo em carteiras de menor índice $\mathrm{B} / \mathrm{M}$ para outro fortemente positivo em carteiras de maior índice B/M. Com exceção do segundo quintil formado a partir do índice $\mathrm{B} / \mathrm{M}$, os coeficientes HML estavam a mais de 
cinco erros padrão de zero.

Outra análise realizada pelos autores foi se o intercepto das três regressões era estatisticamente igual a zero. A hipótese levantada levou em consideração o modelo multifatorial desenvolvido por Ross (1976), que indicava que, se os fatores a serem considerados na análise eram comuns a todos os investidores, o intercepto da regressão linear em série de tempo deveria ser igual a zero e o resíduo do modelo deveria ser aleatório e não correlacionado com os fatores de risco do modelo (FAMA e FRENCH, 1993, p. 35).

Considerando o modelo de três fatores, os autores verificaram que somente três, das vinte e cinco carteiras, apresentavam interceptos estatisticamente diferentes de zero e em dezesseis destas carteiras o intercepto era inferior a $0,1 \%$ ao mês, o que indicou que os três fatores explicavam de forma satisfatória o retorno médio dos ativos (FAMA e FRENCH, 1993, p. 38). Na análise dos resíduos foi possível observar que estes não eram correlacionados com os demais fatores e nem possuíam autocorrelação no tempo, além de serem aleatoriamente distribuídos.

\subsubsection{Principais Estudos no Brasil}

Málaga (2003), em estudo sobre o mercado brasileiro, testou se as variações dos retornos das ações listadas na BOVESPA poderiam ser explicadas pelo modelo de três fatores de Fama e French (1993), para o período de 1995 a 2003, utilizando regressões em série de tempo entre os retornos mensais das carteiras e os fatores mercado, tamanho e índice book-tomarket. Além disso, foi analisada a superioridade do modelo de três fatores em relação ao CAPM. Foi testada a significância de cada um dos fatores a partir da estatística $t$ de Student e do modelo a partir do coeficiente de determinação ajustado, $\mathrm{R}^{2}$ ajustado.

Os resultados encontrados pelo autor indicaram que o modelo de três fatores de Fama e French (1993) era superior ao CAPM na explicação das variações dos retornos. Os fatores tamanho e índice B/M se mostraram significativos e pareciam estar associados a fatores que não eram captados pelo fator de mercado. $O$ fator B/M, HML, se mostrou positivo e estatisticamente significante, enquanto o fator tamanho, SMB, se mostrou negativo e estatisticamente significante, contrário às evidências encontradas por Fama e French (1993). Os resultados de Málaga (2003) sinalizavam que empresas maiores ofereciam taxas de retorno superiores àquelas oferecidas pelas empresas menores.

Rogers e Securato (2009) testaram e compararam os modelos CAPM, o modelo de três 
fatores de Fama e French (1993) e o Reward Beta Model de Bornholt (2007), utilizando metodologia preditiva em dois estágios para as ações cotadas na BOVESPA no período de dezembro de 1994 a junho de 2006.

Segundo os autores, o Reward Beta Model "é derivado de uma classe de medidas de risco-médio, baseadas na APT, e consistentes com a teoria da utilidade esperada e com a hipótese de aversão ao risco" (ROGERS e SECURATO, 2009, p. 161).

Os autores utilizaram o método de carteiras conforme Fama e French (1993). Como citado anteriormente, Fama e French (1993) construíram carteiras pela interseção dos quintis da ordenação da variável tamanho com os quintis da ordenação da variável B/M, o que fez com que o número de ações em cada carteira fosse diferente, entre as carteiras e a cada ano.

Rogers e Securato (2009) levantaram o problema do tamanho da amostra e a possibilidade de existência de carteiras formadas por poucas ações, o que não proporcionaria a diversificação adequada. Assim, decidiram formar as carteiras de forma diferente de Fama e French (1993).

Dessa forma, a presente pesquisa não deixou a intercessão ser aleatória, mas forçou-a de forma a equilibrar o número de ações nas carteiras. As 25 carteiras de teste foram compostas, em média, por 8 a 11 ações em cada ano. (ROGERS e SECURATO, 2009, 169)

Os resultados obtidos apontaram para a superioridade do modelo de três fatores em explicar a variação dos retornos dos ativos no mercado brasileiro. Contudo, os resultados sugeriram um modelo de dois fatores, composto pelo fator mercado e pelo fator tamanho somente, uma vez que o fator book-to-market não se mostrou estatisticamente significativo.

Os autores comentam que o efeito tamanho se justificaria por quatro motivos: 1) empresas pequenas tendem a ser negligenciadas pelos analistas, o que faz com que o mercado tenha menos informação e atribua mais risco a este investimento; 2) empresas com menor acompanhamento pelos analistas tendem a ser menos líquidas e 3) empresas menores têm menor probabilidade de sobrevivência; e 4) os custos de transação são maiores para empresas menores (ROGERS e SECURATO, 2009, p. 176).

\subsection{Modelo de Quatro Fatores para o Apreçamento de Ativos}

Neste capítulo é discutido o modelo de quatro fatores desenvolvido por Carhart (1997) e alguns trabalhos já realizados utilizando este modelo. 


\subsubsection{O modelo}

Conforme foi mencionado anteriormente, Jegadeesh e Titman (1993) foram os primeiros a analisar a estratégia de relative strength. Documentaram que estratégias de compra de ações que apresentaram bom desempenho e venda de ações que mostraram pior desempenho em um determinado intervalo de tempo ofereciam retornos acumulados positivos para períodos entre três e doze meses. Os autores testaram trinta e duas estratégias, considerando a análise dos retornos acumulados nos períodos de três, seis, nove e doze meses para a formação das carteiras e os mesmos períodos para sua manutenção, totalizando dezesseis estratégias.

As demais dezesseis foram construídas da mesma forma, separando o período de formação e o período de manutenção das carteiras em uma semana, para evitar spread nos preços de compra e venda, pressões nos preços e efeito de reações tardias nos preços. Havia evidência de retornos anormais em todas as combinações de períodos analisados. Contudo, os altos retornos encontrados no primeiro ano se dispersavam nos dois anos subsequentes.

Diversos estudos realizados posteriormente encontraram evidências parecidas, como os de Fama e French (1996), Jegadeesh e Titman (2001), além de Rouwehorst (1998) para o mercado europeu e Rouwehorst (1999) para mercados emergentes.

Conforme anteriormente citado, Fama e French (1996) mostraram que muitas anomalias não capturadas pelo modelo CAPM eram capturadas pelo modelo de três fatores, contudo os autores ressaltaram que o modelo de três fatores não era capaz de explicar a persistência dos retornos de curto prazo testados por Jegadeesh e Titman (1993).

Em seu trabalho, Carhart (1997) analisou a persistência do desempenho de fundos mútuos de investimento. Para isso, o autor desenvolveu um quarto fator, momento, a partir da estratégia de momento de doze meses estudada por Jegadeesh e Titman (1993), e o agregou ao modelo de três fatores de Fama e French (1993), idealizando assim o modelo que ficou conhecido como modelo de quatro fatores.

Além de desenvolver e testar a previsibilidade dos retornos dos fundos a partir dos modelos CAPM, três e quatro fatores, o autor ainda analisou outras razões que poderiam explicar o desempenho dos fundos mútuos de investimento. Dentre as variáveis que poderiam exercer algum impacto no retorno para o investidor, encontravam-se as seguintes: as despesas totais de gerenciamento e administração dos fundos em relação ao total líquido de ativos dos fundos, o volume negociado de compra e o volume negociado de venda, além de outras 
variáveis específicas para o mercado de fundos de investimento que impactavam os retornos dos cotistas.

Assim como a definição dos fatores no caso do modelo de três fatores, a definição do quarto fator, momento, não estava relacionada com um fundamento econômico, e sim com a observação de um efeito que não era captado por outros modelos e por este motivo foi chamado de anomalia.

Para realizar seu estudo, Carhart (1997, p. 58) obteve dados dos fundos ainda abertos na Micropal/Investment Company Data, Inc. (ICDI), e os dados dos fundos já encerrados foram coletados na FundScope Magazine, United Babson Reports, Wiesenberger Investment Companies, Wall Street Journal e edições impressas anteriores da ICDI. Esta base, segundo o autor, englobava diversos fundos de ações com dados mensais para o período de janeiro de 1962 a dezembro de 1993, sendo livre do viés de sobrevivência, pois incluía todos os fundos já abertos para o período. O autor acredita que sua base era a maior e mais completa base de dados de fundos mútuos de investimento livre do viés de sobrevivência disponível.

"O modelo de quatro fatores é consistente com um modelo de equilíbrio de mercado de quatro fatores de risco" (CARHART, 1997, p. 61). Ainda, o modelo poderia ser interpretado como um modelo de avaliação de desempenho, no qual os coeficientes e os prêmios das carteiras indicavam a proporção do retorno médio atribuível a cada uma das quatro estratégias: retorno da carteira de mercado em relação ao ativo livre de risco, ações de empresas de tamanho pequeno contra empresas de tamanho grande, ações de empresa com alto índice $\mathrm{B} / \mathrm{M}$ contra baixo índice $\mathrm{B} / \mathrm{M}$ e ações "vencedoras" em relação a ações "perdedoras".

O modelo foi empregado pelo autor para explicar os retornos dos ativos. Sua formulação foi motivada pela falta de habilidade do modelo de três fatores em explicar as variações encontradas nas carteiras formuladas a partir do fator momento em Fama e French (1996a). Chan, Jegadeesh e Lakonishok (1996) sugeriram que o efeito momento era uma ineficiência de mercado que derivava de reações tardias do mercado a informações divulgadas. Porém, o efeito podia ser verificado em intervalos de tempo diferentes, conforme estratégias de Jegadeesh e Titman (1993) e Rouwehorst (1998; 1999) (CARHART, 1997, p. $61)$.

O modelo desenvolvido por Carhart (1997) é:

$$
R_{c(t)}-R_{(t)}=a+b\left[\operatorname{RMRF}_{(t)}\right]+s[\operatorname{SMB}(t)]+h\left[H M L_{(t)}\right]+w\left[\operatorname{WinMLos}_{(t)}\right]+e_{(t)}
$$


em que

$R_{c(t)}-R F_{(t)}=$ retorno de uma carteira em excesso à taxa livre de risco (Treasury) de um mês;

$R M R F_{(t)}=$ é o retorno da proxy da carteira de mercado menos o ativo livre de risco;

$S M B_{(t)}=$ retorno em uma carteira ponderada, de investimento zero, que compra ações de empresas pequenas e vende ações de empresas grandes;

$H M L_{(t)}=$ retorno em uma carteira ponderada, de investimento zero, que compra ações de empresas com alto índice B/M e vende ações de empresas com baixo índice B/M;

$\operatorname{WinMLos}_{(t)}=$ retorno em uma carteira ponderada, de investimento zero, que compra ações "ganhadoras" e vende ações "perdedoras";

$e_{(t)}=$ resíduo do modelo.

Os parâmetros $S M B_{(t)}$ e $H M L_{(t)}$ foram cedidos por Fama e French. Para construir o fator $\operatorname{WinMLos}_{(t)}$, os autores calcularam o retorno das ações durante onze meses, com um mês de defasagem do período de manutenção, ou seja, os retornos considerados para a formação das carteiras foram os do mês de janeiro do ano $t-1$ a novembro do ano $t-1$ (CARHART, 1997, p. 61). Após calcular os retornos acumulados no período $t-2$ a $t$-12, as ações foram ordenadas de forma crescente em função do retorno acumulado e separadas em três grupos: 30\% inferiores (Losers ou perdedoras), 40\% intermediarias (Medium) e 30\% superiores (Winners ou vencedoras). Os retornos mensais das carteiras ganhadoras e perdedoras são calculados a partir da média simples dos retornos das ações pertencentes a cada carteira e o fator $\operatorname{WinMLos}_{(t)}$ é finalmente calculado subtraindo o retorno mensal da carteira perdedora do retorno da carteira ganhadora.

Além deste modelo, Carhart (1997) utiliza outros dois: o modelo de três fatores de Fama e French (1993) e o modelo CAPM, utilizando como proxy para a carteira de mercado o excesso de retorno do índice CRSP ponderado, que contém todas as ações negociadas na NYSE, AMEX e NASDAQ.

A estatística descritiva dos fatores indica que o modelo de quatro fatores é capaz de explicar consideravelmente a variação dos retornos. Primeiramente, os fatores $S M B, H M L$ e WinMLos apresentam alta variância e baixa correlação entre si e com as carteiras proxy da carteira de mercado. Além disso, os altos retornos desses fatores sugerem que eles podem explicar as variações nos retornos das carteiras.

Em seguida, Carhart (1997) testa o poder de explicação dos modelos CAPM, três e 
quatro fatores em relação a carteiras formadas em função do retorno de um ano, conforme metodologia de Hendricks, Patel e Zeckhauser (1993).

Para calcular os retornos das carteiras usadas como variável dependente, o autor ordena em janeiro de cada ano $t$ o retorno dos fundos, calculado para o período de janeiro do ano $t-1$ a novembro do ano $t$ - 1 , e as divide em 10 grupos, formando assim dez carteiras, cujo retorno é calculado a partir da média aritmética dos retornos dos fundos pertencentes àquela carteira. Os retornos dos fundos são líquidos de todas as despesas operacionais e custos de transação. As carteiras são mantidas pelo período de um ano e depois reformuladas, repetindo-se os passos descritos. As carteiras foram reajustadas apropriadamente ao longo do ano, quando fundos desaparecem. Para obter mais detalhes, as carteiras 1 e 10 foram subdivididas em três outras carteiras.

Estas dez carteiras apresentam forte variação no retorno médio. O excesso de retorno mensal parece decrescer de forma constante. O spread entre as subcarteiras formadas das carteiras 1 e 10 é ainda maior: $0,12 \%$ e $0,50 \%$, respectivamente.

O modelo CAPM não é capaz de explicar o retorno dessas carteiras, e os betas das subcarteiras formadas das carteiras 1 e 10 são muito similares e próximos a 1, deixando muito da explicação dos retornos a cargo do intercepto.

Contudo, ao contrário do modelo CAPM, o modelo de quatro fatores explica a maior parte do spread entre as carteiras, sendo que os fatores mais relevantes foram SMB e WinMLos. A carteira 1 parece concentrar empresas pequenas, pois apresenta o coeficiente $S M B$ bem mais elevado que as demais carteiras. Além disso, os retornos das carteiras ganhadoras parecem estar positivamente correlacionados com o fator WinMLos, e os retornos das carteiras perdedoras parecem estar negativamente correlacionado com o fator.

Assim, o modelo de quatro fatores explica de forma satisfatória quase toda a variação em corte transversal do retorno esperado nas carteiras formadas a partir da ordenação dos fundos em função de seus retornos de um ano, sendo superior ao modelo CAPM e ao modelo de três fatores.

\subsubsection{Principais Estudos no Brasil}

Mussa, Santos e Famá (2007) investigam a validade do modelo de quatro fatores para o mercado acionário brasileiro. Foram utilizadas todas as ações listadas na BOVESPA no período de 1995 a 2006. A metodologia utilizada para investigação foi a regressão em série de 
tempo, conforme Fama e French (1993), e testou-se a significância estatística de cada fator a partir da estatística $t$ de Student, assim como a validade do modelo através da análise do coeficiente de determinação $\mathrm{R}^{2}$. Na análise realizada, os autores compararam os resultados obtidos com o modelo CAPM e com o modelo de três fatores de Fama e French (1993).

Os resultados indicaram que o modelo de quatro fatores se mostrou sempre superior ao modelo de três fatores, que por sua vez se mostrou sempre superior ao modelo CAPM, sendo que a média das diferenças foi de $4,6 \%$ e $19,4 \%$, respectivamente. O fator mercado se mostrou sempre significante, porém não foi suficiente para explicar as variações nos retornos das ações, necessitando, assim, do complemento dos fatores tamanho, índice B/M e momento para explicar os retornos, mesmo a correlação existente entre os fatores mercado e tamanho sendo de $-0,56$. A exclusão de qualquer fator provocou uma diminuição no poder explicativo dos modelos.

O autor ainda comenta que o fator tamanho possui coeficiente negativo, contrapondo os resultados encontrados por Fama e French (1993), mas corroborando os resultados encontrados por Málaga e Securato (2004), e parece explicar melhor as variações das carteiras pequenas. $\mathrm{O}$ fator momento apresentou coeficiente também negativo e, ao contrário dos resultados observados por Jegadeesh e Titman (1993), ele parece explicar melhor as variações das carteiras "perdedoras". Já o fator B/M possui coeficiente positivo e parece explicar melhor as variações das carteiras de alto índice $\mathrm{B} / \mathrm{M}$.

Mussa, Rogers e Securato (2009) testaram e compararam os modelos CAPM, três e quatro fatores a partir de metodologia preditiva, utilizando duas etapas - regressões em série de tempo e em corte transversal - conforme Fama e Macbeth (1973), utilizando todas as ações listadas na BOVESPA no período de 1995 a 2007. Para dar maior robustez à análise, foram considerados diferentes períodos within-sample e out-of-sample.

Os resultados obtidos indicam que nenhum dos três modelos foi capaz de explicar as variações dos retornos das ações para o mercado brasileiro, segundo os autores em virtude da alta significância dos interceptos. Contudo, o modelo de quatro fatores apresentou valores de $\mathrm{R}^{2}$ superiores ao modelo de três fatores, que, por sua vez, apresentou valores de $\mathrm{R}^{2}$ superiores ao modelo CAPM.

Quando considerado o modelo CAPM, o fator mercado não se mostrou significativo na explicação das variações dos retornos. Já nos modelos de três e quatro fatores, somente as variáveis mercado e índice $\mathrm{B} / \mathrm{M}$ foram estatisticamente significativas. Os fatores momento e tamanho não se mostraram significativos em nenhum dos modelos e períodos testados. Assim, os resultados sugerem a utilização de um modelo de dois fatores, composto pelos fatores 
mercado e índice B/M. Além disso, foram encontradas evidências da não linearidade do CAPM (MUSSA, ROGERS e SECURATO, 2009, p. 213). 


\section{Metodologia}

Neste capítulo serão descritos os procedimentos utilizados para realizar as análises dos modelos CAPM, três fatores de Fama e French (1993) e quatro fatores de Carhart (1997) no mercado brasileiro.

\subsection{O modelo de pesquisa}

O modelo mais utilizado para estimar a taxa de retorno esperada de um investimento é, de acordo com Raifur (2008, p. 135), o CAPM - Capital Asset Pricing Model, mesmo apresentando resultados não significantes estatisticamente, de acordo com alguns trabalhos empíricos anteriormente citados. Conforme detalhado no Capítulo 2, o CAPM é um modelo de equilíbrio que define que o retorno de um ativo é determinado pela taxa de retorno do ativo livre de risco adicionada ao prêmio da carteira de mercado ajustada pelo fator beta, o qual mede a sensibilidade do ativo em relação à carteira de mercado.

Os modelos utilizados no presente trabalho são: o CAPM, desenvolvido por Sharpe (1964), Lintner (1965) e Mossin (1966); o modelo de três fatores, desenvolvido por Fama e French (1993) e o modelo de quatro fatores, desenvolvido por Carhart (1997). Buscou-se comparar os três modelos a partir de metodologia de teste preditivo, que consiste na aplicação de regressão em dois estágios - série de tempo e corte transversal - a partir de técnica desenvolvida por Fama e Macbeth (1973).

De acordo com trabalho realizado por Carhart (1997) para o mercado norte-americano, o modelo de quatro fatores apresentou maior poder preditivo em relação ao modelo de três fatores e ao CAPM, sendo que os quatro coeficientes, mercado, tamanho, índice B/M e momento, foram estatisticamente significantes para o modelo. Fama e French (1993), por sua vez, encontraram evidência de que o modelo de três fatores era capaz de prever o retorno dos ativos, enquanto o modelo CAPM não explicava essa questão, e os três coeficientes utilizados, mercado, tamanho e índice B/M, mostravam-se estatisticamente significantes.

As expressões algébricas dos modelos comparados seguem na seguinte ordem: CAPM, três fatores e quatro fatores. 


$$
\begin{aligned}
& R_{c(t)}-R F_{(t)}=a+b\left[R M_{(t)}-R F_{(t)}\right]+e_{(t)} \\
& R_{c(t)}-R F_{(t)}=a+b\left[R M_{(t)}-R F_{(t)}\right]+s\left[S M B_{(t)}\right]+h\left[H M L_{(t)}\right]+e_{(t)} \\
& R_{c(t)}-R F_{(t)}=a+b\left[R M R F_{(t)}\right]+s\left[S M B_{(t)}\right]+h\left[H M L_{(t)}\right]+w\left[\operatorname{WinMLos}_{(t)}\right]+e_{(t)}
\end{aligned}
$$

em que

$R_{c(t)}-R F_{(t)}=$ retorno de uma carteira em excesso à taxa livre de risco de um mês;

$R M_{(t)}-R F_{(t)}=$ retorno da carteira de mercado em excesso à taxa livre de risco de um mês;

$S M B_{(t)}=$ retorno em uma carteira ponderada, de investimento zero, que compra ações de empresas pequenas e vende ações de empresas grandes;

$H M L_{(t)}=$ retorno em uma carteira ponderada, de investimento zero, que compra ações de empresas com alto índice B/M e vende ações de empresas com baixo índice B/M;

$\operatorname{WinMLos}_{(t)}=$ retorno em uma carteira ponderada, de investimento zero, que compra ações "ganhadoras" e vende ações "perdedoras";

$e_{(t)}=$ resíduo do modelo.

\subsection{Hipóteses formuladas}

No teste de hipótese, segundo Anderson et al. (2003, p. 319), o primeiro passo é fazer uma hipótese sobre um parâmetro da amostra. A hipótese que se quer testar é chamada hipótese nula e denotada $\mathrm{H}_{0}$. A hipótese alternativa, denotada de $\mathrm{H}_{\mathrm{A}}$, é exatamente o oposto da hipótese nula. Assim, o procedimento de teste de hipótese envolve o uso de dados amostrais para testar as declarações.

Há evidências de que o modelo de quatro fatores é superior ao de três fatores, que por sua vez é superior ao CAPM. Contudo, para que os modelos possam ser comparados, todos devem ser significantes na explicação dos retornos dos ativos. As seguintes hipóteses podem ser, portanto, formuladas:

$\mathrm{H}_{0,1}$ : o modelo CAPM não é significante na explicação dos retornos dos ativos brasileiros; $\mathrm{H}_{\mathrm{A}, 1}$ : o modelo CAPM é significante na explicação dos retornos dos ativos brasileiros; 
$\mathrm{H}_{0,2}$ : o modelo de três fatores não é significante na explicação dos retornos dos ativos brasileiros;

$\mathrm{H}_{\mathrm{A}, 2}$ : o modelo de três fatores é significante na explicação dos retornos dos ativos brasileiros;

$\mathrm{H}_{0,3}$ : o modelo de quatro fatores não é significante na explicação dos retornos dos ativos brasileiros;

$\mathrm{H}_{\mathrm{A}, 3}$ : o modelo de quatro fatores é significante na explicação dos retornos dos ativos brasileiros;

$\mathrm{H}_{0,4}$ : a variável carteira de mercado não é significante na explicação dos retornos dos ativos brasileiros;

$\mathrm{H}_{\mathrm{A}, 4}$ : a variável carteira de mercado é significante na explicação dos retornos dos ativos brasileiros;

$\mathrm{H}_{0,5}$ : uma ou mais variáveis no modelo de três fatores não são significantes na explicação dos retornos dos ativos brasileiros;

$\mathrm{H}_{\mathrm{A}, 5}$ : todas as variáveis no modelo de três fatores são significantes na explicação dos retornos dos ativos brasileiros;

$\mathrm{H}_{0,6}$ : uma ou mais variáveis no modelo de quatro fatores não são significantes na explicação dos retornos dos ativos brasileiros;

$\mathrm{H}_{\mathrm{A}, 6}$ : todas as variáveis no modelo de quatro fatores são significantes na explicação dos retornos dos ativos brasileiros.

Se não for possível rejeitar as hipóteses $\mathrm{H}_{0,4}, \mathrm{H}_{0,5}$ e $\mathrm{H}_{0,6}$, os modelos de quatro e três fatores, respectivamente, serão rejeitados, mesmo que eles sejam estatisticamente significantes na explicação dos retornos, ou seja, mesmo que seja possível rejeitar as hipóteses $\mathrm{H}_{0,1}, \mathrm{H}_{0,2}$ e $\mathrm{H}_{0,3}$.

Assim, foi possível formular as seguintes hipóteses:

$\mathrm{H}_{0,7}$ : o modelo de quatro fatores não é superior ao de três fatores na explicação dos retornos dos ativos brasileiros;

$\mathrm{H}_{\mathrm{A}, 7}$ : o modelo de quatro fatores é superior ao de três fatores na explicação dos retornos dos ativos brasileiros; 
$\mathrm{H}_{0,8}$ : o modelo de três fatores não é superior ao CAPM na explicação dos retornos dos ativos brasileiros;

$\mathrm{H}_{\mathrm{A}, 8}$ : o modelo de três fatores é superior ao CAPM na explicação dos retornos dos ativos brasileiros.

Além disso, como se utilizou o retorno das carteiras e dos fatores excluindo o ativo livre de risco, o intercepto deve ser estatisticamente não significante e os fatores devem ser capazes de explicar os retornos das carteiras. Se o intercepto for estatisticamente significante, isso indicaria que os modelos são insuficientes para a explicação dos retornos das carteiras e outros fatores, não especificados no modelo, devem ter poder explanatório sobre os retornos. Assim, é possível formular a seguinte hipótese:

$\mathrm{H}_{0,9}$ : o intercepto é estatisticamente significante e diferente de zero;

$\mathrm{H}_{\mathrm{A}, 9}$ : o intercepto não é estatisticamente significante e diferente de zero.

\subsection{Coleta dos dados}

Para a realização desta pesquisa, foram utilizados somente dados secundários, coletados no banco de dados Economática. Os dados usados foram:

- cotações mensais ajustadas a proventos e dividendos de todas as ações listadas na Bolsa de Valores de São Paulo - BOVESPA;

- cotações mensais sem ajuste de todas as ações listadas na Bolsa de Valores de São Paulo - BOVESPA;

- quantidade de ações Outstanding por classe de ação;

- valor do Patrimônio Líquido, por empresa;

- taxa de retorno mensal da Caderneta de Poupança.

Optou-se por utilizar o rendimento mensal da Caderneta de Poupança como taxa livre de risco, conforme recomendação de Silveira, Barros e Famá (2003). De acordo com esses autores, assim como a Caderneta de Poupança, o CDI (Certificado de Depósito Interbancário) 
também se adéqua ao conceito de taxa livre de risco, porém sua utilização necessita de um tratamento mais detalhado.

A amostra das ações utilizadas inicialmente continha todas as ações listadas na BOVESPA no período de junho de 1995 a junho de 2011. Utilizou-se este período de tempo em virtude da maior estabilidade econômica brasileira após o Plano Real, no ano de 1994.

A escolha do período de 15 anos foi influenciada pela metodologia adotada para teste dos modelos, que necessita de uma janela de tempo longa o suficiente para, na primeira etapa, estimar os betas por meio de regressão em série de tempo e, na segunda etapa, utilizar estes betas como variável independente em regressões com dados em corte transversal, mês a mês, no período subsequente ao utilizado na estimação dos betas.

Foram feitas as seguintes exclusões:

a. empresas financeiras, seguradoras e fundos, devido ao alto grau de endividamento, característico do setor. $\mathrm{O}$ alto endividamento poderia influenciar o índice $\mathrm{B} / \mathrm{M}$, além do fato de o endividamento em empresas financeiras ter um significado diferente do endividamento em empresas não financeiras;

b. ações que não apresentavam cotações mensais consecutivas para o período de 12 meses anteriores e 12 meses posteriores ao mês de junho, mês de formação das carteiras;

c. ações sem valor de mercado em dezembro e junho;

d. ações cujas empresas não possuíam patrimônio líquido positivo em dezembro.

Estas exclusões e ajustes foram realizados com o objetivo de gerar uma base que possibilitasse a formação das carteiras com número significante de ações, para que fosse possível obter resultados representativos do mercado brasileiro. Contudo, esta pesquisa não está livre do viés de sobrevivência, mesmo com a reformulação das carteiras a cada ano, no mês de junho, o que certamente atenua o viés. Do total de 1030 ações no período, 512 foram utilizadas na análise e 518 foram excluídas.

\subsection{Descrição das variáveis utilizadas}

Discute-se aqui a construção das variáveis dependentes e independentes que foram utilizadas nas regressões realizadas. 


\subsubsection{Variáveis Dependentes}

No presente trabalho foi utilizado o método de carteiras para teste dos modelos, conforme adotado por Fama e French (1993), Carhart (1997) e Mussa, Rogers e Securato (2009).

De acordo com Black et al. (1972, p. 8), agrupar os dados em carteiras pode ser uma solução para o problema dos erros não serem transversalmente independentes.

Formamos carteiras (ou grupos) dos títulos individuais e estimamos [a equação] definindo $\widetilde{R}_{K t}$ como o retorno médio de todos os ativos na carteira K para o período t. Dada esta definição de $\tilde{R}_{K t}, \hat{\beta}_{K}$ será o risco médio dos títulos na carteira e $\hat{\alpha}_{K}$ será o intercepto médio. Além disso, uma vez que a variância residual irá incorporar os efeitos de qualquer interdependência transversal no resíduo $\tilde{e}_{j t}$ entre os títulos em cada carteira, o erro padrão de $\hat{\alpha}_{K}$ irá incorporar adequadamente a não independência de $\tilde{e}_{j t}$. (BLACK et al, 1972, p. 8)

Em junho de cada ano $t$, todas as empresas são ordenadas de forma crescente a partir do tamanho de mercado, que corresponde ao preço de sua ação, ordinária e preferencial, multiplicado pela respectiva quantidade da classe. A mediana foi utilizada para separar a amostra em dois grupos: das empresas pequenas, chamado de Small e das empresas grandes, chamado de Big.

Para chegar ao valor de mercado da empresa, somou-se o valor de mercado das classes de ações. Caso a empresa não tenha apresentado valor de mercado para alguma das classes, considerou-se o mesmo valor da outra classe. Assim, se a empresa apresentou cotações mensais para a ação preferencial, mas não para a ação ordinária, foi considerado o mesmo valor da ação preferencial para a ação ordinária.

$$
V M_{i, t}=\sum P_{y, i, t} * N_{y, i, t}
$$

em que

$V M_{i, t}=$ valor de mercado total da empresa $i$ em junho do ano $t$;

$P_{y, i, t}=$ preço da classe $y$ da empresa $i$ em junho do ano $t$;

$N_{y, i, t}=$ número de ações da classe $y$ da empresa $i$ em junho do ano $t$.

No mesmo mês de junho de cada ano $t$, as ações são ordenadas de forma crescente de acordo com o índice book-to-market (B/M), ou valor contábil das ações dividido pelo seu 
valor de mercado. A amostra é separada em três grupos: 30\% superiores (Low), 40\% intermediárias (Medium) e 30\% inferiores (High).

Para cálculo do índice $\mathrm{B} / \mathrm{M}$, foram empregados os dados de dezembro de $t-1$ e foi considerado como valor contábil o valor do patrimônio líquido, conforme metodologia de Fama e French (1993), adaptada por Málaga (2003) e Mussa, Rogers e Securato (2009).

$$
B / M_{i, t}=\frac{V C_{i, P L, d e z}(t-1)}{V M_{i, d e z}(t-1)}
$$

em que

$B / M_{i, t}=$ índice book-to-market da empresa $i$ em dezembro do ano $t$ - 1 ;

$V C_{i, P L, d e z(t-1)}=$ valor contábil do Patrimônio Líquido em dezembro do ano $t$ - 1 ;

$V M_{i, \operatorname{dez}(t-1)}=$ valor de mercado do Patrimônio Líquido, que equivale ao valor da empresa em dezembro do ano $t-1$.

Também no mês de junho de cada ano $t$ os retornos mensais dos períodos entre $t-12 \mathrm{e}$ $t$-2 foram acumulados, ou seja, utilizaram-se os retornos de junho de $t-1$ a abril de $t$. As ações foram ordenadas em ordem crescente de acordo com este retorno acumulado do período de junho de $t-1$ a abril de $t$ e foi utilizada a mediana para separá-las em dois grupos: 50\% inferiores, chamado de Loser, grupo das empresas que apresentaram desempenho ruim e os $50 \%$ superiores, chamado de Winner, das que apresentaram desempenho bom.

$$
D_{y, i, t}=\left[\left(\mathbf{1}+\boldsymbol{R}_{y, i, m-12}\right) * \ldots *\left(\mathbf{1}+\boldsymbol{R}_{y, i, m-2}\right)\right]-\mathbf{1}
$$

em que

$D_{y, i, t}=$ desempenho acumulado ação $y$ da empresa $i$ em junho do ano $t$; $R_{y, i, m}=$ retorno obtido na ação $y$ da empresa $i$ para o mês $m$.

Assim, foram formadas doze carteiras a partir da interseção das três classificações, e estas carteiras são utilizadas como variável dependente nas análises. No mês de junho de cada ano, entre os anos de 1996 e 2010, este processo é repetido e cada carteira é reformulada. É importante observar que cada carteira é formada por uma quantidade diferente de ações, uma vez que as classificações são independentes. 
A Tabela 3 resume as carteiras formadas a partir do processo descrito.

Tabela 3 - Carteiras formadas a partir dos fatores tamanho, índice B/M e momento, utilizadas na análise como variável dependente

\begin{tabular}{|l|l|}
\hline \multicolumn{1}{|c|}{ Carteira } & \multicolumn{1}{c|}{ Descrição } \\
\hline Big/High/Loser - BHL & $\begin{array}{l}\text { ações de empresas com valor de mercado e índice B/M } \\
\text { alto e que apresentaram desempenho ruim }\end{array}$ \\
\hline Big/High/Winner - BHW & $\begin{array}{l}\text { ações de empresas com valor de mercado e índice B/M } \\
\text { alto e que apresentaram desempenho bom }\end{array}$ \\
\hline Big/Low/Loser - BLL & $\begin{array}{l}\text { ações de empresas com valor de mercado alto, índice } \\
\text { B/M baixo e que apresentaram desempenho ruim }\end{array}$ \\
\hline Big/Low/Winner - BLW & $\begin{array}{l}\text { ações de empresas com valor de mercado alto, índice } \\
\text { B/M baixo e que apresentaram desempenho bom }\end{array}$ \\
\hline Big/Medium/Loser - BML & $\begin{array}{l}\text { ações de empresas com valor de mercado alto, índice } \\
\text { B/M intermediário e que apresentaram desempenho ruim }\end{array}$ \\
\hline $\begin{array}{l}\text { Big/Medium/Winner } \\
\text { BMW }\end{array}$ & $\begin{array}{l}\text { ações de empresas com valor de mercado alto, índice } \\
\text { B/M intermediário e que apresentaram desempenho bom }\end{array}$ \\
\hline Small/High/Loser - SHL & $\begin{array}{l}\text { ações de empresas com valor de mercado baixo, índice } \\
\text { B/M alto e que apresentaram desempenho ruim }\end{array}$ \\
\hline Small /High/Winner - SHW & $\begin{array}{l}\text { ações de empresas com valor de mercado baixo, índice } \\
\text { B/M alto e que apresentaram desempenho bom }\end{array}$ \\
\hline Small /Low/Loser - SLL & $\begin{array}{l}\text { ações de empresas com valor de mercado e índice B/M } \\
\text { baixos e que apresentaram desempenho ruim }\end{array}$ \\
\hline Small /Low/Winner - SLW & $\begin{array}{l}\text { ações de empresas com valor de mercado e índice B/M } \\
\text { baixos e que apresentaram desempenho bom }\end{array}$ \\
\hline $\begin{array}{l}\text { Small /Medium/Loser }- \\
\text { SML }\end{array}$ & $\begin{array}{l}\text { ações de empresas com valor de mercado baixo, índice } \\
\text { B/M intermediário e que apresentaram desempenho ruim }\end{array}$ \\
\hline $\begin{array}{l}\text { Small /Medium/Winner - } \\
\text { SMW }\end{array}$ & $\begin{array}{l}\text { ações de empresas com valor de mercado baixo, índice } \\
\text { B/M intermediário e que apresentaram desempenho bom }\end{array}$ \\
\hline
\end{tabular}

Para exemplificar o processo de construção das carteiras, montou-se a Figura 1, que mostra como as carteiras foram construídas em junho de 1997. Este mesmo processo foi repetido todos os anos até junho de 2010. 
Figura 1 - Processo de Construção das Carteiras

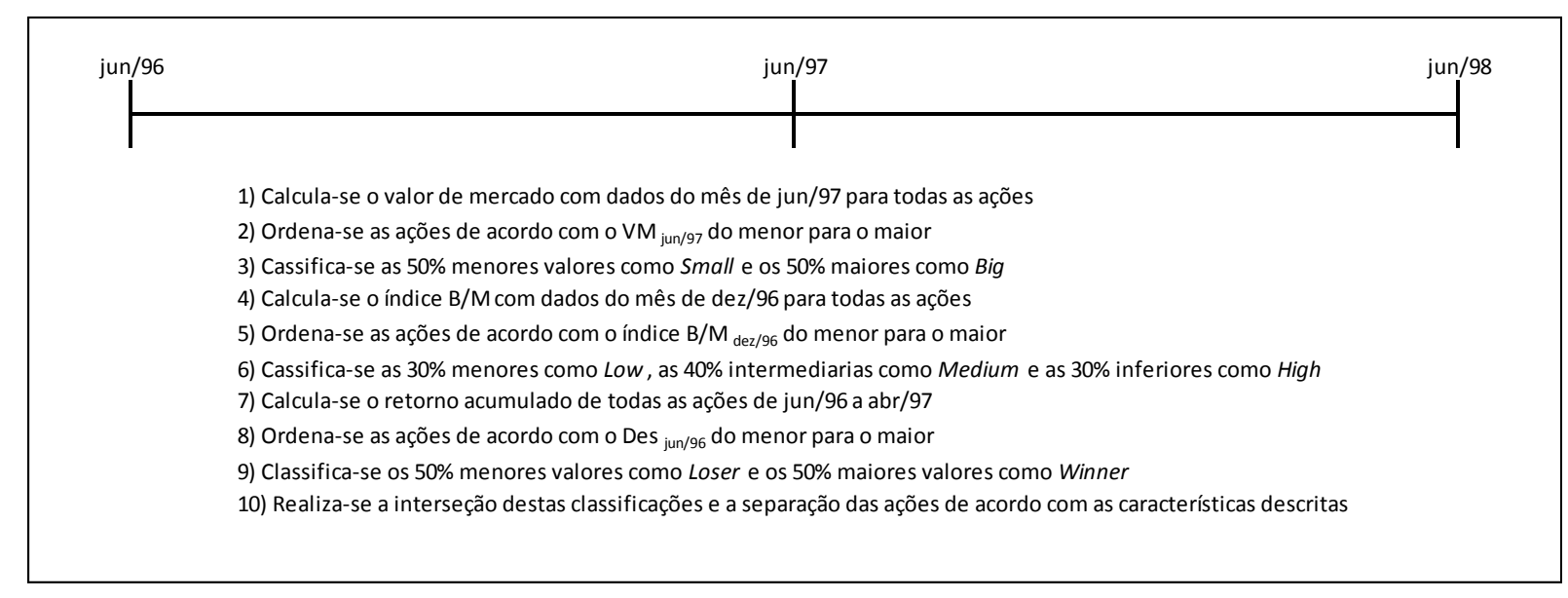

Os retornos das ações foram calculados para todo o período de acordo com Málaga (2003) e Mussa, Rogers e Securato (2009):

$$
R_{y, i, m}=\frac{D i v_{y, i, m}}{P_{y, i, m-1}}+\frac{P_{y, i, m}}{P_{y, i, m-1}}
$$

em que

$R_{y, i, m}=$ retorno obtido na ação $y$ da empresa $i$ para o mês $m$;

$D i v_{y, i, m}=$ dividendo da ação $y$ da empresa $i$ distribuído durante o período $m$;

$P_{y, i, m}=$ preço da ação $y$ da empresa $i$ no fim do período $m$;

$P_{y, i, m-1}=$ preço da ação $y$ da empresa $i$ no fim do período $m-1$.

Como é possível obter na base Economática as cotações das ações já ajustadas a dividendos, bonificações, desdobramentos, redução de capital, grupamentos, subscrição e cisão, os retornos foram calculados mensalmente de acordo com a equação 3.8.

(3.8) $\quad \boldsymbol{R}_{\boldsymbol{y}, i, m}=\frac{\boldsymbol{P}_{y, i, m}}{\boldsymbol{P}_{y, i, m-1}}-\mathbf{1}$

em que

$R_{y, i, m}=$ retorno obtido na ação $y$ da empresa $i$ para o mês $m$; 
$P_{y, i, m}=$ preço de fechamento da ação $y$ ajustado para proventos e subscrições no fim do período $m$;

$P_{y, i, m-1}=$ preço de fechamento da ação $y$ ajustado para proventos e subscrições no fim do período $m-1$.

Os excessos dos retornos das carteiras são obtidos ponderando-se os retornos das ações pelo valor de mercado da classe da ação em relação ao valor de mercado da carteira, menos os retornos do ativo livre de risco. De acordo com Silveira, Barros e Famá (2003), ambas as taxas do CDI (Certificado de Depósito Interbancário) e a Caderneta de Poupança se adéquam ao conceito de taxa livre de risco. Contudo, a utilização da série do CDI necessita de um tratamento estatístico mais detalhado. Assim, decidiu-se utilizar o rendimento mensal do último dia útil do mês da Caderneta de Poupança como proxy da taxa livre de risco.

$$
R_{c, m}=\left(\sum_{i=1}^{n} \frac{V M_{y, m}}{V M_{c, m}} * R_{y, i, m}\right)-R_{L R}
$$

em que

$R_{c, m}=$ retorno da carteira $c$ no mês $m$;

$V M_{y, m}=$ valor de mercado da ação $y$ no mês $m$;

$V M_{c, m}=$ valor de mercado da carteira $c$ no mês $m$;

$R_{y, i, m}=$ retorno obtido na ação $y$ da empresa $i$ para o mês $m$;

$R_{L R}=$ retorno do ativo livre de risco.

\subsubsection{Variáveis Independentes}

As variáveis independentes utilizadas nas análises foram a carteira de mercado, o fator tamanho, o fator índice B/M e o fator momento.

Adotou-se o retorno de todas as ações da amostra, ponderadas pelo valor de mercado de cada ação para aquele ano, menos o rendimento mensal da Caderneta de Poupança como proxy do fator de risco de mercado, em vez de adotar um índice existente no mercado, como o Índice Bovespa. O Índice Bovespa é o indicador mais importante de desempenho médio do mercado de ações brasileiro. Contudo, sua composição e ponderação são baseadas no volume negociado das ações e não nas características da economia brasileira, conforme sugeriu 
Sharpe (1964).

(3.10) $M k t_{m}=\left(\sum_{i=1}^{n} \frac{V M_{i, m}}{V M_{M, m}} * R_{y, i, m}\right)-R_{L R}$

sendo que

(3.11) $V M_{M, m}=\sum_{i=1}^{n} V M_{i, m}$

em que

$M k t_{m}=$ Fator de Risco de Mercado;

$V M_{i, m}=$ valor de mercado da ação $i$ no mês $m$;

$V M_{M, m}=$ valor de mercado da Carteira de Mercado no mês $m$;

$R_{y, i, m}=$ retorno obtido na ação $y$ da empresa $i$ para o mês $m$;

$R_{L R}=$ retorno do ativo livre de risco.

O prêmio pelo Fator Tamanho foi obtido a partir da diferença da média simples dos retornos mensais das carteiras Small e das Big.

(3.12) $\boldsymbol{S M} \boldsymbol{B}_{\boldsymbol{m}}=\overline{\boldsymbol{R}}_{\boldsymbol{S}, \boldsymbol{m}}-\overline{\boldsymbol{R}}_{\boldsymbol{B}, \boldsymbol{m}}$

em que

$S M B_{m}=$ prêmio pelo Fator Tamanho no mês $m$;

$\bar{R}_{S, m}=\frac{S H L_{m}+S H W_{m}+S L L_{m}+S L W_{m}+S M L_{m}+S M W_{m}}{6}=$ retorno médio das carteiras Small no mês $m$;

$\bar{R}_{S, m}=\frac{B H L_{m}+B H W_{m}+B L L_{m}+B L W_{m}+B M L_{m}+B M W_{m}}{6}=$ retorno médio das carteiras Big no mês $m$.

Fama e French $(1992 ; 1993)$ identificaram em seus trabalhos que empresas menores ofereciam retornos superiores, mesmo quando ajustados ao risco, e, se este efeito fosse adicionado ao modelo CAPM, ajudaria a explicar os retornos dos ativos. Apesar de não existir uma explicação clara para o efeito tamanho, Banz (1981) levantou a hipótese de que este efeito poderia ser explicado pela falta de informação a respeito das empresas menores, o que faria com que os investidores desejassem um prêmio maior para manter esta ação na carteira, o que se refletiria num maior retorno esperado. Outra hipótese levantada por Fama e French 
(1992) para o efeito tamanho foi que empresas menores têm maiores perspectivas de crescimento, por isso ofereceriam um retorno esperado maior.

O prêmio pelo Fator Índice B/M foi alcançado a partir da diferença da média simples dos retornos mensais das carteiras High e das Low.

(3.13) $H M L_{m}=\bar{R}_{H, m}-\bar{R}_{L, m}$

em que

$H M L_{m}=$ prêmio pelo Fator Índice $\mathrm{B} / \mathrm{M}$ no mês $m$;

$\bar{R}_{H, m}=\frac{S H L_{m}+S H W_{m}+B H L_{m}+B H W_{m}}{4}=$ retorno médio das carteiras High no mês $m$;

$\bar{R}_{L, m}=\frac{S L L_{m}+S L W_{m}+B L L_{m}+B L W_{m}}{4}=$ retorno médio das carteiras Low no mês $m$.

De acordo com Fama e French (1992, p. 427), empresas de índice B/M alto oferecem retorno superior em relação a empresas de baixo índice B/M. Os autores explicaram que empresas que os agentes de mercado julgam ter perspectivas pobres estão associadas a um baixo valor de mercado (ou alto índice B/M) e possuem um alto custo de capital em relação a empresas com boas perspectivas (ou baixo índice B/M).

Já o prêmio pelo Fator Momento foi calculado a partir da diferença da média simples dos retornos mensais das carteiras Winner e das Loser.

(3.14) $\operatorname{WinMLos}_{m}=\overline{\boldsymbol{R}}_{\text {Win,m }}-\overline{\boldsymbol{R}}_{\text {Los,m }}$

em que

WinMLos ${ }_{m}=$ prêmio pelo Fator Momento no mês $m$;

$\bar{R}_{W i n, m}=\frac{B H W_{m}+B L W_{m}+B M W_{m}+S H W_{m}+S L W_{m}+S M W_{m}}{6}=$ retorno médio das carteiras Winner no mês $m$;

$\bar{R}_{L o s, m}=\frac{B H L_{m}+B L L_{m}+B M L_{m}+S H L_{m}+S L L_{m}+S M L_{m}}{6}=$ retorno médio das carteiras Loser no mês $m$.

De acordo com Jegadeesh e Titman (1993), estratégias que compram ações que apresentaram melhor desempenho em um ano e vendem ações que apresentaram pior desempenho em um ano, as chamadas estratégias de relative strength, são capazes de explicar parte das variações dos retornos das ações não explicadas pelo modelo de três fatores (FAMA 
e FRENCH, 1996). Assim, ao inserir este fator no modelo de três fatores, seria possível explicar um efeito existente no mercado e que não era captado pelo modelo.

\subsection{Processamento e análise dos dados}

Foram utilizados os softwares Microsoft Office Excel e SPSS versão 19 para análise e processamento dos dados. Hair et al. (2009, p. 163) comentaram que a regressão múltipla é uma das técnicas de análise multivariada mais usadas, possuindo ampla aplicabilidade. De acordo com os autores, sua aplicação recai sobre duas grandes classes de problemas de pesquisa: previsão e explicação.

Previsão envolve o quanto que uma variável estatística de regressão (...) pode prever da variável dependente. Explicação examina os coeficientes de regressão (...) para cada variável independente e tenta desenvolver uma razão substantiva ou teórica para os efeitos das variáveis independentes. (HAIR et al., 2009, p. 163)

Na classe de problemas que envolvem previsão, ainda de acordo com os autores, o objetivo da regressão múltipla é prever a variável dependente a partir das variáveis independentes. Assim, a precisão preditiva do modelo é crucial. Pode ainda comparar dois ou mais conjuntos de variáveis independentes e examinar o poder preditivo de cada variável.

Já nos problemas cujo objetivo é a explicação da variável dependente, a regressão fornece uma forma de avaliar o grau e caráter da relação entre a variável dependente e as independentes, além da magnitude, sinal e significância estatística.

O presente trabalho tem por objetivo principal testar os modelos CAPM, três e quatro fatores a partir de metodologia de teste preditivo, que aplica regressão em dois estágios a partir de técnica desenvolvida por Fama e Macbeth (1973).

Contudo, foi proposto nos objetivos específicos testar os modelos também a partir de regressões em séries temporais, utilizando o período completo, de junho de 1996 a junho de 2011, com a finalidade de observar a sensibilidade dos retornos das carteiras em relação a cada fator, além de comparar os resultados com os obtidos por Málaga e Securato (2004) e Mussa, Santos e Famá (2007), que adotam esta metodologia de teste. 


\subsubsection{Análise de Observações Influentes}

A análise de observações influentes tem como objetivo encontrar observações que estão fora dos padrões gerais do conjunto de dados e que influenciam fortemente os resultados das regressões (HAIR et al, 2009, p. 185). Estas observações não são necessariamente ruins para a análise, pois mostram a diversidade do conjunto de dados. Entretanto, seu impacto deve ser analisado antes de considerá-las na análise.

Segundo Wooldridge (2010, p. 306), observações influentes são aquelas que, se eliminadas, alteram as estimativas dos coeficientes. O método de mínimos quadrados ordinários é muito influenciado por observações extremas, por minimizar a soma dos quadrados dos resíduos. Assim, grandes resíduos recebem muito peso no processo de minimização.

Hair et al. (2009, p. 187) recomendaram "eliminar observações verdadeiramente excepcionais, mas ainda assim evitar a eliminação daquelas que, apesar de diferentes, são representativas da população". Para análise dos possíveis pontos influentes, será utilizada análise da distância de Cook.

A distância de Cook foi desenvolvida por Denis Cook $(1977$; 1979) e tem como objetivo analisar a influência de determinado ponto em uma estimativa de mínimos quadrados. A medida avalia o efeito nos coeficientes estimados pelo método de mínimos quadrados, se cada ponto for excluído.

A distância é medida a partir da diferença entre a variável dependente estimada com todos os dados e a variável dependente estimada, excluindo-se a observação em questão, de acordo com a equação 3.15 .

(3.15) $D_{i}=\frac{\sum_{j=1}^{n}\left(\widehat{Y}_{j}-\widehat{Y}_{j-i}\right)^{2}}{p * M S E}$

em que

$D_{i}=$ distância de Cook;

$\hat{Y}_{j}=$ variável dependente estimada com todos os dados;

$\widehat{Y}_{j-i}=$ variável dependente estimada excluindo a observação $i$;

$p=$ número de coeficientes estimados;

$M S E=\frac{\sum e^{2}}{n-p}=$ média dos erros ao quadrado. 
De acordo com Bollen e Jackman (1990), deve-se utilizar o valor de 4/n para detectar pontos de grande influência. Considerando todos os meses da amostra, o $n$ é igual a 180 dados, ou seja, observações que apresentem distância superior a 0,022 devem ser consideradas influentes na estimativa dos parâmetros.

\subsubsection{Regressão em Série Temporal}

Os modelos serão analisados, primeiramente, por meio de regressões em série de tempo calculadas utilizando dados de todo o período amostral.

De acordo com Fama e French (1993, p. 4), as regressões em série de tempo são importantes para analisar duas características dos modelos: 1) se os ativos são precificados de forma racional, eles devem apresentar sensibilidade às variáveis relacionadas aos retornos médios, como o tamanho e o índice B/M; e 2) como é utilizado o excesso de retorno na variável dependente e nas independentes em cada modelo, o intercepto deve ser estatisticamente igual a zero.

Assim, analisou-se a validade dos modelos a partir dos coeficientes de determinação $\left(\mathrm{R}^{2}\right)$ e do teste $t$ de Student de significância de cada coeficiente nos modelos CAPM, três e quatro fatores.

De acordo com Wooldridge (2010, p. 113), o teste $t$ de Student é um procedimento pelo qual se testam hipóteses sobre um parâmetro da população a partir da amostra e utiliza-se de inferência estatística para testar estas hipóteses. O teste $t$ permite que seja analisado se um coeficiente obtido com a regressão é igual a zero. Esta hipótese é chamada de hipótese nula. A hipótese contrária, ou seja, que o coeficiente é diferente de zero, recebe o nome de hipótese alternativa. O teste corresponde a uma hipótese bilateral e o objetivo do teste de hipótese é rejeitar a hipótese nula:

$$
\begin{aligned}
& H_{0}: \beta_{j}=0 \\
& H_{A}: \beta_{j} \neq 0
\end{aligned}
$$

Para realizar o teste é necessário calcular a estatística $t$, ou a razão $t$ e esta é comparada ao valor $t$ crítico, que corresponde a um nível de confiança, normalmente de $90 \%, 95 \%$ ou 99\%, e ao número de Graus de Liberdade (quantidade de dados na amostra menos um). Este 
valor $t$ crítico é obtido na Tabela de Valores Críticos da Distribuição $t$. A estatística $t$ é encontrada a partir da expressão:

(3.16) $\boldsymbol{t}_{\widehat{\boldsymbol{\beta}}_{j}}=\frac{\widehat{\boldsymbol{\beta}}_{j}}{\boldsymbol{e p}\left(\widehat{\boldsymbol{\beta}}_{j}\right)}$

em que

$t_{\widehat{\beta}_{j}}=$ estatística $t$ da variável independente $j$;

$\hat{\beta}_{j}=$ coeficiente calculado a partir da regressão correspondente à variável independente $j$;

$\operatorname{ep}\left(\hat{\beta}_{j}\right)=\frac{\frac{\sum_{i=1}^{n}\left(Y_{i}-\widehat{Y}_{i}\right)^{2}}{n-2}}{\sum_{i=1}^{n}\left(X_{i}-\bar{X}\right)^{2}}=$ erro padrão do coeficiente angular estimado.

Segundo Wooldridge (2010, p. 120), quando a alternativa é bilateral, o que interessa é o valor absoluto da estatística $t$, independentemente de se o coeficiente seria positivo ou negativo. Assim, compara-se a estatística $t$ obtida com o $t$ crítico. No caso da Figura 2, utilizou-se nível de confiança igual a 95\%, e o $t$ crítico dependerá do tamanho da amostra.

Figura 2 - Intervalo de Confiança e Região de Rejeição da Hipótese Nula Bilateral

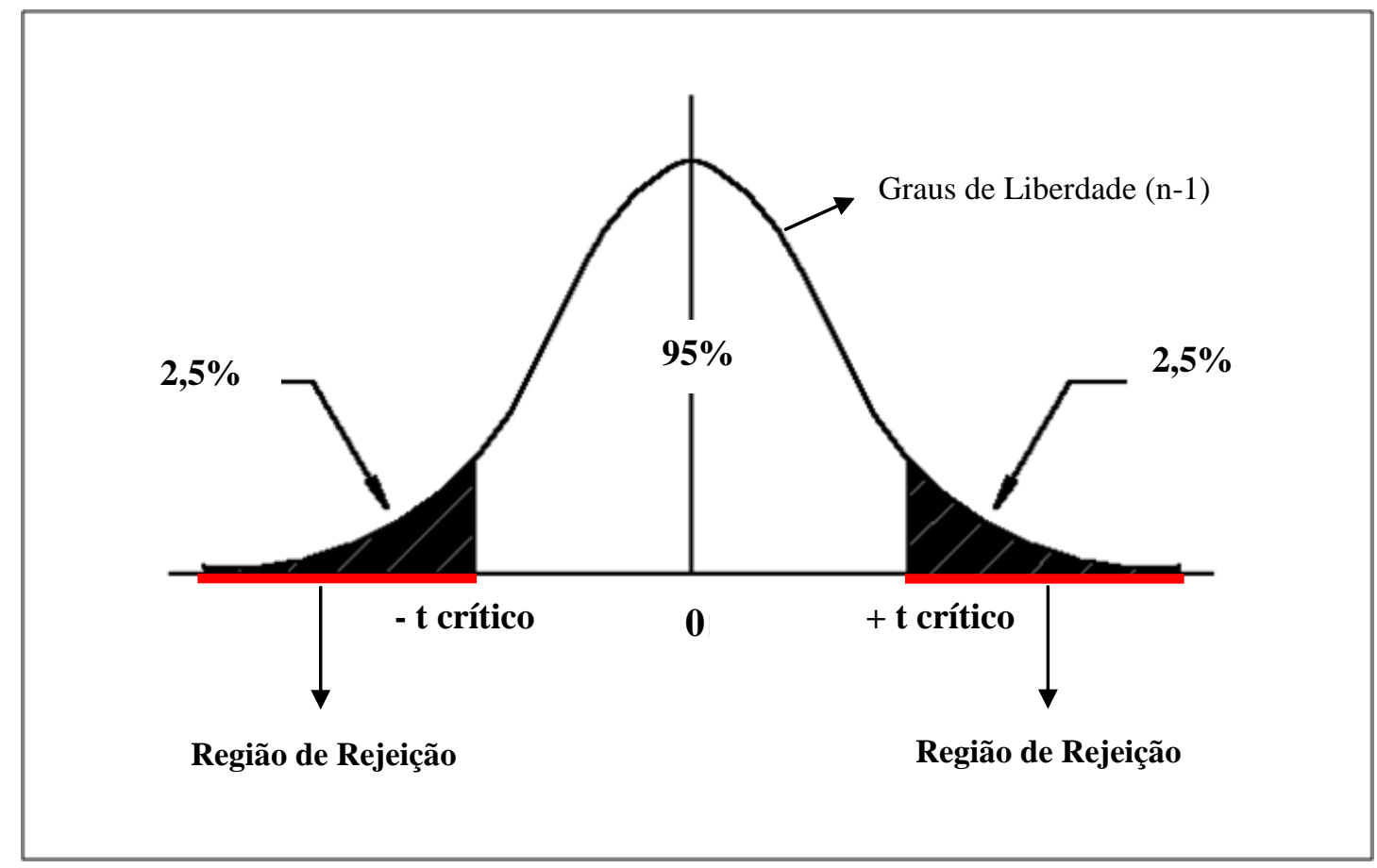

Fonte: Adaptado de Wooldridge (2010, p. 121)

Se a estatística $t$ fosse inferior ao t crítico, ela se encontraria na região branca da Figura 2, o que não permitiria rejeitar a hipótese nula de que o coeficiente é estatisticamente 
igual a zero. Contudo, se a estatística $t$ fosse maior do que o $t$ crítico, ela estaria na região escura de rejeição, e a hipótese nula seria rejeitada. Consequentemente, seria aceita a hipótese alternativa de que o coeficiente é estatisticamente diferente de zero.

\subsubsection{Regressão em Duas Etapas}

No teste preditivo com regressão em dois estágios, o primeiro envolve a utilização de regressões em séries temporais para estimar as sensibilidades dos fatores de risco do modelo em relação aos prêmios pelo risco das carteiras. No segundo, essas sensibilidades estimadas são usadas como variáveis independentes nas regressões em corte transversal, para obter os prêmios pelo risco.

Fama e Macbeth (1973, p. 618) comentam que esta metodologia é preditiva no sentido de estimar os coeficientes, utilizando dados anteriores ao período testado.

Para melhor entender o procedimento de regressão em dois estágios, foi elaborada a Figura 3.

Figura 3 - Regressão em Dois Estágios

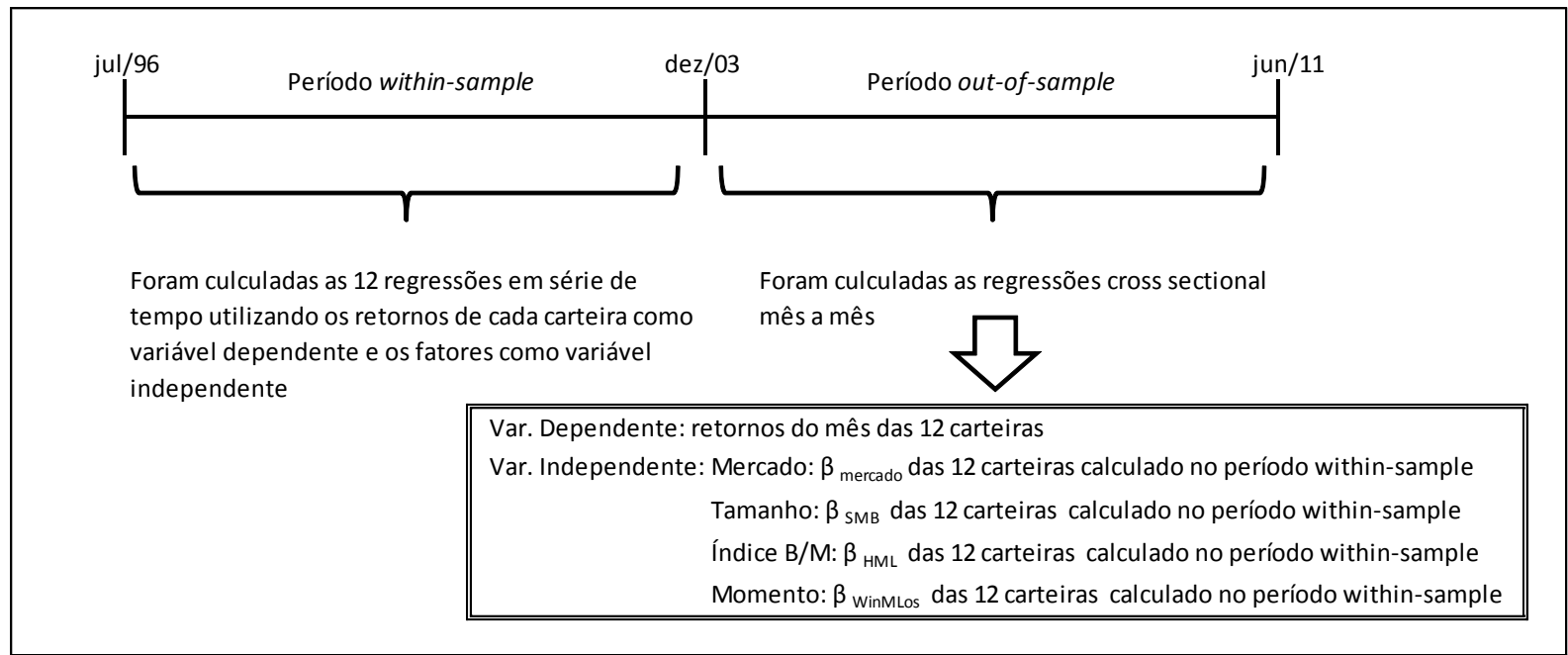

A metodologia de regressão em dois estágios exige a subdivisão da amostra em dois períodos. A primeira etapa, ou estágio, em que os betas são estimados por meio de regressões em séries temporais é chamada de dentro-da-amostra, do inglês within-sample. A segunda etapa, em que o modelo é testado, é chamada de fora-da-amostra, do inglês out-of-sample.

Propõe-se dividir a amostra da mesma forma realizada por Mussa, Rogers e Securato (2009, p. 201): “o ponto de corte em 2001 pautou-se, principalmente, no balanceamento do número de observações entre as amostras”. Igualmente, seguindo o mesmo princípio de 
balanceamento do número de observações na amostra, o presente trabalho definiu como ponto de corte o ano de 2004: o período within-sample compreende de julho de 1996 a dezembro de 2003, enquanto o período out-of-sample compreende de janeiro de 2004 a junho de 2011.

Assim como Mussa, Rogers e Securato (2009) e Bellizia (2009), para minimizar possíveis vieses amostrais em virtude do período definido, além de aumentar a robustez das análises, serão utilizados os seguintes pontos de corte para a definição do período withinsample: julho de 1996 a dezembro de 2002, julho de 1996 a junho de 2003, julho de 1996 a junho de 2004 e julho de 1996 a dezembro de 2004.

Definidos os períodos within-sample e out-of-sample, iniciam-se os cálculos da primeira etapa, que consiste na estimação dos betas de cada carteira em relação aos fatores risco mercado, tamanho, índice B/M e momento, a partir de regressão em série de tempo, conforme detalhado no item 3.5.2. Ressalta-se que os betas foram recalculados anualmente, incorporando o ano subsequente. Assim, para o cálculo das regressões mensais no ano de 2004 foi utilizado beta calculado com os dados de julho de 1996 a dezembro de 2003. Já para as regressões mensais no ano de 2005 foram utilizados betas calculados com os dados de julho de 1996 a dezembro de 2004, conforme procedimento de Fama e Macbeth (1973, p. $615)$.

Para calcular os testes de hipótese dos coeficientes das regressões em corte transversal, foi utilizada técnica de Fama e Macbeth (1973) no cálculo dos erros padrões. Uma vez que o verdadeiro beta não é observável, o método de Mínimos Quadrados Ordinários (MQO) estima o verdadeiro beta a partir de uma amostra de dados. Mesmo que esta estimativa seja não viesada, ela estará sujeita a erros de amostragem, o que faria com que os coeficientes calculados nas regressões em corte transversal fossem viesados para baixo, com o intercepto para cima.

Assim, Fama e Macbeth (1973) sugerem duas formas de diminuir o erro amostral e a correlação entre os resíduos da equação: a primeira é calcular os betas de carteiras e não de títulos individuais, e a segunda é estimar coeficientes a partir de $n$ regressões em cortes transversais mensais e usar o valor médio destes coeficientes em equação em corte transversal de todo o período. A segunda recomendação ficou conhecida como técnica de Fama e Macbeth (1973).

Para calcular a estatística t do teste de significância de cada coeficiente, ou seja, se o coeficiente é igual a zero, utiliza-se a seguinte equação: 
(3.17) $t\left(\overline{\widehat{\gamma}}_{J}\right)=\frac{\bar{\gamma}_{J}}{s\left(\widehat{\gamma}_{j}\right) / \sqrt{n}}$

em que

$\overline{\hat{\gamma}}_{J}=$ média aritmética dos coeficientes mensais;

$s\left(\hat{\gamma}_{j}\right)=$ desvio padrão dos coeficientes mensais;

$n=$ número de meses no período.

A regra de rejeição da hipótese nula é a mesma explicada na subseção 3.5.2: se a estatística $t$ for maior do que o $t$ crítico, definido a partir do nível de confiança e dos Graus de Liberdade, rejeita-se a hipótese nula de que o coeficiente é estatisticamente igual a zero e aceita-se a hipótese alternativa, de que o coeficiente é estatisticamente diferente de zero.

Ao se estimar as equações para cada mês, é possível examinar como os parâmetros variam no tempo, e reduzir possível correlação serial entre o risco residual e o "verdadeiro beta". (MUSSA, ROGERS e SECURATO, 2009, p. 205)

\subsubsection{Comparação dos Modelos}

Os modelos CAPM, três fatores e quatro fatores foram comparados a partir do coeficiente de determinação ajustado, conforme Mussa, Rogers e Securato (2009).

\footnotetext{
...o coeficiente múltiplo de determinação pode ser interpretado como a porção da variabilidade na variável dependente que pode ser explicada pela equação de regressão múltipla estimada. Dessa forma, quando ele é multiplicado por 100, pode ser interpretado como a porcentagem de variação em y que pode ser explicada pela equação de regressão estimada. (ANDERSON et al., 2003, p. 490)
}

O coeficiente de determinação pode ser obtido a partir da seguinte equação:

(3.18) $R^{2}=1-\frac{S Q R}{S T Q}$

em que

$R^{2}=$ coeficiente de determinação;

$S Q R=$ soma dos quadrados da regressão; 
$S T Q=$ soma total dos quadrados, obtida a partir do somatório da soma dos quadrados da regressão e da soma dos quadrados dos erros.

O coeficiente de determinação ajustado é um tipo de medida de eficiência do modelo testado, assim como o coeficiente de determinação, mas que leva em consideração a quantidade de variáveis independentes incluídas na regressão e o tamanho da amostra.

Segundo Wooldridge (2010, p. 77), o coeficiente de determinação nunca diminui à medida que outras variáveis independentes são adicionadas ao modelo. Assim, mesmo que a adição de uma variável independente contribua muito pouco para a explicação da variável dependente, o coeficiente irá aumentar, dando a impressão que o modelo está melhor, sendo que, na verdade, continua com o mesmo poder preditivo.

Por esse motivo, recomenda-se a utilização do coeficiente de determinação ajustado, que leva em consideração a quantidade de variáveis independentes utilizadas no modelo. Pode ser obtido, de acordo com Gujarati (2006, p. 175), a partir da seguinte equação:

$$
R^{2} \text { Ajustado }=1-\frac{S Q R /(n-k)}{S T Q /(n-1)}=1-\left(1-R^{2}\right) \frac{n-1}{n-k}
$$

em que

$R^{2}=$ coeficiente de determinação;

$n$ = número de dados na amostra, ou número de variações;

$k=$ número de parâmetros do modelo, incluindo o intercepto.

\subsection{Limitações da pesquisa}

A presente dissertação tem como objetivo testar os modelos CAPM, três e quatro fatores no mercado brasileiro, a partir da mesma metodologia utilizada por Mussa, Rogers e Securato (2009). Não se pretende aqui questionar os modelos ou propor alterações neles.

Uma importante limitação dos trabalhos realizados no mercado brasileiro diz respeito ao tamanho da amostra utilizada, especialmente nos primeiros anos de análise. Um número reduzido de ativos negociados e com liquidez reduzida limita o número de carteiras formadas e, principalmente, a diversificação das carteiras, o que tem impacto direto nos resultados das regressões em corte transversal, conforme comentado por Bellizia (2009, p. 91). Por outro 
lado, estas limitações refletem algumas características do mercado brasileiro e não podem ser evitadas.

Além disso, Roll (1977) questionou os testes do modelo CAPM, uma vez que não é possível observar a carteira de mercado. No presente trabalho, utilizou-se como proxy da carteira de mercado uma carteira composta por todos os ativos incluídos na amostra, ponderados pelo seu valor de mercado, ao invés de índices de mercado, como o Índice Bovespa e o IBRX-50, conforme Málaga (2003), por ser uma carteira mais ampla e que abrange um número maior de ativos. Ressalta-se, porém, que esta carteira não representa de forma exata a carteira de mercado conforme proposto por Sharpe (1964). 


\section{Análise dos Dados}

Neste capítulo serão apresentados e discutidos os resultados obtidos neste trabalho, conforme procedimentos detalhados no capítulo 3.

\subsection{Estatística descritiva das carteiras}

Para realizar análises multivariadas, é necessário que a distribuição dos dados seja normal. Um método de transformação das variáveis que pode ser empregado é aplicar o logaritmo neperiano aos valores iniciais. Entretanto, Fama e French (1993) dizem que, ao se agrupar os dados, é possível alcançar a distribuição normal, mesmo que as distribuições das ações individualmente não o sejam. Assim, seguindo metodologia aplicada por Fama e French (1993), Carhart (1997), Málaga (2003), Mussa (2007) e Mussa, Rogers e Securato (2009), calcularam-se os retornos discretos mensais das ações utilizando o período de julho de 1996 a junho de 2011 para compor as doze carteiras e os fatores.

Para verificar se as distribuições dos retornos das carteiras, e consequentemente dos fatores, seguiam a distribuição normal, aplicou-se o teste Komolgorov-Smirnov utilizando um intervalo de confiança de $95 \%$.

Tabela 4 - Teste Kolmogorov-Smirnov

\begin{tabular}{|c|c|c|c|c|c|c|c|c|c|c|c|c|c|c|c|c|c|}
\hline \multicolumn{18}{|c|}{ One-Sample Kolmogorov-Smirnov Test } \\
\hline & & BHL & BHW & BLL & BLW & BML & BMW & $\mathrm{SHL}$ & SHW & SLL & SLW & SML & SMW & Mkt_TR & SMB & HML & WinMLos \\
\hline \multirow{2}{*}{\multicolumn{2}{|c|}{ No }} & 180 & 180 & 180 & 180 & 180 & 180 & 180 & 180 & 180 & 180 & 180 & 180 & 180 & 180 & 180 & 180 \\
\hline & & $1,80 \%$ & $1,32 \%$ & $0,74 \%$ & $0,94 \%$ & $1,44 \%$ & $1,65 \%$ & $2,19 \%$ & $1,87 \%$ & $0,57 \%$ & $-0,01 \%$ & $1,60 \%$ & $1,66 \%$ & $1,32 \%$ & $0,03 \%$ & $1,25 \%$ & $-0,14 \%$ \\
\hline Parameters & $\begin{array}{l}\text { Std. } \\
\text { Deviation }\end{array}$ & $12,73 \%$ & $11,19 \%$ & $8,60 \%$ & $9,33 \%$ & $9,30 \%$ & $9,54 \%$ & $9,32 \%$ & $8,71 \%$ & $12,67 \%$ & $11,55 \%$ & $8,41 \%$ & $8,16 \%$ & $8,35 \%$ & $6,15 \%$ & $5,72 \%$ & $3,41 \%$ \\
\hline \multirow{3}{*}{\begin{tabular}{|l|} 
Most \\
Extreme \\
Differences
\end{tabular}} & Absolute &, 124 &, 051 & ,074 & 093 & ,086 & ,074 & 097 & ,082 & ,102 & 086 & ,089 & ,112 & 098 & 082 & 091 & ,077 \\
\hline & Positive & ,124 & 039 & 061 & 077 & 064 & 074 & 097 & 082 & ,102 & 086 & 084 & ,101 & 098 & 082 & 091 & ,077 \\
\hline & Negative &,- 072 &,- 051 &,- 074 &,- 093 &,- 086 &,- 066 &,- 062 &,- 072 & \begin{tabular}{|c|}
,- 077 \\
\end{tabular} &,- 050 &,- 089 &,- 112 & -079 & $-0,079$ & -,080 &,- 073 \\
\hline \multicolumn{2}{|c|}{ Kolmogorov-SmirnovZ } & 1,666 & ,681 & ,996 & 1,248 & 1,160 & ,993 & 1,299 & 1,098 & 1,366 & 1,160 & 1,188 & 1,502 & 1,319 & 1,094 & 1,221 & 1,032 \\
\hline \multicolumn{2}{|c|}{\begin{tabular}{|l|} 
Asymp. Sig. (2-tailed) \\
\end{tabular}} &, 008 & ,743 & ,275 & ,089 & ,135 & 277 & 069 & ,180 & ,054 & ,136 & ,119 & ,022 & ,062 & , 182 & ,101 & ,237 \\
\hline
\end{tabular}

É possível observar que a maior parte dos valores do teste $p$ são superiores a 5\%, o que não permite rejeitar a hipótese de normalidade. Contudo, o valor $p$ das carteiras Big|High|Loser e Small|Medium|Winner são inferiores a 5\%, o que indicou a rejeição da hipótese de que estas duas distribuições são normais.

Para analisar as distribuições das carteiras Big|High|Loser e Small|Medium|Winner e os pontos influentes que poderiam estar desviando a distribuição da normalidade, optou-se por utilizar a Distância de Cook, comentada no Capítulo 3. 

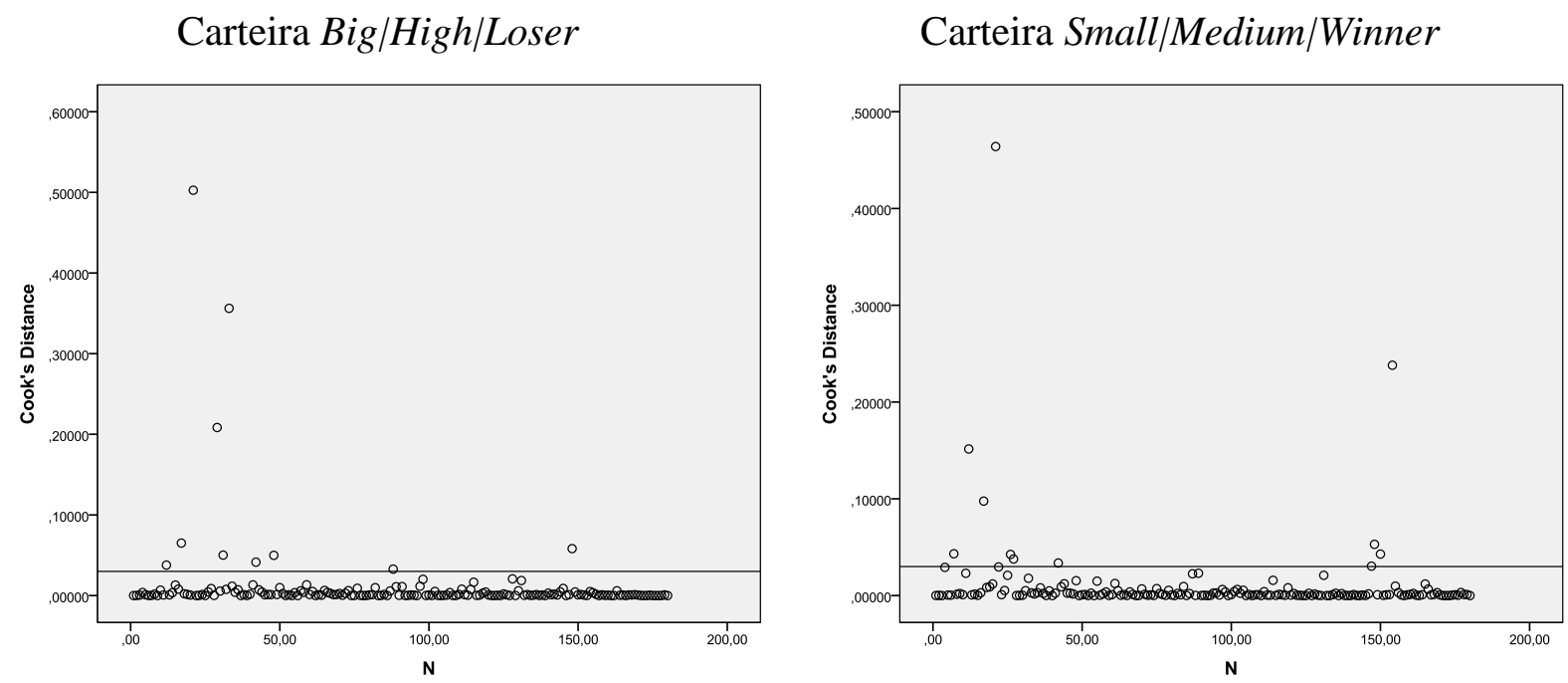

Gráfico 8 - Distância de Cook das carteiras Big|High|Loser e Small|Medium|Winner Obs.: Os gráficos mostram a Distância de Cook a partir do modelo de quatro fatores. Os dados resultantes das regressões de três fatores e do CAPM foram similares

Os resultados da Distância de Cook da carteira Big|High|Loser indicaram dez pontos acima do valor de referência 0,022 . Ao analisar o maior valor, que corresponde ao ponto 21 (março/1998) foi possível observar que ambas as ações da Acesita, ACES3 e ACES4 apresentaram retornos extremos de $110 \%$ e $114 \%$, respectivamente. Este aumento dos retornos poderia ser relacionado com a conclusão do plano de expansão que elevou a capacidade de produção da linha de inox de 160 mil toneladas/ano para 290 mil toneladas/ano. Além disso, neste mesmo ano a empresa associou-se à Unisor, o que trouxe um investimento de $\mathrm{R} \$ 1,02$ bilhão. Optou-se por retirar os retornos destas ações no mês de março/1998.

Já os resultados da Distância de Cook da carteira Small|Medium|Winner indicaram dez pontos acima do valor de referência 0,022. Ao analisar o maior valor, que corresponde também ao ponto 21 (março/1998), observou-se que o retorno da ação da empresa Makro, MAKR3, foi de 30\%. Ponderado pelo valor de mercado, somente esta observação aumentou o retorno da carteira em 16\%. Este aumento do retorno poderia estar associado a uma reestruturação ocorrida no grupo que envolveu a venda das operações na Europa e a criação de um escritório regional responsável pelo suporte à região da América do Sul, no início de 1998. Optou-se por retirar os retornos destas ações no mês de março de 1998.

Assim, após os ajustes descritos, realizou-se novamente o teste Komolgorov-Smirnov, e os resultados estão apresentados na Tabela 5. 
Tabela 5 - Teste Kolmogorov-Smirnov sem pontos influentes

\begin{tabular}{|c|c|c|c|c|c|c|c|c|c|c|c|c|c|c|c|c|c|}
\hline \multicolumn{18}{|c|}{ One-Sample Kolmogorov-Smirnov Test } \\
\hline & & BHL & BHW & BLL & BLW & BML & BMW & SHL & SHW & SLL & SLW & SML & SMW & Mkt_TR & SMB & HML & WinMLos \\
\hline \multicolumn{2}{|l|}{$\mathrm{N}$} & 180 & 180 & 180 & 180 & 180 & 180 & 180 & 180 & 180 & 180 & 180 & 180 & 180 & 180 & 180 & 180 \\
\hline \multirow{2}{*}{\begin{tabular}{|l|} 
Normal \\
Parameters
\end{tabular}} & Mean & $1,58 \%$ & $1,32 \%$ & $0,74 \%$ & $0,94 \%$ & $1,44 \%$ & $1,65 \%$ & $2,19 \%$ & $1,87 \%$ & $0,57 \%$ & $-0,01 \%$ & $1,60 \%$ & $1,66 \%$ & ,0134 & ,0007 & ,0119 &,- 0012 \\
\hline & $\begin{array}{l}\text { Std. } \\
\text { Deviation }\end{array}$ & $12,05 \%$ & $11,19 \%$ & $8,60 \%$ & $9,33 \%$ & $9,30 \%$ & $9,54 \%$ & $9,32 \%$ & $8,71 \%$ & $12,67 \%$ & $11,55 \%$ & $8,41 \%$ & $8,02 \%$ & 08371 & ,06170 & 05546 & 03388 \\
\hline \multirow{3}{*}{$\begin{array}{l}\text { Most } \\
\text { Extreme } \\
\text { Differences }\end{array}$} & Absolute & ,108 & ,051 & 074 & 093 & ,086 & 074 & ,097 & ,082 & ,102 & ,086 & ,089 & 109 & 099 & ,079 & 083 & ,076 \\
\hline & Positive & 108 &, 039 & 061 & 077 & 064 &, 074 &, 097 & 082 & ,102 & 086 &, 084 & 097 & 099 & 079 &, 083 & 075 \\
\hline & Negative &,- 066 &,- 051 &,- 074 &,- 093 &,- 086 &,- 066 &,- 062 &,- 072 &,- 077 &,- 050 &,- 089 & -109 &,- 078 &,- 078 &,- 082 &,- 076 \\
\hline \multicolumn{2}{|c|}{ Kolmogorov-SmirnovZ } & 1,452 & 681 & ,996 & 1,248 & 1,160 & ,993 & 1,299 & 1,098 & 1,366 & 1,160 & 1,188 & 1,458 & 1,334 & 1,054 & 1,115 & 1,018 \\
\hline \multicolumn{2}{|c|}{ Asymp. Sig. (2-tailed) } & ,061 & ,743 & ,275 & 089 & 135, & 2777, & ,069 & 180, & ,054 & ,136 & 119, & ,052 & ,057 & ,216 & 166 & 252, \\
\hline
\end{tabular}

A partir dos novos dados, foi possível observar que todos os valores $p$ estão acima de $5 \%$, o que indica que não é possível rejeitar a hipótese de normalidade dos dados. Deste ponto em diante, todas as estatísticas apresentadas nesta dissertação foram calculadas com os dados sem as observações influentes citadas acima.

As Tabelas 6, 7 e 8 apresentam as estatísticas descritivas das doze carteiras construídas, bem como as estatísticas descritivas dos fatores calculados a partir destas carteiras, de acordo com a metodologia apresentada anteriormente.

Tabela 6 - Análise descritiva das carteiras

\begin{tabular}{|c|c|r|r|r|r|}
\hline \multicolumn{7}{|c|}{ Quantidade média de ações por carteira } \\
\hline \multirow{2}{*}{ Big } & B/M Low & B/M Medium & B/M High & \multicolumn{1}{c|}{ TOTAL } \\
\cline { 2 - 6 } & Loser & 18 & 18 & 8 & 44 \\
\cline { 2 - 6 } & Winner & 26 & 23 & 7 & 56 \\
\hline \multirow{2}{*}{ Small } & Loser & 8 & 20 & 27 & 55 \\
\cline { 2 - 6 } & Winner & 7 & 18 & 18 & 43 \\
\hline \multicolumn{2}{|c|}{ TOTAL } & 59 & 79 & 60 & \\
\hline
\end{tabular}

\begin{tabular}{|c|c|r|r|r|r|}
\hline \multicolumn{7}{|c|}{ Valor de Mercado Médio da Carteira } \\
\hline \multirow{2}{*}{ Big } & B/M Low & B/M Medium & B/M High & \multicolumn{1}{c|}{ TOTAL } \\
\cline { 2 - 6 } & Winner & 87.043 & 105.745 & 23.349 & 216.137 \\
\hline \multirow{2}{*}{ Small } & Loser & 212.260 & 116.110 & 22.494 & 350.864 \\
\cline { 2 - 6 } & Winner & 2.845 & 5.425 & 3.658 & 11.928 \\
\hline \multicolumn{2}{|c|}{ TOTAL } & 304.984 & 5.022 & 2.717 & 10.575 \\
\hline
\end{tabular}

\begin{tabular}{|c|c|r|r|r|r|}
\hline \multicolumn{6}{|c|}{ Média do Percentual do Valor de Mercado da Carteira } \\
\hline \multirow{2}{*}{ Big } & B/M Low & B/M Medium & B/M High & \multicolumn{1}{c|}{ TOTAL } \\
\cline { 2 - 6 } & Loser & $17,6 \%$ & $14,3 \%$ & $3,8 \%$ & $35,7 \%$ \\
\cline { 2 - 6 } & Winner & $32,1 \%$ & $21,9 \%$ & $6,4 \%$ & $60,4 \%$ \\
\hline \multirow{2}{*}{ Small } & Loser & $0,5 \%$ & $0,9 \%$ & $0,7 \%$ & $2,0 \%$ \\
\cline { 2 - 6 } & Winner & $0,4 \%$ & $0,9 \%$ & $0,5 \%$ & $1,8 \%$ \\
\hline \multicolumn{2}{|c|}{ TOTAL } & $50,6 \%$ & $38,0 \%$ & $11,3 \%$ & \\
\hline
\end{tabular}




\begin{tabular}{|c|c|r|r|r|r|}
\hline \multicolumn{7}{|c|}{ Média do Índice Book-to-Market } \\
\hline \multirow{2}{*}{ Big } & B/M Low & B/M Medium & B/M High & \multicolumn{1}{c|}{ TOTAL } \\
\cline { 2 - 6 } & Winner & 0,507 & 1,157 & 3,051 & 1,572 \\
\hline \multirow{2}{*}{ Small } & Loser & 0,479 & 1,075 & 2,734 & 1,429 \\
\cline { 2 - 6 } & Winner & 0,517 & 1,267 & 3,155 & 1,647 \\
\hline \multicolumn{2}{|c|}{ TOTAL } & 0,568 & 1,301 & 3,000 & 1,623 \\
\hline
\end{tabular}

De acordo com o trabalho de Lintz e Renyi (1998), com 11 ativos obtém-se o máximo do efeito diversificação para o modelo de Sharpe no mercado brasileiro. Sendo assim, é possível observar na Tabela 6 que, com exceção das carteiras Small|Low e Big|High, as demais carteiras, que possuem em média mais de 18 ativos, apresentaram um nível adequado de diversificação. Málaga (2003) também encontrou uma quantidade inferior a 11 ativos nestas carteiras.

Assim como constatado por Málaga (2003), o número de ações nas carteiras Big diminui à medida que o índice $\mathrm{B} / \mathrm{M}$ aumenta, e o efeito inverso é observado nas carteiras Small: o número de ações aumenta à medida que o índice $\mathrm{B} / \mathrm{M}$ aumenta, efeito também registrado por Fama e French (1993) no mercado norte-americano. De acordo com os autores, a justificativa deste efeito seria de que altos índices B/M estariam associados a oportunidades de crescimento, o que se concentraria em empresas pequenas.

Observa-se, na Tabela 6, que as empresas Small representam menos de 5\% do valor de mercado, efeito também observado por Fama e French (1993). Entre as empresas Big, cerca de 50\% delas estão associados a baixo índice B/M (Low B/M), efeito também observado pelos autores. É possível ainda observar que $60 \%$ do mercado são compostos por empresas de grande porte (Big) e que tiveram os maiores retornos acumulados em um ano (Winner).

Conforme apresentado na Tabela 7 , o prêmio mensal médio variou entre $0,01 \%$ a 2,20\%, enquanto no estudo de Mussa, Rogers e Securato (2009) a média dos prêmios mensais oscilou entre $0,06 \%$ e 2,74\%. Málaga (2003) e Mussa (2007) observaram prêmios de 0,06\% a $1,87 \%$ e $0,04 \%$ a 2,72\%, respectivamente. Fama e French (1993) constataram prêmios entre $0,32 \%$ e $1,05 \%$ para o mercado norte-americano. 
Tabela 7 - Prêmio e Desvio Padrão Médio das Carteiras

\begin{tabular}{|c|c|r|r|r|r|}
\hline \multicolumn{7}{|c|}{ Prêmio Médio das Carteiras } \\
\hline \multirow{2}{*}{ Big } & B/M Low & B/M Medium & B/M High & \multicolumn{1}{c|}{ TOTAL } \\
\cline { 2 - 6 } & Loser & $0,74 \%$ & $1,43 \%$ & $1,57 \%$ & $1,25 \%$ \\
\cline { 2 - 6 } & Winner & $0,93 \%$ & $1,63 \%$ & $1,33 \%$ & $1,30 \%$ \\
\hline \multirow{2}{*}{ Small } & Loser & $0,57 \%$ & $1,64 \%$ & $2,20 \%$ & $1,47 \%$ \\
\cline { 2 - 6 } & Winner & $0,01 \%$ & $1,68 \%$ & $1,91 \%$ & $1,20 \%$ \\
\hline \multicolumn{2}{|c|}{ TOTAL } & $0,56 \%$ & $1,60 \%$ & $1,75 \%$ & \\
\hline
\end{tabular}

\begin{tabular}{|c|c|r|r|r|r|}
\hline \multicolumn{6}{|c|}{ Desvio Padrão Médio dos Retornos das Carteiras } \\
\hline \multirow{2}{*}{ Big } & B/M Low & B/M Medium & B/M High & \multicolumn{1}{c|}{ TOTAL } \\
\cline { 2 - 6 } & Loser & $8,6 \%$ & $9,3 \%$ & $12,1 \%$ & $10,1 \%$ \\
\cline { 2 - 6 } & Winner & $9,3 \%$ & $9,5 \%$ & $11,2 \%$ & $10,0 \%$ \\
\hline \multirow{2}{*}{ Small } & Loser & $12,7 \%$ & $8,4 \%$ & $9,3 \%$ & $10,3 \%$ \\
\cline { 2 - 6 } & Winner & $11,6 \%$ & $8,0 \%$ & $8,7 \%$ & $9,6 \%$ \\
\hline \multicolumn{2}{|c|}{ TOTAL } & $10,7 \%$ & $8,8 \%$ & $10,4 \%$ & \\
\hline
\end{tabular}

É possível verificar que somente duas das seis carteiras Small (Small|Low|Loser e Small|Low|Winner) apresentaram retorno médio inferior ao retorno médio das respectivas carteiras Big, e este comportamento está concentrado nas empresas de baixo índice B/M. Os dados apresentados na Tabela 7 se aproximam dos observados por Fama e French (1993) no mercado norte-americano e divergem dos observados por Málaga (2003) no mercado brasileiro. Esta alteração de resultados pode ser decorrente da metodologia empregada para montar as carteiras e do período utilizado na análise.

Observou-se que somente três das seis carteiras Winner apresentaram retornos superiores às respectivas carteiras Loser, o que não permitiu confirmar a suposição de Jegadeesh e Titman (1993) e Carhart (1997) de que há uma relação positiva entre o retorno das carteiras e a estratégia de compra de ações que apresentaram um alto retorno acumulado do ano anterior e venda de ações que apresentaram um retorno acumulado baixo no ano anterior, assim como observado por Mussa (2007).

Com exceção da carteira Big|High|Winner, é possível notar que o retorno médio das carteiras aumenta à medida que o índice B/M aumenta. Fama e French (1992) observaram esta relação para o mercado norte-americano, porém Málaga (2003) não observou um padrão definido entre o prêmio das carteiras e o índice B/M em seu estudo. Além disso, observou-se que o intervalo do prêmio das carteiras pequenas em relação ao índice $B / M$ é muito maior do que o intervalo das empresas grandes: $1,90 \%$ e $1,63 \%$ contra $0,83 \%$ e $0,40 \%$.

O desvio padrão dos prêmios mensais variou 8,0\% e 12,7\%, enquanto Málaga (2003) observou uma variação de $8,81 \%$ a $15,54 \%$ e Mussa (2007) de 7,96\% a 13,01\%, ambos para o 
mercado brasileiro. Fama e French (1993) encontraram um desvio padrão que variou de $4,27 \%$ a 7,76\%, o que indicou o maior risco do mercado brasileiro. Ao observar o desvio padrão dos retornos das carteiras, não foi possível afirmar que as empresas pequenas oferecem mais risco, o que deveria estar associado a retornos superiores: somente as carteiras Small|Low possuem desvio padrão mais alto do que as carteiras Big|Low. Essa falta de padrão do comportamento dos retornos das carteiras em relação ao tamanho não permite confirmar ou rejeitar a relação tamanho-retorno observada por Fama e French (1993).

Na Tabela 8, observou-se que o prêmio médio mensal de mercado foi de 1,30\%, enquanto Fama e French (1993) observaram um prêmio de 0,43\% para o mercado norteamericano e Málaga (2003, p. 107) documentou um prêmio de 1,09\%.

Tabela 8 - Estatística Descritiva dos Fatores de Risco dos Modelos

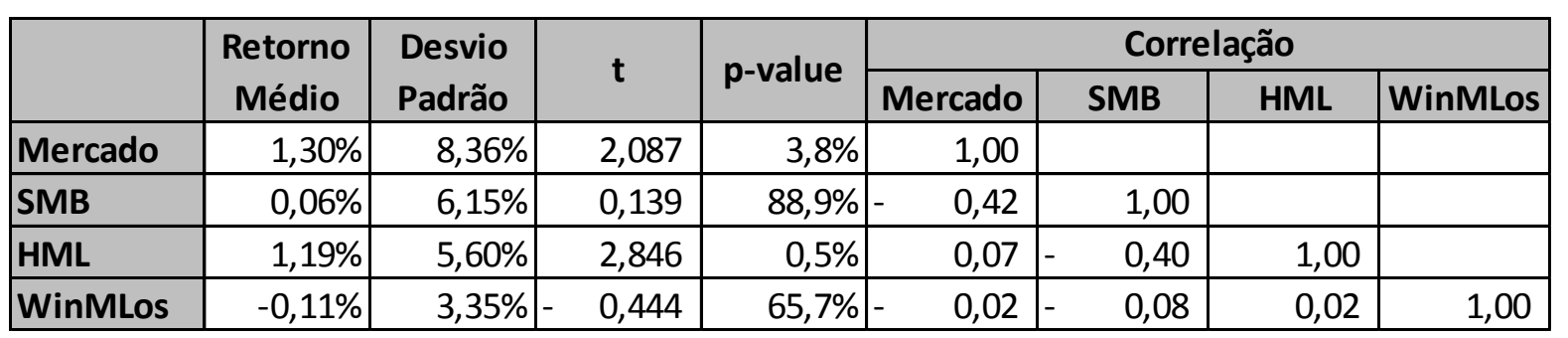

Não foi possível identificar um prêmio pelo fator momento (WinMLos), uma vez que o retorno médio deste fator se mostrou negativo. Assim, não foi possível confirmar, no mercado brasileiro, a existência do mesmo efeito encontrado por Jegadeesh e Titman (1993). Málaga (2003, p. 107) observou um prêmio do fator tamanho (SMB) negativo de $-0,32 \%$, enquanto o presente trabalho observou um prêmio de $0,06 \%$. Já o prêmio do fator $\mathrm{B} / \mathrm{M}(H M L)$ foi de 1,19\% para os dados desta pesquisa, enquanto Málaga (2003, p. 107) encontrou um prêmio de $0,6 \%$.

Ao aplicar o teste $t$ (intervalo de confiança de 95\%) de comparação de médias, para avaliar se as médias são diferentes de zero, observou-se que somente o fator B/M e a carteira de mercado são estatisticamente diferentes de zero, assim como evidências encontradas por Fama e French (1993). Já a correlação de Pearson encontrada entre os fatores indicou baixo índice de correlação. $\mathrm{O}$ fator tamanho $(S M B)$ foi o que apresentou índice de correlação mais alto em relação aos fatores mercado e índice B/M. Contudo, ainda foi inferior a 50\%. 


\subsection{Análise dos Modelos por Regressão em Série Temporal}

As Tabelas 9, 10 e 11 indicam os coeficientes das regressões em série temporal calculados utilizando os 180 meses de dados. Para análise da significância dos coeficientes, utilizou-se um $t$ crítico de 1,96 para um nível de significância de 5\%.

A Tabela 9 apresenta os resultados do primeiro modelo, CAPM, conforme proposto por Sharpe (1964).

\section{Tabela 9 - Regressão Temporal dos modelos CAPM com e sem intercepto para o}

período de julho de 1996 a junho de 2011

\begin{tabular}{|c|c|c|c|c|c|c|}
\hline & \multirow{2}{*}{\begin{tabular}{|c|}
$R^{2}$ \\
ajustado
\end{tabular}} & \multirow{2}{*}{\begin{tabular}{|c|} 
Teste \\
Durbin-Watson
\end{tabular}} & \multicolumn{2}{|c|}{$a$ (Intercepto) } & \multicolumn{2}{|c|}{$b$ (Mercado) } \\
\hline & & & Coeficientes & Estatística t & Coeficientes & Estatística t \\
\hline BigHighLoser & 0,49 & 2,09 & 0,00 & 0,39 & 1,01 & 13,21 \\
\hline BigHighWinner & 0,48 & 1,88 & 0,00 & 0,18 & 0,93 & 13,00 \\
\hline BigLowLoser & 0,66 & 1,82 & 0,00 & 0,94 & 0,84 & 18,79 \\
\hline BigLowWinner & 0,76 & 2,15 & 0,00 & 0,97 & 0,97 & 23,90 \\
\hline BigMediumLoser & 0,70 & 2,05 & 0,00 & 0,59 & 0,93 & 20,32 \\
\hline BigMediumWinner & 0,82 & 2,09 & 0,00 & 0,92 & 1,03 & 28,62 \\
\hline SmallHighLoser & 0,48 & 1,60 & 0,01 & 2,35 & 0,77 & 12,77 \\
\hline SmallHighWinner & 0,29 & 1,81 & 0,01 & 2,12 & 0,57 & 8,69 \\
\hline SmallLowLoser & 0,19 & 1,89 & 0,00 & 0,34 & 0,66 & 6,52 \\
\hline SmallLowWinner & 0,20 & 1,87 & 0,01 & 1,02 & 0,62 & 6,74 \\
\hline SmallMediumLoser & 0,36 & 1,81 & 0,01 & 1,68 & 0,61 & 10,14 \\
\hline SmallMediumWinner & 0,43 & 1,33 & 0,01 & 1,88 & 0,63 & 11,74 \\
\hline BigHighLoser & 0,50 & 2,09 & - & - & 1,02 & 13,46 \\
\hline BigHighWinner & 0,49 & 1,88 & - & - & 0,94 & 13,22 \\
\hline BigLowLoser & 0,66 & 1,81 & - & - & 0,83 & 18,88 \\
\hline BigLowWinner & 0,76 & 2,13 & - & - & 0,97 & 24,05 \\
\hline BigMediumLoser & 0,70 & 2,05 & - & - & 0,93 & 20,70 \\
\hline BigMediumWinner & 0,82 & 2,08 & - & - & 1,04 & 29,12 \\
\hline SmallHighLoser & 0,49 & 1,59 & - & - & 0,79 & 13,13 \\
\hline SmallHighWinner & 0,31 & 1,78 & - & - & 0,59 & 9,04 \\
\hline SmallLowLoser & 0,19 & 1,89 & - & - & 0,66 & 6,56 \\
\hline SmallLowWinner & 0,19 & 1,85 & - & - & 0,61 & 6,66 \\
\hline SmallMediumLoser & 0,37 & 1,80 & - & - & 0,62 & 10,47 \\
\hline SmallMediumWinner & 0,44 & 1,33 & - & - & 0,65 & 12,09 \\
\hline
\end{tabular}

$\mathrm{Na}$ análise dos coeficientes de determinação ajustados ( $\mathrm{R}^{2}$ ajustado) observou-se que o modelo CAPM ainda deixa de explicar uma parte significativa das variações dos retornos das carteiras. Somente uma carteira para ambos os modelos com e sem intercepto (Big $\mid$ Medium $\mid$ Winner) apresentou $\mathrm{R}^{2}$ ajustado superior a $80 \%$, valor de referência utilizado por Málaga (2003, p. 108).

É possível observar também que os coeficientes de determinação ajustado das empresas Big são maiores do que os das empresas Small: enquanto nas empresas Big ele vai de $48 \%$ a $82 \%$, nas empresas Small vai de $19 \%$ a $48 \%$. Isso pode ser explicado pela diferença 
de dimensão dos coeficientes de mercado: os das empresas Big se aproximam de 1, enquanto os das empresas Small se aproximam de 0,6. Observa-se este mesmo efeito nos dados de Málaga (2003) e Mussa (2007). Todos os coeficientes de mercado são estatisticamente significantes.

É importante observar que todos os coeficientes de mercado se aproximam de 1 para as empresas Big e de 0,6 para as empresas Small. Este efeito pode ser explicado pela baixa correlação entre as empresas que compõem cada carteira: a correlação entre as empresas fica muito próxima a 0 , o que indica um alto nível de diversificação. $\mathrm{O}$ alto nível de diversificação de cada carteira faz com que a correlação entre os retornos das carteiras e os retornos da carteira de mercado seja próxima a 0,7 .

Em relação aos interceptos, somente as duas carteiras Small|High apresentaram interceptos estatisticamente significativos e diferentes de zero. Os testes Durbin-Watson, que indicam se os dados são autocorrelacionados, devem ficar próximos a 2, podendo ir de 0 a 4 . Para 22 das 24 carteiras, os resultados dos testes variaram em torno de 2, o que indica baixa correlação no tempo entre os retornos. Somente nas carteiras Small|Medium|Winner dos modelos com e sem intercepto os resultados dos testes indicaram autocorrelação. Contudo, vale ressaltar que estes resultados não invalidam o modelo.

Nas regressões temporais do modelo de 3 fatores de Fama e French (1993), conforme Tabela 10, as diferenças entre os $\mathrm{R}^{2}$ ajustados e os $b$ das carteiras Small e Big já não são mais diretamente observáveis à medida que os demais fatores foram incluídos.

Os coeficientes de determinação ajustados aumentaram consideravelmente e ficaram situados entre $56 \%$ e $83 \%$ para os modelos com e sem intercepto. Já os coeficientes de mercado se aproximaram de 1 para todas as carteiras, inclusive os das carteiras Small. Este efeito foi comentado por Fama e French (1993), Málaga (2003) e Mussa (2007). Contudo, é importante destacar que o aumento observado nos coeficientes de mercado desta dissertação foi o dobro do aumento apresentado para o mercado norte-americano no trabalho de Fama e French (1993).

Os coeficientes do fator tamanho são próximos de 1 para as empresas Small e variaram de 0,24 a -0,2 para empresas Big, o que indica que a informação sobre tamanho auxilia mais a explicar os retornos das empresas menores do que das maiores. Além disso, para as empresas Small, todos os coeficientes foram estatisticamente significantes, enquanto somente duas das seis carteiras Big para ambos os modelos (Big $\mid$ Low $\mid$ Winner e Big $\mid$ Medium $\mid$ Winner) tiveram os coeficientes tamanho estatisticamente significantes. 
Tabela 10 - Regressão Temporal do modelo de 3 Fatores de Fama e French (1993) com e sem intercepto para o período de julho de 1996 a junho de 2011

\begin{tabular}{|c|c|c|c|c|c|c|c|c|c|c|}
\hline & \multirow{2}{*}{$\begin{array}{c}\mathbf{R}^{\mathbf{2}} \\
\text { ajustado }\end{array}$} & \multirow{2}{*}{$\begin{array}{c}\text { Teste } \\
\text { Durbin-Watson }\end{array}$} & \multicolumn{2}{|c|}{$a$ (Intercepto) } & \multicolumn{2}{|c|}{$b$ (Mercado) } & \multicolumn{2}{|c|}{$s$ (SMB) } & \multicolumn{2}{|c|}{$h$ (HML) } \\
\hline & & & Coeficientes & Estatísticat & Coeficientes & Estatística t & Coeficientes & Estatísticat & Coeficientes & Estatística t \\
\hline BigHighLoser & 0,56 & 2,00 & 0,01 & 0,93 & 1,06 & 13,36 & 0,24 & 2,02 & 0,64 & 5,50 \\
\hline BigHighWinner & 0,57 & 1,91 & 0,01 & 1,09 & 0,93 & 12,74 & 0,09 & 0,80 & 0,62 & 5,70 \\
\hline BigLowLoser & 0,68 & 1,85 & 0,00 & 0,12 & 0,82 & 17,10 & 0,08 & 1,09 & 0,24 & 3,38 \\
\hline BigLowWinner & 0,80 & 2,06 & 0,00 & 0,44 & 0,93 & 22,13 & 0,20 & 3,27 & 0,34 & 5,52 \\
\hline BigMediumLoser & 0,71 & 2,01 & 0,00 & 0,02 & 0,92 & 18,48 & 0,01 & 0,14 & 0,19 & 2,56 \\
\hline BigMediumWinner & 0,83 & 2,18 & 0,00 & 0,18 & 1,08 & 27,67 & 0,18 & 3,11 & 0,13 & 2,18 \\
\hline SmallHighLoser & 0,76 & 1,84 & 0,00 & 0,37 & 1,04 & 22,78 & 0,96 & 14,14 & 0,55 & 8,11 \\
\hline SmallHighWinner & 0,72 & 1,87 & 0,00 & 0,55 & 0,86 & 18,70 & 1,05 & 15,47 & 0,78 & 11,48 \\
\hline SmallLowLoser & 0,71 & 1,71 & 0,00 & 0,91 & 1,12 & 16,45 & 1,42 & 14,03 & 0,41 & 4,09 \\
\hline SmallLowWinner & 0,66 & 1,86 & 0,01 & 1,69 & 1,01 & 15,17 & 1,19 & 12,06 & 0,41 & 4,20 \\
\hline SmallMediumLoser & 0,65 & 2,13 & 0,00 & 0,24 & 0,87 & 17,51 & 0,88 & 12,04 & 0,31 & 4,20 \\
\hline SmallMediumWinner & 0,65 & 1,69 & 0,00 & 0,82 & 0,85 & 18,24 & 0,74 & 10,63 & 0,19 & 2,73 \\
\hline BigHighLoser & 0,56 & 1,99 & - & - & 1,04 & 13,44 & 0,22 & 1,89 & 0,62 & 5,44 \\
\hline BigHighWinner & 0,57 & 1,89 & - & - & 0,92 & 12,77 & 0,07 & 0,62 & 0,59 & 5,60 \\
\hline BigLowLoser & 0,68 & 1,85 & - & - & 0,82 & 17,47 & 0,08 & 1,13 & 0,24 & 3,52 \\
\hline BigLowWinner & 0,79 & 2,06 & - & - & 0,93 & 22,72 & 0,20 & 3,25 & 0,34 & 5,60 \\
\hline BigMediumLoser & 0,71 & 2,01 & - & - & 0,92 & 18,90 & 0,01 & 0,15 & 0,19 & 2,66 \\
\hline BigMediumWinner & 0,83 & 2,18 & - & - & 1,09 & 28,34 & 0,18 & 3,20 & 0,13 & 2,30 \\
\hline SmallHighLoser & 0,76 & 1,84 & - & - & 1,04 & 23,37 & 0,96 & 14,46 & 0,55 & 8,48 \\
\hline SmallHighWinner & 0,73 & 1,87 & - & - & 0,85 & 19,01 & 1,04 & 15,64 & 0,77 & 11,74 \\
\hline SmallLowLoser & 0,70 & 1,70 & - & - & 1,11 & 16,61 & 1,40 & 14,10 & 0,44 & 4,46 \\
\hline SmallLowWinner & 0,65 & 1,84 & - & - & 0,99 & 15,05 & 1,16 & 11,89 & 0,46 & 4,74 \\
\hline SmallMediumLoser & 0,66 & 2,13 & - & - & 0,87 & 17,95 & 0,89 & 12,30 & 0,31 & 4,41 \\
\hline SmallMediumWinner & 0,66 & 1,69 & - & - & 0,86 & 18,78 & 0,75 & 10,96 & 0,20 & 3,03 \\
\hline
\end{tabular}

Já o fator B/M se mostrou estatisticamente significativo para todas as carteiras. Contudo, as carteiras Low apresentaram coeficientes negativos, o que indica um efeito contrário ao encontrado por Fama e French (1993), que postulam que empresas de baixo índice B/M estariam associadas a retornos mais baixos. Málaga (2003) encontrou valores estatisticamente iguais a zero para duas das três carteiras de baixo índice B/M.

Os interceptos foram estatisticamente iguais a zero para todas as carteiras no modelo de 3 fatores. Os resultados dos testes Durbin-Watson indicam que todas as carteiras possuem baixa correlação no tempo, uma vez que todos os valores estão em torno de 2 .

Já nas regressões temporais do modelo de 4 fatores de Carhart (1997), conforme apresentado na Tabela 11, os coeficientes de determinação ajustados do modelo são pouco maiores do que os do modelo de 3 fatores.

Os interceptos são estatisticamente iguais a zero, o que reforça a validade do modelo, uma vez que somente os fatores devem ser capazes de explicar os retornos das carteiras. As estatísticas de Durbin-Watson indicaram que a correlação no tempo é baixa, uma vez que todos os resultados estão próximos a 2.

Os coeficientes do fator de mercado permaneceram próximos a 1 e foram estatisticamente significantes. A inclusão do fator momento não fez com que os coeficientes $b$ mudassem de magnitude.

Para as carteiras Small, os coeficientes do fator tamanho permaneceram próximos a 1 e estatisticamente significantes. Já para as carteiras Big, somente duas das seis carteiras 
possuem coeficientes estatisticamente significantes. Contudo, o coeficiente da carteira Big $\mid$ Low $\mid$ Winner se apresentou negativo, e o da carteira Big $\mid$ Medium $\mid$ Winner positivo, o que não permite definir uma relação para este fator de risco.

Todos os coeficientes do fator B/M são estatisticamente significantes. As carteiras Low possuem coeficiente negativo, o que indica que empresas de baixo índice B/M não necessariamente possuem baixo retorno, evidência contrária à encontrada por Fama e French (1993).

O fator de risco momento apresentou coeficientes negativos para todas as carteiras Loser, indicando que empresas que tiveram um retorno abaixo da mediana no ano anterior não possuem retorno baixo no ano seguinte. A magnitude dos coeficientes $w$ das carteiras Loser é superior à magnitude dos respectivos coeficientes $w$ das carteiras Winner, o que indica que, no mercado brasileiro, a estratégia não produz resultados positivos como os encontrados no mercado norte-americano por Jegadeesh e Titman (1993). Mussa (2007) encontrou este mesmo efeito. Além disso, enquanto todos os coeficientes das carteiras Loser são estatisticamente significantes, somente três dos seis coeficientes das carteiras Winner são estatisticamente significantes. 
Tabela 11 - Regressão Temporal do modelo de 4 Fatores de Carhart (1997) com e sem intercepto para o período de julho de 1996 a junho de 2011

\begin{tabular}{|c|c|c|c|c|c|c|c|c|c|c|c|c|}
\hline & \multirow{2}{*}{\begin{tabular}{|c|}
$R^{2}$ \\
ajustado
\end{tabular}} & \multirow{2}{*}{$\begin{array}{c}\text { Teste } \\
\text { Durbin-Watson }\end{array}$} & \multicolumn{2}{|c|}{$a$ (Intercepto) } & \multicolumn{2}{|c|}{$b$ (Mercado) } & \multicolumn{2}{|c|}{$s$ (SMB) } & \multicolumn{2}{|c|}{$h$ (HML) } & \multicolumn{2}{|c|}{$w$ (WinMLos) } \\
\hline & & & Coeficientes & Estatística t & Coeficientes & Estatística t & Coeficientes & Estatística t & Coeficientes & Estatística t & Coeficientes & Estatística t \\
\hline BigHighLoser & 0,66 & 1,99 & 0,01 & 1,18 & 1,03 & 14,75 & 0,16 & 1,58 & 0,63 & 6,13 & 1,16 & 7,39 \\
\hline BigHighWinner & 0,59 & 1,85 & 0,01 & 1,07 & 0,95 & 13,38 & 0,12 & 1,18 & 0,63 & 5,97 & 0,58 & 3,66 \\
\hline BigLowLoser & 0,74 & 1,80 & 0,00 & 0,23 & 0,81 & 18,67 & 0,12 & 1,87 & 0,25 & 3,91 & 0,66 & 6,74 \\
\hline BigLowWinner & 0,80 & 2,10 & 0,00 & 0,47 & 0,93 & 22,28 & 0,19 & 3,11 & 0,34 & 5,51 & 0,15 & 1,57 \\
\hline BigMediumLoser & 0,75 & 2,11 & 0,00 & 0,07 & 0,91 & 19,69 & 0,03 & 0,41 & 0,18 & 2,67 & 0,60 & 5,76 \\
\hline BigMediumWinner & 0,84 & 2,16 & 0,00 & 0,25 & 1,09 & 29,07 & 0,20 & 3,63 & 0,13 & 2,36 & 0,34 & 4,06 \\
\hline SmallHighLoser & 0,82 & 1,75 & 0,00 & 0,31 & 1,02 & 26,23 & 0,91 & 15,75 & 0,54 & 9,37 & 0,73 & 8,29 \\
\hline SmallHighWinner & 0,73 & 1,87 & 0,00 & 0,52 & 0,86 & 19,12 & 1,07 & 15,88 & 0,78 & 11,71 & 0,26 & 2,56 \\
\hline SmallLowLoser & 0,74 & 1,85 & 0,01 & 1,04 & 1,10 & 17,17 & 1,37 & 14,39 & 0,42 & 4,46 & 0,72 & 4,96 \\
\hline SmallLowWinner & 0,66 & 1,87 & 0,01 & 1,67 & 1,02 & 15,24 & 1,20 & 12,15 & 0,41 & 4,18 & 0,19 & 1,25 \\
\hline SmallMediumLoser & 0,68 & 2,12 & 0,00 & 0,18 & 0,85 & 18,12 & 0,85 & 12,19 & 0,30 & 4,33 & 0,48 & 4,52 \\
\hline SmallMediumWinner & 0,66 & 1,72 & 0,00 & 0,84 & 0,86 & 18,32 & 0,74 & 10,74 & 0,19 & 2,76 & 0,14 & 1,34 \\
\hline BigHighLoser & 0,66 & 1,98 & - & - & 1,01 & 14,79 & 0,14 & 1,40 & 0,60 & 6,02 & 1,15 & 7,36 \\
\hline BigHighWinner & 0,59 & 1,83 & - & - & 0,93 & 13,43 & 0,11 & 1,02 & 0,60 & 5,88 & 0,59 & 3,68 \\
\hline BigLowLoser & 0,74 & 1,79 & - & - & 0,80 & 19,04 & 0,12 & 1,95 & 0,25 & 4,11 & 0,66 & 6,76 \\
\hline BigLowWinner & 0,79 & 2,10 & - & - & 0,94 & 22,87 & 0,19 & 3,09 & 0,33 & 5,58 & 0,15 & 1,57 \\
\hline BigMediumLoser & 0,75 & 2,11 & - & - & 0,91 & 20,12 & 0,03 & 0,43 & 0,18 & 2,75 & 0,60 & 5,77 \\
\hline BigMediumWinner & 0,84 & 2,16 & - & - & 1,10 & 29,77 & 0,21 & 3,74 & 0,13 & 2,50 & 0,34 & 4,07 \\
\hline SmallHighLoser & 0,83 & 1,75 & - & - & 1,02 & 26,87 & 0,91 & 16,09 & 0,54 & 9,77 & 0,73 & 8,32 \\
\hline SmallHighWinner & 0,74 & 1,87 & - & - & 0,86 & 19,44 & 1,06 & 16,07 & 0,77 & 11,98 & 0,26 & 2,57 \\
\hline SmallLowLoser & 0,73 & 1,84 & - & - & 1,09 & 17,29 & 1,36 & 14,42 & 0,45 & 4,87 & 0,72 & 4,94 \\
\hline SmallLowWinner & 0,65 & 1,85 & - & - & 1,00 & 15,13 & 1,18 & 11,98 & 0,45 & 4,71 & 0,19 & 1,27 \\
\hline SmallMediumLoser & 0,69 & 2,12 & - & - & 0,86 & 18,57 & 0,86 & 12,44 & 0,30 & 4,53 & 0,48 & 4,53 \\
\hline SmallMediumWinner & 0,67 & 1,71 & - & - & 0,86 & 18,87 & 0,75 & 11,06 & 0,20 & 3,07 & 0,14 & 1,33 \\
\hline
\end{tabular}




\subsection{Análise dos Modelos por Regressão em Dois Estágios}

Na Tabela 12 são apresentados os resultados das regressões em corte transversal em que os betas dos prêmios pelos riscos de mercado, tamanho, índice B/M e momento, calculados within-sample em regressões em série de tempo para o período de jun/1996 a dez/2003, foram utilizados como variável independente nas regressões em relação aos prêmios dos retornos das carteiras, calculados out-of-sample. As entradas da tabela indicam os coeficientes calculados, a estatística $t$ calculada conforme Fama e Macbeth (1973) e os asteriscos indicam a qual nível o $t$ calculado foi estatisticamente significante.

Os interceptos se mostraram significativos ao nível de $1 \%$ para o modelo de três e quatro fatores, e para o modelo CAPM o intercepto não se mostrou significativo. Mussa, Rogers e Securato (2009) constataram que o intercepto era significativo a 1\% para os três modelos. Tais resultados indicam a existência de outros fatores, não incluídos nos modelos, que seriam capazes de explicar os retornos das carteiras e contrariam a expectativa teórica de que somente os fatores de risco deveriam explicar os excessos de retorno das carteiras.

A carteira de mercado se apresentou significativa ao nível de 5\% para os modelos de três e quatro fatores com intercepto, e para o modelo CAPM sem intercepto este fator de risco foi significante somente a $10 \%$. Tais resultados se mostram diferentes dos encontrados por Mussa, Rogers e Securato (2009), segundo os quais a carteira de mercado era significante para todos os modelos, exceto para o CAPM com intercepto.

Os coeficientes da carteira de mercado nos modelos de três e quatro fatores com intercepto se apresentaram negativos e significantes. Contudo, quando os interceptos foram retirados dos modelos, os coeficientes passaram a ser positivos e próximos a 1, mas não significativos estatisticamente. Esta mudança no coeficiente de mercado ao retirar o intercepto também foi observada por Mussa, Rogers e Securato (2009), mas para esses autores todos os coeficientes foram estatisticamente significativos. Conforme comentado anteriormente, para o modelo CAPM sem intercepto a carteira de mercado foi significante a 10\%, e para o modelo com intercepto a carteira de mercado não foi significante. 
Tabela 12 - Regressão em Corte Transversal do período Out-of-Sample (jan/2004 a jun/2011)

\begin{tabular}{|c|c|c|c|c|c|c|c|c|c|c|c|}
\hline \multirow{2}{*}{ Modelos } & \multirow{2}{*}{\begin{tabular}{c|c|}
$R^{2}$ \\
Ajustado
\end{tabular}} & \multicolumn{2}{|c|}{$a$ (Intercepto) } & \multicolumn{2}{|c|}{$b$ (Mercado) } & \multicolumn{2}{|c|}{$s$ (SMB) } & \multicolumn{2}{|c|}{$h$ (HML) } & \multicolumn{2}{|c|}{ w (WinMLos) } \\
\hline & & Coeficientes & Estatística t & Coeficientes & Estatística t & Coeficientes & Estatística t & Coeficientes & Estatística t & Coeficientes & Estatística t \\
\hline \begin{tabular}{|l} 
CAPM + \\
Intercepto \\
\end{tabular} & $19,3 \%$ & 1,417 & 1,086 & 0,453 & $-0,364$ & & & & & & \\
\hline \begin{tabular}{|l} 
Fatores + \\
Intercepto
\end{tabular} & $32,1 \%$ & 3,947 & $2,854 * * *$ & 3,060 & $-2,281 \quad * *$ & 0,050 & 0,100 & 0,754 & 1,438 & & \\
\hline \begin{tabular}{|l}
4 Fatores + \\
Intercepto
\end{tabular} & $31,9 \%$ & 4,256 & $3,019 * * *$ & 3,483 & $-2,513 \quad * *$ & 0,063 & 0,126 & 0,750 & 1,425 & 0,268 & - 1,008 \\
\hline CAPM & $36,2 \%$ & & & 1,240 & $1,650 *$ & & & & & & \\
\hline 3 Fatores & $50,0 \%$ & & & 0,996 & 1,530 & 0,190 & $-0,383$ & 1,007 & $1,944 \quad *$ & & \\
\hline 4 Fatores & $45,5 \%$ & & & 0,934 & 1,422 & 0,193 & $-0,388$ & 1,014 & $1,932 *$ & 0,263 & $-0,992$ \\
\hline
\end{tabular}

Nota: *** indica que o coeficiente é estatisticamente significante a $1 \%$; ** indica que o coeficiente é estatisticamente significante a $5 \%$ e $*$ indica que o coeficiente é estatisticamente significante a $10 \%$. 
Assim como as evidências encontradas por Mussa, Rogers e Securato (2009), os coeficientes tamanho e momento não foram significantes na explicação dos excessos de retornos das carteiras. Os coeficientes do fator tamanho foram negativos para os modelos sem intercepto, o que indicou que empresas maiores possuem retornos superiores às empresas menores. Para os modelos com intercepto, estes coeficientes foram positivos, porém pequenos. Já os coeficientes do fator momento foram negativos, o que indicou que ações com bom desempenho no ano anterior não possuem um retorno superior.

Estes resultados do fator tamanho e momento já eram esperados em função dos resultados encontrados por Mussa, Rogers e Securato (2009) e das evidências encontradas a partir das regressões em série de tempo, conforme detalhado anteriormente: os coeficientes do fator tamanho só foram significantes para as carteiras de empresas pequenas, e os coeficientes de empresas perdedoras se mostraram negativos, o que indicou a não existência do fator momento conforme proposto por Carhart (1997).

O fator de risco índice B/M, que no trabalho de Mussa, Rogers e Securato (2009) mostrou-se fortemente significativo, na presente dissertação não foi significativo nos modelos com intercepto e só foi significativo a $10 \%$ nos modelos sem intercepto. Este efeito pode indicar que na ausência do intercepto, o índice B/M oferece uma proxy de uma informação relevante na explicação dos retornos das carteiras. Porém, quando o intercepto é adicionado aos modelos, esta informação é incluída no modelo através do intercepto, fazendo com que a informação presente no fator do índice B/M não seja mais estatisticamente significante na explicação dos retornos dos ativos.

Finalmente, a análise dos coeficientes de determinação ajustados indicou que os modelos deixaram de explicar boa parte dos excessos de retornos das carteiras, o que sugere, portanto, a ineficiência dos modelos apresentados e a existência de outros fatores não pertencentes ao modelo que auxiliariam a explicar os retornos das carteiras.

Os $\mathrm{R}^{2}$ dos modelos CAPM se mostraram superiores aos encontrados por Mussa, Rogers e Securato (2009): 19,3\% e 36,2\% contra 3\% e -7\%. Os coeficientes de determinação ajustados dos modelos de três fatores foram superiores aos dos modelos de quatro fatores, o que indicou, mais uma vez, que o fator momento não foi relevante na explicação dos excessos dos retornos das carteiras. De acordo com os resultados obtidos, os modelos sem intercepto explicam uma parte maior da variação dos retornos das carteiras, uma vez que os coeficientes de determinação ajustados destes modelos foram superiores em relação aos modelos com intercepto. Um efeito semelhante foi encontrado por Bellizia (2009).

Em resumo, os baixos $\mathrm{R}^{2}$ ajustados dos modelos, a alta significância dos interceptos e 
a baixa significância estatística dos coeficientes sugerem a existência de outros fatores que seriam capazes de explicar os retornos das carteiras. Não há evidências de que estes modelos sejam capazes de explicar os retornos dos ativos no mercado brasileiro. Assim, os modelos CAPM, três fatores de Fama e French (1993) e quatro fatores de Carhart (1997) não parecem adequados para o mercado brasileiro, por não fornecerem resultados satisfatórios como os obtidos pelos autores no mercado norte-americano.

Com o objetivo de minimizar eventuais vieses em virtude da definição arbitrária dos períodos within-sample e out-of-sample, os testes foram realizados da mesma forma para quatro períodos, alterando o período within-sample em seis meses. Os resultados obtidos nestas simulações são apresentados na Tabela 13.

Em todos os períodos, os interceptos mostraram-se altamente significativos para os modelos de três e quatro fatores, o que corrobora com os indícios de que os fatores parecem não ser suficientes para explicar os retornos das carteiras e de que este não parece ser um efeito relacionado com o período utilizado para análise. Para o modelo CAPM, os interceptos não foram estatisticamente significantes em nenhum dos quatro períodos, resultado em linha com o obtido no período original.

Já em relação à análise dos fatores de mercado e índice $\mathrm{B} / \mathrm{M}$, foi possível observar algumas alterações entre os períodos. O fator mercado permaneceu negativo nos modelos de três e quatro fatores com intercepto, porém não foi estatisticamente significativo para o período de jul/1996 a dez/2002 para os modelos de três e quatro fatores e para o modelo de três fatores no período de jul/1996 a jun/2003. O fator de mercado dos modelos CAPM com intercepto não foi estatisticamente significante em nenhum dos períodos, resultado também em linha com o obtido no período original.

Nos modelos sem intercepto, o fator de mercado foi estatisticamente significativo nos períodos jul/1996 a dez/2002 e jul/1996 a jun/2003 para os três modelos, resultados diferentes dos apresentados no período original de análise, que indicaram que este fator não era estatisticamente significante para o modelo de três e quatro fatores. No período jul/1996 a jun/2004, somente o fator de mercado do modelo CAPM foi significante a $10 \%$. No período jul/1996 a dez/2004, o fator de mercado não foi significante em nenhum dos modelos. 
Tabela 13 - Regressão em Corte Transversal: Análise de Períodos

\begin{tabular}{|c|c|c|c|c|c|c|c|c|c|c|c|c|c|c|}
\hline \multirow{2}{*}{$\begin{array}{l}\text { Within- } \\
\text { sample }\end{array}$} & \multirow{2}{*}{ Modelos } & \multicolumn{3}{|c|}{$a$ (Intercepto) } & \multicolumn{3}{|c|}{$b$ (Mercado) } & \multicolumn{2}{|c|}{$s$ (SMB) } & \multicolumn{3}{|c|}{$h$ (HML) } & \multicolumn{2}{|c|}{$w$ (WinMLos) } \\
\hline & & Coeficientes & Estatístic & cat & Coeficientes & Estatísti & ica t & Coeficientes & Estatística t & Coeficientes & Estatístic & ica t & Coeficientes & Estatística t \\
\hline \multirow{6}{*}{$\begin{array}{c}\mathrm{jul} / 1996 \\
\mathrm{a} \\
\mathrm{dez} / 2002\end{array}$} & \begin{tabular}{l|} 
CAPM + \\
Intercepto
\end{tabular} & 1,920 & 1,566 & & 0,447 & $-0,380$ & & & & & & & & \\
\hline & $\begin{array}{l}3 \text { Fatores + } \\
\text { Intercepto }\end{array}$ & 3,458 & $2,483 *$ & ** & 2,089 & $-1,453$ & & 0,117 & 0,242 & 0,747 & 1,554 & & & \\
\hline & $\begin{array}{l}4 \text { Fatores + } \\
\text { Intercepto }\end{array}$ & 3,672 & $2,585 *$ & *** & 2,312 & $-1,514$ & & 0,158 & 0,316 & 0,728 & 1,491 & & 0,197 & $-0,776$ \\
\hline & CAPM & & & & 1,852 & 2,529 & ** & & & & & & & \\
\hline & 3 Fatores & & & & 1,464 & 2,329 & $* *$ & 0,093 & $-0,190$ & 0,969 & $2,014 *$ & $* *$ & & \\
\hline & 4 Fatores & & & & 1,491 & 2,306 & ** & 0,064 & $-0,128$ & 0,956 & $1,942 *$ & & 0,190 & $-0,761$ \\
\hline \multirow{6}{*}{$\begin{array}{c}\text { jul/1996 } \\
\text { a } \\
\text { jun/2003 }\end{array}$} & $\begin{array}{l}\text { CAPM + } \\
\text { Intercepto }\end{array}$ & 1,910 & 1,498 & & 0,398 & $-0,328$ & & & & & & & & \\
\hline & $\begin{array}{l}3 \text { Fatores + } \\
\text { Intercepto }\end{array}$ & 3,580 & $2,530 *$ & ** & 2,180 & $-1,540$ & & 0,108 & 0,210 & 0,707 & 1,395 & & & \\
\hline & \begin{tabular}{|l|}
4 Fatores + \\
Intercepto
\end{tabular} & 3,837 & $2,669 *$ & *** & 2,525 & - 1,734 & $*$ & 0,111 & 0,218 & 0,698 & 1,373 & & 0,249 & $-0,956$ \\
\hline & CAPM & & & & 1,876 & 2,484 & & & & & & & & \\
\hline & 3 Fatores & & & & 1,486 & 2,291 & $* *$ & 0,114 & $-0,225$ & 0,938 & $1,859 *$ & & & \\
\hline & 4 Fatores & & & & 1,441 & 2,195 & ** & 0,121 & $-0,238$ & 0,936 & $1,839 *$ & & 0,251 & $-0,970$ \\
\hline \multirow{6}{*}{$\begin{array}{c}\mathrm{jul} / 1996 \\
\mathrm{a} \\
\mathrm{jun} / 2004\end{array}$} & \begin{tabular}{l|} 
CAPM + \\
Intercepto
\end{tabular} & 1,515 & 1,107 & & 0,411 & $-0,321$ & & & & & & & & \\
\hline & $\begin{array}{l}3 \text { Fatores + } \\
\text { Intercepto }\end{array}$ & 3,860 & $2,641 *$ & $* * *$ & 2,855 & $-2,064$ & $* *$ & 0,065 & 0,123 & 0,749 & 1,348 & & & \\
\hline & $\begin{array}{l}4 \text { Fatores + } \\
\text { Intercepto }\end{array}$ & 4,259 & $2,857 *$ & $* * *$ & 3,395 & $-2,375$ & $* *$ & 0,076 & 0,143 & 0,746 & 1,340 & & 0,398 & - 1,462 \\
\hline & CAPM & & & & 1,388 & 1,771 & & & & & & & & \\
\hline & 3 Fatores & & & & 1,099 & 1,636 & & 0,170 & $-0,328$ & 0,996 & $1,820 *$ & & & \\
\hline & 4 Fatores & & & & 1,009 & 1,488 & & 0,180 & $-0,347$ & 1,010 & $1,829 *$ & & 0,400 & 1,470 \\
\hline \multirow{6}{*}{$\begin{array}{c}\mathrm{jul} / 1996 \\
\mathrm{a} \\
\mathrm{dez} / 2004\end{array}$} & $\begin{array}{l}\text { CAPM + } \\
\text { Intercepto }\end{array}$ & 0,752 & 0,561 & & 0,219 & 0,180 & & & & & & & & \\
\hline & $\begin{array}{l}3 \text { Fatores + } \\
\text { Intercepto }\end{array}$ & 3,152 & $2,125 *$ & ** & 2,304 & $-1,668$ & $*$ & 0,205 & $-0,425$ & 0,996 & $2,019 *$ & $* *$ & & \\
\hline & $\begin{array}{l}4 \text { Fatores + } \\
\text { Intercepto } \\
\end{array}$ & 3,481 & $2,318 *$ & ** & 2,752 & - 1,948 & $*$ & 0,191 & - 0,397 & 0,990 & $2,004 *$ & $* *$ & 0,318 & $-1,172$ \\
\hline & CAPM & & & & 1,129 & 1,367 & & & & & & & & \\
\hline & 3 Fatores & & & & 0,962 & 1,349 & & 0,363 & $-0,762$ & 1,178 & $2,428 *$ & ** & & \\
\hline & 4 Fatores & & & & 0,884 & 1,228 & & 0,367 & $-0,770$ & 1,189 & $2,438 *$ & ** & 0,301 & $-1,114$ \\
\hline
\end{tabular}

Nota: *** indica que o coeficiente é estatisticamente significante a $1 \%$; ** indica que o coeficiente é estatisticamente significante a $5 \%$ e * indica que o coeficiente é estatisticamente significante a $10 \%$.

O fator índice B/M $(H M L)$ se mostrou significativo a 5\% para o período de jul/1996 a dez/2004 em todos os modelos, com e sem intercepto, bem como para o modelo de três fatores sem intercepto, no período de jul/1996 a dez/2002. Foi significante a 10\% para os períodos jul/1996 a jun/2003 e jul/1996 a jun/2004, nos modelos de três e quatro fatores sem intercepto, além do modelo de quatro fatores sem intercepto no período jul/1996 a jun/2002. Para os modelos com intercepto, o fator índice B/M só foi estatisticamente significante no período de jul/1996 a dez/2004, conforme citado anteriormente. No teste utilizando o período original, o fator de risco índice $\mathrm{B} / \mathrm{M}$ se mostrou significante a $10 \%$ nos modelos sem intercepto e nos modelos com intercepto não foi estatisticamente significante. Estes resultados indicam que o período pode influenciar a significância do fator. Estas evidências foram diferentes das encontradas por Mussa, Rogers e Securato (2009), que compararam os modelos CAPM, três fatores e quatro fatores, e das encontradas por Bellizia (2009), que comparou quatro modelos de precificação de ativos.

Além disso, observa-se que, nos modelos de três e quatro fatores sem intercepto, o coeficiente do fator índice B/M (HML) é estatisticamente significante em todos os períodos e, 
quando o intercepto é adicionado ao modelo, este coeficiente passa a não ser significante para três dos quatro períodos analisados.

Os coeficientes dos fatores tamanho e momento não foram estatisticamente significantes para nenhum dos modelos e períodos, conforme observado no período original e anteriormente publicado por Mussa, Rogers e Securato (2009). O coeficiente do fator tamanho $(S M B)$ foi negativo em todos os modelos sem intercepto e positivo para três dos quatro períodos analisados dos modelos com intercepto, conforme observado no período original. Já os coeficientes do fator momento (WinMLos) foram negativos para todos os períodos, o que confirma as evidências encontradas no período original, de que parece não existir no mercado brasileiro o efeito documentado por Jegadeesh e Titman (1993). Estas evidências indicam que estes efeitos não foram decorrentes da escolha do período de análise.

Assim, é possível notar que há algumas mudanças nos coeficientes em função da escolha dos períodos within-sample utilizado, especialmente para os fatores da carteira de mercado e do índice B/M $(H M L)$. Quando comparadas as magnitudes dos coeficientes estatisticamente significantes, estas não são divergentes em função do período. Contudo, a significância muda. Estes resultados indicam que é necessário utilizar mais de um período de análise, pois os resultados podem ser influenciados pelo período escolhido.

\subsection{Análise das hipóteses formuladas}

Com base na análise dos dados e nos resultados apresentados, é possível analisar as hipóteses formuladas no Capítulo 3.

- $\mathrm{H}_{0,1}$ : o modelo CAPM não é significante na explicação dos retornos dos ativos brasileiros.

Não foi possível rejeitar a hipótese nula $\mathrm{H}_{0,1}$, uma vez que o modelo CAPM com intercepto só foi capaz de explicar $19 \%$ dos excessos dos retornos das carteiras e $36 \%$ no modelo sem intercepto.

- $\mathrm{H}_{0,2}$ : o modelo de três fatores não é significante na explicação dos retornos dos ativos brasileiros. 
Não foi possível rejeitar a hipótese nula $\mathrm{H}_{0,2}$, pois o modelo de três fatores com intercepto foi capaz de explicar $32 \%$ dos retornos das carteiras e o modelo sem intercepto foi capaz de explicar 50\%.

- $\mathrm{H}_{0,3}$ : o modelo de quatro fatores não é significante na explicação dos retornos dos ativos brasileiros.

Não foi possível rejeitar a hipótese nula $\mathrm{H}_{0,3}$, visto que o modelo de quatro fatores com intercepto explicou $32 \%$ dos retornos das carteiras, e o modelo sem intercepto explicou $46 \%$.

- $\mathrm{H}_{0,4}$ : a variável carteira de mercado não é significante na explicação dos retornos dos ativos brasileiros.

No modelo CAPM com intercepto, a carteira de mercado não foi significante na explicação dos retornos das carteiras, portanto não foi possível rejeitar a hipótese $\mathrm{H}_{0,6}$. Já no modelo CAPM sem intercepto, a carteira de mercado se mostrou estatisticamente significante ao nível de $10 \%$. Assim, é possível rejeitar a hipótese nula $\mathrm{H}_{0,6}$.

- $\mathrm{H}_{0,5}$ : uma ou mais variáveis no modelo de três fatores não são significantes na explicação dos retornos dos ativos brasileiros.

Não foi possível rejeitar a hipótese nula $\mathrm{H}_{0,5}$, uma vez que, no modelo de três fatores com intercepto, os fatores tamanho $(S M B)$ e índice $\mathrm{B} / \mathrm{M}(H M L)$ se apresentaram estatisticamente iguais a zero, e no modelo sem intercepto os fatores mercado e tamanho $(S M B)$ não foram estatisticamente significantes.

- $\mathrm{H}_{0,6}$ : uma ou mais variáveis no modelo de quatro fatores não são significantes na explicação dos retornos dos ativos brasileiros.

No modelo de quatro fatores com intercepto, os fatores de risco tamanho (SMB), índice B/M (HML) e momento (WinMLos) não se mostraram estatisticamente significantes. Já no modelo sem intercepto, os fatores carteira de mercado, tamanho (SMB) e momento (WinMLos) foram estatisticamente iguais a zero. Portanto, não foi possível rejeitar a hipótese 
nula $\mathrm{H}_{0,4}$ para ambos os modelos.

- $\mathrm{H}_{0,7}$ : o modelo de quatro fatores não é superior ao de três fatores na explicação dos retornos dos ativos brasileiros.

Como ambos os coeficientes de determinação ajustados dos modelos de quatro fatores (com e sem intercepto) não foram superiores aos apresentados pelos respectivos modelos de três fatores na explicação dos retornos das carteiras, não foi possível rejeitar a hipótese nula $\mathrm{H}_{0,7}$.

- $\mathrm{H}_{0,8}$ : o modelo de três fatores não é superior ao CAPM na explicação dos retornos dos ativos brasileiros.

É possível rejeitar a hipótese nula $\mathrm{H}_{0,8}$. Os coeficientes dos modelos de três fatores com e sem intercepto foram superiores aos apresentados pelos respectivos modelos CAPM.

- $\quad \mathrm{H}_{0,9}$ : o intercepto é estatisticamente significante e diferente de zero.

Não é possível rejeitar a hipótese nula $\mathrm{H}_{0,9}$ de que o intercepto é estatisticamente significante e diferente de zero para os modelos de três e quatro fatores. Para o modelo CAPM, o intercepto foi estatisticamente igual a zero. De acordo com os resultados obtidos, os modelos se apresentaram insuficientes para a explicação dos retornos das carteiras, uma vez que o intercepto diferente de zero indica que outros fatores não especificados no modelo devem ter poder de explicação sobre os retornos.

Por fim, a Tabela 14 resume as hipóteses discutidas. 
Tabela 14 - Resumo das hipóteses

\begin{tabular}{|l|l|}
\hline \multicolumn{1}{|c|}{ Hi póteses } & \multicolumn{1}{|c|}{ Conclusão } \\
\hline $\begin{array}{l}\mathrm{H}_{0,1}: \text { o modelo CAPM não é significante na explicação dos } \\
\text { retornos dos ativos brasileiros }\end{array}$ & $\begin{array}{l}\text { Não rejeita a hipótese para os modelos } \\
\text { com e sem intercepto }\end{array}$ \\
\hline $\begin{array}{l}\mathrm{H}_{0,2}: \text { o modelo de três fatores não é significante na explicação dos } \\
\text { retornos dos ativos brasileiros }\end{array}$ & $\begin{array}{l}\text { Não rejeita a hipótese para os modelos } \\
\text { com e sem intercepto }\end{array}$ \\
\hline $\begin{array}{l}\mathrm{H}_{0,3}: \text { o modelo de quatro fatores não é significante na explicação } \\
\text { dos retornos dos ativos brasileiros }\end{array}$ & $\begin{array}{l}\text { Não rejeita a hipótese para os modelos } \\
\text { com e sem intercepto }\end{array}$ \\
\hline $\begin{array}{l}\mathrm{H}_{0,4}: \text { a variável carteira de mercado não é significante na } \\
\text { explicação dos retornos dos ativos brasileiros }\end{array}$ & $\begin{array}{l}\text { Não rejeita a hipótese para o modelo } \\
\text { com intercepto e rejeita a hipótese para } \\
\text { o modelo sem intercepto }\end{array}$ \\
\hline $\begin{array}{l}\mathrm{H}_{0,5}: \text { uma ou mais variáveis no modelo de três fatores não são } \\
\text { significantes na explicação dos retornos dos ativos brasileiros }\end{array}$ & $\begin{array}{l}\text { Não rejeita a hipótese para os modelos } \\
\text { com e sem intercepto }\end{array}$ \\
\hline $\begin{array}{l}\mathrm{H}_{0,6}: \text { uma ou mais variáveis no modelo de quatro fatores não são } \\
\text { significantes na explicação dos retornos dos ativos brasileiros }\end{array}$ & $\begin{array}{l}\text { Não rejeita a hipótese para os modelos } \\
\text { com e sem intercepto }\end{array}$ \\
\hline $\begin{array}{l}\mathrm{H}_{0,7}: \text { o modelo de quatro fatores não é superior ao de três fatores } \\
\text { na explicação dos retornos dos ativos brasileiros }\end{array}$ & $\begin{array}{l}\text { Não rejeita a hipótese para os modelos } \\
\text { com e sem intercepto }\end{array}$ \\
\hline $\begin{array}{l}\mathrm{H}_{0,8}: \text { o modelo de três fatores não é superior ao CAPM na } \\
\text { explicação dos retornos dos ativos brasileiros }\end{array}$ & $\begin{array}{l}\text { Rejeita a hipótese para os modelos com } \\
\text { e sem intercepto }\end{array}$ \\
\hline $\begin{array}{l}\mathrm{H}_{0,9}: \text { o intercepto é estatisticamente significante e diferente de } \\
\text { zero }\end{array}$ & $\begin{array}{l}\text { Não rejeita a hipótese para os modelos } \\
\text { de três e quatro fatores e rejeito a } \\
\text { hipótese para o modelo CAPM }\end{array}$ \\
\hline
\end{tabular}




\section{Considerações Finais}

A melhora na estabilidade econômica e o consequente desenvolvimento do mercado de capitais brasileiro, adicionado às incertezas sobre os efeitos da crise de crédito na economia mundial, colocaram em evidência um tema controverso na teoria de finanças: a análise da taxa de retorno esperada em um investimento.

Diante desta realidade, o objetivo da presente dissertação foi comparar os modelos CAPM, três fatores de Fama e French (1993) e quatro fatores de Carhart (1997) a partir de metodologia de teste preditivo, que aplica a regressão em dois estágios - regressão em série temporal e em corte transversal -, com erro padrão calculado conforme técnica aplicada por Fama e Macbeth (1973). Para isto utilizaram-se 513 ações listadas na Bolsa no período de julho de 1995 a junho de 2011.

Primeiramente, realizou-se regressão em série de tempo utilizando os dados de todo o período amostral, o que permitiu analisar a sensibilidade dos prêmios das carteiras em relação aos fatores carteira de mercado, tamanho, índice B/M e momento de acordo com o respectivo modelo. Os resultados observados indicaram que o modelo CAPM deixa de explicar uma parte significativa das variações dos retornos das carteiras. Os $\mathrm{R}^{2}$ e os coeficientes da carteira de mercado das carteiras Small são menores do que os das carteiras Big.

$\mathrm{O}$ modelo de três fatores apresentou coeficientes do índice $\mathrm{B} / \mathrm{M}(H M L)$ negativos para as carteiras Low, o que indicou que não necessariamente empresas de alto índice B/M oferecem retornos superiores para o mercado brasileiro. Todos os coeficientes de mercado foram fortemente significativos e ficaram próximos a 1. Os coeficientes do fator tamanho $(S M B)$ foram mais significativos para explicar as variações dos retornos das carteiras Small do que das carteiras Big. O R ${ }^{2}$ ficou entre $56 \%$ e $83 \%$, sendo maior do que $80 \%$ para 3 das 24 carteiras.

Já o modelo de quatro fatores apresentou $\mathrm{R}^{2}$ entre $59 \%$ e $84 \%$, sendo que 5 das 24 carteiras foram maiores de $80 \%$. Os coeficientes do fator momento (WinMLos) foram negativos e maiores para as carteiras Winner do que para as carteiras Loser, o que significa que não foi possível observar o mesmo efeito documentado por Jegadeesh e Titman (1993). Os coeficientes do fator de mercado explicam fortemente as variações dos retornos das carteiras, e os do índice B/M (HML) foram negativos para as carteiras Low. Os coeficientes do fator tamanho (SMB) explicam fortemente as variações dos retornos das carteiras Small.

O modelo de três fatores foi superior para a explicação dos retornos das carteiras em relação ao modelo CAPM, e o modelo de quatro fatores, por sua vez, foi superior ao de três 
fatores.

Após a análise das regressões em série de tempo, foi realizado teste preditivo com regressão em dois estágios, o que permitiu testar o modelo calculado no primeiro estágio com regressões em corte transversal mês a mês, analisando a variação dos parâmetros ao longo do tempo.

Os resultados obtidos por meio dessa técnica indicaram que o modelo CAPM não foi capaz de explicar a variação dos retornos das carteiras e somente o coeficiente de mercado do modelo sem intercepto foi significativo a $10 \%$.

Uma vez que os interceptos dos modelos de três e quatro fatores foram fortemente significativos, há evidências de que outros fatores não incluídos nos modelos seriam capazes de explicar os retornos das carteiras.

No modelo de três fatores com intercepto, somente a carteira de mercado e o intercepto foram significantes, mas o coeficiente de mercado foi negativo. No modelo sem intercepto, somente o fator índice $\mathrm{B} / \mathrm{M}(H M L)$ foi estatisticamente significante na explicação dos retornos das carteiras.

Já no modelo de quatro fatores, a inclusão do fator momento (WinMLos) não alterou de forma significativa os resultados do modelo de três fatores, e seus coeficientes foram negativos e não significantes para as carteiras Winner. Somente o fator índice B/M $(H M L)$ foi significante na explicação dos retornos das carteiras no modelo sem intercepto. No modelo com intercepto os coeficientes mercado e o intercepto foram estatisticamente significantes. $\mathrm{O}$ fator tamanho foi negativo para as carteiras Loser, mas não significante nos modelos com e sem intercepto.

O modelo de três fatores foi superior na explicação das variações dos retornos dos ativos em relação ao modelo de quatro fatores e ao CAPM. O CAPM foi o que apresentou os menores $\mathrm{R}^{2}$ entre os três modelos.

Entre todos os modelos, o que melhor explicou os retornos dos ativos foi o de três fatores sem intercepto, que explicou $50 \%$ dos retornos. Contudo, nenhum deles foi capaz de explicar de forma significativa os retornos das carteiras, uma vez que todos os coeficientes de determinação ajustados ficaram entre $19 \%$ e $50 \%$, inferiores a $80 \%$.

Com o objetivo de verificar se a escolha dos períodos within-sample e out-of-sample poderia influenciar nos resultados obtidos, definiram-se outros quatro períodos within-sample e os testes foram repetidos.

Os resultados obtidos indicaram que os coeficientes do intercepto foram fortemente significativos para todos os períodos, o que indicou que os fatores parecem não ser suficientes 
para explicar as variações dos retornos das carteiras, independentemente dos períodos withinsample escolhidos.

Os coeficientes dos fatores tamanho $(S M B)$ e momento (WinMLow) permaneceram sem significância estatística, o que indicou que este efeito não está associado ao período escolhido. Os coeficientes de mercado e índice $\mathrm{B} / \mathrm{M}(H M L)$ apresentaram diferenças de significância entre os períodos, o que indicou que é necessário utilizar mais de um período para análise.

É possível concluir, portanto, que apesar de o modelo de três fatores ter apresentado resultados superiores aos demais na explicação das variações dos retornos das carteiras, nenhum dos modelos foi capaz de explicar estas variações, por terem apresentado baixos coeficientes de determinação e pela significância estatística do intercepto ter sido alta. Foram observadas evidências de que os fatores incluídos nos modelos não são suficientes para explicar os retornos das carteiras.

Uma importante limitação observada nesta dissertação diz respeito à quantidade pequena de empresas com ações listadas na Bolsa e dos menores níveis de liquidez observados no mercado brasileiro. Tais limitações restringiram a quantidade de ações utilizadas para formar as carteiras e comprometeu também a diversificação das carteiras, principalmente nos primeiros anos. Além disso, o reduzido número de ações restringiu o número de carteiras que poderiam ser formadas, o que pode ter prejudicado os resultados das regressões em corte transversal. Contudo, como estas limitações são uma característica do mercado brasileiro, não foi possível evitá-las.

Em segundo lugar, a carteira de mercado utilizada neste trabalho foi composta por todos os retornos dos ativos incluídos na amostra, ponderados por seu valor de mercado. Contudo, esta carteira pode não representar de forma exata a carteira de mercado, conforme proposto por Sharpe (1964), o que adiciona mais uma limitação para esta pesquisa.

Poucos estudos conduzidos no mercado brasileiro utilizam o modelo preditivo conforme realizado nesta dissertação, em adição ao modelo de teste contemporâneo. Neste ponto, os resultados aqui apresentados podem ter despertado mais questionamentos do que respostas. Porém acredita-se ter contribuído para discussões acerca do tema e no direcionamento de futuras pesquisas, sugerindo analisar outros fatores que possam explicar as variações dos retornos dos ativos no mercado brasileiro, como uma carteira setorial, nível de endividamento, alavancagem, índice preço/lucro, entre outros, conforme realizado por Fama e French (1992). 
6 Bibliografia

ANDERSON, David R.; SWEENEY, Dennis J.; WILLIAMS, Thomas A. Estatística Aplicada à Administração e Economia. 2. Ed. São Paulo: Pioneira Thomson Learning, 2003.

ANBIMA. Associação Brasileira das Entidades dos Mercados Financeiros e de Capitais. Informativo Anbima: Especial Fusões e Aquisições. Ano II, março de 2011. Disponível em: <http://www.anbima.com.br/mostra.aspx/?id=4275>. Acesso em 04/07/2011.

ANDRADE, Maria Margarida de. Como preparar trabalhos para cursos de pósgraduação: noções práticas. 7. Ed. São Paulo: Atlas, 2008.

ARAÚJO, Eurilton; FAJARDO, José; e TAVANI, Leonardo C. di. CAPM Usando Uma Carteira Sintética do PIB Brasileiro. Estudos em Economia, São Paulo, v. 36, n. 3, pp. 465505, 2006.

BANZ, R. The relationship between return and market value of common stock. Journal of Financial Economics, 9, pp. 3-18, March, 1981.

BASU, S. Investment performance of common stocks in relation to their price-earnings ratios: a test of market efficiency. The Journal of Finance, 32, pp. 663-682, June, 1977.

BELliZIA, Nathália W. Aplicação do CAPM Para a Determinação do Custo de Capital Próprio no Brasil. São Paulo, 2009. Dissertação (Mestrado em Administração) - Programa de Pós-Graduação em Administração, Departamento de Administração, Faculdade de Administração, Economia e Contabilidade da Universidade de São Paulo.

BERGMAnN, Daniel. Avaliação Empírica do Modelo CAPM no Mercao de Capitais Brasileiro Via Método de Momento Generalizado. São Paulo, 2006. Dissertação (Mestrado em Ciências Contábeis) - Programa de Pós-Graduação em Ciências Contábeis, Departamento de Administração, Faculdade de Administração, Economia e Contabilidade da Universidade de São Paulo. 
BLACK, F., JENSEN, M. C., SCHOLES, M. The Capital asset pricing model: some empirical testes. In M.C. Jensen (org.). Studies in the Theory of Capital Markets. New York, Praeger, 1972.

BLACK, Fisher. Beta and return. The Journal of Portfolio Management. Vol. 20, n. 1, pp. 8-18, 1993.

BLUME, Marshals E.; FRIEND, Irwin. A New Look At The Capital Asset Pricing Model. The Journal of Finance. v. 28, n. 1, pp. 19-33, 1973.

BLUME, Marshals E.; HUSIC, Frank. Price, Beta, and Exchange Listing. The Journal of Finance. v. 28, n. 2, pp. 283-299, 1973.

BOLLEN, Kenneth A.; JACKMAN, Robert W. Regression diagnostics: An expository treatment of outliers and influential cases, in FOX, John; LONG, J. Scott (eds.). Modern Methods of Data Analysis. Newbury Park, CA, Sage, pp. 257-91, 1990.

BRUNI, Adriano L. Risco, retorno e equilíbrio: uma análise do modelo de precificação de ativos financeiros na avaliação de ações negociadas na BOVESPA. São Paulo, 1998. Dissertação (Mestrado em Administração) - Programa de Pós-Graduação em Administração, Departamento de Administração, Faculdade de Administração, Economia e Contabilidade da Universidade de São Paulo.

CARHART, Mark M. On persistence in mutual fund performance. The Journal of Finance. v. 52, n. 1, pp. 57-82, 1997.

CHAN, Louis C.; JEGADEESH, Narasihan ; LAKONISHOK, Josef. Momentum Strategies. The Journal of Finance. v. 51, n. 5, pp. 1681-1713, 1996.

CHAN, Louis C.; LAKONISHOK, Josef. Are reports of beta's death premature?. The Journal of Porfolio Management. vol. 19, n. 4, pp. 51-62, 1993.

CHEN, Nai-fu; ROLL, Richard; ROSS, Stephen. Economic Forces and the Stock Market. Journal of Business. 59, pp. 386-403, 1986. 
COOK, R. Denis. Detection of Influential Observation in Linear Regression. Technometrics, vol. 19, n. 1, pp. 15-18, 1977.

Influential Observations in Linear Regression. Journal of the American Statistical Association, Vol. 74, No. 365, pp. 169-174, 1979.

COPELAND, Thomas E.; WESTON, J. Fred; e SHASTRI, Kuldeep. Financial Theory and Corporate Policy. USA: Pearson Education, Inc. 2005.

COSTA Jr., Newton C. A. da; NEVES, Myrian B. E. Variáveis fundamentalistas e retornos das ações. Revista Brasileira de Economia. Vol. 54, n. 1, pp. 123-137, 2000.

DE BONDT, Werner F. M.; THALER, Richard H. Does The Stock Market Overreact?. The Journal of Finance, v. 40, n. 3, pp. 793-805, 1985.

Further Evidence on Investor Overreaction and Stock Market Seasonality. The Journal of Finance, v. 42, n. 3, pp. 557-581, 1987.

DHRYMES, Pheobus; FRIEND, Irwin; GULTEKIN, N. Bulent. A Critical Reexamination of the Empirical Evidence on the Arbitrage Pricing Theory. The Journal of Finance. vol. 39, n. 2, pp. 323-346, 1984.

DOUGLAS, G.W. Risk in the equity markets: an empirical appraisal of market efficiency. Yale Economic Essay, 9, pp. 3-45, Spring, 1969.

ELTON, Edwin J. e GRUBER, Martin J. Modern portfolio theory and investment analysis. USA: John Wiley e Sons, 1995.

FAMA, Eugene F. Efficient Capital Markets: A Review of Theory and Empirical Work. The Journal of Finance, v. 25, n. 2, pp.383-417, 1970.

. Efficient Capital Markets: II. The Journal of Finance, v. 46, n. 5, pp.1575-1617, 1991. 
FAMA, Eugene F.; FRENCH, Kenneth R. The cross-section of expected stock returns. The Journal of Finance, 47, pp.427-465, June, 1992.

. Common risk factors in the returns on stock and bonds. The Journal of Finance. v. 33, pp. 3-56, 1993.

Kenneth R. Multifactor explanation of asset pricing anomalies. The Journal of Finance, 56, pp. 55-84, January, 1996.

. The Capital Asset Pricing Model: Theory and Evidence. Journal of Economic Perspective, v. 18, n. 3, pp. 25-46, 2004.

FAMA, Eugene F.; MACBETH James D. Risk, return and equilibrium: empirical tests. Journal of Political Economy, pp. 607-636, May/June, 1973.

FRIEND, Irwin, BLUME, Marshall. Measurement of Portfolio Performance Under Uncertainty. The American Economic Review. v. 60, n. 4, pp. 561-575, 1970.

FRIEND, Irwin; WESTERFIELD, Randolph. Risk and capital asset prices. Journal of Banking and Finance, 5, pp. 291-315, 1981.

GAlEnO, Marcela M. Aplicação do CAPM (Capital Asset Pricing Model) Condicional por meio de métodos não-paramétricos para a economia brasileira: um estudo empírico do período 2002-2009. São Paulo: 2010. Dissertação (Mestrado em Administração) Programa de Pós-Graduação em Administração, Departamento de Administração, Faculdade de Administração, Economia e Contabilidade da Universidade de São Paulo.

GRINOLD, Richard C. Is beta dead again?. The Financial Analysts Journal, pp. 28-34, 1993.

GUJARATI, Damodar. Econometria Básica. 4a edição, 5ª tiragem. Rio de Janeiro: Elsevier, 2006. 
HAIR, Joseph F.; BLACK, Bill; BABIN, Barry; ANDERSON, Rolph E.; TATHAM, Ronald L. Análise Multivariada de Dados. 6a edição, Porto Alegre: Bookman, 2009.

HOU, Yuanfeng. Testing the CAPM by a synthetic return on GDP as the market return. Economics Department, Yale University, 2002.

JAGANNATHAN, Ravi; WANG, Zhenyu. An Asymptotic Theory for Estimating BetaPricing Models Using Cross-Sectional Regression. The Journal of Finance. v. 53, n. 4, pp. 1285-1309, 1998.

JEGADEESH, Narasihan, TITMAN, Sheridan. Returns to buying winners and selling losers: implications for stosk market efficiency. The Journal of Finance. v. 48, n. 1, pp. 65-91, 1993. Profitability of Momentum Strategies: An Evaluation of Alternative Explanations. The Journal of Finance. v. 56, n. 2, pp. 699-720, 2001.

KIM, Dongcheol. A reexamination of firm size, book-to-market and earnings price in the cross section of expected stock return. Journal of Financial and Quantitative Analysis. Vol. 32, n. 4, pp. 463-489, 1997.

LAKONISHOK, Josef; SHAPIRO, Alan C. Systematic risk, total risk and size as determinants of stock market returns. Journal of Banking and Finance, 10, pp. 115-132, 1986.

LAKONISHOK, Josef; SHLEIFER, Andrei; VISHNY, Robert W. Contrarian Investment, Extrapolation, and Risk. The Journal of Finance, v. 49, n. 5, pp. 1541-1578, 1994.

LINTNER, John. The Valuation of Risk Assets and the Selection of Risky Investments in Stock Portfolios and Capital Budgets. Review of Econometrics and Statistics. v. 47, n. 1, pp. 1337, 1965.

LINTZ, Alexandre; e RENYI, Liliane. Análise de Diversificação de Carteiras de Investimento Compostas por Ações Pertencentes ao Índice Bovespa: Um Confronto entre os 
Modelos de Sharpe e Markowitz. In: Seminários em Administração (SEMEAD), 3, 1998. Anais... Universidade de São Paulo, 1998.

MACKINLAY, A. Craig. Multifactor models do not explain deviations from the CAPM. Journal of Financial Economics, Vol. 38, pp. 3-28, 1995.

MÁlAGA, Flávio Kezan. Aplicação do modelo de três fatores de Fama e French no Mercado acionário brasileiro: um estudo empírico do período de 1995-2003. São Paulo, 2003. Dissertação (Mestrado em Administração) - Programa de Pós-Graduação em Administração, Departamento de Administração, Faculdade de Administração, Economia e Contabilidade da Universidade de São Paulo.

MÁlAGA, Flávio Kezan, SECURATO, José Roberto. Aplicação do modelo de três fatores de Fama \& French no mercado acionário brasileiro - um estudo empírico do período 19952003. In: Encontro Anual da Associação Nacional dos Programas de Pós-Graduação em Administração, 28, 2004, Curitiba. Anais...Curitiba: ANPAD, 2004.

MARKOWITZ, Harry M. Portfolio Selection. The Journal of Finance, vol. 7, No. 1, pp. 77$91,1952$.

Portfolio Selection: Efficient Diversification of Investments. Cowles Foundation Monograph, 16. Yale University Press, New Haven, 1959.

Foundations of Portfolio Theory. The Journal of Finance. vol. 46, No. 2, pp. 469477, 1991.

MARTINS, Gilberto de A. Epistemologia da pesquisa em administração. São Paulo, Tese de Livre-Docência, Universidade de São Paulo, 1994.

MOSSIN, Jan. Equilibrium in a Capital Asset Market. Econometrica. v. 34, n. 4, pp. 768783, 1966.

MUSSA, Adriano. A Adição do Fator de Risco Momento ao Modelo de Precificação de Ativos dos Três Fatores de Fama \& French, Aplicado ao Mercado Acionário Brasileiro. 
São Paulo: 2007. Dissertação (Mestrado em Administração) - Programa de Pós-Graduação em Administração, Pontifícia Universidade Católica de São Paulo.

MUSSA, Adriano, ROGERS, Pablo, SECURATO, José Roberto. Modelos de retornos esperados no mercado brasileiro: testes empíricos utilizando metodologia preditiva. Revista de Ciências da Administração. v. 11, n. 23, pp. 192-216, 2009.

MUSSA, Adriano, SANTOS, José O. FAMÁ, Rubens. A. A Adição do Fator de Risco Momento ao Modelo de Precificação de Ativos dos Três Fatores de Fama \& French, Aplicado ao Mercado Acionário Brasileiro. In: Congresso USP de Controladoria e Contabilidade, 7. 2007, São Paulo. Anais... São Paulo: USP, 2007.

MUSSA, Adriano; TROVÃO, Ricardo; SANTOS, José O. FAMÁ, Rubens. A. A estratégia de momento de Jegadeesh e Titman e suas implicações para a hipótese de eficiência do Mercado acionário brasileiro. In: Seminários em Administração (SEMEAD), 10, 2007. Anais... Universidade de São Paulo, 2007.

MURPHY, John J. Technical analysis of the futures markets. USA: New York Institute of Finance, 1999.

NAGANO, Marcelo S.; MERLO, Edgard M.; SILVA, Maristela C. da. As variáveis fundamentalistas e seus impactos na taxa de retorno de ações no Brasil. Revista FAE. Vol. 6, n. 2, pp. 13-28, 2003.

RAIFUR, Leo. Teoria e prática em avaliação de empresas: estudo exploratório dos laudos da CVM nos anos de 2006 e 2007. Curitiba: 2008. Dissertação (Mestrado em Contabilidade) - Programa de Mestrado em Contabilidade, Setor de Ciências Sociais Aplicadas da Universidade Federal do Paraná.

REINGANUM, Marc R. Misspecification of capital asset pricing: empirical anomalies based on earnings yields and market values. The Journal of Financial Economics, v. 9, pp. 19-46, 1981a. 
. New empirical perspective on the CAPM. Journal of Financial and Quantitative Analysis, v. 16, n. 4, pp. 439-463, 1981 b.

ROBERTS, Harry V. Stock-Market "Patterns" and Financial Analysis: Methodological Suggestions. The Journal of Finance. Vol. 14, n. 1, pp. 1-10, 1959.

ROGERS, Pablo; SECURATO, José R. Estudo Comparativo no Mercado Brasileiro do Capital Asset Pricing Model (CAPM), Modelo 3-Fatores de Fama e French e Reward Beta Approach. RAC-Eletrônica. Vol. 3, n. 1, pp. 159-179, 2009.

ROLL, Richard. A critique of the asset pricing theory's tests: part I. On past and potential testability of the theory. Journal of Financial Economics, 4, pp. 129-176, 1977.

ROLL, Richard; ROSS, Stephen A. An Empirical Investigation of the Arbitrage Pricing Theory. The Journal of Finance. v. 35, n. 5, pp. 1073-1103, 1980.

A Critical Reexamination of the Empirical Evidence on the Arbitrage Pricing Theory: A Reply. The Journal of Finance. v. 39, n. 2, pp. 347-350, 1984.

ROSS, Stephen A. The Arbitrage Theory of Capital Asset Pricing. The Journal of Economic Theory. 13, pp. 341-360, 1976.

ROSS, Stephen A.; WESTERFIELD, Randolph W.; JAFFE, Jeffrey F. Administração Financeira. 2 ed, 6 reimpressão, São Paulo: Atlas, 2007.

ROSTAGNO, Luciano M.; KLOECKNER, Gilberto de O.; BECKER, João L. Previsibilidade de Retorno das Ações na Bovespa: Um Teste Envolvendo o Modelo de Fator de Retorno Esperado. Revista Brasileira de Finanças. Vol. 2, n. 2, pp. 183-206, 2005.

ROUWENHORST, K. Geert. International Momentum Strategies. The Journal of Finance. Vol. 53, n. 1 pp. 267-284, 1998.

International Momentum Strategies. The Journal of Finance. Vol. 54, n. 4 pp. 1439-1464, 1999. 
RUBINSTEIN, Mark. A History of Investments: My Annotated Bibliography. USA: John Wiley e Sons, 2006.

SECURATO, José Roberto. Decisões Financeiras em Condições de Risco. São Paulo: Saint Paul editor, 2007.

SHARPE, William F. A Simplified Model for Protfolio Analysis. Management Science. Vol. 9, n. 2, pp. 277-293, September, 1963.

. Capital asset prices: a theory of market equilibrium under conditions of risk. The Journal of Finance, 19, pp. 425-443, September, 1964.

Portfolio Theory and Capital Markets. USA: McGraw-Hill Inc. 1970.

SILVEIRA, Héber P. da; BARROS, Lucas A. B. de C.; FAMÁ, Rubens. Aspectos da Teoria de Portfolio em Mercados Emergentes: Uma Análise de Aproximações para a Taxa Livre de Risco no Brasil. In: Seminários em Administração (SEMEAD), 6, 2003. Anais... Universidade de São Paulo, 2003.

SOLNIK, Bruno. International Investments. $4^{\text {th }}$ edition, Addison Wesley Longman, 2000.

TOBIN, James. Liquidity Preference as Behavior Towards Risk. The Review of Economic Studies. Vol. 25, No. 2, pp. 65-86, 1958.

WOOLDRIDGE, Jeffrey M. Introdução à econometria: uma abordagem moderna. Tradução da $4^{\mathrm{a}}$ edição norte americana, São Paulo: Cengage Learning, 2010.

WORKING, Holbrook. A Theory of Anticipatory Prices. The American Economic Review. Vol. 48, n. 2, pp. 188-199, 1958.

ZAROWIN, Paul. Size, Seasonality, and Stock Market Overreaction. Journal of Financial and Quantitative Analysis. Vol. 25, n. 1, pp. 113-125, 1990. 


\section{Anexos}

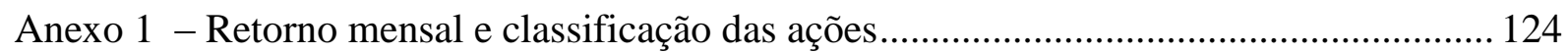

Anexo 2 - Retorno mensal das carteiras ........................................................................ 188

Anexo 3 - Prêmio mensal dos fatores de risco .................................................................... 196 
Anexo 1 - Retorno mensal e classificação das ações

\begin{tabular}{|c|c|c|c|c|c|c|c|c|c|c|c|c|c|c|c|c|c|c|c|c|}
\hline Código & $1996-1997$ & $\begin{array}{l}\text { Índice } B / M \\
\text { de dez/1995 }\end{array}$ & \begin{tabular}{|c} 
Grupo com \\
base no \\
indice B/M \\
\end{tabular} & \begin{tabular}{|c|} 
Valor de Mercado \\
em jun/1996
\end{tabular} & $\begin{array}{c}\text { Grupo com } \\
\text { base no } \\
\text { tamanho } \\
\end{array}$ & \begin{tabular}{|c|} 
Retorno \\
acumulado \\
de jun/1996 \\
\end{tabular} & \begin{tabular}{|c|} 
Grupo com \\
base no \\
retorno \\
acumulado \\
\end{tabular} & Carteiras & jul/96 & ago/96 & set/96 & out/96 & nov/96 & dez/96 & jan/97 & $\mathrm{fev} / 97$ & mar/97 & $\mathrm{abr} / 97$ & mai/97 & jun/97 \\
\hline CEEB5 & Coelba PNA & 6,19 & High & 329.632.491 & Big & 0,53 & Loser & Big|High|Loser & $24,40 \%$ & $3,85 \%$ & $-3,70 \%$ & $34,62 \%$ & $14,29 \%$ & $0,00 \%$ & $35,00 \%$ & $12,96 \%$ & $6,56 \%$ & $13,85 \%$ & $2,03 \%$ & $19,21 \%$ \\
\hline CEEB3 & Coelba ON & 6,19 & High & 329.632 .491 & Big & 0,48 & Loser & Big|High|Loser & $5,71 \%$ & $-4,05 \%$ & $8,45 \%$ & $37,66 \%$ & $-0,94 \%$ & $8,57 \%$ & \begin{tabular}{|l|l|}
$10,53 \%$ \\
\end{tabular} & $11,11 \%$ & $13,57 \%$ & $6,29 \%$ & $6,51 \%$ & $10,00 \%$ \\
\hline PTQS4 & Petroquisa PN & 8,72 & High & 594.020.417 & Big & 0,40 & Loser & Big|High|Loser & $-11,17 \%$ & $-1,43 \%$ & $4,76 \%$ & $12,65 \%$ & $-0,65 \%$ & $3,90 \%$ & $24,94 \%$ & $50,08 \%$ & $16,81 \%$ & $-11,13 \%$ & $3,59 \%$ & $-6,03 \%$ \\
\hline ARCE4 & Arcelor BR PN & 4,96 & High & 302.558.847 & Big & 0,39 & Loser & Big|High|Loser & $6,25 \%$ & $0,00 \%$ & $-8,81 \%$ & $11,27 \%$ & $-2,90 \%$ & $0,00 \%$ & $32,84 \%$ & $6,74 \%$ & $-9,47 \%$ & $1,38 \%$ & $-14,12 \%$ & $5,48 \%$ \\
\hline ARCE3 & Arcelor BR ON & \begin{tabular}{l|l|l}
4,96 \\
\end{tabular} & High & 302.558 .847 & Big & 0,34 & Loser & Big|High|Loser & $0,01 \%$ & $1,39 \%$ & $-1,37 \%$ & $-2,78 \%$ & $1,43 \%$ & $-4,93 \%$ & $30,37 \%$ & $9,09 \%$ & $-2,60 \%$ & $-5,67 \%$ & $-13,14 \%$ & $9,77 \%$ \\
\hline CESP3 & Cesp ON & 5,36 & High & 3.182 .355 .864 & Big & 0,17 & Loser & Big|High|Loser & \begin{tabular}{|l|}
$-13,64 \%$ \\
\end{tabular} & $8,77 \%$ & $6,45 \%$ & $24,24 \%$ & $-2,41 \%$ & $12,97 \%$ & \begin{tabular}{|l|l|}
$19,03 \%$ \\
\end{tabular} & $14,29 \%$ & $-6,49 \%$ & $-0,87 \%$ & $\begin{array}{l}4,91 \% \\
\end{array}$ & $17,22 \%$ \\
\hline CESP5 & $\begin{array}{l}\text { Cesp PNA } \\
\end{array}$ & 5,36 & High & 3.182 .355 .864 & \begin{tabular}{|l|} 
Big \\
\end{tabular} & 0,12 & Winner & Big|High |Winner & $-17,14 \%$ & $3,48 \%$ & $-1,37 \%$ & $16,55 \%$ & $-3,04 \%$ & $21,11 \%$ & $25,43 \%$ & $13,17 \%$ & $-8,17 \%$ & $7,01 \%$ & $6,55 \%$ & $19,60 \%$ \\
\hline ELET3 & Eletrobras ON & 4,84 & High & 14.657 .052 .822 & Big & 0,04 & Winner & Big|High|Winner & $3,70 \%$ & $-3,58 \%$ & $-0,37 \%$ & $18,59 \%$ & $3,45 \%$ & $12,73 \%$ & $14,78 \%$ & $8,20 \%$ & $-5,19 \%$ & $12,04 \%$ & $4,99 \%$ & $19,21 \%$ \\
\hline ELET6 & Eletrobras PNB & 4,84 & High & 14.657.052.822 & Big & 0,05 & Winner & Big $\mid$ High $\mid$ Winner & $2,44 \%$ & $-5,10 \%$ & $2,15 \%$ & $16,84 \%$ & $1,80 \%$ & $13,86 \%$ & $14,51 \%$ & $7,92 \%$ & $-4,40 \%$ & $13,39 \%$ & $6,25 \%$ & $21,82 \%$ \\
\hline ELPL11-old & Eletropaulo (Old) PNB & 4,52 & High & 3.641 .914 .970 & Big & 0,17 & Winner & Big|High|Winner & $-11,02 \%$ & $-4,76 \%$ & $-2,00 \%$ & $12,24 \%$ & $13,64 \%$ & $22,80 \%$ & $28,66 \%$ & $3,29 \%$ & $-0,49 \%$ & $5,17 \%$ & \begin{tabular}{ll|}
$19,44 \%$ \\
\end{tabular} & $23,53 \%$ \\
\hline $\operatorname{cgOs} 6$ & Celg PNB & 8,01 & High & 218.827.995 & Big & 0,30 & Winner & Big|High|Winner & $29,97 \%$ & $-13,44 \%$ & $-22,22 \%$ & $48,57 \%$ & $9,62 \%$ & $0,02 \%$ & \begin{tabular}{|l|}
$128,03 \%$ \\
\end{tabular} & $-15,38 \%$ & $31,82 \%$ & $7,59 \%$ & $8,97 \%$ & $1,76 \%$ \\
\hline CSNA3 & Sid Nacional ON & 3,84 & High & 1.904.626.153 & Big & 0,39 & Winner & Big|High|Winner & $-8,59 \%$ & $1,90 \%$ & $-7,04 \%$ & $16,97 \%$ & $10,59 \%$ & $4,61 \%$ & $15,42 \%$ & $13,66 \%$ & $-1,83 \%$ & $3,15 \%$ & $-7,87 \%$ & $1,43 \%$ \\
\hline DPPI3 & Ipiranga Dis ON & 1,49 & Low & $\begin{array}{ll}190.323 .243 \\
\end{array}$ & Big & 0,40 & Loser & Big|Low|Loser & $10,24 \%$ & $1,95 \%$ & $3,91 \%$ & $-2,72 \%$ & $1,56 \%$ & $-0,40 \%$ & \begin{tabular}{|l|}
$5,69 \%$ \\
\end{tabular} & $18,44 \%$ & $10,74 \%$ & $9,09 \%$ & \begin{tabular}{l|l}
$0,00 \%$ \\
\end{tabular} & $0,00 \%$ \\
\hline RHDS3 & MG Poliest ON & 0,89 & Low & 312.493 .022 & Big & 0,40 & Loser & Big|Low|Loser & $-33,87 \%$ & $4,88 \%$ & $-9,30 \%$ & $-12,82 \%$ & $0,00 \%$ & $-11,76 \%$ & $10,00 \%$ & $-3,03 \%$ & $-3,12 \%$ & $0,00 \%$ & $0,00 \%$ & $0,00 \%$ \\
\hline DPPl4 & Ipiranga Dis PN & 1,49 & Low & 190.323 .243 & Big & 0,35 & Loser & Big|Low|Loser & $-0,65 \%$ & $6,78 \%$ & $-1,59 \%$ & $-3,31 \%$ & $-1,58 \%$ & $14,41 \%$ & $-2,02 \%$ & $15,63 \%$ & $14,86 \%$ & $0,00 \%$ & $1,47 \%$ & $4,35 \%$ \\
\hline PIRE3 & Pirelli ON & 1,42 & Low & \begin{tabular}{ll|l|}
188.758 .756 \\
\end{tabular} & Big & 0,29 & Loser & Big|Low|Loser & 4,11\% & $7,89 \%$ & $18,90 \%$ & $-7,69 \%$ & $25,00 \%$ & $0,00 \%$ & $35,55 \%$ & $17,24 \%$ & $-6,50 \%$ & $46,03 \%$ & $58,70 \%$ & $-6,99 \%$ \\
\hline PIRE4 & Pirelli PN & 1,42 & Low & \begin{tabular}{ll|l|}
188.758 .756 \\
\end{tabular} & Big & 0,28 & Loser & Big|Low|Loser & $-2,99 \%$ & $10,49 \%$ & $13,41 \%$ & $-1,97 \%$ & $13,07 \%$ & $0,00 \%$ & $39,31 \%$ & $18,31 \%$ & $11,75 \%$ & $51,28 \%$ & $40,51 \%$ & $-5,91 \%$ \\
\hline SUZBS & Suzano Papel PNA & 1,40 & Low & 9.736 .989 & Big & 0,26 & Loser & Big|Low|Loser & $2,11 \%$ & $3,09 \%$ & $-15,96 \%$ & $-19,70 \%$ & $1,89 \%$ & $0,00 \%$ & $-3,70 \%$ & $7,69 \%$ & $-5,36 \%$ & $-9,43 \%$ & \begin{tabular}{l|l}
$0,42 \%$ \\
\end{tabular} & $18,26 \%$ \\
\hline PIPN4 & Pirelli Pneus PN & 1,51 & Low & 9.922 .285 & \begin{tabular}{|l|l|} 
Big \\
\end{tabular} & 0,26 & Loser & Big|Low|Loser & $-6,32 \%$ & $-4,49 \%$ & $25,88 \%$ & $12,15 \%$ & $12,50 \%$ & $-2,96 \%$ & $4,92 \%$ & $4,00 \%$ & $7,73 \%$ & $22,22 \%$ & $1,52 \%$ & $-5,67 \%$ \\
\hline ETER3 & Eternit ON & 1,20 & Low & 187.479.277 & \begin{tabular}{|l|l} 
Big \\
\end{tabular} & 0,20 & Loser & Big|Low|Loser & $-7,06 \%$ & $-4,00 \%$ & $8,33 \%$ & $-11,54 \%$ & $2,17 \%$ & $14,89 \%$ & $5,56 \%$ & $-5,26 \%$ & $9,73 \%$ & $-3,57 \%$ & $0,00 \%$ & $29,63 \%$ \\
\hline VALE3 & Vale ON & 1,03 & Low & 8.591 .552 .960 & Big & 0,19 & Loser & Big|Low|Loser & $-10,17 \%$ & $3,18 \%$ & $13,20 \%$ & $-1,18 \%$ & $0,40 \%$ & $6,72 \%$ & $2,96 \%$ & $15,07 \%$ & $-4,66 \%$ & $-1,96 \%$ & $-9,90 \%$ & $-10,53 \%$ \\
\hline \begin{tabular}{|l|} 
WEGE4 \\
\end{tabular} & Weg PN & 0,81 & Low & 320.606 .177 & Big & 0,16 & Loser & Big|Low|Loser & $-0,63 \%$ & $0,58 \%$ & $1,48 \%$ & $-1,04 \%$ & $3,16 \%$ & $0,00 \%$ & $1,02 \%$ & $19,82 \%$ & $0,52 \%$ & $-19,83 \%$ & $31,18 \%$ & $21,31 \%$ \\
\hline SDIA4 & Sadia S/A & 1,25 & Low & 24.692 & Big & 0,13 & Winner & Big|Low|Winner & $-4,29 \%$ & $-5,97 \%$ & $-4,76 \%$ & $15,00 \%$ & $13,94 \%$ & $2,56 \%$ & $-7,50 \%$ & $-1,35 \%$ & $9,34 \%$ & $16,67 \%$ & $13,19 \%$ & $8,74 \%$ \\
\hline PTIP3 & Ipiranga Pet ON & 1,40 & Low & 738.067.882 & \begin{tabular}{|l|l|} 
Big \\
\end{tabular} & 0,11 & Winner & Big|Low|Winner & $6,95 \%$ & $0,00 \%$ & $0,00 \%$ & $-1,47 \%$ & $0,75 \%$ & $9,63 \%$ & $-2,75 \%$ & $2,84 \%$ & $6,90 \%$ & $3,23 \%$ & $0,00 \%$ & $9,37 \%$ \\
\hline ANTA3 & Antarctica Paulista ON & 0,94 & Low & 1.399 .125 .000 & \begin{tabular}{|l|l|} 
Big \\
\end{tabular} & 0,11 & Winner & Big|Low/Winner & $-14,35 \%$ & $-18,07 \%$ & $7,37 \%$ & $3,72 \%$ & $6,50 \%$ & $5,26 \%$ & $19,98 \%$ & $8,35 \%$ & $-3,85 \%$ & $1,67 \%$ & $-4,00 \%$ & $-8,33 \%$ \\
\hline ARC26 & Aracruz PNB & 1,25 & Low & 1.872.066.409 & Big & 0,09 & Winner & Big|Low|Winner & $-8,56 \%$ & $5,26 \%$ & $-1,67 \%$ & $-8,47 \%$ & $2,47 \%$ & $1,81 \%$ & 4,73\% & $8,47 \%$ & $0,52 \%$ & $3,63 \%$ & $10,01 \%$ & $0,00 \%$ \\
\hline VAGV4 & Savarg PN & 1,66 & Low & \begin{tabular}{|l|l|}
342.879 .151 \\
\end{tabular} & Big & 0,01 & Winner & Big|Low|Winner & $-4,08 \%$ & $-37,45 \%$ & $7,48 \%$ & $0,00 \%$ & $7,59 \%$ & $11,76 \%$ & $5,26 \%$ & $0,00 \%$ & $0,00 \%$ & $-5,00 \%$ & $4,21 \%$ & $51,01 \%$ \\
\hline PTIP4 & Ipiran & 1,40 & Low & & Big & 0,03 & Winner & Big|Low|Winner & $-5,83 \%$ & $-1,13 \%$ & $1,53 \%$ & $3,08 \%$ & $-1,53 \%$ & $11,78 \%$ & $-4,44 \%$ & $11,35 \%$ & $7,01 \%$ & $-1,49 \%$ & $2,72 \%$ & $3,00 \%$ \\
\hline PRGA4 & BRF Foods PN & 1,21 & Low & 398.648 .720 & Big & 0,03 & Winner & Big|Low|Winner & $-7,26 \%$ & $-7,23 \%$ & $4,55 \%$ & $19,25 \%$ & $3,12 \%$ & $1,01 \%$ & $7,50 \%$ & $9,30 \%$ & $-7,66 \%$ & $12,12 \%$ & $0,00 \%$ & $15,91 \%$ \\
\hline IBAN5 & Antarct Nordeste PNA & 1,03 & Low & 1.141 .288 & Big & 0,03 & Winner & Big|Low|Winner & $0,75 \%$ & $-0,19 \%$ & $-3,44 \%$ & $0,20 \%$ & $0,00 \%$ & $0,00 \%$ & $0,00 \%$ & $-2,00 \%$ & $-1,04 \%$ & $0,71 \%$ & $-4,23 \%$ & $-6,98 \%$ \\
\hline BRDT4 & Petrobras Distrib PN & 1,41 & Low & \begin{tabular}{l|l|}
913.679 .531 \\
\end{tabular} & Big & 0,04 & Winner & Big|Low/Winner & $-10,17 \%$ & $-5,00 \%$ & $-7,76 \%$ & $5,41 \%$ & $-12,36 \%$ & $7,28 \%$ & $20,00 \%$ & $6,06 \%$ & $-9,60 \%$ & $11,61 \%$ & $24,25 \%$ & $13,08 \%$ \\
\hline LAME3 & Lojas Americ ON & 0,49 & Low & 81.022 & Big & 0,04 & Winner & Big|Low|Winner & $0,56 \%$ & $-16,67 \%$ & $-4,67 \%$ & $8,39 \%$ & $-12,90 \%$ & $1,85 \%$ & $-0,36 \%$ & $-5,11 \%$ & $2,31 \%$ & $0,00 \%$ & $5,11 \%$ & $9,44 \%$ \\
\hline KLBN4 & Klabin & 1,65 & Low & 715.250 & Big & 0,04 & Winner & Big|Low|Winner & $-17,32 \%$ & $7,62 \%$ & $-4,42 \%$ & $-4,36 \%$ & $-2,94 \%$ & $-3,03 \%$ & \begin{tabular}{|l|l|}
$-5,21 \%$ \\
\end{tabular} & $12,09 \%$ & $-2,94 \%$ & $12,27 \%$ & \begin{tabular}{|l|}
$-7,27 \%$ \\
\end{tabular} & $2,94 \%$ \\
\hline FFTL4 & Valefer & 1,46 & Low & 3.267 .486 & \begin{tabular}{|l|} 
Big \\
\end{tabular} & 0,05 & Winner & Big|Low|Winner & $-4,21 \%$ & $14,63 \%$ & $5,32 \%$ & $11,72 \%$ & $-3,83 \%$ & $-13,40 \%$ & $-1,67 \%$ & $2,91 \%$ & $0,00 \%$ & $8,24 \%$ & \begin{tabular}{|l|l|}
$13,48 \%$ \\
\end{tabular} & $15,90 \%$ \\
\hline ICPI4 & Cim Itau PN & 0,91 & Low & 3.885 .172 & Big & 0,06 & Winner & Big|Low/Winner & $-13,03 \%$ & $7,29 \%$ & $2,64 \%$ & $-0,74 \%$ & $9,26 \%$ & $23,72 \%$ & $0,01 \%$ & $11,23 \%$ & $-2,71 \%$ & $-5,06 \%$ & $-2,82 \%$ & $4,67 \%$ \\
\hline VSMA3 & S Gobain Vidro ON & 73 & Low & \begin{tabular}{|l|l|}
837.226 .210 \\
\end{tabular} & Big & 0,08 & Winner & Big|Low/Winner & $-7,59 \%$ & $1,37 \%$ & $-8,11 \%$ & $-0,59 \%$ & $-2,37 \%$ & $-1,52 \%$ & \begin{tabular}{l|l|}
$1,54 \%$ \\
\end{tabular} & $-3,03 \%$ & $6,05 \%$ & $-5,20 \%$ & $-3,23 \%$ & $-1,00 \%$ \\
\hline VALE5 & Vale PNA & 1,03 & Low & 8.591 .552 .960 & Big & 0,08 & Winner & Big|Low|Winner & $-1,29 \%$ & $2,60 \%$ & $3,71 \%$ & $5,19 \%$ & $1,88 \%$ & $-7,83 \%$ & $18,00 \%$ & $18,22 \%$ & $-13,62 \%$ & $14,72 \%$ & $-12,73 \%$ & $0,68 \%$ \\
\hline CTNM3 & Coteminas $\mathrm{O}$ & 0,92 & Low & 714.445.550 & Big & 0,15 & Winner & Big|Low|Winner & $-16,43 \%$ & $0,00 \%$ & $3,33 \%$ & $1,61 \%$ & $1,27 \%$ & $-3,45 \%$ & $-2,59 \%$ & $33,33 \%$ & $0,00 \%$ & $-19,56 \%$ & $13,87 \%$ & $-1,14 \%$ \\
\hline LAME4 & Lojas Am & 0,49 & Low & 870.181 .022 & \begin{tabular}{|l|l|} 
Big \\
\end{tabular} & 0,17 & Winner & Big|Low|Winner & $-11,11 \%$ & $0,00 \%$ & $-1,70 \%$ & $-6,65 \%$ & $-9,60 \%$ & $-6,16 \%$ & $26,28 \%$ & $-12,72 \%$ & $-5,96 \%$ & $6,34 \%$ & $-10,60 \%$ & $8,15 \%$ \\
\hline USIMS & Usiminas PN & 1,61 & Low & 7.155 .421 & \begin{tabular}{|l|} 
Big \\
\end{tabular} & 0,21 & Winner & Big|Low/Winner & $1,89 \%$ & $-0,23 \%$ & $-4,72 \%$ & 6,93 & $-4,63 \%$ & $2,91 \%$ & $12,26 \%$ & $1,68 \%$ & $2,48 \%$ & $5,88 \%$ & $-7,94 \%$ & $3,36 \%$ \\
\hline ITSA3 & Itausa ON & 1,38 & Low & 2.365.773.351 & Big & 0,24 & Winner & Big|Low/Winner & $2,60 \%$ & $5,65 \%$ & $-0,92 \%$ & $0,00 \%$ & $-3,66 \%$ & $-0,96 \%$ & \begin{tabular}{|l|l|}
$1,28 \%$ \\
\end{tabular} & $13,92 \%$ & $-0,17 \%$ & $-1,12 \%$ & $-6,82 \%$ & $10,06 \%$ \\
\hline DXTG4 & Dixie Toga PN & 0,84 & Low & 320.499 .649 & Big & 0,32 & Winner & Big|Low/Winner & $-7,22 \%$ & $3,33 \%$ & $-1,08 \%$ & $-16,30 \%$ & $9,09 \%$ & $-5,95 \%$ & $5,06 \%$ & $4,82 \%$ & $-1,15 \%$ & $-6,98 \%$ & $-10,91 \%$ & $-17,14 \%$ \\
\hline ITSA4 & Itausa & 1,38 & Low & 2.365.773.351 & Big & 0,40 & Winner & Big|Low|Winner & $1,30 \%$ & $8,30 \%$ & $-4,48 \%$ & $1,25 \%$ & $-4,94 \%$ & $1,61 \%$ & $2,56 \%$ & $12,50 \%$ & $0,94 \%$ & $0,00 \%$ & $-1,11 \%$ & $11,52 \%$ \\
\hline BMTO4 & Brasmotor P & 0,83 & Low & 786.440.475 & Big & 0,40 & Winne & Big|Low|Winner & $16,36 \%$ & $-6,61 \%$ & $12,14 \%$ & $-7,43 \%$ & $-16,34 \%$ & $-1,20 \%$ & $-3,82 \%$ & 5,5 & $6,28 \%$ & $-15,81 \%$ & $-5,88 \%$ & $0,00 \%$ \\
\hline \begin{tabular}{|l|} 
CTNM4 \\
\end{tabular} & Cot & 0,92 & Low & 445.550 & \begin{tabular}{|l|} 
Big \\
\end{tabular} & 0,41 & Winner & Big|Low|Wir & \begin{tabular}{|l|}
$-11,74 \%$ \\
\end{tabular} & $-1,28 \%$ & $7,24 \%$ & $-6,76 \%$ & $2,90 \%$ & $-6,59 \%$ & $11,88 \%$ & $21,29 \%$ & $-5,78 \%$ & $7,87 \%$ & $-5,61 \%$ & $-0,24 \%$ \\
\hline BRTO4 & Brasil Telec PN & 1,55 & Low & 1.357 .786 .159 & Big & 0,49 & Winner & Big|Low/Winner & $-4,93 \%$ & $5,40 \%$ & $1,43 \%$ & $-5,25 \%$ & $-1,49 \%$ & $25,78 \%$ & \begin{tabular}{l|l}
$7,04 \%$ \\
\end{tabular} & $10,93 \%$ & $-1,31 \%$ & $10,45 \%$ & $-2,74 \%$ & $12,68 \%$ \\
\hline TMAR3 & Telemar N L ON & 1,34 & Low & 2.863 .860 .355 & Big & 0,51 & Winner & Big|Low/Winner & $6,57 \%$ & $-3,49 \%$ & $3,70 \%$ & $-11,16 \%$ & $20,60 \%$ & $10,00 \%$ & $10,52 \%$ & $0,08 \%$ & $-1,37 \%$ & $20,55 \%$ & $-2,81 \%$ & $-2,69 \%$ \\
\hline CRUZ3 & Souza $\mathrm{Cr}$ & 0,82 & Low & 2.674 .787 .500 & Big & 0,51 & Winner & Big|Low|Winner & $-6,63 \%$ & $-0,74 \%$ & $-4,90 \%$ & $-9,12 \%$ & $-4,69 \%$ & $15,79 \%$ & $2,64 \%$ & $24,29 \%$ & $6,85 \%$ & $-2,82 \%$ & 15,81\% & $13,96 \%$ \\
\hline BRTO3 & Brasil & 1,55 & 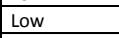 & & pia & 0.52 & Win & & $-2,78 \%$ & $-1,90 \%$ & $-1,46 \%$ & $3,69 \%$ & $4.51 \%$ & $205.5-2$ & $3,51 \%$ & & $698 \%$ & 2006 & $-7.55 \%$ & 00 \\
\hline POMO4 & Marcopolo PN & 1,36 & Low & 209.820 .526 & Big & 0,62 & Winner & Big|Low|Winner & $-14,31 \%$ & $7,61 \%$ & $-3,30 \%$ & $98 \%$ & $-11,59 \%$ & $-4,92 \%$ & $9,20 \%$ &, $63 \%$ & $6,70 \%$ & $11,34 \%$ & $-11,42 \%$ & $-0,7$ \\
\hline
\end{tabular}


Anexo 1 - Retorno mensal e classificação das ações

\begin{tabular}{|c|c|c|c|c|c|c|c|c|c|c|c|c|c|c|c|c|c|c|c|c|}
\hline Código & 1996- 1997 & $\begin{array}{l}\text { Índice } \mathrm{B} / \mathrm{M} \\
\text { de dez/1995 }\end{array}$ & $\begin{array}{c}\text { Grupo com } \\
\text { base no } \\
\text { indice B/M } \\
\end{array}$ & $\begin{array}{l}\text { Valor de Mercado } \\
\text { em jun/1996 }\end{array}$ & \begin{tabular}{|c} 
Grupo com \\
base no \\
tamanho \\
\end{tabular} & $\begin{array}{c}\text { Retorno } \\
\text { acumulado } \\
\text { de jun/1996 }\end{array}$ & \begin{tabular}{|l} 
Grupo com \\
base no \\
retorno \\
acumulado \\
\end{tabular} & Carteiras & $\mathrm{jul} / 96$ & ago/96 & set/96 & out $/ 96$ & nov/96 & $\operatorname{dez} / 96$ & jan/97 & fev/97 & $\mathrm{mar} / 97$ & $\mathrm{abr} / 97$ & $\mathrm{mai} / 97$ & jun/97 \\
\hline WHRL4 & Whirlpool PN & 0,54 & Low & 1.693 .764 .709 & Big & 0,62 & Winner & Big|Low|Winner & $21,78 \%$ & $-7,41 \%$ & $5,33 \%$ & $5,70 \%$ & $-18,56 \%$ & $-3,68 \%$ & $-7,43 \%$ & $11,02 \%$ & $3,05 \%$ & $-6,67 \%$ & $-13,49 \%$ & $1,83 \%$ \\
\hline WHMT3 & White Martins ON & 0,46 & Low & 2.706.303.217 & Big & 0,64 & Winner & Big|Low|Winner & $-10,61 \%$ & $8,00 \%$ & 7,41\% & $10,66 \%$ & $-5,03 \%$ & $0,23 \%$ & $-2,67 \%$ & $18,49 \%$ & $-0,10 \%$ & $9,65 \%$ & $-3,87 \%$ & $-9,48 \%$ \\
\hline TMAR6 & Telemar N L PNB & 1,34 & Low & 2.863 .860 .355 & Big & 0,65 & Winner & Big|Low|Winner & $-0,88 \%$ & $-2,68 \%$ & $5,60 \%$ & $-13,99 \%$ & $9,08 \%$ & $21,76 \%$ & $12,94 \%$ & $7,07 \%$ & $-7,56 \%$ & $23,59 \%$ & $-6,78 \%$ & $0,61 \%$ \\
\hline WET4 & Wentex PN & 1,00 & Low & 228.599 .997 & Big & 0,66 & Winner & Big|Low|Winner & $25,98 \%$ & $6,25 \%$ & $4,41 \%$ & $-15,49 \%$ & $10,00 \%$ & $0,00 \%$ & $12,12 \%$ & $3,78 \%$ & $0,52 \%$ & $19,17 \%$ & $15,47 \%$ & $-11,32 \%$ \\
\hline CPSL3 & Copesul ON & 1,54 & Low & 961.389.934 & Big & 0,67 & Winner & Big|Low|Winner & $-1,41 \%$ & $-0,86 \%$ & $-10,50 \%$ & $-1,80 \%$ & $-8,53 \%$ & $28,36 \%$ & $-17,10 \%$ | & $-4,94 \%$ ] & $-2,13 \%$ & $-1,08 \%$ & $-3,46 \%$ & $0,00 \%$ \\
\hline \begin{tabular}{|l} 
REPA4 \\
\end{tabular} & Electrolux PN & 1,14 & Low & 322.182.873 & Big & 0,74 & Winner & Big|Low|Winner & $12,00 \%$ & $-6,07 \%$ & $-4,56 \%$ & $-0,40 \%$ & $-16,00 \%$ & $11,90 \%$ & $-13,62 \%$ & $3,45 \%$ & $2,38 \%$ & $-5,12 \%$ & $-3,71 \%$ & $-6,56 \%$ \\
\hline AMBV4 & Amber PN & 0,36 & Low & 4.079.083.492 & Big & 0,86 & Winner & Big|Low|Winner & $3,34 \%$ & $4,20 \%$ & $-0,83 \%$ & $0,00 \%$ & $-3,78 \%$ & $-7,04 \%$ & $11,97 \%$ & $10,22 \%$ & $-0,60 \%$ & $4,78 \%$ & $7,39 \%$ & 5,53\% \\
\hline AMBV3 & Ambev ON & 0,36 & Low & 4.079 .083 .492 & Big & 0,89 & Winner & Big|Low|Winner & $-0,80 \%$ & $3,23 \%$ & $-0,53 \%$ & $0,47 \%$ & $-3,15 \%$ & $-2,44 \%$ & $10,00 \%$ & $10,76 \%$ & $-3,34 \%$ & $4,21 \%$ & $6,99 \%$ & $5,25 \%$ \\
\hline TMGR3 & Telemig ON & 1,45 & Low & 2.235 .399 .699 & Big & 1,12 & Winner & Big|Low|Winner & $10,98 \%$ & $0,00 \%$ & $7,09 \%$ & $26,22 \%$ & $-4,80 \%$ & $11,01 \%$ & $-3,05 \%$ & $15,05 \%$ & $-2,07 \%$ & $6,36 \%$ & $0,18 \%$ & $21,45 \%$ \\
\hline |LREN4 & Lojas Renner PN & 0,50 & Low & 186.923.644 & | Big & 1,26 & Winner & Big|Low|Winner & $0,94 \%$ ] & $6,54 \%$ & $3,51 \%$ | & $-6,78 \%$ ] & $-7,27 \%$ & $-5,88 \%$ & $14,58 \%$ & $8,18 \%$ ] & $-6,72 \%$ & $18,10 \%$ & $-3,13 \%$ |, & $-10,97 \%$ \\
\hline CBEE3 & Ampla Energ ON & 0,39 & Low & 646.715 .962 & Big & 1,62 & Winner & Big|Low|Winner & $14,29 \%$ & $-12,50 \%$ & $14,29 \%$ & $4,17 \%$ & $6,00 \%$ & $1,89 \%$ & $1,85 \%$ & $3,64 \%$ & $3,51 \%$ & $13,56 \%$ & $0,00 \%$ & $16,42 \%$ \\
\hline TMGR6 & Telemig PNB & 1,45 & Low & 2.235.399.699 & Big & 1,66 & Winner & Big|Low/Winner & $8,20 \%$ & $3,12 \%$ & $4,76 \%$ ] & $-5,21 \%$ & $0,65 \%$ & $11,30 \%$ & $12,45 \%$ & $6,78 \%$ [ & $-7,00 \%$ & $21,47 \%$ & $-3,85 \%$ & $16,94 \%$ \\
\hline TAMR4 & Tam Transp PN & 0,50 & Low & 338.504 .375 & 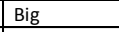 & 3,20 & Winner & Big|Low|Winner & $4,14 \%$ & $-5,96 \%$ & $-11,27 \%$ & $-19,81 \%$ & $-11,94 \%$ & $29,24 \%$ & $-4,35 \%$ & $5,45 \%$ & $0,69 \%$ & $30,05 \%$ & $-0,74 \%$ & $-12,49 \%$ \\
\hline BSUL5 & Bahia Sul PNA & 2,72 & Medium & 5.604.995 & Big & 0,61 & Loser & Big|Medium|Loser & $0,42 \%$ & $-16,67 \%$ & $-14,00 \%$ & $-6,92 \%$ & $0,57 \%$ & $5,58 \%$ & $-0,29 \%$ ] & $4,13 \%$ | & $-3,68 \%$ & $49,41 \%$ | & $-1,57 \%$ & $-4,00 \%$ \\
\hline RAPT4 & Randon Part PN & 2,07 & Medium & 182.439 .697 & Big & 0,46 & Loser & Big|Medium|Loser & $-18,87 \%$ & $4,65 \%$ & $8,89 \%$ & $8,16 \%$ & $1,89 \%$ & $-5,56 \%$ & $11,76 \%$ & $12,28 \%$ & $-1,56 \%$ & $6,35 \%$ & $25,37 \%$ & $2,38 \%$ \\
\hline \begin{tabular}{|l|l}
$\mathrm{VCPA} 4$ \\
\end{tabular} & Fibria PN & 3,33 & Medium & 653.017 .443 & Big & 0,43 & Loser & Big|Medium|Loser & $-13,64 \%$ & $-4,74 \%$ & $11,10 \%$ & $-10,16 \%$ & $5,71 \%$ & $0,48 \%$ & $11,17 \%$ & $22,97 \%$ & $-2,72 \%$ & $20,00 \%$ & $-0,88 \%$ & $11,68 \%$ \\
\hline MAKR3 & Makro ON & 2,02 & Medium & 182.429 .448 & Big & 0,42 & Loser & Big|Medium|Loser & $3,16 \%$ & $-13,27 \%$ & $10,59 \%$ & $5,32 \%$ & $-9,09 \%$ & -21,11\% & $-1,41 \%$ & $72,86 \%$ & $17,36 \%$ & $-2,20 \%$ & $-3,62 \%$ & $-6,02 \%$ \\
\hline ACES4 & Am Inox BR PN & 1,76 & Medium & 352.583 .434 & Big & 0,37 & Loser & Big|Medium|Loser & $3,23 \%$ & $-21,48 \%$ & $-3,85 \%$ & $-4,44 \%$ & $5,12 \%$ & $8,41 \%$ & $30,61 \%$ & $-7,81 \%$ & $-8,47 \%$ & $-7,41 \%$ & $-11,65 \%$ & $0,91 \%$ \\
\hline ACES3 & Am Inox BR ON & 1,76 & Medium & 352.583.434 & |Big & 0,30 & Loser & Big|Medium|Loser & $-2,67 \%$ & $-5,36 \%$ & $-9,43 \%$ ] & $-12,50 \%$ & $2,38 \%$ & $-0,47 \%$ & $49,07 \%$ & $-10,66 \%$ & $-7,72 \%$ & $-6,84 \%$ & $-13,93 \%$ | & $0,95 \%$ ] \\
\hline BRKM5 & Braskem PNA & 3,40 & Medium & 874.656 .696 & Big & 0,26 & Loser & Big|Medium|Loser & $-6,69 \%$ & $-2,70 \%$ & $-5,89 \%$ & $-0,73 \%$ & $-3,43 \%$ & $5,26 \%$ & $-17,55 \%$ & $20,78 \%$ & $-2,71 \%$ & $0,55 \%$ & $-6,43 \%$ & $14,33 \%$ \\
\hline PQUN4 & Petroq Uniao PN & 2,32 & Medium & 200.398 .556 & 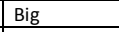 & 0,24 & Loser & Big|Medium|Loser & $-50,00 \%$ & $0,00 \%$ & $0,00 \%$ & $100,00 \%$ & $0,00 \%$ & $0,00 \%$ & $0,00 \%$ & $0,00 \%$ & $0,00 \%$ & $50,00 \%$ & $-30,80 \%$ & $20,00 \%$ \\
\hline PMAM4 & Paranapanema PN & 1,83 & Medium & 453.101.659 & Big & 0,23 & Loser & Big|Medium|Loser & $-28,13 \%$ & $18,26 \%$ & $2,94 \%$ & $21,43 \%$ & $11,76 \%$ & $17,37 \%$ & $10,31 \%$ & $-15,61 \%$ & $-4,62 \%$ & $-12,12 \%$ & $3,45 \%$ & $-11,11 \%$ \\
\hline MAGS5 & Magnesita PNA & 2,84 & Medium & 206.094 .026 & Big & 0,21 & Loser & Big|Medium|Loser & $-14,29 \%$ & $-12,50 \%$ & $9,52 \%$ & $-14,35 \%$ & $5,58 \%$ & $3,85 \%$ & $8,80 \%$ & $6,38 \%$ & $-10,00 \%$ & $-10,22 \%$ & $8,72 \%$ & $10,05 \%$ \\
\hline SAMI4 & Samitri PN & 2,31 & Medium & 264.385.580 & Big & 0,18 & Loser & Big|Medium|Loser & $1,75 \%$ & $-5,17 \%$ & $3,64 \%$ ] & $-1,61 \%$ & $3,42 \%$ & $3,45 \%$ & $33,33 \%$ & $0,00 \%$ ] & $-1,27 \%$ & $-3,21 \%$ | $>$ & $4,69 \%$ & $-7,14 \%$ \\
\hline GUAR4 & Guararapes PN & 3,02 & Medium & 206.036.131 & Big & 0,15 & Loser & Big|Medium/Loser & $-0,86 \%$ & $-2,31 \%$ & $2,95 \%$ & $1,72 \%$ & $-4,23 \%$ & $11,76 \%$ & $-2,63 \%$ & $18,92 \%$ & $11,36 \%$ & $0,00 \%$ & $15,79 \%$ & $18,18 \%$ \\
\hline BOBR4 & Bombril PN & 2,02 & Medium & 188.944.689 & Big & 0,15 & Winner & Big|Medium/Winner & $2,16 \%$ & $-1,65 \%$ & $4,63 \%$ & $-10,67 \%$ & $-17,55 \%$ & $3,09 \%$ & $1,18 \%$ & $-1,80 \%$ & $-2,37 \%$ & $-1,21 \%$ & $-20,32 \%$ & $4,86 \%$ \\
\hline CLSC6 & Celesc PNB & 3,70 & Medium & 37.915.804 & Big & 0,13 & Winner & Big|Medium/Winner & $6,38 \%$ & $-10,00 \%$ & $-2,22 \%$ & $-1,14 \%$ & $-2,30 \%$ & $14,12 \%$ & $20,62 \%$ & $24,79 \%$ & $-17,12 \%$ & $23,97 \%$ & $-12,89 \%$ & $24,03 \%$ \\
\hline PETR3 & Petrobras ON & 3,15 & Medium & 10.654.752.634 & Big & 0,04 & Winner & Big|Medium/Winner & $-4,12 \%$ & $12,13 \%$ & $-9,88 \%$ & $21,29 \%$ & $4,78 \%$ & $26,92 \%$ & $27,20 \%$ & $8,81 \%$ & $-3,80 \%$ & $3,64 \%$ & $21,64 \%$ & $13,22 \%$ \\
\hline DURA4 & Duratex-Old PN & 1,88 & Medium & 386.563 .364 & Big & 0,04 & Winner & Big|Medium/Winner & $-5,76 \%$ & $-1,90 \%$ & $-1,49 \%$ & $-5,40 \%$ & $11,44 \%$ & $-4,90 \%$ & $7,69 \%$ & $18,23 \%$ & $8,59 \%$ & $-0,38 \%$ & $3,75 \%$ & $3,64 \%$ \\
\hline CSTB4 & Sid Tubarao PN & 3,56 & Medium & 830.275.685 & Big & 0,00 & Winner & Big $\mid$ Medium /Winner & $-6,15 \%$ & $9,46 \%$ & $-10,49 \%$ & $6,90 \%$ [ & $0,00 \%$ & $3,29 \%$ & $-5,06 \%$ ] & $21,14 \%$ & $-5,71 \%$ & $-10,43 \%$ & $-1,67 \%$ & $1,97 \%$ \\
\hline GUAR3 & Guararapes ON & 3,02 & Medium & 206.036 .131 & Big & 0,02 & Winner & Big|Medium/Winner & $15,81 \%$ & $-2,51 \%$ & $0,00 \%$ & $4,29 \%$ & $4,11 \%$ & $7,89 \%$ & $3,66 \%$ & $15,29 \%$ & $6,12 \%$ & $4,84 \%$ & $22,64 \%$ & $20,00 \%$ \\
\hline LIGT3 & Light S/A ON & 2,09 & Medium & 795.137.779 & Big & 0,07 & Winner & Big|Medium/Winner & $1,49 \%$ & $6,59 \%$ & $8,76 \%$ & $7,42 \%$ & $-3,97 \%$ & $13,02 \%$ & $-1,81 \%$ & $21,47 \%$ & $4,18 \%$ & $0,65 \%$ & $21,15 \%$ & $0,04 \%$ \\
\hline CMIG3 & Cemig ON & 3,23 & Medium & 3.425.903.489 & Big & 0,14 & Winner & Big|Medium|Winner & $10,04 \%$ & $16,08 \%$ & $4,22 \%$ & $35,84 \%$ & $14,04 \%$ & $-25,56 \%$ & $17,54 \%$ & $-5,76 \%$ ] $>>$ & $1,81 \%$ & $4,47 \%$ ] & $1,70 \%$ & $4,72 \%$ \\
\hline CEVA3 & Bunge Alimentos ON & 2,22 & Medium & 346.519.337 & Big & 0,16 & Winner & Big $\mid$ Medium /Winner & $-5,56 \%$ & $-24,71 \%$ & $23,44 \%$ & $-11,39 \%$ & $10,86 \%$ & $9,54 \%$ & $4,71 \%$ & $-10,11 \%$ & $25,00 \%$ & $10,00 \%$ & $4,63 \%$ & $2,74 \%$ \\
\hline PALF5 & Paul F Luz PNA & 2,62 & Medium & 1.750.495.180 & |Big & 0,19 & Winner & Big|Medium |Winner & $-8,33 \%$ & $2,48 \%$ & $12,90 \%$ | & $12,86 \%$. & $-0,25 \%$ & $20,43 \%$ & $5,37 \%$. & $21,00 \%$ & $4,13 \%$ & $20,45 \%$ & $-0,67 \%$ & $20,07 \%$ \\
\hline CEVA4 & Bunge Alimentos PN & 2,22 & Medium & 346.519 .337 & Big & 0,23 & Winner & Big|Medium/Winner & $-16,27 \%$ & $-8,57 \%$ & $17,50 \%$ & $2,66 \%$ & $5,08 \%$ & $-10,26 \%$ & $4,40 \%$ & $29,47 \%$ & $-7,32 \%$ & $-4,82 \%$ & $6,01 \%$ & $11,60 \%$ \\
\hline CMIG4 & Cemig P & 3,23 & Medium & 3.425.903.489 & |Big & 0,24 & Winner & Big|Medium |Winner & $4,12 \%$ [ & $10,07 \%$ & $-0,33$ & 7,219 & $1,83 \%$ & $6,31 \%$ & $24,01 \%$ ] & $-3,53 \%$ ] & $2,95 \%$ & $11,22 \%$ & $3,18 \%$ & 13,2 \\
\hline PALF3 & Paul F Luz ON & 2,62 & Medium & 750.495.180 & Big & 26 & Winner & Big|Medium/Winner & $-3,26 \%$ & $2,81 \%$ & $1,42 \%$ & $1,84 \%$ & $9,51 \%$ & $18,84 \%$ & $5,68 \%$ & $12,32 \%$ & $0,62 \%$ & $13,61 \%$ & $-5,10 \%$ & $15,58 \%$ \\
\hline ODBE4 & Odebrecht PN & 3,68 & Medium & 560.999 .990 & Big & 0,31 & Winner & Big|Medium|Winner & $-1,96 \%$ | $>$ & $10,00 \%$ & $3,64 \%$ & $9,30 \%$ & $16,85 \%$ & $-1,10 \%$ & $0,00 \%$ & $-13,33 \%$ & $15,38 \%$ & $16,50 \%$ & $9,22 \%$ & $2,78 \%$ \\
\hline CPLE3 & Copel ON & 2,41 & Medium & 753.187.111 & Big & 0,33 & Winner & Big|Medium/Winner & $-3,51 \%$ & $-8,18 \%$ & $0,99 \%$ & $3,92 \%$ & $-1,04 \%$ & $4,86 \%$ & $28,18 \%$ & $6,03 \%$ & $7,02 \%$ & $5,69 \%$ & $-3,60 \%$ & $17,09 \%$ \\
\hline CPLE5 & Copel PNA & 2,41 & Medium & 2.753.187.111 & Big & 0,35 & Winner & Big $\mid$ Medium $\mid$ Winner & $-9,23 \%$ & $2,82 \%$ & 3,69\% & $9,20 \%$ & $-22,11 \%$ & $24,32 \%$ & $30,43 \%$ & $4,17 \%$ & $21,60 \%$ & 9,90\% & $-2,47 \%$ & 18,99\% \\
\hline TBCP4 & Tel B $\mathrm{C}$ & 2,70 & Medit & 553.290 .830 & Big & 0,38 & Winner & $B i g \mid \mathbb{A}$ & $2,94 \%$ | & $12,70 \%$ & $-3,66 \%$ ] & $-0,29 \%$ & $10,56 \%$ & $7,43 \%$ & $23,46 \%$ & $12,00 \%$ & $-3,57 \%$ & $14,25 \%$ & $-5,74 \%$ & 7,1 \\
\hline PETR4 & Petrobras PN & 3,15 & Medium & & Big & 0,42 & Winner & Big $\mid$ Medium $/$ Winner & $-8,10 \%$ & $7,05 \%$ & $-1,24 \%$ & $10,84 \%$ & $6,77 \%$ & $16,55 \%$ & $21,45 \%$ & $6,97 \%$ & $0,70 \%$ & $6,18 \%$ & $14,54 \%$ & $16,80 \%$ \\
\hline TELB3-old & Telebras (Old) ON & 1,89 & Medium & 21.099.219.730 & Big & 0,51 & Winner & Big|Medium/Winner & $3,37 \%$ & $0,82 \%$ & $7,99 \%$ & $-5,72 \%$ & $6,71 \%$ & $11,53 \%$ & $13,29 \%$ & $17,88 \%$ & $7,34 \%$ & $9,05 \%$ & $21,83 \%$ & $4,67 \%$ \\
\hline ERIC4 & Ericsson PN & 1,76 & Medium & 616.477 .916 & Big & 0,54 & Winner & Big|Medium/Winner & $-0,33 \%$ & $24,67 \%$ & $-13,10 \%$ & $-5,85 \%$ & $5,03 \%$ & $-0,37 \%$ & $41,47 \%$ & $24,94 \%$ & $4,95 \%$ & $31,99 \%$ & $56,86 \%$ & $6,67 \%$ \\
\hline TBRS4 & Telebrasilia PN & 2,22 & edium & 8.528 .643 & Big & 0,58 . & Winner & Big|Medium|Winner & $0,00 \%$ ] & $-3,90 \%$ & $1,22 \%$ & $-11,88 \%$, & $-4,55 \%$ & $20,63 \%$ & $7,90 \%$ ] & $12,20 \%$ & $14,1:$ & $-2,00 \%$ | & $5,00 \%$ & \\
\hline ERIC3 & & 1,76 & $\mathrm{Mc}$ & & Big & 1 & & Big $\mid \mathrm{N}$ & $5,07 \%$ & $17,24 \%$ & $-17,65 \%$ & $-6,36 \%$ & $18,23 \%$ & $8,39 \%$ & $32,32 \%$ & $26,41 \%$ & $6,76 \%$ & $29,13 \%$ & $45,48 \%$ & $1,86 \%$ \\
\hline TELB4-old & Telebras (Old) PN & 1,89 & Medium & 21.099 .219 .730 & Big & 0,75 & Winner & Big|Medium/Winner & $4,99 \%$ & $2,58 \%$ & $6,36 \%$ & $-4,98 \%$ & $2,49 \%$ & $2,30 \%$ & $13,88 \%$ & $12,62 \%$ & $6,82 \%$ & $13,09 \%$ & $21,08 \%$ & $10,56 \%$ \\
\hline MFLU3 & Santista Alimentos & 1,81 & Medium & 486.745 .873 & Big & 0,90 & Winner & Big|Medium|Winner & $10,76 \%$. & $6,86 \%$ & $8,02 \%$ ] & $3,47 \%$ & $10,05 \%$ & $4,78 \%$ & $3,32 \%$ & $-11,65 \%$ & $4,55 \%$ ] & $0,87 \%$ [ & $-5,88 \%$ & $-4,17 \%$ \\
\hline FCAP4 & Sam Industr PN & 8,90 & tigh & 15.750.977 & Small & 0,84 & Loser & Small|High|Loser & $-1,23 \%$ | & $5,00 \%$ & 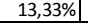 & $10,29 \%$ ] & & $8 \%$ & $2,86 \%$ & & $52,94 \%$ &, $50 \%$ & $44 \%$ ] & $5,00 \%$ \\
\hline
\end{tabular}


Anexo 1 - Retorno mensal e classificação das ações

\begin{tabular}{|c|c|c|c|c|c|c|c|c|c|c|c|c|c|c|c|c|c|c|c|c|}
\hline Código & 1996 - 1997 & $\begin{array}{l}\text { Índice } \mathrm{B} / \mathrm{M} \\
\text { de dez/1995 }\end{array}$ & \begin{tabular}{|c} 
Grupo com \\
base no \\
indice $\mathrm{B} / \mathrm{M}$
\end{tabular} & $\begin{array}{c}\text { Valor de Mercado } \\
\text { em jun/1996 }\end{array}$ & $\begin{array}{c}\text { Grupo com } \\
\text { base no } \\
\text { tamanho }\end{array}$ & $\begin{array}{c}\text { Retorno } \\
\text { acumulado } \\
\text { de jun/1996 }\end{array}$ & \begin{tabular}{|c|} 
Grupo com \\
base no \\
retorno \\
acumulado \\
\end{tabular} & Carteiras & $\mathrm{jul} / 96$ & ago/96 & set/96 & out/96 & nov/96 & $\operatorname{dez} / 96$ & jan/97 & $\mathrm{fev} / 97$ & $\mathrm{mar} / 97$ & $\mathrm{abr} / 97$ & mai/97 & jun/97 \\
\hline IMPE4 & Imperio PN & 7,25 & High & 2.160 .000 & Small & 0,74 & Loser & Small|High|Loser & $-30,56 \%$ & $-19,20 \%$ & $1,98 \%$ & $-2,91 \%$ & $-17,00 \%$ & $-27,71 \%$ & $50,00 \%$ & $42,22 \%$ & $2,69 \%$ & $-2,22 \%$ & $-4,55 \%$ & $30,95 \%$ \\
\hline TRMB4 & Trombini PN & 5,25 & High & \begin{tabular}{|l|l|}
14.459 .535 \\
\end{tabular} & Small & 0,73 & Loser & Small|High|Loser & $-5,56 \%$ & $-26,47 \%$ & $44,00 \%$ & $8,33 \%$ & $-10,77 \%$ & $6,32 \%$ & $-13,51 \%$ & $-0,62 \%$ & $-8,81 \%$ & $10,34 \%$ & $-6,25 \%$ & $25,33 \%$ \\
\hline EMBR4 & Embraer PN & 3,71 & High & 116.775.664 & Small & 0,72 & Loser & Small|High|Loser & $-30,23 \%$ & $4,44 \%$ & $27,66 \%$ & $23,33 \%$ & $8,11 \%$ & $20,00 \%$ & $-6,25 \%$ & $44,44 \%$ & $-3,85 \%$ & $13,60 \%$ & $9,15 \%$ & $41,94 \%$ \\
\hline BBDU4 & J B Duarte PN & 4,19 & High & 1.719 .044 & Small & 0,71 & Loser & Small|High|Loser & \begin{tabular}{|l|}
$-30,77 \%$ \\
\end{tabular} & $11,11 \%$ & $-10,00 \%$ & $-7,41 \%$ & $0,00 \%$ & $0,00 \%$ & $80,00 \%$ & $-11,11 \%$ & $-12,50 \%$ & $-22,86 \%$ & $3,70 \%$ & $10,71 \%$ \\
\hline LUXM4 & Trevisa PN & 18,75 & High & 5.479 .811 & Small & 0,68 & Loser & Small|High|Loser & $4,17 \%$ & $0,80 \%$ & $7,14 \%$ & $14,81 \%$ & $-7,10 \%$ & $-13,19 \%$ & $4,00 \%$ & $7,69 \%$ & $10,71 \%$ & $9,68 \%$ & $-17,65 \%$ & $3,57 \%$ \\
\hline EUCA4 & Eucatex PN & 5,05 & High & 56.413 .280 & Small & 0,67 & Loser & Small|High|Loser & $-7,14 \%$ & $7,69 \%$ & $0,00 \%$ & $-0,71 \%$ & $0,72 \%$ & $0,00 \%$ & $-12,14 \%$ & $34,15 \%$ & $-6,07 \%$ & $32,27 \%$ & $-9,76 \%$ & $40,55 \%$ \\
\hline LLMD4 & Yara Brasil PN & \begin{tabular}{ll|l|}
12,84 & \\
\end{tabular} & High & 6 & Small & 0,65 & Loser & Small|High|Loser & $-26,67 \%$ & $-9,09 \%$ & $10,00 \%$ & $43,18 \%$ & $-1,59 \%$ & $-10,00 \%$ & $0,36 \%$ & $-8,93 \%$ & $25,10 \%$ & $-12,23 \%$ & $-26,79 \%$ & $51,22 \%$ \\
\hline TEKA4 & Teka PN & 5,55 & High & \begin{tabular}{ll|}
18.412 .686 \\
\end{tabular} & Small & 0,64 & Loser & Small|High|Loser & $22,92 \%$ & $-8,47 \%$ & $5,56 \%$ & $-10,53 \%$ & $0,00 \%$ & $-7,84 \%$ & $6,38 \%$ & $6,00 \%$ & $20,75 \%$ & $-1,56 \%$ & $-0,05 \%$ & $13,33 \%$ \\
\hline HGTX4-old & Hering Text PN & 4,65 & High & \begin{tabular}{|l|l|}
15.739 .977 \\
\end{tabular} & Small & 0,63 & Loser & Small|High|Loser & $-7,69 \%$ & $0,00 \%$ & $16,67 \%$ & $92,86 \%$ & $51,11 \%$ & $7,03 \%$ & $-2,86 \%$ & $5,39 \%$ & $\begin{array}{ll}0,00 \% \\
\end{array}$ & $2,33 \%$ & $-2,27 \%$ & $16,28 \%$ \\
\hline PTNT4 & Pettenati PN & 4,47 & High & 16.761 .669 & Small & 0,63 & Loser & Small|High|Loser & $-10,71 \%$ & $-9,60 \%$ & $19,47 \%$ & $10,05 \%$ & $-20,14 \%$ & $10,81 \%$ & $-20,33 \%$ & $14,29 \%$ & $-1,79 \%$ & $-6,36 \%$ & $-12,62 \%$ & $-2,33 \%$ \\
\hline CREM4-old & Cremer (Antiga) PN & 8,82 & High & 0.000 & Small & 0,62 & $\begin{array}{ll}\text { Loser } \\
\end{array}$ & Small|High|Loser & $1,67 \%$ & $-24,59 \%$ & $-23,91 \%$ & $-25,66 \%$ & $7,61 \%$ & $-3,57 \%$ & $-2,59 \%$ & $40,68 \%$ & $14,05 \%$ & $-38,39 \%$ & $-7,69 \%$ & $-8,33 \%$ \\
\hline CHAP4 & Chapeco PN & 4,23 & High & 26.950 .862 & Small & 0,61 & Loser & Small|High|Loser & $-6,25 \%$ & $-6,67 \%$ & $-7,14 \%$ & $0,00 \%$ & $-7,69 \%$ & $-16,67 \%$ & $100,00 \%$ & $-25,00 \%$ & $-6,67 \%$ & $-7,14 \%$ & $0,00 \%$ & $-15,38 \%$ \\
\hline FTSE4 & Ferti Serrana PN & 7,96 & High & \begin{tabular}{|l|l|}
26.053 .088 \\
\end{tabular} & Small & 0,59 & Loser & Small|High|Loser & $-6,98 \%$ & $-17,50 \%$ & $-23,64 \%$ & $0,00 \%$ & $26,98 \%$ & $4,37 \%$ & $10,18 \%$ & $50,00 \%$ & $-16,59 \%$ & $1,65 \%$ & $2,56 \%$ & $16,58 \%$ \\
\hline SULT4 & Sultepa PN & 14,09 & High & 6.048 .000 & Small & 0,58 & Loser & Small|High|Loser & $-8,33 \%$ & $25,00 \%$ & $18,18 \%$ & $7,69 \%$ & $22,86 \%$ & $45,35 \%$ & $28,00 \%$ & $-6,25 \%$ & $10,00 \%$ & $26,67 \%$ & $0,00 \%$ & $6,27 \%$ \\
\hline FITA4 & Forjas & 4,87 & High & 376.599 & Small & 0,56 & Loser & & $-7,41 \%$ & $-16,00 \%$ & $-28,57 \%$ & $26,67 \%$ & $10,53 \%$ & $19,05 \%$ & $-16,00 \%$ & $19,05 \%$ & \begin{tabular}{l|l|}
$12,00 \%$ \\
\end{tabular} & $21,43 \%$ & $-9,60 \%$ & $3,85 \%$ \\
\hline SCLO4 & Schlosser PN & 9,11 & High & 2.304 .000 & Small & 0,56 & Loser & Small|High|Loser & $25,00 \%$ & $-63,33 \%$ & $36,36 \%$ & $33,33 \%$ & $-15,00 \%$ & $-17,65 \%$ & $0,00 \%$ & $-35,71 \%$ & $11,11 \%$ & $50,00 \%$ & $60,00 \%$ & $25,00 \%$ \\
\hline ESTR4 & Estrela PN & 3,84 & High & 11.209.110 & Small & 0,53 & Loser & Small|High|Loser & $-21,67 \%$ & $31,91 \%$ & $-20,97 \%$ & $18,37 \%$ & $29,31 \%$ & $-4,00 \%$ & $-33,33 \%$ & $0,00 \%$ & $-6,25 \%$ & $-2,22 \%$ & $-4,55 \%$ & $47,62 \%$ \\
\hline MNPR4 & Minupar PN & 7,07 & High & 14.771 .400 & Small & 0,53 & Loser & Small|High|Loser & $-16,13 \%$ & $-7,69 \%$ & $-25,00 \%$ & $0,00 \%$ & $-11,11 \%$ & $12,50 \%$ & $22,22 \%$ & $31,82 \%$ & $-6,90 \%$ & $-7,41 \%$ & $-16,00 \%$ & $-4,76 \%$ \\
\hline CMET4 & Caemi PN & 5,68 & High & 139.934.959 & Small & 0,49 & Loser & Small|High|Loser & $-12,61 \%$ & $-6,73 \%$ & $18,56 \%$ & $9,57 \%$ & $-4,76 \%$ & $-15,03 \%$ & $-1,92 \%$ & $18,00 \%$ & $-5,08 \%$ & $25,00 \%$ & $-21,41 \%$ & $-6,20 \%$ \\
\hline ROSI4 & An & 12,82 & High & 000 & $S \mathrm{ma}$ & 8 & Loser & |Loser & $0,00 \%$ & $10,81 \%$ & $-2,44 \%$ & $-12,50 \%$ & $-5,71 \%$ & $36,36 \%$ & $-31,11 \%$ & $16,13 \%$ & $-16,67 \%$ & $16,67 \%$ & $14,29 \%$ & $00 \%$ \\
\hline MANM3 & Mannesmann ON & 3,88 & High & 116.587 .750 & Small & 0,47 & Loser & Small|High|Loser & $7,53 \%$ & $0,70 \%$ & $0,69 \%$ & $0,01 \%$ & $1,43 \%$ & $1,99 \%$ & $2,00 \%$ & $-5,23 \%$ & $-6,90 \%$ & $9,63 \%$ & $-2,70 \%$ & $-9,72 \%$ \\
\hline MANM4 & Mannesmann PN & 3,88 & High & 116.587 .750 & Small & 0,46 & Loser & Small|High|Loser & $3,70 \%$ & $0,71 \%$ & $4,26 \%$ & $8,84 \%$ & $-1,87 \%$ & $-4,46 \%$ & $3,33 \%$ & $0,00 \%$ & $-3,23 \%$ & $0,67 \%$ & $-0,66 \%$ & $-7,33 \%$ \\
\hline PLTO6 & Politeno PNB & 9,40 & High & \begin{tabular}{|l|l|}
41.059 .087 \\
\end{tabular} & Small & 0,44 & $\begin{array}{l}\text { Loser } \\
\end{array}$ & Small|High|Loser & $12,00 \%$ & $0,00 \%$ & $-6,79 \%$ & $-23,37 \%$ & $0,50 \%$ & $19,40 \%$ & $24,17 \%$ & $0,67 \%$ & \begin{tabular}{|l|l|}
$13,33 \%$ \\
\end{tabular} & $-8,82 \%$ & $82,07 \%$ & $0,99 \%$ \\
\hline CNFB4 & Confab & 5,06 & High & & Small & 0,40 & Loser & Small|High|Loser & $5,41 \%$ & $17,95 \%$ & $50,00 \%$ & $13,04 \%$ & $24,36 \%$ & $15,46 \%$ & $13,39 \%$ & $-3,15 \%$ & $12,20 \%$ & 7,51\% & $24,09 \%$ & $5,29 \%$ \\
\hline GGBR4 & Gerdac & 7,96 & High & \begin{tabular}{|l|l|}
114.326 .418 \\
\end{tabular} & Small & 0,40 & Loser & Small|High|Loser & $-5,16 \%$ & $11,36 \%$ & $5,88 \%$ & $13,93 \%$ & $5,13 \%$ & $5,61 \%$ & $10,85 \%$ & $22,73 \%$ & $31,49 \%$ & $0,07 \%$ & $14,53 \%$ & $12,34 \%$ \\
\hline LETO5 & Micheletto PNA & 5,01 & High & \begin{tabular}{|l|}
3.683 .633 \\
\end{tabular} & Small & 0,39 & Loser & Small|High|Loser & $14,13 \%$ & $-6,67 \%$ & $2,04 \%$ & $5,00 \%$ & $4,76 \%$ & $0,00 \%$ & $-9,09 \%$ & $15,00 \%$ & $-0,87 \%$ & $-1,75 \%$ & $-15,18 \%$ & $5,26 \%$ \\
\hline GOAU4 & Gerdau Met PN & 6,02 & High & 90.580 .930 & Small & 0,37 & Loser & Small|High|Loser & $9,63 \%$ & $9,56 \%$ & $9,09 \%$ & $5,33 \%$ & $0,40 \%$ & $-6,00 \%$ & $0,00 \%$ & $24,62 \%$ & $30,21 \%$ & $5,60 \%$ & $11,69 \%$ & $20,93 \%$ \\
\hline HGTX4 & Cia He & 6,40 & High & 6.073 & Small & 0,30 & Loser & Small|High|Loser & $-8,75 \%$ & $-2,15 \%$ & $16,00 \%$ & $20,69 \%$ & $-4,29 \%$ & $-1,49 \%$ & $-8,33 \%$ & $14,05 \%$ & $23,19 \%$ & $-11,06 \%$ & $20,37 \%$ & $37,36 \%$ \\
\hline SGAS3 & WIm & 4 & High & 458 & Small & 26 & Loser & Small|High|Loser & $1,82 \%$ & $1,79 \%$ & $-3,51 \%$ & $5,45 \%$ & $-12,07 \%$ & $1,96 \%$ & $0,00 \%$ & $-3,85 \%$ & $36,00 \%$ & $-2,94 \%$ & $-4,55 \%$ & $12,70 \%$ \\
\hline MGEL4 & Mangels Indl PN & 5,31 & High & 173.649 & Small & 0,25 & Loser & Small|High|Loser & $-16,67 \%$ & $-5,00 \%$ & $-15,79 \%$ & $-1,87 \%$ & $29,94 \%$ & $-2,45 \%$ & $70,85 \%$ & $1,47 \%$ & $1,45 \%$ & $-2,86 \%$ & $2,94 \%$ & $-14,29 \%$ \\
\hline RIO4 & Sid Riogran PN & 6,88 & High & 121.527 .528 & Small & 0,25 & Loser & Small|High|Loser & $-7,45 \%$ & $9,79 \%$ & $6,76 \%$ & $2,17 \%$ & $-2,52 \%$ & $12,33 \%$ & $7,47 \%$ & $15,77 \%$ & $38,31 \%$ & $9,71 \%$ & $14,75 \%$ & $17,14 \%$ \\
\hline BARB4 & S Gobain Canal PN & 4,59 & High & 88.090 & Small & 0,24 & Loser & Small|High|Loser & $-11,63 \%$ & $7,89 \%$ & $2,44 \%$ & $38,10 \%$ & 70,69\% & $4,04 \%$ & $40,78 \%$ & $-5,52 \%$ & \begin{tabular}{l|l|}
$9,49 \%$ \\
\end{tabular} & $28,00 \%$ & $32,29 \%$ & $8,27 \%$ \\
\hline FTSU4 & Fertisul $\mathrm{P}$ & 10,64 & High & 7.072 & Small & 0,23 & $\begin{array}{ll}\text { Loser } \\
\end{array}$ & Small|High|Loser & $13,82 \%$ & $17,86 \%$ & $57,58 \%$ & $-3,85 \%$ & $6,00 \%$ & $-5,66 \%$ & $44,00 \%$ & $-6,94 \%$ & $-19,40 \%$ & $0,00 \%$ & $11,11 \%$ & $126,67 \%$ \\
\hline ELEK4 & Elekeirc & 5,45 & High & \begin{tabular}{|l|l|}
31.936 .831 \\
\end{tabular} & Small & 22 & Loser & Loser & $-22,73 \%$ & $-3,92 \%$ & $12,24 \%$ & $0,00 \%$ & $18,18 \%$ & $-15,38 \%$ & $23,64 \%$ & $-4,41 \%$ & $-6,15 \%$ & $-9,84 \%$ & $9,09 \%$ & $6,67 \%$ \\
\hline ITPS4 & Brampac & 20,58 & High & \begin{tabular}{|l|l|}
7.862 .130 \\
\end{tabular} & Small & 20 & Loser & Small|High|Loser & $-22,22 \%$ & $0,03 \%$ & $17,11 \%$ & $0,00 \%$ & $0,00 \%$ & $0,00 \%$ & $21,95 \%$ & $-10,00 \%$ & $-11,11 \%$ & $-23,75 \%$ & $16,39 \%$ & $29,58 \%$ \\
\hline PLDN4 & Polialde & 7,35 & High & \begin{tabular}{|l|l|}
25.810 .119 \\
\end{tabular} & Small & 0,18 & Loser & Small|High|Loser & $8,75 \%$ & $3,45 \%$ & $0,22 \%$ & $-0,22 \%$ & $-4,44 \%$ & $-13,95 \%$ & $8,11 \%$ & $7,50 \%$ & $-6,91 \%$ & $34,90 \%$ & $19,30 \%$ & $-4,67 \%$ \\
\hline MNDL4 & Mundial PN & 4,95 & High & 6.169 .500 & Small & 0,17 & Loser & Small|High|Loser & $0,00 \%$ & $-33,33 \%$ & $0,00 \%$ & $0,00 \%$ & $51,49 \%$ & $0,00 \%$ & $50,00 \%$ & $0,00 \%$ & $-33,33 \%$ & $50,00 \%$ & $-33,33 \%$ & $0,00 \%$ \\
\hline SOLO4 & Cargill! & 5,01 & High & 4.799 & Small & 6 & Loser & Small|High|Loser & $1,25 \%$ & $23,91 \%$ & $31,58 \%$ & $12,00 \%$ & $-11,90 \%$ & $0,00 \%$ & $2,70 \%$ & $13,16 \%$ & $2,09 \%$ & \begin{tabular}{ll|}
$11,31 \%$ \\
\end{tabular} & $12,00 \%$ & $33,33 \%$ \\
\hline FLCL5 & $\mathrm{FCa}$ & 1 & Hig & 922 & $\mathrm{Sm}$ & 9 & Win & ner & $16,47 \%$ & $7,07 \%$ & $11,20 \%$ & $10,43 \%$ & $-7,09 \%$ & $-4,24 \%$ & $32,74 \%$ & $21,33 \%$ & $-1,10 \%$ & $-0,52 \%$ & $7,51 \%$ & 36,6 \\
\hline TIBR5 & $\mathrm{MI}$ & & Hig & & $\mathrm{Sm}$ & 0,09 & Wir & $\mathrm{Sr}_{\mathrm{r}}$ & $-15,56 \%$ & $-8,22 \%$ & $-3,23 \%$ & $2,50 \%$ & $13,82 \%$ & $7,14 \%$ & $-16,00 \%$ & $-20,63 \%$ & $35,00 \%$ & $11,11 \%$ & $-6,73 \%$ & $28,66 \%$ \\
\hline SGAS4 & WIm Ind & 6,14 & High & 8 & Small & 0,07 & Winner & Small|High|Winner & $9,09 \%$ & $-18,33 \%$ & $-12,24 \%$ & $2,33 \%$ & $6,82 \%$ & $17,02 \%$ & $3,64 \%$ & $8,77 \%$ & $-4,84 \%$ & $-13,56 \%$ & $1,96 \%$ & $21,15 \%$ \\
\hline FBRA4 & Fertibras PN & 4,58 & High & 20.300.390 & Small & 0,04 & Winner & Small|High|Winner & $7,82 \%$ & $13,99 \%$ & $10,91 \%$ & $14,75 \%$ & $-2,14 \%$ & $-8,76 \%$ & $13,04 \%$ & $9,62 \%$ & $-2,11 \%$ & $-1,47 \%$ & $8,89 \%$ & $51,36 \%$ \\
\hline MAHS4 & Bunge Fertilizantes & 3,81 & High & 87.826 .569 & Small & 0,02 & Winner & Small|High|Winner & $7,95 \%$ & $22,81 \%$ & $0,29 \%$ & $9,69 \%$ & $-4,78 \%$ & $-16,99 \%$ & $12,79 \%$ & $11,94 \%$ & $4,00 \%$ & $5,16 \%$ & $22,28 \%$ & 27 \\
\hline MTSA & $\mathrm{Me}$ & & Hig & & $\mathrm{Sm}$ & 2 & W & & & $2,27 \%$ & $24,44 \%$ & $7,32 \%$ & $-0,17$ & $3,33 \%$ & $-4,84 \%$ & $1,69 \%$ & \begin{tabular}{l|l}
$5,00 \%$ \\
\end{tabular} & 17,4 & $9,38 \%$ & \\
\hline PRBN4 & Paraibun: & 4,30 & High & 39.056 .128 & Small & 0,37 & Winner & Small|High|Winner & $-30,92 \%$ & $9,13 \%$ & $-18,37 \%$ & $2,50 \%$ & $-2,44 \%$ & $30,25 \%$ & $19,96 \%$ & $-20,80 \%$ & $-9,09 \%$ & $-11,11 \%$ & $-5,50 \%$ & 3,17 \\
\hline ClQU4 & Cacique PN & 4,35 & High & \begin{tabular}{l|l|l|}
13.388 .760 \\
\end{tabular} & Small & 0,75 & Winner & Small|High|Winner & $-0,19 \%$ & $22,87 \%$ & $10,77 \%$ & $4,17 \%$ & $26,67 \%$ & $2,11 \%$ & $8,25 \%$ & $23,81 \%$ & $13,85 \%$ & $-8,78 \%$ & $-6,60 \%$ & $2,73 \%$ \\
\hline ENER6 & Enersul PNB & 6,40 & High & \begin{tabular}{l|l|}
117.006 .007 \\
\end{tabular} & Small & 1,48 & Winner & Small|High|Winner & $32,38 \%$ & $-18,47 \%$ & $5,88 \%$ & $33,33 \%$ & $-4,17 \%$ & $-2,17 \%$ & $44,44 \%$ & $-4,62 \%$ & $-6,13 \%$ & $-3,78 \%$ & $3,57 \%$ & $18,97 \%$ \\
\hline CPFL4 & & 111 & 4 & 58.005 . & $5 \mathrm{sed}$ & $07 \mathrm{C}$ & Loser & & 23 & $-25,00$ & $33,3=$ & $25,00 \%$ & $-20,00$ & 25,0 & & $25,00 \%$ & 20,0 & & 201 & \\
\hline & & & Low & & & & & & & $0,00 \%$ & & $0,00 \%$ & $0,00 \%$ & 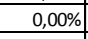 & , & $25,00 \%$ & $16,6 \%$ & 0 & $5,67 \%$ & \\
\hline BDLL4 & Bardella PN & 1,72 & Low & 177.600 .000 & Small & 0,37 & Loser & Small|Low|Loser & $-0,92 \%$ & $\mid-9,98 \%$ & $\mid-9,14 \%$ & $22,29 \%$ & $-5,45 \%$ & $-4,82 \%$ & $44,47 \%$ & $-0,01 \%$ & $5,60 \%$ & $-8,91 \%$ & $22,31 \%$ & $-0,63$ \\
\hline
\end{tabular}


Anexo 1 - Retorno mensal e classificação das ações

\begin{tabular}{|c|c|c|c|c|c|c|c|c|c|c|c|c|c|c|c|c|c|c|c|c|}
\hline Código & 1996 - 1997 & $\begin{array}{l}\text { Índice } B / M \\
\text { de dez/1995 }\end{array}$ & $\begin{array}{c}\text { Grupo com } \\
\text { base no } \\
\text { indice B/M } \\
\end{array}$ & $\begin{array}{c}\text { Valor de Mercado } \\
\text { em jun/1996 }\end{array}$ & \begin{tabular}{|c} 
Grupo com \\
base no \\
tamanho \\
\end{tabular} & $\begin{array}{c}\text { Retorno } \\
\text { acumulado } \\
\text { de jun/1996 }\end{array}$ & \begin{tabular}{|l} 
Grupo com \\
base no \\
retorno \\
acumulado \\
\end{tabular} & Carteiras & $\mathrm{jul} / 96$ & ago/96 & set/96 & out $/ 96$ & nov/96 & $\operatorname{dez} / 96$ & $\mathrm{jan} / 97$ & fev/97 & $\mathrm{mar} / 97$ & $\mathrm{abr} / 97$ & $\mathrm{mai} / 97$ & jun/97 \\
\hline RHER4 & Ren Hermann PN & 0,88 & Low & 140.252 .859 & Small & 0,30 & Loser & Small|Low|Loser & $7,14 \%$ & $-8,67 \%$ & $0,73 \%$ & $-23,91 \%$ & $-14,29 \%$ & $3,33 \%$ & $-6,45 \%$ & $18,39 \%$ & $9,71 \%$ & $-18,46 \%$ & $28,09 \%$ & $24,56 \%$ \\
\hline MRSL4 & Marisol PN & 1,35 & Low & 93.875 .856 & Small & 0,26 & Loser & Small|Low|Loser & $-1,33 \%$ & $8,11 \%$ & $3,26 \%$ & $2,47 \%$ & $-12,05 \%$ & $-1,37 \%$ & $5,56 \%$ & $5,26 \%$ & $7,03 \%$ & $4,82 \%$ & $9,20 \%$ & $1,05 \%$ \\
\hline RIPI4 & Ipiranga Ref PN & 1,58 & Low & 128.252 .200 & Small & 0,24 & Loser & Small|Low|Loser & $-5,00 \%$ & $-2,50 \%$ & $-13,35 \%$ & $3,70 \%$ & $-0,29 \%$ & $8,74 \%$ & $21,04 \%$ & $12,99 \%$ & $-10,00 \%$ & $0,00 \%$ & $16,56 \%$ & $12,49 \%$ \\
\hline FRI4 & Frigobras PN & 1,21 & Low & 165.429 .007 & Small & 0,21 & Loser & Small|Low|Loser & $-18,52 \%$ & $13,64 \%$ & $8,00 \%$ & $-11,11 \%$ & $-1,01 \%$ & $-2,13 \%$ & $-4,35 \%$ & $9,09 \%$ & $16,26 \%$ & $18,52 \%$ & $29,69 \%$ & $6,02 \%$ \\
\hline IGBR5 & IGB S/A PNA & 1,02 & Low & 162.827 .036 & Small & 0,15 & Winner & Small|Low|Winner & $1,87 \%$ & $-11,34 \%$ & $-3,57 \%$ ] & $-3,71 \%$ & $-15,38 \%$ & $9,08 \%$ & $16,68 \%$ & $0,00 \%$ & $0,00 \%$ & $-21,43 \%$ & $11,21 \%$ & $-14,90 \%$ \\
\hline IVIL4 & Coinvest PN & 1,72 & Low & $\begin{array}{l}86.437 .842 \\
\end{array}$ & Small & 0,22 & Winner & Small|Low|Winner & $9,32 \%$ & $10,28 \%$ & $27,50 \%$ & $-13,55 \%$ & $3,09 \%$ & $-6,00 \%$ & $1,06 \%$ & $18,95 \%$ & $13,27 \%$ & $-4,69 \%$ & $22,40 \%$ & $-1,37 \%$ \\
\hline PMET6 & Pro Metalurg PNB & 2,97 & Medium & 7.203 .000 & Small & 0,84 & Loser & Small|Medium|Loser & $38,10 \%$ & $-25,86 \%$ & $-25,58 \%$ & $-3,12 \%$ & $-19,35 \%$ & $16,00 \%$ & $-6,90 \%$ & $-18,52 \%$ & $0,00 \%$ & $27,27 \%$ & $89,29 \%$ & $-1,89 \%$ \\
\hline SIBR7 & Sibra PNC & 3,19 & Medium & 42.450 .782 & Small & 0,77 & Loser & Small|Medium|Loser & $-42,86 \%$ & $25,00 \%$ & $0,00 \%$ & $0,00 \%$ & $-20,00 \%$ & $0,00 \%$ & $25,00 \%$ & $20,00 \%$ & $50,00 \%$ & $-11,11 \%$ & $-37,50 \%$ & $0,00 \%$ \\
\hline LEVE4 & Metal Leve PN & 3,07 & Medium & 50.182 .149 & Small & 0,72 & Loser & Small|Medium|Loser & $1,01 \%$ & $-16,00 \%$ & $11,90 \%$ & $-6,38 \%$ & $-6,82 \%$ & $-12,20 \%$ & $11,81 \%$ & $39,13 \%$ & $-7,14 \%$ & $3,85 \%$ & $-12,04 \%$ & $11,58 \%$ \\
\hline MYPK4 & Iochp-Maxion PN & 2,54 & Medium & 107.942 .335 & Small & 0,71 & Loser & Small|Medium|Loser & $4,00 \%$ & $-11,54 \%$ & $13,04 \%$ & $-23,85 \%$ & $-23,74 \%$ & $-22,52 \%$ & $36,75 \%$ & $19,38 \%$ & $-3,14 \%$ & $-3,78 \%$ & $23,60 \%$ & $17,16 \%$ \\
\hline ARTE4 & Kuala PN & 2,02 & Medium & 67.066 .445 & Small & 0,71 & Loser & Small|Medium|Loser & $3,08 \%$ & $-32,84 \%$ & $-21,11 \%$ & $-15,49 \%$ & $-21,67 \%$ & $0,00 \%$ & $-14,89 \%$ & $20,00 \%$ & $-10,42 \%$ & $6,98 \%$ & $-4,35 \%$ & $22,73 \%$ \\
\hline ITEC3 & Itautec ON & 2,60 & Medium & 116.265 .520 & Small & 0,63 & Loser & Small|Medium|Loser & $-18,42 \%$ & $0,00 \%$ & $0,00 \%$ & $6,13 \%$ & $51,37 \%$ & $-3,82 \%$ & $-20,67 \%$ & $5,26 \%$ & $7,50 \%$ & $-6,98 \%$ & $-0,25 \%$ & $-4,76 \%$ \\
\hline CPCA4 & Trikem PN & 2,89 & Medium & 94.378.197 & Small & 0,60 & Loser & Small|Medium|Loser & $-21,51 \%$ & $32,42 \%$ & $-8,62 \%$ & $32,08 \%$ & $-1,43 \%$ & $-1,45 \%$ & $-14,71 \%$ & $35,86 \%$ & $1,52 \%$ & $15,00 \%$ & $-15,43 \%$ & $-22,88 \%$ \\
\hline DHBI4 & DHB PN & 1,84 & Medium & 3.232.620 & Small & 0,58 & Loser & Small|Medium|Loser & $-11,11 \%$ & $-37,50 \%$ & $0,00 \%$ ] & $-30,00 \%$. & $2,86 \%$ & $-8,33 \%$ & $-9,09 \%$ & $-23,33 \%$ | & $0,43 \%$ & $-12,99 \%$ & $-0,50 \%$ & $15,00 \%$ \\
\hline MSAN3 & Bunge Brasil ON & 2,11 & Medium & 178.333 .500 & Small & 0,56 & Loser & Small|Medium|Loser & $1,23 \%$ & $-15,85 \%$ & $26,09 \%$ & $4,60 \%$ & $48,35 \%$ & $-11,11 \%$ & $85,00 \%$ & $91,59 \%$ & $15,52 \%$ & $-8,96 \%$ & $13,11 \%$ & $56,52 \%$ \\
\hline RPSA4 & Ripasa PN & 3,22 & Medium & 112.387 .702 & Small & 0,52 & Loser & Small|Medium|Loser & $-5,02 \%$ & $-5,24 \%$ & $-17,78 \%$ & $-8,11 \%$ & $-8,82 \%$ & $6,45 \%$ & $-18,18 \%$ & $59,26 \%$ & $-25,58 \%$ & $0,00 \%$ & $3,13 \%$ & $51,52 \%$ \\
\hline INEP4 & Inepar PN & 3,17 & Medium & 86.405 .004 & Small & 0,47 & Loser & Small|Medium|Loser & $-3,00 \%$ & $-6,19 \%$ & $15,38 \%$ & $-9,52 \%$ & $5,26 \%$ & $-10,00 \%$ & $-1,11 \%$ & $20,22 \%$ & $-2,80 \%$ & $2,88 \%$ & $68,75 \%$ & $54,32 \%$ \\
\hline FAPC4 & Cofap PN & 2,46 & Medium & 134.583.181 & Small & 0,46 & Loser & Small|Medium|Loser & $-12,07 \%$ & $21,57 \%$ & $24,19 \%$ & $3,90 \%$ & $5,62 \%$ & $-5,33 \%$ & $25,00 \%$ & $17,00 \%$ & $-23,08 \%$ & $27,86 \%$ & $0,00 \%$ & $5,91 \%$ \\
\hline DOCA4 & Docas PN & 2,50 & Medium & 35.155 .570 & Small & 0,46 & Loser & Small|Me & $-14,29 \%$ & $-27,78 \%$ & $-3,85 \%$ & $0,00 \%$ & $0,00 \%$ & $40,00 \%$ & $8,57 \%$ & $0,00 \%$ & $0,00 \%$ & $-19,74 \%$ & $11,20 \%$ & $0,00 \%$ \\
\hline CABR4 & Casa Anglo PN & 2,92 & Medium & 72.365 .920 & Small & 0,43 & Loser & Small|Medium|Loser & $-14,55 \%$ & $-23,38 \%$ & $36,07 \%$ & $-10,20 \%$ & $-8,07 \%$ & $-22,13 \%$ & $11,08 \%$ & $2,89 \%$ & $17,75 \%$ & $17,95 \%$ & $7,66 \%$ & $-3,77 \%$ \\
\hline ALPA4 & Alpargatas PN & 1,78 & Medium & 155.122.485 & Small & 0,39 & Loser & Small|Medium|Loser & $-5,92 \%$ & $-6,92 \%$ & $0,09 \%$ & $-13,60 \%$ & $6,23 \%$ & $-6,02 \%$ & $6,42 \%$ & $-2,94 \%$ & $-16,67 \%$ & $-5,04 \%$ & $-11,33 \%$ & $34,45 \%$ \\
\hline ALPA3 & Alpargatas ON & 1,78 & Medium & 155.122.485 & Small & 0,35 & Loser & Small|Medium|Loser & $-1,31 \%$ ] $<>$ & $-6,80 \%$ & $-4,27 \%$ | & $-8,96 \%$ ] $<>$ & $-14,75 \%$ & $-1,92 \%$ & $36,25 \%$ & $0,59 \%$. & $-14,16 \%$ ] $<>$ & $-7,91 \%$ & $-16,36 \%$ & $63,04 \%$ \\
\hline SAGR4 & Agroce & 3,35 & Medium & 51.404 & Small & 0,35 & Loser & Small|Medium|Loser & $12,24 \%$ & $-9,09 \%$ & $20,00 \%$ & $0,00 \%$ & $-5,00 \%$ & $5,26 \%$ & $-5,83 \%$ & $31,42 \%$ & $-15,89 \%$ & $-5,02 \%$ & $60,38 \%$ & $1,76 \%$ \\
\hline FGOS4 & Frangosul PN & 3,18 & Medium & 46.624 .002 & Small & 0,31 & Loser & Small|Medium|Loser & $18,75 \%$ & $-31,58 \%$ & $-15,38 \%$ & $-10,00 \%$ & $-11,11 \%$ & $13,64 \%$ & $-10,00 \%$ & $44,44 \%$ & $-23,08 \%$ & $25,00 \%$ & $-12,00 \%$ & $47,36 \%$ \\
\hline ROMI4 & Inds Romi PN & 2,94 & Medium & 50.400 .100 & Small & 0,28 & Loser & Small|Medium|Loser & $-0,59 \%$ & $-26,32 \%$ & $33,93 \%$ & $-3,33 \%$ & $6,83 \%$ & $-3,81 \%$ & $-6,04 \%$ & $14,29 \%$ & $18,75 \%$ & $0,28 \%$ & $11,73 \%$ & $10,00 \%$ \\
\hline MSAN4 & Bunge Brasil PN & 2,11 & Medium & 178.333 .500 & Small & 0,28 & Loser & Small|Medium|Loser & $13,33 \%$ & $-17,65 \%$ & $14,29 \%$ & $8,75 \%$ & $49,43 \%$ & $-7,69 \%$ & $83,33 \%$ & $100,00 \%$ & $6,67 \%$ & $-6,25 \%$ & $15,00 \%$ & $57,97 \%$ \\
\hline TOYB4 & Tectoy PN & 2,42 & Medium & 18.000 .001 & Small & 0,26 & Loser & Small|Medium|Loser & $-3,33 \%$ & $-13,79 \%$ & $-4,00 \%$ & $-16,67 \%$ & $5,00 \%$ & $85,71 \%$ & $-28,21 \%$ & $-14,29 \%$ & $0,00 \%$ & $-16,67 \%$ & $20,00 \%$ & $20,83 \%$ \\
\hline PLAS4 & Plascar Part & 1,95 & Medium & 102.267.443 & Small & 0,26 & Loser & Small|Me & $2,99 \%$ & $-4,40 \%$ & $-9,95 \%$ & $-12,79 \%$ & $-9,33 \%$ & $-4,56 \%$ & $-18,34 \%$ & $28,30 \%$ & $4,26 \%$ & $-22,43 \%$ & $-9,09 \%$ & $0,00 \%$ \\
\hline ELEV3 & Eleva ON & 2,75 & Medium & 113.173.829 & Small & 0,25 & Loser & Small|Medium|Loser & $-6,86 \%$ & $1,23 \%$ & $0,00 \%$ & $33,94 \%$ & $4,07 \%$ & $26,09 \%$ & $5,17 \%$ & $16,39 \%$ & $14,08 \%$ & $-6,17 \%$ & $-0,76 \%$ & $21,25 \%$ \\
\hline UNIP6 & Unipar PNB & 2,97 & Medium & 123.088.578 & Small & 0,21 & Loser & Small|Medium|Loser & $-5,17 \%$ & $-1,82 \%$ & $-9,62 \%$ & $-10,64 \%$ & $2,38 \%$ & $6,98 \%$ & $-4,35 \%$ & $9,09 \%$ & $-8,33 \%$ & $-6,82 \%$ & $26,83 \%$ & $13,46 \%$ \\
\hline PVLT3 & Souto Vidig ON & 3,53 & Medium & 147.981.757 & Small & 0,20 & Loser & Small|Medium|Loser & $-31,25 \%$ & $13,64 \%$ & $-8,00 \%$ & $-0,43 \%$ & $13,54 \%$ & $15,38 \%$ & $-3,33 \%$ & $-13,79 \%$ & $0,00 \%$ & $12,00 \%$ & $0,34 \%$ & $0,00 \%$ \\
\hline SHAP4 & Sharp PN & 2,50 & Medium & 95.678.176 & Small & 0,20 & Loser & Small|Medium|Loser & $-5,13 \%$ & $14,86 \%$ & $22,35 \%$ & $36,54 \%$ & $9,15 \%$ & $-9,68 \%$ & $-1,43 \%$ & $-4,35 \%$ & $6,06 \%$ & $-5,71 \%$ & $-20,45 \%$ & $3,81 \%$ \\
\hline RCSL4 & Recrusul PN & 2,76 & Medium & 979.199 & Small & 0,11 & Winner & Small|Medium|Winner & $-19,94 \%$ & $1,90 \%$ & $-11,58 \%$ & $8,66 \%$ & $-0,41 \%$ & $-2,56 \%$ & $-3,16 \%$ & $-7,61 \%$ & $-5,88 \%$ & $0,43 \%$ & $-5,42 \%$ & $32,35 \%$ \\
\hline PEFX3 & Petroflex ON & 2,30 & Medium & .736 .577 & Small & 0,09 & Winner & Small|Medium|Winner & $-12,00 \%$ & $-16,67 \%$ & $0,00 \%$ & $0,00 \%$ & $0,00 \%$ & $9,09 \%$ & $-5,00 \%$ & $-7,89 \%$ & $8,57 \%$ & $5,26 \%$ & $8,33 \%$ & $-4,62 \%$ \\
\hline LORZ4 & Lorenz PN & 3,44 & Medium & 9.999 & Small & 0,24 & Winner & Small|Medium|Winner & $-4,99 \%$ & $2,06 \%$ & $15,27 \%$ & $4,95 \%$ & $19,10 \%$ & $-2,00 \%$ & $18,57 \%$ & $8,92 \%$ & $3,98 \%$ & $0,00 \%$ & $2,91 \%$ & $26,74 \%$ \\
\hline FTZA4 & Fertiza PN & 3,42 & Medium & 13.012.601 & Small & 0,32 & Winner & Small|Medium|Winner & $11,83 \%$ & $2,60 \%$ & $-4,05 \%$ & $-2,37 \%$ & $16,64 \%$ & $-3,75 \%$ & $6,49 \%$ & $9,76 \%$ & $0,00 \%$ & $-8,89 \%$ & $1,27 \%$ & $40,00 \%$ \\
\hline RPAD5 & Alfa Holding PN & 2,36 & Medium & 161.826 .714 & Small & 0,32 & Winner & Small|Medium|Winner & $-2,86 \%$ & $7,28 \%$ & $3,33 \%$ & $-0,54 \%$ & $8,11 \%$ & $5,00 \%$ & $-0,48 \%$ & $9,18 \%$ & $-4,65 \%$ & $0,00 \%$ & $-4,88 \%$ & $-1,54 \%$ \\
\hline IGUA5 & Iguacu Cafe PNA & 3,52 & Medium & 22.808 .920 & Small & 0,32 & Winner & Small|Medium |Winner & $6,25 \%$ & $0,00 \%$ & $11,76 \%$ & $3,16 \%$ & $5,10 \%$ & $-2,91 \%$ & $7,00 \%$ & $12,15 \%$ & $9,17 \%$ & $16,19 \%$ & $3,85 \%$ & $3,70 \%$ \\
\hline IGUAG & Iguacu Cafe PNB & 3,52 & Medium & 22.808 .920 & Small & 0,35 & Winner & Small|Medium|Winner & $-10,26 \%$ & $7,14 \%$ & $13,33 \%$ & $5,88 \%$ & $1,11 \%$ & $9,89 \%$ & $6,00 \%$ & $22,64 \%$ & $3,85 \%$ & $4,70 \%$ & $0,00 \%$ & $-2,34 \%$ \\
\hline RPAD6 & Alfa Holding PNB & 2,36 & Medium & 161.826 .714 & Small & 0,35 & Winner & Small|Medium|Winner & $3,01 \%$ & $4,87 \%$ & $15,25 \%$ & $-8,33 \%$ & $9,63 \%$ & $0,00 \%$ & $-1,43 \%$ & $7,69 \%$ & $-3,81 \%$ & $-2,97 \%$ & $0,51 \%$ & $-5,08 \%$ \\
\hline BRGE3 & Alfa Consorc ON & 2,88 & Medium & 148.371 .742 & Small & 0,45 & Winner & Small|Medium|Winner & $4,65 \%$ & $3,35 \%$ & $5,65 \%$ & $-7,41 \%$ & $8,89 \%$ & $-4,08 \%$ & $6,14 \%$ & $3,73 \%$ & $-3,60 \%$ & $0,41 \%$ & $3,31 \%$ & $-1,20 \%$ \\
\hline BRGE11 & Alfa Con & 2,88 & Medic & .371 .742 & Small & 6 & Winne & Small|M & $-2,94 \%$ & $10,77 \%$ & $5,00 \%$ & 0,53 & 6,3 & $-0,9$ & 5,0 & 6,6 & $-4,65 \%$ & $0,00 \%$ & $-1,95 \%$ & $-1,4$ \\
\hline CARB5 & Nitroca & 2,09 & $\mathrm{Me}$ & & Small & 0,48 & Winner & Small|Medium |Winner & $0,00 \%$ & $-13,67 \%$ & $-11,20 \%$ & $1,30 \%$ & $-1,29 \%$ & $0,00 \%$ & $-6,52 \%$ & $9,30 \%$ & $10,64 \%$ & $-13,46 \%$ & $-11,11 \%$ & $-5,00 \%$ \\
\hline BRGE12 & Alfa Consorc PNF & 2,88 & Medium & 148.371 .742 & Small & 0,49 & Winner & Small|Medium|Winner & $14,71 \%$ & $-2,33 \%$ & $9,04 \%$ & $-7,32 \%$ & $22,11 \%$ & $-12,93 \%$ & $7,92 \%$ & $9,68 \%$ & $-4,78 \%$ & $-3,20 \%$ & $-0,94 \%$ & $-2,38 \%$ \\
\hline ITLMS & Antarctica MG PNA & 2,30 & Medium & 52.227.104 & Small & 0,51 & Winner & Small|Medium|Winner & $5,26 \%$ & $0,00 \%$ & $2,49 \%$ & $-3,89 \%$ & $-8,86 \%$ & $-5,00 \%$ & $0,88 \%$ & $15,94 \%$ & $12,50 \%$ & $-5,57 \%$ & $-2,44 \%$ & $-27,50 \%$ \\
\hline BIOB4 & iobras PN & 3,54 & hedium & 2.046 .320 & Small & 0,54 & Winner & Small|M & $11,11 \%$ & $-16,32 \%$ & $11,90 \%$ & $-2,9$ & $-5,00 \%$ & $-10,5$ & $8,24 \%$ & $3,25 \%$ & $-10,52 \%$ & $5,88 \%$ & $30,38 \%$ & $19,69 \%$ \\
\hline RPAD3 & Alf & 2,36 & $M$ & & $\mathrm{Sm}$ & 8 & $\mathrm{Wi}_{\mathrm{i}}$ & $\mathrm{Sm}$ & $4,37 \%$ & & 0,5 & -0, & $7,62 \%$ & $-2,08 \%$ & $0, \mathrm{~s}$ & & & $1,26 \%$ & $-0,83 \%$ & -3, \\
\hline PNOR5 & Pronor PNA & 2,90 & Medium & 101.409 .598 & Small & 0,71 & Winner & Small|Medium|Winner & $18,18 \%$ & $0,00 \%$ & $0,00 \%$ & $15,38 \%$ & $0,00 \%$ & $10,00 \%$ & $-6,06 \%$ & $19,35 \%$ & $-16,22 \%$ & $19,35 \%$ & $-18,92 \%$ & $6,67 \%$ \\
\hline UCOP4 & Usin C Pinto PN & 2,29 & Medium & 30.420 .001 & Small & 1,20 & Winner & Small|Medium|Winner & $-4,62 \%$ & $3,45 \%$ & $2,40 \%$ & $3,91 \%$ & $-9,77 \%$ & $29,17 \%$ & $-9,68 \%$ & $-0,01 \%$ & $10,00 \%$ & $-9,09 \%$ ] & $-4,99 \%$, & $1,50 \%$ \\
\hline PNOR6 & Pronor PNB & 2,90 & Medium & 101.409.598 & Small & 1,29 & Winner & Small|Medium|Winner & $9,09 \%$ & $4,17 \%$ & $20,00 \%$ & $20,00 \%$ & $33 \%$ & $5 \%$ & 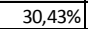 & $-6,67 \%$ & $25,00 \%$ & (1) & $5,00 \%$ & $00 \%$ \\
\hline
\end{tabular}


Anexo 1 - Retorno mensal e classificação das ações

\begin{tabular}{|c|c|c|c|c|c|c|c|c|c|c|c|c|c|c|c|c|c|c|c|c|}
\hline Código & $1997-1998$ & $\begin{array}{l}\text { Índice } \mathrm{B} / \mathrm{M} \\
\text { de dez/1996 }\end{array}$ & $\begin{array}{c}\text { Grupo com } \\
\text { base no } \\
\text { indice } \mathrm{B} / \mathrm{M}\end{array}$ & $\begin{array}{c}\text { Valor de Mercado } \\
\text { em jun/1997 }\end{array}$ & $\begin{array}{c}\text { Grupo com } \\
\text { base no } \\
\text { tamanho }\end{array}$ & $\begin{array}{c}\text { Retorno } \\
\text { acumulado } \\
\text { de jun/1997 }\end{array}$ & \begin{tabular}{|c|} 
Grupo com \\
base no \\
retorno \\
acumulado
\end{tabular} & Carteiras & $\mathrm{jul} / 97$ & ago/97 & set/97 & out $/ 97$ & nov/97 & dez/97 & jan/98 & $\mathrm{fev} / 98$ & $\mathrm{mar} / 98$ & $\mathrm{abr} / 98$ & mai/98 & jun/98 \\
\hline ACES4 & Am Inox BR PN & 3,04 & High & 370.238 .475 & Big & 0,39 & \begin{tabular}{|l} 
Loser \\
\end{tabular} & Big|High|Loser & $0,90 \%$ & $1,79 \%$ & $4,39 \%$ & $-30,67 \%$ & \begin{tabular}{|l|}
$-33,94 \%$ \\
\end{tabular} & $-18,35 \%$ & $-4,49 \%$ & $17,65 \%$ & \begin{tabular}{|l|}
$110,00 \%$ \\
\end{tabular} & $-15,24 \%$ & $-13,51 \%$ & $-8,50 \%$ \\
\hline ACES3 & Am Inox BR ON & 3,04 & High & \begin{tabular}{|l|}
370.238 .475 \\
\end{tabular} & Big & 0,30 & Loser & Big|High|Loser & $-3,30 \%$ & $-0,49 \%$ & $7,35 \%$ & $-31,51 \%$ & $-33,33 \%$ & $-20,00 \%$ & $-6,25 \%$ & $16,00 \%$ & \begin{tabular}{|l|}
$144,83 \%$ \\
\end{tabular} & $-8,92 \%$ & $-11,92 \%$ & $-24,71 \%$ \\
\hline BRKM5 & Braskem PNA & 3,89 & High & $\begin{array}{l}715.027 .270 \\
\end{array}$ & Big & 0,18 & Loser & Big|High|Loser & $22,48 \%$ & $-10,11 \%$ & $-8,67 \%$ & $-12,66 \%$ & $-28,79 \%$ & $44,68 \%$ & $-6,71 \%$ & $0,49 \%$ & $11,26 \%$ & $2,25 \%$ & $-17,19 \%$ & $-8,54 \%$ \\
\hline CSTB4 & Sid Tubarao PN & 3,59 & High & 742.452 .856 & Big & 0,14 & Loser & Big|High|Loser & $33,11 \%$ & $-6,15 \%$ & $1,09 \%$ & $-23,53 \%$ & $16,43 \%$ & $-3,07 \%$ & $-17,72 \%$ & $17,39 \%$ & $31,29 \%$ & $4,80 \%$ & $-9,39 \%$ & $-11,93 \%$ \\
\hline CEVA4 & Bunge Alimentos PN & 2,61 & High & 426.940 .652 & Big & 0,07 & Loser & Big|High|Loser & $3,97 \%$ & $-13,74 \%$ & $-10,18 \%$ & $-13,40 \%$ & $-2,16 \%$ & $0,00 \%$ & $-37,21 \%$ & $-25,93 \%$ & $55,00 \%$ & $1,61 \%$ & $-30,16 \%$ & $-6,36 \%$ \\
\hline ARCE3 & Arcelor BR ON & 4,69 & High & \begin{tabular}{|l|}
352.007 .019 \\
\end{tabular} & Big & 0,38 & Winner & | Big|High|Winner & $-13,41 \%$ & $21,55 \%$ & $-0,93 \%$ & $-8,89 \%$ & $-22,98 \%$ & $-1,68 \%$ & $-1,68 \%$ & $-1,72 \%$ & $29,65 \%$ & $3,58 \%$ & $-2,04 \%$ & $4,17 \%$ \\
\hline ARCE4 & Arcelor BR PN & 4,69 & High & \begin{tabular}{|l|}
352.007 .019 \\
\end{tabular} & Big & 0,50 & Winner & Big|High|Winner & $-8,44 \%$ & $11,21 \%$ & $5,87 \%$ & $-15,66 \%$ & $-8,59 \%$ & $-17,17 \%$ & $9,42 \%$ & $-10,16 \%$ & $31,00 \%$ & $7,35 \%$ & $2,21 \%$ & $-6,36 \%$ \\
\hline VCPA4 & Fibria PN & 2,70 & High & 1.210.326.443 & Big & 0,70 & Winner & Big|High|Winner & $-4,31 \%$ & $-6,43 \%$ & $4,81 \%$ & $-13,74 \%$ & $-8,78 \%$ & $-10,42 \%$ & $-20,93 \%$ & $-2,94 \%$ & $45,45 \%$ & $-8,33 \%$ & $-20,78 \%$ & $2,85 \%$ \\
\hline PTOS4 & \begin{tabular}{|l|} 
Petroquisa PN \\
\end{tabular} & 6,79 & High & 1.079 .137 .089 & Big & 0,95 & Winner & Big|High/Winner & $28.44 \%$ & $-7,14 \%$ & $9,23 \%$ & $0,70 \%$ & $0,70 \%$ & $2,78 \%$ & $-1,35 \%$ & $5,48 \%$ & $12,13 \%$ & $5,00 \%$ & $1,19 \%$ & $-5,88 \%$ \\
\hline ELET6 & Eletrobras PNB & 2,97 & High & 32.696 .571 .692 & Big & 1,00 & Winner & Big|High|Winner & $-0,31 \%$ & $-22,34 \%$ & $24,75 \%$ & $-23,06 \%$ & $13,21 \%$ & $5,56 \%$ & $-11,40 \%$ & $4,95 \%$ & $6,04 \%$ & $-4,48 \%$ & $-19,43 \%$ & $-8,61 \%$ \\
\hline ELET3 & Eletrobras ON & 2,97 & High & 32.696 .571 .692 & Big & 1,02 & Winner & Big|High|Winner & $-2,00 \%$ & $-21,19 \%$ & $24,73 \%$ & $-23,28 \%$ & $14,61 \%$ & $8,82 \%$ & $-12,61 \%$ & $4,74 \%$ & $3,94 \%$ & $-5,90 \%$ & $-18,51 \%$ & $-4,99 \%$ \\
\hline $\begin{array}{ll}\text { CESP5 } \\
\text { CES }\end{array}$ & Cesp PNA & $\frac{2,37}{3,16}$ & \begin{tabular}{|l} 
High \\
\end{tabular} & \begin{tabular}{r|}
$2.050 .31 / .052$ \\
6.654 .045 .682
\end{tabular} & \begin{tabular}{|l} 
Big \\
\end{tabular} & $\frac{1,02}{1,17}$ & Winner & \begin{tabular}{|l} 
Big|High|Winner \\
\end{tabular} & - $13,19 \%$ & - & $24,56 \%$ & $\begin{array}{l}-25,2010 \\
-25,65 \% \\
\end{array}$ & $\mid$ & $\frac{-0,010}{-1,81 \%}$ & - & $\begin{array}{l}13,40 \% \\
\end{array}$ & \begin{tabular}{|l|}
$7,340 \%$ \\
\end{tabular} & \begin{tabular}{|l|}
$-5,93 \%$ \\
$-5,93 \%$
\end{tabular} & $\begin{array}{l}-10,0110 \\
-32,43 \% \\
\end{array}$ & $-4,-14,40 \%$ \\
\hline GOAU4 & Gerdau Met PN & 5,28 & High & \begin{tabular}{|l|}
511.725 .927 \\
\end{tabular} & Big & 1,32 & Winner & Big|High / Winner & $-16,84 \%$ & $17,05 \%$ & $0,00 \%$ & $-10,45 \%$ & $-24,34 \%$ & $0,90 \%$ & $-3,94 \%$ & $13,00 \%$ & $23,32 \%$ & $14,12 \%$ & $-6,69 \%$ & $-15,91 \%$ \\
\hline CESP3 & Cesp ON & 3.16 & High & 6.654 .045 .682 & Bip & 1.53 & Winner & Big/Hithinger & $770 \%$ & $-984 \%$ & $13,71 \%$ & $-18.60 \%$ & $-5.63 \%$ & $-2.36 \%$ & $-33,32 \%$ & $1389 \%$ & $576 \%$ & $-8.90 \% \mathrm{f}$ & $-21.52 \%$ & $-12.58 \%$ \\
\hline GGBR4 & Gerdau PN & 4,06 & High & \begin{tabular}{|l|l}
990.832 .086 \\
\end{tabular} & Big & 1,80 & Winner & Big|High|Winner & $16,58 \%$ & $-3,64 \%$ & $16,82 \%$ & $-31,60 \%$ & $-10,00 \%$ & $-9,03 \%$ & $-3,96 \%$ & $38,46 \%$ & $18,33 \%$ & $4,69 \%$ & $-23,77 \%$ & $-2,88 \%$ \\
\hline \begin{tabular}{|l|} 
VAGV4 \\
\end{tabular} & Savarg PN & 0,89 & \begin{tabular}{|l|} 
Low \\
\end{tabular} & 375.811 .200 & \begin{tabular}{|l|l|} 
Big \\
\end{tabular} & 0,30 & \begin{tabular}{|l|} 
Loser \\
\end{tabular} & \begin{tabular}{|l|} 
Big|Low|Loser \\
\end{tabular} & - & \begin{tabular}{|l|}
$-10,20 \%$ \\
\end{tabular} & $20,45 \%$ & $-13,21 \%$ & $28,26 \%$ & $0,00 \%$ & \begin{tabular}{|l|l|}
$-8,47 \%$ \\
\end{tabular} & $\begin{array}{l}3,410 \% \\
1,11 \% \\
\end{array}$ & 13,55\% & $-42,90 \%$ & $-11,45 \%$ & $\begin{array}{l}-5,01 \% \\
-5,91 \% \\
\end{array}$ \\
\hline LAME3 & Lojas Americ ON & 0,77 & Low & \begin{tabular}{|c|}
678.149 .015 \\
\end{tabular} & Big & 0,23 & Loser & Big|Low|Loser & $0,33 \%$ & $-15,31 \%$ & $3,85 \%$ & $-25,93 \%$ & \begin{tabular}{|l|}
$-35,00 \%$ \\
\end{tabular} & $5,38 \%$ & $\mid-40,88 \%$ & $60,25 \%$ & $4,78 \%$ & $47,06 \%$ & $-5,00 \%$ & $-16,95 \%$ \\
\hline LAME4 & Lojas Americ PN & 0,77 & Low & \begin{tabular}{|l|}
678.149 .015 \\
\end{tabular} & Big & 0,20 & Loser & Big|Low|Loser & 4,79\% & $-5,88 \%$ & $-5,56 \%$ & $-33,82 \%$ & \begin{tabular}{|l|}
$-12,78 \%$ \\
\end{tabular} & $-33,76 \%$ & \begin{tabular}{|l|}
$-15,19 \%$ \\
\end{tabular} & $61,00 \%$ & $-1,41 \%$ & $30,00 \%$ & $-17,58 \%$ & $-14,27 \%$ \\
\hline CPSL3 & Copesul ON & 0,97 & Low & \begin{tabular}{|c|}
645.933 .853 \\
\end{tabular} & Big & 0,17 & Loser & Big|Low|Loser & $26,68 \%$ & $1,71 \%$ & $-6,60 \%$ & $-15,54 \%$ & $2,53 \%$ & $-1,73 \%$ & $-5,43 \%$ & $7,50 \%$ & $19,59 \%$ & $-1,13 \%$ & $-10,47 \%$ & $5,19 \%$ \\
\hline VSMA3 & s Gobain Vidro ON & 0,78 & $\begin{array}{l}\text { Low } \\
\end{array}$ & \begin{tabular}{|l|}
629.509 .326 \\
\end{tabular} & \begin{tabular}{|l|} 
Big \\
\end{tabular} & 0,13 & \begin{tabular}{|l|} 
Loser \\
\end{tabular} & Big|Low|Loser & \begin{tabular}{|l|l|}
$4,04 \%$ \\
\end{tabular} & \begin{tabular}{|l|l|}
$-17,48 \%$ \\
\end{tabular} & $0,78 \%$ & \begin{tabular}{|l|l|}
$-16,73 \%$ \\
\end{tabular} & 0,00\% & $-0,93 \%$ & \begin{tabular}{|l|}
$-10,38 \%$ \\
\end{tabular} & $-1,21 \%$ & $13,14 \%$ & $7,34 \%$ & $0,00 \%$ & $0,00 \%$ \\
\hline REPA4 & Electrolux PN & 0,95 & Low & 282.193 .381 & Big & 0,11 & Loser & Big|Low|Loser & $-4,68 \%$ & $-14,11 \%$ & $2,86 \%$ & $-11,11 \%$ & $58,59 \%$ & $0,00 \%$ & $0,00 \%$ & $0,00 \%$ & $0,00 \%$ & $-0,36 \%$ & $0,00 \%$ & $0,00 \%$ \\
\hline CTNM3 & Coteminas ON & 0,79 & Low & 740.518 .150 & Big & 0,07 & Loser & Big|Low|Loser & $-8,02 \%$ & $12,15 \%$ & $-8,33 \%$ & $21,22 \%$ & $0,00 \%$ & $-7,50 \%$ & \begin{tabular}{|l|}
$-26,22 \%$ \\
\end{tabular} & $2,57 \%$ & $5,36 \%$ & $0,00 \%$ & $6,71 \%$ & $1,61 \%$ \\
\hline \begin{tabular}{|l|} 
BMTO4 \\
\end{tabular} & Brasmotor PN & 0,82 & Low & \begin{tabular}{|c|}
674.710 .629 \\
\end{tabular} & Big & 0,01 & Loser & Big|Low|Loser & $-8,85 \%$ & $-3,51 \%$ & $3,41 \%$ & $-27,24 \%$ & $-20,00 \%$ & $-11,29 \%$ & $-5,65 \%$ & $17,82 \%$ & $39,50 \%$ & $-4,52 \%$ & $-26,18 \%$ & $-9,40 \%$ \\
\hline CTNM4 & Coteminas PN & 0,79 & Low & \begin{tabular}{|l|l}
740.518 .150 \\
\end{tabular} & Big & 0,06 & Loser & Big|Low|Loser & $-2,86 \%$ & $-1,96 \%$ & $5,01 \%$ & $-2,41 \%$ & $-2,42 \%$ & $0,00 \%$ & $-36,40 \%$ & $13,99 \%$ & $-1,33 \%$ & $-2,15 \%$ & $-29,22 \%$ & $-10,26 \%$ \\
\hline WEGE4 & Weg PN & 0,82 & Low & \begin{tabular}{|l|l|}
486.527 .066 \\
\end{tabular} & Big & 0,06 & Loser & Big|Low|Loser & $2,42 \%$ & $18,69 \%$ & $-6,51 \%$ & $-9,64 \%$ & $-9,33 \%$ & $0,00 \%$ & $-0,76 \%$ & $3,08 \%$ & $11,94 \%$ & $13,33 \%$ & $0,00 \%$ & $-11,76 \%$ \\
\hline WHRL4 & Whirlpool PN & 0,57 & Low & \begin{tabular}{|l|}
1.222 .409 .716 \\
\end{tabular} & Big & 0,13 & Loser & Big|Low|Loser & $-9,68 \%$ & $-13,27 \%$ & $7,06 \%$ & $-35,16 \%$ & $-22,03 \%$ & $2,17 \%$ & $-7,88 \%$ & $16,67 \%$ & $32,65 \%$ & $16,92 \%$ & $-35,53 \%$ & $-4,08 \%$ \\
\hline ITSA3 & Itausa C & 1,02 & Low & 2.947 .983 .565 & Big & 0,19 & Loser & Big|Low|Loser & $3,33 \%$ & $0,78 \%$ & $7,78 \%$ & $-27,00 \%$ & $-9,59 \%$ & $4,90 \%$ & $2,90 \%$ & $0,00 \%$ & $32,57 \%$ & $-1,10 \%$ & $-2,22 \%$ & $-22,46 \%$ \\
\hline AMBV4 & Ambev PN & 0,30 & \begin{tabular}{|l|l|} 
Low \\
\end{tabular} & 5.963 .075 .795 & \begin{tabular}{|l|l} 
Big \\
\end{tabular} & 0,24 & \begin{tabular}{|l|} 
Loser \\
\end{tabular} & Big|Low|Loser & $0,00 \%$ & $-10,73 \%$ & $16,37 \%$ & $-18,05 \%$ & 6,52\% & $2,04 \%$ & $2,67 \%$ & $\begin{array}{ll}, 0,39 \% \\
\end{array}$ & $3,65 \%$ & $-14,42 \%$ & $-10,07 \%$ & $7,46 \%$ \\
\hline \begin{tabular}{|l|} 
AMBVV \\
\end{tabular} & Ambev ON & 0,30 & \begin{tabular}{|l} 
Low \\
\end{tabular} & 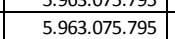 & \begin{tabular}{|l|} 
Big \\
Big
\end{tabular} & $\begin{array}{l}0,24 \\
0,24 \\
\end{array}$ & \begin{tabular}{|l} 
Loserer \\
\end{tabular} & \begin{tabular}{|l} 
Big |Low/Loser \\
\end{tabular} & $\begin{array}{c}-0,04 \% \\
-0,24 \% \\
\end{array}$ & $\mid-7,32 \%$ & $\begin{array}{l}70,370 \% \\
7,09 \% \\
\end{array}$ & \begin{tabular}{|c|}
$-1,0,0 \%$ \\
$-7,83 \%$ \\
\end{tabular} & $\mid$ & $\begin{array}{l}, 047 \% \\
0,72 \%\end{array}$ & $\begin{array}{l}, 0,47 \% \\
\end{array}$ & $\begin{array}{l}2,30 \% \\
2,70 \% \\
\end{array}$ & \begin{tabular}{|l}
$, 0,26 \%$ \\
\end{tabular} & | & $\mid$ & $\begin{array}{l}-4,408 \% \\
-4,48 \% \\
\end{array}$ \\
\hline ITSA4 & Itausa PN & 1,02 & Low & 2.947.983.565 & Big & 0,25 & Loser & Big|Low|Loser & $6,06 \%$ & $-4,05 \%$ & $4,26 \%$ & $-27,88 \%$ & $-4,00 \%$ & $21,22 \%$ & $-19,54 \%$ & $11,43 \%$ & $30,74 \%$ & $-2,02 \%$ & $-12,37 \%$ & $-13,85 \%$ \\
\hline PTIP4 & Ipiranga Pet PN & 0,85 & Low & 927.432 .737 & Big & 0,25 & Loser & \begin{tabular}{|l} 
Big|Low/Loser \\
\end{tabular} & $31,33 \%$ & - $21,87 \%$ & $0,57 \%$ & $\begin{array}{l}\frac{2,000 \%}{-9,09 \%} \\
\end{array}$ & $-13,75 \%$ & $28,27 \%$ & - & - & $\mid$ & $-8,02 \%$ & $-12,82 \%$ & $-18,71 \%$ \\
\hline ICPI4 & cim Itau PN & 0,74 & Low & \begin{tabular}{|l|}
841.678 .902 \\
\end{tabular} & Big & 0,33 & Winner & Big|Low /Winner & $-4,06 \%$ & $-1,41 \%$ & $-4,29 \%$ & $-15,52 \%$ & $-28,98 \%$ & $6,97 \%$ & $-11,63 \%$ & $34,74 \%$ & $4,69 \%$ & $-2,99 \%$ & $-15,57 \%$ & $-2,33 \%$ \\
\hline GLOB4 & Globex PN & 0,38 & \begin{tabular}{|l|l|} 
Low \\
\end{tabular} & 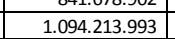 & \begin{tabular}{|l} 
Big \\
\end{tabular} & 0,33 & Winner & \begin{tabular}{|l} 
Big|Low|Winner \\
\end{tabular} & \begin{tabular}{|c|}
$-43,506 \%$ \\
$-23,5$
\end{tabular} & $0,00 \%$ & $\begin{array}{l}-2,29 \% \\
1,92 \% \\
\end{array}$ & \begin{tabular}{|l|}
$-9,43 \%$ \\
$-9,40$
\end{tabular} & | & $\begin{array}{l}, 3,33 \% \\
-13 \%\end{array}$ & $\mid$ & $22,54 \%$ & |4,05\% & | & \begin{tabular}{|l|}
$-18,18 \%$ \\
\end{tabular} & 11,11\% \\
\hline PRGA4 & BRF Foods PN & 0,92 & Low & \begin{tabular}{|l|l}
567.919 .746 \\
\end{tabular} & Big & 0,35 & Winner & Big|Low|Winner & $-3,14 \%$ & $-8,65 \%$ & $0,45 \%$ & $-13,33 \%$ & $-7,69 \%$ & $-18,89 \%$ & $-4,11 \%$ & $28,57 \%$ & $4,75 \%$ & $2,70 \%$ & \begin{tabular}{|l|}
$-23,68 \%$ \\
\end{tabular} & $0,00 \%$ \\
\hline PCAR4 & P.Acucar-Cbd PN & 0,44 & Low & 1.913.845.012 & Big & 0,36 & Winner & \begin{tabular}{|l|l|} 
Big Low Winner \\
\end{tabular} & $-3,27 \%$ & $-2,95 \%$ & $11,52 \%$ & $-18,13 \%$ & $-21.43 \%$ & $23,64 \%$ & $-1,96 \%$ & $28.55 \%$ & $191 \%$ & $1971 \%$ & $-12,40 \%$ & $-3,63 \%$ \\
\hline PTIP3 & Ipiranga Pet ON & 0,85 & Low & \begin{tabular}{|l|l}
927.432 .737 \\
\end{tabular} & Big & 0,39 & Winner & ig|Low|Winner & $16,96 \%$ & $-12,50 \%$ & $-2,86 \%$ & $0,00 \%$ & $-11,76 \%$ & $7,84 \%$ & $-0,64 \%$ & $-2,44 \%$ & $6,67 \%$ & $0,00 \%$ & $-3,13 \%$ & $-16,13 \%$ \\
\hline LIGT3 & Light S/A ON & $0,0,62$ & \begin{tabular}{|l|l|} 
Low \\
\end{tabular} & \begin{tabular}{|l|}
5.566 .792 .5358 \\
\end{tabular} & \begin{tabular}{|l} 
Big \\
\end{tabular} & $\begin{array}{l}0,37 \\
0,41\end{array}$ & Winner & \begin{tabular}{|l}
$\mid$ Big|Low|Winner \\
\end{tabular} & \begin{tabular}{|c|}
$\mid$ \\
$9,11 \%$
\end{tabular} & $\begin{array}{l}-1,50,70 \% \\
-28,0\end{array}$ & $\begin{array}{l}-2,000 \% \\
14,39 \% \\
\end{array}$ & \begin{tabular}{|r|}
$-21,96 \%$ \\
-260
\end{tabular} & $\mid$ & $2,19 \%$ & \begin{tabular}{|l|l|}
$-4,0408 \%$ \\
$-4,68 \%$
\end{tabular} & $-1,14 \%$ & $\begin{array}{l}0,00 \% \\
0,00 \%\end{array}$ & 9,35\% & \begin{tabular}{|l|}
$-11,96 \%$ \\
\end{tabular} & $-12,35 \%$ \\
\hline FFTL4 & Valefert PN & 1,03 & Low & \begin{tabular}{l|}
654.852 .402 \\
\end{tabular} & Big & 0,42 & Winner & Big|Low|Winner & $13,72 \%$ & $-12,28 \%$ & $-3,64 \%$ & $-16,98 \%$ & $-6,82 \%$ & $14,39 \%$ & $5,56 \%$ & $-1,19 \%$ & $23,37 \%$ & $3,52 \%$ & \begin{tabular}{|l|}
$-14,15 \%$ \\
\end{tabular} & $5,45 \%$ \\
\hline CRUZ3 & Souza Cruz ON & 0,54 & Low & 3.469 .582 .752 & Big & 0,43 & Winner & Big|Low|Winner & $-8,72 \%$ & $3,48 \%$ & $1,55 \%$ & $-14,16 \%$ & $-4,68 \%$ & $5,26 \%$ & $-3,11 \%$ & $12,96 \%$ & $1,64 \%$ & $-1,37 \%$ & $-15,51 \%$ & $8,86 \%$ \\
\hline \begin{tabular}{|l|} 
WHMT3 \\
\end{tabular} & White Martins on & 0,45 & Low & 3.150 .000 .095 & Big & 0,49 & Winner & Big|Low|Winner & $-5,23 \%$ & $-14,81 \%$ & $0,79 \%$ & $-26,96 \%$ & $-18,92 \%$ & $8,67 \%$ & $-6,13 \%$ & $5,88 \%$ & $10,60 \%$ & $-6,74 \%$ & $-31,33 \%$ & $-6,14 \%$ \\
\hline CBEE3 & Ampla Energ ON & 0,27 & Low & 289.822 & Big & 0,52 & Winner & g|Low|Winner & $8,97 \%$ & $-16,47 \%$ & $16,90 \%$ & $-16,87 \%$ & $-2,90 \%$ & $7,46 \%$ & $-19,44 \%$ & $15,52 \%$ & $17,91 \%$ & $5,06 \%$ & $-15,66 \%$ & $-18,57 \%$ \\
\hline \begin{tabular}{|l|} 
BRTO4 \\
\end{tabular} & Brasil Telec PN & 0,99 & Low & 2.245 .593 .180 & Big & 0,63 & Winner & Big|Low|Winner & $7,50 \%$ & $-6,98 \%$ & $1,25 \%$ & $-29,01 \%$ & $-12,17 \%$ & $18,81 \%$ & $-28,34 \%$ & $19,77 \%$ & $34,84 \%$ & $-2,53 \%$ & $-5,29 \%$ & $-28,40 \%$ \\
\hline MFLU3 & Santista Alimentos ON & 0,99 & Low & 708.554 .085 & Big & 0,65 & Winner & Big|Low|Winner & $-4,35 \%$ & $6,82 \%$ & $0,00 \%$ & $-4,26 \%$ & $-15,56 \%$ & $-18,42 \%$ & $-16,13 \%$ & $-4,62 \%$ & $-3,23 \%$ & $-20,00 \%$ & $-6,25 \%$ & $-11,11 \%$ \\
\hline EMBR4 & Embraer PN & 0,34 & Low & 644.003 .203 & Big & 0,66 & Winner & Big|Low|Winner & $-14,55 \%$ & $-4,79 \%$ & $-10,61 \%$ & $-6,88 \%$ & $-22,82 \%$ & $47,83 \%$ & $-11,76 \%$ & $13,27 \%$ & $8,89 \%$ & $8,11 \%$ & $-7,50 \%$ & $10,81 \%$ \\
\hline TMAR3 & Telem & 0,74 & Low & 64.535 .931 & Big & 0,67 & Winner & ow/Win & $4,41 \%$ & $-21,69 \%$ & $11,54 \%$ & $-30,34 \%$ & $5,94 \%$ & $-8,41 \%$ & $19,39 \%$ & $4,27 \%$ & $0,82 \%$ & $-6,50 \%$ & $1,38 \%$ & $-30,15 \%$ \\
\hline \begin{tabular}{|l|l|l} 
BRTO3 \\
\end{tabular} & Brasil Telec ON & 0,99 & Low & \begin{tabular}{|l|}
2.245 .593 .180 \\
\end{tabular} & Big & 0,68 & Winner & \begin{tabular}{|l|} 
Big|Low|Winner \\
\end{tabular} & $2,78 \%$ & $-5,68 \%$ & $\begin{array}{l}-1,86 \% \\
-1,860 \\
\end{array}$ & $-15,33 \%$ & $-29,31 \%$ & $15,85 \%$ & $-24,21 \%$ & $2,78 \%$ & $31,89 \%$ & $-14,96 \%$ & $-12,57 \%$ & $-28,37 \%$ \\
\hline TMAR6 & Telemar N L PNB & 0,74 & Low & 4.264 .535 .931 & Big & 0,75 & Winner & Big|Low|Winner & $3,92 \%$ & $-14,78 \%$ & $2,72 \%$ & $-30,46 \%$ & $11,43 \%$ & $-0,85 \%$ & $20,60 \%$ & $11,51 \%$ & $8,77 \%$ & $12,36 \%$ & $1,18 \%$ & $-9,38 \%$ \\
\hline TMGR6 & Telemig PNB & 0,59 & Low & \begin{tabular}{|l|}
4.422 .114 .453 \\
\end{tabular} & Big & 0,77 & Winner & \begin{tabular}{|l|} 
Big Low /Winner \\
\end{tabular} & $-4,20 \%$ & $-6,85 \%$ & $-5,00 \%$ & $-14,55 \%$ & $\mid-5,80 \%$ & $8,46 \%$ & $-16,32 \%$ & $26,71 \%$ & $25,08 \%$ & $-3,03 \%$ & $4,48 \%$ & $-30,61 \%$ \\
\hline \begin{tabular}{|l|l|} 
PIPN4 \\
\end{tabular} & Pirelli Pneus PN & 0.84 & Low & 412.097 .848 & Big & 0.88 & Winner & \begin{tabular}{|l|} 
BiglLow|Winner \\
\end{tabular} & $26,27 \%$ & $7,77 \%$ & $23.26 \%$ & $15.09 \%$ & $-39,63 \%$ & $1303 \%$ & $-9,19 \%$ & $8.95 \%$ & $14,74 \%$ & $3,51 \%$ & $-13,56 \%$ & $-1.96 \%$ \\
\hline
\end{tabular}


Anexo 1 - Retorno mensal e classificação das ações

\begin{tabular}{|c|c|c|c|c|c|c|c|c|c|c|c|c|c|c|c|c|c|c|c|c|}
\hline Código & $1997-1998$ & $\begin{array}{l}\text { Índice } B / M \\
\text { de dez/1996 }\end{array}$ & $\begin{array}{c}\text { Grupo com } \\
\text { base no } \\
\text { indice B/M }\end{array}$ & \begin{tabular}{|c|} 
Valor de Mercado \\
em jun/1997
\end{tabular} & $\begin{array}{c}\text { Grupo com } \\
\text { base no } \\
\text { tamanho }\end{array}$ & \begin{tabular}{|c|} 
Retorno \\
acumulado \\
de jun/1997 \\
\end{tabular} & \begin{tabular}{|l|} 
Grupo com \\
base no \\
retorno \\
acumulado
\end{tabular} & Carteiras & jul/97 & ago/97 & set/97 & out $/ 97$ & nov/97 & $\operatorname{dez} / 97$ & $\mathrm{jan} / 98$ & $\mathrm{fev} / 98$ & $\mathrm{mar} / 98$ & $a b r / 98$ & mai/98 & jun/98 \\
\hline TMGR3 & Telemig ON & 0,59 & Low & \begin{tabular}{|l|l}
4.422 .114 .453 \\
\end{tabular} & Big & 0,89 & Winner & \begin{tabular}{|l} 
Big|Low|Winner \\
\end{tabular} & $3,21 \%$ & $-10,48 \%$ & $0,00 \%$ & $-10,58 \%$ & $-22,70 \%$ & $-6,39 \%$ & $-14,54 \%$ & $11,69 \%$ & $25,71 \%$ & $-5,32 \%$ & $-29,19 \%$ & $-25,45 \%$ \\
\hline PALF3 & Paul F Luz ON & 0,75 & Low & \begin{tabular}{|c|}
3.491 .966 .326 \\
\end{tabular} & Big & 1,40 & Winner & Big|Low|Winner & $22,10 \%$ & $-14,93 \%$ & $5,32 \%$ & $-18,44 \%$ & $-13,31 \%$ & $5,00 \%$ & $-1,36 \%$ & $-6,86 \%$ & $14,77 \%$ & $1,94 \%$ & $-26,90 \%$ & $2,17 \%$ \\
\hline LOAR4 & Lojas Arapua PN & 0,51 & Low & 532.282 .960 & Big & 1,42 & Winner & Big|Low|Winner & $-20,57 \%$ & $-33,09 \%$ & $24,19 \%$ & $-42,86 \%$ & $-31,82 \%$ & $-11,11 \%$ & $27,75 \%$ & $0,35 \%$ & $31,03 \%$ & $-15,79 \%$ & $-78,44 \%$ & $5,80 \%$ \\
\hline TBCP4 & Tel B Campo PN & 1,04 & Low & \begin{tabular}{|l|}
1.084 .703 .199 \\
\end{tabular} & Big & 1,87 & Winner & Big|Low/Winner & $-8,32 \%$ & $-26,36 \%$ & $18,27 \%$ & $4,38 \%$ & $-2,22 \%$ & $-16,55 \%$ & $-24,02 \%$ & $-2,90 \%$ & $42,02 \%$ & $2,72 \%$ & $-33,01 \%$ & $15,11 \%$ \\
\hline PALF5 & Paul F Luz PNA & 0,75 & Low & \begin{tabular}{|c|}
3.491 .966 .326 \\
\end{tabular} & Big & 2,16 & Winner & Big|Low|Winner & $8,43 \%$ & $-9,27 \%$ & $-0,57 \%$ & $-13,14 \%$ & $-24,34 \%$ & $0,00 \%$ & $-4,35 \%$ & $-5,45 \%$ & $13,56 \%$ & $13,55 \%$ & $-17,96 \%$ & $-3,65 \%$ \\
\hline ERIC4 & Ericsson PN & 0,60 & Low & \begin{tabular}{|l|l|}
2.583 .874 .014 \\
\end{tabular} & Big & 2,53 & Winner & Big|Low|Winner & $2,34 \%$ & $-17,86 \%$ & $-1,38 \%$ & $-38,75 \%$ & $20,00 \%$ & $-8,21 \%$ & $0,56 \%$ & $5,83 \%$ & $-3,41 \%$ & $0,50 \%$ & $-33,29 \%$ & $-5,78 \%$ \\
\hline PIRE3 & Pirelli ON & 0,67 & Low & 880.485 .474 & Big & 3,07 & Winner & Big|Low|Winner & $-6,48 \%$ & $-1,10 \%$ & $-1,27 \%$ & $-17,74 \%$ & $-12,48 \%$ & $-18,73 \%$ & $-5,71 \%$ & $-3,33 \%$ & $0,64 \%$ & $3,33 \%$ & $-0,97 \%$ & $3,91 \%$ \\
\hline PIRE4 & Pirelli PN & 0,67 & Low & 880.485 .474 & Big & 3,18 & Winner & Big|Low|Winner & \begin{tabular}{|l|}
$-11,54 \%$ \\
\end{tabular} & $-14,49 \%$ & $-8,47 \%$ & $-10,74 \%$ & $3,11 \%$ & $-3,38 \%$ & $-13,98 \%$ & $-1,25 \%$ & $12,84 \%$ & $-3,53 \%$ & $-9,76 \%$ & $3,78 \%$ \\
\hline COCE5 & Coelce PNA & 1,06 & Low & \begin{tabular}{|l|l|l}
787.707 .946 \\
\end{tabular} & Big & 7,53 & Winner & Big|Low|Winner & $17,99 \%$ & $-16,39 \%$ & $4,90 \%$ & $-25,23 \%$ & $-5,25 \%$ & $0,26 \%$ & $-11,84 \%$ & $16,42 \%$ & $5,13 \%$ & $30,63 \%$ & $-28,02 \%$ & $10,81 \%$ \\
\hline SUZB5 & Suzano Papel PNA & 2,41 & Medium & \begin{tabular}{|l|l|l}
633.167 .379 \\
\end{tabular} & Big & 0,32 & Loser & Big|Medium|Loser & $17,96 \%$ & $-5,07 \%$ & $-8,49 \%$ & $-17,87 \%$ & $-20,50 \%$ & $5,26 \%$ & $-17,50 \%$ & $12,12 \%$ & $-8,11 \%$ & $2,35 \%$ & $-14,37 \%$ & $-20,81 \%$ \\
\hline BRDT4 & Petrobras Distrib PN & 1,63 & Medium & \begin{tabular}{|l|l}
1.213 .919 .384 \\
\end{tabular} & Big & 0,00 & Loser & Big|Medium|Loser & $27,05 \%$ & $-21,54 \%$ & $-0,04 \%$ & $-28,93 \%$ & $-19,10 \%$ & $21,12 \%$ & $-2,56 \%$ & $4,21 \%$ & $7,53 \%$ & $0,25 \%$ & $-21,18 \%$ & $0,12 \%$ \\
\hline USIM3 & Usiminas & 1,26 & Medium & \begin{tabular}{|l|}
2.315 .181 .677 \\
\end{tabular} & Big & 0,02 & Loser & Big|Medium|Loser & $19,89 \%$ & $-8,80 \%$ & $-8,83 \%$ & $-13,28 \%$ & $-13,45 \%$ & $46,15 \%$ & $3,33 \%$ & $-14,84 \%$ & $1,01 \%$ & $-16,25 \%$ & $-3,43 \%$ & $-5,72 \%$ \\
\hline KLBN4 & Klabin & 1,44 & Medium & 878.521 .834 & Big & 0,03 & Loser & Big|Medium|Loser & $16,19 \%$ & $-19,67 \%$ & $-1,02 \%$ & $-12,00 \%$ & $-29,41 \%$ & $-15,00 \%$ & $-13,73 \%$ & $9,09 \%$ & $70,83 \%$ & $-11,81 \%$ & $16,67 \%$ & $-20,00 \%$ \\
\hline ANTA3 & Antarctica Paulis & 1,12 & Medium & \begin{tabular}{|l|l}
1.313 .627 .350 \\
\end{tabular} & Big & 0,08 & Loser & Big|Medium|Loser & $-9,09 \%$ & $-2,37 \%$ & $-1,03 \%$ & $0,00 \%$ & $-3,14 \%$ & $-24,72 \%$ & $0,00 \%$ & $21,41 \%$ & $-5,87 \%$ & $-3,32 \%$ & $-6,42 \%$ & $-14,29 \%$ \\
\hline ARCZ6 & Aracruz PNB & 1,34 & Medium & \begin{tabular}{|l|l}
1.891 .113 .580 \\
\end{tabular} & Big & 0,12 & Loser & Big|Medium|Loser & $2,75 \%$ & $-0,89 \%$ & $0,90 \%$ & $-24,55 \%$ & $-6,51 \%$ & $-2,53 \%$ & $2,60 \%$ & $0,63 \%$ & $10,06 \%$ & $2,49 \%$ & $-12,43 \%$ & $-16,13 \%$ \\
\hline VALE3 & Vale ON & 1,10 & Medium & \begin{tabular}{|l|l}
8.947 .633 .873 \\
\end{tabular} & Big & 0,15 & Loser & Big|Medium|Loser & $14,98 \%$ & $-7,81 \%$ & $2,82 \%$ & $-17,65 \%$ & $0,00 \%$ & $0,48 \%$ & $-2,84 \%$ & $6,83 \%$ & $14,61 \%$ & $3,78 \%$ & $-14,80 \%$ & $-3,76 \%$ \\
\hline INEP4 & & 1,46 & Medi & & Big & 0,20 & Loser & $\mathrm{m}$ |Loser & $-3,20 \%$ & $-9,09 \%$ & $-0,91 \%$ & $-14,22 \%$ & $-29,95 \%$ & $-5,34 \%$ & $7,26 \%$ & $-0,75 \%$ & $31,82 \%$ & $15,52 \%$ & $-29,46 \%$ & $9,42 \%$ \\
\hline USIM5 & Usiminas PNA & 1,26 & Medium & \begin{tabular}{|l|l|}
2.315 .181 .677 \\
\end{tabular} & Big & 0,22 & Loser & \begin{tabular}{|l|} 
Big|Medium|Loser \\
\end{tabular} & $5,42 \%$ & $-12,18 \%$ & $11,25 \%$ & $-33,17 \%$ & $-11,87 \%$ & $-6,38 \%$ & $8,36 \%$ & $15,73 \%$ & $21,45 \%$ & $-18,48 \%$ & $-15,87 \%$ & $-6,50 \%$ \\
\hline DURA4 & Duratex-Old PN & 1,71 & \begin{tabular}{|l|} 
Medium \\
\end{tabular} & \begin{tabular}{|l|}
509.241 .566 \\
\end{tabular} & Big & 0,23 & Loser & Big|Medium|Loser & $0,89 \%$ & $7,57 \%$ & $9,02 \%$ & $-9,77 \%$ & $-33,00 \%$ & $9,45 \%$ & $-15,68 \%$ & $15,52 \%$ & $33,33 \%$ & $-12,50 \%$ & $-8,18 \%$ & $0,02 \%$ \\
\hline SDIA4 & Sadia S/A PN & 1,11 & Medium & \begin{tabular}{|l|}
707.079 .523 \\
\end{tabular} & Big & 0,32 & Winner & Big|Medium|Winner & $12,50 \%$ & $-16,14 \%$ & $4,81 \%$ & $-26,61 \%$ & $-5,00 \%$ & $-3,95 \%$ & $-12,33 \%$ & $15,77 \%$ & $16,67 \%$ & $-3,57 \%$ & $-9,88 \%$ & $-1,37 \%$ \\
\hline VALE5 & Vale PNA & 1,10 & Medium & \begin{tabular}{|l|l}
8.947 .633 .873 \\
\end{tabular} & Big & 0,33 & Winner & Big|Medium/Winner & $20,64 \%$ & $-10,56 \%$ & $5,47 \%$ & $-20,49 \%$ & $-8,45 \%$ & $15,13 \%$ & $-3,34 \%$ & $13,36 \%$ & $10,98 \%$ & $2,77 \%$ & $11,48 \%$ & $-3,77 \%$ \\
\hline SAMI4 & Samitri & 1,82 & Medium & & Big & 0,47 & Winner & Winner & $1,81 \%$ & $-5,31 \%$ & $15,26 \%$ & $-17,57 \%$ & $-4,92 \%$ & $0,00 \%$ & $-13,86 \%$ & $-3,92 \%$ & $41,67 \%$ & $8,05 \%$ & $-16,92 \%$ & $3,70 \%$ \\
\hline DPPI4 & Ipiranga Dis PN & 1,22 & \begin{tabular}{|l|} 
Medium \\
\end{tabular} & \begin{tabular}{l|l|}
287.999 .992 \\
\end{tabular} & Big & 0,54 & Winner & $\begin{array}{l}\text { Big|Medium/Winner } \\
\end{array}$ & $35,25 \%$ & $-19,15 \%$ & $-5,79 \%$ & $3,91 \%$ & $-22,04 \%$ & $6,27 \%$ & $-3,51 \%$ & $1,49 \%$ & $21,34 \%$ & $-3,53 \%$ & $-17,68 \%$ & $-7,41 \%$ \\
\hline ODBE4 & Odebrecht PN & 2,06 & \begin{tabular}{|l|} 
Medium \\
\end{tabular} & \begin{tabular}{|l|l}
1.017 .500 .013 \\
\end{tabular} & Big & 0,55 & Winner & Big|Medium|Winner & $8,11 \%$ & $10,00 \%$ & $-9,09 \%$ & $5,00 \%$ & $-24,76 \%$ & $-5,06 \%$ & $-39,60 \%$ & $10,38 \%$ & $0,00 \%$ & $-10,00 \%$ & $0,69 \%$ & $-15,91 \%$ \\
\hline TBRS4 & Telebrasilia PN & 1,23 & Medium & 1.009.752.421 & Big & 0,56 & Winner & Big|Medium|Winner & $-5,45 \%$ & $-5,77 \%$ & $0,00 \%$ & $-3,06 \%$ & $-22,11 \%$ & $-14,83 \%$ & $-9,56 \%$ & $10,88 \%$ & $25,77 \%$ & $-5,56 \%$ & $1,19 \%$ & $-8,00 \%$ \\
\hline CSNA3 & $\operatorname{sid~N}$ & 2,02 & Medium & & Big & 0,58 & Winner & $\mathrm{m} /$ Winner & $4,83 \%$ & $2,78 \%$ & $13,49 \%$ & $-4,74 \%$ & $-25,00 \%$ & $8,61 \%$ & $-9,68 \%$ & $4,64 \%$ & $14,98 \%$ & $7,92 \%$ & $-17,60 \%$ & $-1,76 \%$ \\
\hline CPLE3 & Copel ON & 1,53 & Medi & 18.052 & Big & 0,77 & Winne & Big|Medium/Winner & $4,32 \%$ & $-22,28 \%$ & $11,87 \%$ & $-23,12 \%$ & $3,88 \%$ & $-4,87 \%$ & $-12,00 \%$ & $0,00 \%$ & $24,60 \%$ & $-1,49 \%$ & $-22,73 \%$ & $-10,78 \%$ \\
\hline CLSC6 & Celesc PNB & 1,93 & Medium & \begin{tabular}{|l|l|}
12.713 .019 \\
\end{tabular} & Big & 0,81 & Winner & Big|Medium/Winner & $0,00 \%$ & $-13,13 \%$ & $10,79 \%$ & $-22,73 \%$ & $-1,68 \%$ & $18,80 \%$ & $-26,62 \%$ & $0,98 \%$ & $32,04 \%$ & $-1,47 \%$ & $-21,52 \%$ & $-15,38 \%$ \\
\hline CMIG4 & Cemig PN & 1,80 & Medium & 8.894 & Big & 0,83 & Winner & Big|Medium/Winner & $9,91 \%$ & $-19,67 \%$ & $24,90 \%$ & $-28,10 \%$ & $21,59 \%$ & $-8,11 \%$ & $-8,43 \%$ & $9,23 \%$ & $13,81 \%$ & $0,54 \%$ & $-13,71 \%$ & $-5,26 \%$ \\
\hline PETR4 & Petrob & 1,30 & Medium & & Big & 0,91 & Winner & dium/Winner & $10,03 \%$ & $-19,15 \%$ & $17,29 \%$ & $-34,29 \%$ & $18,54 \%$ & $7,41 \%$ & $-8,05 \%$ & $6,67 \%$ & $8,28 \%$ & $7,01 \%$ & $-23,45 \%$ & $-3,15 \%$ \\
\hline TEBA3 & & 1,55 & Med & & Big & 0,92 & Win & Wir & $5,00 \%$ & $-4,76 \%$ & $-1,67 \%$ & $-15,25 \%$ & $-15,01 \%$ & $-5,89 \%$ & $-23,74 \%$ & $4,92 \%$ & $24,86 \%$ & $5,54 \%$ & $-34,63 \%$ & $41,05 \%$ \\
\hline TELB4-ol & Telebr & 1,18 & Medi & & Big & 2 & Winn & 1001 & $-1,41 \%$ & $-20,19 \%$ & $10,12 \%$ & $-22,26 \%$ & $3,64 \%$ & $11,67 \%$ & $-3,38 \%$ & $12,20 \%$ & $8,48 \%$ & $5,25 \%$ & $-12,61 \%$ & $3,11 \%$ \\
\hline ELEV3 & Eleva C & 1,92 & Medi & 864 & Big & 1,00 & Winn & $\mathrm{m} / \mathrm{Winr}$ & $3,15 \%$ & $-9,80 \%$ & $-1,45 \%$ & $-16,67 \%$ & $-12,06 \%$ & $-10,37 \%$ & $-29,10 \%$ & $31,58 \%$ & $16,80 \%$ & $-7,49 \%$ & $-18,85 \%$ & $-12,80 \%$ \\
\hline CMIG3 & Cemig & 1,80 & Medi & & Big & 1,05 & Winner & Big|Medium/Winner & $10,20 \%$ & $-17,78 \%$ & 16,6 & $-24,71 \%$ & $17,95 \%$ & $-8,34 \%$ & $-9,64 \%$ & $-3,20 \%$ & $11,85 \%$ & $6,40 \%$ & $-16,14 \%$ & $-8,07 \%$ \\
\hline TELB3-old & Telebr & 1,18 & Medi & & Big & 1,34 & Winner & $\mathrm{m} / \mathrm{Win}$ & $1,71 \%$ & $-21,21 \%$ & $8,12 \%$ & $-22,54 \%$ & $5,11 \%$ & $10,19 \%$ & $-9,25 \%$ & $8,73 \%$ & $4,92 \%$ & $-1,50 \%$ & $-14,54 \%$ & $-5,15 \%$ \\
\hline PETR3 & Petro & 1,30 & Medi & 01 & Big & 1,40 & Winr & Win & $13,80 \%$ & $-18,28 \%$ & $11,64 \%$ & $-30,88 \%$ & $9,47 \%$ & $0,00 \%$ & $0,54 \%$ & $2,15 \%$ & $8,28 \%$ & $5,39 \%$ & $-22,80 \%$ & \\
\hline CPLE5 & cor & 1,53 & 1 & & Big & 1, & Win & 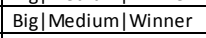 & 7,98 & $-6,40 \%$ & $2,63 \%$ & $1,03 \%$ & $-17,51 \%$ & $-7,29 \%$ & $-6,76 \%$ & $2,90 \%$ & $23,07 \%$ & $-3,61 \%$ & $-0,69 \%$ & $-37,07 \%$ \\
\hline CEEB3 & & 1,45 & $\mathrm{Mec}$ & & Big & 1, & Winner & Big|Medium/Winner & $6,06 \%$ & $-16,67 \%$ & $-9,71 \%$ & $-24,05 \%$ & $5,00 \%$ & $19,05 \%$ & $-10,67 \%$ & $9,55 \%$ & $-1,91 \%$ & $-4,30 \%$ & $-11,94 \%$ & $-20,77 \%$ \\
\hline ENER6 & Enersul $\mathrm{P}$ & 2,54 & Mediu & 50 & Big & 1,79 & Winner & Big|Medium|Winner & $2,17 \%$ & $-8,65 \%$ & $11,80 \%$ & $8,33 \%$ & $-35,90 \%$ & $0,00 \%$ & $-6,00 \%$ & $-8,51 \%$ & $53,49 \%$ & $-19,70 \%$ & $-3,77 \%$ & $1,96 \%$ \\
\hline CEEB5 & Coelba PNA & 1,45 & Medium & \begin{tabular}{|l|l}
1.243 .836 .412 \\
\end{tabular} & Big & 2,52 & Winner & Big|Medium|Winner & $-3,33 \%$ & $-5,75 \%$ & $-13,41 \%$ & $-1,55 \%$ & $-24,18 \%$ & $-3,19 \%$ & $-0,60 \%$ & $17,65 \%$ & $-5,00 \%$ & $16,76 \%$ & $-1,16 \%$ & $-28,13 \%$ \\
\hline ARTE4 & Kuala P & 2,87 & High & \begin{tabular}{l|l|}
85.190 .571 \\
\end{tabular} & Smal & 0,70 & Loser & 4 & $48,15 \%$ & $-26,25 \%$ & $1,69 \%$ & $-50,00 \%$ & $-26,67 \%$ & $-54,55 \%$ & $-10,00 \%$ & $11,11 \%$ & $100,00 \%$ & $-25,00 \%$ & $-26,67 \%$ & 0,0 \\
\hline CREM4-O & iga) PN & 4,56 & $\mathrm{Hi}$ & & $\mathrm{Sm}$ & & loser & Loser & $-1,82 \%$ & $-1,85 \%$ & 32,0 & $-17,86 \%$ & $-12,17 \%$ & $-22,77 \%$ & $0,00 \%$ & $15,51 \%$ & $-12,75 \%$ & $7,83 \%$ & $-11,45 \%$ & -16, \\
\hline ALPA4 & Alparga & & High & 69 & Small & 0,46 & Loser & Small|High|Loser & $-5,61 \%$ & $-16,26 \%$ & $0,02 \%$ & $-2,24 \%$ & $-14,41 \%$ & $-4,88 \%$ & $2,56 \%$ & $7,50 \%$ & $16,30 \%$ & $17,98 \%$ & $-3,39 \%$ & \\
\hline ROSI4 & Amadeo Rossi PN & 20,17 & High & 1.200 .000 & Small & 0,42 & Loser & Small|High|Loser & $-10,00 \%$ & $8,33 \%$ & $-30,77 \%$ & $0,00 \%$ & $-7,41 \%$ & $8,00 \%$ & $3,70 \%$ & $0,00 \%$ & $7,14 \%$ & $100,00 \%$ & $-28,33 \%$ & $-13,95 \%$ \\
\hline RPSA4 & Ripasa P & 8,64 & $\mathrm{Hig}$ & 112.387 .500 & Small & 0,36 & Loser & loser & $10,00 \%$ & $-3,64 \%$ & $-11,32 \%$ & $-23,40 \%$ & $-2,78 \%$ & $5,71 \%$ & $-18,92 \%$ & $3,33 \%$ & $9,68 \%$ & $26,47 \%$ & $-20,93 \%$ & $-11,76 \%$ \\
\hline ALPA3 & & - 12 & $\mathrm{Hic}$, & & Sma & & 10 & & $27,33 \%$ & $-9,19 \%$ & & $170 \mathrm{r}+\mathrm{d}$ & $7+2+3$ & $17-7 \mathrm{r}$ & & & & 25, & & \\
\hline MNPR4 & & 10 & High & & Sm & 0,34 & Los & & & $-5,00 \%$ & -10, & -23, & -15 , & $-9,09 \%$ & -10 & & & $14,29 \%$ & $-12,50 \%$ & 0,6 \\
\hline MYPK4 & Iochp-Maxion PN & 4,87 & High & 94 & Small & 0,34 & Loser & Small|H & \begin{tabular}{|l|}
$-14,06 \%$ \\
\end{tabular} & $-9,09 \%$ & $0,00 \%$ & $-4,50 \%$ & $-8,07 \%$ & $-16,85 \%$ & $-16,23 \%$ & $-5,15 \%$ & $46,55 \%$ & $-7,06 \%$ & $-8,86 \%$ & $-26,40 \%$ \\
\hline UNIPG & Unipar PNB & 4,18 & High & 122.018 .576 & Small & 0,33 & Loser & Small|High|Loser & $\begin{array}{l}-18,64 \% \\
\end{array}$ & $-18,75 \%$ & $2,56 \%$ & $-15,00 \%$ & $-26,47 \%$ & $-8,00 \%$ & $-4,35 \%$ & $18,18 \%$ & $15,38 \%$ & $3,23 \%$ & $-13,33 \%$ & $-3,85 \%$ \\
\hline ILMD4 & Yara Brasil PN & 3,33 & High & 071.430 & Small & 0,33 & Loser & Small|High|Loser & $11,29 \%$ & $1,74 \%$ & $-2,85 \%$ & $23 \%$ & $-26,97 \%$ & $24,07 \%$ & $5 \%$ & $-7,50 \%$ & $35,14 \%$ & $8,57 \%$ & $-11,84 \%$ & $-22,77 \%$ \\
\hline
\end{tabular}


Anexo 1 - Retorno mensal e classificação das ações

\begin{tabular}{|c|c|c|c|c|c|c|c|c|c|c|c|c|c|c|c|c|c|c|c|c|}
\hline Código & 1997 - 1998 & $\begin{array}{l}\text { Índice B/M } \\
\text { de dez/1996 }\end{array}$ & \begin{tabular}{|c|} 
Grupo com \\
baseno \\
indice B/M \\
\end{tabular} & $\begin{array}{c}\text { Valor de Mercado } \\
\text { em jun/1997 }\end{array}$ & $\begin{array}{c}\text { Grupo com } \\
\text { base no } \\
\text { tamanho }\end{array}$ & \begin{tabular}{|c|} 
Retorno \\
acumulado \\
de jun/1997
\end{tabular} & \begin{tabular}{|l|} 
Grupo com \\
base no \\
retorno \\
acumulado
\end{tabular} & Carteiras & $\mathrm{jul} / 97$ & ago/97 & set/97 & out/97 & nov/97 & dez/97 & $\mathrm{jan} / 98$ & fev/98 & $\mathrm{mar} / 98$ & $\mathrm{abr} / 98$ & $\mathrm{mai} / 98$ & jun/98 \\
\hline FGOS4 & \begin{tabular}{|l|} 
Frangosul PN \\
\end{tabular} & 6,23 & High & 47.235 .937 & Small & 0,31 & Loser & Small|High|Loser & $-1,30 \%$ & $-12,50 \%$ & $0,00 \%$ & $-7,14 \%$ & $-11,62 \%$ & $-12,97 \%$ & $0,00 \%$ & $0,00 \%$ & $5,00 \%$ & $14,29 \%$ & $-1,19 \%$ & $6,98 \%$ \\
\hline PMET6 & Pro Metalurg PNB & 11,73 & High & 8.918 .000 & Small & 0,30 & Loser & Small|High|Loser & $1,92 \%$ & $-15,09 \%$ & $-4,44 \%$ & $-25,58 \%$ & $-25,00 \%$ & $-8,33 \%$ & $-9,09 \%$ & $0,00 \%$ & $30,00 \%$ & $3,85 \%$ & $11,11 \%$ & $3,33 \%$ \\
\hline SGAS4 & WIm Ind Com PN & 8,87 & High & 19.413.555 & Small & 0,29 & Loser & Small|High|Loser & $11,11 \%$ & $14,29 \%$ & $-1,25 \%$ & $-11,39 \%$ & $-28,57 \%$ & $26,00 \%$ & $-1,59 \%$ & $29,03 \%$ & $8,75 \%$ & $-2,30 \%$ & $-14,12 \%$ & $-8,22 \%$ \\
\hline ELEK4 & Elekeiroz PN & 3,58 & High & 30.969.047 & Small & 0,21 & Loser & Small|High|Loser & $9,37 \%$ & $0,00 \%$ & $8,57 \%$ & $11,84 \%$ & $-17,65 \%$ & $2,86 \%$ & $-2,78 \%$ & $-4,29 \%$ & $-22,39 \%$ & $21,15 \%$ & $4,76 \%$ & $-27,27 \%$ \\
\hline FESA4 & Ferbasa PN & 6,36 & High & \begin{tabular}{|l|l|}
29.793 .016 \\
\end{tabular} & Small & 0,21 & Loser & Small|High|Loser & $-7,41 \%$ & $5,96 \%$ & $-5,62 \%$ & $-26,00 \%$ & $-13,51 \%$ & $-6,19 \%$ & $-2,07 \%$ & $-0,68 \%$ & $36,99 \%$ & $-7,50 \%$ & $-7,87 \%$ & $-6,06 \%$ \\
\hline TRMB4 & Trombini PN & 9,89 & High & \begin{tabular}{|l|l|}
15.102 .181 \\
\end{tabular} & Small & 0,20 & Loser & Small|High|Loser & $-12,23 \%$ & $15,15 \%$ & $10,53 \%$ & $-19,05 \%$ & $-2,35 \%$ & $1,81 \%$ & $-24,85 \%$ & $9,45 \%$ & $0,72 \%$ & $0,00 \%$ & $-7,14 \%$ & $-7,69 \%$ \\
\hline BIOB4 & Biobras PN & 2,73 & High & \begin{tabular}{|l|l|}
14.711 .112 \\
\end{tabular} & Small & 0,18 & Loser & Small|High|Loser & $-13,15 \%$ & $42,86 \%$ & $3,34 \%$ & $4,90 \%$ & $-7,75 \%$ & $20,00 \%$ & $-25,00 \%$ & $-11,11 \%$ & $8,33 \%$ & $33,19 \%$ & $-6,67 \%$ & $-7,14 \%$ \\
\hline WISA4 & Wiest PN & 3,17 & High & $\begin{array}{l}9.598 .400 \\
\end{array}$ & Small & 0,07 & Loser & Small|High|Loser & $-8,57 \%$ & $-2,34 \%$ & $-17,60 \%$ & $-4,85 \%$ & $2,04 \%$ & $-10,00 \%$ & $-22,22 \%$ & $17,14 \%$ & $-4,88 \%$ & $-10,85 \%$ & $-10,61 \%$ & $77,97 \%$ \\
\hline TIBR5 & Millennium PNA & 3,57 & High & 40.483 .376 & Small & 0,06 & Loser & Small|High|Loser & $0,00 \%$ & $11,11 \%$ & $10,00 \%$ & $-9,55 \%$ & $-9,60 \%$ & $-11,06 \%$ & $-6,38 \%$ & $-3,20 \%$ & $3,45 \%$ & $13,33 \%$ & $2,94 \%$ & $14,29 \%$ \\
\hline UCOP4 & Usin C Pinto PN & 3,31 & High & 26.323.051 & Small & 0,12 & Loser & Small|High|Loser & $-3,70 \%$ & $-33,85 \%$ & $-6,98 \%$ & $78,14 \%$ & $5,71 \%$ & $21,62 \%$ & $-11,67 \%$ & $-5,69 \%$ & $-9,97 \%$ & $-14,81 \%$ & $13,04 \%$ & $7,69 \%$ \\
\hline CABR4 & Casa Anglo PN & 3,85 & High & \begin{tabular}{|c|}
91.203 .605 \\
\end{tabular} & Small & 0,12 & Loser & Small|High|Loser & $-11,76 \%$ & $0,00 \%$ & $-0,44 \%$ & $-6,25 \%$ & $-23,81 \%$ & $75,00 \%$ & $-12,50 \%$ & $-4,08 \%$ & $-0,02 \%$ & $-2,13 \%$ & $-7,06 \%$ & $9,78 \%$ \\
\hline MNDL4 & Mundial PN & 6,32 & High & 4.113 .000 & Small & 0,14 & Loser & Small|High|Loser & $50,00 \%$ & $-33,33 \%$ & $50,00 \%$ & $-33,33 \%$ & $0,00 \%$ & $0,00 \%$ & $0,00 \%$ & $0,00 \%$ & $50,00 \%$ & $0,00 \%$ & $-33,33 \%$ & $0,00 \%$ \\
\hline SIBR7 & Sibra PNC & 5,45 & High & 30.321.986 & Small & 0,14 & Loser & Small|High|Loser & $0,00 \%$ & $20,00 \%$ & $0,00 \%$ & $-16,67 \%$ & $-20,00 \%$ & $-25,00 \%$ & $0,00 \%$ & $0,00 \%$ & $33,33 \%$ & $0,00 \%$ & $-50,00 \%$ & $50,00 \%$ \\
\hline ROMI4 & Inds Romi PN & 4,89 & High & 64.555 .201 & Small & 0,15 & Loser & Small|High|Loser & $6,82 \%$ & $10,64 \%$ & $11,54 \%$ & $1,38 \%$ & $-25,54 \%$ & $11,92 \%$ & $-0,16 \%$ & $-10,87 \%$ & $12,20 \%$ & $0,00 \%$ & $2,17 \%$ & $-10,77 \%$ \\
\hline MANM3 & Mannesmann ON & 3,81 & High & \begin{tabular}{|l|l|}
114.699 .419 \\
\end{tabular} & Small & 0,17 & Loser & Small|High|Loser & $0,00 \%$ & $19,23 \%$ & $9,68 \%$ & $1,18 \%$ & $-21,51 \%$ & $11,11 \%$ & \begin{tabular}{|l|l|}
$-0,07 \%$ \\
\end{tabular} & $-6,61 \%$ & $-4,99 \%$ & $6,77 \%$ & $-15,49 \%$ & $12,50 \%$ \\
\hline $\begin{array}{lll}\text { LEVE4 } & \\
\end{array}$ & Metal Leve PN & 3,21 & High & 53.730.381 & Small & 0,17 & Loser & Small|High|Loser & $0,00 \%$ & $-6,60 \%$ & $-9,09 \%$ & $-11,11 \%$ & $-18,75 \%$ & $-10,77 \%$ & $6,90 \%$ & $-14,52 \%$ & $24,53 \%$ & $66,77 \%$ & $-6,54 \%$ & $-27,00 \%$ \\
\hline MANM4 & Mannesmann PN & 3,81 & High & \begin{tabular}{|c|}
114.699 .419 \\
\end{tabular} & Small & 0,18 & Loser & Small|High|Loser & $-6,47 \%$ & $19,23 \%$ & $19,35 \%$ & $0,00 \%$ & $-5,41 \%$ & $-20,00 \%$ & \begin{tabular}{|l|l|}
$13,91 \%$ \\
\end{tabular} & $-0,93 \%$ & $-5,06 \%$ & $3,33 \%$ & $-3,23 \%$ & $-15,33 \%$ \\
\hline CMET4 & Caemi PN & 3,85 & High & 202.258.952 & Small & 0,24 & Loser & Small|High|Loser & $35,66 \%$ & $-12,86 \%$ & $1,64 \%$ & $-13,71 \%$ & $-27,10 \%$ & $2,56 \%$ & $10,00 \%$ & $11,36 \%$ & $32,14 \%$ & $35,54 \%$ & $-12,20 \%$ & $-6,97 \%$ \\
\hline LETO5 & Micheletto PNA & 3,91 & High & 4.003 .950 & Small & 0,24 & Loser & Small|High|Loser & $3,00 \%$ & $6,80 \%$ & $4,55 \%$ & $0,00 \%$ & $\begin{array}{l}-13,04 \% \\
\end{array}$ & $5,00 \%$ & $-2,86 \%$ & $2,94 \%$ & $14,29 \%$ & $-7,50 \%$ & $-3,60 \%$ & $-9,35 \%$ \\
\hline HGTX4 & Cia Hering PN & 4,70 & High & \begin{tabular}{|l|l|}
148.986 .776 \\
\end{tabular} & Small & 0,26 & Loser & Small|High|Loser & $19,20 \%$ & $10,74 \%$ & $-27,33 \%$ & $-54,73 \%$ & 4,00\% & $-23,08 \%$ & $0,00 \%$ & $0,00 \%$ & $5,00 \%$ & $14,29 \%$ & $-12,50 \%$ & $-28,57 \%$ \\
\hline TEKA4 & Teka PN & 7,97 & High & 26.084.639 & Small & 0,29 & Loser & Small|High|Loser & $8,82 \%$ & $-22,97 \%$ & $-26,32 \%$ & $-23,81 \%$ & $-21,87 \%$ & $-4,00 \%$ & $-33,33 \%$ & $18,75 \%$ & $21,05 \%$ & $4,35 \%$ & $-25,00 \%$ & $-16,67 \%$ \\
\hline FTSE4 & Ferti Serra & 4,57 & High & 43.062 .447 & Small & 0,30 & Loser & Small|High|Loser & $-21,37 \%$ & $-9,18 \%$ & $-9,91 \%$ & $-4,44 \%$ & $-34,88 \%$ & $-10,71 \%$ & $-1,00 \%$ & $31,31 \%$ & $6,92 \%$ & $13,67 \%$ & $-21,52 \%$ & $20,97 \%$ \\
\hline LUXM4 & Trevisa PN & 11,70 & High & 6.621 .438 & Small & 0,36 & Winner & Small| |High|Winner & $37,93 \%$ & $-1,50 \%$ & $-1,02 \%$ & $38,46 \%$ & $-31,85 \%$ & $-4,89 \%$ & $2,86 \%$ & $-22,22 \%$ & $7,14 \%$ & $33,33 \%$ & $-0,50 \%$ & $-19,65 \%$ \\
\hline MGEL4 & Mangels Indl PN & 5,32 & High & 27.717 .060 & Small & 0,48 & Winner & Small|High|Winner & $10,00 \%$ & $-3,03 \%$ & $-12,50 \%$ & $-25,00 \%$ & $-33,33 \%$ & $0,00 \%$ & $-14,29 \%$ & $13,33 \%$ & $25,00 \%$ & $20,00 \%$ & $-1,96 \%$ & $3,49 \%$ \\
\hline PQUN4 & Petroq Uniao PN & 4,37 & High & 219.928.269 & Small & 0,50 & Winner & Small|High|Winner & $-37,50 \%$ & $6,67 \%$ & $0,62 \%$ & $-6,83 \%$ & $-13,33 \%$ & $15,38 \%$ & $-0,67 \%$ & $-12,75 \%$ & $55,79 \%$ & $-4,08 \%$ & $-21,21 \%$ & $0,00 \%$ \\
\hline EUCA4 & Eucater & 4,61 & High & 104.767.516 & Small & 0,52 & Winner & Small|High|Winner & $11,54 \%$ & $-0,01 \%$ & $-0,68 \%$ & $-4,51 \%$ & $-5,45 \%$ & $17,69 \%$ & $0,33 \%$ & $27,04 \%$ & $28,72 \%$ & $-0,40 \%$ & $0,20 \%$ & $-8,18 \%$ \\
\hline MTSA4 & Metisa PN & 2,77 & High & 6.210 .559 & Small & 0,85 & Winner & Small|High|Winner & $17,43 \%$ & $-0,58 \%$ & $24,64 \%$ & $10,23 \%$ & $0,21 \%$ & $-11,68 \%$ & $1,19 \%$ & $11,90 \%$ & $0,00 \%$ & $21,05 \%$ & $0,00 \%$ & $-3,85 \%$ \\
\hline CPCA4 & Trikem PN & 3,89 & High & 182.531 .807 & Small & 0,85 & Winner & Small||High | Winner & $33,00 \%$ & $-4,76 \%$ & $-1,05 \%$ & $-20,48 \%$ & $-41,47 \%$ & $-5,71 \%$ & $-22,42 \%$ & $-2,34 \%$ & $36,00 \%$ & $26,47 \%$ & $-19,53 \%$ & $-4,62 \%$ \\
\hline SULT4 & Sultepa PN & 6,28 & High & 26.964.001 & Small & 3,18 & Winner & Small|High|Winner & $-3,74 \%$ & $11,65 \%$ & $86,96 \%$ & $-6,98 \%$ & $-2,50 \%$ & $15,13 \%$ & $-15,37 \%$ & $8,95 \%$ & $-5,07 \%$ & $9,16 \%$ & $-6,25 \%$ & $0,00 \%$ \\
\hline ESTR4 & Estrela PN & 0,45 & Low & 23.540 & Small & 0,27 & Loser & Small |Low |Loser & $6,45 \%$ & $-24,24 \%$ & $12,00 \%$ & $-39,29 \%$ & $-2,94 \%$ & $-3,03 \%$ & $18,75 \%$ & $-18,42 \%$ & $6,45 \%$ & $27,27 \%$ & $16,67 \%$ & $12,24 \%$ \\
\hline CHAP4 & Chapeco PN & 0,44 & Low & 18.528 .718 & Small & 0,24 & Loser & Small|Low|Loser & $18,18 \%$ & $-7,69 \%$ & $-8,33 \%$ & $0,00 \%$ & $-27,27 \%$ & $12,50 \%$ & $-22,22 \%$ & $14,29 \%$ & $25,00 \%$ & $20,00 \%$ & $-33,33 \%$ & $-12,50 \%$ \\
\hline DXTG4 & Dixie Toga PN & 0,95 & Low & 191.638 .954 & Small & 0,18 & Loser & Small|Low|Loser & $0,00 \%$ & $-13,79 \%$ & $18,00 \%$ & $-6,78 \%$ & $-27,27 \%$ & $42,50 \%$ & $-22,81 \%$ & $15,91 \%$ & $1,96 \%$ & $25,00 \%$ & $-14,78 \%$ & $-10,91 \%$ \\
\hline MAGS5 & Magnesita PNA & 1,05 & Low & \begin{tabular}{|l|l|}
184.414 .516 \\
\end{tabular} & Small & 0,09 & Loser & Small|Low|Loser & $-9,13 \%$ & $-6,70 \%$ & $4,10 \%$ & $-13,30 \%$ & $-3,41 \%$ & $4,72 \%$ & \begin{tabular}{|l|l|l|}
$0,61 \%$ \\
\end{tabular} & $-4,85 \%$ & $27,39 \%$ & $22,50 \%$ & $-14,79 \%$ & $2,45 \%$ \\
\hline TAMR4 & Tam Transp PN & 0,41 & Low & 277.807.053 & Small & 0,21 & Loser & Small|Low|Loser & $-5,88 \%$ & $1,79 \%$ & $5,26 \%$ & $0,00 \%$ & $-16,67 \%$ & $26,50 \%$ & $-5,14 \%$ & $-1,67 \%$ & $1,69 \%$ & $25,00 \%$ & $-11,27 \%$ & $14,29 \%$ \\
\hline $\begin{array}{ll}\text { LREN4 } \\
\end{array}$ & Lojas Renner PN & 0,33 & Low & 204.279 .023 & Small & 0,60 & Winner & Small| Low|Winner & $3,26 \%$ & $-17,53 \%$ & $7,42 \%$ & $-21,78 \%$ & $-16,58 \%$ & $6,22 \%$ & $-7,13 \%$ & $27,42 \%$ & $8,86 \%$ & $4,65 \%$ & $-14,44 \%$ & $-11,69 \%$ \\
\hline \begin{tabular}{|l|} 
IVIL4 \\
\end{tabular} & Coinvest PN & 0,87 & Low & 508.007 & Small & 0,74 & Winner & Small|Low|Winner & $31,94 \%$ & $-17,37 \%$ & $8,02 \%$ & $3,77 \%$ & $-5,68 \%$ & $1,20 \%$ & \begin{tabular}{|l|}
$-7,14 \%$ \\
\end{tabular} & $-1,28 \%$ & $-14,60 \%$ & $112,00 \%$ & $-3,90 \%$ & $-46,77 \%$ \\
\hline SHAP4 & Sharp PN & 0,98 & Low & 133.704 .122 & Small & 0,91 & Winner & Small|Low|Winner & $10,09 \%$ & $3,33 \%$ & $-3,23 \%$ & $-15,00 \%$ & $-19,61 \%$ & $0,00 \%$ & $-2,44 \%$ & $8,75 \%$ & $-3,45 \%$ & $-4,76 \%$ & $-35,00 \%$ & $0,00 \%$ \\
\hline FRAS4 & Fras-Le PN & 0,17 & Low & $\begin{array}{l}98.650 .398 \\
\end{array}$ & Small & 1,95 & Winner & Small|Low|Winner & $-8,29 \%$ & $-2,01 \%$ & $-2,56 \%$ & $-8,42 \%$ & \begin{tabular}{|l|}
$-25,86 \%$ \\
\end{tabular} & $-20,16 \%$ & $6,80 \%$ & $0,00 \%$ & $36,36 \%$ & $20,00 \%$ & $1,74 \%$ & $-8,57 \%$ \\
\hline CGOs6 & Celg PNB & 0,23 & Low & 279.343.912 & Small & 2,39 & Winner & Small|Low|Winner & $-19,08 \%$ & $-30,72 \%$ & $-48,45 \%$ & $30,00 \%$ & $-7,69 \%$ & $-33,33 \%$ & $-29,50 \%$ & $-0,71 \%$ & $3,57 \%$ & $3,45 \%$ & $-20,03 \%$ & $-16,63 \%$ \\
\hline SNSY5 & Sansuy PNA & 0,24 & Low & 12.153.330 & Small & 2,50 & Winner & Small| Low|Winner & $-7,94 \%$ & $-23,62 \%$ & $-4,06 \%$ & $-17,65 \%$ & $-24,57 \%$ & $13,64 \%$ & $-6,67 \%$ & $17,86 \%$ & $21,21 \%$ & $22,50 \%$ & $-13,27 \%$ & $-8,24 \%$ \\
\hline RHDS3 & M G Poliest O & 1,30 & Medic & 156.246 .201 & Small & 0,54 & Loser & Small|Medium|Loser & $-6,45 \%$ & $-20,69 \%$ & $21,74 \%$ & $-25,00 \%$ & $-28,57 \%$ & $-20,00 \%$ & $8,33 \%$ & $0,00 \%$ & $46,15 \%$ & $10,53 \%$ & $-19,05 \%$ & $-5,88 \%$ \\
\hline PLAS4 & Plascar Part PN & 2,22 & Mediu & & Small & 0,42 & Loser & Small|Medium|Loser & $26,00 \%$ & $9,52 \%$ & $1,45 \%$ & $-14,29 \%$ & $-35,67 \%$ & $10,10 \%$ & $-15,29 \%$ & $2,78 \%$ & $17,57 \%$ & $37,93 \%$ & $-23,29 \%$ & $15,45 \%$ \\
\hline RHER4 & Ren Hermann PN & 1,74 & Medium & 142.256 .469 & Small & 0,34 & Loser & Small|Medium|Loser & $-1,41 \%$ & $3,57 \%$ & $3,45 \%$ & $6,67 \%$ & $-13,13 \%$ & $-4,32 \%$ & $-12,78 \%$ & $-13,79 \%$ & $13,00 \%$ & $1,77 \%$ & $-0,48 \%$ & $9,09 \%$ \\
\hline CPFL4 & \begin{tabular}{|l|} 
Ferro Ligas PN \\
\end{tabular} & 2,08 & Medium & 38.670 .152 & Small & 0,29 & Loser & Small|Medium |Loser & $0,00 \%$ & $-25,00 \%$ & $33,33 \%$ & $0,00 \%$ & $0,00 \%$ & $0,00 \%$ & $-25,00 \%$ & $0,00 \%$ & $33,33 \%$ & $0,00 \%$ & $-50,00 \%$ & $100,00 \%$ \\
\hline RCSL4 & Recrusul PN & 2,40 & Medium & 18.719.999 & Small & 0,27 & Loser & Small|Medium|Loser & $-5,56 \%$ & $-14,12 \%$ & $6,85 \%$ & $-29,49 \%$ & $-40,00 \%$ & $12,12 \%$ & $-8,11 \%$ & $-2,65 \%$ & $10,63 \%$ & $-14,85 \%$ & $11,18 \%$ & $0,00 \%$ \\
\hline PMAM4 & Parar & 1,44 & $\mathrm{Mec}$ & 16 & $\mathrm{Sm}$ & 0,13 & Los & Small & $10,00 \%$ & $-3,64 \%$ & $4,60 \%$ & $-13,19 \%$ & $-7,79 \%$ & $12,68 \%$ & $-23,75 \%$ & $21,31 \%$ & $-16,22 \%$ & $44,35 \%$ & $-12,74 \%$ & $-14,21 \%$ \\
\hline BOBR4 & Bombril PN & 1,80 & Medium & 115.065 .609 & Small & 0 & Loser & Small|Medium|Loser & $-17,76 \%$ & - & - $-0,61 \%$ & $-4,62 \%$ & $-10,66 \%$ & $-27,71 \%$ & - $27,00 \%$ & $12,79 \%$ & $29,55 \%$ & 9, & $\mid-19,89 \%$ & 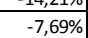 \\
\hline IBAN5 & Antarct Nordeste PNA & 1,08 & Medium & $\begin{array}{l}256.609 .556 \\
\end{array}$ & Small & 0,04 & Loser & Small|Medium|Loser & $3,75 \%$ & $-1,20 \%$ & $3,36 \%$ & $4,88 \%$ & $-3,49 \%$ & $-10,84 \%$ & $-1,35 \%$ & $0,00 \%$ & $4,11 \%$ & $5,26 \%$ & $-3,83 \%$ & $1,41 \%$ \\
\hline POLA4 & Polar PN & 1,57 & Medium & 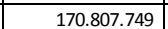 & Small & 0,08 & Loser & Small|Medium | Loser & $10,26 \%$ & $2,33 \%$ & $-2,30 \%$ & $-0,99 \%$ & $-10,00 \%$ & $5,00 \%$ & $0,53 \%$ & $0,00 \%$ & $11,58 \%$ & $6,13 \%$ & $4,31 \%$ & $0,00 \%$ \\
\hline ETER3 & Eternit ON & 1,40 & Medium & 243.925.188 & Small & 0,08 & Loser & Small|Medium|Loser & $18,57 \%$ & $0,00 \%$ & $-6,02 \%$ & $-1,54 \%$ & $-15,36 \%$ & $-4,95 \%$ & $-6,44 \%$ & $3,81 \%$ & $14,40 \%$ & $3,23 \%$ & $-3,12 \%$ & $-9,68 \%$ \\
\hline
\end{tabular}


Anexo 1 - Retorno mensal e classificação das ações

\begin{tabular}{|c|c|c|c|c|c|c|c|c|c|c|c|c|c|c|c|c|c|c|c|c|}
\hline Código & 1997 - 1998 & $\begin{array}{l}\text { Índice } B / M \\
\text { de dez/1996 }\end{array}$ & $\begin{array}{c}\text { Grupo com } \\
\text { base no } \\
\text { indice } B / M \\
\end{array}$ & $\begin{array}{c}\text { Valor de Mercado } \\
\text { em jun/1997 }\end{array}$ & $\begin{array}{c}\text { Grupo com } \\
\text { base no } \\
\text { tamanho }\end{array}$ & $\begin{array}{c}\text { Retorno } \\
\text { acumulado } \\
\text { de jun/1997 }\end{array}$ & \begin{tabular}{|c|} 
Grupo com \\
base no \\
retorno \\
acumulado \\
\end{tabular} & Carteiras & $\mathrm{jul} / 97$ & ago/97 & set/97 & out/97 & nov/97 & $\mathrm{dez} / 97$ & $\mathrm{jan} / 98$ & fev/98 & $\mathrm{mar} / 98$ & abr/98 & mai/98 & jun/98 \\
\hline RIP14 & |lpiranga Ref PN & 2,02 & Medium & 167.153 .201 & Small & 0,08 & Loser & Small|Medium|Loser & $12,21 \%$ & $-11,90 \%$ & $-5,86 \%$ & $-10,14 \%$ & $-13,21 \%$ & $4,87 \%$ & $-9,87 \%$ & $14,29 \%$ & $23,62 \%$ & $3,13 \%$ & $-11,76 \%$ & $-7,78 \%$ \\
\hline \begin{tabular}{|l|l|} 
RAPT4 \\
\end{tabular} & indon Part PN & 2,35 & Medium & 129.053.490 & Small & 0,08 & Loser & Small|Medium|Loser & $-8,14 \%$ & $-11,39 \%$ & $8,57 \%$ & $-34,21 \%$ & $-20,00 \%$ & $-10,00 \%$ & $0,00 \%$ & $11,11 \%$ & $22,50 \%$ & $22,90 \%$ & $-15,79 \%$ & $20,83 \%$ \\
\hline SAGR4 & roceres PN & 2,36 & Medium & 40.516 .255 & Small & 0,12 & Loser & Small|Medium|Loser & $5,20 \%$ & $-15,93 \%$ & $8,17 \%$ & $-9,97 \%$ & $16,24 \%$ & $-1,85 \%$ & $17,65 \%$ & $0,00 \%$ & $0,00 \%$ & $2,50 \%$ & $5,90 \%$ & $0,18 \%$ \\
\hline POMO4 & Marcopolo PN & 1,24 & Medium & 176.517.079 & Small & 0,14 & Loser & Small|Medium |Loser & $10,13 \%$ & $-10,38 \%$ & $10,53 \%$ & $-10,51 \%$ & $-20,00 \%$ & $-0,33 \%$ & $-4,55 \%$ & $38,89 \%$ & $2,86 \%$ & $19,44 \%$ & $-4,65 \%$ & $3,41 \%$ \\
\hline CTLU4 & ntinental PN & 1,31 & Medium & 99.229 .157 & Small & 0,14 & Loser & Small|Medium|Loser & $-0,69 \%$ & $-18,38 \%$ & $13,34 \%$ & $-18,37 \%$ & $-29,17 \%$ & $0,00 \%$ & $1,18 \%$ & $8,14 \%$ & $-0,85 \%$ & $-5,38 \%$ & $-29,55 \%$ & $-16,13 \%$ \\
\hline FTZA4 & tiza PN & 2,05 & Medium & 9.964 .537 & Small & 0,20 & Loser & Small|Medium|Loser & $5,36 \%$ & $-10,97 \%$ & $0,00 \%$ & $-4,00 \%$ & $-9,38 \%$ & $-3,45 \%$ & $-11,90 \%$ & $0,86 \%$ & $34,29 \%$ & $-10,64 \%$ & $0,62 \%$ & $9,52 \%$ \\
\hline RPAD6 & $\mathrm{Hol}$ & 01 & $\mathrm{~N}$ & 30 & Small & 0,21 & Loser & $\mathrm{m} \mid$ Loser & $8,88 \%$ & $1,99 \%$ & $2,44 \%$ & $-4,76 \%$ & $-15,00 \%$ & 0,00 & $-5,29$ & $4,36 \%$ & $11,25 \%$ & $16,29 \%$ & $4,35 \%$ & $-12,04 \%$ \\
\hline RPAD3 & Alfa Holding ON & 2,01 & Medium & 179.836 .730 & Small & 0,22 & Loser & Small|Medium | Loser & $4,07 \%$ & $-0,84 \%$ & $2,12 \%$ & $-4,56 \%$ & $-12,61 \%$ & $4,48 \%$ & $-4,77 \%$ & $-10,36 \%$ & $-0,58 \%$ & $48,26 \%$ & $-4,31 \%$ & $\begin{array}{ll}-9,84 \% \\
-9,40\end{array}$ \\
\hline BRGE3 & Alfa Consorc ON & 41 & Medium & .244 .669 & Small & 0,22 & Loser & Small|Medium|Loser & $1,87 \%$ & $1,20 \%$ & $1,59 \%$ & $-1,95 \%$ & $-16,33 \%$ & $0,00 \%$ & $2,86 \%$ & $-12,77 \%$ & $7,26 \%$ & $31,77 \%$ & $0,79 \%$ & $-5,88 \%$ \\
\hline BRGE12 & Alfa Consorc PNF & 1 & Medium & 44.669 & Small & 0,25 & Loser & Small| Medium | Loser & $18,98 \%$ & $-7,05 \%$ & $0,45 \%$ & $-4,44 \%$ & $-13,95 \%$ & $2,70 \%$ & $-5,26 \%$ & $1,11 \%$ & $11,76 \%$ & $13,68 \%$ & $4,63 \%$ & $-12,39 \%$ \\
\hline LITS3 & & 06 & . & & Small & 0,27 & & Small|Me & $62,78 \%$ & $-3,07 \%$ & $-7,39 \%$ & $-6,08 \%$ & $-29,15 \%$ & $22,86 \%$ & $-12,59 \%$ & $15,25 \%$ & $52,16 \%$ & $-2,06 \%$ & $15,79 \%$ & $-3,13 \%$ \\
\hline ITEC3 & Itautec ON & 2,16 & Medium & 116.265 .520 & Small & 0,29 & Loser & Small|Medium|Loser & $15,79 \%$ & $-22,73 \%$ & $9,71 \%$ & $-23,59 \%$ & $-5,26 \%$ & $-11,11 \%$ & $-16,25 \%$ & $4,48 \%$ & $-11,90 \%$ & $10,81 \%$ & $-27,32 \%$ & $14,09 \%$ \\
\hline FTA4 & Forjas Taurus PN & 2,58 & Medium & 41.558.399 & Small & 0,31 & Winner & Small|Medium|Winner & $11,11 \%$ & $-20,00 \%$ & $12,50 \%$ & $-11,11 \%$ & $4,17 \%$ & $-4,00 \%$ & $-4,17 \%$ & $8,70 \%$ & $29,03 \%$ & $-10,71 \%$ & $8,00 \%$ & $-3,70 \%$ \\
\hline BRGE11 & Alfa Consorc PNE & 2,41 & Medium & 4.669 & Small & 0,31 & Winner & Small|Medium|Winner & $3,47 \%$ & $8,91 \%$ & $-4,55 \%$ & $-2,38 \%$ & $-12,20 \%$ & $2,78 \%$ & $-8,18 \%$ & $7,59 \%$ & $8,82 \%$ & $16,22 \%$ & $3,26 \%$ & $-10,36 \%$ \\
\hline RPAD5 & & & & & Small & & & Small|Mec & $6,51 \%$ & $1,98 \%$ & $1,94 \%$ & $-1,90 \%$ & $-12,62 \%$ & $-2,78 \%$ & $-3,57 \%$ & $4,52 \%$ & $17,28 \%$ & $11,05 \%$ & $4,74 \%$ & $11,31 \%$ \\
\hline BDLL4 & Bardella PN & 1,35 & Medium & 800.000 & Small & 0,45 & Winner & Small|Medium/Winner & $21,51 \%$ & $-6,77 \%$ & $0,00 \%$ & $-5,03 \%$ & $-30,58 \%$ & $1,69 \%$ & $-25,00 \%$ & $4,44 \%$ & $25,53 \%$ & $11,51 \%$ & $-8,01 \%$ & $2,17 \%$ \\
\hline MAKR3 & Makro ON & 63 & Medium & 038.750 & Small & 0,46 & Winner & Small|Medium|Winner & $28,00 \%$ & $-3,13 \%$ & $-6,45 \%$ & $-4,83 \%$ & $-27,54 \%$ & $0,00 \%$ & $-34,00 \%$ & $65,15 \%$ & $33,03 \%$ & $-13,79 \%$ & $-12,30 \%$ & $-18,69 \%$ \\
\hline FBRA4 & Fertibras PN & 2,39 & Medium & 7.448 & Small & 0,68 & Winner & Small|Medium|Winner & $11,24 \%$ & $-17,17 \%$ & $0,00 \%$ & $-30,26 \%$ & $-24,07 \%$ & $-17,07 \%$ & $17,06 \%$ & $5,53 \%$ & $53,42 \%$ & $-11,46 \%$ & $-16,86 \%$ & $-8,02 \%$ \\
\hline MAHS4 & Bunge & 52 & Mediu & 9.077 & Small & 0,69 & Winn & Small|Med & $-0,85 \%$ & $-17,95 \%$ & $2,08 \%$ & $-44,90 \%$ & $1,12 \%$ & $-18,43 \%$ & $5,77 \%$ & $4,50 \%$ & $47,89 \%$ & $-7,35 \%$ & $-19,09 \%$ & $-10,00 \%$ \\
\hline LORZ4 & Lorenz $\mathrm{P}$ & 7 & Medium & 6.746 & Small & 0,95 & Winner & Small|Medium|Winner & $6,58 \%$ & $-8,88 \%$ & $-1,22 \%$ & $6,30 \%$ & $-9,52 \%$ & $5,26 \%$ & $-21,27 \%$ & $4,80 \%$ & $9,09 \%$ & $-8,33 \%$ & $5,45 \%$ & $-16,67 \%$ \\
\hline FAPC4 & Cofap F & & Medium & & Small & 1,04 & Winner & Small|Medium / Winner & $-12,45 \%$ & $.11,76 \%$ & $-3,33 \%$ & $-19,54 \%$ & $-40,00 \%$ & $-23,81 \%$ & $-6,25 \%$ & $18,33 \%$ & $32,11 \%$ & $112,79 \%$ & $0,50 \%$ & $0,00 \%$ \\
\hline FLCL5 & F Cataguazes PNA & 2,00 & Medium & 119.044 .110 & Small & 1,19 & Winner & Small|Medium|Winner & $6,72 \%$ & $-7,41 \%$ & $11,49 \%$ & $-18,52 \%$ & $-13,64 \%$ & $20,50 \%$ & $-17,33 \%$ & $18,28 \%$ & $2,27 \%$ & $-6,67 \%$ & $-10,48 \%$ & $-1,06 \%$ \\
\hline FTSU4 & Fertisu & 2,22 & Medium & 74.009.834 & Small & 1,23 & Winner & Small|Medium|Winner & $0,74 \%$ & $0,73 \%$ & $-10,14 \%$ & $-32,26 \%$ & $-15,48 \%$ & $-6,76 \%$ & $-12,39 \%$ & $13,79 \%$ & $66,36 \%$ & $13,77 \%$ & $-10,19 \%$ & $-13,40 \%$ \\
\hline SOLO4 & te PN & 0 & Medium & 148.799 & Small & 1,24 & Winn & Winner & $5,18 \%$ & $-6,62 \%$ & $-13,64 \%$ & $-9,47 \%$ & $-11,03 \%$ & $2,22 \%$ & $-2,17 \%$ & $0,00 \%$ & $25,93 \%$ & $-8,82 \%$ & $0,00 \%$ & $-11,29 \%$ \\
\hline CIQU4 & $\mathrm{Ca}$ & 2,16 & $\mathrm{Me}$ & & $\mathrm{Sm}$ & $\begin{array}{l}1,24 \\
1,35\end{array}$ & Winner & Small|Medium | Winner & - & $\mid-6,25 \%$ & 6,67\% & $8,04 \%$ & $19,01 \%$ & $21,53 \%$ & $-26,86 \%$ & $0,00 \%$ & $3,13 \%$ & $2,27 \%$ & $4,29 \%$ & $-4,80 \%$ \\
\hline BARB4 & S Gobain Canal PN & 2,12 & Medium & 179.825.252 & Small & 2,69 & Winner & Small|Medium|Winner & $18,18 \%$ & $-7,08 \%$ & $-6,29 \%$ & $-32,86 \%$ & $1,05 \%$ & $6,77 \%$ & $-16,59 \%$ & $13,45 \%$ & $28,35 \%$ & $34,94 \%$ & $-13,67 \%$ & $-7,34 \%$ \\
\hline CNFB4 & Confab PN & 1,81 & Medium & 194.490.617 & Small & 3,12 & Winner & Small|Medium|Winner & $6,15 \%$ & $28,95 \%$ & $2,04 \%$ & $-20,00 \%$ & $-5,00 \%$ & $4,21 \%$ & $-16,67 \%$ & $12,73 \%$ & $31,18 \%$ & $4,68 \%$ & $-9,66 \%$ & $-9,77 \%$ \\
\hline BARB3 & S Gobain Can & 212 & sod & 252 & Small & 3,35 & Ninn & Smal & $-2,27 \%$ & $4,65 \%$ & $11,11 \%$ & $2,50 \%$ & $-19,02$ & $27,71 \%$ & & $-3,8$ & 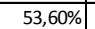 & $37,08 \%$ & $14,89 \%$ & $15,00 \%$ \\
\hline MSAN3 & Bun & 1,21 & & & Small & 4,66 & Winner & Small|Medium / Winner & $-2,78 \%$ & $-14,29 \%$ & $42,22 \%$ & $0,00 \%$ & $23,44 \%$ & $-22,45 \%$ & $-7,89 \%$ & $12,86 \% \mid$ & $39,34 \%$ & $21,18 \%$ & $12,09 \%$ & $28,41 \%$ \\
\hline MSAN4 & Bunge Brasil PN & 1,21 & Medium & 243.208 .069 & Small & 5,47 & Winner & Small|Medium|Winner & $-8,26 \%$ & $-10,00 \%$ & $38,89 \%$ & $2,40 \%$ & $-49,22 \%$ & $-18,46 \%$ & $0,00 \%$ & $15,09 \%$ & $26,23 \%$ & $23,38 \%$ & $-23,83 \%$ & $-12,86 \%$ \\
\hline
\end{tabular}


Anexo 1 - Retorno mensal e classificação das ações

\begin{tabular}{|c|c|c|c|c|c|c|c|c|c|c|c|c|c|c|c|c|c|c|c|c|}
\hline Código & 1998 - 1999 & $\begin{array}{l}\text { Índice } \mathrm{B} / \mathrm{M} \\
\text { de dez/1997 }\end{array}$ & $\begin{array}{c}\text { Grupo com } \\
\text { base no } \\
\text { indice B/M }\end{array}$ & $\begin{array}{c}\text { Valor de Mercado } \\
\text { em jun/1998 }\end{array}$ & $\begin{array}{c}\text { Grupo com } \\
\text { base no } \\
\text { tamanho }\end{array}$ & \begin{tabular}{|c|} 
Retorno \\
acumulado \\
de jun/1998
\end{tabular} & \begin{tabular}{|c|} 
Grupo com \\
base no \\
retorno \\
acumulado \\
\end{tabular} & Carteiras & $\mathrm{jul} / 98$ & ago/98 & set $/ 98$ & out/98 & nov/98 & dez/98 & $\mathrm{jan} / 99$ & fev/99 & $\mathrm{mar} / 99$ & $\mathrm{abr} / 99$ & $\mathrm{mai} / 99$ & jun/99 \\
\hline CESP3 & Cesp ON & 2,54 & High & $\begin{array}{l}2.765 .005 .953 \\
\end{array}$ & Big & \begin{tabular}{l|l|l|l|l}
0,29 \\
\end{tabular} & Loser & Big|High|Loser & $20,66 \%$ & $-48,40 \%$ & $-3,87 \%$ & $2,56 \%$ & $62,86 \%$ & $-17,11 \%$ & $-25,19 \%$ & $18,03 \%$ & $77,35 \%$ & $-2,65 \%$ & $-16,67 \%$ & $16,60 \%$ \\
\hline KLBN4 & Klabin S/A PN & 2,96 & High & \begin{tabular}{|l|}
533.625 .634 \\
\end{tabular} & Big & \begin{tabular}{|l|l|}
0,29 & \\
\end{tabular} & Loser & Big|High|Loser & $-10,42 \%$ & $-30,23 \%$ & $-33,33 \%$ & $10,00 \%$ & $-18,18 \%$ & $27,78 \%$ & $69,57 \%$ & $0,00 \%$ & $-2,56 \%$ & $34,21 \%$ & $7,84 \%$ & $63,64 \%$ \\
\hline VCPA4 & Fibria PN & 2,37 & High & 659.162 .416 & Big & \begin{tabular}{l|l}
0,24 & \\
\end{tabular} & Loser & Big|High|Loser & $-1,13 \%$ & $-17,14 \%$ & $-17,24 \%$ & $-12,50 \%$ & $23,81 \%$ & $0,00 \%$ & 76,92\% & $2,17 \%$ & $16,60 \%$ & $53,28 \%$ & $10,71 \%$ & $9,68 \%$ \\
\hline CESP5 & Cesp PNA & 2,54 & High & 2.765 .005 .953 & Big & \begin{tabular}{l|l}
0,02 & 1 \\
\end{tabular} & Loser & Big|High|Loser & $4,67 \%$ & $-44,33 \%$ & $3,06 \%$ & $7,64 \%$ & $78,20 \%$ & $-17,80 \%$ & $-26,15 \%$ & $20,57 \%$ & $52,05 \%$ & $0,92 \%$ & $-16,73 \%$ & $14,97 \%$ \\
\hline BRKM5 & Braskem PNA & 5,12 & High & 401.963.906 & Big & 0,10 & Winner & Big|High|Winner & 4,94\% & $-22,47 \%$ & $-19,51 \%$ & $-7,35 \%$ & $22,69 \%$ & $-18,79 \%$ & $12,74 \%$ & $14,14 \%$ & $23,87 \%$ & $41,76 \%$ & $8,57 \%$ ] & $-9,54 \%$ \\
\hline GOAU4 & Gerdau Met PN & 2,47 & High & 341.685 .975 & Big & \begin{tabular}{ll|}
0,23 \\
\end{tabular} & Winner & Big|High|Winner & $16,14 \%$ & $-44,12 \%$ & $-2,08 \%$ & $-19,15 \%$ & $13,16 \%$ & $1,86 \%$ & $17,50 \%$ & $4,26 \%$ & $19,59 \%$ & $38,23 \%$ & $-0,47 \%$ & $32,72 \%$ \\
\hline CSTB4 & Sid Tubarao PN & 4,27 & High & $\begin{array}{l}762.377 .222 \\
\end{array}$ & Big & \begin{tabular}{l|l|l|l|}
0,48 \\
\end{tabular} & Winner & Big|High|Winner & \begin{tabular}{l|l|}
$0,55 \%$ \\
\end{tabular} & $-45,81 \%$ & $-9,52 \%$ & $-19,08 \%$ & $4,07 \%$ & $-20,94 \%$ & $56,13 \%$ & $-11,39 \%$ & $39,29 \%$ & $41,54 \%$ & $17,39 \%$ & $18,21 \%$ \\
\hline PTOS4 & Petroquisa PN & 3,49 & High & 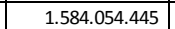 & Big & \begin{tabular}{l|l|l}
0,56 \\
\end{tabular} & Winner & Big|High|Winner & $2,50 \%$ & $-17,07 \%$ & $-19,12 \%$ & $36,18 \%$ & $-26,56 \%$ & $11,19 \%$ & $10,87 \%$ & $70,18 \%$ & $23,82 \%$ & $-8,45 \%$ & $17,64 \%$ & $-3,99 \%$ \\
\hline PIRE3 & Pirelli ON & 0,36 & Low & \begin{tabular}{|l|}
427.460 .736 \\
\end{tabular} & Big & 0,53 & Loser & Big|Low|Loser & $25,39 \%$ & $-28,75 \%$ & $11,94 \%$ & $-5,00 \%$ & $14,39 \%$ & $17,01 \%$ & $-5,41 \%$ & $-12,12 \%$ & $6,90 \%$ & $2,90 \%$ & $22,26 \%$ & $-13,08 \%$ \\
\hline WHMT3 & White Martins ON & 0,84 & Low & 1.070 .000 .052 & Big & 0,51 & Loser & Big|Low|Loser & $1,05 \%$ & $-27,10 \%$ & $-6,41 \%$ & $-21,93 \%$ & $23,21 \%$ & $-15,94 \%$ & $9,72 \%$ & $-4,69 \%$ & $18,03 \%$ & $34,73 \%$ & $-4,17 \%$ & $-10,23 \%$ \\
\hline \begin{tabular}{|l|} 
PIRE4 \\
\end{tabular} & \begin{tabular}{|l} 
Pirelli PN \\
\end{tabular} & 0,36 & Low & 427.460 .736 & \begin{tabular}{|l|l|} 
Big \\
\end{tabular} & \begin{tabular}{ll|l|l|l|l|l|l|}
0,46 \\
\end{tabular} & Loser & \begin{tabular}{|l} 
Big|Low/Loser \\
\end{tabular} & $\begin{array}{l}-1,04 \% \\
\end{array}$ & $-21,05 \%$ & $34,28 \%$ & $-13,42 \%$ & $6,08 \%$ & $-2,52 \%$ & $-9,09 \%$ & $-3,57 \%$ & $14,81 \%$ & $3,55 \%$ & $9,03 \%$ & $0,00 \%$ \\
\hline ERIC4 & Ericsson PN & 0,43 & Low & \begin{tabular}{l|l}
839.762 .747 \\
\end{tabular} & Big & 0,38 & Loser & Big|Low|Loser & $32,27 \%$ & $27,29 \%$ & $-0,11 \%$ & $-51,35 \%$ & $-8,33 \%$ & $61,44 \%$ & $-12,50 \%$ & $30,95 \%$ & $52,73 \%$ & $-35,71 \%$ & $11,07 \%$ & $-9,97 \%$ \\
\hline BRTO3 & Brasil Telec ON & 1,05 & Low & \begin{tabular}{|l|}
805.107 .071 \\
\end{tabular} & Big & 0,36 & Loser & Big|Low|Loser & $48,72 \%$ & $-54,15 \%$ & $-4,00 \%$ & $-25,83 \%$ & $67,42 \%$ & $-29,53 \%$ & $14,29 \%$ & $11,67 \%$ & $-2,99 \%$ & $15,38 \%$ & $23,33 \%$ & $5,41 \%$ \\
\hline CTNM4 & Coteminas PN & 0,53 & Low & \begin{tabular}{|l|}
895.981 .686 \\
\end{tabular} & Big & 0,33 & Loser & Big|Low|Loser & $1,71 \%$ & $-29,78 \%$ & $0,00 \%$ & $10,40 \%$ & $15,94 \%$ & $-18,75 \%$ & $15,38 \%$ & $-6,67 \%$ & $4,99 \%$ & $-25,15 \%$ & $10,87 \%$ & $25,42 \%$ \\
\hline TMAR3 & Telemar N L ON & 0,98 & Low & 2.170 .966 .386 & Big & 0,30 & Loser & Big|Low|Loser & $4,21 \%$ & $-39,39 \%$ & $-26,67 \%$ & $-9,55 \%$ & $55,78 \%$ & $-38,71 \%$ & $15,79 \%$ & $-2,27 \%$ & $9,30 \%$ & $23,40 \%$ & $0,00 \%$ & $-32,76 \%$ \\
\hline GLOB4 & Globex PN & 1,04 & Low & \begin{tabular}{|l|}
639.561 .290 \\
\end{tabular} & Big & 0,29 & Loser & Big|Low|Loser & $-20,00 \%$ & $-31,25 \%$ & $-47,09 \%$ & $3,09 \%$ & $66,67 \%$ & $-16,00 \%$ & $0,00 \%$ & $30,95 \%$ & $19,82 \%$ & $6,22 \%$ & $26,86 \%$ & $6,49 \%$ \\
\hline $\begin{array}{lll}\text { CEPE5 } & \\
\end{array}$ & Celpe PNA & 1,06 & Low & 442.244 .710 & Big & 0,27 & Loser & \begin{tabular}{|l} 
Big/Low/Loser \\
\end{tabular} & $9,68 \%$ & $0,96 \%$ & $-54,00 \%$ & $17,06 \%$ & $14,29 \%$ & $40,00 \%$ & $\mid-16,08 \%$ & $-14,44 \%$ & $6,49 \%$ & $21,95 \%$ & $5,44 \%$ & $-2,16 \%$ \\
\hline CEEB3 & Coelba ON & 0,84 & Low & \begin{tabular}{|l|}
844.832 .933 \\
\end{tabular} & Big & \begin{tabular}{l|l|l}
0,23 & \\
\end{tabular} & Loser & Big|Low/Loser & $32,22 \%$ & $-32,77 \%$ & $-10,00 \%$ & $13,04 \%$ & $17,80 \%$ & $-4,44 \%$ & $-23,28 \%$ & $0,03 \%$ & $40,91 \%$ & $8,08 \%$ & $4,35 \%$ & $-10,42 \%$ \\
\hline \begin{tabular}{|l|} 
TMGR3 \\
\end{tabular} & Telemig ON & 0,71 & Low & \begin{tabular}{|l|}
1.564 .963 .098 \\
\end{tabular} & Big & 0,18 & Loser & Big|Low/Loser & $17,02 \%$ & $-33,35 \%$ & $-21,88 \%$ & $-20,00 \%$ & $30,00 \%$ & $-7,69 \%$ & $-4,17 \%$ & $-6,52 \%$ & $7,44 \%$ & $25,54 \%$ & $10,34 \%$ & $-7,08 \%$ \\
\hline CEEB5 & Coelba PNA & 0,84 & Low & 844.832 .933 & Big & 0,12 & Loser & Big|Low|Loser & $32,62 \%$ & $-38,58 \%$ & $8,54 \%$ & $6,35 \%$ & $15,79 \%$ & $-6,84 \%$ & $-20,47 \%$ & $11,96 \%$ & $27,67 \%$ & $10,19 \%$ & $-6,38 \%$ & $-4,55 \%$ \\
\hline PRGA4 & BRF Foods PN & 1,09 & Low & 317.521.675 & Big & 0,11 & Loser & Big|Low|Loser & $19,47 \%$ & $-25,88 \%$ & $-8,73 \%$ & $26,09 \%$ & $-13,79 \%$ & $22,46 \%$ & $2,70 \%$ & $11,84 \%$ & $10,59 \%$ & $9,57 \%$ & $26,21 \%$ & $-2,38 \%$ \\
\hline AMBV3 & Ambev ON & 0,26 & Low & 4.831.305.438 & Big & 0,11 & Loser & Big|Low|Loser & $4,69 \%$ & $-17,91 \%$ & $-16,36 \%$ & $-0,65 \%$ & $15,55 \%$ & $1,92 \%$ & $17,19 \%$ & $0,17 \%$ & $4,13 \%$ & $-3,17 \%$ & $4,51 \%$ & $8,86 \%$ \\
\hline PALF5 & Paul F Luz PNA & 0,53 & Low & \begin{tabular}{|l|}
2.275 .578 .971 \\
\end{tabular} & Big & 0,10 & Loser & Big|Low|Loser & $13,22 \%$ & $-17,92 \%$ & $2,54 \%$ & $-16,81 \%$ & $7,14 \%$ & $-1,43 \%$ & $6,25 \%$ & $8,82 \%$ & $10,27 \%$ & $6,37 \%$ & $6,61 \%$ & $-6,03 \%$ \\
\hline LIGT3 & Light S/A ON & 0,50 & Low & 3.648 .244 .966 & Big & \begin{tabular}{l|l}
0,08 & \\
0
\end{tabular} & Loser & Big|Low|Loser & \begin{tabular}{l|l|l}
$8,89 \%$ \\
\end{tabular} & $-44,74 \%$ & $-29,52 \%$ & $5,53 \%$ & $48,24 \%$ & $-31,62 \%$ & $-46,26 \%$ & $33,54 \%$ & $51,66 \%$ & $-4,25 \%$ & $-2,11 \%$ & $0,72 \%$ \\
\hline PTIP4 & Ipiranga Pet PN & 0,90 & Low & \begin{tabular}{l|l}
602.625 .929 \\
\end{tabular} & Big & 0,05 & Loser & Big|Low|Loser & $-3,20 \%$ & $-5,26 \%$ & $-17,22 \%$ & $-14,09 \%$ & $35,16 \%$ & $-15,45 \%$ & $22,39 \%$ & $-3,66 \%$ & $41,27 \%$ & $-1,43 \%$ & $6,82 \%$ & $10,55 \%$ \\
\hline \begin{tabular}{|l|l|l|l|l|} 
BRTO4 &
\end{tabular} & Brasil Telec PN & 1.05 & Low & 805.107 .071 & Big & 0,05 & Loser & Big/Low/Loser & $44,83 \%$ & $-55,95 \%$ & $4,32 \%$ & $3,63 \%$ & $24,50 \%$ & $-13,66 \%$ & $-5,58 \%$ & $25,62 \%$ & $-7.45 \%$ & $10,93 \%$ & $22,90 \%$ & $6,02 \%$ \\
\hline AMBV4 & Ambev PN & 0,26 & Low & 1.831 .305 .438 & Big & \begin{tabular}{ll|l|}
0,02 \\
\end{tabular} & Loser & \begin{tabular}{|l} 
Big|Low|Loser \\
\end{tabular} & $15,97 \%$ & $-33,65 \%$ & $-14,73 \%$ & $20,43 \%$ & $15,71 \%$ & $-18,52 \%$ & $37,35 \%$ & $9,22 \%$ & $4,81 \%$ & $-3,35 \%$ & $11,02 \%$ & $15,36 \%$ \\
\hline \begin{tabular}{|l} 
PALF3 \\
\end{tabular} & Paul F Luz ON & 0,53 & Low & $\frac{4.251 .505 .450}{2.275 .578 .971}$ & \begin{tabular}{|l} 
Big \\
\end{tabular} & 0,01 & Winner & \begin{tabular}{|l|} 
Big|Low|Winner \\
\end{tabular} & $24,57 \%$ & - & $3,71 \%$ & $2,07 \%$ & $13,50 \%$ & -16,75\% & $\begin{array}{l}14,94 \% \\
14,0\end{array}$ & $\mid$ & 14,54\% & $-6,40 \%$ & $2,93 \%$ & $-6,10 \%$ \\
\hline CRUZ3 & Souza Cruz ON & 0,46 & Low & 2.628.934.977 & Big & 0,03 & Winner & Big|Low|Winner & $5,13 \%$ & $-13,73 \%$ & $4,75 \%$ & $8,00 \%$ & $-3,70 \%$ & $2,72 \%$ & $47,44 \%$ & $13,04 \%$ & $-15,72 \%$ & $6,73 \%$ & $-2,34 \%$ & $14,85 \%$ \\
\hline PETR3 & Petrobr & 0.90 & Low & 19.229 .143 .745 & Big & 0.04 & Winner & Big/Low/Winner & $14,66 \%$ & $-56,39 \%$ & $-16,00 \%$ & $30,16 \%$ & $9,76 \%$ & $-17,78 \%$ & $1.35 \%$ & $9,33 \% \mathrm{f}-\mathrm{L}$ & $138,89 \%$ & $-2.37 \%$ & $-1.90 \%$ & $5.51 \%$ \\
\hline CRGT5 & Crt Ciargtelec PN & 0,68 & Low & 2.466 .964 .886 & Big & 0,05 & Winner & Big|Low|Winner & $-15,94 \%$ & $-52,83 \%$ & $-28,60 \%$ & $-1,96 \%$ & $68,57 \%$ & $-22,93 \%$ & $-10,11 \%$ & $18,93 \%$ & $11,83 \%$ & $27,88 \%$ & $\begin{array}{ll}4,11 \% \\
\end{array}$ & $-1,49 \%$ \\
\hline PTIP3 & Ipiranga Pet ON & 0,90 & Low & \begin{tabular}{|c|}
602.625 .929 \\
\end{tabular} & \begin{tabular}{|l} 
Big \\
\end{tabular} & 0,07 & Winner & \begin{tabular}{|l} 
Big|Low|Winner \\
\end{tabular} & 6,05\% & $-23,08 \%$ & $-5,00 \%$ & $-26,21 \%$ & $\begin{array}{ll}1,28 \% \\
\end{array}$ & $17,50 \%$ & $0,00 \%$ & $8,55 \%$ & 年, & $27,78 \%$ & $-4,35 \%$ & $0,00 \%$ \\
\hline PIPN4 & Pirelli Pneus PN & 0,84 & Low & 331.625 .000 & Big & \begin{tabular}{l|l|}
0,08 \\
\end{tabular} & Winner & Big|Low|Winner & $20,00 \%$ & $-20,00 \%$ & $29,09 \%$ & $1,79 \%$ & $-12,28 \%$ & $-9,73 \%$ & $32,70 \%$ & $15,20 \%$ & $4,24 \%$ & $11,86 \%$ & $21,21 \%$ & $-5,00 \%$ \\
\hline TAMR4 & Tam Transp PN & 0,46 & Low & 336.169 .858 & \begin{tabular}{|l|l|} 
Big \\
\end{tabular} & 0,10 & Winner & Big|Low/Winner & $4,15 \%$ & $-14,66 \%$ & $-6,25 \%$ & $-8,35 \%$ & $12,29 \%$ & $5,25 \%$ & $-15,39 \%$ & $-29,08 \%$ & $7,69 \%$ & $-18,81 \%$ & $8,50 \%$ & $24,32 \%$ \\
\hline TMGR6 & Telemig PNB & 0,71 & Low & 1.564.963.098 & Big & 0,11 & Winner & Big|Low|Winner & $-4,35 \%$ & $-31,17 \%$ & $-20,75 \%$ & $-12,14 \%$ & $23,58 \%$ & $-22,59 \%$ & $-7,93 \%$ & $3,08 \%$ & $19,10 \%$ & $15,37 \%$ & \begin{tabular}{|l|l|}
$15,12 \%$ \\
\end{tabular} & $-12,00 \%$ \\
\hline COCE5 & Coelce PNA & 0,77 & Low & \begin{tabular}{|l|}
456.163 .461 \\
\end{tabular} & Big & 0,12 & Winner & \begin{tabular}{|l|} 
Big|Low|Winner \\
\end{tabular} & $21,21 \%$ & $-28,00 \%$ & $-42,71 \%$ & $26,06 \%$ & $75,48 \%$ & $-17,81 \%$ & $3,67 \%$ & $-0,82 \%$ & $43,33 \%$ & $4,63 \%$ & $\mid-3,64 \%$ & $13,21 \%$ \\
\hline ITSA4 & Itausa PN & 1,11 & Low & 2.190 .806 .636 & Big & 0,14 & Winner & Big|Low|Winner & $6,85 \%$ & $-19,31 \%$ & $5,26 \%$ & $5,21 \%$ & $34,92 \%$ & $-20,83 \%$ & $5,97 \%$ & $18,31 \%$ & $5,18 \%$ & $3,41 \%$ & $4,40 \%$ & $-0,76 \%$ \\
\hline IISA3 & Itausa ON & 1,11 & Low & 2.190 .806 .636 & Big & 0,15 & Winner & Big/Low/Winner & $17,65 \%$ & $-2,52 \%$ & $-10,05 \%$ & $8,91 \%$ & $22,86 \%$ & $-10,47 \%$ & $-6,15 \%$ & $12,50 \%$ & $24,11 \%$ & $-10,00 \%$ & \begin{tabular}{|l|l}
$14,44 \%$ \\
\end{tabular} & $2,22 \%$ \\
\hline TMAR6 & Telemar N L PNB & 0,98 & Low & 2.170 .966 .386 & Big & 0,16 & Winner & Big|Low/Winner & $-5,86 \%$ & $-48,11 \%$ & $-21,18 \%$ & $11,34 \%$ & $16,62 \%$ & $-24,14 \%$ & $1,82 \%$ & $-0,27 \%$ & $21,90 \%$ & $-0,86 \%$ & $-13,58 \%$ & $-13,43 \%$ \\
\hline PETR4 & Petrobras PN & 0,90 & Low & 19.229 .143 .745 & Big & 0,16 & Winner & Big|Low/Winner & $18,60 \%$ & $-52,94 \%$ & $1,66 \%$ & $22,96 \%$ & $14,00 \%$ & $-19,88 \%$ & $-0,73 \%$ & $18,46 \%$ & $52,51 \%$ & $12,23 \%$ & $-5,84 \%$ & $9,35 \%$ \\
\hline CBEE3 & Ampla Energ ON & 0,23 & Low & 882.250 .213 & Big & 0,24 & Winner & Big|Low|Winner & $7,02 \%$ & $-39,34 \%$ & $13,51 \%$ & $-7,14 \%$ & $15,38 \%$ & $-11,11 \%$ & $-45,00 \%$ & $45,45 \%$ & $21,88 \%$ & $15,38 \%$ & $-13,33 \%$ & $10,26 \%$ \\
\hline EMBR4 & Embraer PN & 0,23 & Low & 2.775 .912 .785 & Big & 0,29 & Winner & Big|Low/Winner & $-8,78 \%$ & $-14,44 \%$ & $-12,30 \%$ & $-8,09 \%$ & $12,00 \%$ & $7,14 \%$ & $-10,00 \%$ & $7,41 \%$ & $23,45 \%$ & $-10,87 \%$ & $27,12 \%$ & $54,24 \%$ \\
\hline FFTL4 & Valefert PN & 0,83 & Low & \begin{tabular}{l|}
602.536 .376 \\
\end{tabular} & Big & 0,31 & Winner & Big|Low|Winner & $-3,22 \%$ & $-21,62 \%$ & $4,55 \%$ & $-15,94 \%$ & $6,90 \%$ & $0,00 \%$ & $49,76 \%$ & $0,00 \%$ & $23,49 \%$ & $9,05 \%$ & $-3,51 \%$ & $18,18 \%$ \\
\hline PCAR4 & P.Acu & 0,54 & Low & 9.292 & Big & 0,43 & Winner & g|Low |Winner & $1,92 \%$ & $-38,87 \%$ & $-2,47 \%$ & $26,58 \%$ & $17,50 \%$ & $-17,02 \%$ & $5,64 \%$ & $16,50 \%$ & $5,42 \%$ & $14,62 \%$ & $12,58 \%$ & $2,97 \%$ \\
\hline ELAT3 & Elevad Atlas ON & 0,14 & Low & 487.500 .000 & Big & $\begin{array}{l}0,45 \\
0,45 \\
\end{array}$ & Winner & \begin{tabular}{|l}
$\mid$ Big|Low|Winner \\
\end{tabular} & \begin{tabular}{|c|c|}
$-7,14 \%$ \\
\end{tabular} & | & $11,82 \%$ & $\mid-2,52 \%$ & $19,59 \%$ & - & 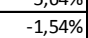 & $0,02 \%$ & $44,12 \%$ & $-5,56 \%$ & $\begin{array}{l}44,76 \% \\
44,70 \%\end{array}$ & $2,60 \%$ \\
\hline WEGE4 & Weg PN & 0,68 & Low & 480.537 .750 & Big & 0,47 & Winner & Big|Low/Winner & $9,07 \%$ & $-6,25 \%$ & $-5,33 \%$ & $-18,31 \%$ & $0,00 \%$ & $3,45 \%$ & $5,04 \%$ & $26,32 \%$ & $1,39 \%$ & $-8,22 \%$ & $2,99 \%$ & $8,70 \%$ \\
\hline ODBE4 & Odebrecht PN & 1,95 & Medium & 407.000 .000 & Big & 0,50 & Loser & \begin{tabular}{|l|} 
Big $\mid$ Medium/Loser \\
\end{tabular} & $2,70 \%$ & $-34,21 \%$ & $-4,00 \%$ & $-20,83 \%$ & $0,00 \%$ & $57,89 \%$ & $-36,67 \%$ & $21,05 \%$ & $-17,39 \%$ & $5,26 \%$ & $3,00 \%$ & $-2.91 \%$ \\
\hline TBRS3 & The & 1,66 & Nod & 086 & Big & 0,39 & Inser & 然 & $0,64 \%$ & $-9,03 \%$ & $-21,99 \%$ & $-19,09$ & 1,1 & $-22,22 \%$ & $30,00 \%$ & $-1,1$ & $22,22 \%$ & $9,09 \%$ & 22,8 & $0,22 \%$ \\
\hline \begin{tabular}{|l|} 
ANTA3 \\
\end{tabular} & Antarctica Paulista ON & 1,64 & Medium & 714.900 .000 & \begin{tabular}{|l} 
Big \\
\end{tabular} & 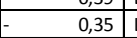 & Loser & \begin{tabular}{|l|} 
Big|Medium|Loser \\
\end{tabular} & $2,50 \%$ & $-17,53 \%$ & $-23,42 \%$ & $\begin{array}{l}-16,43 \% \\
\end{array}$ & $-12,50 \%$ & $0,00 \%$ & $-8,93 \%$ & $-11,76 \%$ & $24,44 \%$ & $31,90 \%$ & $10,92 \%$ & $1,01 \%$ \\
\hline
\end{tabular}


Anexo 1 - Retorno mensal e classificação das ações

\begin{tabular}{|c|c|c|c|c|c|c|c|c|c|c|c|c|c|c|c|c|c|c|c|c|}
\hline Código & $1998-1999$ & $\begin{array}{l}\text { Índice B/M } \\
\text { de dez/1997 }\end{array}$ & \begin{tabular}{|c} 
Grupo com \\
base no \\
indice B/M
\end{tabular} & $\begin{array}{l}\text { Valor de Mercado } \\
\text { em jun/1998 }\end{array}$ & $\begin{array}{c}\text { Grupo com } \\
\text { base no } \\
\text { tamanho }\end{array}$ & \begin{tabular}{|c|} 
Retorno \\
acumulado \\
de jun/1998
\end{tabular} & \begin{tabular}{|c|} 
Grupo com \\
base no \\
retorno \\
acumulado
\end{tabular} & Carteiras & $\mathrm{jul} / 98$ & ago/98 & set/98 & out $/ 98$ & nov/98 & $\mathrm{dez} / 98$ & $\mathrm{jan} / 99$ & fev/99 & $\mathrm{mar} / 99$ & abr/99 & mai/99 & jun/99 \\
\hline VSMA3 & s Gobain Vidro ON & 1,24 & Medium & 402.716 .395 & Big & 0,34 & Loser & Big|Medium|Loser & $0,00 \%$ & $2,63 \%$ & $-12,31 \%$ & $7,60 \%$ & $3,80 \%$ & $-0,52 \%$ & $23,68 \%$ & $6,38 \%$ & $0,08 \%$ & $0,00 \%$ & $-6,00 \%$ & $-12,34 \%$ \\
\hline LAME4 & Lojas Americ PN & 1,67 & Medium & 327.296 .699 & Big & 0,33 & Loser & Big|Medium|Loser & $-14,46 \%$ & $-24,55 \%$ & $22,89 \%$ & $25,49 \%$ & $23,28 \%$ & $-13,18 \%$ & $14,70 \%$ & $4,47 \%$ & $25,82 \%$ & $-16,07 \%$ & $12,18 \%$ & $-14,63 \%$ \\
\hline TBRS4 & Telebrasilia PN & 1,66 & Medium & 372.078 .086 & Big & 0,29 & Loser & Big|Medium|Loser & $6,77 \%$ & $-42,08 \%$ & $-25,78 \%$ & $1,05 \%$ & $40,63 \%$ & $-18,53 \%$ & $18,20 \%$ & $3,08 \%$ & $10,45 \%$ & $21,94 \%$ & $28,49 \%$ & $-2,17 \%$ \\
\hline USIM5 & Usiminas PNA & 1,80 & Medium & 1.282 .510 .698 & Big & 0,27 & Loser & Big|Medium|Loser & $6,78 \%$ & $-15,85 \%$ & $-28,57 \%$ & $7,43 \%$ & $-5,10 \%$ & $-18,10 \%$ & $3,00 \%$ & $-9,82 \%$ & $18,15 \%$ & $65,53 \%$ & $-4,12 \%$ & $28,17 \%$ \\
\hline WHRL4 & Whirlpool PN & 1,27 & Medium & 590.717 .300 & Big & 0,26 & Loser & Big|Medium|Loser & $9,23 \%$ & $-22,00 \%$ & $-12,82 \%$ & $47,06 \%$ & $-6,00 \%$ & $4,26 \%$ & $11,39 \%$ & $-11,32 \%$ & $-8,51 \%$ & $4,65 \%$ & $28,89 \%$ & $8,62 \%$ \\
\hline ICPI4 & Cim Itau PN & 1,15 & Medium & 624.917 .980 & Big & 0,26 & Loser & Big|Medium|Loser & $-0,05 \%$ & $-21,95 \%$ & $3,06 \%$ & $-2,97 \%$ & $0,00 \%$ & $-14,06 \%$ & $7,64 \%$ & $-4,05 \%$ & $11,51 \%$ & $13,68 \%$ & $0,15 \%$ & $0,59 \%$ \\
\hline TBCP4 & Tel B Campo PN & 1,21 & Medium & 580.484.147 & Big & 0,22 & Loser & Big|Medium|Loser & $-7,81 \%$ & $-32,22 \%$ & $10,02 \%$ & $4,55 \%$ & $80,39 \%$ & $-27,21 \%$ | $>$ & $-12,68 \%$ & $12,52 \%$ & $16,65 \%$ & $-14,29 \%$ & $35,56 \%$ | & $28,42 \%$ \\
\hline ANTA4 & Antarctica Paulista PN & 1,64 & Medium & 714.900 .000 & Big & 0,21 & Loser & Big|Medium|Loser & $7,14 \%$ & $-15,49 \%$ & $-10,00 \%$ & $-4,44 \%$ & $-18,60 \%$ & $0,00 \%$ & $11,43 \%$ & $-0,26 \%$ & $0,00 \%$ & $0,26 \%$ & $19,27 \%$ & $4,44 \%$ \\
\hline SDIA4 & Sadia S/A PN & 1,25 & Medium & 433.020 .977 & Big & 0,18 & Loser & Big|Medium|Loser & $-2,78 \%$ & $-11,88 \%$ & $-13,79 \%$ & $2,00 \%$ & $17,65 \%$ & $10,73 \%$ & $9,68 \%$ & $7,35 \%$ & $9,59 \%$ & $20,00 \%$ & $16,67 \%$ & $-1,79 \%$ \\
\hline ARCZ6 & Aracruz PNB & 1,44 & Medium & 1.140 .388 .456 & Big & 0,18 & Loser & Big|Medium|Loser & $-14,62 \%$ & $-30,63 \%$ & $2,60 \%$ & $29,11 \%$ & $22,55 \%$ & $-28,00 \%$ & $222,22 \%$ & $-10,34 \%$ & $-2,81 \%$ & $15,60 \%$ & $13,84 \%$ & $19,15 \%$ \\
\hline BRDT4 & Petrobras Distrib PN & 1,50 & Medium & 692.063 .631 & Big & 0,14 & Loser & Big|Medium|Loser & $1,12 \%$ & $-29,07 \%$ & $-17,32 \%$ & $21,05 \%$ & $12,17 \%$ & $-18,60 \%$ & $34,29 \%$ & $-6,38 \%$ & $46,97 \%$ & $6,78 \%$ & $-9,58 \%$ & $-2,28 \%$ \\
\hline CPLE3 & Copel ON & 1,29 & Medium & 2.708 .155 .995 & Big & 0,13 & Loser & Big|Medium|Loser & $3,30 \%$ & $-49,26 \%$ & $19,92 \%$ & $27,80 \%$ & $5,34 \%$ & $-10,39 \%$ & $-17,39 \%$ & $7,02 \%$ & $47,43 \%$ & $-1,18 \%$ & $1,31 \%$ & $3,29 \%$ \\
\hline DURA4 & Duratex-Old PN & 1,58 & Medium & 402.103 .366 & Big & 0,08 & Loser & Big|Medium|Loser & $2,20 \%$ & $-26,88 \%$ & $-21,21 \%$ & $-22,27 \%$ & $64,10 \%$ & $3,12 \%$ & $-6,00 \%$ & $4,77 \%$ & $12,00 \%$ & $8,52 \%$ & $18,99 \%$ & $0,00 \%$ \\
\hline CMIG3 & Cemig ON & 1,35 & Medium & 5.042 .926 .119 & Big & 0,06 & Loser & Big|Medium|Loser & $11,07 \%$ & $-43,64 \%$ & $11,81 \%$ & $-15,46 \%$ & $34,74 \%$ & $-3,94 \%$ & $-5,88 \%$ & $0,00 \%$ & $48,12 \%$ & $3,93 \%$ & $-5,53 \%$ & $2,70 \%$ \\
\hline ELET3 & Eletrobras ON & 2,06 & Medium & 18.343 .093 .855 & Big & 0,02 & Loser & Big|Medium|Loser & $4,41 \%$ & $-52,68 \%$ & $46,43 \%$ & $4,88 \%$ & $19,42 \%$ & $-32,49 \%$ & $20,19 \%$ & $8,04 \%$ & $23,95 \%$ & $2,49 \%$ & $4,42 \%$ & $-5,65 \%$ \\
\hline VALE3 & Vale ON & 1,17 & Medium & 8.203 .799 .500 & Big & 0,00 & Winner & Big|Medium/Winner & $9,76 \%$ & $-30,96 \%$ & $-15,22 \%$ & $7,62 \%$ & $-3,85 \%$ & $-10,40 \%$ & $91,59 \%$ & $-10,24 \%$ & $-0,54 \%$ & $16,94 \%$ & $13,97 \%$ & $2,50 \%$ \\
\hline ELET6 & Eletrobras PNB & 2,06 & Medium & 18.343 .093 .855 & Big & 0,02 & Winner & Big|Medium/Winner & $6,29 \%$ & $-51,34 \%$ & $45,56 \%$ & $5,34 \%$ & $23,19 \%$ & $-31,76 \%$ & $12,93 \%$ & $6,49 \%$ & $28,85 \%$ & $3,31 \%$ & $4,25 \%$ & $-3,54 \%$ \\
\hline SAMI4 & Samitri PN & 1,68 & Medium & 366.676 .531 & Big & 0,02 & Winner & Big|Medium/Winner & $-13,89 \%$ & $-14,97 \%$ & $-31,71 \%$ & $-10,71 \%$ & $-18,00 \%$ & $-1,80 \%$ & $78,37 \%$ & $-15,63 \%$ & $3,70 \%$ & $25,07 \%$ & $2,80 \%$ & $27,78 \%$ \\
\hline TEBA5 & Telebahia PNA & 2,05 & Medium & 476.155 .307 & Big & 0,03 & Winner & Big|Medium/Winner & $-13,74 \%$ & $-56,99 \%$ & $-10,43 \%$ & $23,79 \%$ & $5,88 \%$ & $-7,41 \%$ & $-4,40 \%$ & $17,15 \%$ & $-0,04 \%$ & $30,80 \%$ & $25,65 \%$ & $-8,32 \%$ \\
\hline SBSP3 3 & Sabesp ON & 1,14 & Medium & $\begin{array}{l}3.870 .477 .061 \\
\end{array}$ & Big & 0,03 & Winner & Big|Medium/Winner & $15,18 \%$ & $-36,03 \%$ & $-25,56 \%$ & $38,48 \%$ & $37,50 \%$ & $-30,70 \%$ & $-25,94 \%$ & $31,93 \%$ & $30,82 \%$ & $30,86 \%$ & $-6,66 \%$ & $6,98 \%$ \\
\hline CLSC6 & Celesc PNB & 1,63 & Medium & 656.902 .191 & Big & 0,04 & Winner & Big|Medium/Winner & $11,36 \%$ & $-50,00 \%$ & $10,20 \%$ & $24,07 \%$ & $13,43 \%$ & $-28,95 \%$ & $-9,26 \%$ & $8,16 \%$ & $41,51 \%$ & $2,67 \%$ & $-12,99 \%$ & $1,49 \%$ \\
\hline \begin{tabular}{|l|l|} 
CPLE6 \\
\end{tabular} & Copel PNB & 1,29 & Medium & 2.708 .155 .995 & \begin{tabular}{|l|l} 
Big \\
\end{tabular} & 0,05 & Winner & Big|Medium|Winner & $16,48 \%$ & $-44,36 \%$ & $11,43 \%$ & $19,23 \%$ & $24,19 \%$ & $-24,68 \%$ & $-3,45 \%$ & $10,48 \%$ & $45,42 \%$ & $3,09 \%$ & $-1,05 \%$ & $7,65 \%$ \\
\hline CSNA3 & Sid Nacional ON & 1,96 & Medium & 2.179.972.331 & Big & 0,13 & Winner & Big|Medium/Winner & $0,55 \%$ & $-31,49 \%$ & $5,57 \%$ & $-7,79 \%$ & $30,56 \%$ & $22,28 \%$ & $-18,15 \%$ & $-16,29 \%$ & $56,70 \%$ & $22,46 \%$ & $-5,35 \%$ & $44,86 \%$ \\
\hline CMIG4 & Cemig PN & 1,35 & Medium & 5.042 .926 .119 & Big & 0,15 & Winner & Big|Medium/Winner & $9,72 \%$ & $-44,30 \%$ & $24,01 \%$ & $-7,44 \%$ & $31,03 \%$ & $-22,28 \%$ & $12,61 \%$ & $3,47 \%$ & $43,10 \%$ & $7,46 \%$ & $-7,50 \%$ & $0,03 \%$ \\
\hline VALE5 & Vale PNA & 1,17 & Medium & 8.203 & Big & 0,20 & Winner & Big|Medium/Winner & $4,35 \%$ & $-32,85 \%$ & $15,38 \%$ & $3,68 \%$ & $-2,78 \%$ & $-11,43 \%$ & $100,00 \%$ & $-13,17 \%$ & $-3,07 \%$ & $26,65 \%$ & $-2,44 \%$ & $11,54 \%$ \\
\hline CPSL3 & Copesul ON & 1,51 & Medium & 608.379 .540 & Big & 0,23 & Winner & Big|Medium/Winner & $9,74 \%$ & $-3,70 \%$ & $-8,72 \%$ & $9,50 \%$ & $5,43 \%$ & $-7,72 \%$ & $25,00 \%$ & $-4,37 \%$ & $14,29 \%$ & $4,17 \%$ & $4,00 \%$ & $9,16 \%$ \\
\hline INEP4 & Inepar PN & 1,21 & Medium & $\begin{array}{r}1.649 .538 .651 \\
\end{array}$ & \begin{tabular}{|l|} 
Big \\
\end{tabular} & 0,24 & Winner & $\begin{array}{l}\text { Big|Medium/Winner } \\
\end{array}$ & $-5,30 \%$ & $-23,08 \%$ & $-18,18 \%$ & - & $8,75 \%$ & $-19,54 \%$ & $-24,29 \%$ & $-7,55 \%$ & $8,16 \%$ & $-7,33 \%$ & $-40,00 \%$ & $-3,01 \%$ \\
\hline GGBR4 & Gerdau PN & 2,01 & Medium & 821.489 .671 & Big & 0,36 & Winner & Big|Medium/Winner & $22,00 \%$ & $-41,09 \%$ & $-10,43 \%$ & $4,27 \%$ & $9,87 \%$ & $-18,68 \%$ & $62,22 \%$ & $-4,11 \%$ & $26,43 \%$ & $46,44 \%$ & $4,05 \%$ & $9,38 \%$ \\
\hline TEKA4 & Teka PN & 15,39 & High & 23.015 .858 & Small & 0,60 & Loser & Small|High|Loser & $0,00 \%$ & $-20,00 \%$ & $0,00 \%$ & $34,62 \%$ & $-13,33 \%$ & $0,00 \%$ & $169,23 \%$ & $-25,71 \%$ & $15,38 \%$ & $16,67 \%$ & $0,00 \%$ & $-11,76 \%$ \\
\hline CREM4-0 & Cremer (An & 2,68 & High & 2.359 .800 & \begin{tabular}{|l} 
Small \\
\end{tabular} & 0,48 & Loser & Small|High|Loser & $-17,39 \%$ & $2,63 \%$ & $23,08 \%$ & $0,00 \%$ & $-2,08 \%$ & $-1,06 \%$ & $-1,08 \%$ & $17,17 \%$ & $2,04 \%$ & $-10,91 \%$ & $224,49 \%$ & $6,92 \%$ \\
\hline WISA4 & Wiest PN & 4,51 & High & 7.198 .800 & Small & 0,47 & Loser & Small| High | Loser & $-16,19 \%$ & $-7,95 \%$ & $-2,47 \%$ & $-8,86 \%$ & $-8,33 \%$ & $-27,27 \%$ & $0,00 \%$ & $25,00 \%$ & $30,00 \%$ & $-5,81 \%$ & $-14,08 \%$ & $8,20 \%$ \\
\hline CPCA4 & Trikem PN & 8,07 & High & 100.392 .492 & Small & 0,45 & Loser & Small|High|Loser & $3,03 \%$ & $-23,53 \%$ & $-33,85 \%$ & $-24,42 \%$ & $3,08 \%$ & $-17,91 \%$ & $12,73 \%$ & $8,06 \%$ & $83,58 \%$ & $1,63 \%$ & $-16,00 \%$ & $100,95 \%$ \\
\hline BOBR4 & Bombril PN & 2,63 & High & 189.753 .139 & Small & 0,43 & Loser & Small|High|Loser & $1,67 \%$ & $-20,08 \%$ & $-11,28 \%$ & $-0,58 \%$ & $15,70 \%$ & $-1,26 \%$ & $32,32 \%$ & $3,85 \%$ & $16,67 \%$ & $-6,35 \%$ & $4,18 \%$ & $-7,14 \%$ \\
\hline HGTX4 & Cia Hering PN & 2,98 & High & 64.139 .206 & \begin{tabular}{|l|l|} 
Small \\
\end{tabular} & 0,43 & Loser & Small|High|Loser & $13,33 \%$ & $-41,18 \%$ & $0,00 \%$ & $0,00 \%$ & $0,00 \%$ & $4,00 \%$ & $7,69 \%$ & $-3,57 \%$ & $5,56 \%$ & $5,26 \%$ & $66,67 \%$ & $0,00 \%$ \\
\hline MGEL4 & Mangels Indl PN & 7,71 & High & 778.041 & \begin{tabular}{|l|l|} 
Small \\
\end{tabular} & 0,42 & Loser & Small|High|Loser & $-6,50 \%$ & $-14,44 \%$ & $-28,12 \%$ & $5,22 \%$ & $11,57 \%$ & $-14,81 \%$ & $3,48 \%$ & $17,65 \%$ & $-7,14 \%$ & $19,23 \%$ & $18,06 \%$ & $3,83 \%$ \\
\hline UNIPG & Unipar PNB & 6,75 & High & 54.057 .250 & \begin{tabular}{|l|l|} 
Small \\
\end{tabular} & 0,40 & \begin{tabular}{|l|} 
Loser \\
\end{tabular} & Small|High|Loser & $8,00 \%$ & $-15,12 \%$ & $-4,55 \%$ & $0,00 \%$ & $38,10 \%$ & $-10,20 \%$ & $24,00 \%$ & $-3,23 \%$ & $33,33 \%$ & $-2,50 \%$ & $16,67 \%$ & $-2,38 \%$ \\
\hline RAPT4 & Randon Part PN & 3,45 & High & 57.023 .639 & Small & 0,28 & Loser & Small|High|Loser & $5,26 \%$ & $-30,00 \%$ & \begin{tabular}{|l|l|}
$-14,29 \%$ \\
\end{tabular} & $-16,67 \%$ & $-10,00 \%$ & $0,00 \%$ & $50,00 \%$ & $-14,81 \%$ & $26,09 \%$ & $6,90 \%$ & $3,27 \%$ & $-3,23 \%$ \\
\hline SUZB5 & Suzano Papel PNA & 3,17 & High & 265.108 .228 & Small & 0,28 & Loser & Small| |High| Loser & $-9,52 \%$ & $-35,85 \%$ & $2,94 \%$ & $-40,00 \%$ & $9,52 \%$ & $19,57 \%$ & $54,55 \%$ & $-7,06 \%$ & $18,99 \%$ & $24,47 \%$ & $12,82 \%$ & $4,55 \%$ \\
\hline MNPR4 & Minupar PN & 14,44 & High & 2.704 .800 & \begin{tabular}{|l|l|} 
Small \\
\end{tabular} & 0,24 & Loser & Small|High|Loser & $-21,43 \%$ & $-9,09 \%$ & $-10,00 \%$ & $0,00 \%$ & $11,11 \%$ & $-10,00 \%$ & $66,67 \%$ & $6,67 \%$ & $0,00 \%$ & $6,25 \%$ & $-9,09 \%$ & $33,33 \%$ \\
\hline SIBR7 & Sibra PNC & 3,30 & High & 23.618 .361 & Small & 0,20 & $\begin{array}{l}\text { Loser } \\
\end{array}$ & Small| High | Loser & $-33,33 \%$ & $0,00 \%$ & $0,00 \%$ & $-50,00 \%$ & $100,00 \%$ & $0,00 \%$ & $-50,00 \%$ & $0,00 \%$ & $100,00 \%$ & $0,00 \%$ & $-50,00 \%$ & $0,00 \%$ \\
\hline ACES4 & Am Inox BR PN & 8,22 & High & 226.943 .289 & Small & 0,19 & Loser & Small|High|Loser & $-5,71 \%$ & $-41,67 \%$ & $-9,09 \%$ & $-27,14 \%$ & $13,73 \%$ & $1,72 \%$ & $-11,86 \%$ & $5,77 \%$ & $25,45 \%$ & $17,39 \%$ & $-19,75 \%$ & $-3,08 \%$ \\
\hline ACES3 & Am Inox BR ON & 8,22 & High & 226.943 .289 & Small & 0,08 & Loser & Small| |igh| Loser & $-6,25 \%$ & $-40,83 \%$ & $-15,49 \%$ & $-16,67 \%$ & $4,00 \%$ & $-9,62 \%$ & $-4,26 \%$ & $13,33 \%$ & $33,33 \%$ & $8,82 \%$ & $-22,97 \%$ & $-5,26 \%$ \\
\hline TRMB4 & Trombini PN & 8,26 & High & 9.639 .690 & \begin{tabular}{|l|l|} 
Small \\
\end{tabular} & 0,07 & Loser & Small|High|Loser & $-7,50 \%$ & $-9,91 \%$ & $-3,00 \%$ & $-2,06 \%$ & $-8,42 \%$ & $-13,79 \%$ & $0,00 \%$ & $21,33 \%$ & $9,89 \%$ & $15,00 \%$ & $4,35 \%$ & $0,00 \%$ \\
\hline FESA4 & Ferbasa PN & 8,81 & High & 17.103 .397 & Small & 0,03 & Loser & Small|High|Loser & $-3,23 \%$ & $0,00 \%$ & $-39,67 \%$ & $43,65 \%$ & $23,08 \%$ & $-12,50 \%$ & $42,86 \%$ & $8,75 \%$ & $-3,40 \%$ & $-9,57 \%$ & $1,81 \%$ & $11,05 \%$ \\
\hline MANM3 & Mannesm & 3,68 & High & 03.874 & Small & 0,01 & \begin{tabular}{|l|} 
Loser \\
\end{tabular} & Small|High|Loser & $0,37 \%$ & $-26,20 \%$ & $-5,00 \%$ & $-5,26 \%$ & $-8,89 \%$ & $-14,63 \%$ & $42,86 \%$ & $15,00 \%$ & $65,22 \%$ & $-5,26 \%$ & $-27,78 \%$ & $-0,23 \%$ \\
\hline ARCE4 & Arcelor BR PN & 5,52 & High & 315.792 .307 & Small & 0,00 & Winner & Small|High|Winner & $2,99 \%$ & $-26,09 \%$ & $-9,21 \%$ & $-10,76 \%$ & $-6,33 \%$ & $9,89 \%$ & $13,51 \%$ & $-16,19 \%$ & $10,80 \%$ & $36,42 \%$ & $-1,96 \%$ & $-4,00 \%$ \\
\hline ARCE3 & Arcelor BR ON & 5,52 & High & 315.792 .307 & Small & 0,02 & Winner & Small|High|Winner & $-13,33 \%$ & $-9,54 \%$ & $5,33 \%$ & $-3,13 \%$ & $-3,23 \%$ & $34,98 \%$ & $-7,69 \%$ \% & $-26,39 \%$ & $-22,64 \%$ & $41,93 \%$ & $-16,07 \%$ & $0,00 \%$ \\
\hline FBRA4 & Fertibras PN & 3,42 & High & 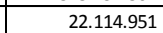 & smoll & 0,03 & Winner & Smallyightwinger & $-6,67 \%$ & $-17,58 \%$ & $10,00 \%$ & $-4,24 \%$ & $13,92 \%$ & $0,17 \%$ & $28,75 \%$ & $-12,62 \%$ & $36,11 \%$ & $28,29 \%$ & $-9,67 \%$ & $62,36 \%$ \\
\hline BRGE3 & Alfa Conso & 3,03 & High & 167.818 .760 & Small & 0,08 & Win & |Higr & & & 0, & $-0,47 \%$ & 64,62 & 18,66 & $-8,16 \%$ & $2,34 \%$ & $-25,29 \%$ & $-0,7$ & 4,7 & \\
\hline FJTA4 & Forjas Taurus PN & 5,12 & \begin{tabular}{|l|l|} 
High \\
\end{tabular} & 22.510 .800 & Small & 0,11 & Winner & Small| High | Winner & $11,54 \%$ & $-17,24 \%$ & $-12,50 \%$ & $14,29 \%$ & 4, $4,17 \%$ & $23,07 \%$ & $25,00 \%$ & $0,00 \%$ & $26,67 \%$ & $10,53 \%$ & $\begin{array}{c}-14,29 \% \\
-140 \% \\
\end{array}$ & $11,11 \%$ \\
\hline
\end{tabular}


Anexo 1 - Retorno mensal e classificação das ações

\begin{tabular}{|c|c|c|c|c|c|c|c|c|c|c|c|c|c|c|c|c|c|c|c|c|}
\hline Código & $1998-1999$ & $\begin{array}{c}\text { Índice } \mathrm{B} / \mathrm{M} \\
\text { de dez/1997 }\end{array}$ & $\begin{array}{c}\text { Grupo com } \\
\text { base no } \\
\text { indice } \mathrm{B} / \mathrm{M}\end{array}$ & $\begin{array}{l}\text { Valor de Mercado } \\
\text { em jun/1998 }\end{array}$ & \begin{tabular}{|c} 
Grupo com \\
base no \\
tamanho
\end{tabular} & $\begin{array}{c}\text { Retorno } \\
\text { acumulado } \\
\text { de jun/1998 }\end{array}$ & \begin{tabular}{|c|} 
Grupo com \\
base no \\
retorno \\
acumulado
\end{tabular} & Carteiras & $\mathrm{jul} / 98$ & ago/98 & set/98 & out $/ 98$ & nov/98 & dez/98 & jan/99 & fev/99 & mar/99 & abr/99 & mai/99 & jun/99 \\
\hline \begin{tabular}{|l|} 
BRGE12 \\
\end{tabular} & Alfa Consorc PNF & 3,03 & High & 167.818 .760 & Small & 0,11 & \begin{tabular}{|l} 
Winner \\
\end{tabular} & Small|High|Winner & $1,01 \%$ & $4,46 \%$ & $-4,88 \%$ & $12,82 \%$ & $59,09 \%$ & $32,81 \%$ & $-23,08 \%$ & $9,09 \%$ & $-26,79 \%$ & $14,63 \%$ & $-14,89 \%$ & $3,33 \%$ \\
\hline RPAD3 & Alfa Holding ON & 2,66 & High & 176.088 .359 & Small & 0,12 & Winner & Small|High /Winner & $0,00 \%$ & $-2,74 \%$ & $-0,47 \%$ & $0,00 \%$ & $63,11 \%$ & $15,88 \%$ & $-8,63 \%$ & $-3,37 \%$ & $-30,49 \%$ & $-4,39 \%$ & $16,51 \%$ & $1,57 \%$ \\
\hline RPAD6 & Alfa Holding PNB & 2,66 & High & 176.088 .359 & Small & 0,12 & Winner & Small|High|Winner & $2,63 \%$ & $-2,94 \%$ & $-3,23 \%$ & $2,78 \%$ & $96,76 \%$ & $6,83 \%$ & $-6,74 \%$ & $15,01 \%$ & $-40,21 \%$ & $-6,90 \%$ & 1,85\% & $7,27 \%$ \\
\hline LEVE4 & Metal Leve PN & 4,09 & High & 37.003 .000 & Small & 0,16 & Winner & Small|High|Winner & $-5,34 \%$ & $4,20 \%$ & $-21,53 \%$ & $-6,55 \%$ & $6,06 \%$ & $10,71 \%$ & $43,55 \%$ & $5,62 \%$ & $38,19 \%$ & $10,08 \%$ & $18,88 \%$ & $7,65 \%$ \\
\hline BRGE11 & Alfa Consorc PNE & 3,03 & High & 167.818 .760 & Small & 0,17 & Winner & Small|High|Winner & $0,50 \%$ & $0,00 \%$ & $-1,14 \%$ & $3,61 \%$ & $79,10 \%$ & $27,94 \%$ & $-17,43 \%$ & $-0,84 \%$ & $-20,00 \%$ & $-9,09 \%$ & $0,00 \%$ & $3,33 \%$ \\
\hline FLCL5 & F Cataguazes PNA & 2,74 & High & 233.474 .411 & Small & 0,19 & Winner & Small|High|Winner & $4,84 \%$ & $-17,95 \%$ & $0,00 \%$ & $0,00 \%$ & $5,00 \%$ & $-16,67 \%$ & $-10,00 \%$ & $-12,70 \%$ & $11,82 \%$ & $-8,94 \%$ & $-8,04 \%$ & $-0,97 \%$ \\
\hline RPAD5 & Alfa Holding PNA & 2,66 & High & 176.088 .359 & Small & 0,19 & Winner & Small | High | Winner & $-3,06 \%$ & $1,71 \%$ & $0,53 \%$ & $4,71 \%$ & $75,00 \%$ & $13,99 \%$ & $-9,09 \%$ & $-6,46 \%$ & $-27,67 \%$ & $0,87 \%$ & $-1,72 \%$ & $7,02 \%$ \\
\hline PLAS4 & Plascar Part PN & 3,57 & High & 53.558 .618 & Small & 0,20 & Winner & Small|High|Winner & $-17,32 \%$ & $43,10 \%$ & $-1,83 \%$ & $-6,78 \%$ & $-15,45 \%$ & $-22,58 \%$ & $-5,56 \%$ & $26,47 \%$ & $41,63 \%$ & $5,91 \%$ & $-7,75 \%$ & $26,89 \%$ \\
\hline \begin{tabular}{|l|l|l|l} 
ALPA4 &
\end{tabular} & Alpargatas PN & 3,47 & High & 91.545 .991 & Small & 0,28 & Winner & Small|High|Winner & $-8.41 \%$ & $-24,47 \%$ & $26,17 \%$ & $-2,17 \%$ & $33,33 \%$ & $-6,87 \%$ & $\mid-10,52 \%$ & $28,00 \%$ & $5,11 \%$ & $3,12 \%$ & $2,27 \%$ & $6,67 \%$ \\
\hline RPSA4 & Ripasa PN & 7,32 & High & 67.432 .503 & Small & 0,30 & Winner & Small| |High |Winner & $10,00 \%$ & $-33,33 \%$ & $-13,64 \%$ & $-10,53 \%$ & $-17,65 \%$ & $-14,29 \%$ & \begin{tabular}{|l|}
$150,00 \%$ \\
\end{tabular} & $-6,67 \%$ & $0,00 \%$ & $14,29 \%$ & $12,50 \%$ & $25,00 \%$ \\
\hline ALPA3 & Alpargatas ON & 3,47 & High & 91.545 .991 & Small & 0,30 & Winner & Small|High |Winner & $4,88 \%$ & $27,67 \%$ & $17,65 \%$ & $-25,00 \%$ & $72,90 \%$ & $-33,73 \%$ & $-5,45 \%$ & $34,60 \%$ & $-0,18 \%$ & $-7,46 \%$ & $20,97 \%$ & $0,00 \%$ \\
\hline $\begin{array}{l}\text { ALAS } \\
\text { LUM4 } \\
\end{array}$ & $\begin{array}{l}\text { Trevisa PN } \\
\end{array}$ & $\begin{array}{ll}8,47 \\
8,48\end{array}$ & \begin{tabular}{|l} 
High \\
\end{tabular} & $\begin{array}{l}71.54 .078 .089 \\
\end{array}$ & \begin{tabular}{|l|} 
Small \\
\end{tabular} & $0,0,43$ & \begin{tabular}{|l|} 
Winner \\
\end{tabular} & \begin{tabular}{|l} 
Small| High |Winner \\
\end{tabular} & $\begin{array}{r}-3,00 \% \\
-3,23 \% \\
\end{array}$ & $\frac{-20,00 \%}{-20,00 \%}$ & $\begin{array}{l}1,030 \% \\
0,00 \% \\
\end{array}$ & $\begin{array}{c}-2,0603 \% \\
0,83 \% \\
\end{array}$ & $\mid 81,82 \%$ & $\frac{-3,5,5 \% \%}{4,55 \%}$ & $\begin{array}{c}-3,430 \% \\
-13,04 \% \\
\end{array}$ & $\begin{array}{l}-5,0,00 \% \\
-5,0 \% \\
\end{array}$ & \begin{tabular}{|l|l|}
$21,05 \%$ \\
\end{tabular} & $\begin{array}{r}-1,400 \% \\
-43,48 \% \\
\end{array}$ & $\mid$ & $10,77 \%$ \\
\hline CMET4 & Caemi PN & 4,11 & High & 262.544 .642 & Small & 0,60 & Winner & Small| |High |Winner & $-20,13 \%$ & $-34,58 \%$ & $-20,00 \%$ & $-8,93 \%$ & $0,00 \%$ & $3,31 \%$ & $79,59 \%$ & $-7,95 \%$ & $13,58 \%$ & $8,15 \%$ & $-4,17 \%$ & $30,43 \%$ \\
\hline OXIT4 & Oxiteno PN & 3.52 & High & $170,722,662$ & Small & 0.63 & Winner & SmallHigh/Winner & $4.35 \%$ & $-5.56 \%$ & $-1618 \%$ & $-175 \%$ & $361 \%$ & $0,00 \%$ & $5.36 \%$ & $18,64 \%$ & $32,31 \%$ & $-15.56 \%$ & $61.44 \%$ & $-484 \%$ \\
\hline SGAS4 & WIm In & 5,20 & High & 162 & Small & 0,63 & Winner & Small|Hig & $-2,99 \%$ & 0,00\% & $-16,92 \%$ & $7,41 \%$ & $-1,72 \%$ & $-5,26 \%$ & $3,70 \%$ & $-7,14 \%$ & $32,69 \%$ & $-10,14 \%$ & $-11,29 \%$ & $-7,27 \%$ \\
\hline $\begin{array}{l}\text { ILMD4 } \\
\text { ILMP }\end{array}$ & Yara Brasil PN & 9,28 & High & 8.928 .571 & \begin{tabular}{|l|} 
Small \\
\end{tabular} & 0,85 & \begin{tabular}{|l} 
Winner \\
\end{tabular} & \begin{tabular}{|l} 
Small||High |Winner \\
\end{tabular} & $-4,00 \%$ & $-16,67 \%$ & $-39,50 \%$ & $14,05 \%$ & $60,14 \%$ & -9,50\% & $-15,00 \%$ & $-34,71 \%$ & $154,95 \%$ & $-29,33 \%$ & \begin{tabular}{|l|l|}
$0,00 \%$ \\
\end{tabular} & $25,00 \%$ \\
\hline RHDS3 & MG Poliest ON & 0,67 & Low & 80.643 .198 & Small & 0,32 & Loser & Small|Low|Loser & $-25,00 \%$ & $-16,67 \%$ & $-40,00 \%$ & $-16,67 \%$ & $-40,00 \%$ & $66,67 \%$ & $40,00 \%$ & $14,29 \%$ & $0,00 \%$ & $-25,00 \%$ & $33,33 \%$ & $0,00 \%$ \\
\hline \begin{tabular}{|l|l|l|l|l|l} 
LIPR3 \\
\end{tabular} & Eletropar ON & 0,79 & Low & 4.260 .247 & Small & 0,20 & Loser & Small|Low|Loser & $141,46 \%$ & $-52,53 \%$ & $80,85 \%$ & $-11,76 \%$ & $-5,33 \%$ & $-9,86 \%$ & $-9,37 \%$ & $20,69 \%$ & $1285,71 \%$ & $-56,70 \%$ & $-2,14 \%$ & $-9,00 \%$ \\
\hline FRAS4 & Fras-Le PN & 0,43 & Low & 78.016 .203 & Small & 0,18 & Loser & Small|Lo & $-3,12 \%$ & $-14,84 \%$ & $-9,09 \%$ & $-19,17 \%$ & $-1,03 \%$ & $-7,29 \%$ & $12,36 \%$ & $15,00 \%$ & $-3,48 \%$ & $5,41 \%$ & $-23,26 \%$ & $2,35 \%$ \\
\hline PMAM4 & Paranapanema PN & 0,62 & $\begin{array}{l}\text { Low } \\
\end{array}$ & 169.668 .946 & Small & 0,01 & \begin{tabular}{|l|} 
Loser \\
\end{tabular} & Small|Low|Loser & $-16,42 \%$ & $12,50 \%$ & $-28,57 \%$ & $-31,11 \%$ & 19,35\% & $-10,81 \%$ & $\mid-3,29 \%$ & $-4,00 \%$ & $12,85 \%$ & $\begin{array}{r}-3,4,08 \% \\
-3,0 \%\end{array}$ & $-5,08 \%$ & $\begin{array}{l}-3,34 \% \\
-1340\end{array}$ \\
\hline ESTR4 & Estrela PN & 1,04 & Low & 8.568 .510 & Small & 0,00 & Winner & Small|Low|Winner & $-43,64 \%$ & $-41,94 \%$ & $38,89 \%$ & $-28,00 \%$ & $77,78 \%$ & $18,75 \%$ & $-7,89 \%$ & $-8,57 \%$ & $0,00 \%$ & $15,63 \%$ & $-18,92 \%$ & $6,67 \%$ \\
\hline CPFL4 & Ferro Ligas PN & 0,04 & Low & 38.670 .152 & Small & & Winner & Small|Low|Winner & $-50,00 \%$ & $0,00 \%$ & $0,00 \%$ & $0,00 \%$ & $0,00 \%$ & $-50,00 \%$ & $100,00 \%$ & $0,00 \%$ & $50,00 \%$ & $-33,33 \%$ & $0,00 \%$ & $50,00 \%$ \\
\hline LORZ4 & Lorenz PN & 0,69 & Low & 24.998 & Small & 0,02 & Winner & Small|Low|Winner & $-33,44 \%$ & $-18,89 \%$ & $-10,96 \%$ & $-6,15 \%$ & $-17,62 \%$ & $-10,45 \%$ & $44,44 \%$ & $-3,85 \%$ & $-6,40 \%$ & $-23,08 \%$ & $-26,67 \%$ & $13,64 \%$ \\
\hline ALBA3 & Albarus ON & 1,09 & Low & 193.600 .003 & Small & 0,02 & Winner & Small|Low |Winner & $-12,50 \%$ & $-21,43 \%$ & $-9,09 \%$ & $-10,00 \%$ & $51,11 \%$ & $35,21 \%$ & $0,00 \%$ & $-2,53 \%$ & $16,88 \%$ & $0,00 \%$ & $0,00 \%$ & $37,78 \%$ \\
\hline ARTE4 & Kuala PN & 2,31 & Medium & 18.405 .371 & Small & 0,66 & Loser & Small|Medium|Loser & $0,00 \%$ & $-27,27 \%$ & $-25,00 \%$ & $0,00 \%$ & $0,00 \%$ & $-16,67 \%$ & $200,00 \%$ & $-20,00 \%$ & $41,67 \%$ & $0,00 \%$ & $5,88 \%$ & $0,00 \%$ \\
\hline MFLU3 & Santista Alimentos ON & 1,43 & Medium & 113.348 .002 & Small & 0,60 & Loser & Small|Medium | Loser & $-7,50 \%$ & $-18,92 \%$ & $-11,67 \%$ & $43,40 \%$ & $5,26 \%$ & $26,25 \%$ & $-35,64 \%$ & $-27,69 \%$ & $14,89 \%$ & $-11,11 \%$ & $-8,33 \%$ & $6,82 \%$ \\
\hline ITEC3 $>2>C$ & 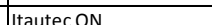 & 182 & Medium & & small & 049 & Loser & SmallIMediumloser & $-2647 \%$ & $-720 \%$ & $-1379 \%$ & $-10.00 \%$ & $-778 \%$ & $361 \%$ & $-698 \%$ & $-8,75 \%$ & $3014 \%$ & $0.00 \%$ & $1579 \%$ & $63.64 \%$ \\
\hline CEVA4 & Bunge Alim & $\frac{1,162}{1,19}$ & Medium & 564.814 & Small & 0,44 & \begin{tabular}{|l|l|} 
Loser \\
\end{tabular} & Small|Medium|Loser & $16,50 \%$ & $-17,71 \%$ & $-11,39 \%$ & $-14,29 \%$ & $30,00 \%$ & $-10,26 \%$ & $13,43 \%$ & $-8,06 \%$ & $28,58 \%$ & $0,00 \%$ & $-10,96 \%$ & $-16,92 \%$ \\
\hline $\begin{array}{ll}\text { CEBAR5 } \\
\end{array}$ & Ceb PNA & $\frac{1,19}{1,26}$ & Medium & 201.044 .299 & \begin{tabular}{|l|} 
Small \\
Small
\end{tabular} & 0,36 & \begin{tabular}{|l} 
Loser \\
\end{tabular} & Small| Medium | Loser & $\begin{array}{l}-10,00 \% \\
-8,89 \% \\
\end{array}$ & - & $\begin{array}{l}-81,390 \\
-8,74 \% \\
\end{array}$ & \begin{tabular}{|c|}
$-14,4513 \%$ \\
$14,34 \%$ \\
\end{tabular} & $24,58 \%$ & $\begin{array}{l}-10,02 \% \\
-9,70 \% \\
\end{array}$ & $\mid$\begin{tabular}{|c|}
$5,45 \%$ \\
$5,19 \%$
\end{tabular} & $\begin{array}{l}-0,00 \% \\
19,65 \% \\
\end{array}$ & \begin{tabular}{|c|c|}
$-30,44 \%$ \\
$-3,4$
\end{tabular} & $\begin{array}{l}0,00 \% \\
6,06 \% \\
\end{array}$ & \begin{tabular}{|l|}
$-5,18 \%$ \\
$-50 \%$
\end{tabular} & $\begin{array}{l}-10,9270 \\
26,79 \% \\
\end{array}$ \\
\hline TRFO4 & Trafo PN & 1,60 & Medit & 21.448 .051 & Small & 0,35 & Loser & Small|Medium |Loser & $4,10 \%$ & $0,00 \%$ & $-30,05 \%$ & $-7,04 \%$ & $-5,30 \%$ & $-16,00 \%$ & $13,25 \%$ & $17,02 \%$ & $13,64 \%$ & $-16,00 \%$ & $3,81 \%$ & $19,27 \%$ \\
\hline SNSY5 & Sansu & 1,53 & Mediun & 3.490 & Small & 0,31 & Loser & Small|Medium Loser & $-3,85 \%$ & $-28,00 \%$ & $-16,67 \%$ & $-11,11 \%$ & $15,00 \%$ & $-13,04 \%$ & $0,00 \%$ & $-12,50 \%$ & $20,00 \%$ & $\mid-13,81 \%$ & $10,50 \%$ & $30,00 \%$ \\
\hline BMTO4 & Brasmotor PN & 2,36 & Medit & 827.709 & Small & 30 & Loser & Small |Me & $14,22 \%$ & $5,49 \%$ & $-18,00 \%$ & $21,95 \%$ & $-12,01 \%$ & $9,10 \%$ & $-12,93 \%$ & $11,76 \%$ & $14,04 \%$ & $-9,24 \%$ & $20,35 \%$ & $-1,48 \%$ \\
\hline \begin{tabular}{|l|l} 
MAHS4 \\
\end{tabular} & Bunge Fertilizantes PN & 2,22 & Medium & 038.693 & \begin{tabular}{|l|l|} 
Small \\
\end{tabular} & 0,30 & \begin{tabular}{|l|} 
Loserer \\
\end{tabular} & Small|Medium|Loser & $\frac{14,220}{0,00 \%}$ & $\frac{0,4501}{-24,44 \%}$ & $-1.0,40 \%$ & \begin{tabular}{|l|l|}
$-19,43 \%$ \\
$-193 \%$
\end{tabular} & $\mid$ & $\begin{array}{l}, 1070 \\
4,76 \% \\
\end{array}$ & \begin{tabular}{|l|}
$-17,27 \%$ \\
$-17 \%$
\end{tabular} & $-17,58 \%$ & 73,20\% & $\begin{array}{l}-3,240 \\
-3,77 \% \\
\end{array}$ & $\mid \begin{array}{l}\mid-4,16 \% \\
-4,16 \%\end{array}$ & $62,77 \%$ \\
\hline MYPK4 & lochp-Maxion PN & 2,19 & Medium & 72.256 .794 & Small & 0,28 & Loser & Small|Medium|Loser & $-18,85 \%$ & $-18,60 \%$ & $-0,03 \%$ & $5,74 \%$ & $-51,38 \%$ & $-44,41 \%$ & $20,00 \%$ & $5,00 \%$ & $-24,60 \%$ & $87,37 \%$ & $-26,97 \%$ & $-0,77 \%$ \\
\hline ELEV3 & Eleva ON & 2,23 & Medium & 118.994 .196 & Small & 0,26 & Loser & Small|Medium Loser & $14,13 \%$ & $-23,81 \%$ & $-18,75 \%$ & $15,38 \%$ & $13,33 \%$ & $-3,53 \%$ & $15.85 \%$ & $-2.63 \%$ & $12.97 \%$ & $305 \%$ & $-8.65 \%$ & $9,47 \%$ \\
\hline SHAP4 & Sharp : & 1,87 & Medi & 990.521 & Small & 0,24 & Loser & Small|Me & $-1,92 \%$ & $-47,06 \%$ & $3,70 \%$ & $-21,43 \%$ & $-13,64 \%$ & $-5,26 \%$ & $-5,56 \%$ & $-17,65 \%$ & $42,86 \%$ & $5,00 \%$ & $-9,52 \%$ & $0,00 \%$ \\
\hline BDL44 & Bardella PN & 1,17 & Medi & 227.568 & Small & 7 & $\begin{array}{ll}\text { Loser } \\
\end{array}$ & Small|Medium |Loser & $-1,27 \%$ & $-5,18 \%$ & $-31,81 \%$ & $-2,68 \%$ & $-6,84 \%$ & $-18,09 \%$ & $-6,25 \%$ & $8,89 \%$ & $24,49 \%$ & $1,48 \%$ & $-11,15 \%$ & $-9,09 \%$ \\
\hline \begin{tabular}{|l|} 
DXTG4 \\
\end{tabular} & Dixie Tog & 1,34 & Medl & 44 & Small & 0,07 & Loser & Small|Medium | Loser & $-8,16 \%$ & $-22,22 \%$ & $-17,14 \%$ & $6,90 \%$ & $19,35 \%$ & $-2,70 \%$ & $11,11 \%$ & $15,00 \%$ & $-2,17 \%$ & $8,89 \%$ & $-9,94 \%$ & $-22,73 \%$ \\
\hline IBAN5 & Antarct Nordeste PNA & 1,15 & Medium & 235.807 .955 & Small & 0,04 & Loser & Small|Medium | Loser & $0,02 \%$ & $-0,28 \%$ & $-28,42 \%$ & $-2,80 \%$ & $-17,70 \%$ & $-7,50 \%$ & $-5,41 \%$ & $-28,00 \%$ & $7,13 \%$ & $-0,18 \%$ & $18,45 \%$ & $-12,34 \%$ \\
\hline SOLO4 & Cargill Fert & 2,37 & Mediun & 30.519 .500 & Small & 0,05 & Winner & Small|Medium | Winne & $1,82 \%$ & $-21,43 \%$ & $-9,09 \%$ & $5,00 \%$ & $0,00 \%$ & $28,13 \%$ & $29,41 \%$ & $22,73 \%$ & $51,85 \%$ & $9,76 \%$ & $-13,30 \%$ & $16,36 \%$ \\
\hline DPPI4 & Ipirange & 1,23 & led & & Sma & 0,06 & Win & all $\mid \mathrm{M}$ & $4,17 \%$ & $-20,83 \%$ & $-15,79 \%$ & $-3,13 \%$ & $25,16 \%$ & $-4,21 \%$ & $10,12 \%$ & $1 \%$ & $23,81 \%$ & $5 \%$ & 2,2 & $30,36 \%$ \\
\hline CETE4 & Ceterp PN & 1,79 & Medi & 80 & Small & & Winner & Small|Medium/Winner & $-20,62 \%$ & $-30,91 \%$ & $-14,81 \%$ & $-6,35 \%$ & $-3,57 \%$ & $-11,48 \%$ & $21,34 \%$ & $18,97 \%$ & $1,45 \%$ & $3,15 \%$ & $27,27 \%$ & $54,52 \%$ \\
\hline \begin{tabular}{|l|} 
RIPI4 \\
\end{tabular} & Ipiranga Ref PN & 2,11 & Medium & 133.820 .643 & Small & 0,12 & Winner & Small|Medium/Winner & $20,81 \%$ & $-13,19 \%$ & $-7,47 \%$ & $-11,08 \%$ & $43,08 \%$ & $-1,88 \%$ & $7,78 \%$ & $9,14 \%$ & $34,83 \%$ & $0,00 \%$ & $5,00 \%$ & $26,98 \%$ \\
\hline BARB3 & s Gobain & 1,27 & Mediun & 169.922 .376 & Small & 0,17 & Winner & Small|Medium/Winner & $11,30 \%$ & $-21,87 \%$ & $-30,00 \%$ & $-7,14 \%$ & $15,38 \%$ & $-6,67 \%$ & $-7,14 \%$ & $7,69 \%$ & $42,86 \%$ & $-1,99 \%$ & $20,00 \%$ & $-2,78 \%$ \\
\hline EBCO4 & Embr & & 4 & & $\mathrm{Sm}$ & & Win & Small|M & $12,38 \%$ & $-22,86 \%$ & $-18,52 \%$ & $13,64 \%$ & $32,00 \%$ & $6,06 \%$ & 36, & $8,70 \%$ & $6,00 \%$ & $-9,43 \%$ & $22,92 \%$ & \\
\hline \begin{tabular}{|l|} 
DOMO4 \\
POMO
\end{tabular} & Marcopolo PN & 1,71 & Medi & 91 & \begin{tabular}{|l|} 
Small \\
\end{tabular} & 26 & \begin{tabular}{|l} 
Winner \\
\end{tabular} & Small|Medium/Winner & $\begin{array}{l}1,30 \% \\
0,62 \% \\
\end{array}$ & - & $\begin{array}{l}-1 ., 252 \% \\
-12,50 \% \\
\end{array}$ & $\begin{array}{c}-19,64 \% \% \\
-19,62 \% \\
\end{array}$ & | $32,07 \%$ & $\begin{array}{l}0,00 \% \\
10,00 \% \\
\end{array}$ & 25,05\% | 25,4 & $\begin{array}{l}0,0 \% \\
0,72 \% \\
\end{array}$ & - & $\begin{array}{l}-\frac{-1,45 \%}{1,32 \%} \\
\end{array}$ & | & $\begin{array}{l}1,0,01 \% \\
29,01 \%\end{array}$ \\
\hline POLA4 & Polar PN & 1,56 & Medium & 182.203 .653 & Small & 0,26 & Winner & Small|Medium/Winner & $-5,00 \%$ & $-7,89 \%$ & $-9,51 \%$ & $-11,84 \%$ & $-2,99 \%$ & $-9,23 \%$ & $6,78 \%$ & $-4,76 \%$ & $29,17 \%$ & $14,19 \%$ & $-1,23 \%$ & $-3,23 \%$ \\
\hline MAGS5 & Magnesita PI & 2,25 & Medium & 96.678 .312 & Small & 0.27 & Winner & Small/Medium/Winner & $3.35 \%$ & $-28,24 \%$ & $-10,97 \%$ & $1,45 \%$ & $-1,43 \%$ & $13,29 \%$ & $11.94 \%$ & $-4,67 \%$ & $22,38 \%$ & $620 \%$ & $0.54 \%$ & $10,70 \%$ \\
\hline ETER3 & Eternit ON & 1,38 & Medium & 195.145 .721 & Small & 0,31 & Winner & \begin{tabular}{|l} 
SmalluMedium/Winer \\
\end{tabular} & $5,36 \%$ & $-21,53 \%$ & $-1361 \%$ & $15,00 \%$ & $4,35 \%$ & $23,59 \%$ & $11,11 \%$ & $800 \%$ & $13,70 \%$ & $-2,28 \%$ & $-4.33 \%$ & $-7,67 \%$ \\
\hline
\end{tabular}


Anexo 1 - Retorno mensal e classificação das ações

\begin{tabular}{|c|c|c|c|c|c|c|c|c|c|c|c|c|c|c|c|c|c|c|c|c|}
\hline Código & 1998 - 1999 & $\begin{array}{l}\text { Índice } B / M \\
\text { de dez/1997 }\end{array}$ & $\begin{array}{c}\text { Grupo com } \\
\text { base no } \\
\text { indice B/M }\end{array}$ & $\begin{array}{c}\text { Valor de Mercado } \\
\text { em jun/1998 }\end{array}$ & $\begin{array}{c}\text { Grupo com } \\
\text { base no } \\
\text { tamanho }\end{array}$ & $\begin{array}{c}\text { Retorno } \\
\text { acumulado } \\
\text { de jun/1998 }\end{array}$ & $\begin{array}{c}\text { Grupo com } \\
\text { base no } \\
\text { retorno } \\
\text { acumulado }\end{array}$ & Carteiras & $\mathrm{jul} / 98$ & ago/98 & set/98 & out $/ 98$ & nov/98 & $\mathrm{dez} / 98$ & $\mathrm{jan} / 99$ & $\mathrm{fev} / 99$ & $\mathrm{mar} / 99$ & $\mathrm{abr} / 99$ & mai/99 & jun/99 \\
\hline BARB4 & S Gobain Canal PN & 1,27 & Medium & 169.922 .376 & Small & 0,32 & Winner & Small|Medium|Winner & $18,75 \%$ & $-18,30 \%$ & $-34,78 \%$ & $1,33 \%$ & $15,13 \%$ & $-17,71 \%$ & $21,53 \%$ & $0,00 \%$ & $40,57 \%$ & $-13,54 \%$ & $9,30 \%$ & $0,00 \%$ \\
\hline VAGV4 & Savarg PN & 1,39 & Medium & \begin{tabular}{ll|l|l}
144.748 .885 \\
\end{tabular} & Small & 0,36 & Winner & Small|Medium|Winner & $-7,25 \%$ & $-8,85 \%$ & $-20,00 \%$ & $-7,14 \%$ & $31,54 \%$ & $1,12 \%$ & $-11,11 \%$ & $3,75 \%$ & $-31,33 \%$ & $24,56 \%$ & $-15,49 \%$ & $125,00 \%$ \\
\hline MSAN4 & Bunge Brasil PN & 1,77 & Medium & 140.312 .740 & Small & 0,38 & Winner & Small|Medium|Winner & $11,48 \%$ & $-22,06 \%$ & $-1,89 \%$ & $-19,23 \%$ & $-4,76 \%$ & $12,50 \%$ & $2,22 \%$ & $-2,17 \%$ & $17,78 \%$ & $0,00 \%$ & $1,89 \%$ & $-1,85 \%$ \\
\hline LITS3 & Brasilit ON & 1,64 & Medium & 235.874 .343 & Small & 0,40 & Winner & Small|Medium|Winner & $6,45 \%$ & $-27,27 \%$ & $0,00 \%$ & $0,00 \%$ & $8,33 \%$ & $-3,85 \%$ & $8,00 \%$ & $0,00 \%$ & $3,70 \%$ & $-2,29 \%$ & $4,62 \%$ & $6,62 \%$ \\
\hline MSAN3 & Bunge Brasil ON & 1,77 & Medium & 140.312 .740 & Small & 0,49 & Winner & Small|Medium|Winner & $9,52 \%$ & $-13,04 \%$ & $-16,67 \%$ & $-16,00 \%$ & $11,90 \%$ & $17,02 \%$ & $-18,18 \%$ & $8,89 \%$ & $4,08 \%$ & $5,88 \%$ & $12,96 \%$ & $-1,64 \%$ \\
\hline CNFB4 & Confab PN & 1.14 & Medium & 186.046 .184 & Small & 0,50 & Winner & Small/Medium/Winner & $3,09 \%$ & $-33,50 \%$ & $-24,81 \%$ & $-2,00 \%$ & $15,31 \%$ & $-13,27 \%$ & $-1,96 \%$ & $24,71 \%$ & $29,35 \%$ & $5,19 \%$ & $7,04 \%$ & $0,66 \%$ \\
\hline
\end{tabular}

\begin{tabular}{|c|c|c|c|c|c|c|c|c|c|c|c|c|c|c|c|c|c|c|c|c|}
\hline Código & $1999-2000$ & $\begin{array}{l}\text { Índice } B / M \\
\text { de dez/1998 }\end{array}$ & $\begin{array}{c}\text { Grupo com } \\
\text { base no } \\
\text { indice B/M }\end{array}$ & $\begin{array}{c}\text { Valor de Mercado } \\
\text { em jun/1999 }\end{array}$ & $\begin{array}{c}\text { Grupo com } \\
\text { base no } \\
\text { tamanho }\end{array}$ & \begin{tabular}{|c|} 
Retorno \\
acumulado \\
de jun/1999
\end{tabular} & \begin{tabular}{|l} 
Grupo com \\
base no \\
retorno \\
acumulado
\end{tabular} & Carteiras & $\mathrm{jul} / 99$ & ago/99 & set/99 & out $/ 99$ & nov/99 & dez/99 & jan/00 & fev/00 & $\mathrm{mar} / 00$ & $\mathrm{abr} / 00$ & mai/00 & jun/00 \\
\hline TEBA5 & Telebahia PNA & 5,94 & High & 365.940 .849 & Big & 0,41 & Loser & Big|High|Loser & $-3,30 \%$ & $9,54 \%$ & $0,20 \%$ & $-4,42 \%$ & $59,27 \%$ & $17,50 \%$ & $-4,46 \%$ & $14,30 \%$ & $13,20 \%$ & $-16,88 \%$ & $-7,44 \%$ & $9,33 \%$ \\
\hline CSTB4 & Sid Tubarao PN & 12,09 & High & 860.158 .247 & Big & 0,21 & Loser & Big|High|Loser & $-24,80 \%$ & $18,06 \%$ & $-5,29 \%$ & $3,11 \%$ & $64,40 \%$ & $8,10 \%$ & $-5,80 \%$ & $-1,40 \%$ & $-0,36 \%$ & $-7,69 \%$ & $-2,19 \%$ & $-6,14 \%$ \\
\hline SUZB5 & Suzano Papel PNA & 11,24 & High & 307.780 .019 & Big & 0,21 & Loser & Big|High|Loser & $21,01 \%$ & $17,37 \%$ & $22,45 \%$ & $58,33 \%$ & $21,05 \%$ & $19,57 \%$ & $-10,00 \%$ & $-15,15 \%$ & $-8,33 \%$ & $-9,09 \%$ & $13,66 \%$ & $16,88 \%$ \\
\hline ARCE3 & Arcelor BR ON & 5,75 & High & 317.406 .322 & Big & 0,19 & Loser & Big|High|Loser & $9,38 \%$ & $1,15 \%$ & $23,56 \%$ & $40,08 \%$ & $3,33 \%$ & $20,43 \%$ & $13,84 \%$ & $1,95 \%$ & $-12,30 \%$ & $8,89 \%$ & $15,70 \%$ & $-10,71 \%$ \\
\hline KLBN4 & Klabin S/A PN & 4,68 & High & \begin{tabular}{|l|}
672.247 .688 \\
\end{tabular} & Big & 0,15 & Loser & Big|High|Loser & $4,44 \%$ & $-3,19 \%$ & $\begin{array}{ll}12,09 \% \\
\end{array}$ & $2,01 \%$ & $20,39 \%$ & $20,97 \%$ & $12,00 \%$ & $-1,79 \%$ & $-3,03 \%$ & $-0,56 \%$ & $-1,27 \%$ & $-2,58 \%$ \\
\hline ARCE4 & Arcelor BR PN & 5,75 & High & 317.406 .322 & Big & 0,15 & Loser & Big|High|Loser & $20,83 \%$ & $6,88 \%$ & $20,99 \%$ & $21,32 \%$ & $5,51 \%$ & $25,00 \%$ & $38,33 \%$ & $-9,64 \%$ & $-2,00 \%$ & $-1,15 \%$ & $10,56 \%$ & $-1,90 \%$ \\
\hline USIM5 & Usiminas PNA & 4,43 & High & 1.080.958.411 & Big & 0,09 & Loser & Big|High|Loser & $-11,07 \%$ & $8,38 \%$ & $9,91 \%$ & $16,39 \%$ & $14,65 \%$ & $20,39 \%$ & $7,14 \%$ & $-8,57 \%$ & $-7,94 \%$ & $-12,72 \%$ & $5,96 \%$ & $4,25 \%$ \\
\hline ELET3 & Eletrobras ON & 5,27 & High & 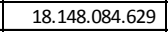 & Big & 0,04 & Winner & Big|High|Winner & $-12,84 \%$ & $2,71 \%$ & $7,02 \%$ & $5,00 \%$ & $16,04 \%$ & $1,33 \%$ & $-17,05 \%$ & $-4,39 \%$ & $1,01 \%$ & $-13,87 \%$ & $8,91 \%$ & $27,24 \%$ \\
\hline ELET6 & Eletrobras PNB & 5,27 & High & 18.148 .084 .629 & Big & 0,02 & Winner & Big|High|Winner & $-14,59 \%$ & $-0,46 \%$ & $7,41 \%$ & $6,44 \%$ & $14,70 \%$ & $8,29 \%$ & $-13,72 \%$ & $-7,17 \%$ & $3,55 \%$ & $-11,04 \%$ & $3,69 \%$ & $29,13 \%$ \\
\hline GOAU4 & Gerdau Met PN & \begin{tabular}{ll|l}
4,41 \\
\end{tabular} & High & 509.408.855 & Big & 0,01 & Winner & Big|High|Winner & $2,28 \%$ & $7,62 \%$ & $-1,06 \%$ & $13,60 \%$ & $15,43 \%$ & $22,95 \%$ & $\begin{array}{ll}0,00 \% \\
\end{array}$ & $-3,45 \%$ & $-4,76 \%$ & $1,25 \%$ & $-3,70 \%$ & $2,61 \%$ \\
\hline CESP3 & Cesp ON & 7,58 & High & 2.838 .723 .676 & Big & 0,10 & Winner & Big|High|Winner & $-23,72 \%$ & $-8,60 \%$ & $2,35 \%$ & $-4,76 \%$ & $29,31 \%$ & $10,67 \%$ & $-13,86 \%$ & $6,29 \%$ & $0,00 \%$ & $-5,26 \%$ & $30,56 \%$ & $34,04 \%$ \\
\hline CESP5 & Cesp PNA & 7,58 & High & 2.838 .723 .676 & Big & 0,11 & Winner & Big|High|Winner & $-23,52 \%$ & $7,15 \%$ & $1,26 \%$ & $-0,50 \%$ & $20,00 \%$ & $18,75 \%$ & $-12,81 \%$ & $19,72 \%$ & $-0,92 \%$ & $-20,27 \%$ & $37,70 \%$ & $22,28 \%$ \\
\hline GOAU3 & Gerdau Met ON & 4,41 & High & 509.408 .855 & Big & 0,14 & Winner & Big|High/Winner & $-2,86 \%$ & $8,59 \%$ & $11,94 \%$ & $14,89 \%$ & $7,35 \%$ & $17,09 \%$ & $3,23 \%$ & $-1,56 \%$ & $-1,59 \%$ & $-2,42 \%$ & $5,79 \%$ & $-12,57 \%$ \\
\hline BRKM5 & Braskem PNA & 8,93 & High & 456.878 .422 & Big & 0,25 & Winner & Big|High|Winner & $11,64 \%$ & $0,55 \%$ & $15,44 \%$ & 6,69\% & $29,77 \%$ & $29,16 \%$ & $2,01 \%$ & $2,22 \%$ & $-1,15 \%$ & $1,33 \%$ & $1,51 \%$ & $11,82 \%$ \\
\hline PTQS4 & Petroquisa PN & 5,26 & High & 1.900 .865 .393 & Big & 0,54 & Winner & Big|High/Winner & $14,58 \%$ & $15,45 \%$ & $2,37 \%$ & $7,68 \%$ & $43,33 \%$ & $3,18 \%$ & $-7,69 \%$ & $14,00 \%$ & $-2,80 \%$ & $-7,36 \%$ & $-0,56 \%$ & $-0,56 \%$ \\
\hline EMBR3 & Embraer ON & 0,72 & Low & $\begin{array}{l}1.441 .228 .180 \\
\end{array}$ & Big & 0,89 & Loser & Big|Low|Loser & $65,89 \%$ & $13,10 \%$ & $8,59 \%$ & $10,63 \%$ & $-10,96 \%$ & $51,77 \%$ & $-7,89 \%$ & $1,75 \%$ & $8,80 \%$ & $6,15 \%$ & $-13,79 \%$ & $34,74 \%$ \\
\hline LIGT3 & Light S/A ON & 1,53 & Low & 1.960 .802 .830 & Big & 0,59 & Loser & Big|Low|Loser & $-16,59 \%$ & $-6,47 \%$ & $29,57 \%$ & $13,68 \%$ & $16,05 \%$ & $5,85 \%$ & $20,63 \%$ & $1,64 \%$ & $-9,83 \%$ & $-5,30 \%$ & $-12,64 \%$ & $12,63 \%$ \\
\hline TMGC7 & Telemig Cl PNC & 0,85 & Low & 341.583 .476 & Big & 0,58 & Loser & Big|Low|Loser & $-4,13 \%$ & $1,32 \%$ & $18,30 \%$ & $11,05 \%$ & $24,38 \%$ & $31,76 \%$ & $-11,29 \%$ & 17,24\% & $67,65 \%$ & $-19,07 \%$ & $-13,26 \%$ & $15,29 \%$ \\
\hline TRJC6 & Telerj Cel PNB & 0,55 & Low & 1.759.563.975 & Big & 0,53 & Loser & Big|Low|Loser & $-30,80 \%$ & $-8,75 \%$ & $0,00 \%$ & $7,95 \%$ & $-2,31 \%$ & $29,64 \%$ & $-17,84 \%$ & $3,90 \%$ & $11,03 \%$ & $0,42 \%$ & $13,68 \%$ & $7,04 \%$ \\
\hline EBEN4 & Bandeirante Energ PN & 0,60 & Low & 362.081 .408 & Big & 0,52 & Loser & Big|Low|Loser & $-1,02 \%$ & $-7,22 \%$ & $2,22 \%$ & $2,17 \%$ & $10,53 \%$ & $5,87 \%$ & $0,00 \%$ & $11,36 \%$ & $10,20 \%$ & $-1,48 \%$ & $-17,29 \%$ & $14,55 \%$ \\
\hline TMGC3 & Telemig Cl ON & 0,85 & Low & 341.583 .476 & Big & 0,50 & Loser & Big|Low|Loser & $-20,83 \%$ & $-4,21 \%$ & $20,88 \%$ & $49,91 \%$ & $23,71 \%$ & $37,21 \%$ & \begin{tabular}{l|l|}
$1,82 \%$ \\
\end{tabular} & $-26,32 \%$ & $71,57 \%$ & $-16,74 \%$ & $-13,33 \%$ & $15,38 \%$ \\
\hline CTNM4 & Coteminas PN & 1,43 & Low & 366.121 .839 & Big & 0,44 & Loser & Big|Low|Loser & $-5,41 \%$ & $-17,85 \%$ & $-0,10 \%$ & $20,10 \%$ & $8,70 \%$ & $9,99 \%$ & $-5,99 \%$ & $16,70 \%$ & $-12,71 \%$ & $-14,56 \%$ & $-7,13 \%$ & $25,83 \%$ \\
\hline CGAS5 & Comgas PNA & 0,65 & Low & 575.149 .445 & Big & 0,41 & Loser & Big|Low|Loser & $-10,42 \%$ & $-9,30 \%$ & $0,26 \%$ & $3,32 \%$ & $18,81 \%$ & $2,08 \%$ & $-4,10 \%$ & $21,30 \%$ & $-5,26 \%$ & $-13,33 \%$ & $-12,39 \%$ & $36,34 \%$ \\
\hline CBEE3 & Ampla Energ ON & 0,51 & Low & 665.557 .185 & Big & 0,36 & Loser & Big/Low /Loser & $-11,63 \%$ & $-21,05 \%$ & $23,33 \%$ & $8,11 \%$ & $22,50 \%$ & $12,24 \%$ & $-7,27 \%$ & $-17,65 \%$ & $26,19 \%$ & $7,55 \%$ & $19,30 \%$ & $2,94 \%$ \\
\hline ICPI4 & Cim Itau PN & 1,53 & Low & $\begin{array}{l}595.193 .999 \\
\end{array}$ & Big & 0,14 & Loser & \begin{tabular}{|l|} 
Big|Low|Loser \\
\end{tabular} & $-8,23 \%$ & $2,56 \%$ & $13,12 \%$ & $6,35 \%$ & $27,79 \%$ & $2,85 \%$ & $2,14 \%$ & $1,99 \%$ & $-8,20 \%$ & $-3,62 \%$ & $-0,90 \%$ & $13,64 \%$ \\
\hline ELPL5 & Eletropaulo PNA & 1,12 & Low & 3.305.041.940 & Big & 0,12 & Loser & Big|Low|Loser & $-8,61 \%$ & $-7,20 \%$ & $35,82 \%$ & $-2,20 \%$ & $12,35 \%$ & $17,01 \%$ & $-0,01 \%$ & $4,28 \%$ & $10,46 \%$ & $-20,37 \%$ & $-1,44 \%$ & $23,90 \%$ \\
\hline EMBR4 & Embraer PN & 0,72 & Low & 1.441 .228 .180 & Big & 0,11 & Loser & Big|Low|Loser & $67,67 \%$ & $5,77 \%$ & $2,98 \%$ & $20,37 \%$ & $-6,92 \%$ & $34,71 \%$ & $-0,61 \%$ & $1,12 \%$ & $1,13 \%$ & $17,39 \%$ & $-12,17 \%$ & $24,81 \%$ \\
\hline WEGE4 & Weg PN & 1,00 & Low & 471.897 .750 & Big & 0,11 & Loser & Big Low /Loser & $13,63 \%$ & $-3,61 \%$ & $6,25 \%$ & $5,88 \%$ & $\mid 14,44 \%$ & $9,17 \%$ & $1,82 \%$ & $-3,57 \%$ & $-14,81 \%$ & $-2,17 \%$ & $4,44 \%$ & $4,26 \%$ \\
\hline AMBV3 & Amber ON & 0,39 & Low & 6.097 .041 .544 & Big & 0,05 & Winner & Big|Low |Winner & $15,02 \%$ & $-1,27 \%$ & $3,85 \%$ & $3,70 \%$ & $3,57 \%$ & $-2,87 \%$ & $6,13 \%$ & $-9,09 \%$ & $12,87 \%$ & $5,20 \%$ & $0,00 \%$ & $22,58 \%$ \\
\hline PIRE4 & Pirelli PN & 0,44 & Low & 408.589 .264 & Big & 0,02 & Winner & Big Low|Winner & $-14,29 \%$ & $-26,67 \%$ & $11,36 \%$ & $9,49 \%$ & $11,54 \%$ & $36,97 \%$ & $-12,82 \%$ & $6,18 \%$ & $\begin{array}{l}-3,74 \% \\
\end{array}$ & $-13,82 \%$ & $-11,26 \%$ & $-1,92 \%$ \\
\hline PCAR4 & P.Acucar-Cbd PN & 0,64 & Low & 2.583 .453 .896 & Big & 0,07 & Winner & Big|Low|Winner & $-6,10 \%$ & $35,71 \%$ & $-7,84 \%$ & $8,53 \%$ & $21,90 \%$ & $17,19 \%$ & $-1,67 \%$ & $1,53 \%$ & $3,51 \%$ & $-16,67 \%$ & $6,80 \%$ & $6,36 \%$ \\
\hline PALF5 & Paul F Luz PNA & 1,02 & Low & 2.155 .314 .122 & Big & 0,09 & Winner & Big|Low|Winner & $1,83 \%$ & $-3,60 \%$ & $10,47 \%$ & $3,69 \%$ & $-29,01 \%$ & $-1,37 \%$ & $\begin{array}{ll}0,00 \% \\
\end{array}$ & $-6,87 \%$ & $2,01 \%$ & $-10,53 \%$ & $42,72 \%$ & $85,70 \%$ \\
\hline PALF3 & Paul FL & 1,02 & $10 \mathrm{w}$ & & Big & 011 & Wi: & & $2,63 \%$ & $-5,98 \%$ & 8,0 & $3,20 \%$ & $-28,63 \%$ & $7,69 \%$ & $-8,43 \%$ & $-13,94 \%$ & $-2,2$ & F & $43,80 \%$ & \\
\hline ITSA3 & Itausa & 1,49 & Low & 784 & Big & 0,13 & Winner & Big|Low|Winner & $4,76 \%$ & $-2,19 \%$ & $7,83 \%$ & $0,00 \%$ & $19,30 \%$ & $30,30 \%$ & $16,96 \%$ & $-4,23 \%$ & $5,41 \%$ & $-2,50 \%$ & $2,56 \%$ & \\
\hline ITSA4 & Itausa PN & 1,49 & Low & 3.038 .584 .784 & Big & 0,20 & Winner & |Big|Low|Winner & $-5,32 \%$ & $2,89 \%$ & $15,90 \%$ & $13,46 \%$ & $20,34 \%$ & $36,41 \%$ & $-8,50 \%$ & $-3,53 \%$ & $3,84 \%$ & $-8,82 \%$ & $-3,87 \%$ & $17,65 \%$ \\
\hline
\end{tabular}


Anexo 1 - Retorno mensal e classificação das ações

\begin{tabular}{|c|c|c|c|c|c|c|c|c|c|c|c|c|c|c|c|c|c|c|c|c|}
\hline Código & $1999-2000$ & $\begin{array}{l}\text { Índice } \mathrm{B} / \mathrm{M} \\
\text { de dez/1998 }\end{array}$ & $\begin{array}{c}\text { Grupo com } \\
\text { base no } \\
\text { indice B/M }\end{array}$ & $\begin{array}{c}\text { Valor de Mercado } \\
\text { em jun/1999 }\end{array}$ & $\begin{array}{c}\text { Grupo com } \\
\text { base no } \\
\text { tamanho }\end{array}$ & $\begin{array}{c}\text { Retorno } \\
\text { acumulado } \\
\text { de jun/1999 }\end{array}$ & \begin{tabular}{|c|} 
Grupo com \\
base no \\
retorno \\
acumulado \\
\end{tabular} & Carteiras & $\mathrm{jul} / 99$ & ago/99 & set/99 & out $/ 99$ & nov/99 & dez/99 & $\mathrm{jan} / 00$ & fev/00 & $\mathrm{mar} / 00$ & $\mathrm{abr} / 00$ & $\mathrm{mai} / 00$ & jun/00 \\
\hline PIRE3 & Pirelli ON & 0,44 & Low & 408.589 .264 & Big & 0,21 & Winner & Big|Low|Winner & $-8,55 \%$ & $-29,03 \%$ & $9,09 \%$ & $10,21 \%$ & $0,39 \%$ & $29,58 \%$ & \begin{tabular}{|l|}
$-18,18 \%$ \\
\end{tabular} & $12,96 \%$ & \begin{tabular}{l|l}
$1,01 \%$ \\
\end{tabular} & $-4,00 \%$ & $-10,42 \%$ & $-5,04 \%$ \\
\hline AMBV4 & Ambev PN & 0,39 & Low & 6.097 .041 .544 & Big & 0,22 & Winner & Big|Low|Winner & 5,66\% & $-2,87 \%$ & $13,96 \%$ & $7,42 \%$ & $-0,72 \%$ & $6,80 \%$ & $-4,81 \%$ & $-12,10 \%$ & $26,42 \%$ & $-4,93 \%$ & \begin{tabular}{l|l}
$0,38 \%$ \\
\end{tabular} & $16,35 \%$ \\
\hline COCE5 & Coelce PNA & 0,79 & Low & 766.638 .058 & Big & 0,25 & Winner & Big|Low|Winner & $-20,83 \%$ & $10,53 \%$ & $-4,76 \%$ & $2,50 \%$ & $26,25 \%$ & $5,10 \%$ & $-3,00 \%$ & $-2,83 \%$ & \begin{tabular}{|l|l|}
$10,42 \%$ \\
\end{tabular} & $-5,40 \%$ & $-4,12 \%$ & $2,15 \%$ \\
\hline ERIC4 & Ericsson PN & 0,60 & Low & 1.109 .238 .760 & Big & 0,28 & Winner & Big|Low/Winner & $3,70 \%$ & $\mid-16,07 \%$ | & $-17,02 \% \mid$ & $-4,92 \%$ & $18,66 \%$ & $46,30 \%$ & $-18,59 \%$ & $4,21 \%$ | & $0,76 \%$ & $-8,73 \%$ & $0,00 \%$ & $-6,52 \%$ \\
\hline VSMA3 & S Gobain Vidro ON & 1,40 & Low & 436.629.348 & Big & 0,32 & Winner & Big|Low|Winner & $-2,91 \%$ & $-12,50 \%$ & $5,71 \%$ & $-13,51 \%$ & $30,93 \%$ & $6,83 \%$ & $2,74 \%$ & $0,00 \%$ & $\begin{array}{l}9,86 \% \\
\end{array}$ & $-9,09 \%$ & \begin{tabular}{l|l}
$0,45 \%$ \\
\end{tabular} & $10,41 \%$ \\
\hline PRGA4 & \begin{tabular}{|l} 
BRF Foods PN \\
\end{tabular} & 1,42 & Low & 507.353 .100 & Big & 0,50 & Winner & Big|Low|Winner & $-8,00 \%$ & $2,17 \%$ & $13,19 \%$ & $1,50 \%$ & $25,93 \%$ & $-2,48 \%$ & $-11,85 \%$ & $-11,97 \%$ & $-1,96 \%$ & $-20,00 \%$ & $-6,00 \%$ & $19,04 \%$ \\
\hline FFTL4 & Valefert PN & 1,21 & Low & 920.040 .577 & Big & 0,52 & Winner & Big|Low|Winner & $-10,77 \%$ & $4,31 \%$ & $0,47 \%$ & $0,17 \%$ & $28,12 \%$ & $1,30 \%$ & $-3,15 \%$ & $-5,00 \%$ & $0,75 \%$ & $-10,45 \%$ & $-16,46 \%$ & $10,20 \%$ \\
\hline CPSL3 & Copesul ON & 1,56 & Low & 811.172 .727 & Big & 0,54 & Winner & Big|Low/Winner & $1,85 \%$ & $-2,18 \%$ & $5,93 \%$ & $-4,88 \%$ & $6,99 \%$ & $38,08 \%$ & $-3,90 \%$ & $1,28 \%$ & $-1,63 \%$ & $-1,68 \%$ & \begin{tabular}{|l|l|}
$13,01 \%$ \\
\end{tabular} & $24,80 \%$ \\
\hline CRUZ3 & Souza Cruz ON & 0,56 & Low & 3.805.840.442 & Big & 0,66 & Winner & Big|Low|Winner & $-10,04 \%$ & $5,64 \%$ & $8,52 \%$ & $-4,86 \%$ & $23,32 \%$ & $-0,97 \%$ & $-12,80 \%$ & $-8,58 \%$ & $4,49 \%$ & $8,37 \%$ & $-8,64 \%$ & $7,36 \%$ \\
\hline PIPN4 & Pirelli Pneus PN & 1,08 & Low & 534.585.926 & Big & 0,75 & Winner & Big|Low|Winner & $31,58 \%$ & $-32,00 \%$ & $17,94 \%$ & $7,23 \%$ & $16,28 \%$ & $6,55 \%$ & $-1,61 \%$ & $10,20 \%$ & $6,64 \%$ & $1,73 \%$ & $-5,29 \%$ & $9,78 \%$ \\
\hline TMGR6 & Telemig PNB & 2,52 & \begin{tabular}{|l} 
Medium \\
\end{tabular} & 952.525 .640 & \begin{tabular}{|l|l|} 
Big \\
\end{tabular} & 0,60 & Loser & \begin{tabular}{|l} 
Big|Medium|Loser \\
\end{tabular} & $-1,02 \%$ & $3,33 \%$ & $-4,89 \%$ & $-5,37 \%$ & $45,68 \%$ & $18,47 \%$ & $-8,44 \%$ & $7,03 \%$ & $8,73 \%$ & $-14,06 \%$ & $2,39 \%$ & $10,92 \%$ \\
\hline TMAR6 & Telemar N L PNB & 3,21 & Medium & 1.535 .373 .560 & Big & 0,58 & Loser & Big|Medium|Loser & $0,66 \%$ & $-10,33 \%$ & $4,20 \%$ & $-2,53 \%$ & $59,07 \%$ & $1,38 \%$ & $8,26 \%$ & $5,61 \%$ & $5,92 \%$ & $-20,72 \%$ & $-2,35 \%$ & $21,43 \%$ \\
\hline TMAR3 & Telemar N L ON & 3,21 & Medium & 1.535 .373 .560 & Big & 0,57 & Loser & \begin{tabular}{|l} 
Big $/$ Medium/Loser \\
\end{tabular} & $-2,56 \%$ & $-6,32 \%$ & $5,06 \%$ & $-2.14 \%$ & $55,74 \%$ & $22,81 \%$ & $-17,14 \%$ & $18.97 \%$ & $2.03 \%$ & $-7.67 \%$ & $-3,69 \%$ & $5,11 \%$ \\
\hline PMAM4 & Paranapanema P & 2,29 & Medi & 5.140 .299 & Big & 0,57 & Loser & Big|Medium|Loser & $28,03 \%$ & $-31,08 \%$ & $-1,96 \%$ & $-10,00 \%$ & $62,22 \%$ & $13,70 \%$ & $20,48 \%$ & $-14,00 \%$ & $-9,30 \%$ & $-15,38 \%$ & $0,61 \%$ & $23,49 \%$ \\
\hline CLSC3 & Celesc ON & 3,44 & Medium & 436.381 .821 & Big & 0,53 & Loser & \begin{tabular}{|l|} 
Big|Medium|Loser \\
\end{tabular} & $2,56 \%$ & $-12,50 \%$ & $8,57 \%$ & $31,58 \%$ & $36,00 \%$ & $2,94 \%$ & $\begin{array}{l}2,5,71 \% \\
\end{array}$ & $-5,41 \%$ & $14,29 \%$ & $-12,50 \%$ & $-9,94 \%$ & $0,00 \%$ \\
\hline TMGR3 & Telemig ON & 2,52 & Medium & 952.525 .640 & Big & 0,47 & Loser & Big|Medium|Loser & $1,48 \%$ & $-9,53 \%$ & $-3,57 \%$ & $5,56 \%$ & $61,40 \%$ & $8,70 \%$ & $-8,00 \%$ & $21,72 \%$ & $-7,13 \%$ & $-5,79 \%$ & $-4,46 \%$ & $13,64 \%$ \\
\hline CRGT5 & Crt Ciargtelec PNA & 2,09 & Medium & 863.247 .341 & Big & 0,44 & Loser & \begin{tabular}{|l|} 
Big|Medium|Loser \\
\end{tabular} & $-16,65 \%$ & $11,73 \%$ & $7,51 \%$ & $-10,47 \%$ & $22,08 \%$ & $19,15 \%$ & $7,14 \%$ & $10,83 \%$ & $18,80 \%$ & $-17,09 \%$ & $-14,50 \%$ & $8,93 \%$ \\
\hline BRTO3 & Brasil Te & 3,17 & Medium & 896.778 .120 & Big & 0,41 & Loser & Big|Medium|Loser & $7,69 \%$ & $-4,76 \%$ & $54,99 \%$ & $11,29 \%$ & $37,68 \%$ & $1,89 \%$ & $7,23 \%$ & $34,87 \%$ & $5,71 \%$ & $-20,41 \%$ & $-11,53 \%$ & $4,10 \%$ \\
\hline \begin{tabular}{|l|} 
BRTO4 \\
\end{tabular} & Brasil Telec PN & 3,17 & Medium & 896.778 .120 & Big & 0,35 & Loser & \begin{tabular}{|l|} 
Big|Medium|Loser \\
\end{tabular} & $-4,76 \%$ & $0,00 \%$ & $20,00 \%$ & $9,72 \%$ & $20,76 \%$ & $23,69 \%$ & $2,54 \%$ & $20,66 \%$ & $2,74 \%$ & $-16,53 \%$ & $-15,73 \%$ & $24,26 \%$ \\
\hline CLSC6 & Celesc PNB & 3,44 & Medium & 436.381 .821 & Big & 0,26 & Loser & Big|Medium|Loser & $-25,00 \%$ & $-3,63 \%$ & $10,20 \%$ & $12,96 \%$ & $29,51 \%$ & $8,86 \%$ & $-15,12 \%$ & $-5,48 \%$ & $-2,90 \%$ & $-4,48 \%$ & $-13,99 \%$ & $21,82 \%$ \\
\hline GLOB4 & Globex PN & 1,70 & Medium & 589.484 .000 & Big & 0,22 & Loser & Big|Medium|Loser & $-8,11 \%$ & $0,00 \%$ & $5,76 \%$ & $-4,34 \%$ & $39,53 \%$ & $20,83 \%$ & $37,93 \%$ & $-5,00 \%$ & $5,26 \%$ & $-2,50 \%$ & $-16,80 \%$ & $7,12 \%$ \\
\hline CEPE5 & Celpe PNA & 1,76 & Medium & 355.935 .662 & Big & 0,15 & Loser & Big|Medium|Loser & $6,21 \%$ & $3,77 \%$ & $27,27 \%$ & $-9,99 \%$ & $8,33 \%$ & $32,31 \%$ & $4,27 \%$ & $-2,51 \%$ & $9,76 \%$ & $0,00 \%$ & $-16,67 \%$ & $11,33 \%$ \\
\hline SBSP3 & Sabesp ON & 3,31 & Medium & 3.965 .875 .067 & Big & 0,14 & Loser & \begin{tabular}{|l|} 
Big|Medium/Loser \\
\end{tabular} & $-4,96 \%$ & $-5,23 \%$ & $-2,35 \%$ & $6,05 \%$ & $41,91 \%$ & $13,74 \%$ & $-5,70 \%$ & $-12,25 \%$ & $0,57 \%$ & $-3,40 \%$ & $-21,99 \%$ & $10,52 \%$ \\
\hline PTIP3 & Ipiranga Pet ON & 2,45 & Medium & 652.925 .970 & Big & 0,14 & Loser & Big|Medium|Loser & $6,01 \%$ & $-1,79 \%$ & $9,09 \%$ & $25,00 \%$ & $8,67 \%$ & $11,82 \%$ & $0,00 \%$ & $11,11 \%$ & $-15,00 \%$ & $-2,94 \%$ & $-4,24 \%$ & $-1,90 \%$ \\
\hline TBLE6 & Tractebel PNB & 2,71 & Medium & 756.426 .047 & Big & 0,13 & Loser & Big|Medium|Loser & $-13,38 \%$ & $9,76 \%$ & $0,00 \%$ & $7,41 \%$ & $20,00 \%$ & $13,22 \%$ & $10,15 \%$ & $-4,61 \%$ & $-1,93 \%$ & $-15,27 \%$ & $4,65 \%$ & $26,67 \%$ \\
\hline \begin{tabular}{|l|l|l|} 
CPLE3 & \\
\end{tabular} & Copel ON & 2,10 & Medium & 3.100 .668 .983 & Big & 0,13 & Loser & \begin{tabular}{|l|} 
Big $\mid$ Medium/Loser \\
\end{tabular} & $-14,35 \%$ & $1,06 \%$ & $2,63 \%$ & $0,00 \%$ & $20,77 \%$ & $27,39 \%$ & $-12,92 \%$ & $-3,83 \%$ | & $3,29 \%$ & $-5,00 \%$ & $6,32 \%$ & $12,77 \%$ \\
\hline TBLE3 & Tractebel C & 2,71 & Medium & 756.426 .047 & Big & 0,09 & Loser & \begin{tabular}{|l|} 
Big|Medium|Loser \\
\end{tabular} & $-15,71 \%$ & $-2,54 \%$ & $1,74 \%$ & $5,98 \%$ & $29,03 \%$ & $14,38 \%$ & $10,38 \%$ & $-1,98 \%$ & $-4,55 \%$ & $-13,76 \%$ & $11,04 \%$ & $20,99 \%$ \\
\hline \begin{tabular}{|l|} 
DURA4 \\
\end{tabular} & Duratex-Old PN & $\frac{2,11}{2,21}$ & Medium & 392.550 .097 & \begin{tabular}{|l} 
Big \\
\end{tabular} & 0,07 & \begin{tabular}{|l|l|} 
Loser \\
\end{tabular} & \begin{tabular}{|l|} 
Big|Medium|Loser \\
\end{tabular} & $-2,15 \%$ & $-14,35 \%$ & $19,02 \%$ & $15,22 \%$ & $13,21 \%$ & $\mid-5,83 \%$ & $22,14 \%$ & $\mid-14,03 \%$ & $-3,25 \%$ & $-11,50 \%$ & - & $26,10 \%$ \\
\hline PTIP4 & Ipiranga Pet PN & 2,45 & Medium & 652.925 .970 & Big & 0,01 & Winner & Big|Medium/Winner & $-1,96 \%$ & $-10,65 \%$ & $19,65 \%$ & $18,86 \%$ & $20,92 \%$ & $3,37 \%$ & $-1,61 \%$ & $21,00 \%$ & $-7,79 \%$ & $-5,66 \%$ & $-5,00 \%$ & $-5,37 \%$ \\
\hline CMIG3 $>$ \& & $\mathrm{Ce}$ & 2.47 & Me & 4.894 .531 .944 & Big & 0.02 & Winner & dium/Winner & $-7.89 \%$ & $-9,05 \% \mathrm{f}, \mathrm{C}, \mathrm{C}$ & $-4,71 \% \mathrm{f}, 2<-3$ & $-4,01 \%$ & $31,65 \%$ & $12.31 \%$ & $-10,44 \%$ & $-1,64 \%$ | & $0.97 \%$ & $-3,02 \% \mathrm{~m}$ & $2.49 \%$ & $15.94 \%$ \\
\hline BMTO4 & Brasmotor PI & 2,43 & Medium & 344.593 .368 & Big & 0,06 & Winner & um $\mid$ Winner & $-10,65 \%$ & $-0,20 \%$ & $24,65 \%$ & $18,97 \%$ & $4,06 \%$ & $31,57 \%$ & $-3,67 \%$ & $-22,38 \%$ & $-36,31 \%$ & $18,99 \%$ & $6,25 \%$ & $-21,57 \%$ \\
\hline VALE3 & Vale ON & 2,07 & Medium & 10.944.686.497 & Big & 0,15 & Winner & \begin{tabular}{|l} 
Big|Medium|Winner \\
\end{tabular} & $8,84 \%$ & $19,11 \%$ & $-1,61 \%$ & $-6,56 \%$ & $30,35 \%$ & $16,42 \%$ & $14,29 \%$ & $-15,00 \%$ & $-1,96 \%$ & $0,00 \%$ & $2,50 \%$ & $9,73 \%$ \\
\hline PETR3 & Petrobras ON & 2,01 & Medium & 24.604.264.964 & Big & 0,15 & Winner & Big|Medium/Winner & $-5,42$ & $0,23 \%$ & $23,62 \%$ & $18,00 \%$ & $20,53 \%$ & $24,99 \%$ & $-14,99 \%$ & $26,47 \%$ & $4,30 \%$ & $-9,09 \%$ & $1,25 \%$ & $30,81 \%$ \\
\hline \begin{tabular}{|l|} 
LAME4 \\
\end{tabular} & Lojas Americ PN & 2,09 & Medium & 351.552 .498 & \begin{tabular}{|l|l} 
Big \\
\end{tabular} & 0,16 & Winner & \begin{tabular}{|l} 
Big|Medium|Winner \\
\end{tabular} & $-6,75 \%$ & $0,20 \%$ & $43,04 \%$ & $4,17 \%$ & $16,00 \%$ & \begin{tabular}{|l|}
$141,38 \%$ \\
\end{tabular} & $40,71 \%$ & $-10,66 \%$ & $-2,27 \%$ & $-19,35 \%$ & $-40,95 \%$ & $50,25 \%$ \\
\hline CPLE6 & Copel PNB & 2,10 & Medium & 3.100 .668 .983 & Big & 0,19 & Winner & um $\mid$ Winner & $-14,22 \%$ & $9,11 \%$ & $-4,89 \%$ & $4,35 \%$ & $12,50 \%$ & $17,85 \%$ & $-17,71 \%$ & $12,50 \%$ & $-6,51 \%$ & $-9,08 \%$ & $9,62 \%$ & $15,65 \%$ \\
\hline DPPI4 & Ipiranga Dis PN & 2,62 & Medium & 384.250 .850 & \begin{tabular}{|l|l|} 
Big \\
\end{tabular} & 0,20 & Winner & Big|Medium/Winner & $4,04 \%$ & $-1,41 \%$ & $6,02 \%$ & $13,51 \%$ & $21,43 \%$ & $23,82 \%$ & $-11,67 \%$ & $-1,89 \%$ & $-1,92 \%$ & $6,47 \%$ & $-9,54 \%$ & $7,90 \%$ \\
\hline CMIG4 & Cemig PN & 2,47 & Medium & 4.894.531.944 & Big & 0,21 & Winner & Big|Medium/Winner & $-16,24 \%$ & $-4,52 \%$ & $-2,03 \%$ & $-4,14 \%$ & $30,07 \%$ & $15,88 \%$ & $-23,95 \%$ & $-5,49 \%$ & $4,71 \%$ & $-7,69 \%$ & $2,18 \%$ & $14,31 \%$ \\
\hline PETR4 & Petrobras PN & 2,01 & Medium & 24.604 .264 .964 & Big & 0,24 & Winner & Big|Medium|Winner & $-6,51 \%$ & $-0,04 \%$ & $11,67 \%$ & $8,19 \%$ & $25,12 \%$ & $18,40 \%$ & $-11,30 \%$ & $12,75 \%$ & $4,45 \%$ & $-8,88 \%$ & $-2,58 \%$ & $30,07 \%$ \\
\hline BRDT4 & Petrobras Distrib PN & 3,20 & Medium & 721.439 .597 & Big & 0,29 & Winner & $\mid$ Big|Medium/Winner & $-17,07 \%$ & $-6,43 \%$ & $24,61 \%$ & $9,47 \%$ & $49,83 \%$ & $13,25 \%$ & $-5,83 \%$ & $-15,04 \%$ & $-4,17 \%$ & $-8,61 \%$ & $-9,13 \%$ & $28,27 \%$ \\
\hline EBCO4 & Embraco $\mathrm{P}$ & 1,96 & Medium & 342.925 .325 & Big & 0,32 & Winner & Big|Medium|Winner & $5,68 \%$ & $17,74 \%$ & $2,74 \%$ & $5,33 \%$ & $-2,53 \%$ & $9,09 \%$ & $-6,90 \%$ & $-5,19 \%$ & $9,59 \%$ & $0,00 \%$ & $1,25 \%$ & $7,41 \%$ \\
\hline CSNA3 & Sid Nacional ON & 2,37 & Medium & 3.317 .478 .364 & Big & 0,38 & Winner & Big|Medium/Winner & $-10,27 \%$ & $12,02 \%$ & $4,32 \%$ & $7,01 \%$ & $27,17 \%$ & $7,69 \%$ & $-16,43 \%$ & $-6,26 \%$ & $13,86 \%$ & $-17,22 \%$ & $17,67 \%$ & $-5,70 \%$ \\
\hline VALE5 & Vale PNA & 2,07 & Medium & 10.944.686.497 & Big & 0,48 & Winner & Big|Medium/Winner & $1,72 \%$ & $24,34 \%$ & $-3,99 \%$ & $-5,16 \%$ & $19,28 \%$ & $10,84 \%$ & $0,00 \%$ & $-6,00 \%$ & $1,06 \%$ & $-5,89 \%$ & $1,79 \%$ & $11,87 \%$ \\
\hline SDIA4 & Sadia S/A PN & 1,79 & Medium & 750.965 .616 & Big & 0,50 & Winner & Big|Medium/Winner & $4,55 \%$ & $3,29 \%$ & $9,40 \%$ & $0,00 \%$ & $11,72 \%$ & $14,69 \%$ & $-8,01 \%$ & $-5,41 \%$ & $-7,86 \%$ & $-21,71 \%$ & $-10,89 \%$ & $20,00 \%$ \\
\hline GGBR4 & Gerdau & 3,38 & Medium & 1.404 .336 .100 & Big & 0,68 & Winner & $\frac{\mathrm{g} \mid \mathrm{N}}{\mathrm{s}}$ & $0,42 \%$ & $0,00 \%$ & $3,45 \%$ & $17,67 \%$ & $7,65 \%$ & $29,25 \%$ & $4,17 \%$ & $-1,6$ & $-7,52 \%$ & $-4,18 \%$ & $-4,86 \%$ & 8,2 \\
\hline \begin{tabular}{|l|l|l} 
ARCZ6 \\
\end{tabular} & Aracruz PNB & 2,94 & Medium & 2.970 .988 .498 & \begin{tabular}{|l|l} 
Big \\
\end{tabular} & 0,88 & Winner & \begin{tabular}{|l} 
Big/Medium/Winner \\
\end{tabular} & $-13,01 \%$ & 12,90\% & $3,90 \%$ & $-5,00 \%$ & $3,16 \%$ & $11,73 \%$ & $-7,08 \%$ & - & $-0,54 \%$ & $-3,89 \%$ & \begin{tabular}{|c|c|}
$-11,40 \%$ \\
\end{tabular} & $13,20 \%$ \\
\hline VCPA4 & Fibria PN & 3,87 & Medium & 1.896 .440 .830 & Big & 1,44 & Winner & Big|Medium/Winner & $-1,00 \%$ & $18,84 \%$ & $-2,67 \%$ & $-2,40 \%$ & $12,96 \%$ & $28,90 \%$ & $-28,92 \%$ & $3,37 \%$ & $5,76 \%$ & $-15,14 \%$ & $7,81 \%$ & $14,62 \%$ \\
\hline MYPK4 & lochp-Maxion & 4,57 & High & 34.959 .195 & Small & 0,75 & Loser & Small|High/Loser & $55,04 \%$ & $55,05 \%$ & $25,77 \%$ & $32.05 \%$ & $13,79 \%$ & $19,45 \%$ & $-5,71 \%$ & $9,09 \%$ & $-16,68 \%$ & $-34,32 \%$ & $4,06 \%$ & $9,76 \%$ \\
\hline SNSY5 & Sansuy PNA & 5,65 & t & 15.660 & $\mathrm{Sm}$ & 0,57 & $10 \mathrm{se}$ & $5 m a x+2$ & $-3,85$ & $-4,40 \%$ & $-7,95 \%$ & 0,00 & 59,0 & $12, \varepsilon$ & $-13,9$ & 13,2 & $50,39 \%$ & $-13,64 \%$ & $-4,00 \%$ & $4,17 \%$ \\
\hline ACES3 & Am Inox BR ON & 4,29 & High & 288.275 .348 & Small & 0,56 & \begin{tabular}{|l|l|} 
Loser \\
\end{tabular} & Small|High|Loser & $-7,41 \%$ & $-6,00 \%$ & $-2,13 \%$ & $2,17 \%$ & $28,49 \%$ & $41,67 \%$ & $41,18 \%$ & $\mid-4,17 \%$ & $-5,22 \%$ & $4,59 \%$ & $-15,79 \%$ & $12,50 \%$ \\
\hline
\end{tabular}


Anexo 1 - Retorno mensal e classificação das ações

\begin{tabular}{|c|c|c|c|c|c|c|c|c|c|c|c|c|c|c|c|c|c|c|c|c|}
\hline Código & 1999 - 2000 & $\begin{array}{l}\text { Índice } \mathrm{B} / \mathrm{M} \\
\text { de dez/1998 }\end{array}$ & $\begin{array}{c}\text { Grupo com } \\
\text { base no } \\
\text { indice B/M }\end{array}$ & $\begin{array}{c}\text { Valor de Mercado } \\
\text { em jun/1999 }\end{array}$ & $\begin{array}{c}\text { Grupo com } \\
\text { base no } \\
\text { tamanho }\end{array}$ & \begin{tabular}{|c|} 
Retorno \\
acumulado \\
de jun/1999 \\
\end{tabular} & \begin{tabular}{|c|} 
Grupo com \\
base no \\
retorno \\
acumulado \\
\end{tabular} & Carteiras & jul/99 & ago/99 & set/99 & out/99 & nov/99 & $\mathrm{dez} / 99$ & jan/00 & fev/00 & $\mathrm{mar} / 00$ & $\mathrm{abr} / 00$ & mai/00 & jun/00 \\
\hline ODBE4 & Odebrecht PN & 4,82 & High & 218.124 .530 & Small & 0,55 & Loser & Small|High|Loser & $2,50 \%$ & $-2,44 \%$ & $2,50 \%$ & $26,83 \%$ & $7,31 \%$ & $21,86 \%$ & $0,00 \%$ & $-11,76 \%$ & $-10,00 \%$ & $18,52 \%$ & $13,68 \%$ & $37,54 \%$ \\
\hline MAHS4 & Bunge Fertilizantes PN & 4,16 & High & 61.367.379 & Small & 0,50 & Loser & Small|High|Loser & $-0,05 \%$ & $-13,29 \%$ & $18,34 \%$ & $-0,50 \%$ & $33,17 \%$ & $-7,55 \%$ & $18,37 \%$ & $23,79 \%$ & $-10,86 \%$ & $-44,74 \%$ & $3,81 \%$ & $5,60 \%$ \\
\hline ACES4 & Am Inox BR PN & 4,29 & High & 288.275.348 & Small & 0,47 & Loser & Small|High|Loser & $-4,76 \%$ & $-5,00 \%$ & $-1,75 \%$ & $-1,79 \%$ & $46,26 \%$ & $41,25 \%$ & $25,66 \%$ & $-16,90 \%$ & $0,85 \%$ & $12,61 \%$ & $-11,94 \%$ & $13,56 \%$ \\
\hline CETE4 & Ceterp PN & 4,15 & High & 161.361.474 & Small & 0,39 & Loser & Small|High|Loser & $-7,70 \%$ & $4,84 \%$ & $1,27 \%$ & $27,99 \%$ & $14,25 \%$ & $21,51 \%$ & $1,33 \%$ & $4,80 \%$ & $-1,67 \%$ & $-2,12 \%$ & $0,95 \%$ & $1,29 \%$ \\
\hline LLMD4 & Yara Brasil PN & 6,51 & High & \begin{tabular}{l|l|}
8.928 .572 \\
\end{tabular} & Small & 0,38 & Loser & Small|High|Loser & $-25,60 \%$ & $-70,43 \%$ & $9,09 \%$ & $-10,00 \%$ & $235,19 \%$ & $10,50 \%$ & $39,50 \%$ & $20,07 \%$ & $-26,87 \%$ & $-18,37 \%$ & $44,50 \%$ & $38,06 \%$ \\
\hline TRFO4 & Trafo PN & 4,81 & High & \begin{tabular}{|l|l|}
14.782 .299 \\
\end{tabular} & Small & 0,36 & Loser & Small|High|Loser & $-7,69 \%$ & $-16,67 \%$ & $-19,00 \%$ & $14,81 \%$ & $37,63 \%$ & $17,19 \%$ & $0,00 \%$ & $6,00 \%$ & $-5,66 \%$ & $0,67 \%$ & $-20,53 \%$ & $0,00 \%$ \\
\hline RAPT4 & Randon Part PN & 5,97 & High & \begin{tabular}{ll|}
45.018 .663 \\
\end{tabular} & Small & 0,35 & Loser & Small|High|Loser & $-3,33 \%$ & $-13,79 \%$ & $-4,00 \%$ & $37,50 \%$ & $15,15 \%$ & $13,16 \%$ & $-6,98 \%$ & $0,00 \%$ & $2,50 \%$ & $4,88 \%$ & $2,33 \%$ & $38,64 \%$ \\
\hline CPCA4 & Trikem PN & 22,66 & High & 128.380 .703 & Small & 0,28 & Loser & Small|High|Loser & $6,16 \%$ & $-24,55 \%$ & $15,38 \%$ & $31,28 \%$ & $13,67 \%$ & $6,19 \%$ & $-9,39 \%$ & $-14,29 \%$ & $-0,42 \%$ & $-15,90 \%$ & $79,10 \%$ & $49,72 \%$ \\
\hline SAMI4 & Samitri PN & 6,30 & High & 301.198.571 & Small & 0,27 & Loser & Small|High |Loser & $30,43 \%$ & $6,00 \%$ & $21,07 \%$ & $-5,19 \%$ & $31,51 \%$ & $-3,96 \%$ & $3,04 \%$ & $1,05 \%$ & $4,17 \%$ & $-4,54 \%$ | & $31,11 \%$ & $15,04 \%$ \\
\hline CMET4 & Caemi PN & 6,80 & High & 235.184 .815 & Small & 0,26 & Loser & Small|High|Loser & $\begin{array}{l}1,67 \% \\
\end{array}$ & $0,00 \%$ & $16,39 \%$ & $28,87 \%$ & $19,13 \%$ & $19,17 \%$ & $30,88 \%$ & $2,94 \%$ & $-10,99 \%$ & $5,81 \%$ & $-4,27 \%$ & $42,04 \%$ \\
\hline VGOR4 & Vigor PN & 7,76 & High & 51.288 .570 & Small & 0,25 & Loser & Small|High|Loser & $-8,06 \%$ & $13,33 \%$ & $-8,67 \%$ & $5,08 \%$ & $10,32 \%$ & $-0,59 \%$ & $-4,41 \%$ & $-7,69 \%$ & $-13,33 \%$ & $-18,85 \%$ & $-5,21 \%$ & $30,00 \%$ \\
\hline MGEL4 & Mangels Ind PN & 8,77 & High & 17.554.138 & Small & 0,20 & Loser & Small|High|Loser & $-2,63 \%$ | & $-5,41 \%$ & $2,86 \%$ & $27,78 \%$ & $30,87 \%$ & $12,62 \%$ & $9,44 \%$ & $7,28 \% \mid$ & $-3,52 \%$ & $-6,25 \%$ & $-7,75 \%$ & $3,13 \%$ \\
\hline SGAS4 & WIm Ind Com PN & 4,83 & High & 14.857.187 & Small & 0,15 & Loser & Small|High|Loser & $3,92 \%$ & $-5,66 \%$ & $6,00 \%$ & $32,08 \%$ & $1,43 \%$ & $9,86 \%$ & $-6,41 \%$ & $-2,74 \%$ & $-1,41 \%$ & $-2,86 \%$ & $-22,06 \%$ ] & $11,32 \%$ \\
\hline CREM4-old & Cremer (Antiga) PN & 4,21 & High & 8.721 .000 & Small & 0,11 & Loser & Small|High|Loser & $10,59 \%$ & $-20,21 \%$ & $0,00 \%$ & $16,67 \%$ & $-7,43 \%$ & $12,35 \%$ & $70,33 \%$ & $27,42 \%$ & $11,39 \%$ & $-13,64 \%$ & $0,00 \%$ & $-5,26 \%$ \\
\hline RPSA4 & Ripasa PN & 20,74 & High & 101.148 .747 & Small & 0,06 & Winner & Small|High|Winner & $31,11 \%$ & $6,78 \%$ & $-1,59 \%$ & $22,58 \%$ & $56,58 \%$ & $15,97 \%$ & $-8,70 \%$ & $13,81 \%$ & $0,75 \%$ & $-19,40 \%$ & $0,00 \%$ & $16,14 \%$ \\
\hline MAGS5 & Magnesita PNA & 5,39 & High & 111.711.009 & Small & 0,06 & Winner & Small||High|Winner & $0,48 \%$ | & $0,00 \%$ [ & $5,77 \%$ & $17,27 \%$ & $12,40 \%$ & $15,52 \%$ & $-3,23 \%$ & $13,33 \%$ | & $1,47 \%$ & $-6,09 \%$ [ & $-2,78 \%[->>$ & $20,00 \%$ \\
\hline FESA4 & Ferbasa PN & 9,48 & High & .282.689 & Small & 0,15 & Winner & Small||High|Winner & $16,11 \%[$ & $-2,04 \%$ & $0,42 \%$ & $3,73 \%$ & $68,00 \%$ & $47,36 \%[$ & $-13,85 \%$ & $11,28 \%$ | $>$ & $1,72 \%$ & 7,49\% ] & $0,00 \%$ & $9,84 \%$ \\
\hline MNPR4 & Minupar PN & 16,06 & High & 54.000 & Small & 0,21 & Winner & Small||High|Winner & $0,00 \%$ ] & $5,00 \%$ ] & $-14,29 \%$ ] & $38,89 \%$ ] & $8,00 \%$ & $18,52 \%$. & $90,63 \%$ ] & $-31,15 \%$ | & $-14,29 \%$ & $-33,33 \%$ & $-25,00 \%$ & $16,67 \%$ \\
\hline WISA4 & Wiest PN & 8,89 & High & 4.524 .960 & Small & 0,25 & Winner & Small|High|Winner & $-1,52 \%$ & $-4,62 \%$ & $-4,84 \%$ & $-11,86 \%$ & $11,54 \%$ & $0,00 \%$ & $1,72 \%$ & $-15,25 \%$ & $4,00 \%$ & $-19,23 \%$ & $-16,67 \%$ & $0,00 \%$ \\
\hline PLAS4 & Plascar Part PN & 3,96 & High & 79.599.916 _ _ _ _ & Small & 0,47 & Winner & Small||High|Winner & $-7,28 \%$ ] & $-14,29 \%$ & $1,67 \%$ & $-12,30 \%$ & $37,38 \%$ | & $11,56 \%$ & $-22,44 \%$ & $-11,79 \%$ | & $-11,76 \%$ & $-9,09 \%$ | & $11,11 \%$ ] & $-5,20 \%$ \\
\hline $\begin{array}{lll}\text { PLDN4 } & \\
\end{array}$ & Polialden PN & 7,01 & High & 30.326 .890 & Small & 0,49 & Winner & Small|High|Winner & $10,64 \%$ & $\mid 17,67 \%$ & $17,83 \%$ & $30,36 \%$ & $48,96 \%$ | & $71,41 \%$ | & $-20,83 \%$ & $12,92 \%$ | & $-15,00 \%$ & $-23,53 \%$ & $20,77 \%$ & $28,66 \%$ \\
\hline MANM3 & Mannesmann & 7,24 & High & 307 & Small & 0,50 & Winner & Small|High|Winner & $-24,44 \%$ & $-23,47 \%$ & $-10,67 \%$ & $13,43 \%$ & $64,47 \%$ & $0,00 \%$ & $5,60 \%$ & \begin{tabular}{l|l}
$0,00 \%$ \\
\end{tabular} & $-1,59 \%$ & $10,85 \%$ & $-16,67 \%$ & $21,67 \%$ \\
\hline ARTE4 & Kuala PN & 6,61 & High & 26.819 .256 & Small & 0,55 & Winner & Small|High|Winner & $5,56 \%$ & $-10,53 \%$ & $0,00 \%$ & $29,41 \%$ & $0,00 \%$ & $13,64 \%$ & $4,00 \%$ & $-11,54 \%$ & $-4,35 \%$ & $-22,73 \%$ & $-17,65 \%$ & $-21,43 \%$ \\
\hline ARTE3 & Kuala ON & 6,61 & High & 26.819 .256 & Small & 0,56 & Winner & Small|High|Winner & $13,33 \%$ & $-17,65 \%$ & $0,00 \%$ & $35,71 \%$ & $5,26 \%$ & $15,00 \%$ & $4,35 \%$ & $-4,17 \%$ & $-30,43 \%$ & $-18,75 \%$ & $7,69 \%$ & $0,00 \%$ \\
\hline EPTE4 & Epte PN & 15,68 & High & 302.227.127 & Small & 0,56 & Winner & Small|High|Winner & $-21,64 \%$ & $-10,30 \%$ & $0,87 \%$ & $18,97 \%$ & $40,29 \%$ & $33,78 \%$ & $-11,20 \%$ & $91,30 \%$ & $-0,91 \%$ & $-22,02 \%$ & $-16,60 \%$ & $20,50 \%$ \\
\hline UNIP6 & Unipa & 7,12 & High & & Small & 0,63 & Winr & Small|High|W & $12,20 \%$ & $10,47 \%$ & $10,20 \%$ & $22,22 \%$ & $39,39 \%$ & $39,90 \%$ & $-6,98 \%$ & $1,79 \%$ & $22,81 \%$ & $1,43 \%$ & $3,81 \%$ & $22,92 \%$ \\
\hline FBRA4 & Fertibras PN & 4,15 & High & 801.601 & Small & 0,67 & Winner & Small|High|Winner & $-27,27 \%$ & $37,50 \%$ & $6,82 \%$ & $-2,55 \%$ & $9,17 \%$ & $10,00 \%$ & $-1,82 \%$ & $5,56 \%$ & $13,11 \%$ & $-1,64 \%$ & $15,00 \%$ & $-11,59 \%$ \\
\hline FITA4 & Forjas Taurus PN & 5,50 & High & 631.999 & Small & 0,99 & Winner & Small|High|Winner & $15,00 \%$ & $-6,52 \%$ & $4,65 \%$ & $6,67 \%$ & $20,83 \%$ & $6,66 \%$ & $-14,29 \%$ & $2,08 \%$ & $2,04 \%$ & $-2,00 \%$ & $-7,69 \%$ & $-6,67 \%$ \\
\hline TEKA4 & Teka PN & 28,76 & High & 507.929 & Small & 1,09 & Winner & Small|High|Winner & $43,33 \%$ & $-18,60 \%$ & $14,29 \%$ & $12,50 \%$ & $15,56 \%$ & $25,00 \%$ & $-9,23 \%$ & $-8,47 \%$ & $0,00 \%$ & $7,41 \%$ & $-12,07 \%$ & $17,65 \%$ \\
\hline EMAE4 & En & 20,31 & High & .037 & Small & 2,79 & Winner & Small|High|Winner & $-13,41 \%$ & $-9,58 \%$ & $1,56 \%$ & $1,23 \%$ & $40,91 \%$ & $-2,15 \%$ & $-12,09 \%$ & $25,00 \%$ & $-0,20 \%$ & $-17,84 \%$ & $3,66 \%$ & $15,29 \%$ \\
\hline LIPR3 & Eletropar ON & 7,10 & High & 361.769 & Small & 7,28 & Winner & Small|High|Winner & $89,84 \%$ & $-41,55 \%$ & $-7,23 \%$ & $7,79 \%$ & $7,23 \%$ & $19,10 \%$ & $18,68 \%$ & $-3,02 \%$ & $-14,75 \%$ & $-15,38 \%$ & $-5,91 \%$ & $-2,66 \%$ \\
\hline VAGV4 & Savarg PN & 1,50 & Low & 401.452 & Small & 0,68 & Loser & Small|Low|Loser & $-7,41 \%$ & $-28,00 \%$ & $16,67 \%$ & $185,71 \%$ & $-21,67 \%$ & $2,13 \%$ & $65,83 \%$ & $8,29 \%$ & $-7,19 \%$ & $-35,00 \%$ & $5,77 \%$ & $0,36 \%$ \\
\hline RHDS3 & MG Poliest ON & 0,46 & Low & 40.321 .599 & Small & 0,65 & Loser & Small| Low|Loser & $-12,50 \%$ & $-14,29 \%$ & $0,00 \%$ & $16,67 \%$ & $10,34 \%$ & $142,86 \%$ & $-17,65 \%$, $>$ & $0,00 \%$ & $-14,29 \%$ | $>$ & $-16,67 \%$ & $10,00 \%$ & $18,18 \%$ \\
\hline INEP4 & Inepar PN & 0,34 & Low & .183.273 & Small & 0,64 & Loser & Small| Low|Loser & $-9,07 \%$ & 6,04\% & $-9,16 \%$ & $7,63 \%$ & $11,90 \%$ & $70,81 \%$ & $-11,26 \%$ & $-3,73 \%$ & $-26,82 \%$ & $2,33 \%$ ] & $-24,43 \%$ & $5,48 \%$ \\
\hline TPRC3 & Tim Sul ON & 1,31 & Low & 688.729 & Small & 0,52 & Loser & Small| Low|Loser & $-1,68 \%$ & $-33,90 \%$ [ & $17,95 \%$ & $-2,17 \%$ & $11,11 \%$ | & $55,98 \%$ & $25,66 \%$, $>$ & $-10,20 \%$ | & $93,17 \%$ & $-7,05 \% \mid$ & $-30,38 \%$ & $9,09 \%$, \\
\hline TAMR4 & $\operatorname{Tam} \operatorname{Tra}$ & 0,49 & Low & & Small & 0,46 & Loser & Small| Low|Loser & $-13,59 \%$ & $-9,43 \%$ & $-2,78 \%$ & $57,14 \%$ & $-18,16 \%$ & $32,19 \%$ & $-32,52 \%$ & $12,08 \%$ & $-11,11 \%$ & $-25,00 \%$ & $-6,67 \%$ & $17,86 \%$ \\
\hline TPRC6 & Tim Sul PNB & & Low & 29 & Small & 0,45 & Loser & Small| Low |Loser & $-7,37 \%$ & $-21,59 \%$ & $7,97 \%$ | & $-4,63 \%$ & $22,45 \%$ & $43,68 \%$. & $-8,02 \%$ & $29,59 \% \mid$ & $45,65 \%$ & $-12,45 \%$ & $-21,40 \% \mid$ & $7,15 \%$ \\
\hline ITEC3 & Itautec ON & 1,45 & Low & 295.074 .333 & Small & 0,36 & Loser & Small|Low|Loser & $-15,00 \%$ & $7,84 \%$ & $0,00 \%$ & $3,03 \%$ & $76,47 \%$ & $230,00 \%$ & $28,99 \%$ & $-23,00 \%$ & $-15,20 \%$ & $-0,12 \%$ & $-18,31 \%$ & $18,29 \%$ \\
\hline FRAS4 & Fras-Le & 0,74 & Lot & 788.981 & Small & 0,33 & Loser & Small| Low|Loser & $-8,05 \%$ & $-6,25 \%$ & $17,33 \%$ ] & $-3,41 \%$ & $23,53 \%$ ] & $4,76 \%$ & $7,27 \%$ & 1,69\% | & $4,17 \%$ | & $0,66 \%$ | & $-11,29 \%$ & $14,55 \%$ \\
\hline ESTR4 & Estrela & & Low & 5. & $\mathrm{Sn}$ & 24 & Loser & Small|Low|Loser & $-9,38 \%$ [ & $10,34 \%$ & $87,50 \%$ & $15,00 \%$ & $5,80 \%$ & $16,44 \%$ & $-14,12 \%$ & $10,96 \%$ & $-12,35 \%$ & $-4,23 \%$ & $2,94 \%$ & $1,43 \%$ \\
\hline BARB4 & s sobain & 1,58 & Low & 131.340.494 & Small & 0,17 & Loser & Small| Low|Loser & $-11,17 \%$ & $-13,17 \%$ & $24,14 \%$ ] & $3,89 \%$ & $12,30 \%$ | & $8,57 \%$ & $-5,70 \%$ & 4,65\% | & $14,67 \%$ & $-14,08 \%$ | $\quad>\quad>$ & $-7,69 \%$ & $4,44 \%$ \\
\hline FTSE4 & Ferti Serrana PN & 1,59 & Low & 83.285 .231 & Small & 0,16 & Loser & Small|Low|Loser & $-25,56 \%$ & $48,66 \%$ & $4,42 \%$ & $5,77 \%$ & $1,82 \%$ & $25,00 \%$ & $21,43 \%$ & $3,53 \%$ & $-9,09 \%$ & $-24,12 \%$ & $-17,14 \%$ & $1,72 \%$ \\
\hline TBAC6 & lar PNB & 0,89 & Low & 61.707 & Small & 0,07 & Winner & Small|Low|Winner & $-37,28 \%$ & $-11,11 \%$ ] & $12,56 \%$ [ & $2,72 \%$ & $0,00 \%$ & $56,76 \%$ ] & $-17,24 \%$ & $25,00 \%$ & $16,70 \%$ & $-26,88 \%$ | $>2$ & $-14,37 \%$ & $-2,17 \%$ \\
\hline RPAD3 & Alfa Hol & 1,37 & Low & 57.306 & Small & 0,03 & Winner & Small| Low /Wint & $-3,10 \%$ & $-4,87 \%$ & $6,03 \%$ & $6,50 \%$ & $9,16 \%$ & $11,89 \%$ & $8,12 \%$ & \begin{tabular}{ll|}
$12,47 \%$ \\
\end{tabular} & $7,53 \%$ & $0,00 \%$ & $-7,00 \%$ & $0,00 \%$ \\
\hline BARB3 & $S$ Gobain Canal ON & 1,58 & Low & 131.340.494 & Small & 0,02 & Winner & Small|Low|Winner & $-5,71 \%$ & $0,00 \%$ & $-3,03 \%$ | & $0,00 \%$ ] & $3,75 \%$ & $5,42 \%$ & $8,00 \%$ & \begin{tabular}{l|l|}
$1,59 \%$ \\
\end{tabular} & $15,10 \%$ & $-11,81 \%$ & $11,18 \%$ & $-10,05 \%$ \\
\hline TMAC6B & Amazonia Celular PN & 0,41 & Low & 29.759 .082 & Small & 0,03 & Winner & Small|Low|Winner & $34,33 \%$ & $-3,70 \%$ & $-15,00 \%$ & $20,36 \%$ & $-17,29 \%$ & $18,64 \%$ & $4,38 \%$ & $1,59 \%$ & $26,56 \%$ & $17,28 \%$ & $-10,53 \%$ & $7,65 \%$ \\
\hline RPAD6 & AlfaH & 1,37 & Le & 7.306 & mall & 0,09 & $v^{2}$ & Small|L & $3,39 \%$ & $-0,54 \%$ & $420 \% \mathrm{t}$ & $13,01 \%$ & $10,07 \%$ & $7,84 \%$ & $11,37 \%$ & $8,57 \%$ & $5,79 \%$ & $1,99 \%$ & $-6,83 \%$ & $2 \%$ \\
\hline RPAD5 & Alfa Ho & 1, & Lo & & $\mathrm{Sm}$ & t & & Smanllec & 2,4 & $0,87 \%$ & $-0,81 \%$ & $75 \%$ & $9,29 \%$ & $7,84 \%$ & $12 \%$ & $12,77 \%$ & $0,00 \%$ & $1,00 \%$ & $-8,91 \%$ & $09 \%$ \\
\hline BRGE3 & Alfa Consorc ON & 1,63 & Low & 97.808 .860 & Small & 0,15 & Winner & Small|Low|Winner & $-0,75 \%$ | & $-2,77 \%$ ] & 1,59\% | & $10,16 \%$ & $15,60 \%$ & $17,18 \%$ | & $20,94 \%$ & 7,98\% ] & $-1,67 \%$ & $0,00 \%$ ] & $0,00 \%$ & $-6,78 \%$ \\
\hline
\end{tabular}


Anexo 1 - Retorno mensal e classificação das ações

\begin{tabular}{|c|c|c|c|c|c|c|c|c|c|c|c|c|c|c|c|c|c|c|c|c|}
\hline Código & $1999-2000$ & $\begin{array}{l}\text { Índice } B / M \\
\text { de dez/1998 }\end{array}$ & $\begin{array}{c}\text { Grupo com } \\
\text { base no } \\
\text { indice B/M }\end{array}$ & $\begin{array}{c}\text { Valor de Mercado } \\
\text { em jun/1999 }\end{array}$ & $\begin{array}{c}\text { Grupo com } \\
\text { base no } \\
\text { tamanho }\end{array}$ & $\begin{array}{c}\text { Retorno } \\
\text { acumulado } \\
\text { de jun/1999 }\end{array}$ & $\begin{array}{l}\text { Grupo com } \\
\text { base no } \\
\text { retorno } \\
\text { acumulado }\end{array}$ & Carteiras & $\mathrm{jul} / 99$ & ago/99 & set/99 & out/99 & nov/99 & dez/99 & $\mathrm{jan} / 00$ & $\mathrm{fev} / 00$ & mar/00 & $\mathrm{abr} / 00$ & mai/00 & jun/00 \\
\hline ALBA3 & Ibarus ON & 0,97 & Low & 300.080 .002 & Small & 0,57 & Winner & Small|Low|Winner & $-16,13 \%$ & $14,42 \%$ & $-21,01 \%$ & $23,40 \%$ & $-16,38 \%$ & $2,06 \%$ & $-1,01 \%$ & $4,64 \%$ & $-5,00 \%$ & $20,78 \%$ & $3,53 \%$ & $32,95 \%$ \\
\hline RSID3 & ossi Resid ON & 3,45 & Medium & 54.074.998 & Small & 0,70 & Loser & Small|Medium|Loser & $-23,81 \%$ & $18,75 \%$ & $-5,26 \%$ & $2,78 \%$ & $43,24 \%$ & $18,87 \%$ & $0,00 \%$ & $25,40 \%$ & $14,89 \%$ & $18,06 \%$ & $-11,48 \%$ & $18,52 \%$ \\
\hline IBAN5 & tarct Nordeste PNA & 2,48 & Medium & 229.663 .934 & Small & 0,61 & Loser & Small|Medium|Loser & $-1,47 \%$ & $9,33 \%$ & $46,15 \%$ & $26,32 \%$ & $4,17 \%$ & $4,00 \%$ & $-1,33 \%$ & $-14,00 \%$ & $6,98 \%$ & $6,52 \%$ & $-6,12 \%$ & $-6,04 \%$ \\
\hline TPECGB & Tim Nordeste PNB & 1,79 & Medium & 82.780 .624 & Small & 0,50 & Loser & Small|Medium | Loser & $7,92 \%$ & $-15,06 \%$ & $-1,82 \%$ & $10,19 \%$ & $-11,76 \%$ & $38,10 \%$ & $3,45 \%$ & $13,33 \%$ & $41,18 \%$ & $8,33 \%$ & $-26,92 \%$ & $47,89 \%$ \\
\hline MFLU3 & Santista Alimentos ON & 1,93 & Medium & 267.946 .059 & Small & 0,47 & Loser & Small|Medium|Loser & $2,13 \%$ & $-8,33 \%$ & $-9,09 \%$ & $2,50 \%$ & $9,76 \%$ & $17,78 \%$ & $-3,77 \%$ & $-17,65 \%$ & $-7,14 \%$ & $-10,26 \%$ & $-20,00 \%$ & $35,71 \%$ \\
\hline TRBR4 & ansbrasil PN & 2,31 & Medium & 508.899 & Small & 0,43 & Loser & Small|Medium|Loser & $-13,79 \%$ & $11,33 \%$ & $34,59 \%$ & $22,91 \%$ & $9,09 \%$ & $-1,75 \%$ & $13,83 \%$ & $3,35 \%$ & $-19,05 \%$ & $75,29 \%$ & $42,95 \%$ & $5,88 \%$ \\
\hline FLCL5 & F Cataguazes PNA & 2,27 & Medium & 306.884 & Small & 0,40 & Loser & Small|Medium|Loser & $6,86 \%$ & $-8,26 \%$ & $2,00 \%$ & $0,00 \%$ & $17,65 \%$ & $47,50 \%$ & $17,51 \%$ & $2,88 \%$ & $-6,54 \%$ & $-2,50 \%$ & $-0,51 \%$ & $-1,03 \%$ \\
\hline MSAN3 & Bunge Brasil ON & 1,82 & Medium & 130.557 .022 & Small & 0,39 & Loser & Small|Medium|Loser & $-10,00 \%$ & $-5,56 \%$ & $-1,96 \%$ & $42,00 \%$ & $16,90 \%$ & $25,30 \%$ & $-13,46 \%$ & $38,89 \%$ & $-12,00 \%$ & $-22,73 \%$ & $2,55 \%$ & $10,75 \%$ \\
\hline BDLL4 & Bardella PN & 3,04 & Medium & .463 .000 & Small & 0,38 & Loser & Small|Medium |Loser & $-20,00 \%$ & $2,50 \%$ & $24,75 \%$ & $12,48 \%$ & $15,07 \%$ & $22,83 \%$ & $4,11 \%$ & $25,35 \%$ & $-7,99 \%$ & $-14,52 \%$ & $-11,43 \%$ & $1,94 \%$ \\
\hline CEBR5 & Dov & 44 & Medium & & Small & 0,29 & Loser & Small|Medium|Loser & $-7,04 \%$ & $-6,03 \%$ & $3,19 \%$ & $1,56 \%$ & $35,69 \%$ & $-4,76 \%$ & $238 \% \mathrm{t}-2 \mathrm{c}$ & $0,00 \%$ & $4,88 \%$ & $0,00 \%$ & $2,91 \%$ & $0,03 \%$ \\
\hline CNFB4 & Confab P & 2,69 & Medium & 477 & Small & 0,24 & Loser & Small|Me & $-7,19 \%$ & $26,76 \%$ & $7,69 \%$ & $-1,79 \%$ & $10,00 \%$ & $56,60 \%$ & $-8,57 \%$ & $-3,75 \%$ & $-5,84 \%$ & $-20,69 \%$ & $12,17 \%$ & $4,95 \%$ \\
\hline CEVA3 & Bunge Alimentos ON & 3,02 & Medium & 386.946 & Small & 0,22 & Loser & Small|Medium | Loser & $30,21 \%$ & $8,00 \%$ & $4,07 \%$ & $6,76 \%$ & $16,67 \%$ & $20,00 \%$ & $7,14 \%$ & $-11,11 \%$ & $-22,50 \%$ & $12,89 \%$ & $-8,96 \%$ & $4,92 \%$ \\
\hline LTS3 & Brasilit ON & 1,99 & Medium & .656 .657 & Small & 0,15 & Loser & Small|Medium|Loser & $-15,86 \%$ & $2,46 \%$ & $12,00 \%$ & $38,57 \%$ & $-8,76 \%$ & $12,99 \%$ & $0,00 \%$ & $0,00 \%$ & $6,00 \%$ & $-2,85 \%$ & $8,42 \%$ & $-0,49 \%$ \\
\hline DXTG4 & & & Medit & & Small & & Los & Small|Me & $-2,94 \%$ & $3,03 \%$ & $2,94 \%$ & $0,00 \%$ & $37,14 \%$ & $33,33 \%$ & $1,56 \%$ & $-9,23 \%$ & $0,00 \%$ & $8,47 \%$ & $1,85 \%$ & $0,00 \%$ \\
\hline POLA4 & Polar PI & 7 & Medium & & Small & 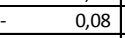 & Lose & Small|Medium|Loser & $3,33 \%$ & $21,79 \%$ & $30,06 \%$ & $11,11 \%$ & $16,00 \%$ & $-3,45 \%$ & 5,61\% & $-3,57 \%$ & $-11,11 \%$ & $8,33 \%$ & $-7,69 \%$ & $7,08 \%$ \\
\hline POMO4 & Marcopolo PN & 2,18 & Medium & 515.506 & Small & 0,07 & Loser & Small|Medium|Loser & $-6,70 \%$ & $-5,13 \%$ & $3,78 \%$ & $-1,04 \%$ & $7,89 \%$ & $6,35 \%$ & $-7,98 \%$ & $42,86 \%$ & $-16,07 \%$ & $10,64 \%$ & $8,85 \%$ & $-1,06 \%$ \\
\hline GUAR3 & Guararapes ON & 4 & Medium & 234.297 & Small & 0,07 & Winner & Small|Medium|Winner & $-4,55 \%$ & $-14,29 \%$ & $11,11 \%$ & $6,67 \%$ & $39,06 \%$ & $28,09 \%$ & $-5,26 \%$ & $-5,56 \%$ & $20,59 \%$ & $0,48 \%$ & $-8,04 \%$ & $-8,93 \%$ \\
\hline ELEV3 & Eleva ON & 3,82 & Medium & 515.175 & Small & 0,02 & Winner & Small|Medium|Winner & $-9,62 \%$ & $-14,89 \%$ & $3,13 \%$ & $11,52 \%$ & $25,00 \%$ & $8,70 \%$ & $1,60 \%$ & $-0,79 \%$ & $-2,78 \%$ & $-5,17 \%$ & $-4,35 \%$ & $14,09 \%$ \\
\hline CEVA4 & Bu & 3,02 & Medium & 386.946 & Small & 0,07 & Winne & Small|Med & $28,89 \%$ & $2,01 \%$ & $9,86 \%$ & $0,00 \%$ & $8,72 \%$ & $10,85 \%$ & 6,38 & $-4,00 \%$ & $-13,54 \%$ & $0,13 \%$ & $-13,75 \%$ & $15,94 \%$ \\
\hline BOBR4 & Bombril & 3,90 & Mediun & 565.891 & Small & 3 & Winner & Small|Medium|Winner & $-11,54 \%$ & $13,04 \%$ & $-6,73 \%$ & $25,57 \%$ & $39,90 \%$ & $64,32 \%$ & $4,29 \%$ & $-10,96 \%$ & $-2,31 \%$ & $-12,52 \%$ & $11,32 \%$ & $32,32 \%$ \\
\hline OXIT4 & Oxiter & & Med & & Small & & Winner & Small|Medium|Winner & $-0,70 \%$ & $-0,69 \%$ & $18,18 \%$ & $6,15 \%$ & $7,91 \%$ & $9,59 \%$ & $-6,25 \%$ & $9,23 \%$ & $24,87 \%$ & $-0,10 \%$ & $-15,26 \%$ & $2,04 \%$ \\
\hline ALPA4 & Alpargatas PN & 2,86 & Medium & 138.155 .481 & Small & 0,24 & Winner & Small|Medium|Winner & $12,50 \%$ & $-13,58 \%$ & $14,22 \%$ & $0,01 \%$ & $40,15 \%$ & $-0,92 \%$ & $-6,36 \%$ & $2,43 \%$ & $9,95 \%$ & $-5,12 \%$ & $14,81 \%$ & $0,02 \%$ \\
\hline BRGE11 & Alfa Co & 1,63 & Medium & \begin{tabular}{ll|}
97.808 .860 \\
\end{tabular} & Small & 0,26 & Winne & Small|Medi & $0,81 \%$ & $-1,31 \%$ & $8,33 \%$ & $22,31 \%$ & $4,40 \%$ & $20,48 \%$ & 20,00 & 3,7 & $-3,7$ & & $1,72 \%$ & $-6,7$ \\
\hline ETER3 & Eternit & 4 & M & & Small & 0,28 & Wi & Small|Medi & $-0,94$ & $7,30 \%$ & $16,00 \%$ & $13,79 \%$ & $14,85 \%$ & $1,54 \%$ & 32, & 3,5 & $-0,25 \%$ & $8,53 \%$ & $-4,23 \%$ & $2,94 \%$ \\
\hline ALPA3 & Alpargatas & 2,86 & Medium & 155.481 & Small & 0,37 & Win & Small|Medic & $4,00 \%$ & $17,95 \%$ & $2,17 \%$ & $-2,13 \%$ & $14,13 \%$ & $10,58 \%$ & $-11,30 \%$ & $17,65 \%$ & $3,34 \%$ & $0,92 \%$ & $0,00 \%$ & $0,00 \%$ \\
\hline LEVE4 & Metal Leve PN & 2,85 & Medium & \begin{tabular}{|l|}
158.201 .492 \\
\end{tabular} & Small & 0,43 & Winner & Small|Medium|Winner & $3,83 \%$ & $20,53 \%$ & $19,21 \%$ & $8,79 \%$ & $14,14 \%$ & $-4,13 \%$ & $4,92 \%$ & $-7,92 \%$ & $-7,80 \%$ & $7,19 \%$ & $-4,92 \%$ & $2,69 \%$ \\
\hline RGE12 & & 1,63 & the & 8.860 & mall & 0,48 & Nipn & & $3,07 \%$ & $1,61 \%$ & 20 & $15,94 \%$ & & 20 & $24,86 \%$ & & $2,08 \%$ & & $-3,85 \%$ & $12,00 \%$ \\
\hline & & 2,57 & & & & & & & & $5,63 \%$ & & & & & & & & & S1\% & \\
\hline & Cargill & 3,71 & Medium & 49.719 .040 & imall & 1,30 & inner & Small|Medium/Winner & $0.45 \%$ & $24.44 \%$ & 4,719 & $7.69 \%$ & $19.44 \%$ & $581 \%$ & $31,65 \%$ & $13,19 \%$ & 0,00 & & $300 \%$ & $963 \%$ \\
\hline
\end{tabular}

\begin{tabular}{|c|c|c|c|c|c|c|c|c|c|c|c|c|c|c|c|c|c|c|c|c|}
\hline Código & 2000 - 2001 & $\begin{array}{l}\text { Índice } B / M \\
\text { de dez/1999 }\end{array}$ & $\begin{array}{c}\text { Grupo com } \\
\text { base no } \\
\text { indice B/M }\end{array}$ & $\begin{array}{c}\text { Valor de Mercado } \\
\text { em jun } / 2000\end{array}$ & $\begin{array}{c}\text { Grupo com } \\
\text { base no } \\
\text { tamanho }\end{array}$ & $\begin{array}{c}\text { Retorno } \\
\text { acumulado } \\
\text { de jun/2000 }\end{array}$ & \begin{tabular}{|c|} 
Grupo com \\
base no \\
retorno \\
acumulado
\end{tabular} & Carteiras & jul/00 & ago/00 & set/00 & out/00 & nov/00 & dez/00 & jan/01 & fev/01 & $\mathrm{mar} / 01$ & $\mathrm{abr} / 01$ & mai/01 & jun/01 \\
\hline PALF3 & Paul F Luz ON & 2,36 & High & \begin{tabular}{|l|}
2.164 .556 .875 \\
\end{tabular} & Big & 0,44 & \begin{tabular}{|l|} 
Loser \\
\end{tabular} & Big|High|Loser & $11,03 \%$ & $-4,49 \%$ & $-0,82 \%$ & $-5,10 \%$ & $-8,93 \%$ & $-10,78 \%$ & $22,85 \%$ & $-0,91 \%$ & $-2,75 \%$ & $11,86 \%$ & $-13,97 \%$ & $-0,80 \%$ \\
\hline PALF5 & aul F Luz PNA & 2,36 & High & 2.164.556.875 & Big & 0,37 & Loser & Big|High|Loser & $-13,58 \%$ & $-10,00 \%$ & $1,43 \%$ & $-13,93 \%$ & $-0,18 \%$ & $-18,03 \%$ & $26,70 \%$ & $-14,29 \%$ & $-2,08 \%$ & $27,66 \%$ & $-21,67 \%$ & $1,06 \%$ \\
\hline ELET3 & Eletrobras ON & 2,84 & High & 20.133 .559 .874 & Big & 0,23 & Loser & Big|High|Loser & $6,76 \%$ & $-13,67 \%$ & $5,28 \%$ & $-5,57 \%$ & $-4,10 \%$ & $10,89 \%$ & $20,06 \%$ & $-4,23 \%$ & $3,67 \%$ & $-9,64 \%$ & \begin{tabular}{|l|l|}
$-19,68 \%$ \\
\end{tabular} & $-2,06 \%$ \\
\hline ELET6 & Eletrobras PNB & 2,84 & High & 20.133 .559 .874 & Big & 0,14 & Loser & Big|High|Loser & $6,54 \%$ & $-12,96 \%$ & $1,27 \%$ & $-9,53 \%$ & $-2,39 \%$ & $8,82 \%$ & $20,17 \%$ & $-8,80 \%$ & $9,56 \%$ & $-13,85 \%$ & $-25,98 \%$ & $6,67 \%$ \\
\hline CESP3 & Cesp ON & 11,90 & High & 1.169.308.969 & Big & 0,02 & Loser & Big|High|Loser & $34,92 \%$ & $5,29 \%$ & $2,91 \%$ & $-11,02 \%$ & $7,99 \%$ & $-13,33 \%$ & $35,59 \%$ & $-0,05 \%$ & $0,77 \%$ & $-8,35 \%$ & $-25,52 \%$ & $2,10 \%$ \\
\hline CESP5 & Cesp PNA & 11,90 & High & 1.169 .308 .969 & Big & 12 & Loser & Big|High|Loser & $42,91 \%$ & $6,80 \%$ & $4,67 \%$ & $-5,63 \%$ & $11,98 \%$ & $-14,15 \%$ & $25,75 \%$ & $1,29 \%$ & $-2,24 \%$ & $-21,04 \%$ & $-17,61 \%$ & $0,00 \%$ \\
\hline TBLE3 & Tractebel $\mathrm{O}$ & 2,22 & High & \begin{tabular}{|l|l|l|l|}
1.252 .311 \\
\end{tabular} & $\mathrm{Big}$ & 0,25 & Loser & Big|High|Loser & $13,70 \%$ & $15,66 \%$ & $-1,04 \%$ & $3,51 \%$ & $-3,39 \%$ & $3,16 \%$ & $12,59 \%$ & $-4,53 \%$ & $12,03 \%$ & $6,18 \%$ & $4,00 \%$ & $23,35 \%$ \\
\hline TBLE6 & Tractebel PNB & 2,22 & High & \begin{tabular}{|l|}
1.188 .252 .311 \\
\end{tabular} & Big & 0,26 & Loser & Big|High|Loser & $13,60 \%$ & $11,20 \%$ & $1,74 \%$ & $-0,68 \%$ & $-2,06 \%$ & $0,00 \%$ & $12,28 \%$ & $1,25 \%$ & $10,80 \%$ & $-1,06 \%$ & 6,06\% & $-5,71 \%$ \\
\hline CSTB4 & Sid Tubarao PN & 2,86 & High & \begin{tabular}{|l|}
1.049 .178 .514 \\
\end{tabular} & Big & 0,56 & Loser & Big|High|Loser & $5,64 \%$ & $7,69 \%$ & $-1,28 \%$ & $-6,71 \%$ & $-13,37 \%$ & 9,95\% & $11,57 \%$ & $-7,21 \%$ & $-0,52 \%$ & $0,00 \%$ & $21,43 \%$ & $14,16 \%$ \\
\hline USIM3 & Usiminas ON & 1,97 & High & \begin{tabular}{|l|l|}
1.41 .714 .553 \\
\end{tabular} & Big & 0,70 & Winner & Big|High|WWinner & $11,76 \%$ & $10,22 \%$ & $-1,64 \%$ & $0,00 \%$ & $-3,33 \%$ & $-1,72 \%$ & $36,84 \%$ & $-5,13 \%$ & $-7,09 \%$ & $5,26 \%$ & $-7,29 \%$ & $-1,39 \%$ \\
\hline USIM5 & Usiminas PNA & 1,97 & High & \begin{tabular}{|l|l|}
1.431 .714 .553 \\
\end{tabular} & Big & 0,72 & Winner & Big|High|Winner & $17,51 \%$ & $10,11 \%$ & $-0,94 \%$ & $-6,67 \%$ & $-18,37 \%$ & $9,75 \%$ & $35,54 \%$ & $-12,61 \%$ & $-15,38 \%$ & $-0,81 \%$ & \begin{tabular}{|l|}
$-23,71 \%$ \\
\end{tabular} & $0,62 \%$ \\
\hline
\end{tabular}


Anexo 1 - Retorno mensal e classificação das ações

\begin{tabular}{|c|c|c|c|c|c|c|c|c|c|c|c|c|c|c|c|c|c|c|c|c|}
\hline Código & $2000-2001$ & $\begin{array}{l}\text { Índice } B / M \\
\text { de dez/1999 }\end{array}$ & $\begin{array}{c}\text { Grupo com } \\
\text { base no } \\
\text { indice B/M } \\
\end{array}$ & $\begin{array}{c}\text { Valor de Mercado } \\
\text { em jun/2000 }\end{array}$ & $\begin{array}{c}\text { Grupo com } \\
\text { base no } \\
\text { tamanho }\end{array}$ & $\begin{array}{c}\text { Retorno } \\
\text { acumulado } \\
\text { de jun/2000 }\end{array}$ & \begin{tabular}{|c} 
Grupo com \\
base no \\
retorno \\
acumulado
\end{tabular} & Carteiras & $\mathrm{jul} / 00$ & ago/00 & set $/ 00$ & out $/ 00$ & nov/00 & dez/00 & $\mathrm{jan} / 01$ & fev/01 & $\mathrm{mar} / 01$ & $\mathrm{abr} / 01$ & mai/01 & jun/01 \\
\hline ACES3 & Am Inox BR ON & 1,88 & High & 931.184.282 & Big & 1,01 & \begin{tabular}{|l} 
Winner \\
\end{tabular} & Big|High|Winner & $2,78 \%$ & $0,00 \%$ & $-8,11 \%$ & $-7,84 \%$ & $-14,89 \%$ & $6,25 \%$ & $12,94 \%$ & $-6,25 \%$ & $-4,44 \%$ & $-3,49 \%$ & $-24,10 \%$ & $-1,59 \%$ \\
\hline ACES4 & Am Inox BR PN & 1,88 & High & 931.184.282 & Big & 1,07 & Winner & Big|High|Winner & $-2,24 \%$ & $12,98 \%$ & $-11,49 \%$ & $-9,16 \%$ & $-23,53 \%$ & $10,99 \%$ & $14,85 \%$ & $-8,62 \%$ & $-10,38 \%$ & $-8,42 \%$ & $-21,84 \%$ & $0,00 \%$ \\
\hline BRKM5 & Braskem PNA & 2,19 & High & 1.118.811.064 & Big & 1,19 & Winner & Big|High|Winner & $18,74 \%$ & $-2,70 \%$ & $-1,32 \%$ & $-1,60 \%$ & $-13,83 \%$ & $-3,38 \%$ & $12,50 \%$ & $-4,97 \%$ & $-4,00 \%$ & $-3,33 \%$ & $-8,81 \%$ & $9,17 \%$ \\
\hline EPTE4 & Epte PN & 4,24 & High & 627.730 .937 & Big & 1,20 & Winner & Big|High|Winner & $19,95 \%$ & $-5,79 \%$ & $-7,86 \%$ & $-20,86 \%$ & $-8,93 \%$ & $2,47 \%$ & $39,43 \%$ & $1,43 \%$ & $-17,39 \%$ & $-1,84 \%$ & $-17,45 \%$ & $13,82 \%$ \\
\hline ARCE3 & Arcelor BR ON & 2,02 & High & 917.628 .813 & Big & 1,64 & Winner & Big|High|Winner & $10,00 \%$ & $43,27 \%$ & $1,27 \%$ & $-12,28 \%$ & $-14,29 \%$ & $-2,98 \%$ & $20,54 \%$ & $-0,96 \%$ & $-5,19 \%$ & $0,54 \%$ & $-21,13 \%$ & $6,60 \%$ \\
\hline $\begin{array}{ll}\text { ARCE4 } \\
\end{array}$ & \begin{tabular}{|l|} 
Arcelor BR PN \\
\end{tabular} & 2,02 & High & 917.628 .813 & Big & 1,91 & Winner & Big/High/Winner & $-2,27 \%$ & $32,89 \%$ & $2,50 \%$ & $-12,68 \%$ & $-10,61 \%$ & $-7,52 \%$ & $33,60 \%$ & $-4,29 \%$ & $2,69 \%$ & $-0,91 \%$ & $-21,21 \%$ & $3,76 \%$ \\
\hline CGAS5 & Comgas PNA & 0,48 & Low & $\begin{array}{l}669.809 .452 \\
\end{array}$ & Big & 0,01 & Loser & Big|Low|Loser & $10,91 \%$ & $46,61 \%$ & $6,48 \%$ & $17,77 \%$ & $4,40 \%$ & $-3,77 \%$ & $34,31 \%$ & $3,63 \%$ & $8,85 \%$ & $-24,54 \%$ & $22,30 \%$ & $-9,11 \%$ \\
\hline ARCZ6 & Aracruz PNB & 0,61 & Low & 2.970 .866 .358 & Big & 0,07 & Loser & Big|Low|Loser & $\begin{array}{l}9,91 \% \\
\end{array}$ & $-2,92 \%$ & $-15,85 \%$ & $-8,44 \%$ & $-18,09 \%$ & $22,94 \%$ & $0,70 \%$ & $-5,59 \%$ & $6,30 \%$ & $15,31 \%$ & $30,16 \%$ & $2,44 \%$ \\
\hline VCPA4 & Fibria PN & 0,64 & Low & 2.472 .066 .701 & Big & 0,18 & Loser & Big|Low|Loser & $17,18 \%$ & $-7,57 \%$ & $2,50 \%$ & $-13,55 \%$ & $-19,31 \%$ & $13,04 \%$ & $13,27 \%$ & $-9,33 \%$ & $-2,67 \%$ & $10,95 \%$ & $0,00 \%$ & $13,11 \%$ \\
\hline CRUZ3 & Souza Cruz ON & 0,34 & Low & 3.298 .395 .088 & Big & 0,24 & Loser & Big|Low|Loser & $-14,36 \%$ & $13,41 \%$ & $-11,84 \%$ & $17,62 \%$ & $-14,76 \%$ & $8,72 \%$ & $42,30 \%$ & $0,00 \%$ & $0,83 \%$ & $-2,81 \%$ & $10,09 \%$ & $-3,20 \%$ \\
\hline TNCP3 & Tele Nort $\mathrm{Cl}$ ON & $\begin{array}{ll}0,67 \\
\end{array}$ & Low & 590.010 .436 & Big & 0,25 & Loser & Big|Low|Loser & $-4,24 \%$ & $-8,23 \%$ & $6,90 \%$ & $-1,29 \%$ & $11,11 \%$ & $-14,71 \%$ & $18,62 \%$ & $4,65 \%$ & $11,11 \%$ & $-8,00 \%$ & $1,24 \%$ & $8,11 \%$ \\
\hline BRTP4 & Brasil T Par PN & 0,68 & Low & 7.757.736.338 & Big & 0,34 & Loser & Big|Low|Loser & $-2,18 \%$ & $1,84 \%$ & $-17,31 \%$ & $-3,86 \%$ & $-17,27 \%$ & $30,99 \%$ & $12,95 \%$ & $-17,00 \%$ & $-19,24 \%$ & $17,33 \%$ & $-3,66 \%$ & $2,66 \%$ \\
\hline WEGE4 & Weg PN & 0,58 & Low & 611.766 .647 & Big & 0,37 & Loser & Big|Low|Loser & $10,83 \%$ & $13,33 \%$ & $0,84 \%$ & $-1,67 \%$ & $9,32 \%$ & $3,32 \%$ & $1,54 \%$ & $6,11 \%$ & $7,91 \%$ & $0,67 \%$ & $32,45 \%$ & $-7,70 \%$ \\
\hline TLCP4 & Tele Leste Celular PN & 0,35 & Low & 702.578 .051 & Big & 0,39 & Loser & Big|Low/Loser & $6,25 \%$ & $10,00 \%$ & $-19,25 \%$ & $-2,65 \%$ & $-23,81 \%$ & $16,07 \%$ & $29,23 \%$ & $0,60 \%$ & $-7,69 \%$ & $3,21 \%$ & $23,60 \%$ & $-5,53 \%$ \\
\hline ELPL5 & Eletropaulo PNA & 0,57 & Low & 5.313.168.614 & Big & 0,45 & Loser & Big|Low/Loser & $-5,12 \%$ & $-7,05 \%$ & $-1,33 \%$ & $-3,18 \%$ & $-14,77 \%$ & $9,14 \%$ & $26,65 \%$ & $-4,83 \%$ & $-23,39 \%$ & $-17,79 \%$ & $-3,30 \%$ & $11,75 \%$ \\
\hline CBEE3 & Ampla E & 0,29 & Low & 1.083.465.183 & Big & 0,46 & Loser & \begin{tabular}{|l|l|l|l} 
Big|Low|Loser \\
\end{tabular} & $4,29 \%$ & $-19,18 \%$ & $-1,69 \%$ & $-18,97 \%$ & $-14,89 \%$ & $0,00 \%$ & $2,50 \%$ & $-4,88 \%$ & $-7,69 \%$ & $44,44 \%$ & $-1,92 \%$ & $5,88 \%$ \\
\hline TLCP3 & Tele Leste Celular ON & 0,35 & Low & 702.578 .051 & Big & 0,46 & \begin{tabular}{|l|} 
Loser \\
\end{tabular} & Big|Low|Loser & $-8,24 \%$ & $6,41 \%$ & $-6,63 \%$ & $-0,65 \%$ & $10,39 \%$ & $17,06 \%$ & $-12,06 \%$ & $2,86 \%$ & $11,11 \%$ & $-13,00 \%$ & $27,59 \%$ & $3,60 \%$ \\
\hline VALE5 & Vale PNA & 0,60 & Low & 18.114.011.095 & Big & 0,52 & Loser & Big|Low|Loser & $-3,34 \%$ & $0,00 \%$ & $-5,89 \%$ & $-4,97 \%$ & $-10,68 \%$ & $20,81 \%$ & $19,57 \%$ & $-0,36 \%$ & $0,76 \%$ & $-3,96 \%$ & $11,98 \%$ & $-8,04 \%$ \\
\hline ARCZ3 & Aracruz ON & 0,61 & Low & 2.970 .866 .358 & Big & 0,52 & Loser & Big|Low|Loser & $4,88 \%$ & $4,19 \%$ & $-10,71 \%$ & $-7,50 \%$ & $5,41 \%$ & $7,69 \%$ & $9,52 \%$ & $-4,35 \%$ & $2,27 \%$ & $8,27 \%$ & $8,70 \%$ & $0,00 \%$ \\
\hline AMBV3 & Ambev & 0,18 & Low & 88.882 .528 & Big & 0,53 & Loser & Big|Low/Loser & $20,22 \%$ & $3,57 \%$ & $8,44 \%$ & $21,79 \%$ & $2,37 \%$ & $22,10 \%$ & $10,64 \%$ & $-5,77 \%$ & $0,00 \%$ & $6,12 \%$ & $-1,92 \%$ & $1,18 \%$ \\
\hline AMBV4 & Amber PN & 0,18 & Low & 9.838 .882 .528 & Big & 0,55 & \begin{tabular}{|l|l|} 
Loser \\
\end{tabular} & Big|Low|Loser & $22,22 \%$ & $-2,41 \%$ & $11,92 \%$ & $4,93 \%$ & $-2,58 \%$ & $14,43 \%$ & $18,89 \%$ & $-10,52 \%$ & $1,00 \%$ & $6,53 \%$ & $-0,56 \%$ & $0,94 \%$ \\
\hline TNCP4 & Tele Nort Cl PN & 0,67 & Low & 590.010 .436 & Big & 0,55 & Loser & Big|Low|Loser & $-4,37 \%$ & $-8,00 \%$ & $-7,45 \%$ & $-10,07 \%$ & $-10,45 \%$ & $8,33 \%$ & $30,00 \%$ & $-9,47 \%$ & $-21,57 \%$ & $-5,00 \%$ & $11,75 \%$ & $-0,79 \%$ \\
\hline TSEP3 & Tele Sudeste Celula ON & 0,25 & Low & 3.006 .104 .803 & Big & 0,61 & Loser & Big|Low/Loser & $1,63 \%$ & $0,00 \%$ & $-5,36 \%$ & $-7,74 \%$ & $0,52 \%$ & $2,08 \%$ & $58,16 \%$ & $-8,39 \%$ & $0,60 \%$ & $-1,27 \%$ & $2,71 \%$ & $4,31 \%$ \\
\hline \begin{tabular}{|l|l|} 
PCAR4 & \\
\end{tabular} & P.Acucar-cbd PN & 0,40 & Low & 4.177 .044 .736 & Big & 0,61 & $\begin{array}{ll}\text { Loser } \\
\end{array}$ & Big|Low/Loser & $-3,25 \%$ & $21.91 \%$ & $0.28 \%$ & $-1,71 \%$ & $-1.53 \%$ & $8.48 \% \mathrm{f}$ & $-0,20 \%$ & $-4,39 \%$ & $-1.48 \%$ & $-6,32 \%$ & $-0,16 \%$ & $-11.58 \%$ \\
\hline EBTP4 & Embratel Part PN & 0,43 & Low & 13.167.166.124 & Big & 0,65 & \begin{tabular}{|l|l|} 
Loser \\
\end{tabular} & Big|Low|Loser & $-11,83 \%$ & $6,32 \%$ & $-15,84 \%$ & $-9,91 \%$ & $-21,32 \%$ & $22,82 \%$ & $13,56 \%$ & $-25,65 \%$ & $-17,51 \%$ & $2,46 \%$ & $-3,59 \%$ & $-11,13 \%$ \\
\hline CRTP3 & Crt Celular ON & 0 & Low & 1.831 .340 .446 & \begin{tabular}{|l|l} 
Big \\
\end{tabular} & 0,05 & Winner & Big|Low|Winner & $24,32 \%$ & $10,87 \%$ & $\begin{array}{l}-15,69 \% \% \\
-150\end{array}$ & - & $-6,58 \%$ & $\mid-4,20 \%$ & $20,55 \%$ & $70,73 \%$ & $28,57 \%$ & $5,00 \%$ & $0,53 \%$ & $-4,21 \%$ \\
\hline PETR4 & Petrobras PN & 0,38 & Low & 58.228 .732 .350 & Big & 0,74 & Winner & Big|Low|Winner & $-14,09 \%$ & $17,68 \%$ & $-4,36 \%$ & $-3,97 \%$ & $-6,15 \%$ & $-3,62 \%$ & $19,07 \%$ & $0,73 \%$ & $-10,32 \%$ & $13,69 \%$ & $11,99 \%$ & $-9,72 \%$ \\
\hline ITSA4 & Itausa PN & 0,70 & Low & 5.562.435.457 & Big & 0,74 & Winner & Big|Low|Winner & $2,29 \%$ & $8,83 \%$ & $-2,96 \%$ & $-13,90 \%$ & $-1,24 \%$ & $25,22 \%$ & $6,22 \%$ & $-10,24 \%$ & $-3,45 \%$ & $8,62 \%$ & $8,47 \%$ & $0,63 \%$ \\
\hline VALE3 & Vale ON & 0,60 & Low & 18.114.011.095 & Big & 0,77 & Winner & Big|Low|Winner & $-1,09 \%$ & $3,82 \%$ & $-8,98 \%$ & $4,64 \%$ & $-15,91 \%$ & $25,68 \%$ & $18,14 \%$ & $-3,92 \%$ & $1,02 \%$ & $-2,02 \%$ & $6,70 \%$ & $2,42 \%$ \\
\hline TSEP4 & Tele Sudeste Celula PN & 0,25 & Low & $\begin{array}{l}3.006 .104 .803 \\
\end{array}$ & Big & 0,78 & Winner & \begin{tabular}{|l} 
Big|Low|Winner \\
\end{tabular} & $\begin{array}{l}-13,12 \% \\
\end{array}$ & $\begin{array}{l}-9,38 \% \\
-9,28 \\
\end{array}$ & 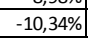 & $0,00 \%$ & $-4,81 \%$ & $-6,98 \%$ & $53,53 \%$ & $-10,92 \%$ & $-13,79 \%$ & $7,77 \%$ & $4,65 \%$ & $3,11 \%$ \\
\hline TNEP4 & \begin{tabular}{|l|} 
Tele Nordeste Celul PN \\
\end{tabular} & 0,25 & Low & 2.014 .121 .796 & Big & 0,85 & \begin{tabular}{|l|l} 
Winner \\
\end{tabular} & Big|Low|Winner & $-23,58 \%$ & $9,37 \%$ & $-21,43 \%$ & $-10,45 \%$ & $-20,05 \%$ & $27,30 \%$ & $3,34 \%$ & $-19,66 \%$ & $-11,78 \%$ & $7,53 \%$ & $29,25 \%$ & $-7,41 \%$ \\
\hline VIVO4 & Vivo PN & 0,26 & Low & 11.605 .909 .598 & Big & 0,99 & Winner & Big|Low|Winner & $-18,71 \%$ & $1,51 \%$ & $-9,63 \%$ & $-7,12 \%$ & $-26,22 \%$ & $23,35 \%$ & $5,35 \%$ & $-12,83 \%$ & $-32,37 \%$ & $20,87 \%$ & $8,56 \%$ & $-14,49 \%$ \\
\hline TNEP3 & Tele Nord & 0,25 & Low & 2.014 .121 .796 & Big & 1,01 & Winner & Big|Low|Winner & $-3,69 \%$ & $-6,38 \%$ & $-4,55 \%$ & $-6,43 \%$ & $-9,67 \%$ & $29,58 \%$ & $-4,96 \%$ & $-10,80 \%$ & $-27,84 \%$ & $16,07 \%$ & $32,31 \%$ & $-8,16 \%$ \\
\hline ITSA3 & Itausa ON & 0,70 & Low & 562.435 .457 & Big & 1,02 & Winner & Big|Low|Winner & $5,77 \%$ & $5,41 \%$ & $4,47 \%$ & $0,00 \%$ & $4,17 \%$ & $0,10 \%$ & $4,08 \%$ & $-1,96 \%$ & $2,54 \%$ & $6,80 \%$ & $4,87 \%$ & $3,67 \%$ \\
\hline BRTP3 & Brasil T Par ON & 0,68 & Low & 7.757.736.338 & Big & 1,04 & Winner & Big|Low|Winner & $1,15 \%$ & $8,05 \%$ & $-19,70 \%$ & $-6,60 \%$ & $-12,60 \%$ & $32,72 \%$ & $25,86 \%$ & $-22,19 \%$ & $2,11 \%$ & $5,46 \%$ & $1,42 \%$ & $4,23 \%$ \\
\hline TCSL4 & Tim Part S/A PN & 0,32 & Low & 2.617.004.331 & Big & 1,17 & Winner & Big|Low|Winner & $-28,74 \%$ & $20,16 \%$ & $-24,97 \%$ & $-14,85 \%$ & $-17,44 \%$ & $31,04 \%$ & $4,04 \%$ & $-22,06 \%$ & $-6,24 \%$ & $12,27 \%$ & $10,32 \%$ & $-3,33 \%$ \\
\hline PETR3 & Petrobras ON & 0,38 & Low & 58.228 .732 .350 & Big & 1,24 & Winner & Big/Low/Winner & $-12.42 \%$ & $24,25 \%$ & $-4,25 \%$ & $0,18 \%$ & $-7,79 \%$ & $-4,88 \%$ & $12,99 \%$ & $4,95 \%$ & $-6,45 \%$ & $14,37 \%$ & $13,75 \%$ & $-10,22 \%$ \\
\hline GLOB4 & Globex PN & 0,65 & Low & 1.088.081.099 & Big & 1,24 & Winner & Big|Low|Winner & $16,69 \%$ & $20,00 \%$ & $2,92 \%$ & $-2,83 \%$ & $-13,75 \%$ & $30,43 \%$ & $-5,56 \%$ & $-3,92 \%$ & $3,20 \%$ & $3,20 \%$ & $-22,60 \%$ & $-12,37 \%$ \\
\hline \begin{tabular}{|l|} 
TMGC7 \\
\end{tabular} & Telemig Cl PNC & 0,54 & Low & 952.612 .340 & \begin{tabular}{|l} 
Big \\
\end{tabular} & 1,27 & \begin{tabular}{|l|l|} 
Winner \\
\end{tabular} & \begin{tabular}{|l} 
Big|Low|Winner \\
\end{tabular} & \begin{tabular}{|l|l|}
$-4,78 \%$ \\
\end{tabular} & $-8,68 \%$ & $1,25 \%$ & $-1,23 \%$ & $-4,06 \%$ & $24,30 \%$ & $15,24 \%$ & $-8,49 \%$ & $-1,24 \%$ & $-5,50 \%$ & $-4,23 \%$ & $-6,98 \%$ \\
\hline CRTP5 & Crt Celular PNA & 0,47 & Low & 1.831 .340 .446 & Big & 1,32 & Winner & Big|Low|Winner & $6,97 \%$ & $1,77 \%$ & $-25,58 \%$ & $-2,19 \%$ & $-13,74 \%$ & $16,67 \%$ & $25,40 \%$ & $2,91 \%$ & $11,93 \%$ & $11,65 \%$ & $5,22 \%$ & $-10,66 \%$ \\
\hline TMGC3 & Telemig Cl ON & 0,54 & Low & 952.612 .340 & Big & 1,40 & \begin{tabular}{|l|l|} 
Winner \\
\end{tabular} & Big|Low|Winner & $26,67 \%$ & $-3,95 \%$ & $-9,62 \%$ & $-6,03 \%$ & $4,84 \%$ & $19,11 \%$ & $0,75 \%$ & $2,56 \%$ & $0,00 \%$ & $0,00 \%$ & $1,11 \%$ & $3,75 \%$ \\
\hline EBTP3 & Embratel Part ON & 0,43 & Low & 3.167 .166 .124 & Big & 1,66 & Winner & Big|Low|Winner & $-10,71 \%$ & $15,00 \%$ & $-21,42 \%$ & $-10,37 \%$ & $-21,85 \%$ & $18,54 \%$ & $21,05 \%$ & $-25,77 \%$ & $-4,89 \%$ & $2,35 \%$ & $-1,52 \%$ & $-4,41 \%$ \\
\hline VIVO3 & Vivo ON & 0,26 & Low & 505.909.598 & Big & 2,09 & Winn & Big|Low/Wir & $-5,84 \%$ & $6,15 \%$ & $-18,95 \%$ & $3,90 \%$ & $-28,13 \%$ & $16,35 \%$ & $26,82 \%$ & $-14,29 \%$ & $-24,86 \%$ & $22,92 \%$ & $7,67 \%$ & $-14,04 \%$ \\
\hline EMBR4 & Embraer PN & 0,18 & Low & 5.212.220.404 & Big & 4,07 & Winner & Big|Low|Winner & $-1,41 \%$ & $29,00 \%$ & $9,71 \%$ & $0,00 \%$ & $-1,77 \%$ & $31,87 \%$ & $13,46 \%$ & $-7,99 \%$ & $14,66 \%$ & $8,42 \%$ & $5,53 \%$ & $-7,60 \%$ \\
\hline NETC4 & Net PN & 0,05 & Low & 5.614.737.857 & Big & 5,55 & Winner & Big|Low|Winner & $8,70 \%$ & $8,00 \%$ & $-16,16 \%$ & $-17,27 \%$ & $-24,27 \%$ & $36,54 \%$ & $2,82 \%$ & $-21,00 \%$ & $-18,50 \%$ & $-11,35 \%$ & $-34,40 \%$ & $32,93 \%$ \\
\hline EMBR3 & Embraer O & 0,18 & Low & 5.212 .220 .404 & Big & 5,92 & Winner & Big|Low|Winner & $-7,47 \%$ & $16,95 \%$ & $7,98 \%$ & $-12,04 \%$ & $-8,38 \%$ & $21,99 \%$ & $28,74 \%$ & $-2,20 \%$ & $3,48 \%$ & $18,69 \%$ & $1,06 \%$ & $-5,66 \%$ \\
\hline ITEC3 & Itaute & 0,14 & Low & & Big & 6,57 & & B & $-5,24 \%$ & $3,28 \%$ & $-12,82 \%$ & $-21,91 \%$ & $5,65 \%$ & $-5,53 \%$ & $22,45 \%$ & $-12,63 \%$ & $-11,04 \%$ & $-2,00 \%$ & $-9,80 \%$ & $-9,73 \%$ \\
\hline CMIG4 & Cemig PN & 1,43 & Medium & 4.463 .589 .365 & Big & 0,21 & Loser & Big|Medium|Loser & $6,19 \%$ & $-2,54 \%$ & $-6,29 \%$ & $-5,14 \%$ & $-13,04 \%$ & $11,90 \%$ & $26,91 \%$ & $-14,22 \%$ & $-10,75 \%$ & $-7,85 \%$ & $-8,91 \%$ & $19,13 \%$ \\
\hline SDIA4 & Sadia S/A PN & 0,77 & \begin{tabular}{|l|} 
Medium \\
\end{tabular} & 737.311 .709 & Big & 0,07 & Loser & Big|Medium|Loser & $1,00 \%$ & $7,41 \%$ & $-1,72 \%$ & $-7,02 \%$ & $-14,15 \%$ & $27,47 \%$ & $18,10 \%$ & $-0,17 \%$ & $-7,52 \%$ & $-1,63 \%$ & $-3,31 \%$ & $-4,27 \%$ \\
\hline
\end{tabular}


Anexo 1 - Retorno mensal e classificação das ações

\begin{tabular}{|c|c|c|c|c|c|c|c|c|c|c|c|c|c|c|c|c|c|c|c|c|}
\hline Código & $2000-2001$ & $\begin{array}{l}\text { Índice B/M } \\
\text { de dez/1999 }\end{array}$ & \begin{tabular}{|c} 
Grupo com \\
base no \\
indice B/M
\end{tabular} & $\begin{array}{c}\text { Valor de Mercado } \\
\text { em jun/2000 }\end{array}$ & $\begin{array}{c}\text { Grupo com } \\
\text { base no } \\
\text { tamanho }\end{array}$ & $\begin{array}{c}\text { Retorno } \\
\text { acumulado } \\
\text { de jun/2000 }\end{array}$ & \begin{tabular}{|l|} 
Grupo com \\
base no \\
retorno \\
acumulado \\
\end{tabular} & Carteiras & $\mathrm{jul} / 00$ & ago/00 & set $/ 00$ & out $/ 00$ & nov/00 & dez $/ 00$ & $\mathrm{jan} / 01$ & fev/01 & $\mathrm{mar} / 01$ & $a b r / 01$ & mai/01 & jun/01 \\
\hline CMIG3 & Cemig ON & 1,43 & Medium & 4.463 .589 .365 & Big & 0,00 & Loser & Big|Medium|Loser & $-4,77 \%$ & $6,38 \%$ & $-1,92 \%$ & $-6,54 \%$ & $6,82 \%$ & $-0,09 \%$ & $34,97 \%$ & $-16,06 \%$ & $-2,26 \%$ & $-3,81 \%$ & $-7,64 \%$ & $14,29 \%$ \\
\hline CPLE6 & Copel PNB & 1,16 & Medium & \begin{tabular}{|l|l|}
3.837 .846 .190 \\
\end{tabular} & Big & 0,04 & Loser & Big|Medium|Loser & $-3,94 \%$ & $1,10 \%$ & $-0,06 \%$ & $5,03 \%$ & $-9,98 \%$ & $2,97 \%$ & $24,68 \%$ & $-4,57 \%$ & $-4,61 \%$ & $-6,19 \%$ & $-3,09 \%$ & $8,12 \%$ \\
\hline TMAR3 & Telemar N L ON & 1,47 & Medium & $\begin{array}{l}2.588 .383 .381 \\
\end{array}$ & Big & 0,12 & Loser & Big|Medium|Loser & $9,42 \%$ & $18,19 \%$ & $-0,78 \%$ & $1,82 \%$ & $-6,96 \%$ & $5,00 \%$ & $30,00 \%$ & 0,73\% & $-18,18 \%$ & $0,00 \%$ & $-6,67 \%$ & $28,57 \%$ \\
\hline CPLE3 & Copel ON & 1,16 & Medium & 3.837 .846 .190 & Big & 0,16 & Loser & Big|Medium|Loser & $13,26 \%$ & $6,59 \%$ & $3,27 \%$ & $-5,63 \%$ & $-9,48 \%$ & $9,14 \%$ & $39,34 \%$ & $-9,45 \%$ & $-1,63 \%$ & $1,96 \%$ & $-5,65 \%$ & $1,38 \%$ \\
\hline TMAR6 & Telemar N L PNB & 1,47 & Medium & 2.588.383.381 & Big & 0,23 & Loser & Big|Medium/Loser & $-4,90 \%$ & $11,36 \%$ & $5,15 \%$ & $-1,39 \%$ & $-0,88 \%$ & $1,78 \%$ ] & $18,57 \%$ & $-10,29 \%$ & $-18,64 \%$ & $-2,86 \%$ ] $>$ & $-2,11 \%$ ] $>$ & $21,18 \%$ \\
\hline BRDT4 & Petrobras Distrib PN & 0,98 & Medium & 1.058.399.433 & Big & 0,23 & Loser & Big|Medium|Loser & $7,35 \%$ & $8,37 \%$ & $3,51 \%$ & $6,68 \%$ & $-5,34 \%$ & $-6,01 \%$ & $26,89 \%$ & $9,77 \%$ & $-8,34 \%$ & $-0,88 \%$ & $0,44 \%$ & $-14,58 \%$ \\
\hline COCE5 & Coelce PNA & 1,79 & Medium & 732.141 .369 & Big & 0,26 & Loser & \begin{tabular}{|l|} 
Big|Medium|Loser \\
\end{tabular} & $30,53 \%$ & $12,23 \%$ & $-8,56 \%$ & $-11,11 \%$ & $-12,84 \%$ & $28,42 \%$ & $6,56 \%$ & \begin{tabular}{l|l}
$-0,77 \%$ \\
\end{tabular} & $-1,55 \%$ & $2,36 \%$ & $49,82 \%$ & $7,50 \%$ \\
\hline TNLP4 & Telemar PN & 0,81 & Medium & 14.738.831.273 & Big & 0,27 & Loser & Big|Medium/Loser & $0,95 \%$ & $8,09 \%$ & $-8,89 \%$ | & $-0,76 \%$ & $-14,11 \%$ & $17,32 \%$ & $16,71 \%$ & $-9,63 \%$ & $-20,99 \%$ & $9,71 \%$ & $-1,93 \%$ & $-4,73 \%$ \\
\hline TMGR6 & Telemig PNB & 1,25 & Medium & 1.497.090.397 & Big & 0,28 & Loser & Big|Medium|Loser & $5,21 \%$ & $17,13 \%$ & $-0,31 \%$ & $-0,64 \%$ & $5,13 \%$ & $7,50 \%$ & $17,42 \%$ & $6,53 \%$ & $-8,50 \%$ & $1,04 \%$ & $-4,08 \%$ & $59,57 \%$ \\
\hline SBSP3 & Sabesp ON & 1,37 & Medium & 3.897.553.396 & Big & 0,29 & \begin{tabular}{|l|l} 
Loser \\
\end{tabular} & Big|Medium/Loser & $\mid 16,79 \%$ & $23,13 \%$ & $-7,19 \%$ & $-3,38 \% \mid$ & $-11,25 \% \mid$ & $17,01 \%$ & $27,01 \%$ & $4,98 \%$ & $-18,53 \%$ & $-4,24 \%$ & $-8,29 \%$ & $0,01 \%$ \\
\hline BSUL5 & Bahia Sul PNA & 1,33 & Medium & 1.028.677.097 & Big & 0,30 & Loser & Big|Medium/Loser & $9,38 \%$ & $-3,88 \%$ & $-0,91 \%$ & $-14,06 \%$ & $-17,44 \%$ & $2,16 \%$ & $26,58 \%$ & $-8,33 \%$ & $-14,63 \%$ & $-0,43 \%$ & $-15,29 \%$ & $7,22 \%$ \\
\hline ICPI4 & Cim Itau PN & 1,17 & Medium & 621.043.750 & Big & 0,38 & Loser & Big|Medium/Loser & $14,00 \%$ & $8,43 \%$ & $3,97 \%$ & $-5,38 \%$ & $1,32 \%$ & $2,27 \%$ & $28,16 \%$ & $-0,13 \%$ & $2,18 \%$ & $-0,50 \%$ & $-0,35 \%$ & $2,85 \%$ \\
\hline LIGT3 & Light S/A ON & 0,90 & Medium & 2.852 .048 .412 & Big & 0,49 & Loser & Big|Medium|Loser & $18,54 \%$ & $0,42 \%$ & $2,87 \%$ & $-13,15 \%$ & $-3,21 \%$ & $6,16 \%$ & $14,29 \%$ & $-16,02 \%$ & $-6,05 \%$ & $-25,74 \%$ & $-8,01 \%$ & $2,91 \%$ \\
\hline TMGR3 & Telemig ON & 1,25 & Medium & 1.497.090.397 & Big & 0,49 & \begin{tabular}{|l|l|} 
Loser \\
\end{tabular} & Big|Medium|Loser & $7,95 \%$ & $26,67 \%$ & $6,01 \%$ & $8,70 \%$ ] & $-2,17 \%$ & $11,11 \%$ & $27,00 \%$ & $-2,00 \%$ & $-6,12 \%$ & $3,26 \%$ & $3,89 \%$ & $50,16 \%$ \\
\hline CPSL3 & Copesul ON & 0,78 & Medium & 1.427.063.077 & Big & 0,52 & Loser & Big|Medium/Loser & $2,42 \%$ & $-4,77 \%$ & $2,79 \%$ & $8,15 \%$ & $-14,47 \%$ & $17,51 \%$ & $-2,50 \%$ & $-10,87 \%$ & $-8,24 \%$ & $12,82 \%$ & $-6,82 \%$ & $-4,88 \%$ \\
\hline PTIP3 & Ipiranga Pet ON & 0,97 & Medium & 908.600 .936 & Big & 0,58 & Loser & Big|Medium|Loser & $3,23 \%$ & $8,18 \%$ & $-5,88 \%$ & $-2,50 \%$ & $5,77 \%$ & $-9,58 \%$ & $-4,05 \%$ & $-7,04 \%$ & $5,68 \%$ & $1,79 \%$ & $-0,70 \%$ & $7,09 \%$ \\
\hline CSNA3 & Sid Nacional ON & 1,20 & Medium & 4.058 .441 .561 & Big & 0,64 & Loser & Big|Medium|Loser & $0,74 \%$ & $15,96 \%$ & $-11,82 \%$ & $-9,09 \%$ & $-2,81 \%$ & $20,58 \%$ & $28,70 \%$ & $-6,08 \%$ & $-1,33 \%$ & $10,26 \%$ & $-6,96 \%$ & $14,45 \%$ \\
\hline GGBR4 & Gerdau PN & 0,85 & Medium & 2.141.985.512 & Big & 0,69 & Winner & | Big|Medium|Winner & $6,73 \%$ & $11,16 \%$ & $-9,39 \%$ ] & $-15,43 \%$ & $-25,05 \%$ & $18,88 \%$ | & $25,21 \%$ & $-11,21 \%$ | & $0,00 \%$ & $6,26 \%$ ] & $-21,50 \%$ & $12,87 \%$ \\
\hline PTIP4 & Ipiranga & 0,97 & Medium & 908.600 .936 & Big & 0,78 & Winner & Big|Medium/Winner & $6,18 \%$ & $2,77 \%$ & $-1,81 \%$ & $-4,27 \%$ & $-9,14 \%$ & $-1,78 \%$ & $5,72 \%$ & $-15,87 \%$ & $18,03 \%$ & $-5,27 \%$ & $0,31 \%$ & $10,28 \%$ \\
\hline TMCP3 & Telemig Part ON & 0,83 & Medium & 2.086 .598 .076 & Big & 0,78 & Winner & Big|Medium / Winner & $-17,93 \%$ & $-2,10 \%$ & $3,22 \%$ & $14,35 \%$ & $9,09 \%$ & $36,67 \%$ & $-9,76 \%$ & $0,00 \%$ & $0,68 \%$ & $-9,80 \%$ & $7,77 \%$ & $1,39 \%$ \\
\hline TEBA5 & Telebahia PNA & 1,57 & Medium & \begin{tabular}{|l|l|}
761.932 .561 \\
\end{tabular} & Big & 0,79 & Winner & Big|Medium/Winner & $8,16 \%$ & $17,71 \%$ & $0,00 \%$ & $-2,92 \%$ & $8,01 \%$ & $8,33 \%$ & $8,98 \%$ & $3,67 \%$ & $-9,45 \%$ & $-3,49 \%$ & $-3,86 \%$ & $43,69 \%$ \\
\hline TNLP3 & Telema & 0,81 & Medium & 14.73 & Big & 0,94 & Winner & dium|Winner & $0,86 \%$ & 1,13\% & $-8,96 \%$ & $-3,38 \%$ | & $-13,85 \%$ ] & $18,30 \%$ ] & $25,00 \%$ & $-19,55 \%$ & $-2,14 \%$ & $3,08 \%$ [ & $0,57 \%$ ] & $-4,22 \%$ \\
\hline PTQS4 & Petroquisa PN & 1,45 & Medium & 3.524.521.279 & Big & 0,96 & Winner & Big $\mid$ Medium /Winner & $8,99 \%$ & $-1,55 \%$ & $-3,14 \%$ & $2,70 \%$ & $-5,26 \%$ & $3,33 \%$ & $-3,23 \%$ & $2,71 \%$ & $-7,95 \%$ & $10,49 \%$ & $-10,73 \%$ & $7,64 \%$ \\
\hline CEPE5 & Celpe PNA & 1,12 & Medium & 595.603.763 & Big & 0,98 & Winner & Big|Medium|Winner & $-1,08 \%$ & $15,01 \%$ & $0,00 \%$ & $-15,89 \%$ & $6,26 \%$ & $0,12 \%$ & $1,68 \%$ & $2,56 \%$ & $25,00 \%$ & $-5,00 \%$ & $0,00 \%$ & $-5,26 \%$ \\
\hline TMCP4 & Telemig Part PN & 0,83 & Medium & 2.086 .598 .076 & Big & 1,02 & \begin{tabular}{|l} 
Winner \\
\end{tabular} & Big|Medium/Winner & $-10,63 \%$ & $2,59 \%$ & $-17,82 \%$ & $1,84 \%$ & $-1,81 \%$ & $20,86 \%$ & \begin{tabular}{|c|}
$9,31 \%$ \\
\end{tabular} & $\begin{array}{ll}-7,89 \% \\
\end{array}$ & $-26,89 \%$ & $-3,68 \%$ & $21,83 \%$ & $-5,34 \%$ \\
\hline GOAU3 & Gerdau & 22 & Medium & & Big & 1,08 & Wint & $B i_{\xi}$ & $12,59 \%$ & $6,91 \%$ ] & $-7,69 \%$ & $0,00 \%$ & $-16,67 \%$ & 4,00 & $35,56 \%$ & $-3,06 \%$ & -3, & $0,00 \%$ & $-13,55 \%$ & $4,48 \%$ \\
\hline BRTO4 & Brasil T & 0,92 & Medium & 7.030.566.794 & Big & 1,11 & Winner & | Winner & 9,52\% & $1,45 \%$ & $-10,13 \%$ & $-8,31 \%$ & $-14,79 \%$ & $32,72 \%$ & $17,08 \%$ & $-20,33 \%$ ] & $-15,65 \%$ & $11,21 \%$ & $-7,54 \%$ & $6,35 \%$ \\
\hline GOAU4 & Gerdau Met PN & 1,22 & Medium & 727.726 .942 & Big & 1,17 & Winner & Big|Medium/Winner & $-0,51 \%$ & $10,82 \%$ & $-4,65 \%$ & $-5,12 \%$ & $-24,19 \%$ & $16,99 \%$ & $14,55 \%$ & $-7,85 \%$ & $-0,14 \%$ & $-1,34 \%$ & $-24,98 \%$ & $19,61 \%$ \\
\hline SUZB5 & Suzano Papel PNA & 1,19 & Medium & 999.216.000 & Big & 1,65 & Winner & Big|Medium/Winner & $19,11 \%$ & $28,73 \%$ & $-6,09 \%$ & $-1,38 \%$ & $-3,20 \%$ & $0,83 \%$ & $6,56 \%$ & 9,23\% & $-15,49 \%$ & $4,99 \%$ & $-4,13 \%$ & $-6,90 \%$ \\
\hline KLBN4 & Klabin S/A & 0,91 & Medium & 4.773 & Big & 1,92 & Winner & Big|Medium/Winner & $19,21 \%$ & $-2,78 \%$ & $0,57 \%$ & $-10,09 \%$ & $-10,32 \%$ & $5,04 \%$ & $1,37 \%$ & $-10,14 \%$ & $-24,06 \%$ & $-4,27 \%$ & $-20,21 \%$ & $14,67 \%$ \\
\hline BRTO3 & Brasil Telec ON & 0,92 & Medium & 1.566.794 & Big & 2,18 & Winner & Big|Medium|Winner & $-19,23 \%$ ] & $19,05 \%$ ] & $-13,22 \%$ & $-5,45 \%$ | $>2$, & $-6,73 \%$ ] & $63,92 \%$ & $20,19 \%$ & $-22,69 \%$ | & $-19,64 \%$ & $16,44 \%$ & $-14,50 \%$ ] & $0,89 \%$ \\
\hline TCOC4 & Tele Centroeste Cel PN & 81 & Medium & 22.976 .368 & Big & 2,37 & Winner & Big|Medium/Winner & $-2,06 \%$ & $10,80 \%$ & $-16,46 \%$ & $-2,27 \%$ & $-7,75 \%$ & $13,78 \%$ & $22,60 \%$ & $-9,31 \%$ & $-23,18 \%$ & $11,38 \%$ & $5,51 \%$ & $0,15 \%$ \\
\hline TCOC3 & Tele Centroeste Cel ON & 0,81 & Medium & 2.622 .976 .368 & Big & 2,44 & Winner & Big|Medium/Winner & $12,22 \%$ & $18,61 \%$ & $-14,51 \%$ & $-0,25 \%$ & $8,01 \%$ & $6,26 \%$ & $-3,38 \%$ & $1,09 \%$ & $-9,60 \%$ & $1,23 \%$ & $-4,69 \%$ & $10,10 \%$ \\
\hline CMET4 & Caemi PN & 1,40 & \begin{tabular}{|l} 
\\
\end{tabular} & 874.103 .600 & Big & 2,58 & Winner & Big|Medium/Winner & $14,35 \%$. & $-0,59 \%$ & $-5,33 \%$ & $8,33 \%$ & $-17,31 \% \mid$ & $6,98 \%$ & $29,13 \%$ & $1,01 \%$ | & $0,00 \%$ & $-2,33 \%$ | & $2,39 \%$ & $0,00 \%$ \\
\hline EKTR4 & Elektro PN & 2,07 & High & 542.188.114 & Small & 0,57 & Loser & Small|High|Loser & $25,00 \%$ & $-18,33 \%$ & $22,45 \%$ & $-16,67 \%$ & $-15,80 \%$ & $41,33 \%$ & $78,57 \%$ & 4,17\% & $-20,00 \%$ & $-12,25 \%$ & $-0,28 \%[$ & $-2,29 \%$ \\
\hline TELB4 & Telebrs & 3,94 & High & 31.688 & Small & 44 & \begin{tabular}{|l|l|} 
Loser \\
\end{tabular} & hall|Hi & $0,00 \%$ & $0,00 \%$ & $-25,00 \%$ & $0,00 \%$ & $0,00 \%$ & $-33,33 \%$ & $200,00 \%$ & $0,00 \%$ & $-16,67 \%$ & $0,00 \%$ & $-40,00 \%$ & $0,00 \%$ \\
\hline TELB3 & Telebras ON & 3,94 & High & 688 & Small & 43 & Loser & Small|High|Loser & $0,00 \%$ & $33,33 \%$ & $-25,00 \%$ & $-33,33 \%$ & $50,00 \%$ & $0,00 \%$ & $66,67 \%$ & $0,00 \%$ & $0,00 \%$ & $-20,00 \%$ & $-25,00 \%$ & $0,00 \%$ \\
\hline PTBL4 & Portobello PN & 3,58 & High & 51.230 & Small & 0,23 & Loser & Small|High|Loser & $-2,44 \%$ & $7,50 \%$ & $-16,28 \%$ & $-5,56 \%$ & $20,59 \%$ & $2,44 \%$ & $2,38 \%$ & $0,00 \%$ & $-16,28 \%$ & $-19,44 \%$ & $-6,90 \%$ & $0,00 \%$ \\
\hline VGOR4 & Vigor PN & 4,52 & High & \begin{tabular}{|l|l|}
43.016 .218 \\
\end{tabular} & Small & 0,19 & Loser & Small|High|Loser & $19,23 \%$ & $51,61 \%$ & $-4,26 \%$ & $11,11 \%$ & $-4,00 \%$ & $4,17 \%$ & $53,00 \%$ & \begin{tabular}{l|l|}
$8,50 \%$ \\
\end{tabular} & $-11,45 \%$ & $\begin{array}{l}-57,96 \% \\
\end{array}$ & $12,21 \%$ & $-33,53 \%$ \\
\hline RCSL4 & Recru & 5,08 & High & 9.445 .333 & $\mathrm{Sm}$ & 0,15 & Lo & & $7,14 \%$ & $33,33 \%$ & $-10,50 \%$ & $0,00 \%$ & $-21,79 \%$ & $\mid-21,43 \%$ & $44,55 \%$ & $-2,52 \%$ & $-6,45 \%$ & $13,10 \%$ & $-5,06 \%$ & $-0,67 \%$ \\
\hline CLSC6 & Celesc PNB & 89 & High & 7.726 & Sma & 4 & Loser & |High|Loser & $4,48 \%$ & $4,29 \%$ & $-6,85 \%$ & $-2,94 \%$ & $-15,15 \%$ & $3,57 \%$ & $15,52 \%$ & $-10,45 \%$ & $0,00 \%$ & \begin{tabular}{|l|}
$-18,11 \%$ \\
\end{tabular} & $-10,20 \%$ & $2,27 \%$ \\
\hline EMAE4 & Emae PN & 5,42 & High & 181.040 .704 & Small & 0,01 & Loser & Small|High|Loser & $18,37 \%$ & $17,24 \%$ & $-4,41 \%$ & $-10,62 \%$ & $1,55 \%$ & $-4,24 \%$ & $36,28 \%$ & $53,38 \%$ & $-19,56 \%$ & $8,67 \%$ & $-2,15 \%$ & $14,80 \%$ \\
\hline RSIP4 & Rasip Agro P & 3,32 & High & \begin{tabular}{l|l|}
10.431 .102 \\
\end{tabular} & Small & 18 & Loser & Small|High|Loser & $-12,50 \%$ & $0,00 \%$ & $0,00 \%$ & $-14,29 \%$ & $0,00 \%$ & $0,00 \%$ & $-16,67 \%$ & \begin{tabular}{l|l|}
$0,00 \%$ \\
\end{tabular} & $0,00 \%$ & $-20,00 \%$ & $25,00 \%$ & $20,00 \%$ \\
\hline ELEV3 & Eleva d & 2,56 & High & 162.323.601 & Small & 0,22 & Loser & Small |H & $7,57 \%$ ] & $-3,70 \%$ ] & $0,00 \%$ & $-2,31 \%$ & $-11,02 \%$ & $3,98 \%$ ] & $18,01 \%$ | & $-3,70 \%$ & $-7,69 \%$ | & $8,33 \%$ ] & $7,14 \%$ ] & $-4,58 \%$ \\
\hline SGEN4 & $\mathrm{Se}$ & 5 & Hig & & $\mathrm{Sm}$ & 0,23 & Lo & $\mathrm{St}_{\mathrm{i}}$ & $31,67 \%$ & $15,19 \%$ & $5,49 \%$ & $-7,29 \%$ & $-7,87 \%$ & $12,20 \%$ & $4,35 \%$ & $0,00 \%$ & $19,79 \%$ & $8,70 \%$ & $1,88 \%$ & $0,00 \%$ \\
\hline SGAS4 & WIm Ind Com PN & 4,31 & High & 27.528.170 & Small & 0,24 & Loser & Small|High|Loser & $33,90 \%$ & $96,20 \%$ & $-12,26 \%$ & $1,47 \%$ & $-8,70 \%$ & $3,17 \%$ & $63,08 \%$ & $41,04 \%$ & $-3,01 \%$ & $-13,79 \%$ & $26,00 \%$ & $-4,76 \%$ \\
\hline LATS3 & Rexam Bcsa ON & 2,24 & High & 142.863 .000 & Small & 0,32 & er & Small|Hig & $13,33 \%$ & $61,76 \%$ & $16,36 \%$ & $4,69 \%$ & $-10,45 \%$ & $-0,50 \%$ & $3,85 \%$ & $11,29 \%$ & $-2,90 \%$ & $8,96 \%[$ & $-15,28 \%$ & $37,70 \%$ \\
\hline TRFO4 & Trafo PN & 2,41 & igh & 5.850 & mall & 0,39 & ser & Small & $3,33 \%$ & $-5,88 \%$ & $-4,69 \%$ & $-2,46 \%$ & $-15,97 \%$ & $2,00 \%$ & $17,65 \%$ & $-16,67 \%$ & $-10,00 \%$ & $-17,78 \%$ & $-2,70 \%$ & $-6,41 \%$ \\
\hline ROMI4 & Inds Romi PN & 5,16 & High & 45.232 .669 & Small & 0,50 & \begin{tabular}{|l|l|} 
Loser \\
\end{tabular} & Small|High|Loser & $18,52 \%$ & $22,98 \%$ | & $3,46 \%$ & $-15,68 \%$ & $-1,83 \%$ | & $7,95 \%$ & $12,12 \%$ & $0,00 \%$ & $-2,81 \%$ & $-4,63 \%$ ] & $-14,37 \%$ & 4,69\% \\
\hline
\end{tabular}


Anexo 1 - Retorno mensal e classificação das ações

\begin{tabular}{|c|c|c|c|c|c|c|c|c|c|c|c|c|c|c|c|c|c|c|c|c|}
\hline Código & $2000-2001$ & $\begin{array}{l}\text { Índice } B / M \\
\text { de dez/1999 }\end{array}$ & \begin{tabular}{|c|} 
Grupo com \\
base no \\
indice $B / M$ \\
\end{tabular} & $\begin{array}{c}\text { Valor de Mercado } \\
\text { em jun/2000 }\end{array}$ & $\begin{array}{c}\text { Grupo com } \\
\text { base no } \\
\text { tamanho }\end{array}$ & $\begin{array}{c}\text { Retorno } \\
\text { acumulado } \\
\text { de jun/2000 }\end{array}$ & \begin{tabular}{|c|} 
Grupo com \\
base no \\
retorno \\
acumulado \\
\end{tabular} & Carteiras & $\mathrm{jul} / 00$ & ago/00 & set $/ 00$ & out $/ 00$ & nov/00 & dez/00 & $\mathrm{jan} / 01$ & fev/01 & $\mathrm{mar} / 01$ & $\mathrm{abr} / 01$ & mai/01 & jun/01 \\
\hline FJTA4 & Forjas Taurus PN & 2,68 & High & 36.363 .600 & Small & 0,50 & \begin{tabular}{|l} 
Loser \\
\end{tabular} & Small|High|Loser & $2,38 \%$ & $2,33 \%$ & $-4,55 \%$ & $2,38 \%$ & $0,00 \%$ & $7,77 \%$ & $17,50 \%$ & $2,13 \%$ & $0,00 \%$ & $12,50 \%$ & $3,70 \%$ & $7,14 \%$ \\
\hline BDLL4 & Bardella PN & 2,22 & High & 101.120 .001 & Small & 0,52 & Loser & Small|High|Loser & $9,95 \%$ & $6,49 \%$ & $-2,72 \%$ & $-2,21 \%$ & $-0,57 \%$ & $4,41 \%$ & $10,00 \%$ & $-0,70 \%$ & $-2,11 \%$ & $0,71 \%$ & $-9,99 \%$ & $9,52 \%$ \\
\hline \begin{tabular}{|l|} 
SALM4 \\
\end{tabular} & Seara Alim PN & 2,80 & High & 64.595 .000 & Small & 0,52 & Loser & Small|High|Loser & $-10,00 \%$ & $15,28 \%$ & $0,00 \%$ & $2,41 \%$ & $12,94 \%$ & $-10,42 \%$ & $26,74 \%$ & $0,92 \%$ & $-0,07 \%$ & $0,00 \%$ & $-8,57 \%$ & $51,04 \%$ \\
\hline RSID3 & Rossi Resid ON & 2,30 & High & 82.399 .998 & Small & 0,59 & \begin{tabular}{|l|} 
Loser \\
\end{tabular} & Small| |High | Loser & $0,00 \%$ & $-6,25 \%$ & $-8,33 \%$ & $-9,09 \%$ & $10,00 \%$ & $3,64 \%$ & $19,30 \%$ & $7,35 \%$ & $6,85 \%$ & $-4,38 \%$ & $-16,67 \%$ & $-5,00 \%$ \\
\hline SHUL4 & Schulz PN & 5,62 & High & 15.180.567 & Small & 0,71 & Winner & Small|High|Winner & $-10,14 \%$ & $4,51 \%$ & $-2,88 \%$ & $3,70 \%$ & $-21,43 \%$ & $27,18 \%$ & $-15,65 \%$ & $1,69 \%$ & $-15,00 \%$ & $-3,92 \%$ & $4,08 \%$ & $-3,92 \%$ \\
\hline SALM3 & Seara Alim ON & 2,80 & High & 64.595 .000 & Small & 0,78 & Winner & Small|High|Winner & $0,00 \%$ & $10,67 \%$ & $0,00 \%$ & $8,43 \%$ & $-7,78 \%$ & $16,87 \%$ & $23,71 \%$ & $-5,00 \%$ & $-6,18 \%$ & $14,56 \%$ & $-11,02 \%$ & $22,86 \%$ \\
\hline IBAN5 & Antarct Nordeste PNA & 2,15 & High & 373.173 .280 & Small & 0,83 & Winner & Small|High|Winner & $11,06 \%$ & $-3,75 \%$ & $-1,52 \%$ & $-3,30 \%$ & $-0,02 \%$ & $9,12 \%$ & $-2,50 \%$ & $-3,85 \%$ & $-11,06 \%$ & $-0,05 \%$ & $0,00 \%$ & $34,99 \%$ \\
\hline MAGSS & Magnesita PNA & 2,17 & High & 147.160 .643 & Small & 0,87 & Winner & Small| High|Winner & $3,17 \%$ & $5,90 \%$ & $-8,96 \%$ & $-5,05 \%$ & $-5,04 \%$ & $9,14 \%$ & $16,67 \%$ & $-3,06 \%$ & $-2,63 \%$ & $-2,70 \%$ & $-2,78 \%$ & $4,00 \%$ \\
\hline FLCL5 & F Cataguazes PNA & 2,07 & High & 243.756 .437 & Small & 0,89 & Winner & Small|High|Winner & $2,60 \%$ & $2,03 \%$ & $0,50 \%$ & $-2,55 \%$ & $-2,15 \%$ & $-9,34 \%$ & $21,21 \%$ & $-9,00 \%$ & $1,65 \%$ & $5,95 \%$ & $-8,16 \%$ & $4,87 \%$ \\
\hline BRGE3 & Alfa Consorc ON & 1,98 & High & \begin{tabular}{|l|l|}
166.333 .201 \\
\end{tabular} & Small & 0,91 & Winner & Small|High|Winner & $0,83 \%$ & $5,48 \%$ & $-1,30 \%$ & $-3,51 \%$ & $-2,27 \%$ & $-4,65 \%$ & $0,00 \%$ & $2,93 \%$ & $-7,04 \%$ & $2,56 \%$ & $-2,50 \%$ & $-2,05 \%$ \\
\hline CPCA4 & Trikem PN & 2,66 & High & \begin{tabular}{|l|l|}
327.948 .814 \\
\end{tabular} & Small & 0,91 & Winner & Small|High|Winner & $31,35 \%$ & $4,24 \%$ & $-9,89 \%$ & $-8,42 \%$ & $-4,76 \%$ & $20,69 \%$ & $2,00 \%$ & $-0,56 \%$ & $-1,41 \%$ & $-8,57 \%$ & $-26,56 \%$ & $6,38 \%$ \\
\hline PLTO6 & Politeno PNB & 2,24 & High & 152.590 .457 & Small & 0,96 & Winner & Small|High|Winner & $5,00 \%$ & $-3,49 \%$ & $-9,09 \%$ & $0,00 \%$ & $-6,88 \%$ & $-5,37 \%$ & $17,73 \%$ & $10,12 \%$ & $-10,28 \%$ & $7,32 \%$ & $-19,32 \%$ & $17,61 \%$ \\
\hline MGEL4 & Mangels Indl PN & 4,57 & High & 30.488 .766 & Small & 0,97 & Winner & Small|High|Winner & $3,03 \%$ & $-4,41 \%$ & $-4,00 \%$ & $-7,37 \%$ & $2,08 \%$ & $-15,25 \%$ & $14,00 \%$ & $-1,75 \%$ & $-7,14 \%$ & $-19,81 \%$ & $-5,00 \%$ & $4,21 \%$ \\
\hline RPAD6 & Alfa Holding PNB & 1,85 & High & 157.508.520 & Small & 1,01 & Winner & Small|High|Winner & $0,04 \%$ & $12,02 \%$ & $-3,41 \%$ & $-3,03 \%$ & $-1,04 \%$ & $-5,26 \%$ & $3,33 \%$ & $8,54 \%$ & $-7,46 \%$ & $7,53 \%$ & $-6,50 \%$ & $-1,07 \%$ \\
\hline BRGE11 & Alfa Consorc PNE & 1,98 & High & 166.333.201 & Small & 1,06 & Winner & Small|High|Winner & $0,83 \%$ & $5,94 \%$ & $-0,86 \%$ & $0,00 \%$ & $-6,52 \%$ & $-4,65 \%$ & $12,20 \%$ & $-4,33 \%$ & $-2,33 \%$ & $-6,67 \%$ & $-2,04 \%$ & $-0,52 \%$ \\
\hline ASTA4 & Santist & 2,41 & High & $\begin{array}{ll}147.990 .003 \\
\end{array}$ & Small & 1,13 & Winner & Small|High|Winner & $1,36 \%$ & $2,33 \%$ & $-8,79 \%$ & $-5,71 \%$ & $1,52 \%$ & $2,99 \%$ & $31,88 \%$ & $-4,40 \%$ & $-6,53 \%$ & $2,03 \%$ & $-5,30 \%$ & $-6,29 \%$ \\
\hline MNDL4 & Mundial PN & 61,97 & High & 8.706 .329 & Small & 1,25 & Winner & Small| High|Winner & $65,00 \%$ & $61,37 \%$ & $7,98 \%$ & $-20,00 \%$ & $6,63 \%$ & $-0,10 \%$ & $27,55 \%$ & $-12,00 \%$ & $-4,55 \%$ & $-4,76 \%$ & $0,00 \%$ & $30,00 \%$ \\
\hline BRGE12 & Alfa Consorc PNF & 1,98 & High & \begin{tabular}{|l|l|}
166.333 .201 \\
\end{tabular} & Small & 1,33 & Winner & Small|High|Winner & $1,42 \%$ & $15,91 \%$ & $-10,59 \%$ & $-3,51 \%$ & $-2,27 \%$ & $-4,65 \%$ & $0,00 \%$ & $3,10 \%$ & $-6,67 \%$ & $0,00 \%$ & $-1,53 \%$ & $1,55 \%$ \\
\hline CREM4-old & Cremer (Antiga) PN & 2,04 & High & 18.467.999 & Small & 1,39 & Winner & Small|High | Winner & $4,17 \%$ & $-8,53 \%$ & $-3,79 \%$ & $-4,55 \%$ & $-6,35 \%$ & $1,69 \%$ & $24,33 \%$ & $-0,80 \%$ & $-8,11 \%$ & $-2,35 \%$ & $14,46 \%$ & $-9,21 \%$ \\
\hline SNSY5 & Sansuy & 3,27 & High & 9.645 .500 & Small & 1,50 & Winner & Small|High|Winner & $-3,00 \%$ & $-1,03 \%$ & $-6,25 \%$ & $5,11 \%$ & $-9,08 \%$ & $-0,01 \%$ & $27,91 \%$ & $-9,80 \%$ & $-13,32 \%$ & $27,91 \%$ & $-20,00 \%$ & $12,50 \%$ \\
\hline RPSA4 & Ripasa PN & 1,95 & High & 452.186.911 & Small & 2,23 & Winner & Small| High|Winner & $13,11 \%$ & $1,45 \%$ & $-5,00 \%$ & $-15,04 \%$ & $-10,00 \%$ & $0,00 \%$ & $27,55 \%$ & $-12,00 \%$ & $-13,64 \%$ & $7,68 \%$ & $-21,78 \%$ & $14,87 \%$ \\
\hline FESA4 & Ferbasa PN & 2,27 & High & \begin{tabular}{ll|}
72.060 .521 \\
\end{tabular} & Small & 2,41 & Winner & Small|High|Winner & $4,48 \%$ & $0,71 \%$ & $-5,11 \%$ & $-8,82 \%$ & $-9,84 \%$ & $9,07 \%$ & $16,69 \%$ & $-8,57 \%$ & $-6,25 \%$ & $0,89 \%$ & $-7,14 \%$ & $-8,13 \%$ \\
\hline JBDU4 4 & J B Duarte PN & 5,91 & High & 2.248 .013 & Small & 2,67 & Winner & Small|High|Winner & $15,00 \%$ & $-13,04 \%$ & $-25,00 \%$ & $0,00 \%$ & $-6,67 \%$ & $35,71 \%$ & $0,00 \%$ & $15,79 \%$ & $-31,82 \%$ & $-20,00 \%$ & $-25,00 \%$ & $11,11 \%$ \\
\hline UNIPG & Unipar & 1,94 & High & 49.138 .209 & Small & 2,75 & Winner & Small|High|Winner & $21,19 \%$ & $-0,70 \%$ & $-7,04 \%$ & $-7,58 \%$ & $-9,02 \%$ & $6,31 \%$ & $15,93 \%$ & $-3,05 \%$ & $-3,15 \%$ & $5,82 \%$ & $-17,31 \%$ & $4,71 \%$ \\
\hline PRGA4 & \begin{tabular}{|l|l|} 
BRF Foods PN \\
\end{tabular} & 0,67 & Low & 555.426 .115 & Small & 0,21 & Loser & Small| Low|Loser & $13,25 \%$ & $-0,79 \%$ & $19,92 \%$ & $-11,94 \%$ & $-7,58 \%$ & $24,00 \%$ & $7,12 \%$ & $1,57 \%$ & $-7,41 \%$ & $6,67 \%$ & $-15,62 \%$ & $-1,67 \%$ \\
\hline ARTE3 & Kuala ON & 0,50 & Low & 18.931 .239 & Small & 0,13 & Loser & Small|Low|Loser & $-7,14 \%$ & $7,69 \%$ & $-7,14 \%$ & $-15,38 \%$ & $-27,27 \%$ & $-25,00 \%$ & $33,33 \%$ & $-12,50 \%$ & $0,00 \%$ & $14,29 \%$ & $-12,50 \%$ & $0,00 \%$ \\
\hline ARTE4 & Kuala PN & 0,50 & Low & 18.931.239 & Small & 0,06 & Loser & Small|Low|Loser & $45,45 \%$ & $6,25 \%$ & $-11,76 \%$ & $-20,00 \%$ & $-16,67 \%$ & $-20,00 \%$ & $25,00 \%$ & $-10,00 \%$ & $-11,11 \%$ & $0,00 \%$ & $-25,00 \%$ & $16,67 \%$ \\
\hline LIPR3 & Eletrop & 0,65 & Low & 41.875.113 & Small & 0,07 & Loser & Small|Low|Loser & $21,59 \%$ & $-18,16 \%$ & $-5,24 \%$ & $0,00 \%$ & $-11,05 \%$ & $-12,72 \%$ & $49,15 \%$ & $-18,18 \%$ & $-8,33 \%$ & $-9,09 \%$ & $-6,67 \%$ & $-3,57 \%$ \\
\hline PMAM4 & Paranat & 0,61 & Low & 575.054.281 & Small & 0,10 & Loser & Small|Low|Loser & $9,51 \%$ & $-3,12 \%$ & $-3,22 \%$ & $2,14 \%$ & $-11,63 \%$ & $2,63 \%$ & $-12,56 \%$ & $-6,16 \%$ & $-15,62 \%$ & $0,00 \%$ & $-22,22 \%$ & $-4,76 \%$ \\
\hline FFTL4 & Valefert PN & 0,42 & Low & 584.496 .377 & Small & 0,19 & Loser & Small|Low|Loser & $14,81 \%$ & $-1,42 \%$ & $0,84 \%$ & $-4,17 \%$ & $-15,65 \%$ & $4,33 \%$ & $15,88 \%$ & $-6,00 \%$ & $0,19 \%$ & $1,54 \%$ & $-4,94 \%$ & $5,77 \%$ \\
\hline FRAS4 & Fras-Le PN & 0,73 & Low & 74.529.820 & Small & 0,48 & Loser & Small|Low|Loser & $3,17 \%$ & $19,23 \%$ & $-19,35 \%$ & $-8,00 \%$ & $4,35 \%$ & $-1,67 \%$ & $1,69 \%$ & $0,00 \%$ & $-3,64 \%$ & $0,00 \%$ & $-7,27 \%$ & $15,69 \%$ \\
\hline MNPR4 & Minupar PN & 0,29 & Low & 4.057 .200 & Small & 0,60 & Loser & Small| Low|Loser & $-19,05 \%$ & $0,00 \%$ & $-5,88 \%$ & $-25,00 \%$ & $0,00 \%$ & $0,00 \%$ & $25,00 \%$ & $-6,67 \%$ & $-7,14 \%$ & $-7,69 \%$ & $-8,33 \%$ & $9,09 \%$ \\
\hline TPRC6 & Tim Su & 0,56 & Low & 471.763.989 & Small & 0,98 & Winner & Small| Low|Winner & $14,38 \%$ & $-20,49 \%$ & $-5,27 \%$ & $-11,68 \%$ & $-11,86 \%$ & $-3,85 \%$ & $14,00 \%$ & $-2,64 \%$ & $-15,31 \%$ & $6,37 \%$ & $15,01 \%$ & $4,36 \%$ \\
\hline TPRC3 & Tim Sul ON & 0,56 & Low & 763.989 & Small & 1,11 & Winner & Small|Low|Winner & $8,33 \%$ & $-7,69 \%$ & $4,17 \%$ & $-15,20 \%$ & $-7,55 \%$ & $-10,20 \%$ & $13,64 \%$ & $-9,93 \%$ & $-5,63 \%$ & $-2,35 \%$ & $20,48 \%$ & $20,00 \%$ \\
\hline DPPI4 & Ipiranga Dis PN & 72 & Low & 999.995 & Small & \begin{tabular}{l|l|l|}
1,19 \\
\end{tabular} & Winner & Small|Low|Winner & $0,13 \%$ & $9,80 \%$ & $0,00 \%$ & $-7,14 \%$ & $0,00 \%$ & $17,97 \%$ & $33,78 \%$ & $-17,50 \%$ & $-9,09 \%$ & $-13,33 \%$ & $-10,77 \%$ & $-1,72 \%$ \\
\hline LAME3 & Lojas Americ ON & 0,48 & Low & .775 .403 & Small & 1,71 & Winner & Small|Low|Winner & $-19,39 \%$ & $0,76 \%$ & $5,53 \%$ & $1,67 \%$ & $-11,24 \%$ & $-11,61 \%$ & $19,40 \%$ & $0,00 \%$ & $-12,50 \%$ & $-0,57 \%$ & $-20,40 \%$ & $1,08 \%$ \\
\hline LAME4 & Lojas Americ PN & 0,48 & Low & 382.775 .403 & Small & 2,30 & Winner & Small/Low/Winner & $-20,57 \%$ & $8.42 \%$ & $-4.85 \%$ & $-7.35 \%$ & $-27,31 \%$ & $7,58 \% \mid$ & $29,58 \%$ & $6.52 \%$ & $-29,59 \%$ & $-26,38 \%$ & $-21,65 \%$ & $4.52 \%$ \\
\hline VAGV4 & Savarg $\mathrm{P}$ & 0,18 & Low & 2.998 .519 & Small & 3,33 & Winner & Small|Low|Winner & $8,70 \%$ & $1,79 \%$ & $5,37 \%$ & $48,15 \%$ & $14,38 \%$ & $-1,64 \%$ & $-9,72 \%$ & $23,08 \%$ & $-25,00 \%$ & $-13,00 \%$ & $-23,37 \%$ & $-12,50 \%$ \\
\hline \begin{tabular}{|l|} 
CHAP4 \\
\end{tabular} & Chapeco PN & 0,21 & Low & 572.756 .574 & Small & 6,38 & \begin{tabular}{|l|} 
Winner \\
\end{tabular} & \begin{tabular}{|l|} 
Small|Low|Winner \\
\end{tabular} & $0,00 \%$ & $15,85 \%$ & $-11,11 \%$ & $-12,14 \%$ & $-14,29 \%$ & $0,00 \%$ & $33,33 \%$ & $-12,50 \%$ & $0,00 \%$ & $14,29 \%$ & $-25,00 \%$ & $0,00 \%$ \\
\hline WISA4 & Wiest PN & 0,92 & Mediu & 2.399 .600 & Small & 0,31 & Loser & Small|Medium|Loser & $-14,29 \%$ & $10,00 \%$ & $3,03 \%$ & $-5,88 \%$ & $-6,25 \%$ & $-16,67 \%$ & $8,00 \%$ & $-3,70 \%$ & $15,38 \%$ & $-26,67 \%$ & $-4,55 \%$ & $4,76 \%$ \\
\hline PLAS4 & Plascar Part PN & 1,11 & Medium & 49.973.983 & Small & 0,24 & Loser & Small|Medium|Loser & $-4,01 \%$ & $23,08 \%$ & $-6,43 \%$ & $-9,35 \%$ & $-9,47 \%$ & $-9,30 \%$ & $-0,51 \%$ & $-2,58 \%$ & $-10,58 \%$ & $-20,12 \%$ & $-11,48 \%$ & $-7,95 \%$ \\
\hline CNFB4 & Confab PN & 1,62 & Medium & 4.920 .954 & Small & 0,18 & Loser & Small|Medium|Loser & $17,92 \%$ & $-2,40 \%$ & $-6,56 \%$ & $0,88 \%$ & $0,00 \%$ & $0,00 \%$ & $16,52 \%$ & $-2,99 \%$ & $-3,85 \%$ & $14,92 \%$ & $17,42 \%$ & $5,81 \%$ \\
\hline CYRE4 & Cyrela & 1,06 & & 225.603 & Small & 0,09 & \begin{tabular}{|l|l|} 
Loser \\
\end{tabular} & Small|Medium |L & $-7,41 \%$ & $0,00 \%$ & $0,00 \%$ & $-13,60 \%$ & \begin{tabular}{l|l}
$15,74 \%$ \\
\end{tabular} & $13,60 \%$ & $12,68 \%$ & $8,71 \%$ & $0,00 \%$ & $-6,25 \%$ & $-1,33 \%$ & $1,35 \%$ \\
\hline DURA4 & Duratex-Old PN & 1,37 & Medium & $\begin{array}{lll}476.613 .484 \\
\end{array}$ & Small & 0,10 & Loser & Small|Medium|Loser & $7,83 \%$ & $5,78 \%$ & $0,78 \%$ & $-10,01 \%$ & $-8,77 \%$ & $5,77 \%$ & $15,45 \%$ & $-4,69 \%$ & $-7,56 \%$ & $3,64 \%$ & $-9,30 \%$ & $-14,91 \%$ \\
\hline INEP4 & Inepar PN & 1,34 & Medium & 201.750 .648 & Small & 0,12 & Loser & Small|Medium|Loser & $11,69 \%$ & $5,12 \%$ & $-13,94 \%$ & $-15,42 \%$ & $-24,62 \%$ & $12,90 \%$ & $17,86 \%$ & $-21,52 \%$ & $-5,41 \%$ & $-26,12 \%$ & $-21,55 \%$ & $40,85 \%$ \\
\hline CTNM4 & Coteminas & 1,55 & Medium & 27.909 .408 & Small & 0,14 & 10 & Small|Mediu & $-5,54 \%$ & $13,45 \%$ & $-13,68 \%$ & $-0,70 \%$ & $8,01 \%$ & $10,94 \%$ & $31,56 \%$ & $2,94 \%$ & $-11,43 \%$ & $5,81 \%$ & $-5,86 \%$ & $-9,81 \%$ \\
\hline CEVA4 & Bunge & 1,62 & & & - & 28 & Los & $\mathrm{IM}$ & $-7,50$ & 8,11 & $-1,2$ & $-6,33 \%$ & $1,35 \%$ & $0,00 \%$ & $1,60 \%$ & $-8,14 \%$ & $-5,71 \%$ & $-3,03 \%$ & $-15,00 \%$ & $28,68 \%$ \\
\hline EBEN4 & Bandeirante Energ PN & 1,43 & Medium & 465.533.234 & Small & 0,30 & Loser & Small|Medium|Loser & $67,14 \%$ & $2,56 \%$ & $-2,82 \%$ & $3,86 \%$ & $1,15 \%$ & $-13,83 \%$ & $17,42 \%$ & $-22,68 \%$ & $29,57 \%$ & $-10,51 \%$ & $12,34 \%$ & $0,23 \%$ \\
\hline ALBA3 & Albarus ON & 0,85 & \begin{tabular}{|l|} 
Medium \\
\end{tabular} & 283.139 .990 & Small & 0,31 & Loser & Small|Medium|Loser & $-5,98 \%$ & $14,55 \%$ & $-2,38 \%$ & $2,70 \%$ & $-2,91 \%$ & $12,00 \%$ & $1,79 \%$ & $-1,75 \%$ & $0,00 \%$ & $-6,25 \%$ & $-9,52 \%$ & $1,05 \%$ \\
\hline
\end{tabular}


Anexo 1 - Retorno mensal e classificação das ações

\begin{tabular}{|c|c|c|c|c|c|c|c|c|c|c|c|c|c|c|c|c|c|c|c|c|}
\hline Código & $2000-2001$ & $\begin{array}{l}\text { Índice B/M } \\
\text { de dez/1999 }\end{array}$ & $\begin{array}{c}\text { Grupo com } \\
\text { base no } \\
\text { indice } B / M\end{array}$ & $\begin{array}{c}\text { Valor de Mercado } \\
\text { em jun/2000 }\end{array}$ & $\begin{array}{c}\text { Grupo com } \\
\text { base no } \\
\text { tamanho }\end{array}$ & $\begin{array}{c}\text { Retorno } \\
\text { acumulado } \\
\text { de jun/2000 }\end{array}$ & \begin{tabular}{c|} 
Grupo com \\
base no \\
retorno \\
acumulado \\
\end{tabular} & Carteiras & $\mathrm{jul} / 00$ & ago/00 & set/00 & out $/ 00$ & nov/00 & $\operatorname{dez} / 00$ & $\mathrm{jan} / 01$ & $\mathrm{fev} / 01$ & $\mathrm{mar} / 01$ & $\mathrm{abr} / 01$ & mai/01 & jun/01 \\
\hline CTNM3 & Coteminas ON & 1,55 & Medium & 527.909 .408 & Small & 0,35 & Loser & Small|Medium|Loser & $4,86 \%$ & $0,00 \%$ & $8,18 \%$ & $-11,76 \%$ & $14,93 \%$ & $32,18 \%$ & $15,40 \%$ & $-3,47 \%$ & $3,99 \%$ & $-7,69 \%$ & $4,21 \%$ & $-0,17 \%$ \\
\hline RAPT4 & Randon Part PN & 1,81 & Medium & 77.887 .051 & Small & 0,39 & Loser & Small|Medium|Loser & $-8,20 \%$ & $23,21 \%$ & $-5,80 \%$ & $-12,31 \%$ & $-19,30 \%$ & $4,35 \%$ & $6,25 \%$ & $-5,88 \%$ & $-4,17 \%$ & $-5,80 \%$ & $4,76 \%$ & $2,27 \%$ \\
\hline MSAN3 & Bunge Brasil ON & 1,24 & Medium & 402.346 .334 & Small & 0,39 & Loser & Small|Medium|Loser & $0,00 \%$ & $0,97 \%$ & $-13,46 \%$ & $0,00 \%$ & $4,44 \%$ & $2,13 \%$ & $2,08 \%$ & $-2,04 \%$ & $-1,04 \%$ & $6,32 \%$ & $8,91 \%$ & $-9,09 \%$ \\
\hline EBCO4 & Embraco PN & 0,99 & Medium & 452.513 .011 & Small & 0,41 & Loser & Small|Medium|Loser & $3,45 \%$ & $20,37 \%$ & $8,57 \%$ & $-1,75 \%$ & $-1,79 \%$ & $-13,35 \%$ & $-4,26 \%$ & $-11,11 \%$ & 0,00\% & $-12,50 \%$ & $-1,43 \%$ & $34,55 \%$ \\
\hline PNVL3 & Dimed ON & 1,47 & Medium & 9.490 .098 & Small & 0,45 & Loser & Small|Medium|Loser & $1,01 \%$ & $-9,90 \%$ & $-0,11 \%$ & $8,89 \%$ & $-15,31 \%$ & $-1,89 \%$ & $0,00 \%$ & $-17,72 \%$ & $4,62 \%$ & $2,94 \%$ & $0,00 \%$ & $30,00 \%$ \\
\hline MAHS4 & ge Fertilizantes PN & 0,97 & Medium & 144.974 & Small & 0,48 & Loser & Small|Medium|Loser & $17,29 \%$ & $-26,85 \%$ & $-3,85 \%$ & $-2,58 \%$ & $-21,56 \%$ & $13,36 \%$ & $11,84 \%$ & $-2,86 \%$ & $11,44 \%$ & $-4,62 \%$ & $-10,97 \%$ & $12,32 \%$ \\
\hline MTSA4 & Metisa F & 1,42 & $\mathrm{~N}$ & 8 & Small & 0,49 & Loser & |Loser & $23,08 \%$ & $-5,63 \%$ & $-0,66 \%$ & $-1,33 \%$ & $-4,05 \%$ & $2,11 \%$ & $11,03 \%$ & $-3,73 \%$ & $-3,29 \%$ & $8,52 \%$ & $6,53 \%$ & $12,64 \%$ \\
\hline CEVA3 & Bunge Alime & 1,62 & Medium & .017 .329 & Small & 0,52 & Loser & Small|Medium|Loser & $-6,25 \%$ & $26,67 \%$ & $-2,37 \%$ & $-7,82 \%$ & $-0,58 \%$ & $9,12 \%$ & $4,85 \%$ & $-5,40 \%$ & $-15,76 \%$ & $2,90 \%$ & $-15,36 \%$ & $29,63 \%$ \\
\hline POMO4 & Marcopolo PN & 1,26 & Medium & $\begin{array}{l}3.259 .898 \\
\end{array}$ & Small & 0,64 & Loser & Small|Medium|Loser & $-4,64 \%$ & $-14,61 \%$ & $4,39 \%$ & $-3,36 \%$ & $-0,43 \%$ & $4,79 \%$ & $7,83 \%$ & $4,84 \%$ & $-3,46 \%$ & $12,75 \%$ & $0,71 \%$ & $-3,16 \%$ \\
\hline ALPA4 & Alpargatas PN & 1,67 & \begin{tabular}{|l|} 
Medium \\
\end{tabular} & 629.955 & Small & 0,65 & Loser & Small|Medium|Loser & $8,34 \%$ & $10,49 \%$ & $-0,70 \%$ & $-6,38 \%$ & $-1,52 \%$ & $0,00 \%$ & $32,31 \%$ & $-9,88 \%$ & $0,08 \%$ & $1,35 \%$ & $-4,00 \%$ & $-6,25 \%$ \\
\hline ALPA3 & & 1,67 & 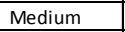 & & Small & 0,68 & & Small|N & $13,58 \%$ & $1,61 \%$ & $5,88 \%$ & $5,47 \%$ & $4,58 \%$ & $-6,25 \%$ & $16,67 \%$ & $-8,57 \%$ & $1,10 \%$ & $-0,65 \%$ & $0,65 \%$ & $-3,55 \%$ \\
\hline RPAD3 & Alfa Holding ON & 1,85 & Medium & 157.508 .520 & Small & 0,69 & Winner & Small|Medium /Winner & $-0,11 \%$ & $7,65 \%$ & $-0,51 \%$ & $-2,04 \%$ & $-3,65 \%$ & $-2,70 \%$ & $5,56 \%$ & $5,69 \%$ & $-7,00 \%$ & $0,00 \%$ & $-0,54 \%$ & $0,54 \%$ \\
\hline TEKA4 & Teka PN & 0,83 & Medium & 23.015 .859 & Small & 0,71 & Winner & Small|Medium|Winner & $50,00 \%$ & $-1,11 \%$ & $-3,37 \%$ & $-5,81 \%$ & $-4,94 \%$ & $2,60 \%$ & $27,85 \%$ & $0,99 \%$ & $-1,96 \%$ & $-1,00 \%$ & $-19,19 \%$ & $-5,00 \%$ \\
\hline OXIT4 & Oxiteno PN & 1,50 & Medium & 409.351 .500 & Small & 0,78 & Winner & Small|Medium /Winner & $11,76 \%$ & $6,87 \%$ & $-5,00 \%$ & $5,26 \%$ & $-8,69 \%$ & $0,00 \%$ & $0,00 \%$ & $0,43 \%$ & $6,74 \%$ & $-7,26 \%$ & $-3,06 \%$ & $-9,52 \%$ \\
\hline GUAR4 & & & & & & & & & & $4,01 \%$ & $-13,29 \%$ & $-8,67 \%$ & $-14,84 \%$ & $15,71 \%$ & $28,89 \%$ & & & $6,69 \%$ & $-7,51 \%$ & $33 \%$ \\
\hline LEVE4 & Metal Lev & 4 & Medium & & $\mathrm{Sm}$ & & Winr & & $6,90 \%$ & $-3,23 \%$ & $3,00 \%$ & $-2,91 \%$ & $3,33 \%$ & $3,23 \%$ & $4,06 \%$ & $6,61 \%$ & $-1,41 \%$ & $1,43 \%$ & $10,28 \%$ & $85 \%$ \\
\hline \begin{tabular}{|l|l|} 
RIPI4 \\
\end{tabular} & Ipiranga Ref PN & 1,12 & \begin{tabular}{|l|} 
Medium \\
\end{tabular} & 126.222 & Small & 0,87 & Winner & Small|Medium / Winner & $0,87 \%$ & $-6,25 \%$ & $-6,67 \%$ & $-4,71 \%$ & $2,45 \%$ & $0,76 \%$ & $7,43 \%$ & $-5,53 \%$ & $-1,95 \%$ & $-0,50 \%$ & $-24,50 \%$ & $0,00 \%$ \\
\hline RPAD5 & Alfa Holding & 85 & Medium & 508.520 & Small & 0,89 & Winner & Small|Medium /Winner & $0,44 \%$ & $11,41 \%$ & $-3,41 \%$ & $-1,52 \%$ & $-5,13 \%$ & $-2,70 \%$ & $4,44 \%$ & $1,60 \%$ & $2,87 \%$ & $3,74 \%$ & $0,52 \%$ & $-4,62 \%$ \\
\hline GUAR3 & Guara & 9 & & & Small & 0,90 & & Small |N & $0,00 \%$ & & $-3,85 \%$ & $0,00 \%$ & $-5,20 \%$ & $6,54 \%$ & $6,93 \%$ & $0,00 \%$ & $9,26 \%$ & $0,68 \%$ & $2,64 \%$ & $-5,82 \%$ \\
\hline IENG5 & & 6 & alu & & $\mathrm{Sm}$ & & $\mathrm{Wi}_{\mathrm{i}}$ & & $7,14 \%$ & $-16,00 \%$ & $-1,59 \%$ & $-11,29 \%$ & $9,09 \%$ & $25,00 \%$ & $-6,67 \%$ & $-28,57 \%$ & $-10,00 \%$ & $-13,33 \%$ & $17,95 \%$ & $28,13 \%$ \\
\hline BIOB4 & Biobras PN & 79 & \begin{tabular}{|l|} 
Medium \\
\end{tabular} & 01.199 & Small & 1,24 & Winner & Small|Medium /Winner & $-3,66 \%$ & $-11,39 \%$ & $1,43 \%$ & $1,41 \%$ & $-20,83 \%$ & $-7,02 \%$ & $28,30 \%$ & $1,47 \%$ & $-20,29 \%$ & $-3,27 \%$ & $5,16 \%$ & $13,21 \%$ \\
\hline ETER3 & Eternit & & Medic & & Small & 1,25 & Winner & Small|Medium / Winner & $12,21 \%$ & $3,25 \%$ & $0,29 \%$ & $1,43 \%$ & $-5,07 \%$ & $18,17 \%$ & \begin{tabular}{|l|l|}
$10,79 \%$ \\
\end{tabular} & $-0,82 \%$ & $-4,48 \%$ & $5,15 \%$ & $-16,07 \%$ & $-9,38 \%$ \\
\hline TMAC6B & Amazonia Celular PNB & 1,53 & Medium & 267.514 .866 & Small & 1,26 & Winner & Small|Medium /Winner & $-0,27 \%$ & $-0,55 \%$ & $-6,06 \%$ & $9,38 \%$ & $28,69 \%$ & $0,00 \%$ & \begin{tabular}{|l|l|}
$14,58 \%$ \\
\end{tabular} & $1,82 \%$ & $-21,43 \%$ & $-17,95 \%$ & $38,69 \%$ & $0,20 \%$ \\
\hline ESTR4 & Estrela & 0,87 & \begin{tabular}{|l|} 
Medium \\
\end{tabular} & 9.807 .980 & Small & 1,27 & Winner & dium/Winner & $-11,27 \%$ & $-4,76 \%$ & $1,67 \%$ & $4,92 \%$ & $-21,87 \%$ & $20,00 \%$ & $18,33 \%$ & $-9,86 \%$ & $-15,62 \%$ & $14,81 \%$ & $-8,06 \%$ & $26 \%$ \\
\hline FBRA4 & Fertibr & & \begin{tabular}{|l|} 
Medium \\
\end{tabular} & 64.190 .299 & Small & 1,34 & Winner & Winner & $-4,10 \%$ & $11,11 \%$ & $-7,69 \%$ & $6,67 \%$ & $-9,37 \%$ & $18,97 \%$ & $-0,72 \%$ & $-0,73 \%$ & $7,94 \%$ & $-1,45 \%$ & $-6,20 \%$ & $62 \%$ \\
\hline TPEC6 & $\operatorname{Tim~Nc}$ & 1,28 & $\mathrm{Me}$ & 4 & Small & $\begin{array}{l}1,44 \\
1,48\end{array}$ & Winne & Small|Medic & $10,85 \%$ & $12,36 \%$ & -5,71\% & $-18,18 \%$ & - & 7,50\% & $-0,72 \%$ & $9,34 \%$ & $-10,73 \%$ & $-18,02 \%$ & $47,24 \%$ & $3,39 \%$ \\
\hline PQUN4 & Petroq U & 1 & Medium & 154.219 & Small & 1,65 & Winner & Small|Medium |Winner & $5,82 \%$ & $5,51 \%$ & $-4,96 \%$ & $-6,90 \%$ & $14,97 \%$ & $2,89 \%$ & $3,57 \%$ & $-3,27 \%$ & $5,20 \%$ & $0,54 \%$ & $-3,37 \%$ & $3,36 \%$ \\
\hline TPEC7B & Tim Nordeste PNC & 1,28 & Medium & 199.678 .094 & Small & 1,84 & Winner & Small|Medium|Winner & $5,66 \%$ & $3,70 \%$ & $14,08 \%$ & $-37,50 \%$ & $-9,75 \%$ & $21,88 \%$ & $17,04 \%$ & $11,11 \%$ & $-25,00 \%$ & $-21,19 \%$ & $49,60 \%$ & $22,68 \%$ \\
\hline & & & & & & 2,03 & & & & 4,30 & & $-6,12 \%$ & $-16,56 \%$ & $-7,5$ & & $2,22 \%$ & & & $-15,68 \%$ & \\
\hline DN4 & Polialden PN & 1,37 & dium & 130.341 .111 & Small & 2,03 & Ninner & Small|Medium / Winner & $-5,94 \%$ & $21 \%$ & $-1,49 \%$ & $-5,56 \%$ & $-11,76 \%$ & $-1,33 \%$ & $1,86 \%$ & $1,41 \%$ & $13,06 \%$ & $10,71 \%$ & $3,87 \%$ & $14 \%$ \\
\hline
\end{tabular}

\begin{tabular}{|c|c|c|c|c|c|c|c|c|c|c|c|c|c|c|c|c|c|c|c|c|}
\hline Código & $2001-2002$ & $\begin{array}{l}\text { Índice } \mathrm{B} / \mathrm{M} \\
\text { de dez/2000 }\end{array}$ & $\begin{array}{c}\text { Grupo com } \\
\text { base no } \\
\text { índice } \mathrm{B} / \mathrm{M}\end{array}$ & $\begin{array}{c}\text { Valor de Mercado } \\
\text { em jun/2001 }\end{array}$ & \begin{tabular}{|c} 
Grupo com \\
base no \\
tamanho \\
\end{tabular} & \begin{tabular}{|c|} 
Retorno \\
acumulado \\
de jun/2001
\end{tabular} & \begin{tabular}{|c|} 
Grupo com \\
base no \\
retorno \\
acumulado
\end{tabular} & Carteiras & $\mathrm{jul} / 01$ & ago/01 & set/01 & out/01 & nov/01 & dez/01 & jan/02 & fev/02 & $\mathrm{mar} / 02$ & abr/02 & mai/02 & jun/02 \\
\hline BSUL5 & Bahia Sul PNA & 1,87 & High & 670.146 .894 & Big & 0,22 & Loser & Big|High|Loser & \begin{tabular}{|l|}
$-10,10 \%$ \\
\end{tabular} & $2,20 \%$ & $-2,75 \%$ & $10,99 \%$ & $14,22 \%$ & $4,72 \%$ & $16,80 \%$ & $-7,01 \%$ & $1,88 \%$ & $5,56 \%$ & $-4,79 \%$ & $2,61 \%$ \\
\hline CMIG4 & Cemig PN & 1,88 & High & 4.285 .233 .478 & Big & 0,08 & Loser & Big|High|Loser & $-4,01 \%$ & $5,29 \%$ & $-7,19 \%$ & $3,89 \%$ & $14,27 \%$ & $10,29 \%$ & $6,00 \%$ & $4,63 \%$ & $-5,46 \%$ & $7,80 \%$ & $-3,58 \%$ & $-5,44 \%$ \\
\hline GOAU4 & Gerdau Met PN & 1,86 & High & 616.835 .217 & Big & 0,06 & Loser & Big|High|Loser & $6,46 \%$ & $-6,05 \%$ & $-14,24 \%$ & $18,58 \%$ & $16,67 \%$ & $-0,86 \%$ & $18,89 \%$ & $14,47 \%$ & $0,69 \%$ & $11,64 \%$ & $3,02 \%$ & $-9,38 \%$ \\
\hline CSTB4 & Sid Tubarao PN & 3,47 & High & 1.123.370.755 & Big & 0,04 & Loser & Big|High|Loser & $-7,26 \%$ & $-1,48 \%$ & $-21,00 \%$ & $-0,89 \%$ & $27,08 \%$ & $8,09 \%$ & $6,67 \%$ & $7,83 \%$ & $5,98 \%$ & $14,92 \%$ & $2,11 \%$ & $-0,38 \%$ \\
\hline TRPL4 & Tran Paulist PN & 3,36 & High & 570.646 .118 & Big & 0,03 & Loser & Big|High|Loser & $-0,45 \%$ & $0,92 \%$ & $-30,45 \%$ & $20,92 \%$ & $7,75 \%$ & $10,09 \%$ & $8,31 \%$ & $7,24 \%$ & $-3,31 \%$ & $-10,92 \%$ & $5,71 \%$ & $-6,31 \%$ \\
\hline BRKM5 & Braskem PNA & 2,18 & High & \begin{tabular}{|c|}
997.015 .063 \\
\end{tabular} & Big & 0,04 & Loser & Big|High|Loser & $-6,10 \%$ & $-15,67 \%$ & $-21,23 \%$ & $10,14 \%$ & $12,63 \%$ & $11,42 \%$ & $20,17 \%$ & $-4,22 \%$ & $-0,76 \%$ & $0,38 \%$ & $-15,77 \%$ & $-9,72 \%$ \\
\hline GOAU3 & Gerdau Met ON & 1,86 & High & 616.835 .217 & Big & 0,07 & Loser & Big|High|Loser & \begin{tabular}{ll|}
$-0,02 \%$ \\
\end{tabular} & $-0,26 \%$ & $6,63 \%$ & $4,17 \%$ & $16,67 \%$ & $14,29 \%$ & $6,64 \%$ & $10,00 \%$ & $-1,11 \%$ & $14,92 \%$ & $-1,86 \%$ & $6,36 \%$ \\
\hline USIMS & Usiminas PNA & 2,26 & High & 1.391.083.387 & Big & 0,11 & Loser & Big|High|Loser & $-3,82 \%$ & $-5,92 \%$ & $-30,35 \%$ & $-0,50 \%$ & $44,30 \%$ & $14,21 \%$ & $10,14 \%$ & $11,72 \%$ & $-3,12 \%$ & $6,52 \%$ & $-4,37 \%$ & $-10,46 \%$ \\
\hline ARCE3 & Arcelor BR ON & 2,18 & High & 842.498 .265 & Big & 0,18 & Winner & Big|High|Winner & $-6,20 \%$ & $6,25 \%$ & $-18,49 \%$ & $9,79 \%$ & $25,81 \%$ & $3,95 \%$ & $11,54 \%$ & $18,62 \%$ & $-6,40 \%$ & $24,22 \%$ & $5,00 \%$ & $9,52 \%$ \\
\hline ELET6 & \begin{tabular}{|l|l|l} 
Eletrobras $\mathrm{PNB}$ \\
\end{tabular} & 3,34 & High & 15.660 .845 .710 & Big & $\begin{array}{ll}0,21 \\
\end{array}$ & Winner & Big|High|Winner & $13,93 \%$ & $3,26 \%$ & $-8,13 \%$ & $13,23 \%$ & $-7,78 \%$ & $1,63 \%$ & $13,71 \%$ & $11,45 \%$ & $-4,23 \%$ & $-4,38 \%$ & $-9,89 \%$ & $-9,18 \%$ \\
\hline MIG3 & emig ON & $\begin{array}{ll}1,88 \\
\end{array}$ & नlgh & \begin{tabular}{|l|}
4.285 .233 .478 \\
\end{tabular} & BIg & $\begin{array}{ll}0,22 \\
\end{array}$ & Winner & Big|High|Winne & $-0,80 \%$ & $4,58 \%$ | & $-9,46 \%$ & $6,81 \%$ & $5,70 \%$ & $14,87 \%$ & $-3,81 \%$ & $11,22 \%$ & $-4,72 \%$ & $1,21 \%$ & $4,54 \%$ & $-6,29 \%$ \\
\hline
\end{tabular}


Anexo 1 - Retorno mensal e classificação das ações

\begin{tabular}{|c|c|c|c|c|c|c|c|c|c|c|c|c|c|c|c|c|c|c|c|c|}
\hline Código & $2001-2002$ & $\begin{array}{l}\text { Índice } B / M \\
\text { de dez } / 2000\end{array}$ & $\begin{array}{c}\text { Grupo com } \\
\text { base no } \\
\text { indice } B / M\end{array}$ & $\begin{array}{c}\text { Valor de Mercado } \\
\text { em jun/2001 }\end{array}$ & $\begin{array}{c}\text { Grupo com } \\
\text { base no } \\
\text { tamanho }\end{array}$ & $\begin{array}{c}\text { Retorno } \\
\text { acumulado } \\
\text { de jun/2001 }\end{array}$ & \begin{tabular}{|c|} 
Grupo com \\
base no \\
retorno \\
acumulado
\end{tabular} & Carteiras & $\mathrm{jul} / 01$ & ago/01 & set/01 & out/01 & nov/01 & dez/01 & $\mathrm{jan} / 02$ & $\mathrm{fev} / 02$ & $\mathrm{mar} / 02$ & $a b r / 02$ & mai/02 & jun/02 \\
\hline ARCE4 & Arcelor BR PN & 2,18 & High & 842.498 .265 & Big & 0,23 & Winner & Big|High/Winner & $-4,00 \%$ & $-3,48 \%$ & $-18,79 \%$ & $16,26 \%$ & $25,42 \%$ & $6,17 \%$ & $6,36 \%$ & $23,08 \%$ & $-4,64 \%$ & $22,88 \%$ & $4,72 \%$ & $3,99 \%$ \\
\hline ELET3 & Eletrobras ON & 3,34 & High & 15.660 .845 .710 & Big & 0,34 & Winner & Big|High|Winner & $22,03 \%$ & $1,39 \%$ & $-12,27 \%$ & $9,31 \%$ & $-7,71 \%$ & $3,10 \%$ & $12,98 \%$ & $16,12 \%$ & $-4,48 \%$ & $-7,49 \%$ & $-9,78 \%$ & $-9,10 \%$ \\
\hline GEPA4 & Ger Paranap PN & 3,14 & High & 772.164.440 & Big & 0,34 & Winner & Big|High|Winner & $5,88 \%$ & $-4,22 \%$ & $-2,55 \%$ & $-1,67 \%$ & $1,69 \%$ & $7,14 \%$ & $-1,11 \%$ & $12,36 \%$ & $-3,00 \%$ & $-1,86 \%$ & $-5,45 \%$ & $3,41 \%$ \\
\hline TRPL3 & Tran Paulist ON & 3,36 & High & 570.646 .118 & Big & 0,46 & Winner & Big|High|Winner & $22,71 \%$ & $-1,56 \%$ & $-28,57 \%$ & $10,00 \%$ & $2,02 \%$ & $3,63 \%$ & $3,88 \%$ & $10,28 \%$ & $-4,24 \%$ & $-2,26 \%$ & $-5,66 \%$ & $-3,00 \%$ \\
\hline CESP5 & Cesp PNA & 6,89 & High & 1.363.478.962 & Big & 0,74 & Winner & Big|High|Winner & $-8,28 \%$ & $-9,02 \%$ & $-33,06 \%$ & $62,10 \%$ & $12,34 \%$ & $1,69 \%$ & $0,00 \%$ & $4,00 \%$ & $-5,77 \%$ & $-12,93 \%$ & $-16,80 \%$ & $-16,43 \%$ \\
\hline CESP3 & Cesp ON & 6,89 & High & 1.363.478.962 & Big & 1,04 & Winner & Big|High|Winner & $-11,64 \%$ & $-9,30 \%$ & $-34,19 \%$ & $59,87 \%$ & $7,23 \%$ & $0,00 \%$ & $2,27 \%$ & $-2,22 \%$ & $-1,97 \%$ & $-15,69 \%$ & $-15,22 \%$ & $-15,68 \%$ \\
\hline VIVO3 & Vivo ON & 0,47 & Low & 6.176 .336 .882 & Big & 0,55 & \begin{tabular}{|l|l|} 
Loser \\
\end{tabular} & Big|Low|Loser & $-0,49 \%$ & $-5,96 \%$ & $-56,34 \%$ & $-4,57 \%$ & $44,79 \%$ & $6,47 \%$ & $-19,32 \%$ & $5,70 \%$ & $-17,43 \%$ & $11,32 \%$ & $-14,66 \%$ & $-19,39 \%$ \\
\hline EBTP4 & Embratel Part PN & 0,69 & Low & 5.916 .054 .351 & Big & 0,45 & Loser & Big|Low/Loser & $-24,99 \%$ & $-18,43 \%$ & $-30,65 \%$ & $1,47 \%$ & $40,79 \%$ & $-7,48 \%$ & $-13,13 \%$ & $1,74 \%$ & $-10,97 \%$ & $-21,82 \%$ & $-24,63 \%$ & $-68,41 \%$ \\
\hline TSEP4 & Tele Sudeste Celula PN & 0,67 & Low & 3.433 .720 .451 & Big & 0,44 & Loser & Big|Low|Loser & $-11,53 \%$ & $-8,16 \%$ & $-5,97 \%$ & $-12,27 \%$ & $1,29 \%$ & $-3,81 \%$ & $-0,05 \%$ & $2,92 \%$ & $-5,74 \%$ & $0,87 \%$ & $5,17 \%$ & $6,56 \%$ \\
\hline VIVO4 & Vivo PN & 0,47 & Low & 6.176 .336 .882 & Big & 0,44 & Loser & Big|Low|Loser & $1,77 \%$ & $-8,71 \%$ & $-56,41 \%$ & $-4,03 \%$ & $38,69 \%$ & $11,84 \%$ & $-14,12 \%$ & $2,88 \%$ & $-23,83 \%$ & $4,90 \%$ [ & $-9,17 \%$ & $-17,98 \%$ \\
\hline NETC4 & Net PN & 0,04 & Low & 3.064 .265 .864 & Big & 0,42 & Loser & Big|Low|Loser & $-11,01 \%$ & $-10,31 \%$ & $-24,14 \%$ & $0,00 \%$ & $15,15 \%$ & $6,58 \%$ & $-25,93 \%$ & $15,00 \%$ & $-27,54 \%$ & $-30,00 \%$ & $11,43 \%$ & $-56,92 \%$ \\
\hline TNEP4 & Tele Nordeste Celul PN & 0,41 & Low & 1.290 .902 .730 & Big & 0,35 & Loser & Big|Low|Loser & $-8,27 \%$ & $-14,53 \%$ & $-19,39 \%$ & $12,66 \%$ & $13,48 \%$ & $6,27 \%$ & $-10,52 \%$ & $5,24 \%$ & $-7,64 \%$ & $-10,50 \%$ & $6,20 \%$ & $3,11 \%$ \\
\hline EBTP3 & Embratel Part ON & 0,69 & Low & 5.916 .054 .351 & Big & 0,34 & Loser & Big|Low/Loser & $-22,09 \%$ & $-16,43 \%$ & $-33,33 \%$ & $7,69 \%$ & $39,40 \%$ & $-6,92 \%$ & $-7,34 \%$ & $4,06 \%$ & $-11,51 \%$ & $\mid-13,98 \%$ & $-22,50 \%$ & $-56,45 \%$ \\
\hline TCSL4 & Tim Part S/A PN & $\begin{array}{ll}0,49 \\
\end{array}$ & Low & 1.476.490.719 & Big & 0,28 & Loser & Big|Low|Loser & $-9,68 \%$ & $-21,67 \%$ & $-15,50 \%$ & $3,24 \%$ & $21,25 \%$ & $3,74 \%$ & $-14,05 \%$ & $6,56 \%$ & $-7,38 \%$ & $-3,24 \%$ & $3,09 \%$ & $5,67 \%$ \\
\hline ITEC3 & Itautec ON & 0,30 & Low & 695.441 .042 & Big & 0,27 & Loser & Big|Low|Loser & $-4,76 \%$ & $-2,55 \%$ & $-19,84 \%$ & $1,69 \%$ & $-15,00 \%$ & $21,57 \%$ & $9,68 \%$ & $1,18 \%$ & $-10,78 \%$ & $11,48 \%$ & $-11,76 \%$ & $3,00 \%$ \\
\hline ELPL5 & Eletropaulo PNA & 0,68 & Low & 3.028 .924 .526 & Big & 0,26 & Loser & Big|Low|Loser & $\begin{array}{l}-15,06 \% \\
\end{array}$ & $12,37 \%$ & $-15,35 \%$ & $11,26 \%$ & $18,30 \%$ & $1,30 \%$ & $-10,88 \%$ & $-3,90 \%$ & $10,78 \%$ & $-15,39 \%$ & $-13,85 \%$ & $-12,80 \%$ \\
\hline CBEE3 & Ampla Energ ON & 0,56 & Low & 920.173 .685 & Big & 0,24 & Loser & Big|Low|Loser & $9,26 \%$ & $-10,17 \%$ & $-5,66 \%$ & $-8,00 \%$ & $6,52 \%$ & $-8,16 \%$ & $8,89 \%$ & $0,00 \%$ & $0,00 \%$ & $-16,33 \%$ & $-17,07 \%$ & $-8,82 \%$ \\
\hline TNEP3 & Tele Nordeste Celul ON & 0,41 & Low & 1.290 .902 .730 & Big & 0,22 & Loser & Big|Low/Loser & $-17,51 \%$ & $-12,62 \%$ & $-26,06 \%$ & $17,62 \%$ & $23,48 \%$ & $1,97 \%$ & $-10,57 \%$ & $8,70 \%$ & $13,33 \%$ & $-9,80 \%$ & $3,01 \%$ & $-10,71 \%$ \\
\hline TMCP4 & Telemig Part PN & 0,29 & Low & 1.926.294.429 & Big & 0,21 & Loser & Big|Low|Loser & $-3,34 \%$ & $-25,05 \%$ & $-12,10 \%$ & $6,56 \%$ & $27,69 \%$ & $0,96 \%$ & $-13,84 \%$ & $1,11 \%$ & $-10,96 \%$ & $-20,94 \%$ & $20,55 \%$ & $-4,92 \%$ \\
\hline LIGT3 & Light S/A ON & 0,70 & Low & 1.975 .661 .685 & Big & 0,18 & Loser & Big|Low|Loser & $-19,72 \%$ & $1,75 \%$ & $-29,74 \%$ & $12,27 \%$ & $30,56 \%$ & $2,55 \%$ & $0,45 \%$ & $-0,37 \%$ & $-11,11 \%$ & $-9,17 \%$ & $-2,95 \%$ & $-11,61 \%$ \\
\hline TSEP3 & Tele Sudeste Celula ON & 0,67 & Low & 3.433 .720 .451 & Big & 0,07 & Loser & Big|Low|Loser & $-6,79 \%$ & $-4,29 \%$ & $-11,94 \%$ & $-3,73 \%$ & $-1,41 \%$ & $-10,36 \%$ & $0,55 \%$ & $4,95 \%$ & $-6,20 \%$ & $2,07 \%$ & $1,21 \%$ & $3,00 \%$ \\
\hline TCOC4 & Tele Centroeste Cel PN & 0,32 & Low & 2.685.284.672 & Big & 0,04 & Loser & Big|Low/Loser & $-9,98 \%$ & $-13,33 \%$ & $-15,77 \%$ & $5,02 \%$ & $20,65 \%$ & $-2,70 \%$ & $-15,03 \%$ & $7,28 \%$ & $-3,00 \%$ & $2,39 \%$ & $-8,28 \%$ & $-4,63 \%$ \\
\hline TNLP4 & Telemar PN & 0,72 & Low & 12.462 .941 .264 & Big & 0,07 & Loser & Big|Low/Loser & $-11,63 \%$ & $-10,75 \%$ & $-12,91 \%$ & $12,39 \%$ & $21,65 \%$ & $10,27 \%$ & $-12,38 \%$ & $11,79 \%$ & $-18,27 \%$ & $5,01 \%$ & $6,59 \%$ & $-11,20 \%$ \\
\hline TLCP4 & Tele Leste Celular PN & 0,61 & Low & 971.080 .059 & Big & 0,09 & Loser & Big|Low|Loser & $-13,83 \%$ & $-17,90 \%$ & $-51,13 \%$ & $12,31 \%$ & $20,55 \%$ & $10,23 \%$ & $-9,28 \%$ & $-4,55 \%$ & $-2,38 \%$ & $-5,45 \%$ & $-5,41 \%$ & $-15,71 \%$ \\
\hline TNLP3 & Telemar ON & 0,72 & Low & 12.462.941.264 & Big & 0,13 & Loser & Big|Low|Loser & $-8,97 \%$ & $-6,81 \%$ & $-15,77 \%$ & $14,11 \%$ & $15,45 \%$ & $5,72 \%$ & $-8,20 \%$ & $10,00 \%$ & $-16,23 \%$ & \begin{tabular}{l|l}
$5,39 \%$ \\
\end{tabular} & $-0,76 \%$ & $-10,31 \%$ \\
\hline TLCP3 & Tele Leste Celular ON & 0,61 & Low & 971.080 .059 & Big & 0,16 & Loser & Big|Low|Loser & $-18,70 \%$ & $-19,79 \%$ & $-30,00 \%$ & $16,19 \%$ & $18,85 \%$ & $-1,38 \%$ & $-8,39 \%$ & $1,53 \%$ & $12,78 \%$ & $0,00 \%$ & $2,00 \%$ & $-5,88 \%$ \\
\hline PCAR4 & P.Acuca & 0,39 & Low & 6.187.302.461 & Big & 0,16 & Loser & Big|Low|Loser & $-11,82 \%$ & $2,06 \%$ & $-32,83 \%$ & $18,50 \%$ & $12,94 \%$ & $11,21 \%$ & $5,07 \%$ & $7,48 \%$ & $-7,37 \%$ & $7,29 \%$ & $-3,45 \%$ & $-4,90 \%$ \\
\hline FFTL4 & Valefert PN & 0,58 & Low & 546.612 .317 & Big & 0,18 & Winner & Big|Low|Winner & $-0,99 \%$ & $-3,00 \%$ & $-13,40 \%$ & $16,67 \%$ & $11,22 \%$ & $9,91 \%$ & $1,48 \%$ & $7,83 \%$ & $9,68 \%$ & $-0,74 \%$ & $3,70 \%$ & $7,14 \%$ \\
\hline TMGC7 & Telemig Cl PNC & 0,41 & Low & 965.762 .361 & Big & 0,18 & Winner & Big|Low|Winner & $-0,02 \%$ & $-5,20 \%$ & $-12,95 \%$ & $-0,20 \%$ & $16,13 \%$ & $-1,39 \%$ & $-1,41 \%$ & $1,43 \%$ & $-4,51 \%$ & $1,62 \%$ & $7,82 \%$ & $-2,78 \%$ \\
\hline VALE5 & Vale PNA & 0,63 & Low & 20.328.415.693 & Big & 0,20 & Winner & Big|Low|Winner & $0,72 \%$ & $-2,84 \%$ & $2,92 \%$ & $6,65 \%$ & $2,35 \%$ & $1,70 \%$ & $-0,35 \%$ & $12,13 \%$ & $1,67 \%$ & $4,10 \%$ & $17,32 \%$ & $-2,01 \%$ \\
\hline \begin{tabular}{|l|l} 
CPSL3 \\
\end{tabular} & Copesul ON & 0,60 & Low & 1.693 .933 & Big & 0,22 & Winner & Big|Low|Winner & $-12,81 \%$ & $-12,51 \%$ & $-10,92 \%$ & $-7,55 \%$ & $-1,02 \%$ & $7,22 \%$ & $11,54 \%$ & $-2,93 \%$ & $4,62 \%$ & $-1,73 \%$ & $-0,91 \%$ & $-9,89 \%$ \\
\hline VALE3 & Vale ON & 0,63 & Low & 20.328 .415 .693 & Big & 0,27 & Winner & Big|Low|Winner & $-0,38 \%$ & $-2,84 \%$ & $-1,56 \%$ & $4,93 \%$ & $2,50 \%$ & $5,05 \%$ & $0,38 \%$ & $19,39 \%$ & $1,89 \%$ & $1,42 \%$ & $18,00 \%$ & $2,25 \%$ \\
\hline \begin{tabular}{|l|l|} 
PETR4 \\
\end{tabular} & Petrobras PN & 0,49 & Low & $\begin{array}{l}61.437 .405 .486 \\
\end{array}$ & Big & 0,34 & Winner & Big|Low|Winner & $2,32 \%$ & $1,53 \%$ & $-6,73 \%$ & $1,17 \%$ & $-5,39 \%$ & $4,18 \%$ & $-5,96 \%$ & $16,63 \%$ & $6,95 \%$ & $-4,90 \%$ & $-0,73 \%$ & $-9,94 \%$ \\
\hline ITSA4 & Itausa PN & 0,69 & Low & 7.272.199.176 & Big & 0,35 & Winner & Big|Low|Winner & $0,00 \%$ & $-4,96 \%$ & $-7,59 \%$ & $6,15 \%$ & $12,11 \%$ & $2,01 \%$ & $-0,88 \%$ & $14,22 \%$ & $-1,13 \%$ & $0,39 \%$ & $-9,91 \%$ & $-8,90 \%$ \\
\hline CRUZ3 & Souza Cruz ON & 0,46 & Low & 3.491 .713 .526 & Big & 0,40 & Winner & Big|Low|Winner & $-1,07 \%$ & $8,30 \%$ & $-1,58 \%$ & $11,61 \%$ & $2,82 \%$ & $11,37 \%$ & $4,95 \%$ & $4,73 \%$ & $2,93 \%$ & $8,98 \%$ & $-10,53 \%$ & $0,55 \%$ \\
\hline ITSA3 & Itausa ON & 0,69 & Low & 2.199 .176 & Big & 0,41 & Winner & Big |Low|Winner & $0,00 \%$ & $-0,03 \%$ & $-0,94 \%$ & $5,61 \%$ & $9,30 \%$ & $4,95 \%$ & $1,21 \%$ & $0,00 \%$ & $1,53 \%$ & $-1,43 \%$ & $3,15 \%$ & $-3,36 \%$ \\
\hline TCOC3 & Tele Centroeste Cel ON & 0,32 & Low & 2.685 .284 .672 & Big & 0,48 & Winner & Big|Low/Winner & $-6,56 \%$ & $-16,96 \%$ & $5,18 \%$ & $17,25 \%$ & $1,36 \%$ & $-2,44 \%$ & $-4,18 \%$ & $6,58 \%$ & $-1,10 \%$ & $5,06 \%$ & $2,41 \%$ & $4,71 \%$ \\
\hline PETR3 & Petrobras ON & 0,49 & Low & 61.437.405.486 & Big & 0,52 & Winner & Big|Low|Winner & $-1,08 \%$ & $-1,47 \%$ & $-8,16 \%$ & $0,95 \%$ & $-4,49 \%$ & $2,92 \%$ & $-5,52 \%$ & $17,36 \%$ & $9,26 \%$ & $-5,14 \%$ & $0,36 \%$ & $-9,18 \%$ \\
\hline TMCP3 & Telemig Part ON & 0,29 & Low & 1.926.294.429 & Big & 0,53 & Winner & Big|Low|Winner & $-15,75 \%$ & $-7,15 \%$ & $-24,69 \%$ & $18,84 \%$ & $26,61 \%$ & $2,01 \%$ & $-9,09 \%$ & $-9,17 \%$ & $19,27 \%$ & $-2,56 \%$ & $-8,00 \%$ & $-4,35 \%$ \\
\hline TMGC3 & Telemir Cl ON & 0,41 & Low & 965.762 .361 & Big & 0.54 & Winner & Big/Low/Winner & $-15,42 \%$ & $-8.80 \%$ & $-6.31 \%$ & $-3,23 \%$ & $682 \%$ & $8.06 \%$ & $-0.73 \%$ & $0,00 \%$ & $3.12 \%$ & $0,00 \%$ & $6,06 \%$ & $0,00 \%$ \\
\hline GLOB4 & Globex PN & 0,30 & Low & 1.115.887.500 & Big & 0,63 & Winner & Big|Low|Winner & $-15,14 \%$ & $-21,21 \%$ & $-14,53 \%$ & $-6,10 \%$ & $11,82 \%$ & $9,33 \%$ & $20,99 \%$ & $-2,81 \%$ & $-6,41 \%$ & $-0,10 \%$ & $13,64 \%$ & $-18,00 \%$ \\
\hline \begin{tabular}{|l|} 
WEGE4 \\
\end{tabular} & Weg PN & 0,58 & Low & 12.318 .971 & \begin{tabular}{|l} 
Big \\
\end{tabular} & 0,72 & \begin{tabular}{|l|} 
Winner \\
\end{tabular} & \begin{tabular}{|l} 
Big|Low|Winner \\
\end{tabular} & 5,56\% & $-11,58 \%$ & $2,38 \%$ & $7,56 \%$ & $4,86 \%$ & $3,48 \%$ & $-1,03 \%$ & $3,13 \%$ & $7,07 \%$ & $-0,94 \%$ & 1,90\% & $-0,93 \%$ \\
\hline CRTP5 & Crt Celular PNA & 0,43 & Low & 2.706 .758 .003 & Big & 0,86 & Winner & Big|Low|Winner & $-5,03 \%$ & $1,43 \%$ & $-62,39 \%$ & $6,94 \%$ & $31,62 \%$ & $2,46 \%$ & $-8,43 \%$ & $2,32 \%$ & $-1,09 \%$ & $-8,66 \%$ & $0,48 \%$ & $-1,92 \%$ \\
\hline AMBV4 & Ambev PN & 0,17 & Low & 20.549 .036 .374 & Big & 1,08 & Winner & Big|Low|Winner & $-7,41 \%$ & $-2,88 \%$ & $-11,20 \%$ & $2,69 \%$ & $9,22 \%$ & $-0,83 \%$ & $-1,71 \%$ & $3,55 \%$ & $-5,01 \%$ & $7,69 \%$ & $-4,28 \%$ & $-6,72 \%$ \\
\hline EMBR3 & Embraer ON & 0,19 & Low & 12.914 .736 .465 & Big & 1,39 & Winner & Big Low|Winner & $-1,79 \%$ & $-22,69 \%$ & $-43,77 \%$ & $32,43 \%$ & $-1,43 \%$ & $30,50 \%$ & $-3,68 \%$ & $3,15 \%$ & $4,55 \%$ & $8,65 \%$ & $10,03 \%$ & $5,10 \%$ \\
\hline CRTP3 & Crt Celt & 0,43 & Low & 2.706 .758 .003 & Big & 1,70 & Winner & Big|Low|Winner & $-3,30 \%$ & $6,25 \%$ & $-67,91 \%$ & $10,00 \%$ & $27,27 \%$ & $4,76 \%$ & $10,99 \%$ & $-8,24 \%$ & $-9,09 \%$ & $-7,35 \%$ & $3,78 \%$ & $-14,06 \%$ \\
\hline AMBV3 & Ambev ON & 0,17 & Low & 20.549 .036 .374 & Big & 1,79 & Winner & Big|Low|Winner & $-5,04 \%$ & $-6,92 \%$ & $-20,53 \%$ & $8,34 \%$ & $3,84 \%$ & $5,68 \%$ & $-5,46 \%$ & $2,50 \%$ & $-2,44 \%$ & $2,00 \%$ & $-0,98 \%$ & $-6,93 \%$ \\
\hline EMBR4 & Embraer PN & 0,19 & Low & 12.914 .736 .465 & Big & 1,93 & Winner & Big|Low/Winner & $-2,91 \%$ & $-24,09 \%$ & $-48,33 \%$ & $39,17 \%$ & $-5,47 \%$ & $20,37 \%$ & $0,91 \%$ & $-2,93 \%$ & $5,32 \%$ & $15,73 \%$ & $8,94 \%$ & $2,34 \%$ \\
\hline $\begin{array}{ll}\text { CGAS5 } \\
\end{array}$ & $\begin{array}{l}\text { Comgas PNA } \\
\end{array}$ & 0,61 & \begin{tabular}{|l|l|l|l|l} 
Low & \\
\end{tabular} & 1.740 .024 .521 & Big & 2,19 & \begin{tabular}{|l|l|} 
Winner \\
\end{tabular} & Big/Low/Winner & $-9,35 \%$ & $-0,76 \%$ & $-39,40 \%$ & $3,21 \%$ & $10,68 \%$ & $1.68 \%$ & $-7.10 \%$ & $5.88 \%$ & $-9.94 \%$ & $-8,17 \%$ & $-2,62 \%$ & $-12,79 \%$ \\
\hline
\end{tabular}


Anexo 1 - Retorno mensal e classificação das ações

\begin{tabular}{|c|c|c|c|c|c|c|c|c|c|c|c|c|c|c|c|c|c|c|c|c|}
\hline Código & $2001-2002$ & $\begin{array}{l}\text { Índice B/M } \\
\text { de dez/2000 }\end{array}$ & \begin{tabular}{|c} 
Grupo com \\
base no \\
indice B/M
\end{tabular} & $\begin{array}{c}\text { Valor de Mercado } \\
\text { em jun/2001 }\end{array}$ & $\begin{array}{c}\text { Grupo com } \\
\text { base no } \\
\text { tamanho }\end{array}$ & $\begin{array}{c}\text { Retorno } \\
\text { acumulado } \\
\text { de jun/2001 }\end{array}$ & \begin{tabular}{|l|} 
Grupo com \\
base no \\
retorno \\
acumulado \\
\end{tabular} & Carteiras & $\mathrm{jul} / 01$ & ago/01 & set/01 & out/01 & nov/01 & dez/01 & $\mathrm{jan} / 02$ & $\mathrm{fev} / 02$ & $\mathrm{mar} / 02$ & $a b r / 02$ & mai/02 & jun/02 \\
\hline KLBN4 & Klabin S/A PN & 1,03 & Medium & 833.575 .889 & Big & 0,36 & Loser & Big|Medium|Loser & $-5,81 \%$ & $0,00 \%$ & $-11,11 \%$ & $18,06 \%$ & $16,47 \%$ & $-1,01 \%$ & $20,77 \%$ & $8,70 \%$ & $-11,20 \%$ & $-3,60 \%$ & $0,93 \%$ & $-11,11 \%$ \\
\hline PTIP4 & Ipiranga Pet PN & 1,20 & Medium & 891.643 .100 & Big & 0,14 & Loser & Big|Medium|Loser & $-9,55 \%$ & $-14,83 \%$ & $-11,48 \%$ & $-3,77 \%$ & $8,78 \%$ & $2,23 \%$ & $-3,73 \%$ & $12,12 \%$ & $4,04 \%$ & $1,34 \%$ & $-2,37 \%$ & $-11,43 \%$ \\
\hline EBCO4 & Embraco PN & 0,99 & Medium & 531.036 .907 & Big & 0,10 & Loser & Big|Medium|Loser & $-5,62 \%$ & $-4,76 \%$ & $-8,75 \%$ & $12,33 \%$ & $20,73 \%$ & $2,26 \%$ & $10,26 \%$ & $16,28 \%$ & $2,00 \%$ & $-2,94 \%$ & $0,00 \%$ & $-0,12 \%$ \\
\hline BRTP4 & Brasil T Par PN & 0,87 & Medium & 6.682 .819 .100 & Big & 0,09 & Loser & Big|Medium|Loser & $-7,15 \%$ & $-16,85 \%$ & $-1,34 \%$ & $1,36 \%$ & $24,77 \%$ & $-2,04 \%$ & $-6,86 \%$ & $11,79 \%$ & $-2,95 \%$ & $1,54 \%$ & $-4,64 \%$ & $-7,09 \%$ \\
\hline PTIP3 & Ipiranga Pet ON & 1,20 & Medium & 891.643 .100 & Big & 0,08 & Loser & Big|Medium/Loser & $5,96 \%$ & $-5,39 \%$ & $-26,67 \%$ & $0,00 \%$ & $20,91 \%$ & $-2,26 \%$ & $-11,02 \%$ & $9,65 \%$ & $0,80 \%$ & $-3,97 \%$ [ & $-0,83 \%$ & $-12,50 \%$ \\
\hline GGBR4 & Gerdau PN & 1,35 & Medium & 1.916 .552 .622 & Big & 0,04 & Loser & Big|Medium|Loser & $-2,65 \%$ & $-2,83 \%$ & $-17,58 \%$ & $38,97 \%$ & $16,40 \%$ & $-2,73 \%$ & $14,48 \%$ & $12,49 \%$ & $7,25 \%$ & $12,10 \%$ & $-1,59 \%$ & $-5,48 \%$ \\
\hline BRTO3 & Brasil Telec ON & 0,87 & Medium & 6.651.888.896 & Big & 0,09 & Loser & \begin{tabular}{|l|} 
Big|Medium|Loser \\
\end{tabular} & $-11,50 \%$ & $-17,40 \%$ & $-3,15 \%$ & \begin{tabular}{l|l}
$7,50 \%$ \\
\end{tabular} & $30,23 \%$ & $-2,20 \%$ & $-7,71 \%$ & $3,20 \%$ & $0,00 \%$ & $3,55 \%$ & $-1,96 \%$ & $-5,29 \%$ \\
\hline ARCZ6 & Aracruz PNB & 0,94 & Medium & 3.561 .354 .490 & Big & 0,09 & Loser & Big|Medium |Loser & $-5,24 \%$ & $11,06 \%$ & $-9,95 \%$ & $20,60 \%$ & $-8,96 \%$ & $-10,53 \%$ & $7,67 \%$ & $16,39 \%$ & $-2,65 \%$ & $7,97 \%$ & $4,66 \%$ & $9,42 \%$ \\
\hline VCPA4 & Fibria PN & 1,11 & Medium & 2.628.023.565 & Big & 0,11 & Loser & Big|Medium|Loser & $-13,04 \%$ ] & $24,17 \%$ & $-6,44 \%$ & $15,93 \%[$ & $-7,18 \%$ & $7,72 \%$ ] & $-4,23 \%$ & $13,09 \%$ ] & $-1,53 \%$ & 9,50\% & $10,02 \%$ ] & $2,48 \%$ \\
\hline BRTP3 & Brasil T Par ON & 0,87 & Medium & 6.682.819.100 & Big & 0,12 & \begin{tabular}{|l|l} 
Loser \\
\end{tabular} & Big|Medium/Loser & $-9,43 \%$ & $-20,35 \%$ & $2,19 \%$ & $5,36 \%$ & $22,71 \%$ & $-1,44 \%$ & $-7,12 \%$ & $11,95 \%$ & $-3,77 \%$ & $-0,90 \%$ & $-7,51 \%$ & $-4,04 \%$ \\
\hline BRTO4 & Brasil Telec PN & 0,87 & Medium & 6.651 .888 .896 & Big & 0,13 & Loser & Big|Medium/Loser & $-10,40 \%$ & $-17,12 \%$ & $-2,68 \%$ & $5,41 \%$ & $29,72 \%$ & $1,81 \%$ & $-8,33 \%$ & $14,05 \%$ & $-4,35 \%$ & $-2,66 \%$ & $1,38 \%$ & $-11,72 \%$ \\
\hline TMAR6 & Telemar N L PNB & 1,20 & Medium & 13.354.036.686 & Big & 0,13 & Loser & Big|Medium/Loser & $-10,56 \%$ & $-2,36 \%$ & $-23,80 \%$ & $5,33 \%$ & $23,29 \%$ | & $14,61 \%$ | & $-8,36 \%$ & $9,78 \%$ | & $-16,20 \%$ & $13,09 \%$ & 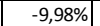 & $-6,67 \%$ \\
\hline PALF7 & Paul F Luz PNC & 1,82 & Medium & 2.322 .659 .245 & Big & 0,15 & Loser & Big|Medium|Loser & $6,25 \%$ & $16,47 \%$ & $-9,09 \%$ & $-5,56 \%$ & $1,18 \%$ & $0,59 \%$ & $4,05 \%$ & $1,10 \%$ & $4,40 \%$ & $-2,62 \%$ & $2,69 \%$ & $-6,84 \%$ \\
\hline CPLE6 & Copel PNB & 1,25 & Medium & 4.458.678.997 & Big & 0,16 & \begin{tabular}{|l|l|} 
Loser \\
\end{tabular} & Big|Medium|Loser & $2,31 \%$ & $3,67 \%$ & $-15,53 \%$ & $-11,80 \%$ | & $13,13 \%$ & $10,82 \%$ & $1,19 \%$ & $5,88 \%$ & $-4,39 \%$ & $-1,22 \%$ & $-12,63 \%$. & $-20,62 \%$ \\
\hline UGPA4 & Ultrapar PN & 0,93 & Medium & 928.030 .033 & Big & 0,22 & Winner & Big|Medium/Winner & $-2,91 \%$ & $22,35 \%$ & $-15,28 \%$ & $9,03 \%$ & $6,58 \%$ & $10,98 \%$ & $8,56 \%$ & $1,97 \%$ & $8,64 \%$ & $-4,55 \%$ & $9,00 \%$ & $-10,44 \%$ \\
\hline GET14 & AES Tiete PN & 0,79 & Medium & 1.153.057.340 & Big & 0,29 & Winner & Big|Medium/Winner & $1,00 \%$ & $4,88 \%$ & $-47,77 \%$ & $56,63 \%$ & $-7,69 \%$ & $38,48 \%$ & $-5,00 \%$ & $-1,32 \%$ & $7,00 \%$ & $11,54 \%$ & $-16,25 \%$ & $0,00 \%$ \\
\hline ARCZ3 & Aracruz ON & 0,94 & Medium & 3.561 .354 .490 & Big & 0,32 & Winner & Big|Medium/Winner & $4,00 \%$ & $7,69 \%$ & $0,00 \%$ & $1,79 \%$ & $5,26 \%$ & $3,00 \%$ & $-2,91 \%$ & $8,67 \%$ & $-5,21 \%$ & $23,30 \%$ & $15,23 \%$ & $7,14 \%$ \\
\hline CSNA3 & Sid Nacional ON & 1,39 & Medium & 3.083.640.863 & Big & 0,36 & Winner & | Big|Medium|Winner & $-9,28 \%$ ] & $-8,72 \%$ & $-24,10 \%$ & $3,66 \%$ & $25,13 \%$ & $4,14 \%$ & $2,19 \%$ & $17,88 \%$. & $-4,71 \%$ & $13,12 \%$ & $6,28 \%$ ] & $-6,85 \%$ \\
\hline SDIA4 & Sadia S/A PN & 1,20 & Medium & 900.829 .516 & Big & 0,40 & Winner & Big|Medium/Winner & $-3,57 \%$ & $7,69 \%$ & $-11,50 \%$ & $24,00 \%$ & $6,45 \%$ & $-5,30 \%$ & $6,83 \%$ & $3,23 \%$ & $0,78 \%$ & $0,00 \%$ & $-10,08 \%$ & $-6,03 \%$ \\
\hline PALF5 & Paul F Luz PNA & 1,82 & Medium & 2.322 .659 .245 & Big & 0,40 & Winner & Big|Medium / Winner & $11,58 \%$ & $17,04 \%$ & $17,68 \%$ & $2,77 \%$ & $0,64 \%$ & $-0,66 \%$ & $4,00 \%$ & $-2,56 \%$ & $7,91 \%$ & $1,21 \%$ & $-5,73 \%$ & $-10,26 \%$ \\
\hline CEPE5 & Celpe PNA & 0,96 & Medium & 615.626 .036 & Big & 0,40 & Winner & | Big|Medium/Winner & $4,28 \%$ & $-5,56 \%$ & $-3,53 \%$ & $-2,44 \%$ & $16,25 \%$ & $-1,08 \%$ & $-1,93 \%$ & $0,00 \%$ & $2,84 \%$ & $9,39 \%$ & $3,68 \%$. & $-5,66 \%$ \\
\hline PALF3 & Paul F : & 1,82 & Medium & 59.245 & Big & 0,42 & Winner & dium / Winner & $71,72 \%$ & $-14,12 \%$ & $8,90 \%$ & $-6,92 \%$ | $>$ & $0,68 \%$ & $-0,67 \%$ & $17,57 \%$ & $-3,45 \%$ & , 00\% & $-3,57 \%$ [ & $0,29 \%$ ] & $-13,58 \%$ \\
\hline GETI3 & AES Tiete ON & 0,79 & Medium & 1.153.057.340 & Big & 0,43 & Winner & Big $\mid$ Medium /Winner & $3,06 \%$ & $9,50 \%$ & $-11,48 \%$ & $30,75 \%$ | & $1,56 \%$ & $17,58 \%$ | & $13,51 \%$ & $2,38 \%$ & $4,65 \%$ & $10,33 \%$ & $-0,26 \%$ & $-2,86 \%$ \\
\hline TMAR3 & Telemar N L ON & 1,20 & Medium & 13.354 .036 .686 & Big & 0,44 & Winner & Big|Medium|Winner & $-6,48 \%$ & $0,00 \%$ & $-27,72 \%$ & $2,74 \%$ & $14,67 \%$ & $10,03 \%$ & $-6,54 \%$ & $11,63 \%$ & $-14,58 \%$ & $4,88 \%$ & $-9,05 \%$ & $-7,95 \%$ \\
\hline PQUN4 & Petroq Uniao PN & 0,88 & Medium & 593.178 .088 & Big & 0,45 & \begin{tabular}{|l} 
Winner \\
\end{tabular} & Big|Medium/Winner & $1,91 \%$ & $3,91 \%$ & $-1,07 \%$ & $-2,56 \%$ & $5,93 \%$ & $1,87 \%$ & $2,17 \%$ & $1,32 \%$ & $-0,24 \%$ & \begin{tabular}{l|l|}
$8,52 \%$ \\
\end{tabular} & $-0,27 \%$ & $-5,00 \%$ \\
\hline COCE5 & Coelce & 1,30 & Medi & & Big & 0,45 & Winner & $B i_{\xi}$ & $-6,9$ & $-4,71 \%$ ], & $-10,63 \%$ & $-3,26 \%$ & $13,25 \%$ & $-2,1$ & $-2,17 \%$ & 1,1 & $-2,86 \%$ & $19,07 \%$ ] & $-3,45 \%$ & $-16,67 \%$ \\
\hline SBSP3 & Sabesp ON & 1,67 & Medium & 4.727.609.602 & Big & 0,54 & Winner & | Big $\mid$ Medium|Winner & $-0,30 \%$ & $1,21 \%$ & $-34,93 \%$ & $2,75 \%$ & $18,30 \%$ & $-0,38 \%$ & $3,03 \%$ & $10,23 \%$ & $-2,66 \%$ & $13,52 \%$ & $-22,23 \%$ ] & $-8,16 \%$ \\
\hline CPLE3 & Copel ON & 1,25 & Medium & 58.678.997 & Big & 0,66 & Winner & Big|Medium/Winner & $31,49 \%$ & $16,05 \%$ & $-11,06 \%$ & $-10,28 \%$ & $-10,27 \%$ & $-4,82 \%$ & $-3,48 \%$ & $4,92 \%$ & $0,31 \%$ & $-1,00 \%$ & $-4,35 \%$ & $-23,83 \%$ \\
\hline SUZB5 & Suzano Papel PNA & 1,38 & Medium & 1.194.447.621 & Big & 0,67 & Winner & Big|Medium/Winner & $-5,56 \%$ & $-16,60 \%$ & $-11,06 \%$ & $26,76 \%$ & $18,34 \%$ & $0,90 \%$ & $21,43 \%$ & $2,21 \%$ & $7,91 \%$ & \begin{tabular}{l|l|}
$1,89 \%$ \\
\end{tabular} & $1,69 \%$ & $-1,67 \%$ \\
\hline PRGA4 & BRF Foods PN & 0,84 & Medium & 302 & Big & 0,74 & Winner & Big|Medium/Winner & $-4,01 \%$ & $8,43 \%$ & $-8,95 \%$ & $17,08 \%$ & $6,76 \%$ & $3,30 \%$ & $4,00 \%$ & $0,36 \%$ & $2,56 \%$ & $2,65 \%$ & $-7,06 \%$ & $-4,95 \%$ \\
\hline CTNM4 & Cotemi & 1,45 & Medium & 7.140 .660 & Big & 76 & Winner & |Medium|Winner & $-2,16 \%$ & $7,41 \%$ & $-17,24 \%$ & $16,67 \%$ & $7,14 \%$ & $1,34 \%$ & $-4,07 \%$ & $9,87 \%$ & $17,94 \%$ & $14,52 \%$ & $-11,96 \%$ & $7,07 \%$ \\
\hline BRDT4 & Petrobras Distrib PN & 22 & Medium & 1.252.799.326 & Big & 0,86 & Winner & Big|Medium/Winner & $9,14 \%$ & $-0,04 \%$ & $-11,94 \%$ & $6,15 \%$ & $13,87 \%$ & $4,28 \%$ & $-2,08 \%$ & $17,58 \%$ & $9,08 \%$ & $\begin{array}{ll}9,11 \% \\
\end{array}$ & $2,20 \%$ & $-5,83 \%$ \\
\hline CMET4 & Caemi PN & 0,88 & Medium & 1.175.884.896 & Big & 0,87 & Winner & Big|Medium/Winner & $-7,33 \%$ & $-1,98 \%$ & $-0,22 \%$ & $8,13 \%$ & $0,51 \%$ & $-7,94 \%$ & $8,44 \%$ & $7,80 \%$ & $19,37 \%$ & $8,11 \%$ & $6,25 \%$ & $2,36 \%$ \\
\hline CTNM3 & Coteminas & 1,45 & \begin{tabular}{|l} 
\\
\end{tabular} & 697.140 .660 & Big & 0,90 & Winner & Big|Medium/Winner & $0,01 \%$. & $-1,05 \%$ & $-1,64 \%$ & $-12,50 \% \mid$ & $14,29 \%$ ] & $4,17 \%$ & $4,94 \%$ & $0,79 \%$ & $9,38 \%$ & $29,85 \%$ & $-0,28 \%$ & $-9,19 \%$ \\
\hline TBLE6 & Tractebel PNB & 1,38 & Medium & 546.299.139 & Big & 0,97 & Winner & Big|Medium/Winner & $1,52 \%$ & $-8,36 \%$ ] $<>$ & $-21,82 \%$ & $9,17 \%$ & $3,05 \%$ & $25,19 \%$ & $1,31 \%$ & $12,12 \%$ & $-1,35 \%$ & $3,94 \%$ & $1,38 \%$ ] & $-13,04 \%$ \\
\hline TBLE3 & Tracteb & 38 & Medium & 39.139 & Big & 1,08 & Winner & |lWinner & $-6,46 \%$ & $-7,38 \%$ & $-24,16 \%$ & $2,37 \%$ & $-1,99 \%$ & $34,80 \%$ & $-4,33 \%$ & $1,35 \%$ & $17,07 \%$ & $5,93 \%$ & $-11,61 \%$ & $-1,01 \%$ \\
\hline SAPR4 & Sanepar PN & 1 & Medium & 365 & Big & 2,29 & Winner & Big|Medium/Winner & $-4,00 \%$ & $-2,08 \%$ & $-2,13 \%$ & $2,17 \%$ & $-6,38 \%$ & $9,09 \%$ & $-9,17 \%$ & $12,39 \%$ & $-2,04 \%$ & $36,46 \%$ & $-16,03 \%$ & $-9,09 \%$ \\
\hline INEP4 & Inepar PN & 2,25 & High & 114.656 .929 & Small & 0,50 & Loser & Small|High|Loser & $7,50 \%$ & $-4,65 \%$ & $-26,83 \%$ & $5,33 \%$ & $18,99 \%$ & $-11,70 \%$ & $-16,87 \%$ & $1,45 \%$ & $-2,86 \%$ & $-34,56 \%$ & $-28,09 \%$ & $-23,44 \%$ \\
\hline RSIP4 & Rasip Agro PN & 3,23 & High & $\begin{array}{l}9.004 .654 \\
\end{array}$ & Small & 0,43 & Loser & Small|High|Loser & $0,00 \%$ & $-16,67 \%$ & $-20,00 \%$ & $25,00 \%$ & $20,00 \%$ & $33,33 \%$ & $-12,50 \%$ & $14,29 \%$ & $0,00 \%$ & $12,50 \%$ & $11,11 \%$ & $0,00 \%$ \\
\hline TRFO4 & Trafo & 2,36 & High & 510 & $\mathrm{Sm}$ & 0,38 & Lo: & & $12,33 \%$ & $-7,32 \%$ & $-1,32 \%$ & $-8,00 \%$ & $-15,94 \%$ & $1,72 \%$ & $11,86 \%$ & $-6,06 \%$ & $-6,45 \%$ & $-1,72 \%$ & $0,00 \%$ & $-8,77 \%$ \\
\hline MGEL4 & Mangels Indl PN & & $\mathrm{Hi}$ & 293.259 & $\mathrm{Sm}$ & & Loser & |High|Loser & $-6,57 \%$ & $8,11 \%$ & $-10,00 \%$ & $-5,56 \%$ & $8,82 \%$ & $-2,70 \%$ & $5,56 \%$ & $0,00 \%$ & $-2,63 \%$ & $-2,16 \%$ & $-12,33 \%$ & $-5,16 \%$ \\
\hline PNVL3 & Dimed ON & 2,06 & High & 43.918.002 & Small & 0,28 & Loser & Small|High|Loser & $0,57 \%$ & $-9,89 \%$ [ & $-7,11 \%$ & $34,23 \%$ ] & $-8,00 \%$ & $-1,67 \%$ & $-2,30 \%$ & $3,53 \%$ & $4,55 \%$ & $-1,09 \%$ & $0,00 \%$ & $-4,40 \%$ \\
\hline BRGE12 & Alfa Consorc & 1,90 & High & 145.611 .531 & Small & 0,20 & Loser & Small|High|Loser & $-3,06 \%$ & $0,04 \%$ & $-11,76 \%$ & $-8,48 \%$ & $29,14 \%$ & $2,05 \%$ & $3,52 \%$ & $8,16 \%$ & $12,27 \%$ & $-8,91 \%$ & $11,11 \%$ & $6,00 \%$ \\
\hline ARLA4 & Arthur & 1,87 & High & 11.150.256 & Small & 0,14 & Loser & Small|H & $12,00 \%$ & $-10,71 \%$ & $-28,00 \%$ & $0,00 \%$ ] & $0,00 \%$ & $0,00 \%$ & $-5,56 \%$ & $0,00 \%$ ] & $0,00 \%$ & $5,88 \%$ & $27,78 \%$ ] & $-13,04 \%$ \\
\hline BRGE11 & & 0 & Hig & & $\mathrm{Sm}$ & 0,14 & Lo & $\mathrm{St}_{\mathrm{i}}$ & $0,00 \%$ & $0,96 \%$ & $-13,16 \%$ & $-9,09 \%$ & $34,00 \%$ & $-0,50 \%$ & $2,50 \%$ & $10,50 \%$ & $9,50 \%$ & $-4,96 \%$ & $17,39 \%$ & $2,22 \%$ \\
\hline BRGE3 & Alfa Consorc ON & 1,90 & High & \begin{tabular}{|l|l|}
145.611 .531 \\
\end{tabular} & Small & 0,14 & Loser & Small|High|Loser & $0,00 \%$ & $1,48 \%$ & $-13,61 \%$ & $-8,48 \%$ & $5,96 \%$ & $28,12 \%$ & $0,00 \%$ & $9,59 \%$ & $14,86 \%$ & $-9,80 \%$ & $17,39 \%$ & $1,85 \%$ \\
\hline CLSC6 & Celesc Pl & 2,29 & High & 347.144.391 & Small & 0,11 & er & Small|Hig & $-4,44 \%$ & $-2,33 \%$ & $-11,90 \%$ & $16,22 \%$ & $11,63 \%$ & $-4,17 \%$ & $8,70 \%$ & $14,00 \%$ & $-3,51 \%$ & $3,64 \%$ & $-1,75 \%$ & $8,93 \%$ \\
\hline PTBL3 & rto & 2,63 & ligh & 8.310 & mall & 03 & oser & Small & $-14,29 \%$ & $0,00 \%$ & $-16,67 \%$ &, $00 \%$ & $0,00 \%$ & $-4,76 \%$ & $25,00 \%$ & $4,00 \%$ & $-7,69 \%$ & $1,17 \%$ & $8,00 \%$ & $13,04 \%$ \\
\hline FESA4 & Ferbasa PN & 2,58 & High & 52.711 .569 & Small & 0,01 & \begin{tabular}{|l|l|} 
Loser \\
\end{tabular} & Small|High|Loser & $-5,80 \%$ & $11,11 \%$ ] & $-17,00 \%$ & $25,30 \%$ | & $33,65 \%$ & $2,16 \%$ & $1,41 \%$ & $2,78 \%$ & $17,57 \%$ & $-0,76 \%$ & $0,26 \%$ & $-7,69 \%$ \\
\hline
\end{tabular}


Anexo 1 - Retorno mensal e classificação das ações

\begin{tabular}{|c|c|c|c|c|c|c|c|c|c|c|c|c|c|c|c|c|c|c|c|c|}
\hline Código & $2001-2002$ & $\begin{array}{l}\text { Índice } B / M \\
\text { de dez/2000 }\end{array}$ & \begin{tabular}{|c} 
Grupo com \\
base no \\
indice $B / M$
\end{tabular} & $\begin{array}{c}\text { Valor de Mercado } \\
\text { em jun/2001 }\end{array}$ & \begin{tabular}{|c} 
Grupo com \\
base no \\
tamanho
\end{tabular} & $\begin{array}{c}\text { Retorno } \\
\text { acumulado } \\
\text { de jun/2001 }\end{array}$ & \begin{tabular}{|c} 
Grupo com \\
base no \\
retorno \\
acumulado
\end{tabular} & Carteiras & $\mathrm{jul} / 01$ & ago/01 & set/01 & out/01 & nov/01 & dez/01 & $\mathrm{jan} / 02$ & fev/02 & $\mathrm{mar} / 02$ & $a b r / 02$ & mai/02 & jun/02 \\
\hline SULT4 & Sultepa PN & 11,47 & High & 21.850 .500 & Small & 0,00 & Loser & Small|High|Loser & $-0,90 \%$ & $-6,36 \%$ & $-15,53 \%$ & $-3,45 \%$ & $4,76 \%$ & $11,36 \%$ & $-9,18 \%$ & $15,73 \%$ & $-3,88 \%$ & $-9,09 \%$ & $-6,67 \%$ & $-16,67 \%$ \\
\hline RPSA4 & Ripasa PN & 2,16 & High & 326.167 .598 & Small & 0,01 & Loser & Small|High|Loser & $-2,27 \%$ & $0,00 \%$ & $-6,98 \%$ & $18,75 \%$ & $17,31 \%$ & $16,35 \%$ & $-1,65 \%$ & $5,88 \%$ & $-0,79 \%$ & $-1,60 \%$ & $15,45 \%$ & $3,37 \%$ \\
\hline FLCL5 & F Cataguazes PNA & 1,98 & High & \begin{tabular}{ll|}
206.875 .553 \\
\end{tabular} & Small & 0,07 & Loser & Small|High|Loser & $2,94 \%$ & $-8,57 \%$ & $-3,12 \%$ & $5,81 \%$ & $1,83 \%$ & $-5,39 \%$ & $-5,06 \%$ & \begin{tabular}{ll|}
$6,67 \%$ \\
\end{tabular} & $0,00 \%$ & $-9,37 \%$ & $-8,97 \%$ & $-12,88 \%$ \\
\hline PLDN4 & Polialden PN & 2,40 & High & 118.391 .017 & Small & 0,15 & Loser & Small| |High | Loser & $30,80 \%$ & $0,00 \%$ & $-8,33 \%$ & $0,00 \%$ & $18,64 \%$ & $7,28 \%$ & $23,21 \%$ & $1,45 \%$ & $17,15 \%$ & $-4,88 \%$ & $-21,65 \%$ & $-2,03 \%$ \\
\hline SCAR4 & Sao Carlos PN & 2,16 & High & 286.217.153 & Small & 0,16 & Winner & Small|High|Winner & $1,89 \%$ & $3,89 \%$ & $3,39 \%$ & $3,45 \%$ & $3,33 \%$ & $4,84 \%$ & $-2,92 \%$ & $3,01 \%$ & $-4,62 \%$ & $1,31 \%$ & $4,84 \%$ & $-4,62 \%$ \\
\hline SCAR3 & Sao Carlos ON & 2,16 & High & 286.217 .153 & Small & 0,19 & Winner & Small|High|Winner & $1,89 \%$ & $3,70 \%$ & $5,36 \%$ & $10,17 \%$ & $6,92 \%$ & $-6,47 \%$ & $4,62 \%$ & $-4,41 \%$ & $0,00 \%$ & $1,54 \%$ & $0,12 \%$ & $-0,61 \%$ \\
\hline ELEV3 & Eleva ON & 2,99 & High & 148.096 .032 & Small & 0,21 & Winner & Small|High|Winner & $-3,93 \%$ & $9,09 \%$ & $-16,67 \%$ & $9,00 \%$ & $14,22 \%$ & $-5,62 \%$ & $6,38 \%$ & $8,00 \%$ & $-0,37 \%$ & $-1,88 \%$ & $-14,89 \%$ & $-2,00 \%$ \\
\hline TELB4 & Telebras PN & 6,83 & High & 16.692 .875 & Small & 0,25 & Winner & Small|High|Winner & $0,00 \%$ & $0,00 \%$ & $-33,33 \%$ & $50,00 \%$ & $0,00 \%$ & $-33,33 \%$ & $50,00 \%$ & $0,00 \%$ & $-33,33 \%$ & $0,00 \%$ & $0,00 \%$ & $-50,00 \%$ \\
\hline \begin{tabular}{|l|l|l} 
MAGSS \\
\end{tabular} & Magnesita PNA & 2,032 & \begin{tabular}{|l} 
High \\
\end{tabular} & $\begin{array}{l}153.972 .020 .204 \\
\end{array}$ & Small & 0,26 & Winner & Small|High $\mid$ Winner & $0,0,27 \%$ & $\begin{array}{c}-7,95 \% \\
-7,95 \% \\
\end{array}$ & $\begin{array}{l}\mid-3,530 \\
-13,99 \% \\
\end{array}$ & $\begin{array}{l}3,0,15 \% \\
3,10\end{array}$ & 12,96\% & 年, & $6,52 \%$ & $\begin{array}{l}, 00 \% \\
1,49 \%\end{array}$ & $\mid-3,24 \%$ & \begin{tabular}{|c|}
$-5,78 \%$ \\
$-0,70$
\end{tabular} & $\begin{array}{c}-1,61 \% \\
-1,61 \% \\
\end{array}$ & $0,0,66 \%$ \\
\hline BDLL4 & Bardella PN & 2,39 & High & 110.400.000 & Small & 0,27 & Winner & Small|High|Winner & $13,77 \%$ & $-12,10 \%$ & $-2,90 \%$ & $4,48 \%$ & $-8,29 \%$ & $-5,72 \%$ & $2,22 \%$ & $10,33 \%$ & $-10,51 \%$ & $-4,59 \%$ & $-1,54 \%$ & $-2,54 \%$ \\
\hline ASTA4 & Santistextil PN & 3,24 & High & 133.794.715 & Small & 0,28 & Winner & Small|High|Winner & $4,85 \%$ & $13,87 \%$ & $-7,49 \%$ & $21,62 \%$ & $13,89 \%$ & $-1,95 \%$ & $0,50 \%$ & $16,34 \%$ & $-10,64 \%$ & $-2,89 \%$ & $-12,50 \%$ & $-0,01 \%$ \\
\hline LIXC4 & Lix da Cunha PN & 7,26 & High & 10.793 .700 & Small & 0,30 & Winner & Small|High|Winner & $-43,33 \%$ & $56,86 \%$ & $-25,00 \%$ & $58,33 \%$ & $10,53 \%$ & $-14,29 \%$ & $11,11 \%$ & $58,23 \%$ & $-16,67 \%$ & $15,16 \%$ & $-18,60 \%$ & $24,76 \%$ \\
\hline PLTO6 & Politeno PNB & 3,12 & High & 141.570 .038 & Small & 0,30 & Winner & Small| High | Winner & $7,19 \%$ & $-16,31 \%$ & $-11,36 \%$ & $7,94 \%$ & $4,41 \%$ & $-0,70 \%$ & $4,82 \%$ & $2,84 \%$ & $-7,89 \%$ & $-1,43 \%$ & $-5,80 \%$ & $-17,69 \%$ \\
\hline TELB3 & Telebras ON & 6,83 & High & 16.692 .875 & Small & 0,33 & Winner & Small|High|Winner & $0,00 \%$ & $0,00 \%$ & $-33,33 \%$ & $50,00 \%$ & $0,00 \%$ & $0,00 \%$ & $-33,33 \%$ & $50,00 \%$ & $-33,33 \%$ & $0,00 \%$ & $0,00 \%$ & $50,00 \%$ \\
\hline PTNT4 & Pettenati PN & 3,08 & High & 32.720 .487 & Small & 0,35 & Winner & Small| High | Winner & $-8,77 \%$ & $-3,88 \%$ & $-14,37 \%$ & $18,93 \%$ & $-13,60 \%$ & $15,96 \%$ & $-5,53 \%$ & $-4,19 \%$ & $-4,72 \%$ & $6,41 \%$ & $-10,26 \%$ & $4,76 \%$ \\
\hline FJTA4 & Forjas Taurus PN & 4,18 & High & 51.948 .002 & Small & 0,39 & Winner & Small|High |Winner & $25,00 \%$ & $-6,67 \%$ & $1,43 \%$ & $15,49 \%$ & $4,88 \%$ & $2,34 \%$ & $5,06 \%$ & $3,61 \%$ & $22,09 \%$ & $-8,57 \%$ & $5,21 \%$ & $3,40 \%$ \\
\hline CNFB4 & Confab PN & 2,36 & High & 177.802 .238 & Small & 0,42 & Winner & Small|High|Winner & $2,44 \%$ & $10,71 \%$ & $-5,91 \%$ & $7,43 \%$ & $15,43 \%$ & $9,70 \%$ & $-2,34 \%$ & $-2,87 \%$ & $17,24 \%$ & $3,78 \%$ & $-1,62 \%$ & $-13,58 \%$ \\
\hline SALM4 & Seara Alim PN & 2,80 & \begin{tabular}{|l} 
High \\
\end{tabular} & $\begin{array}{ll}112.7002 .200 \\
12.002\end{array}$ & \begin{tabular}{|l|l|l|l|} 
Small \\
\end{tabular} & 0,42 & \begin{tabular}{|l|l|} 
Winner \\
\end{tabular} & Small||High|Winner & $\begin{array}{c}-4,440 \% \\
-4,14 \%\end{array}$ & $22,30 \%$ & $\begin{array}{l}-16,47 \% \\
-16,4\end{array}$ & $33,450 \%$ & $35,79 \%$ & $\begin{array}{ll}, 1,55 \% \\
\end{array}$ & $8,82 \%$ & $\begin{array}{l}-0,0710 \\
6,87 \%\end{array}$ & 0 & $\frac{\mid-1,06 \%}{-2,06 \%}$ & $\begin{array}{l}-1,0<1 \\
-3,85 \% \\
\end{array}$ & $0,00 \%$ \\
\hline ROMI4 & Inds Romi PN & 4,16 & High & 52.816 .521 & Small & 0,45 & Winner & Small|High | Winner & $9,55 \%$ & $-2,44 \%$ & $-6,63 \%$ & $-12,99 \%$ & $38,46 \%$ & $20,40 \%$ & $-2,44 \%$ & $11,00 \%$ & $12,44 \%$ & $-4,47 \%$ & $-2,00 \%$ & $-9,09 \%$ \\
\hline SALM3 & Seara Alim ON & 2.86 & High & 112.798 .002 & Small & 0,57 & Winner & Small/High/Winner & $12.40 \%$ & $20,69 \%$ & $7.43 \%$ & $106 \%$ & $28.42 \%$ & $9.84 \%$ & $-1.49 \%$ & $10,20 \%$ & $185 \%$ & $-4.59 \%$ & $4.80 \%$ & $-3.44 \%$ \\
\hline \begin{tabular}{|l|l|} 
LUXM4 \\
\end{tabular} & Trevisa PN & 6,19 & High & 4.159 .303 & Small & 0,58 & \begin{tabular}{|l|l|} 
Winner \\
\end{tabular} & Small| High|Winner & $25,26 \%$ & $-15,97 \%$ & $-34,00 \%$ & $72,73 \%$ & $-29,82 \%$ & $-15,00 \%$ & $17,65 \%$ & $18,75 \%$ & $-15,79 \%$ & $-4,48 \%$ & $-16,67 \%$ & $0,00 \%$ \\
\hline \begin{tabular}{|l|l} 
CSPC3 \\
\end{tabular} & Cosipa ON & $\begin{array}{ll}0,154 \\
5,64\end{array}$ & \begin{tabular}{|l} 
High \\
\end{tabular} & $\begin{array}{l}18.58 .634 .3353 \\
\end{array}$ & Small & 0,30 & Winner & Small||High|Winner & $\begin{array}{l}\mid-11,90 \% \\
-11\end{array}$ & $0,00 \%$ & $\begin{array}{l}-5,40,22 \% \\
-16,2 \%\end{array}$ & $-6,45 \%$ & 17,24\% & $5,88 \%$ & $5,56 \%$ & \begin{tabular}{|l|r|}
$0,00 \%$ \\
\end{tabular} & $15,79 \%$ & $-4,35 \%$ & $-14,29 \%$ & $\begin{array}{l}-16,67 \% \\
-16,610\end{array}$ \\
\hline CSPC4 & Cosipa PN & 5,64 & High & 188.634.337 & Small & 0,70 & Winner & Small|High|Winner & $-6,82 \%$ & $2,44 \%$ & $-11,90 \%$ & $-18,92 \%$ & $43,33 \%$ & $13,95 \%$ & $0,00 \%$ & $-6,12 \%$ & $10,87 \%$ & $-13,54 \%$ & $-13,64 \%$ & $-15,79 \%$ \\
\hline JFEN3 & Joao Fortes ON & 3,54 & High & 23.770 .535 & Small & 0,77 & Winner & Small|High | Winner & $\begin{array}{l}-10,78 \% \\
\end{array}$ & $0,42 \%$ & $-2,86 \%$ & $-6,02 \%$ & $2,32 \%$ & $11,06 \%$ & $2,00 \%$ & $12,94 \%$ & $-2,78 \%$ & $21,79 \%$ & $0,74 \%$ & $16,63 \%$ \\
\hline TEKA4 & Teka PN & 2,30 & High & 29.153 .421 & Small & 0,94 & Winner & Small|High | Winner & $9,21 \%$ & $-13,25 \%$ & $-13,89 \%$ & $29,03 \%$ & $18,75 \%$ & $0,00 \%$ & $-5,26 \%$ & $-1,11 \%$ & $10,11 \%$ & $-0,56 \%$ & $-3,26 \%$ & $1,12 \%$ \\
\hline PVPR4 & Peve Predios PN & 2,40 & High & 140.209 .966 & Small & 1,09 & Winner & Small|High|Winner & $3,32 \%$ & $1,08 \%$ & $0,00 \%$ & $-4,26 \%$ & $\begin{array}{c}0,1,15 \% \\
0,00 \% \\
\end{array}$ & $0,00 \%$ & $11,11 \%$ & $\begin{array}{l}, 1,00 \% \\
0,00\end{array}$ & $0,00 \%$ & 10,00\% & $8,38 \%$ & $\begin{array}{r}-3,208 \% \\
-3,08 \%\end{array}$ \\
\hline EMAE4 & Emae PN & 4,42 & High & 424.152.497 & Small & 1,43 & Winner & Small|High|Winner & $-11,15 \%$ & $-1,96 \%$ & $-25,00 \%$ & $17,20 \%$ & $13,77 \%$ & $-2,00 \%$ & $1,02 \%$ & $-1,52 \%$ & $-8,72 \%$ & $-10,11 \%$ & $-2,50 \%$ & $-10,38 \%$ \\
\hline SGAS4 & WIm Ind Com PN & 2,79 & High & 78.910 .757 & Small & 3,72 & Winner & Small| High | Winner & $6,67 \%$ & $0,00 \%$ & $-23,44 \%$ & $22,45 \%$ & $-11,67 \%$ & $-17,36 \%$ & $9,13 \%$ & $17,15 \%$ & $-12,50 \%$ & $0,00 \%$ & $-10,20 \%$ & $0,00 \%$ \\
\hline MNDL4 & Mund & 2,37 & High & & Small & 4,71 & Winner & Small|High | Winner & $-16,92 \%$ & $0,00 \%$ & $-7,41 \%$ & $-1,00 \%$ & $21,21 \%$ & $15,83 \%$ & $-15,11 \%$ & $-13,56 \%$ & $22,55 \%$ & $12,80 \%$ & $-11,35 \%$ & $-12,00 \%$ \\
\hline IDNT3 & Ideiasnet ol & 0,39 & Low & 1.113 .277 & Small & 0,90 & Loser & Small | Low| Loser & $13,04 \%$ & $-8,97 \%$ & $9,86 \%$ & $26,92 \%$ & $-15,15 \%$ & $\begin{array}{c}3,5,52 \% \\
9,5 \% \\
\end{array}$ & $-17,39 \%$ & $-19,74 \%$ & $14,75 \%$ & $-22,86 \%$ & $20,37 \%$ & $-8,97 \%$ \\
\hline \begin{tabular}{|l|l|l|l|l|l|l} 
ARTE4 \\
\end{tabular} & Kuala PN & $\begin{array}{l}0,037 \\
0,67\end{array}$ & \begin{tabular}{|l|l|l} 
Low \\
\end{tabular} & 11.043 .223 & \begin{tabular}{|l|l|l|l|} 
Small \\
\end{tabular} & $\mid 0,43$ & \begin{tabular}{|l|} 
Loserer \\
\end{tabular} & Small|Low|Loser & $\begin{array}{l}1,3,47 \% \\
-28,57 \%\end{array}$ & $0,00 \%$ & \begin{tabular}{r|}
$-40,00 \%$ \\
$-40 \%$
\end{tabular} & $33,33 \%$ & $0,00 \%$ & $25,00 \%$ & $\frac{-11,050 \%}{-20,00 \%}$ & $\mid$ & $0,00 \%$ & $\mid \begin{array}{l}\mid c 2,000 \% \\
0,00 \%\end{array}$ & $\frac{\mid 25,00 \%}{-25,00 \%}$ & $0,00 \%$ \\
\hline LAME4 & Lojas Americ PN & 75 & Low & 161.180 .789 & Small & 0,36 & Loser & Small| Low|Loser & $-8,17 \%$ & $25,65 \%$ & $-12,50 \%$ & $32,86 \%$ & $16,85 \%$ & $23,93 \%$ & $25,00 \%$ & $20,79 \%$ & $13,88 \%$ & $12,69 \%$ & $-14,97 \%$ & $-12,77 \%$ \\
\hline CPFL4 & Ferro L & 0.78 & Low & $96.499,204$ & Small & 034 & Loser & Small|Low|Loser & $-4.69 \%$ & $20.87 \%$ & $-778 \%$ & $588 \%$ & $185 \%$ & $-0.82 \%$ & $3.39 \%$ & $1,77 \%$ & $226 \%$ & $0.51 \%$ & $-2.54 \%$ & $-0.78 \%$ \\
\hline MNPR4 & Minupa & 0,31 & Low & 2.318 .400 & Small & 0,33 & \begin{tabular}{|l} 
Loser \\
\end{tabular} & Small| Low|Loser & $-8,33 \%$ & $0,00 \%$ & $-36,36 \%$ & $28,57 \%$ & $77,78 \%$ & $0,00 \%$ & $-12,50 \%$ & $-7,14 \%$ & $7,69 \%$ & $14,29 \%$ & $-6,25 \%$ & $-20,00 \%$ \\
\hline TNCP4 & Tele Nort CI PN & 0,57 & \begin{tabular}{|l|l|l} 
Low \\
\end{tabular} & $\begin{array}{r}512.323 .0801 \\
\end{array}$ & \begin{tabular}{|l|l} 
Small \\
\end{tabular} & 0,32 & \begin{tabular}{|l|} 
Loser \\
\end{tabular} & Small| Low|Loser & $4,00 \%$ & -6,92\% & $\begin{array}{l}-9,92 \% \\
-9,\end{array}$ & $-6,42 \%$ & $5,88 \%$ & $\begin{array}{c}-3,70 \% \\
\end{array}$ & $-16,35 \%$ & $\mid-8,05 \%$ & $-7,50 \%$ & $\begin{array}{l}-18,92 \% \\
-18,92 \% \\
\end{array}$ & $-20,00 \%$ & $-39,58 \%$ \\
\hline CHAP3 & Chapeco ON & 0,25 & Low & 265.718 .149 & Small & 0,28 & Loser & Small|Low|Loser & $33,33 \%$ & $0,00 \%$ & $-25,00 \%$ & $0,00 \%$ & $0,00 \%$ & $33,33 \%$ & $0,00 \%$ & $0,00 \%$ & $-25,00 \%$ & $0,00 \%$ & $-31,67 \%$ & $-47,56 \%$ \\
\hline PMAM4 & Paranapanema PN & 0,49 & Low & 280.961 .873 & Small & 0,19 & Loser & Small|Low|Loser & $17,00 \%$ & $-18,80 \%$ & $-21,05 \%$ & $-10,00 \%$ & $0,00 \%$ & $10,37 \%$ & $-16,11 \%$ & $4,00 \%$ & $-11,54 \%$ & $-17,39 \%$ & $3,16 \%$ & $-8,16 \%$ \\
\hline LAME3 & Lojas A & 0,75 & Low & 180.789 & Small & 0,08 & Loser & Small|Low|Loser & $-11,07 \%$ & $8,43 \%$ & $14,44 \%$ & $-3,24 \%$ & $7,69 \%$ & $27,95 \%$ & $16,26 \%$ & $16,91 \%$ & $0,98 \%$ & $31,19 \%$ & $-6,99 \%$ & $-5,41 \%$ \\
\hline $\begin{array}{ll}\text { RHDS3 } \\
\end{array}$ & MG Poliest ON & 0,77 & Low & .608 .203 & Small & & \begin{tabular}{|l|} 
Loser \\
\end{tabular} & Small|Low|Loser & \begin{tabular}{|l|}
$-20,00 \%$ \\
\end{tabular} & $0,00 \%$ & $-37,50 \%$ & $0,00 \%$ & $60,00 \%$ & $25,00 \%$ & $20,00 \%$ & 8, & $7,69 \%$ & $0,00 \%$ & $0,00 \%$ & $-7,14 \%$ \\
\hline ILMD4 & Yara Brasil PN & 0,58 & Low & 108.786.391 & Small & 0,00 & Loser & Small|Low|Loser & $-11,54 \%$ & $4,35 \%$ & $-6,25 \%$ & $40,00 \%$ & $-25,40 \%$ & $-6,38 \%$ & $125,00 \%$ & $1,01 \%$ & $-16,00 \%$ & $13,10 \%$ & $-26,32 \%$ & $-2,86 \%$ \\
\hline CHAP4 & Chapeco PN & 0,25 & Low & 265.718 .149 & Small & 0,16 & Loser & Small| Low|Loser & $-16,67 \%$ & $0,00 \%$ & $-20,00 \%$ & $25,00 \%$ & $0,00 \%$ & $0,00 \%$ & $20,00 \%$ & $16,67 \%$ & $-28,57 \%$ & $-20,00 \%$ & $-18,75 \%$ & $-42,31 \%$ \\
\hline TNCP3 & Tele Nort Cl ON & 0,57 & Low & 512.323 .081 & Small & 0,22 & Winner & Small |Low|Winner & $-7,50 \%$ & $2,70 \%$ & $-15,26 \%$ & $4,97 \%$ & $0,59 \%$ & $5,88 \%$ & $-13,33 \%$ & $-3,85 \%$ & $-13,33 \%$ & $-11,54 \%$ & $-9.57 \%$ & $-13,46 \%$ \\
\hline ALBA3 & Albarus & 0,72 & Low & 32.319 .995 & Small & 0,46 & Winn & Small|Low|Winner & $-2,08 \%$ & $-5,32 \%$ & $-12,36 \%$ & $-3,85 \%$ & $13,33 \%$ & $-4,71 \%$ & $11,11 \%$ & $5,56 \%$ & $-12,63 \%$ & $-3,61 \%$ & $5,00 \%$ & $-27,38 \%$ \\
\hline $\begin{array}{l}\text { SLEDS } \\
\text { SLED4 }\end{array}$ & Saraiva Livr & $0,0,33$ & Low & & Small & \begin{tabular}{ll|l}
0,40 & 0 \\
0,48 & 0
\end{tabular} & \begin{tabular}{|l|l|} 
Winner \\
\end{tabular} & Small|Low|Winner & $|-|-2,07 \%$ & - & $-34,78 \%$ & $\begin{array}{l}-3,0,50 \% \\
5,56 \%\end{array}$ & $\begin{array}{c}1,3,50 \% \\
5,26 \% \\
\end{array}$ & $-8,1,5 \%$ & $\begin{array}{l}-1,1110 \\
-8,76 \%\end{array}$ & $\begin{array}{l}, 01 \% \\
1,01 \% \\
\end{array}$ & $\begin{array}{l}-1,200 \% \\
-1,30 \%\end{array}$ & - & $\begin{array}{l}0,001 \\
-9,82 \% \\
\end{array}$ & $\begin{array}{l}-5,56 \% \\
-2,56 \% \\
-20\end{array}$ \\
\hline PLAS4 & Plascar Part PN & 1,12 & Medium & 23.194 .677 & Small & 0,46 & Loser & Small|Medium|Loser & $-10,91 \%$ & $-8,16 \%$ & $-12,22 \%$ & $1,90 \%$ & $-0,62 \%$ & $3,13 \%$ & $0,61 \%$ & $8,43 \%$ & $-13,33 \%$ & $12,18 \%$ & $-20,00 \%$ & $-21,43 \%$ \\
\hline IENG5 & Ienergia PNA & 1,11 & Medium & 163.625 .689 & Small & 0,41 & Loser & Small|Medium|Loser & $-12,20 \%$ & $-5,56 \%$ & $-8,82 \%$ & $-9,68 \%$ & $3,57 \%$ & $-10,34 \%$ & $-15,38 \%$ & $-4,55 \%$ & $-9,52 \%$ & $-15,79 \%$ & $-6,25 \%$ & $26,67 \%$ \\
\hline TPRC6 & & 0,84 & $y=$ & - & sine & 0,31 & Loser & & $4,16 \%$ & $-11,20 \%$ & $-23,4$ & $0,00 \%$ & $-9,42 \%$ & $-5,18$ & $2,74 \%$ & Th & & & $1,59 \%$ & $0,01 \%$ \\
\hline LPR3 & Eletrc & 1,58 & Mes & 88 & Small & 0,28 & Loser & Small|Medi & $-18,52 \%$ & $13,64 \%$ & $-24,00 \%$ & $11,58 \%$ & $6,13 \%$ & $6,67 \%$ & $3,33 \%$ & $-1,61 \%$ & $-1,64 \%$ & $-30,00 \%$ & $-13,69 \%$ & $0,00 \%$ \\
\hline ACES4 & Am Inox BR PN & 1,76 & Medium & 490.347 .930 & Small & 0,26 & Loser & Small|Medium|Loser & $-14,71 \%$ & $-10,34 \%$ & $-17,31 \%$ & $11,63 \%$ & $41,67 \%$ & $1,47 \%$ & $-10,14 \%$ & $16,13 \%$ & $5,56 \%$ & $-1,32 \%$ & $-10,67 \%$ & $-5,97 \%$ \\
\hline
\end{tabular}


Anexo 1 - Retorno mensal e classificação das ações

\begin{tabular}{|c|c|c|c|c|c|c|c|c|c|c|c|c|c|c|c|c|c|c|c|c|}
\hline Código & $2001-2002$ & $\begin{array}{l}\text { Índice } B / M \\
\text { de dez/2000 }\end{array}$ & \begin{tabular}{|c} 
Grupo com \\
base no \\
indice $B / M$ \\
\end{tabular} & $\begin{array}{c}\text { Valor de Mercado } \\
\text { em jun/2001 }\end{array}$ & $\begin{array}{c}\text { Grupo com } \\
\text { base no } \\
\text { tamanho }\end{array}$ & \begin{tabular}{|c|} 
Retorno \\
acumulado \\
de jun/2001
\end{tabular} & \begin{tabular}{|c} 
Grupo com \\
base no \\
retorno \\
acumulado
\end{tabular} & Carteiras & jul/01 & ago/01 & set/01 & out/01 & nov/01 & dez/01 & $\mathrm{jan} / 02$ & fev/02 & $\mathrm{mar} / 02$ & $\mathrm{abr} / 02$ & mai/02 & jun/02 \\
\hline BIOB4 & Biobras PN & 1,29 & Medium & 35.196 .000 & Small & 0,17 & Loser & Small|Medium|Loser & $1,67 \%$ & $4,92 \%$ & $-7,11 \%$ & $34,48 \%$ & $-5,13 \%$ & $40,81 \%$ & $3,09 \%$ & $9,04 \%$ & $1,08 \%$ & $-0,18 \%$ & $-1,56 \%$ & $0,00 \%$ \\
\hline ACES3 & Am Inox BR ON & 1,76 & Medium & 490.347 .930 & Small & 0,14 & Loser & Small|Medium|Loser & $-9,68 \%$ & $-7,14 \%$ & $-17,31 \%$ & $18,60 \%$ & $21,57 \%$ & $-1,61 \%$ & $-9,84 \%$ & $16,36 \%$ & $7,81 \%$ & $-2,90 \%$ & $-13,43 \%$ & $-8,62 \%$ \\
\hline ESTR4 & Estrela PN & 1,18 & edium & 8.730 .180 & Small & 0,11 & Loser & Small|Medium|Loser & $-9,26 \%$ & $-20,41 \%$ & $-5,13 \%$ & $-2,70 \%$ & $5,67 \%$ & $11,67 \%$ & $-17,91 \%$ & $9,09 \%$ & $-16,67 \%$ & $-4,00 \%$ & $10,42 \%$ & $-15,09 \%$ \\
\hline TMAC8B & Amazonia Celular PND & 0,78 & Medium & 362.441 .632 & Small & 0,03 & \begin{tabular}{|l|} 
Loser \\
\end{tabular} & Small|Medium|Loser & $11,54 \%$ & $3,45 \%$ & $-23,33 \%$ & $-13,04 \%$ & $22,50 \%$ & $-22,45 \%$ & $-7,63 \%$ & $-14,25 \%$ & $6,31 \%$ & $-50,00 \%$ & $40,63 \%$ & $7,56 \%$ \\
\hline RAPT4 & Randon Part PN & 1,57 & Medium & 70.153 .163 & Small & 0,02 & Loser & Small|Medium|Loser & $8,89 \%$ & $-0,19 \%$ & $-4,26 \%$ & $-6,67 \%$ & $50,00 \%$ & $0,00 \%$ & $1,59 \%$ & $-3,12 \%$ & $11,29 \%$ & $-11,59 \%$ & $9,84 \%$ & $5,97 \%$ \\
\hline RIPI4 & Ipiranga Ref PN & 1,23 & Medium & 247.936 .894 & Small & 0,00 & Loser & Small|Medium|Loser & $29,14 \%$ & $-15,61 \%$ & $-16,13 \%$ & $3,08 \%$ & $4,48 \%$ & $6,56 \%$ & $3,50 \%$ & $6,90 \%$ & $6,45 \%$ & $-4,24 \%$ & $-1,90 \%$ & $-13,48 \%$ \\
\hline HGTX4 & Cia Hering PN & 1,22 & Medium & .212 .452 & Small & & Loser & Small|Medium|Loser & $36,36 \%$ & $-37,78 \%$ & $-7,14 \%$ & $-11,54 \%$ & $8,70 \%$ & $12,00 \%$ & $17,86 \%$ & $-15,15 \%$ & $-10,71 \%$ & $8,00 \%$ & $-14,81 \%$ & $13,04 \%$ \\
\hline RPAD3 & Alfa Hold & 1,73 & Medium & 7.264 .957 & Small & 0,02 & Loser & Small|Medium|Loser & $0,00 \%$ & $3,66 \%$ & $-18,42 \%$ & $-3,23 \%$ & $0,00 \%$ & $36,67 \%$ & $0,00 \%$ & $8,09 \%$ & $9,09 \%$ & $-4,17 \%$ & $8,70 \%$ & $6,00 \%$ \\
\hline POMO4 & Marcopolo PN & 1,05 & Medium & 243.460 .280 & Small & 0,04 & Loser & Small|Medium|Loser & $-0,36 \%$ & $3,27 \%$ & $-4,93 \%$ & $9,26 \%$ & $8,47 \%$ & $1,25 \%$ & $5,73 \%$ & $14,29 \%$ & $2,78 \%$ & $-2,70 \%$ & $-0,56 \%$ & $-3,63 \%$ \\
\hline FBRA4 & Fertibras PN & 1,21 & Medium & 61.481 .358 & Small & 0,05 & Loser & Small|Medium|Loser & $-28,21 \%$ & $-6,98 \%$ & $-12,50 \%$ & $2,86 \%$ & $3,06 \%$ & $15,90 \%$ & $13,95 \%$ & $8,16 \%$ & $13,21 \%$ & $0,00 \%$ & $-3,56 \%$ & $-1,82 \%$ \\
\hline PTQS4 & $\mathrm{Pe}$ & 59 & Medium & & Small & 0,05 & Loser & Small|Me & $4567,67 \%$ & $0,00 \%$ & $-4,82 \%$ & $-2,53 \%$ & $49,35 \%$ & $23,48 \%$ & $-2,11 \%$ & $22,30 \%$ & $8,13 \%$ & $36,84 \%$ & $-11,36 \%$ & $-4,26 \%$ \\
\hline FRAS4 & Fras-Le PN & 0,83 & Medium & 80.539 .721 & Small & 0,05 & Loser & Small|Medium|Loser & $-2,06 \%$ & $0,00 \%$ & $-9,09 \%$ & $-10,00 \%$ & $7,78 \%$ & $9,62 \%$ & $-0,98 \%$ & $1,98 \%$ & $14,56 \%$ & $-1,87 \%$ & $-1,74 \%$ & $5,31 \%$ \\
\hline TMAC6B & Amazonia Celular PNB & 0,78 & Medium & 362.441 .632 & Small & 0,06 & Loser & Small|Medium|Loser & $11,98 \%$ & $6,95 \%$ & $-22,50 \%$ & $-3,23 \%$ & $6,67 \%$ & $-20,83 \%$ & $-7,63 \%$ & $-12,82 \%$ & $4,58 \%$ & $-31,25 \%$ & $2,73 \%$ & $14,16 \%$ \\
\hline RPAD6 & Alfa Holding PNB & 1,73 & Medium & 7.264 .957 & Small & 0,07 & Loser & Small|Medium|Loser & $0,00 \%$ & $3,33 \%$ & $-14,89 \%$ & $-6,25 \%$ & $26,67 \%$ & $7,89 \%$ & $-2,44 \%$ & $5,87 \%$ & $18,57 \%$ & $-7,63 \%$ & $10,87 \%$ & $1,96 \%$ \\
\hline TPEC6B & & 33 & Medium & & Small & 0,08 & Loser & Small $\mid \mathrm{Me}$ & $7,07 \%$ & $-6,60 \%$ & $-3,45 \%$ & $-7,14 \%$ & $11,54 \%$ & $-7,59 \%$ & $0,93 \%$ & $-2,03 \%$ & $-9,06 \%$ & $6,02 \%$ & $-9,98 \%$ & $4,13 \%$ \\
\hline MSAN3 & Bun & & Medi & & $\mathrm{Sm}$ & 09 & Los & Small|Medium|Loser & $9,00 \%$ & $0,92 \%$ & $-9,09 \%$ & $16,00 \%$ & $4,31 \%$ & $21,49 \%$ & $-11,56 \%$ & $-2,31 \%$ & 13,39 & $-2,78 \%$ & $2 \%$ & $4,00 \%$ \\
\hline \begin{tabular}{|l|} 
OXIT4 \\
\end{tabular} & Oxiteno PN & 1,42 & Medium & 5008.395 & Small & 0,11 & \begin{tabular}{|l|} 
Loser \\
\end{tabular} & Small|Medium|Loser & $3,95 \%$ & $12,16 \%$ & $-8,05 \%$ & $5,72 \%$ & $15,15 \%$ & $22,11 \%$ & $-5,17 \%$ & $19,10 \%$ & $4,65 \%$ & $0,00 \%$ & $-7,70 \%$ & $-10,57 \%$ \\
\hline RPAD5 & Alfa Holding PNA & 73 & Medium & 264.957 & Small & 0,12 & Loser & Small|Medium|Loser & $0,00 \%$ & $3,66 \%$ & $-15,79 \%$ & $-6,25 \%$ & $16,67 \%$ & $14,29 \%$ & $2,50 \%$ & $12,72 \%$ & $9,55 \%$ & $-4,56 \%$ & $8,70 \%$ & $6,00 \%$ \\
\hline DPPI4 & & 78 & $\mathrm{M}$ & & Small & 0,13 & Loser & Small|Medium|Loser & $0,88 \%$ & $8,55 \%$ & & & $9,09 \%$ & & $-2,17 \%$ & $4,49 \%$ & $6,76 \%$ & $5,54 \%$ & $-13,17 \%$ & $-13,04 \%$ \\
\hline GUAR4 & & & $+a^{2}$ & & $\mathrm{Sm}$ & & Loser & Small|Me & $11,36 \%$ & $-16,33 \%$ & -0, & & & -2, & $-2,38 \%$ & 9,7 & $-2,22 \%$ & $0,36 \%$ & $0,00 \%$ & $-3,57 \%$ \\
\hline \begin{tabular}{|l|} 
MYPK4 \\
\end{tabular} & Iochp-Maxion PN & 1,85 & Medium & 942.420 & Small & 0,16 & \begin{tabular}{|l|} 
Loser \\
\end{tabular} & Small|Medium|Loser & $-2,82 \%$ & $4,93 \%$ & $-25,41 \%$ & $14,74 \%$ & $-8,01 \%$ & $5,26 \%$ & $13,30 \%$ & $-1,15 \%$ & $-0,09 \%$ & $-11,67 \%$ & $-16,98 \%$ & $-2,27 \%$ \\
\hline PNOR5 & Pronor PNA & 1,69 & Medium & & Small & 0,22 & Winner & Small|Medium|Winner & $-19,01 \%$ & $-5,22 \%$ & $-40,37 \%$ & $26,15 \%$ & $70,73 \%$ & $6,43 \%$ & $0,67 \%$ & $0,00 \%$ & $-6,67 \%$ & $-3,57 \%$ & $-4,44 \%$ & $-30,23 \%$ \\
\hline LEVE4 & Metal & 92 & Medium & & Small & 0,26 & Winner & Small|Medium|Winner & $3,08 \%$ & $4,48 \%$ & $-9,52 \%$ & $13,18 \%$ & $4,39 \%$ & $0,22 \%$ & $2,22 \%$ & $4,33 \%$ & $4,19 \%$ & $-7,18 \%$ & $2,38 \%$ & $1,16 \%$ \\
\hline MTSA4 & Metisa & 88 & Medium & .769 .607 & Sma & 0,30 & Winner & Small|Medium|Winner & $-8,33 \%$ & $2,97 \%$ & $-3,06 \%$ & $-1,34 \%$ & $23,08 \%$ & $5,50 \%$ & $-0,47 \%$ & $2,38 \%$ & $11,58 \%$ & $-2,08 \%$ & $5,07 \%$ & $-0,43 \%$ \\
\hline$\longdiv { I G B R 5 }$ & IGB S/A PNA & 10 & Medium & 807.500 & Small & 0,32 & Winner & Small|Medium|Winner & $-21,74 \%$ & $-28,89 \%$ & $-12,50 \%$ & $32,14 \%$ & $8,11 \%$ & $2,50 \%$ & $-12,20 \%$ & $13,89 \%$ & $-4,88 \%$ & $-5,05 \%$ & $-2,72 \%$ & $-10,00 \%$ \\
\hline ALPA4 & Alpargata & & Medium & & $\mathrm{Sm}$ & 0,33 & Winner & Small|Medium |Winner & $5,93 \%$ & $-6,81 \%$ & $-6,11 \%$ & $-3,25 \%$ & $-8,40 \%$ & $-0,92 \%$ & $1,85 \%$ & $7,27 \%$ & $-5,04 \%$ & $2,17 \%$ & $-8,22 \%$ & $1,99 \%$ \\
\hline DURA4 & Duratex-Old PN & 1,45 & Medium & \begin{tabular}{ll|l}
798.943 \\
\end{tabular} & Small & 0,33 & Winner & Small|Medium|Winner & $-7,93 \%$ & $7,44 \%$ & $-14,12 \%$ & $6,85 \%$ & $15,38 \%$ & $5,33 \%$ & $-1,92 \%$ & $8,82 \%$ & $7,52 \%$ & $0,56 \%$ & $-8,41 \%$ & $-10,41 \%$ \\
\hline TMAC3B & Amazonia Celular O & 0,78 & Medium & 362.441 .632 & Small & 0,39 & Winner & Small|Medium|Winner & $14,89 \%$ & $22,96 \%$ & $-27,71 \%$ & $-12,50 \%$ & $23,81 \%$ & $-26,92 \%$ & $-5,26 \%$ & $-22,22 \%$ & $14,29 \%$ & $-6,25 \%$ & $-11,67 \%$ & $-21.51 \%$ \\
\hline CYRE4 & come & t & Medi & & Sma & 0,40 & Winn & Small|Mes & $-5,00 \%$ & $-8,77 \%$ & $0,00 \%$ & $3,85 \%$ & $-20,37 \%$ & $-6,98 \%$ & $0,00 \%$ & $10,00 \%$ & 570 & 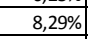 & $-0,90 \%$ & $11,36 \%$ \\
\hline UNIP6 & & & $\mathrm{Me}$ & & $\mathrm{Sn}$ & 2 & $w_{i}$ & $\mathrm{~m} / \mathrm{Wi}$ & $-5,81 \%$ & $2,47 \%$ & -12, & $13,70 \%$ & $20,48 \%$ & $5,92 \%$ & $6,86 \%$ & $5,50 \%$ & 6,09\% & $-9,75 \%$ & $-8,33 \%$ & $-10,10 \%$ \\
\hline TPEСЗВ & Tim No & 1,33 & Medium & \begin{tabular}{|l|l|}
199.283 .594 \\
\end{tabular} & Small & 0,44 & Winner & Small|Medium|Winner & $8,80 \%$ & $12,03 \%$ & $-18,52 \%$ & $-18,18 \%$ & $36,11 \%$ & $12,24 \%$ & $0,00 \%$ & $-16,36 \%$ & $8,70 \%$ & $-19,60 \%$ & $-0,50 \%$ & $0,00 \%$ \\
\hline MYPK3 & lochp-Maxion ON & 1,85 & Medium & 90.942 .420 & Small & 0,49 & Winner & Small|Medium /Winner & $-13,33 \%$ & $7,69 \%$ & $-17,86 \%$ & $-4,35 \%$ & $20,45 \%$ & $-7,55 \%$ & $6,12 \%$ & $7,69 \%$ & $25,00 \%$ & $-20,93 \%$ & $-20,00 \%$ & $0,00 \%$ \\
\hline ETER3 & & 117 & S $>2$ & & 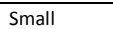 & & 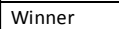 & Sma & $-3,299$ & 0,0 & -11 & $-2,7$ & & & & & & & & 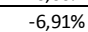 \\
\hline EKTR4 & & 9 & & & $\mathrm{Sn}$ & & & $\mathrm{Sm}$ & & & -12 & OU, & $-10,91 \%$ & $\%$ & $1,67 \%$ & $31,0,0$ & $-2,63 \%$ & 0,00\% & $-1,5,2,0$ & \\
\hline CPCA4 & Trikem PN & 1,19 & Medium & 304.343 .808 & Small & 0,78 & Winner & Small|Medium|Winner & $-8,00 \%$ & $20,65 \%$ & $-29,73 \%$ & $6,41 \%$ & $0,00 \%$ & $6,02 \%$ & $33,86 \%$ & $8,66 \%$ & $-6,25 \%$ & $16,67 \%$ & $-13,00 \%$ & $-21,18 \%$ \\
\hline LATS3 & Rexam Bcsa ON & 1,29 & Medium & 400.016 .382 & Small & 1,44 & Winner & Small|Medium|Winner & $1,19 \%$ & $21,18 \%$ & $22,82 \%$ & $-0,47 \%$ & $4,05 \%$ & $4,24 \%$ & $-0,62 \%$ & $1,80 \%$ & $-5,53 \%$ & $38,21 \%$ & $0,25 \%$ & $-3,09 \%$ \\
\hline
\end{tabular}


Anexo 1 - Retorno mensal e classificação das ações

\begin{tabular}{|c|c|c|c|c|c|c|c|c|c|c|c|c|c|c|c|c|c|c|c|c|}
\hline Código & $2002-2003$ & $\begin{array}{l}\text { Índice } B / M \\
\text { de dez/2001 }\end{array}$ & $\begin{array}{c}\text { Grupo com } \\
\text { base no } \\
\text { indice } B / M\end{array}$ & $\begin{array}{c}\text { Valor de Mercado } \\
\text { em jun/2002 }\end{array}$ & $\begin{array}{c}\text { Grupo com } \\
\text { base no } \\
\text { tamanho }\end{array}$ & $\begin{array}{c}\text { Retorno } \\
\text { acumulado } \\
\text { de jun/2002 }\end{array}$ & \begin{tabular}{|l|} 
Grupo com \\
base no \\
retorno \\
acumulado
\end{tabular} & Carteiras & $\mathrm{jul} / 02$ & ago/02 & set/02 & out/02 & nov/02 & dez/02 & $\mathrm{jan} / 03$ & $\mathrm{fev} / 03$ & mar/03 & $a b r / 03$ & mai/03 & jun/03 \\
\hline CESP3 & Cesp ON & 7,51 & High & 780.518.695 & Big & 0,24 & Loser & Big|High|Loser & $-15,26 \%$ & $5,60 \%$ & $-5,44 \%$ & $-6,82 \%$ & $3,25 \%$ & $1,57 \%$ & $0,78 \%$ & $-15,38 \%$ & $0,00 \%$ & $27,64 \%$ & 3,99\% & $-13,97 \%$ \\
\hline CESP5 & Cesp PNA & 7,51 & High & 780.518.695 & Big & 0,12 & Loser & Big|High|Loser & $-15,73 \%$ & $8,27 \%$ & $-24,88 \%$ & $7,54 \%$ & $5,95 \%$ & $2,73 \%$ & $-5,04 \%$ & $-11,65 \%$ & $-1,84 \%$ & $33,84 \%$ & $5,46 \%$ & $-16,87 \%$ \\
\hline SBSP3 & Sabesp ON & 2,13 & High & 2.842 .831 .459 & Big & 0,00 & Loser & Big|High|Loser & $-20,35 \%$ & $7,04 \%$ & $-8,39 \%$ & $12,61 \%$ & $-5,47 \%$ & $10,84 \%$ & $-6,61 \%$ & $-10,51 \%$ & $6,01 \%$ & $26,36 \%$ & $7,30 \%$ & $-2,04 \%$ \\
\hline BRKM5 & Braskem PNA & 2,75 & High & \begin{tabular}{|l|l|}
645.729 .119 \\
\end{tabular} & Big & 0,08 & Winner & Big|High/Winner & $-7,69 \%$ & $-12,50 \%$ & $-25,40 \%$ & $-5,53 \%$ & $-11,71 \%$ & $12,24 \%$ & $-16,36 \%$ & $-10,27 \%$ & $29,07 \%$ & $57,67 \%$ & $7,14 \%$ & $3,83 \%$ \\
\hline CSTB4 & Sid Tubarao PN & 3,23 & High & \begin{tabular}{|l|}
1.392 .235 .708 \\
\end{tabular} & Big & 0,18 & Winner & Big|High|Winner & $-1,69 \%$ & $-8,77 \%$ & $11,50 \%$ & $29,61 \%$ & $-2,71 \%$ & $12,68 \%$ & $-2,45 \%$ & $26,76 \%$ & $-7,25 \%$ & $10,34 \%$ & $-4,17 \%$ & $8,48 \%$ \\
\hline GEPA4 & Ger Paranap PN & 2,67 & High & 795.419 .714 & Big & 0,19 & Winner & Big|High|Winner & $-9,09 \%$ & $0,00 \%$ & $0,12 \%$ & $6,06 \%$ & $3,87 \%$ & $2,70 \%$ & $2,50 \%$ & $-0,73 \%$ & $-8,97 \%$ & $-1,35 \%$ & $1,23 \%$ & $-5,41 \%$ \\
\hline TRPL4 & Tran Paulist PN & 3,76 & High & \begin{tabular}{|l|l|}
844.582 .087 \\
\end{tabular} & Big & 0,20 & Winner & Big|High|Winner & $-11,25 \%$ & $3,65 \%$ & $-8,52 \%$ & $8,58 \%$ & $1,95 \%$ & $13,34 \%$ & $-4,63 \%$ & \begin{tabular}{l|l|}
$1,50 \%$ \\
\end{tabular} & $10,13 \%$ & $6,44 \%$ & $28,33 \%$ & $-12,27 \%$ \\
\hline ELET3 & Eletrobras ON & 3,80 & High & 15.563.497.599 & Big & 0,28 & Winner & Big|High/Winner & \begin{tabular}{|l|}
$-26,77 \%$ \\
\end{tabular} & $3,72 \%$ & $-32,96 \%$ & $35,18 \%$ & $-1,14 \%$ & $18,12 \%$ & $-17,80 \%$ & $-13,40 \%$ & $8,51 \%$ & $22,82 \%$ & $6,12 \%$ & $-14,71 \%$ \\
\hline TRPL3 & Tran Paulist ON & 3,76 & High & 844.582 .087 & Big & 0,28 & Winner & Big|High|Winner & $-1,33 \%$ & $3,84 \%$ & $1,96 \%$ & $7,01 \%$ & $3,34 \%$ & $17,17 \%$ & $-6,61 \%$ & $0,20 \%$ & $3,92 \%$ & $7,35 \%$ & $27,85 \%$ & $-10,45 \%$ \\
\hline USIM5 & Usiminas PNA & 2,69 & High & 1.405 .543 .963 & Big & 0,32 & Winner & Big|High|Winner & $-24,67 \%$ & $11,43 \%$ & $-22,43 \%$ & $19,73 \%$ & $14,42 \%$ & $7,36 \%$ & $12,80 \%$ & $2,30 \%$ & $21,00 \%$ & $17,03 \%$ & $1,59 \%$ & $20,75 \%$ \\
\hline ELET6 & Eletrobras PNB & 3,80 & High & 15.563 .497 .599 & Big & 0,42 & Winner & Big|High/Winner & $-22,76 \%$ & $5,31 \%$ & $-30,73 \%$ & $27,15 \%$ & $0,52 \%$ & $21,45 \%$ & $-13,27 \%$ & $-12,44 \%$ & $13,03 \%$ & $23,26 \%$ & $12,18 \%$ & $-12,26 \%$ \\
\hline ARCE4 & Arcelor BR PN & 2,19 & High & 1.581 .515 .040 & Big & 0,85 & Winner & Big|High|Winner & $5,31 \%$ & $10,48 \%$ & $5,95 \%$ & $9,93 \%$ & $4,67 \%$ & $6,47 \%$ & $10,83 \%$ & $5,82 \%$ & $-7,89 \%$ & $6,49 \%$ & $12,44 \%$ & $3,36 \%$ \\
\hline ARCE3 & Arcelor BR ON & 2,19 & High & 1.581 .515 .040 & Big & 0,91 & Winner & Big|High|Winner & $0,00 \%$ & $10,87 \%$ & $7,45 \%$ & $11,31 \%$ & $3,25 \%$ & $14,16 \%$ & $3,13 \%$ & $6,15 \%$ & $-7,89 \%$ & $2,86 \%$ & $9,72 \%$ & $5,82 \%$ \\
\hline $\begin{array}{ll}\text { VIVO4 } \\
\end{array}$ & Vivo PN & \begin{tabular}{ll|}
0,74 \\
\end{tabular} & Low & \begin{tabular}{|l|}
1.972 .037 .254 \\
\end{tabular} & Big & 0,64 & Loser & Big|Low/Loser & $-19,50 \%$ & $16,95 \%$ & $-31,20 \%$ & $35,00 \%$ & $1,85 \%$ & $10,39 \%$ & $-9,88 \%$ & $-11,23 \%$ & $25,88 \%$ & $4,21 \%$ & $6,28 \%$ & $-6,33 \%$ \\
\hline CRTP5 & Crt Celular PNA & 0,52 & Low & 1.127.100.837 & Big & 0,60 & Loser & Big|Low/Loser & $-1,95 \%$ & $-7,73 \%$ & $-11,63 \%$ & $1,55 \%$ & $-4,27 \%$ & $0,38 \%$ & $9,64 \%$ & $-10,85 \%$ & $9,72 \%$ & $8,84 \%$ & $-7,57 \%$ & $2,73 \%$ \\
\hline CRTP3 & Crt Celular ON & 0,52 & Low & 1.127.100.837 & Big & 0,60 & Loser & $\begin{array}{l}\text { Big|Low|Loser } \\
\end{array}$ & $1,52 \%$ & $-17,91 \%$ & $-5,45 \%$ & $-10,04 \%$ & $8,70 \%$ & $9,64 \%$ & $2,26 \%$ & $7,01 \%$ & $0,00 \%$ & $-3,45 \%$ & $-1,43 \%$ & $5,07 \%$ \\
\hline VIVO3 & Vivo ON & 0,74 & Low & 1.972 .037 .254 & Big & 0,59 & Loser & Big|Low|Loser & $-18,55 \%$ & $23,08 \%$ & $-35,00 \%$ & $32,31 \%$ & $-1,16 \%$ & $12,06 \%$ & $-4,20 \%$ & $-5,48 \%$ & $26,09 \%$ & $2,30 \%$ & $6,74 \%$ & $-11,16 \%$ \\
\hline CGAS5 & Comgas PNA & 0,76 & Low & 843.704 .723 & Big & 0,53 & Loser & Big|Low|Loser & $-17,74 \%$ & $19,61 \%$ & $-10,74 \%$ & $4,70 \%$ & $-3,72 \%$ & $-3,26 \%$ & $-7,97 \%$ & $-10,78 \%$ & $15,60 \%$ & $17,40 \%$ & $6,84 \%$ & $5,51 \%$ \\
\hline TMCP4 & Telemig Part P & 0,42 & Low & 1.316.443.652 & Big & 0,49 & Loser & Big/Low /Loser & $7,24 \%$ & $-9,32 \%$ & $-9,57 \%$ & $15,69 \%$ & $1,36 \%$ & $-0,33 \%$ & $-12,42 \%$ & $-0,77 \%$ & $13,67 \%$ & $-3,48 \%$ & $1,08 \%$ & $6,43 \%$ \\
\hline TDBH4 & Telefonica Dat & 0,42 & Low & 706.711 .485 & Big & 0,48 & Loser & Big|Low|Loser & $-9,86 \%$ & $-25,00 \%$ & $-29,17 \%$ & $23,53 \%$ & $-7,14 \%$ & $5,13 \%$ & $-2,44 \%$ & $-10,00 \%$ & $5,56 \%$ & $0,00 \%$ & $-2,63 \%$ & $-2,70 \%$ \\
\hline TDBH3 & Telefonica Data HId ON & 0,42 & Low & $\begin{array}{l}706.711 .485 \\
\end{array}$ & Big & 0,44 & \begin{tabular}{|l|l|} 
Loser \\
\end{tabular} & Big|Low|Loser & $-5,36 \%$ & $-15,09 \%$ & $-28,89 \%$ & $12,50 \%$ & $-2,78 \%$ & $0,00 \%$ & $0,00 \%$ & $-5,71 \%$ & $6,06 \%$ & $-2,86 \%$ & $-2,94 \%$ & $-3,03 \%$ \\
\hline TCSL4 & Tim Part S/A PN & 0,72 & Low & 1.018 .655 .052 & Big & 0,38 & Loser & Big|Low|Loser & $-2,52 \%$ & $-17,15 \%$ & $-2,73 \%$ & $14,86 \%$ & $-2,80 \%$ & $-1,44 \%$ & $-6,71 \%$ & $-13,15 \%$ & $9,85 \%$ & $6,78 \%$ & $4,37 \%$ & $-9,51 \%$ \\
\hline TNEP4 & Tele Nordeste Celul PN & 0,58 & Low & 929.285.288 & Big & 0,38 & Loser & Big|Low/Loser & $5,66 \%$ & $-10,71 \%$ & $-6,00 \%$ & $6,81 \%$ & $9,56 \%$ & $-1,45 \%$ & $-1,48 \%$ & $-14,61 \%$ & $8,61 \%$ & $2,09 \%$ & $4,10 \%$ & $-7,87 \%$ \\
\hline GLOB4 & Globex PN & 0,75 & Low & 6.015.583 & Big & 0,37 & Loser & Big|Low/Loser & $-26,83 \%$ & $-16,67 \%$ & $9,80 \%$ & $5,65 \%$ & $-5,17 \%$ & $23,64 \%$ & $-8,97 \%$ & $-15,19 \%$ & $23,62 \%$ & $11,70 \%$ & $2,86 \%$ & $5,56 \%$ \\
\hline TSEP4 & \begin{tabular}{|l|} 
Tele Sudeste Celula PN \\
\end{tabular} & 0,79 & Low & 2.482 .559 .604 & Big & 0,34 & \begin{tabular}{|l|l|} 
Loser \\
\end{tabular} & Big|Low|Loser & $1,54 \%$ & $0,00 \%$ & $-3,07 \%$ & $7,90 \%$ & $3,14 \%$ & $-2,43 \%$ & $-2,39 \%$ & $0,15 \%$ & $4,78 \%$ & $5,26 \%$ & $2,78 \%$ & $-4,05 \%$ \\
\hline EMBR4 & Embraer PN & 0,32 & Low & 10.393.675.641 & Big & 0,33 & Loser & Big|Low|Loser & $-1,47 \%$ & $-11,03 \%$ & $-0,41 \%$ & $10,00 \%$ & $-4,97 \%$ & $4,60 \%$ & $-10,79 \%$ & $-26,74 \%$ & $6,78 \%$ & $4,30 \%$ & $7,95 \%$ & $23,54 \%$ \\
\hline TSEP3 & Tele Sudeste Celula ON & 0,79 & Low & 2.482 .559 .604 & Big & 0,30 & Loser & Big|Low|Loser & $0,19 \%$ & $2,71 \%$ & $-3,03 \%$ & $9,31 \%$ & $-5,74 \%$ & $-0,15 \%$ & $0,00 \%$ & $-2,97 \%$ & $4,08 \%$ & $2,94 \%$ & $2,86 \%$ & $-4,63 \%$ \\
\hline TNEP3 & Tele Nordeste Celul ON & 0,58 & Low & 929.285 .288 & Big & 0,28 & Loser & Big|Low|Loser & $3,64 \%$ & $3,51 \%$ & $13,56 \%$ & $-31,64 \%$ & $6,99 \%$ & $2,04 \%$ & $-20,00 \%$ & $-17,00 \%$ & $51,05 \%$ & $-2,92 \%$ & $5,15 \%$ & $-4,08 \%$ \\
\hline TCOC4 & Tele Centroest & 0,44 & Low & 2.155 .513 .682 & Big & 0,27 & Loser & Big|Low|Loser & $-1,67 \%$ & $-16,75 \%$ & $-11,59 \%$ & $23,79 \%$ & $30,92 \%$ & $1,28 \%$ & $5,95 \%$ & $-12,07 \%$ & $25,58 \%$ & $1,85 \%$ & $6,91 \%$ & $-7,14 \%$ \\
\hline EMBR3 & Embraer ON & 0,32 & Low & $\begin{array}{r}10.393 .675 .641 \\
\end{array}$ & Big & 0,23 & Loser & Big|Low|Loser & $-1,15 \%$ & $-13,72 \%$ & $0,13 \%$ & $13,62 \%$ & \begin{tabular}{l|l}
$-7,04 \%$ \\
\end{tabular} & $4,73 \%$ & $-12,89 \%$ & $-30,13 \%$ & $6,29 \%$ & $2,05 \%$ & $6,04 \%$ & $17,76 \%$ \\
\hline AMBV3 & Ambev ON & 0,20 & Low & 15.893 .862 .117 & Big & 0,19 & Loser & Big|Low|Loser & $0,53 \%$ & $3,17 \%$ & $-1,54 \%$ & $23,25 \%$ & $2,88 \%$ & $-0,93 \%$ & $-6,07 \%$ & $-1,93 \%$ & $9,95 \%$ & $6,32 \%$ & $2,97 \%$ & $-3,84 \%$ \\
\hline TNLP4 & Telemar PN & 0,79 & Low & \begin{tabular}{|l|}
10.020 .142 .690 \\
\end{tabular} & Big & 0,17 & Loser & Big|Low|Loser & $-15,90 \%$ & $10,92 \%$ & $-19,09 \%$ & $17,93 \%$ & $6,39 \%$ & $1,87 \%$ & $3,98 \%$ & $-12,22 \%$ & $16,24 \%$ & $13,25 \%$ & $13,97 \%$ & $-6,92 \%$ \\
\hline TNLP3 & Telemar ON & 0,79 & Low & 10.020.142.690 & Big & 0,15 & Loser & Big|Low|Loser & $-21,28 \%$ & $10,00 \%$ & $-21,82 \%$ & $16,91 \%$ & $7,42 \%$ & $0,10 \%$ & $5,64 \%$ & $-13,79 \%$ & $17,06 \%$ & $13,52 \%$ & $13,32 \%$ & $-5,86 \%$ \\
\hline TMGC3 & Telemig Cl ON & 0,61 & Low & 832.842 .719 & Big & 0,14 & \begin{tabular}{|l|l|} 
Loser \\
\end{tabular} & Big|Low|Loser & $-1,43 \%$ & $-4,35 \%$ & $-6,06 \%$ & $6,45 \%$ & $0,00 \%$ & $7,79 \%$ & $19,32 \%$ & $-5,00 \%$ & $-1,29 \%$ & $-1,33 \%$ & $13,51 \%$ & $7,14 \%$ \\
\hline TMCP3 & Telemig Part ON & 0,42 & Low & 1.316 .443 .652 & Big & 0,12 & Loser & Big|Low|Loser & $\begin{array}{l}-21,82 \% \\
\end{array}$ & $16,28 \%$ & $-18,00 \%$ & $-2,44 \%$ & $2,75 \%$ & $-7,30 \%$ & $8,92 \%$ & $-12,05 \%$ & $16,78 \%$ & $5,01 \%$ & $-4,55 \%$ & $7,14 \%$ \\
\hline PCAR4 & P.Acucar-Cbd P & 0,61 & Low & 5.709 .759 .418 & Big & 0,11 & Loser & Big|Low|Loser & $-16,83 \%$ & $11,79 \%$ & $0,11 \%$ & $22,34 \%$ & $0,87 \%$ & $-6,03 \%$ & $-8,81 \%$ & $-10,87 \%$ & $-3,61 \%$ & $2,08 \%$ & $3,05 \%$ & $-1,10 \%$ \\
\hline PETR3 & Petrobras ON & 0,53 & Low & 55.800 .960 .910 & Big & 0,08 & Loser & Big|Low|Loser & \begin{tabular}{|l|}
$-15,09 \%$ \\
\end{tabular} & $7,33 \%$ & $-16,77 \%$ & $20,90 \%$ & $0,91 \%$ & $10,00 \%$ & $-1,89 \%$ & $-7,70 \%$ & $9,66 \%$ & $6,71 \%$ & $7,01 \%$ & $-4,14 \%$ \\
\hline AMBV4 & Ambev PN & 0,20 & Low & 893.862 .117 & Big & 0,07 & Loser & Big|Low|Loser & $-3,54 \%$ & $0,95 \%$ & $-1,53 \%$ & $28,16 \%$ & $3,19 \%$ & $-1,82 \%$ & $-6,48 \%$ & $1,23 \%$ & $11,95 \%$ & $3,74 \%$ & $1,72 \%$ & $-2,19 \%$ \\
\hline PETR4 & Petrobras PN & 0,53 & Low & 55.800 .960 .910 & Big & 0,03 & Loser & Big|Low/Loser & $-16,68 \%$ & $7,55 \%$ & $-16,14 \%$ & $20,05 \%$ & $2,72 \%$ & $4,39 \%$ & $2,39 \%$ & $-10,15 \%$ & $12,54 \%$ & $7,52 \%$ & $5,81 \%$ & $-3,58 \%$ \\
\hline TCOC3 & Tele Centroeste Cel ON & 0,44 & Low & 2.155.513.682 & Big & 0,11 & Winner & Big|Low|Winner & $-5,57 \%$ & $5,30 \%$ & $-8,47 \%$ & $-4,38 \%$ & $8,37 \%$ & $12,18 \%$ & $35,44 \%$ & $-4,03 \%$ & $10,08 \%$ & $10,69 \%$ & $-2,41 \%$ & $3,82 \%$ \\
\hline WEGE4 & Weg PN & 0,48 & Low & 1.275 .504 .562 & Big & 0,11 & \begin{tabular}{|l|l} 
Winner \\
\end{tabular} & Big|Low|Winner & $2,50 \%$ & $4,25 \%$ & $8,60 \%$ & $15,42 \%$ & $10,11 \%$ & $2,30 \%$ & $-5,45 \%$ & $\begin{array}{ll}6,83 \% \\
\end{array}$ & $-4,92 \%$ & $0,00 \%$ & $12,07 \%$ & $1,54 \%$ \\
\hline ITSA4 & Itausa PN & 0,69 & Low & 7.647 .479 .313 & Big & 0,21 & Winner & Big|Low|Winner & $-17,89 \%$ & $16,11 \%$ & $-19,92 \%$ & $31,47 \%$ & $-5,32 \%$ & $8,72 \%$ & $-1,60 \%$ & $-1,62 \%$ & $16,83 \%$ & $7,20 \%$ & $12,73 \%$ & $-9,06 \%$ \\
\hline VALE5 & Vale PNA & 0,58 & Low & 29.195 .142 .837 & Big & 0,22 & Winner & Big|Low|Winner & $4,11 \%$ & $-9,21 \%$ & $20,26 \%$ & $12,20 \%$ & $2,95 \%$ & $4,97 \%$ & $-5,85 \%$ & $6,64 \%$ & $-10,61 \%$ & $-9,86 \%$ & $7,30 \%$ & $-5,78 \%$ \\
\hline GET14 & AES Tiete PN & 0,46 & Low & 1.412 .729 .431 & Big & 0,25 & Winner & Big|Low|Winner & $0,00 \%$ & $-7,69 \%$ & $0,11 \%$ & $-4,10 \%$ & $2,33 \%$ & $4,55 \%$ & $0,00 \%$ & $0,00 \%$ & $0,09 \%$ & $4,26 \%$ & $0,00 \%$ & $0,00 \%$ \\
\hline ARCZ6 & Aracruz PNB & 0,67 & Low & 5.331.143.503 & Big & 0,26 & Winner & Big|Low|Winner & $11,60 \%$ & $-17,32 \%$ & $8,38 \%$ & $2,11 \%$ & $5,85 \%$ & $9,92 \%$ & $-0,30 \%$ & $4,01 \%$ & $-4,14 \%$ & $-8,93 \%$ & $-0,24 \%$ & $1,72 \%$ \\
\hline ITSA3 & Itausa ON & 0,69 & Low & \begin{tabular}{|l|}
7.647 .479 .313 \\
\end{tabular} & Big & 0,26 & Winne & $\mid$ Big| & $-4,19 \%$ & $3,74 \%$ & 0,12 & $0,00 \%$ & $0,00 \%$ & 1,59 & $0,00 \%$ & $3,33 \%$ & $-3,43 \%$ & 1,3 & $0,31 \%$ & $0,17 \%$ \\
\hline VALE3 & Vale ON & 0,58 & Low & 29.1 & Big & 0,37 & Win & BIg|LO & $6,82 \%$ & $-9,64 \%$ & $15,59 \%$ & $10,74 \%$ & $7,22 \%$ & $2,90 \%$ & $-5,93 \%$ & $7,44 \%$ & $-12,50 \%$ & $-8,19 \%$ & $6,12 \%$ & $-3,46 \%$ \\
\hline CMET4 & Caemi PN & 0,82 & Low & \begin{tabular}{|l|l}
1.705 .089 .954 \\
\end{tabular} & Big & 0,37 & Winner & Big|Low|Winner & $12,64 \%$ & $-14,49 \%$ & $16,71 \%$ & $8,38 \%$ & $1,89 \%$ & $-2,78 \%$ & $-3,90 \%$ & $-11,79 \%$ & $0,67 \%$ & \begin{tabular}{|l|}
$-11,61 \%$ \\
\end{tabular} & $10,61 \%$ & $11,14 \%$ \\
\hline ARCZ3 & Aracruz ON & 0,67 & Low & 5.331 .143 .503 & Big & 0,52 & Winner & Big|Low|Winner & $11,11 \%$ & $-4,00 \%$ & $-0,42 \%$ & $0,42 \%$ & $-2,08 \%$ & $-2,13 \%$ & $-0,22 \%$ & $1,74 \%$ & $4,93 \%$ & $-0,41 \%$ & $2,36 \%$ & $0,00 \%$ \\
\hline
\end{tabular}


Anexo 1 - Retorno mensal e classificação das ações

\begin{tabular}{|c|c|c|c|c|c|c|c|c|c|c|c|c|c|c|c|c|c|c|c|c|}
\hline Código & $2002-2003$ & $\begin{array}{l}\text { Índice } \mathrm{B} / \mathrm{M} \\
\text { de dez/2001 }\end{array}$ & \begin{tabular}{|c} 
Grupo com \\
base no \\
indice B/M
\end{tabular} & $\begin{array}{c}\text { Valor de Mercado } \\
\text { em jun/2002 }\end{array}$ & $\begin{array}{c}\text { Grupo com } \\
\text { base no } \\
\text { tamanho }\end{array}$ & $\begin{array}{c}\text { Retorno } \\
\text { acumulado } \\
\text { de jun/2002 }\end{array}$ & \begin{tabular}{|l|} 
Grupo com \\
base no \\
retorno \\
acumulado \\
\end{tabular} & Carteiras & $\mathrm{jul} / 02$ & ago/02 & set/02 & out $/ 02$ & nov/02 & dez/02 & $\mathrm{jan} / 03$ & fev/03 & $\mathrm{mar} / 03$ & $a b r / 03$ & mai/03 & jun/03 \\
\hline UGPA4 & Ultrapar PN & 0,81 & Low & 1.086 .085 .930 & Big & 0,53 & Winner & Big|Low|Winner & $-2,44 \%$ & $2,06 \%$ & $3,50 \%$ & $11,11 \%$ & $10,43 \%$ & $-1,97 \%$ & $-6,83 \%$ & $4,28 \%$ & $-1,49 \%$ & $1,94 \%$ & $-2,97 \%$ & $15,72 \%$ \\
\hline CRUZ3 & Souza Cruz ON & 0,29 & Low & 4.437 .212 .521 & Big & 0,61 & Winner & Big|Low|Winner & $-0,69 \%$ & $8,35 \%$ & $6,42 \%$ & $18,21 \%$ & $-1,08 \%$ & $-2,05 \%$ & $0,22 \%$ & $11,59 \%$ & $3,65 \%$ & $-4,40 \%$ & $13,30 \%$ & $15,40 \%$ \\
\hline GET13 & AES Tiete ON & 0,46 & Low & 1.412.729.431 & Big & 1,18 & Winner & Big|Low|Winner & $1,12 \%$ & $1,74 \%$ & $-4,38 \%$ & $-1,19 \%$ & $1,33 \%$ & $6,18 \%$ & $1,18 \%$ & \begin{tabular}{l|l}
$0,00 \%$ \\
\end{tabular} & $-1,16 \%$ & $5,88 \%$ & $0,00 \%$ & $-4,72 \%$ \\
\hline LATS3 & Rexam Bcsa ON & 0,81 & Low & 747.649 .691 & Big & 1,96 & Winner & Big|Low|Winner & $1,91 \%$ & $3,12 \%$ & $1,82 \%$ & $-1,79 \%$ & $59,19 \%$ & $-0,83 \%$ & $-19,03 \%$ & 0,00\% & $0,00 \%$ & $-0,76 \%$ & $21,92 \%$ & $-2,95 \%$ \\
\hline EBTP4 & Embratel Part PN & 1,56 & Medium & 638.213.217 & Big & 0,69 & Loser & Big|Medium / Loser & $8,97 \%$ & $81,65 \%$ & $-19,51 \%$ & $-2,16 \%$ & $30,53 \%$ & $26,78 \%$ & $-3,74 \%$ & $-3,89 \%$ & $-2,60 \%$ & $35,91 \%$ & $24,24 \%$ & $0,88 \%$ \\
\hline EBTP3 & Embratel Part ON & 1,56 & Medium & 638.213 .217 & Big & 0,57 & Loser & Big|Medium|Loser & $-2,96 \%$ & $40,84 \%$ & $-17,89 \%$ & $-10,23 \%$ & $31,25 \%$ & $17,09 \%$ & $2,63 \%$ & $-5,83 \%$ & $0,25 \%$ & $27,16 \%$ & $23,50 \%$ & $-1,42 \%$ \\
\hline CPSL3 & Copesul ON & 1,18 & Medium & 751.085.850 & Big & 0,29 & Loser & \begin{tabular}{|l|} 
Big|Medium|Loser \\
\end{tabular} & $-6,00 \%$ & $-2,13 \%$ & $-17,39 \%$ & $0,00 \%$ & 19,76\% & $-3,32 \%$ & $2,27 \%$ & $8,89 \%$ & $16,20 \%$ & $8,57 \%$ & $28,07 \%$ & $19,86 \%$ \\
\hline BRAP3 & Bradespar ON & 1,26 & Medium & \begin{tabular}{|c|}
760.006 .319 \\
\end{tabular} & Big & 0,27 & Loser & Big|Medium |Loser & $-6,52 \%$ & $2,33 \%$ & $-15,91 \%$ & $5,41 \%$ & $10,26 \%$ & $23,26 \%$ & $-3,77 \%$ & $11,76 \%$ & $-5,26 \%$ & $1,85 \%$ & $1,82 \%$ & $-5,36 \%$ \\
\hline BRAP4 & Bradespar PN & 1,26 & Medium & 760.006.319 & Big & 0,17 & Loser & Big|Medium|Loser & $-10,91 \%$ & $2,04 \%$ & $-12,00 \%$ & $9,09 \%$ ] & $4,17 \%$ & $16,00 \%$ & $5,17 \%$ & $8,20 \%$ ] & $-3,03 \%$ & $0,00 \%$ & 1,56\% & $-3,08 \%$ \\
\hline PTIP3 & Ipiranga Pet ON & 1,38 & Medium & 623.263 .569 & Big & 0,12 & \begin{tabular}{|l|l} 
Loser \\
\end{tabular} & Big|Medium/Loser & $-13,24 \%$ & $9,77 \%$ & $-10,00 \%$ & $-5,56 \%$ & $-4,82 \%$ & $-18,42 \%$ & $16,67 \%$ & $-3,77 \%$ & $1,21 \%$ & $6,67 \%$ & $12,50 \%$ & $-5,44 \%$ \\
\hline \begin{tabular}{|l|l|l|} 
PTIP4 \\
\end{tabular} & Ipiranga Pet PN & 1,38 & Medium & 623.263 .569 & Big & 0,08 & Loser & Big|Medium/Loser & $-8,06 \%$ & $5,96 \%$ & $-25,91 \%$ & $-5,92 \%$ & $-16,86 \%$ & $11,71 \%$ & $-7,67 \%$ & $-0,28 \%$ & $-2,22 \%$ & $23,01 \%$ & $-6,47 \%$ & $13,58 \%$ \\
\hline BRTO3 & Brasil Telec ON & 1,08 & Medium & 5.605.422.683 & Big & 0,04 & Loser & Big|Medium/Loser & $-7,45 \%$ & $9,20 \%$ & $4,53 \%$ & $25,26 \%$ & $-6,28 \%$ & $0,79 \%$ & $-7,52 \%$ & $0,86 \%$ & $4,47 \%$ & $19,60 \%$ & $0,79 \%$ & $-3,54 \%$ \\
\hline ELPL5 & Eletropaulo PNA & 0,91 & Medium & 1.838.690.924 & Big & 0,03 & Loser & Big|Medium|Loser & $-40,36 \%$ & $46,89 \%$ & $-40,39 \%$ & $11,11 \%$ & $-8,67 \%$ & $11,64 \%$ & $9,62 \%$ & $-18,25 \%$ & $-6,01 \%$ & $33,79 \%$ & $-12,94 \%$ & $-5,88 \%$ \\
\hline BRTP3 & Brasil T Par ON & 0,96 & Medium & 5.468 .845 .860 & Big & 0,03 & \begin{tabular}{|l|l|} 
Loser \\
\end{tabular} & Big|Medium|Loser & $-15,28 \%$ & $7,56 \%$ & $-6,37 \%$ & $20,72 \%$ & $-5,79 \%$ & $-4,26 \%$ & $-3,62 \%$ & $6,15 \%$ & $5,76 \%$ & $8,32 \%$ ] & $5,71 \%$, & $-3,70 \%$ \\
\hline BRTP4 & Brasil T Par PN & 0,96 & Medium & 5.468 .845 .860 & Big & 0,01 & Loser & Big|Medium/Loser & $2,84 \%$ & $8,28 \%$ & $-4,65 \%$ & $22,70 \%$ & $-10,44 \%$ & $-0,89 \%$ & $-2,20 \%$ & $-0,03 \%$ & $6,59 \%$ & $11,10 \%$ & $7,07 \%$ & $-3,42 \%$ \\
\hline BRTO4 & Brasil Telec PN & 1,08 & Medium & 5.605 .422 .683 & Big & 0,04 & Loser & Big|Medium|Loser & $-3,54 \%$ & $8,26 \%$ & $-6,29 \%$ & $16,96 \%$ & $-7,82 \%$ & $1,89 \%$ & $-8,86 \%$ & $2,18 \%$ & $0,94 \%$ & $20,14 \%$ & $1,97 \%$ & $-0,77 \%$ \\
\hline COCE5 & Coelce PNA & 1,68 & Medium & 545.921 .809 & Big & 0,04 & Loser & Big|Medium|Loser & $-14,29 \%$ & $-5,33 \%$ & $-19,37 \%$ & $13,54 \%$ & $5,38 \%$ & $9,49 \%$ & $-1,67 \%$ & $-3,39 \%$ & $14,39 \%$ & $3,13 \%$ & $2,76 \%$ & $-2,01 \%$ \\
\hline CSPC4 & Cosipa PN & 0,89 & Medium & 1.255.497.217 & Big & 0,05 & Loser & m|loser & $-6,25 \%$ & $0,00 \%$ & $-20,00 \%$ & $12,50 \%$ ] & $7,41 \%$ & $13,79 \%$ & $3,03 \%$ & $-8,82 \%$ & $12,90 \%$ & $11,43 \%$ & $5,13 \%$ ] & $-4,88 \%$ \\
\hline TMAR3 & Telemar N LC & 0,83 & Medium & 10.579.101.042 & Big & 0,05 & Winner & Big|Medium/Winner & $-8,33 \%$ & $1,52 \%$ & $-1,49 \%$ & $-3,03 \%$ & $3,16 \%$ & $22,66 \%$ & $-3,11 \%$ & $-10,42 \%$ & $2,33 \%$ & $9,09 \%$ & $10,83 \%$ & $-6,02 \%$ \\
\hline CPLE3 & Copel ON & 1,13 & Medium & $\begin{array}{l}3.131 .713 .412 \\
\end{array}$ & Big & 0,06 & Winner & Big|Medium/Winner & $-12,25 \%$ & $5,32 \%$ & $-32,32 \%$ & $2,11 \%$ & $-8,28 \%$ & $20,30 \%$ & $-11,88 \%$ & $-15,60 \%$ & $2,52 \%$ & $12,13 \%$ & $3,22 \%$ & $-8,78 \%$ \\
\hline CPLE6 & Copel PNB & 1,13 & Medium & 3.131.713.412 & Big & 0,08 & Winner & | Big|Medium/Winner & $-9,09 \%$ & $2,76 \%$ & $-33,73 \%$ & $18,32 \%$ & $-7,92 \%$ & $28,37 \%$ | & $-13,90 \%$ & $-8,25 \%$ & $4,56 \%$ & $15,62 \%$ & $3,14 \%$ & $-16,14 \%$ \\
\hline TBLE6 & Tracte & 1,22 & Medium & 2.496 & Big & 0,12 & Winner & Big|Medium/Winner & $0,63 \%$ & $-11,49 \%$ & $-8,77 \%$ & $-3,85 \%$ & $-2,00 \%$ & $3,67 \%$ & $-6,30 \%$ & $-16,81 \%$ | & $15,15 \%$ & $27,93 \%$ ] & $15,38 \%$ ] & $33,33 \%$ \\
\hline TMAR6 & Telemar N L PNB & 0,83 & Medium & 10.579.101.042 & Big & 0,14 & Winner & Big $\mid$ Medium /Winner & $-10,48 \%$ & $9,04 \%$ & $-18,29 \%$ & $13,67 \%$ & $0,05 \%$ & $-0,26 \%$ & $3,85 \%$ & $-11,81 \%$ | & $7,40 \%$ & $6,98 \%$ & $6,91 \%$ & $-2,56 \%$ \\
\hline CSPC3 & Cosipa ON & 0,89 & Medium & 1.255.497.217 & Big & 0,17 & Winner & Big|Medium|Winner & $-16,67 \%$ & $0,00 \%$ & $-12,00 \%$ & $13,64 \%$ & $0,00 \%$ & $0,00 \%$ & $12,00 \%$ & $-3,57 \%$ & $3,70 \%$ & $3,57 \%$ & $6,90 \%$ & $-6,45 \%$ \\
\hline SDIA4 & Sadia S/A PN & 1,25 & Medium & 875.208 .660 & Big & 0,22 & \begin{tabular}{|l} 
Winner \\
\end{tabular} & Big|Medium/Winner & $0,92 \%$ & $-2,07 \%$ & $3,77 \%$ & $4,55 \%$ & $0,00 \%$ & $18,26 \%$ & $-6,64 \%$ & $4,63 \%$ & $-6,50 \%$ & \begin{tabular}{l|l}
$9,57 \%$ \\
\end{tabular} & $8,73 \%$ & $8,76 \%$ \\
\hline CSNA3 & $\operatorname{sid} N$ & 97 & Medi & & Big & 0,26 & Winner & eer & -5, & $-4,71 \%$ & -24 & $22,88 \%$ & $28,72 \%$ & $5,68 \%$ & $12,90 \%$ & \begin{tabular}{l|l|}
$7,36 \%$ \\
\end{tabular} & & $6,03 \%$ & $-0,87 \%$ & $22,73 \%$ \\
\hline MSAN3 & Bunge $B$ & 1,94 & Medium & 1.103.958.321 & Big & 0,27 & Winner & Im|Winner & $5,38 \%$ & $-5,11 \%$ & $0,00 \%$ & $15,38 \%$ & $-3,33 \%$ & $2,76 \%$ ] & $20,81 \%$ & $-5,56 \%$ & $8,82 \%$ & $40,54 \%[$ & $7,69 \%$ ] & $3,57 \%$ \\
\hline SAPR4 & Sanepar PN & 1,28 & Medium & 786.291 .714 & Big & 0,32 & Winner & Big|Medium/Winner & $-7,84 \%$ & $0,00 \%$ & $-2,86 \%$ & $-8,82 \%$ & $0,00 \%$ & $3,23 \%$ & $-5,15 \%$ & $-8,97 \%$ & $0,76 \%$ & $12,78 \%$ & $6,00 \%$ & $-0,63 \%$ \\
\hline TBLE3 & Tractebel ON & 1,22 & Medium & 2.422 .892 .496 & Big & 0,32 & Winner & Big|Medium/Winner & $10,97 \%$ & $-8,97 \%$ & $-1,52 \%$ & $-10,26 \%$ & $-4,57 \%$ & $4,79 \%$ & $2,57 \%$ & $-13,65 \%$ ] & $38,71 \%$ & $36,64 \%$ ] & $-6,18 \%$ & $39,53 \%$ \\
\hline MSAN4 & Bunge & 1,94 & Medium & 88.321 & Big & 0,32 & Winner & Big|Medium/Winner & $-4,70 \%$ & $-8,45 \%$ & $8,46 \%$ & $9,93 \%$ & $-4,52 \%$ & $8,11 \%$ & $11,25 \%$ & $-2,81 \%$ & $4,05 \%$ & $44,44 \%$ & $11,54 \%$ & $4,14 \%$ \\
\hline PRGA4 & BRF Fo & 1,01 & Medium & 648.660 .013 & Big & 32 & Winner & Big|Medium/Winner & $-13,89 \%$ & $-2,02 \%$ & $-9,47 \%$ & $7,27 \%$ & $0,00 \%$ & $3,39 \%$ & $-12,46 \%$ & $-8,24 \%$ & , 18\% & $8,22 \%$ & $13,99 \%$ & $-9,47 \%$ \\
\hline SUZB5 & Suzano Papel PNA & 1,05 & Medium & 1.305 .044 .621 & Big & 0,35 & Winner & Big|Medium/Winner & $-3,39 \%$ & $-3,33 \%$ & $-2,00 \%$ & $-10,00 \%$ & $-5,56 \%$ & $13,29 \%$ & $11,54 \%$ & \begin{tabular}{l|l}
$0,86 \%$ \\
\end{tabular} & $9,40 \%$ & $-9,53 \%$ & $24,08 \%$ & $6,57 \%$ \\
\hline CTNM4 & Coteminas PN & 1,46 & Medium & 966.984.443 & Big & 0,41 & Winner & Big|Medium/Winner & $-1,02 \%$ & $1,54 \%$ & $24,87 \%$ & $16,28 \%$ & $-9,51 \%$ & $17,27 \%$ & $-6,98 \%$ & $-9,58 \%$ & $0,46 \%$ & $-9,72 \%$ & $4,31 \%$ & $-2,46 \%$ \\
\hline CMIG3 & Cemig & 1,34 & Medium & 8.278 & Big & 0,44 & Winner & Big|Medium/Winner & $-13,09 \%$ & $-4,98 \%$ & $-20,73 \%$ & $14,67 \%$ & $-3,40 \%$ & $11,73 \%$ & $-7,23 \%$ & $-11,28 \%$ & $-0,36 \%$ & $17,80 \%$ & $6,43 \%$ & $-12,67 \%$ \\
\hline KLBN4 & Klabin S/A PN & 1,50 & Medium & 1.975 .660 & Big & 0,47 & Winner & Big|Medium/Winner & $-6,25 \%$ & $5,56 \%$ & $-10,53 \%$ & $4,71 \%$ | & $13,48 \%$ | & $1,98 \%$ ] & $2,91 \%$ & $36,79 \%$ ] & $26,21 \%$ & $10,38 \%$ & $28,71 \%[$ & $13,46 \%$ \\
\hline BSUL5 & Bahias & 91 & Medium & 1.519 & Big & 0,49 & Winner & um /Winner & $0,55 \%$ & $1,26 \%$ & $-5,35 \%$ & $5,66 \%$ & $-10,71 \%$ & $12,40 \%$ & $10,50 \%$ & $4,67 \%$ [ & $16,92 \%$ & $-3,93 \%$ & $4,56 \%$ [ & $10,49 \%$ \\
\hline FFTL4 & Valefert PN & 5 & Medium & .521 .235 & Big & 0,49 & Winner & Big|Medium/Winner & $9,33 \%$ & $4,11 \%$ & $6,66 \%$ & $5,20 \%$ & $12,09 \%$ & $10,91 \%$ & $-3,09 \%$ & $14,68 \%$ & $3,43 \%$ & $3,95 \%$ & $3,54 \%$ & $23,04 \%$ \\
\hline PALF7 & Paul F Luz PNC & 1,38 & Medium & 2.699.986.467 & Big & 0,53 & Winner & Big|Medium|Winner & $2,60 \%$ & $-1,18 \%$ & $-0,81 \%$ & $-2,81 \%$ & $2,89 \%$ & $-4,49 \%$ & $-3,53 \%$ & $0,00 \%$ & $0,00 \%$ & $0,61 \%$ & $-0,61 \%$ & $0,00 \%$ \\
\hline VCPA4 & Fibria PN & 0,85 & Medium & 551.464 .340 & Big & 0,55 & Winner & Big|Medium/Winner & $0,48 \%$ & $-5,76 \%$ & $\begin{array}{ll}9,17 \% \\
\end{array}$ & $6,36 \%$ & $4,57 \%$ & $0,84 \%$ & $1,75 \%$ & \begin{tabular}{ll|}
$10,88 \%$ \\
\end{tabular} & $-6,20 \%$ & $-10,25 \%$ & $-0,37 \%$ & $-0,47 \%$ \\
\hline PALF3 & Paul F Luz On & 1,38 & Mediu & 6.467 & Big & 0,62 & Winne & Fvertict & $-7,14 \%$ & $3,57 \%$ & $3,25 \%$ & $-13,68 \%$ & $0,00 \%$ & $-8,30 \%$ & $10,87 \%$ & $-18,03 \%$ & $0,00 \%$ & $0,10 \%$ & $9,09 \%$ & $\%$ \\
\hline CMIG4 & Cemig F & 34 & Mediu & 278 & Big & 65 & Winner & Big|Medium/Winner & $-17,19 \%$ & $5,28 \%$ & $-25,59 \%$ & $18,98 \%$ & $-2,83 \%$ & $12,92 \%$ & $-5,29 \%$ & $-9,38 \%$ & $11,28 \%$ & $21,93 \%$ & $-1,79 \%$ & $-12,89 \%$ \\
\hline GGBR3 & Gerdau ON & 1,22 & Medium & 3.093.547.273 & Big & 0,80 & Winner & Big|Medium/Winner & $1,65 \%$ & $1,21 \%$ & $-4,00 \%$ & $-1,04 \%$ & $-2,74 \%$ & $15,15 \%$ & $2,12 \%$ & $1,96 \%$ & $3,81 \%$ & $9,72 \%$ & $5,71 \%$ & $6,38 \%$ \\
\hline EBCO4 & Embraco PN & 1,03 & Medium & 622.172 .168 & Big & 0,94 & Winner & Big|Medium/Winner & $1,05 \%$ & $25,00 \%$ & $25,00 \%$ & $3,33 \%$ & $18,71 \%$ & $8,97 \%$ & $-11,39 \%$ & $-1,76 \%$ & $-17,37 \%$ & $3,62 \%$ & $-0,70 \%$ & $-3,52 \%$ \\
\hline GGBR4 & Gerdau P & 1,22 & Medium & 3.093.547.273 & Big & 1,14 & Winner & um /Winner & $1,75 \%$ & $12,89 \%$ ] & $-22,07 \%$ & $32,77 \%$ & $-3,21 \%$ & $4,86 \%$ ] & $-3,56 \%$ & 4,83\% & $-7,07 \%$ & $17,93 \%[$ & $10,49 \%$ _ & $8,68 \%$ \\
\hline GOAU4 & Gerda & & $M$ & & Big & 1,15 & & B & $7,73 \%$ & $8,67 \%$ & $-13,80 \%$ & $16,73 \%$ & $-2,64 \%$ & $24,01 \%$ & $-3,86 \%$ & $1,34 \%$ & $1,32 \%$ & $27,57 \%$ & $0,90 \%$ & $3,04 \%$ \\
\hline PTQS4 & Petroquisa PN & 0,89 & Medium & 3.564 .122 .722 & Big & 151,27 & Winner & Big|Medium/Winner & $-5,56 \%$ & $-2,35 \%$ & $-9,64 \%$ & $35,38 \%$ & $-23,70 \%$ & $1,94 \%$ & $0,00 \%$ & $-2,86 \%$ & $0,67 \%$ & $-10,00 \%$ & $11,11 \%$ & $15,50 \%$ \\
\hline BOBR4 & Bombril PN & 3,12 & High & 298.465 .869 & Smal & 0,54 & Loser & Small|High|Loser & $-7,95 \%$ & $7,91 \%$ & $0,13 \%$ & $31,82 \%$ & $3,84 \%$ & $-7,39 \%$ & $-13,29 \%$ & $-19,71 \%$ & $-7,27 \%$ & $2,94 \%$ & $3,62 \%$ & $-4,41 \%$ \\
\hline IENG5 & ner & 4,09 & High & 99.710 & ima & 0,50 & oser & Loser & $21,05 \%$ & $40,00 \%$ & $-19,05 \%$ & $0,00 \%$ & $-23,53 \%$ & $7,69 \%$ ] & $57,14 \%$ & $-36,36 \%[$ & $0,00 \%$ & $14,29 \%$ ] & $-6,25 \%[$ & $-6,67 \%$ \\
\hline \begin{tabular}{ll|l} 
LPR3 \\
\end{tabular} & Eletropar ON & 2,09 & High & 15.066.728 & Small & 0,40 & \begin{tabular}{|l|l|} 
Loser \\
\end{tabular} & Small|High|Loser & $-10,34 \%$ & $-2,31 \%$ & $-4,72 \%$ & $14,88 \%$ | & $-3,60 \%$ & $-9,70 \%$ & $4,96 \%$ & 3,15\% & $0,76 \%$ & $-9,09 \%$ & $0,00 \%$ & $-13,33 \%$ \\
\hline
\end{tabular}


Anexo 1 - Retorno mensal e classificação das ações

\begin{tabular}{|c|c|c|c|c|c|c|c|c|c|c|c|c|c|c|c|c|c|c|c|c|}
\hline Código & $2002-2003$ & $\begin{array}{l}\text { Índice } B / M \\
\text { de dez/2001 }\end{array}$ & $\begin{array}{c}\text { Grupo com } \\
\text { base no } \\
\text { indice } B / M\end{array}$ & $\begin{array}{c}\text { Valor de Mercado } \\
\text { em jun/2002 }\end{array}$ & $\begin{array}{c}\text { Grupo com } \\
\text { base no } \\
\text { tamanho }\end{array}$ & $\begin{array}{c}\text { Retorno } \\
\text { acumulado } \\
\text { de jun/2002 }\end{array}$ & $\begin{array}{l}\text { Grupo com } \\
\text { base no } \\
\text { retorno } \\
\text { acumulado }\end{array}$ & Carteiras & $\mathrm{jul} / 02$ & ago/02 & set/02 & out $/ 02$ & nov/02 & $\mathrm{dez} / 02$ & jan/03 & $\mathrm{fev} / 03$ & $\mathrm{mar} / 03$ & $\mathrm{abr} / 03$ & $\mathrm{mai} / 03$ & jun/03 \\
\hline IGBR5 & IGB S/A PNA & 3,60 & High & 47.272 .500 & Small & 0,38 & Loser & Small|High|Loser & $54,22 \%$ & $-30,84 \%$ & $-6,25 \%$ & $20,00 \%$ & $29,63 \%$ & $11,43 \%$ & $-3,85 \%$ & $-9,33 \%$ & $-11,76 \%$ & $6,67 \%$ & $-14,06 \%$ & $-9,09 \%$ \\
\hline MEND5 & Mendes Jr PNA & 5,90 & High & \begin{tabular}{|l|}
97.029 .551 \\
\end{tabular} & Small & 0,38 & Loser & Small|High|Loser & $-14,29 \%$ & $50,00 \%$ & $11,11 \%$ & $37,50 \%$ & $-9,09 \%$ & $57,00 \%$ & $-36,31 \%$ & $9,80 \%$ & $-14,19 \%$ & $6,13 \%$ & $8,96 \%$ & $-26,58 \%$ \\
\hline INEP4 & Inepar PN & 2,86 & High & \begin{tabular}{|l|l|}
28.090 .947 \\
\end{tabular} & Small & 0,37 & Loser & Small|High|Loser & $-22,45 \%$ & $81,58 \%$ & $-11,59 \%$ & $-3,28 \%$ & \begin{tabular}{|l|l|}
$5,08 \%$ \\
\end{tabular} & $-12,90 \%$ & $0,00 \%$ & $-14,81 \%$ & $-10,87 \%$ & $21,95 \%$ & $-4,00 \%$ & $-18,75 \%$ \\
\hline MEND6 & Mendes Jr PNB & 5,90 & High & \begin{tabular}{|l|l|}
97.029 .551 \\
\end{tabular} & Small & 0,35 & Loser & Small|High|Loser & $-14,25 \%$ & $58,27 \%$ & $23,42 \%$ & $19,40 \%$ & 3,39\% & $31,26 \%$ & $-27,63 \%$ & $-0,18 \%$ & $-16,21 \%$ & $6,52 \%$ & $-4,08 \%$ & $-19,15 \%$ \\
\hline TELB3 & Telebras ON & 6,03 & High & \begin{tabular}{l|l|}
12.492 .275 \\
\end{tabular} & Small & 0,33 & Loser & Small|High|Loser & $-66,67 \%$ & $0,00 \%$ & $0,00 \%$ & $0,00 \%$ & \begin{tabular}{l|l|l}
$0,00 \%$ & \\
\end{tabular} & $0,00 \%$ & $0,00 \%$ & $0,00 \%$ & $100,00 \%$ & $-50,00 \%$ & $200,00 \%$ & $-33,33 \%$ \\
\hline TELB4 & Telebras PN & 6,03 & High & \begin{tabular}{|l|l|}
12.492 .275 \\
\end{tabular} & Small & 0,33 & Loser & Small|High|Loser & $100,00 \%$ & $0,00 \%$ & $-50,00 \%$ & $0,00 \%$ & $0,00 \%$ & $100,00 \%$ & $-50,00 \%$ & $0,00 \%$ & $100,00 \%$ & $-50,00 \%$ & $200,00 \%$ & $-33,33 \%$ \\
\hline PLAS4 & Plascar Part PN & 2,17 & High & \begin{tabular}{|l|l|}
11.597 .338 \\
\end{tabular} & Small & 0,27 & Loser & Small|High|Loser & $-9,09 \%$ & $18,00 \%$ & $-23,73 \%$ & $0,00 \%$ & \begin{tabular}{|l|}
$-1,11 \%$ \\
\end{tabular} & $-32,58 \%$ & $25,00 \%$ & $-32,00 \%$ & $49,02 \%$ & $-22,37 \%$ & $-20,34 \%$ & $-14,89 \%$ \\
\hline PTBL3 & Portobello ON & 2,55 & High & 26.900 .460 & Small & 0,22 & Loser & Small|High|Loser & $-25,00 \%$ & $26,67 \%$ & $15,79 \%$ & $27,27 \%$ & $-28,57 \%$ & $0,00 \%$ & $50,00 \%$ & $0,00 \%$ & $-6,67 \%$ & $-3,57 \%$ & $48,15 \%$ & $-22,50 \%$ \\
\hline SULT4 & Sultepa PN & 17,62 & High & 8.969 .800 & Small & 0,20 & Loser & Small|High|Loser & $-18,57 \%$ & $8,77 \%$ & $-11,88 \%$ & $4,00 \%$ & $-5,77 \%$ & $-10,20 \%$ & $-15,91 \%$ & $-16,22 \%$ & $-3,23 \%$ & $20,00 \%$ & $-2,78 \%$ & $-2,86 \%$ \\
\hline MYPK4 & Iochp-Maxion PN & 2,39 & High & 56.531.654 & Small & 0,20 & Loser & Small|High|Loser & $\begin{array}{l}0,47 \% \\
\end{array}$ & $11,57 \%$ & $-12,86 \%$ & $-2,38 \%$ & $12,20 \%$ & $8,70 \%$ & $2,00 \%$ & $-1,96 \%$ & \begin{tabular}{l|l|}
$-5,96 \%$ \\
\end{tabular} & $2,51 \%$ & $5,81 \%$ & $5,88 \%$ \\
\hline EMAE4 & Emae PN & 2,38 & High & 258.260 .108 & Small & 0,20 & Loser & Small|High|Loser & $-15,59 \%$ & $-2,20 \%$ & $9,01 \%$ & $-7,79 \%$ & \begin{tabular}{|l|}
$-1,90 \%$ \\
\end{tabular} & $5,27 \%$ & $-4,84 \%$ & $-27,89 \%$ & \begin{tabular}{l|l|}
$7,06 \%$ \\
\end{tabular} & $9,09 \%$ & $3,54 \%$ & $-10,06 \%$ \\
\hline ESCE3 & Escelsa ON & 2,01 & High & \begin{tabular}{|l|}
331.710 .215 \\
\end{tabular} & Small & 0,19 & Loser & Small|High|Loser & $-1,92 \%$ & $-5,32 \%$ & $-5,45 \%$ & $-45,39 \%$ & $31,62 \%$ & $-13,04 \%$ & 9,95\% & $-9,05 \%$ & $0,00 \%$ & $12,20 \%$ & $-13,21 \%$ & $-15,28 \%$ \\
\hline FLCL5 & F Cataguazes PNA & 2,05 & High & 138.393 .625 & Small & 0,11 & Loser & Small|High|Loser & $-4,35 \%$ & $-5,45 \%$ & $-1,92 \%$ & $11,76 \%$ & $\begin{array}{l}7,89 \% \\
\end{array}$ & $-2,44 \%$ & $2,50 \%$ & $-8,94 \%$ & $-1,79 \%$ & $3,64 \%$ & $-0,88 \%$ & $-0,88 \%$ \\
\hline PNOR5 & Pronor PNA & 3,60 & High & 41.360 .940 & Small & 0,09 & Loser & Small|High|Loser & $0,00 \%$ & $-11,11 \%$ & $11,25 \%$ & $0,00 \%$ & $-26,97 \%$ & $3,08 \%$ & $-13,43 \%$ & $-31,03 \%$ & $50,00 \%$ & $16,67 \%$ & $17,14 \%$ & $-20,73 \%$ \\
\hline GUAR4 & Guararapes PN & 2,08 & High & 252.720 .012 & Small & 0,08 & Loser & Small|High|Loser & $0,99 \%$ & $6,60 \%$ & $1,83 \%$ & $26,13 \%$ & \begin{tabular}{l|l|l}
$6,07 \%$ \\
\end{tabular} & $17,68 \%$ & $6,58 \%$ & $-5,37 \%$ & $-0,71 \%$ & $-1,48 \%$ & $6,22 \%$ & $0,00 \%$ \\
\hline BDLL4 & Bardella PN & 2,83 & High & 79.840 .002 & Small & 0,07 & Loser & Small|High|Loser & $-5,81 \%$ & $-4,26 \%$ & $0,00 \%$ & $10,89 \%$ & $6,21 \%$ & $-3,92 \%$ & $2,25 \%$ & $-6,65 \%$ & $5,95 \%$ & $1,10 \%$ & $-2,40 \%$ & $0,20 \%$ \\
\hline CEBR5 & Ceb PNA & 3,79 & High & \begin{tabular}{|l|l|l|l}
112.487 .755 \\
\end{tabular} & Small & 0,07 & Loser & Small|High|Loser & $-15,38 \%$ & $-1,82 \%$ & $-25,56 \%$ & $2,54 \%$ & $-0,53 \%$ & $3,95 \%$ & $-1,45 \%$ & $-14,29 \%$ & $0,11 \%$ & $0,83 \%$ & $15,63 \%$ & $-0,05 \%$ \\
\hline MGEL4 & Mangels Indl PN & 8,83 & High & \begin{tabular}{l|l|}
13.581 .360 \\
\end{tabular} & Small & 0,05 & Loser & Small|High|Loser & $-9,52 \%$ & $27,82 \%$ & $0,00 \%$ & $47,06 \%$ & $-26,00 \%$ & $-5,41 \%$ & $0,00 \%$ & $16,57 \%$ & $21,57 \%$ & $27,02 \%$ & $-1,59 \%$ & $9,35 \%$ \\
\hline FBRA4 & Fertibras PN & 2,06 & High & 54.491.401 & Small & 0,04 & Loser & Small|High|Loser & $11,30 \%$ & $-2,00 \%$ & $3,57 \%$ & $-13,11 \%$ & $-20,75 \%$ & $9,52 \%$ & $8,70 \%$ & $-10,00 \%$ & $11,11 \%$ & $14,40 \%$ & $18,88 \%$. & $17,65 \%$ \\
\hline MAGS5 & Magnes & 2,84 & High & \begin{tabular}{|l|}
126.811 .907 \\
\end{tabular} & Small & 0,04 & Loser & Small|High|Loser & $-8,79 \%$ & $10,71 \%$ & $-2,90 \%$ & $27,91 \%$ & $12,47 \%$ & $12,01 \%$ & $0,91 \%$ & $2,38 \%$ & $10,47 \%$ & $13,68 \%$ & $13,89 \%$ & $9,76 \%$ \\
\hline \begin{tabular}{|l|} 
PLTO6 \\
\end{tabular} & Politeno PNB & 3,24 & High & 90.706 .557 & Small & 0,02 & Loser & Small| High| Loser & $1,87 \%$ & $16,43 \%$ & $-12,50 \%$ & $7,62 \%$ & $13,27 \%$ & $3,91 \%$ & $-27,82 \%$ & $12,29 \%$ & $-20,41 \%$ & $7,23 \%$ & $3,91 \%$ & $8,79 \%$ \\
\hline ARLA4 & Arthur Lange PN & 2,15 & High & \begin{tabular}{l|l|}
17.842 .723 \\
\end{tabular} & Small & 0,06 & Winner & Small|High|Winner & $-5,00 \%$ & $5,26 \%$ & $-5,00 \%$ & $5,26 \%$ & $0,00 \%$ & $0,00 \%$ & $-10,00 \%$ & $11,11 \%$ & $-5,00 \%$ & $5,26 \%$ & $10,00 \%$ & $-9,09 \%$ \\
\hline ACES3 & Am Inox BR ON & 2,34 & High & 443.300 .168 & Small & 0,06 & Winner & Small|High|Winner & $-5,66 \%$ & $18,00 \%$ & $-15,25 \%$ & $20,00 \%$ & $20,00 \%$ & $18,06 \%$ & $-11,76 \%$ & $32,00 \%$ & $-2,02 \%$ & $19,59 \%$ & $9,48 \%$ & $2,36 \%$ \\
\hline PTNT4 & Petten & 3,14 & High & 26.339 .764 & Small & 0,06 & Winner & Small|High|Winner & $-11,36 \%$ & $-15,38 \%$ & $-3,03 \%$ & $-3,06 \%$ & $5,74 \%$ & $-8,54 \%$ & $13,33 \%$ & $-5,88 \%$ & $-12,44 \%$ & $21,34 \%$ & $-5,88 \%$ & $9,94 \%$ \\
\hline ELEV3 & Eleva ON & 2,87 & High & 126.754 .685 & Small & 0,10 & Winner & Small|High|Winner & $1,02 \%$ & $-4,04 \%$ & $-5,26 \%$ & $12,22 \%$ & $16,34 \%$ & $-6,38 \%$ & $4,55 \%$ & $-4,35 \%$ & $0,00 \%$ & $-9,09 \%$ & $0,50 \%$ & $-5,47 \%$ \\
\hline ACES4 & Am Inox BR PN & 2,34 & High & \begin{tabular}{|l|l|}
443.300 .168 \\
\end{tabular} & Small & 0,10 & Winner & Small|High|Winner & $-1,59 \%$ & $9,68 \%$ & $-17,65 \%$ & $26,79 \%$ & $14,08 \%$ & $13,58 \%$ & $-4,35 \%$ & $35,23 \%$ & \begin{tabular}{l|l}
$0,00 \%$ \\
\end{tabular} & $10,92 \%$ & $7,58 \%$ & $3,52 \%$ \\
\hline PVPR4 & Peve Predios PN & 2,45 & High & 171.352 .504 & Small & 0,16 & Winner & Small|High|Winner & $13,73 \%$ & $3,92 \%$ & $3,85 \%$ & $-7,41 \%$ & $-20,00 \%$ & $25,00 \%$ & $57,26 \%$ & $0,00 \%$ & $116,17 \%$ & $0,25 \%$ & $-0,50 \%$ & $-5,00 \%$ \\
\hline BRGE12 & Alfa Co & 2,06 & High & 933.364 & Small & 0,20 & \begin{tabular}{|l|l|} 
Winner \\
\end{tabular} & Small|High|Winner & $6,86 \%$ & $-10,71 \%$ & $-4,00 \%$ & $6.67 \%$ & $-25,78 \%$ & $0,00 \%$ & $-2,11 \%$ & $1,83 \%$ & $8,20 \%$ & $11.62 \%$ & $-0,45 \%$ & $2,27 \%$ \\
\hline \begin{tabular}{|l|} 
BRGE3 \\
\end{tabular} & Alfa Consorc ON & 2,06 & High & \begin{tabular}{|l|l|}
200.933 .364 \\
\end{tabular} & Small & 0,21 & Winner & Small|High|Winner & $4,65 \%$ & $-5,26 \%$ & $-5,56 \%$ & $0,00 \%$ & $-25,49 \%$ & $0,00 \%$ & $-1,58 \%$ & $2,60 \%$ & $8,60 \%$ & $6,93 \%$ & $0,00 \%$ & $10,65 \%$ \\
\hline TEKA4 & Teka PN & 2,08 & \begin{tabular}{|l|l|} 
High \\
\end{tabular} & \begin{tabular}{|l|}
34.523 .786 \\
\end{tabular} & Small & 0,22 & Winner & Small|High|Winner & $-22,22 \%$ & $-2,86 \%$ & $-10,29 \%$ & $3,28 \%$ & $-4,76 \%$ & $3,33 \%$ & $-11,29 \%$ & $0,00 \%$ & $-3,64 \%$ & $-3,77 \%$ & $-1,96 \%$ & $14,00 \%$ \\
\hline BRGE11 & Alfa Consorc PNE & 2,06 & High & 200.933 .364 & Small & 0,25 & Winner & Small|High|Winner & $6,10 \%$ & $-6,90 \%$ & $-1,85 \%$ & $-4,91 \%$ & $-24,60 \%$ & $0,00 \%$ & $-5,26 \%$ & $11,86 \%$ & $2,58 \%$ & $8,54 \%$ & $0,93 \%$ & $4,59 \%$ \\
\hline CLSC6 & Celesc PNB & 2,56 & High & 470.573 .531 & Small & 0,30 & Winner & Small|High|Winner & $-13,11 \%$ & $11,32 \%$ & $-13,56 \%$ & $1,96 \%$ & $-7,69 \%$ & $12,50 \%$ & $-5,56 \%$ & $-9,80 \%$ & $-4,35 \%$ & $6,82 \%$ & $6,38 \%$ & $-8,00 \%$ \\
\hline JFEN3 & Joao $\mathrm{F}$ & 3,27 & High & 30.919 .370 & Small & 0,36 & Winner & Small|High|Winner & $-25,69 \%$ & $0,00 \%$ & $-3,85 \%$ & $14,00 \%$ & $0,00 \%$ & $0,04 \%$ & $-0,04 \%$ & $0,00 \%$ & $21,05 \%$ & $-3,46 \%$ & $3,41 \%$ & $0,47 \%$ \\
\hline PNVL3 & Dimed ON & 2,06 & High & 290.699 & Small & 0,39 & Winner & Small|High|Winner & $-8,05 \%$ & $0,51 \%$ & $0,00 \%$ & $2,56 \%$ & $15,75 \%$ & $7,99 \%$ & $5,43 \%$ & $3,35 \%$ & $4,86 \%$ & $0,00 \%$ & $0,00 \%$ & $9,09 \%$ \\
\hline \begin{tabular}{|l|} 
ASTA4 \\
\end{tabular} & Santistextil PN & 2,23 & \begin{tabular}{|l|l|} 
High \\
\end{tabular} & \begin{tabular}{|l|}
174.400 .807 \\
\end{tabular} & \begin{tabular}{|l} 
Small \\
\end{tabular} & $\begin{array}{ll}0,43 \\
0,43\end{array}$ & \begin{tabular}{|l} 
Winner \\
\end{tabular} & Small|High|Winner & 7, & $4,79 \%$ & $3,55 \%$ & $37,25 \%$ & |3,57\% & $\mid$ & $3,99 \%$ & 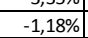 & $0,30 \%$ & $-5,60 \%$ & $\begin{array}{l}-3,82 \% \\
-3,1 \\
\end{array}$ & $4,69 \%$ \\
\hline CPCA4 & Trikem & 2,82 & High & 292.170 .076 & Small & 0,49 & Winner & Small|High|Winner & $47,92 \%$ & $15,49 \%$ & $-15,85 \%$ & $1,45 \%$ & $-14,86 \%$ & $1,34 \%$ & $-17,38 \%$ & $-7,82 \%$ & $-2,17 \%$ & $32,22 \%$ & $24,37 \%$ & $14,86 \%$ \\
\hline FESA4 & Ferbasa PN & 2,79 & High & \begin{tabular}{|l|l|}
79.451 .997 \\
\end{tabular} & Small & 0,66 & Winner & Small|High|Winner & $13,19 \%$ & $10,71 \%$ & $6,51 \%$ & $32,15 \%$ & $0,01 \%$ & $23,93 \%$ & $-5,98 \%$ & $14,88 \%$ & $6,22 \%$ & $2,14 \%$ & $25,29 \%$ & $5,50 \%$ \\
\hline ROMI4 & Inds Romi PI & 3,43 & High & 65.454 .719 & Small & 0,76 & Winner & Small|High|Winner & $-5,00 \%$ & $2,63 \%$ & $24,87 \%$ & $0,62 \%$ & $17,54 \%$ & $11,15 \%$ & $3,33 \%$ & $0,00 \%$ & $6,45 \%$ & $0,00 \%$ & $16,20 \%$ & $11,57 \%$ \\
\hline RSIP4 & Rasip Agro PN & 2,57 & \begin{tabular}{|l|l|} 
High \\
\end{tabular} & 15.007 .756 & Small & 0,80 & Winner & Small|High|Winner & $\begin{array}{l}, 0,00 \% \\
\end{array}$ & $30,00 \%$ & $0,00 \%$ & $38,46 \%$ & $-5,56 \%$ & $\mid-5,88 \%$ & $0,00 \%$ & $-12,50 \%$ & 7,14\% & $34,31 \%$ & $\begin{array}{ll}-20,00 \% \\
\end{array}$ & $-18,75 \%$ \\
\hline FJTA4 & Forjas Taurus PN & 2,51 & High & 82.539 .601 & Small & 0,91 & Winner & Small|High|Winner & $12,24 \%$ & $34,55 \%$ & $7,43 \%$ & $24,53 \%$ & $-11,62 \%$ & $18,13 \%$ & $-11,17 \%$ & $-0,57 \%$ & $-16,67 \%$ & $-10,15 \%$ & $3,10 \%$ & $3,01 \%$ \\
\hline LIXC4 & Lix da Cunha PN & 3,98 & High & \begin{tabular}{|l|l|}
15.710 .829 \\
\end{tabular} & Small & 1,53 & Winner & Small|High|Winner & $-4,58 \%$ & $6,40 \%$ & $12,03 \%$ & $-0,67 \%$ & $20,27 \%$ & $1,12 \%$ & $\mid-11,67 \%$ & $-6,29 \%$ & $23,49 \%$ & $-2,17 \%$ & $-16,67 \%$ & $16,67 \%$ \\
\hline TLCP4 & Tele Leste Celular & 0,82 & Low & 423.979.417 & Small & 0,61 & Loser & Small| Low|Loser & $-32,20 \%$ & $12,50 \%$ & $-17,78 \%$ & $8,11 \%$ & $5,00 \%$ & $4,76 \%$ & $-2,27 \%$ & $-11,63 \%$ & $10,53 \%$ & $4,76 \%$ & $0,00 \%$ & $0,00 \%$ \\
\hline NETC4 & Net PN & 0,14 & Low & 289.985 & Small & 0,57 & Loser & Small | Low|Loser & $-53,57 \%$ & $-33,33 \%$ & $-50,00 \%$ & $0,00 \%$ & $46,15 \%$ & $10,53 \%$ & $-11,90 \%$ & $-18,92 \%$ & $-6,67 \%$ & $46,43 \%$ & $-14,63 \%$ & $-17,14 \%$ \\
\hline PMAM4 & Paranapanema PN & 0,22 & Low & 126.432 .835 & Small & 0,55 & Loser & Small|Low|Loser & $5,56 \%$ & $3,16 \%$ & $-7,14 \%$ & $-1,10 \%$ & $5,56 \%$ & $-13,68 \%$ & $-2,44 \%$ & $-11,25 \%$ & $5,63 \%$ & $105,33 \%$ & $46,10 \%$ & $13,33 \%$ \\
\hline TNCP4 & Tele Nort Cl PN & 0,57 & Low & \begin{tabular}{|l|l}
173.194 .946 \\
\end{tabular} & Small & 0,52 & Loser & Small|Low|Loser & $-6,90 \%$ & $3,70 \%$ & $-3,57 \%$ & $11,11 \%$ & $6,67 \%$ & $6,25 \%$ & $0,00 \%$ & $-5,88 \%$ & $3,13 \%$ & $6,06 \%$ & $2,86 \%$ & $0,00 \%$ \\
\hline TNCP3 & Tele Nort $\mathrm{ClO}$ & 0,57 & Low & 3.194.946 & ( & 0,38 & Loser & |Loser & $-34,44 \%$ & $-11,86 \%$ & $-15,38 \%$ & $36,36 \%$ & $15,00 \%$ & $-10,14 \%$ & $9,68 \%$ & $2,94 \%$ & $-2,86 \%$ & $11,76 \%$ & $10,53 \%$ & $-14,7$ \\
\hline TPRC6 & & 0,74 & Low & & $\mathrm{Sm}$ & 5 & Lo & $\mathrm{Sm} \mathrm{m}_{\mathrm{z}}$ & $-4,61 \%$ & $-3,4$ & $-0,0$ & $-0,7$ & $-2,30 \%$ & $3,11 \%$ & $-2,8$ & $\%$ & $9,22 \%$ & & $0,75 \%$ & \\
\hline CHAP4 & Chapeco PN & 0,14 & Low & 94.839 .452 & Small & 0,33 & Loser & Small|Low|Loser & $-13,33 \%$ & $-47,69 \%$ & $-2,94 \%$ & $0,00 \%$ & $-9,09 \%$ & $-6,67 \%$ & $-10,71 \%$ & $-16,00 \%$ & $4,76 \%$ & $\begin{array}{l}140,91 \% \\
\end{array}$ & $-13,21 \%$ & $-17,39 \%$ \\
\hline TLCP3 & Tele Leste Celular ON & 0,82 & Low & 423.979.417 & Small & 0,32 & Loser & Small|Low|Loser & $-16,67 \%$ & $-15,00 \%$ & $-13,73 \%$ & $-34,09 \%$ & $-6,90 \%$ & $25,93 \%$ & $-10,29 \%$ & $-34,43 \%$ & $5,00 \%$ & $30,95 \%$ & $5,45 \%$ & $\begin{array}{l}-17,24 \% \\
\end{array}$ \\
\hline
\end{tabular}


Anexo 1 - Retorno mensal e classificação das ações

\begin{tabular}{|c|c|c|c|c|c|c|c|c|c|c|c|c|c|c|c|c|c|c|c|c|}
\hline Código & $2002-2003$ & $\begin{array}{l}\text { Índice } B / M \\
\text { de dez/2001 }\end{array}$ & \begin{tabular}{|c} 
Grupo com \\
base no \\
indice $B / M$
\end{tabular} & $\begin{array}{c}\text { Valor de Mercado } \\
\text { em jun/2002 }\end{array}$ & $\begin{array}{c}\text { Grupo com } \\
\text { base no } \\
\text { tamanho }\end{array}$ & \begin{tabular}{|c|} 
Retorno \\
acumulado \\
de jun/2002
\end{tabular} & \begin{tabular}{|c|} 
Grupo com \\
base no \\
retorno \\
acumulado
\end{tabular} & Carteiras & jul/02 & ago/02 & set/02 & out/02 & nov/02 & dez/02 & $\mathrm{jan} / 03$ & fev/03 & $\mathrm{mar} / 03$ & abr/03 & mai/03 & jun/03 \\
\hline SLED4 & Saraiva Livr PN & 0,35 & Low & 197.786.500 & Small & 0,28 & \begin{tabular}{|l|} 
Loser \\
\end{tabular} & Small|Low|Loser & $-14,12 \%$ & $16,44 \%$ & $0,00 \%$ & $0,00 \%$ & $5,88 \%$ & $5,50 \%$ & $-4,40 \%$ & $-1,15 \%$ & $-11,51 \%$ & $18,00 \%$ & $-0,89 \%$ & $0,00 \%$ \\
\hline CHAP3 & Chapeco ON & 0,14 & Low & 94.839 .452 & Small & 0,25 & Loser & Small|Low|Loser & $-27,91 \%$ & $-16,13 \%$ & $-11,54 \%$ & $0,00 \%$ & $4,35 \%$ & $0,00 \%$ & $12,50 \%$ & $-14,81 \%$ & $17,39 \%$ & $88,89 \%$ & $-5,88 \%$ & $-16,67 \%$ \\
\hline$\longdiv { \text { ITEC3 } }$ & Itautec ON & 0,50 & Low & 538.574 .625 & Small & 0,22 & Loser & Small|Low|Loser & $-15,86 \%$ & $14,49 \%$ & $-14,97 \%$ & $-6,00 \%$ & $19,15 \%$ & $0,42 \%$ & $-3,64 \%$ & $3,77 \%$ & $1,82 \%$ & $32,14 \%$ & $-2,70 \%$ & $-8,61 \%$ \\
\hline CBEE3 & Ampla Energ ON & 0,24 & Low & 528.247 .882 & Small & 0,20 & Loser & Small|Low|Loser & $3,23 \%$ & $12,50 \%$ & $-16,67 \%$ & $-6,67 \%$ & $-10,71 \%$ & $-4,00 \%$ & $16,67 \%$ & $-3,57 \%$ & $-33,33 \%$ & $11,11 \%$ & $5,00 \%$ & $0,00 \%$ \\
\hline LEVE4 & Metal Leve PN & 0,79 & Low & 397.419 .077 & Small & 0,27 & Winner & Small|Low|Winner & $1,15 \%$ & $-4,55 \%$ & $3,31 \%$ & $16,67 \%$ & $16,33 \%$ & $6,64 \%$ & $3,42 \%$ & $-0,17 \%$ & $7,62 \%$ & $1,60 \%$ & $2,92 \%$ & $0,15 \%$ \\
\hline POMO4 & Marcopolo PN & 0,77 & Low & 304.325 .352 & Small & 0,37 & Winner & Small|Low|Winner & $4,35 \%$ & $6,94 \%$ & $-8,05 \%$ & $20,32 \%$ & $7,32 \%$ & $0,99 \%$ & $-8,25 \%$ & $6,17 \%$ & $-1,94 \%$ & $-4,53 \%$ & $3,17 \%$ & $-6,91 \%$ \\
\hline RHDS3 & MG Poliest ON & 0,74 & $\mathrm{w}$ & 262.090 .650 & Small & 0,75 & Winner & Small|Low|Winner & $23,08 \%$ & $-12,50 \%$ & $35,71 \%$ & $-63,16 \%$ & $42,86 \%$ & $-30,00 \%$ & $14,29 \%$ & $-12,50 \%$ & $14,29 \%$ & $0,00 \%$ & $-12,50 \%$ & $85,71 \%$ \\
\hline LAME3 & Lojas Americ ON & 0,79 & Low & 394.109 .026 & Small & 1,68 & Winner & Small|Low|Winner & $-4,61 \%$ & $16,67 \%$ & $17,14 \%$ & $-0,18 \%$ & $14,57 \%$ & $9,85 \%$ & $-2,84 \%$ & $5,14 \%$ & $27,78 \%$ & $19,19 \%$ & $-12,87 \%$ & $10,72 \%$ \\
\hline LAME4 & Lojas Americ PN & 0,79 & Low & 394.109 .026 & Small & 2,93 & Winner & Small|Low|Winner & $-1,79 \%$ & $10,00 \%$ & $-4,13 \%$ & $30,94 \%$ & $14,63 \%$ & $30,50 \%$ & $-6,41 \%$ & $-3,02 \%$ & $31,62 \%$ & $8,86 \%$ & $-5,91 \%$ & $19,19 \%$ \\
\hline TMAC8B & Amazonia Celular PND & 0,93 & Medium & 173.397 .622 & Small & 0,67 & Loser & Small|Medium|Loser & $-33,88 \%$ & $-11,25 \%$ & $-15,49 \%$ & $-14,17 \%$ & $13,59 \%$ & $-5,98 \%$ & $10,00 \%$ & $-20,66 \%$ & $-16,67 \%$ & $-35,00 \%$ & $15,38 \%$ & $0,00 \%$ \\
\hline TMAC6B & Amazonia Celular PNB & 0,93 & Medium & 173.397 .622 & Small & 0,56 & Loser & Small|Medium|Loser & $-37,98 \%$ & $8,75 \%$ & $-25,29 \%$ & $-20,77 \%$ & $0,00 \%$ & $15,53 \%$ & $0,84 \%$ & $-16,67 \%$ & $0,00 \%$ & $-40,00 \%$ & $0,00 \%$ & $0,00 \%$ \\
\hline EKTR4 & Elektro & 1,82 & Medium & 225.281 .736 & Small & 0,47 & Loser & Small|Medium|Loser & $-4,49 \%$ & $0,00 \%$ & $-11,76 \%$ & $6,67 \%$ & $25,00 \%$ & $25,00 \%$ & $4,00 \%$ & $0,00 \%$ & $-19,23 \%$ & $42,86 \%$ & $40,00 \%$ & $-1,19 \%$ \\
\hline SGAS3 & WIm Ind Com ON & 1,42 & Medium & 58.787.039 & Small & 0,41 & Loser & Small|Medium|Loser & $-1,11 \%$ & $4,49 \%$ & $-0,54 \%$ & $-25,41 \%$ & $1,45 \%$ & $14,29 \%$ & $-15,00 \%$ & $-0,74 \%$ & $24,44 \%$ & $0,00 \%$ & $9,52 \%$ & $-14,13 \%$ \\
\hline TMAC3B & Amazonia Celular ON & 0,93 & Medium & \begin{tabular}{ll|l|}
173.397 .622 \\
\end{tabular} & Small & 0,40 & Loser & Small|Medium|Loser & $-12,98 \%$ & $-17,13 \%$ & $-6,67 \%$ & $0,00 \%$ & $-28,57 \%$ & $18,00 \%$ & $1,69 \%$ & $0,00 \%$ & $-16,67 \%$ & $-40,00 \%$ & $0,00 \%$ & $0,00 \%$ \\
\hline IDNT3 & Ideiasnet ON & 0,92 & Medium & 213.561 & Small & 0,40 & Loser & Small|Medium|Loser & $-15,25 \%$ & $2,00 \%$ & $-11,76 \%$ & $0,00 \%$ & $0,00 \%$ & $-8,89 \%$ & $-14,63 \%$ & $-11,43 \%$ & $-3,23 \%$ & $-14,99 \%$ & $72,00 \%$ & $51,16 \%$ \\
\hline HGTX4 & $\mathrm{Cia}$ & 3 & edi & & $\mathrm{Sm}$ & t & Loser & Small|M & $-19,23 \%$ & $9,52 \%$ & $-17,39 \%$ & 0, & $5,26 \%$ & $-5,00 \%$ & $5,26 \%$ & $0,00 \%$ & $30,00 \%$ & $-26,92 \%$ & $26,32 \%$ & $-16,67 \%$ \\
\hline \begin{tabular}{|l|} 
ARTE4 \\
\end{tabular} & Kuala PN & 1,28 & Medium & 5.258 .677 & Small & 0,33 & Loser & Small|Medium|Loser & $-33,33 \%$ & $50,00 \%$ & $-33,33 \%$ & $0,00 \%$ & $0,00 \%$ & $-45,00 \%$ & $0,00 \%$ & $4,55 \%$ & $-1,74 \%$ & $-9,29 \%$ & $-9,76 \%$ & $-20,00 \%$ \\
\hline TRFO4 & Trafo PN & 1,97 & Medium & 10.847.200 & Small & 0,27 & Loser & Small|Medium|Loser & $-9,62 \%$ & $-21,28 \%$ & $-8,11 \%$ & $11,76 \%$ & $-7,89 \%$ & $0,00 \%$ & $22,86 \%$ & $11,63 \%$ & $-2,08 \%$ & $10,64 \%$ & $-9,62 \%$ & $6,38 \%$ \\
\hline SGAS4 & WIm Ind Com PN & 1,42 & Medium & \begin{tabular}{|c|}
787.039 \\
\end{tabular} & Small & 0,22 & Loser & Small|Medium|Loser & $-20,45 \%$ & $25,71 \%$ & $-22,73 \%$ & $-2,94 \%$ & $-6,06 \%$ & $12,26 \%$ & $-2,30 \%$ & $-5,88 \%$ & $10,63 \%$ & $12,99 \%$ & $-5,00 \%$ & $0,00 \%$ \\
\hline ALPA4 & & 5 & 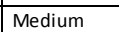 & & $\mathrm{Sm}$ & 9 & Loser & Small|Me & $-2,92 \%$ & $14,99 \%$ & $-12,17 \%$ & $18,81 \%$ & $8,32 \%$ & $-6,78 \%$ & $17,41 \%$ & $-2,73 \%$ & $26,23 \%$ & $-3,33 \%$ & $13,79 \%$ & $-0,67 \%$ \\
\hline ESTR4 & Estrela PN & 1,13 & Medium & 9.215 .190 & Small & 0,16 & Loser & Small|Medium|Loser & $0,00 \%$ & $-11,11 \%$ & $-2,50 \%$ & $66,67 \%$ & $21,54 \%$ & $-11,39 \%$ & $2,86 \%$ & $18,06 \%$ & $-1,18 \%$ & $-4,76 \%$ & $6,25 \%$ & $0,00 \%$ \\
\hline ALBA3 & Albarus ON & 1,09 & Medium & 147.620 .003 & Small & 0,16 & Loser & Small|Medium|Loser & $24,59 \%$ & $6,58 \%$ & $-17,28 \%$ & $4,48 \%$ & $24,29 \%$ & $2,30 \%$ & $0,00 \%$ & $0,00 \%$ & $0,83 \%$ & $0,00 \%$ & $5,88 \%$ & $-7,78 \%$ \\
\hline ETER3 & Eternit ON & 1,62 & \begin{tabular}{|l|} 
Medium \\
\end{tabular} & 242.667 & Small & 0,16 & Loser & Small|Medium|Loser & $4,42 \%$ & $11,77 \%$ & $-3,15 \%$ & $44,67 \%$ & $7,63 \%$ & $10,10 \%$ & $7,88 \%$ & $6,21 \%$ & $6,01 \%$ & $-6,25 \%$ & $-4,22 \%$ & $-1,73 \%$ \\
\hline TPEC3B & $\operatorname{Tim}$ & 25 & Medium & & Small & 0.09 & Loser & um/Loser & $0,25 \%$ & $-0,25 \%$ & $-5,00 \%$ & $-5,26 \%$ & $0.28 \%$ & $-5,82 \%$ & $47.06 \%$ & $-4,00 \%$ & $57 \%$ & $4.17 \%$ & $0,00 \%$ & $-28.00 \%$ \\
\hline TPEC6B & & 25 & Medium & 222.503 & Sma & 09 & \begin{tabular}{|l|l|} 
Lose \\
\end{tabular} & Small|Medium|Loser & $4,38 \%$ & $-12,00 \%$ & $6,36 \%$ & $-1,71 \%$ & $-4,78 \%$ & $9,59 \%$ & $-2,08 \%$ & $-2,13 \%$ & $-1,65 \%$ & $-4,55 \%$ & $-9,52 \%$ & $-1,58 \%$ \\
\hline DURA4 & Duratex-Old PN & 55 & Medium & 281.976 & Small & | & \begin{tabular}{|l|} 
Winner \\
\end{tabular} & Small|Medium|Winner & \begin{tabular}{|c|c|}
$-10,02 \%$ \\
\end{tabular} & $6,01 \%$ & $\begin{array}{l}-0,74 \% \\
-0,750\end{array}$ & $8,62 \%$ & $11,37 \%$ & $8,59 \%$ & $-5,77 \%$ & $11,20 \%$ & $\mid-0,90 \%$ & $5,56 \%$ & 7,02\% & $4,10 \%$ \\
\hline SCAR4 & Sao Car & & Medi & & Small & & Winner & Small|Medium|Winner & $-8,06 \%$ & $4,39 \%$ & $14,29 \%$ & $3,09 \%$ & $6,99 \%$ & $13,33 \%$ & $0,00 \%$ & $0,12 \%$ & & $13,51 \%$ & $9,40 \%$ & $8,09 \%$ \\
\hline$\overline{\text { RIPI4 }}$ & 1pirang & 1,44 & Medium & 418.089 & Small & 0,18 & Winner & Small|Medium|Winner & $-3,06 \%$ & $-15,46 \%$ & $-25,39 \%$ & $-21,59 \%$ & $-6,69 \%$ & $0,00 \%$ & $-16,67 \%$ & $-20,80 \%$ & $5,56 \%$ & $36,60 \%$ & $31,35 \%$ & $40,00 \%$ \\
\hline SCAR3 & & 65 & M & 40.842 & $\mathrm{Sm}$ & 20 & Wir & Small|Me & $-9,38 \%$ & $11,21 \%$ & $6,87 \%$ & $7,14 \%$ & $9,33 \%$ & $9,76 \%$ & $-7,89 \%$ & $3,74 \%$ & $4,65 \%$ & $16,67 \%$ & $11,44 \%$ & $10,22 \%$ \\
\hline DPPI4 & Ipiranga Dis PN & 18 & Medium & 999.993 & Small & 23 & Winner & Small|Medium |Winner & $6,07 \%$ & $-2,44 \%$ & $2,50 \%$ & $-8,83 \%$ & $1,66 \%$ & $0,00 \%$ & $-3,10 \%$ & $-1,47 \%$ & $-8,57 \%$ & $0,00 \%$ & $6,25 \%$ & $20,59 \%$ \\
\hline FRAS4 & Fras-Le & & $\mathrm{Me}$ & 082 & $\mathrm{Sm}$ & & Winner & Small|Medium|Wir & & $8,33 \%$ & $0,00 \%$ & $17,69 \%$ & $20,92 \%$ & $-2,98 \%$ & $0,00 \%$ & $14,29 \%$ & $-5,00 \%$ & $29,90 \%$ & $-4,35 \%$ & $-2,15 \%$ \\
\hline RPAD5 & Alfa Holding & 1,62 & Medium & 223.189 .479 & Small & 0,26 & Winner & Small|Medium |Winner & $2,95 \%$ & $-5,56 \%$ & $-3,92 \%$ & $-6,12 \%$ & $-26,09 \%$ & $-2,94 \%$ & $-2,42 \%$ & $5,16 \%$ & $6,92 \%$ & $3,53 \%$ & $2,27 \%$ & $11,11 \%$ \\
\hline RPAD6 & & 62 & Medium & 189.479 & Small & 26 & Winner & Small|Medium |Winner & $5,00 \%$ & $-5,56 \%$ & $-7,84 \%$ & $-2,13 \%$ & $-26,09 \%$ & $-2,94 \%$ & $-2,42 \%$ & $-1,34 \%$ & $6,45 \%$ & $-2,42 \%$ & $1,86 \%$ & $18,90 \%$ \\
\hline RPAD3 & & & edi & & $\mathrm{Sm}$ & 7 & Win & Small|Me & 6,7 & $-8,93 \%$ & $-7,84 \%$ & $-2,13 \%$ & $-25,65 \%$ & $-3,51 \%$ & $-3,03 \%$ & $-4,13 \%$ & $0,00 \%$ & $11,33 \%$ & $-11,98 \%$ & $22,45 \%$ \\
\hline ILMD4 & Yar & $\frac{1,024}{1,26}$ & \begin{tabular}{|l|l} 
Mes \\
\end{tabular} & & \begin{tabular}{|l|l|} 
Small \\
\end{tabular} & 0 & \begin{tabular}{|l|l|} 
Win \\
\end{tabular} & Small|Medium|Winner & $-1,47 \%$ & $4,48 \%$ & $10,00 \%$ & $-22,08 \%$ & $96,67 \%$ & $-13,56 \%$ & $6,86 \%$ & $-12,84 \%$ & $29,47 \%$ & $6,50 \%$ & $\mid-7,62 \%$ & $3,48 \%$ \\
\hline UNIP6 & Unipar PI & 1,77 & Medium & 0.571 .127 & Small & 0,39 & Winner & Small|Medium|Winner & $-6,74 \%$ & $14,46 \%$ & $-11,58 \%$ & $20,99 \%$ & $10,53 \%$ & $10,17 \%$ & $-10,53 \%$ & $0,00 \%$ & $7,84 \%$ & $20,00 \%$ & $22,88 \%$ & $-3,45 \%$ \\
\hline RAPT4 & Randon Part PN & 1,25 & Medium & 102.868 .924 & Small & 0.44 & Winner & Small/Medium/Winner & $2.82 \%$ & $4,11 \%$ & $-5,26 \%$ & $6,94 \%$ & $49,35 \%$ & $12,49 \%$ & $-8,80 \%$ & $0,88 \%$ & $10,43 \%$ & $3,79 \%$ & $6,20 \%$ & $5,54 \%$ \\
\hline$\widehat{\text { MTSA4 }}$ & Metisa & 120 & Medit & 23.157 .694 & Sma & 2 t & Win & Small|Me & $-0,04 \%$ & $0,48 \%$ & 0, & 19,5 & $-3,64 \%$ & 16, & 16,1 & & $-5,3$ & 10, & $-2,7$ & $2,83 \%$ \\
\hline$\overline{\text { RPSA4 }}$ & & 1,91 & $\mathrm{Me}$ & & $\mathrm{sm}$ & 0,72 & & Small|Medium|Wi & $3,47 \%$ & $-4,03 \%$ & $-6,29 \%$ & $1,49 \%$ & $-4,31 \%$ & $11,02 \%$ & $-4,96 \%$ & $-2,24 \%$ & $1,53 \%$ & $10,92 \%$ & $6,85 \%$ & $5,13 \%$ \\
\hline CNFB4 & Confab PN & 1,49 & Medium & \begin{tabular}{ll|}
7.673 .590 \\
\end{tabular} & Small & 0,77 & Winner & Small|Medium |Wi & $10,00 \%$ & $9,02 \%$ & $8,05 \%$ & $31,76 \%$ & $30,49 \%$ & $2,63 \%$ & $-9,30 \%$ & $-3,33 \%$ & $-10,08 \%$ & $18,09 \%$ & $1,69 \%$ & $17,83 \%$ \\
\hline PLDN4 & Polialden PN & 1,97 & Medium & \begin{tabular}{|l|}
7.116 .923 \\
\end{tabular} & Small & 1,62 & Winner & Small|Medium |Winner & $-0,69 \%$ & $0,69 \%$ & $-15,52 \%$ & $-11,43 \%$ & $19,82 \%$ & $1,92 \%$ & $-10,19 \%$ & $-9,66 \%$ & $29,76 \%$ & $5,70 \%$ & $31,77 \%$ & $-0,82 \%$ \\
\hline$\widehat{\text { SALM3 }}$ & & 1,39 & 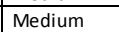 & 0.995 & s. & 1,69 & 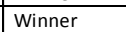 & Small| & $-1,19 \%$ & $-1,20 \%$ & 170 & & 71 & 16,92 & & 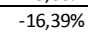 & & $14,00 \%$ & $-3,8$ & -7 \\
\hline $\mathrm{M} 4$ & Seara Alim PI & 1,39 & dium & .995 & nall & 2,11 & Winner & dium /Winner & $0,00 \%$ & t,009 & 2,50 & 7,18 & 0,47 & 15,609 & , 36 & 3,049 & $1,29 \%$ & $5,58 \%$ & $1,89 \%$ & $3,70 \%$ \\
\hline
\end{tabular}


Anexo 1 - Retorno mensal e classificação das ações

\begin{tabular}{|c|c|c|c|c|c|c|c|c|c|c|c|c|c|c|c|c|c|c|c|c|}
\hline Código & 2003 - 2004 & $\begin{array}{l}\text { Índice } B / M \\
\text { de dez/2002 }\end{array}$ & $\begin{array}{c}\text { Grupo com } \\
\text { base no } \\
\text { indice } B / M\end{array}$ & $\begin{array}{c}\text { Valor de Mercado } \\
\text { em jun/2003 }\end{array}$ & $\begin{array}{c}\text { Grupo com } \\
\text { base no } \\
\text { tamanho }\end{array}$ & $\begin{array}{c}\text { Retorno } \\
\text { acumulado } \\
\text { de jun/2003 }\end{array}$ & \begin{tabular}{|l} 
Grupo com \\
base no \\
retorno \\
acumulado
\end{tabular} & Carteiras & $\mathrm{jul} / 03$ & ago/03 & set/03 & out/03 & nov/03 & dez/03 & $\mathrm{jan} / 04$ & fev/04 & $\mathrm{mar} / 04$ & $a b r / 04$ & mai/04 & jun/04 \\
\hline \begin{tabular}{|l|} 
CPLE3 \\
\end{tabular} & Copel ON & 1,93 & High & \begin{tabular}{|l|}
1.996 .436 .806 \\
\end{tabular} & Big & 0,54 & Loser & Big|High|Loser & $-3,73 \%$ & $2,42 \%$ & $3,15 \%$ & $13,74 \%$ & $18,39 \%$ & $-1,36 \%$ & $-12,64 \%$ & $-3,82 \%$ & $0,96 \%$ & $-0,72 \%$ & $-3,90 \%$ & $6,52 \%$ \\
\hline ELPL5 & Eletropaulo PNA & 1,94 & High & 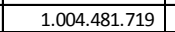 & Big & 0,42 & Loser & Big|High|Loser & $-2,96 \%$ & $26,70 \%$ & $25,71 \%$ & $-0,97 \%$ & $63,81 \%$ & $20,93 \%$ & $1,72 \%$ & $-14,54 \%$ & $17,34 \%$ & $-18,52 \%$ & $-18,76 \%$ & $20,04 \%$ \\
\hline CPLE6 & Copel PNB & 1,93 & High & \begin{tabular}{|l|l|}
1.996 .436 .806 \\
\end{tabular} & Big & 0,34 & Loser & Big|High|Loser & $-1,94 \%$ & $2,47 \%$ & $9,28 \%$ & $17,42 \%$ & $19,62 \%$ & $6,75 \%$ & $-15,81 \%$ & $-4,80 \%$ & $0,37 \%$ & $-10,64 \%$ & $-3,74 \%$ & $8,53 \%$ \\
\hline ELET3 & Eletrobras ON & 5,25 & High & \begin{tabular}{|l|l|l|}
10.813 .774 .793 \\
\end{tabular} & Big & 0,31 & Loser & Big|High|Loser & $-0,96 \%$ & $12,36 \%$ & $10,00 \%$ & $48,14 \%$ & $14,34 \%$ & $18,32 \%$ & $-27,63 \%$ & $-7,12 \%$ & $12,88 \%$ & $-17,39 \%$ & $-5,01 \%$ & $7,66 \%$ \\
\hline BRKM5 & Braskem PNA & 2,54 & High & \begin{tabular}{|l|}
1.250 .500 .459 \\
\end{tabular} & Big & 0,22 & Loser & Big|High|Loser & $14,50 \%$ & $41,36 \%$ & $17,36 \%$ & $12,68 \%$ & $17,62 \%$ & $42,08 \%$ & $0,37 \%$ & $14,75 \%$ & $-2,60 \%$ & $-22,67 \%$ & $-20,00 \%$ & $21,77 \%$ \\
\hline EBTP3 & Embratel Part ON & 3,63 & High & \begin{tabular}{|c|}
1.975 .208 .078 \\
\end{tabular} & Big & 0,17 & Loser & Big|High|Loser & $3,99 \%$ & $-2,76 \%$ & $12,46 \%$ & $10,38 \%$ & $65,31 \%$ & $8,38 \%$ & $0,71 \%$ & $-9,44 \%$ & $-1,87 \%$ & $4,99 \%$ & $5,66 \%$ & $0,36 \%$ \\
\hline ELET6 & Eletrobras PNB & 5,25 & High & \begin{tabular}{|l|l|l|}
10.8134 .793 \\
\end{tabular} & Big & 0,16 & Loser & Big|High|Loser & $1,73 \%$ & $10,07 \%$ & $9,96 \%$ & $39,19 \%$ & $10,78 \%$ & $8,37 \%$ & $-21,90 \%$ & $-2,27 \%$ & $9,57 \%$ & $-14,60 \%$ & $-2,76 \%$ & $5,79 \%$ \\
\hline SBSP3 & Sabesp ON & 2,77 & High & \begin{tabular}{|l|l|}
2.933 .681 .193 \\
\end{tabular} & Big & 0,05 & Loser & Big|High|Loser & $10,18 \%$ & $14,10 \%$ & $-2,76 \%$ & $1,72 \%$ & $14,14 \%$ & $15,42 \%$ & $-13,95 \%$ & $13,26 \%$ & $-5,87 \%$ & $-6,00 \%$ & $-11,49 \%$ & $12,98 \%$ \\
\hline EBTP4 & Embratel Part PN & 3,63 & High & \begin{tabular}{|l|}
1.975 .208 .078 \\
\end{tabular} & Big & 0,00 & Loser & Big|High|Loser & $3,14 \%$ & $2,70 \%$ & $23,36 \%$ & $25,07 \%$ & $11,41 \%$ & $-2,34 \%$ & $-14,53 \%$ & $-3,23 \%$ & $5,32 \%$ & $6,58 \%$ & $-24,26 \%$ & $24,45 \%$ \\
\hline TRPL4 & Tran Paulist PN & 4,05 & High & \begin{tabular}{|r|}
952.082 .345 \\
\end{tabular} & Big & 0,12 & Winner & Big|High|Winner & $10,53 \%$ & $18,23 \%$ & $14,15 \%$ & $22,12 \%$ & $14,30 \%$ & $5,00 \%$ & $-3,32 \%$ & $-6,20 \%$ & $-6,05 \%$ & $-13,39 \%$ & $8,46 \%$ & $7,54 \%$ \\
\hline USIM3 & Usiminas ON & 2,20 & High & \begin{tabular}{|l|}
2.440 .668 .366 \\
\end{tabular} & Big & 0,33 & Winner & Big|High|Winner & $33,00 \%$ & $11,92 \%$ & $3,65 \%$ & $20,69 \%$ & $17,20 \%$ & $25,46 \%$ & $-2,04 \%$ & $2,92 \%$ & $14,18 \%$ & \begin{tabular}{|l|l|}
$-11,04 \%$ \\
\end{tabular} & $-2,01 \%$ & $6,56 \%$ \\
\hline TRPL3 & Tran Paulist ON & 4,05 & High & \begin{tabular}{|r|}
952.082 .345 \\
\end{tabular} & Big & 0,37 & Winner & Big|High|Winner & $10,00 \%$ & $20,45 \%$ & $19,26 \%$ & $10,56 \%$ & $8,54 \%$ & $5,56 \%$ & $-0,09 \%$ & $-4,30 \%$ & $-8,26 \%$ & $-6,50 \%$ & $3,09 \%$ & $7,20 \%$ \\
\hline USIMS & Usiminas PNA & 2,20 & High & 2.440 .668 .366 & Big & 0,40 & Winner & Big|High|Winner & $19,32 \%$ & $11,33 \%$ & $14,71 \%$ & $17,64 \%$ & $21,62 \%$ & $26,56 \%$ & $-9,40 \%$ & $8,09 \%$ & $18,80 \%$ & $-26,58 \%$ & $2,24 \%$ & $8,60 \%$ \\
\hline CSTB4 & Sid Tubarao PN & 1,86 & High & \begin{tabular}{|l|l|}
2.508 .745 .663 \\
\end{tabular} & Big & 0,79 & Winner & Big|High|Winner & $9,76 \%$ & $22,97 \%$ & $3,91 \%$ & $10,99 \%$ & $16,47 \%$ & $31,25 \%$ & $-6,14 \%$ & $1,26 \%$ & $7,30 \%$ & $-19,90 \%$ & $4,24 \%$ & $13,80 \%$ \\
\hline LIGT3 & Light S/A ON & 0,57 & Low & \begin{tabular}{|l|}
981.421 .009 \\
\end{tabular} & Big & 0,63 & Loser & Big|Low|Loser & $-6,18 \%$ & $20,58 \%$ & $52,56 \%$ & $-0,67 \%$ & $18,00 \%$ & $52,51 \%$ & $-9,51 \%$ & $-22,53 \%$ & $3,02 \%$ & $-17,66 \%$ & $-5,18 \%$ & $19,87 \%$ \\
\hline CCRO3 & CCR SA ON & 0,81 & Low & 770.995 .660 & Big & 0,41 & Loser & Big|Low|Loser & $7,81 \%$ & $32,65 \%$ & $16,15 \%$ & $13,91 \%$ & $27,62 \%$ & $17,54 \%$ & $-7,02 \%$ & $1,92 \%$ & $2,42 \%$ & $2,90 \%$ & $4,93 \%$ & $34,43 \%$ \\
\hline \begin{tabular}{|l|} 
EMBR3 \\
\end{tabular} & Embraer ON & 0,35 & Low & \begin{tabular}{|l|l}
8.880 .837 .166 \\
\end{tabular} & Big & 0,34 & Loser & Big|Low|Loser & $0,96 \%$ & $11,37 \%$ & $-2,98 \%$ & $16,67 \%$ & $9,02 \%$ & $34,20 \%$ & $-7,25 \%$ & $-5,98 \%$ & $6,94 \%$ & $-18,81 \%$ & $-1,86 \%$ & $18,16 \%$ \\
\hline EMBR4 & Embraer PN & 0,35 & Low & \begin{tabular}{|l|l|}
8.880 .837 .166 \\
\end{tabular} & Big & 0,29 & Loser & Big|Low|Loser & $1,19 \%$ & $11,07 \%$ & $-0,92 \%$ & $23,92 \%$ & $15,05 \%$ & $20,90 \%$ & $-16,23 \%$ & $2,32 \%$ & $7,42 \%$ & $-21,23 \%$ & $6,16 \%$ & $13,42 \%$ \\
\hline PTOS4 & Petroquisa PN & 0,51 & Low & 2.286 .978 .717 & Big & $\begin{array}{ll}0,26 \\
\end{array}$ & Loser & Big Low|Loser & $2,16 \%$ & $14,32 \%$ & $5,26 \%$ & $-3,94 \%$ & $-3,96 \%$ & $5,34 \%$ & $23,19 \%$ & $-8,82 \%$ & $-4,15 \%$ & $-6,90 \%$ & $-7,41 \%$ & $0,00 \%$ \\
\hline TMCP3 & Telemig Part ON & 0,68 & Low & \begin{tabular}{|l|}
1.229 .344 .986 \\
\end{tabular} & Big & 0,22 & Loser & Big|Low|Loser & $7,78 \%$ & $13,40 \%$ & $14,55 \%$ & $23,81 \%$ & $8,97 \%$ & $-9,29 \%$ & $20,49 \%$ & $-13,89 \%$ & $11,00 \%$ & $-15,61 \%$ & $4,73 \%$ & $-4,52 \%$ \\
\hline TNEP3 & Tele Nordeste Celul ON & 0,78 & Low & \begin{tabular}{|l|}
838.670 .120 \\
\end{tabular} & Big & 0,21 & Loser & Big|Low|Loser & $1,28 \%$ & $-7,14 \%$ & $7,69 \%$ & $18,91 \%$ & $7,77 \%$ & $-0,66 \%$ & $-1,98 \%$ & $-8,42 \%$ & $19,49 \%$ & $-8,39 \%$ & $6,21 \%$ & $-4,87 \%$ \\
\hline CSPC3 & Cosipa ON & 0,85 & Low & 1.429.129.791 & Big & 0,19 & Loser & Big|Low|Loser & $20,69 \%$ & $34,29 \%$ & $29,79 \%$ & $19,67 \%$ & $-1,37 \%$ & $-12,50 \%$ & $3,17 \%$ & $-7,69 \%$ & $-5,00 \%$ & $7,02 \%$ & $-1,64 \%$ & $38,33 \%$ \\
\hline PCAR4 & P.Acucar-Cbd PN & 0,58 & Low & \begin{tabular}{|l|l|}
4.967 .739 .572 \\
\end{tabular} & Big & 0,18 & Loser & Big|Low|Loser & $24,17 \%$ & $7,34 \%$ & $-8,55 \%$ & $8,22 \%$ & $13,13 \%$ & $7,48 \%$ & $-4,30 \%$ & $-0,62 \%$ & $-9,34 \%$ & $-16,80 \%$ & $-5,98 \%$ & $11,79 \%$ \\
\hline VIVO4 & Vivo PN & 0,84 & Low & \begin{tabular}{|l|l|}
5.112 .657 .933 \\
\end{tabular} & Big & 0,15 & Loser & Big|Low|Loser & $-5,63 \%$ & $13,84 \%$ & $11,74 \%$ & $21,01 \%$ & $14,11 \%$ & $2,85 \%$ & $13,61 \%$ & $1,16 \%$ & $19,77 \%$ & $-18,43 \%$ & $0,35 \%$ & $13,83 \%$ \\
\hline VIVO3 & Vivo ON & 0,84 & Low & 5.112 .657 .933 & Big & 0,10 & Loser & Big|Low|Loser & $-9,95 \%$ & $2,63 \%$ & $8,46 \%$ & $19,15 \%$ & $11,11 \%$ & $5,36 \%$ & $-1,36 \%$ & $9,79 \%$ & $12,36 \%$ & $-18,94 \%$ & $-2,06 \%$ & $12,28 \%$ \\
\hline TMCP4 & Telemig Part PN & 0,68 & Low & \begin{tabular}{|l|l}
1.229 .344 .986 \\
\end{tabular} & Big & 0,07 & Loser & Big|Low|Loser & $0,67 \%$ & $11,67 \%$ & $11,94 \%$ & $22,93 \%$ & $10,85 \%$ & $-6,07 \%$ & $25,00 \%$ & $-1,00 \%$ & $-4,04 \%$ & $-17,68 \%$ & $-4,78 \%$ & $3,65 \%$ \\
\hline CMET4 & Caemi PN & 0,26 & Low & \begin{tabular}{|l|l|}
1.908 .132 .781 \\
\end{tabular} & Big & 0,07 & Loser & Big|Low|Loser & $19,76 \%$ & $20,93 \%$ & $14,47 \%$ & $3,97 \%$ & $19,18 \%$ & $27,01 \%$ & $3,94 \%$ & $6,06 \%$ & $-2,14 \%$ & $-21,90 \%$ & $18,69 \%$ & $-7,09 \%$ \\
\hline PETR4 & Petrobras P & 0,68 & Low & 58.794.373.538 & Big & 0,03 & Loser & Big|Low|Loser & $11,00 \%$ & $7,61 \%$ & $-0,25 \%$ & $3,87 \%$ & $10,95 \%$ & $14,23 \%$ & $2,47 \%$ & $4,74 \%$ & $7,16 \%$ & $-12,63 \%$ & $-3,91 \%$ & $7,70 \%$ \\
\hline PETR3 & Petrobras ON & 0,68 & Low & \begin{tabular}{|l|l|}
58.794 .373 .538 \\
\end{tabular} & Big & 0,02 & Loser & Big|Low|Loser & $9,17 \%$ & $8,24 \%$ & $0,23 \%$ & $2,05 \%$ & $10,44 \%$ & $18,12 \%$ & $1,07 \%$ & $6,24 \%$ & $10,24 \%$ & $-13,02 \%$ & $-4,75 \%$ & $6,47 \%$ \\
\hline TNEP4 & Tele Nordeste Celul PN & 0,78 & Low & 838.670 .120 & Big & 0,02 & Loser & Big|Low|Loser & $2,99 \%$ & $4,15 \%$ & $15,54 \%$ & $27,24 \%$ & $8,13 \%$ & $2,76 \%$ & $-2,44 \%$ & $-10,00 \%$ & $9,17 \%$ & $\begin{array}{l}-4,19 \% \\
\end{array}$ & $-0,27 \%$ & $-2,72 \%$ \\
\hline ITSA3 & Itausa ON & 0,90 & Low & $\begin{array}{l}8.433 .250 .750 \\
\end{array}$ & Big & 0,01 & Loser & Big|Low|Loser & $-0,31 \%$ & $0,95 \%$ & $0,17 \%$ & $7,69 \%$ & $-7,43 \%$ & $14,40 \%$ & $4,23 \%$ & $6,35 \%$ & $-13,14 \%$ & $-2,57 \%$ & $14,85 \%$ & $0,26 \%$ \\
\hline GETI4 & AES Tiete PN & 0,32 & Low & \begin{tabular}{|l|l|}
1.374 .368 .652 \\
\end{tabular} & Big & 0,01 & Loser & Big|Low|Loser & $0,00 \%$ & $-0,85 \%$ & $-2,13 \%$ & $-4,35 \%$ & $0,45 \%$ & $23,26 \%$ & $85,38 \%$ & $-6,64 \%$ & $6,22 \%$ & $-1,67 \%$ & $-10,93 \%$ & $10,05 \%$ \\
\hline CSPC4 & Cosipa PN & 0,85 & Low & \begin{tabular}{|l|l|}
1.429 .129 .791 \\
\end{tabular} & Big & 0,03 & Winner & Big|Low/Winner & $20,51 \%$ & $23,40 \%$ & $27,59 \%$ & $1,35 \%$ & $0,00 \%$ & $4,00 \%$ & $-6,41 \%$ & $-5,48 \%$ & $8,70 \%$ & $-8,00 \%$ & $0,00 \%$ & $17,39 \%$ \\
\hline GETI3 & AES Tiete ON & 0,32 & Low & $\begin{array}{l}1.374 .368 .652 \\
\end{array}$ & Big & 0,08 & Winner & Big|Low|Winner & $2,04 \%$ & $-2,68 \%$ & $6,51 \%$ & $0,00 \%$ & $0,00 \%$ & $2,64 \%$ & $22,22 \%$ & $-8,91 \%$ & $4,79 \%$ & $4,76 \%$ & $-3,22 \%$ & $8,19 \%$ \\
\hline UGPA4 & Ultrapar PN & 0,80 & Low & 1.613.907.124 & Big & 0,08 & Winner & Big|Low|Winner & $1,13 \%$ & $7,52 \%$ & $8,83 \%$ & $5,49 \%$ & $-0,89 \%$ & $15,81 \%$ & $-6,14 \%$ & $1,40 \%$ & $-0,60 \%$ & $-10,64 \%$ & $-0,81 \%$ & $7,22 \%$ \\
\hline VALE5 & Vale PNA & 0,33 & Low & 31.479.468.709 & Big & 0,09 & Winner & Big|Low|Winner & $20,31 \%$ & $9,88 \%$ & $2,96 \%$ & $11,27 \%$ & $-0,35 \%$ & $28,67 \%$ & $-5,78 \%$ & $5,27 \%$ & $-6,51 \%$ & $-15,14 \%$ & $18,43 \%$ & $-10,71 \%$ \\
\hline TSEP3 & Tele Sudeste Celula ON & 0,71 & Low & 2.734 .052 .172 & Big & 0,10 & Winner & Big/Low/Winner & $-22,33 \%$ & $3,75 \%$ & $9,40 \%$ & $5,29 \%$ & $-4,60 \%$ & $6.58 \%$ | & $3,83 \%$ & $-7,07 \%$ & $5,49 \%$ & $4,95 \%$ & $-15,13 \%$ & $7,64 \%$ \\
\hline TMGC3 & Telemig Cl ON & 0,63 & Low & \begin{tabular}{|l|l|}
1.016 .997 .277 \\
\end{tabular} & Big & 0,12 & Winner & Big|Low|Winner & $-6,67 \%$ & $2,38 \%$ & $-6,98 \%$ & $7,78 \%$ & $11,57 \%$ & $2,40 \%$ & $15,96 \%$ & $2,22 \%$ & $9,43 \%$ & $6,90 \%$ & $8,07 \%$ & $7,46 \%$ \\
\hline \begin{tabular}{|l|l|} 
VCPA4 \\
\end{tabular} & Fibria PN & 0,62 & Low & 4.204.067.170 & Big & o, & Winner & Big|Low/Winner & $24,53 \%$ & $13,14 \%$ & $-1,61 \%$ & $2,30 \%$ & $-5,45 \%$ & $23,86 \%$ & $-3,67 \%$ & $12,51 \%$ & $2,78 \%$ & $-6,59 \%$ & $5,71 \%$ & $0,26 \%$ \\
\hline VALE3 & Vale ON & 0,33 & Low & 31.479.468.709 & Big & 0,13 & Winner & Big|Low|Winner & $22,50 \%$ & $9,63 \%$ & $5,60 \%$ & $12,36 \%$ & $-0,77 \%$ & $31,40 \%$ & $-7,96 \%$ & $8,01 \%$ & $-5,34 \%$ & $-17,18 \%$ & $20,57 \%$ & $-7,39 \%$ \\
\hline ITSA4 & Itausa PN & 0,90 & Low & \begin{tabular}{l|l}
8.433 .250 .750 \\
\end{tabular} & Big & 0,14 & Winner & Big|Low/Winner & $11,11 \%$ & $14,11 \%$ & $-9,00 \%$ & $12,06 \%$ & $6,25 \%$ & $16,52 \%$ & $-3,23 \%$ & $6,51 \%$ & $-4,13 \%$ & $-14,70 \%$ & $15,09 \%$ & $9,99 \%$ \\
\hline ARCZ3 & Aracruz ON & 0,38 & Low & \begin{tabular}{|l|l|}
5.535 .199 .068 \\
\end{tabular} & Big & 0,16 & Winner & Big|Low|Winner & $8,51 \%$ & $8,82 \%$ & $-2,70 \%$ & $1,85 \%$ & $-1,82 \%$ & $35,19 \%$ & $-17,81 \%$ & $6,67 \%$ & $17,19 \%$ & $-1,46 \%$ & $-0,85 \%$ & $0,00 \%$ \\
\hline ARCZ6 & Aracruz & 0,38 & Low & \begin{tabular}{|l|l|}
5.535 .199 .068 \\
\end{tabular} & Big & 0,18 & Winn & Big|Low /Win & $24,58 \%$ & $10,20 \%$ & $-3,46 \%$ & $2,30 \%$ & $-0,63 \%$ & $33,33 \%$ & $-12,74 \%$ & $12,43 \%$ & $5,87 \%$ & $-13,11 \%$ & $10,22 \%$ & $-1,08 \%$ \\
\hline TSEP4 & Tele Sudeste Celula PN & 0,71 & Low & \begin{tabular}{|l|l|}
2.734 .052 .172 \\
\end{tabular} & Big & 0,23 & Winner & Big|Low|Winner & $-26,76 \%$ & $0,96 \%$ & $8,57 \%$ & $7,89 \%$ & $-5,20 \%$ & $13,55 \%$ & $0,95 \%$ & $-6,53 \%$ & $-2,72 \%$ & $-4,68 \%$ & $-11,40 \%$ & $16,83 \%$ \\
\hline CTNM4 & Coteminas PN & 0,81 & Low & 1.142.269.180 & Big & 0,26 & Winner & Big|Low|Winner & $-4,04 \%$ & $17,37 \%$ & $-2,69 \%$ & $-10,14 \%$ & $0,77 \%$ & $11,20 \%$ & $-8,92 \%$ & $4,02 \%$ & $9,18 \%$ & $-7,11 \%$ & $0,89 \%$ & $10,84 \%$ \\
\hline AMBV4 & Ambev PN & 0,21 & Low & 20.808.805.906 & Big & 0,28 & Winner & Big|Low|Winner & $2,24 \%$ & $10,46 \%$ & $-3,04 \%$ & $-0,52 \%$ & $13,21 \%$ & $6,48 \%$ & $-4,74 \%$ & $10,65 \%$ & $-24,17 \%$ & $-7,47 \%$ & $9,01 \%$ & $4,94 \%$ \\
\hline AMBV3 & Ambe & 0,21 & Low & 805.906 & Big & 0,29 & Wir & Biglt & $0,00 \%$ & $12,00 \%$ & $7,14 \%$ & $-5,5$ & 13,4 & $1,76 \%$ & $2,20 \%$ & $10,94 \%$ & $30,85 \%$ & 10,16 & $11,07 \%$ & \\
\hline TCOC4 & Tele Centroeste Cel PN & 0,54 & Low & \begin{tabular}{|l|l|}
3.152 .336 .317 \\
\end{tabular} & Big & 0,35 & Winner & Big|Low|Winner & $-5,68 \%$ & $16,89 \%$ & $15,28 \%$ & $18,88 \%$ & $11,39 \%$ & $4,57 \%$ & $0,29 \%$ & $6,14 \%$ & $14,11 \%$ & $-25,18 \%$ & $1,07 \%$ & $11,18 \%$ \\
\hline \begin{tabular}{|l|} 
WEGE4 \\
\end{tabular} & Weg PN & 0,36 & Low & \begin{tabular}{|l|l|}
2.011 .881 .271 \\
\end{tabular} & Big & 0,44 & Winner & Big|Low|Winner & $10,34 \%$ & $16,90 \%$ & $-2,17 \%$ & $19,46 \%$ & $-4,54 \%$ & $3,85 \%$ & $10,42 \%$ & $12,33 \%$ & $18,18 \%$ & $-7,69 \%$ & $12,42 \%$ & $2,80 \%$ \\
\hline
\end{tabular}


Anexo 1 - Retorno mensal e classificação das ações

\begin{tabular}{|c|c|c|c|c|c|c|c|c|c|c|c|c|c|c|c|c|c|c|c|c|}
\hline Código & $2003-2004$ & $\begin{array}{l}\text { Índice } B / M \\
\text { de dez/2002 }\end{array}$ & $\begin{array}{c}\text { Grupo com } \\
\text { base no } \\
\text { indice } B / M\end{array}$ & $\begin{array}{c}\text { Valor de Mercado } \\
\text { em jun/2003 }\end{array}$ & $\begin{array}{c}\text { Grupo com } \\
\text { base no } \\
\text { tamanho }\end{array}$ & $\begin{array}{c}\text { Retorno } \\
\text { acumulado } \\
\text { de jun/2003 }\end{array}$ & $\begin{array}{l}\text { Grupo com } \\
\text { base no } \\
\text { retorno } \\
\text { acumulado }\end{array}$ & Carteiras & $\mathrm{jul} / 03$ & ago/03 & set/03 & out $/ 03$ & nov/03 & $\operatorname{dez} / 03$ & $\mathrm{jan} / 04$ & fev/04 & $\mathrm{mar} / 04$ & $\mathrm{abr} / 04$ & mai/04 & jun/04 \\
\hline CRUZ3 & Souza Cruz ON & 0,28 & Low & \begin{tabular}{|l|l|}
7.214 .284 .117 \\
\end{tabular} & Big & 0,46 & Winner & Big|Low|Winner & $-1,78 \%$ & $5,37 \%$ & $5,31 \%$ & $5,16 \%$ & $9,48 \%$ & $6,58 \%$ & $1,85 \%$ & $-0,33 \%$ & $2,47 \%$ & $-15,79 \%$ & \begin{tabular}{l|l|l}
$6,67 \%$ \\
\end{tabular} & $8,46 \%$ \\
\hline EBCO4 & Embraco PN & 0,56 & Low & 924.653.711 & Big & 0,57 & Winner & Big|Low|Winner & $25,55 \%$ & $-9,88 \%$ & $-0,65 \%$ & $-4,55 \%$ & $2,72 \%$ & $7,88 \%$ & $-8,18 \%$ & $-4,11 \%$ & $-6,43 \%$ & $0,76 \%$ & $-3,79 \%$ & $2,36 \%$ \\
\hline TCOC3 & Tele Centroeste Cel ON & 0,54 & Low & \begin{tabular}{|l|}
3.152 .336 .317 \\
\end{tabular} & Big & 0,75 & Winner & Big|Low/Winner & \begin{tabular}{|c|}
$-3,68 \%$ \\
\end{tabular} & $0,71 \%$ & $12,28 \%$ & $3,06 \%$ & $-39,36 \%$ & $-15,20 \%$ & $-1,62 \%$ & $1,24 \%$ & $16,17 \%$ & $9,35 \%$ & $-5,25 \%$ & $10,77 \%$ \\
\hline FFTL4 & Valefert PN & 0,53 & Low & 1.508.480.112 & Big & 1,03 & Winner & Big|Low|Winner & $12,33 \%$ & $14,07 \%$ & $15,93 \%$ & $-1,72 \%$ & $0,25 \%$ & $15,00 \%$ & $4,78 \%$ & $-0,46 \%$ & $5,04 \%$ & $-14,27 \%$ & $6,69 \%$ & $8,18 \%$ \\
\hline LAME4 & Lojas Americ PN & 0,36 & Low & 857.949 .153 & Big & 1,30 & Winner & Big|Low|Winner & $1,50 \%$ & $25,95 \%$ & $22,84 \%$ & $10,05 \%$ & $20,72 \%$ & $22,09 \%$ & $-16,42 \%$ & $1,96 \%$ & $4,65 \%$ & $-8,12 \%$ & $3,20 \%$ & $1,94 \%$ \\
\hline LAME3 & Lojas Americ ON & 0,36 & Low & \begin{tabular}{|l|l|}
857.949 .153 \\
\end{tabular} & Big & 1,41 & Winner & Big|Low|Winner & $0,61 \%$ & $28,86 \%$ & $23,46 \%$ & $2,31 \%$ & $24,35 \%$ & $16,67 \%$ & $-7,14 \%$ & $-7,69 \%$ & $12,08 \%$ & $-1,26 \%$ & $7,30 \%$ & $-1,75 \%$ \\
\hline PALF3 & Paul F Luz ON & 1,40 & Medium & \begin{tabular}{|l|}
2.091 .375 .027 \\
\end{tabular} & Big & 0,38 & Loser & Big|Medium|Loser & $-10,00 \%$ & $-7,56 \%$ & $20,24 \%$ & $-4,04 \%$ & $8,56 \%$ & $5,55 \%$ & $18,18 \%$ & $-15,38 \%$ & $18,18 \%$ & $-10,77 \%$ & $-5,36 \%$ & $29,35 \%$ \\
\hline CMIG3 & Cemig ON & 1,39 & Medium & 3.898.842.273 & Big & 0,27 & Loser & Big|Medium|Loser & $0,43 \%$ & $15,62 \%$ & $6,41 \%$ & $16,19 \%$ & $7,30 \%$ & $19,31 \%$ & $-2,96 \%$ & $0,83 \%$ & $-3,42 \%$ & $-4,16 \%$ & $-0,60 \%$ & $5,36 \%$ \\
\hline CRTP3 & Crt Celular ON & 0,94 & Medium & \begin{tabular}{|l|}
988.415 .690 \\
\end{tabular} & Big & 0,23 & Loser & Big|Medium|Loser & $5,18 \%$ & $21,31 \%$ & $-10,81 \%$ & $45,45 \%$ & $-10,42 \%$ & $4,65 \%$ & $14,25 \%$ & $-19,19 \%$ & $12,50 \%$ & $-12,25 \%$ & $-11,37 \%$ & $10,00 \%$ \\
\hline TBLE6 & Tractebel PNB & 1,31 & \begin{tabular}{|l|} 
Medium \\
\end{tabular} & 4.095 .871 .638 & Big & 0,21 & Loser & Big|Medium|Loser & \begin{tabular}{ll|}
$-6,98 \%$ \\
\end{tabular} & $3,43 \%$ & $-8,56 \%$ & $6,04 \%$ & $13,19 \%$ & $5,74 \%$ & $57,04 \%$ & $-13,52 \%$ & $7,27 \%$ & $-0,83 \%$ & $0,36 \%$ & $14,13 \%$ \\
\hline CGAS5 & Comgas PNA & 1,39 & Medium & \begin{tabular}{l|}
839.784 .663 \\
\end{tabular} & Big & 0,17 & Loser & Big|Medium|Loser & $12,94 \%$ & $14,32 \%$ & $34,32 \%$ & $16,69 \%$ & $15,49 \%$ & $20,13 \%$ & $16,20 \%$ & $-6,73 \%$ & $-10,82 \%$ & $-9,94 \%$ & $5,86 \%$ & $12,00 \%$ \\
\hline TCSL4 & Tim Part S/A PN & 1,03 & Medium & \begin{tabular}{|l|}
810.771 .949 \\
\end{tabular} & Big & 0,13 & Loser & Big|Medium|Loser & $-5,46 \%$ & $13,33 \%$ & $6,27 \%$ & $24,72 \%$ & $21,30 \%$ & $0,73 \%$ & $-1,13 \%$ & $-12,10 \%$ & $20,22 \%$ & $0,96 \%$ & $-8,47 \%$ & $2,31 \%$ \\
\hline PALF7 & Paul F Luz PNC & 1,40 & Medium & 2.091.375.027 & Big & 0,13 & Loser & Big|Medium|Loser & $0,00 \%$ & $-12,20 \%$ & $11,11 \%$ & $0,00 \%$ & $-5,61 \%$ & $0,69 \%$ & $-5,29 \%$ & $-0,01 \%$ & $4,18 \%$, & $5,32 \%$ & $-5,09 \%$ & $2,69 \%$ \\
\hline TMAR5 & Telemar N L PNA & 1,12 & Medium & 9.318.910.944 & Big & 0,11 & Loser & Big|Medium|Loser & $0,74 \%$ & $13,28 \%$ & $12,01 \%$ ] & $20,31 \%$ & $-0,87 \%$ & $-0,09 \%$ ] & $18,99 \%$. & $-10,06 \%$ ] & $-11,50 \%$. & $-3,88 \%$ | $>$ & $-3,46 \%$ ] & $12,13 \%$ \\
\hline TMAR6 & Telemar N L PNB & 1,12 & Medium & 9.318.910.944 & Big & 0,11 & Loser & Big|Medium|Loser & $-5,26 \%$ & $13,89 \%$ & $1,34 \%$ & $15,26 \%$ & $4,35 \%$ & $2,00 \%$ & $15,11 \%$ & $-16,07 \%$ & $-11,22 \%$ & $-2,50 \%$ & $-2,56 \%$ & $12,81 \%$ \\
\hline \begin{tabular}{|l|} 
CRTP5 \\
\end{tabular} & Crt Celular PNA & \begin{tabular}{l|l|l}
0,94 & \\
\end{tabular} & Medium & \begin{tabular}{|l|l}
988.415 .690 \\
\end{tabular} & Big & 0,11 & Loser & Big|Medium|Loser & $8,94 \%$ & $17,47 \%$ & $7,19 \%$ & $12,90 \%$ & $4,57 \%$ & $10,02 \%$ & $-0,10 \%$ & $-5,13 \%$ & $7,75 \%$ & $-21,40 \%$ & $1,49 \%$ & $13,21 \%$ \\
\hline TPRC6 & Tim Sul PNB & 0,99 & Medium & 1.092 .122 .306 & Big & 0,09 & Loser & Big|Medium|Loser & $-16,39 \%$ & $0,91 \%$ & $2,50 \%$ & $24,80 \%$ & $12,11 \%$ & $0,87 \%$ & $10,99 \%$ & $-9,66 \%$ & $-0,75 \%$ & $-0,10 \%$ & $-13,18 \%$ & $11,61 \%$ \\
\hline TNLP3 & Telemar ON & 1,04 & Medium & 11.502.540.487 & Big & 0,08 & Loser & Big|Medium|Loser & $0,83 \%$ & $16,83 \%$ & $9,19 \%$ & $4,32 \%$ & $-2,29 \%$ & $11,39 \%$ & $7,35 \%$ & $-7,56 \%$ & $3,58 \%$ & $-5,33 \%$ & \begin{tabular}{|l|l|l|}
$-5,41 \%$ \\
\end{tabular} & $10,31 \%$ \\
\hline CMIG4 & Cemig PN & 1,39 & Medium & 3.898.842.273 & Big & 0,07 & Loser & Big|Medium|Loser & $2,85 \%$ & $19,52 \%$ & $6,05 \%$ & $23,67 \%$ & $10,88 \%$ & $15,57 \%$ & $-5,69 \%$ & $4,52 \%$ & $-2,60 \%$ & $-9,38 \%$ & $-4,31 \%$ & $9,32 \%$ \\
\hline SUZB5 & Suzano Papel PNA & 1,36 & Medium & \begin{tabular}{|l|l|}
1.887 .174 .149 \\
\end{tabular} & Big & 0,04 & Loser & Big|Medium|Loser & $17,81 \%$ & $12,79 \%$ & $5,67 \%$ & $-2,44 \%$ & $1,90 \%$ & $27,10 \%$ & $-5,75 \%$ & $13,55 \%$ & $3,83 \%$ & $-4,65 \%$ & $1,62 \%$ & $-6,13 \%$ \\
\hline TPRC3 & Tim Sul ON & 0,99 & Medium & 1.092.122.306 & Big & 0,01 & Loser & Big|Medium|Loser & $-4,82 \%$ & $-7,33 \%$ & $0,68 \%$ & $-11,39 \%$ & $8,06 \%$ & $-2,99 \%$ & $3,29 \%$ & $-6,82 \%$ & $0,81 \%$ & $10,64 \%$ & $-1,64 \%$ & $0,15 \%$ \\
\hline BRAP4 & Bradespar PN & 1,45 & Medium & 872.922 .374 & Big & 0,00 & Winner & Big|Medium/Winner & $14,29 \%$ & $5,56 \%$ & $1,32 \%$ & $14,29 \%$ & $0,00 \%$ & $43,18 \%$ & $-5,56 \%$ & $8,40 \%$ & $6,98 \%$, & $-21,74 \%$ & $7,41 \%$ & $-5,17 \%$ \\
\hline TMAR3 & Telem & 1,12 & Medium & & Big & 0,00 & Winner & $\mathrm{m} /$ Winner & $-3,73 \%$ & $2,49 \%$ & $8,19 \%$ & $19,65 \%$ & $0,00 \%$ & $2,88 \%$ & $13,86 \%$ & $-8,03 \%$ & $-7,63 \%$ & $-0,07 \%$ & $-9,30 \%$ & $12,32 \%$ \\
\hline TNLP4 & Telemar PN & 1,04 & Medium & 11.502.540.487 & Big & 0,03 & Winner & Big|Medium |Winner & $-0,91 \%$ & $17,65 \%$ & $5,21 \%$ & $0,47 \%$ & $3,26 \%$ & $7,83 \%$ & $5,16 \%$ & $-7,44 \%$ & $-10,93 \%$ & $-6,83 \%$ & $-0,72 \%$ & $13,31 \%$ \\
\hline BRTP3 & Brasil T Par ON & 1,07 & Medium & 6.832.339.564 & Big & 0,04 & Winner & Big|Medium/Winner & $-6,23 \%$ & $13,16 \%$ & $-3,50 \%$ & $3,01 \%$ & $11,10 \%$ & $-0,33 \%$ & $6,25 \%$ & $-6,68 \%$ & $2,51 \%$ & $-11,17 \%$ & \begin{tabular}{|c|}
$-7,92 \%$ \\
\end{tabular} & $9,53 \%$ \\
\hline BRAP3 & Bradespar ON & 1,45 & Medium & 872.922 .374 & Big & 0,06 & Winner & Big|Medium/Winner & $16,98 \%$ & $8,06 \%$ & $1,49 \%$ & $10,29 \%$ & $1,33 \%$ & $32,89 \%$ & $2,97 \%$ & $4,81 \%$ & $13,76 \%$ & $-15,32 \%$ & $4,76 \%$ & $-2,73 \%$ \\
\hline BRTO4 & Brasil & 1,13 & Medium & & Big & 0,07 & Winner & um $/$ Winner & $-8,95 \%$ & $16,67 \%$ & $-4,84 \%$ & $1,31 \%$ & $15,65 \%$ & $-0,13 \%$ & $3,82 \%$ & $-6,11 \%$ & $-14,01 \%$ & $-10,48 \%$ & $-7,66 \%$ & $10,73 \%$ \\
\hline CPSL3 & Copesul ON & 1,51 & Medium & 1.314.400.196 & Big & 0,11 & Winner & Big|Medium/Winner & $2,86 \%$ & $32,23 \%$ & $4,47 \%$ & $-0,75 \%$ & $7,09 \%$ & $11,82 \%$ & $3,80 \%$ & $3,37 \%$ & $9,45 \%$ & $-9,54 \%$ & $8,28 \%$ & $12,00 \%$ \\
\hline GGBR3 & Gerdau ON & 0,96 & Medium & 4.477.156.010 & Big & 0,16 & Winner & Big|Medium/Winner & $10,30 \%$ & $25,00 \%$ & $2,62 \%$ & $2,88 \%$ & $2,82 \%$ & $41,76 \%$ & $-7,08 \%$ & $-2,13 \%$ & $7,93 \%$ & $6,12 \%$ & $-7,69 \%$ & $14,58 \%$ \\
\hline SDIA4 & Sadia S/A PN & 1,34 & Medium & 1.076.327.051 & Big & 0,19 & Winner & Big|Medium/Winner & $26,49 \%$ & $27,78 \%$ & $10,87 \%$ & $18,43 \%$ & $18,54 \%$ & $11,17 \%$ & $12,88 \%$ & $-0,59 \%$ & $-3,26 \%$ & $-3,13 \%$ & $-2,98 \%$ & $3,58 \%$ \\
\hline DURA4 & Duratex-Old PN & 1,51 & Medium & 728.243 .169 & Big & 0,22 & Winner & Big/Medium/Winner & $-5,51 \%$ & $6,84 \%$ & $-1,59 \%$ & $16,16 \%$ & $12,47 \%$ & $4,04 \%$ & $-4,59 \%$ & $1,01 \%$ & $-3,75 \%$ & $-9,09 \%$ & $-11.43 \%$ & $11,94 \%$ \\
\hline BRTP4 & Brasil T Par PN & 1,07 & Medium & 5.832.339.564 & Big & 0,24 & Winner & Big|Medium /Winner & $-7,08 \%$ & $14,16 \%$ & $-2,18 \%$ & $-4,77 \%$ & $9,73 \%$ & $-4,76 \%$ & $12,45 \%$ & $-7,85 \%$ & $-10,72 \%$ & $-8,63 \%$ & $-4,31 \%$ & $9,18 \%$ \\
\hline GGBR4 & Gerdau PN & 0,96 & Medium & 177.156 .010 & Big & 0,26 & Winner & Big|Medium/Winner & $3,62 \%$ & $31,31 \%$ & $-7,93 \%$ & $3,34 \%$ & $17,39 \%$ & $24,49 \%$ & $2,12 \%$ & $1,71 \%$ & $8,89 \%$ & $-7,74 \%$ & $5,81 \%$ & $13,26 \%$ \\
\hline BSUL5 & Bahia Sul PNA & 1,82 & Medic & 8464.213 & Big & 0,36 & Winner & Big|Medium /Winner & $15,91 \%$ & $24,47 \%$ & $-1,71 \%$ & $-7,83 \%$ & $1,51 \%$ & $21,24 \%$ & $0,00 \%$ & $-1,72 \%$ & $16,07 \%$ & $-6,71 \%$ & $-1,06 \%$ & $1,51 \%$ \\
\hline BRTO3 & Brasil Telec ON & 1,13 & Medium & 6.789 .127 .579 & Big & 0,38 & Winner & Big|Medium / Winner & $-9,39 \%$ & $18,02 \%$ & $-3,05 \%$ & $2,44 \%$ & $9,92 \%$ & $11,54 \%$ & $-18,50 \%$ & $-3,68 \%$ & $0,83 \%$ & $-9,84 \%$ & $-5,45 \%$ & $6,63 \%$ \\
\hline CSNA3 3 & Sid Na & 1,34 & Medium & 5.035.394.386 & Big & 0,43 & \begin{tabular}{|l|l} 
Winner \\
\end{tabular} & |Winner & $15,38 \%$ & $22,84 \%$ & $3,72 \%$ & $14,32 \%$ & $13,58 \%$ & $16,94 \%$ & $4,34 \%$ [ & $13,76 \%$ & $6,94 \%$. & $-25,06 \%$ & $4,66 \%$ & $4,14 \%$ \\
\hline TBLE3 & Tractebel ON & 1,31 & Medium & 95.871 .638 & Big & 48 & Winner & Big|Medium /Winner & $-5,98 \%$ & $17,20 \%$ & $-8,44 \%$ & $-0,71 \%$ & $0,87 \%$ & $15,75 \%$ & $56,18 \%$ & $-29,66 \%$ & $7,95 \%$ & $-0,48 \%$ & $-5,19 \%$ & $19,11 \%$ \\
\hline GOAU4 & Gerdau Me & 1,44 & Medium & 1.442.132.973 & Big & 0,62 & Winner & Big|Medium/Winner & $7,65 \%$ & $21,42 \%$ & $-2,39 \%$ & $6,46 \%$ & $13,61 \%$ & $29,31 \%$ & $7,32 \%$ & $2,88 \%$ & $15,56 \%$ & $-8,59 \%$ & \begin{tabular}{l|l|}
$6,98 \%$ \\
\end{tabular} & $10,92 \%$ \\
\hline \begin{tabular}{|l|} 
ARCE3 \\
\end{tabular} & Arcelor BR ON & 0,93 & Medium & 3.114 .600 .023 & Big & 0,78 & Winner & Big|Medium/Winner & $5,26 \%$ & $7,95 \%$ & $-3,16 \%$ & $-3,26 \%$ & $14,83 \%$ & $21,33 \%$ & $17,59 \%$ & $-10,64 \%$ & $3,17 \%$ & $-9,88 \%$ & $-5,13 \%$ & $29,37 \%$ \\
\hline ARCE4 & Arcelor BR PN & 0,93 & Medium & .023 & Big & 81 & Winner & Big|Medium/Winner & $4,93 \%$ & $13,60 \%$ & $-2,82 \%$ & $0,64 \%$ & $14,12 \%$ & $15,77 \%$ & $10,90 \%$ & $-0,51 \%$ & $3,82 \%$ & $-15,96 \%$ & $0,44 \%$ & $23,73 \%$ \\
\hline KLBN4 & bins & 1,15 & diu & 7.130 & Big & 7 & Winner & Winner & $-3,05 \%$ & $9,79 \%$ & $-0,40 \%$ & $-1,64 \%$ & $19,33 \%$ & $5,03 \%$ & $-2,93 \%$ & $8,22 \%$ & $6,08 \%$ & $-7,69 \%$ & $7,92 \%$ & $3,80 \%$ \\
\hline MSAN4 & Bunge Brasi & $\frac{1,151}{1,71}$ & Medium & 179.359 & \begin{tabular}{|l|l|} 
Big \\
\end{tabular} & 0,93 & Winner & Big|Medium /Winner & $31,78 \%$ & $3,93 \%$ & $46,05 \%$ & $18,69 \%$ & $\begin{array}{l}-7,78 \% \\
-7,78 \% \\
\end{array}$ & $33,54 \%$ & $-7,78 \%$ & $1,69 \%$ & $-8,17 \%$ & $3,99 \%$ & $2,97 \%$ & $-0,51 \%$ \\
\hline ACES4 & Am Inox BR PN & 1,26 & Medium & 1.050.043.272 & Big & 0,97 & Winner & Big|Medium/Winner & $-10,20 \%$ & $8,33 \%$ & $-8,39 \%$ & $0,00 \%$ & $9,16 \%$ & $13,99 \%$ & $0,00 \%$ & $4,91 \%$ & $14,62 \%$ & $16,84 \%$ & $0,44 \%$ & $4,78 \%$ \\
\hline ACES3 & Am Inox BR ON & 1,26 & Medium & 1.050 .043 .272 & Big & 1,00 & Winner & Big|Medium/Winner & $-6,92 \%$ & $12,40 \%$ & $-5,88 \%$ & $7,03 \%$ & $4,38 \%$ & $16,78 \%$ & $-1,20 \%$ & $1,82 \%$ & $8,93 \%$ & $15,85 \%$ & $1,89 \%$ & $3,24 \%$ \\
\hline MSAN3 & Bunge & 1,71 & Medium & 2.410 .179 .359 & $D$ & 100 t & Winner & Winner & 32,96 & $0,28 \%$ & $44,64 \%$ & $16,05 \%$ & $-4,68 \%$ & $27,01 \%$ & $-5,46 \%$ & $2,26 \%$ & 11,8 & $-6,27 \%$ & 3,8 & $-0,51 \%$ \\
\hline TMAC8B & Ama & 2, & \begin{tabular}{|l} 
High \\
\end{tabular} & .274 & $\mathrm{Sm}$ & 0,77 & Loser & Small|High|Loser & $0,00 \%$ & $0,00 \%$ & $53,33 \%$ & $-8,70 \%$ & $19,05 \%$ & $0,20 \%$ & $-0,20 \%$ & $10,00 \%$ & $9,18 \%$ & $9,91 \%$ & $-8,94 \%$ & $0,67 \%$ \\
\hline TMACGB & Amazonia Celular PNB & 2,71 & High & 62.783.274 & Small & 0,73 & Loser & Small|High|Loser & $0,00 \%$ & $0,00 \%$ & $66,67 \%$ & $0,00 \%$ & $0,00 \%$ & $20,00 \%$ & $16,67 \%$ & $-28,50 \%$ & $19,88 \%$ & $10,00 \%$ & $-7,58 \%$ & $-0,82 \%$ \\
\hline ARTE4 & Kuala PN & 2,51 & High & 1.225.270 & Small & 0,66 & Loser & Small|High|Loser & $-7,43 \%$ & $-23,36 \%$ & $10,48 \%$ & $3,45 \%$ & $-0,17 \%$ & $4,51 \%$ & $-0,96 \%$ & $-12,90 \%$ & $-12,96 \%$ & $-6,60 \%$ & $-20,27 \%$ & $20,00 \%$ \\
\hline SULT4 & Sultepa PN & 32,97 & High & 4.284 .000 & Small & 0,53 & Loser & Small|High|Loser & $38,24 \%$ & $6,38 \%$ & $-6,00 \%$ & $-4,26 \%$ & $2,22 \%$ & $2,17 \%$ & $2,13 \%$ & $-6,25 \%$ & $2,22 \%$ & $0,00 \%$ & $-2,17 \%$ & $24,44 \%$ \\
\hline
\end{tabular}


Anexo 1 - Retorno mensal e classificação das ações

\begin{tabular}{|c|c|c|c|c|c|c|c|c|c|c|c|c|c|c|c|c|c|c|c|c|}
\hline Código & $2003-2004$ & $\begin{array}{l}\text { Índice } B / M \\
\text { de dez/2002 }\end{array}$ & \begin{tabular}{|c|} 
Grupo com \\
base no \\
indice $B / M$ \\
\end{tabular} & $\begin{array}{c}\text { Valor de Mercado } \\
\text { em jun/2003 }\end{array}$ & $\begin{array}{c}\text { Grupo com } \\
\text { base no } \\
\text { tamanho }\end{array}$ & \begin{tabular}{|c|} 
Retorno \\
acumulado \\
de jun/2003
\end{tabular} & \begin{tabular}{|c|} 
Grupo com \\
base no \\
retorno \\
acumulado \\
\end{tabular} & Carteiras & $\mathrm{jul} / 03$ & ago/03 & set/03 & out $/ 03$ & nov/03 & dez/03 & $\mathrm{jan} / 04$ & $\mathrm{fev} / 04$ & $\mathrm{mar} / 04$ & abr/04 & mai/04 & jun/04 \\
\hline TELB4 & Telebras PN & 12,23 & High & 11.128.584 & Small & 0,50 & Loser & Small|High|Loser & $0,00 \%$ & $50,00 \%$ & $0,00 \%$ & $0,00 \%$ & $33,33 \%$ & $0,00 \%$ & $-50,00 \%$ & $50,00 \%$ & $-33,33 \%$ & $0,00 \%$ & $50,00 \%$ & $-33,33 \%$ \\
\hline TELB3 & Telebras ON & 12,23 & High & 11.128 .584 & Small & 0,50 & Loser & Small|High|Loser & $0,00 \%$ & $0,00 \%$ & $50,00 \%$ & $0,00 \%$ & $0,00 \%$ & $33,33 \%$ & $-50,00 \%$ & $50,00 \%$ & $-33,33 \%$ & $0,00 \%$ & $0,00 \%$ & $0,00 \%$ \\
\hline PNOR5 & Pronor PNA & 6,20 & High & 29.862 .083 & Small & 0,46 & Loser & Small||High|Loser & $-7,69 \%$ & $51,67 \%$ & $31,87 \%$ & $0,00 \%$ & $11,67 \%$ & $34,33 \%$ & $28,33 \%$ & $8,66 \%$ & $3,59 \%$ & $-3,85 \%$ & $-15,20 \%$ & $33,96 \%$ \\
\hline $\begin{array}{l}\text { CEBR5 } \\
\end{array}$ & Ceb PNA & 3,53 & High & 74.379.619 & Small & 0,43 & Loser & Small|High|Loser & $0,05 \%$ & $-13,85 \%$ & $21,55 \%$ & $0,00 \%$ & $29,55 \%$ & $8,77 \%$ & $12,87 \%$ & $-7,12 \%$ & $0,00 \%$ & $-35,38 \%$ & $19,00 \%$ & $3,84 \%$ \\
\hline EMAE4 & Emae PN & 4,07 & High & 165.153 .458 & Small & 0,38 & Loser & Small|High|Loser & $5,59 \%$ & $8,05 \%$ & $11,76 \%$ & $-5,26 \%$ & $11,85 \%$ & $8,44 \%$ & $2,29 \%$ & $-12,39 \%$ & $9,03 \%$ & $-6,41 \%$ & $-20,20 \%$ & $6,28 \%$ \\
\hline PTIP4 & Ipiranga Pet PN & 2,18 & High & 475.162.998 & Small & 0,38 & Loser & Small|High|Loser & $16,85 \%$ & $11,93 \%$ & $16,44 \%$ & $-4,07 \%$ & $2,00 \%$ & $13,14 \%$ & $17,16 \%$ & $-14,04 \%$ & $5,28 \%$ & $4,35 \%$ & $-20,51 \%$ & $7,98 \%$ \\
\hline \begin{tabular}{|l|} 
PTIP3 \\
\end{tabular} & Ipiranga Pet ON & 2,18 & High & 475.162 .998 & Small & 0,33 & Loser & Small|High|Loser & $5,88 \%$ & $8,10 \%$ & $33,19 \%$ & $-8,33 \%$ & $0,00 \%$ & $16,37 \%$ & $60,00 \%$ & $-5,00 \%$ & $0,00 \%$ & $-29,47 \%$ & $-17,16 \%$ & $3,60 \%$ \\
\hline RPAD3 & Alfa Holding ON & 2,25 & High & 158.943 .783 & Small & 0,31 & Loser & Small|High|Loser & $6,11 \%$ & $0,10 \%$ & $14,97 \%$ & $16,28 \%$ & $-8,00 \%$ & $4,35 \%$ & $2,08 \%$ & $-11,15 \%$ & $31,16 \%$ & $0,00 \%$ & $-9,57 \%$ & $-1,96 \%$ \\
\hline CESP5 & Cesp PNA & 10,19 & High & 616.422 .173 & Small & 0,26 & Loser & Small|High|Loser & $-3,77 \%$ & $18,22 \%$ & $22,29 \%$ & $7,40 \%$ & $36,76 \%$ & $1,70 \%$ & $-8,65 \%$ & $-7,94 \%$ & $-8,79 \%$ & $-9,09 \%$ & $-14,90 \%$ & $17,04 \%$ \\
\hline CESP3 & Cesp ON & 10,19 & High & \begin{tabular}{|l|l|}
616.422 .173 \\
\end{tabular} & Small & 0,24 & Loser & Small|High|Loser & $0,48 \%$ & $7,77 \%$ & $17,65 \%$ & $5,00 \%$ & $36,90 \%$ & $-3,48 \%$ & $-5,41 \%$ & $-9,52 \%$ & $-2,32 \%$ & $-7,22 \%$ & $-13,47 \%$ & $11,95 \%$ \\
\hline BOBR4 & Bombril PN & 5,13 & High & \begin{tabular}{|l|}
211.920 .291 \\
\end{tabular} & Small & 0,24 & Loser & Small|High|Loser & $\begin{array}{l}-15,38 \% \\
\end{array}$ & $-20,45 \%$ & $11,43 \%$ & $33,59 \%$ & $9,21 \%$ & $-10,37 \%$ & $-31,37 \%$ & $-10,57 \%$ & $-9,27 \%$ & $10,92 \%$ & $0,95 \%$ & $20,75 \%$ \\
\hline COCE5 & Coelce PNA & 2,50 & High & 481.592.996 & Small & 0,20 & Loser & Small|High|Loser & $-1,37 \%$ & $23,97 \%$ & $5,11 \%$ & $8,57 \%$ & $14,47 \%$ & $0,18 \%$ & \begin{tabular}{|l|l|}
$17,69 \%$ & \\
\end{tabular} & $-5,81 \%$ & $3,13 \%$ & $2,61 \%$ & $-11,58 \%$ & $2,38 \%$ \\
\hline \begin{tabular}{|l|} 
PTNT4 \\
\end{tabular} & Pettenati PN & 4,28 & High & 21.059.838 & Small & 0,19 & Loser & Small|High|Loser & $-0,51 \%$ & $-1,71 \%$ & $4,01 \%$ & $6,20 \%$ & 3,68\% & $1,52 \%$ & $-5,00 \%$ & $3,16 \%$ & $-4,59 \%$ & $1,55 \%$ & $-5,74 \%$ & $6,09 \%$ \\
\hline LIPR3 & Eletropar ON & 6,12 & High & \begin{tabular}{|l|}
10.806 .481 \\
\end{tabular} & Small & 0,17 & Loser & Small|High|Loser & $-11,54 \%$ & $25,00 \%$ & $333,91 \%$ & $-8,82 \%$ & $61,54 \%$ & $14,97 \%$ & $9,94 \%$ & $-2,05 \%$ & $-0,55 \%$ & $-0,55 \%$ & $-6,22 \%$ & $0,71 \%$ \\
\hline BRGE3 & Alfa Consorc O & 2,52 & High & 171.391.430 & Small & 0,17 & Loser & Small||High|Loser & $0,42 \%$ & $-6,95 \%$ & $18,18 \%$ & $26,92 \%$ & $-12,12 \%$ & $0,00 \%$ & $3,79 \%$ & $-3,80 \%$ & $5,61 \%$ & $2,99 \%$ & $-9,35 \%$ & $-2,14 \%$ \\
\hline FLCL5 & F Cataguazes $P$ & 2,33 & High & 146.987.758 & Small & 0,14 & Loser & Small|High|Loser & $-2,68 \%$ & $-0,92 \%$ & $26,85 \%$ & $-12,41 \%$ & $26,67 \%$ & $-6,58 \%$ & $16,90 \%$ & $2,41 \%$ & $4,89 \%$ & $-3,23 \%$ & $-9,33 \%$ & $2,94 \%$ \\
\hline ARLA4 & Arthur Lange PN & 2,23 & High & 8.920 .204 & Small & 0,13 & Loser & Small|High|Loser & $15,00 \%$ & $0,00 \%$ & $26,09 \%$ & $6,90 \%$ & $-19,35 \%$ & $4,00 \%$ & $7,69 \%$ & $7,14 \%$ & $-6,67 \%$ & $-7,14 \%$ & $-11,54 \%$ & $30,43 \%$ \\
\hline TRFO4 & Trafo PN & 4,25 & High & 10.451 .500 & Small & 0,09 & Loser & Small|High|Loser & $2,00 \%$ & $11,76 \%$ & $8,77 \%$ & $0,00 \%$ & $14,52 \%$ & $2,82 \%$ & $\begin{array}{ll}9,59 \% \\
\end{array}$ & $-1,25 \%$ & \begin{tabular}{|l|l|}
$-7,59 \%$ \\
\end{tabular} & $-1,37 \%$ & $1,39 \%$ & $9,59 \%$ \\
\hline BRGE12 & Alfa Consorc PNF & 2,52 & High & 171.391.430 & Small & 0,07 & Loser & Small|High|Loser & $2,22 \%$ & $1,18 \%$ & $17,90 \%$ & $20,37 \%$ & $-18,15 \%$ & $-0,38 \%$ & $4,15 \%$ & $0,08 \%$ & $-0,37 \%$ & $1,85 \%$ & $-4,73 \%$ & $-2,67 \%$ \\
\hline GEPA3 & Ger Para & 3,06 & High & & Small & 0,05 & Loser & Small|High|Loser & $-1,41 \%$ & $2,86 \%$ & $1,59 \%$ & $5,71 \%$ & $4,05 \%$ & $10,39 \%$ & $17,65 \%$ & $20,00 \%$ & $12,50 \%$ & $11,11 \%$ & $2,41 \%$ & $-5,81 \%$ \\
\hline GEPA4 & Ger Paranap PN & 3,06 & High & \begin{tabular}{|l|l|}
660.742 .011 \\
\end{tabular} & Small & 0,03 & Loser & Small|High|Loser & $-1,43 \%$ & $1,45 \%$ & $12,09 \%$ & $-3,07 \%$ & $1,93 \%$ & $16,06 \%$ & $7,09 \%$ & $19,00 \%$ & $-0,55 \%$ & $-1,83 \%$ & $-20,01 \%$ & $9,73 \%$ \\
\hline PLDN4 & Polialden PN & 2,21 & High & 233.575 .137 & Small & 0,00 & Loser & Small|High|Loser & $9,12 \%$ & $8,86 \%$ & $9,30 \%$ & $-10,64 \%$ & $34,52 \%$ & $12,39 \%$ & $-2,68 \%$ & $5,18 \%$ & $-0,31 \%$ & $-10,49 \%$ & $-12,49 \%$ & $1,73 \%$ \\
\hline ELEV3 & Eleva ON & 2,87 & High & 122.874 .440 & Small & & Winner & Small|High|Winner & $0,00 \%$ & $5,26 \%$ & $17,50 \%$ & $-7,23 \%$ & $60,55 \%$ & $-8,57 \%$ & $25,00 \%$ & $0,00 \%$ & $7,25 \%$ & $17,72 \%$ & $-0,28 \%$ & $2,00 \%$ \\
\hline BDLL4 & Bardella PI & 3,51 & High & 70.400 .000 & Small & 0,02 & Winner & Small|High|Winner & $-7,95 \%$ & $6,17 \%$ & $6,98 \%$ & $17,17 \%$ & $1,30 \%$ & $23,63 \%$ & $-2,22 \%$ & $-1,52 \%$ & $1,52 \%$ & $4,11 \%$ & $-9,24 \%$ & $3,51 \%$ \\
\hline FBRA4 & Fertibras PN & 2,04 & High & 80.728 .000 & Small & 0,04 & Winner & Small|High|Winner & $12,50 \%$ & $38,14 \%$ & $18,18 \%$ & $15,38 \%$ & $12,87 \%$ & $20,56 \%$ & $-12,44 \%$ & $0,00 \%$ & $18,37 \%$ & $-11,52 \%$ & $0,05 \%$ & $21,05 \%$ \\
\hline IENG5 & Ienergia PNA & 4,84 & High & 52.689 .260 & Small & 0,07 & Winner & Small|High|Winner & $-14,29 \%$ & $0,00 \%$ & $58,33 \%$ & $-26,32 \%$ & $7,14 \%$ & $-6,67 \%$ & $14,29 \%$ & $0,00 \%$ & $-6,25 \%$ & $-6,67 \%$ & $-14,29 \%$ & $25,00 \%$ \\
\hline MYPK4 & Iochp-Maxion PN & 2,57 & High & 71.863 .607 & Small & 0,10 & Winner & Small|High|Winner & $-0,74 \%$ & $38,06 \%$ & $51,35 \%$ & $51,79 \%$ & $2,24 \%$ & $-4,49 \%$ & $14,46 \%$ & $-11,32 \%$ & $-6,24 \%$ & $7,61 \%$ & $-7,65 \%$ & $8,28 \%$ \\
\hline PTBL3 & Portobello ON & 1,87 & High & 43.756 .650 & Small & 0,17 & Winner & Small|High|Winner & $-3,23 \%$ & $33,33 \%$ & $10,00 \%$ & $0,00 \%$ & $36,36 \%$ & $5,00 \%$ & $31,75 \%$ & $-3,61 \%$ & $-12,50 \%$ & $-21,43 \%$ & $25,45 \%$ & $30,43 \%$ \\
\hline IGBR5 & IGB S/A PNA & 3,55 & High & 525.000 & Small & 0,28 & Winner & Small|High|Winner & $-10,00 \%$ & $-4,89 \%$ & $19,16 \%$ & $17,84 \%$ & $-0,17 \%$ & $-5,00 \%$ & $-11,40 \%$ & $5,74 \%$ & $-17,98 \%$ & $-10,96 \%$ & $12,31 \%$ & $-5,25 \%$ \\
\hline CGRA4 & Grazziotin PN & 2,94 & High & 38.761 .189 & Small & 0,41 & Winner & Small||High|Winner & $0,00 \%$ & $0,20 \%$ & $17,11 \%$ & $11,30 \%$ & $0,00 \%$ & $9,37 \%$ & $10,10 \%$ & $-3,36 \%$ & $0,00 \%$ & $8,56 \%$ & $-29,03 \%$ & $27,36 \%$ \\
\hline SZPQ4 & Quattor Petr PN & 2,74 & High & 384.879.302 & Small & 0,49 & Winner & Small|High|Winner & $3,45 \%$ & $26,11 \%$ & $8,81 \%$ & $-2,83 \%$ & $6,25 \%$ & $21,57 \%$ & $16,13 \%$ & $13,61 \%$ & $-4,65 \%$ & $-0,38 \%$ & $-9,09 \%$ & $8,57 \%$ \\
\hline \begin{tabular}{|l|l|} 
ALPA3 \\
\end{tabular} & Alpargatas ON & 1,97 & High & 320.269 .025 & Small & 0,56 & Winner & Small|High | Winner & $55,56 \%$ & $-31,80 \%$ & $1,05 \%$ & $-1,04 \%$ & $-5,27 \%$ & $17,61 \%$ & $-7,04 \%$ & $5,80 \%$ & $-7,18 \%$ & $4,97 \%$ & $-3,72 \%$ & $19,44 \%$ \\
\hline ROMI4 & Inds Rc & 2,51 & High & 8.230 .069 & Small & 0,60 & Winner & Small| High | Winner & $13,58 \%$ & $10,87 \%$ & $11,76 \%$ & $12,28 \%$ & $9,37 \%$ & $7,14 \%$ & $0,00 \%$ & $-2,00 \%$ & $14,15 \%$ & $-3,58 \%$ & $-12,24 \%$ & $5,63 \%$ \\
\hline MEND6 & Mendes Jr PNB & 2,52 & High & 714.812 & Small & 0,60 & Winner & Small|High|Winner & $-5,26 \%$ & $2,78 \%$ & $-5,41 \%$ & $-17,14 \%$ & $24,10 \%$ & $5,58 \%$ & $-14,47 \%$ & $1,54 \%$ & $-3,03 \%$ & $-5,59 \%$ & $-0,70 \%$ & $10,00 \%$ \\
\hline MEND5 & Mendes Jr PNA & 2,52 & High & 132.714 .812 & Small & 0,67 & Winner & Small|High|Winner & $-7,50 \%$ & $14,32 \%$ & $-0,71 \%$ & $-19,05 \%$ & $12,62 \%$ & $1,85 \%$ & $-7,69 \%$ & $-5,00 \%$ & $-6,43 \%$ & $-6,22 \%$ & $-0,03 \%$ & $11,67 \%$ \\
\hline ALPA4 & Alparga & 1,97 & High & 320.269 .025 & Small & 0,67 & Winner & Small|High|Winner & $2,50 \%$ & $1,63 \%$ & $5,33 \%$ & $-4,49 \%$ & $11,75 \%$ & $12,11 \%$ & $-3,00 \%$ & $-1,70 \%$ & $5,26 \%$ & $0,00 \%$ & $1,77 \%$ & $22,00 \%$ \\
\hline MGEL4 & Mangels Ind PN & 8,81 & High & 31.320 .278 & Small & 1,03 & Winner & Small|High/Winner & $15,04 \%$ & $15,38 \%$ & $11,11 \%$ | & $-12,00 \%$ & $1,14 \% \mathrm{f}$ & $4,27 \%$ & $-5,82 \%$ & $-2,75 \%$ & $8,24 \%$ & $-0,81 \%$ & $10,34 \%$ & $3,13 \%$ \\
\hline MAGSS & Magnesita PNA & 2,62 & High & 281.589.311 & Small & 1,06 & Winner & Small||High|Winner & $1,93 \%$ & $7,56 \%$ & $3,78 \%$ & $6,64 \%$ & $18,44 \%$ & $10,31 \%$ & $2,48 \%$ & $-4,35 \%$ & $0,00 \%$ & $-0,51 \%$ & $-8,54 \%$ & $-0,11 \%$ \\
\hline \begin{tabular}{|l|l|} 
NETC4 \\
\end{tabular} & Net PN & 0,12 & Low & 668.087 & Small & 0,89 & Loser & Small|Low|Loser & $10,34 \%$ & $12,50 \%$ & $66,67 \%$ & $26,67 \%$ & $43,42 \%$ & $-16,51 \%$ & $-25,27 \%$ & $-7,35 \%$ & $31,75 \%$ & $-12,05 \%$ & $5,48 \%$ & $-16,88 \%$ \\
\hline RIPI4 & Ipiranga Ref PN & 0,06 & Low & $\begin{array}{ll}157.845 .688 \\
\end{array}$ & Small & 0,63 & Loser & Small|Low|Loser & $-4,76 \%$ & $4,50 \%$ & $25,36 \%$ & $3,51 \%$ & $13,94 \%$ & $31,97 \%$ & $22,61 \%$ & $-6,00 \%$ & $-0,64 \%$ & $-5,78 \%$ & $-20,91 \%$ & $-3,51 \%$ \\
\hline RHDS3 & M G Poliest ON & 0,60 & Low & 262.090 .650 & Small & 0,43 & Loser & Small|Low|Loser & $-15,38 \%$ & $45,45 \%$ & $-6,25 \%$ & $33,33 \%$ & $15,00 \%$ & $-8,70 \%$ & $-9,52 \%$ & $-5,26 \%$ & $5,56 \%$ & $-10,53 \%$ & $-29,41 \%$ & $0,00 \%$ \\
\hline CBEE3 & Ampla Energ ON & 0,62 & Low & 608.068.408 & Small & 0,41 & Loser & Small | Low |Loser & $-19,05 \%$ & $5,88 \%$ & $38,89 \%$ & $12,00 \%$ & $82,14 \%$ & $-13,73 \%$ & $-4,55 \%$ & $16,67 \%$ & $-4,08 \%$ & $-2,13 \%$ & $-10,87 \%$ & $2,44 \%$ \\
\hline GLOB4 & Globex & 0,92 & Low & 160.791 & Small & 0,28 & Loser & Small|Low|Loser & $13,16 \%$ & $10,47 \%$ & $17,16 \%$ & $-2,70 \%$ & $-21,51 \%$ & $38,82 \%$ & $-2,54 \%$ & $-13,04 \%$ & $-24,27 \%$ & $-8,00 \%$ & $17,96 \%$ & $23,21 \%$ \\
\hline PLTO6 & Politeno PNB & 0,31 & Low & 240.880 .512 & Small & 0,25 & Loser & Small|Low|Loser & $15,38 \%$ & $5,00 \%$ & $11,11 \%$ & $0,19 \%$ & $-0,75 \%$ & $-11,28 \%$ & \begin{tabular}{|l|l|}
$11,86 \%$ \\
\end{tabular} & $-9,09 \%$ & $-19,00 \%$ & $2,47 \%$ & $-10,64 \%$ & $7,64 \%$ \\
\hline HGTX4 & Cia Hering PN & 0,08 & Low & 53.983 .052 & Small & 0,17 & Loser & Small|Low|Loser & $-5,00 \%$ & $57,89 \%$ & $26,67 \%$ & $13,16 \%$ & $-11,63 \%$ & $10,53 \%$ & $-16,67 \%$ & $-14,29 \%$ & $0,00 \%$ & $-6,67 \%$ & $-13,93 \%$ & $-2,49 \%$ \\
\hline SLED4 & Saraiva Livr PN & 0,43 & Low & 204.130.391 & Small & 0,04 & Winne: & Small|Low|Winne & $-2,25 \%$ & $3,45 \%$ & $-8,89 \%$ & $-6,71 \%$ & $11,11 \%$ & $17,06 \%$ & $-3,02 \%$ & $3,63 \%$ & $2,81 \%$ & $-13,06 \%$ & $5,63 \%$ & 2000 \\
\hline POMO4 & Mar & 0,75 & Low & 7 & Smal & & & & $-5,77 \%$ & $12,24 \%$ & $5,19 \%$ & $-2,22 \%$ & 9,85 & 16,8 & $14,79 \%$ & $-5,63 \%$ & 9,6 & $-12,11 \%$ & $5,59 \%$ & \\
\hline ITEC3 & Itautec ON & 0,65 & Low & 573.433.833 & Small & 0,28 & Winner & Small|Low|Winner & $-2,74 \%$ & $6,83 \%$ & $-8,55 \%$ & $1,29 \%$ & $0,32 \%$ & $9,52 \%$ & $20,29 \%$ & $-15,33 \%$ & $-19,48 \%$ & $6,05 \%$ & $-9,40 \%$ & $41 \%$ \\
\hline PMAM4 & Paranapanema PN & 0,85 & Low & 554.963.343 & Small & 0,57 & Winner & Small|Low|Winner & $-12,94 \%$ & $30,63 \%$ & $44,83 \%$ & $15,48 \%$ & $-0,82 \%$ & $-1,25 \%$ & $-17,89 \%$ & $-8,46 \%$ & $10,64 \%$ & $-8,61 \%$ & $-12,47 \%$ & $4,43 \%$ \\
\hline
\end{tabular}


Anexo 1 - Retorno mensal e classificação das ações

\begin{tabular}{|c|c|c|c|c|c|c|c|c|c|c|c|c|c|c|c|c|c|c|c|c|}
\hline Código & $2003-2004$ & $\begin{array}{l}\text { Índice } B / M \\
\text { de dez/2002 }\end{array}$ & \begin{tabular}{|c} 
Grupo com \\
base no \\
indice B/M
\end{tabular} & $\begin{array}{c}\text { Valor de Mercado } \\
\text { em jun/2003 }\end{array}$ & $\begin{array}{c}\text { Grupo com } \\
\text { base no } \\
\text { tamanho }\end{array}$ & \begin{tabular}{|c|} 
Retorno \\
acumulado \\
de jun/2003
\end{tabular} & \begin{tabular}{|c|} 
Grupo com \\
base no \\
retorno \\
acumulado
\end{tabular} & Carteiras & $\mathrm{jul} / 03$ & ago/03 & set/03 & out/03 & nov/03 & dez/03 & $\mathrm{jan} / 04$ & fev/04 & $\operatorname{mar} / 04$ & abr/04 & mai/04 & jun/04 \\
\hline LEVE4 & Metal Leve PN & 0,82 & Low & 612.116 .772 & Small & 0,65 & \begin{tabular}{|l|} 
Winner \\
\end{tabular} & Small|Low|Winner & $13,43 \%$ & $11,84 \%$ & $0,00 \%$ & $4,12 \%$ & $6,10 \%$ & $14,50 \%$ & $12,38 \%$ & $6,63 \%$ & $4,53 \%$ & $-2,77 \%$ & $-8,94 \%$ & $15,18 \%$ \\
\hline ILMD4 & Yara Brasil PN & 0,69 & Low & 248.953 .466 & Small & 0,87 & Winner & Small|Low|Winner & $0,84 \%$ & $60,00 \%$ & $-6,77 \%$ & $7,82 \%$ & $22,80 \%$ & $7,59 \%$ & $28,24 \%$ & $-3,36 \%$ & $-12,03 \%$ & $-9,35 \%$ & $29,18 \%$ & $12,24 \%$ \\
\hline RAPT4 & Randon Part PN & 0,63 & Low & 217.590 .194 & Small & 1,04 & Winner & Small|Low|Winner & $20,69 \%$ & $14,29 \%$ & $13,50 \%$ & $17,62 \%$ & $-7,49 \%$ & $16,60 \%$ & $4,17 \%$ & $20,00 \%$ & $7,50 \%$ & $-3,62 \%$ & $3,41 \%$ & $22,25 \%$ \\
\hline FRAS4 & Fras-Le PN & 0,64 & Low & 142.650 .866 & Small & 1,34 & Winner & Small|Low|Winner & $1,91 \%$ & $15,02 \%$ & $-6,12 \%$ & $11,74 \%$ & $-0,39 \%$ & $7,26 \%$ & $14,23 \%$ & $3,93 \%$ & $16,40 \%$ & $22,86 \%$ & $15,68 \%$ & $37,52 \%$ \\
\hline TLCP3 & Tele Leste Celular ON & 1,77 & Medium & 217.596.138 & Small & 0,64 & Loser & Small|Medium|Loser & $12,50 \%$ & $1,85 \%$ & $23,64 \%$ & $2,94 \%$ & $1,43 \%$ & $16,90 \%$ & $-2,41 \%$ & $-11,11 \%$ & $-4,17 \%$ & $-4,35 \%$ & $0,00 \%$ & $4,55 \%$ \\
\hline IDNT3 & Ideiasnet ON & 1,69 & Medium & 16.507 .313 & Small & 0,61 & Loser & Small|Medium|Loser & $0,00 \%$ & $4,62 \%$ & $16,18 \%$ & $0,00 \%$ & $-3,80 \%$ & $-1,32 \%$ & $0,00 \%$ & $-9,33 \%$ & $16,18 \%$ & $-11,39 \%$ & $-4,29 \%$ & $-12,73 \%$ \\
\hline TDBH4 & Telefonica Data HId PN & 1,55 & Medium & 371.266 .575 & Small & 0,46 & Loser & Small|Medium|Loser & $0,00 \%$ & $-2,78 \%$ & $45,71 \%$ & $-1,96 \%$ & $-4,00 \%$ & $29,17 \%$ & $1,61 \%$ & $-12,70 \%$ & $-3,64 \%$ & $-1,89 \%$ & $-9,62 \%$ & $-2,13 \%$ \\
\hline TEKA4 & Teka PN & 1,10 & Medium & 21.865 .064 & Small & 0,43 & Loser & Small|Medium|Loser & $-10,53 \%$ & $-1,96 \%$ & $2,00 \%$ & $7,84 \%$ & $3,64 \%$ & $10,53 \%$ & $-9,52 \%$ & $-12,28 \%$ & $-10,00 \%$ & $-8,89 \%$ & $-2,44 \%$ & $2,50 \%$ \\
\hline ESCE3 & Escelsa ON & 1,23 & Medium & 150.177 .489 & Small & 0,42 & Loser & Small|Medium|Loser & $-9,09 \%$ & $40,00 \%$ & $28,57 \%$ & $0,93 \%$ & $6,42 \%$ & $20,69 \%$ & $-2,86 \%$ & $-1,47 \%$ & $32,93 \%$ & $-1,89 \%$ & $1,14 \%$ & $3,25 \%$ \\
\hline TDBH3 & Telefonica Data HId ON & 1,55 & Medium & 371.266 .575 & Small & 0,39 & Loser & Small|Medium|Loser & $3,13 \%$ & $0,00 \%$ & $51,52 \%$ & $-16,00 \%$ & $2,38 \%$ & $27,91 \%$ & $3,64 \%$ & $-19,30 \%$ & $-6,52 \%$ & $-2,33 \%$ & $0,00 \%$ & $0,00 \%$ \\
\hline CPFG4 & CPFL Ger & 1,37 & Medium & 4.695.455 & Small & 0,38 & Loser & Small|Medium|Loser & $-1,67 \%$ & $14,41 \%$ & $37,78 \%$ & $-13,71 \%$ & $22,43 \%$ & $63,10 \%$ & $2,96 \%$ & $10,61 \%$ & $-17,81 \%$ & $9,83 \%$ & $-15,47 \%$ & $2,33 \%$ \\
\hline TLCP4 & Tele Leste $\mathrm{Ce}$ & 1,77 & Medium & 217.596 .138 & Small & 0,37 & Loser & Small|Medium|Loser & $-4,55 \%$ & $4,76 \%$ & $18,18 \%$ & $11,54 \%$ & $12,07 \%$ & $24,62 \%$ & $-11,11 \%$ & $-12,50 \%$ & $1,59 \%$ & $0,00 \%$ & $14,06 \%$ & $10,96 \%$ \\
\hline CPFG3 & CPFL Geracao ON & 1,37 & Medium & 334.695 .455 & Small & 0,36 & Loser & Small|Medium|Loser & $-4,00 \%$ & $12,50 \%$ & $58,89 \%$ & $-30,07 \%$ & $16,67 \%$ & $83,14 \%$ & $6,08 \%$ & $5,88 \%$ & $-8,47 \%$ & $2,58 \%$ & $-11,41 \%$ & $5,64 \%$ \\
\hline TNCP4 & Tele Nort Cl PN & 1,53 & \begin{tabular}{|l|} 
Medium \\
\end{tabular} & 148.047 .541 & Small & 0,27 & Loser & Small|Medium|Loser & $0,00 \%$ & $-2,78 \%$ & $22,86 \%$ & $6,98 \%$ & $21,74 \%$ & $14,29 \%$ & $-1,56 \%$ & $-6,35 \%$ & $3,39 \%$ & $0,01 \%$ & $-6,78 \%$ & $1,82 \%$ \\
\hline TNCP3 & Tele $\mathrm{N}$ & 1,53 & Medium & 047.541 & Small & 0,27 & Loser & Small|Medium|Loser & $-18,97 \%$ & $6,38 \%$ & $6,00 \%$ & $16,98 \%$ & $9,68 \%$ & $67,65 \%$ & $-7,02 \%$ & $-18,87 \%$ & $0,00 \%$ & $-6,98 \%$ & $-7,50 \%$ & $-5,41 \%$ \\
\hline DPPI4 & Ipiran & 7 & Medium & & $\mathrm{Sm}$ & 0,25 & Los & Small|Me & 1,950 & $5,09 \%$ & $19,56 \%$ & $-0,04 \%$ & $-4,49 \%$ & $10,60 \%$ & $6,12 \%$ & $5,38 \%$ & $2,19 \%$ & $1,39 \%$ & $-15,29 \%$ & $6,44 \%$ \\
\hline SAPR4 & Sanepar PN & 1,74 & Medium & 654.249 .865 & Small & 0,25 & Loser & Small|Medium|Loser & $-5,06 \%$ & $9,33 \%$ & $-2,44 \%$ & $1,25 \%$ & $1,23 \%$ & $33,54 \%$ & $-13,88 \%$ & $0,60 \%$ & $4,79 \%$ & $-3,43 \%$ & $-3,55 \%$ & $7,36 \%$ \\
\hline PRGA4 & BRF Foods PN & 1,26 & Medium & 531.881.215 & Small & 0,24 & Loser & Small|Medium|Loser & $15,65 \%$ & $21,92 \%$ & $1,25 \%$ & $2,58 \%$ & $11,31 \%$ & $31,22 \%$ & $19,03 \%$ & $2,38 \%$ & $1,99 \%$ & $-14,27 \%$ & $4,86 \%$ & $13,03 \%$ \\
\hline INEP4 & Inepz & 64 & Medium & 558.100 & Small & 0,22 & Loser & Small|Medium |Loser & $-10,26 \%$ & $-8,57 \%$ & $28,13 \%$ & $14,63 \%$ & $2,13 \%$ & $-8,33 \%$ & & $5,66 \%$ & $-14,29 \%$ & $0,00 \%$ & $-10,42 \%$ & $11,63 \%$ \\
\hline CLSC6 & & & $+a^{2}$ & & & & Loser & Small|M & $-4,35 \%$ & $4,55 \%$ & $26,09 \%$ & $1,72 \%$ & $27,12 \%$ & $13,01 \%$ & -6 , & 3, & $24,05 \%$ & $-10,20 \%$ & $-4,55 \%$ & $-1,19 \%$ \\
\hline \begin{tabular}{|l|} 
BMTO4 \\
\end{tabular} & Brasmotor PN & 1,68 & Medium & 398.157 .712 & Small & 0,12 & \begin{tabular}{|l|} 
Loser \\
\end{tabular} & Small|Medium|Loser & $7,91 \%$ & $-8,67 \%$ & $5,84 \%$ & $6,90 \%$ & $8,38 \%$ & $-7,73 \%$ & $0,00 \%$ & $-3,23 \%$ & $-6,67 \%$ & $9,29 \%$ & $1,31 \%$ & $2,26 \%$ \\
\hline SGAS4 & WIm Ind Com PN & 1,76 & Medium & 51.108 .075 & Small & 0,09 & Loser & Small|Medium|Loser & $-7,89 \%$ & $5,71 \%$ & $43,24 \%$ & $-13,21 \%$ & $-8,70 \%$ & $-0,95 \%$ & $-10,58 \%$ & $2,15 \%$ & $2,63 \%$ & $-12,82 \%$ & $15,88 \%$ & $73,60 \%$ \\
\hline TPEC6B & Tim Nordeste PNB & 67 & Medium & 13.045 & Small & 0,06 & Loser & Small|Medium|Loser & $6,95 \%$ & $-5,00 \%$ & $7,89 \%$ & $16,10 \%$ & $26,89 \%$ & $5,96 \%$ & $16,75 \%$ & $-5,69 \%$ & $5,29 \%$ & $-2,23 \%$ & $1,43 \%$ & $0,00 \%$ \\
\hline ALBA3 & & & $F$ & & $\mathrm{Sm}$ & 07 & Wir & m $/$ Winner & $2,41 \%$ & $15,29 \%$ & $13,27 \%$ & $-5,41 \%$ & $7,62 \%$ & $5,31 \%$ & $-4,20 \%$ & $10,28 \%$ & $1,69 \%$ & $12,50 \%$ & $5,19 \%$ & $0,70 \%$ \\
\hline RPSA4 & Ripasa PN & 76 & Medium & 857.795 & Small & 0,09 & Winner & Small|Medium|Winner & $15,24 \%$ & $30,16 \%$ & $4,47 \%$ & $-0,17 \%$ & $6,43 \%$ & $19,25 \%$ & $-8,54 \%$ & $-3,11 \%$ & $5,71 \%$ & $-14,33 \%$ & $7,14 \%$ & $2,96 \%$ \\
\hline SALM4 & Seara Alim PI & 40 & Medium & 412.001 & Small & 0,20 & Winner & Small|Medium|Winner & $6,79 \%$ & $8,03 \%$ & $28,59 \%$ & $7,50 \%$ & $0,00 \%$ & $16,28 \%$ & $18,00 \%$ & $3,39 \%$ & $11,08 \%$ & $-11,94 \%$ & $-15,25 \%$ & $-6,00 \%$ \\
\hline SALM3 & Seara & 40 & Medi & 001 & Small & 0,22 & Winner & Small|Medium|Winner & $6,52 \%$ & $2,04 \%$ & $43,14 \%$ & $5,78 \%$ & $-3,19 \%$ & $17,65 \%$ & $20,00 \%$ & $5,00 \%$ & $18,48 \%$ & $-12,16 \%$ & $0,00 \%$ & $-15,23 \%$ \\
\hline TPEC3B & $\operatorname{Tim~N}$ & 1,67 & Medium & 613.045 & Small & 0,28 & Winner & Small|Medium|Winner & $0,00 \%$ & $11,11 \%$ & $-5,00 \%$ & $55,26 \%$ & $1,69 \%$ & $13,33 \%$ & $5,88 \%$ & $-0,28 \%$ & $-3,90 \%$ & $-6,96 \%$ & $5,76 \%$ & $-11.63 \%$ \\
\hline UNIP3 & & 88 & Medic & & $\mathrm{Sm}$ & 1 & $F$ & Small $\mid \mathrm{M}$ & $0,51 \%$ & $-5,03 \%$ & $0,53 \%$ & $15,79 \%$ & $-8,30 \%$ & $20,00 \%$ & 22,8 & $-3,45 \%$ & $0,00 \%$ & $3,43 \%$ & $-6,67 \%$ & $-1,79 \%$ \\
\hline FJTA4 & us PN & 0 & Mediu & 397 & $\mathrm{Sm}$ & 4 & Win & Small|Medium /Winner & $-8,76 \%$ & $10,40 \%$ & $-5,80 \%$ & $-6,92 \%$ & $10,02 \%$ & $12,00 \%$ & $-1,43 \%$ & $2,17 \%$ & $10,64 \%$ & $-5,77 \%$ & $0,68 \%$ & $-5,41 \%$ \\
\hline UNIP6 & Unipar & & M & & Small & 45 & Wir & Small|Medium|Winner & $6,43 \%$ & $25,50 \%$ & $3,21 \%$ & $3,11 \%$ & $-0,01 \%$ & $19,29 \%$ & $12,55 \%$ & $8,85 \%$ & $5,65 \%$ & $-19,06 \%$ & $-8,00 \%$ & $14,13 \%$ \\
\hline ESTR4 & Estrela PN & 1,62 & Medium & 13.741 .950 & Small & 0,51 & Winner & Small|Medium |Winner & $29,41 \%$ & $18,18 \%$ & $42,31 \%$ & $-2,70 \%$ & $2,78 \%$ & $-1,62 \%$ & $9,89 \%$ & $7,50 \%$ & $-5,12 \%$ & $-1,96 \%$ & $10,00 \%$ & $9,09 \%$ \\
\hline SCAR3 & Sao Ca & 84 & not. & 0.837 .062 & Smal & 61 & Winn & Small|Medium /Winner & $-23,23 \%$ & $26,05 \%$ & $-8,33 \%$ & $-16,36 \%$ & $14,13 \%$ & $-4,86 \%$ & $0,00 \%$ & $-7,91 \%$ & $0,00 \%$ & $0,00 \%$ & $1,64 \%$ & $3,15 \%$ \\
\hline \begin{tabular}{|l} 
SCAR4 \\
\end{tabular} & Sa & 4 & Medic & 062 & $\mathrm{sm}$ & 2 & Wir & Small|Medium |Winner & $-11,69 \%$ & $9,43 \%$ & $-4,26 \%$ & $-16,36 \%$ & $8,70 \%$ & $-7,90 \%$ & -0, & 0,0 & & $0,00 \%$ & 1,6 & $-0,54 \%$ \\
\hline GUAR4 & Guararapes PN & 1,50 & Medium & 680.003 & Small & 0,64 & Winner & Small|Medium|Winner & $7,14 \%$ & $17,33 \%$ & $19,32 \%$ & $7,71 \%$ & $1,68 \%$ & $-8,70 \%$ & $-7,62 \%$ & $0,00 \%$ & $0,93 \%$ & $-1,94 \%$ & $4,14 \%$ & $11,22 \%$ \\
\hline MTSA4 & Metisa PN & 1,10 & Medium & 36.405 .106 & Small & 0,68 & Winner & Small|Medium|Winner & $0,00 \%$ & $5,56 \%$ & $10,53 \%$ & $4,76 \%$ & $2,27 \%$ & $10,19 \%$ & $7,76 \%$ & $9,00 \%$ & $6,42 \%$ & $1,72 \%$ & $1,69 \%$ & $8,33 \%$ \\
\hline ASTA4 & Santistextil & 1,54 & Mediu & 695.202 & Small & 81 & Winner & Small|Me & $13,79 \%$ & $-5,09 \%$ & $9,68 \%$ & $0,00 \%$ & $-8,82 \%$ & $12,71 \%$ & $10,15 \%$ & $0,27 \%$ & $7,86 \%$ & $4,02 \%$ & $-8,21 \%$ & $1,58 \%$ \\
\hline CNFE & & & & & $\mathrm{Sn}$ & & & 5 & 1,3 & 10020 & $-6,2$ & & $5,01 \%$ & & $-0,1$ & & & -22, & & \\
\hline \begin{tabular}{|l|l|} 
RSIP4 \\
\end{tabular} & Rasip Agro PN & 1,31 & \begin{tabular}{|l|l|} 
Medit \\
\end{tabular} & 15.83 & Small & 1,01 & \begin{tabular}{|l|} 
Winner \\
\end{tabular} & Small|Medium|Winner & $0,00 \%$ & $0,00 \%$ & $23,08 \%$ & $43,75 \%$ & $-17,39 \%$ & $10,53 \%$ & $-4,76 \%$ & $0,00 \%$ & $15,00 \%$ & $0,00 \%$ & $0,00 \%$ & $4,35 \%$ \\
\hline ETER3 & Eternit & 1,31 & Medit & 172.340 .089 & Small & 1,05 & Wir & Small|Medium|Winner & $-2,40 \%$ & $-7,17 \%$ & $8,17 \%$ & $0,00 \%$ & $-5,27 \%$ & $20,00 \%$ & $3,33 \%$ & $8,52 \%$ & $-0,34 \%$ & $-2,08 \%$ & $-2,89 \%$ & $15,20 \%$ \\
\hline FESA4 & Ferbasa PN & 1,69 & Medium & 253.805 .005 & Small & 1,36 & Winner & Small|Medium|Winner & $11,74 \%$ & $10,89 \%$ & $.02 \%$ & $-4,92 \%$ & $-1,72 \%$ & $6,32 \%$ & $15,51 \%$ & $2,86 \%$ & $5,83 \%$ & $-5,40 \%$ & $-3,79 \%$ & $3,03 \%$ \\
\hline
\end{tabular}


Anexo 1 - Retorno mensal e classificação das ações

\begin{tabular}{|c|c|c|c|c|c|c|c|c|c|c|c|c|c|c|c|c|c|c|c|c|}
\hline Código & 2004-2005 & $\begin{array}{l}\text { Índice } B / M \\
\text { de dez/2003 }\end{array}$ & $\begin{array}{c}\text { Grupo com } \\
\text { base no } \\
\text { indice } B / M\end{array}$ & $\begin{array}{c}\text { Valor de Mercado } \\
\text { em jun/2004 }\end{array}$ & $\begin{array}{c}\text { Grupo com } \\
\text { base no } \\
\text { tamanho }\end{array}$ & \begin{tabular}{|c|} 
Retorno \\
acumulado \\
de jun/2004
\end{tabular} & $\begin{array}{l}\text { Grupo com } \\
\text { base no } \\
\text { retorno } \\
\text { acumulado }\end{array}$ & Carteiras & $\mathrm{jul} / 04$ & ago/04 & set/04 & out/04 & nov/04 & dez/04 & jan/05 & $\mathrm{fev} / 05$ & $\mathrm{mar} / 05$ & $\mathrm{abr} / 05$ & mai/05 & jun/05 \\
\hline PALF7 & Paul F Luz PNC & 1,46 & High & \begin{tabular}{|l|}
2.498 .622 .285 \\
\end{tabular} & Big & 0,04 & Loser & Big|High|Loser & $-7,79 \%$ & $38,03 \%$ & $22,44 \%$ & $-16,66 \%$ & $20,00 \%$ & $-12,08 \%$ & $13,74 \%$ & $20,00 \%$ & $-13,19 \%$ & $0,00 \%$ & $20,00 \%$ & $3,33 \%$ \\
\hline CPLE6 & Copel PNB & 1,61 & High & 2.359 .043 .311 & Big & 0,01 & Loser & Big|High|Loser & $9,45 \%$ & $-9,09 \%$ & $2,30 \%$ & $0,20 \%$ & $22,15 \%$ & $-7,35 \%$ & $1,29 \%$ & $20,77 \%$ & $-11,84 \%$ & $13,44 \%$ & $0,07 \%$ & $-3,48 \%$ \\
\hline CPLE3 & Copel ON & 1,61 & High & \begin{tabular}{|l|}
2.359 .043 .311 \\
\end{tabular} & Big & 0,04 & Loser & Big|High|Loser & $4,63 \%$ & $4,03 \%$ & $4,38 \%$ & $1,80 \%$ & $18,82 \%$ & $-2,97 \%$ & $5,00 \%$ & $10,59 \%$ & $-6,06 \%$ & $1,35 \%$ & $3,34 \%$ & $1,29 \%$ \\
\hline PALF3 & Paul F Luz ON & 1,46 & High & 2.498 .622 .285 & Big & 0,06 & Loser & Big|High|Loser & $23,10 \%$ & $34,94 \%$ & $16,07 \%$ & $-23,55 \%$ & $40,87 \%$ & $-14,28 \%$ & $2,46 \%$ & $32,23 \%$ & $-18,75 \%$ & $7,68 \%$ & $13,48 \%$ & $0,00 \%$ \\
\hline ELET6 & Eletrobras PNB & 2,63 & High & 16.542 .736 .601 & Big & 0,29 & Loser & Big|High|Loser & $35,15 \%$ & $-8,39 \%$ & $11,81 \%$ & $-0,64 \%$ & $2,89 \%$ & $-9,78 \%$ & $-16,10 \%$ & $10,06 \%$ & $-5,52 \%$ & $-4,65 \%$ & $10,44 \%$ & $-8,21 \%$ \\
\hline ELET3 & Eletrobras ON & 2,63 & High & 16.542 .736 .601 & Big & 0,31 & Loser & Big|High|Loser & $41,47 \%$ & $-7,71 \%$ & $13,68 \%$ & $-1,97 \%$ & $-1,79 \%$ & $-12,50 \%$ & $-11,95 \%$ & $11,47 \%$ & $-6,09 \%$ & $-11,52 \%$ & $15,06 \%$ & $-8,13 \%$ \\
\hline SBSP3 & Sabesp ON & 1,63 & High & 3.816.263.318 & Big & 0,38 & Loser & Big|High|Loser & \begin{tabular}{l|l|}
$4,49 \%$ \\
\end{tabular} & $-0,49 \%$ & $-3,81 \%$ & $-13,45 \%$ & $25,84 \%$ & $9,95 \%$ & $-12,51 \%$ & $14,74 \%$ & $-17,03 \%$ & $0,96 \%$ & $9,04 \%$ & $-0,36 \%$ \\
\hline TRPL4 & Tran Paulist PN & 1,79 & High & 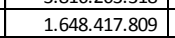 & Big & 0,42 & Loser & Big|High|Loser & $12,39 \%$ & $-0,68 \%$ & $-7,43 \%$ & $0,91 \%$ & $5,66 \%$ & $16,11 \%$ & $-2,33 \%$ & $27,21 \%$ & $-7,99 \%$ & $13,24 \%$ & $10,00 \%$ & $9,52 \%$ \\
\hline TRPL3 & Tran Paulist ON & 1,79 & High & 1.648 .417 .809 & Big & 0,47 & Loser & Big|High|Loser & $14,02 \%$ & $0,87 \%$ & $-5,58 \%$ & $-4,55 \%$ & $4,76 \%$ & $13,30 \%$ & $-0,83 \%$ & $55,83 \%$ & $-13,37 \%$ & $11,05 \%$ & $33,13 \%$ & $7,94 \%$ \\
\hline GEPA4 & Ger Paranap PN & 2,82 & High & 1.079 .016 .024 & Big & 0,51 & Loser & Big|High|Loser & $3,37 \%$ & $6,41 \%$ & $-0,92 \%$ & $13,29 \%$ & $0,09 \%$ & $9,17 \%$ & $-2,91 \%$ & $-3,00 \%$ & $6,01 \%$ & $0,08 \%$ & $-10,64 \%$ & $-1,07 \%$ \\
\hline EBTP4 & Embratel Part PN & 1,28 & High & 3.522.408.183 & Big & 0,67 & Winner & Big|High|Winner & $-7,25 \%$ & $-4,16 \%$ & $-15,00 \%$ & $-21,05 \%$ & $24,71 \%$ & $-11,95 \%$ & $-27,32 \%$ & $12,29 \%$ & \begin{tabular}{l|l|}
$7,12 \%$ \\
\end{tabular} & $-0,46 \%$ & $17,09 \%$ & $-3,75 \%$ \\
\hline EBTP3 & Embratel Part ON & 1,28 & High & \begin{tabular}{|l|}
3.522 .408 .183 \\
\end{tabular} & Big & 1,08 & Winner & Big|High /Winner & $2,78 \%$ & $2,29 \%$ & $1,15 \%$ & $0,80 \%$ & $2,72 \%$ & $-39,24 \%$ & $-31,28 \%$ & $40,87 \%$ & $-5,03 \%$ & $-25,83 \%$ & $7,87 \%$ & $-10,83 \%$ \\
\hline GEPA3 & Ger Paranap ON & 2,82 & High & 1.079.016.024 & Big & 1,12 & Winner & Big|High|Winner & $-21,09 \%$ & $0,00 \%$ & $-1,91 \%$ & $11,21 \%$ & \begin{tabular}{l|l}
$0,00 \%$ \\
\end{tabular} & $5,83 \%$ & $10,16 \%$ & $0,07 \%$ & $-1,07 \%$ & $-0,07 \%$ & $0,99 \%$ & $-3,70 \%$ \\
\hline TCOC3 & Tele Centroeste Cel ON & 0,45 & Low & 3.766.206.148 & Big & 0,24 & Loser & Big|Low|Loser & $-3,24 \%$ & $0,48 \%$ & $4,76 \%$ & $11,82 \%$ & $1,22 \%$ & $3,61 \%$ & $4,46 \%$ & $4,15 \%$ & $3,26 \%$ & $7,68 \%$ & $-42,21 \%$ & $-33,02 \%$ \\
\hline AMBV4 & Ambev PN & 0,17 & Low & \begin{tabular}{|l|l}
31.740 .155 .760 \\
\end{tabular} & Big & 0,05 & Loser & Big|Low|Loser & \begin{tabular}{l|l|l}
$1,94 \%$ & \\
\end{tabular} & $1,60 \%$ & $2,44 \%$ & $10,28 \%$ & $-1,48 \%$ & $5,26 \%$ & $-7,25 \%$ & $14,65 \%$ & $0,78 \%$ & $-8,80 \%$ & $2,14 \%$ & $16,99 \%$ \\
\hline TNLP4 & Telemar PN & 0,58 & Low & \begin{tabular}{|l|l}
14.364 .684 .378 \\
\end{tabular} & Big & 0,03 & Loser & Big|Low|Loser & \begin{tabular}{l|l|}
$1,92 \%$ \\
\end{tabular} & $0,53 \%$ & $-6,13 \%$ & $-0,27 \%$ & $11,19 \%$ & $6,35 \%$ & $-15,27 \%$ & $14,14 \%$ & $-4,05 \%$ & $-2,41 \%$ & $-1,56 \%$ & $6,23 \%$ \\
\hline PCAR4 & P.Acucar-Cbd PN & 0,47 & Low & 5.964.458.437 & Big & 0,14 & Loser & Big|Low|Loser & $10,18 \%$ & $5,20 \%$ & $-4,96 \%$ & $17,48 \%$ & $-1,91 \%$ & $3,00 \%$ & $-15,28 \%$ & $5,84 \%$ & $-8,28 \%$ & $-10,27 \%$ & $2,26 \%$ & $-8,14 \%$ \\
\hline VIVO3 & Vivo ON & 0,41 & Low & 10.022.965.468 & Big & 0,23 & Loser & Big|Low|Loser & $-10,16 \%$ & $-1,04 \%$ & $-11,60 \%$ & -9,94\% & \begin{tabular}{l|l}
$9,66 \%$ \\
\end{tabular} & $-0,20 \%$ & $-4,00 \%$ & $12,50 \%$ & $-8,33 \%$ & $-5,05 \%$ & $-15,74 \%$ & $-13,29 \%$ \\
\hline GETI3 & \begin{tabular}{|l|} 
AES Tiete ON \\
\end{tabular} & 0,30 & \begin{tabular}{|l|} 
Low \\
\end{tabular} & \begin{tabular}{r|}
2.064 .725 .829 \\
\end{tabular} & Big & 0,26 & Loser & Big|Low|Loser & $11,83 \%$ & $4,17 \%$ & $24,00 \%$ & $-3,87 \%$ & $3,45 \%$ & $18,61 \%$ & $21,18 \%$ & $-0,94 \%$ & $-4,59 \%$ & $-8,22 \%$ & $2,78 \%$ & $2,70 \%$ \\
\hline TNLP3 & Telemar ON & 0,58 & Low & \begin{tabular}{|l|l|}
14.364 .684 .378 \\
\end{tabular} & Big & 0,34 & Loser & Big|Low|Loser & $11,56 \%$ & $2,42 \%$ & $-7,05 \%$ & $2,09 \%$ & $17,40 \%$ & $9,62 \%$ & $-1,70 \%$ & $12,01 \%$ & $-1,36 \%$ & $4,96 \%$ & $-0,50 \%$ & $8,45 \%$ \\
\hline CRUZ3 & Souza Cruz ON & 0,17 & Low & $\begin{array}{r}9.017 .855 .000 \\
\end{array}$ & Big & 0,35 & Loser & Big|Low|Loser & $4,74 \%$ & $-3,29 \%$ & $7,57 \%$ & $4,34 \%$ & $7,80 \%$ & $3,11 \%$ & $-15,64 \%$ & $15,81 \%$ & $-5,38 \%$ & $-8,28 \%$ & $1,57 \%$ & $-3,59 \%$ \\
\hline PTQS4 & Petroquisa PN & 0,46 & Low & 2.475 .085 .125 & Big & 0,38 & Loser & Big|Low|Loser & \begin{tabular}{l|l}
$0,80 \%$ \\
\end{tabular} & $12,70 \%$ & $-9,86 \%$ & $1,56 \%$ & $10,00 \%$ & $24,48 \%$ & $-4,49 \%$ & $8,30 \%$ & $-2,22 \%$ & $-1,42 \%$ & $3,75 \%$ & $0,00 \%$ \\
\hline UGPA4 & Ultrapar PN & 0,58 & Low & \begin{tabular}{|l|}
2.290 .579 .309 \\
\end{tabular} & Big & 0,40 & Loser & Big|Low|Loser & $3,73 \%$ & $25,33 \%$ & $11,09 \%$ & $-0,41 \%$ & $9,50 \%$ & $1,69 \%$ & $0,00 \%$ & $-0,95 \%$ & $-0,28 \%$ & $6,79 \%$ & $-9,56 \%$ & $-1,16 \%$ \\
\hline VALE5 & Vale PNA & 0,24 & Low & 52.391 .348 .600 & Big & 0,44 & Loser & Big|Low|Loser & $10,99 \%$ & $7,49 \%$ & $14,31 \%$ & $-2,74 \%$ & $7,69 \%$ & $14,55 \%$ & $2,42 \%$ & $13,55 \%$ & $-3,75 \%$ & $-16,88 \%$ & $1,54 \%$ & $-0,27 \%$ \\
\hline CRTP5 & Crt Celular PNA & 0,59 & Low & \begin{tabular}{|l|l|}
1.503 .005 .105 \\
\end{tabular} & Big & 0,47 & Loser & Big|Low|Loser & $12,96 \%$ & $-3,28 \%$ & $7,29 \%$ & $-17,85 \%$ & $1,92 \%$ & $0,95 \%$ & $-3,98 \%$ & $6,73 \%$ & $-3,25 \%$ & $-3,56 \%$ & $-1,64 \%$ & $-1,66 \%$ \\
\hline TCOC4 & Tele Centroeste Cel PN & 0,45 & Low & $\begin{array}{l}3.50 .06 .206 .148 \\
\end{array}$ & \begin{tabular}{|l|l|} 
Big \\
\end{tabular} & 00,49 & Loser & Big|Low|Loser & $\mid$ & $0,77 \%$ & $5,56 \%$ & $\mid-9,71 \%$ & $\begin{array}{l}4,46 \% \% \\
4,460\end{array}$ & $\mid-4,38 \%$ & $-0,17 \%$ & $14,71 \%$ & $\begin{array}{ll}-9,74 \% \\
\end{array}$ & $8,47 \%$ & -10,60\% & $-8,37 \%$ \\
\hline CRTP3 & Crt Celular ON & 0,59 & Low & \begin{tabular}{|l|}
1.503 .005 .105 \\
\end{tabular} & Big & 0,49 & Loser & Big|Low|Loser & $36,36 \%$ & $-4,76 \%$ & $6,00 \%$ & $-28,30 \%$ & $1,84 \%$ & $4,64 \%$ & $-7,97 \%$ & $10,51 \%$ & $1,29 \%$ & $1,52 \%$ & $5,00 \%$ & $-0,73 \%$ \\
\hline PETR4 & Petro & 0,58 & Low & 90.094.022.300 & Big & 0,52 & Loser & Big|Low|Loser & $1,02 \%$ & $4,99 \%$ & $14,44 \%$ & $2,87 \%$ & $-0,59 \%$ & $4,57 \%$ & $-2,93 \%$ & $17,95 \%$ & $-7,26 \%$ & $-6,88 \%$ & $6,40 \%$ & $6,71 \%$ \\
\hline KLBN4 & Klabin S/A PN & 0,53 & Low & 3.762 .500 .300 & Big & 0,53 & Loser & Big|Low|Loser & $6,34 \%$ & $6,65 \%$ & $4,67 \%$ & $0,21 \%$ & $0,21 \%$ & $12,50 \%$ & $-10,93 \%$ & $4,57 \%$ & $-10,06 \%$ & $-15,16 \%$ & $7,73 \%$ & $0,00 \%$ \\
\hline \begin{tabular}{|l|} 
ARCE4 \\
\end{tabular} & Arcelor BR PN & $0,0,59$ & Low & 5.447.994.518 & \begin{tabular}{|l|l|} 
Big \\
\end{tabular} & 0,53 & Loser & Big|Low|Loser & $8,26 \%$ & $31,60 \%$ & $11,25 \%$ & $-10,79 \%$ & $19,38 \%$ & $8,24 \%$ & $-13,21 \%$ & $13,44 \%$ & $-7,92 \%$ & $-13,42 \%$ & $-9,40 \%$ & $-0,48 \%$ \\
\hline ARCE3 & Arcelor BR ON & 0,59 & Low & 5.447.994.518 & Big & 0,53 & Loser & Big|Low|Loser & \begin{tabular}{l|l}
$9,15 \%$ & \\
\end{tabular} & $29,22 \%$ & $17,09 \%$ & $-0,43 \%$ & $7,08 \%$ & $7,40 \%$ & $-10,00 \%$ & $8,47 \%$ & $-2,43 \%$ & $-17,01 \%$ & $-2,91 \%$ & $0,50 \%$ \\
\hline PETR3 & Petrobras ON & 0,58 & Low & \begin{tabular}{|l|l}
90.094 .022 .300 \\
\end{tabular} & Big & 0,56 & Loser & Big|Low|Loser & $0,00 \%$ & $5,48 \%$ & $14,71 \%$ & $1,79 \%$ & $-0,34 \%$ & $4,26 \%$ & $0,75 \%$ & $18,36 \%$ & $-7,48 \%$ & $-7,19 \%$ & $4,29 \%$ & $8,21 \%$ \\
\hline VALE3 & Vale ON & 0,24 & Low & 52.391 .348 .600 & Big & 0,56 & Winner & Big|Low|Winner & $12,65 \%$ & $2,50 \%$ & $14,64 \%$ & $-2,90 \%$ & $9,18 \%$ & $13,36 \%$ & $4,95 \%$ & $14,21 \%$ & $-6,08 \%$ & $-18,15 \%$ & $2,12 \%$ & $-0,93 \%$ \\
\hline \begin{tabular}{|l|} 
ARCZ3 \\
\end{tabular} & Aracruz ON & 0,30 & Low & 8.959 .479 .550 & Big & 0,57 & Winner & Big|Low|Winner & $7,14 \%$ & $0,00 \%$ & $-6,67 \%$ & $4,14 \%$ & $13,26 \%$ & $-9,05 \%$ & $-2,76 \%$ & $2,70 \%$ & 7,73\% & $-6,11 \%$ & $-3,12 \%$ & $5,50 \%$ \\
\hline ARCZ6 & Aracruz PNB & 0,30 & Low & 8.959 .479 .550 & Big & 0,65 & Winner & Big|Low|Winner & $5,58 \%$ & $-2,74 \%$ & $-8,35 \%$ & $4,38 \%$ & $5,54 \%$ & $0,09 \%$ & $-9,09 \%$ & $7,39 \%$ & $-3,44 \%$ & $-19,29 \%$ & $9,60 \%$ & $-0,15 \%$ \\
\hline EMBR3 & Embraer ON & 0,23 & Low & 14.493.585.244 & Big & 0,66 & Winner & Big|Low/Winner & $-2,71 \%$ & $-8,11 \%$ & $-5,41 \%$ & $-2,39 \%$ & $2,59 \%$ & $15,75 \%$ & $-5,89 \%$ & $11,30 \%$ & $-2,98 \%$ & $-12,06 \%$ & $2,86 \%$ & $1,91 \%$ \\
\hline LIGT3 & Light S/A ON & 0,17 & Low & \begin{tabular}{|l|l|}
2.046 .205 .908 \\
\end{tabular} & Big & 0,67 & Winner & Big|Low|Winner & $7,83 \%$ & $5,62 \%$ & $-2,20 \%$ & $-5,57 \%$ & $10,92 \%$ & $-0,57 \%$ & $-12,21 \%$ & $3,47 \%$ & $-2,48 \%$ & $-23,41 \%$ & $47,06 \%$ & $-8,80 \%$ \\
\hline TMCP4 & Telemig Part PN & 0,43 & Low & 1.961 .694 .044 & \begin{tabular}{|l|l} 
Big \\
\end{tabular} & 0,68 & Winner & Big|Low/Winner & $-6,17 \%$ & $2,58 \%$ & $-7,32 \%$ & $-6,91 \%$ & $4,24 \%$ & $-3,31 \%$ & $-5,79 \%$ & $9,22 \%$ & $-1,79 \%$ & $17,96 \%$ & $-7,29 \%$ & $-2,79 \%$ \\
\hline EMBR4 & Embraer PN & 0,23 & Low & 14.493.585.244 & Big & 0,72 & Winner & Big|Low/Winner & $-1,18 \%$ & $-10,51 \%$ & $-2,41 \%$ & $1,06 \%$ & \begin{tabular}{l|l|}
$0,53 \%$ \\
\end{tabular} & $17,59 \%$ & $-7,21 \%$ & $6,31 \%$ & $-4,11 \%$ & $-13,67 \%$ & $-1,06 \%$ & $8,64 \%$ \\
\hline VCPA4 & Fibria PN & 0,50 & Low & 7.462 .330 .005 & Big & 0,72 & Winner & Big|Low|Winner & $11,28 \%$ & $-4,60 \%$ & $-4,83 \%$ & $1,66 \%$ & $3,54 \%$ & $5,60 \%$ & $-12,61 \%$ & $2,77 \%$ & $-10,77 \%$ & $-18,34 \%$ & $5,11 \%$ & $0,31 \%$ \\
\hline TMCP3 & Telemig Part ON & 0,43 & Low & 1.961 .694 .044 & Big & 0,78 & Winner & Big|Low|Winner & $1,35 \%$ & $0,00 \%$ & $12,67 \%$ & $2,96 \%$ & $-2,30 \%$ & $-0,82 \%$ & $-12,10 \%$ & $6,61 \%$ & $16,46 \%$ & $3,09 \%$ & $-1,62 \%$ & $-0,55 \%$ \\
\hline VIVO4 & Vivo PN & 0,41 & Low & \begin{tabular}{|l|l}
10.022 .965 .468 \\
\end{tabular} & Big & 0,79 & Winner & Big|Low/Winner & $-16,27 \%$ & $-5,78 \%$ & $-9,14 \%$ & $-3,02 \%$ & $14,67 \%$ & $0,56 \%$ & $-11,13 \%$ & $10,64 \%$ & $-9,76 \%$ & $-13,32 \%$ & $-12,48 \%$ & $-17,57 \%$ \\
\hline TBLE3 & Tractebel & 0, & Low & 5.931 .337 .450 & \begin{tabular}{|l} 
Big \\
\end{tabular} & 0,93 & Winner & Big|Low/Winner & - & $-2,31 \%$ & $2,14 \%$ & $0,44 \%$ & $2,52 \%$ & $9,01 \%$ & $-17,65 \%$ & $11,77 \%$ & $32,82 \%$ & $4,67 \%$ & $-0,36 \%$ & $-6,28 \%$ \\
\hline FFTL4 & Valefert PN & 0,34 & Low & 2.537.231.535 & Big & 0,95 & Winner & Big|Low|Winner & $9,24 \%$ & $13,65 \%$ & $-5,58 \%$ & $4,66 \%$ & $7,30 \%$ & $7,15 \%$ & $-5,91 \%$ & $2,91 \%$ & $-6,32 \%$ & $0,44 \%$ & $-2,64 \%$ & $2,53 \%$ \\
\hline WEGE4 & Weg PN & 0,29 & Low & 4.307 .430 .600 & Big & 1,05 & Winner & Big|Low/Winner & $-3,27 \%$ & $14,63 \%$ & $-11,53 \%$ & $3,05 \%$ & $-5,11 \%$ & $1,46 \%$ & $6,86 \%$ & $-1,70 \%$ & $-5,18 \%$ & $0,00 \%$ & $5,63 \%$ & $-2,58 \%$ \\
\hline AMBV3 & Amber O & 0,17 & Low & 5.760 & Big & 1,06 & Winner & Big| & $-4,17 \%$ & $3,57 \%$ & $2,93 \%$ & $12,70 \%$ & $-1,3$ & $0,81 \%$ & $-5,9$ & $2,90 \%$ & $-19,66 \%$ & $-39,29 \%$ & $1,33 \%$ & $11,46 \%$ \\
\hline GETI4 & AES Tie & 0,30 & Low & 225.829 & Big & 1,08 & $\mathrm{Wi}$ & Big|Low/Winner & $13,54 \%$ & $1,03 \%$ & $24,49 \%$ & $-3,28 \%$ & $-0,22 \%$ & $24,96 \%$ & $17,18 \%$ & $2,44 \%$ & $1,40 \%$ & $-0,27 \%$ & $-3,57 \%$ & $5,00 \%$ \\
\hline GGBR4 & Gerdau PN & 0,49 & Low & 9.970 .932 .850 & Big & 1,15 & Winner & Big|Low/Winner & $18,33 \%$ & $13,23 \%$ & $-3,82 \%$ & $-9,46 \%$ & $17,44 \%$ & $-2,98 \%$ & $-7,79 \%$ & $18,84 \%$ & $-13,05 \%$ & $-17,62 \%$ & $1,92 \%$ & $-7,00 \%$ \\
\hline CPSL3 & Copesul ON & 0,52 & Low & \begin{tabular}{|l|}
2.522 .146 .248 \\
\end{tabular} & Big & 1,15 & Winner & Big|Low|Winner & $28,65 \%$ & $30,74 \%$ & $-7,27 \%$ & $16,66 \%$ & $11,88 \%$ & $19,21 \%$ & $8,42 \%$ & $-12,14 \%$ & $-3,85 \%$ & $-0,59 \%$ & $-2,25 \%$ & $-3,13 \%$ \\
\hline
\end{tabular}


Anexo 1 - Retorno mensal e classificação das ações

\begin{tabular}{|c|c|c|c|c|c|c|c|c|c|c|c|c|c|c|c|c|c|c|c|c|}
\hline Código & $2004-2005$ & $\begin{array}{l}\text { Índice B/M } \\
\text { de dez/2003 }\end{array}$ & $\begin{array}{c}\text { Grupo com } \\
\text { base no } \\
\text { indice B/M }\end{array}$ & $\begin{array}{c}\text { Valor de Mercado } \\
\text { em jun/2004 }\end{array}$ & $\begin{array}{c}\text { Grupo com } \\
\text { base no } \\
\text { tamanho }\end{array}$ & \begin{tabular}{|c|} 
Retorno \\
acumulado \\
de jun/2004
\end{tabular} & \begin{tabular}{|c|} 
Grupo com \\
base no \\
retorno \\
acumulado \\
\end{tabular} & Carteiras & jul/04 & ago/04 & set/04 & out/04 & nov/04 & dez/04 & $\mathrm{jan} / 05$ & fev/05 & $\mathrm{mar} / 05$ & abr/05 & mai/05 & jun/05 \\
\hline TBLE6 & Tractebel PNB & 0,58 & Low & 5.931.337.450 & Big & 1,15 & Winner & Big|Low|Winner & $-2,38 \%$ & $-1,46 \%$ & $5,61 \%$ & $4,53 \%$ & $0,30 \%$ & $2,76 \%$ & $2,29 \%$ & $18,66 \%$ & $17,99 \%$ & $8,26 \%$ & $9,17 \%$ & $8,54 \%$ \\
\hline CBEE3 & Ampla Energ ON & 0,28 & Low & 1.778 .778 .335 & Big & 1,19 & Winner & Big|Low|Winner & $-4,76 \%$ & $2,50 \%$ & $14,63 \%$ & $17,02 \%$ & $-3,64 \%$ & $5,66 \%$ & $-14,29 \%$ & $4,17 \%$ & $0,00 \%$ & $-16,00 \%$ & $2,38 \%$ & $-6,98 \%$ \\
\hline PQUN4 & Petroq Uniao PN & 0,57 & Low & 1.377 .487 .500 & Big & 1,33 & Winner & Big|Low|Winner & $3,28 \%$ & $-5,81 \%$ & $7,15 \%$ & $2,59 \%$ & $29,93 \%$ & $3,24 \%$ & $1,88 \%$ & $-14,61 \%$ & $-8,39 \%$ & $-2,78 \%$ & $-2,55 \%$ & $8,05 \%$ \\
\hline GGBR3 & Gerdau ON & 0,49 & Low & 9.970 .932 .850 & Big & 1,35 & Winner & Big|Low|Winner & $24,80 \%$ & $33,57 \%$ & $-6,30 \%$ & $-8,41 \%$ & $15,49 \%$ & $-4,18 \%$ & $-8,31 \%$ & $10,52 \%$ & $-9,51 \%$ & $-14,69 \%$ & $-1,05 \%$ & $-7,89 \%$ \\
\hline CMET4 & Caemi PN & 0,20 & Low & 4.625 .301 .460 & Big & 1,44 & Winner & Big|Low|Winner & $13,56 \%$ & $17,16 \%$ & $14,65 \%$ & $-5,00 \%$ & $15,20 \%$ & $15,74 \%$ & $4,82 \%$ & $11,72 \%$ & $-7,12 \%$ & $-19,43 \%$ & $8,81 \%$ & $4,76 \%$ \\
\hline CCRO3 & CCR SA ON & 0,29 & Low & 3.576 .520 .721 & Big & 1,45 & Winner & Big/Low/Winner & $-6,73 \%$ & $14,02 \%$ & $0,96 \%$ & $11,53 \%$ & $19,98 \%$ & $17,83 \%$ & $-8,78 \%$ & $1,89 \%$ & $-1,50 \%$ & $1,55 \%$ & $11,32 \%$ & $-6,98 \%$ \\
\hline LAME4 & Lojas Americ PN & 0,11 & Low & 1.791 .841 .213 & Big & 1,49 & Winner & Big|Low|Winner & $10,95 \%$ & $24,93 \%$ & $5,78 \%$ & $2,69 \%$ & $-5,48 \%$ & $13,22 \%$ & $-6,90 \%$ & $25,66 \%$ & $-5,89 \%$ & $-4,47 \%$ & $4,22 \%$ & $1,80 \%$ \\
\hline LAME3 & Lojas Americ ON & 0,11 & Low & 1.791.841.213 & Big & 1,50 & Winner & Big|Low|Winner & $3,75 \%$ & $23,30 \%$ & $10,03 \%$ & $22,07 \%$ & $3,70 \%$ & $2,66 \%$ & $-1,01 \%$ & $22,43 \%$ & $3,35 \%$ & $-3,24 \%$ & $0,85 \%$ & $-9,01 \%$ \\
\hline CGAS5 & Comgas PNA & 0,48 & Low & 2.229 .479 .798 & Big & 1,58 & Winner & Big|Low|Winner & $7,14 \%$ & $10,77 \%$ & $6,25 \%$ & $-5,93 \%$ & $0,56 \%$ & $21,60 \%$ & $-1,52 \%$ & $15,39 \%$ & $-6,17 \%$ & $-2,23 \%$ & $0,38 \%$ & $-14,01 \%$ \\
\hline SDIA3 & Sadia S/A ON & 0,55 & Low & 2.713 .518 .800 & Big & 1,60 & Winner & Big|Low|Winner & $7,17 \%$ & $16,05 \%$ & $6,38 \%$ & $0,00 \%$ & $2,00 \%$ & $6,86 \%$ & $-9,91 \%$ & $-1,04 \%$ & $-7,13 \%$ & $-9,09 \%$ & $-6,25 \%$ & $14,67 \%$ \\
\hline SDIA4 & Sadia S/A PN & 0,55 & Low & 2.713 .518 .800 & Big & 2,20 & Winner & Big|Low|Winner & $10,21 \%$ & $14,16 \%$ & $6,80 \%$ & $-2,62 \%$ & $5,77 \%$ & $8,73 \%$ & $-14,81 \%$ & $-0,80 \%$ & $-10,49 \%$ & $-8,39 \%$ & $-2,72 \%$ & $15,78 \%$ \\
\hline BRKM5 & Braskem PNA & 0,53 & Low & 3.974 .330 .032 & Big & 2,22 & Winner & Big|Low/Winner & $8,32 \%$ & $38,56 \%$ & $12,26 \%$ & $10,29 \%$ & $12,76 \%$ & $13,18 \%$ & $-11,38 \%$ & $12,21 \%$ & $-17,34 \%$ & $-9,26 \%$ & $-6,53 \%$ & $-14,85 \%$ \\
\hline TSEP4 & Tele Sudeste Celula PN & 0,76 & Medium & 2.412.365.267 & Big & 0,22 & Loser & Big|Medium|Loser & $12,37 \%$ & $-1,66 \%$ & $10,89 \%$ & $-15,77 \%$ & $0,16 \%$ & $3,11 \%$ & $-11,97 \%$ & $-2,55 \%$ & $-7,18 \%$ & $-1,01 \%$ & $-21,38 \%$ & $-2,59 \%$ \\
\hline BRTP4 & Brasil T Par PN & 0,85 & \begin{tabular}{|l|} 
Medium \\
\end{tabular} & 6.451.617.699 & Big & 0,16 & Loser & Big|Medium|Loser & $-3,54 \%$ & $4,00 \%$ & $-2,48 \%$ & $-5,35 \%$ & $15,36 \%$ & $-0,50 \%$ & $-14,95 \%$ & $5,09 \%$ & $-1,14 \%$ & $-5,76 \%$ & $5,34 \%$ & $7,03 \%$ \\
\hline BRT04 & Brasil Telec PN & 0,79 & Medium & 6.119 .343 .662 & Big & 0,12 & Loser & Big|Medium|Loser & $-3,88 \%$ & $3,94 \%$ & $0,26 \%$ & $-3,25 \%$ & $20,36 \%$ & $3,47 \%$ & $-17,34 \%$ & $1,27 \%$ & $-2,60 \%$ & $-9,59 \%$ & $3,58 \%$ & $4,12 \%$ \\
\hline TPRC3 & Tim Sul ON & 1,01 & Medium & 1.087 .854 .876 & Big & 0,11 & Loser & Big|Medium|Loser & $-3,03 \%$ & $3,13 \%$ & $1,21 \%$ & $7,78 \%$ & $4,17 \%$ & $1,33 \%$ & $1,90 \%$ & $25,69 \%$ & $13,30 \%$ & $-0,98 \%$ & $20,79 \%$ & $1,64 \%$ \\
\hline BRTO3 & Brasil Telec ON & 0,79 & Medium & 6.119 .343 .662 & Big & 0,10 & Loser & Big|Medium|Loser & $10,91 \%$ & $-2,44 \%$ & $1,67 \%$ & $-1,56 \%$ & $19,48 \%$ & $0,14 \%$ & $1,49 \%$ & $0,70 \%$ & $-5,94 \%$ & $8,55 \%$ & $-11,00 \%$ & $23,81 \%$ \\
\hline TSEP3 & Tele Sudeste Celula ON & 0,76 & \begin{tabular}{|l|} 
Medium \\
\end{tabular} & 2.412 .365 .267 & Big & 0,04 & Loser & Big|Medium|Loser & $13,98 \%$ & $2,08 \%$ & $9,06 \%$ & $-5,08 \%$ & $-10,71 \%$ & $-4,40 \%$ & $-6,80 \%$ & $5,44 \%$ & $-6,12 \%$ & $0,92 \%$ & $-15,32 \%$ & $-3,38 \%$ \\
\hline BRTP3 & Brasil T Par ON & 0,85 & Medium & 6.451 .617 .699 & Big & 0,02 & Loser & Big|Medium|Loser & $33,84 \%$ & $-3,82 \%$ & $-3,31 \%$ & $0,24 \%$ & $26,34 \%$ & $3,47 \%$ & $-2,79 \%$ & $-0,43 \%$ & $2,00 \%$ & $-19,23 \%$ & $10,62 \%$ & $18,56 \%$ \\
\hline CTNM4 & Cotem & 1,13 & Medium & 1.291.107.620 & Big & 0,03 & Loser & Big|Medium/Loser & $6,22 \%$ & $6,28 \%$ & $7,87 \%$ & $-0,73 \%$ & $-3,71 \%$ & $14,55 \%$ & $-9,00 \%$ & $-4,40 \%$ & $-11,88 \%$ & $-6,97 \%$ & $1,55 \%$ & $1,91 \%$ \\
\hline ITSA3 & Itausa ON & 0,68 & Medium & 11.840 .861 .359 & Big & 0,08 & Loser & Big|Medium|Loser & $-2,44 \%$ & $-2,31 \%$ & $8,85 \%$ & $4,62 \%$ & $2,94 \%$ & $23,15 \%$ & $-4,00 \%$ & $8,33 \%$ & $0,58 \%$ & $-5,77 \%$ & $2,19 \%$ & $2,19 \%$ \\
\hline TMAR6 & Telemar N LPNB & 0,85 & \begin{tabular}{|l|} 
Medium \\
\end{tabular} & 11.732 .093 .440 & Big & 0,09 & Loser & Big|Medium|Loser & $-6,88 \%$ & $7,39 \%$ & $-4,59 \%$ & $32,65 \%$ & $-0,77 \%$ & $1,76 \%$ & $-8,59 \%$ & $16,67 \%$ & $-8,93 \%$ & $-5,88 \%$ & $-0,23 \%$ & $-1,50 \%$ \\
\hline CTNM3 & Coteminas ON & 1,13 & \begin{tabular}{|l|} 
Medium \\
\end{tabular} & 1.291 .107 .620 & Big & 0,16 & Loser & Big|Medium|Loser & $10,53 \%$ & $4,29 \%$ & $5,02 \%$ & $2,17 \%$ & $-4,26 \%$ & $11,11 \%$ & $-12,40 \%$ & $-6,39 \%$ & $-9,76 \%$ & $-5,41 \%$ & $-0,51 \%$ & $3,04 \%$ \\
\hline TPRC6 & & 1,01 & Medium & & Big & 0,19 & Loser & Loser & $0,00 \%$ & $9,33 \%$ & $-3,05 \%$ & $0,38 \%$ & $2,13 \%$ & $-1,85 \%$ & $1,82 \%$ & $20,39 \%$ & $3,26 \%$ & $11,17 \%$ & $4,31 \%$ & $-2,75 \%$ \\
\hline TMAR3 & Telemar N LON & 0,85 & Medium & 11.732 .093 .440 & $\begin{array}{ll}\text { Big } \\
\end{array}$ & 0,19 & Loser & Big|Medium/Loser & $5,81 \%$ & $-3,30 \%$ & $-2,55 \%$ & $9,52 \%$ & $13,26 \%$ & $11,63 \%$ & $-1,04 \%$ & $14,23 \%$ & $1,20 \%$ & $-3,62 \%$ & $11,58 \%$ & $3,60 \%$ \\
\hline ITSA4 & Itausa PN & 0,68 & Medium & 11.840 .861 .359 & Big & 0,23 & Loser & Big|Medium|Loser & $-4,17 \%$ & $4,79 \%$ & $6,61 \%$ & $7,85 \%$ & $3,16 \%$ & $11,90 \%$ & $-1,74 \%$ & $12,17 \%$ & $-2,40 \%$ & $0,00 \%$ & $0,14 \%$ & $3,45 \%$ \\
\hline TMAR5 & Telemar N LPNA & 0,85 & \begin{tabular}{|l|} 
Medium \\
\end{tabular} & 11.732 .093 .440 & Big & 0,23 & Loser & Big|Medium|Loser & $2,20 \%$ & $-1,21 \%$ & $-4,25 \%$ & $4,00 \%$ & $21,02 \%$ & $7,23 \%$ & $-13,25 \%$ & $19,45 \%$ & $-11,43 \%$ & $-6,49 \%$ & $3,89 \%$ & $0,18 \%$ \\
\hline CMIG3 & & 0,88 & Medium & & Big & 0,45 & Loser & n|loser & $24,04 \%$ & $2,48 \%$ & $16,70 \%$ & $-0,59 \%$ & $1,42 \%$ & $17,73 \%$ & $-14,39 \%$ & $13,10 \%$ & $-3,30 \%$ & $2,87 \%$ & $7,54 \%$ & $4,14 \%$ \\
\hline CMIG4 & Cemig PN & 88 & Medium & 667.082 & Big & 57 & Winner & Big|Medium/Winner & $20,52 \%$ & $-3,02 \%$ & $12,83 \%$ & $9,63 \%$ & $-4,32 \%$ & $4,38 \%$ & $-10,26 \%$ & $16,03 \%$ & $-8,62 \%$ & $18,54 \%$ & $1,71 \%$ & $1,92 \%$ \\
\hline \begin{tabular}{|l|l|} 
ACES4 \\
\end{tabular} & Am Inox BR PN & 0,85 & Medium & 45.931 .538 & \begin{tabular}{|l} 
Big \\
\end{tabular} & 0,61 & Winner & Big|Medium/Winner & $24,48 \%$ & $13,00 \%$ & $-1,77 \%$ & $-4,50 \%$ & $12,23 \%$ & $11,07 \%$ & $-5,00 \%$ & $19,40 \%$ & $-3,91 \%$ & \begin{tabular}{|l|}
$-10,99 \%$ \\
\end{tabular} & $-11,70 \%$ & $-8,80 \%$ \\
\hline TMGC3 & Telem & 0,62 & Medi & 35.821 & Big & 0,63 & Winner & Big|Medium/Winner & $4,17 \%$ & $13,33 \%$ & $41,18 \%$ & $-0,92 \%$ & $-0,76 \%$ & $-11,01 \%$ & $3,71 \%$ & $0,00 \%$ & $1,01 \%$ & $6,82 \%$ & $-2,61 \%$ & $-3,13 \%$ \\
\hline TCSL4 & $\operatorname{Tim} \mathrm{P}$ & 0,71 & Medium & & Big & 0,66 & Winner & Big|Medium / Winner & $-2,01 \%$ & $3,59 \%$ & $0,25 \%$ & $-2,22 \%$ & $5,81 \%$ & $-3,34 \%$ & $-7,17 \%$ & $13,71 \%$ & $-4,88 \%$ & $1,27 \%$ & $-5,50 \%$ & $-1,59 \%$ \\
\hline BRAP4 & & 0,65 & Medium & 0.605 & Big & 66 & Winn & Winner & $7,29 \%$ & $26,59 \%$ & $11,78 \%$ & $-18,56 \%$ & $18,82 \%$ & $8,29 \%$ & $5,87 \%$ & $13,81 \%$ & $-1,12 \%$ & $-23,22 \%$ & $3,58 \%$ & $-0,62 \%$ \\
\hline \begin{tabular}{|l|l|} 
ACES3 \\
\end{tabular} & Am Inox BR ON & 0,85 & Medium & 5.931 .538 & Big & 67 & Winner & Big|Medium/Winner & $31,39 \%$ & $17,06 \%$ & $-3,79 \%$ & $-3,94 \%$ & $8,83 \%$ & $7,94 \%$ & $-4,08 \%$ & $22,00 \%$ & $-4,92 \%$ & $-8,91 \%$ & $-4,52 \%$ & $-3,85 \%$ \\
\hline RPSA4 & Ripasa PN & 0,86 & $\mathrm{Mec}$ & 393.100 & Big & 67 & Winner & Big|Medium/Winner & $11,87 \%$ & $-4,82 \%$ & $23,65 \%$ & $6,83 \%$ & $5,01 \%$ & $2,72 \%$ & $-6,49 \%$ & $3,34 \%$ & $0,92 \%$ & $-18,52 \%$ & $8,18 \%$ & $-5,88 \%$ \\
\hline UNIP3 & Unipar ON & 0,86 & Medium & 2.954 .700 & Big & 0,69 & Winner & Big|Medium /Winner & $18,18 \%$ & $33,03 \%$ & $16,62 \%$ & $-5,25 \%$ & $2,90 \%$ & $17,33 \%$ & $-1,56 \%$ & $13,38 \%$ & $-2,00 \%$ & $-6,69 \%$ & $5,26 \%$ & $-12,50 \%$ \\
\hline UNIP6 & Ur & 0,86 & Medium & 2.954 .700 & Big & 72 & Winner & Big|Medium/Winner & $26,67 \%$ & $28,12 \%$ & $14,79 \%$ & $-7,22 \%$ & $-0,28 \%$ & $19,61 \%$ & $-6,43 \%$ & $9,16 \%$ & $-9,56 \%$ & $-6,63 \%$ & $-0,67 \%$ & $-18,12 \%$ \\
\hline BRAP3 & Bradespar ON & 0,65 & Medium & 5.010 .605 & Big & 0,87 & Winner & Big|Medium/Winner & $5,63 \%$ & $23,69 \%$ & $17,31 \%$ & $-14,63 \%$ & $13,57 \%$ & $8,18 \%$ & $6,85 \%$ & $10,00 \%$ & $-0,61 \%$ & $-17,68 \%$ & $-1,21 \%$ & $-2,52 \%$ \\
\hline LEVE4 & Metal Le & 0,61 & Medi & 1.178.553.159 & Big & 0,96 & Winner & Big|Medium/Winner & $13,57 \%$ & $12,63 \%$ & $10,30 \%$ & $-4,95 \%$ & $0,00 \%$ & $1,62 \%$ & $-5,60 \%$ & $0,31 \%$ & $-0,31 \%$ & $-0,01 \%$ & $-7,00 \%$ & $-3,00 \%$ \\
\hline SUZB5 & Suzano Papel PNA & 0,69 & Medium & 3.522 .521 .928 & Big & 1,00 & Winner & Big|Medium/Winner & $12,82 \%$ & $-11,01 \%$ & $-3,35 \%$ & $2,19 \%$ & $1,16 \%$ & $14,01 \%$ & $-10,56 \%$ & $5,86 \%$ & $-6,31 \%$ & $-11,30 \%$ & $-5,14 \%$ & $-4,43 \%$ \\
\hline PRGA4 & BRF Foods P & 0,75 & Medium & 73.535 .780 & Big & 1,06 & Winner & Big|Medium/Winner & $24,04 \%$ & $20,38 \%$ & $2,00 \%$ & $-1,11 \%$ & $6,05 \%$ & $20,56 \%$ & $-6,63 \%$ & $1,67 \%$ & $-4,95 \%$ & $-7,25 \%$ & $5,77 \%$ & $10,01 \%$ \\
\hline CSTB4 & Sid Tu & 1,16 & Mediu & 85.700 & Big & 11 & Winner & Big|Medium/Winner & $17,58 \%$ & $12,66 \%$ & $-1,06 \%$ & $-4,62 \%$ & $22,84 \%$ & $12,79 \%$ & $-9,27 \%$ & $20,34 \%$ & $-1,09 \%$ & $-23,01 \%$ & $3,27 \%$ & $-16,20 \%$ \\
\hline GOAU3 & Gerdau & 0,76 & Medi & 3.562 .756 .400 & Big & 1,27 & Winner & Big|Medium/Winner & $25,87 \%$ & $16,47 \%$ & $3,45 \%$ & $-10,00 \%$ & $16,66 \%$ & $-6,44 \%$ & $2,40 \%$ & $8,38 \%$ & $-7,70 \%$ & $-15,22 \%$ & $0,49 \%$ & $-12,23 \%$ \\
\hline CPFG4 & CPFL Geracao PN & 0,78 & Medium & 1.119 .908 .052 & Big & 1,27 & Winner & Big|Medium/Winner & $18,04 \%$ & $33,33 \%$ & $6,25 \%$ & $-29,41 \%$ & $13,33 \%$ & $25,00 \%$ & $-11,76 \%$ & $46,67 \%$ & $-18,27 \%$ & $0,11 \%$ & $10,70 \%$ & $14,29 \%$ \\
\hline CPFG3 & CPFLGe & 0,78 & Mediu & 1.119 .908 .052 & Big & 1,36 & Winner & Big|Medium/Winner & $6,52 \%$ & $33,33 \%$ & $11,88 \%$ & $-21,79 \%$ & $0,00 \%$ & $21,43 \%$ & $-8,24 \%$ & $41,03 \%$ & $-18,64 \%$ & $0,56 \%$ & $29,71 \%$ & $-9,13 \%$ \\
\hline ELPL5 & & & & & $\mathrm{Bi}$ & & & & -7 & 0,9 & 15,15 & $-5,7$ & $0,22 \%$ & & -14, & 15, & $-3,5$ & & 18, & \\
\hline GOAU4 & Gerda & 6 & & 0 & Big & 1,40 & Wir & Big|Medium/Winner & $21,41 \%$ & $17,09 \%$ & $-2,48 \%$ & $-6,10 \%$ & $17,39 \%$ & $5,30 \%$ & $-5,79 \%$ & $7,25 \%$ & $-8,42 \%$ & $-17,55 \%$ & $2,79 \%$ & $-9,55 \%$ \\
\hline CSNA3 & Sid Nacional ON & 0,66 & Medium & 10.773 .223 .520 & Big & 1,61 & Winner & Big|Medium/Winner & $16,13 \%$ & $3,09 \%$ & $-2,09 \%$ & $-5,09 \%$ & $22,92 \%$ & $-1,95 \%$ & $2,87 \%$ & $28,61 \%$ & $-5,80 \%$ & $-12,84 \%$ & $-9,05 \%$ & $-11,24 \%$ \\
\hline USIM5 & Usiminas PNA & 0,63 & \begin{tabular}{|l|} 
Medium \\
\end{tabular} & 6.366 .660 .252 & Big & 1,85 & Winner & Big|Medium/Winner & $34,01 \%$ & $10,40 \%$ & $-4,32 \%$ & $-2,87 \%$ & $27,70 \%$ & $-0,74 \%$ & $-1,02 \%$ & $29,03 \%$ & $-12,37 \%$ & $-13,04 \%$ & $-9,80 \%$ & $-15,52 \%$ \\
\hline USIM3 & Usiminas ON & 0,63 & Medium & 6.366 .660 .252 & Sis & 2,16 & Winner & Big|Medium/Winner & 23,46 & 25,37 & $-5,13 \%$ & $0,00 \%$ & $29,73 \%$ & $5,29 \%$ & & & $14,05 \%$ & & $a^{2}$ & 1 \\
\hline
\end{tabular}


Anexo 1 - Retorno mensal e classificação das ações

\begin{tabular}{|c|c|c|c|c|c|c|c|c|c|c|c|c|c|c|c|c|c|c|c|c|}
\hline Código & $2004-2005$ & $\begin{array}{l}\text { Índice B/M } \\
\text { de dez/2003 }\end{array}$ & $\begin{array}{c}\text { Grupo com } \\
\text { base no } \\
\text { indice B/M }\end{array}$ & $\begin{array}{c}\text { Valor de Mercado } \\
\text { em jun/2004 }\end{array}$ & $\begin{array}{c}\text { Grupo com } \\
\text { base no } \\
\text { tamanho }\end{array}$ & \begin{tabular}{|c|} 
Retorno \\
acumulado \\
de jun/2004
\end{tabular} & \begin{tabular}{|c|} 
Grupo com \\
base no \\
retorno \\
acumulado \\
\end{tabular} & Carteiras & jul/04 & ago/04 & set/04 & out/04 & nov/04 & dez/04 & jan/05 & fev/05 & $\mathrm{mar} / 05$ & abr/05 & mai/05 & jun/05 \\
\hline MENDS & Mendes Jr PNA & 4,95 & High & $\begin{array}{l}114.614 .218 \\
\end{array}$ & Small & 0,45 & Loser & Small|High|Loser & $1,49 \%$ & $-8,72 \%$ & $-1,43 \%$ & $-10,14 \%$ & $-3,55 \%$ & $-23,08 \%$ & $-5,65 \%$ & $10,60 \%$ & $10,42 \%$ & $-16,98 \%$ & $-20,45 \%$ & $-19,89 \%$ \\
\hline MEND6 & Mendes Jr PNB & 4,95 & High & 114.614 .218 & Small & 0,36 & Loser & Small|High|Loser & $7,55 \%$ & $-13,16 \%$ & $-4,69 \%$ & $-8,20 \%$ & $-0,36 \%$ & $-28,32 \%$ & $0,00 \%$ & $12,50 \%$ & $-13,33 \%$ & $12,82 \%$ & $-18,18 \%$ & $-27,78 \%$ \\
\hline TELB3 & Telebras ON & 4,68 & High & \begin{tabular}{|l|l|}
11.128 .584 \\
\end{tabular} & Small & 0,33 & Loser & Small|High|Loser & $150,00 \%$ & $-20,00 \%$ & $200,00 \%$ & $-8,33 \%$ & $-36,36 \%$ & $14,29 \%$ & $-12,50 \%$ & $0,00 \%$ & $-14,29 \%$ & $-16,67 \%$ & $20,00 \%$ & $-16,67 \%$ \\
\hline TELB4 & Telebras PN & 4,68 & High & \begin{tabular}{|l|l|}
11.128 .584 \\
\end{tabular} & Small & 0,33 & Loser & Small|High|Loser & $150,00 \%$ & $-20,00 \%$ & $250,00 \%$ & $-21,43 \%$ & $-36,36 \%$ & $14,29 \%$ & $0,00 \%$ & $0,00 \%$ & $-12,50 \%$ & $-14,29 \%$ & $0,00 \%$ & $-16,67 \%$ \\
\hline IGBR5 & IGB S/A PNA & 1,48 & High & 47.321 .270 & Small & 0,29 & Loser & SSall|High| Loser & $6,75 \%$ & $80,59 \%$ & $-8,75 \%$ & $2,05 \%$ & $15,44 \%$ & $62,79 \%$ & $-15,07 \%$ & $0,93 \%$ & $10,83 \%$ & $-0,75 \%$ & $-12,88 \%$ & $-4,78 \%$ \\
\hline SCAR3 & Sao Carlos ON & 1,55 & High & 407.715 .006 & Small & 0,18 & Loser & Small|High|Loser & $-5,26 \%$ & $0,00 \%$ & $36,11 \%$ & $-2,12 \%$ & $0,08 \%$ & $-8,33 \%$ & $-13,64 \%$ & $47,37 \%$ & $-20,36 \%$ & $-18,83 \%$ & $0,00 \%$ & $-0,55 \%$ \\
\hline SCAR4 & Sao Carlos PN & 1,55 & High & 407.715 .006 & Small & 0,16 & Loser & Small|High|Loser & $-18,03 \%$ & $20,27 \%$ & $21,95 \%$ & $-0,09 \%$ & $-8,10 \%$ & $-5,94 \%$ & $-2,63 \%$ & $24,22 \%$ & $-21,67 \%$ & $0,00 \%$ & $-1,11 \%$ & $-10,11 \%$ \\
\hline SGAS4 & WIm Ind Com PN & 2,35 & High & 101.884 .240 & Small & 0,11 & Loser & Small|High| Loser & $17,84 \%$ & $-3,47 \%$ & $25,96 \%$ & $26,12 \%$ & $-3,07 \%$ & $11,77 \%$ & $-1,00 \%$ & $1,01 \%$ & $-3,67 \%$ & $5,54 \%$ & $-19,81 \%$ & $26,92 \%$ \\
\hline VINE5 & Vicunha Text PNA & 3,44 & High & 166.151 .880 & Small & 0,08 & Loser & Small|High|Loser & $0,00 \%$ & $-5,56 \%$ & $32,35 \%$ & $2,22 \%$ & $1,09 \%$ & $7,53 \%$ & $-6,00 \%$ & $8,51 \%$ & $-5,88 \%$ & $0,00 \%$ & $-2,08 \%$ & $8,51 \%$ \\
\hline IENG5 & Ienergia PNA & 3,32 & High & 89.131 .350 & Small & 0,07 & Loser & Small|High|Loser & $0,00 \%$ & $-13,33 \%$ & $92,31 \%$ & $-16,00 \%$ & $28,57 \%$ & $18,52 \%$ & $-18,75 \%$ & $3,85 \%$ & $-14,81 \%$ & $-21,74 \%$ & $11,11 \%$ & $-5,00 \%$ \\
\hline RCSL4 & Recrusul PN & 1,91 & High & \begin{tabular}{|l|l|}
4.925 .067 \\
\end{tabular} & Small & 0,06 & Loser & Small|High|Loser & $-10,96 \%$ & $10,77 \%$ & $20,83 \%$ & $-28,74 \%$ & $-6,45 \%$ & $-1,72 \%$ & $1,75 \%$ & $3,45 \%$ & $-16,67 \%$ & $-16,00 \%$ & $-4,76 \%$ & $-15,00 \%$ \\
\hline ALPA3 & Alpargatas ON & 1,33 & High & 428.005 .861 & Small & 0,03 & Loser & Small|High|Loser & $2,32 \%$ & $6,47 \%$ & $29,87 \%$ & $6,67 \%$ & $-7,64 \%$ & $15,52 \%$ & $3,66 \%$ & $45,59 \%$ & $-23,23 \%$ & $-21,05 \%$ & $13,01 \%$ & $-3,03 \%$ \\
\hline MNDL4 & Mundial PN & 1,90 & High & \begin{tabular}{|l|l|}
42.726 .150 \\
\end{tabular} & Small & 0,01 & Loser & Small|High|Loser & $-7,06 \%$ & $-10,13 \%$ & \begin{tabular}{|l|l|}
$12,68 \%$ \\
\end{tabular} & $3,75 \%$ & $50,60 \%$ & $64,00 \%$ & $-11,71 \%$ & $-11,60 \%$ & \begin{tabular}{|l|l|}
$19,38 \%$ \\
\end{tabular} & $-10,47 \%$ & $-0,58 \%$ & $8,24 \%$ \\
\hline CEBR5 & Ceb PNA & 3,88 & High & 51.743.166 & Small & 0,00 & Loser & Small|High|Loser & $4,05 \%$ & $-25,89 \%$ & $2,45 \%$ & $-1,02 \%$ & $-6,36 \%$ & $0,53 \%$ & $-20,94 \%$ & $\mid-0,66 \%$ & $-1,33 \%$ & $-1,35 \%$ & $2,88 \%$ & $-2,13 \%$ \\
\hline STRP4 & Botucatu Tex PN & 1,31 & High & 3.046.992 & Small & 0,08 & Loser & Small|High|Loser & $16,67 \%$ & $-28,57 \%$ & $70,00 \%$ & $-17,65 \%$ & $35,71 \%$ & $-10,53 \%$ & $23,53 \%$ & $33,33 \%$ & $-3,57 \%$ & $0,00 \%$ & $-25,93 \%$ & $-20,00 \%$ \\
\hline BMTO4 & Brasmotor PN & 1,80 & High & 445.632 .864 & Small & 0,09 & Loser & Small|High|Loser & $7,26 \%$ & $26,47 \%$ & $2,79 \%$ & $-7,24 \%$ & $4,88 \%$ & $-2,33 \%$ & $-2,62 \%$ & $0,10 \%$ & $-6,27 \%$ & $-15,84 \%$ & $-7,44 \%$ & $-2,03 \%$ \\
\hline FITA4 & Forjas Taurus PN & 1,78 & High & 121.212 .000 & Small & 0,18 & Loser & Small|High|Loser & $-7,14 \%$ & $6,15 \%$ & $2,17 \%$ & $0,71 \%$ & $-1,19 \%$ & $1,52 \%$ & $-5,97 \%$ & $4,76 \%$ & $3,79 \%$ & $-6,57 \%$ & $-11,72 \%$ & $-2,65 \%$ \\
\hline CESP3 & Cesp ON & 5,99 & High & \begin{tabular}{|l|}
854.597 .213 \\
\end{tabular} & Small & 0,18 & Loser & Small|High|Loser & $10,91 \%$ & $-2,70 \%$ & $22,22 \%$ & $-3,91 \%$ & $9,74 \%$ & $-12,07 \%$ & $-5,88 \%$ & $4,17 \%$ & $-4,00 \%$ & $-8,33 \%$ & $11,36 \%$ & $-12,14 \%$ \\
\hline PTNT4 & Pettenati PN & 3,17 & High & 22.736 .005 & Small & 0,19 & Loser & Small|High|Loser & $0,05 \%$ & $10,53 \%$ & $28,57 \%$ & $6,26 \%$ & $1,03 \%$ & $-0,79 \%$ & $-3,96 \%$ & $16,62 \%$ & $3,57 \%$ & $-5,17 \%$ & $-16,36 \%$ & $-4,35 \%$ \\
\hline ETER4 & Eternit PN & 1,29 & High & 214.680 .554 & Small & 0,19 & Loser & Small|High|Loser & $7,95 \%$ & $9,23 \%$ & $0,29 \%$ & $1,37 \%$ & $5,88 \%$ & $0,00 \%$ & $17,71 \%$ & $4,80 \%$ & $-2,71 \%$ & $-3,80 \%$ & $-2,17 \%$ & $-1,39 \%$ \\
\hline ETER3 & Eternit ON & 1,29 & High & 214.680 .554 & Small & 0,20 & Loser & Small|High|Loser & $8,08 \%$ & $9,57 \%$ & $-1,13 \%$ & $1,19 \%$ & $5,29 \%$ & $4,75 \%$ & $15,39 \%$ & $2,07 \%$ & $-4,94 \%$ & $-5,71 \%$ & $2,88 \%$ & $-3,07 \%$ \\
\hline JBDU4 & J B Duarte PN & 1,41 & High & \begin{tabular}{|l|l|}
1.409 .257 \\
\end{tabular} & Small & 0,20 & Loser & Small|High|Loser & $-16,67 \%$ & $10,00 \%$ & $63,64 \%$ & $33,33 \%$ & $0,00 \%$ & $4,17 \%$ & $112,00 \%$ & $-16,98 \%$ & $22,73 \%$ & \begin{tabular}{|l|}
$-29,63 \%$ \\
\end{tabular} & $5,26 \%$ & $-5,00 \%$ \\
\hline CESP5 & Cesp PNA & 5,99 & High & \begin{tabular}{|l|}
854.597 .213 \\
\end{tabular} & Small & 0,20 & Loser & Small|High|Loser & $12,65 \%$ & $1,96 \%$ & $21,68 \%$ & $-1,08 \%$ & $10,97 \%$ & $-15,25 \%$ & $-16,99 \%$ & $6,79 \%$ & $-5,49 \%$ & \begin{tabular}{|l|}
$-13,82 \%$ \\
\end{tabular} & $26,63 \%$ & $-8,87 \%$ \\
\hline EMAE4 & Emae PN & 3,62 & High & & Small & 0,21 & Loser & Small|High|Loser & $7,28 \%$ & $9,36 \%$ & $9,23 \%$ & $2,00 \%$ & $8,43 \%$ & $-13,06 \%$ & $-17,25 \%$ & $7,14 \%$ & $3,60 \%$ & $-0,87 \%$ & $-7,37 \%$ & $7,95 \%$ \\
\hline SAPR4 & Sanepar PN & 2,09 & High & 4.643 .819 & Small & 0,21 & Loser & Small|High| Loser & $0,57 \%$ & $3,98 \%$ & $3,28 \%$ & $0,53 \%$ & $16,84 \%$ & $9,91 \%$ & $-13,40 \%$ & $11,62 \%$ & $0,90 \%$ & $-4,48 \%$ & $-1,41 \%$ & $-1,43 \%$ \\
\hline BRGE12 & Alfa Consorc PNF & 1,80 & High & 196.082 .300 & Small & 0,29 & Loser & Small|High|Loser & $0,00 \%$ & $-4,25 \%$ & $2,49 \%$ & $-2,83 \%$ & $-3,75 \%$ & $4,76 \%$ & $0,00 \%$ & $-0,02 \%$ & $25,00 \%$ & $18,64 \%$ & $0,00 \%$ & $2,86 \%$ \\
\hline ALPA4 & Alpargatas PN & 1,33 & High & 428.005 .861 & Small & 0,31 & Loser & Small|High|Loser & $-1,64 \%$ & $18,18 \%$ & $14,25 \%$ & $3,16 \%$ & $-10,02 \%$ & $26,65 \%$ & $-0,01 \%$ & $2,79 \%$ & $-7,03 \%$ & $-8,43 \%$ & $7,88 \%$ & $6,03 \%$ \\
\hline SULT4 & & 19,94 & High & 7.730 .100 & Small & 0,31 & Loser & Small|High|Loser & $8,93 \%$ & $-1,64 \%$ & $20,00 \%$ & $11,11 \%$ & $-16,25 \%$ & $19,40 \%$ & $18,75 \%$ & $-3,16 \%$ & $-17,28 \%$ & $-6,67 \%$ & $5,71 \%$ & $-17,57 \%$ \\
\hline CEPE5 & Celpe PNA & 2,15 & High & 527.697 .257 & Small & 0,46 & Loser & Small|High|Loser & $7,43 \%$ & $-1,89 \%$ & $5,13 \%$ & $5,49 \%$ & $8,67 \%$ & $6,03 \%$ & $-0,54 \%$ & $6,56 \%$ & $8,16 \%$ & $3,41 \%$ & $8,02 \%$ & $5,68 \%$ \\
\hline MGEL4 & Mangels Indl PN & 3,65 & High & \begin{tabular}{|l|l|}
45.733 .144 \\
\end{tabular} & Small & 0,47 & Loser & Small|High|Loser & $41,21 \%$ & $2,29 \%$ & $14,55 \%$ & $3,79 \%$ & $19,65 \%$ & $1,08 \%$ & $3,11 \%$ & $17,83 \%$ & $3,68 \%$ & $0,99 \%$ & $-21,22 \%$ & $-14,63 \%$ \\
\hline BRGE3 & Alfa Consor & 1,80 & High & 196.082 .300 & Small & 0,48 & Loser & Small|High|Loser & $0,73 \%$ & $-14,57 \%$ & $2,56 \%$ & $5,42 \%$ & $0,00 \%$ & $6,72 \%$ & $2,22 \%$ & $-7,23 \%$ & $39,44 \%$ & $0,00 \%$ & $-8,29 \%$ & $9,35 \%$ \\
\hline FLCL5 & F Cat & 1,95 & High & \begin{tabular}{|l|l|}
183.514 .694 \\
\end{tabular} & Small & 0,53 & Loser & Small|High|Loser & $-3,57 \%$ & $-3,70 \%$ & $3,08 \%$ & $0,00 \%$ & $-6,72 \%$ & $36,00 \%$ & $-16,47 \%$ & $9,15 \%$ & $1,29 \%$ & $0,64 \%$ & $-2,98 \%$ & $6,77 \%$ \\
\hline BDLL4 & \begin{tabular}{|l|l|l|} 
Bardella PN \\
\end{tabular} & 2,19 & \begin{tabular}{|l} 
High \\
\end{tabular} & 000.000 & Small & 56 & Winner & Small|High|Winner & $0,85 \%$ & $4,20 \%$ & $-0,32 \%$ & $-0,49 \%$ & $-1,30 \%$ & $5,22 \%$ & $-3,51 \%$ & $3,64 \%$ & $0,18 \%$ & $-3,68 \%$ & $-11,82 \%$ & $0,82 \%$ \\
\hline ASTA4 & Santistextil PN & 1,58 & High & 385.482 .374 & Small & 0,58 & Winner & Small| High|Winner & $2,33 \%$ & $-7,33 \%$ & $3,85 \%$ & $3,76 \%$ & $-0,26 \%$ & $9,64 \%$ & $0,44 \%$ & $-4,29 \%$ & $4,83 \%$ & $3,61 \%$ & $-18,20 \%$ & $5,71 \%$ \\
\hline SHUL4 & Schulz $\mathrm{F}$ & 3,36 & High & 23.591 .422 & Small & 0,59 & Winner & Small|High|Winner & $45,65 \%$ & $4,48 \%$ & $14,29 \%$ & $9,75 \%$ & $-2,05 \%$ & $44,19 \%$ & $-0,32 \%$ & $21,36 \%$ & $0,00 \%$ & $-1,33 \%$ & $-2,12 \%$ & $3,57 \%$ \\
\hline PTIP3 & Ipiranga Pet ON & 1,32 & High & 675.886 .190 & Small & 0,65 & Winner & Small|High|Winner & $4,78 \%$ & $17,57 \%$ & $2,21 \%$ & $4,32 \%$ & $22,51 \%$ & $38,77 \%$ & $5,71 \%$ & $29,17 \%$ & $-12,90 \%$ & $7,41 \%$ & $6,90 \%$ & $-19,35 \%$ \\
\hline CGRA4 & & 1,49 & High & 54.134.962 & Small & 0,65 & Winner & Small|High|Winner & $7,07 \%$ & $20,00 \%$ & $-2,78 \%$ & $14,29 \%$ & $0,00 \%$ & $3,70 \%$ & $3,62 \%$ & $10,54 \%$ & $-2,33 \%$ & $-4,58 \%$ & $0,00 \%$ & $-5,00 \%$ \\
\hline \begin{tabular}{|l|l|} 
RSID3 \\
\end{tabular} & Rossi Resid ON & 1,56 & High & 154.725 .806 & Small & 0,67 & Winner & Small| |High|Winner & $-2,50 \%$ & $25,64 \%$ & $12,24 \%$ & $0,00 \%$ & $5,45 \%$ & $-1,72 \%$ & $-7,02 \%$ & $1,89 \%$ & $-1,85 \%$ & $18,87 \%$ & $-9,84 \%$ & $1,82 \%$ \\
\hline COCE5 & Coelce PNA & 1,84 & High & .101 .230 & $\mathrm{Sm}$ & 0,84 & Winner & Small|High|Winner & $-1,86 \%$ & $-1,66 \%$ & $-1,45 \%$ & $-4,65 \%$ & $-2,56 \%$ & $8,42 \%$ & $16,99 \%$ & $26,56 \%$ & $-11,48 \%$ & $8,00 \%$ & $-16,07 \%$ & $0,00 \%$ \\
\hline RPAD3 & Alfa Holding ON & 1,72 & High & 213.638 .500 & Small & 0,99 & Winner & Small|High|Winner & $-2,00 \%$ & $-17,60 \%$ & $2,51 \%$ & $6,37 \%$ & $-2,76 \%$ & $-0,47 \%$ & $0,00 \%$ & $-8,11 \%$ & $22,11 \%$ & $\mid 1,72 \%$ & $-4,24 \%$ & $1,77 \%$ \\
\hline PTIP4 & Ipirang & 1,32 & High & 675.886 .190 & Small & 1,12 & Winner & Small|High|Winner & $7,32 \%$ & $11,92 \%$ & $11,03 \%$ & $1,10 \%$ & $18,14 \%$ & $40,92 \%$ & $6,87 \%$ & $7,99 \%$ & $-12,22 \%$ & $-4,36 \%$ & $1,26 \%$ & $-17,93 \%$ \\
\hline TMAC6B & Amazon & 2,87 & High & 90.394.499 & Small & 1,20 & Winner & Small|High|Winner & $2,48 \%$ & $0,16 \%$ & $0,24 \%$ & $0,08 \%$ & $0,00 \%$ & $0,32 \%$ & $0,00 \%$ & $-0,48 \%$ & $-3,54 \%$ & $0,00 \%$ & $0,00 \%$ & $0,00 \%$ \\
\hline TMAC8E & Amazonia Celular PND & 2,87 & High & \begin{tabular}{|l|l|}
90.394 .499 \\
\end{tabular} & Small & 1,20 & Winner & Small|High|Winner & $2,48 \%$ & $0,16 \%$ & $0,24 \%$ & $-0,08 \%$ & $0,00 \%$ & $4,50 \%$ & $-3,85 \%$ & $-0,48 \%$ & $-3,54 \%$ & $0,00 \%$ & $0,00 \%$ & $0,00 \%$ \\
\hline RANI3 & Celul Irani ON & 1,89 & High & \begin{tabular}{ll|}
41.049 .716 \\
\end{tabular} & Small & 1,21 & Winner & Small|High|Winner & $29,34 \%$ & $22,87 \%$ & $1,86 \%$ & $6,72 \%$ & $11,11 \%$ & $8,33 \%$ & $3,23 \%$ & $13,26 \%$ & $-0,27 \%$ & $1,01 \%$ & $-7,07 \%$ & $-7,46 \%$ \\
\hline ELEV3 & Eleva 0 & 2,19 & High & 30.630 .996 & Small & 1,51 & Winner & Small|High|Winner & $18,24 \%$ & $18,57 \%$ & $4,90 \%$ & $9,33 \%$ & $-2,68 \%$ & $3,88 \%$ & $-2,29 \%$ & $1,23 \%$ & $1,71 \%$ & $-0,01 \%$ & $-5,05 \%$ & $-0,89 \%$ \\
\hline $\mathrm{PNO}$ & & & $\mathrm{HI}$ & & $\mathrm{Sm}$ & & & & 6 & $26,04 \%$ & 27,2 & $-2,35 \%$ & 5,7 & & & & & 10, & -11, & 10, \\
\hline PLAS4 & Plascar Part PI & 2,15 & High & 1 & Small & 6,55 & Winner & Small|High|Winner & $-14,57 \%$ & $3,05 \%$ & $3,70 \%$ & $34,05 \%$ & $-1,42 \%$ & $7,21 \%$ & $7,39 \%$ & $0,16 \%$ & $0,78 \%$ & $-6,98 \%$ & $25,00 \%$ & $-4,93 \%$ \\
\hline ITEC3 & Itautec ON & 0,52 & Low & 505.458 .400 & Small & 0,16 & Loser & Small|Low|Loser & $0,87 \%$ & $96,55 \%$ & $-15,79 \%$ & $-16,67 \%$ & $0,00 \%$ & $24,01 \%$ & $-14,81 \%$ & $4,76 \%$ & $-4,55 \%$ & $-9,52 \%$ & $5,26 \%$ & $-13,75 \%$ \\
\hline $\begin{array}{ll}\text { GLOB4 } \\
\end{array}$ & Globex PN & $\begin{array}{ll}0,53 \\
\end{array}$ & Low & 881.327 .240 & Small & 0,03 & Loser & Small|Low|Loser & $-0,80 \%$ & $16,16 \%$ & $12,17 \%$ & $-6,98 \%$ & $-4,17 \%$ & $-0,09 \%$ & $-4,61 \%$ & $-2,37 \%$ & $-3,74 \%$ & $6,21 \%$ & $-0,82 \%$ & $-6,91 \%$ \\
\hline SLED4 & Saraiva Livr & 0,45 & Low & 241.033 .980 & Small & 0,00 & Loser & Small|Low|Loser & 7,149 & $14,29 \%$ & $2,50 \%$ & $-2,44 \%$ & $0,83 \%$ & $83 \%$ & 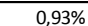 & 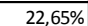 & $10,10 \%$ & $11,39 \%$ & 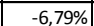 & re \\
\hline
\end{tabular}


Anexo 1 - Retorno mensal e classificação das ações

\begin{tabular}{|c|c|c|c|c|c|c|c|c|c|c|c|c|c|c|c|c|c|c|c|c|}
\hline Código & $2004-2005$ & $\begin{array}{l}\text { Índice } \mathrm{B} / \mathrm{M} \\
\text { de dez } / 2003\end{array}$ & $\begin{array}{c}\text { Grupo com } \\
\text { base no } \\
\text { indice B/M }\end{array}$ & $\begin{array}{c}\text { Valor de Mercado } \\
\text { em jun/2004 }\end{array}$ & $\begin{array}{c}\text { Grupo com } \\
\text { base no } \\
\text { tamanho }\end{array}$ & \begin{tabular}{|c|} 
Retorno \\
acumulado \\
de jun/2004
\end{tabular} & \begin{tabular}{|c|} 
Grupo com \\
base no \\
retorno \\
acumulado
\end{tabular} & Carteiras & $\mathrm{jul} / 04$ & ago/04 & set/04 & out/04 & nov/04 & dez/04 & $\mathrm{jan} / 05$ & $\mathrm{fev} / 05$ & mar/05 & $\mathrm{abr} / 05$ & mai/05 & jun/05 \\
\hline HGTX4 & Cia Hering PN & 0,15 & Low & 77.770 .900 & Small & 0,17 & Loser & Small|Low|Loser & $-4,26 \%$ & $-6,67 \%$ & $42,86 \%$ & $-3,33 \%$ & $0,00 \%$ & $-3,10 \%$ & $-7,47 \%$ & 5,77\% & $-12,73 \%$ & $-1,67 \%$ & $0,00 \%$ & $-2,54 \%$ \\
\hline ELEK4 & Elekeiroz PN & 0,48 & Low & 409.306 .950 & Small & 0,79 & Winner & Small|Low|Winner & $3,08 \%$ & $13,43 \%$ & $38,16 \%$ & $0,00 \%$ & $0,00 \%$ & $-2,33 \%$ & $93,00 \%$ & $-1,55 \%$ & $42,11 \%$ & $-30,37 \%$ & $-12,23 \%$ & $-1,82 \%$ \\
\hline FRAS4 & Fras-Le PN & 0,51 & Low & \begin{tabular}{|l|}
477.778 .000 \\
\end{tabular} & Small & 1,18 & Winner & Small|Low|Winner & $-6,27 \%$ & $8,31 \%$ & $4,40 \%$ & $-0,68 \%$ & $12,33 \%$ & $-1,57 \%$ & $-3,88 \%$ & $-2,47 \%$ & $-5,47 \%$ & $-1,97 \%$ & $-14,70 \%$ & $0,34 \%$ \\
\hline LLMD4 & Yara Brasil PN & 0,39 & Low & 575.312 .642 & Small & 1,19 & Winner & Small|Low|Winner & $2,91 \%$ & $4,24 \%$ & $7,46 \%$ & $-4,42 \%$ & $7,26 \%$ & $-4,92 \%$ & $-6,15 \%$ & $3,10 \%$ & $0,33 \%$ & $0,00 \%$ & $-24,10 \%$ & $-1,04 \%$ \\
\hline ESTR4 & Estrela PN & 0,49 & w & 38.800 .800 & Small & 1,35 & Winner & Small|Low|Winner & $8,33 \%$ & $5,77 \%$ & $20,00 \%$ & $-3,03 \%$ & $-17,19 \%$ & $-1,89 \%$ & $-11,54 \%$ & $-30,43 \%$ & $-1,88 \%$ & $-10,83 \%$ & $-13,57 \%$ & $-15,70 \%$ \\
\hline RIPI3 & Ipiranga Ref ON & 0,39 & Low & 244.548 .950 & Small & 1,57 & Winner & Small|Low|Winner & $6,88 \%$ & $11,11 \%$ & $2,63 \%$ & $7,69 \%$ & $30,95 \%$ & $38,18 \%$ & $7,89 \%$ & $70,73 \%$ & $-21,43 \%$ & $18,18 \%$ & $17,25 \%$ & $2,67 \%$ \\
\hline RAPT4 & Randon Part PN & 0,40 & Low & 661.575 .900 & Small & 1,72 & Winner & \begin{tabular}{|l|l|l|} 
Small|Lowner \\
\end{tabular} & $15,11 \%$ & $11,20 \%$ & $9,38 \%$ & $1,27 \%$ & $-2,82 \%$ & $21,66 \%$ & $-5,22 \%$ & \begin{tabular}{l|l|}
$0,99 \%$ \\
\end{tabular} & $-1,54 \%$ & $-3,41 \%$ & $-6,83 \%$ & $-11,29 \%$ \\
\hline RIPI4 & Ipiranga Ref PN & 0,39 & Low & 244.548 .950 & Small & 1,93 & Winner & Small|Low|Winner & $21,98 \%$ & $11,77 \%$ & $3,54 \%$ & $20,17 \%$ & $19,35 \%$ & $33,86 \%$ & $5,49 \%$ & $22,92 \%$ & $-16,27 \%$ & $1,62 \%$ & $15,18 \%$ & $-11,52 \%$ \\
\hline KEPL3 & Kepler Weber ON & 0,34 & N & 904.200 & Small & 3,19 & Winner & Small|Low|Winner & $26,32 \%$ & $18,06 \%$ & $10,59 \%$ & $-7,45 \%$ & $19,54 \%$ & $2,39 \%$ & $-7,55 \%$ & $2,04 \%$ & $-5,50 \%$ & $-5,13 \%$ & $-23,94 \%$ & $12,35 \%$ \\
\hline TEKA4 & Teka PN & 1,14 & Medium & \begin{tabular}{|l|l|}
15.727 .503 \\
1
\end{tabular} & Small & 0,18 & Loser & Small|Medium|Loser & $14,63 \%$ & $76,60 \%$ & $-15,66 \%$ & $-14,29 \%$ & $3,33 \%$ & $20,97 \%$ & $-5,33 \%$ & $2,82 \%$ & $12,33 \%$ & $-2,44 \%$ & $2,50 \%$ & $-3,66 \%$ \\
\hline EBCO3 & Embraco ON & \begin{tabular}{l|l}
0,86 \\
\end{tabular} & Medium & \begin{tabular}{ll|}
789.597 .260 \\
\end{tabular} & Small & 0,08 & Loser & Small|Medium|Loser & $10,67 \%$ & $1,60 \%$ & $2,36 \%$ & $2,31 \%$ & $-11,28 \%$ & $10,17 \%$ & $-19,23 \%$ & \begin{tabular}{l|l}
$4,76 \%$ \\
\end{tabular} & $2,73 \%$ & $-24,78 \%$ & $-3,53 \%$ & $-1,22 \%$ \\
\hline EBCO4 & Embraco PN & 0,86 & Medium & 789.597.260 & Small & 0,05 & Loser & Small|Medium|Loser & $-1,34 \%$ & $2,36 \%$ & $9,23 \%$ & $-6,34 \%$ & $-1,50 \%$ & $6,11 \%$ & $-16,55 \%$ | & $12,07 \%$ | & $-19,23 \%$ & $-14,29 \%$ & $0,00 \%$ & $-5,56 \%$ \\
\hline MLFT4 & Jereiss. & 01 & edium & 729.070 & Small & 0,07 & Loser & Small|Medium|Loser & $0,00 \%$ & $0,00 \%$ & $-3,77 \%$ & $-5,88 \%$ & $0,00 \%$ & $4,17 \%$ & $-2,00 \%$ & $2,04 \%$ & $2,00 \%$ & $-1,96 \%$ & $0,00 \%$ & $0,00 \%$ \\
\hline PLTO6 & Poll & 18 & Mediu & 0.591 & Small & 0,09 & Loser & Small|Medium|Loser & $23,17 \%$ & $1,36 \%$ & $-4,68 \%$ & $-3,51 \%$ & $19,47 \%$ & $-0,80 \%$ [ & $-7,42 \%$ & $9,93 \%$ | & $-0,16 \%$ & $-12,70 \%$ | & $-5,45 \%$ & $5,77 \%$ \\
\hline CNFB4 & Confab PN & 0,74 & Medium & 500.881 .920 & Small & 0,13 & Loser & Small|Medium|Loser & $3,90 \%$ & $18,75 \%$ & $30,53 \%$ & $1,61 \%$ & $10,87 \%$ & $18,01 \%$ & $-7,17 \%$ & $3,36 \%$ & $-12,34 \%$ & $7,04 \%$ & $16,26 \%$ & $-3,27 \%$ \\
\hline TLCP3 & Tele Leste Celular ON & 1,02 & Medium & 369.232.970 & Small & 0,14 & Loser & Small|Medium|Loser & $5,80 \%$ ] & $2,74 \%$ & $4,00 \%$ & $-25,64 \%$ & $-5,17 \%$ & $-3,64 \%$ & $-24,53 \%$ | $<2$ & $2,50 \%$ & $2,44 \%$ & $-2,38 \%$ & $-9,76 \%$ ] $>2$ & $-10,74 \%$ \\
\hline TNCP3 & Tele Nor & 82 & Medium & 094.465 & Small & 18 & Loser & Small|Medium|Loser & $-4,29 \%$ & $-2,99 \%$ & $4,62 \%$ & $0,00 \%$ & $-2,94 \%$ & $-3,03 \%$ & $-17,19 \%$ & $5,66 \%$ & $23,21 \%$ & $1,45 \%$ & $28,57 \%$ & $-4,44 \%$ \\
\hline DURA4 & Durat & 0,97 & Medium & 39.322 & Small & 0,19 & Loser & Small|Medium|Loser & $15,27 \%$ & $32,02 \%$ & $15,29 \%$ & $-0,33 \%$ & $1,47 \%$ & $3,33 \%$ & $-4,03 \%$ & $4,43 \%$ & $-3,28 \%$ & $0,00 \%$ & $-6,78 \%$ & $-10,91 \%$ \\
\hline TDBH3 & Telefonica Data HId ON & 0,95 & Medium & .381.912 & Small & 0,27 & Loser & Small|Medium|Loser & $2,38 \%$ & $-2,33 \%$ & $11,90 \%$ & $-4,26 \%$ & $0,00 \%$ & $0,00 \%$ & $-2,22 \%$ & $4,55 \%$ & $-6,52 \%$ & $-2,33 \%$ & $-2,38 \%$ & $0,00 \%$ \\
\hline TPEСЗВ & Tim Nordeste ON & 1,18 & Medium & 68.924.672 & Small & 0,28 & Loser & Small|Medium|Loser & $-5,00 \%$ & $5,26 \%$ & $-2,83 \%$ & $3,77 \%$ & $5,79 \%$ & $21,88 \%$ & $-15,38 \%$ & $6,06 \%$ & $11,43 \%$ & $17,95 \%$ & $19,57 \%$ & $-1,82 \%$ \\
\hline POMO4 & Marcopolo PN & 0,76 & Medium & 8.386 .730 & Small & 0,36 & Loser & Small|Medium|Loser & $3,57 \%$ & $7,76 \%$ & $1,60 \%$ & $0,94 \%$ & $-1,09 \%$ & $13,52 \%$ & $-0,58 \%$ & $-5,88 \%$ & $-13,91 \%$ & $-12,34 \%$ & $-10,97 \%$ & $10,47 \%$ \\
\hline GUAR4 & & 1,07 & Med & & Sma & , 37 & Loser & all $\mid \mathrm{M}$ & $14,50 \%$ & $20,19 \%$ & $13,27 \%$ & $-2,88 \%$ & $19,39 \%$ & $14,21 \%$ | & $-2,2$ & $71,36 \%$ | & $0,24 \%$ & $-1,69 \%$ ] & $-7,23 \%$ & $-4,41 \%$ \\
\hline PTBL3 & Portobello ON & 0,64 & Medium & 1.553 .620 & Small & 0,37 & Loser & Small|Medium|Loser & $44,44 \%$ & $-15,38 \%$ & $27,27 \%$ & $28,57 \%$ & $11,11 \%$ & $-0,50 \%$ & $-3,02 \%$ & $-4,15 \%$ & $-0,54 \%$ & $-2,17 \%$ & $1,67 \%$ & $8,20 \%$ \\
\hline TDBH4 & Telefonica Data HId PN & 0,95 & Medium & 478.381.912 & Small & 0,41 & Loser & Small|Medium|Loser & $10,87 \%$ & $-3,92 \%$ [ & $8,16 \%$ & $0,00 \%$ & $1,89 \%$ & $-1,85 \%$ & $0,00 \%$ & $1,89 \%$ & $-1,85 \%$ & $-1,89 \%$ & $-5,77 \%$ & $0,00 \%$ \\
\hline RSIP4 & Rasip Agro PN & 1,00 & Medium & 36.018 .480 & Small & 0,44 & Loser & Small|Medium|Loser & $4,17 \%$ & $-4,99 \%$ & $-8,33 \%$ & $9,09 \%$ & $0,00 \%$ & $3,91 \%$ | & $37,50 \%$ | & $3,03 \%$ | & $-26,47 \%$ & $-8,00 \%$ [ $>2$ & $4,35 \%$ & $-8,33 \%$ \\
\hline TLCP4 & Tele I & 1,02 & Mediu & & Sma & 0,45 & Loser & Small|M & 16,05 & $-4,26 \%$ ] & $-1,11 \%$ & $-26,97 \%$ & $-1,54 \%$ & $0,00 \%$ ] & $-26,56 \%$ & $0,00 \%$ & $-4,26 \%$ & $-8,89 \%$ ] $>$ & $0,98 \%$ & $-8,19 \%$ \\
\hline TRFO4 & Trafo PN & 1,05 & Medium & 240.480 & Small & 0,53 & Loser & Small|Medium|Loser & $7,50 \%$ & $27,91 \%$ & $0,00 \%$ & $8,18 \%$ & $7,56 \%$ & $-10,16 \%$ & $3,48 \%$ & $0,84 \%[$ & $0,00 \%$ & $-8,33 \%$ & $-9,09 \%$ & $-2,00 \%$ \\
\hline GUAR3 & Guararapes ON & 7 & Medium & 448.000 & Small & 0,54 & Loser & Small|Medium|Loser & $13,26 \%$ & $15,50 \%$ & $11,41 \%$ & $5,42 \%$ & $14,29 \%$ & $-1,50 \%$ & $9,14 \%$ & $51,16 \%$ & $-1,11 \%$ & $-10,54 \%$ & $-11,70 \%$ & $14,05 \%$ \\
\hline PLDN4 & Polialder & 09 & Medium & & Small & 0,59 & Winner & Small|Medium|Winner & $7,32 \%$ & $45,79 \%$ & $10,26 \%$ & $4,65 \%$ & $22,22 \%$ & $10,82 \%$ & $-10,09 \%$ & $9,40 \%$ & $-14,93 \%$ & $-3,92 \%$ & $-13,17 \%$ & $-4,82 \%$ \\
\hline MAGS3 & Magn & 1,24 & Medium & 2.876 & Small & 59 & Winner & Small|Medium|Winner & $12,04 \%$ & $22,34 \%$ & $17,39 \%$ & $4,44 \%$ & $-0,71 \%$ & 7,14\% & 4, & \begin{tabular}{l|l}
$8,00 \%$ \\
\end{tabular} & $1,85 \%$ & $-15,15 \%$ & $-0,86 \%$ & $-9,94 \%$ \\
\hline ALBA3 & Albar & 06 & ediu & 060.000 & Small & 60 & Win & fall $\mid \mathrm{M}$ & $18,18 \%$ | & $0,59 \%$ & $5,88 \%$ & $0,00 \%$ & $5,56 \%$ & $-3,16 \%$ & $-2,17 \%$ & $12,22 \%$ ] & $4,69 \%$ & $0,00 \%$ [ & $4,06 \%$ & $4,39 \%$ \\
\hline IDNT3 & Ideiasnet ON & 61 & Medium & 967.727 & Small & 63 & Winner & Small|Medium|Winner & $-3,64 \%$ & $66,04 \%$ & $50,00 \%$ & $28,79 \%$ & $-4,12 \%$ & $0,61 \%$ & $-4,27 \%$ & $42,68 \%$ [ & $15,18 \%$ & $-10,85 \%$ & $-4,35 \%$ & $-18,18 \%$ \\
\hline FESA4 & Ferbas. & 04 & Medium & 0.000 & Small & 65 & Winner & Small|Medium|Winner & $11,76 \%$ & $10,53 \%$ & $2,02 \%$ & $-8,05 \%$ & & $-2,34 \%$ & & $11,25 \%$ & $-6,74 \%$ & $-4,92 \%$ & $-20,59 \%$ & $-5,03 \%$ \\
\hline TNCP4 & Tele N & 0,82 & Medium & .094.465 & Small & 0,69 & Winner & Small|Medium|Winner & $-1,79 \%$ & $0,00 \%$ & $-1,82 \%$ & $-1,85 \%$ & $-3,77 \%$ & $-1,96 \%$ & $-26,00 \%$ & $7,08 \%$ & $-5,26 \%$ & $-8,33 \%$ & $-6,06 \%$ & $-3,23 \%$ \\
\hline MAGS5 & Magn & 4 & dium & 062.876 & Small & 70 & Winner & | Winner & $12,12 \%$ & $24,01 \%$ & $14,40 \%$ & $-1,40 \%$ & $3,19 \%$ & $8,93 \%$ & $-1,33 \%$ & $10,74 \%$ | & $-0,55 \%$ & $-13,47 \%$ ] & $-6,69 \%$ & $-10,34 \%$ \\
\hline MTSA4 & Metis & & Medii & 814.100 & Small & 0 & Winner & n|Winner & $15,38 \%$ & $5,33 \%$ & $17,72 \%$ & $0,00 \%$ & $1,61 \%$ & $10,66 \%$ & $-0,01 \%$ & $-4,99 \%$ & $7,37 \%$ & $-3,92 \%$ & $-1,02 \%$ & $-0,10 \%$ \\
\hline CLSC6 & Celesc PNB & & Medium & 972.270 & Small & 34 & Winner & Small|Medium|Winner & $14,46 \%$ & $5,26 \%$ & $5,00 \%$ & $-5,7,7$, & $7,07 \%$ & $6,60 \%$ & $-15,58 \%$ & $10,00 \%$ & $-9,09 \%$ & $-1,11 \%$ | $>$ & $-2,21 \%$ & $4,60 \%$ \\
\hline DPPI4 & Ipirang & 07 & Medium & 364.506 & Small & 89 & Winner & Small|Medium|Winner & $13,28 \%$ & $14,96 \%$ & $3,45 \%$ & $-9,09 \%$ & $19,93 \%$ & $23,16 \%$ & $0,66 \%$ & \begin{tabular}{l|l}
$7,32 \%$ \\
\end{tabular} & $-6,82 \%$ & $-9,76 \%$ & $2,70 \%$ & $-6,05 \%$ \\
\hline TPECGB & $\operatorname{Tim} \mathbf{n}$ & 8 & ediur & 772 & Smal & 91 & Winner & $\mathrm{m} /$ Winner & $-8,45 \%$ & $4,46 \%$ ] & $-1,33 \%$ & 8,81 & $4,66 \%$ & $2,23 \%$ & $-7,69 \%$ & $17,92 \%$ & $\%$ & $22,62 \%$ ] & $5 \%$ ] & $3 \%$ \\
\hline ROMI3 & Inds R & 6 & Mediu & & Small & 02 & Winner & Ninner & $16,71 \%$ & $17,16 \%$ & $16,82 \%$ & $5,52 \%$ & $7,13 \%$ & $4,77 \%$ & $-5,45 \%$ & $2,50 \%$ & $-0,09 \%$ & $0,00 \%$ & $6,93 \%$ & $1,79 \%$ \\
\hline SZPQ4 & Quattor Petr & 1,25 & Medium & & Small & 1,07 & Winner & nall|Medium|Winner & $13,16 \%$ & $24,81 \%$ & $10,19 \%$ & $9,59 \%$ & $10,00 \%$ & $-5,68 \%$ & $-15,51 \%$ & $10,16 \%$ & $-15,37 \%$ & $-7,70 \%$ & $-1,91 \%$ & $-3,69 \%$ \\
\hline PEFX5 & Petrofle & 0,95 & Medium & 807.524 & Small & 88 & Winner & Small|Medium|Winner & $21,19 \%$ & $-0,35 \%$ & $3,51 \%$ & $10,00 \%$ & $7,86 \%$ & $4,08 \%$ & $12,34 \%$ & $5,32 \%$ & $-8,08 \%$ & $20 \%$ & $4,49 \%$ & $-5,91 \%$ \\
\hline ROMI4 & Inds F & 1,16 & Medi & 600 & Smal & 1,23 & Win & nall|M & $18,45 \%$ & $17,65 \%$ & $12,00 \%$ & $3,97 \%$ & $54 \%$ & $10,68 \%$ ] & $0,39 \%$ & $2,31 \%$ & $-0,68 \%$ & $0,00 \%$ ] & $4 \%$ & $0 \%$ \\
\hline ESCE3 & Escels & 12 & Medit & 50 & Small & 4 & $v$ & fall $\mid \mathrm{M}$ & $-2,89 \%$ & $13,51 \%$ & $-10,90 \%$ & & $4,29 \%$ & $-2,35 \%$ & $-1,81 \%$ & $10,43 \%$ _ & $15,56 \%$ & $17,90 \%$ & $6,19 \%$ & 50, \\
\hline DXTG4 & Dixie Tc & 70 & $\mathrm{Me}$ & & $\mathrm{Sm}$ & 1,37 & & nall|Me & 40,8 & $0,00 \%$ & $6,00 \%$ & $3,77 \%$ & $9,09 \%$ & $70,83 \%$ & $-17,07 \%$ & $-2,94 \%$ & $15,15 \%$ & $-10,53 \%$ & $-6,45 \%$ & $-14,19 \%$ \\
\hline RHDS3 & MGPo & 62 & $m$ & 840 & Small & 43 & $\mathrm{Wit}_{\mathrm{i}}$ & hall|Medium|Winner & $16,67 \%$ & $21,43 \%$ ] & $35,29 \%$ & $13,04 \%$ & $-19,23 \%$ & $9,52 \%$ & $-13,04 \%$ & $30,00 \%$ ] & $-15,38 \%$ & $-9,09 \%$ ] & $-5,00 \%$ & $0,00 \%$ \\
\hline AVIL3 & Acos Vill ON & 59 & um & 227.700 & Small & 57 & Winner & m/Winner & $38,93 \%$ & $-4,87 \%$ & $27,01 \%$ & $21,03 \%$ & $37,04 \%$ & $76 \%$ & $-6,67 \%$ & $20,12 \%$ & $1,30 \%$ & $69 \%$ & $-0,28 \%$ & $-11,86 \%$ \\
\hline FBRA4 & & & & & $m a+2+2$ & & & & $5,00 \%$ ] & $7,66 \%$ | & & 0,0 & $2,64 \%$ & 3,6 & -3, & $4,17 \%$ & & $-2,0$ & $-12,70 \%$ & \\
\hline MYPK4 & 10 & 5 & & 0 & Sn & 2,33 & & (n) & 47,0 & 34,42 & $5,64 \%$ & 2,5 & 9,8 & 49,0 & $-4, c$ & $6,29 \%$ & 7,1 & $-1,81 \%$ & $5,10 \%$ & $-9,76 \%$ \\
\hline R3 & Eletropar ON & 1,11 & dium & 88.322.200 & Small & 6,50 | & Winner & Small|Medium|Winner & $0,94 \%$ | & $-1,05 \%$ | $>$ & $0,12 \%$ & $-2,35 \%$ & $-1,45 \%$ & $3,67 \%$ & $-2,24 \%$ & $20,02 \%$ & $20,30 \%$ & $-1,50 \%$ | $<>$ & $18,74 \%$ & $4,29 \%$ \\
\hline
\end{tabular}


Anexo 1 - Retorno mensal e classificação das ações

\begin{tabular}{|c|c|c|c|c|c|c|c|c|c|c|c|c|c|c|c|c|c|c|c|c|}
\hline Código & 2005 - 2006 & $\begin{array}{l}\text { Índice B/M } \\
\text { de dez/2004 }\end{array}$ & $\begin{array}{c}\text { Grupo com } \\
\text { base no } \\
\text { indice } B / M\end{array}$ & $\begin{array}{l}\text { Valor de Mercado } \\
\text { em jun/2005 }\end{array}$ & $\begin{array}{c}\text { Grupo com } \\
\text { base eno } \\
\text { tamanho }\end{array}$ & $\begin{array}{c}\text { Retorno } \\
\text { acumulado } \\
\text { de jun/2005 }\end{array}$ & \begin{tabular}{|c|} 
Grupo com \\
base no \\
retorno \\
acumulado \\
\end{tabular} & Carteiras & jul/05 & ago/05 & set/05 & out/05 & nov/05 & dez/05 & $\mathrm{jan} / 06$ & $\mathrm{fev} / 06$ & mar/06 & $\mathrm{abr} / 06$ & mai/06 & jun/06 \\
\hline \begin{tabular}{|l|} 
EBTP3 \\
\end{tabular} & Embratel Part ON & 1,94 & High & 3.525 .268 .140 & Big & 0,54 & \begin{tabular}{|l|} 
Loser \\
\end{tabular} & Big|High|Loser & $1,17 \%$ & $-2,31 \%$ & $4,26 \%$ & $4,31 \%$ & $12,83 \%$ & $9,83 \%$ & $-7,54 \%$ & $4,36 \%$ & $-16,36 \%$ & $21,74 \%$ & $5,36 \%$ & $11,86 \%$ \\
\hline EBTP4 & Embratel Part PN & 1,94 & High & 3.525 .268 .140 & Big & 0,29 & Loser & Big|High|Loser & $-3,69 \%$ & $1,06 \%$ & $9,47 \%$ & $4,23 \%$ & $10,52 \%$ & $13,52 \%$ & $-13,24 \%$ & $-8,14 \%$ & $-11,44 \%$ & $22,58 \%$ & $10,81 \%$ & $8,29 \%$ \\
\hline GEPA3 & Ger Paranap ON & 1,95 & High & 1.091 .638 .898 & Big & 0,06 & Loser & Big|High|Loser & $-1,54 \%$ & $17,70 \%$ & $10,34 \%$ & $6,25 \%$ & $-8,82 \%$ & $34,27 \%$ & $8,70 \%$ & $5,00 \%$ & $19,05 \%$ & $2,74 \%$ & $-2,00 \%$ & $6,08 \%$ \\
\hline ELET3 & Eletrobras ON & 3,37 & High & \begin{tabular}{|c|}
18.282 .785 .397 \\
\end{tabular} & Big & 0,10 & Loser & Big|High|Loser & $-0,15 \%$ & $-0,73 \%$ & $37,12 \%$ & $-11,86 \%$ & $2,28 \%$ & $-5,71 \%$ & $4,74 \%$ & $13,04 \%$ & $8,36 \%$ & $23,60 \%$ & $-28,19 \%$ & $9,30 \%$ \\
\hline ELET6 & Eletrobras PNB & 3,37 & High & 18.282 .785 .397 & Big & 0,12 & Loser & Big|High|Loser & $0,86 \%$ & $2,78 \%$ & $36,94 \%$ & $-9,53 \%$ & $4,24 \%$ & $-2,34 \%$ & $6,06 \%$ & $11,07 \%$ & $2,79 \%$ & $20,02 \%$ & $-25,55 \%$ & $10,05 \%$ \\
\hline SBSP3 & Sabesp ON & 1,77 & High & 4.029.575.350 & Big & 0,14 & Loser & Big|High|Loser & $4,95 \%$ ] & 1,36\% & $6,35 \%$ ] & $-8,57 \%$ [ & $-1,44 \%$ | & $17,05 \%$ & $17,20 \%$, & $-7,01 \%$ ] & $11,63 \%$ ] & $6,81 \%$ ] & 1,86\% & $-0,34 \%$ \\
\hline GEPA4 & Ger Paranap PN & 1,95 & High & 1.091 .638 .898 & Big & 0,48 & Winner & Big|High|Winner & $3,53 \%$ & $28,26 \%$ & $7,69 \%$ & $7,14 \%$ & $0,00 \%$ & $21,02 \%$ & $8,64 \%$ & $13,64 \%$ & $25,00 \%$ & $-5,15 \%$ & $-4,76 \%$ & $0,91 \%$ \\
\hline \begin{tabular}{|l|} 
CPLE6 \\
\end{tabular} & \begin{tabular}{|l|} 
Copel PNB \\
\end{tabular} & 1,76 & High & 3.305 .716 .883 & Big & 0,53 & Winner & Big|High|Winner & $\mid-0,15 \%$ & $1,73 \%$ & $28,68 \%$ & $-5,46 \%$ & $16,04 \%$ & $-5,81 \%$ & $12,56 \%$ & $15,06 \%$ & $-6,91 \%$ & $7,76 \%$ & $-17,03 \%$ & $7,37 \%$ \\
\hline CPLE3 & Copel ON & 1,76 & High & 3.305 .716 .883 & Big & 0,57 & Winner & Big|High|Winner & $-1,64 \%$ & $3,61 \%$ & $21,54 \%$ & $-2,28 \%$ & $12,79 \%$ & $-0,27 \%$ & $10,37 \%$ & $13,64 \%$ & $-2,03 \%$ & $3,97 \%$ & $-11,62 \%$ & $6,06 \%$ \\
\hline 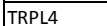 & Tran Paulist PN & 1,83 & High & 3.537 .291 .053 & Big & 0,78 & Winner & Big|High/Winner & $-13,39 \%$ & $10,62 \%$ & $21,93 \%$ & $-2,78 \%$ & $0,52 \%$ & $8,38 \%$ & $4,55 \%$ & $-7,54 \%$ & $-2,98 \%$ & $-4,47 \%$ & $-9,84 \%$ & $9,07 \%$ \\
\hline TRPL3 & Tran Paulist ON & 1,83 & High & 3.537 .291 .053 & Big & 0,96 & Winner & Big|High/Winner & $-10,98 \%$ & $10,18 \%$ & $12,25 \%$ & $-4,74 \%$ & $9,20 \%$ & $13,74 \%$ & $2,17 \%$ & $-9,20 \%$ & $-5,08 \%$ & $-1,98 \%$ & $-13,44 \%$ & $23,41 \%$ \\
\hline AMBV3 & Ambev ON & 0,31 & Low & 43.000 .338 .636 & Big & 0,43 & Loser & Big|Low|Loser & $-1,00 \%$ & $2,19 \%$ & $12,07 \%$ & $-5,22 \%$ & $16,38 \%$ & $2,95 \%$ & $2,59 \%$ & $1,10 \%$ & $5,63 \%$ & $5,13 \%$ & $-2,10 \%$ & $-4,24 \%$ \\
\hline \begin{tabular}{|l|} 
VIVO4 \\
\end{tabular} & Vivo PN & 0,39 & Low & 5.984 .857 .490 & Big & 0,30 & Loser & Big|Low|Loser & $4,63 \%$ & $-6,06 \%$ & $-8,90 \%$ & $-10,11 \%$ & $-2,50 \%$ & $13,46 \%$ & $20,90 \%$ & $1,40 \%$ & $-14,93 \%$ & $-6,39 \%$ & \begin{tabular}{|l|}
$-34,03 \%$ \\
\end{tabular} & $-7,72 \%$ \\
\hline VCPA4 & Fibria PN & 0,48 & Low & 5.498 .403 .400 & Big & 0,26 & Loser & Big|Low|Loser & $0,35 \%$ & $-5,38 \%$ & $9,17 \%$ & $-9,24 \%$ & $0,33 \%$ & $13,08 \%$ & $-5,17 \%$ & $18,18 \%$ & $7,72 \%$ & $-3,60 \%$ & $0,15 \%$ & $0,30 \%$ \\
\hline ARCZ6 & Aracruz PNB & 0,38 & Low & 7.945.724.410 & Big & 0,22 & Loser & Big|Low|Loser & $9,26 \%$ & $-2,82 \%$ & $4,65 \%$ & $-3,56 \%$ & $-2,07 \%$ & $11,44 \%$ & $-7,53 \%$ & $22,09 \%$ & $9,45 \%$ & $0,44 \%$ & $2,65 \%$ & $-1,31 \%$ \\
\hline VIVO3 & Vivo ON & 0,39 & Low & 5.984.857.490 & Big & 0,18 & Loser & Big|Low|Loser & $0,58 \%$ & $-3,49 \%$ & $-6,14 \%$ & $-6,03 \%$ & $1,09 \%$ & $14,73 \%$ & $21,08 \%$ & $27,43 \%$ & $-4,58 \%$ & $5,60 \%$ & $-22,73 \%$ & $-5,98 \%$ \\
\hline TMGC7 & Telemig Cl PNC & 0,48 & Low & 1.651 .668 .786 & Big & 0,10 & Loser & Big|Low|Loser & $0,00 \%$ & $0,00 \%$ & $22,46 \%$ & $-11,17 \%$ & $12,90 \%$ & $-4,29 \%$ & $7,46 \%$ & $-1,67 \%$ & $7,34 \%$ & $-5,26 \%$ & $3,63 \%$ & $-1,77 \%$ \\
\hline \begin{tabular}{|l|l|}
$G T 3$ \\
\end{tabular} & Light S/A ON & 0,18 & Low & 2.159 .884 .014 & Big & 0,06 & Loser & Big|Low|Loser & $-7,47 \%$ & $-12,46 \%$ & $-10,57 \%$ & $-16,49 \%$ & $5,95 \%$ & $-6,35 \%$ & $-2,87 \%$ & $34,00 \%$ & $-25,38 \%$ & $7,44 \%$ & $\begin{array}{l}-16,98 \% \\
\end{array}$ & $9,02 \%$ \\
\hline EMBR4 & Embraer PN & 0,32 & Low & 12.699 .312 .850 & Big & 0,05 & Loser & Big|Low/Loser & $0,26 \%$ & $10,65 \%$ & $3,15 \%$ & $-0,46 \%$ & $-3,69 \%$ & $10,57 \%$ & $-0,87 \%$ & $-5,49 \%$ & $-7,21 \%$ & $1,00 \%$ & $-6,70 \%$ & $4,79 \%$ \\
\hline KLBN4 & Klabin S/A PN & 0,45 & Low & 4.011.593.240 & Big & 0,01 & Loser & Big|Low|Loser & $-0,74 \%$ & $13,22 \%$ & $3,84 \%$ & $-6,52 \%$ & $0,00 \%$ & $-3,49 \%$ & $3,86 \%$ & $16,01 \%$ & $-2,79 \%$ & $11,92 \%$ & $-7,48 \%$ & $2,42 \%$ \\
\hline \begin{tabular}{|l|} 
WEGE4 \\
\end{tabular} & Weg PN & 0,26 & Low & 4.562 .980 .830 & Big & 0,00 & Loser & Big|Low|Loser & $0,05 \%$ & $4,31 \%$ & $-0,10 \%$ & $-1,87 \%$ & $2,72 \%$ & $0,82 \%$ & $9,87 \%$ & $-7,02 \%$ & $4,90 \%$ & $6,12 \%$ & $-5,29 \%$ & $6,77 \%$ \\
\hline EMBR3 & Embraer ON & 0,32 & Low & 12.699 .312 .850 & Big & 0,04 & Loser & Big|Low|Loser & $0,41 \%$ & $9,59 \%$ & $4,10 \%$ & $-2,48 \%$ & $-3,05 \%$ & $16,32 \%$ & $21,67 \%$ & $-5,71 \%$ & $-5,47 \%$ & $-0,10 \%$ & $-2,82 \%$ & $5,33 \%$ \\
\hline PQUN4 & Petroq Uniao PN & 0,36 & Low & 1.400 .176 .550 & Big & 0,07 & Loser & Big|Low|Loser & $-8,18 \%$ & $-5,23 \%$ & $6,90 \%$ & $-10,83 \%$ & $-8,24 \%$ & $6,37 \%$ & $-4,84 \%$ & $3,96 \%$ & $-9,07 \%$ & $2,46 \%$ & $-5,14 \%$ & $-3,58 \%$ \\
\hline SDIA4 & Sadia S/A PN & 0,46 & Low & 3.041 .015 .800 & Big & 0,08 & Loser & Big|Low|Loser & $6,49 \%$ & $10,50 \%$ & $27,38 \%$ & $-17,01 \%$ & $9,53 \%$ & $8,37 \%$ & $15,17 \%$ & $-7,56 \%$ & $-13,66 \%$ & $-3,45 \%$ & $4,82 \%$ & $-2,04 \%$ \\
\hline ARCZ3 & Aracruz ON & 0,38 & Low & 7.945.724.410 & Big & 0,08 & Loser & Big|Low|Loser & $4,17 \%$ & $-2,67 \%$ & $9,45 \%$ & $0,13 \%$ & $-4,37 \%$ & $-0,09 \%$ & $7,33 \%$ & $9,32 \%$ & $15,71 \%$ & $17,82 \%$ & $0,32 \%$ & $1,45 \%$ \\
\hline SDIA3 & Sadia S/A ON & 0,46 & Low & 3.041 .015 .800 & Big & 0,13 & Loser & Big|Low|Loser & $3,10 \%$ & $14,71 \%$ & $20,24 \%$ & $-14,33 \%$ & $14,79 \%$ & $10,17 \%$ & $\begin{array}{ll}10,66 \% \\
\end{array}$ & $-5,91 \%$ & $-7,63 \%$ & $5,41 \%$ & $-3,97 \%$ & $2,48 \%$ \\
\hline CRUZ3 & Souza Cruz ON & 0,15 & Low & 8.742 .734 .000 & Big & 0,16 & Loser & Big|Low|Loser & $-2,13 \%$ & $-3,44 \%$ & $2,76 \%$ & $-1,07 \%$ & $14,19 \%$ & $-4,41 \%$ & $7,59 \%$ & $12,28 \%$ & $-2,39 \%$ & $20,27 \%$ & $-17,88 \%$ & $-0,81 \%$ \\
\hline PQUN3 & Petroq Uniao ON & 0,36 & Low & 1.400 .176 .550 & Big & 0,17 & Loser & Big|Low|Loser & $1,31 \%$ & $-0,76 \%$ & $1,93 \%$ & $-5,53 \%$ & $-4,74 \%$ & $5,38 \%$ & $0,79 \%$ & $0,00 \%$ & $6,17 \%$ & $-4,30 \%$ & $-1,56 \%$ & $-5,33 \%$ \\
\hline GGBR4 & Gerdau PN & 0,45 & Low & 9.404 .555 .550 & Big & 0,18 & Loser & Big|Low|Loser & $10,18 \%$ & $16,56 \%$ & $17,23 \%$ & $-8,75 \%$ & $8,84 \%$ & $19,89 \%$ & $22,14 \%$ & $3,00 \%$ & $-0,82 \%$ & $11,30 \%$ & $-10,47 \%$ & $1,72 \%$ \\
\hline \begin{tabular}{|l|} 
AMBV4 \\
\end{tabular} & Ambev PN & 0,31 & \begin{tabular}{|l|} 
Low \\
\end{tabular} & 43.000 .338 .636 & Big & 0,24 & Loser & Big|Low|Loser & $3,42 \%$ & $2,43 \%$ & $11,53 \%$ & $-3,83 \%$ & $7,46 \%$ & $5,20 \%$ & $1,33 \%$ & $-0,98 \%$ & $4,04 \%$ & $3,11 \%$ & $-3,12 \%$ & $-2,48 \%$ \\
\hline GOLL4 & Gol PN & 0,13 & Low & 6.795 .361 .200 & Big & 0,35 & Loser & Big|Low|Loser & $0,43 \%$ & $14,31 \%$ & $-9,39 \%$ & $8,31 \%$ & $29,79 \%$ & $30,52 \%$ & $2,08 \%$ & $3,35 \%$ & $-16,37 \%$ & $34,41 \%$ & $-9,43 \%$ & $9,29 \%$ \\
\hline $\begin{array}{ll}\text { VALE3 } \\
\end{array}$ & Vale ON & 0,22 & Low & 75.659 .735 .340 & Big & 0.36 & Loser & Big|Low/Loser & $13,26 \% \mathrm{f}$ & $3.33 \%$ & $22.07 \%$ & $-4,22 \%$ & $2.72 \%$ & $-0,21 \% \mathrm{f}$ & $18.52 \%$ & $-7,72 \%$ & $110 \% \mathrm{f}$ & $2.49 \%$ & $-1.51 \%$ & $-0.80 \%$ \\
\hline VALES & Vale PNA & 0,22 & Low & 75.659 .735 .340 & Big & 0,36 & Loser & Big|Low|Loser & $12,82 \%$ & $5,75 \%$ & $22,70 \%$ & $-2,66 \%$ & $1,29 \%$ & $-0,25 \%$ & $16,78 \%$ & $-7,57 \%$ & $3,44 \%$ & $0,17 \%$ & $-4,78 \%$ & $0,09 \%$ \\
\hline \begin{tabular}{|l|l|l|} 
FFTL4 \\
\end{tabular} & Valefert PN & 0,29 & Low & 3.027 .620 .823 & Big & $0,0,39$ & Loser & Big|Low|Loser & $-1,41 \%$ & $4,10 \%$ & $3,51 \%$ & $-9,15 \%$ & $\mid-4,84 \%$ & $6,72 \%$ & $-4,26 \%$ & $-7,16 \%$ & $-0,92 \%$ & $2,63 \%$ & $0,42 \%$ & $0,0,38 \%$ \\
\hline GGBR3 & Gerdau ON & 0,45 & Low & 9.404 .555 .550 & Big & 0,42 & Loser & Big|Low|Loser & $4,84 \%$ & $13,33 \%$ & $19,85 \%$ & $-10,50 \%$ & $13,24 \%$ & $13,76 \%$ & $26,65 \%$ & $4,34 \%$ & $-2,01 \%$ & $9,74 \%$ & $0,38 \%$ & $-3,08 \%$ \\
\hline PTQS4 & Petroquisa PN & 0,43 & Low & 3.564 .122 .580 & Big & 0,42 & Loser & Big|Low|Loser & $0,00 \%$ & $1,67 \%$ & $9,28 \%$ & $-9,99 \%$ & $-3,89 \%$ & $1,16 \%$ & $25,71 \%$ & $0,00 \%$ & $-5,90 \%$ & $-19,74 \%$ & $14,13 \%$ & $0,54 \%$ \\
\hline ALLL4 & All Amer Lat PN & 0,23 & Low & 2.699.787.352 & Big & 0,43 & Winner & Big|Low /Winner & $14,41 \%$ & $-8,15 \%$ & $12,90 \%$ & $17,86 \%$ & $18,67 \%$ & $-1,94 \%$ & $30,82 \%$ & $-8,40 \%$ & $12,38 \%$ & $9,12 \%$ & $12,54 \%$ & $-7,94 \%$ \\
\hline LEVE4 & Metal Leve PN & 0,37 & Low & 1.209 .615 .800 & Big & 0,48 & Winner & Big|Low|Winner & $-1,90 \%$ & $-4,54 \%$ & $12,91 \%$ & $-7,88 \%$ & $8,56 \%$ & $-9,37 \%$ & $3,31 \%$ & $4,00 \%$ & $10,23 \%$ & $4,91 \%$ & $2,09 \%$ & $-2,59 \%$ \\
\hline TBLE3 & Tractebel ON & 0,48 & Low & 7.237.382.698 & Big & 0,52 & Winner & Big|Low|Winner & $2,17 \%$ & $-5,58 \%$ & $24,77 \%$ & $20,30 \%$ & $-10,23 \%$ & $9,52 \%$ & $3,72 \%$ & $11,79 \%$ & $5,44 \%$ & $-2,72 \%$ & $-0,64 \%$ & $0,58 \%$ \\
\hline CGASS & Comgas PNA & 0,38 & Low & 2.765 .555 .022 & Big & 0,69 & Winner & Big|Low|Winner & $6,30 \%$ & $4,39 \%$ & $8,85 \%$ & $3,98 \%$ & $-1,28 \%$ & $-4,77 \%$ & $1,30 \%$ & $7,99 \%$ & $9,75 \%$ & $-0,36 \%$ & $-8,03 \%$ & $1,88 \%$ \\
\hline LAME4 & Lojas Americ PI & 0,06 & Low & 3.256 .162 .034 & Big & 0,73 & Winner & Big|Low|Winner & $4,64 \%$ & $-8,65 \%$ & $21,48 \%$ & $-8,74 \%$ & $30,21 \%$ & $16,81 \%$ & $18,88 \%$ & $7,54 \%$ & $1,25 \%$ & $-5,04 \%$ & $-7,19 \%$ & $-3,29 \%$ \\
\hline \begin{tabular}{|l|} 
UGPA4 \\
\end{tabular} & Ultrapar PN & 0,45 & Low & 3.327 .848 .767 & Big & 0,81 & Winner & Big|Low|Winner & $-4,83 \%$ & $1,88 \%$ & $-2,69 \%$ & $-7,51 \%$ & $1,14 \%$ & $-8,45 \%$ & $2,15 \%$ & $7,60 \%$ & $10,14 \%$ & $-4,61 \%$ & $-5,93 \%$ & $0,00 \%$ \\
\hline \begin{tabular}{|l|} 
NATU3 \\
\end{tabular} & Natura ON & 0,07 & Low & 6.355 .090 .510 & Big & 0,85 & Winner & Big|Low|Winner & $6,82 \%$ & $1,52 \%$ & $11,25 \%$ & $0,13 \%$ & $5,50 \%$ & $9,67 \%$ & $13,13 \%$ & $6,44 \%$ & $5,54 \%$ & $3,89 \%$ & $-13,86 \%$ & $-1,30 \%$ \\
\hline BRKM3 & Braskem ON & 0,39 & Low & 6.754.721.668 & Big & 0,93 & Winner & Big|Low|Winner & $11,05 \%$ & $0,48 \%$ & $-1,43 \%$ & $-16,22 \%$ & $1,03 \%$ & $10,41 \%$ & $-6,93 \%$ & $-3,87 \%$ & $-10,40 \%$ & $-6,76 \%$ & $-4,72 \%$ & $4,95 \%$ \\
\hline ARCE3 & Arcelor BR ON & 0,35 & Low & 7.206.138.759 & Big & 0,93 & Winner & Big|Low|Winner & $25,37 \%$ & $-3,57 \%$ & $20,00 \%$ & $-12,21 \%$ & $3,83 \%$ & $7,81 \%$ & $18,75 \%$ & $-1,09 \%$ & $5,69 \%$ & $13,91 \%$ & $-12,21 \%$ & $-0,83 \%$ \\
\hline GET13 & AES Ti & 0,14 & Low & .454 & Big & 0,94 & Winner & $\mathrm{w} / \mathrm{wu}$ & $6,58 \%$ & $3,21 \%$ & $9,25 \%$ & 1,17 & 4,5 & $9,72 \%$ & 10,8 & $-3,4$ & $6,54 \%$ & $0,84 \%$ & $-8,44 \%$ & $2,20 \%$ \\
\hline UNIP6 & Unipar PNB & 0,46 & Low & 1.636 .936 .599 & Big & 1,03 & Winner & Big|Low|Winner & 11,44\% & $-3,75 \%$ & $8,56 \%$ & $-18,19 \%$ & $-1,33 \%$ & $-3,06 \%$ & $3,74 \%$ & $-4,05 \%$ & $-7,51 \%$ & $1,71 \%$ & - & $-8,33 \%$ \\
\hline UNIP3 & Unipar ON & 0,46 & Low & 1.636 .936 .599 & Big & 1,10 & Winner & Big|Low|Winner & $-1,73 \%$ & $-7,65 \%$ & $-1,59 \%$ & $-18,43 \%$ & $-1,60 \%$ & $-2,44 \%$ & $6,72 \%$ & $-1,57 \%$ & $-7,20 \%$ & $-3,23 \%$ & $1,48 \%$ & $-6,80 \%$ \\
\hline CCRO3 & CCR SA ON & 0,18 & Low & 5.530 .556 .696 & Big & 1,12 & Winner & Big|Low|Winner & $-2,33 \%$ & $4,85 \%$ & $17,07 \%$ & $-6,23 \%$ & $12,44 \%$ & $10,61 \%$ & $21,62 \%$ & $-10,89 \%$ & $2,28 \%$ & $-9,67 \%$ & $-5,74 \%$ & $2,61 \%$ \\
\hline
\end{tabular}


Anexo 1 - Retorno mensal e classificação das ações

\begin{tabular}{|c|c|c|c|c|c|c|c|c|c|c|c|c|c|c|c|c|c|c|c|c|}
\hline Código & $2005-2006$ & $\begin{array}{l}\text { Índice } B / M \\
\text { de dez/2004 }\end{array}$ & $\begin{array}{c}\text { Grupo com } \\
\text { base no } \\
\text { indice } \mathrm{B} / \mathrm{M}\end{array}$ & $\begin{array}{l}\text { Valor de Mercado } \\
\text { em jun/2005 }\end{array}$ & \begin{tabular}{|c} 
Grupo com \\
base no \\
tamanho
\end{tabular} & $\begin{array}{c}\text { Retorno } \\
\text { acumulado } \\
\text { de jun/2005 }\end{array}$ & \begin{tabular}{|c|} 
Grupo com \\
base no \\
retorno \\
acumulado
\end{tabular} & Carteiras & jul/05 & ago/05 & set/05 & out/05 & nov/05 & dez/05 & $\mathrm{jan} / 06$ & fev/06 & $\mathrm{mar} / 06$ & $\mathrm{abr} / 06$ & mai/06 & jun/06 \\
\hline BRKM5 & Braskem PNA & 0,39 & Low & 6.754 .721 .668 & Big & 1,15 & Winner & Big|Low|Winner & $16,62 \%$ & $2,76 \%$ & $-1,88 \%$ & $-15,62 \%$ & $2,58 \%$ & $-4,52 \%$ & $-6,76 \%$ & $7,17 \%$ & $-11,62 \%$ & $-7,89 \%$ & $-3,95 \%$ & $-5,88 \%$ \\
\hline LAME3 & Lojas Americ ON & 0,06 & Low & 3.256.162.034 & Big & 1,18 & Winner & Big|Low|Winner & $-0,09 \%$ & $9,09 \%$ & $1,54 \%$ & $5,00 \%$ & $22,22 \%$ & $9,74 \%$ & $13,48 \%$ & $14,71 \%$ & $-11,06 \%$ & $5,15 \%$ & $-0,50 \%$ & $-6,91 \%$ \\
\hline GET14 & AES Tiete PN & 0,14 & Low & 3.805 .700 .454 & Big & 1,30 & Winner & Big|Low|Winner & $5,71 \%$ & $-1,24 \%$ & $10,47 \%$ & $7,38 \%$ & $-3,03 \%$ & $7,08 \%$ & $10,24 \%$ & $-1,10 \%$ & $8,13 \%$ & $3,52 \%$ & $-7,06 \%$ & $-4,76 \%$ \\
\hline \begin{tabular}{|l|l|} 
CPSL3 \\
\end{tabular} & Copesul ON & 0,20 & Low & 4.641 .705 .300 & Big & 1,47 & Winner & Big|Low|Winner & $-5,24 \%$ & $5,88 \%$ & $7,96 \%$ & $-11,73 \%$ & $14,95 \%$ & $-1,51 \%$ & $-4,31 \%$ & $5,00 \%$ & $-3,07 \%$ & $-2,99 \%$ & $-4,32 \%$ & $4,99 \%$ \\
\hline SUZB5 & Suzano Papel PNA & 0,71 & Medium & 2.754 .011 .914 & Big & 0,16 & Loser & Big|Medium|Loser & $0,93 \%$ & $5,31 \%$ & $21,73 \%$ & $3,59 \%$ & $-2,31 \%$ & $-3,26 \%$ & $16,40 \%$ & $5,55 \%$ & $2,49 \%$ & $-0,34 \%$ & $-9,95 \%$ & $-4,29 \%$ \\
\hline BRTP4 & Brasil T Par PN & 0,76 & Medium & 7.255.360.364 & Big & 0,03 & Loser & Big|Medium|Loser & $-1,13 \%$ & $3,86 \%$ & $10,47 \%$ & $-3,42 \%$ & $-5,78 \%$ & $4,49 \%$ & $-9,24 \%$ & $7,82 \%$ & $-7,55 \%$ & $7,46 \%$ & $-17,46 \%$ & $2,46 \%$ \\
\hline CTNM3 & Coteminas ON & 0,93 & Medium & 1.196.755.533 & Big & 0,03 & Loser & Big|Medium|Loser & $-14,71 \%$ & $2,06 \%$ & $14,87 \%$ & $-0,59 \%$ & $-5,33 \%$ & $3,12 \%$ & $21,21 \%$ & $-5,00 \%$ & $-2,11 \%$ & $-3,74 \%$ & $-9,06 \%$ & $12,66 \%$ \\
\hline BRTO4 & Brasil Telec PN & 0,85 & Medium & 6.843 .134 .655 & Big & 0,01 & Loser & Big|Medium|Loser & $-10,89 \%$ & $2,78 \%$ & $15,14 \%$ & $-0,38 \%$ & $-2,17 \%$ & $2,65 \%$ & $-4,98 \%$ & $11,10 \%$ & $-3,86 \%$ & $7,84 \%$ & $-21,78 \%$ & $4,19 \%$ \\
\hline CBEE3 & Ampla Energ ON & 0,55 & Medium & 1.694 .074 .604 & Big & 0,02 & Loser & Big|Medium|Loser & $-5,00 \%$ & $10,53 \%$ & $23,81 \%$ & $-13,46 \%$ & $6,67 \%$ & $14,58 \%$ & $41,82 \%$ & $-2,56 \%$ & $-5,26 \%$ & $11,11 \%$ & $-12,50 \%$ & $-2,86 \%$ \\
\hline TMCP4 & Telemig Part PN & 0,51 & Medium & 2.042.655.527 & Big & 0,03 & Loser & Big|Medium|Loser & $2,35 \%$ & $-5,10 \%$ & $2,42 \%$ & $-2,89 \%$ & $12,16 \%$ & $9,40 \%$ & $21,15 \%$ & $9,09 \%$ & $-13,33 \%$ & $-5,15 \%$ & $-10,68 \%$ & $-7,18 \%$ \\
\hline CTNM4 & Coteminas PN & 0,93 & Medium & 1.196 .755 .533 & Big & 0,05 & Loser & Big|Medium|Loser & $-16,03 \%$ & $-4,49 \%$ & $24,12 \%$ & $9,00 \%$ & $-7,17 \%$ & $0,23 \%$ & $21,50 \%$ & $-8,85 \%$ & $-7,17 \%$ & $-6,82 \%$ & $-10,86 \%$ & $13,48 \%$ \\
\hline TCSL4 & Tim Part S/A PN & 0,73 & Medium & 3.427.823.286 & Big & 0,06 & Loser & Big|Medium|Loser & $3,76 \%$ & $-4,40 \%$ & $12,47 \%$ & $8,43 \%$ & $25,78 \%$ & $5,71 \%$ & $38,98 \%$ & $0,49 \%$ & $-2,05 \%$ & $0,62 \%$ & $-31,55 \%$ & $8,71 \%$ \\
\hline PCAR4 & P.Acucar-Cbd PN & 0,52 & Medium & 6.421 .972 .859 & Big & 0,08 & Loser & Big|Medium |Loser & $11,85 \%$ & $7,63 \%$ & $13,48 \%$ & $-4,67 \%$ & $16,54 \%$ & $8,16 \%$ & $8,43 \%$ & $7,94 \%$ & $0,47 \%$ & $-10,12 \%$ & $-6,44 \%$ & $-11,28 \%$ \\
\hline TMGC13 & Telemig Cl PNG & 0,48 & Medium & 1.651 .668 .786 & Big & 0,09 & Loser & Big|Medium|Loser & $5,22 \%$ & $1,24 \%$ & $2,04 \%$ & $0,00 \%$ & $4,00 \%$ & $3,84 \%$ & $14,82 \%$ & $8,06 \%$ & $2,99 \%$ & $1,45 \%$ & $4,41 \%$ & $-0,72 \%$ \\
\hline TNLP4 & Telemar PN & 0,49 & Medium & 16.789 .128 .040 & Big & 0,16 & Loser & Big|Medium|Loser & $-3,71 \%$ & $-1,71 \%$ & $3,23 \%$ & $7,29 \%$ & $5,38 \%$ & $0,10 \%$ & $-6,02 \%$ & $3,85 \%$ & $-10,94 \%$ & $9,21 \%$ & $-19,97 \%$ & $-8,10 \%$ \\
\hline TMCP3 & Telemig Part ON & 0,51 & Medium & 2.042.655.527 & Big & 0,22 & Loser & Big|Medium|Loser & $-5,19 \%$ & $1,40 \%$ & $13,45 \%$ & $0,20 \%$ & $-10,01 \%$ & $2,25 \%$ & $2,42 \%$ & $12,66 \%$ & $-4,86 \%$ & $-4,19 \%$ & $-5,04 \%$ & $1,69 \%$ \\
\hline RPSA4 & Ripasa PN & 0,69 & Medium & 1.245 .367 .200 & Big & 0,24 & Loser & Big|Medium|Loser & $-6,85 \%$ & $0,64 \%$ & $12,70 \%$ & $2,82 \%$ & $0,27 \%$ & $-1,69 \%$ & $4,48 \%$ & $12,33 \%$ & $9,79 \%$ & $10,21 \%$ & $-2,77 \%$ & $-0,20 \%$ \\
\hline TMAR5 & Telemar N L & 0,67 & Medium & 14.838.335.768 & Big & 0,26 & Loser & Big|Medium|Loser & $-3,27 \%$ & $-2,33 \%$ & $10,96 \%$ & $6,84 \%$ & $7,08 \%$ & $-0,80 \%$ & $-6,14 \%$ & $5,20 \%$ & $-9,43 \%$ & $5,14 \%$ & $-23,84 \%$ & $-1,92 \%$ \\
\hline TMAR6 & Telemar N L PNB & 0,67 & Medium & 14.838 .335 .768 & Big & 0,32 & Loser & Big|Medium|Loser & $1,14 \%$ & $-4,79 \%$ & $8,20 \%$ & $6,24 \%$ & $13,68 \%$ & $2,76 \%$ & $1,75 \%$ & $0,86 \%$ & $-8,72 \%$ & $2,92 \%$ & $-20,74 \%$ & $-4,44 \%$ \\
\hline ITSA3 & Itausa ON & 0,61 & Medium & 16.449.519.680 & Big & 0,36 & Loser & Big|Medium|Loser & $12,55 \%$ & $0,88 \%$ & $10,25 \%$ & $-2,05 \%$ & $19,52 \%$ & $4,42 \%$ & $17,35 \%$ & $6,09 \%$ & $10,03 \%$ & $-7,67 \%$ & $0,11 \%$ & $2,34 \%$ \\
\hline GOAU4 & Gerdau Met PN & 0,56 & Medium & 3.637 .010 .290 & Big & 0,36 & Loser & Big|Medium|Loser & $6,92 \%$ & $14,12 \%$ & $18,01 \%$ & $-5,40 \%$ & $7,09 \%$ & $14,39 \%$ & $18,47 \%$ & $4,74 \%$ & $-0,79 \%$ & $9,04 \%$ & $-6,24 \%$ & $0,76 \%$ \\
\hline BRAP4 & Bradespar PN & 0,59 & Medium & 3.480 .403 .000 & Big & 0,38 & Loser & Big|Medium |Loser & $13,04 \%$ & $8,15 \%$ & $26,52 \%$ & $-3,27 \%$ & $1,69 \%$ & $-1,17 \%$ & $26,31 \%$ & $-4,94 \%$ & $2,53 \%$ & $14,04 \%$ & $-8,25 \%$ & $-1,33 \%$ \\
\hline PETR4 & Petrob & 0,57 & Medium & 26.543 .221 .080 & Big & 0,38 & Loser & Big|Medium|Loser & $3,49 \%$ & $19,29 \%$ & $9,69 \%$ & $-9,65 \%$ & $6,33 \%$ & $8,64 \%$ & $28,03 \%$ & $-4,79 \%$ & $-3,60 \%$ & $8,70 \%$ & $-4,82 \%$ & $-1,86 \%$ \\
\hline PETR3 & Petrobras ON & 0,57 & Medium & 126.543 .221 .080 & \begin{tabular}{|l|l} 
Big \\
\end{tabular} & 0,40 & Loser & Big|Medium|Loser & $5,02 \%$ & $18,68 \%$ & $8,27 \%$ & $-11,43 \%$ & $5,47 \%$ & $9,84 \%$ & $26,69 \%$ & $-5,98 \%$ & $-4,12 \%$ & $10,90 \%$ & $-3,10 \%$ & $-2,08 \%$ \\
\hline BRTP3 & Brasil T Par ON & 0,76 & Medium & 7.255 .360 .364 & Big & 0,42 & Loser & Big|Medium|Loser & $2,02 \%$ & $20,95 \%$ & $4,13 \%$ & $-18,82 \%$ & $0,41 \%$ & $-8,68 \%$ & $3,83 \%$ & $7,82 \%$ & $-12,78 \%$ & $37,50 \%$ & $-21,63 \%$ & $14,20 \%$ \\
\hline BRTO3 & Brasil Telec ON & 0,85 & Medium & 6.843 .134 .655 & Big & 0,44 & Winner & Big $\mid$ Medium / Winner & $-4,49 \%$ & $10,67 \%$ & $18,86 \%$ & $-13,27 \%$ & $2,94 \%$ & $3,84 \%$ & $2,86 \%$ & $16,67 \%$ & $-9,52 \%$ & $26,32 \%$ & $4,19 \%$ & $-6,28 \%$ \\
\hline BRAP3 & Brades & 0,59 & Medium & 3.480 .403 .000 & Big & 0,50 & Winner & Big|Medium/Winner & $15,38 \%$ & $7,11 \%$ & $30,71 \%$ & $-6,98 \%$ & $6,09 \%$ & $-3,28 \%$ & $23,73 \%$ & $-2,74 \%$ & $0,00 \%$ & $19,72 \%$ & $-4,46 \%$ & $-7,38 \%$ \\
\hline CSNA3 & Sid Nacional ON & 0,49 & Medium & $\begin{array}{l}10.238 .988 .200 \\
\end{array}$ & Big & 0,52 & Winner & Big|Medium/Winner & $18,21 \%$ & $3,42 \%$ & $11,74 \%$ & $-16,46 \%$ & $6,36 \%$ & $9,35 \%$ & $29,20 \%$ & $4,08 \%$ & $6,43 \%$ & $7,71 \%$ & $-5,01 \%$ & $4,51 \%$ \\
\hline ITSA4 & Itausa PN & 0,61 & Medium & 16.449 .519 .680 & Big & 0,58 & Winner & Big|Medium/Winner & $1,57 \%$ & $14,77 \%$ & $9,35 \%$ & $4,98 \%$ & $12,02 \%$ & $0,51 \%$ & $21,62 \%$ & $2,78 \%$ & $1,41 \%$ & $2,14 \%$ & $-7,76 \%$ & $-0,66 \%$ \\
\hline GOAU3 & Gerdau Met ON & 0,56 & Medium & 3.637 .010 .290 & Big & 0,59 & Winner & Big $\mid$ Medium /Winner & $10,71 \%$ & $10,60 \%$ & $16,42 \%$ & $-10,21 \%$ & $11,82 \%$ & $22,43 \%$ & $13,83 \%$ & $0,37 \%$ & $0,00 \%$ & $13,15 \%$ & $-7,42 \%$ & $-1,64 \%$ \\
\hline ELPL5 & Eletropa & 0,71 & Medium & 3.291 .052 .640 & Big & 0,61 & Winner & Big $\mid$ Medium / Winner & $-5,22 \%$ & $4,35 \%$ & $12,94 \%$ & $0,74 \%$ & $-2,34 \%$ & $0,00 \%$ & $1,00 \%$ & $3,67 \%$ & $-1,16 \%$ & $0,00 \%$ & $-14,01 \%$ & $1,11 \%$ \\
\hline ACES4 & Am Inox BR PN & 0,54 & Medium & 36.200 .200 & Big & 0,67 & Winner & Big|Medium /Winn & $-5,88 \%$ & $19,82 \%$ & $8,93 \%$ & $-11,86 \%$ & $-2,41 \%$ & $-0,75 \%$ & $13,22 \%$ & $0,92 \%$ & $6,35 \%$ & $11,30 \%$ & $-1,89 \%$ & $-1,64 \%$ \\
\hline TMAR3 & Telemar N L ON & $0,0,67$ & Medium & $\begin{array}{r}24.233 .2035 .2768 \\
\end{array}$ & \begin{tabular}{|l} 
Big \\
\end{tabular} & 0,71 & Winner & Big|Medium/Winner & - & $\begin{array}{l}1,080 \\
1,08 \% \\
\end{array}$ & 5,42\% & 6, & 2,36\% & 4, & $\begin{array}{l}1,2,27 \% \\
1,88 \% \\
\end{array}$ & $3,07 \%$ & - $-4,77 \%$ & $57,69 \%$ & $\begin{array}{l}-1,1,350 \% \\
-21,36 \% \\
\end{array}$ & $\begin{array}{l}-7,0470 \\
-7,69 \% \\
\end{array}$ \\
\hline ACES3 & Am Inox BR ON & 0,54 & Medium & 2.236 .200 .200 & Big & 0,75 & Winner & Big $\mid$ Medium /Winner & $-10,15 \%$ & $16,44 \%$ & $8,82 \%$ & $-7,97 \%$ & $-0,45 \%$ & $0,46 \%$ & $6,92 \%$ & $1,15 \%$ & $4,39 \%$ & $2,82 \%$ & $-0,20 \%$ & $-0,03 \%$ \\
\hline $\begin{array}{ll}\text { TMGC3 } \\
\end{array}$ & Telemig Cl ON & 0,48 & Medium & 1.651 .668 .786 & Big & 0,75 & Winner & 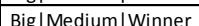 & $0.37 \%$ & $-3.58 \%$ & $6.67 \%$ & $3.5 \% \%$ & $0.00 \%$ & $-5.17 \%$ & $4.55 \%$ & $4.35 \%$ & $0.00 \%$ & $0,66 \%$ & $6.80 \%$ & $0.00 \%$ \\
\hline TNLP3 & Telemar ON & 0,49 & Mediu & 789.128 .040 & Big & 75 & Winner & Big|Medi & $-5,72 \%$ & $-2,90 \%$ & $5,75 \%$ & $6,52 \%$ & $2,19 \%$ & $-3,09 \%$ & $-3,77 \%$ & $8,79 \%$ & $-14,09 \%$ & $82,15 \%$ & $-24,70 \%$ & $-7,97 \%$ \\
\hline 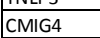 & Cemig PN & 0,73 & Medium & .338 .158 & Big & 0 & Winner & Big|Medium/Winner & $6,76 \%$ & $6,31 \%$ & $3,22 \%$ & $\begin{array}{c}-, 3,530 \\
-3,53 \% \\
\end{array}$ & $10,47 \%$ & $6,61 \%$ & $18,89 \%$ & $2,29 \%$ & $\begin{array}{l}-9,40 \% \\
-9,40 \% \\
\end{array}$ & | & $-9,65 \%$ & $5,15 \%$ \\
\hline CMIG3 & Cemig ON & 0,73 & Medium & 11.024 .338 .158 & Big & 0,79 & Winner & Big $\mid$ Medium/Winner & $7,32 \%$ & $2,88 \%$ & $5,34 \%$ & $-3,25 \%$ & $10,02 \%$ & $13,48 \%$ & $12,64 \%$ & $4,11 \%$ & $-8,81 \%$ & $4,74 \%$ & $-4,54 \%$ & $7,26 \%$ \\
\hline USIM5 & Usiminas PNA & 0,53 & Medium & 8.426 .211 .392 & Big & 0,84 & Winner & Big|Medium / Winner & $12,26 \%$ & $14,24 \%$ & $12,26 \%$ & $-12,35 \%$ & $13,65 \%$ & $7,54 \%$ & $33,03 \%$ & $-3,19 \%$ & $16,92 \%$ & $-0,93 \%$ & $-5,03 \%$ & $2,85 \%$ \\
\hline CEEB3 & Coelba ON & 0,98 & Medium & 2.465.123.154 & Big & 0,89 & Winner & Big|Medium / Winner & $0,01 \%$ & $11,58 \%$ & $-2,03 \%$ & $13,30 \%$ & $-2,83 \%$ & $8,80 \%$ & $20,00 \%$ & $7,14 \%$ & $15,62 \%$ & $0,01 \%$ & $-5,87 \%$ & $0,53 \%$ \\
\hline \begin{tabular}{|l|} 
DURA4 \\
\end{tabular} & Duratex-Old PN & 0,68 & $M$ & 9.200 & Big & 99 & w & Win & $16,58 \%$ & $-0,91 \%$ & $17,12 \%$ & $-3,85 \%$ & $-6,80 \%$ & $27,47 \%$ & $17,85 \%$ & $11,06 \%$ & $9,09 \%$ & $9,52 \%$ & $-16,09 \%$ & $0,98 \%$ \\
\hline USIM3 & Usiminas ON & 0,53 & Medium & 8.426 .211 .392 & Big & 1,11 & Winner & Big $\mid$ Medium $\mid$ Winner & $5,43 \%$ & $14,95 \%$ & $5,36 \%$ & $-8,76 \%$ & $8,55 \%$ & $10,44 \%$ & $40,50 \%$ & $-0,70 \%$ & $22,05 \%$ & $7,31 \%$ & $1,111 \%$ & $-6,59 \%$ \\
\hline PTIP4 & Ipiranga Pet PN & 0,84 & Medium & 1.208 .004 .555 & Big & 1,35 & Winner & Big $\mid$ Medium /Winner & $6,91 \%$ & $16,34 \%$ & $2,14 \%$ & $-7,71 \%$ & $9,55 \%$ & $13,36 \%$ & $9,06 \%$ & $7,03 \%$ & $-2,96 \%$ & $13,81 \%$ & $-6,22 \%$ & $7,03 \%$ \\
\hline GUAR3 & Guararapes ON & 0,61 & Medium & 1.903.200.000 & Big & 1,50 & Winner & um $/$ Winner & $5,26 \%$ & $15,50 \%$ & $33,62 \%$ & $20,09 \%$ & $18,71 \%$ & $2,79 \%$ & $65,09 \%$ & $-5,54 \%$ & $-6,91 \%$ & $3,70 \%$ & $-14,10 \%$ & $-9,69 \%$ \\
\hline PTIP3 & Ipiran & 0,84 & & & Big & 36 & $w_{i}$ & & $12,00 \%$ & $8,15 \%$ & $-3,45 \%$ & $-5,36 \%$ & $13,21 \%$ & $21,43 \%$ & $14,12 \%$ & $0,00 \%$ & $0,00 \%$ & $0,00 \%$ & $10,00 \%$ & $2,18 \%$ \\
\hline GUAR4 & Guararapes PN & 0,61 & Medium & 1.903 .200 .000 & Big & 2,79 & Winner & Big|Medium/Winner & $-6,49 \%$ & $13,52 \%$ & $26,26 \%$ & $18,23 \%$ & $27,17 \%$ & $-3,80 \%$ & $66,67 \%$ & $-8,56 \%$ & $2,98 \%$ & $-2,58 \%$ & $-10,93 \%$ & $-12,32 \%$ \\
\hline LIXC4 & Lix da Cunha PN & 3,50 & High & 23.612 .100 & Small & 0,44 & Loser & Small|High|Loser & $-5,56 \%$ & $-12,94 \%$ & $1,35 \%$ & $18,67 \%$ & $-11,24 \%$ & $1,27 \%$ & $-12,50 \%$ & $-2,86 \%$ & $29,41 \%$ & $7,95 \%$ & $-22,11 \%$ & $8,11 \%$ \\
\hline TNCP4 & Tele 1 & 1,22 & High & .598 & -1 & \begin{tabular}{l|l}
0,37 \\
\end{tabular} & Loser & oser & $-6,67 \%$ & $7,14 \%$ & $10,00 \%$ & $-3,03 \%$ & $-12,50 \%$ & $10,71 \%$ & $51,61 \%$ & $29,79 \%$ & $-24,59 \%$ & $4,35 \%$ & $-2,08 \%$ & $-12,77 \%$ \\
\hline MEND6 & Mendes Jr PNB & 3,81 & High & 5.582.230 & Small & 0,29 & Loser & Small|High|Loser & $-11,69 \%$ & $8,89 \%$ & $4,00 \%$ & $1,15 \%$ & $-5,06 \%$ & $18,85 \%$ & $6,90 \%$ & $0,00 \%$ & $22,52 \%$ & $-5,21 \%$ & $-12,78 \%$ & $7,20 \%$ \\
\hline
\end{tabular}


Anexo 1 - Retorno mensal e classificação das ações

\begin{tabular}{|c|c|c|c|c|c|c|c|c|c|c|c|c|c|c|c|c|c|c|c|c|}
\hline Código & 2005 - 2006 & $\begin{array}{l}\text { Índice B/M } \\
\text { de dez/2004 }\end{array}$ & $\begin{array}{c}\text { Grupo com } \\
\text { base no } \\
\text { indice } B / M\end{array}$ & $\begin{array}{l}\text { Valor de Mercado } \\
\text { em jun/2005 }\end{array}$ & $\begin{array}{c}\text { Grupo com } \\
\text { base no } \\
\text { tamanho }\end{array}$ & \begin{tabular}{|c|} 
Retorno \\
acumulado \\
de jun/2005
\end{tabular} & \begin{tabular}{|c|} 
Grupo com \\
base no \\
retorno \\
acumulado \\
\end{tabular} & Carteiras & jul/05 & ago/05 & set/05 & out/05 & nov/05 & dez/05 & $\mathrm{jan} / 06$ & $\mathrm{fev} / 06$ & mar/06 & abr/06 & mai/06 & jun/06 \\
\hline \begin{tabular}{|l|} 
WHRL4 \\
\end{tabular} & Whirlpool PN & 1,35 & High & 665.425 .600 & Small & \begin{tabular}{l|l|}
0,16 & 1 \\
\end{tabular} & Loser & Small|High|Loser & $9,43 \%$ & $5,17 \%$ & $22,95 \%$ & $-6,67 \%$ & $-14,29 \%$ & $8,64 \%$ & $2,79 \%$ & $13,85 \%$ & $28,38 \%$ & $-1,05 \%$ & $-1,06 \%$ & $7,53 \%$ \\
\hline IGUAG & Iguacu Cafe PNB & 1,15 & High & 145.265 .000 & Small & \begin{tabular}{l|l}
0,12 & 1 \\
\end{tabular} & Loser & Small|High|Loser & $0,00 \%$ & $0,00 \%$ & $1,00 \%$ & $0,00 \%$ & $0,00 \%$ & $-0,30 \%$ & $0,00 \%$ & $6,38 \%$ & $0,00 \%$ & $0,00 \%$ & $-4,00 \%$ & $0,00 \%$ \\
\hline FITA4 & Forjas Taurus PN & 1,94 & High & 99.278 .400 & Small & \begin{tabular}{l|l|l}
0,08 & 1 \\
\end{tabular} & Loser & Small|High|Loser & $-10,91 \%$ & $-8,16 \%$ & $8,89 \%$ & $18,37 \%$ & $35,34 \%$ & $-5,10 \%$ & $10,87 \%$ & $31,65 \%$ & $46,63 \%$ & $16,72 \%$ & $-12,08 \%$ & $6,39 \%$ \\
\hline TNCP3 & Tele Nort Cl ON & 1,22 & High & 170.314 .598 & Small & \begin{tabular}{l|l}
0,05 & 1 \\
\end{tabular} & Loser & Small|High|Loser & $-9,30 \%$ & $8,97 \%$ & $-5,88 \%$ & $-6,25 \%$ & $29,33 \%$ & $13,21 \%$ & $28,33 \%$ & $77,92 \%$ & $-41,61 \%$ & $17,50 \%$ & $-18,09 \%$ & $12,99 \%$ \\
\hline RPAD3 & Alfa Holding ON & 1,98 & High & 198.422 .056 & Small & \begin{tabular}{l|l|}
0,05 & 1 \\
\end{tabular} & Loser & Small|High|Loser & $0,87 \%$ & $-4,04 \%$ & $0,00 \%$ & $-8,18 \%$ & $7,43 \%$ & $5,99 \%$ & $0,00 \%$ & $-0,28 \%$ & $0,00 \%$ & $-1,32 \%$ & $0,00 \%$ & $-4,44 \%$ \\
\hline RPAD5 & Alfa Holding PNA & 1,98 & High & 198.422.056 & Small & \begin{tabular}{l|l}
0,04 & 1 \\
\end{tabular} & Loser & Small|High|Loser & $3,48 \%$ & $3,81 \%$ & $-4,17 \%$ & $-13,04 \%$ & $2,50 \%$ & $2,44 \%$ & $-0,95 \%$ & $6,93 \%$ & $5,24 \%$ & $-0,45 \%$ & $18,18 \%$ & $0,00 \%$ \\
\hline SCAR4 & Sao Carlos PN & 1,44 & High & 366.537 .107 & Small & $\begin{array}{ll}0,02 & 1 \\
\end{array}$ & Loser & Small|High|Loser & $6,25 \%$ & $5,88 \%$ & $16,67 \%$ & $-20,38 \%$ & $13,64 \%$ & $58,00 \%$ & 7,93\% & $0,00 \%$ & $6,79 \%$ & $2,89 \%$ & $27,72 \%$ & $31,79 \%$ \\
\hline SCAR3 & Sao Carlos ON & 1,44 & High & 366.537 .107 & Small & \begin{tabular}{ll|l}
0,02 & 1 \\
\end{tabular} & Loser & Small|High|Loser & $-8,33 \%$ & $9,09 \%$ & $16,11 \%$ & $-14,83 \%$ & $17,98 \%$ & $23,90 \%$ & $11,45 \%$ & $-3,45 \%$ & $7,07 \%$ & $86,79 \%$ & $-19,02 \%$ & $-9,14 \%$ \\
\hline TMAC8B & Amazonia Celular PND & 2,48 & High & 88.662 .169 & Small & 0,00 & Loser & Small|High|Loser & $0,00 \%$ & $0,00 \%$ & $1,67 \%$ & $0,00 \%$ & $1,64 \%$ & $0,16 \%$ & $0,64 \%$ & $20,00 \%$ & $-13,20 \%$ & $7,53 \%$ & $1,43 \%$ & $0,14 \%$ \\
\hline TDBH3 & Telefonica Data HId ON & 1,09 & High & 496.167 .869 & Small & & Loser & Small|High|Loser & $0,00 \%$ & $2,44 \%$ & $14,29 \%$ & $0,00 \%$ & $12,50 \%$ & $16,67 \%$ & $0,00 \%$ & $12,70 \%$ & $-23,94 \%$ & $1,85 \%$ & $-20,00 \%$ & $6,82 \%$ \\
\hline RPAD6 & Alfa Holding PNB & 1,98 & High & 198.422.056 & Small & \begin{tabular}{l|l}
0,01 & 1 \\
\end{tabular} & Loser & Small|High|Loser & $-6,12 \%$ & $-0,68 \%$ & $-2,22 \%$ & $-8,18 \%$ & $-2,97 \%$ & $7,14 \%$ & $0,00 \%$ & $0,72 \%$ & $0,48 \%$ & $13,74 \%$ & $4,17 \%$ & $0,00 \%$ \\
\hline BMTO4 & Brasmotor PN & 1,35 & High & 415.315.736 & Small & $0,04 \quad 1$ & Loser & Small|High|Loser & $-9,65 \%$ & $-0,76 \%$ & $21,54 \%$ & $-5,06 \%$ & $6,67 \%$ & $-15,62 \%$ & $0,18 \%$ & $7,68 \%$ & $31,37 \%$ & $0,60 \%$ & $-13,51 \%$ & $6,25 \%$ \\
\hline BDLL4 & Bardella PN & 2,51 & High & 78.240 .000 & Small & \begin{tabular}{l|l}
0,08 & 1 \\
\end{tabular} & Loser & Small|High|Loser & $-7,98 \%$ & $-4,44 \%$ & $0,70 \%$ & $-7,62 \%$ & $-10,00 \%$ & $40,05 \%$ & $29,76 \%$ & $-2,57 \%$ & $3,58 \%$ & $7,27 \%$ & $-13,56 \%$ & $3,92 \%$ \\
\hline CESP5 & Cesp PNA & 6,61 & High & 905.183 .446 & Small & \begin{tabular}{l|l}
0,10 & 1 \\
1
\end{tabular} & Loser & Small|High|Loser & $-6,12 \%$ & $0,49 \%$ & $38,51 \%$ & $-7,80 \%$ & $5,00 \%$ & $-3,52 \%$ & $35,16 \%$ & $43,26 \%$ & $-1,96 \%$ & $0,80 \%$ & $-26,59 \%$ & $-2,32 \%$ \\
\hline TDBH4 & Telefonica Data HId PN & 1,09 & High & 496.167 .869 & Small & \begin{tabular}{l|l}
0,11 & $\mathrm{~L}$ \\
\end{tabular} & Loser & Small|High|Loser & $-2,04 \%$ & $4,17 \%$ & $10,00 \%$ & $5,45 \%$ & $15,52 \%$ & $7,46 \%$ & $6,94 \%$ & $9,09 \%$ & $-21,43 \%$ & $-4,55 \%$ & $-12,70 \%$ & $-3,64 \%$ \\
\hline CLSC6 & Celesc PNB & 1,16 & High & 714.424 .840 & Small & 0,12 & Loser & Small|High|Loser & $18,68 \%$ & $9,26 \%$ & $22,88 \%$ & $0,00 \%$ & $-1,38 \%$ & $2,10 \%$ & $17,38 \%$ & $1,82 \%$ & $2,98 \%$ & $-2,77 \%$ & $-10,78 \%$ & $5,37 \%$ \\
\hline FLCL5 & F Cataguazes PNA & 1,43 & High & 185.071.253 & Small & \begin{tabular}{l|l}
0,16 & $\mathrm{~L}$ \\
\end{tabular} & Loser & Small|High|Loser & $4,93 \%$ & $24,16 \%$ & $-3,24 \%$ & $5,59 \%$ & $0,53 \%$ & $0,00 \%$ & $42,11 \%$ & $-3,38 \%$ & $45,88 \%$ & $59,95 \%$ & $-0,88 \%$ & $-8,79 \%$ \\
\hline CESP3 & Cesp ON & 6,61 & High & 905.183.446 & Small & \begin{tabular}{l|l|}
0,18 & $\mid$
\end{tabular} & Loser & Small||High|Loser & $1,05 \%$ & $2,30 \%$ & $26,97 \%$ & $-2,65 \%$ & $0,09 \%$ & $-5,09 \%$ & $58,85 \%$ & $49,40 \%$ & $-8,67 \%$ & $1,10 \%$ & $-10,48 \%$ & $-9,76 \%$ \\
\hline \begin{tabular}{|l|l|l|l} 
ASTA4 &
\end{tabular} & Santistextil PN & 1,31 & High & 368.834 .500 & Small & $\begin{array}{ll}0,19 & \mathrm{~L}\end{array}$ & Loser & Small/High/Loser & $2,70 \%$ & $-10,63 \%$ & $-0,47 \%$ & $-12,29 \%$ & $3,40 \%$ & $12,50 \% \mathrm{f}, \mathrm{C}$ & $8,19 \%$ & $8,11 \%$ & $0,00 \%$ & $-6.55 \%$ & $-2,70 \%$ & $5,56 \%$ \\
\hline EMAE4 & Emae PN & 3,83 & High & 210.598 .367 & Small & \begin{tabular}{l|l}
0,19 & 1 \\
\end{tabular} & Loser & Small|High|Loser & $-8,77 \%$ & $-9,04 \%$ & $13,95 \%$ & $-5,38 \%$ & $-5,69 \%$ & $3,95 \%$ & $8,00 \%$ & $20,37 \%$ & $-12,31 \%$ & $-7,02 \%$ & $-5,66 \%$ & $10,00 \%$ \\
\hline \begin{tabular}{|l|} 
PNOR6 \\
\end{tabular} & Pronor PNB & 1,11 & High & 181.932 .183 & Small & \begin{tabular}{l|l|l|l|l|l|l|}
0,22 & 1 \\
\end{tabular} & Loser & Small|High|Loser & $-6,93 \%$ & $-5,88 \%$ & $10,42 \%$ & $-3,77 \%$ & $-1,96 \%$ & $2,00 \%$ & $5,10 \%$ & $-7,80 \%$ & $-0,44 \%$ & $-4,82 \%$ & $-7,83 \%$ & $-0,50 \%$ \\
\hline BRGE3 & Alfa Consorc ON & 2,03 & High & 260.868 .150 & Small & \begin{tabular}{l|l|}
0,28 & 1 \\
\end{tabular} & Loser & Small|High|Loser & $0,00 \%$ & $-2,15 \%$ & $-4,41 \%$ & $-4,31 \%$ & $12,54 \%$ & $0,00 \%$ & $0,00 \%$ & $-0,02 \%$ & $5,48 \%$ & $-3,01 \%$ & $-7,04 \%$ & $-1,52 \%$ \\
\hline BRGE12 & Alfa Consorc PNF & 2,03 & High & 260.868 .150 & Small & \begin{tabular}{l|l}
0,39 & 1
\end{tabular} & Loser & Small| High|Loser & $0,00 \%$ & $-16,62 \%$ & $-5,41 \%$ & $-1,79 \%$ & $2,18 \%$ & $10,32 \%$ & $1,94 \%$ & $4,23 \%$ & $-1,84 \%$ & $1,25 \%$ & $0,62 \%$ & $0,00 \%$ \\
\hline COCE5 & Coelce PNA & 1,97 & High & 693.385 .470 & Small & \begin{tabular}{l|l|l}
0,39 & 1 \\
\end{tabular} & Loser & Small|High|Loser & $8,51 \%$ & $11,76 \%$ & $10,35 \%$ & $-3,02 \%$ & $11,48 \%$ & $10,40 \%$ & $30,99 \%$ & $23,66 \%$ & $-4,35 \%$ & $-5,06 \%$ & $6,95 \%$ & $2,00 \%$ \\
\hline SAPR4 & Sanepar PN & 1,98 & High & 857.150 .117 & Small & \begin{tabular}{l|l|}
0,39 & 1 \\
\end{tabular} & Loser & Small|High|Loser & $-1,00 \%$ & $7,07 \%$ & $1,42 \%$ & $-6,05 \%$ & $-0,50 \%$ & $3,98 \%$ & $18,77 \%$ & $-3,33 \%$ & $-4,31 \%$ & $0,90 \%$ & $0,45 \%$ & $2,22 \%$ \\
\hline LIPR3 & Eletropar ON & 1,12 & High & 151.706 .366 & Small & \begin{tabular}{l|l|l}
0,40 & 1 \\
\end{tabular} & Loser & Small|High|Loser & $-4,18 \%$ & $-1,57 \%$ & $29,92 \%$ & $-1,62 \%$ & $5,11 \%$ & $-2,70 \%$ & $0,56 \%$ & $1,05 \%$ & $-1,31 \%$ & $0,06 \%$ & $-0,39 \%$ & $0,33 \%$ \\
\hline VGOR4 & Vigor PN & 2,25 & High & 59.560 .920 & Small & \begin{tabular}{l|l|}
0,43 \\
\end{tabular} & Winner & Small|High|Winner & $-28,87 \%$ & $1,54 \%$ & $15,38 \%$ & $-13,33 \%$ & $7,69 \%$ & $57,14 \%$ & $20,90 \%$ & $-12,62 \%$ & $-0,22 \%$ & $8,69 \%$ & $33,74 \%$ & $-1,69 \%$ \\
\hline IENG5 & Ienergia PI & 1,62 & High & 74.399.710 & Small & 0,50 & Winner & Small|High|Winner & $-10,53 \%$ & $11,76 \%$ & $-10,53 \%$ & $-5,88 \%$ & $18,75 \%$ & $-15,79 \%$ & $12,50 \%$ & $27,78 \%$ & $30,43 \%$ & $120,00 \%$ & $-4,55 \%$ & $-14,29 \%$ \\
\hline RSID3 & Rossi Resid ON & 1,26 & High & 216.616 .129 & Small & 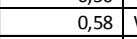 & Winner & Small|High|Winner & $0,00 \%$ & $-1,79 \%$ & $40,00 \%$ & $46,75 \%$ & $46,90 \%$ & $59,64 \%$ & $8,49 \%$ & $23,04 \%$ & $-8,48 \%$ & $-15,06 \%$ & $-13,40 \%$ & $8,95 \%$ \\
\hline SULT4 & Sultepa PN & 18,90 & High & 7.686 .000 & Small & $0,58 \quad 1$ & Winner & Small|High|Winner & $13,11 \%$ & $-8,70 \%$ & $-9,52 \%$ & $-10,53 \%$ & $-1,96 \%$ & $10,00 \%$ & $27,27 \%$ & $31,43 \%$ & $3,26 \%$ & $-13,68 \%$ & $-4,88 \%$ & $-7,69 \%$ \\
\hline CEPE5 & Celpe PNA & 1,76 & High & 862.807 .855 & Small & \begin{tabular}{l|l|l|l|l|}
0,64 & 1 \\
\end{tabular} & Winner & Small| |High|Winner & $-0,83 \%$ & $-0,42 \%$ & $9,21 \%$ & $4,29 \%$ & $4,34 \%$ & $4,63 \%$ & $8,57 \%$ & $11,84 \%$ & $11,63 \%$ & $12,33 \%$ & $-3,27 \%$ & $-5,13 \%$ \\
\hline TKNO4 & Tekno PN & 1,19 & High & 114.492 .000 & Small & \begin{tabular}{c|c|c}
0,73 & 1 \\
\end{tabular} & Winner & Small|High|Winner & $-4,26 \%$ & $-0,18 \%$ & $-1,86 \%$ & $-1,70 \%$ & $-1,15 \%$ & $-2,72 \%$ & $8,89 \%$ & $2,04 \%$ & $-2,00 \%$ & $5,10 \%$ & $-0,97 \%$ & $9,80 \%$ \\
\hline PTNT4 & Pettenati PN & 2,47 & High & 26.339 .764 & Small & 0,77 & Winner & Small|High|Winner & $0,00 \%$ & $0,00 \%$ & $-2,27 \%$ & $-6,98 \%$ & $1,44 \%$ & $-5,00 \%$ & $-4,21 \%$ & $2,75 \%$ & $-14,44 \%$ & $-6,25 \%$ & $-1,67 \%$ & $15,25 \%$ \\
\hline SGAS3 & WIm Ind Com ON & 1,45 & High & 142.213 .571 & Small & 0,18 & Winner & Small|High|Winner & $-10,42 \%$ & $16,28 \%$ & $9,40 \%$ & $9,87 \%$ & $-2,06 \%$ & $5,47 \%$ & $0,00 \%$ & $5,56 \%$ & $0,00 \%$ & $5,26 \%$ & $-0,17 \%$ & $11,52 \%$ \\
\hline TELB4 & Telebras PN & 2,40 & High & 27.821 .461 & Small & 1,001 & Winner & Small|High|Winner & $0,00 \%$ & $20,00 \%$ & $16,67 \%$ & $-14,29 \%$ & $16,67 \%$ & $0,00 \%$ & $14,29 \%$ & $-12,50 \%$ & $14,29 \%$ & $12,50 \%$ & $-11,11 \%$ & $-12,50 \%$ \\
\hline CGRA4 & Grazziotin PN & 1,19 & High & 77.852 .157 & Small & 1,01 & Winner & Small|High | Winner & $-0,11 \%$ & $-10,43 \%$ & $-5,88 \%$ & $25,00 \%$ & $0,00 \%$ & $0,08 \%$ & $19,44 \%$ & $16,28 \%$ & $2,04 \%$ & $9,20 \%$ & $-0,04 \%$ & $-0,15 \%$ \\
\hline PNOR5 & Pronor PNA & 1,11 & High & 181.932.183 & Small & 1,06 & Winner & Small|High|Winner & $2,51 \%$ & $-15,44 \%$ & $15,94 \%$ & $-12,50 \%$ & $-7,14 \%$ & $-10,77 \%$ & $-13,79 \%$ & $-0,25 \%$ & $-2,17 \%$ & $8,44 \%$ & $-12,29 \%$ & $2,34 \%$ \\
\hline STRP4 & Botucatu Tex PN & 1,34 & High & 4.062 .656 & Small & \begin{tabular}{l|l|l|l|l|l|}
1,08 \\
\end{tabular} & Winner & Small|High|Winner & $0,00 \%$ & $6,25 \%$ & $-5,88 \%$ & $0,00 \%$ & $18,75 \%$ & $0,00 \%$ & $53,85 \%$ & $-15,00 \%$ & $-11,76 \%$ & $6,67 \%$ & $-12,50 \%$ & $0,00 \%$ \\
\hline TELB3 & Telebras ON & 2,40 & High & 27.821 .461 & Small & 1,501 & Winner & Small|High|Winner & $0,00 \%$ & $0,00 \%$ & $20,00 \%$ & $0,00 \%$ & $16,67 \%$ & $-14,29 \%$ & $50,00 \%$ & $0,00 \%$ & $11,11 \%$ & $60,00 \%$ & $\begin{array}{l}-18,75 \% \\
\end{array}$ & $30,77 \%$ \\
\hline MGEL4 & Mangels Indl PN & 1,80 & High & 77.607 .768 & Small & 1,721 & Winner & Small|High|Winner & $0,95 \%$ & $1,42 \%$ & $15,12 \%$ & $-7,58 \%$ & $-1,64 \%$ & $-6,22 \%$ & $7,82 \%$ & $-3,30 \%$ & $-2,27 \%$ & $-2,44 \%$ & $-9,43 \%$ & $1,37 \%$ \\
\hline RANI3 & Celul Irani ON & 1,11 & High & 81.541 .739 & Small & 1,78 & Winner & Small|High|Winner & $-5,12 \%$ & $-6,86 \%$ & $-7,89 \%$ & $-5,24 \%$ & $0,30 \%$ & $0,00 \%$ & $-6,81 \%$ & $-13,98 \%$ & $7,55 \%$ & $5,76 \%$ & $-11,01 \%$ & $0,00 \%$ \\
\hline JBDU4 & J B Duarte PN & 1,78 & High & 6.394 .475 & Small & \begin{tabular}{l|l|l|}
1,92 \\
\end{tabular} & Winner & Small| |High|Winner & $-18,42 \%$ & $19,35 \%$ & $-8,11 \%$ & $-14,71 \%$ & $17,24 \%$ & $-8,82 \%$ & $0,00 \%$ & $-7,10 \%$ & $-6,67 \%$ & $0,00 \%$ & $25,00 \%$ & $-19,05 \%$ \\
\hline $\begin{array}{ll}\text { SGAS4 } \\
\end{array}$ & WIm Ind Com PN & $\begin{array}{l}1,46 \\
1,45\end{array}$ & High & 142.213.4571 & \begin{tabular}{|l|l|l|l|} 
Small \\
\end{tabular} & $\begin{array}{ll}2,425 \\
2,45\end{array}$ & Winner & Small|High|Winner & $\begin{array}{l}-8,4,08 \% \\
\end{array}$ & 9, & $12,00 \%$ & $17,68 \%$ & $\mid-3,24 \%$ & - & $-2,18 \%$ & $0,00 \%$ & $2,23 \%$ & 10,34\% & $\frac{-4,61 \%}{-4,61 \%}$ & 1,38\% \\
\hline HGTX4 & Cia Hering PN & 0,02 & Low & 56.586 .600 & Small & 0,02 & Loser & Small| Low |Loser & $7,83 \%$ & $-9,27 \%$ & $4,44 \%$ & $-12,77 \%$ & $60,00 \%$ & $7,01 \%$ & $13,96 \%$ & $0,00 \%$ & $-25,00 \%$ & $-1,67 \%$ & $11,19 \%$ & $-7,01 \%$ \\
\hline ILMD4 & Yara Brasil F & 0.30 & Low & 397.488 .734 & Small & $0,221 \mathrm{~L}, \mathrm{C}$ & Loser & Small|Lor & $-8.42 \%$ & $-3.45 \%$ & $7.14 \%$ & $-8.33 \%$ & $1.21 \% \mathrm{f}$ & $-7,19 \%$ & $-6.45 \%$ & 0.00 & $-621 \%$ & $-4,41 \%$ & $-27.90 \%$ & $-8.70 \%$ \\
\hline FRAS4 & & 0, & Low & 00 & Smal & 0, & Lose & |Lo & 2,2 & $14,29 \%$ & $-2,94 \%$ & 2,27 & $2,07 \%$ & $-8,7$ & & $-0,1$ & 0,0 & $0,00 \%$ & $-1,72 \%$ & $0,88 \%$ \\
\hline ITEC3 & Itautec ON & 0,38 & Low & 601.321 .200 & Small & \begin{tabular}{ll|l}
0,43 & 1 \\
0,45
\end{tabular} & Winner & Small|Low|Winner & $-4,35 \%$ & $-2,27 \%$ & $-1,56 \%$ & $-26,98 \%$ & $25,22 \%$ & $3,13 \%$ & $22,24 \%$ & $-5,56 \%$ & $-8,08 \%$ & $-3,23 \%$ & $-7,07 \%$ & $6,62 \%$ \\
\hline SLED4 & Saraiva Livr PN & 0,38 & Low & 275.444 .400 & Small & 0,61 & Winner & Small|Low|Winner & $-4,58 \%$ & $-7,20 \%$ & $0,86 \%$ & $8,97 \%$ & $9,73 \%$ & $22,94 \%$ & $5,14 \%$ & $29,10 \%$ & $11,50 \%$ & $-4,94 \%$ & $-16,36 \%$ & $10,33 \%$ \\
\hline KEPL3 & Kepler Weber ON & 0,11 & Low & 757.169 .840 & Small & $\begin{array}{l}0,73 \\
\end{array}$ & Winner & Small/Low/Winner & $-1.96 \%$ & $12,15 \%$ & $6,55 \%$ & $-1,68 \%$ & $-5,68 \%$ & $46 \%$ | & $7,47 \%$ & $-2,25 \%$ & $-8,82 \%$ & $7.58 \%$ & $-18,28 \%$ & $12.50 \%$ \\
\hline
\end{tabular}


Anexo 1 - Retorno mensal e classificação das ações

\begin{tabular}{|c|c|c|c|c|c|c|c|c|c|c|c|c|c|c|c|c|c|c|c|c|}
\hline Código & $2005-2006$ & $\begin{array}{l}\text { Índice } B / M \\
\text { de dez/2004 }\end{array}$ & $\begin{array}{c}\text { Grupo com } \\
\text { base no } \\
\text { indice } B / M\end{array}$ & $\begin{array}{c}\text { Valor de Mercado } \\
\text { em jun/2005 }\end{array}$ & $\begin{array}{c}\text { Grupo com } \\
\text { base no } \\
\text { tamanho }\end{array}$ & $\begin{array}{c}\text { Retorno } \\
\text { acumulado } \\
\text { de jun/2005 }\end{array}$ & \begin{tabular}{|c|} 
Grupo com \\
base no \\
retorno \\
acumulado \\
\end{tabular} & Carteiras & $\mathrm{jul} / 05$ & ago/05 & set/05 & out/05 & nov/05 & $\mathrm{dez} / 05$ & $\mathrm{jan} / 06$ & fev/06 & $\operatorname{mar} / 06$ & $\mathrm{abr} / 06$ & mai/06 & jun/06 \\
\hline RAPT4 & Randon Part PN & 0,23 & Low & $\begin{array}{l}827.876 .500 \\
\end{array}$ & Small & 0,87 & \begin{tabular}{|l|} 
Winner \\
\end{tabular} & Small|Low|Winner & $13,48 \%$ & $-3,58 \%$ & $9,61 \%$ & $-0,46 \%$ & $8,96 \%$ & $9,78 \%$ & $16,08 \%$ & $10,92 \%$ & $-4,77 \%$ & $-10,69 \%$ & $-9,40 \%$ & $-5,32 \%$ \\
\hline PEFX5 & Petroflex PNA & 0,47 & Low & 615.825 .000 & Small & 1,08 & Winner & Small|Low|Winner & $-4,06 \%$ & $2,99 \%$ & $-4,06 \%$ & $-1,84 \%$ & $4,19 \%$ & $3,22 \%$ & $3,55 \%$ & $-1,83 \%$ & $-5,57 \%$ & $-0,94 \%$ & $-11,39 \%$ & $0,00 \%$ \\
\hline CNFBA & Confab PN & 0,41 & $\mathrm{ww}$ & 1.057 .056 .000 & small & 1,19 & Winner & Small|Low|Winner & $2,46 \%$ & $5,20 \%$ & $3,78 \%$ & $-3,08 \%$ & $-1,24 \%$ & $-0,30 \%$ & $15,87 \%$ & $5,68 \%$ & $4,16 \%$ & $17,46 \%$ & $-5,87 \%$ & $-2,77 \%$ \\
\hline \begin{tabular}{|l|l|l|} 
DXTG4 \\
\end{tabular} & Dixie Toga PN & 0,40 & Low & 376.020 .260 & Small & 1,39 & Winner & Small|Low|Winner & $2,26 \%$ & $0,74 \%$ & $\begin{array}{ll}-2,19 \% \\
-19 \%\end{array}$ & $-2,99 \%$ & $1,54 \%$ & $-0,76 \%$ & $25,95 \%$ & $\begin{array}{l}-3,03 \% \\
-3,1\end{array}$ & $6,25 \%$ & $-1,18 \%$ & $2,55 \%$ & $0,00 \%$ \\
\hline PTBL3 & Portobello ON & 0,21 & Low & 255.137 .220 & Small & 1,61 & Winner & Small|Low|Winner & $-10,61 \%$ & $-6,21 \%$ & $-4,22 \%$ & $12,58 \%$ & $-10,06 \%$ & $24,22 \%$ & $-9,50 \%$ & $37,02 \%$ & $0,40 \%$ & $0,80 \%$ & $1,59 \%$ & $2,75 \%$ \\
\hline ELEK4 & Elekeiroz PN & 0,45 & Low & 1.008 .504 .340 & Small & 1.88 & Winner & Small/Low/Winner & $-6,17 \%$ & $11,84 \%$ & $-7,65 \%$ & $-17,20 \%$ & $-7,69 \%$ & $10,83 \%$ & $5,10 \%$ & $-6.47 \%$ & $-5,38 \%$ & $-27.64 \%$ & $3,37 \%$ & $-13,04 \%$ \\
\hline AVIL3 & Acos Vill & 0,28 & $\mathrm{w}$ & 1.027.433.160 & Small & 1,94 & Winner & Small|Low|Winner & $6,38 \%$ & $-2,07 \%$ & $21,13 \%$ & $-3,56 \%$ & $-1,25 \%$ & $-5,06 \%$ & $26,33 \%$ & $-5,01 \%$ & $-1,39 \%$ & $4,22 \%$ & $5,82 \%$ & $11,69 \%$ \\
\hline IDNT3 & Ideiasnet ON & 0,29 & Low & 100.112 .400 & Small & 2,65 & Winner & Small|Low|Winner & $-9,44 \%$ & $-19,63 \%$ & $34,35 \%$ & $12,50 \%$ & $10,10 \%$ & $7,80 \%$ & $38,72 \%$ & $-1,84 \%$ & $-1,88 \%$ & $8,92 \%$ & $-23,39 \%$ & $6,49 \%$ \\
\hline MYPK4 & Iochp-Maxion PN & 0,25 & Low & \begin{tabular}{l|l|}
792.624 .480 \\
\end{tabular} & Small & 3,07 & Winner & Small|Low|Winner & $-12,63 \%$ & $12,84 \%$ & $-0,27 \%$ & $14,75 \%$ & $-6,55 \%$ & $21,02 \%$ & $3,68 \%$ & $-11,34 \%$ & $10,91 \%$ & $0,00 \%$ & \begin{tabular}{|c|}
$6,91 \%$ \\
\end{tabular} & $4,48 \%$ \\
\hline EBCO4 & Embraco PN & 0,89 & Medium & 546.380 .990 & Small & 0,28 & Loser & Small|Medium|Loser & $3,34 \%$ & $-9,30 \%$ & $10,26 \%$ & $-13,95 \%$ & $1,35 \%$ & $1,02 \%$ & $-7,55 \%$ & $1,45 \%$ & $45,71 \%$ & $12,75 \%$ & $-1,74 \%$ & $-11,50 \%$ \\
\hline EBCO3 & Embra & 0,89 & ledium & 6.380 .990 & Small & 0,25 & Loser & Small|Medium | Loser & $-1,74 \%$ & $-3,85 \%$ & $12,00 \%$ & $-7,14 \%$ & $-3,85 \%$ & $-4,44 \%$ & $0,46 \%$ & $-1,41 \%$ & $47,14 \%$ | & $-3,88 \%$ | & $0,00 \%$ [ & $6,06 \%$ \\
\hline POMO4 & Marcopolo PN & 0,60 & Medium & 533.078 .250 & Small & 0,04 & Loser & Small|Medium|Loser & $-0,21 \%$ & $0,84 \%$ & $10,67 \%$ & $-11,15 \%$ & $1,06 \%$ & $31,50 \%$ & $1,37 \%$ & $10,17 \%$ & $-7,38 \%$ & $1,33 \%$ & $14,59 \%$ & $-0,57 \%$ \\
\hline RSIP4 & Rasip Agro PN & 0,95 & Medium & 44.016 .940 & Small & 0,03 & Loser & Small|Medium|Loser & $4,55 \%$ & $-4,35 \%$ & $0,00 \%$ & $-13,64 \%$ & $-5,26 \%$ & $0,00 \%$ & $5,56 \%$ & $-5,26 \%$ & $0,00 \%$ & $0,00 \%$ & $5,56 \%$ & $0,00 \%$ \\
\hline RPMG4 & Pet Manguinh PN & 1,05 & Medium & \begin{tabular}{l|}
174.414 .450 \\
\end{tabular} & Small & 0,09 & Loser & Small|Medium|Loser & $-22,22 \%$ & $24,29 \%$ & $-16,67 \%$ & $-3,45 \%$ & $-14,29 \%$ & $16,67 \%$ & $0,71 \%$ & $-0,71 \%$ & $0,00 \%$ & $0,00 \%$ & $-7,14 \%$ & $1,54 \%$ \\
\hline FESA4 & Ferbas & 1,05 & Medium & 0.414 .550 & Small & 0,20 & Loser & Small|Medium|Loser & $-5,83 \%$ & $9,32 \%$ & $2,90 \%$ & $-9,40 \%$ & $-5,19 \%$ & $10,94 \%$ & $-0,35 \%$ & $-6,36 \%$ & $-3,77 \%$ & $2,34 \%$ & $-4,08 \%$ & $0,08 \%$ \\
\hline PNVL3 & Dimes & 1,03 & $\mathrm{~N}$ & & Sma & 0,24 & Loser & Small|Medium|Loser & $2,13 \%$ & $0,90 \%$ & $-5,24 \%$ & $-3,05 \%$ & $-4,15 \%$ & $-1,47 \%$ & $8,91 \%$ & $3,18 \%$ & $1,32 \%$ & $4,35 \%$ & $2,08 \%$ & $0,00 \%$ \\
\hline PLTO6 & Politeno PNB & 1,07 & Medium & 380.882 .592 & Small & 0,30 & Loser & Small|Medium | Loser & $-5,09 \%$ & $0,13,03 \%$ & $-5,18 \%$ & $0,95 \%$ & $-5,47 \%$ & $0,00 \%$ & $4,79 \%$ & 16,19\% & $2,30 \%$ & $8,81 \%$ & $-8,69 \%$ & $-1,61 \%$ \\
\hline MNDL3 & Mundial ON & 1,07 & Medium & 78.594.540 & Small & 0,32 & Loser & Small|Medium|Loser & $-2,68 \%$ & $2,76 \%$ & $-22,15 \%$ & $6,03 \%$ & $-6,50 \%$ & $20,87 \%$ & $-7,91 \%$ & $-10,16 \%$ & $0,87 \%$ & $16,38 \%$ & $-8,15 \%$ & $-4,84 \%$ \\
\hline GLOB4 & Globex PN & 0,58 & Medium & 906.555 .800 & Small & 0,35 & Loser & Small|Medium/Loser & $2.97 \%$ & $-9,04 \%$ & $7,72 \%$ & $-5,30 \%$ & $1.45 \%$ & $27,68 \%$ & $20,00 \%$ & $-3,33 \%$ & $8,97 \%$ & $28.48 \%$ & $-10,18 \%$ & $2.22 \%$ \\
\hline SZPQ4 & Quatt & 0,63 & $\mathrm{M}$ & 1.006 .5 & Small & 0,40 & Loser & Small|Medium|Loser & $-4,73 \%$ & $0,47 \%$ & $27,76 \%$ & $-10,13 \%$ & $4,71 \%$ & $-6,46 \%$ & $-3,14 \%$ & $0,86 \%$ & $-14,35 \%$ & $-3,51 \%$ & $-11,20 \%$ & $-1,17 \%$ \\
\hline TRFO4 & Trafo PN & 0,78 & Medium & 30.729 .860 & Small & 0,51 & Winner & Small|Medium|Winner & $-12,24 \%$ & $-1,16 \%$ & $-1,18 \%$ & $14,29 \%$ & $3,13 \%$ & $11,11 \%$ & $9,09 \%$ & $5,00 \%$ & $3,17 \%$ & $20,77 \%$ & $-20,38 \%$ & $-8,00 \%$ \\
\hline FBRA4 & Fertibras PN & 0,74 & Medium & 246.724 .950 & Small & 0,57 & Winner & Small|Medium|Winner & $2,21 \%$ & $3,24 \%$ & $8,14 \%$ & $-0,36 \%$ & $-10,11 \%$ & $8,57 \%$ & $-2,70 \%$ & $-6,93 \%$ & $-4,05 \%$ & $3,39 \%$ & $-0,80 \%$ & $-2,13 \%$ \\
\hline ETER3 & Eternit ON & 0,93 & Medium & 91.364 & Small & 0,59 & Winner & Small|Medium|Winner & $-1,28 \%$ & $0,00 \%$ & $0,60 \%$ & $-9,05 \%$ & $6,69 \%$ & $3,60 \%$ & $38,58 \%$ & $-3,98 \%$ & $24,14 \%$ & $9,09 \%$ & $-14,82 \%$ & $4,72 \%$ \\
\hline MAGS3 & Mag & 66 & & & Small & 0,60 & Winner & Small|Me & $-1,20 \%$ & $-2,83 \%$ & $14,17 \%$ & $-5,11 \%$ & $11,54 \%$ & $11,03 \%$ & $8,95 \%$ & $6,51 \%$ & $3,33 \%$ & $5,38 \%$ & $-2,09 \%$ & $4,22 \%$ \\
\hline \begin{tabular}{ll|} 
PLAS4 \\
\end{tabular} & Plascar Part PN & 0,59 & Medium & $\begin{array}{l}75.171 .840 \\
\end{array}$ & Small & 0,62 & Winner & Small|Medium|Winner & $2,24 \%$ & $-2,88 \%$ & $6,92 \%$ & $2,25 \%$ & $9,82 \%$ & $-3,53 \%$ & $10,37 \%$ & $-0,66 \%$ & $33,15 \%$ & $117,21 \%$ & $15,38 \%$ & $15,00 \%$ \\
\hline MAGS5 & Magnesita PNA & 0,96 & Medium & \begin{tabular}{|l|}
519.304 .403 \\
\end{tabular} & Small & 0,66 & Winner & Small|Medium|Winner & $4,29 \%$ & $-5,57 \%$ & $13,68 \%$ & $-6,02 \%$ & $13,20 \%$ & $9,47 \%$ & $-3,66 \%$ & $0,35 \%$ & $-2,44 \%$ & $0,71 \%$ & $-14,54 \%$ & $2,07 \%$ \\
\hline ALPA4 & Alparga & 0,86 & Medium & 772.740 & Small & 0,67 & Winner & Small|Medium|Winner & $-0,89 \%$ & $24,63 \%$ & $6,41 \%$ & $1,82 \%$ & $23,86 \%$ & $32,59 \%$ & $14,92 \%$ & $7,59 \%$ & $-1,00 \%$ & $6,56 \%$ & $6,14 \%$ & $0,91 \%$ \\
\hline RHDS3 & st ON & 0 & Medium & 580 & Small & 67 & Winner & Small|Me & $-10,53 \%$ & $-5,88 \%$ & $0,00 \%$ & $0,00 \%$ & $-6,25 \%$ & $0,00 \%$ & $6,67 \%$ & $12,50 \%$ & $-16,67 \%$ & $13,33 \%$ & $-5,88 \%$ & $-12,50 \%$ \\
\hline ELEV3 & Eleva & $\theta$ & diu & 7.527 & Sma & 57 & Winner & Small|Me & $\begin{array}{l}-5,63 \% \\
\end{array}$ & $-3,93 \%$ & $12,83 \%$ & $-7,50 \%$ & $-1,62 \%$ & $28,98 \%$ & $0,43 \%$ & $-0,42 \%$ & $-18,00 \%$ & $-0,26 \%$ & $-3,78 \%$ & $8,25 \%$ \\
\hline ETER4 & \begin{tabular}{|l|} 
Eternit PN \\
\end{tabular} & 0,93 & Medium & 1.364 & \begin{tabular}{|l|l|} 
Small \\
\end{tabular} & $0,0,67$ & Winner & Small|Medium|Winner & $\begin{array}{ll}-1,41 \% \\
-1,41 \%\end{array}$ & -2,80\% & 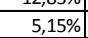 & $-8,47 \%$ & $0,00 \%$ & 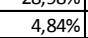 & $40,80 \%$ & $0,00 \%$ & $21,02 \%$ & $\begin{array}{l}6,28 \% \\
6,48 \\
\end{array}$ & - & $4,17 \%$ \\
\hline MTSA4 & Metisa PN & 0,50 & Medium & $\begin{array}{l}96.900 .000 \\
\end{array}$ & Small & 0,71 & Winner & Small|Medium|Winner & $0,92 \%$ & $-2,85 \%$ & $5,26 \%$ & $-2,60 \%$ & $1,54 \%$ & $19,62 \%$ & $4,36 \%$ & $-0,83 \%$ & $-0,59 \%$ & $14,12 \%$ & $-2,23 \%$ & $-0,76 \%$ \\
\hline DPPI4 & Ipira & 0,79 & Mediu & 99.312 .147 & Small & 0,75 & Winner & Im/Winner & $0.00 \%$ & $11.37 \%$ & $8.00 \%$ & $-6.17 \%$ & $250 \%$ & $10,27 \%$ & $8.42 \%$ & $6.16 \%$ & $-3.66 \%$ | & $8.26 \% \mathrm{t}$ & $0,00 \%$ & $4.85 \%$ \\
\hline ALPA3 & Alpar & 0,86 & dit & 0.972 .740 & Smal & 76 & Winner & Small|Me & $2,17 \%$ & $33,82 \%$ & $0,00 \%$ & $1,24 \%$ & $16,43 \%$ & $42,84 \%$ & 2,8 & $4,17 \%$ & $13,46 \%$ & $0,86 \%$ & $5,56 \%$ & $3,31 \%$ \\
\hline MNDL4 & $\mathrm{Mu}$ & 1,07 & Medic & 94.540 & Smal & 94 & Winner & Small|Med & $15,76 \%$ & $-1,41 \%$ & $0,00 \%$ & $\begin{array}{c}-1,90 \% \\
-1,90 \% \\
\end{array}$ & $-0,97 \%$ & $-1,96 \%$ & $-10,00 \%$ & $2,78 \%$ & $-1,08 \%$ & $-3,28 \%$ & $4,52 \%$ & $-1,62 \%$ \\
\hline PLDN4 & Polialden PN & 0,58 & Medium & 509.750 .170 & Small & 1,00 & Winner & Small|Medium|Winner & $4,94 \%$ & $0,12 \%$ & $1,20 \%$ & $-9,52 \%$ & $-2,63 \%$ & $-9,46 \%$ & $-7,76 \%$ & $1,13 \%$ & $-6,40 \%$ & $-14,53 \%$ & $3,11 \%$ & $-0,82 \%$ \\
\hline ROMI3 & Inds Rc & 0,81 & Medium & 5.480 & Small & 1,04 & Winner & Small|Medi & $-1,61 \%$ & $0,02 \%$ & $8,20 \%$ & $7,26 \%$ & $3,79 \%$ & & $5,56 \%$ & $5,26 \%$ & $5,00 \%$ & $7,14 \%$ & $23,34 \%$ & $0,00 \%$ \\
\hline ROMI4 & Inds Rc & t & Anditis a & 6.480 & $t$ & 1,20 & Winner & Small|Me & $-7,28 \%$ & $6,28 \%$ & $5,29 \%$ & $2,88 \%$ & $0,00 \%$ & $6,34 \%$ & $7,28 \%$ & $7,41 \%$ & oncol & $6,63 \%$ & $21,89 \%$ & $-2,16 \%$ \\
\hline TUPY3 & Tupy & & & & $S$ & 5 & $w_{i}$ & Small|Me & $-11,1$ & $-2,50 \%$ & $2,56 \%$ & 1,88 & $0,00 \%$ & $-1,8$ & $53,75 \%$ & $-18,70 \%$ & $-0,60 \%$ & $8,65 \%$ & $11,02 \%$ & $-4,09 \%$ \\
\hline INEP4 & Inepar PN & 0,60 & Medium & 60.768 .170 & Small & 1,37 & Winner & Small|Medium|Winner & $-2,83 \%$ & $4,85 \%$ & $-18,98 \%$ & $-18,63 \%$ & $23,60 \%$ & $0,00 \%$ & $-11,48 \%$ & $-0,51 \%$ & $12,39 \%$ & $15,27 \%$ & $21,10 \%$ & $-8,18 \%$ \\
\hline RIPI4 & Ipiranga Ref PN & 0,49 & Medium & \begin{tabular}{|l|}
874.762 .454 \\
\end{tabular} & Small & 1,89 & Winner & Small|Medium|Winner & $-6,80 \%$ & $6,55 \%$ & $1,91 \%$ & $-14,62 \%$ & $2,34 \%$ & $21,44 \%$ & $-6,76 \%$ & $-0,72 \%$ & $-5,23 \%$ & $\mid 11,31 \%$ & $21,62 \%$ & $-0,03 \%$ \\
\hline IGBB5 & 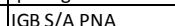 & 57 & 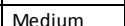 & & 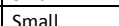 & 201 & Win & Sma & $502 \%$ & $1304 \%$ & 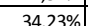 & (1) & $-24.38 \%$ & $-0.83 \%$ & $37.42 \%$ & $39.48 \%$ & $-891 \%$ & $-9.31 \%$ & $-8.68 \%$ & $-778 \%$ \\
\hline PATI & & & & & & & & & 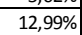 & 急 & 127 & $-8,5$ & $-8,2$ & & $\%$ & $-10,4$ & $-9,5$ & $\begin{array}{cc}-11, \\
-11,\end{array}$ & -10, & $-11,54 \%$ \\
\hline RIPI3 & Ipiranga Ref ON & 0,49 & Medium & 874.762 .454 & Small & 2,94 & Winner & Small|Medium|Winner & $-0,13 \%$ & $-8,97 \%$ & $-4,29 \%$ & $2,99 \%$ & $-14,49 \%$ & $54,24 \%$ & $15,38 \%$ & $-9,99 \%$ & $-20,64 \%$ & $-2,25 \%$ & $2,78 \%$ & $4,05 \%$ \\
\hline
\end{tabular}


Anexo 1 - Retorno mensal e classificação das ações

\begin{tabular}{|c|c|c|c|c|c|c|c|c|c|c|c|c|c|c|c|c|c|c|c|c|}
\hline Código & $2006-2007$ & $\begin{array}{c}\text { Índice } \mathrm{B} / \mathrm{M} \\
\text { de dez/2005 }\end{array}$ & $\begin{array}{c}\text { Grupo com } \\
\text { base no } \\
\text { indice } \mathrm{B} / \mathrm{M}\end{array}$ & $\begin{array}{c}\text { Valor de Mercado } \\
\text { em jun/2006 }\end{array}$ & \begin{tabular}{|c} 
Grupo com \\
base no \\
tamanho
\end{tabular} & $\begin{array}{c}\text { Retorno } \\
\text { acumulado } \\
\text { de jun/2006 }\end{array}$ & \begin{tabular}{|c|} 
Grupo com \\
base no \\
retorno \\
acumulado
\end{tabular} & Carteiras & $\mathrm{jul} / 06$ & ago/06 & set/06 & out/06 & nov/06 & dez/06 & jan/07 & fev/07 & $\operatorname{mar} / 07$ & $\mathrm{abr} / 07$ & mai/07 & jun/07 \\
\hline EBTP4 & Embratel Part PN & 1,20 & High & 6.547 .586 .840 & Big & 0,16 & Loser & Big|High|Loser & $1,20 \%$ & $0,00 \%$ & $2,23 \%$ & $1,31 \%$ & $0,86 \%$ & $0,14 \%$ & $0,43 \%$ & $-19,21 \%$ & $5,24 \%$ & $22,79 \%$ & $1,55 \%$ & $-1,39 \%$ \\
\hline EBTP3 & Embratel Part ON & 1,20 & High & 6.547 .586 .840 & Big & 0,17 & Loser & Big|High|Loser & $1,82 \%$ & $-0,30 \%$ & $2,39 \%$ & $1,46 \%$ & $1,15 \%$ & $0,14 \%$ & $0,14 \%$ & $-19,97 \%$ & $5,49 \%$ & $19,97 \%$ & $-0,70 \%$ & $8,45 \%$ \\
\hline SBSP3 & Sabesp ON & 1,90 & High & 5.767.114.343 & Big & 0,55 & Winner & Big|High|Winner & $7,16 \%$ & $8,30 \%$ & $10,62 \%$ & \begin{tabular}{|c|c|} 
& $-0,95 \%$ \\
\end{tabular} & $1,36 \%$ & $14,17 \%$ & $-7,85 \%$ & $5,00 \%$ & $-2,47 \%$ & $-0,52 \%$ & $12,37 \%$ & $8,77 \%$ \\
\hline ELET3 & Eletrobras ON & 3,50 & High & 26.307 .516 .072 & Big & 0,68 & Winner & Big|High|Winner & $-2,55 \%$ & $2,18 \%$ & $2,56 \%$ & $-6,04 \%$ & $13,97 \%$ & $-0,60 \%$ & $-2,13 \%$ & $-10,00 \%$ & $2,00 \%$ & $-0,65 \%$ & $13,29 \%$ & $12,95 \%$ \\
\hline CPLE6 & Copel PNB & 1,22 & High & 5.161 .821 .852 & Big & 0,69 & Winner & Big|High|Winner & $7,60 \%$ & $5,01 \%$ & $6,29 \%$ & $-0,41 \%$ & $-2,05 \%$ & $4,60 \%$ & $3,36 \%$ & $-4,80 \%$ & $-2,44 \%$ & $12,92 \%$ & $10,23 \%$ & $16,23 \%$ \\
\hline ELET6 & Eletrobras PNB & 3,50 & High & 26.307 .516 .072 & Big & 0,74 & Winner & Big|High|Winner & $-2,90 \%$ & $-1,83 \%$ & $5,14 \%$ & $-4,67 \%$ & $7,44 \%$ & $3,93 \%$ & $0,21 \%$ & $-7,08 \%$ & $0,45 \%$ & $6,67 \%$ & $13,04 \%$ & $12,85 \%$ \\
\hline CPLE3 & Copel ON & 1,22 & High & $\begin{array}{l}.161 .821 .852 \\
\end{array}$ & Big & 0,76 & Winner & Big|High|Winner & $5,14 \%$ & $4,89 \%$ & $8,29 \%$ & $-2,49 \%$ & $-0,88 \%$ & $6,44 \%$ & $1,86 \%$ & $-4,11 \%$ & $4,29 \%$ & $12,01 \%$ & $13,33 \%$ & $19,90 \%$ \\
\hline CESP5 & Cesp PNA & 5,70 & High & 1.956 .623 .454 & Big & 1,13 & Winner & Big|High|Winner & $-5,92 \%$ & $11,65 \%$ & $-17,76 \%$ & $3,78 \%$ & $12,35 \%$ & $8,74 \%$ & $-1,47 \%$ & $-4,87 \%$ & $11,05 \%$ & $11,60 \%$ & $9,18 \%$ & $5,58 \%$ \\
\hline CESP3 & Cesp ON & 5,70 & High & 1.956 .623 .454 & Big & 1,34 & Winner & Big|High|Winner & $-8,92 \%$ & $-5,64 \%$ & $2,52 \%$ & $4,91 \%$ & $3,22 \%$ & $10,48 \%$ & $-1,59 \%$ & $-4,12 \%$ & $16,85 \%$ & $12,56 \%$ & $17,77 \%$ & $10,18 \%$ \\
\hline FFTL4 & Valefert PN & 0,37 & Low & 2.549.207.795 & Big & 0,09 & Loser & Big|Low|Loser & $-6,59 \%$ & $2,14 \%$ & $-5,20 \%$ & $4,15 \%$ & $30,53 \%$ & $18,73 \%$ & $6,20 \%$ & $8,20 \%$ & $22,14 \%$ & $-0,46 \%$ & $10,51 \%$ & $6,99 \%$ \\
\hline CPSL3 & Copesul ON & 0,26 & Low & 4.206 .076 .000 & Big & 0,01 & Loser & Big|Low|Loser & $-1,07 \%$ & $6,81 \%$ & $3,91 \%$ & $11,82 \%$ & $14,08 \%$ & $2,80 \%$ & $1,31 \%$ & $-1,30 \%$ & $-1,54 \%$ & $-2,07 \%$ & $1,13 \%$ & $2,31 \%$ \\
\hline TMCP3 & Telemig Part ON & 0,47 & Low & 2.069 .053 .536 & Big & 0,05 & Loser & Big|Low|Loser & $-14,44 \%$ & $-13,64 \%$ & $15,79 \%$ & $2,99 \%$ & $13,62 \%$ & $-20,20 \%$ & $11,27 \%$ & $5,25 \%$ & $-7,01 \%$ & $7,25 \%$ & $30,76 \%$ & $-3,60 \%$ \\
\hline TMGC3 & Telemig Cl ON & 0,50 & Low & 2.135 .553 .230 & Big & 0,08 & Loser & Big|Low|Loser & $0,00 \%$ & $0,00 \%$ & $0,00 \%$ & $0,00 \%$ & $1,60 \%$ & $-7,09 \%$ & $8,47 \%$ & $0,00 \%$ & $5,47 \%$ & $0,00 \%$ & $3,70 \%$ & $3,57 \%$ \\
\hline ELPL5 & Eletropaulo PNA & 0,47 & Low & 3.764 .819 .120 & Big & 0,11 & Loser & Big|Low|Loser & 1,68\% & $3,80 \%$ & $-5,24 \%$ & $1,77 \%$ & $2,09 \%$ & $9,61 \%$ & $0,50 \%$ & $-0,18 \%$ & $-7,62 \%$ & $9,77 \%$ & $17,83 \%$ & $-1,67 \%$ \\
\hline TNLP4 & Telemar PN & 0,48 & Low & \begin{tabular}{|c|}
14.584 .295 .200 \\
\end{tabular} & Big & 0,11 & Loser & Big|Low|Loser & $2,88 \%$ & $-2,80 \%$ & $6,83 \%$ & $5,22 \%$ & $2,40 \%$ & $0,00 \%$ & $-8,67 \%$ & $-3,19 \%$ & $3,44 \%$ & $19,53 \%$ & $7,20 \%$ & $1,23 \%$ \\
\hline GRND3 & Grendene ON & 0,38 & Low & 1.738 .000 .000 & Big & 0,19 & Loser & Big|Low|Loser & \begin{tabular}{|l|}
$5,01 \%$ \\
\end{tabular} & $-3,67 \%$ & $-0,58 \%$ & $5,26 \%$ & $23,54 \%$ & $5,28 \%$ & $10,46 \%$ & $1,22 \%$ & $2,92 \%$ & $-3,28 \%$ & $-4,99 \%$ & $4,54 \%$ \\
\hline CGAS5 & Comgas PNA & 0,29 & Low & 3.247 .197 .880 & Big & 0,21 & Loser & Big|Low|Loser & $2,62 \%$ & $10,39 \%$ & $-2,11 \%$ & $-1,84 \%$ & $16,44 \%$ & $8,59 \%$ & $-3,95 \%$ & $3,24 \%$ & $15,95 \%$ & $10,58 \%$ & $4,33 \%$ & $0,54 \%$ \\
\hline TMCP4 & Telemig Part PN & 0,47 & \begin{tabular}{|l|} 
Low \\
\end{tabular} & 2.069 .053 .536 & Big & 0,25 & Loser & Big|Low|Loser & $-3,35 \%$ & $-4,80 \%$ & $12,04 \%$ & $-9,00 \%$ & $9,34 \%$ & $1,76 \%$ & $-0,74 \%$ & $-3,98 \%$ & $0,78 \%$ & $17,98 \%$ & $5,27 \%$ & $3,18 \%$ \\
\hline CCRO3 & CCR SA ON & 0,18 & Low & 7.134.901.860 & Big & 0,30 & Loser & Big|Low|Loser & $15,54 \%$ & $5,46 \%$ & $0,53 \%$ & $8,90 \%$ & $20,46 \%$ & $4,72 \%$ & $-3,29 \%$ & $-2,15 \%$ & $2,51 \%$ & $15,65 \%$ & $1,51 \%$ & $10,11 \%$ \\
\hline EMBR3 & Embraer ON & 0,32 & Low & 14.626.244.299 & Big & 0,39 & Loser & Big|Low|Loser & $-7,07 \%$ & $14,08 \%$ & $2,28 \%$ & $4,32 \%$ & $1,22 \%$ & $-1,47 \%$ & $-3,36 \%$ & $12,06 \%$ & $-1,39 \%$ & $2,17 \%$ & $-3,13 \%$ & $1,02 \%$ \\
\hline CRUZ3 & Souza Cruz ON & 0,19 & Low & 9.846.274.900 & Big & 0,43 & Winner & Big|Low|Winner & $7,73 \%$ & $2,99 \%$ & $-4,14 \%$ & $-2,66 \%$ & $14,69 \%$ & $2,05 \%$ & $5,12 \%$ & $-3,75 \%$ & $12,65 \%$ & $8,17 \%$ & $6,04 \%$ & $-2,52 \%$ \\
\hline ARCZ6 & Aracruz PNB & 0,48 & \begin{tabular}{|l|} 
Low \\
\end{tabular} & 11.985 .698 .296 & \begin{tabular}{|l|} 
Big \\
\end{tabular} & 0,45 & Winner & Big|Low|Winner & $-5,45 \%$ & $2,79 \%$ & $-2,01 \%$ & $9,77 \%$ & $11,95 \%$ & $-0,03 \%$ & $-9,60 \%$ & $-4,72 \%$ & $-4,87 \%$ & $4,43 \%$ & $4,64 \%$ & $12,58 \%$ \\
\hline VALE3 & Vale ON & 0,23 & Low & 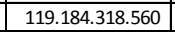 & Big & 0,57 & Winner & Big|Low|Winner & $-3,31 \%$ & $-9,00 \%$ & $1,85 \%$ & $16,87 \%$ & $10,29 \%$ & $6,66 \%$ & $11,62 \%$ & $1,98 \%$ & $5,23 \%$ & $10,98 \%$ & $3,60 \%$ & $-0,97 \%$ \\
\hline TBLE3 & Tractebel & 0,27 & Low & 11.227.165.702 & Big & 0,59 & Winner & Big|Low|Winner & $-0,58 \%$ & $16,83 \%$ & $-8,81 \%$ & $-3,41 \%$ & $-3,94 \%$ & $11,24 \%$ & $1,39 \%$ & $-5,48 \%$ & $4,35 \%$ & $2,49 \%$ & $14,85 \%$ & $5,48 \%$ \\
\hline $\begin{array}{l}\text { PCAR4 } \\
\end{array}$ & P.Acucar-Cbd PN & 0,49 & Low & 7.671 .243 .690 & Big & 0,59 & Winner & Big|Low|Winner & $-2,96 \%$ & $-10,77 \%$ & $-2,95 \%$ & $13,70 \%$ & $5,44 \%$ & $11,10 \%$ & $-7,30 \%$ & $-9,57 \%$ & $-4,53 \%$ & $6,67 \%$ & $2,56 \%$ & $14,59 \%$ \\
\hline VALE5 & Vale PNA & 0,23 & Low & 119.184 .318 .560 & Big & 0,61 & Winner & Big|Low|Winner & $-1,77 \%$ & $-8,04 \%$ & $1,26 \%$ & $15,93 \%$ & $\begin{array}{ll}9,62 \% \\
\end{array}$ & 6,96\% & $10,91 \%$ & $4,10 \%$ & $3,11 \%$ & $10,21 \%$ & $4,45 \%$ & $-1,28 \%$ \\
\hline CPFE3 & CPFL Energia ON & 0,36 & Low & 12.694 .363 .076 & Big & 0,61 & Winner & Big|Low|Winner & $2,23 \%$ & $8,34 \%$ & $-0,71 \%$ & $-2,16 \%$ & $4,41 \%$ & $5,63 \%$ & $-6,67 \%$ & $0,89 \%$ & $8,01 \%$ & $8,43 \%$ & $14,29 \%$ & $7,67 \%$ \\
\hline AMBV4 & Ambev PN & 0,37 & Low & 55.038 .730 .596 & Big & 0,62 & Winner & Big|Low|Winner & $-3,22 \%$ & $10,56 \%$ & $3,03 \%$ & $-4,57 \%$ & $6,33 \%$ & $6,33 \%$ & $3,84 \%$ & $-5,89 \%$ & $11,01 \%$ & $4,45 \%$ & $10,13 \%$ & $4,32 \%$ \\
\hline GET13 & AES Tiete ON & 0,10 & Low & 4.906 .930 .093 & Big & 0,65 & Winner & Big|Low|Winer & $6,45 \%$ & $8,75 \%$ & $0,73 \%$ & $-3,88 \%$ & $6,75 \%$ & $9,93 \%$ & $7,58 \%$ & $-1,05 \%$ & $-3,03 \%$ & $20,54 \%$ & $-1,22 \%$ & $0,68 \%$ \\
\hline GET/4 & AES Tiete PN & 0,10 & Low & 4.906 .930 .093 & Big & 0,65 & Winner & Big|Low|Winner & $4,27 \%$ & $9,02 \%$ & $3,05 \%$ & $-5,50 \%$ & $11,29 \%$ & $5,95 \%$ & $2,97 \%$ & $2,10 \%$ & $-0,76 \%$ & $10,13 \%$ & $1,37 \%$ & $8,70 \%$ \\
\hline AMBV3 & Ambev ON & \begin{tabular}{ll|}
0,37 \\
\end{tabular} & Low & 55.038 .730 .596 & Big & 0,65 & Winner & Big|Low|Winner & $-1,88 \%$ & $7,65 \%$ & $4,68 \%$ & $-3,53 \%$ & $6,91 \%$ & $5,03 \%$ & $3,34 \%$ & $0,57 \%$ & $10,37 \%$ & $9,50 \%$ & $10,64 \%$ & $6,02 \%$ \\
\hline NATU3 & Natura ON & 0,06 & Low & 9.674 .513 .000 & Big & 0,68 & Winner & Big|Low|Winner & $6,39 \%$ & $12,15 \%$ & $-0,04 \%$ & $10,53 \%$ & $-0,68 \%$ & $2,90 \%$ & $-4,81 \%$ & $-6,17 \%$ & $-11,94 \%$ & $3,02 \%$ & $9,87 \%$ & $6,63 \%$ \\
\hline LAME3 & Lojas Americ ON & 0,06 & Low & 5.694 .074 .879 & Big & 0,73 & Winner & Big|Low|Winner & $5,84 \%$ & $-5,05 \%$ & $-10,48 \%$ & $12,94 \%$ & $6,24 \%$ & $5,61 \%$ & $8,41 \%$ & $2,29 \%$ & $5,08 \%$ & $1,21 \%$ & $12,35 \%$ & $-0,71 \%$ \\
\hline ARCZ3 & Aracruz ON & 0,48 & Low & 11.985.698.296 & Big & 0,79 & Winner & Big|Low|Winner & $-5,29 \%$ & $-0,71 \%$ & $1,36 \%$ & $9,14 \%$ & $10,16 \%$ & $-3,55 \%$ & $3,46 \%$ & $-3,35 \%$ & $0,47 \%$ & $9,66 \%$ & $8,51 \%$ & $8,11 \%$ \\
\hline DASA3 & Dasa ON & 0,11 & Low & 2.468 .329 .000 & Big & 0,81 & Winner & Big|Low|Winner & $-11,88 \%$ & $8,47 \%$ & $-0,24 \%$ & $2,44 \%$ & $9,52 \%$ & $-0,76 \%$ & $-6,90 \%$ & $8,47 \%$ & $-1,30 \%$ & $-3,28 \%$ & $2,80 \%$ & $-5,81 \%$ \\
\hline TNLP3 & Telemar ON & 0,48 & Low & 14.584.295.200 & Big & 0,81 & Winner & Big|Low|Winner & $5,26 \%$ & $-13,06 \%$ & $24,30 \%$ & $-4,78 \%$ & $8,46 \%$ & $-19,51 \%$ & $1,43 \%$ & $-2,15 \%$ & $9,54 \%$ & $13,21 \%$ & $7,26 \%$ & $6,08 \%$ \\
\hline PETR3 & Petrobras ON & 0,47 & Low & 202.635 .481 .640 & Big & 0,90 & Winner & Big|Low|Winner & $3,20 \%$ & $-4,86 \%$ & $-4,57 \%$ & $4,52 \%$ & $9,91 \%$ & $6,84 \%$ & $-3,77 \%$ & $-7,98 \%$ & $8,13 \%$ & $-0,35 \%$ & $1,09 \%$ & $13,56 \%$ \\
\hline \begin{tabular}{|l|} 
ALLL11 \\
\end{tabular} & All Amer Lat UNT N2 & 0,22 & Low & $\begin{array}{l}8.547 .547 .922 \\
\end{array}$ & Big & 0,90 & Winner & Big|Low|Winner & $0,61 \%$ & $21,78 \%$ & $-6,11 \%$ & $10,65 \%$ & $2,41 \%$ & $15,77 \%$ & $4,35 \%$ & $5,87 \%$ & $2,59 \%$ & $-5,03 \%$ & $4,47 \%$ & $6,54 \%$ \\
\hline PETR4 & $\begin{array}{l}\text { Petrobras PN } \\
\end{array}$ & 0,47 & \begin{tabular}{|l|} 
Low \\
\end{tabular} & 202.635 .481 .640 & Big & 0,93 & Winner & Big|Low|Winner & $3,98 \%$ & $-4,23 \%$ & $-5,60 \%$ & $5,94 \%$ & $9,12 \%$ & $8,66 \%$ & $-5,03 \%$ & $-8,51 \%$ & $7,60 \%$ & $-1,26 \%$ & $1,64 \%$ & $12,41 \%$ \\
\hline NETC4 & Net PN & 0,15 & Low & \begin{tabular}{|l|l}
435.976 .060 \\
\end{tabular} & Big & 0,94 & Winner & Big|Low|Winner & $4,27 \%$ & $5,19 \%$ & $1,51 \%$ & $11,46 \%$ & $1,15 \%$ & $10,17 \%$ & $5,77 \%$ & $5,30 \%$ & $3,26 \%$ & $11,55 \%$ & $4,18 \%$ & $-1,23 \%$ \\
\hline CEEB3 & Coelba ON & 0,44 & Low & 3.541 .645 .504 & Big & 0,95 & Winner & Big|Low|Winner & $-1,98 \%$ & $-4,54 \%$ & $5,46 \%$ & $9,15 \%$ & $11,82 \%$ & $6,56 \%$ & $4,27 \%$ & $0,00 \%$ & $2,73 \%$ & $9,99 \%$ & $-4,22 \%$ & $7,14 \%$ \\
\hline GOLL4 & Gol PN & 0,12 & Low & 15.107.862.000 & Big & 0,97 & Winner & Big|Low|Winner & $-10,10 \%$ & $6,92 \%$ & $1,54 \%$ & $-12,13 \%$ & $-6,10 \%$ & $3,01 \%$ & $0,24 \%$ & $-4,43 \%$ & $4,15 \%$ & $-7,96 \%$ & $10,28 \%$ & $0,70 \%$ \\
\hline ITSA3 & Itausa ON & 0,43 & Low & 29.025.991.160 & Big & 0,98 & Winner & Big|Low|Winner & $2,78 \%$ & $-0,91 \%$ & $-2,93 \%$ & $5,76 \%$ & $18,81 \%$ & $7,84 \%$ & $10,55 \%$ & $-10,24 \%$ & $10,48 \%$ & $16,52 \%$ & $13,25 \%$ & $15,22 \%$ \\
\hline LAME4 & Lojas Amer & 0,06 & Low & \begin{tabular}{|l|}
5.694 .074 .879 \\
\end{tabular} & Big & 1,02 & Winner & Big|Low|Winner & $-0,14 \%$ & $21,97 \%$ & $-7,06 \%$ & $9,87 \%$ & $7,84 \%$ & $14,99 \%$ & $2,94 \%$ & $-3,13 \%$ & 9,70\% & $-0,78 \%$ & $12,33 \%$ & $6,28 \%$ \\
\hline ITSA4 & Itausa PN & 0,43 & \begin{tabular}{|l|} 
Low \\
\end{tabular} & 29.025 .991 .160 & \begin{tabular}{|l|} 
Big \\
\end{tabular} & 1,02 & Winner & Big|Low/Winner & $3,21 \%$ & $1,10 \%$ & $-0,97 \%$ & $8,60 \%$ & $3,40 \%$ & $10,12 \%$ & $7,60 \%$ & $-1,38 \%$ & $0,97 \%$ & $6,46 \%$ & $8,38 \%$ & $0,76 \%$ \\
\hline ALLL4 & All Amer Lat PN & \begin{tabular}{ll|}
0,22 \\
\end{tabular} & Low & 8.547 .547 .922 & Big & 1,11 & Winner & Big|Low|Winner & $-0,34 \%$ & $31,49 \%$ & $-9,21 \%$ & $6,09 \%$ & $-9,29 \%$ & $9,34 \%$ & $10,35 \%$ & $14,50 \%$ & $0,22 \%$ & $1,33 \%$ & $-4,09 \%$ & $-2,02 \%$ \\
\hline TAMM4 & Tam S/A PN & 0,12 & Low & $\begin{array}{l}7.880 .317 .200 \\
\end{array}$ & Big & 1,40 & Winner & Big|Low|Winner & $-0,36 \%$ & $12,81 \%$ & $3,47 \%$ & $-5,38 \%$ & $-6,30 \%$ & $9,02 \%$ & $3,31 \%$ & $-9,32 \%$ & $-10,83 \%$ & $-4,88 \%$ & $26,11 \%$ & $-2,13 \%$ \\
\hline GUAR4 & Guararapes $\mathrm{P}$ & 0,22 & Low & 4.803.864.000 & Big & 1,83 & Winner & Big|Low/Winner & $-8,10 \%$ & $17,56 \%$ & $1,22 \%$ & $6,60 \%$ & $5,26 \%$ & $-0,54 \%$ & $-5,05 \%$ & $-7,93 \%$ & $-8,13 \%$ & $21,09 \%$ & $-3,41 \%$ & -7. \\
\hline SUBA3 & Submarino ON & \begin{tabular}{l|l|}
0,10 \\
\end{tabular} & Low & 2.236 .000 .557 & Big & 2,16 & Winner & Big|Low|Winner & $-5,73 \%$ & $6,96 \%$ & $-2,97 \%$ & $3,15 \%$ & $46,97 \%$ & $10,69 \%$ & $4,02 \%$ & $8,37 \%$ & $-0,72 \%$ & $4,53 \%$ & $13,07 \%$ & $-2,07 \%$ \\
\hline
\end{tabular}


Anexo 1 - Retorno mensal e classificação das ações

\begin{tabular}{|c|c|c|c|c|c|c|c|c|c|c|c|c|c|c|c|c|c|c|c|c|}
\hline Código & $2006-2007$ & $\begin{array}{l}\text { Índice B/M } \\
\text { de dez/2005 }\end{array}$ & $\begin{array}{c}\text { Grupo com } \\
\text { base no } \\
\text { índice } \mathrm{B} / \mathrm{M}\end{array}$ & $\begin{array}{l}\text { Valor de Mercado } \\
\text { em jun/2006 }\end{array}$ & \begin{tabular}{|c} 
Grupo com \\
base no \\
tamanho
\end{tabular} & $\begin{array}{c}\text { Retorno } \\
\text { acumulado } \\
\text { de jun/2006 }\end{array}$ & \begin{tabular}{|l|} 
Grupo com \\
base no \\
retorno \\
acumulado
\end{tabular} & Carteiras & jul/06 & ago/06 & set/06 & out/06 & nov/06 & dez/06 & jan/07 & fev/07 & $\operatorname{mar} / 07$ & $a b r / 07$ & mai/07 & jun/07 \\
\hline $\begin{array}{ll}\text { LREN33 } \\
\end{array}$ & Lojas Renner ON & 0,28 & Low & 2.828.803.400 & Big & 2,33 & Winner & Big|Low|Winner & $9,02 \%$ & $1,26 \%$ & $-1,25 \%$ & $6,31 \%$ & $5,75 \%$ & $8,92 \%$ & $-3,09 \%$ & $0,47 \%$ & $-10,67 \%$ & $8,78 \%$ & $14,75 \%$ & $10,03 \%$ \\
\hline GUAR3 & Guararapes ON & 0,22 & Low & 4.803 .864 .000 & Big & 3,09 & Winner & Big|Low|Winner & $-7,09 \%$ & $11,72 \%$ & $1,22 \%$ & $13,13 \%$ & $4,79 \%$ & $8,23 \%$ & $-12,69 \%$ & $1,09 \%$ & $-5,85 \%$ & $11,31 \%$ & $1,33 \%$ & $1,97 \%$ \\
\hline RENT3 & Localiza ON & 0,19 & Low & 2.790 .169 .500 & Big & 3,09 & Winner & Big|Low|Winner & $9,63 \%$ & $-1,46 \%$ & $0,92 \%$ & $18,54 \%$ & $4,11 \%$ & $15,79 \%$ & $0,21 \%$ & $-12,84 \%$ & $12,75 \%$ & $4,00 \%$ & $5,52 \%$ & $-1,14 \%$ \\
\hline LIGT3 & Light S/A ON & 0,83 & Medium & 1.941 .641 .238 & Big & 0,43 & Loser & Big|Medium|Loser & $3,17 \%$ & $5,15 \%$ & $0,45 \%$ & $16,46 \%$ & $10,27 \%$ & $13,41 \%$ & $8,56 \%$ & $-5,32 \%$ & $3,59 \%$ & $21,63 \%$ & $3,32 \%$ & $0,03 \%$ \\
\hline BRKM5 & Braskem PNA & 0,72 & Medium & 4.737 .439 .003 & Big & 0,33 & Loser & Big|Medium|Loser & $-14,97 \%$ & $23,45 \%$ & $-3,01 \%$ & $11,97 \%$ & $4,16 \%$ & $-4,94 \%$ & $3,53 \%$ & $-11,27 \%$ & $11,53 \%$ & $14,07 \%$ & $-5,48 \%$ & $5,24 \%$ \\
\hline BRKM3 & Braskem ON & 0,72 & Medium & 4.737 .439 .003 & Big & 0,30 & Loser & Big|Medium|Loser & $-13,58 \%$ & $7,34 \%$ & $-1,40 \%$ & $9,42 \%$ & $13,89 \%$ & $-7,28 \%$ & $1,54 \%$ & $-4,55 \%$ & $7,94 \%$ & $15,44 \%$ & $2,87 \%$ & $2,54 \%$ \\
\hline \begin{tabular}{|l|} 
VIVO4 \\
\end{tabular} & Vivo PN & 0,70 & Medium & 9.834 .852 .540 & Big & \begin{tabular}{ll|}
0,28 \\
\end{tabular} & Loser & Big|Medium|Loser & $4,37 \%$ & $22,40 \%$ & $-0,45 \%$ & $10,01 \%$ & $12,77 \%$ & $5,30 \%$ & $-7,32 \%$ & $-2,47 \%$ & $-9,14 \%$ & $31,28 \%$ & $-0,21 \%$ & $2,67 \%$ \\
\hline UGPA4 & Ultrapar PN & 0,68 & Medium & 2.766 .737 .600 & Big & 0,08 & Loser & Big|Medium|Loser & $-4,96 \%$ & $21,36 \%$ & $0,00 \%$ & $8,20 \%$ & $17,81 \%$ & $0,08 \%$ & $4,69 \%$ & $3,19 \%$ & $16,89 \%$ & $3,45 \%$ & $-6,00 \%$ & $8,73 \%$ \\
\hline BRKM6 & Braskem PNB & 0,72 & Medium & 4.737 .439 .003 & Big & 0,01 & Loser & Big|Medium|Loser & $-14,77 \%$ & $2,67 \%$ & $10,13 \%$ & $-10,14 \%$ & $13,65 \%$ & $1,85 \%$ & $-1,02 \%$ & $3,09 \%$ & $24,34 \%$ & $11,14 \%$ & $-2,20 \%$ & $7,08 \%$ \\
\hline TMAR5 & Telemar N L PNA & 0,64 & \begin{tabular}{|l|} 
Medium \\
\end{tabular} & 15.342 .263 .969 & Big & 0,12 & Loser & Big|Medium|Loser & $1,24 \%$ & $0,02 \%$ & $6,53 \%$ & $6,28 \%$ & $2,62 \%$ & $-0,82 \%$ & $-11,11 \%$ & $-2,55 \%$ & $0,48 \%$ & $12,55 \%$ & $8,80 \%$ & $3,96 \%$ \\
\hline BRTP4 & Brasil T Par PN & 0,74 & Medium & 7.035 .644 .470 & ig & 0,12 & Loser & Big|Medium|Loser & $-2,25 \%$ & $-3,61 \%$ & $1,25 \%$ & $9,78 \%$ & $14,39 \%$ & $16,25 \%$ & $-2,29 \%$ & $-1,34 \%$ & $7,87 \%$ & $18,84 \%$ & $9,69 \%$ & $-1,54 \%$ \\
\hline ACES3 & Am Inox BR ON & 1,04 & Medium & 2.732 .281 .300 & Big & 0,17 & $\begin{array}{l}\text { Loser } \\
\end{array}$ & Big|Medium|Loser & $0,43 \%$ & $5,79 \%$ & $1,78 \%$ & $7,50 \%$ & $23,26 \%$ & 5,96\% & $13,69 \%$ & $5,81 \%$ & $18,14 \%$ & $1,92 \%$ & $-8,40 \%$ & $-0,56 \%$ \\
\hline TMGC7 & Telemig Cl PNC & 0,50 & Medium & 2.135.553.230 & Big & 0,20 & Loser & Big|Medium|Loser & $0,00 \%$ & $4,48 \%$ & $1,43 \%$ & $-1,41 \%$ & $28,57 \%$ & $22,22 \%$ & $-5,45 \%$ & $0,00 \%$ & $-3,84 \%$ & $0,00 \%$ & $4,00 \%$ & $-1,92 \%$ \\
\hline BRTO4 & Brasil Telec PN & 0,75 & Medium & 8.515 .228 .145 & Big & 0,20 & Loser & Big|Medium|Loser & $0,82 \%$ & $-7,48 \%$ & $-1,52 \%$ & $10,90 \%$ & $13,87 \%$ & $13,12 \%$ & $-5,48 \%$ & $1,58 \%$ & $6,75 \%$ & $19,26 \%$ & $8,11 \%$ & $2,62 \%$ \\
\hline TRPL3 & Tran Paulist ON & 0,89 & \begin{tabular}{|l|} 
Medium \\
\end{tabular} & 3.693 .816 .074 & Big & 0,21 & Loser & Big|Medium|Loser & $0,32 \%$ & $3,57 \%$ & $0,65 \%$ & $0,37 \%$ & $1,39 \%$ & $2,03 \%$ & $9,05 \%$ & $-16,14 \%$ & $-3,64 \%$ & $4,47 \%$ & $5,13 \%$ & $8,77 \%$ \\
\hline TRPL4 & $\operatorname{Tran} \mathrm{P}$ & 0,89 & edium & & ig & 0,21 & Loser & um|Loser & $-12,22 \%$ & $8,60 \%$ & $8,35 \%$ & $11,40 \%$ & $3,83 \%$ & $13,24 \%$ & $1,99 \%$ & $-7,62 \%$ & $4,01 \%$ & $8,07 \%$ & $11,53 \%$ & $6,20 \%$ \\
\hline TMAR6 & Telemar N L PNB & 0,64 & \begin{tabular}{|l|} 
Medium \\
\end{tabular} & 15.342 .263 .969 & Big & 0,23 & Loser & Big|Medium|Loser & $2,62 \%$ & $3,65 \%$ & $2,14 \%$ & $3,96 \%$ & $6,15 \%$ & $-0,28 \%$ & $-10,64 \%$ & $-5,48 \%$ & $0,76 \%$ & $17,68 \%$ & 11,67\% & $2,91 \%$ \\
\hline VCPA4 & Fibria PN & 0,76 & Medium & 6.883 .869 .600 & Big & 0,25 & Loser & Big|Medium|Loser & $-0,62 \%$ & $3,44 \%$ & $6,17 \%$ & $6,68 \%$ & $9,96 \%$ & $-0,43 \%$ & $-7,02 \%$ & $-0,41 \%$ & $-1,84 \%$ & $7,20 \%$ & $3,56 \%$ & $4,20 \%$ \\
\hline ACES4 & Am Inox BR PN & 1,04 & Medium & 2.732 .281 .300 & Big & 0,29 & Loser & Big|Medium|Loser & $5,26 \%$ & $2,67 \%$ & $0,96 \%$ & $7,47 \%$ & $16,26 \%$ & $12,04 \%$ & $5,48 \%$ & $11,97 \%$ & $13,50 \%$ & $1,65 \%$ & $-2,62 \%$ & $-3,72 \%$ \\
\hline \begin{tabular}{|l|l|} 
VIVO3 \\
\end{tabular} & Vivo on & 0,70 & \begin{tabular}{|l|} 
Medium \\
\end{tabular} & 352.540 & Big & 0,34 & $\begin{array}{ll}\text { Loser } \\
\end{array}$ & Big|Medium|Loser & $-10,32 \%$ & $24,07 \%$ & $10,59 \%$ & $1,69 \%$ & $24,17 \%$ & $-1,34 \%$ & $-5,44 \%$ & $-7,19 \%$ & $21,71 \%$ & $5,10 \%$ & $-7,27 \%$ & 0,59\% \\
\hline RGEG3 & Rio Gd & 0,98 & Medium & 1.702.187.640 & Big & 0,37 & Loser & Big|Medium|Loser & $-5,21 \%$ & $0,00 \%$ & $0,00 \%$ & $8,50 \%$ & $3,69 \%$ & $6,67 \%$ & $4,17 \%$ & $52,40 \%$ & $-0,67 \%$ & $-6,85 \%$ & $25,88 \%$ & $-18,22 \%$ \\
\hline KLBN4 & Klabin S/A PN & 0,60 & Medium & 4.652 .652 .810 & Big & 0,38 & Loser & Big|Medium|Loser & $-6,90 \%$ & $-9,75 \%$ & $11,76 \%$ & $0,00 \%$ & $12,55 \%$ & $2,88 \%$ & $-4,49 \%$ & $0,39 \%$ & $13,57 \%$ & $9,82 \%$ & $1,44 \%$ & $7,09 \%$ \\
\hline PTIP3 & Ipiranga Pet ON & 0,83 & Medium & \begin{tabular}{|l|}
2.048 .773 .224 \\
\end{tabular} & Big & 0,40 & Loser & Big|Medium|Loser & $13,59 \%$ & $-7,96 \%$ & $-6,52 \%$ & $2,33 \%$ & $0,00 \%$ & $-1,93 \%$ & $13,71 \%$ & $13,07 \%$ & $94,48 \%$ & $1,89 \%$ & $3,18 \%$ & $1,70 \%$ \\
\hline SDIA4 & Sadia S/A PN & 0,51 & Medium & 4.028.502.000 & Big & 0,52 & Winner & Big|Medium/Winner & $5,74 \%$ & $-5,43 \%$ & $2,78 \%$ & $6,94 \%$ & $9,02 \%$ & $3,92 \%$ & $-3,37 \%$ & $-1,91 \%$ & $17,34 \%$ & $12,62 \%$ & $12,16 \%$ & $-9,02 \%$ \\
\hline CMIG4 & Cemig PN & 0,50 & Med & 14.15 & Big & 0,52 & Winner & $\mathrm{m} /$ Winner & $2,95 \%$ & $-5,90 \%$ & $-3,62 \%$ & $8,35 \%$ & $6,03 \%$ & $7,14 \%$ & $-3,13 \%$ & $-0,70 \%$ & $0,01 \%$ & $13,98 \%$ & $6,00 \%$ & $8,00 \%$ \\
\hline SUZB5 & Suzano Papel PNA & 0,93 & Medium & 3.985.381.100 & Big & 0,52 & Winner & Big|Medium/Winner & $0,43 \%$ & $3,57 \%$ & $16,09 \%$ & $17,49 \%$ & $16,12 \%$ & $3,63 \%$ & $9,91 \%$ & $-6,87 \%$ & $-10,14 \%$ & $10,32 \%$ & $7,96 \%$ & $12,50 \%$ \\
\hline BRTP3 & Brasil T Par ON & 0,74 & Medium & 7.035.644.470 & Big & 0,52 & Winner & Big|Medium|Winner & $-0,01 \%$ & $-25,21 \%$ & $20,82 \%$ & $3,56 \%$ & $25,95 \%$ & $7,92 \%$ & $2,86 \%$ & $2,57 \%$ & $14,11 \%$ & $8,68 \%$ & $8,89 \%$ & $10,00 \%$ \\
\hline PTIP4 & Ipiranga Pet PN & 0,83 & \begin{tabular}{|l|} 
Medium \\
\end{tabular} & 448.773 .224 & Big & 0,54 & Winner & Big|Medium/Winner & $2,22 \%$ & $-8,70 \%$ & $2,38 \%$ & $10,47 \%$ & $-2,16 \%$ & $5,66 \%$ & $9,21 \%$ & $6,51 \%$ & $13,80 \%$ & $3,38 \%$ & $-8,08 \%$ & $7,95 \%$ \\
\hline CMIG3 & Cemig & 0,50 & Med & & Big & 64 & Winner & $\mathrm{n} \mid$ Winner & $-0,05 \%$ & $-5,02 \%$ & $-3,64 \%$ & $8,18 \%$ & $8,75 \%$ & ( & $-1,32 \%$ & $56 \%$ & $11,15 \%$ & $11,89 \%$ & $1,43 \%$ & $18,34 \%$ \\
\hline SDIA3 & Sadia S/AO & 51 & $x_{x}$ & & Big & 79 & Winner & ig|Medium|Winner & $7,26 \%$ & $-5,26 \%$ & $1,59 \%$ & $9,38 \%$ & $-2,71 \%$ & $9,25 \%$ & $-0,52 \%$ & $6,16 \%$ & $3,10 \%$ & $4,99 \%$ & $11,26 \%$ & 0,8 \\
\hline \begin{tabular}{|l|} 
CSNA3 \\
\end{tabular} & Sid Nacional ON & 0,50 & Medium & 17.890 .203 .500 & Big & 82 & Winner & Big|Medium/Winner & $0,29 \%$ & $-8,51 \%$ & $-0,96 \%$ & $7,26 \%$ & $-2,71 \%$ & $-0,31 \%$ & $6,81 \%$ & $7,56 \%$ & $19,91 \%$ & $0,17 \%$ & $14,81 \%$ & 0,7 \\
\hline CBEE3 3 & Ampla Energ ON & 0,60 & $\mathrm{M}$ & 24 & Big & 36 & Winner & Big|Medium/Winner & $2,94 \%$ & $-8,57 \%$ & $-6,25 \%$ & $18,33 \%$ & $0,00 \%$ & $23,94 \%$ & $32,95 \%$ & 11, & $-14,50 \%$ & $17,86 \%$ & $-9,05 \%$ & 52,9 \\
\hline GLOB4 & Globex PN & 0,56 & Medium & 200 & Big & 0,87 & Winner & ium/Winner & $0,54 \%$ & $-8,16 \%$ & $1,18 \%$ & $4,48 \%$ & $-1,17 \%$ & $12,68 \%$ & $14,50 \%$ & $13,54 \%$ & $7,69 \%$ & $17,33 \%$ & $15,38 \%$ & $7,60 \%$ \\
\hline USIM5 & Usimir & 7 & 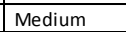 & 243 & Bir & 4 & Winner & $\mathrm{n} \mid \mathrm{Win}$ & $-3,41 \%$ & $-10,37 \%$ & $-0,83 \%$ & $12,00 \%$ & $0,48 \%$ & $10,05 \%$ & $1,43 \%$ & $10,24 \%$ & $12,86 \%$ & $-2,35 \%$ & 10,88\% & \\
\hline TMAR3 & Telemar & 4 & Medium & .969 & Big & 6 & Winner & ig|Medium|Winner & $4,32 \%$ & $-8,61 \%$ & $15,31 \%$ & $-5,35 \%$ & $7,61 \%$ & $-16,14 \%$ & $1,18 \%$ & 4,7 & $2,27 \%$ & $12,79 \%$ & $6,40 \%$ & 7,4 \\
\hline BRTO3 & Brasil Te & & Medi & & Big & 8 & Winner & Big|Medium/Winner & $-6,33 \%$ & $-16,28 \%$ & $3,33 \%$ & $7,26 \%$ & $20,30 \%$ & $16,84 \%$ & $-6,64 \%$ & 5,6 & $7,41 \%$ & $6,94 \%$ & $3,20 \%$ & \\
\hline GOAU3 & Gerdau M & 0,65 & Medium & 7.178 .400 & Big & 99 & Winner & Big|Medium/Winner & $5,01 \%$ & $-5,55 \%$ & $-0,28 \%$ & $5,14 \%$ & $7,66 \%$ & $5,13 \%$ & $4,88 \%$ & $5,50 \%$ & $6,70 \%$ & $9,41 \%$ & $6,24 \%$ & 18,2 \\
\hline ARCE3 & Arcelor BR ON & 0,61 & Medium & 21.706.814.560 & Big & 1,03 & Winner & Big|Medium|Winner & $3,85 \%$ & $6,87 \%$ & $3,23 \%$ & $-1,95 \%$ & $6,24 \%$ & $7,29 \%$ & $2,14 \%$ & $13,05 \%$ & $-0,62 \%$ & $5,32 \%$ & $1,12 \%$ & $6,93 \%$ \\
\hline GOAU4 & Gerdau I & 0,65 & $\mathrm{~N}$ & & Big & 03 & Winne & $\mathrm{Bi}$ & $1,25 \%$ & $-4,90 \%$ & $-4,92 \%$ & 7,11 & $9,18 \%$ & 5,5 & 0 & 6,7 & $3,97 \%$ & 13, & & 17,2 \\
\hline BRAP4 & Bradesp & 0,51 & $\mathrm{~N}$ & & Big & 0 & $\mathrm{v}$ & $\mathrm{n} \mid \mathrm{Wi}$ & 1, & $1,05 \%$ & -4, & $15,72 \%$ & $9,66 \%$ & $12,56 \%$ & $12, \mathrm{C}$ & & $2,17 \%$ & $11,11 \%$ & $8,99 \%$ & 0,1 \\
\hline GGBR3 & Gerdau ON & 0,51 & Med & 20.250 .089 .000 & Big & 1,15 & Winner & Big|Medium/Winner & $3,89 \%$ & $-7,34 \%$ & $-4,68 \%$ & \begin{tabular}{l|l|}
$9,83 \%$ \\
\end{tabular} & $7,78 \%$ & $10,03 \%$ & $-2,73 \%$ & $1,60 \%$ & $6,20 \%$ & $6,34 \%$ & \begin{tabular}{l|l|}
$7,10 \%$ \\
\end{tabular} & 11,8 \\
\hline DURA4 & Duratex-Old PN & 0,67 & Medium & .709 .530 & Big & 1,15 & Winner & Big|Medium/Winner & $10,31 \%$ & $0,00 \%$ & $15,12 \%$ & \begin{tabular}{l|l}
$4,04 \%$ \\
\end{tabular} & $13,20 \%$ & $13,89 \%$ & $21,99 \%$ & $-1,89 \%$ & $3,17 \%$ & $10,73 \%$ & $21,84 \%$ & 1,2 \\
\hline BRAP3 & Brades: & 0,51 & Medium & 28.000 & & 17 & Ninner & $\mathrm{m} /$ Winner & $1,08 \%$ & $-3,07 \%$ & $0,00 \%$ & $14,40 \%$ & $9,76 \%$ & $12,56 \%$ & $17,40 \%$ & $-0,32 \%$ & $4,26 \%$ & $1130 \%$ & $10,24 \%$ & \\
\hline TCSL4 & $\operatorname{Tim}$ & & & & B & & & & $-10,68 \%$ & 15,1 & $-2,7$ & 20,0 & $1,81 \%$ & & -3, & & $-1,6$ & 11, & $-3,56 \%$ & \\
\hline USIM3 & Usimina & 0,77 & $\mathrm{Me}$ & 43 & Big & 19 & Wir & Big|Medium|Winner & $1,64 \%$ & $-9,71 \%$ & $-3,24 \%$ & $13,31 \%$ & $11,09 \%$ & $3,06 \%$ & $1,90 \%$ & $13,89 \%$ & $9,10 \%$ & $-5,07 \%$ & $11,94 \%$ & 0,8 \\
\hline GGBR4 & Gerdau PN & 0,51 & Medium & 20.250 .089 .000 & Big & 1,32 & Winner & Big|Medium/Winner & $4,45 \%$ & $-8,00 \%$ & $-5,53 \%$ & $\begin{array}{ll}7,39 \% \\
\end{array}$ & $9,74 \%$ & $2,38 \%$ & $2,55 \%$ & $2,04 \%$ & $4,28 \%$ & $9,88 \%$ & \begin{tabular}{l|l|}
$5,07 \%$ \\
\end{tabular} & $14,48 \%$ \\
\hline LPA3 & Alpa & 0,50 & dic & .100 & 2 & 1,74 & & Itvitimer & $0,00 \%$ & $-6,92 \%$ & 4,4 & 2000 & $12,59 \%$ & $25,24 \%$ & $17,83 \%$ & $40 \%$ & $11,95 \%$ & -2, & $13,11 \%$ & \\
\hline ALPA4 & & & Mediu & & & & nne & & & & -1 & & & & & & & & & \\
\hline RANI3 & & 1,46 & High & & $\mathrm{sm}$ & 0,35 & Los & & $x$ & $29 \%$ & 3,83 & $7,8 \%$ & $3,64 \%$ & & 0,8 & $1,94 \%$ & 2,4 & $-3,33 \%$ & $51,72 \%$ & \\
\hline NIT & tte & 3,1 & $=$ & 20.353 .454 & $\mathrm{Sm}$ & 0,34 & Lo & Small|High | Lose & $0 \%$ & $2,94 \%$ & $8,57 \%$ & $23,68 \%$ & $19 \%$ | & $30,00 \%$ & 14,87 & , ,88\% & 年 & $-12,18 \%$ & $18,06 \%$ & \\
\hline
\end{tabular}


Anexo 1 - Retorno mensal e classificação das ações

\begin{tabular}{|c|c|c|c|c|c|c|c|c|c|c|c|c|c|c|c|c|c|c|c|c|}
\hline Código & $2006-2007$ & $\begin{array}{l}\text { Índice } B / M \\
\text { de dez/2005 }\end{array}$ & $\begin{array}{c}\text { Grupo com } \\
\text { base no } \\
\text { indice B/M }\end{array}$ & $\begin{array}{c}\text { Valor de Mercado } \\
\text { em jun/2006 }\end{array}$ & $\begin{array}{c}\text { Grupo com } \\
\text { base no } \\
\text { tamanho }\end{array}$ & $\begin{array}{c}\text { Retorno } \\
\text { acumulado } \\
\text { de jun/2006 }\end{array}$ & \begin{tabular}{|c|} 
Grupo com \\
base no \\
retorno \\
acumulado \\
\end{tabular} & Carteiras & $\mathrm{jul} / 06$ & ago/06 & set/06 & out/06 & nov/06 & dez/06 & jan/07 & $\mathrm{fev} / 07$ & $\mathrm{mar} / 07$ & abr/07 & mai/07 & jun/07 \\
\hline JBDU4 & J B Duarte PN & 1,86 & High & 6.468 .451 & Small & 0,33 & \begin{tabular}{|l|} 
Loser \\
\end{tabular} & Small|High|Loser & $17,65 \%$ & $-15,00 \%$ & $-11,76 \%$ & $13,33 \%$ & $17,65 \%$ & $15,00 \%$ & $8,70 \%$ & $-20,00 \%$ & $0,00 \%$ & $18,11 \%$ & $0,00 \%$ & $45,45 \%$ \\
\hline RNAR3 & Renar ON & 1,06 & High & 26.800.000 & Small & 0,32 & Loser & Small|High|Loser & $8,96 \%$ [ & $-6,85 \%$ & $0,00 \%$ ] & $-1,47 \%$ & $-2,99 \%$ & $23,08 \%$ & $5,00 \%$ & $-5,95 \%$ & $1,27 \%$ & $9,10 \%$ & $6,90 \%$ ] & $2,15 \%$ \\
\hline PNOR5 & Pronor PNA & 1,67 & High & \begin{tabular}{|c|}
100.712 .771 \\
\end{tabular} & Small & 0,27 & Loser & Small|High|Loser & $-6,85 \%$ & $-4,90 \%$ & $15,98 \%$ & $-2,67 \%$ & $-7,76 \%$ & $4,95 \%$ & $-0,47 \%$ & $4,74 \%$ & $-9,50 \%$ & $0,00 \%$ & $24,00 \%$ & $4,84 \%$ \\
\hline RSIP4 & Rasip Agro PN & 1,25 & High & 40.114 .480 & Small & 0,25 & Loser & Small|High|Loser & $5,26 \%$ & $5,00 \%$ & $9,52 \%$ & $4,35 \%$ & $4,17 \%$ & $4,00 \%$ & $88,46 \%$ & $-10,20 \%$ & $-4,55 \%$ & $16,31 \%$ & $4,17 \%$ & $18,00 \%$ \\
\hline STRP4 & Botucatu Tex PN & 1,25 & High & \begin{tabular}{|l|}
3.554 .824 \\
\end{tabular} & Small & 0,20 & Loser & Small|High|Loser & $-7,14 \%$ & $0,00 \%$ & $7,69 \%$ & $7,14 \%$ & $26,67 \%$ & $226,32 \%$ & $-27,42 \%$ & $0,00 \%$ & $-2,22 \%$ & $154,55 \%$ & $-13,39 \%$ & $1,03 \%$ \\
\hline INEP4 & Inepar PN & 2,30 & High & \begin{tabular}{|l|l|}
65.327 .141 \\
\end{tabular} & Small & 0,15 & Loser & Small|High|Loser & $9,00 \%$ & $-9,09 \%$ & $-9,17 \%$ & $3,64 \%$ & $23,29 \%$ & $-0,79 \%$ & $-7,89 \%$ & $6,40 \%$ & $6,91 \%$ & $42,21 \%$ & $49,73 \%$ & $21,39 \%$ \\
\hline MGEL4 & Mangels Indl PN & 2,31 & High & \begin{tabular}{|l|l|}
68.368 .748 \\
\end{tabular} & Small & 0,15 & Loser & Small|High|Loser & $2,03 \%$ & $-8,74 \%$ & $-2,03 \%$ & $4,44 \%$ & $14,33 \%$ & $1,74 \%$ & $38,41 \%$ & $27,75 \%$ & $1,38 \%$ & $9,87 \%$ & $31,88 \%$ & $20,09 \%$ \\
\hline FESA4 & Ferbasa PN & 1,59 & High & 264.840 .000 & Small & 0,12 & Loser & Small|High|Loser & $1,62 \%$ & $-2,26 \%$ & $-1,01 \%$ & $14,87 \%$ & $6,23 \%$ & $-0,29 \%$ & $9,58 \%$ & $1,65 \%$ & $-1,59 \%$ & $-3,64 \%$ & $49,20 \%$ & $0,86 \%$ \\
\hline LIXC4 & Lix da Cunha PN & 4,39 & High & \begin{tabular}{l|l|}
11.120 .400 \\
\end{tabular} & Small & 0,09 & Loser & Small|High|Loser & $-1,25 \%$ & $21,52 \%$ & $-15,63 \%$ & $4,94 \%$ & $94,12 \%$ & $-1,72 \%$ & $5,00 \%$ & $71,43 \%$ & $30,90 \%$ & $32,36 \%$ & $5,61 \%$ & $11,76 \%$ \\
\hline MNDL3 & Mundial ON & 1,32 & High & \begin{tabular}{ll|}
70.501 .500 \\
\end{tabular} & Small & 0,08 & Loser & Small|High|Loser & $3,39 \%$ & $4,92 \%$ & $1,56 \%$ & $-3,85 \%$ & $3,20 \%$ & $-13,95 \%$ & $38,74 \%$ & $-11,04 \%$ & $-5,11 \%$ & $46,15 \%$ & $32,63 \%$ & $20,99 \%$ \\
\hline BRGE12 & Alfa Consorc PNF & 1,71 & High & 239.349.180 & Small & 0,05 & Loser & Small|High|Loser & $0,00 \%$ & $-10,13 \%$ & $-2,76 \%$ & $6,74 \%$ & $-3,32 \%$ & $11,68 \%$ & $18,63 \%$ & $-9,74 \%$ & $16,62 \%$ & $-4,50 \%$ & $20,42 \%$ & $-1,96 \%$ \\
\hline CTNM4 & Coteminas PN & 1,43 & High & 1.126 .182 .178 & Small & \begin{tabular}{l|l|}
0,01 \\
\end{tabular} & Loser & Small|High|Loser & $-6,19 \%$ & $2,36 \%$ & $-5,92 \%$ & $10,64 \%$ & $13,91 \%$ & $8,70 \%$ & $-1,94 \%$ & $9,92 \%$ & $14,29 \%$ & $8,12 \%$ & $2,90 \%$ & $-10,29 \%$ \\
\hline MEND6 & Mendes Jr PNB & 4,66 & High & 138.774 .072 & Small & 0,00 & Loser & Small|High|Loser & $3,77 \%$ & $-3,63 \%$ & $-6,08 \%$ & $31,04 \%$ & $-9,31 \%$ & $10,27 \%$ & $12,50 \%$ & $-13,83 \%$ & $-10,38 \%$ & $51,08 \%$ & $12,38 \%$ & $73,73 \%$ \\
\hline IGUA5 & Iguacu Cafe PNA & 1,20 & High & 137.614 .440 & Small & 0,00 & Loser & Small|High|Loser & $1,88 \%$ & $-9,00 \%$ & $2,25 \%$ & $-4,40 \%$ & $-1,15 \%$ & $36,36 \%$ & $9,26 \%$ & $10,17 \%$ & $-0,15 \%$ & $-6,78 \%$ & $0,83 \%$ & $-1,64 \%$ \\
\hline EMAE4 & Emae PN & 4,51 & High & 166.261 .869 & Small & 0,00 & Loser & Small|High|Loser & $13,33 \%$ & $-0,98 \%$ & $-4,95 \%$ & $4,17 \%$ & $-5,00 \%$ & $24,63 \%$ & $4,22 \%$ & $20,75 \%$ & $-6,04 \%$ & $34,86 \%$ & $12,29 \%$ & $9,43 \%$ \\
\hline IGUA6 & Iguacu Cafe PNB & 1,20 & High & 14.440 & Small & 0,01 & Loser & Small|High|Loser & $-2,08 \%$ & $-4,26 \%$ & $-4,44 \%$ & $0,00 \%$ & $0,00 \%$ & $7,24 \%$ & $20,88 \%$ & $34,17 \%$ & $-14,16 \%$ & $1,67 \%$ & $0,00 \%$ & $0,00 \%$ \\
\hline RPAD3 & Alfa Holding ON & 1,97 & High & \begin{tabular}{|l|}
197.032 .163 \\
\end{tabular} & Small & 0,01 & Loser & Small|High|Loser & $-4,65 \%$ & $19,36 \%$ & $3,31 \%$ & $0,00 \%$ & $-7,60 \%$ & $1,73 \%$ & $28,74 \%$ & $0,00 \%$ & $7,00 \%$ & $40,19 \%$ & $0,00 \%$ & $2,44 \%$ \\
\hline TKNO4 & Tekno PN & 1,27 & High & 113.680 .000 & Small & 0,01 & Loser & Small|High|Loser & $3,57 \%$ & $0,00 \%$ & $1,72 \%$ & $6,78 \%$ & $23,81 \%$ & $10,26 \%$ & $9,18 \%$ & $-3,60 \%$ & $4,90 \%$ & $9,11 \%$ & $31,73 \%$ & $1,17 \%$ \\
\hline MNDL4 & Mundial PN & 1,32 & High & 70.501.500 & Small & 0,04 & Loser & Small|High|Loser & $1,38 \%$ & $-0,56 \%$ & $-5,03 \%$ & $-6,47 \%$ & $-5,03 \%$ & $-5,96 \%$ & $30,28 \%$ & $-5,41 \%$ & $-6,29 \%$ & $33,54 \%$ & $51,14 \%$ & $-9,97 \%$ \\
\hline RPAD6 & Alfa Holding & 1,97 & High & \begin{tabular}{|l|l|}
197.032 .163 \\
\end{tabular} & Small & 0,04 & Loser & Small|High|Loser & $0,00 \%$ & $-2,93 \%$ & $-2,08 \%$ & $-0,85 \%$ & $0,00 \%$ & $-1,29 \%$ & $-5,52 \%$ & $2,33 \%$ & $50,00 \%$ & $-0,61 \%$ & $12,80 \%$ & $-2,16 \%$ \\
\hline TNCP3 & Tele Nort $\mathrm{Cl}$ ON & 1,28 & High & \begin{tabular}{|l|}
194.711 .471 \\
\end{tabular} & Small & 0,04 & Loser & Small|High|Loser & $-11,49 \%$ & $-5,19 \%$ & $17,81 \%$ & $1,16 \%$ & $2,30 \%$ & $-7,87 \%$ & $31,71 \%$ & $12,96 \%$ & $-1,64 \%$ & $-3,33 \%$ & $-2,59 \%$ & $9,73 \%$ \\
\hline ASTA4 & Santistextil PN & 1,62 & High & 379.494.391 & Small & 0,08 & Loser & Small|High|Loser & $-0,53 \%$ & $-1,06 \%$ & $-9,09 \%$ & $-5,88 \%$ & $1,25 \%$ & $10,19 \%$ & $-4,76 \%$ & $12,94 \%$ & $-16,67 \%$ & $55,31 \%$ & $-0,36 \%$ & $-1,05 \%$ \\
\hline CTNM3 & Coteminas ON & 1,43 & High & 1.126.182.178 & Small & 0,09 & Loser & Small|High|Loser & $-2,81 \%$ & $5,20 \%$ & $-6,32 \%$ & $17,30 \%$ & $6,00 \%$ & $22,64 \%$ & $-2,88 \%$ & $12,87 \%$ & \begin{tabular}{ll|}
$15,79 \%$ \\
\end{tabular} & $-0,30 \%$ & $4,16 \%$ & $-4,41 \%$ \\
\hline RPAD5 & Alfa Holding PNA & 1,97 & High & 197.032 .163 & Small & 0,09 & Loser & Small|High|Loser & $-3,46 \%$ & $-1,84 \%$ & $-4,17 \%$. & $6,52 \%$ & $-1,63 \%$ & $1,66 \%$ & $8,67 \%$ & $20,00 \%$ & $9,67 \%$ & $10,94 \%$ & $3,84 \%$ & $5,28 \%$ \\
\hline SULT4 & Sultepa PN & 23,36 & High & 9.671 .200 & Small & 0,11 & Loser & Small|High|Loser & $4,17 \%$ & $5,33 \%$ & $-7,59 \%$ & $202,74 \%$ & $119,46 \%$ & $28,87 \%$ & $-27,20 \%$ & $-12,31 \%$ & $-14,79 \%$ & $29,41 \%$ & $56,82 \%$ & $-17,20 \%$ \\
\hline \begin{tabular}{|l|} 
BRGE3 \\
\end{tabular} & Alfa Consorc ON & 1,71 & High & 239.349 .180 & Small & 0,13 & Loser & Small|High|Loser & $-7,38 \%$ & $4,67 \%$ & $2,88 \%$ & $-1,87 \%$ & $-7,94 \%$ & $18,97 \%$ & $0,12 \%$ & $5,87 \%$ & $10,80 \%$ & $3,50 \%$ & $25,60 \%$ & $15,19 \%$ \\
\hline SAPR4 & Sanepar PN & 2,55 & High & 952.389 .019 & Small & 0,14 & Loser & Small|High|Loser & $-0,41 \%$ & $-0,45 \%$ & $9,95 \%$ & $2,88 \%$ & $0,00 \%$ & $14,00 \%$ & $-1,53 \%$ & $1,45 \%$ & $-2,15 \%$ & $3,66 \%$ & $4,24 \%$ & $0,00 \%$ \\
\hline TMAC8B & Amazonia Celular PND & 2,44 & High & 162.013 .210 & Small & 0,17 & Loser & Small|High|Loser & $0,00 \%$ & $-0,14 \%$ & $0,14 \%$ & $5,49 \%$ & $-5,07 \%$ & $-0,14 \%$ & 0,28\% & $-0,28 \%$ & $-0,14 \%$ & $0,00 \%$ & $0,00 \%$ & $0,00 \%$ \\
\hline \begin{tabular}{|l|} 
PNVL3 \\
\end{tabular} & Dimed ON & 1,16 & High & 113.256 .500 & Small & 0,19 & Loser & Small|High|Loser & $2,49 \%$ & $3,30 \%$ & $7,84 \%$ & $0,00 \%$ & $10,91 \%$ & $7,86 \%$ & $8,98 \%$ & $38,81 \%$ & $2,04 \%$ & $-2,00 \%$ & $-0,41 \%$ & $51,23 \%$ \\
\hline VGOR4 & Vigor PN & 3,09 & High & 55.720 .633 & Small & 0,29 & Loser & Small|High|Loser & $0,16 \%$ & $26,56 \%$ & $-14,81 \%$ & $-7,25 \%$ & $3,13 \%$ & $21,21 \%$ & $15,00 \%$ & $11,96 \%$ & $11,65 \%$ & $6,96 \%$ & $60,98 \%$ & $35,35 \%$ \\
\hline BMTO4 & Brasmotor PN & 2,18 & High & 486.955 .480 & Small & 0,30 & Loser & Small|High|Loser & $2,35 \%$ & $3,45 \%$ & $7,22 \%$ & $9,33 \%$ & $33,18 \%$ & $11,74 \%$ & $4,75 \%$ & $32,81 \%$ & $-14,08 \%$ & $81,81 \%$ & $106,06 \%$ & $0,00 \%$ \\
\hline BDLL4 & Bardella PN & 3,16 & High & 84.800 .000 & Small & 0,46 & Winner & Small|High|Winner & $0,00 \%$ & $13,19 \%$ & $-7,98 \%$ & $19,57 \%$ & $7,58 \%$ & $8,55 \%$ & $-5,43 \%$ & $11,93 \%$ & $14,71 \%$ & $34,12 \%$ & $33,33 \%$ & $13,16 \%$ \\
\hline SGAS3 & WIm Ind Com ON & 1,40 & High & \begin{tabular}{|l|l|}
181.900 .219 \\
\end{tabular} & Small & 0,47 & Winner & Small|High|Winner & $-10,18 \%$ & $-0,83 \%$ & $-3,36 \%$ & $-2,61 \%$ & $-0,89 \%$ & $38,69 \%$ & $-13,57 \%$ & $-3,31 \%$ & $-4,96 \%$ & $11,69 \%$ & $12,72 \%$ & $4,29 \%$ \\
\hline TELB4 & Telebras PN & 3,40 & High & 73.589.968 & Small & 0,50 & Winner & Small|High|Winner & $0,00 \%$ & $-14,29 \%$ & $0,00 \%$ & $0,00 \%$ & $-16,67 \%$ & $20,00 \%$ & 0,00\% & $-16,67 \%$ & $20,00 \%$ & $-16,67 \%$ & $0,00 \%$ & $20,00 \%$ \\
\hline TNCP4 & Tele Nort Cl PN & 1,28 & High & 194.711.471 & Small & 0,55 & Winner & Small|High|Winner & $-9,76 \%$ & $-8,11 \%$ & $14,71 \%$ & $-2,56 \%$ & $2,63 \%$ & $-2,56 \%$ & $10,53 \%$ & $0,00 \%$ & $-11,90 \%$ & $0,00 \%$ & $8,11 \%$ & $5,00 \%$ \\
\hline CGRA4 & Grazziotin PN & 1,27 & High & 129.811 .042 & Small & 0,55 & Winner & Small|High|Winner & $-1,64 \%$ & $1,11 \%$ & $0,77 \%$ & $7,27 \%$ & $18,30 \%$ & $10,78 \%$ & $36,46 \%$ & $30,72 \%$ & $20,93 \%$ & $6,78 \%$ & $2,34 \%$ & $0,01 \%$ \\
\hline \begin{tabular}{|l|} 
WHRL4 \\
\end{tabular} & Whirlpool PN & 1,75 & High & 1.358.767.860 & Small & 0,61 & Winner & Small|High|Winner & $4,00 \%$ & $13,46 \%$ & $8,47 \%$ & $47,66 \%$ & $26,98 \%$ & $-16,22 \%$ & $0,51 \%$ & $15,11 \%$ & $8,44 \%$ & $38,81 \%$ & $78,91 \%$ & $-3,46 \%$ \\
\hline SGAS4 & WIm Ind Com PN & 1,40 & High & 181.900 .219 & Small & 0,80 & Winner & Small|High|Winner & $-2,21 \%$ & $-2,61 \%$ & $4,46 \%$ & $-2,74 \%$ & $1,41 \%$ & $15,69 \%$ & $0,33 \%$ & $-3,81 \%$ & $-2,24 \%$ & $14,46 \%$ & $4,47 \%$ & $7,67 \%$ \\
\hline SGEN4 & Sergen PN & 5,85 & High & 38.501 .747 & Small & 0,86 & Winner & Small| |High | Winner & $-10,00 \%$ & $-16,67 \%$ & $26,67 \%$ & $24,21 \%$ & $18,64 \%$ & $-17,86 \%$ & $24,35 \%$ & $62,94 \%$ & $-5,58 \%$ & $-3,18 \%$ & $2,82 \%$ & $25,57 \%$ \\
\hline CEPE5 & Celpe PNA & 1,06 & High & 1.380 .329 .215 & Small & 0,98 & Winner & Small|High|Winner & $-1,04 \%$ & $-5,00 \%$ & $2,63 \%$ & $0,00 \%$ & $3,70 \%$ & $13,98 \%$ & $17,07 \%$ & $4,17 \%$ & $1,35 \%$ & $5,51 \%$ & $10,09 \%$ & $10,46 \%$ \\
\hline TELB3 & Telebras ON & 3,40 & High & 73.589 .968 & Small & 1,67 & Winner & Small|High|Winner & $-23,53 \%$ & $0,00 \%$ & $-15,38 \%$ & $0,00 \%$ & $0,00 \%$ & $-18,18 \%$ & $22,22 \%$ & $0,00 \%$ & $-9,09 \%$ & $0,00 \%$ & $0,00 \%$ & $0,00 \%$ \\
\hline FJTA4 & Forjas Taurus PN & 1,70 & High & 287.445 .600 & Small & 2,29 & Winner & Small|High|Winner & $-11,11 \%$ & $4,39 \%$ & $0,97 \%$ & $10,90 \%$ & $5,78 \%$ & $14,33 \%$ & $40,93 \%$ & $26,43 \%$ & $18,29 \%$ & $-0,64 \%$ & $12,30 \%$ & $3,23 \%$ \\
\hline IENG5 & Ienergia PN & 5,58 & High & 194.872.860 & Small & 2,30 & Winner & Small|High|Winner & $9,26 \%$ & $-5,08 \%$ & $-7,14 \%$ & $13,46 \%$ & $8,47 \%$ & $9,38 \%$ & $-4,29 \%$ & $20,90 \%$ & $1,23 \%$ & $10,98 \%$ & $1,10 \%$ & $4,35 \%$ \\
\hline CMGR4 & Cemat PN & 2,08 & High & 0 & Small & 9,56 & Win & Small|High $\mid \mathrm{Wi}$ & $-10,11 \%$ & $8,63 \%$ & $0,12 \%$ & $-25,17 \%$ & $7,53 \%$ & $10,00 \%$ & $3,77 \%$ & $-0,50 \%$ & $0,50 \%$ & $13,27 \%$ & $-12,06 \%$ & $3,14 \%$ \\
\hline CMGR3 & Cemat ON & 2,08 & High & 961.114 .100 & Small & 9,91 & Winner & Small|High|Winner & $-15,79 \%$ & $-0,62 \%$ & $-20,75 \%$ & $3,17 \%$ & $7,69 \%$ & $12,86 \%$ & $-4,68 \%$ & $-2,26 \%$ & $13,99 \%$ & $20,49 \%$ & $-13,86 \%$ & $-4,60 \%$ \\
\hline REDE4 & Rede Energia PN & 1,88 & High & 1.320 .240 .000 & Small & 23,33 & Winner & Small|High|Winner & $4,17 \%$ & $-6,20 \%$ & $-8,32 \%$ & $1,16 \%$ & $0,46 \%$ & $-4,12 \%$ & $\begin{array}{ll}6,21 \% \\
\end{array}$ & $-3,37 \%$ & $-4,65 \%$ & $41,46 \%$ & $10,34 \%$ & $18,28 \%$ \\
\hline REDE3 & Rede & 1,88 & High & 1.320 .240 .000 & 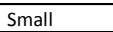 & 29,62 & ing & Small & & $1,06 \%$ & & & $-2,27 \%$ & $-6,51 \%$ & $9,70 \%$ & 6,5 & $0,00 \%$ & 25 , & 2 & $12,63 \%$ \\
\hline ELEK4 & & & Low & & $\mathrm{sm}$ & 0, & & & & & & & $\%$ & & $-14,56 \%$ & $-7,6$ & $-6,4$ & $9,40 \%$ & $13,28 \%$ & \\
\hline \begin{tabular}{ll|} 
RIPI4 \\
\end{tabular} & Ipiranga Ref PN & 0,44 & Low & 992.271 .854 & Small & 0,07 & Loser & Small| Low|Loser & $-0,45 \%$ & $5,35 \%$ | & $6,15 \%$ & $6,38 \%$ & $2,23 \%$ & $1,25 \%$ & $2,92 \%$ & $5,88 \%$ & $14,73 \%$ & $0,29 \%$ & $-5,00 \% \mid$ & $8,17 \%$ \\
\hline SIPI & $\ln (2)$ & & & 354 & crmal & 0,02 & 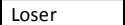 & $c_{0}$ & $-6,49 \%$ & 2 & & & & 0 & $10,0 \% \%$ & & $86,62 \%$ & $2,12 \%$ & $2,02 \%$ & $\%$ \\
\hline
\end{tabular}


Anexo 1 - Retorno mensal e classificação das ações

\begin{tabular}{|c|c|c|c|c|c|c|c|c|c|c|c|c|c|c|c|c|c|c|c|c|}
\hline Código & $2006-2007$ & $\begin{array}{l}\text { Índice } B / M \\
\text { de dez/2005 }\end{array}$ & $\begin{array}{c}\text { Grupo com } \\
\text { base no } \\
\text { indice B/M }\end{array}$ & $\begin{array}{c}\text { Valor de Mercado } \\
\text { em jun/2006 }\end{array}$ & $\begin{array}{c}\text { Grupo com } \\
\text { base no } \\
\text { tamanho }\end{array}$ & $\begin{array}{c}\text { Retorno } \\
\text { acumulado } \\
\text { de jun/2006 }\end{array}$ & \begin{tabular}{|c|} 
Grupo com \\
base no \\
retorno \\
acumulado
\end{tabular} & Carteiras & jul/06 & ago/06 & set/06 & out/06 & nov/06 & $\mathrm{dez} / 06$ & jan/07 & fev/07 & $\mathrm{mar} / 07$ & $\mathrm{abr} / 07$ & mai/07 & jun/07 \\
\hline FRAS4 & Fras-Le PN & 0,33 & Low & 392.460 .500 & Small & 0,01 & Loser & Small|Low|Loser & $-3,48 \%$ & $-2,70 \%$ & $8,33 \%$ & $1,71 \%$ & $0,50 \%$ & $2,45 \%$ & $-0,66 \%$ & $24,63 \%$ & $-3,87 \%$ & $-2,69 \%$ & $1,87 \%$ & $-2,95 \%$ \\
\hline LEVE4 & Metal Leve PN & 0,36 & Low & 1.156 .909 .470 & Small & 0,15 & Loser & Small|Low|Loser & $-3,40 \%$ & $-1,91 \%$ & $0,39 \%$ & $-0,69 \%$ & $8,33 \%$ & $-1,07 \%$ & $12,12 \%$ & $8,84 \%$ & $4,27 \%$ & $0,07 \%$ & $-19,56 \%$ & $-2,12 \%$ \\
\hline MYPK4 & lochp-Maxion PN & 0,26 & Low & 979.662 .000 & Small & 0,17 & Loser & Small|Low|Loser & $-12,38 \%$ & $-5,98 \%$ & $-8,44 \%$ & $-4,48 \%$ & $9,78 \%$ & $9,27 \%$ & $-3,91 \%$ & $22,34 \%$ & $5,34 \%$ & $1,78 \%$ & \begin{tabular}{l|l|}
$11,21 \%$ \\
\end{tabular} & $20,52 \%$ \\
\hline AVIL3 & Acos Vill ON & 0,38 & Low & 1.416 .013 .650 & Small & 0,24 & Loser & Small|Low|Loser & \begin{tabular}{l|l|}
$-3,49 \%$ \\
\end{tabular} & $16,37 \%$ & $0,00 \%$ & $8,11 \%$ & $12,06 \%$ & $7,23 \%$ & $23,67 \%$ & $-2,67 \%$ & $-3,75 \%$ & $8,29 \%$ & $12,86 \%$ & $2,35 \%$ \\
\hline PTBL3 & Portobello ON & 0,17 & w & 34.608 .840 & Small & 0,37 & Loser & Small|Low|Loser & $3,82 \%$ & $-9,19 \%$ & $37,25 \%$ & $12,90 \%$ & $2,29 \%$ & $28,49 \%$ & $13,04 \%$ & $23,08 \%$ & $20,00 \%$ & $4,17 \%$ & $-1,06 \%$ & $10,26 \%$ \\
\hline RAPT4 & Randon Part PN & 0,30 & Low & 1.096 .027 .840 & Small & 0,39 & Loser & Small|Low|Loser & $-4,49 \%$ & $0,29 \%$ & $6,16 \%$ & $2,90 \%$ & $20,00 \%$ & $8,55 \%$ & $7,81 \%$ & $11,11 \%$ & $9,57 \%$ & $11,65 \%$ & $14,30 \%$ & $8,27 \%$ \\
\hline MTSA4 & Metisa PN & 0,49 & Low & 130.990 .000 & Small & 0,43 & Loser & Small|Low|Loser & $-0,76 \%$ & $-5,38 \%$ & $-3,33 \%$ & $3,03 \%$ & $0,08 \%$ & $4,76 \%$ & $5,82 \%$ & $-6,11 \%$ & $7,28 \%$ & $13,68 \%$ & $26,67 \%$ & $2,11 \%$ \\
\hline KEPL3 & Kepler Weber ON & 0,08 & Low & 891.954 .000 & Small & 0,44 & Winner & Small|Low|Winner & $-19,56 \%$ & $-1,80 \%$ & $-2,25 \%$ & $-8,63 \%$ & $17,32 \%$ & $-12,21 \%$ & $-4,43 \%$ & $0,80 \%$ & $4,76 \%$ & $-11,21 \%$ & $-26,62 \%$ & $-6,98 \%$ \\
\hline IDNT3 & Ideiasnet ON & 0,28 & Low & 209.450 .880 & Small & 0,55 & Winner & Small|Low|Winner & $11,11 \%$ & $-0,32 \%$ & $2,91 \%$ & $-13,52 \%$ & $2,18 \%$ & $-4,63 \%$ & $14,18 \%$ & $-6,86 \%$ & $-1,81 \%$ & $33,93 \%$ & $14,67 \%$ & $26,28 \%$ \\
\hline SLED4 & Saraiva Livr PN & 0,34 & Low & 551.034 .620 & Small & 0,90 & Winner & Small|Low|Winner & $-6,40 \%$ & \begin{tabular}{l|l|}
$7,89 \%$ \\
\end{tabular} & $-8,78 \%$ & $0,00 \%$ & $18,72 \%$ & \begin{tabular}{l|l|}
$7,66 \%$ \\
\end{tabular} & $-2,09 \%$ & $13,68 \%$ & $-4,42 \%$ & $-1,04 \%$ & $12,80 \%$ & $5,92 \%$ \\
\hline HGTX3 & Cia Hering ON & 0,35 & Low & 119.245.700 & Small & 0,91 & Winner & Small|Low|Winner & $-2,63 \%$ & $3,24 \%$ & $-5,76 \%$ & $0,00 \%$ & $8,06 \%$ & $25,96 \%$ & $1,02 \%$ & $41,41 \%$ & $35,71 \%$ & $2,11 \%$ & $17,63 \%$ & $-0,44 \%$ \\
\hline RSID3 & Rossi Resid ON & 0,29 & ow & 32.232 .550 & Small & 4,00 & Winner & Small|Low|Winner & $-17,92 \%$ & $29,49 \%$ & $6,59 \%$ & $12,58 \%$ & $-0,76 \%$ & $4,20 \%$ & $-13,19 \%$ & $-4,22 \%$ & $3,52 \%$ & $18,46 \%$ & $33,13 \%$ & $10,87 \%$ \\
\hline UNIP3 & Unipar ON & 0,84 & Medium & 1.029 .505 .475 & Small & 0,42 & Loser & Small|Medium|Loser & $-3,65 \%$ & $8,70 \%$ & $0,50 \%$ & $9,45 \%$ & $-0,88 \%$ & $0,42 \%$ & $6,98 \%$ & $0,00 \%$ & $52,17 \%$ & $17,62 \%$ & $1,75 \%$ & $0,29 \%$ \\
\hline AELP3 & AES Elpa ON & 0,88 & Medium & 1.150.238.741 & Small & 0,41 & Loser & Small|Medium|Loser & \begin{tabular}{|l|l|}
$16,94 \%$ \\
\end{tabular} & $9,54 \%$ & $-6,45 \%$ & $5,86 \%$ & $43,26 \%$ & $-13,60 \%$ & $-0,79 \%$ & $-4,77 \%$ & $3,62 \%$ & $11,42 \%$ & $15,64 \%$ & $-0,38 \%$ \\
\hline PATI4 & Panatlantica P & 0,68 & Medium & 80.500 .000 & Small & 0,39 & Loser & Small|Medium|Loser & $8,61 \%$ & $-7,93 \%$ & $-5,39 \%$ & $-3,49 \%$ & $-9,52 \%$ & $10,53 \%$ & $42,86 \%$ & $-16,67 \%$ & $-27,60 \%$ & $31,77 \%$ & $22,41 \%$ & $40,85 \%$ \\
\hline ILMD4 & Yara Brasil PN & 0,60 & Medium & 175.728 .000 & Small & 0,32 & Loser & Small|Medium|Loser & $7,14 \%$ & $8,67 \%$ & $48,26 \%$ & $19,93 \%$ & $40,89 \%$ & $-6,33 \%$ & $0,65 \%$ & $16,88 \%$ & $8,52 \%$ & $2,39 \%$ & $16,67 \%$ & $25,71 \%$ \\
\hline UNIP6 & Unipar PNB & 0,84 & Medium & 1.029.505.475 & Small & 0,30 & Loser & Small|Medium|Loser & $-8,39 \%$ & $24,60 \%$ & $-3,09 \%$ & $5,73 \%$ & $6,11 \%$ & \begin{tabular}{l|l}
$0,00 \%$ \\
\end{tabular} & $5,23 \%$ & $6,63 \%$ & $2,07 \%$ & $9,08 \%$ & $7,26 \%$ & $0,00 \%$ \\
\hline RPMG3 & Pet Manguinh ON & 0,51 & Medium & 127.297 .500 & Small & 0,25 & Loser & Small|Medium|Loser & $9,09 \%$ & $-30,83 \%$ & $20,48 \%$ & $-15,00 \%$ & $23,53 \%$ & $11,43 \%$ & $19,66 \%$ & $1,43 \%$ & $-15,49 \%$ & $1,67 \%$ & $22,95 \%$ & $5,33 \%$ \\
\hline ITEC3 & Itaute & 0,61 & Medium & & Small & 0,23 & Loser & um|Loser & $-13,95 \%$ & $0,79 \%$ & $-1,96 \%$ & $-4,00 \%$ & $30,53 \%$ & $8,53 \%$ & $15,86 \%$ & $3,04 \%$ & $-5,00 \%$ & $-0,53 \%$ & $58,73 \%$ & $-12,00 \%$ \\
\hline RPMG4 & Pet Manguinh PN & 0,51 & Medium & \begin{tabular}{l|l}
127.297 .500 \\
\end{tabular} & Small & 0,22 & Loser & Small|Medium|Loser & $-19,70 \%$ & $13,21 \%$ & $-22,50 \%$ & $3,23 \%$ & $5,21 \%$ & $20,79 \%$ & $13,11 \%$ & $5,07 \%$ & $-20,69 \%$ & $1,74 \%$ & $5,13 \%$ & $11,38 \%$ \\
\hline PQUN4 & Petroq Uniao PN & 0,61 & Medium & 1.076 .211 .400 & Small & 0,19 & Loser & Small|Medium|Loser & $-6,98 \%$ & $2,38 \%$ & $4,96 \%$ & $7,18 \%$ & $8,99 \%$ & $13,60 \%$ & $-4,74 \%$ & $6,60 \%$ & $-0,88 \%$ & $11,22 \%$ & $8,38 \%$ & $1,56 \%$ \\
\hline SZPQ4 & Quattor Petr PN & 0,89 & Medium & 763.962 .150 & Small & 0,16 & Loser & Small|Medium|Loser & $-6,53 \%$ & $9,52 \%$ & $1,45 \%$ & $5,43 \%$ & $7,59 \%$ & $-1,26 \%$ & $3,83 \%$ & $5,41 \%$ & $6,53 \%$ & $6,13 \%$ & $5,15 \%$ & $-6,27 \%$ \\
\hline RHDS3 & M G Poliest ON & 1,00 & Medium & 251.480 & Small & 0,11 & Loser & Small|Medium|Loser & $0,00 \%$ & $14,29 \%$ & $0,00 \%$ & $12,50 \%$ & $22,22 \%$ & $18,18 \%$ & $61,54 \%$ & $-23,81 \%$ & $-3,13 \%$ & $16,13 \%$ & $-2,78 \%$ & $-5,71 \%$ \\
\hline PEFX5 & Petroflex PNA & 0,54 & Medium & 920.000 & Small & 0,10 & Loser & Small|Medium|Loser & $-1,43 \%$ & $-2,97 \%$ & $-2,99 \%$ & $-0,85 \%$ & $6,37 \%$ & $10,79 \%$ & $7,07 \%$ & $-11,52 \%$ & $-4,64 \%$ & $7,12 \%$ & $1,40 \%$ & $6,21 \%$ \\
\hline ELEV3 & Eleva ON & 0,92 & Medium & 636.856 & Small & 0,03 & Loser & Small|Medium|Loser & $7,38 \%$ & $-1,98 \%$ & $0,83 \%$ & $-10,48 \%$ & $6,45 \%$ & $7,54 \%$ & $6,90 \%$ & $0,54 \%$ & $1,60 \%$ & $12,11 \%$ & $23,38 \%$ & $13,24 \%$ \\
\hline PQUN3 & Petroq & 0,61 & Medic & 1.076 .211 .400 & Small & 04 & Loser & Small|Me & $-2,33 \%$ & $-0,79 \%$ & $0,82 \%$ & $-4,00 \%$ & $-3,79 \%$ & \begin{tabular}{l|l}
$0,87 \%$ \\
\end{tabular} & $-1,24 \%$ & $0,09 \%$ & $3,02 \%$ & $10,62 \%$ & $4,88 \%$ & $1,25 \%$ \\
\hline TUPY4 & Tupy PN & 1,04 & Medium & $\begin{array}{r}06.479 .493 \\
\end{array}$ & Small & 0,05 & Loser & Small|Medium|Loser & $25,00 \%$ & $35,92 \%$ & $-2,88 \%$ & $21,21 \%$ & $0,00 \%$ & $-12,65 \%$ & $-2,69 \%$ & $-5,88 \%$ & $1,25 \%$ & $4,94 \%$ & $23,53 \%$ & $-0,95 \%$ \\
\hline \begin{tabular}{|l|} 
DXTG4 \\
\end{tabular} & Dixie Toga PN & 0,68 & Medium & 30.800 & Small & 0,08 & Loser & Small|Medium|Loser & $-4,76 \%$ & $6,25 \%$ & $2,94 \%$ & $-0,57 \%$ & $4,60 \%$ & $3,85 \%$ & $11,11 \%$ & $16,67 \%$ & $-1,22 \%$ & $8,26 \%$ & $8,46 \%$ & $26,52 \%$ \\
\hline MAGS5 & Magnesita PNA & 1,04 & Medium & 300.306 & Small & 0,11 & Loser & Small|Medium | Loser & $4,23 \%$ & $6,40 \%$ & $1,54 \%$ & $3,90 \%$ & $13,55 \%$ & $17,93 \%$ & $8,64 \%$ & $5,48 \%$ & $9,05 \%$ & $7,69 \%$ & $14,40 \%$ & $9,11 \%$ \\
\hline TUPY3 & Tupy ON & 1,04 & Medium & 479.493 & Small & 15 & Loser & Small|Medium|Loser & $13,04 \%$ & $26,15 \%$ & $6,71 \%$ & $20,00 \%$ & $-19,05 \%$ & $2,94 \%$ & $-7,14 \%$ & $2,83 \%$ & $0,54 \%$ & $11,90 \%$ & $10,59 \%$ & $-1,39 \%$ \\
\hline \begin{tabular}{|l|l|} 
DPPI3 \\
\end{tabular} & Ipiranga Dis ON & 0,90 & Medium & 1.003.480.544 & Small & 21 & Loser & Small|Medium|Loser & $-24,84 \%$ & $-11,27 \%$ & $17,06 \%$ & $-15,74 \%$ & $-2,03 \%$ & $7,51 \%$ & $0,00 \%$ & $16,67 \%$ & $191,49 \%$ & $0,96 \%$ & $4,83 \%$ & $0,27 \%$ \\
\hline PEAB4 & Par Al Bahia PN & 0,82 & Medium & 7.500 & Small & 0,28 & Loser & Small|Medium|Loser & $-4,14 \%$ & $-6,08 \%$ & $-2,96 \%$ & $6,74 \%$ & $3,16 \%$ & $-6,12 \%$ & $8,70 \%$ & $-4,00 \%$ & $0,00 \%$ & $-4,17 \%$ & $7,39 \%$ & $-0,04 \%$ \\
\hline LIPR3 & Eletropar ON & 0,52 & Medium & 187.554 .788 & Small & 29 & Loser & Small|Medium|Loser & $-0,61 \%$ & $-5,24 \%$ & $5,00 \%$ & $-0,28 \%$ & $6,74 \%$ & $15,79 \%$ & $0,91 \%$ & $8,11 \%$ & $0,00 \%$ & $8,33 \%$ & $7,69 \%$ & $1,79 \%$ \\
\hline DPPI4 & Ipiranga Dis PI & 0,90 & Medium & 1.003 .480 .544 & Small & 44 & Winner & Small|Medium/Winner & $2,04 \%$ & $-8,00 \%$ & $1,70 \%$ & $-2,14 \%$ & $7,03 \%$ & $17,81 \%$ & $10,91 \%$ & $4,92 \%$ & $18,78 \%$ & $1,29 \%$ & $-3,90 \%$ & $9,51 \%$ \\
\hline MAGS3 & Magnesita ON & 1,04 & Medium & \begin{tabular}{|l|l|}
695.300 .306 \\
\end{tabular} & Small & 0,47 & Winner & Small|Medium|Winner & $0,00 \%$ & $1,00 \%$ & $5,69 \%$ & $1,64 \%$ & $9,22 \%$ & $9,70 \%$ & $7,46 \%$ & $11,07 \%$ & $10,00 \%$ & $6,06 \%$ & $12,00 \%$ & $14,80 \%$ \\
\hline POMO4 & Marcopolo PN & 0,76 & Medium & \begin{tabular}{|l|}
716.505 .050 \\
\end{tabular} & Small & 0,52 & Winner & Small|Medium/Winner & $17,99 \%$ & $1,22 \%$ & $0,96 \%$ & $8,83 \%$ & $14,69 \%$ & $18,54 \%$ & $5,04 \%$ & $-2,40 \%$ & $2,46 \%$ & $1,44 \%$ & \begin{tabular}{|c|}
$-0,63 \%$ \\
\end{tabular} & $16,19 \%$ \\
\hline ROMI3 & Inds Ro & 0,76 & . & 7777.000 & Sma & 0,53 & Winn & Small & $-3,66 \%$ & $3,80 \%$ & $-4,59 \%$ & $-0,10 \%$ & $12,71 \%$ & $43,90 \%$ & $17,72 \%$ & $4,32 \%$ & $0,00 \%$ & $10,79 \%$ & $0,00 \%$ & $7,06 \%$ \\
\hline CNFB4 & Confab PN & 0,56 & Medium & 1.465 .143 .150 & Small & 0,55 & Winner & Small|Medium/Winner & $7,36 \%$ & $-6,76 \%$ & $0,96 \%$ & $-3,08 \%$ & $13,45 \%$ & $8,41 \%$ & $20,08 \%$ & $2,36 \%$ & $4,88 \%$ & $12,52 \%$ & $-2,10 \%$ & $-3,57 \%$ \\
\hline TRFO4 & Trafo PN & 0,81 & Medium & 44.210 .600 & Small & 0,57 & Winner & Small|Medium|Winner & $0,00 \%$ & $11,30 \%$ & $3,12 \%$ & $-7,58 \%$ & $6,56 \%$ & $22,31 \%$ & $6,92 \%$ & $17,06 \%$ & $-4,52 \%$ & $1,58 \%$ & $8,81 \%$ & $-2,38 \%$ \\
\hline CLSC3 & Celesc ON & 1,03 & Medium & 220.464 .530 & Small & 0,73 & Winner & Small|Medium|Winner & $3,12 \%$ & $-1,21 \%$ & $-3,11 \%$ & $6,91 \%$ & $6,15 \%$ & $2,03 \%$ & $2,27 \%$ & $0,56 \%$ & $0,83 \%$ & $9,59 \%$ & $1,55 \%$ & $10,84 \%$ \\
\hline ETER3 & Eternit $\mathrm{C}$ & 1,05 & $\mathrm{Me}$ & 59 & Small & 0,74 & Wi & Small|Medium|Winner & $0,08 \%$ & $-2,24 \%$ & $-0,1$ & & $12,16 \%$ & $28,62 \%$ & $10,13 \%$ & $0,60 \%$ & $4,21 \%$ & 19,37\% & $15,39 \%$ & $\%$ \\
\hline CLSC6 & Celesc PNB & 1,03 & Medium & 1.220.464.530 & Small & 1,01 & Winner & Small|Medium|Winner & $4,46 \%$ & $1,22 \%$ & $2,97 \%$ & $10,18 \%$ & $-7,86 \%$ & $2,73 \%$ & $-3,07 \%$ & $-5,61 \%$ & $7,99 \%$ & $9,76 \%$ & $9,76 \%$ & $-0,57 \%$ \\
\hline FBMC4 & Fibam PN & 0,63 & Medium & 28.967 .480 & Small & 1,34 & Winner & Small|Medium|Winner & $7,50 \%$ & $-6,98 \%$ & $-0,08 \%$ & $5,08 \%$ & $19,05 \%$ & $0,00 \%$ & $7,00 \%$ & $-4,67 \%$ & $37,25 \%$ & $1,64 \%$ & $0,00 \%$ & $10,14 \%$ \\
\hline COCE5 & Coel & 0,69 & 20 & 3.286 & Sma & 135 & Winn & & 0,00 & 1,7 & & & co & & 0,00 & $7,25 \%$ & $5,05 \%$ & $17,44 \%$ & $-5,84 \%$ & $-7,02 \%$ \\
\hline \begin{tabular}{|l|} 
SCAR3 \\
\end{tabular} & Sao Carlos ON & 1,01 & Medium & 741.875.516 & Small & 2,09 & Winner & Small|Medium/Winner & $20,06 \%$ & $-4,17 \%$ & $4,35 \%$ & $26,67 \%$ & $25,00 \%$ & $2,37 \%$ & $-7,61 \%$ & $4,62 \%$ & $-9,84 \%$ & $-5,01 \%$ & $4,97 \%$ & $12,43 \%$ \\
\hline
\end{tabular}


Anexo 1 - Retorno mensal e classificação das ações

\begin{tabular}{|c|c|c|c|c|c|c|c|c|c|c|c|c|c|c|c|c|c|c|c|c|}
\hline Código & 2007 - 2008 & $\begin{array}{l}\text { Índice } B / M \\
\text { de dez/2006 }\end{array}$ & $\begin{array}{c}\text { Grupo com } \\
\text { base no } \\
\text { indice } \mathrm{B} / \mathrm{M}\end{array}$ & $\begin{array}{c}\text { Valor de Mercado } \\
\text { em jun/2007 }\end{array}$ & $\begin{array}{c}\text { Grupo com } \\
\text { base no } \\
\text { tamanho }\end{array}$ & $\begin{array}{c}\text { Retorno } \\
\text { acumulado } \\
\text { de jun/2007 }\end{array}$ & \begin{tabular}{|c|} 
Grupo com \\
base no \\
retorno \\
acumulado
\end{tabular} & Carteiras & jul/07 & ago/07 & set/07 & out/07 & nov/07 & $\operatorname{dez} / 07$ & $\mathrm{jan} / 08$ & fev/08 & $\mathrm{mar} / 08$ & $\mathrm{abr} / 08$ & mai/08 & jun/08 \\
\hline ELET3 & \begin{tabular}{|l|l|} 
Eletrobras ON \\
\end{tabular} & 2,73 & High & 32.642 .464 .930 & Big & 0,06 & Loser & Big|High|Loser & $-14,22 \%$ & $2,07 \%$ & $5,95 \%$ & $-0,19 \%$ & $-6,89 \%$ & $-4,28 \%$ & $-8,48 \%$ & $13,56 \%$ & $7,76 \%$ & $-6,72 \%$ & $19,89 \%$ & $0,37 \%$ \\
\hline ELET6 & Eletrobras PNB & 2,73 & High & 32.642 .464 .930 & Big & 0,17 & Loser & Big|High|Loser & $\mid-14,20 \%$ & $-1,02 \%$ & $6,20 \%$ & $1,67 \%$ & $-6,05 \%$ & $-6,52 \%$ & $-2,92 \%$ & $11,31 \%$ & $1,61 \%$ & $2,38 \%$ & $11,11 \%$ & $-3,52 \%$ \\
\hline CESP3 & Cesp ON & 1,34 & High & 11.053 .132 .771 & Big & 0,18 & Loser & Big|High|Loser & $-7,80 \%$ & $-8,57 \%$ & $4,65 \%$ & $-7,94 \%$ & $-3,92 \%$ & $44,08 \%$ & $6,23 \%$ & $-0,53 \%$ & $-30,29 \%$ & $-17,27 \%$ & $15,85 \%$ & $0,40 \%$ \\
\hline EBTP4 & Embratel Part PN & 1,05 & High & \begin{tabular}{|l|}
7.322 .911 .859 \\
\end{tabular} & Big & 0,20 & Loser & Big|High|Loser & $0,14 \%$ & $-2,11 \%$ & $0,72 \%$ & $16,42 \%$ & $-14,11 \%$ & $-4,14 \%$ & \begin{tabular}{l|l|}
$3,58 \%$ \\
\end{tabular} & $2,88 \%$ & $-7,13 \%$ & $24,15 \%$ & $2,53 \%$ & $76,54 \%$ \\
\hline EBTP3 & Embratel Part ON & 1,05 & High & 7.322 .911 .859 & Big & 0,21 & Loser & Big|High | Loser & $-8,44 \%$ & $-3,97 \%$ & $3,40 \%$ & $14,24 \%$ & $-12,50 \%$ & $-4,29 \%$ & $-0,60 \%$ & $3,75 \%$ & $-5,79 \%$ & $25,40 \%$ & $-2,55 \%$ & $50,59 \%$ \\
\hline TRPL3 & Tran Paulist ON & 0,83 & High & 5.103 .096 .604 & Big & 0,23 & Loser & Big|High|Loser & $5,80 \%$ & $0,96 \%$ & $4,57 \%$ & $4,12 \%$ & $5,39 \%$ & $6,35 \%$ & $1,00 \%$ & $15,94 \%$ & $-1,30 \%$ & $-0,05 \%$ & $13,94 \%$ & $6,87 \%$ \\
\hline BRKM5 & Braskem PNA & 0,87 & High & 6.043.113.379 & Big & 0,24 & Loser & Big|High|Loser & 0,06\% & $4,81 \%$ & $-4,59 \%$ & $-5,56 \%$ & $-3,43 \%$ & $-8,57 \%$ & \begin{tabular}{l|l|}
$-9,72 \%$ \\
\end{tabular} & $10,31 \%$ & $8,40 \%$ & $-3,89 \%$ & $-7,54 \%$ & $-3,63 \%$ \\
\hline CESP5 & Cesp PNA & 1,34 & High & \begin{tabular}{|l|}
11.053 .132 .771 \\
\end{tabular} & Big & 0,24 & Loser & Big|High|Loser & $-4,53 \%$ & $-5,14 \%$ & $14,58 \%$ & $-8,18 \%$ & $-4,95 \%$ & $37,54 \%$ & $4,82 \%$ & $10,98 \%$ & $-36,07 \%$ & $-10,79 \%$ & $25,28 \%$ & $2,14 \%$ \\
\hline BRKM3 & Braskem ON & 0,87 & High & 6.043 .113 .379 & Big & 0,34 & Loser & Big|High|Loser & $-6,28 \%$ & $6,83 \%$ & $-2,90 \%$ & $-3,73 \%$ & $1,42 \%$ & $-3,31 \%$ & $-11,32 \%$ & $9,35 \%$ & $4,61 \%$ & $-0,68 \%$ & $-4,57 \%$ & $3,65 \%$ \\
\hline SBSP3 & Sabesp ON & 1,08 & High & 9.573 .668 .720 & Big & 0,38 & Loser & Big|High|Loser & $7,66 \%$ & $5,66 \%$ & $-3,87 \%$ & $-0,38 \%$ & $-1,81 \%$ & $-6,14 \%$ & \begin{tabular}{l|l|}
$-9,65 \%$ \\
\end{tabular} & $8,56 \%$ & $-3,96 \%$ & $7,77 \%$ & $10,43 \%$ & $-10,77 \%$ \\
\hline BRKM6 & Braskem PNB & 0,87 & High & 6.043 .113 .379 & Big & 0,38 & Loser & Big|High|Loser & $-2,72 \%$ & $0,00 \%$ & $4,16 \%$ & $-1,23 \%$ & $-4,43 \%$ & $1,71 \%$ & $-12,08 \%$ & $9,19 \%$ & 1,04\% & $2,61 \%$ & $0,00 \%$ & $5,85 \%$ \\
\hline CPLE6 & Copel PNB & 1,01 & High & 8.924.183.625 & Big & 0,43 & Loser & Big|High|Loser & $-6,46 \%$ & $2,73 \%$ & $-8,44 \%$ & $-1,74 \%$ & $-3,27 \%$ & $-3,77 \%$ & $-5,56 \%$ & $8,69 \%$ & $4,29 \%$ & $8,20 \%$ & $-0,53 \%$ & $9,47 \%$ \\
\hline CSMG3 & Copasa ON & 1,13 & High & 3.329 .055 .000 & Big & 0,45 & Winner & Big|High|Winner & $0,00 \%$ & $6,55 \%$ & $-2,03 \%$ & $8,33 \%$ & $-2,83 \%$ & $-1,84 \%$ & $-23,23 \%$ & $8,19 \%$ & \begin{tabular}{l|l|}
$1,12 \%$ \\
\end{tabular} & $7,75 \%$ & $7,55 \%$ & $-0,77 \%$ \\
\hline CPLE3 & Copel ON & 1,01 & High & \begin{tabular}{|c|}
8.924 .183 .625 \\
\end{tabular} & Big & 0,49 & Winner & Big|High|Winner & $6,22 \%$ & $-9,39 \%$ & $-4,22 \%$ & $-5,12 \%$ & $-3,18 \%$ & $8,86 \%$ & $-1,86 \%$ & $0,17 \%$ & 6 & $6,57 \%$ & $-5,66 \%$ & $6,67 \%$ \\
\hline TRPL4 & Tran Paulist PN & 0,83 & High & 5.103 .096 .604 & Big & 0,56 & Winner & Big|High|Winner & $8,65 \%$ & $6,58 \%$ & $1,23 \%$ & $5,62 \%$ & $-3,00 \%$ & $-1,37 \%$ & $14,34 \%$ & $-4,80 \%$ & $-0,12 \%$ & $8,58 \%$ & $9,63 \%$ & $11,03 \%$ \\
\hline BMTO4 & Brasmotor PN & 1,10 & High & 2.980 .896 .480 & Big & 3,26 & Winner & Big|High|Winner & $58,82 \%$ & $-25,93 \%$ & $12,50 \%$ & $-14,81 \%$ & $-14,78 \%$ & $-5,10 \%$ & $-1,57 \%$ & $-2,20 \%$ & $-7,87 \%$ & $2,44 \%$ & $11,90 \%$ & $-4,26 \%$ \\
\hline GOLL4 & Gol PN & 0,17 & Low & \begin{tabular}{|c|}
12.908 .443 .950 \\
\end{tabular} & Big & 0,17 & Loser & Big|Low|Loser & $-27,11 \%$ & $-6,47 \%$ & $3,02 \%$ & $7,34 \%$ & $-3,71 \%$ & $-3,91 \%$ & $-22,42 \%$ & \begin{tabular}{l|l|}
$-13,76 \%$ \\
\end{tabular} & $-10,89 \%$ & $0,96 \%$ & $-3,59 \%$ & $-28,95 \%$ \\
\hline ARCZ6 & Aracruz PNB & 0,36 & Low & 14.871.436.555 & Big & 0,01 & Loser & Big|Low|Loser & $-7,61 \%$ & $4,20 \%$ & $9,03 \%$ & $-1,41 \%$ & $5,51 \%$ & $-7,08 \%$ & $-3,25 \%$ & $-2,08 \%$ & $-1,56 \%$ & $11,95 \%$ & $10,33 \%$ & $-18,94 \%$ \\
\hline TAMM4 & Tam S/A PN & 0,15 & Low & 9.654.186.200 & Big & 0,00 & Loser & Big|Low|Loser & $-20,56 \%$ & $-12,45 \%$ & $12,43 \%$ & $1,79 \%$ & $-1,15 \%$ & $-15,56 \%$ & $-12,68 \%$ & $-4,73 \%$ & $-4,74 \%$ & $14,58 \%$ & $-7,67 \%$ & $-13,99 \%$ \\
\hline GUAR4 & Guararapes PN & 0,17 & Low & 5.754 .840 .000 & Big & 0,04 & Loser & Big|Low|Loser & $11,37 \%$ & $-9,78 \%$ & $-4,12 \%$ & $-5,53 \%$ & $-13,29 \%$ & $-8,94 \%$ & $-19,43 \%$ & $13,57 \%$ & $-1,64 \%$ & $-4,15 \%$ & $7,06 \%$ & $-13,94 \%$ \\
\hline NATU3 & Natura ON & 0,05 & Low & \begin{tabular}{|c|}
12.004 .860 .000 \\
\end{tabular} & Big & 0,08 & Loser & Big|Low|Loser & $\mid-16,45 \%$ & $-9,96 \%$ & $6,28 \%$ & $-5,45 \%$ & $-10,34 \%$ & $-8,85 \%$ & $0,00 \%$ & $1,47 \%$ & 7,01\% & $8,38 \%$ & $-3,09 \%$ & $-12,23 \%$ \\
\hline GUAR3 & Guararapes $\mathrm{C}$ & 0,17 & Low & 0.000 & Big & 0,13 & Loser & Big|Low|Loser & $1,04 \%$ & $-9,71 \%$ & $-2,39 \%$ & $-11,57 \%$ & $-22,08 \%$ & $2,34 \%$ & $-21,14 \%$ & $15,80 \%$ & $-0,69 \%$ & $-7,78 \%$ & $23,52 \%$ & $-24,15 \%$ \\
\hline \begin{tabular}{|l|l|} 
TBLE3 \\
\end{tabular} & Tractebel ON & 0,24 & \begin{tabular}{|l|} 
Low \\
\end{tabular} & 14.027.429.706 & Big & 0,13 & Loser & \begin{tabular}{|l} 
Big|Low|Loser \\
\end{tabular} & $4,23 \%$ & $2,48 \%$ & $0,67 \%$ & $9,93 \%$ & $-10,25 \%$ & $-3,69 \%$ & $-6,10 \%$ & $4,25 \%$ & $7,87 \%$ & $6,89 \%$ & $2,49 \%$ & $0,00 \%$ \\
\hline EKTR4 & Elektro PN & 0,26 & Low & \begin{tabular}{|c|}
7.249 .786 .235 \\
\end{tabular} & Big & 0,13 & Loser & Big|Low|Loser & $-4,89 \%$ & $-5,14 \%$ & $6,28 \%$ & $-16,42 \%$ & $-1,41 \%$ & $-9,63 \%$ & \begin{tabular}{|c|}
$-8,69 \%$ \\
\end{tabular} & $-1,75 \%$ & $0,45 \%$ & $1,24 \%$ & $2,18 \%$ & $-6,67 \%$ \\
\hline CPFE3 & CPFLEnergia ON & 0,34 & Low & 18.595 .370 .855 & Big & 0,21 & Loser & Big Low/Loser & $-7,79 \%$ & $3,27 \%$ & $1.22 \%$ & $6,98 \%$ & $-7.44 \%$ & $-4,35 \%$ & $-10,13 \%$ & $22,27 \%$ & $-0,69 \%$ & $18,80 \%$ & $-8,96 \%$ & $-4,95 \%$ \\
\hline GFSA3 & Gafisa ON & 0,25 & Low & 3.903 .561 .400 & Big & 0,22 & Loser & \begin{tabular}{|l} 
Big|Low|Loser \\
\end{tabular} & $-0,70 \%$ & $-20,97 \%$ & $30,17 \%$ & $0,23 \%$ & $8,18 \%$ & $-0,78 \%$ & $-10,52 \%$ & $11,28 \%$ & $-12,22 \%$ & $26,58 \%$ & $-0,38 \%$ & $-23,91 \%$ \\
\hline \begin{tabular}{|l|} 
ARCZ3 \\
\end{tabular} & Aracruz ON & 0,36 & \begin{tabular}{|l|} 
Low \\
\end{tabular} & \begin{tabular}{|l|l}
14.871 .436 .555 \\
\end{tabular} & Big & 0,24 & Loser & $\begin{array}{l}\text { Big|Low|Loser } \\
\end{array}$ & $\mid-4,07 \%$ & $-5,06 \%$ & $5,83 \%$ & -0,63\% & 9,24\% & -6,48\% & $-2,32 \%$ & |1,09\% & $-2,58 \%$ & |4,58\% & $8,99 \%$ & $-1,64 \%$ \\
\hline LREN3 & Lojas Renner ON & 0,15 & Low & $\begin{array}{r}4.413 .426 .600 \\
\end{array}$ & Big & 0,25 & Loser & Big|Low|Loser & $-2,48 \%$ & $-4,44 \%$ & $8,48 \%$ & $17,14 \%$ & $-2,30 \%$ & $-13,61 \%$ & $-23,33 \%$ & $21,63 \%$ & $-1,40 \%$ & $20,90 \%$ & $3,32 \%$ & $-21,28 \%$ \\
\hline LAME3 & Lojas Americ ON & 0,04 & Low & 10.851 .938 .706 & Big & 0,25 & Loser & Big|Low|Loser & $17,85 \%$ & $-10,30 \%$ & $10,47 \%$ & $10,64 \%$ & $-3,26 \%$ & $-4,14 \%$ & $-14,63 \%$ & $6,29 \%$ & $-8,96 \%$ & $-7,97 \%$ & $2,44 \%$ & $-18,52 \%$ \\
\hline OHLB3 & OHL Brasil ON & 0,28 & Low & \begin{tabular}{|l|}
2.507 .559 .600 \\
\end{tabular} & Big & 0,29 & Loser & Big|Low|Loser & $-3,85 \%$ & $-1,43 \%$ & $5,51 \%$ & $-14,84 \%$ & \begin{tabular}{|l|}
$-17,74 \%$ \\
\end{tabular} & $-11,80 \%$ & $-15,52 \%$ & $0,05 \%$ & $-1,10 \%$ & $23,85 \%$ & $15,65 \%$ & $0,38 \%$ \\
\hline EMBR3 & Embraer ON & 0,32 & Low & \begin{tabular}{|l|}
17.335 .571 .942 \\
\end{tabular} & Big & 0,30 & Loser & Big|Low|Loser & $-13,32 \%$ & $8,37 \%$ & $-7,29 \%$ & $3,51 \%$ & $-6,26 \%$ & $3,37 \%$ & $-5,46 \%$ & $-0,79 \%$ & $-6,16 \%$ & $-0,69 \%$ & $-11,87 \%$ & $-29,69 \%$ \\
\hline AMBV4 & Ambev PN & 0,30 & Low & 85.182 .098 .886 & Big & 0,31 & Loser & Big|Low|Loser & $-4,62 \%$ & $5,02 \%$ & $0,54 \%$ & $5,93 \%$ & $-6,64 \%$ & $-3,26 \%$ & $-4,00 \%$ & $13,04 \%$ & $-5,44 \%$ & $-4,71 \%$ & $-8,50 \%$ & $-10,70 \%$ \\
\hline TCSL4 & Tim Part S/A PN & 0,37 & Low & \begin{tabular}{|l|}
18.776 .858 .766 \\
\end{tabular} & Big & 0,36 & Loser & Big|Low|Loser & $-2,10 \%$ & $5,67 \%$ & $8,41 \%$ & $8,29 \%$ & $-14,69 \%$ & $-12,01 \%$ & $10,20 \%$ & $3,58 \%$ & $-18,16 \%$ & $2,30 \%$ & $-12,01 \%$ & $-8,43 \%$ \\
\hline CSNA3 & Sid Nacional ON & 0,38 & \begin{tabular}{|l|} 
Low \\
\end{tabular} & 25.597 .702 .000 & Big & 0,36 & Loser & \begin{tabular}{|l} 
Big|Low|Loser \\
\end{tabular} & $8,93 \%$ & $2,42 \%$ & $15,73 \%$ & $7,48 \%$ & $-1,44 \%$ & $17,80 \%$ & $\begin{array}{l}4,70 \% \\
\end{array}$ & $14,73 \%$ & $-0,86 \%$ & $19,19 \%$ & $8,93 \%$ & $-9,86 \%$ \\
\hline CYRE3 & Cyrela Realty ON & 0,27 & Low & 8.499 .700 .400 & Big & 0,38 & Loser & Big|Low|Loser & $-7,74 \%$ & $-5,38 \%$ & $35,83 \%$ & $20,45 \%$ & $-7,91 \%$ & $-12,70 \%$ & $-5,37 \%$ & $17,90 \%$ & $-14,81 \%$ & $20,77 \%$ & $-1,62 \%$ & $-18,84 \%$ \\
\hline GET14 & AES Tiete PN & 0,08 & Low & 7.074 .455 .021 & Big & 0,43 & Loser & Big|Low|Loser & $-7,33 \%$ & $-5,71 \%$ & $-0,31 \%$ & $-4,86 \%$ & $9,30 \%$ & $3,30 \%$ & $-10,38 \%$ & $7,38 \%$ & $-8,75 \%$ & $5,33 \%$ & $18,08 \%$ & $-1,74 \%$ \\
\hline AMBV3 & Ambev ON & 0,30 & Low & 85.182 .098 .886 & Big & 0,44 & Loser & Big|Low|Loser & $-4,00 \%$ & $2,27 \%$ & $-1,80 \%$ & $8,40 \%$ & $-8,80 \%$ & $-3,12 \%$ & $-8,00 \%$ & $11,30 \%$ & $-8,99 \%$ & $-3,24 \%$ & $-5,50 \%$ & $-8,10 \%$ \\
\hline ALLL4 & All Amer Lat PN & 0,18 & Low & 16.726 .641 .260 & Big & 0,48 & Winner & Big|Low|Winner & $0,23 \%$ & $-10,96 \%$ & $12,05 \%$ & $2,97 \%$ & $-12,22 \%$ & $-5,06 \%$ & $-18,40 \%$ & \begin{tabular}{l|l|}
$4,58 \%$ & \\
\end{tabular} & $-6,25 \%$ & $1,95 \%$ & $8,55 \%$ & $-11,21 \%$ \\
\hline CRUZ3 & Souza Cruz ON & 0,14 & Low & 14.153 .447 .000 & Big & 0,48 & Winner & Big|Low/Winner & $-5,94 \%$ & $-2,85 \%$ & $16,39 \%$ & $2,96 \%$ & $4,53 \%$ & $-4,74 \%$ & $0,62 \%$ & $1,51 \%$ & $-4,86 \%$ & $2,40 \%$ & $7,62 \%$ & $-8,64 \%$ \\
\hline CEEB3 & Coelba ON & 0,33 & Low & 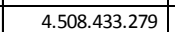 & Big & 0,52 & Winner & Big|Low|Winner & $21,31 \%$ & $3,45 \%$ & $3,33 \%$ & $24,98 \%$ & $-15,98 \%$ & $19,70 \%$ & $-8,05 \%$ & $-3,00 \%$ & $-3,33 \%$ & $0,31 \%$ & $0,32 \%$ & $1,61 \%$ \\
\hline \begin{tabular}{|l|} 
ALPA44 \\
\end{tabular} & Alpargatas PN & 0,33 & Low & 3.102 .231 .090 & Big & 0,53 & Winner & Big|Low/Winner & $6,92 \%$ & $-4,27 \%$ & $1,54 \%$ & $-1,76 \%$ & $-15,42 \%$ & $-5,88 \%$ & $-12,50 \%$ & $-6,43 \%$ & $2,87 \%$ & $-5,60 \%$ & $24,76 \%$ & $-20,32 \%$ \\
\hline ALLL11 & All Amer Lat UNT N2 & 0,18 & Low & 16.726.641.260 & Big & 0,62 & Winner & Big|Low|Winner & $-3,03 \%$ & $-11,33 \%$ & $14,98 \%$ & $5,36 \%$ & $-14,69 \%$ & $-1,79 \%$ & $-17,53 \%$ & $0,00 \%$ & $-6,84 \%$ & $23,14 \%$ & $11,66 \%$ & $-14,86 \%$ \\
\hline LAME4 & Lojas Americ PN & 0,04 & Low & 10.851.938.706 & Big & 0,62 & Winner & Big|Low|Winner & $8,51 \%$ & $-4,25 \%$ & $13,75 \%$ & $11,54 \%$ & $-15,27 \%$ & $-9,46 \%$ & $-14,15 \%$ & $15,36 \%$ & $-15,03 \%$ & \begin{tabular}{|c|}
$-8,81 \%$ \\
\end{tabular} & $9,66 \%$ & $-19,54 \%$ \\
\hline VALE3 & Vale ON & 0,27 & Low & 195.296.289.070 & Big & 0,62 & Winner & Big|Low|Winner & $7,68 \%$ & $4,50 \%$ & $27,76 \%$ & $5,58 \%$ & $-3,54 \%$ & $-5,41 \%$ & $-12,61 \%$ & $13,18 \%$ & $3,14 \%$ & $9,28 \%$ & $-0,20 \%$ & $-12,38 \%$ \\
\hline VALE5 & Vale PNA & 0,27 & \begin{tabular}{|l|} 
Low \\
\end{tabular} & 195.296.289.070 & Big & 0,63 & Winner & Big|Low/Winner & $9,26 \%$ & $2,53 \%$ & $28,57 \%$ & $5,47 \%$ & $-4,57 \%$ & $-2,68 \%$ & $-11,78 \%$ & $11,37 \%$ & $1,87 \%$ & $6,42 \%$ & $1,44 \%$ & $-12,25 \%$ \\
\hline GET13 & AES Tiete ON & 0,08 & Low & \begin{tabular}{l|l|}
7.074 .455 .021 \\
\end{tabular} & Big & 0,67 & Winner & Big|Low|Winner & $4,76 \%$ & $-4,68 \%$ & $-7,44 \%$ & $-3,38 \%$ & $2,70 \%$ & $22,87 \%$ & $-5,08 \%$ & $-4,76 \%$ & $-4,86 \%$ & $-0,88 \%$ & $21,65 \%$ & $-0,56 \%$ \\
\hline BRAP3 & Bradesp & 0,36 & Low & 12.98 & Big & 0,74 & Winner & Big|Low|W & $5,67 \%$ & $4,35 \%$ & $26,07 \%$ & 1,7 & $-1,72 \%$ & $-1,90 \%$ & $-13,01 \%$ & $2,68 \%$ & & $5,31 \%$ & encot & $-12,24 \%$ \\
\hline RENT3 & Localiza ON & 0,09 & Low & 4.380 .538 .222 & Big & 0,74 & Winner & Big|Low|Winner & 年 & 0,7 & -4, & $7,14 \%$ & $-10,75$ & 6,06 & $-15,03 \%$ & 23, & $-15,84 \%$ & $29,55 \%$ & $0,00 \%$ & $17,67 \%$ \\
\hline CGAS5 & Comgas PNA & 0,28 & Low & 5.051.251.922 & Big & 0,78 & Winner & Big|Low|Winner & $-2,55 \%$ & $0,85 \%$ & $0,69 \%$ & $2,35 \%$ & $-8,32 \%$ & $-4,01 \%$ & $-6,75 \%$ & $13,80 \%$ & $5,88 \%$ & $11,46 \%$ & $0,71 \%$ & $-3,69 \%$ \\
\hline
\end{tabular}


Anexo 1 - Retorno mensal e classificação das ações

\begin{tabular}{|c|c|c|c|c|c|c|c|c|c|c|c|c|c|c|c|c|c|c|c|c|}
\hline Código & $2007-2008$ & $\begin{array}{l}\text { Índice B/M } \\
\text { de dez/2006 }\end{array}$ & $\begin{array}{c}\text { Grupo com } \\
\text { base no } \\
\text { indice } \mathrm{B} / \mathrm{M}\end{array}$ & $\begin{array}{c}\text { Valor de Mercado } \\
\text { em jun/2007 }\end{array}$ & $\begin{array}{c}\text { Grupo com } \\
\text { base no } \\
\text { tamanho }\end{array}$ & \begin{tabular}{|c|} 
Retorno \\
acumulado \\
de jun/2007
\end{tabular} & \begin{tabular}{|l} 
Grupo com \\
base no \\
retorno \\
acumulado
\end{tabular} & Carteiras & $\mathrm{jul} / 07$ & ago/07 & set/07 & out $/ 07$ & nov/07 & dez/07 & jan/08 & $\mathrm{fev} / 08$ & mar/08 & abr/08 & mai/08 & jun/08 \\
\hline NETC4 & Net PN & 0,18 & Low & 10.498 .116 .000 & Big & 0,82 & Winner & Big|Low|Winner & $-5,47 \%$ & $-2,48 \%$ & $1,90 \%$ & $-7,19 \%$ & $-4,66 \%$ & $-18,42 \%$ & $-5,81 \%$ & $-8,88 \%$ & $0,75 \%$ & $22,03 \%$ & $2,53 \%$ & $-13,47 \%$ \\
\hline BRAP4 & Bradespar PN & 0,36 & Low & 12.981 .734 .900 & Big & 0,86 & Winner & Big|Low|Winner & $8,32 \%$ & $4,53 \%$ & $26,14 \%$ & $4,11 \%$ & $-3,02 \%$ & $-9,33 \%$ & $-20,59 \%$ & $16,40 \%$ & $7,61 \%$ & $4,86 \%$ & $-0,69 \%$ & $-10,18 \%$ \\
\hline RAPT4 & Randon Part PN & 0,36 & Low & 2.637 .384 .400 & Big & 0,89 & Winner & Big|Low|Winner & $-0,58 \%$ & $-2,92 \%$ & $7,47 \%$ & $14,35 \%$ & $-5,74 \%$ & $-9,59 \%$ & $-19,54 \%$ & $15,27 \%$ & $-17,56 \%$ & $12,89 \%$ & $21,62 \%$ & $-11,19 \%$ \\
\hline CCRO3 & CCR SA ON & 0,13 & Low & 14.314.144.918 & Big & 0,94 & Winner & Big|Low|Winner & $-4,08 \%$ & $2,14 \%$ & $8,53 \%$ & $-13,31 \%$ & $-2,16 \%$ & $-12,14 \%$ & $3,09 \%$ & $1,76 \%$ & $-8,57 \%$ & $23,60 \%$ & $2,22 \%$ & $-3,12 \%$ \\
\hline ALPA3 & Alpargatas ON & 0,33 & Low & 3.102 .231 .090 & Big & 0,94 & Winner & Big|Low|Winner & $4,74 \%$ & $-5,71 \%$ & $1,61 \%$ & $-0,01 \%$ & $-11,77 \%$ & $0,89 \%$ & $-8,01 \%$ & $-9,68 \%$ & $-4,47 \%$ & $4,44 \%$ & $0,37 \%$ & $2,17 \%$ \\
\hline RAPT3 & Randon Part ON & 0,36 & Low & 2.637 .384 .400 & Big & 1,02 & Winner & Big|Low|Winner & $11,87 \%$ & $-4,65 \%$ & $-6,12 \%$ & $13,18 \%$ & $0,00 \%$ & $-7,42 \%$ & $5,71 \%$ & $5,94 \%$ & $-19,86 \%$ & $-7,30 \%$ & $19,30 \%$ & $-2,93 \%$ \\
\hline ALLL3 & All Amer Lat ON & 0,18 & Low & \begin{tabular}{|l|l|}
16.726 .641 .260 \\
\end{tabular} & Big & 1,02 & Winner & Big|Low|Winner & $-5,96 \%$ & $-5,72 \%$ & $2,90 \%$ & $15,38 \%$ & $-5,56 \%$ & $-10,94 \%$ & $-14,13 \%$ & $7,69 \%$ & $-14,29 \%$ & $33,65 \%$ & $31,13 \%$ & $33,27 \%$ \\
\hline AVIL3 & Acos Vill ON & 0,27 & Low & 64.957 .850 & Big & 1,04 & Winner & Big|Low|Winner & $-4,60 \%$ & $-3,79 \%$ & $0,00 \%$ & $3,80 \%$ & $-1,35 \%$ & $10,00 \%$ & $-8,41 \%$ & $7,50 \%$ & $1,16 \%$ & $23,94 \%$ & $18,69 \%$ & $-5,51 \%$ \\
\hline FFTL4 & Valefert PN & 0,35 & Low & 6.002 .546 .450 & Big & 1,05 & Winner & Big|Low|Winner & $15,06 \%$ & $-1,54 \%$ & $2,74 \%$ & $5,08 \%$ & $6,88 \%$ & 9,15\% & $-11,02 \%$ & $17,07 \%$ & $1,23 \%$ & $21,35 \%$ & $22,04 \%$ & $0,00 \%$ \\
\hline ENMA3B & Cemar ON & 0,18 & Low & 3.753.586.301 & Big & 1,18 & Winner & Big|Low|Winner & $4,35 \%$ & $-20,83 \%$ & $5,26 \%$ & $-15,00 \%$ & $-11,76 \%$ & $0,00 \%$ & $0,00 \%$ & $-20,00 \%$ & $0,00 \%$ & $0,46 \%$ & $2,64 \%$ & $-14,97 \%$ \\
\hline WEGE3 & Weg ON & 0,18 & Low & 11.253.159.002 & Big & 1,25 & Winner & Big|Low|Winner & $16,32 \%$ & $-0,90 \%$ & $6,99 \%$ & $18,20 \%$ & $-7,95 \%$ & $4,57 \%$ & $-16,07 \%$ & $8,18 \%$ & $-13,65 \%$ & $1,99 \%$ & $6,55 \%$ & $-5,30 \%$ \\
\hline DURA4 & Duratex-Old PN & 0,36 & Low & 111.465 .500 & Big & 1,35 & Winner & Big|Low|Winner & $-0,36 \%$ & $-11,44 \%$ & $12,55 \%$ & $6,95 \%$ & $-23,08 \%$ & $-2,68 \%$ & $-16,32 \%$ & $-4,22 \%$ & $-2,67 \%$ & $0,36 \%$ & $9,79 \%$ & $-8,11 \%$ \\
\hline DURA3 & Duratex-Old ON & 0,36 & Low & 7.111 .465 .500 & Big & 1,45 & Winner & Big|Low|Winner & $-8,18 \%$ & $-4,19 \%$ & $0,00 \%$ & $-6,25 \%$ & $-1,42 \%$ & $-11,37 \%$ & $-23,06 \%$ & $7,65 \%$ & $-4,42 \%$ & $-9,77 \%$ & $14,50 \%$ & $-6,29 \%$ \\
\hline PMAM4 & Paranapanema PN & 0,02 & Low & 2.636 .189 .000 & Big & 1,62 & Winner & Big|Low|Winner & $4,08 \%$ & $-8,50 \%$ & $-3,86 \%$ & $-12,93 \%$ & $-20,14 \%$ & $-11,11 \%$ & $-26,20 \%$ & $-0,65 \%$ & $6,82 \%$ & $-14,18 \%$ & $5,79 \%$ & $5,41 \%$ \\
\hline PMAM3 & Paranapanema ON & 0,02 & Low & 536.189 .000 & Big & 1,69 & Winner & Big|Low|Winner & $8,22 \%$ & $-11,90 \%$ & $-8,05 \%$ & $-10,31 \%$ & $-16,38 \%$ & $-6,33 \%$ & $-33,94 \%$ & $-2,42 \%$ & $13,94 \%$ & $-22,47 \%$ & $15,94 \%$ & $17,66 \%$ \\
\hline PCAR4 & P.Acuc & & $\pi$ & & Big & 0,15 & Loser & ium/Loser & $-5,01 \%$ & $-11,71 \%$ & $-10,97 \%$ & $-1,21 \%$ & $7,95 \%$ & $14,23 \%$ & $-4,72 \%$ & 12,31 & $-1,37 \%$ & $5,58 \%$ & $3,09 \%$ & $-12,40 \%$ \\
\hline TMCP3 & Telemig Part ON & 0,60 & Medium & 2.514 .690 .004 & Big & 0,05 & Loser & Big|Medium/Loser & $8,13 \%$ & $-3,81 \%$ & $-1,56 \%$ & $2,62 \%$ & $2,00 \%$ & $-0,89 \%$ & $2,70 \%$ & $0,78 \%$ & $2,54 \%$ & $3,61 \%$ & $-0,79 \%$ & $0,83 \%$ \\
\hline TMAR3 & Telemar N LON & 0,78 & Medium & \begin{tabular}{|l|}
19.502 .394 .011 \\
\end{tabular} & Big & 0,06 & Loser & Big|Medium|Loser & $3,44 \%$ & $-2,49 \%$ & $-1,72 \%$ & $-0,26 \%$ & $2,79 \%$ & $-6,89 \%$ & $12,15 \%$ & $-4,17 \%$ & $0,88 \%$ & $-5,83 \%$ & $1,84 \%$ & $-8,63 \%$ \\
\hline PETR4 & Petrobras PN & 0,44 & Medium & 244.658.494.680 & Big & 0,07 & Loser & Big|Medium|Loser & $2,07 \%$ & $0,11 \%$ & $13,41 \%$ & $22,65 \%$ & $-0,17 \%$ & $22,95 \%$ & $-8,71 \%$ & $1,31 \%$ & $-9,16 \%$ & $14,37 \%$ & $16,11 \%$ & $-5,69 \%$ \\
\hline TNLP3 & Telen & 62 & Medium & & Big & 0,07 & Loser & Im|Loser & $-17,19 \%$ & $5,33 \%$ & $-8,96 \%$ & $8,28 \%$ & $-10,36 \%$ & $1,69 \%$ & $15,29 \%$ & $-5,33 \%$ & $-5,18 \%$ & $-15,54 \%$ & $1,76 \%$ & $-10,83 \%$ \\
\hline PETR3 & Petrobr: & 0,44 & Medium & 244.65 & Big & 0,07 & Loser & Big|Medium/Loser & $3,79 \%$ & $0,91 \%$ & $13,61 \%$ & $20,29 \%$ & $2,20 \%$ & $24,11 \%$ & $-7,90 \%$ & $1,35 \%$ & $-8,22 \%$ & $13,10 \%$ & $13,44 \%$ & $-1,66 \%$ \\
\hline TMCP4 & Telemig Part PN & 0,60 & Medium & 2.514 .690 .004 & Big & 0,10 & Loser & Big|Medium|Loser & $12,94 \%$ & $5,45 \%$ & $-7,48 \%$ & $0,63 \%$ & $-7,31 \%$ & $-3,08 \%$ & $3,90 \%$ & $4,17 \%$ & $-2,34 \%$ & $14,24 \%$ & $-14,77 \%$ & $-3,60 \%$ \\
\hline TMAR5 & Telemar N L PNA & 0,78 & Medium & \begin{tabular}{|c|}
19.502 .394 .011 \\
\end{tabular} & Big & 0,12 & Loser & Big|Medium|Loser & $19,22 \%$ & $4,36 \%$ & $-1,49 \%$ & $1,52 \%$ & $-1,19 \%$ & $8,91 \%$ & $21,96 \%$ & $8,93 \%$ & $0,00 \%$ & $6,83 \%$ & $0,26 \%$ & $-8,32 \%$ \\
\hline TNLP4 & Telem & & Podium & & Big & & Loser & Loser & $855 \%$ & $9,60 \%$ & $-5,57 \%$ & & $-1,84 \%$ & $-4,27 \%$ & $32,94 \%$ & $-7,03 \%$ & $10,40 \%$ & $-18,09 \%$ & $11,58 \%$ & $-5,21 \%$ \\
\hline ELPL5 & Eletropa & 18 & Medi & & Big & & Loser & um/Loser & $-0,01 \%$ & $0,94 \%$ & $3,77 \%$ & $10,91 \%$ & $0,89 \%$ & $3,36 \%$ & $-2,79 \%$ & $6,56 \%$ & $-5,38 \%$ & $8,33 \%$ & $0,46 \%$ & $-2,93 \%$ \\
\hline ENBR3 & Energias BR ON & 0,70 & Medium & 34.633 .600 & Big & 0,20 & Loser & Big|Medium|Loser & $-12,02 \%$ & $-11,02 \%$ & $-1,65 \%$ & $-8,23 \%$ & $-4,04 \%$ & $7,64 \%$ & $-16,59 \%$ & $11,49 \%$ & $2,03 \%$ & $5,27 \%$ & $14,94 \%$ & $0,63 \%$ \\
\hline VCPA4 & Fibria PN & 0,60 & Medium & 9.869 .200 & Big & 0,25 & Loser & Big|Medium|Loser & $2,29 \%$ & $4,74 \%$ & $12,13 \%$ & $4,67 \%$ & $7,01 \%$ & $-4,98 \%$ & $-5,33 \%$ & $2,26 \%$ & $-4,33 \%$ & $5,18 \%$ & $4,15 \%$ & $-21,60 \%$ \\
\hline GGBR3 & Gerdau ON & 0,45 & Medium & & Big & 0,29 & Loser & Big|Medium/Loser & $-3,19 \%$ & $1,09 \%$ & $0,40 \%$ & $11,45 \%$ & $-7,79 \%$ & $4,94 \%$ & $-11,29 \%$ & $24,18 \%$ & $-2,88 \%$ & $18,36 \%$ & $25,04 \%$ & $-6,01 \%$ \\
\hline \begin{tabular}{|l|} 
USIM33 \\
\end{tabular} & Usimin & 5 & Med & & Big & & Los & |loser & $5,80 \%$ & $-0,33 \%$ & $8,71 \%$ & $1,67 \%$ & $-0,27 \%$ & $-13,50 \%$ & $3,01 \%$ & $18,71 \%$ & $2,13 \%$ & $24,02 \%$ & $4,12 \%$ & $-14,46 \%$ \\
\hline \begin{tabular}{|l|} 
BRTO3 \\
\end{tabular} & Brasil Telec ON & 54 & Medium & 0.542 .389 & Big & 0,30 & Loser & ig|Medium |Loser & $-5,88 \%$ & $-3,13 \%$ & $5,97 \%$ & $7,76 \%$ & $-9,66 \%$ & $-2,10 \%$ & $28,62 \%$ & $7,50 \%$ & $-5,30 \%$ & $21,34 \%$ & $1,02 \%$ & $-1,01 \%$ \\
\hline CMIG4 & Cemig PN & 77 & Medium & 2.107 .500 & Big & 0,33 & Loser & Big|Medium|Loser & $-7,41 \%$ & $-0,53 \%$ & $3,17 \%$ & $-4,87 \%$ & $2,75 \%$ & $-14,74 \%$ & $-13,97 \%$ & $15,16 \%$ & $-2,17 \%$ & $17,53 \%$ & $10,23 \%$ & $2,24 \%$ \\
\hline KLBN4 & Klabin S/A PN & 13 & Medium & 436.800 & Big & 0,33 & Loser & Big|Medium|Loser & $-6,18 \%$ & $-6,25 \%$ & $21,11 \%$ & $1,57 \%$ & $-0,42 \%$ & $-6,64 \%$ & $-7,87 \%$ & $-6,08 \%$ & $3,92 \%$ & $12,07 \%$ & $-1,08 \%$ & $-6,84 \%$ \\
\hline GGBR4 & Gerdau & & t & & $\mathrm{Big}$ & n & 11 & ser & -4 & $1,78 \%$ & $-0,19 \%$ & $12,71 \%$ & $-5,08 \%$ & $2,08 \%$ & $-12,80 \%$ & $22,64 \%$ & $-2,10 \%$ & $21,57 \%$ & $5,12 \%$ & $-6,20 \%$ \\
\hline BRFS3 & BRF F & & ant & 3.346 & $\mathrm{Big}$ & & Los & nglcoser & $-2,74 \%$ & 7,61\% & $4,69 \%$ & $16,70 \%$ & $-7,61 \%$ & $2,64 \%$ & $-10,52 \%$ & $4,61 \%$ & $-2,21 \%$ & $14,78 \%$ & $16,26 \%$ & $-18,76 \%$ \\
\hline \begin{tabular}{|l|} 
USIM55 \\
\end{tabular} & Usiminas & 5 & Medium & 37.910 & Big & 0,35 & Loser & Big|Medium|Loser & $5,19 \%$ & $3,38 \%$ & $9,52 \%$ & $6,25 \%$ & $0,26 \%$ & $-9,24 \%$ & $1,23 \%$ & $18,79 \%$ & $1,35 \%$ & $23,72 \%$ & $7,81 \%$ & $-9,71 \%$ \\
\hline SDIA3 & Sadias S, & & & & Big & & Lo & $\mathrm{m} \mid$ Loser & & & & $12,54 \%$ & $-3,75 \%$ & $-2,63 \%$ & $-2,34 \%$ & $-0,80 \%$ & $4,71 \%$ & $10,86 \%$ & $10,91 \%$ & $-7,30 \%$ \\
\hline GOAU4 & Gerdau Met PN & 0,60 & Medic & .040 & Big & 0,43 & Loser & |loser & $-5,56 \%$ & $-1,47 \%$ & $0,81 \%$ & $12,87 \%$ & $0,60 \%$ & $1,75 \%$ & $-14,08 \%$ & $22,99 \%$ & $-1,88 \%$ & $21,07 \%$ & $28,42 \%$ & $-7,96 \%$ \\
\hline ITSA4 & Itausa P & 0,39 & ediu & 7719.600 & Big & & & Big| & $-1,57 \%$ & $-0,52 \%$ & $7,32 \%$ & $3,95 \%$ & $-0,83 \%$ & $-9,62 \%$ & $-13,79 \%$ & $8,89 \%$ & $-4,19 \%$ & $17,13 \%$ & $7,31 \%$ & $-13,33 \%$ \\
\hline RSID3 & Rossi Resid ON & & Medit & & Big & & $w_{i}$ & $\mathrm{IWi}$ & $16,87 \%$ & $-7,95 \%$ & $17,05 \%$ & $13,40 \%$ & $-10,02 \%$ & $-13,42 \%$ & $-17,80 \%$ & $3,88 \%$ & $-21,87 \%$ & & & $-24,53 \%$ \\
\hline CMIG3 & Cemig C & & $\mathrm{N}$ & 0 & Big & 0,49 & Winner & Big|Medium|Winner & $-5,97 \%$ & $-3,80 \%$ & $3,95 \%$ & $-6,61 \%$ & $2,98 \%$ & $-11,06 \%$ & $-20,33 \%$ & $11,44 \%$ & $-8,33 \%$ & $17,97 \%$ & $11,98 \%$ & $-0,15 \%$ \\
\hline GOAU3 & Gerdau Met ON & 0,60 & Medium & 12.168 .042 .040 & Big & 0,50 & Winner & Big|Medium/Winner & $-6,46 \%$ & $-2,77 \%$ & $2,46 \%$ & $12,52 \%$ & $1,84 \%$ & $0,98 \%$ & $-12,81 \%$ & $19,21 \%$ & $1,39 \%$ & $21,54 \%$ & $26,50 \%$ & $-6,36 \%$ \\
\hline SDIA4 & Sadia & & Medium & & , & & Winn & & $-0,22 \%$ & $10,89 \%$ & $3,04 \%$ & $16,28 \%$ & $-5,87 \%$ & $-8,50 \%$ & $-8,79 \%$ & $5,09 \%$ & $8,79 \%$ & $17,57 \%$ & $3,67 \%$ & $-17,68 \%$ \\
\hline VIVO3 & Vivo & & 1 & & Big & & & & $3,26 \%$ & $4,49 \%$ & $6,67 \%$ & $-2,55 \%$ & $-2,07 \%$ & $-4,58 \%$ & $-10,6$ & & $-5,6$ & & $\%$ & \\
\hline \begin{tabular}{|l|} 
VIVO4 \\
\end{tabular} & Vivo PN & & Me & & Big & & Wir & Big|Medium|Wi & $-12,77 \%$ & 10,8 & $-4,62 \%$ & $14,98 \%$ & $4,21 \%$ & $-11,56 \%$ & 7,86 & $0,10 \%$ & $0,69 \%$ & $18,28 \%$ & $-7,01 \%$ & $-8,61 \%$ \\
\hline SUZB5 & Suzano $P$ & 1 & Medic & $\begin{array}{l}8.167 .775 .382 \\
\end{array}$ & Big & 0,66 & Win & Big|Medium|Winner & $2,64 \%$ & $0,75 \%$ & $10,42 \%$ & $1,36 \%$ & $0,00 \%$ & $-2,14 \%$ & $-7,59 \%$ & $-1,31 \%$ & $0,15 \%$ & $9,48 \%$ & $3,45 \%$ & $-13,43 \%$ \\
\hline BRTO4 & Brasil Telec PN & 0,54 & Medium & 12.680.542.389 & Big & 0,67 & Winner & Big|Medium|Winner & $15,47 \%$ & $6,02 \%$ & $0,29 \%$ & $-0,35 \%$ & $1,51 \%$ & $5,43 \%$ & $\mid-3,29 \%$ & 6,40\% & $7,04 \%$ & 5,99\% & $-0,65 \%$ & $-13,03 \%$ \\
\hline ITSA3 & Itausa & 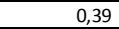 & Prd & s & - & & , & & $-11,05$ & & & & $-7,7$ & $-2,8$ & 178 & 30,8 & & & 56 & \\
\hline BRTPA & & & & & Big & & & & & & & & & & & & & & $\%$ & \\
\hline CBEE3 & Ampla Energ ON & 0,42 & Medium & 7.138.978.971 & Big & 0,89 & Winner & Big|Medium|Winner & $-14,84 \%$ & $-16,13 \%$ & $3,08 \%$ & $10,45 \%$ & $-18,92 \%$ & $-4,17 \%$ & $-18,26 \%$ & $9,57 \%$ & $-6,80 \%$ & $14,53 \%$ & $5,50 \%$ & $-5,22 \%$ \\
\hline & & & & & & 0,90 & 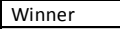 & Big|Medium/Winner & & & & 28 & , & $0,82 \%$ & (1) & & & $10,30 \%$ & & \\
\hline
\end{tabular}


Anexo 1 - Retorno mensal e classificação das ações

\begin{tabular}{|c|c|c|c|c|c|c|c|c|c|c|c|c|c|c|c|c|c|c|c|c|}
\hline Código & $2007-2008$ & $\begin{array}{l}\text { Índice } \mathrm{B} / \mathrm{M} \\
\text { de dez/2006 }\end{array}$ & $\begin{array}{c}\text { Grupo com } \\
\text { baseno } \\
\text { indice B/M } \\
\end{array}$ & $\begin{array}{c}\text { Valor de Mercado } \\
\text { em jun/2007 }\end{array}$ & \begin{tabular}{|c} 
Grupo com \\
base no \\
tamanho \\
\end{tabular} & $\begin{array}{c}\text { Retorno } \\
\text { acumulado } \\
\text { de jun/2007 } \\
\end{array}$ & \begin{tabular}{|l|} 
Grupo com \\
base no \\
retorno \\
acumulado \\
\end{tabular} & Carteiras & $\mathrm{jul} / 07$ & ago/07 & set/07 & out $/ 07$ & nov/07 & dez/07 & $\mathrm{jan} / 08$ & fev/08 & $\operatorname{mar} / 08$ & $\mathrm{abr} / 08$ & mai/08 & jun/08 \\
\hline \begin{tabular}{|l|l|} 
UGPA4 \\
\end{tabular} & Ultrapar PN & 0,49 & Medium & \begin{tabular}{|l|}
5.202 .840 .780 \\
\end{tabular} & Big & 0,92 & \begin{tabular}{|l|} 
Winner \\
\end{tabular} & Big $\mid$ Medium $\mid$ Winner & $-0,22 \%$ & $5,63 \%$ & $4,69 \%$ & $-1,07 \%$ & $-10,23 \%$ & $-0,16 \%$ & $-6,67 \%$ & $10,53 \%$ & $-2,37 \%$ & $-5,28 \%$ & $11,23 \%$ & $-5,25 \%$ \\
\hline LIGT3 & Light S/A ON & 0,49 & Medium & 6.044.568.395 & Big & 1,24 & Winner & Big|Medium/Winner & $-5,84 \%$ & $-6,90 \%$ & $13,70 \%$ & $12,03 \%$ & $-6,76 \%$ & $-3,83 \%$ & $-18,71 \%$ & $6,91 \%$ & $-7,13 \%$ & $12,75 \%$ & $0,56 \%$ & $-8,59 \%$ \\
\hline WHRL4 & Whirlpool PN & 0,62 & Medium & 7.282 .251 .640 & Big & 2,77 & \begin{tabular}{|l|l} 
Winner \\
\end{tabular} & Big|Medium |Winner & $48,42 \%$. & $-22,13 \%$ & $6,74 \%$ & $-5,97 \%$ & $-29,22 \%$ _ & $-3,26 \%$ & $-1,14 \%$ & $-4,41 \%$ | $>$ & $2,02 \%$ & $3,11 \%$. & $5,75 \%$ _ & $-10,88 \%$ \\
\hline WHRL3 & Whirlpool ON & 0,62 & Medium & \begin{tabular}{c|c}
7.282 .251 .640 & \\
\end{tabular} & Big & 3,18 & Winner & Big|Medium/Winner & $32,92 \%$ & $-12,31 \%$ & $2,63 \%$ & $-11,11 \%$ & $-23,08 \%$ & $1,99 \%$ & $-8,75 \%$ & $4,82 \%$ & $-19,95 \%$ & $11,80 \%$ & $0,59 \%$ & $-1,75 \%$ \\
\hline ECPR4 & Encorpar PN & 3,19 & High & \begin{tabular}{|l|l|}
25.627 .080 \\
\end{tabular} & Small & 0,47 & Loser & Small|High|Loser & $32,29 \%$ & $7,47 \%$ & $-4,95 \%$ & $63,16 \%$ & $6,45 \%$ & $12,12 \%$ & $-0,08 \%$ & $2,79 \%$ & $-1,08 \%$ & $6,41 \%$ & $-0,05 \%$ & $0,05 \%$ \\
\hline PATI4 & Panatlantica PN & 1,10 & High & 169.925 .000 & Small & 0,08 & Loser & Small|High|Loser & $-15,68 \%$ & $-4,99 \%$ & $8,41 \%$ & $-9,09 \%$ & $-6,67 \%$ & $0,00 \%$ & $-7,14 \%$ & $7,69 \%$ & $2,15 \%$ & $-17,90 \%$ & $30,63 \%$ & $2,69 \%$ \\
\hline PNOR5 & Pronor PNA & 1,73 & $\mathrm{H}$ & $\begin{array}{l}9.489 .286 \\
\end{array}$ & Small & 0,07 & Loser & Small|High|Loser & $4,62 \%$ & $-7,35 \%$ & $1,19 \%$ & $2,75 \%$ & $-10,31 \%$ ] & $-2,43 \%$ & $-2,27 \%$ & $-3,26 \%$ | & $-3,85 \%$ & $-0,29 \%$ [ & $6,60 \%$ | & $-4,76 \%$ \\
\hline CMGR4 & Cemat PN & 1,23 & High & $\begin{array}{l}.029 .100 \\
\end{array}$ & Small & 0,04 & Loser & Small|High|Loser & $9,76 \%$ & $5,00 \%$ & $0,53 \%$ & $-8,42 \%$ & $-8,44 \%$ & $16,25 \%$ & $-17,20 \%$ & $19,61 \%$ & $0,00 \%$ & $-11,99 \%$ & $1,27 \%$ & $0,00 \%$ \\
\hline CMGR3 & Cemat ON & 1,23 & High & 869.029 .100 & Small & 0,01 & Loser & Small|High|Loser & $22,17 \%$ & $-11,24 \%$ & $-4,44 \%$ & $1,74 \%$ & $-1,50 \%$ & $15,61 \%$ & $-9,00 \%$ & $1,77 \%$ & $9,89 \%$ & $-5,27 \%$ & $-15,34 \%$ & $-2,50 \%$ \\
\hline CTSA4 & Santanense PN & 0,94 & High & 157.196.000 & Small & 0,05 & Loser & Small|High|Loser & $-25,00 \%$ & $-0,33 \%$ ] & $-12,71 \%$ & $-4,21 \%$ | & $-18,00 \%$ & $12,68 \%$ | & $-11,26 \%$ | & $-4,88 \%$ | $\quad<>$ & $2,56 \%$, & $-20,00 \%$ & $53,30 \%$ & $4,58 \%$ \\
\hline JBDU4 & J B Duarte PN & 1,23 & High & $\begin{array}{ll}40.374 .100 \\
\end{array}$ & Small & 0,12 & Loser & Small|High|Loser & $-12,50 \%$ & $-17,86 \%$ & $4,35 \%$ & $-4,17 \%$ & $-13,04 \%$ & $-15,00 \%$ & $-5,88 \%$ & $-12,50 \%$ & $-14,29 \%$ & $0,00 \%$ & $19,58 \%$ & $-28,57 \%$ \\
\hline BRGE12 & Alfa Consorc PNF & 1,81 & $\mathrm{H}$ & \begin{tabular}{l|l}
27.700 & \\
\end{tabular} & Small & 0,20 & \begin{tabular}{|l} 
Loser \\
\end{tabular} & Small|High|Loser & $-3,55 \%$ & $-4,94 \%$ & $9,76 \%$ & $2,22 \%$ & $8,70 \%$ & $0,00 \%$ & $-4,00 \%$ & $1,05 \%$ & $4,17 \%$ & $0,00 \%$ & $0,00 \%$ & $2,60 \%$ \\
\hline MNDL4 & Mundial PN & 1,79 & High & 141.747 .740 & Small & 0,21 & Loser & Small|High|Loser & $0,00 \%$ & $-10,07 \%$ & $8,96 \%$ & $-4,11 \%$ & $-17,86 \%$ & $-6,09 \%$ & $-7,87 \%$ & $20,60 \%$ & $-10,42 \%$ & $-4,65 \%$ & $1,95 \%$ & $19,51 \%$ \\
\hline SGAS4 & WIm Ind Com PN & 1,11 & High & 212.661 .717 & Small & 0,24 & Loser & Small|High|Loser & $6,16 \%$ & $-6,45 \%$ & $-1,38 \%$ & $15,38 \%$ & $-9,09 \%$ & $-6,63 \%$ & $-18,93 \%$ & $14,77 \%$ & $-0,99 \%$ & $4,00 \%$ & $26,92 \%$ & $-6,06 \%$ \\
\hline FESA4 & Ferbasa PN & 1,69 & High & \begin{tabular}{|l|l|}
517.700 .050 \\
\end{tabular} & Small & 0,26 & \begin{tabular}{|l|l} 
Loser \\
\end{tabular} & Small|High|Loser & $7,03 \%$ | & $-2,13 \%$ & $2,93 \%$ & $10,74 \%$ & $-4,70 \%$ & $1,47 \%$ & $-12,00 \%$ & $27,27 \%$ & $15,18 \%$ & $35,32 \%$ & $53,76 \%$ & $8,86 \%$. \\
\hline BRGE3 & Alfa Consorct & 1,81 & $\mathrm{H}$ & . $127.700 \mid$ & Small & 0,28 & Loser & Small|High|Loser & $0,17 \%$ & $-7,84 \%$ ] & $15,45 \%$ & $-0,79 \%$ & $0,79 \%$ ] & $-5,51 \%$ & $-3,17 \%$ & $-1,11 \%$ | & $-4,39 \%$ & $2,75 \%$ ] & $1,79 \%$ & $2,11 \%$ \\
\hline RNAR3 & Renar ON & 1,95 & High & 0.000 & Small & 0,28 & \begin{tabular}{|l} 
Loser \\
\end{tabular} & Small|High|Loser & $\begin{array}{ll}120,00 \% \\
\end{array}$ & $-19,62 \%$ & $28,57 \%$ & $15,74 \%$ & $3,20 \%$ & $-9,30 \%$ & $-10,26 \%$ & $-0,95 \%$ & $-4,33 \%$ & $80,90 \%$ & $18,33 \%$ & $8,16 \%$ \\
\hline CLSC6 & Celesc PNB & 0,90 & High & 1.631 .305 .680 & Small & 0,30 & Loser & Small|High|Loser & $-6,50 \%$ & $1,96 \%$ & $2,64 \%$ & $20,96 \%$ & $-12,53 \%$ & $6,52 \%$ & $-9,53 \%$ & $7,26 \%$ & $4,75 \%$ & $8,30 \%$ & $3,26 \%$ & $-0,21 \%$ \\
\hline SAPR4 & Sanepar PN & 2,02 & High & \begin{tabular}{|c|c|}
1.195 .350 .595 \\
\end{tabular} & Small & 0,32 & Loser & Small|High|Loser & $4,62 \%$ & $-4,30 \%$ & $-2,08 \%$ & $9,89 \%$ & $-10,29 \%$ & $0,36 \%$ & $-2,18 \%$ & $-3,35 \%$ & $-3,85 \%$ & $6,00 \%$ & $16,60 \%$ & $-4,21 \%$ \\
\hline MEND6 & Mendes Ir PNB & 11,70 & High & 08.858.145 $[\mathrm{s}, \mathrm{s}$ & Small & 0,34 & Loser & Small|High|Loser & $60,98 \%$ | & $-27,27 \%$ & $-0,02 \%$ & $-14,57 \%$ & $4,88 \%$ | & $27,91 \%$ & $-27,27 \%$ & $7,50 \%$ & $0,00 \%$ & $23,26 \%$ & $26,62 \%$ & $-16,37 \%$ \\
\hline IGUA5 & Iguacu & 1,36 & High & & Small & 0,34 & Loser & $S m_{2}$ & $16,50 \%$ & $0,14 \%$ & $42,86 \%$ & $-7,00 \%$ & $3,66 \%$ & $32,97 \%$ & $-2,44 \%$ & $23,67 \%$ & $-18,53 \%$ & $3,31 \%$ & $-19,94 \%$ & $-5,00 \%$ \\
\hline RPAD6 & Alfa Holding PNB & 2,00 & High & \begin{tabular}{|l|}
357.396 .763 \\
\end{tabular} & Small & 0,34 & Loser & Small|High|Loser & $-1,93 \%$ & $-1,81 \%$ & $15,32 \%$ & $10,28 \%$ & $-0,23 \%$ & $-13,44 \%$ & $16,84 \%$ & $-17,23 \%$ & $10,14 \%$ & $3,98 \%$ & $0,48 \%$ & $-1,90 \%$ \\
\hline IGUA6 & Iguacu Cafe PNB & 1,36 & High & 175.517 .000 & Small & 0,36 & Loser & Small|High|Loser & $19,67 \%$ & $-4,11 \%$ & $42,71 \%$ & $-10,91 \%$ & $-1,12 \%$ & $37,34 \%$ & $-3,03 \%$ & $5,36 \%$ & $-4,66 \%$ & $-2,31 \%$ & $-18,11 \%$ & $0,00 \%$ \\
\hline UNIP6 & Unipar PNB & 0,94 & High & $\begin{array}{l}1.886 .141 .820 \\
\end{array}$ & Small & 0,42 & Loser & Small|High|Loser & $-4,17 \%$ & $19,07 \%$ & $-3,21 \%$ & $-2,37 \%$ & \begin{tabular}{|l|l|}
$5,83 \%$ \\
\end{tabular} & $-17,40 \%$ & $-8,38 \%$ & $-1,22 \%$ & $-3,68 \%$ & $7,28 \%$ & $16,78 \%$ & $-12,07 \%$ \\
\hline SZPQ4 & Quattor $\mathrm{P}$ & 1,09 & High & $\begin{array}{l}.100 \mid: \\
\end{array}$ & Small & 0,42 & Loser & Smal & $14,02 \%$ & $74,31 \%$ & $-1,26 \%$ & $0,21 \%$ & $7,13 \%$ & $-0,20 \%$ & $1,69 \%$ & $0,68 \%$ & $3,21 \%$ & $1,90 \%$ & $5,42 \%$ & $-4,42 \%$ \\
\hline IENG5 & lenergia & 1,10 & High & 80 & Small & 0,44 & & Sma & $-9,38 \%$ & $-11,49 \%$ & $7,79 \%$ & $-6,02 \%$ & $-19,23 \%$ & $-3,17 \%$ & $-19,67 \%$ & $-4,08 \%$ & $-23,40 \%$ & $5,56 \%$ & $7,89 \%$ & $-14,63 \%$ \\
\hline MNDL3 & Mundial ON & 1,79 & High & 747.740 & Small & 0,53 & Winner & Small| |High|Winner & $36,33 \%$ & $-31,78 \%$ & $7,53 \%$ & $-6,67 \%$ & $1,79 \%$ & $-32,63 \%$ & $13,54 \%$ & $18,81 \%$ & $-16,60 \%$ & $22,22 \%$ & $-4,91 \%$ & $-15,38 \%$ \\
\hline RPAD5 & Alfa Holding PNA & 2,00 & High & \begin{tabular}{l|l}
396.763 & \\
\end{tabular} & Small & 0,53 & Winner & Small|High|Winner & $24,06 \%$ & $-5,28 \%$ & $-1,96 \%$ & $10,00 \%$ & \begin{tabular}{l|l|}
$-9,09 \%$ \\
\end{tabular} & $0,00 \%$ & $-1,37 \%$ & $-2,33 \%$ & $11,67 \%$ & $-8,10 \%$ & $3,02 \%$ & $-0,45 \%$ \\
\hline INEP4 & Inepar PN & 1,65 & High & & Small & 0,56 & Winner & Small|High|Winner & $-18,21 \%$ & $-1,04 \%$ & $18,87 \%$ & $18,04 \%$ & $-0,52 \%$ & $1,54 \%$ & $5,16 \%$ & $1,22 \%$ & $3,61 \%$ & $9,23 \%$ & $17 \%$ & $4,15 \%$ \\
\hline IENG3 & lenergi & 1,10 & High & & Small & 0,61 & Winner & Sma & $-9,04 \%$ & $-6,43 \%$ & $-16,25 \%$ & $6,72 \%$ & $-13,99 \%$ & $-3,25 \%$ & $-24,37 \%$ & $-15,56 \%$ & $-31,58 \%$ & $13,46 \%$ & $67 \%$ & $-8,33 \%$ \\
\hline ClQU4 & Cacique PN & 1,22 & High & 27.200 & Small & 0,70 & Winne & igh|Winn & $2,08 \%$ & $-3,06 \%$ & $11,58 \%$ & $2,83 \%$ & $-2,94 \%$ & $3,02 \%$ & $-0,18 \%$ & $-0,74 \%$ & $0,00 \%$ & $-5,56 \%$ & $0,20 \%$ & $23,89 \%$ \\
\hline SGEN4 & Sergen PN & 3,4 & High & 57.301 & Small & 0,81 & Winner & Small|High|Winner & $-14,55 \%$ & $-14,47 \%$ & $-2,49 \%$ & $-7,14 \%$ & $-17,58 \%$ & $32,00 \%$ & $-20,71 \%$ & $27,39 \%$ & $-11,00 \%$ & $1,12 \%$ & $18,33 \%$ & $-17,84 \%$ \\
\hline RANI3 & Celul Irani ON & & High & s & Small & 0,83 & Winner & Small|High|Winner & \begin{tabular}{|c|c|}
$35,18 \%$ \\
\end{tabular} & \begin{tabular}{ll|}
$-7,41 \%$ \\
\end{tabular} & $84,31 \%$ & $-9,72 \%$ & $-24,64 \%$ & & $-29,77 \%$ & $42,42 \%$ & $-25,53 \%$ & $5,71 \%$ & $-18,82 \%$ & $23,26 \%$ \\
\hline CTNM4 & Coteminas PN & 1,17 & High & \begin{tabular}{|c|c}
1.822 .830 .285 & \\
\end{tabular} & Small & 0,87 & Winner & Small|High|Winner & $-19,66 \%$ & $-1,24 \%$ & $1,82 \%$ & $11,20 \%$ & $-25,47 \%$ & $0,88 \%$ & $-22,33 \%$ & $19,37 \%$ & $-9,95 \%$ & $-11,63 \%$ & $5,26 \%$ & $-1,25 \%$ \\
\hline EMAE4 & Emae PN & 3,45 & High & \begin{tabular}{l|l}
6.151 &
\end{tabular} & Smal & 89 & Wint & $\mathrm{Sm}_{\mathrm{a}}$ & $-6,12 \%$ & $3,31 \%$ & $-4,89 \%$ & $2,80 \%$ & \begin{tabular}{l|l|}
$6,36 \%$ \\
\end{tabular} & $5,47 \%$ & $-1,94 \%$ & $-0,83 \%$ & $-4,25 \%$ & $-12,97 \%$ & $34,08 \%$ & $6,15 \%$ \\
\hline VGOR4 & Vigor PN & 1,46 & High & \begin{tabular}{l|l}
600 \\
650
\end{tabular} & Small & 9 & Winner & gh|Winner & $0,75 \%$ & $1,85 \%$ & $2,55 \%$ & $1,42 \%$ & $-5,59 \%$ & $1,11 \%$ & $3,66 \%$ & $2,47 \%$ & $16,90 \%$ & $-24,48 \%$ & $16,02 \%$ & $0,34 \%$ \\
\hline RPAD3 & Alfa Holding ON & 2, & High & \begin{tabular}{c|c}
3 & 5 \\
5
\end{tabular} & Small & 1,04 & Winner & Small|High|Winner & $6,94 \%$ & $-14,33 \%$ & $7,14 \%$ & $10,44 \%$ & $-5,43 \%$ & $-1,06 \%$ & $23,07 \%$ & $-25,31 \%$ & $-2,82 \%$ & $8,96 \%$ & $5,56 \%$ & 0,8 \\
\hline UNIP3 & Unipar ON & 0,94 & High & 20 & Small & 1,05 & Winner & Small| & $-4,29 \%$ & $25,35 \%$ & $-13,84 \%$ & $-7,20 \%$ & $-7,46 \%$ & $-3,87 \%$ & $-4,71 \%$ & $-8,48 \%$ & $-10,82 \%$ & $13,81 \%$ & $16,10 \%$ & $-9,49 \%$ \\
\hline CTNM3 & Coteminas $\mathrm{O}$ & 1,17 & $\mathrm{H}$ & \begin{tabular}{l|l}
30.285 & 5 \\
\end{tabular} & Small & 1,08 & Winner & Winner & $21,54 \%$ & $-1,96 \%$ & $0,00 \%$ & $15,92 \%$ & $-20,70 \%$ & $-12,10 \%$ & $-18,81 \%$ & $-2,44 \%$ & $14,87 \%$ & $-2,29 \%$ & $0,11 \%$ & $-0,56 \%$ \\
\hline GPCP3 & GPC Par & 1, & $\mathrm{Hig}$ & & $\mathrm{Sm}$ & & Wing & & t & $-17,45 \%$ & $-4,41 \%$ & 6,91 & $-6,9$ & $-0,46 \%$ & $-10,2$ & & -5, & 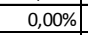 & & $-4,29 \%$ \\
\hline MGEL4 & Mangel & 2, & Hig & & $\mathrm{Sm}$ & & w & $\mathrm{Sm}$ & 12 & $0,56 \%$ & $2,51 \%$ & $8,92 \%$ & 19, & 10, & $-19,7$ & 7,4 & $-6,52 \%$ & $0,87 \%$ & $-0,25 \%$ & -4, \\
\hline UNIP5 & Unipar PNA & 0,94 & High & $\begin{array}{l}1.886 .141 .820 \\
\end{array}$ & Small & 1,27 & Winner & Small|High|Winner & $-25,81 \%$ & $30,90 \%$ & $31,67 \%$ & $-16,46 \%$ & $-14,85 \%$ & $-8,54 \%$ & $1,56 \%$ & $-3,85 \%$ & $22,47 \%$ & $-7,41 \%$ & $8,37 \%$ & 15,8 \\
\hline BDLL4 & Bardella PN & 1,92 & High & 261.846 .000 & Small & 1,46 & Winner & Small|High|Winner & $-4,65 \%$ & $-7,01 \%$ & $4,26 \%$ & $-6,28 \%$ & $-5,37 \%$ & $5,60 \%$ & $40,36 \%$ & $-5,26 \%$ & $-1,99 \%$ & $13,97 \%$ & $14,88 \%$ & $5,06 \%$ \\
\hline RSIP4 & Rasip Agro PI & 0,96 & High & 844.730 & Small & 57 & Winner & Small|High|Winner & $57,63 \%$ & $-18,28 \%$ & $11,84 \%$ & $-9,41 \%$ & \begin{tabular}{l|l|}
$-9,09 \%$ \\
\end{tabular} & $-7,14 \%$ & $-27,69 \%$ & $25,53 \%$ & $-13,56 \%$ & $10,79 \%$ & $7,14 \%$ & $15,00 \%$ \\
\hline SOND6 & & & Hig & & & & & & & $-7,0$ & $-0,1$ & & $-2,0$ & & & & & & & \\
\hline \begin{tabular}{|l|l|} 
JFEN3 \\
\end{tabular} & Joao Fort & 0,5 & High & 4 & Small & 3,26 & Wi & Small|Hi & $-15,24 \%$ & $37,36 \%$ & $24,83 \%$ & $11,76 \%$ & $-8,06 \%$ & $-0,53 \%$ & $-24,19 \%$ & $10,64 \%$ & $-19,87 \%$ & $0,80 \%$ & $9,37 \%$ & $-15,09 \%$ \\
\hline PTNT4 & Pettenati PN & 1, & High & 115.311.231 & Small & 4,05 & Winner & Small|High|Winner & $65,86 \%$ | & $-16,57 \%$ & $5,84 \%$ & $19,26 \%$ & $-12,32 \%$ & $7,77 \%$ & $-8,46 \%$ & $-4,79 \%$ & $0,43 \%$ & $-2,29 \%$ & $-12,10 \%$ & $-4,25 \%$ \\
\hline \begin{tabular}{|l|l|l|l|l|l|} 
SULT4 & \\
\end{tabular} & Sultepa PN & 2,81 & High & \begin{tabular}{|l|l}
69.300 .000 \\
\end{tabular} & Small & 4,64 & Winner & Small|High|Winner & $1,82 \%$ & $-5,36 \%$ & $-8,49 \%$ & $3,09 \%$ & $1,00 \%$ & $21,78 \%$ & $-12,36 \%$ & $-3,53 \%$ & $-0,77 \%$ & $3,68 \%$ & $11,60 \%$ & $8,62 \%$ \\
\hline IXC4 & & 3,4 & 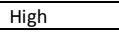 & 410 & & & s. & & $3,58 \%$ & & & & & & 80 & & & & $\pi 0$ & \\
\hline $\mathrm{RP}_{2}$ & exPN & 1,37 & High & \begin{tabular}{c|c}
883.768 & $s$
\end{tabular} & nall & 7,00 & ner & Small|High|Winner & $1,02 \%$ & $16 \%$ & $1 \%$ & & $16 \%$ & ,77\% & $66 \%$ & $71 \%$ &, $00 \%$ & 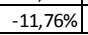 & $899 \%$ & , $12 \%$ \\
\hline
\end{tabular}


Anexo 1 - Retorno mensal e classificação das ações

\begin{tabular}{|c|c|c|c|c|c|c|c|c|c|c|c|c|c|c|c|c|c|c|c|c|}
\hline Código & $2007-2008$ & $\begin{array}{l}\text { Índice } B / M \\
\text { de dez/2006 }\end{array}$ & $\begin{array}{c}\text { Grupo com } \\
\text { base no } \\
\text { indice B/M }\end{array}$ & \begin{tabular}{|c|} 
Valor de Mercado \\
em jun/2007
\end{tabular} & $\begin{array}{c}\text { Grupo com } \\
\text { base no } \\
\text { tamanho }\end{array}$ & $\begin{array}{c}\text { Retorno } \\
\text { acumulado } \\
\text { de jun/2007 }\end{array}$ & \begin{tabular}{|c|} 
Grupo com \\
base no \\
retorno \\
acumulado
\end{tabular} & Carteiras & jul/07 & ago/07 & set/07 & out/07 & nov/07 & dez/07 & $\mathrm{jan} / 08$ & $\mathrm{fev} / 08$ & $\mathrm{mar} / 08$ & $a b r / 08$ & mai/08 & jun/08 \\
\hline CARD3 & Csu Cardsystem ON & 0,23 & Low & 558.578 .000 & Small & 0,22 & Loser & Small|Low|Loser & $-15,91 \%$ & $7,27 \%$ & $-0,75 \%$ & $-4,91 \%$ & $-19,47 \%$ & $-5,43 \%$ & $-19,48 \%$ & $8,42 \%$ & $-4,58 \%$ & $-6,47 \%$ & $9,38 \%$ & $6,12 \%$ \\
\hline DASA3 & Dasa ON & 0,18 & Low & 2.445 .367 .800 & Small & 0,04 & Loser & Small|Low|Loser & $7,04 \%$ & $-3,53 \%$ & $-4,52 \%$ & $-3,14 \%$ & $-14,77 \%$ & $6,43 \%$ & $-17,89 \%$ & $5,61 \%$ & $9,82 \%$ & $9,46 \%$ & $13,87 \%$ & $-5,06 \%$ \\
\hline DSUL3 & Datasul ON & 0,35 & Low & 724.375.000 & Small & 0,26 & Loser & Small|Low|Loser & $-9,20 \%$ & $-10,35 \%$ & $14,99 \%$ & $-0,56 \%$ & $-11,90 \%$ & $-5,78 \%$ & $-21,94 \%$ & $20,61 \%$ & $-1,96 \%$ & $9,77 \%$ & $11,00 \%$ & $8,35 \%$ \\
\hline VLID3 & Valid ON & 0,25 & Low & 1.116 .000 .000 & Small & 0,34 & Loser & Small|Low|Loser & $-0,93 \%$ & $-9,01 \%$ & $-0,85 \%$ & $-6,66 \%$ & $-0,71 \%$ & $-11,92 \%$ & $4,81 \%$ & $3,94 \%$ & $-5,87 \%$ & $2,76 \%$ & $6,27 \%$ & $-7,30 \%$ \\
\hline SLED4 & Saraiva Livr PN & 0,30 & Low & 823.163 .000 & Small & 0,37 & Loser & Small|Low|Loser & $8,31 \%$ & $2,97 \%$ & $-1,82 \%$ & $0,00 \%$ & $5,26 \%$ & $2,94 \%$ & $-11,43 \%$ & $0,61 \%$ & $-12,81 \%$ & $11,98 \%$ & $8,72 \%$ & $-0,46 \%$ \\
\hline ELEK4 & Elekeiroz PN & 0,13 & Low & 1.591 .819 .114 & Small & 0,40 & Loser & Small|Low|Loser & $5,20 \%$ & $-9,64 \%$ & $-8,00 \%$ & $10,87 \%$ & $-18,33 \%$ & $-4,17 \%$ & $-21,28 \%$ & $21,62 \%$ & $-16,22 \%$ & $0,27 \%$ & $19,05 \%$ & $-11,16 \%$ \\
\hline IDNT3 & Ideiasnet ON & 0,23 & Low & 435.176 .490 & Small & 0,43 & Loser & Small|Low|Loser & $17,31 \%$ & $2,04 \%$ & $23,08 \%$ & $19,00 \%$ & $-8,61 \%$ & $1,72 \%$ & $-34,46 \%$ & $3,10 \%$ & $-7,69 \%$ & $-0,54 \%$ & $42,93 \%$ & $-20,13 \%$ \\
\hline TOTS3 & Totvs ON & 0,28 & Low & 1.694 .446 .643 & Small & 0,55 & Winner & Small|Low|Winner & $-9,12 \%$ & $3,97 \%$ & $-1,15 \%$ & $7,59 \%$ & $-4,39 \%$ & $-3,28 \%$ & $-19,49 \%$ & $12,95 \%$ & $2,41 \%$ & $5,60 \%$ & $2,98 \%$ & $-10,43 \%$ \\
\hline PTBL3 & Portobello ON & 0,18 & Low & 594.062.700 & Small & 0,57 & Winner & Small|Low|Winner & $28,14 \%$ & $-9,26 \%$ & $25,00 \%$ & $-22,56 \%$ & $-7,23 \%$ & $-33,18 \%$ & $-40,67 \%$ & $-10,11 \%$ & $-13,13 \%$ & $12,95 \%$ & $33,76 \%$ & $-10,95 \%$ \\
\hline ROMI3 & Inds Romi ON & 0,34 & Low & 1.411 .687 .260 & Small & 0,69 & Winner & Small|Low|Winner & $11,30 \%$ & $-7,50 \%$ & $15,27 \%$ & $5,77 \%$ & $-0,72 \%$ & $0,91 \%$ & $-30,82 \%$ & $10,10 \%$ & $-10,31 \%$ & $9,12 \%$ & $16,16 \%$ & $-12,78 \%$ \\
\hline MYPK3 & lochp-Maxion ON & 0,29 & $\mathrm{w}$ & 131.560 & Small & 0,70 & Winner & Small|Low|Winner & $10,03 \%$ & $-0,06 \%$ & $6,09 \%$ & $5,71 \%$ & \begin{tabular}{l|l}
$0,00 \%$ \\
\end{tabular} & $16,22 \%$ & $-2,33 \%$ & $-11,90 \%$ & $6,49 \%[$ & $-7,91 \%$ & $-7,89 \%$ & $-7,32 \%$ \\
\hline LUPA3 & Lupatech ON & 0,17 & Low & 2.137 .830 .750 & Small & 0,71 & Winner & Small | Low |Winner & $-4,17 \%$ & $-7,03 \%$ & $11,64 \%$ & $-1,08 \%$ & $8,70 \%$ & $20,00 \%$ & $-17,08 \%$ & $7,14 \%$ & $2,35 \%$ & $14,57 \%$ & $1,84 \%$ & $-5,73 \%$ \\
\hline CPNY3 & Company ON & 0,32 & Low & 1.188.099.990 & Small & 1,00 & Winner & Small|Low|Winner & $16,67 \%$ & $-12,23 \%$ & $6,34 \%$ & $18,41 \%$ & $-1,39 \%$ & $-15,07 \%$ & $-13,80 \%$ & $-3,59 \%$ & $-4,27 \%$ & $-13,50 \%$ & $8,75 \%$ & $-10,02 \%$ \\
\hline HGTX3 & Cia Herit & 0,33 & Low & 5.947 .840 & Small & 1,73 & Winner & Small|Low|Winner & $-8,98 \%$ & $-7,16 \%$ & $8,23 \%$ & $7,31 \%$ & $7,62 \%$ & $-12,50 \%$ & $-7,70 \%$ & $-1,04 \%$ & $-5,47 \%$ & $13,59 \%$ & $8,78 \%$ & $-3,73 \%$ \\
\hline REDE3 & Rede Energia ON & 0,65 & Medium & 2.289 .711 .490 & Small & 0,23 & Loser & Small|Medium|Loser & $10,81 \%$ & $-3,73 \%$ & $0,00 \%$ & $6,13 \%$ & $16,75 \%$ & $-1,62 \%$ & $-11,70 \%$ & $-4,07 \%$ & $-3,03 \%$ & $-1,37 \%$ & $-11,53 \%$ & $-10,46 \%$ \\
\hline TNCP4 & Tele Nort CI PN & 0,48 & Medium & 242.926 .896 & Small & 0,21 & Loser & Small|Medium|Loser & $30,95 \%$ & $-3,27 \%$ & $0,30 \%$ & $-1,42 \%$ & $-11,03 \%$ & $13,21 \%$ & $-10,53 \%$ & $10,93 \%$ & $14,79 \%$ & $4,73 \%$ & $0,26 \%$ & $-0,62 \%$ \\
\hline REDE4 & Rede Energia PN & 0,65 & Medium & 2.289 .711 .490 & Small & 0,19 & Loser & Small|Medium |Loser & $1,45 \%$ & $-8,85 \%$ & $4,14 \%$ & $15,23 \%$ & $1,07 \%$ & $2,12 \%$ & $-3,92 \%$ & $3,24 \%$ & $-12,79 \%$ & $8,00 \%$ & $-11,98 \%$ & $-10,80 \%$ \\
\hline UOLL4 & Uol PN & 0,38 & Medium & 1.381 .521 .565 & Small & 0,14 & Loser & Small|Medium|Loser & $-7,83 \%$ & $1,23 \%$ & $9,51 \%$ & $19,32 \%$ & $-10,13 \%$ & $-4,76 \%$ & $-23,33 \%$ & $-7,61 \%$ & $-11,06 \%$ & $-4,65 \%$ & $29,17 \%$ & $-8,60 \%$ \\
\hline RPMG4 & Pet Manguinh PN & 0,45 & Medium & 173.474 .810 & Small & 0,10 & Loser & Small|Medium|Loser & $-4,38 \%$ & $-19,85 \%$ & $0,95 \%$ & $3,77 \%$ & \begin{tabular}{l|l|}
$-8,18 \%$ \\
\end{tabular} & $-2,97 \%$ & $-3,06 \%$ & $-7,37 \%$ & \begin{tabular}{|c|}
$-5,68 \%$ \\
\end{tabular} & $-3,61 \%$ & $22,50 \%$ & $-6,12 \%$ \\
\hline RPMG3 & Pet Manguinh ON & 0,45 & Medium & 173.474 .810 & Small & 0,06 & Loser & Small|Medium|Loser & $-11,39 \%$ & $-7,14 \%$ & $7,69 \%$ & $-1,43 \%$ & $-13,04 \%$ & $-1,67 \%$ & $-16,10 \%$ & $-1,01 \%$ & $-10,20 \%$ & $1,14 \%$ & $26,97 \%$ & $-11,50 \%$ \\
\hline PEAB4 & ParAlE & 0,80 & Medium & & Small & 0,06 & Loser & Small|Mec & $8,77 \%$ & $1,96 \%$ & $5,38 \%$ & $9,49 \%$ & $0,00 \%$ & $3,58 \%$ & $0,00 \%$ & $0,00 \%$ & $3,33 \%$ & $2,58 \%$ & $0,63 \%$ & $0,00 \%$ \\
\hline CTAX3 & Contax ON & 0,43 & Medium & 892.690 .260 & Small & 0,03 & Loser & Small|Medium|Loser & $12,26 \%$ & $2,24 \%$ & $-0,27 \%$ & $0,27 \%$ & $-4,40 \%$ & $-1,15 \%$ & $7,26 \%$ & $-2,70 \%$ & $-16,67 \%$ & $-15,10 \%$ & $19,00 \%$ & $-10,89 \%$ \\
\hline PQUN3 & Petroq Uniao ON & 0,70 & Medium & 1.292 .547 .200 & Small & 0,03 & Loser & Small|Medium|Loser & $-3,15 \%$ & $27,40 \%$ & $-6,55 \%$ & $7,54 \%$ & $-5,00 \%$ & $-0,94 \%$ & $-4,08 \%$ & $2,37 \%$ & $1,75 \%$ & $3,42 \%$ & $0,70 \%$ & $-0,35 \%$ \\
\hline PEFX5 & Petrofl & 0,79 & Medium & & Small & 0,05 & Loser & Small|Me & $11,69 \%$ & $0,00 \%$ & $-6,98 \%$ & $-1,87 \%$ & $-12,10 \%$ & $23,30 \%$ & $2,42 \%$ & $-1,07 \%$ & $1,51 \%$ & $2,38 \%$ & $4,59 \%$ & $2,72 \%$ \\
\hline PEFX3 & Petroflex ON & 0,79 & Medium & 858.331 .700 & Small & 0,06 & Loser & Small|Medium|Loser & $-1,01 \%$ & $8,74 \%$ & $-0,03 \%$ & $-6,49 \%$ & $-3,35 \%$ & $-38,09 \%$ & $-6,43 \%$ & $5,42 \%$ & $-3,59 \%$ & $5,52 \%$ & $1,18 \%$ & $0,29 \%$ \\
\hline TMGC3 & Telemig $\mathrm{Cl} \mathrm{ON}$ & 0,46 & Medium & 2.319 .315 .520 & Small & 0,08 & Loser & Small|Medium|Loser & $6,90 \%$ & $22,58 \%$ & $-2,63 \%$ & $3,24 \%$ & $2,09 \%$ & $-0,49 \%$ & $1,83 \%$ & $5,13 \%$ & \begin{tabular}{l|l}
$4,88 \%$ \\
\end{tabular} & $-2,33 \%$ & $-2,38 \%$ & $-0,98 \%$ \\
\hline MTSA4 & Metisa PN & 0,52 & Medium & 000.000 & Small & $\begin{array}{ll}0,18 \\
\end{array}$ & Loser & Small|Medium |Loser & $-1,55 \%$ & $-0,52 \%$ & $5,26 \%$ & $24,50 \%$ & $-1,61 \%$ & $3,36 \%$ & $-1,17 \%$ & $3,66 \%$ & $-3,96 \%$ & $0,49 \%$ & $3,67 \%$ & $-1,57 \%$ \\
\hline FRAS4 & Fras-Le PN & 0,40 & Medium & 461.262 .748 & Small & 0,24 & Loser & Small|Medium|Loser & $7,35 \%$ & $-3,15 \%$ & $10,33 \%$ & $-3,85 \%$ & $-6,67 \%$ & $-0,24 \%$ & $-15,80 \%$ & $-12,74 \%$ & $-1,58 \%$ & $4,17 \%$ & $9,32 \%$ & $-7,92 \%$ \\
\hline \begin{tabular}{ll|} 
LEVE4 \\
\end{tabular} & Metal Leve PN & 0,39 & Medium & 1.126 .798 .000 & Small & 26 & Loser & Small|Medium|Loser & $-2,70 \%$ & $-6,25 \%$ & $-0,77 \%$ & $-3,25 \%$ & $-1,23 \%$ & $4,62 \%$ & $-8,03 \%$ & $3,04 \%$ & $0,45 \%$ & $-2,42 \%$ & $23,12 \%$ & $6,07 \%$ \\
\hline CTAX4 & Contax PN & 0,43 & Medium & 90.260 & Small & 0,26 & Loser & Small|Medium|Loser & $9,62 \%$ & $-0,76 \%$ & $5,00 \%$ & $-0,73 \%$ & $-4,26 \%$ & $-1,72 \%$ & $-2,55 \%$ & $-2,41 \%$ & $-21,26 \%$ & $2,89 \%$ & $24,68 \%$ & $-4,63 \%$ \\
\hline CEBR5 & Ceb PNA & 0,76 & Medium & 337.914 & Small & 8 & Loser & Small|Medium|Loser & $20,00 \%$ & $3,03 \%$ & $2,94 \%$ & $21,97 \%$ & $0,49 \%$ & $-2,17 \%$ & $-27,40 \%$ & $-0,23 \%$ & $18,39 \%$ & $-2,75 \%$ & $2,86 \%$ & $-5,58 \%$ \\
\hline \begin{tabular}{|l|l|} 
ITECC3 \\
\end{tabular} & Itautec ON & 0,60 & Medium & 759.200 & Small & 39 & Loser & Small|Medium|Loser & $1,01 \%$ & $-15,28 \%$ & $10,45 \%$ & $-12,84 \%$ & $-10,06 \%$ & $2,08 \%$ & $2,92 \%$ & $5,97 \%$ & $-4,78 \%$ & $0,02 \%$ & $-6,67 \%$ & $-7,14 \%$ \\
\hline CEPE5 & Celpe PNA & 0,74 & Medium & 2.204 .107 .260 & Small & 0,41 & Loser & Small|Medium|Loser & $-4,50 \%$ & $2,11 \%$ & $0,00 \%$ & $15,25 \%$ & $-8,12 \%$ & $0,82 \%$ & $-4,14 \%$ & $13,31 \%$ & $-3,17 \%$ & $11,24 \%$ & $0,00 \%$ & $-3,44 \%$ \\
\hline PQUN4 & Petroq Uniao P & 0,70 & Medium & 547.200 & Small & 3 & Lose & nall|Medium|Loser & $-2,50 \%$ & $18,59 \%$ & $2,30 \%$ & $2,38 \%$ & $-3,87 \%$ & $-1,53 \%$ & $-1,84 \%$ & $2,38 \%$ & $1,83 \%$ & $5,46 \%$ & $-2,71 \%$ & $1,14 \%$ \\
\hline LIPR3 & Eletropar ON & 0,45 & Medium & 139.140 & Small & 5 & Winner & Small|Medium|Winner & $5,30 \%$ & $6,63 \%$ & $4,69 \%$ & $7,46 \%$ & $3,47 \%$ & $8,46 \%$ & $4,46 \%$ & $9,29 \%$ & $-8,93 \%$ & $-4,76 \%$ & $5,50 \%$ & $-0,47 \%$ \\
\hline SCAR3 & Sao Carlos ON & 0,40 & Mediu & 1.165 .365 .000 & Small & 0,46 & Winner & Small|Medium|Winner & $15,21 \%$ & $-1,8$ & $0,00 \%$ & $-3,21 \%$ & $-16,39 \%$ & $-5,12 \%$ & $-8,00 \%$ & $-5,14 \%$ & $5,35 \%$ & $-7,71 \%$ & $0,20 \%$ & $-5,60 \%$ \\
\hline TNCP3 & Tele Nort Cl ON & 0,48 & Medium & 242.926 .896 & Small & 0,51 & Winner & Small|Medium|Winner & $12,90 \%$ & $-1,14 \%$ & $1,73 \%$ & $2,27 \%$ & $1,39 \%$ & $-0,27 \%$ & $0,96 \%$ & $3,40 \%$ & $2,64 \%$ & $-0,01 \%$ & $2,56 \%$ & $0,00 \%$ \\
\hline TRFO4 & Trafo PN & 0,66 & Medium & 90.269 .650 & Small & 0,54 & Winner & Small|Medium|Winner & $-3,41 \%$ & $11,11 \%$ & $0,00 \%$ & $4,55 \%$ & $5,65 \%$ & $1,65 \%$ & $-4,86 \%$ & $0,00 \%$ & $2,13 \%$ & $-2,50 \%$ & $1,28 \%$ & $4,64 \%$ \\
\hline \begin{tabular}{|l|} 
DXTG4 \\
\end{tabular} & Dixie Toga & & Mediu & 968.656 .710 & Small & 0,56 & Winner & Small|Medium|Winner & $-3,40 \%$ & & $-9,39 \%$ & $-2,74 \%$ & $-1,25 \%$ & $1,27 \%$ & $-2,51 \%$ & $-5,14 \%$ & $4,07 \%[$ & $21,82 \%$ & 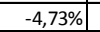 & $11,56 \%$ \\
\hline COCE5 & Coelce PNA & 0,40 & Medium & 2.252 .766 .130 & Small & 0,57 & Winner & Small|Medium|Winner & $5,25 \%$ & $0,40 \%$ & $-1,78 \%$ & $0,00 \%$ & $-11,45 \%$ & $-2,49 \%$ & $-10,70 \%$ & $20,83 \%$ & $4,31 \%$ & $-6,21 \%$ & $7,54 \%$ & $-5,61 \%$ \\
\hline TUPY3 & Tupy ol & 0,54 & Medium & 563.706 .141 & Small & 7 & Winn & Small|Med & $21,46 \%$ & $8,07 \%$ & $10,52 \%$ & 1,40 & $-7,95 \%$ & $-8,58 \%$ & $-12,8$ & $23,57 \%$ & $-1,53 \%$ & $6,38 \%$ & $11,87 \%$ & $-6,82 \%$ \\
\hline GRND3 & Grender & 0,43 & $\mathrm{Me}$ & & Small & 0,60 & Wir & Small|Mec & $0,48 \%$ & $-2,83 \%$ & $-6,88 \%$ & $5,59 \%$ & $-2,87 \%$ & $-4,36 \%$ & $-11,76 \%$ & $7,16 \%$ & $-11,55 \%$ & $1,58 \%$ & $-0,11 \%$ & $1,52 \%$ \\
\hline MRSL4 & Marisol PN & 0,48 & Medium & 516.368 .400 & Small & 0,61 & Winner & Small|Medium|Winner & $-9,78 \%$ & $-27,71 \%$ & $-6,00 \%$ & $3,90 \%$ & $-4,78 \%$ & $2,15 \%$ & $-2,11 \%$ & $3,37 \%$ & $-9,12 \%$ & $-20,08 \%$ & $1,45 \%$ & $-4,76 \%$ \\
\hline CNFB4 & Confab F & 0,40 & Mediun & 2.280 .249 .750 & Small & 0,70 & Winne & Small|M & $-2,07 \%$ & $-2,71 \%$ & $1,25 \%$ & $1870 \mathrm{~T}$ & \begin{tabular}{|l|l|l|}
$-7,14 \%$ \\
\end{tabular} & $3,59 \%$ & $-17,33 \%$ & $9,78 \%$ & \begin{tabular}{|c|}
$-8,00 \%$ \\
\end{tabular} & $24,42 \%$ & $15,25 \%$ & $1,32 \%$ \\
\hline AELP3 & AES Elp & 0 & $\mathrm{Me}$ & & $\mathrm{Sm}$ & & & Small|Med & & & & & $-9,06 \%$ & $-0,96 \%$ & $3,51 \%$ & $\%$ & $-2,22 \%$ & $-2,95 \%$ & $3,80 \%$ & \\
\hline POMO4 & Marcopolo PN & 0,44 & Medium & 1.558 .837 .100 & Small & 0,89 & Winner & Small|Medium|Winner & $14,07 \%$ & $-3,95 \%$ & $9,48 \%$ & $0,23 \%$ & $-12,50 \%$ & $-2,24 \%$ & $-11,81 \%$ & $10,71 \%$ & $-18,21 \%$ & $18,26 \%$ & $13,09 \%$ & $18,21 \%$ \\
\hline $\mathrm{OMO3}$ & arcopolo ON & 0,44 & Medium & 58.837.100 & Small & 0,96 & Winner & Small|Medium|Winner & $15,86 \%$ & $-6,50 \%$ & $1,45 \%$ & $4,86 \%$ | & $-3,27 \%$ & $2,22 \%$ & $-0,87 \%$ & $-9,36 \%$ & $1,45 \%$ | & $3,18 \%$ & $0,15 \%$ & $1,54 \%$ \\
\hline SRN3 & $\mathrm{nON}$ & 0,45 & $\mathrm{um}$ & 1.494 .539 .900 & Small & 0,97 & Ninner & Small|Medium|Winner & $-3,37 \%$ & $-7,78 \%$ & $4,44 \%$ & $18,34 \%$ & $-2,76 \%$ &, $80 \%$ & $4,60 \%$ & $1,10 \%$ & $6,41 \%$ & $5,81 \%$ & $2,31 \%$ & $5,98 \%$ \\
\hline
\end{tabular}


Anexo 1 - Retorno mensal e classificação das ações

\begin{tabular}{|c|c|c|c|c|c|c|c|c|c|c|c|c|c|c|c|c|c|c|c|c|}
\hline Código & 2007 - 2008 & $\begin{array}{l}\text { Índice } B / M \\
\text { de dez/2006 }\end{array}$ & $\begin{array}{c}\text { Grupo com } \\
\text { base no } \\
\text { indice } B / M\end{array}$ & \begin{tabular}{|} 
Valor de Mercado \\
em jun/2007
\end{tabular} & $\begin{array}{c}\text { Grupo com } \\
\text { base no } \\
\text { tamanho }\end{array}$ & $\begin{array}{c}\text { Retorno } \\
\text { acumulado } \\
\text { de jun/2007 }\end{array}$ & \begin{tabular}{c|} 
Grupo com \\
base no \\
retorno \\
acumulado
\end{tabular} & Carteiras & jul/07 & ago/07 & set/07 & out/07 & nov/07 & dez/07 & $\mathrm{jan} / 08$ & fev/08 & $\mathrm{mar} / 08$ & $\mathrm{abr} / 08$ & mai/08 & jun/08 \\
\hline FBMC4 & Fibam PN & 0,47 & Medium & 55.215 .064 & Small & 0,99 & Winner & Small|Medium|Winner & $31,58 \%$ & $2,00 \%$ & $11,76 \%$ & $12,28 \%$ & $-0,01 \%$ & $-5,85 \%$ & $-5,56 \%$ & $-5,98 \%$ & $-14,02 \%$ & $9,54 \%$ & $6,11 \%$ & $-4,80 \%$ \\
\hline TKNO4 & Tekno PN & 0,79 & Medium & 263.900 .000 & Small & 1,03 & Winner & Small|Medium|Winner & $0,00 \%$ & $-3,85 \%$ & $0,00 \%$ & $-6,39 \%$ & $-5,98 \%$ & $3,83 \%$ & $0,91 \%$ & $-1,80 \%$ & $-6,42 \%$ & $72,11 \%$ & $-10,67 \%$ & $-3,36 \%$ \\
\hline ETER3 & Eternit ON & 0,49 & Medium & 792.999.840 & Small & 1,05 & Winner & Small|Medium|Winner & $-7,65 \%$ & $-14,53 \%$ & $-2,91 \%$ & $2,79 \%$ & $-24,59 \%$ & $12,42 \%$ & $-8,45 \%$ & $14,34 \%$ & $-4,02 \%$ & $10,31 \%$ & $29,46 \%$ & $-29,54 \%$ \\
\hline PNVL3 & Dimed ON & 0,78 & Medium & 338.450 .400 & Small & 1,07 & Winner & Small|Medium|Winner & $-20,73 \%$ & $-8,70 \%$ & $3,77 \%$ & $12,73 \%$ & $1,29 \%$ & $2,73 \%$ & $-14,05 \%$ & $-9,09 \%$ & $-24,98 \%$ & $27,97 \%$ & $4,17 \%$ & $10,00 \%$ \\
\hline RHDS3 & M G Poliest ON & 0,57 & Medium & 665.307 .060 & Small & 1,25 & Winner & Small|Medium|Winner & $-6,06 \%$ & $-25,81 \%$ & $-4,35 \%$ & $-18,18 \%$ & $0,00 \%$ & $11,11 \%$ & $-5,00 \%$ & $0,00 \%$ & $-5,26 \%$ & $-5,56 \%$ & $0,00 \%$ & $-5,88 \%$ \\
\hline FITA4 & Forjas Taurus PN & 0,75 & Medium & 874.458 .000 & Small & 1,80 & Winner & Small|Medium|Winner & $7,07 \%$ & $4,72 \%$ & $27,93 \%$ & $5,00 \%$ & $-18,59 \%$ & $-1,42 \%$ & $-20,34 \%$ & $-3,83 \%$ & $-18,69 \%$ & $25,56 \%$ & $22,77 \%$ & $-16,50 \%$ \\
\hline SHUL4 & Schulz PN & 0,69 & Medium & 346.686 .600 & Small & 1,82 & Winner & Small|Medium|Winner & $6,21 \%$ & $4,46 \%$ & $-0,27 \%$ & $-1,15 \%$ & $-0,22 \%$ & $5,69 \%$ & $3,59 \%$ & $-0,98 \%$ & $-0,18 \%$ & $-3,01 \%$ & $-3,44 \%$ & $10,02 \%$ \\
\hline CGRA4 & Grazziotin PN & 0,70 & Medium & 397.633 .020 & Small & 2,24 & Winner & Small|Medium|Winner & $14,24 \%$ & $-8,45 \%$ & $-3,34 \%$ & $6,31 \%$ & $-3,74 \%$ & $0,69 \%$ & $-3,37 \%$ & $0,34 \%$ & $-7,42 \%$ & $-14,95 \%$ & $5,96 \%$ & $-2,85 \%$ \\
\hline LLMD4 & Yara Brasil PN & 0,39 & Medium & 2.248 .224 .000 & Small & 2,26 & Winner & Small|Medium|Winner & $25,00 \%$ & $-2,73 \%$ & $2,80 \%$ & $9,09 \%$ & $-13,33 \%$ & $13,46 \%$ | & $-7,12 \%$ & $2,19 \%$ & $-6,79 \%$ & $21,65 \%$ & $20,69 \%$ & $6,56 \%$ \\
\hline
\end{tabular}

\begin{tabular}{|c|c|c|c|c|c|c|c|c|c|c|c|c|c|c|c|c|c|c|c|c|}
\hline Código & $2008-2009$ & $\begin{array}{l}\text { Índice } B / M \\
\text { de dez/2007 }\end{array}$ & $\begin{array}{c}\text { Grupo com } \\
\text { base no } \\
\text { indice } \mathrm{B} / \mathrm{M}\end{array}$ & $\begin{array}{c}\text { Valor de Mercado } \\
\text { em jun/2008 }\end{array}$ & \begin{tabular}{|c} 
Grupo com \\
base no \\
tamanho
\end{tabular} & $\begin{array}{c}\text { Retorno } \\
\text { acumulado } \\
\text { de jun/2008 }\end{array}$ & \begin{tabular}{|c|} 
Grupo com \\
base no \\
retorno \\
acumulado
\end{tabular} & Carteiras & $\mathrm{jul} / 08$ & ago/08 & set/08 & out/08 & nov/08 & $\mathrm{dez} / 08$ & $\mathrm{jan} / 09$ & fev/09 & $\mathrm{mar} / 09$ & $\mathrm{abr} / 09$ & $\mathrm{mai} / 09$ & jun/09 \\
\hline TNLP3 & Telemar ON & 0,68 & High & 16.140 .919 .600 & Big & 0,27 & Loser & Big|High|Loser & $-11,41 \%$ & $-0,62 \%$ & $6,31 \%$ & $-12,82 \%$ & $8,82 \%$ & $4,59 \%$ & $-7,78 \%$ & $8,37 \%$ & $7,04 \%$ & $8,71 \%$ & $4,09 \%$ & $-13,95 \%$ \\
\hline CESP3 & Cesp ON & 0,78 & High & 9.833 .755 .000 & \begin{tabular}{|l|} 
Big \\
\end{tabular} & 0,25 & Loser & Big|High|Loser & $-8,88 \%$ & $-10,37 \%$ & $-34,01 \%$ & $-45,86 \%$ & $30,90 \%$ & $13,80 \%$ & $-5,74 \%$ & $11,69 \%$ & $1,58 \%$ & $11,26 \%$ & $21,02 \%$ & $9,68 \%$ \\
\hline CESP6 & Cesp PNB & 0,78 & High & 9.833 .755 .000 & Big & 0,24 & Loser & Big|High|Loser & $-11,31 \%$ & $-9,76 \%$ & $-36,83 \%$ & $-39,39 \%$ & $35,00 \%$ & $11,78 \%$ & $-17,16 \%$ & $9,12 \%$ & $-4,69 \%$ & $18,38 \%$ & $13,04 \%$ & $12,91 \%$ \\
\hline ENBR3 & Energias BR ON & 0,85 & High & 5.065 .879 .500 & Big & 0,16 & Loser & Big|High|Loser & $4,70 \%$ & $-14,73 \%$ & $-16,36 \%$ & $-1,76 \%$ & $8,12 \%$ & $-10,67 \%$ & $1,47 \%$ & $5,41 \%$ & $3,63 \%$ & $12,63 \%$ & $4,48 \%$ & $-1,64 \%$ \\
\hline CESP5 & Cesp PNA & 0,78 & High & 9.833 .755 .000 & Big & 0,13 & Loser & Big|High|Loser & $\begin{array}{l}-12,79 \% \\
\end{array}$ & $-5,83 \%$ & $-30,59 \%$ & $-21,29 \%$ & $2,61 \%$ & $11,86 \%$ & $7,58 \%$ & $-1,41 \%$ & $-2,14 \%$ & $9,42 \%$ & $10,55 \%$ & $24,07 \%$ \\
\hline BRKM5 & Braskem PNA & 0,92 & High & 6.945 .485 .144 & Big & 0,09 & Loser & Big|High|Loser & $8,15 \%$ & $-15,36 \%$ & $-12,93 \%$ & $-7,47 \%$ & $-33,48 \%$ & $-11,34 \%$ & $2,88 \%$ & $-5,78 \%$ & $-10,59 \%$ & $28,27 \%$ & $16,05 \%$ & $0,28 \%$ \\
\hline \begin{tabular}{|l|} 
CSMG3 \\
\end{tabular} & Copasa ON & 0,99 & High & 3.405 .967 .650 & Big & 0,08 & Loser & Big|High|Loser & $-1,25 \%$ & $-14,56 \%$ & $-17,96 \%$ & $-32,30 \%$ & $18,17 \%$ & $17,56 \%$ & $1,81 \%$ & $8,56 \%$ & $-6,59 \%$ & $27,26 \%$ & $8,92 \%$ & $-1,73 \%$ \\
\hline BRKM3 & Braskem ON & 0,92 & High & 6.945.485.144 & Big & 0,05 & Loser & Big|High|Loser & $-4,14 \%$ & $-10,80 \%$ & $-7,26 \%$ & $-15,23 \%$ & $-28,13 \%$ & $-20,43 \%$ & $12,93 \%$ & $-3,18 \%$ & $-26,11 \%$ & $33,33 \%$ & $15,50 \%$ & $0,72 \%$ \\
\hline ELET3 & Eletrobras ON & 2,98 & High & 32.636 .644 .301 & Big & 0,03 & Loser & Big|High|Loser & $2,70 \%$ & $-2,96 \%$ & $-4,07 \%$ & $-7,24 \%$ & $2,86 \%$ & $-4,11 \%$ & $1,04 \%$ & $0,15 \%$ & $-1,07 \%$ & $11,11 \%$ & $-1,66 \%$ & $6,74 \%$ \\
\hline \begin{tabular}{|l|} 
UGPA4 \\
\end{tabular} & Ultrapar PN & 0,91 & High & 8.161 .481 .940 & \begin{tabular}{|l|} 
Big \\
\end{tabular} & 0,01 & Winner & Big|High|Winner & $-6,79 \%$ & $3,67 \%$ & $-13,75 \%$ & \begin{tabular}{|l|}
$-20,99 \%$ \\
\end{tabular} & $27,85 \%$ & $-0,35 \%$ & $4,98 \%$ & $2,40 \%$ & $3,46 \%$ & 9,99\% & $5,38 \%$ & $-3,64 \%$ \\
\hline ELET6 & Eletrobras PNB & 2,98 & High & 32.636.644.301 & Big & 0,02 & Winner & Big|High|Winner & $0,69 \%$ & $-4,54 \%$ & $-3,95 \%$ & $-2,70 \%$ & $4,27 \%$ & $-0,90 \%$ & $0,91 \%$ [ & $-0,61 \%$ & $3,42 \%$ & $13,16 \%$ & $-5,16 \%$ & $0,67 \%$ \\
\hline TMAR3 & Telemar N L ON & 0,67 & High & 22.313 .806 .326 & \begin{tabular}{|l|} 
Big \\
\end{tabular} & 0,04 & Winner & Big|High|Winner & $2,49 \%$ & $3,92 \%$ & $-10,47 \%$ & $-31,25 \%$ & $9,09 \%$ & $-2,47 \%$ & $-17,22 \%$ & $14,31 \%$ & $5,69 \%$ & 1,72\% & $10,19 \%$ & $-0,78 \%$ \\
\hline CPLE6 & Copel PNB & 0,94 & High & 8.834.146.577 & Big & 0,08 & Winner & Big|High|Winner & $-1,32 \%$ & $-12,96 \%$ & $-5,71 \%$ & $-9,66 \%$ & $14,80 \%$ & $-12,34 \%$ & $-9,21 \%$ & $2,34 \%$ & $8,07 \%$ & $16,33 \%$ & $4,56 \%$ & $-3,29 \%$ \\
\hline \begin{tabular}{|l|} 
SMTO3 \\
\end{tabular} & Sao Martinho ON & 0,71 & High & 2.926 .700 .000 & Big & 0,09 & Winner & Big|High|Winner & $2,32 \%$ & $-1,89 \%$ & $-29,04 \%$ & $-27,97 \%$ & $-13,47 \%$ & $-20,35 \%$ & $32,64 \%$ & $-10,21 \%$ & $5,41 \%$ & $20,00 \%$ & $23,19 \%$ & $-2,94 \%$ \\
\hline \begin{tabular}{|l|} 
TNLP4 \\
\end{tabular} & $\begin{array}{l}\text { Telemar PN } \\
\end{array}$ & 0,68 & High & 16.140 .919 .600 & \begin{tabular}{|l|} 
Big \\
\end{tabular} & 0,09 & Winner & Big|High|Winner & $-7,44 \%$ & $4,06 \%$ & $-5,59 \%$ & $-13,23 \%$ & $18,83 \%$ & $-3,88 \%$ & $-10,90 \%$ & $15,34 \%$ & $9,61 \%$ & $4,98 \%$ & $2,90 \%$ & $-10,85 \%$ \\
\hline SBSP3 & Sabesp ON & 1,04 & High & 9.341 .276 .000 & Big & 0,11 & Winner & Big|High|Winner & $-5,22 \%$ & $-2,75 \%$ & $-28,57 \%$ & $-5,12 \%$ & $-6,32 \%$ & $18,53 \%$ & $-8,12 \%$ & $-4,22 \%$ & $7,32 \%$ & $20,74 \%$ & $0,78 \%$ & $-5,75 \%$ \\
\hline EBTP4 & Embratel Part PN & 1,18 & $\begin{array}{ll}\text { High } \\
\end{array}$ & 12.970 .861 .230 & \begin{tabular}{|l|} 
Big \\
\end{tabular} & 0,15 & Winner & Big|High|Winner & $-5,52 \%$ & $-25,98 \%$ & $-10,00 \%$ & $-22,22 \%$ & $7,00 \%$ & 9,48\% & $-2,68 \%$ & $5,26 \%$ & $7,14 \%$ & $3,64 \%$ & $21,11 \%$ & $-15,60 \%$ \\
\hline EBTP3 & Embratel Part ON & 1,18 & High & 12.970 .861 .230 & Big & 0,15 & Winner & Big|High|Winner & $7,20 \%$ & $-27,13 \%$ & $-0,67 \%$ & $-27,29 \%$ & $15,38 \%$ & $10,13 \%$ & $-4,36 \%$ & $0,00 \%$ & $13,92 \%$ & $-2,21 \%$ & $17,37 \%$ & $-10,00 \%$ \\
\hline \begin{tabular}{|l|} 
PCAR4 \\
\end{tabular} & P.Acucar-Cbd PN & $0,1,64$ & High & 8.022 .740 .220 & \begin{tabular}{|l|l|} 
Big \\
\end{tabular} & 0,16 & Winner & Big|High|Winner & $4,37 \%$ & $-4,72 \%$ & -2,71\% & | & $13,44 \%$ & $-18,40 \%$ & - $-3,68 \%$ & -3,58\% & $\mid 7,61 \%$ & $13,20 \%$ & \begin{tabular}{|l|}
$8,56 \%$ \\
\end{tabular} & $0,66 \%$ \\
\hline CPLE3 & Copel ON & 0,94 & High & 8.834 .146 .577 & Big & 0,23 & Winner & Big|High|Winner & $-2,19 \%$ & $-7,35 \%$ & $-3,45 \%$ & $-33,93 \%$ & $18,92 \%$ & $0,00 \%$ & $-6,82 \%$ & $-2,44 \%$ & $3,00 \%$ & $20,66 \%$ & $4,65 \%$ & $4,00 \%$ \\
\hline TRPL4 & Tran Paulist PN & 0,71 & High & 7.523 .742 .100 & Big & 0,48 & Winner & Big|High|Winner & $5,56 \%$ & $-15,18 \%$ & $8,15 \%$ & $-16,08 \%$ & $16,83 \%$ & $-11,49 \%$ & $3,19 \%$ & $6,61 \%$ & $6,95 \%$ & $-0,75 \%$ & $-1,79 \%$ & $5,40 \%$ \\
\hline TMAR5 & Telemar N L PNA & 0 & High & 22.313 .806 .326 & \begin{tabular}{|l|} 
Big \\
\end{tabular} & 0,98 & Winner & Big|High|Winner & $6,36 \%$ & $-6,75 \%$ & $-12,50 \%$ & $-9,74 \%$ & $10,21 \%$ & $-3,52 \%$ & $-18,29 \%$ & $2,91 \%$ & $12,06 \%$ & $4,46 \%$ & $4,34 \%$ & $-4,39 \%$ \\
\hline GOLL4 & Gol PN & 0,27 & Low & 3.610 .449 .920 & Big & 0,58 & Loser & Big | Low|Loser & $-10,94 \%$ & $-8,15 \%$ & $-18,49 \%$ & $-21,51 \%$ & $-7,04 \%$ & $13,65 \%$ & $3,43 \%$ & $-8,00 \%$ & $-29,48 \%$ & $13,23 \%$ & $13,55 \%$ & $27,37 \%$ \\
\hline \begin{tabular}{|l|} 
DURA3 \\
\end{tabular} & Duratex-Old ON & 0,29 & Low & 4.133 .319 .120 & Big & 0,42 & Loser & Big|Low|Loser & $-12,43 \%$ & $-5,63 \%$ & $-16,59 \%$ & $-33,53 \%$ & $-15,41 \%$ & $18,13 \%$ & $-8,95 \%$ & $-0,25 \%$ & $9,00 \%$ & $5,28 \%$ & $10,48 \%$ & $43,63 \%$ \\
\hline TAMM4 & Tam S/A PN & 0,23 & Low & 4.561 .553 .040 & Big & 0,41 & Loser & Big|Low|Loser & $5,54 \%$ & $1,00 \%$ & $11,39 \%$ & $-36,14 \%$ & $-32,58 \%$ & $23,16 \%$ & $-9,48 \%$ & $-6,54 \%$ & $-21,36 \%$ & $17,64 \%$ & $12,45 \%$ & $20,24 \%$ \\
\hline \begin{tabular}{|l|l|} 
DURA4 \\
\end{tabular} & Duratex-Old P & 0,29 & Low & 4.133.319.120 & \begin{tabular}{|l|} 
Big \\
\end{tabular} & 0,37 & Loser & Big|Low|Loser & $-16,29 \%$ & $-0,34 \%$ & $-19,38 \%$ & $-15,82 \%$ & $-22,97 \%$ & $-1,37 \%$ & $8,62 \%$ & $-2,18 \%$ & $1,06 \%$ & $13,27 \%$ & $10,77 \%$ & $15,36 \%$ \\
\hline \begin{tabular}{|l|l|l|l|l} 
ALLL4 \\
\end{tabular} & All Amer Lat PN & 0,17 & Low & 12.475 .205 .200 & \begin{tabular}{|l|} 
Big \\
\end{tabular} & 0,31 & Loser & Big|Low|Loser & $5,12 \%$ & $-2,60 \%$ & $-19,33 \%$ & $-36,36 \%$ & $14,94 \%$ & $-3,95 \%$ & $-12,35 \%$ & $-4,03 \%$ & $2,10 \%$ & $24,29 \%$ & $2,78 \%$ & $3,78 \%$ \\
\hline \begin{tabular}{|l|} 
WHRL3 \\
\end{tabular} & Whirlpool ON & 0,30 & Low & 5.097 .574 .770 & Big & 0,28 & Loser & Big|Lo & $-12,46 \%$ & $10,85 \%$ & $-23,24 \%$ & $-6,37 \%$ & $6,22 \%$ & $49,49 \%$ & $-10,67 \%$ & $-0,75 \%$ & $-7,89 \%$ & $30,20 \%$ & $-1,25 \%$ & $11,11 \%$ \\
\hline \begin{tabular}{|l|} 
WHRL4 \\
\end{tabular} & Whirlpool PN & 0,30 & Low & 5.097 .574 .770 & Big & 0,24 & Loser & Big|Low|Loser & $-8,43 \%$ & $-1,90 \%$ & $-11,65 \%$ & $-16,33 \%$ & $14,36 \%$ & $34,72 \%$ & $0,76 \%$ & $-7,55 \%$ & $0,41 \%$ & $27,64 \%$ & $-2,55 \%$ & $23,53 \%$ \\
\hline \begin{tabular}{|l|} 
NATUZ \\
\end{tabular} & Natura ON & 0,09 & Low & 7.064 .442 .000 & Big & 0,22 & Loser & Big|Low|Loser & $14,13 \%$ & $3,26 \%$ & $-2,53 \%$ & $1,08 \%$ & $10,16 \%$ & $-7,82 \%$ & $4,79 \%$ & $9,05 \%$ & $7,99 \%$ & $14,79 \%$ & $-0,38 \%$ & $-0,15 \%$ \\
\hline
\end{tabular}


Anexo 1 - Retorno mensal e classificação das ações

\begin{tabular}{|c|c|c|c|c|c|c|c|c|c|c|c|c|c|c|c|c|c|c|c|c|}
\hline Código & 2008- 2009 & $\begin{array}{l}\text { Índice } B / M \\
\text { de dez/2007 }\end{array}$ & $\begin{array}{c}\text { Grupo com } \\
\text { base no } \\
\text { indice } B / M\end{array}$ & $\begin{array}{c}\text { Valor de Mercado } \\
\text { em jun/2008 }\end{array}$ & $\begin{array}{l}\text { Grupo com } \\
\text { base eo } \\
\text { tamanho }\end{array}$ & $\begin{array}{c}\text { Retorno } \\
\text { acumulado } \\
\text { de jun/2008 }\end{array}$ & \begin{tabular}{|c|} 
Grupo com \\
base no \\
retorno \\
acumulado
\end{tabular} & Carteiras & $\mathrm{jul} / 08$ & ago/08 & set/08 & out/08 & nov/08 & $\operatorname{dez} / 08$ & jan/09 & fev/09 & $\mathrm{mar} / 09$ & $\mathrm{abr} / 09$ & mai/09 & jun/09 \\
\hline BMTO3 & Brasmotor ON & 0,30 & Low & 2.528 .696 .600 & Big & 0,21 & Loser & Big|Low|Loser & \begin{tabular}{l|l|}
$3,53 \%$ \\
\end{tabular} & $-9,09 \%$ & $11,25 \%$ & $-30,74 \%$ & $19,64 \%$ & $16,95 \%$ & $-12,16 \%$ & $-13,85 \%$ & $-3,57 \%$ & $42,59 \%$ & $20,78 \%$ & $22,58 \%$ \\
\hline \begin{tabular}{|l|l|} 
LAME4 \\
\end{tabular} & Lojas Americ PN & 0,02 & Low & \begin{tabular}{|l|l}
7.667 .242 .400 \\
\end{tabular} & Big & 0,18 & Loser & Big|Low|Loser & $13,33 \%$ & $-13,19 \%$ & $-19,17 \%$ & $-28,62 \%$ & $7,38 \%$ & $-2,03 \%$ & $1,91 \%$ & $-11,58 \%$ & $15,58 \%$ & $38,67 \%$ & $4,67 \%$ & $-2,55 \%$ \\
\hline \begin{tabular}{|l|l|} 
BMTO4 & \\
\end{tabular} & Brasmotor PN & 0,30 & Low & 2.528 .696 .600 & Big & 0,17 & Loser & Big|Low|Loser & $-11,11 \%$ & $-10,00 \%$ & $-34,72 \%$ & $-0,97 \%$ & $8,33 \%$ & $33,50 \%$ & $29,79 \%$ & $-8,20 \%$ & $8,93 \%$ & $29,51 \%$ & $0,00 \%$ & $-2,53 \%$ \\
\hline DASA3 & Dasa ON & 0,24 & Low & 2.370 .743 .900 & Big & 0,15 & Loser & Big|Low|Loser & $-8,96 \%$ & $-1,25 \%$ & $-31,46 \%$ & $-1,38 \%$ & $-2,39 \%$ & $-8,24 \%$ & $0,09 \%$ & $4,93 \%$ & $5,04 \%$ & $28,99 \%$ & $6,00 \%$ & $1,45 \%$ \\
\hline ALL11 & All Amer Lat UNT N2 & 0,17 & Low & 12.475.205.200 & Big & 0,12 & Loser & Big|Low|Loser & $1,21 \%$ & $-9,72 \%$ & $-31,03 \%$ & $-22,31 \%$ & $13,86 \%$ & $-13,04 \%$ & $-12,00 \%$ & $-7,16 \%$ & $20,93 \%$ & $15,41 \%$ & $1,68 \%$ & $4,77 \%$ \\
\hline AMBV3 & Ambev ON & 0,22 & Low & 60.465.564.320 & Big & 0,12 & Loser & Big|Low|Loser & $-12,35 \%$ & $6,02 \%$ & $5,86 \%$ & $-12,91 \%$ & $1,06 \%$ & $5,02 \%$ & $-4,62 \%$ & $4,34 \%$ & $10,49 \%$ & \begin{tabular}{l|l}
$7,15 \%$ \\
\end{tabular} & $9,24 \%$ & $-2,04 \%$ \\
\hline \begin{tabular}{|l|l|} 
LAME3 \\
\end{tabular} & Lojas Americ ON & 0,02 & Low & 7.667.242.400 & Big & 0,10 & Loser & Big|Low|Loser & $13,21 \%$ & $-10,00 \%$ & $-10,19 \%$ & $-12,89 \%$ & $0,59 \%$ & $-37,53 \%$ & $1,69 \%$ & $-7,96 \%$ & $15,33 \%$ & $30,05 \%$ & $4,05 \%$ & $2,60 \%$ \\
\hline EKTR4 & Elektro PN & 0,20 & Low & 4.068 .944 .565 & Big & 0,08 & Loser & Big|Low|Loser & $-2,38 \%$ & $6,27 \%$ & $-19,01 \%$ & $-29,41 \%$ & $4,17 \%$ & $-2,40 \%$ & $18,30 \%$ & $-0,14 \%$ & $-10,59 \%$ & $7,49 \%$ & $44,00 \%$ & $4,94 \%$ \\
\hline GETI4 & AES Tiete PN & \begin{tabular}{l|l}
0,07 \\
\end{tabular} & Low & 6.954 .599 .690 & Big & 0,06 & Loser & Big|Low|Loser & $9,17 \%$ & $-15,38 \%$ & $0,85 \%$ & $-12,92 \%$ & $16,30 \%$ & $-0,34 \%$ & $8,22 \%$ & $9,83 \%$ & $-0,28 \%$ & $4,92 \%$ & $5,96 \%$ & $10,57 \%$ \\
\hline RAPT4 & Randon Part PN & 0,23 & Low & 2.485 .433 .280 & Big & 0,06 & Loser & Big|Low|Loser & $-11,85 \%$ & $-4,93 \%$ & $-19,10 \%$ & $-30,30 \%$ & $-8,42 \%$ & $-6,97 \%$ & $-5,90 \%$ & $-14,07 \%$ & $9,07 \%$ & $48,28 \%$ & $15,87 \%$ & $4,17 \%$ \\
\hline GLOB3 & Globex ON & 0,16 & Low & 2.556 .552 .600 & Big & 0,05 & Loser & Big|Low|Loser & $-12,83 \%$ & $-19,50 \%$ & $-13,04 \%$ & $-45,24 \%$ & $-15,94 \%$ & $-12,93 \%$ & $3,96 \%$ & $14,29 \%$ & $7,50 \%$ & $24,81 \%$ & $12,24 \%$ & $14,44 \%$ \\
\hline GET13 & AES Tiete ON & 0,07 & Low & 6.954 .599 .690 & Big & 0,03 & Loser & Big|Low|Loser & $-6,36 \%$ & $-9,26 \%$ & $-11,38 \%$ & $-22,57 \%$ & $24,13 \%$ & $-3,22 \%$ & $4,53 \%$ & $9,20 \%$ & $9,18 \%$ & $3,07 \%$ & $7,35 \%$ & $11,39 \%$ \\
\hline AMBV4 & Amber PN & 0,22 & Low & 60.465 .564 .320 & Big & 0,02 & Loser & Big|Low|Loser & $-6,57 \%$ & $7,87 \%$ & $6,21 \%$ & $-13,33 \%$ & $7,92 \%$ & $3,19 \%$ & $-5,85 \%$ & $0,94 \%$ & $14,05 \%$ & $13,46 \%$ & $4,76 \%$ & $-1,55 \%$ \\
\hline RENT3 & Localiza ON & 0,13 & Low & 9.000 & Big & 0,01 & Loser & Big|Low|Loser & $4,18 \%$ & $-10,87 \%$ & $-39,51 \%$ & $-12,38 \%$ & $-22,66 \%$ & $6,81 \%$ & $15,49 \%$ & $-2,44 \%$ & $1,38 \%$ & $39,84 \%$ & $9,42 \%$ & $-1,71 \%$ \\
\hline RAPT3 & Randon Part ON & 0,23 & Low & $\begin{array}{l}2.485 .433 .280 \\
\end{array}$ & Big & 0,01 & Winner & Big|Low|Winner & $-1,89 \%$ & $-3,71 \%$ & $-20,79 \%$ & $-36,97 \%$ & $-5,24 \%$ & $-10,77 \%$ & $-9,48 \%$ & $-4,76 \%$ & $-10,00 \%$ & $53,97 \%$ & $14,18 \%$ & $3,40 \%$ \\
\hline \begin{tabular}{|l|} 
AEDU11 \\
\end{tabular} & Anhanguera UNT N2 & 0,13 & Low & 3.238 .760 .000 & Big & 0,03 & Winner & Big|Low|Winner & \begin{tabular}{ll|}
$13,38 \%$ \\
\end{tabular} & $-8,20 \%$ & $-33,21 \%$ & $-14,49 \%$ & $-14,95 \%$ & $-10,96 \%$ & $0,74 \%$ & $-10,16 \%$ & $4,93 \%$ & $33,04 \%$ & $30,65 \%$ & $-10,96 \%$ \\
\hline CCRO3 & CCR SA ON & 0,15 & Low & 12.774.296.042 & Big & 0,03 & Winner & Big|Low|Winner & $0,54 \%$ & $-3,13 \%$ & $-16,16 \%$ & $-14,40 \%$ & $5,75 \%$ & $4,42 \%$ & $-3,30 \%$ & $1,44 \%$ & $-10,05 \%$ & $28,09 \%$ & $17,32 \%$ & $1,75 \%$ \\
\hline CRUZ3 & Souza Cruz ON & 0,11 & Low & 13.970 .033 .000 & Big & 0,06 & Winner & Big|Low|Winner & $-3,39 \%$ & $-0,18 \%$ & $6,90 \%$ & $-12,09 \%$ & $14,55 \%$ & $-3,50 \%$ & $6,12 \%$ & $2,56 \%$ & $-4,54 \%$ & $7,18 \%$ & $9,83 \%$ & $8,60 \%$ \\
\hline CGAS3 & Comgas ON & 0,23 & Low & 5.487.598.090 & Big & 0,06 & Winner & Big|Low/Winner & $-6,50 \%$ & $-3,72 \%$ & $-8,21 \%$ & $-25,00 \%$ & $12,28 \%$ & $-0,03 \%$ & $-10,91 \%$ & $1,72 \%$ & $-6,86 \%$ & $13,69 \%$ & $6,90 \%$ & $-0,81 \%$ \\
\hline KLBN4 & Klabin S/A PN & 0,29 & Low & 6.997.542.710 & Big & 0,09 & Winner & Big|Low/Winner & $-10,18 \% \mid$ & $-6,88 \%$ | $>2>$ & $-18,64 \%$ & $\mid-10,61 \%$ & $-4,24 \%$ | & $-2,36 \% \mid$ & $5,74 \%$ & $-12,00 \% \mid$ & $-7,47 \%$ | & $8,42 \%$ & $10,67 \%$ & $-11,54 \%$ \\
\hline CGAS5 & Comgas PNA & 0,23 & Low & 5.487.598.090 & Big & 0,12 & Winner & Big|Low|Winner & $0,33 \%$ & $-5,79 \%$ & $-3,82 \%$ & $-20,73 \%$ & $6,15 \%$ & $-4,14 \%$ & $-5,72 \%$ & $-2,15 \%$ & $-1,84 \%$ & $13,00 \%$ & $10,47 \%$ & $-1,41 \%$ \\
\hline WEGE3 & Weg ON & 0,12 & Low & 12.432.826.055 & Big & 0,17 & Winner & Big|Low|Winner & $-9,79 \%$ | & $-0,56 \%$ & $-20,49 \%$ & $-13,32 \%$ & $-6,50 \%$ & $9,14 \%$ & $-6,80 \%$ & $1,84 \%$ & $0,04 \%$ & $20,12 \%$ & $13,90 \%$ & $-13,35 \%$ \\
\hline ALLL3 & All Amer Lat ON & 0,17 & Low & 12.475.205.200 & Big & 0,17 & Winner & Big|Low|Winner & $22,86 \%$ & $-27,33 \%$ & $-20,00 \%$ & $-17,80 \%$ & $-2,68 \%$ & $-12,00 \%$ & $-19,89 \%$ & $2,84 \%$ & $34,14 \%$ & $3,21 \%$ & $-0,50 \%$ & $3,77 \%$ \\
\hline REDE3 & Rede En & 0,30 & Low & \begin{tabular}{|l|l}
1.914 .257 .860 \\
\end{tabular} & Big & 0,19 & Winner & Big|Low|Winner & $-32,00 \%$ & $5,88 \%$ & $-28,67 \%$ & $86,60 \%$ & $-1,50 \%$ & $-15,25 \%$ & $17,00 \%$ & $-6,15 \%$ & $-12,20 \%$ & $3,73 \%$ & $-14,00 \%$ & $-13,95 \%$ \\
\hline TBLE3 & Tractebel ON & 0,20 & Low & 15.600 .538 .389 & Big & 0,22 & Winner & Big|Low|Winner & $0,54 \%$ & $-12,50 \%$ & $2,73 \%$ & $-17,39 \%$ & $14,64 \%$ & $-4,04 \%$ & $-3,29 \%$ & $-0,84 \%$ & $-3,32 \%$ & $5,17 \%$ & $1,44 \%$ & $3,27 \%$ \\
\hline $\begin{array}{ll}\text { LREN3 } \\
\end{array}$ & Lojas Renner ON & 0,13 & Low & \begin{tabular}{|c|}
3.876 .034 .160 \\
\end{tabular} & Big & 0,22 & Winner & Big|Low|Winner & $-1,54 \%$ & $-6,02 \%$ & $-20,34 \%$ & $-33,19 \%$ & $-15,41 \%$ & $20,16 \%$ & $-9,70 \%$ & $-0,35 \%$ & $1,06 \%$ & $40,90 \%$ & $8,60 \%$ & $-0,46 \%$ \\
\hline CYRE3 & Cyrela Realty ON & 0,24 & Low & 7.875 .242 .280 & Big & 0,26 & Winner & Big|Low|Winner & $2,98 \%$ & $-10,13 \%$ & $-4,83 \%$ & $-45,64 \%$ & $-26,04 \%$ & $17,35 \%$ & $1,09 \%$ & $24,30 \%$ & $30,40 \%$ & $48,26 \%$ & $12,48 \%$ & $-1,66 \%$ \\
\hline REDE4 & Rede Energia PN & 0,30 & Low & 1.914 .257 .860 & Big & 0,27 & Winner & Big|Low|Winner & $-24,84 \%$ & $34,73 \%$ & $-22,36 \%$ & $9,80 \%$ & $9,29 \%$ & $-6,67 \%$ & $7,14 \%$ & $-11,67 \%$ & $-7,92 \%$ & $-14,55 \%$ & $-5,28 \%$ & $-8,86 \%$ \\
\hline CPFE3 & CPFL Energia ON & 0,31 & Low & \begin{tabular}{|l|l|}
17.420 .767 .049 \\
\end{tabular} & Big & 0,27 & Winner & Big|Low|Winner & 0,14\% & $-3,08 \%$ & $4,41 \%$ & $-10,14 \%$ & $0,03 \%$ & $-5,52 \%$ & $-0,33 \%$ & $4,66 \%$ & $4,44 \%$ & $5,71 \%$ & $-3,87 \%$ & $-0,56 \%$ \\
\hline AVIL3 & Acos Vill ON & 0,26 & Low & 3.951 .666 .000 & Big & 0,31 & Winner & Big/Low/Winner & $-8,33 \%$ & $9,27 \%$ & $-24,37 \%$ & $-43,33 \%$ & $1,90 \%$ & $-1,96 \% \mid$ & $-8,00 \%$ & $7,96 \%$ & $-6,12 \%$ & $28,26 \%$ & $10,17 \%$ & $6,80 \%$ \\
\hline BRAP3 & Bradespar ON & 0,23 & Low & \begin{tabular}{l|l}
5.224 .885 .750 \\
\end{tabular} & Big & 0,33 & $\begin{array}{l}\text { Winner } \\
\end{array}$ & Big|Low|Winner & $-16,28 \%$ & $-9,44 \%$ & $-18,71 \%$ & $-27,21 \%$ & $-0,12 \%$ & $-1,12 \%$ & $14,66 \%$ & $-0,94 \%$ & $-5,24 \%$ & $25,63 \%$ & $14,49 \%$ & $-11,63 \%$ \\
\hline BRAP4 & Bradespar PN & 0,23 & Low & 15.224 .885 .750 & Big & 0,37 & Winner & Big|Low|Winner & $-18,55 \%$ & $-8,68 \%$ & $-18,10 \%$ & $-26,59 \%$ & $1,19 \%$ & $-0,10 \%$ & $22,05 \%$ & $-4,31 \%$ & $1,07 \%$ & $18,86 \%$ & $9,92 \%$ & $-11,33 \%$ \\
\hline VALE5 & Vale PNA & 0,21 & Low & 259.054 .245 .900 & Big & 0,48 & Winner & Big|Low|Winner & $-14,36 \%$ & $-6,98 \%$ & $-13,92 \%$ & $-20,08 \%$ & $-3,50 \%$ & $-2,53 \%$ & $17,25 \%$ & $-4,21 \%$ & $-0,30 \%$ & $15,94 \%$ & $6,63 \%$ & $-8,15 \%$ \\
\hline CEEB3 & Coelba ON & 0,22 & Low & 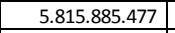 & Big & 0,51 & Winne & Big|Low|Winner & $-9,71 \%$ & $9,44 \%$ & $-1,64 \%$ & $-3,33 \%$ & $3,67 \%$ & $10,53 \%$ & $0,70 \%$ & $-2,56 \%$ & $-2,89 \%$ & $-1,38 \%$ & $10,00 \%$ & $12,91 \%$ \\
\hline $\begin{array}{l}\text { VALE3 } \\
\end{array}$ & Vale ON & 0,21 & Low & 259.054.245.900 & Big & 0,53 & Winner & Big|Low|Winner & $-17,53 \%$ & $-8,17 \%$ & $-15,92 \%$ & $-20,24 \%$ & $-3,03 \%$ & $0,58 \%$ & $17,37 \%$ & $-5,02 \%$ & $0,42 \%$ & $18,11 \%$ & $5,38 \%$ & $-9,26 \%$ \\
\hline LUPA3 & Lupatech ON & 0,09 & Low & 2.853 .636 .900 & Big & 0,59 & Winner & Big|Low|Winner & $-1,67 \%$ & $3,39 \%$ & $-40,98 \%$ & $-48,61 \%$ & $-2,16 \%$ & $29,34 \%$ & $5,51 \%$ & $-5,22 \%$ & $5,08 \%$ & $12,03 \%$ & $-2,98 \%$ & $-7,55 \%$ \\
\hline ILMD4 & Yara Brasil PN & 0,19 & Low & 4.056.511.440 & Big & 0,81 & Winner & Big|Low|Winner & $-1,75 \%$ & $-10,38 \%$ & $1,92 \%$ & $-42,03 \%$ & $24,97 \%$ & $-20,00 \%$ & $10,00 \%$ & $-20,44 \%$ & $-4,29 \%$ & $19,10 \%$ & $15,04 \%$ & $-8,54 \%$ \\
\hline PETR4 & Petrobras PN & 0,27 & Low & 457.401 .125 .240 & Big & 0,88 & Winner & Big|Low|Winner & $-22,31 \%$ & $-2,79 \%$ & $0,57 \%$ & $-33,59 \%$ & $-13,94 \%$ & $18,00 \%$ & $9,59 \%$ & $5,47 \%$ & $8,14 \%$ & $4,66 \%$ & $16,62 \%$ & $-5,81 \%$ \\
\hline FFTL4 & Valefert PN & 0,17 & Low & 13.418.549.751 & Big & 0,95 & Winner & Big|Low|Winner & $-16,26 \%$ & $-5,16 \%$ & $-35,11 \%$ & $-24,00 \%$ & $-5,18 \%$ & $1,64 \%$ & $18,17 \%$ & $9,09 \%$ & $-5,56 \%$ & $22,28 \%$ & $-0,18 \%$ & $-9,94 \%$ \\
\hline PETR3 & Petrobras ON & 0,27 & Low & 457.401.125.240 & $\mathrm{Big}$ & 1,00 & Winner & Big/Low/Winner & $-22,16 \%$ & $-2,91 \%$ & $-1,03 \%$ & $-32,24 \%$ & $-16,99 \%$ & $19,30 \%$ & $10,48 \%$ & $7,67 \%$ & $8,20 \%$ | & $5,08 \%$ & $17,16 \%$ & $-7,11 \%$ \\
\hline \begin{tabular}{|l|l|} 
MMXM3 \\
\end{tabular} & MMX Miner ON & 0,13 & Low & \begin{tabular}{l|l|}
15.078 .195 .000 \\
\end{tabular} & Big & 1,02 & Winner & Big|Low|Winner & $-17,73 \%$ & $-8,21 \%$ & $-44,34 \%$ & $-55,62 \%$ & $-18,23 \%$ & $-14,24 \%$ & $54,15 \%$ & $-27,17 \%$ & $7,07 \%$ & $100,30 \%$ & $2,10 \%$ & $-8,08 \%$ \\
\hline CSNA3 & Sid Nacional ON & 0,19 & Low & 55.001 .715 .600 & Big & 1,30 & Winner & Big|Low|Winner & $-14,24 \%$ & $-7,47 \%$ & $-27,88 \%$ & $-29,55 \%$ & $-9,82 \%$ & $12,01 \%$ & $21,31 \%$ & $-10,89 \%$ & $16,22 \%$ & $17,06 \%$ & $21,50 \%$ & $10,06 \%$ \\
\hline GUAR3 & Guararapes ON & 0,33 & Medium & 2.994 .888 .000 & Big & 0,46 & Loser & Big|Medium|Loser & $-23,47 \%$ & $-14,67 \%$ & $-14,69 \%$ & $-37,73 \%$ & $1,47 \%$ & $4,35 \%$ & $-13,33 \%$ & $-1,99 \%$ & $4,25 \%$ & $25,83 \%$ & $24,04 \%$ & $15,27 \%$ \\
\hline JHSF3 & JHSF & & & & Big & 0,43 & Los & & & & $-50,7$ & $-39,39 \%$ & $17,50 \%$ & & & & $-18,92 \%$ & & & \\
\hline GUAR4 & Guararapes PN & 0,33 & Medium & 2.994.888.000 & Big & 0,39 & Loser & Big|Medium|Loser & $-19,34 \%$ | & $-12,93 \%$ & $-25,76 \%$ & $-42,82 \%$ & $-0,07 \%$ & $10,71 \%$ & $-3,23 \%$ & $3,00 \%$ & $-2,91 \%$ & $10,04 \%$ & \begin{tabular}{|l|l|}
$48,75 \%$ \\
\end{tabular} & $-1,81 \%$ \\
\hline ALPA4 & Alpargatas PN & 0,34 & Medium & 2.122 .992 .000 & Big & 0,34 & Loser & Big|Medium|Loser & $2,50 \%$ & $-28,02 \%$ & $-17,00 \%$ & $-38,94 \%$ & $13,63 \%$ & $14,05 \%$ & $15,96 \%$ & $-12,29 \%$ & $8,82 \%$ & $44,65 \%$ & $8,49 \%$ & $-1,25 \%$ \\
\hline NETC4 & Jet PN & 0,33 & Medium & \begin{tabular}{|c|}
7.126 .244 .410 \\
\end{tabular} & & & oser & Big|Medium|Loser & & $15 \%$ & 6/\% & $-15,47 \%$ & , I5\% & $20 \%$ & $88 \%$ & 2 & 2,81 & $4, / 4 \%$ & $10,89 \%$ & $-4,28 \%$ \\
\hline
\end{tabular}


Anexo 1 - Retorno mensal e classificação das ações

\begin{tabular}{|c|c|c|c|c|c|c|c|c|c|c|c|c|c|c|c|c|c|c|c|c|}
\hline Código & 2008- 2009 & $\begin{array}{l}\text { Índice } B / M \\
\text { de dez/2007 }\end{array}$ & $\begin{array}{c}\text { Grupo com } \\
\text { base no } \\
\text { indice } B / M\end{array}$ & $\begin{array}{c}\text { Valor de Mercado } \\
\text { em jun/2008 }\end{array}$ & $\begin{array}{l}\text { Grupo com } \\
\text { base eo } \\
\text { tamanho }\end{array}$ & $\begin{array}{c}\text { Retorno } \\
\text { acumulado } \\
\text { de jun/2008 }\end{array}$ & \begin{tabular}{|c|} 
Grupo com \\
base no \\
retorno \\
acumulado
\end{tabular} & Carteiras & $\mathrm{jul} / 08$ & ago/08 & set/08 & out/08 & nov/08 & $\operatorname{dez} / 08$ & jan/09 & fev/09 & $\mathrm{mar} / 09$ & $\mathrm{abr} / 09$ & mai/09 & jun/09 \\
\hline ALPA3 & Alpargatas ON & 0,34 & Medium & 2.122.992.000 & Big & 0,27 & Loser & Big|Medium|Loser & $-11,62 \%$ & $4,25 \%$ & $-13,70 \%$ & $0,68 \%$ & $-2,83 \%$ & $-0,73 \%$ & $23,56 \%$ & $6,19 \%$ & \begin{tabular}{l|l}
$0,87 \%$ \\
\end{tabular} & $23,21 \%$ & $16,85 \%$ & $0,13 \%$ \\
\hline EMBR3 & Embraer ON & 0,36 & Medium & \begin{tabular}{|l|l|}
7.721 .506 .019 \\
\end{tabular} & Big & 0,23 & Loser & Big|Medium|Loser & $12,00 \%$ & $15,73 \%$ & $-4,37 \%$ & $-14,12 \%$ & $-23,91 \%$ & $2,92 \%$ & $-1,36 \%$ & $-24,17 \%$ & $17,91 \%$ & $13,90 \%$ & $9,60 \%$ & $15,98 \%$ \\
\hline MDIA3 & M. Diasbranco ON & 0,34 & Medium & 2.615 .560 .000 & Big & 0,21 & Loser & Big|Medium|Loser & $-8,70 \%$ & $-0,95 \%$ & $-2,88 \%$ & $-19,80 \%$ & $18,52 \%$ & $3,07 \%$ & $-8,03 \%$ & $4,40 \%$ & $-5,26 \%$ & $27,17 \%$ & $7,74 \%$ & $17,86 \%$ \\
\hline \begin{tabular}{|l|l|} 
VIVO3 \\
\end{tabular} & Vivo ON & 0,53 & Medium & \begin{tabular}{|l|l}
15.363 .469 .230 \\
\end{tabular} & Big & 0,18 & Loser & Big|Medium|Loser & $-11,64 \%$ & $-3,06 \%$ & $-7,61 \%$ & $-29,41 \%$ & $28,75 \%$ & $-8,41 \%$ & $14,85 \%$ & $20,48 \%$ & $-22,01 \%$ & $19,05 \%$ & $19,94 \%$ & $-13,41 \%$ \\
\hline TCSL4 & Tim Part S/A PN & 0,48 & Medium & 11.821 .509 .540 & Big & 0,17 & Loser & \begin{tabular}{|l|} 
Big|Medium|Loser \\
\end{tabular} & $-9,87 \%$ & $-12,65 \%$ & $10,03 \%$ & $-20,76 \%$ & $22,68 \%$ & $-23,18 \%$ & $13,22 \%$ & $0,60 \%$ & $-13,99 \%$ & $32,22 \%$ & $7,90 \%$ & $-12,12 \%$ \\
\hline BRML3 & BR Malls Par ON & 0,43 & Medium & 2.655 .072 .500 & Big & 0,13 & Loser & Big|Medium|Loser & $-6,19 \%$ & $-0,28 \%$ & $-20,69 \%$ & $-30,43 \%$ & $18,12 \%$ & $-3,70 \%$ & $18,68 \%$ & $11,11 \%$ & $20,00 \%$ & $13,75 \%$ & $3,42 \%$ & $-12,04 \%$ \\
\hline RSID3 & Rossi Resid ON & 0,33 & Medium & 1.874.299.536 & Big & 0,10 & Loser & Big|Medium|Loser & $4,58 \%$ & $-20,32 \%$ & $-46,00 \%$ & $-18,33 \%$ & $-22,00 \%$ & $9,88 \%$ & $18,78 \%$ & $-26,50 \%$ & $12,12 \%$ & \begin{tabular}{l|l}
$104,05 \%$ \\
\end{tabular} & $9,43 \%$ & $1,23 \%$ \\
\hline LIGT3 & Light S/A ON & 0,46 & Medium & \begin{tabular}{|l|l}
4.679 .642 .997 \\
\end{tabular} & Big & 0,09 & Loser & Big|Medium|Loser & $8,70 \%$ & $-8,40 \%$ & $3,45 \%$ & $-5,49 \%$ & $16,56 \%$ & $-8,95 \%$ & $8,23 \%$ & $8,03 \%$ & $-4,27 \%$ & $7,39 \%$ & $3,44 \%$ & $9,37 \%$ \\
\hline CNFB4 & Confab PN & 0,41 & Medium & 2.543 .340 .150 & Big & 0,09 & Loser & Big|Medium|Loser & $-8,27 \%$ & $1,06 \%$ & $-16,69 \%$ & $-24,83 \%$ & $-19,44 \%$ & $19,05 \%$ & $0,80 \%$ & $12,96 \%$ & $-6,32 \%$ & $14,74 \%$ & $13,77 \%$ & $8,68 \%$ \\
\hline CMIG3 & Cemig ON & 0,52 & Medium & 18.142.586.880 & Big & 0,09 & Loser & Big|Medium|Loser & $-4,14 \%$ & $-7,17 \%$ & $5,45 \%$ & $-27,05 \%$ & $14,78 \%$ & $-5,11 \%$ & $-6,19 \%$ & $0,81 \%$ & $\begin{array}{l}9,67 \% \\
\end{array}$ & $4,65 \%$ & $-1,58 \%$ & $3,01 \%$ \\
\hline CBEE3 & Ampla Energ ON & 0,35 & Medium & 4.275.542.351 & Big & 0,08 & Loser & Big|Medium|Loser & $-11,93 \%$ & $-1,04 \%$ & $-21,05 \%$ & $4,00 \%$ & $-14,10 \%$ & $16,42 \%$ & $-7,69 \%$ & $11,11 \%$ & $-1,25 \%$ & $15,19 \%$ & $3,80 \%$ & $-5,43 \%$ \\
\hline \begin{tabular}{|l|l|} 
CMIG4 \\
\end{tabular} & Cemig PN & 0,52 & Medium & 18.142.586.880 & Big & 0,03 & Loser & Big|Medium|Loser & $-4,45 \%$ & $-5,28 \%$ & $6,85 \%$ & $-12,23 \%$ & $10,61 \%$ & $-12,96 \%$ & $-1,01 \%$ & $5,72 \%$ & $3,73 \%$ & $2,09 \%$ & $-0,60 \%$ & $-0,53 \%$ \\
\hline ITSA4 & Itausa PN & 0,36 & Medium & 49.957.218.170 & Big & 0,04 & Winner & Big|Medium|Winner & $1,38 \%$ | & $-7,14 \% \mid$ & $0,05 \%$ & $-24,37 \%$ & $14,58 \%$ & $-2,74 \% \mid$ & $-8,12 \%$ & $-3,42 \% \mid$ & $17,60 \% \mid$ & $17,69 \%$ & $5,80 \%$ & $-2,47 \%$ \\
\hline ARCZ3 & Aracruz & 0,37 & dium & 5.720 & Big & 0,06 & Winner & Big|Medium/Winner & $-5,33 \%$ & $-28,08 \%$ & $-38,57 \%$ & $-38,71 \%$ & $-15,15 \%$ & $9,34 \%$ & $228,89 \%$ & $-2,29 \%$ & $11,34 \%$ & $4,00 \%$ & $2,63 \%$ & $-1,64 \%$ \\
\hline JBSS3 & JBS ON & 0,47 & Medium & 11.489 .274 .900 & Big & 0,07 & Winner & Big $\mid$ Medium $\mid$ Winner & $3,70 \%$ & $-21,07 \%$ & $-28,51 \%$ & $-16,67 \%$ & $27,85 \%$ & $-2,38 \%$ & $-2,64 \%$ & $-3,96 \%$ & $13,88 \%$ & $17,49 \%$ & $9,25 \%$ & $4,46 \%$ \\
\hline \begin{tabular}{|l|} 
MRFG3 \\
\end{tabular} & Marfrig ON & 0,41 & Medium & 4.227.674.596 & Big & 0,07 & Winner & Big|Medium|Winner & $-6,55 \%$ & $-15,47 \%$ & $7,32 \%$ & $-40,31 \%$ & $-18,10 \%$ & $-12,79 \%$ & $-9,33 \%$ & $2,94 \%$ & \begin{tabular}{l|l}
$9,57 \%$ \\
\end{tabular} & $44,72 \%$ & $31,08 \%$ & $-0,34 \%$ \\
\hline GFSA3 & Gafisa ON & 0,36 & Medium & 946.580 & Big & 0,12 & Winner & Big|Medium|Winner & $-2,39 \%$ & $-13,56 \%$ & $3,26 \%$ & $-36,68 \%$ & $-42,60 \%$ & $19,75 \%$ & $11,53 \%$ & $15,30 \%$ & $17,56 \%$ & $62,92 \%$ & $-5,21 \%$ & $-7,92 \%$ \\
\hline TMCP3 & Telemig Par & 0,47 & Medium & 2.700 .941 .920 & Big & 0,13 & Winner & Big|Medium|Winner & $3,14 \%$ & $1,16 \%$ & $-36,63 \%$ & $53,74 \%$ & $-35,36 \%$ & $-58,49 \%$ & $7,26 \%$ & $25,96 \%$ & $15,53 \%$ & $8,05 \%$ & $14,89 \%$ & $12,00 \%$ \\
\hline BRTP3 & Brasil T Par ON & 0,43 & Medium & \begin{tabular}{|l|l}
12.454 .022 .029 \\
\end{tabular} & Big & 0,15 & Winner & Big|Medium|Winner & $-3,30 \%$ & $4,78 \%$ & $-3,17 \%$ & $-10,58 \%$ & $19,44 \%$ & $6,45 \%$ & $1,44 \%$ & $1,00 \%$ & $1,69 \%$ & $2,66 \%$ & $1,35 \%$ & $-46,77 \%$ \\
\hline AELP3 & AES Elpa ON & 0,52 & Medium & 2.328 .043 .890 & Big & 0,16 & Winner & Big|Medium|Winner & $1,27 \%$ & $3,36 \%$ & $-1,67 \%$ & $-25,28 \%$ & $-12,28 \%$ & $10,73 \%$ & $-1,39 \%$ & $26,40 \%$ & $30,23 \%$ & $23,76 \%$ & $-3,23 \%$ & $23,00 \%$ \\
\hline TRNA11 & Taesa UNT N2 & 0,51 & Medium & 2.810.227.552 & Big & 0,16 & Winner & Big|Medium|Winner & $-4,85 \%$ & $-8,47 \%$ & $-9,26 \%$ & $-31,84 \%$ & $22,75 \%$ & $7,27 \%$ & $-13,60 \%$ & $5,32 \%$ & \begin{tabular}{l|l|}
$12,52 \%$ \\
\end{tabular} & $63,77 \%$ & $1,58 \%$ & $1,80 \%$ \\
\hline BRTP4 & Brasil T Par PN & 0,43 & Medium & 12.454.022.029 & Big & 0,18 & Winner & Big|Medium/Winner & $2,08 \%$ & $-12,82 \%$ & $-10,99 \%$ & $-16,90 \%$ & $19,05 \%$ & $-4,77 \%$ & $-12,12 \%$ & $-1,96 \%$ & $11,67 \%$ & $1,13 \%$ & $4,78 \%$ & $-13,75 \%$ \\
\hline ARCZ6 & Aracruz PNB & 0,37 & Medium & 430.365 .720 & Big & 0,19 & Winner & Big|Medium|Winner & $-7,00 \%$ & $-17,71 \%$ & $-24,22 \%$ & $-61,96 \%$ & $-25,00 \%$ & $29,69 \%$ & $-20,08 \%$ & $-14,07 \%$ & \begin{tabular}{|c|c|c|}
$-9,94 \%$ \\
\end{tabular} & $72,08 \%$ & $29,81 \%$ & $-15,41 \%$ \\
\hline ITSA3 & Itausa ON & 0,36 & Medium & 3.170 & Big & 21 & Winr & Big|Medium|Winner & $-4,24 \%$ & $-5,62 \%$ & $-7,97 \%$ & $-19,30 \%$ & $-5,65 \%$ & $4,56 \%$ & $-2,55 \%$ & $-6,82 \%$ & $0,40 \%$ & $7,30 \%$ & $8,01 \%$ & $-5,10 \%$ \\
\hline SDIA3 & Sadia S/A ON & 0,43 & Medium & $\begin{array}{l}7.629 .487 .760 \\
\end{array}$ & Big & 0,23 & Winner & Big $\mid$ Medium $\mid$ Winner & $0,51 \%$ & $-4,42 \%$ & $-30,28 \%$ & $-12,48 \%$ & $-25,04 \%$ & $-11,94 \%$ & $27,59 \%$ & $-9,55 \%$ & $-5,18 \%$ & $6,09 \%$ & $-2,77 \%$ & $-4,68 \%$ \\
\hline PDGR3 & PDG Realt ON & 0,37 & Medium & \begin{tabular}{l|l}
41.962 .890 \\
\end{tabular} & Big & 0,23 & Winner & Big|Medium|Winner & $2,71 \%$ & $-16,50 \%$ & $-31,48 \%$ & $-16,13 \%$ & $-19,24 \%$ & $23,74 \%$ & $10,76 \%$ & $-14,98 \%$ & $23,24 \%$ & $59,20 \%$ & $9,03 \%$ & $-5,21 \%$ \\
\hline TMCP4 & Telemig & 0,47 & Medium & 920 & Big & 24 & Winner & Big|Medium /Winner & $-1,99 \%$ & $-9,92 \%$ & $-13,49 \%$ & $-6,92 \%$ & $7,46 \%$ & $-5,56 \%$ & $10,31 \%$ & $23,80 \%$ & $1,18 \%$ & $17,51 \%$ & $13,54 \%$ & $7,51 \%$ \\
\hline ELPL5 & Eletropaulo PNA & 0,55 & Medium & 86.320 .799 & Big & 0,26 & Winner & Big $\mid$ Medium $\mid$ Winner & $1,59 \%$ & $-3,10 \%$ & $-11,30 \%$ & $-7,84 \%$ & $-2,34 \%$ & $10,90 \%$ & $4,00 \%$ & $9,62 \%$ & $8,77 \%$ & $7,47 \%$ & $2,21 \%$ & $6,67 \%$ \\
\hline SDIA4 & Sadia S/A PN & 0,43 & Medium & 87.760 & Big & 0,27 & Winner & Big|Medium/Winner & $1,42 \%$ & $-5,94 \%$ & $-47,08 \%$ & $-22,46 \%$ & $-25,34 \%$ & $13,64 \%$ & $-11,47 \%$ & $-13,86 \%$ & $9,79 \%$ & $32,80 \%$ & \begin{tabular}{|l|}
$16,79 \%$ \\
\end{tabular} & $-2,26 \%$ \\
\hline SUZB5 & Suzano & 0,49 & Medium & 609.450 & Big & 0,27 & Winner & Big|Medium/Winner & $-10,09 \%$ & $-11,35 \%$ & $-21,50 \%$ & $-18,77 \%$ & $-6,06 \%$ & $-2,50 \%$ & $-3,23 \%$ & $-7,78 \%$ | & $-2,69 \%$ & $32,38 \%$ & $19,28 \%$ & $-8,56 \%$ \\
\hline \begin{tabular}{|l|l|} 
VIVO4 \\
\end{tabular} & Vivo PN & 0,53 & Medium & \begin{tabular}{|l|l|}
15.363 .469 .230 \\
\end{tabular} & Big & 0,29 & Winner & g|Medium $\mid$ Winner & $-12,34 \%$ & $-6,65 \%$ & $-7,48 \%$ & $-24,39 \%$ & $23,09 \%$ & $-2,62 \%$ & $18,70 \%$ & $17,48 \%$ & \begin{tabular}{|c|}
$19,53 \%$ \\
\end{tabular} & $15,45 \%$ & $13,13 \%$ & $-6,47 \%$ \\
\hline $\begin{array}{ll}\text { VCPA4 } \\
\end{array}$ & Fibria PN & 0,51 & Medium & \begin{tabular}{|l|l|}
8.680 .672 .710 \\
\end{tabular} & Big & 0,30 & Winner & Big|Medium/Winner & $-11,55 \%$ & $-8,39 \%$ & $-17,55 \%$ & $-25,28 \%$ & $-39,78 \%$ & $38,35 \%$ & $-24,09 \%$ & $-15,50 \%$ & $-6,09 \%$ & $76,02 \%$ & $22,62 \%$ & $-9,74 \%$ \\
\hline ELPL4 & Eletropaulo PN & 0,55 & Medium & 20.799 & Big & 0,31 & Winner & Big|Medium|Winner & $-0,05 \%$ & $-13,65 \%$ & $-12,25 \%$ & $2,83 \%$ & $-3,30 \%$ & $-1,59 \%$ & $1,96 \%$ & $12,65 \%$ & $11,47 \%$ & $-2,68 \%$ & $9,00 \%$ & $13,35 \%$ \\
\hline BRFS3 & BRF Foc & 0,40 & Medium & 3.374 & Big & 4 & Winr & n|Winr & $-1,18 \%$ & $-4,43 \%$ & $-10,81 \%$ & $-13,46 \%$ & $12,95 \%$ & $-16,41 \%$ & $7,60 \%$ & $-7,47 \%$ & $-2,90 \%$ & $12,17 \%$ & $21,55 \%$ & $-4,34 \%$ \\
\hline CEPES & Celpe P & 0,56 & Medium & & Big & 5 & Wint & Big $\mid$ Medium $\mid$ Winner & $-6,15 \%$ & $4,35 \%$ & $-5,00 \%$ & $-9,82 \%$ & $8,58 \%$ & $16,73 \%$ & $10,93 \%$ & $1,52 \%$ & $5,78 \%$ & $2,10 \%$ & $0,29 \%$ & $17,47 \%$ \\
\hline GVTT3 & GVT Holding ON & 0,38 & Medium & 4.998.591.000 & Big & 0,41 & Winner & Big|Medium|Winner & $-0,13 \%$ & $-4,24 \%$ & $-22,82 \%$ & $-18,34 \%$ & $14,84 \%$ & $-6,04 \%$ & $-2,13 \%$ & $-1,33 \%$ & $8,04 \%$ & \begin{tabular}{l|l}
$9,56 \%$ \\
\end{tabular} & $15,86 \%$ & $-2,98 \%$ \\
\hline GGBR3 & Gerdau ON & 0,35 & Medium & 50.983.656.080 & Big & 50 & Winner & Big|Medium|Winner & $-11,89 \%$ & $-6,01 \%$ & $-28,71 \%$ & $-34,44 \%$ & $3,67 \%$ & $-0,82 \%$ & $-1,24 \%$ & $16,05 \%$ & $3,03 \%$ & $20,78 \%$ & $29,32 \%$ & $-0,81 \%$ \\
\hline GGBR4 & Gerdau PN & 0,35 & Medium & 56.080 & Big & 5 & Winner & Big $\mid$ Medium $\mid$ Winner & $-10,68 \%$ & $-9,34 \%$ & $-30,91 \%$ & $-33,99 \%$ & $5,24 \%$ & $3,51 \%$ & $-0,20 \%$ & $-15,77 \%$ & $2,24 \%$ & $21,71 \%$ & $31,27 \%$ & $-0,53 \%$ \\
\hline BRTO3 & Brasil Telec ON & 0,42 & Medium & 17.127.285.583 & Big & 0,56 & Winner & Big|Medium/Winner & $2,08 \%$ & $1,84 \%$ & $-6,81 \%$ & $-4,30 \%$ & $22,47 \%$ & $2,11 \%$ & $-2,61 \%$ & $11,01 \%$ & $-1,08 \%$ & $-0,17 \%$ & $1,92 \%$ & $-8,10 \%$ \\
\hline \begin{tabular}{|l|l|} 
BRTO4 & \\
\end{tabular} & Brasil Telec PN & 0,42 & Medium & 17.127.285.583 & Big & 0,57 & Winner & Big|Medium|Winner & $7,87 \%$ & $-10,09 \%$ & $-6,09 \%$ & $-20,08 \%$ & $17,65 \%$ & $-6,85 \%$ & $-12,90 \%$ & $-1,60 \%$ & $10,35 \%$ & $4,88 \%$ & $3,47 \%$ & $-6,79 \%$ \\
\hline \begin{tabular}{|l|l|}
$U S I M 3$ \\
\end{tabular} & Usimin & 0.46 & Medium & 2.740 & Big & 0,57 & Winne & Winner & $-11,69 \%$ & $-14,44 \%$ & $31,64 \%$ & $-33,64 \%$ & $-15,91 \%$ & $24,38 \%$ & $4,45 \%$ & $-8,81 \%$ & $9,72 \%$ & $14,34 \%$ & $24,52 \%$ & $9,86 \%$ \\
\hline GOAU4 & Gerdau Met PN & 0, & Medium & 21.065 .238 .500 & Big & 0,59 & Winner & Big|Medium|Winner & $-9,63 \%$ & $-10,28 \%$ & $-28,43 \%$ & $-34,01 \%$ & $5,45 \%$ & $-1,27 \%$ & $-0,94 \%$ & $-16,34 \%$ & \begin{tabular}{l|l}
$1,91 \%$ \\
\end{tabular} & $21,42 \%$ & $27,19 \%$ & $-1,15 \%$ \\
\hline GOAU3 & Gerdau Met ON & 0,42 & Medium & 21.065 .238 .500 & Big & 0,63 & Winner & Big|Medium/Winner & $-10,70 \%$ & $-9,40 \%$ & $-29,51 \%$ & $-38,41 \%$ & $8,18 \%$ & $-5,21 \%$ & $-10,56 \%$ & $-7,70 \%$ & $-8,51 \%$ & $32,67 \%$ & $17,31 \%$ & $-4,81 \%$ \\
\hline USIM5 & & & & & Big & & & & & $-15,41$ & 291 & $-30,88 \%$ & 16,5 & 16,9 & & $-10,15 \%$ & & & 226 & \\
\hline SZPQ4 & Quattor Petr PN & 0,46 & Medium & 2.402.967.000 & Big & 1,12 & Winner & Big|Medium|Winner & $-26,42 \%$ & $6,41 \%$ & $-3,73 \%$ & $2,88 \%$ | & $9,61 \%$ & $-6,77 \%$ & $-7,02 \%$ & $-7,55 \%$ & $-3,05 \%$ & $-11,14 \%[$ & $-1,13 \%[$ & $21,95 \%$ \\
\hline SLCE3 & SLC Agricola ON & 0,35 & Medium & 3.164 .720 .000 & Big & 1,23 & Winner & Big|Medium|Winner & $-15,28 \%$ & $-16,93 \%$ & $-27,22 \%$ & $-31,67 \%$ & $0,80 \%$ & $24,00 \%$ & $-10,71 \%$ & $12,00 \%$ & $-10,71 \%$ & $20,17 \%$ & $6,38 \%$ & $16,72 \%$ \\
\hline IENC & nergia ON & 0,87 & & 133.974.230 & Small & 0,67 & oser & Small| & & $-21,62 \%$ & & $5-50$ t & & t & renct & $4 \%$ & 20 & 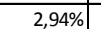 & 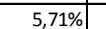 & $-5,41 \%$ \\
\hline
\end{tabular}


Anexo 1 - Retorno mensal e classificação das ações

\begin{tabular}{|c|c|c|c|c|c|c|c|c|c|c|c|c|c|c|c|c|c|c|c|c|}
\hline Código & $2008-2009$ & $\begin{array}{l}\text { Índice } \mathrm{B} / \mathrm{M} \\
\text { de dez/2007 }\end{array}$ & $\begin{array}{c}\text { Grupo com } \\
\text { base no } \\
\text { indice } B / M\end{array}$ & $\begin{array}{c}\text { Valor de Mercado } \\
\text { em jun/2008 }\end{array}$ & $\begin{array}{c}\text { Grupo com } \\
\text { base no } \\
\text { tamanho }\end{array}$ & $\begin{array}{c}\text { Retorno } \\
\text { acumulado } \\
\text { de jun/2008 }\end{array}$ & \begin{tabular}{|c|} 
Grupo com \\
base no \\
retorno \\
acumulado
\end{tabular} & Carteiras & $\mathrm{jul} / 08$ & ago/08 & set/08 & out/08 & nov/08 & $\operatorname{dez} / 08$ & jan/09 & fev/09 & $\mathrm{mar} / 09$ & $\mathrm{abr} / 09$ & mai/09 & jun/09 \\
\hline HBTS5 & Habitasul PNA & 1,79 & High & \begin{tabular}{|l|}
68.502 .653 \\
\end{tabular} & Small & 0,65 & Loser & Small|High|Loser & $-13,33 \%$ & $0,00 \%$ & $-29,23 \%$ & $-34,78 \%$ & $-14,67 \%$ & $32,42 \%$ & $-11,80 \%$ & $-1,67 \%$ & $28,91 \%$ & $2,37 \%$ & $-9,79 \%$ & $43,14 \%$ \\
\hline \begin{tabular}{|l|} 
MRSL4 \\
\end{tabular} & Marisol PN & 0,69 & High & 233.756 .800 & Small & 0,62 & Loser & Small|High|Loser & $-3,00 \%$ & $-24,04 \%$ & $-17,81 \%$ & $-15,00 \%$ & $32,35 \%$ & $-14,07 \%$ & $25,86 \%$ & $12,22 \%$ & $-1,25 \%$ & $13,92 \%$ & $31,67 \%$ & $-0,84 \%$ \\
\hline BEMA3 & Bematech ON & 0,68 & High & 415.134.900 & Small & 0,61 & Loser & Small|High|Loser & $-4,97 \%$ & $-0,28 \%$ & $-27,08 \%$ & $-24,76 \%$ & $35,78 \%$ & $10,29 \%$ & $3,33 \%$ & $11,86 \%$ & $-9,79 \%$ & $0,34 \%$ & $-1,20 \%$ & $11,07 \%$ \\
\hline \begin{tabular}{|l|l|} 
CTSA4 & \\
\end{tabular} & Santanense PN & 1,73 & High & 83.043 .680 & Small & 0,60 & Loser & Small|High|Loser & $19,52 \%$ & $-3,33 \%$ & $-38,97 \%$ & $-20,90 \%$ & $8,57 \%$ & $34,60 \%$ & $2,54 \%$ & $13,86 \%$ & $16,96 \%$ & $29,74 \%$ & $-2,63 \%$ & $0,92 \%$ \\
\hline \begin{tabular}{|l|l|} 
IENG5 \\
\end{tabular} & $\begin{array}{l}\text { Ienergia PNA } \\
\end{array}$ & 0,87 & High & 133.974 .230 & Small & 0,59 & Loser & Small|High|Loser & $-11,43 \%$ & $-19,35 \%$ & $-20,00 \%$ & $-15,00 \%$ & $-17,65 \%$ & $35,71 \%$ & $10,53 \%$ & $-4,76 \%$ & $50,00 \%$ & $0,00 \%$ & $3,33 \%$ & $0,00 \%$ \\
\hline CTNM4 & Coteminas PN & 1,24 & High & 966.713 .480 & Small & 0,55 & Loser & Small|High|Loser & $\mid-15,32 \%$ & $-5,08 \%$ & $-24,41 \%$ & $-26,87 \%$ & $11,11 \%$ & $-3,85 \%$ & $4,00 \%$ & $-12,82 \%$ & $-10,29 \%$ & $32,79 \%$ & $9,89 \%$ & 9,98\% \\
\hline STRP4 & Botucatu Tex PN & 0,69 & High & \begin{tabular}{|l|l|}
11.680 .136 \\
\end{tabular} & Small & 0,54 & Loser & Small|High|Loser & $-21,74 \%$ & $-22,22 \%$ & $-32,14 \%$ & $-21,05 \%$ & $0,00 \%$ & $13,33 \%$ & $17,65 \%$ & $45,00 \%$ & $-6,90 \%$ & $3,70 \%$ & $7,14 \%$ & $-6,67 \%$ \\
\hline CTNM3 & Coteminas ON & 1,24 & High & 966.713 .480 & Small & 0,47 & Loser & Small|High|Loser & $-13,87 \%$ & $3,77 \%$ & $-25,16 \%$ & $-53,18 \%$ & $35,71 \%$ & $-7,89 \%$ & $10,86 \%$ & $0,00 \%$ & $-6,44 \%$ & $6,89 \%$ & $6,95 \%$ & $7,54 \%$ \\
\hline JBDU4 & J B Duarte PN & 1,44 & High & 21.734 .000 & Small & 0,45 & $\begin{array}{l}\text { Loser } \\
\end{array}$ & Small|High|Loser & $-20,00 \%$ & $-12,50 \%$ & $-14,29 \%$ & $-33,33 \%$ & $0,00 \%$ & $0,00 \%$ & $0,00 \%$ & $-25,00 \%$ & $0,00 \%$ & $66,67 \%$ & $40,00 \%$ & $0,00 \%$ \\
\hline \begin{tabular}{|l|l|l|l|l|l|} 
MLFT4 \\
\end{tabular} & Jereissati PN & 0,99 & High & 941.119 .500 & Small & 0,44 & Loser & Small|High|Loser & $-9,59 \%$ | $\quad \longrightarrow$ & $-10,61 \%$ & $-11,86 \%$ & $-19,23 \%$ & $4,76 \%$ | & $18,18 \%$ & $-9,62 \% \mid$ & $23,40 \%$ & $6,90 \%$ | & $-1,93 \%$ & $8,47 \% \mid$ & $6,25 \%$ \\
\hline BISA3 & Brookfield ON & 0,58 & High & 1.579 .240 .353 & Small & 0,43 & Loser & Small|High|Loser & $-12,92 \%$ & $-13,10 \%$ & $-32,31 \%$ & $-29,77 \%$ & $-26,86 \%$ & $9,29 \%$ & $-16,32 \%$ & $-5,03 \%$ & $3,17 \%$ & $92,31 \%$ & $8,69 \%$ & $6,75 \%$ \\
\hline MNDL4 & Mundial PN & 1,72 & High & 89.052 .370 & Small & 0,38 & Loser & Small|High|Loser & 6,06\% & $8,00 \%$ & $-1,06 \%$ & $-19,79 \%$ & $-22,00 \%$ & $-2,56 \%$ & $-14,04 \%$ & $31,63 \%$ & $-6,98 \%$ & $-5,00 \%$ & $8,77 \%$ & $0,00 \%$ \\
\hline JBDU3 & J B Duarte ON & 1,44 & High & 21.734 .000 & Small & 0,38 & Loser & Small|High|Loser & $-25,00 \%$ & $-11,11 \%$ & $-25,00 \%$ & $-16,67 \%$ & $20,00 \%$ & $0,00 \%$ & $-33,33 \%$ & $-25,00 \%$ & $33,33 \%$ & $0,00 \%$ & $75,00 \%$ & $0,00 \%$ \\
\hline LIXC4 & Lix da Cunha & 1,49 & High & & Small & 0,34 & Loser & Small|High|Loser & $-4,50 \%$ & $1,42 \%$ & $-23,49 \%$ & $-20,97 \%$ & $3,85 \%$ & $5,19 \%$ & $2,11 \%$ & $8,62 \%$ & $-8,25 \%$ & $3,11 \%$ & $28,81 \%$ & $-14,86 \%$ \\
\hline ITEC3 & Itautec ON & 0,62 & High & 605.852 .000 & Small & 0,31 & Loser & Small|High|Loser & $-1,92 \%$ & $-10,79 \%$ & $-19,78 \%$ & $-16,69 \%$ & $0,00 \%$ & $-0,03 \%$ & $-3,33 \%$ & $-5,60 \%$ & $-0,18 \%$ & $6,74 \%$ & $-2,85 \%$ & $42,86 \%$ \\
\hline CREM3 & Cremer ON & 0,58 & High & 505.177 .680 & Small & 0,29 & Loser & Small|High|Loser & $-8,00 \%$ & $-0,38 \%$ & $-23,88 \%$ & $-11,76 \%$ & $5,66 \%$ & $2,17 \%$ & $-13,40 \%$ & $-1,72 \%$ & $-6,00 \%$ & $26,87 \%$ & $21,51 \%$ & $10,81 \%$ \\
\hline $\begin{array}{lll} & \end{array}$ & Unipar ON & 0,73 & High & 1.584 .148 .976 & Small & 0,24 & Loser & Small|High|Loser & $-7,66 \%$ & $-12,17 \%$ & $-22,00 \%$ & $-27,56 \%$ & $-19,50 \%$ & $11,11 \%$ & $-5,00 \%$ & $3,07 \%$ & $-6,25 \%$ & $16,67 \%$ & $25,71 \%$ & $-0,76 \%$ \\
\hline TIBR6 & Millennium PNB & 1,45 & High & 239.721 .550 & Small & 0,22 & Loser & Small|High|Loser & $-25,00 \%$ & $16,67 \%$ & $-28,57 \%$ & $-20,00 \%$ & $0,00 \%$ & $0,00 \%$ & $-25,00 \%$ & $0,00 \%$ & $33,33 \%$ & $0,00 \%$ & $50,00 \%$ & $16,67 \%$ \\
\hline SULT4 & Sultepa PN & 2,73 & High & 73.388.000 & Small & 0,19 & Loser & Small|High|Loser & $6,35 \%$ & $-10,45 \%$ & $-16,67 \%$ & $-16,20 \%$ & $6,68 \%$ & $-12,08 \%$ & $1,02 \%$ & $0,50 \%$ & $5,01 \%$ & $17,90 \%$ & $0,66 \%$ & $26,32 \%$ \\
\hline \begin{tabular}{|l|} 
SGEN4 \\
\end{tabular} & Sergen PN & 2,18 & High & 694.062 & Small & 0,18 & Loser & Small|High|Loser & $-5,14 \%$ & $-13,86 \%$ & $-29,37 \%$ & $-3,96 \%$ & $-2,06 \%$ & $5,26 \%$ & $-7,00 \%$ & $-19,35 \%$ & $-13,33 \%$ & $4,62 \%$ & $32,35 \%$ & $28,89 \%$ \\
\hline PNOR5 & Pronor PNA & 1,75 & High & 92.204 .000 & Small & 0,16 & Loser & Small|High|Loser & $-3,00 \%$ & $-17,01 \%$ & $-16,15 \%$ & $-25,93 \%$ & $1,00 \%$ & $8,91 \%$ & $-6,36 \%$ & $16,50 \%$ & $-12,50 \%$ & $19,05 \%$ & $8,00 \%$ & $32,59 \%$ \\
\hline UNIP6 & Unipar PNB & 0,73 & High & 1.584.148.976 & Small & 0,12 & Loser & Small|High|Loser & $-5,88 \%$ & $-2,59 \%$ & $-26,62 \%$ & $-26,47 \%$ & $-15,85 \%$ & $6,45 \%$ & $4,55 \%$ & $-11,63 \%$ & $-3,39 \%$ & $24,56 \%$ & $18,31 \%$ & $-1,19 \%$ \\
\hline TUPY3 & Tupy ON & 0,70 & High & 1.084.680.658 & Small & 0,11 & Loser & Small|High|Loser & $-11,32 \%$ & $4,39 \%$ & $-18,42 \%$ & $-37,98 \%$ & $26,40 \%$ & $-2,31 \%$ & $0,00 \%$ & $27,39 \%$ & $-0,07 \%$ & $-1,24 \%$ & $-0,08 \%$ & $0,00 \%$ \\
\hline SAPR4 & Sanepar PI & 2,23 & High & 1.225 .683 .259 & Small & 0,07 & Loser & Small|High|Loser & \begin{tabular}{|c|}
$-4,87 \%$ \\
\end{tabular} & $-10,91 \%$ & $-16,73 \%$ & $-26,96 \%$ & $4,03 \%$ & $0,00 \%$ & $6,18 \%$ & $-2,48 \%$ & $2,55 \%$ & $5,59 \%$ & $5,88 \%$ & $14,44 \%$ \\
\hline EMAE4 & Emae PN & 1,48 & High & $\begin{array}{r}509.868 .600 \\
\end{array}$ & Small & 0,06 & Loser & Small|High|Loser & $-3,62 \%$ & $-2,26 \%$ & $-15,54 \%$ & $-11,20 \%$ & $-41,54 \%$ & $14,04 \%$ & $1,69 \%$ & $43,72 \%$ & $-10,53 \%$ & $8,24 \%$ & $28,26 \%$ & $-5,08 \%$ \\
\hline SGAS4 & WIm Ind Com PN & 1,33 & High & 219.208 .751 & Small & 0,01 & $\begin{array}{l}\text { Loser } \\
\end{array}$ & Small|High|Loser & $6,45 \%$ & $4,52 \%$ & $-3,04 \%$ & $1,38 \%$ & $-9,14 \%$ & $-6,53 \%$ & $-1,18 \%$ & $-2,19 \%$ & $0,59 \%$ & $11,07 \%$ & $0,82 \%$ & $9,51 \%$ \\
\hline RPAD3 & Alfa Ho & 1,23 & High & 384.011.969 & Small & 0,01 & Winner & Small|High|Winner & $-8,14 \%$ & $-3,70 \%$ & $-0,48 \%$ & $-3,58 \%$ & $27,48 \%$ & $0,00 \%$ & $-25,63 \%$ & $1,60 \%$ & $-20,26 \%$ & $32,90 \%$ & $-4,90 \%$ & $8,51 \%$ \\
\hline TIBR5 & Millennium PNA & 1,45 & High & 239.721 .550 & Small & 0,04 & Winner & Small|High|Winner & $-18,18 \%$ & $0,00 \%$ & $-22,22 \%$ & $-28,57 \%$ & $-20,00 \%$ & $25,00 \%$ & $0,00 \%$ & $-20,00 \%$ & $25,00 \%$ & $20,00 \%$ & $33,33 \%$ & $0,00 \%$ \\
\hline BRGE3 & Alfa Consorc ON & 1,26 & High & 2.005 .660 & Small & 0,09 & Winner & Small|High|Winner & $-1,43 \%$ & $2,54 \%$ & $-1,07 \%$ & $-4,33 \%$ & $-22,26 \%$ & $21,36 \%$ & $0,00 \%$ & $-12,43 \%$ & $0,46 \%$ & $7,14 \%$ & $2,37 \%$ & $19,75 \%$ \\
\hline CMGR3 & Cemat ON & 0,98 & High & 942.620 .400 & Small & 0,10 & Winner & Small|High|Winner & $-11,54 \%$ & $0,14 \%$ & $12,16 \%$ & $-11,10 \%$ & $-18,87 \%$ & $7,16 \%$ & $-0,33 \%$ & $0,00 \%$ & $-7,71 \%$ & $8,89 \%$ & $9,12 \%$ & $1,85 \%$ \\
\hline BRGE12 & Alfa Consorc PNF & 1,26 & High & 005.660 & Small & 0,11 & Winner & Small|High|Winner & \begin{tabular}{l|l|}
$2,92 \%$ \\
\end{tabular} & $-1,13 \%$ & $2,51 \%$ & $-6,78 \%$ & $-7,07 \%$ & $8,70 \%$ & $0,60 \%$ & $-18,70 \%$ & $2,23 \%$ & $14,08 \%$ & $6,38 \%$ & $0,00 \%$ \\
\hline CIQU4 & Cacique PN & 0,75 & High & 881.200 & Small & 0,13 & Winner & Small|High | Winner & $-10,32 \%$ & $-3,54 \%$ & $-22,02 \%$ & $-34,71 \%$ & $-18,92 \%$ & $11,11 \%$ & $9,00 \%$ & $-3,67 \%$ & $-2,48 \%$ & $34,96 \%$ & $-9,15 \%$ & $13,32 \%$ \\
\hline RPAD6 & Alfa Holding PNB & 1,23 & High & .011 .969 & Small & 0,15 & Winner & Small|High|Winner & $0,49 \%$ & $1,98 \%$ & $-1,91 \%$ & $-14,84 \%$ & $-10,00 \%$ & $33,02 \%$ & $-6,92 \%$ & $-6,62 \%$ & $-6,94 \%$ & $18,51 \%$ & $0,76 \%$ & $6,25 \%$ \\
\hline RPAD5 & Alfa Hol & 1,23 & High & \begin{tabular}{l|l|l|}
11.969 \\
\end{tabular} & Small & 0,20 & Winne & Small|High|Winner & $-0,45 \%$ & $2,17 \%$ & $-1,15 \%$ & $-11,63 \%$ & $-7,37 \%$ & $8,81 \%$ & $2,35 \%$ & $-7,87 \%$ & $8,00 \%$ & $5,82 \%$ & $0,25 \%$ & $14,96 \%$ \\
\hline CLSC6 & Celesc PNB & 0,89 & High & 1.837 .509 .675 & Small & 0,21 & Winne & Small| |High | Winner & $0,42 \%$ & $-5,46 \%$ & $-1,56 \%$ & $-24,04 \%$ & $4,46 \%$ & $-0,71 \%$ & $-2,61 \%$ & $-4,53 \%$ & $-3,51 \%$ & $6,85 \%$ & $4,77 \%$ & $-3,28 \%$ \\
\hline CEBR5 & Ceb PNA & 0,64 & High & 365.440 .927 & Small & 0,25 & Winner & Small|High|Winner & $-6,44 \%$ & $-7,23 \%$ & $-15,25 \%$ & $-44,20 \%$ & $64,87 \%$ & $-32,17 \%$ & $34,62 \%$ & $2,38 \%$ & $-16,05 \%$ & $10,80 \%$ & $40,00 \%$ & $7,14 \%$ \\
\hline BRGE11 & Alfa Consorc PNE & 1,26 & High & 402.005 .660 & Small & 0,28 & Winner & Small|High/Winner & $5,26 \%$ & $-6,07 \%$ & $-0,18 \%$ & $-13,36 \%$ & $-16,67 \%$ & $25,00 \%$ & $0,00 \%$ & $-17,31 \%$ & $1,72 \%$ & $12,32 \%$ & $0,86 \%$ & $2,56 \%$ \\
\hline PEAB4 & Par Al Bahia PN & 0,75 & High & 427.262 .500 & Small & 0,40 & Winner & Small|High | Winner & $12,50 \%$ & $13,89 \%$ & $16,73 \%$ & $-13,33 \%$ & $2,56 \%$ & $-2,50 \%$ & $-3,85 \%$ & $12,00 \%$ & $0,00 \%$ & $12,01 \%$ & $0,00 \%$ & $4,97 \%$ \\
\hline TKNO4 & Tekno PN & 0,72 & High & 292.566 .300 & Small & 0,42 & Winner & Small|High|Winner & \begin{tabular}{|l|}
$-19,78 \%$ \\
\end{tabular} & $-4,23 \%$ & $-0,60 \%$ & $-19,12 \%$ & $-10,31 \%$ & $2,36 \%$ & $-5,66 \%$ & $-0,02 \%$ & $-6,12 \%$ & $16,82 \%$ & $-0,02 \%$ & $12,31 \%$ \\
\hline \begin{tabular}{|l|l|l|l|l|l|l|l} 
BDLL4 & \\
\end{tabular} & Bardella PN & 0,90 & High & 415.184.000 & Small & 0,45 & Winner & Small|High |Winner & $19,46 \%$ & $-4,09 \%$ & $-13,42 \%$ & $-20,47 \%$ & $-17,44 \%$ & $-16,46 \% \mid$ & $26,88 \%$ | & $-9,12 \%$ & $-6,79 \%$ & $-0,69 \%$ & $-7,70 \% \mid$ & $-3,40 \%$ \\
\hline CEBR3 & Ceb ON & 0,64 & High & 5.440 .927 & Small & 0,60 & Winner & Small|High|Winner & \begin{tabular}{|c|}
$-6,54 \%$ \\
\end{tabular} & $-18,59 \%$ & $-28,57 \%$ & $-55,56 \%$ & $17,19 \%$ & $15,21 \%$ & $33,33 \%$ & $-10,00 \%$ & $0,00 \%$ & $22,22 \%$ & $36,36 \%$ & $0,17 \%$ \\
\hline EUCA4 & Eucatex PN & 0,58 & High & 558.295 .320 & Small & 0,63 & Winner & Small|High|Winner & $-14,74 \%$ & $-21,55 \%$ & $-23,51 \%$ & $0,32 \%$ & $-12,90 \%$ & $7,41 \%$ & $-1,72 \%$ & $-9,12 \%$ & $-3,47 \%$ & $36,00 \%$ & $-4,71 \%$ & $0,31 \%$ \\
\hline INEP4 & Inepar PN & 0,60 & High & 380.323 .071 & Small & 0,68 & Winner & Small|High|Winner & $8,84 \%$ & $-16,45 \%$ & $-17,31 \%$ & $-61,23 \%$ & $-18,73 \%$ & $26,25 \%$ & $-21,70 \%$ & $9,46 \%$ & $13,72 \%$ & $9,00 \%$ & $31,07 \%$ & $20,39 \%$ \\
\hline MOAR3 & Mon & & High & & Smat & 0,76 & Win & -2 & $-5.53 \%$ & & & 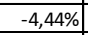 & & & & $-9,43 \%$ & & $2,97 \%$ & $8.16 \%$ & $6,05 \%$ \\
\hline CTKA4 & Karsten PN & 0,16 & High & 141.828 .000 & Small & 0,77 & Winner & Small|High|Winner & $-5,94 \%$ ] $>$ & 4,11\% & $-7,48 \%$ & $-5,03 \%$ & $-15,54 \%$ & $8,99 \%$ & $-3,88 \%$ & $-2,60 \%$ & $-17,36 \%$ & $-4,85 \%$ & $1,53 \%$ & $-3,18 \%$ \\
\hline \begin{tabular}{|l|l|} 
FESA4 \\
\end{tabular} & Ferbasa PN & 1,06 & High & 1.653 .580 .800 & Small & 1,03 & Winner & Small|High|Winner & $-3,85 \%$ & $-7,50 \%$ & $-30,89 \%$ & $-31,80 \%$ & $-5,41 \%$ & $-3,00 \%$ & $-5,15 \%$ & $-5,43 \%$ & $-4,11 \%$ & $\begin{array}{ll}9,07 \% \\
\end{array}$ & $23,67 \%$ & $9,16 \%$ \\
\hline MENDS & Mende & 3,61 & High & 510. & mall & 1,17 & Winner & Small|High/Winner & & 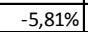 & & $32,84 \%$ & & 20 & & 20001 & & & $7,81 \%$ & $2,10 \% \mid$ \\
\hline
\end{tabular}


Anexo 1 - Retorno mensal e classificação das ações

\begin{tabular}{|c|c|c|c|c|c|c|c|c|c|c|c|c|c|c|c|c|c|c|c|c|}
\hline Código & 2008- 2009 & $\begin{array}{l}\text { Índice } B / M \\
\text { de dez/2007 }\end{array}$ & $\begin{array}{c}\text { Grupo com } \\
\text { base no } \\
\text { indice } B / M\end{array}$ & $\begin{array}{c}\text { Valor de Mercado } \\
\text { em jun/2008 }\end{array}$ & $\begin{array}{c}\text { Grupo com } \\
\text { base no } \\
\text { tamanho }\end{array}$ & $\begin{array}{c}\text { Retorno } \\
\text { acumulado } \\
\text { de jun/2008 }\end{array}$ & \begin{tabular}{|c|} 
Grupo com \\
base no \\
retorno \\
acumulado
\end{tabular} & Carteiras & $\mathrm{jul} / 08$ & ago/08 & set/08 & out/08 & nov/08 & $\operatorname{dez} / 08$ & jan/09 & fev/09 & $\mathrm{mar} / 09$ & $\mathrm{abr} / 09$ & mai/09 & jun/09 \\
\hline MEND6 & Mendes Jr PNB & 3,61 & High & 510.815 .691 & Small & 1,25 & Winner & Small|High|Winner & $-12,00 \%$ & $-3,41 \%$ & $-1,88 \%$ & $-42,47 \%$ & $4,21 \%$ & $20,08 \%$ & $10,03 \%$ & $4,85 \%$ & $9,46 \%$ & $33,90 \%$ & $11,32 \%$ & $10,00 \%$ \\
\hline ECPR4 & Encorpar PN & 1,07 & High & 76.000.000 & Small & 2,79 & Winner & Small|High|Winner & $-20,02 \%$ & $15,60 \%$ & $-20,25 \%$ & $-11,83 \%$ & $-23,12 \%$ & $-25,21 \%$ & $9,30 \%$ & $-2,14 \%$ & $-12,57 \%$ & $6,22 \%$ & $2,15 \%$ & $23,52 \%$ \\
\hline RNAR3 & Renar ON & 0,59 & High & 161.600 .000 & Small & 2,87 & Winner & Small|High|Winner & $-31,44 \%$ & $-16,97 \%$ & $-5,65 \%$ & $-6,45 \%$ & $4,93 \%$ & $17,37 \%$ & $14,00 \%$ & $2,81 \%$ & $5,80 \%$ & $-6,45 \%$ & $-2,76 \%$ & $0,00 \%$ \\
\hline MTIG4 & Metal Iguacu PN & 0,13 & Low & 238.779 .840 & Small & 0,85 & Loser & Small|Low|Loser & $-19,72 \%$ & $-12,28 \%$ & $-24,00 \%$ & $-34,21 \%$ & $24,00 \%$ & $3,23 \%$ & $0,00 \%$ & $12,50 \%$ & $14,29 \%$ & $28,13 \%$ & $-7,32 \%$ & $0,00 \%$ \\
\hline PTBL3 & Portobello ON & 0,05 & Low & 297.346 .830 & Small & 0,60 & Loser & Small|Low|Loser & $-9,63 \%$ & $-2,37 \%$ & $-19,39 \%$ & $-22,56 \%$ & $-0,97 \%$ & $0,98 \%$ & $-3,88 \%$ & $-1,01 \%$ & $-6,12 \%$ & $19,57 \%$ & $2,73 \%$ & $0,88 \%$ \\
\hline ENMA3B & Cemar ON & 0,21 & Low & 1.574 .563 .200 & Small & 0,55 & Loser & Small|Low|Loser & $-16,67 \%$ & $6,25 \%$ & $-1,29 \%$ & $-14,18 \%$ & $-5,56 \%$ & $0,74 \%$ & $-2,48 \%$ & $3,29 \%$ & $8,84 \%$ & $-1,20 \%$ & $8,03 \%$ & $5,19 \%$ \\
\hline PLAS3 & Plascar Part ON & 0,17 & Low & 832.150 .000 & Small & 0,54 & Loser & Small|Low|Loser & $-6,00 \%$ & $-20,43 \%$ & $-10,43 \%$ & $-37,01 \%$ & $-26,07 \%$ & $-10,26 \%$ & $-10,00 \%$ & $-26,19 \%$ & $-1,08 \%$ & \begin{tabular}{|l|}
$154,35 \%$ \\
\end{tabular} & $-2,56 \%$ & $-4,39 \%$ \\
\hline RHDS3 & M G Poliest ON & 0,28 & Low & 1.283 .993 .600 & Small & 0,51 & Loser & Small|Low|Loser & $-18,75 \%$ & $0,00 \%$ & $-23,08 \%$ & $-20,00 \%$ & $-12,50 \%$ & $0,00 \%$ & $14,29 \%$ & $-12,50 \%$ & $14,29 \%$ & $12,50 \%$ & $11,11 \%$ & $0,00 \%$ \\
\hline POSI3 & Positivo Inf ON & 0,14 & Low & 1.393 .752 .360 & Small & 0,43 & $\begin{array}{l}\text { Loser } \\
\end{array}$ & Small|Low|Loser & $-12,45 \%$ & $-13,73 \%$ & $-40,68 \%$ & $-15,86 \%$ & $-2,38 \%$ & $20,00 \%$ & $-21,74 \%$ & $33,33 \%$ & $13,06 \%$ & $12,83 \%$ & $3,34 \%$ & $12,81 \%$ \\
\hline CTPC3 & Marambaia ON & 0,06 & Low & 54.520.200 & Small & 0,34 & Loser & Small |Low|Loser & $-14,29 \%$ & $-6,67 \%$ & $-10,71 \%$ & $0,00 \%$ & $-56,67 \% \mid$ & $44,62 \%$ & $-4,79 \% \mid$ & $11,73 \%$ | & $-7,50 \%$ & $-27,03 \%$ & $2,22 \%$ & $124,64 \%$ \\
\hline ABYA3 & Abyara ON & 0,17 & Low & 678.874 .200 & Small & 0,33 & Loser & Small|Low|Loser & $-1,87 \%$ & $-55,27 \%$ & $-62,46 \%$ & $-29,55 \%$ & $-3,23 \%$ & $0,67 \%$ & $15,23 \%$ & $5,17 \%$ & $-10,38 \%$ & $58,54 \%$ & $-5,77 \%$ & $14,89 \%$ \\
\hline EVEN3 & Even ON & 0,28 & Low & 1.302 .955 .000 & Small & 0,32 & Loser & Small|Low|Loser & $-15,68 \%$ & $-28,59 \%$ & $-28,19 \%$ & $-30,25 \%$ & $-15,77 \%$ & $23,40 \%$ & $-18,28 \%$ & $-15,61 \%$ & $24,50 \%$ & $45,10 \%$ & $-6,53 \%$ & $2,13 \%$ \\
\hline CGRA4 & Grazziotin PN & 0,31 & Low & 346.153 .602 & Small & 0,20 & Loser & Small|Low|Loser & $21,84 \%$ & $-2,29 \%$ & $-10,00 \%$ & $-53,50 \%$ & $-21,09 \%$ & $15,47 \%$ & $-16,50 \%$ & $27,35 \%$ & $-5,96 \%$ & $30,14 \%$ & $6,94 \%$ & $6,73 \%$ \\
\hline \begin{tabular}{|l|} 
ODPV3 \\
\end{tabular} & Odontoprev ON & 0,20 & Low & 0.000 & Small & 0,16 & Loser & Small|Low|Loser & $0,00 \%$ & $-9,52 \%$ & $-22,55 \%$ & $-2,11 \%$ & $-6,20 \%$ & $-11,35 \%$ & $3,91 \%$ & $-3,77 \%$ & $0,00 \%$ & $23,49 \%$ & $14,15 \%$ & $-8,17 \%$ \\
\hline TOTS3 & Totvs ON & 0,23 & Low & 1.398 .205 .381 & Small & 0,15 & Loser & Small|Low|Loser & $0,21 \%$ & $8,51 \%$ & $-21,01 \%$ & $-17,33 \%$ & $4,84 \%$ & $-3,54 \%$ & $7,33 \%$ & $7,81 \%$ & $-3,55 \%$ & $43,68 \%$ & $18,27 \%$ & $-3,47 \%$ \\
\hline FITA4 & Forjas Taurus PN & 0,29 & Low & 815.872 .200 & Small & 0,02 & Loser & Small|Low|Loser & $-16,28 \%$ & $-9,44 \%$ & $-28,83 \%$ & $-26,08 \%$ & $17,34 \%$ & $-2,10 \%$ & $0,80 \%$ & $-2,93 \%$ & $6,03 \%$ & $48,94 \%$ & $3,44 \%$ & $-0,55 \%$ \\
\hline CGRA3 & Grazziotin ON & 0,31 & Low & 153.602 & Small & 0,02 & Winner & Small|Low|Winner & $-2,09 \%$ & $-0,02 \%$ & $-17,09 \%$ & $-61,35 \%$ & $-8,18 \%$ & $15,57 \%$ & $-19,83 \%$ & $35,14 \%$ & $-7,69 \%$ & $25,25 \%$ & $14,69 \%$ & $5,36 \%$ \\
\hline JFEN3 & Joao Fortes ON & 0,10 & Low & 468.000 .000 & Small & 0,05 & Winner & Small|Low|Winner & $-13,68 \%$ & $-8,51 \%$ & $-24,24 \%$ & $-37,14 \%$ & $13,64 \%$ & $0,00 \%$ & $-6,00 \%$ & $0,00 \%$ & $0,00 \%$ & $42,55 \%$ & $12,24 \%$ & $6,38 \%$ \\
\hline SLED4 & Saraiva Livr PN & 0,30 & Low & 59.524 .000 & Small & 0,09 & Winner & Small|Low|Winner & $-0,78 \%$ & $-14,06 \%$ & $-12,76 \%$ & $-19,76 \%$ & $-10,70 \%$ & $-3,20 \%$ & $-12,04 \%$ & $-2,14 \%$ & $10,95 \%$ & $31,92 \%$ & $11,22 \%$ & $3,47 \%$ \\
\hline IDNT3 & Ideiasnet ON & 0,11 & Low & 44.521.000 & Small & 0,28 & Winner & Small | Low |Winner & $-5,04 \%$ | & $2,57 \%$ & $-33,39 \%$ & $-37,84 \%$ & $-6,85 \%$ - & $3,46 \%$ | & $-17,15 \% \mid$ & $-2,02 \%$ & $-5,15 \%$ & $41,85 \%$ | & $11,88 \%$ | $>2$ & $11,30 \%$ \\
\hline \begin{tabular}{|l|l|} 
MTSA4 & \\
\end{tabular} & Metisa PN & 0,31 & Low & 000 & Small & 0,32 & Winner & Small| Low|Winner & $-4,20 \%$ & $-3,97 \%$ & $12,17 \%$ & $-7,02 \%$ & $-12,51 \%$ & $-4,64 \%$ & $2,05 \%$ & $0,50 \%$ & $0,00 \%$ & $9,11 \%$ & $-0,51 \%$ & $5,10 \%$ \\
\hline BAHI4 & Bahema PN & 0,07 & Low & 406.721 .074 & Small & 0,35 & Winner & Small| Low |Winner & $-7,25 \%$ & $0,00 \%$ & $-0,13 \%$ & $-36,51 \%$ & $59,73 \%$ & $17,39 \%$ & $22,67 \%$ & $1,09 \%$ & $3,23 \%$ & $8,33 \%$ & $-19,24 \%$ & $0,61 \%$ \\
\hline LPSB3 & Lopes Brasil ON & 0,02 & Low & 1.607 .060 .000 & Small & 0,35 & Winner & Small|Low|Winner & $-10,77 \%$ & $-21,03 \%$ & $-42,36 \%$ & $-38,26 \%$ & $-23,31 \%$ & $5,60 \%$ & $2,27 \%$ & $3,70 \%$ & $-17,86 \%$ & $30,78 \%$ & $3,59 \%$ & $36,71 \%$ \\
\hline MYPK3 & lochp. & 0,15 & Low & 676.000 & Small & 0,37 & Winner & Small|Low/Winner & $13,11 \%$ & $-19,48 \%$ & $-21,56 \%$ & $-41,40 \%$ & $-24,04 \%$ & $-9,79 \%$ & $10,86 \%$ & $12,37 \%$ & $-1,04 \%$ & $21,81 \%$ & $23,85 \%$ & $2,15 \%$ \\
\hline LPR3 & Eletropar ON & 0,28 & Low & 436.380 .000 & Small & 0,43 & Winner & Small| Low |Winner & $1,43 \%$ & $-5,63 \%$ & $4,48 \%$ & $-2,38 \%$ & $2,44 \%$ & $0,95 \%$ & $2,59 \%$ & $0,34 \%$ & $-0,33 \%$ & $-0,02 \%$ & $-3,51 \%$ & $1,22 \%$ \\
\hline FBMC4 & Fibam PN & 0,29 & Low & 71.346.650 & Small & 0,46 & Winner & Small|Low|Winner & \begin{tabular}{|c|}
$-5,05 \%$ \\
\end{tabular} & $-8,51 \%$ & $-34,90 \%$ & $-10,72 \%$ & $-15,22 \%$ & $-4,25 \%$ & $-1,43 \%$ & $-37,50 \%$ & $3,16 \%$ & $42,64 \%$ & $18,57 \%$ & $7,71 \%$ \\
\hline TCNO4 & Tecnosolo F & 0,25 & Low & 1.440 .000 & Small & 28 & Winner & Small|Low|Winner & $-14,42 \%$ & $5,62 \%$ & $1,06 \%$ & $-3,16 \%$ & $-13,04 \%$ & $21,25 \%$ & $3,17 \%$ & $-26,15 \%$ & $12,50 \%$ & $20,37 \%$ & $-16,87 \%$ & $-3,70 \%$ \\
\hline ECOD3 & Ecodiesel ON & 0,36 & Medium & 9.138 .210 & Small & 0,63 & Loser & Small|Medium|Loser & $-40,88 \%$ & $5,76 \%$ & $-46,69 \%$ & $-36,50 \%$ & $-17,24 \%$ & $-16,67 \%$ & $36,67 \%$ & $3,66 \%$ & $-7,06 \%$ & $27,85 \%$ & $6,11 \%$ & $-7,39 \%$ \\
\hline CARD3 & Csu Cardsystem ON & 0,43 & Medic & 4.400 & Small & 0,62 & Loser & Small|Medium|Loser & $-14,42 \%$ & $-10,34 \%$ & $-28,57 \%$ & $-25,26 \%$ & $0,94 \%$ & 6,98 & 28,7 & $8,11 \%$ & $7,81 \%$ & $36,23 \%$ & $-5,96 \%$ & $5,20 \%$ \\
\hline EZTC3 & Eztec ON & 0,57 & Mediu & 57.820 & Small & $\begin{array}{ll}0,58 \\
\end{array}$ & Loser & Small|Medium|Loser & $-3,83 \%$ & $-33,41 \%$ & $-12,29 \%$ & $-25,38 \%$ & $1,52 \% \mid$ & $17,50 \%$ & $-15,32 \%$ & $10,55 \%$ & $11,36 \%$ & $46,14 \%$ & $25,66 \%$ & $5,57 \%$ \\
\hline KSSA3 & Klabinsegall ON & 0,48 & Medium & 005.100 & Small & 48 & Loser & nall|Medium|Loser & $-8,04 \%$ & $-9,84 \%$ & $-43,64 \%$ & $-39,78 \%$ & $-2,14 \%$ & $-14,23 \%$ & $-1,28 \%$ & $-41,38 \%$ & $1,47 \%$ & $52,90 \%$ & $9,48 \%$ & $36,36 \%$ \\
\hline VIVR3 & Viver ON & 0,40 & Medium & 750.120 .800 & Small & 0,48 & Loser & Small|Medium|Loser & $-40,51 \%$ & $-28,30 \%$ & $-63,50 \%$ & $9,76 \%$ & $14,81 \%$ & $6,45 \%$ & $-3,03 \%$ & $4,38 \%$ & $-6,59 \%$ & $83,33 \%$ & $-7,34 \%$ & $-1,89 \%$ \\
\hline UOLL4 & Uol PN & 0,44 & Medium & 1.021 .124 .635 & Small & 0,42 & Loser & Small|Medium|Loser & $1,18 \%$ & $-21,51 \%$ & $8,15 \%$ & $-9,59 \%$ & $4,55 \%$ & $5,80 \%$ & $3,56 \%$ & $-3,84 \%$ & $-8,25 \%$ & $0,12 \%$ & $8,70 \%$ & $0,00 \%$ \\
\hline MEDI3 & Medial Saude OI & 0,33 & Mediu & 000 & Small & 2 & 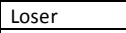 & Small $\mid \mathrm{Me}$ & $-6,17 \%$ & $-30,00 \%$ & $-8,16 \%$ & $-40,44 \%$ & $-15,67 \%$ & $32,74 \%$ & $-5,47 \%$ & $-4,65 \%$ & $-22,49 \%$ & $29,77 \%$ & $18,24 \%$ & $6,34 \%$ \\
\hline CRDE3 & $\mathrm{Cr} 2 \mathrm{ON}$ & 0,54 & Medic & & Small & 0,42 & Loser & Small|Medium|Loser & $-6,39 \%$ & $13,25 \%$ & $-24,33 \%$ & $-36,56 \%$ & $-29,86 \%$ & $15,54 \%$ & $-9,09 \%$ & $8,33 \%$ & $-4,92 \%$ & $69,90 \%$ & $-2,86 \%$ & $10,78 \%$ \\
\hline IGTA3 & Iguatemi $\mathrm{O}$ & 0,46 & Medium & 1.380 .762 .950 & Small & 0,40 & Loser & Small|Medium|Loser & $-6,11 \%$ & $-4,95 \%$ & $-25,79 \%$ & $-27,66 \%$ & $-8,54 \%$ & $43,96 \%$ & $-7,69 \%$ & $9,17 \%$ & $9,54 \%$ & $17,71 \%$ & $17,62 \%$ & $-2,54 \%$ \\
\hline CCIM3 & CC Des In & 0,50 & Medium & 977.588.810 & Small & 39 & Loser & Small|Medium|Loser & $-13,07 \%$ & $-31,11 \%$ & $-16,79 \%$ & $-54,04 \%$ & $33,17 \%$ & $-10,26 \%$ & $-6,94 \%$ & $3,51 \%$ & $-14,14 \%$ & $66,17 \%$ & $17,37 \%$ & $-1,79 \%$ \\
\hline OHLB3 & OHL Bras & 0,46 & Mediu & 6.300 & Small & & Loser & Small|Medium|Loser & $-0,79 \%$ & $0,04 \%$ & $-33,77 \%$ & $-31,91 \%$ & $3,68 \%$ & $1,45 \%$ & $17,74 \%$ & $-9,46 \%$ & $4,48 \%$ & $4,14 \%$ & $32,39 \%$ & $15,90 \%$ \\
\hline ELEK4 & Elekeiroz PN & 0,53 & Mediur & 760.192 .330 & Small & 0,33 & Loser & Small|Medium|Loser & $-4,45 \%$ & $-5,07 \%$ & $12,36 \%$ & $-1,00 \%$ & $-6,62 \%$ & $-17,30 \%$ & $-0,07 \%$ & $-13,06 \%$ & $15,22 \%$ & $-19,95 \%$ & $1,42 \%$ & $-0,58 \%$ \\
\hline AGIN3 & Agra Incorp ON & 0,45 & Medium & 1.411 .866 .720 & Small & 0,30 & Loser & Small|Medium |Loser & $6,16 \%$ & $-9,46 \%$ & $-16,39 \%$ & $-83,24 \%$ & $18,64 \%$ & $28,57 \%$ & $-1,67 \%$ & $-12,99 \%$ & $-9,74 \%$ & $65,47 \%$ & $-4,74 \%$ & $27,98 \%$ \\
\hline LOGN3 & $\log -\ln \mathrm{O}$ & 0,47 & Mediur & & Small & 0,30 & Loser & |Loser & $-5,83 \%$ & $20,44 \%$ & $-32,15 \%$ & $-25,90$ & $9,51 \%$ & $2,02 \%$ & $22,97 \%$ & $6,92 \%$ & $-7,76 \%$ & $25,89 \%$ & & $8,85 \%$ \\
\hline TCSA3 & Tecnisa ON & 0,46 & Medium & 1.162 .025 .650 & Small & 0,27 & Loser & Small|Medium|Loser & $-6,13 \%$ & $-12,40 \%$ & $-29,38 \%$ & $-38,58 \%$ & $1,75 \%$ & $17,24 \%$ & $-5,88 \%$ & $-16,25 \%$ & $29,85 \%$ & $60,52 \%$ & $-4,59 \%$ & $7,31 \%$ \\
\hline FRAS4 & Fras-Le PN & 0,41 & Medium & 348.095 .400 & Small & 0,25 & Loser & Small|Medium|Loser & $-4,12 \%$ & $-3,89 \%$ & $-13,19 \%$ & $-9,56 \%$ & $-24,33 \%$ & $-13,75 \%$ & $7,33 \%$ & $-4,42 \%$ & $0,42 \%$ & $10,88 \%$ & $10,19 \%$ & $-0,09 \%$ \\
\hline GRND3 & & & & & 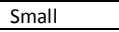 & & Los & & & & & & & & -79 & & & & & \\
\hline CTAX3 & Contax ON & 0,32 & Medium & 159.248 .550 & Small & 0,20 & Loser & Small|Medium|Loser & $-7,56 \%$ | $>2$ & $10,18 \%$ & $-18,52 \%$ & $-27,28 \%$ & 7,85\% & $15,94 \%$ & $14,75 \%$ & $4,55 \%$ & $-4,17 \%$ & $23,31 \%$ & $0,47 \%$ & 1,98\% \\
\hline LEVE4 & Metal Leve PN & 0,52 & Medium & 1.187.096.920 & Small & 0,18 & Loser & Small|Medium|Loser & \begin{tabular}{l|l}
$0,03 \%$ \\
\end{tabular} & $-7,69 \%$ & $-15,25 \%$ & $-34,75 \%$ & $-12,06 \%$ & $0,55 \%$ & $-6,12 \%$ & $0,97 \%$ & $-10,17 \%$ & $33,81 \%$ & $-13,35 \%$ & $-6,26 \%$ \\
\hline ETER3 & ernit ON & 0,45 & ledium & 486.418 .500 & nall & & oser & Small|Medium| & & & & 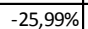 & & & & & 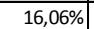 & $10 \operatorname{coc} t$ & 2500 & $0,42 \%$ \\
\hline
\end{tabular}


Anexo 1 - Retorno mensal e classificação das ações

\begin{tabular}{|c|c|c|c|c|c|c|c|c|c|c|c|c|c|c|c|c|c|c|c|c|}
\hline Código & $2008-2009$ & $\begin{array}{l}\text { Índice } B / M \\
\text { de dez/2007 }\end{array}$ & $\begin{array}{c}\text { Grupo com } \\
\text { base no } \\
\text { indice } B / M\end{array}$ & \begin{tabular}{|} 
Valor de Mercado \\
em jun/2008
\end{tabular} & $\begin{array}{c}\text { Grupo com } \\
\text { base no } \\
\text { tamanho }\end{array}$ & $\begin{array}{c}\text { Retorno } \\
\text { acumulado } \\
\text { de jun/2008 }\end{array}$ & \begin{tabular}{|c|} 
Grupo com \\
base no \\
retorno \\
acumulado
\end{tabular} & Carteiras & $\mathrm{jul} / 08$ & ago/08 & set/08 & out/08 & nov/08 & dez/08 & jan/09 & fev/09 & $\mathrm{mar} / 09$ & $\mathrm{abr} / 09$ & mai/09 & jun/09 \\
\hline SCAR3 & aoo Carlos ON & 0,54 & Medium & 756.706 .470 & Small & 0,17 & Loser & Small|Medium|Loser & $0,85 \%$ & $1,45 \%$ & $-25,58 \%$ & $1,01 \%$ & $5,01 \%$ & $-2,29 \%$ & $-1,56 \%$ & $6,05 \%$ & $12,62 \%$ & $21,16 \%$ & $17,12 \%$ & $-7,76 \%$ \\
\hline DXTG4 & Dixie Toga PN & 0,36 & Medium & 688.761 .570 & Small & 0,14 & Loser & Small|Medium|Loser & $3,59 \%$ & $-4,23 \%$ & $10,44 \%$ & $-5,45 \%$ & $-13,46 \%$ & $-33,33 \%$ & $0,00 \%$ & $0,00 \%$ & $0,00 \%$ & $4,00 \%$ & $32,18 \%$ & $.11,62 \%$ \\
\hline CTAX4 & Contax PN & 0,32 & Medium & 759.248 .550 & Small & 0,13 & Loser & Small|Medium|Loser & $-13,39 \%$ & $10,21 \%$ & $-8,44 \%$ & $-30,07 \%$ & $28,66 \%$ & $14,72 \%$ & $2,88 \%$ & $2,38 \%$ & $3,43 \%$ & $5,50 \%$ & $18,16 \%$ & $3,44 \%$ \\
\hline ENGI4 & Energisa PN & 0,32 & Medium & 1.769 .916 .700 & Small & 0,12 & Loser & Small|Medium|Loser & $14,63 \%$ & $-4,26 \%$ & $-10,45 \%$ & $-15,77 \%$ & $-5,63 \%$ & $3,23 \%$ & $-6,25 \%$ & $4,17 \%$ & $-3,84 \%$ & $43,09 \%$ & $11,16 \%$ & $4,29 \%$ \\
\hline COCE5 & Coelce PNA & 0,51 & Medium & 1.572 .671 .000 & Small & 0,12 & Loser & Small|Medium|Loser & $-4,95 \%$ & $9,37 \%$ & $-11,90 \%$ & $-13,46 \%$ & $13,68 \%$ & $23,52 \%$ & $-5,25 \%$ & $5,63 \%$ & $1,33 \%$ & $8,90 \%$ & $9,56 \%$ & $3,02 \%$ \\
\hline ENGI3 & Energisa ON & 0,32 & Medium & 1.769 .916 .700 & Small & 0,10 & Loser & Small|Medium|Loser & $5,26 \%$ & $0,00 \%$ & $-11,17 \%$ & $-20,00 \%$ & $-0,81 \%$ & $0,81 \%$ & $-3,23 \%$ & $4,17 \%$ & \begin{tabular}{l|l}
$8,80 \%$ \\
\end{tabular} & $24,26 \%$ & \begin{tabular}{l|l|}
$12,31 \%$ \\
\end{tabular} & $3,48 \%$ \\
\hline HGTX3 & Cia Hering ON & 0,49 & dium & 1.086 .930 & Small & 0,10 & Loser & Small|Medium|Loser & $-12,18 \%$ & $-5,38 \%$ & $-12,61 \%$ & $-22,11 \%$ & $11,85 \%$ & $18,51 \%$ & $-11,84 \%$ & $-7,14 \%$ & $1,54 \%$ & $37,15 \%$ & $26,55 \%$ & $8,93 \%$ \\
\hline VLID3 & Valid ON & 0,32 & Medium & 845.724 .000 & Small & 0,09 & Loser & Small|Medium|Loser & $3,94 \%$ & $-3,23 \%$ & $-9,42 \%$ & $-26,77 \%$ & $-9,09 \%$ & $9,69 \%$ & $-8,26 \%$ & $10,54 \%$ & $-4,70 \%$ & $19,61 \%$ & $18,85 \%$ & $3,10 \%$ \\
\hline FRIO3 & Metalfrio ON & 0,33 & Medium & 790.664.030 & Small & 0,09 & Loser & Small|Medium|Loser & $-26,23 \%$ & $13,37 \%$ & $17,28 \%$ & $-55,00 \%$ & $2,81 \%$ & $-18,09 \%$ & $-4,31 \%$ & $3,77 \%$ & $-44,06 \%$ & $11,25 \%$ & $-7,87 \%$ & $-11,71 \%$ \\
\hline GPCP3 & GPC Part ON & 0,52 & Medium & 894.250 & Small & 0,04 & Loser & Small|Medium|Loser & $\begin{array}{l}-13,43 \% \\
\end{array}$ & $4,60 \%$ & $-15,38 \%$ & $-4,55 \%$ & $-8,84 \%$ & $-29,10 \%$ & $-37,89 \%$ & $20,34 \%$ & $4,23 \%$ & $8,11 \%$ & $0,00 \%$ & $-20,00 \%$ \\
\hline RDNI3 & Rodob & 0,53 & Medium & & Small & 03 & Loser & Small|Me & $3,23 \%$ & $-4,60 \%$ & $-32,82 \%$ & $-46,72 \%$ & $34,67 \%$ & $-16,49 \%$ & $-0,51 \%$ & $16,65 \%$ & $7,57 \%$ & $53,25 \%$ & $15,25 \%$ & $7,19 \%$ \\
\hline \begin{tabular}{|l|l|l|l|l|l|l|l|} 
RSIP3 \\
\end{tabular} & $\begin{array}{l}\text { Rasip Agro ON } \\
\end{array}$ & 0,38 & Medium & 5038.920 & Small & 0,03 & Loser & Small|Medium|Loser & $3,45 \%$ & $-6,67 \%$ & $-7,14 \%$ & $-9,62 \%$ & $12,77 \%$ & $0,00 \%$ & $5,66 \%$ & $-14,29 \%$ & $14,58 \%$ & $34,95 \%$ & $-21,92 \%$ & $-21,05 \%$ \\
\hline PNVL3 & Dimed ON & 0,42 & Medium & .080 .000 & Small & 0,00 & Loser & Small|Medium|Loser & $2,22 \%$ & $-12,15 \%$ & $-0,02 \%$ & $-16,25 \%$ & $-13,43 \%$ & $4,99 \%$ & $14,08 \%$ & $8,44 \%$ & $-14,84 \%$ & $0,00 \%$ & $4,76 \%$ & $-6,67 \%$ \\
\hline ROMI3 & IInds Ro & 0,37 & Medium & 5.207 .000 & Small & 0,00 & Los & Small|Med & $13,94 \%$ & $-4,58 \%$ & $-32,94 \%$ & $-26,67 \%$ & $3,03 \%$ & $14,27 \%$ & $-10,39 \%$ & $-9,69 \%$ | & $1,14 \%$ & $19,77 \%$ & 6,31\% & $11,11 \%$ \\
\hline PFRM3 & Profarma ON & 0,34 & Medium & $\begin{array}{r}898.062 .000 \\
\end{array}$ & Small & 0,02 & Winner & Small|Medium|Winner & $-38,36 \%$ & $14,75 \%$ & $-9,49 \%$ & $-40,03 \%$ & $-28,95 \%$ & $-21,48 \%$ & $7,55 \%$ & $-12,28 \%$ & $-7,00 \%$ & $60,78 \%$ & $30,61 \%$ & $7,29 \%$ \\
\hline FHER3 & Fer Heringer ON & 0,52 & Medium & 612.680 & Small & 0,11 & Winner & Small|Medium|Winner & $-8,26 \%$ & $-14,59 \%$ & $-47,58 \%$ & $-53,30 \%$ & $0,65 \%$ & $-23,11 \%$ & $23,31 \%$ & $-9,34 \%$ & $-10,30 \%$ & $33,33 \%$ & $47,06 \%$ & $14,57 \%$ \\
\hline TRFO4 & Trafo PN & 0,48 & Medium & .715.150 & Small & 0,11 & Winner & Small|Medium|Winner & $2,42 \%$ & $6,30 \%$ & $0,37 \%$ & $-15,50 \%$ & $6,17 \%$ & $-14,89 \%$ & $-10,00 \%$ & $13,89 \%$ & $16,10 \%$ & $15,61 \%$ & $3,77 \%$ & $-9,09 \%$ \\
\hline DROG3 & Drogasil ON & 0,41 & Medium & 1.015 .800 & Small & 0,12 & Winner & Small|Medium|Winner & $-8,05 \%$ & $-5,26 \%$ & $-21,26 \%$ & $-2,56 \%$ & $6,17 \%$ & $-3,91 \%$ & $-20,00 \%$ & $14,25 \%$ & $15,83 \%$ & $28,00 \%$ & $16,82 \%$ & $19,98 \%$ \\
\hline POMO4 & Marcopolo PN & 0,38 & Medium & |5.989.380 & Small & 0,13 & Winner & Small|Medium|Winner & $0,95 \%$ & $-2,52 \%$ & $-19,39 \%$ & $-24,45 \%$ & $-1,86 \%$ & $-7,55 \%$ & $-5,36 \%$ & $-6,67 \%$ & $17,86 \%$ & $46,97 \%$ & $-5,15 \%$ & $-3,26 \%$ \\
\hline RSIP4 & Rasip Agro PN & 0,38 & Medium & 106.938.920 & Small & 0,13 & Winner & Small|Medium |Winner & $0,00 \%$ & $-1,96 \%$ & $-4,00 \%$ & $-10,42 \%$ & $4,65 \%$ & $11,11 \%$ & $6,00 \%$ & $-15,09 \%$ & $4,44 \%$ & $-0,05 \%$ & $-10,87 \%$ & $0,00 \%$ \\
\hline POMO3 & Marcopolo ON & 0,38 & Medium & 1.435 .989 .380 & Small & 14 & Winner & Small|Medium|Winner & $-7,58 \%$ & $-5,08 \%$ & $-6,74 \%$ & $-41,67 \%$ & $10,48 \%$ & $-7,62 \%$ & $4,03 \%$ & $-4,84 \%$ & $12,54 \%$ & $35,54 \%$ & $1,78 \%$ & $-5,46 \%$ \\
\hline SOND5 & Sondotecnica PNA & 年, & Medium & & Small & 3 & Winner & Small|Medium|Winner & $-10,71 \%$ & $-6,05 \%$ & $-2,45 \%$ & $23,71 \%$ & $-37,46 \%$ & $-10,00 \%$ & $11,22 \%$ & $5,89 \%$ & $-5,66 \%$ & $2,60 \%$ & $21,83 \%$ & $20,00 \%$ \\
\hline SHUL4 & Schulz PN & 0,31 & Medium & 338.219 .500 & Small & 0,36 & Winner & Small|Medium|Winner & $-9,81 \%$ & $10,88 \%$ & $-13,28 \%$ & $0,04 \%$ & $-14,35 \%$ & $-13,71 \%$ & $2,88 \%$ & $-19,91 \%$ & $-19,29 \%$ & $14,51 \%$ & $0,46 \%$ & $-3,85 \%$ \\
\hline BAUH4 & Excelsior PN & 0,39 & Medium & 18.630 .000 & Small & 56 & Winne & Small|Medium|Winner & $-29,15 \%$ & $-4,55 \%$ & & $-26,83 \%$ & $-6,67 \%$ & $-14,29 \%$ & $-14,58 \%$ & $9,76 \%$ & $-6,67 \%$ & $53,33 \%$ & $-5,28 \%$ & $13,11 \%$ \\
\hline PTNT4 & Pettenati PN & 9 & Med & & Small & 4 & Win & Small|Medium|Winner & $-6,01 \%$ & $-4,63 \%$ & -13, & $-26,06 \%$ & $3,50 \%$ & $7,69 \%$ & $2,86 \%$ & $-3,47 \%$ & $-8,06 \%$ & $-3,60 \%$ & $4,71 \%$ & $\%$ \\
\hline MGEL4 & Mangels Indl PN & 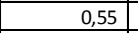 & Medium & 323.825 .518 & Small & 0,64 & Winner & Small|Medium|Winner & $-1,87 \%$ & $-4,46 \%$ & $-26,00 \%$ & $-32,43 \%$ & $-14,67 \%$ & $-21,88 \%$ & $2,40 \%$ & $-2,34 \%$ & \begin{tabular}{l|l}
$9,80 \%$ \\
\end{tabular} & $30,97 \%$ & \begin{tabular}{l|l|}
$-0,84 \%$ \\
\end{tabular} & $-14,08 \%$ \\
\hline TRFO3 & Trafo ON & 0,48 & Medium & 134.715 .150 & Small & 3,17 & Winner & Small|Medium|Winner & $-8,44 \%$ & $10,57 \%$ & $-4,90 \%$ & $-30,41 \%$ & $-21,75 \%$ & $-2,44 \%$ & $12,50 \%$ & $-10,22 \%$ & $23,27 \%$ & $-6,23 \%$ & $21,68 \%$ & $-7,27 \%$ \\
\hline
\end{tabular}

\begin{tabular}{|c|c|c|c|c|c|c|c|c|c|c|c|c|c|c|c|c|c|c|c|c|}
\hline Código & $2009-2010$ & $\begin{array}{l}\text { Índice } B / M \\
\text { de dez/2008 }\end{array}$ & \begin{tabular}{|c} 
Grupo com \\
base no \\
índice B/M \\
\end{tabular} & $\begin{array}{c}\text { Valor de Mercado } \\
\text { em jun/2009 }\end{array}$ & $\begin{array}{c}\text { Grupo com } \\
\text { base no } \\
\text { tamanho }\end{array}$ & \begin{tabular}{|c|} 
Retorno \\
acumulado \\
de jun/2009
\end{tabular} & \begin{tabular}{|c|} 
Grupo com \\
base no \\
retorno \\
acumulado \\
\end{tabular} & Carteiras & $\mathrm{jul} / 09$ & ago/09 & set/09 & out/09 & nov/09 & dez/09 & $\mathrm{jan} / 10$ & fev/10 & $\operatorname{mar} / 10$ & $\mathrm{abr} / 10$ & $\mathrm{mai} / 10$ & jun/10 \\
\hline MPXE3 & MPX Energia ON & 2,19 & High & 1.858.576.000 & Big & 0,75 & \begin{tabular}{|l|} 
Loser \\
\end{tabular} & Big|High|Loser & $19,78 \%$ & $5,59 \%$ & $15,12 \%$ & $22,47 \%$ & $-5,20 \%$ & $-2,13 \%$ & $2,44 \%$ & $16,92 \%$ & $-11,69 \%$ & $-9,71 \%$ & $-1,35 \%$ & $-7,08 \%$ \\
\hline ACGU3 & Guarani ON & 2,86 & High & 74.656 & Big & 0,74 & $\begin{array}{ll}\text { Loser } \\
\end{array}$ & 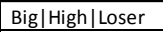 & $25,53 \%$ & $10,07 \%$ & $-0,51 \%$ & $-18,23 \%$ & $6,04 \%$ & $10,02 \%$ & $7,86 \%$ & $-13,91 \%$ & $-10,38 \%$ & $1,93 \%$ & $-14,53 \%$ & $-6,40 \%$ \\
\hline MAGG3 & Magnesita SA ON & 1,43 & High & 1.694.006.535 & $\mathrm{Big}$ & 0,70 & Loser & Big|High|Loser & $25,91 \%$ & $11,32 \%$ & $8,29 \%$ & $13,30 \%$ & $4,14 \%$ & $6,48 \%$ & $2,28 \%$ & $-9,34 \%$ & $6,34 \%$ & $-11,30 \%$ & $-12,18 \%$ & $-6,31 \%$ \\
\hline \begin{tabular}{|l|} 
GUAR4 \\
\end{tabular} & Guararapes PN & 1,31 & High & 1.603 .056 .000 & Big & 0,70 & Loser & 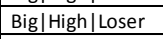 & $24,09 \%$ & $6,55 \%$ & $10,03 \%$ & $14,12 \%$ & $20,49 \%$ & $5,05 \%$ & $11,99 \%$ & $-20,91 \%$ & $12,64 \%$ & $3,35 \%$ & $1,80 \%$ & $4,33 \%$ \\
\hline GUAR3 & Guararapes ON & 1,31 & High & 603.056.000 & Big & 0,69 & Loser & Big|High|Loser & $28,70 \%$ & $7,57 \%$ & $6,76 \%$ & $1,93 \%$ & $35,78 \%$ & $28,80 \%$ & $0,27 \%$ & $-14,19 \%$ & $0,00 \%$ & $-3,48 \%$ & $-2,72 \%$ & $11,51 \%$ \\
\hline \begin{tabular}{|l|} 
STBP11 \\
\end{tabular} & Santos Brp UNT N2 & 1,34 & High & 442.707 .200 & Big & 0,68 & Loser & Big|High|Loser & $12,73 \%$ & $-2,66 \%$ & $15,91 \%$ & $-0,64 \%$ & $7,63 \%$ & $16,98 \%$ & $-10,00 \%$ & $0,95 \%$ & $11,64 \%$ & $-4,29 \%$ & $-7,58 \%$ & $-3,10 \%$ \\
\hline BISA3 & Brookfield ON & 2,44 & High & $\begin{array}{l}1.495 .784 .480 \\
\end{array}$ & Big & 0,57 & $\begin{array}{ll}\text { Loser } \\
\end{array}$ & Big|High|Loser & $39,34 \%$ & $27,73 \%$ & $1,71 \%$ & $-12,16 \%$ & 10,90\% & $3,59 \%$ & $5,90 \%$ & $9,69 \%$ & $-12,14 \%$ & $-1,88 \%$ & $1,31 \%$ & $-0,26 \%$ \\
\hline ALPA3 & Alpargatas ON & 1,32 & High & 1.304.238.180 & Big & 0,54 & Loser & \begin{tabular}{|l|l|} 
Big|High|Loser \\
\end{tabular} & $-1,55 \%$ & $14,29 \%$ & $-8,44 \%$ & $2,74 \%$ & $46,53 \%$ & $10,40 \%$ & $8,26 \%$ & $6,88 \%$ & $19,04 \%$ & $-10,84 \%$ & $-14,51 \%$ & $26,00 \%$ \\
\hline \begin{tabular}{|l|} 
MRFG3 \\
\end{tabular} & Marfrig ON & 1,36 & High & 3.875 .101 .148 & Big & 0,53 & Loser & 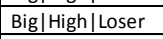 & $9,03 \%$ & $-0,06 \%$ & $6,65 \%$ & $20,06 \%$ & $1,33 \%$ & $-4,32 \%$ & $17,68 \%$ & $-6,40 \%$ & $-3,42 \%$ & $-10,32 \%$ & $-6,13 \%$ & $-1,17 \%$ \\
\hline RSID3 & Rossi Resid ON & 1,72 & High & 1.563.528.342 & Big & 0,53 & Loser & Big|High|Loser & $31,71 \%$ & $10,74 \%$ & $19,15 \%$ & $-17,26 \%$ & $24,68 \%$ & $4,08 \%$ & $-14,38 \%$ & $7,79 \%$ & $-12,25 \%$ & $3,71 \%$ & $3,12 \%$ & $-0,31 \%$ \\
\hline CESP6 & Cesp PNB & 1,77 & High & $\begin{array}{ll}6.122 .565 .140 \\
\end{array}$ & Big & 0,50 & Loser & Big|High|Loser & $-1,38 \%$ & $5,25 \%$ & $7,97 \%$ & $-5,50 \%$ & $4,63 \%$ & $12,03 \%$ & $-2,25 \%$ & $-1,02 \%$ & $5,29 \%$ & $2,86 \%$ & $-12,49 \%$ & $12,28 \%$ \\
\hline CESP3 & Cesp ON & 1,77 & High & \begin{tabular}{ll|}
6.122 .565 .140 \\
\end{tabular} & Big & 0,48 & Loser & Big|High|Loser & $-0,12 \%$ & $5,08 \%$ & $10,68 \%$ & $-11,18 \%$ & $6,94 \%$ & $4,86 \%$ & $2,32 \%$ & $-4,79 \%$ & $4,13 \%$ & $-1,42 \%$ & $-6,59 \%$ & $5,56 \%$ \\
\hline
\end{tabular}


Anexo 1 - Retorno mensal e classificação das ações

\begin{tabular}{|c|c|c|c|c|c|c|c|c|c|c|c|c|c|c|c|c|c|c|c|c|}
\hline Código & $2009-2010$ & $\begin{array}{l}\text { Índice } B / M \\
\text { de dez/2008 }\end{array}$ & $\begin{array}{c}\text { Grupo com } \\
\text { base no } \\
\text { indice } B / M\end{array}$ & $\begin{array}{c}\text { Valor de Mercado } \\
\text { em jun/2009 }\end{array}$ & $\begin{array}{l}\text { Grupo com } \\
\text { base eo } \\
\text { tamanho }\end{array}$ & $\begin{array}{c}\text { Retorno } \\
\text { acumulado } \\
\text { de jun/2009 }\end{array}$ & \begin{tabular}{|c|} 
Grupo com \\
base no \\
retorno \\
acumulado
\end{tabular} & Carteiras & $\mathrm{jul} / 09$ & ago/09 & set/09 & out/09 & nov/09 & dez/09 & jan/10 & fev/10 & $\mathrm{mar} / 10$ & $\mathrm{abr} / 10$ & $\mathrm{mai} / 10$ & jun/10 \\
\hline SMTO3 & Sao Martinho ON & 1,49 & High & 1.862 .206 .500 & Big & 0,44 & Loser & Big|High|Loser & \begin{tabular}{|l|l|}
$-3,94 \% \%$ \\
\end{tabular} & $6,69 \%$ & $-1,83 \%$ & $4,22 \%$ & $-2,31 \%$ & $1,57 \%$ & $5,88 \%$ & $-6,11 \%$ & \begin{tabular}{|l|l|}
$-3,61 \%$ \\
\end{tabular} & \begin{tabular}{|l|}
$-3,93 \%$ \\
\end{tabular} & $-6,39 \%$ & $-4,78 \%$ \\
\hline CESP5 & Cesp PNA & 1,77 & High & 6.122 .565 .140 & Big & 0,40 & Loser & Big|High|Loser & $3,28 \%$ & $12,17 \%$ & $-0,19 \%$ & $-5,01 \%$ & $2,24 \%$ & $32,26 \%$ & $-0,85 \%$ & $-0,26 \%$ & $-2,34 \%$ & $-7,05 \%$ & $10,45 \%$ & $0,00 \%$ \\
\hline ALPA4 & Alpargatas PN & 1,32 & High & 1.304 .238 .180 & Big & 0,38 & Winner & Big|High|Winner & $-3,79 \%$ & $5,66 \%$ & $-5,00 \%$ & $5,25 \%$ & $22,89 \%$ & $17,24 \%$ & $5,83 \%$ & $6,58 \%$ & $-1,60 \%$ & $-2,68 \%$ & $6,38 \%$ & $19,23 \%$ \\
\hline SBSP3 & Sabesp ON & 1,51 & High & 6.614 .079 .080 & Big & 0,29 & Winner & Big|High|Winner & $8,16 \%$ & $10,51 \%$ & $-1,73 \%$ & $-1,76 \%$ & $-2,80 \%$ & $8,80 \%$ & $-8,81 \%$ & $-3,19 \%$ & $5,70 \%$ & $4,57 \%$ & $4,85 \%$ & $7,14 \%$ \\
\hline CSMG3 & Copasa ON & 1,69 & High & $\begin{array}{l}2.935 .797 .200 \\
\end{array}$ & Big & 0,15 & Winner & Big|High/Winner & $0,32 \%$ & $19,25 \%$ & $0,73 \%$ & $4,83 \%$ & $-4,29 \%$ & $10,47 \%$ & $-23,31 \%$ & $-0,78 \%$ & $1,58 \%$ & $1,52 \%$ & $-4,48 \%$ & $3,73 \%$ \\
\hline ELET3 & Eletrobras ON & 2,96 & High & \begin{tabular}{|l|}
30.807 .732 .274 \\
\end{tabular} & Big & 0,02 & Winner & Big|High|Winner & $0,17 \%$ & $-4,01 \%$ & $0,18 \%$ & $-9,75 \%$ & $16,42 \%$ & $25,31 \%$ & $10,18 \%$ & $-18,40 \%$ & \begin{tabular}{ll|}
$11,97 \%$ \\
\end{tabular} & $-5,73 \%$ & \begin{tabular}{l|l|}
$-6,71 \%$ \\
\end{tabular} & $5,34 \%$ \\
\hline ELET6 & Eletrobras PNB & 2,96 & High & 30.807 .732 .274 & Big & 0,05 & Winner & Big|High|Winner & $1,18 \%$ & $-4,07 \%$ & $0,61 \%$ & $-9,64 \%$ & $12,31 \%$ & $25,52 \%$ & $9,39 \%$ & $-16,88 \%$ & $11,05 \%$ & $-5,21 \%$ & $-8,08 \%$ & $7,55 \%$ \\
\hline ALLL3 & All Amer Lat ON & 0,37 & Low & 7.722 .949 .610 & Big & 0,62 & Loser & Big|Low|Loser & $-4,36 \%$ & $16,20 \%$ & $-1,31 \%$ & $-3,19 \%$ & $62,50 \%$ & $-4,62 \%$ & $-14,52 \%$ & $14,72 \%$ & $-7,07 \%$ & $-9,03 \%$ & $-12,42 \%$ & $15,56 \%$ \\
\hline TAMM4 & Tam S/A PN & 0,22 & Low & 2.995 .548 .400 & Big & 0,58 & $\begin{array}{l}\text { Loser } \\
\end{array}$ & Big|Low|Loser & $13,37 \%$ & $5,02 \%$ & $-4,37 \%$ & $9,78 \%$ & $18,57 \%$ & $27,62 \%$ & $-9,40 \%$ & $-2,84 \%$ & $-9,23 \%$ & $1,32 \%$ & $-17,40 \%$ & $2,97 \%$ \\
\hline ALLL11 & All Amer Lat UNT N2 & 0,37 & Low & \begin{tabular}{|l|l}
7.722 .949 .610 \\
\end{tabular} & Big & 0,53 & Loser & Big|Low|Loser & $-2,40 \%$ & $15,62 \%$ & $0,29 \%$ & $-3,36 \%$ & $19,25 \%$ & $5,23 \%$ & $-7,36 \%$ & $6,75 \%$ & $1,12 \%$ & $-2,94 \%$ & $-8,35 \%$ & $-2,00 \%$ \\
\hline SLCE3 & SLC Agricola ON & 0,52 & Low & 1.805.479.750 & Big & 0,52 & Loser & Big|Low|Loser & $-3,51 \%$ & $-15,13 \%$ & $0,59 \%$ & $-12,80 \%$ & $0,30 \%$ & $22,28 \%$ & $10,43 \%$ & $-14,89 \%$ & $-5,09 \%$ & $14,40 \%$ & $-15,47 \%$ & $-4,22 \%$ \\
\hline AVIL3 & Acos Vill ON & 0,58 & Low & 2.239 .277 .400 & Big & 0,52 & Loser & Big|Low|Loser & $8,82 \%$ & $25,68 \%$ & $-4,30 \%$ & $-2,25 \%$ & $10,34 \%$ & $10,89 \%$ & $7,69 \%$ & $14,29 \%$ & $11,25 \%$ & $-11,24 \%$ & $-10,84 \%$ & $2,86 \%$ \\
\hline BTOW3 & B2W Varejo ON & 0,08 & Low & 4.089.299.340 & Big & 0,51 & Loser & Big|Low|Loser & $18,03 \%$ & $11,00 \%$ & $2,43 \%$ & $2,41 \%$ & $-0,98 \%$ & $-5,35 \%$ & $-20,50 \%$ & $-1,32 \%$ & $2,68 \%$ & $-0,08 \%$ & $-20,25 \%$ & $-1,70 \%$ \\
\hline KLBN4 & Klabin S/A PN & 0,64 & Low & 3.387 .168 .380 & Big & 0,51 & Loser & Big|Low|Loser & $11,71 \%$ & $10,88 \%$ & $15,07 \%$ & $-1,19 \%$ & $19,19 \%$ & $8,59 \%$ & $-8,10 \%$ & $-2,66 \%$ & \begin{tabular}{|l|l|}
$15,16 \%$ & \\
\end{tabular} & $1,25 \%$ & $-8,78 \%$ & $0,20 \%$ \\
\hline LREN3 & Lojas Renner ON & 0,37 & Low & 2.629 .510 .880 & Big & 0,50 & Loser & Big|Low|Loser & $26,73 \%$ & $9,12 \%$ & $3,88 \%$ & $-0,19 \%$ & $23,39 \%$ & $3,78 \%$ & $-8,45 \%$ & $8,45 \%$ & $4,56 \%$ & $7,45 \%$ & $1,14 \%$ & $12,64 \%$ \\
\hline RENT3 & Localiza ON & 0,38 & Low & 2.389 .532 .200 & Big & 0,47 & Loser & Big|Low|Loser & $25,90 \%$ & $10,67 \%$ & $5,42 \%$ & $4,72 \%$ & $5,95 \%$ & $-1,43 \%$ & $2,17 \%$ & $-0,20 \%$ & $-4,57 \%$ & $3,97 \%$ & $-1,90 \%$ & $9,69 \%$ \\
\hline CSNA3 & Sid Nacional ON & 0,31 & Low & 33.093.185.400 & Big & 0,46 & Loser & Big|Low|Loser & $10,18 \%$ & $2,00 \%$ & $10,93 \%$ & $7,21 \%$ & $0,34 \%$ & $-3,56 \%$ & $-1,79 \%$ & $7,55 \%$ & $20,61 \%$ & $-9,50 \%$ & $-10,72 \%$ & $-5,73 \%$ \\
\hline ALLL4 & All Amer Lat PN & 0,37 & Low & \begin{tabular}{|l|l}
7.722 .949 .610 \\
\end{tabular} & Big & 0,45 & Loser & Big|Low|Loser & $0,00 \%$ & $14,06 \%$ & $5,02 \%$ & $-9,78 \%$ & $22,50 \%$ & $1,22 \%$ & $-2,82 \%$ & $7,05 \%$ & $6,20 \%$ & $-2,92 \%$ & $-7,07 \%$ & $5,26 \%$ \\
\hline LLMD4 & Yara Brasil PN & 0,10 & Low & 2.145 .010 .080 & Big & 0,45 & $\begin{array}{l}\text { Loser } \\
\end{array}$ & Big|Low|Loser & $-11,86 \%$ & $-5,41 \%$ & $2,57 \%$ & $0,28 \%$ & $-1,39 \%$ & $-7,07 \%$ & $15,19 \%$ & $-7,89 \%$ & $-8,57 \%$ & $18,75 \%$ & $-1,34 \%$ & $30,22 \%$ \\
\hline SZPQ4 & Quattor Petr PN & 0,36 & Low & 1.700 .212 .500 & Big & 0,44 & Loser & Big|Low|Loser & $-2,67 \%$ & $2,88 \%$ & $-4,79 \% \mid$ & $1,68 \%$ & $-0,96 \%$ & $2,78 \%$ | & $-4,05 \%$ & $-4,23 \%$ & $0,74 \%$ & $3,50 \%$ & $5,37 \%$ & $-1,21 \%$ \\
\hline FFTL4 & Valefert PN & 0,41 & Low & \begin{tabular}{|l|}
5.884 .943 .808 \\
\end{tabular} & Big & 0,44 & Loser & 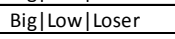 & $17,66 \%$ & $0,34 \%$ & $3,68 \%$ & $-8,63 \%$ & $-4,19 \%$ & $3,00 \%$ & $13,27 \%$ & $-4,23 \%$ & $-5,08 \%$ & $-4,36 \%$ & $-4,37 \%$ & $13,13 \%$ \\
\hline LAME3 & Lojas Americ ON & 0,07 & Low & 6.314 .315 .820 & Big & 0,43 & Loser & Big|Low|Loser & $13,92 \%$ & $8,33 \%$ & $-0,41 \%$ & $-0,93 \%$ & $20,48 \%$ & $10,44 \%$ & $-10,00 \%$ & $-5,38 \%$ & $1,39 \%$ & $\begin{array}{ll}0,91 \% \\
\end{array}$ & $-15,32 \%$ & $7,45 \%$ \\
\hline PETR4 & Petrobras PN & 0,64 & Low & 323.479.137.281 & Big & 0,37 & Winner & Big|Low|Winner & $-2,07 \%$ & $-0,29 \%$ & $11,54 \%$ & $0,69 \%$ & $10,73 \%$ & $-4,92 \%$ & $-6,87 \%$ & $1,29 \%$ & $2,25 \%$ & $-6,62 \%$ & $-9,10 \%$ & $-9,26 \%$ \\
\hline EKTR4 & Elektro PN & 0,47 & Low & 3.660 .112 .516 & Big & 0,36 & Winner & Big|Low|Winner & $-10,01 \%$ & $13,90 \%$ & $0,11 \%$ & $0,00 \%$ & $5,56 \%$ & $1,93 \%$ & $31,58 \%$ & $0,00 \%$ & \begin{tabular}{l|l|}
$18,96 \%$ \\
\end{tabular} & $-19,62 \%$ & $3,45 \%$ & $0,00 \%$ \\
\hline AMIL3 & Amil ON & 0,46 & Low & \begin{tabular}{l|l}
3.376 .173 .150 \\
\end{tabular} & Big & 0,36 & Winner & Big|Low/Winner & $13,23 \%$ & $-6,64 \%$ & $-2,80 \%$ & $2,47 \%$ & $28,14 \%$ & $7,58 \%$ & $-2,92 \%$ & $0,38 \%$ & $4,21 \%$ & $2,89 \%$ & $-3,51 \%$ & $6,55 \%$ \\
\hline ENMA3B & Cemar ON & 0,52 & Low & \begin{tabular}{|c|}
1.231 .102 .500 \\
\end{tabular} & Big & 0,34 & Winner & Big|Low|Winner & $1,47 \%$ & $11,70 \%$ & $27,65 \%$ & $-7,83 \%$ & $7,50 \%$ & $2,33 \%$ & $16,18 \%$ & $-2,19 \%$ & $-15,20 \%$ & \begin{tabular}{l|l|}
$-9,72 \%$ \\
\end{tabular} & $-10,87 \%$ & $-1,22 \%$ \\
\hline ITSA3 & Itausa ON & 0,62 & Low & 39.878 .358 .460 & Big & 0,33 & Winner & Big|Low|Winner & $3,03 \%$ & $7,95 \%$ & $4,97 \%$ & $4,44 \%$ & $-1,25 \%$ & $16,42 \%$ & $-10,44 \%$ & $2,68 \%$ & $-2,07 \%$ & $-1,39 \%$ & $-6,03 \%$ & $1,19 \%$ \\
\hline \begin{tabular}{|l|} 
WEGE3 \\
\end{tabular} & Weg ON & 0,28 & Low & 8.523 .248 .860 & Big & 0,32 & Winner & Big|Low|Winner & $10,30 \%$ & $3,31 \%$ & $8,54 \%$ & $3,08 \%$ & $2,30 \%$ & $3,47 \%$ & $-1,90 \%$ & $-1,04 \%$ & \begin{tabular}{l|l}
$7,89 \%$ \\
\end{tabular} & $-6,58 \%$ & $-4,23 \%$ & $-1,43 \%$ \\
\hline BRTO4 & Brasil Telec PN & 0,35 & Low & \begin{tabular}{|l|l|}
17.743 .124 .196 \\
\end{tabular} & Big & 0,31 & Winner & Big|Low|Winner & $2,68 \%$ & $1,87 \%$ & $14,87 \%$ & $-4,40 \%$ & $13,34 \%$ & $-1,41 \%$ & $-21,85 \%$ & $-5,12 \%$ & $-8,21 \%$ & $-2,11 \%$ & $6,54 \%$ & $2,10 \%$ \\
\hline LAME4 & Lojas Americ PN & 0,07 & Low & 6.314 .315 .820 & Big & 0,31 & Winner & Big|Low|Winner & $14,38 \%$ & $7,14 \%$ & $6,31 \%$ & $-3,01 \%$ & $25,00 \%$ & $7,10 \%$ & $-14,81 \%$ & $-1,74 \%$ & $2,33 \%$ & $-2,42 \%$ & $-4,10 \%$ & $5,48 \%$ \\
\hline \begin{tabular}{|l|l|} 
CGAS3 & \\
\end{tabular} & Comgas ON & 0,29 & Low & 90.796 .450 & Big & 0,29 & Winner & Big|Low|Winner & \begin{tabular}{l|l}
$0,81 \%$ \\
\end{tabular} & $-3,23 \%$ & $-1,67 \%$ & $1,29 \%$ & $2,24 \%$ & $1,27 \%$ & $1,43 \%$ & $10,29 \%$ & $-3,67 \%$ & $6,28 \%$ & $-3,16 \%$ & $-1,42 \%$ \\
\hline CGAS5 & Comgas PNA & 0,29 & Low & 3.790 .796 .450 & Big & 0,28 & Winner & Big|Low|Winner & $-1,29 \%$ & $-2,03 \%$ & $-0,15 \%$ & $-0,59 \%$ & $-0,99 \%$ & $4,42 \%$ & $4,53 \%$ & $0,70 \%$ & $-0,12 \%$ & $1,48 \%$ & $2,10 \%$ & $2,20 \%$ \\
\hline OGXP3 & OGX Petroleo ON & 0,54 & Low & 32.293.103.923 & Big & 0,28 & Winner & Big|Low|Winner & $21,60 \%$ & $-15,64 \%$ & $32,19 \%$ & $5,17 \%$ & $4,21 \%$ & $15,15 \%$ & $-1,75 \%$ & $-6,25 \%$ & \begin{tabular}{|l|l|}
$5,71 \%$ & \\
\end{tabular} & $4,02 \%$ & $-6,41 \%$ & $3,15 \%$ \\
\hline DASA3 & Dasa ON & 0,37 & Low & \begin{tabular}{|c|}
1.974 .663 .200 \\
\end{tabular} & Big & 0,26 & Winner & Big|Low|Winner & $16,28 \%$ & $6,20 \%$ & $7,86 \%$ & $-4,85 \%$ & $24,77 \%$ & $5,58 \%$ & $1,46 \%$ & $2,39 \%$ & $5,41 \%$ & $-3,21 \%$ & \begin{tabular}{l|l|}
$-0,66 \%$ \\
\end{tabular} & $13,27 \%$ \\
\hline NETC4 & Net PN & 0,59 & Low & 6.316 .000 & Big & 0,24 & Winner & Big|Low/Winner & $0,26 \%$ & $4,09 \%$ & $3,93 \%$ & $6,74 \%$ & $9,82 \%$ & $-0,66 \%$ & $-9,17 \%$ & $1,93 \%$ & $4,86 \%$ & $-12,02 \%$ & $-9,51 \%$ & $-8,36 \%$ \\
\hline CBEE3 & Ampla Energ ON & 0,51 & Low & \begin{tabular}{|c|}
3.412 .588 .849 \\
\end{tabular} & Big & 0,21 & Winner & Big|Low|Winner & $19,54 \%$ & $0,96 \%$ & $48,57 \%$ & $-17,31 \%$ & $9,27 \%$ & $1,47 \%$ & $13,77 \%$ & $11,46 \%$ & $2,29 \%$ & $-7,26 \%$ & $-6,80 \%$ & $-3,29 \%$ \\
\hline TBLE3 & Tractebel ON & 0,26 & Low & \begin{tabular}{|l|}
2.369 .464 .538 \\
\end{tabular} & Big & 0,20 & Winner & Big|Low|Winner & $1,58 \%$ & $6,47 \%$ & $4,66 \%$ & $0,10 \%$ & $1,87 \%$ & $2,52 \%$ & $-6,04 \%$ & $2,37 \%$ & $-3,48 \%$ & $10,81 \%$ & $-6,27 \%$ & $2,66 \%$ \\
\hline RDCD3 & $\begin{array}{l}\text { Redecard ON } \\
\end{array}$ & 0,04 & Low & 20.289 .442 .500 & Big & 0,17 & Winner & Big|Low|Winner & $-4,87 \%$ & $-7,03 \%$ & $5,62 \%$ & $-4,04 \%$ & $2,49 \%$ & $8,36 \%$ & $-9,14 \%$ & $-0,19 \%$ & $25,10 \%$ & $-9,62 \%$ & $-4,18 \%$ & $-7,14 \%$ \\
\hline ITSA4 & Itausa PN & 0,62 & Low & 39.878 .358 .460 & Big & 0,16 & Winner & Big|Low|Winner & \begin{tabular}{l|l}
$9,75 \%$ \\
\end{tabular} & $1,69 \%$ & $10,90 \%$ & $-6,62 \%$ & $11,99 \%$ & $5,84 \%$ & $-4,95 \%$ & $2,94 \%$ & $7,17 \%$ & $-1,56 \%$ & \begin{tabular}{l|l|l|}
$-6,88 \%$ \\
\end{tabular} & $-3,83 \%$ \\
\hline CCRO3 & CCR SA ON & 0,17 & Low & 12.669 .489 .574 & Big & 0,15 & Winner & Big|Low|Winner & $-2,96 \%$ & $5,74 \%$ & $-2,38 \%$ & $14,81 \%$ & $8,76 \%$ & $5,39 \%$ & $0,83 \%$ & $-5,15 \%$ & $3,51 \%$ & $2,50 \%$ & $-7,68 \%$ & $0,62 \%$ \\
\hline GET13 & AES Ti & 0,10 & Low & \begin{tabular}{|c|}
7.400 .410 .690 \\
\end{tabular} & Big & 0,11 & Winner & Big|Low|Winner & $-3,46 \%$ & $7,71 \%$ & $-0,27 \%$ & $1,61 \%$ & $-0,80 \%$ & $-5,33 \%$ & $0,00 \%$ & $2,15 \%$ & \begin{tabular}{l|l}
$-0,46 \%$ \\
\end{tabular} & \begin{tabular}{l|l|}
$-0,23 \%$ \\
\end{tabular} & $3,18 \%$ & $4,39 \%$ \\
\hline \begin{tabular}{|l|l|} 
BMTO3 & \\
\end{tabular} & Brasmotor ON & 0,49 & Low & 2.156 .318 .880 & Big & 0,10 & Winner & Big|Low|Winner & $11,11 \%$ & $11,25 \%$ & $-4,49 \%$ & $17,65 \%$ & $-8,34 \%$ & $-3,61 \%$ & $25,00 \%$ & $-8,00 \%$ & $-5,43 \%$ & $-1,15 \%$ & $-5,81 \%$ & $12,35 \%$ \\
\hline MDIA3 & M. Diasbranco ON & 0,54 & Low & $\begin{array}{l}3.254 .723 .500 \\
\end{array}$ & Big & 0,10 & \begin{tabular}{|l|} 
Winner \\
\end{tabular} & Big|Low|Winner & $9,76 \%$ & $7,94 \%$ & $7,21 \%$ & $4,20 \%$ & $2,19 \%$ & $8,22 \%$ & $15,36 \%$ & $-2,17 \%$ & $-6,96 \%$ & $-3,69 \%$ & $-13,38 \%$ & $7,59 \%$ \\
\hline CPFE3 & & & Low & & Big & 0,06 & Winr & & & & $-3,9$ & $-4,8$ & & 10,0 & & & $-1,2$ & & & $7,24 \%$ \\
\hline ENGI3 & Energisa ON & 0,48 & Low & $\begin{array}{l}2.075 .176 .450 \\
\end{array}$ & Big & 0,03 & Winner & Big|Low|Winner & $12,02 \%$ & $-3,64 \%$ & $0,00 \%$ ] & 7,84\% & $-6,36 \%$ & $7,77 \%$ & $-0,90 \%$ & $-1,36 \%$ & $-4,56 \%[$ & $-6,86 \%$ & $-2,63 \%[$ & $-7,57 \%$ \\
\hline AMBV3 & Ambev ON & 0,31 & Low & 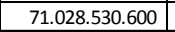 & Big & 0,02 & Winner & Big|Low|Winner & $2,63 \%$ & $12,39 \%$ & $6,05 \%$ & $6,01 \%$ & $6,63 \%$ & $4,62 \%$ & $1,69 \%$ & $-0,58 \%$ & $-6,46 \%$ & \begin{tabular}{l|l}
$6,59 \%$ \\
\end{tabular} & \begin{tabular}{l|l}
$0,12 \%$ \\
\end{tabular} & $5,91 \%$ \\
\hline ENG14 & Energisa PN & 0,48 & Low & \begin{tabular}{|l|}
2.075 .176 .450 \\
\end{tabular} & & 0,01 & Winner & Big|Low|Winner & $1,50 \%$ & & &, $68 \%$ & $47 \%$ & $0,97 \%$ & $y, / 6 \%]$ & $-0,6 / \%]$ & $0,09 \% \mid$ & $-3,38 \% \mid$ & $-14,50 \%$ & $5,85 \%$ \\
\hline
\end{tabular}


Anexo 1 - Retorno mensal e classificação das ações

\begin{tabular}{|c|c|c|c|c|c|c|c|c|c|c|c|c|c|c|c|c|c|c|c|c|}
\hline Código & 2009 - 2010 & $\begin{array}{l}\text { Índice } B / M \\
\text { de dez/2008 }\end{array}$ & $\begin{array}{c}\text { Grupo com } \\
\text { base no } \\
\text { indice } B / M\end{array}$ & $\begin{array}{c}\text { Valor de Mercado } \\
\text { em jun/2009 }\end{array}$ & $\begin{array}{l}\text { Grupo com } \\
\text { base eo } \\
\text { tamanho }\end{array}$ & $\begin{array}{c}\text { Retorno } \\
\text { acumulado } \\
\text { de jun/2009 }\end{array}$ & $\begin{array}{l}\text { Grupo com } \\
\text { base no } \\
\text { retorno } \\
\text { acumulado }\end{array}$ & Carteiras & jul/09 & ago/09 & set/09 & out/09 & nov/09 & dez/09 & jan/10 & fev/10 & $\mathrm{mar} / 10$ & $\mathrm{abr} / 10$ & $\mathrm{mai} / 10$ & jun/10 \\
\hline CRUZ3 & Souza Cruz ON & 0,13 & Low & \begin{tabular}{|c|}
17.063 .615 .800 \\
\end{tabular} & Big & 0,02 & Winner & Big|Low|Winner & $13,76 \%$ & $-2,00 \%$ & $4,13 \%$ & $-0,02 \%$ & $-2,73 \%$ & $-4,38 \%$ & $4,76 \%$ & $2,16 \%$ & $3,49 \%$ & $8,06 \%$ & $-0,75 \%$ & $2,38 \%$ \\
\hline CEEB3 & Coelba ON & 0,28 & Low & 6.418 .515 .259 & Big & 0,03 & Winner & Big|Low|Winner & $-5,80 \%$ & $6,15 \%$ & $-0,06 \%$ & $-0,40 \%$ & $-1,52 \%$ & $3,48 \%$ & $-5,97 \%$ & $7,94 \%$ & $10,26 \%$ & $0,33 \%$ & $-4,47 \%$ & $3,80 \%$ \\
\hline TOTS3 & Totvs ON & 0,39 & Low & 2.082 .538 .074 & Big & 0,03 & Winner & Big|Low|Winner & $12,18 \%$ & $9,23 \%$ & $6,21 \%$ & $10,33 \%$ & $8,52 \%$ & $13,96 \%$ & $-1,78 \%$ & $-5,52 \%$ & $3,77 \%$ & $6,71 \%$ & $8,62 \%$ & $3,20 \%$ \\
\hline \begin{tabular}{|l|} 
WHRL4 \\
\end{tabular} & Whirlpool PN & 0,36 & Low & 5.392 .494 .800 & Big & 0,09 & Winner & Big|Low|Winner & $-4,76 \%$ & $-6,11 \%$ & $1,18 \%$ & $5,56 \%$ & $0,01 \%$ & $5,76 \%$ & $1,72 \%$ & $-1,41 \%$ & $-1,43 \%$ & $-1,74 \%$ & $-2,36 \%$ & $8,16 \%$ \\
\hline TRPL4 & Tran Paulist PN & 0,63 & Low & $\begin{array}{l}7.329 .257 .250 \\
\end{array}$ & Big & 0,09 & Winner & Big|Low/Winner & $-1,01 \%$ & $1,53 \%$ & $3,80 \%$ & $-0,26 \%$ & $2,68 \%$ & $4,56 \%$ & $-6,33 \%$ & $2,11 \%$ & $-3,30 \%$ & $1,39 \%$ & $-1,60 \%$ & $3,33 \%$ \\
\hline \begin{tabular}{|l|l|} 
AMBV4 & \\
\end{tabular} & Ambev PN & 0,31 & Low & 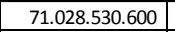 & Big & 0,13 & Winner & Big|Low|Winner & $4,83 \%$ & $6,66 \%$ & $4,98 \%$ & $9,22 \%$ & $4,86 \%$ & $5,57 \%$ & $-0,86 \%$ & $0,59 \%$ & $-5,39 \%$ & $3,97 \%$ & $2,35 \%$ & $3,72 \%$ \\
\hline LIGT3 & Light S/A ON & 0,63 & Low & 5.496.022.917 & Big & 0,14 & Winner & Big|Low|Winner & $-9,83 \%$ & $-1,77 \%$ & $3,48 \%$ & $-0,53 \%$ & $-0,10 \%$ & $7,85 \%$ & $-4,04 \%$ & $6,90 \%$ & $-1,99 \%$ & $-2,37 \%$ & $-12,77 \%$ & $2,54 \%$ \\
\hline GETI4 & AES Tiete PN & 0,10 & Low & 7.400 .410 .690 & Big & 0,15 & Winner & Big|Low|Winner & $-1,47 \%$ & $3,54 \%$ & $-1,38 \%$ & $-0,65 \%$ & $-0,99 \%$ & $5,40 \%$ & $-5,10 \%$ & $0,11 \%$ & $1,58 \%$ & $0,57 \%$ & $5,68 \%$ & $6,46 \%$ \\
\hline COCE5 & Coelce PNA & 0,58 & Low & 1.896 .413 .094 & Big & 0,16 & Winner & Big|Low|Winner & $6,57 \%$ & $-2,33 \%$ & $20,83 \%$ & $-10,05 \%$ & $5,88 \%$ & $6,38 \%$ & $-3,47 \%$ & $0,74 \%$ & $0,07 \%$ & $-3,42 \%$ & $-5,31 \%$ & $5,61 \%$ \\
\hline COCE3 & Coelce ON & 0,58 & Low & 1.896 .413 .094 & Big & 0,19 & Winner & Big|Low|Winner & $6,30 \%$ & $0,00 \%$ & $18,08 \%$ & $-5,67 \%$ & $12,23 \%$ & $0,03 \%$ & $1,54 \%$ & $0,00 \%$ & $1,52 \%$ & $-4,48 \%$ & $-8,76 \%$ & $2,32 \%$ \\
\hline BMTO4 & Brasmotor PN & 0,49 & Low & 2.156.318.880 & Big & 0,20 & Winner & Big|Low|Winner & $5,19 \%$ & $-6,17 \%$ & $5,26 \%$ & $6,25 \%$ & $1,99 \%$ & $5,19 \%$ & $9,88 \%$ & $2,25 \%$ & $0,00 \%$ & $-3,30 \%$ & $-4,55 \%$ & $13,10 \%$ \\
\hline BRTO3 & Brasil Telec ON & 0,35 & Low & 17.743.124.196 & Big & 0,23 & Winner & Big|Low|Winner & $-42,38 \%$ & $-6,50 \%$ & $-6,35 \%$ & $-7,04 \%$ & $7,61 \%$ & $-1,79 \%$ & $-26,32 \%$ & $-2,42 \%$ & $-20,27 \%$ & $-8,88 \%$ & $11,13 \%$ & $0,19 \%$ \\
\hline CEPE5 & Celpe PNA & 0,59 & Low & 2.944.139.867 & Big & 0,25 & Winner & Big|Low|Winner & $3,80 \%$ & $9,76 \%$ & $0,00 \%$ & $7,98 \%$ | & $-0,22 \%$ & $-0,94 \% \mid$ & $-2,09 \% \mid$ & $-2,36 \% \mid$ & $4,56 \%$ & $2,48 \%$ & $-4,02 \%$ & $6,98 \%$ | \\
\hline NATU3 & Natura ON & 0,09 & Low & 8.220 & Big & 0,47 & Winner & Big|Low|Winner & $5,20 \%$ & $14,41 \%$ & $4,79 \%$ & $-1,25 \%$ & $6,34 \%$ & $8,23 \%$ & $-6,53 \%$ & $-1,89 \%$ & $11,09 \%$ & $2,22 \%$ & $2,71 \%$ & $5,54 \%$ \\
\hline GOLL4 & Gol PN & 0,67 & Medium & $\begin{array}{l}2.470 .069 .800 \\
\end{array}$ & Big & 0,70 & Loser & \begin{tabular}{|l|l|} 
Big|Medium|Loser \\
\end{tabular} & $26,08 \%$ & $26,37 \%$ & $5,82 \%$ & $-0,60 \%$ & $37,04 \%$ & $4,28 \%$ & $-11,43 \%$ & $6,28 \%$ & $-6,22 \%$ & $3,59 \%$ & $-12,12 \%$ & $5,32 \%$ \\
\hline GOAU3 & Gerdau Met ON & 1,08 & Medium & 9.687.549.000 & Big & 0,66 & Loser & Big|Medium|Loser & $10,00 \%$ & $10,45 \%$ & $4,61 \%$ & $10,94 \%$ & $6,44 \%$ & $1,38 \%$ & $-6,13 \%$ & $4,72 \%$ & $1,39 \%$ & $-1,34 \%$ & $-15,07 \%$ & $-4,62 \%$ \\
\hline USIM3 & Usiminas ON & 1,17 & Medium & 20.498.459.927 & Big & 0,63 & Loser & Big|Medium|Loser & $11,22 \%$ & $-3,25 \%$ & $1,96 \%$ & $-3,58 \%$ & $13,07 \%$ & $2,64 \%$ & $-0,90 \%$ & $3,14 \%$ & $22,06 \%$ & $-12,38 \%$ & $-17,61 \%$ & $5,33 \%$ \\
\hline GOAU4 & Gerdau Met PN & 1,08 & Medium & 9.687 .549 .000 & Big & 0,62 & Loser & Big|Medium|Loser & $5,43 \%$ & $1,54 \%$ & $7,35 \%$ & $7,93 \%$ & $3,78 \%$ & $6,45 \%$ & $-10,25 \%$ & $4,82 \%$ & $11,05 \%$ & $-6,69 \%$ & $-6,31 \%$ & $-7,94 \%$ \\
\hline GGBR3 & Gerdau ON & 0,90 & Medium & \begin{tabular}{|l|l}
26.837 .557 .440 & \\
\end{tabular} & Big & 0,61 & Loser & Big|Medium|Loser & $5,35 \%$ & $1,91 \%$ & $8,80 \%$ & $8,73 \%$ & $2,00 \%$ & $8,97 \%$ & $-12,00 \%$ & $2,87 \%$ & $9,67 \%$ & $-1,41 \%$ & $-14,24 \%$ & $-5,90 \%$ \\
\hline GGBR4 & Gerdau PN & 0,90 & Medium & 26.837.557.440 & Big & 0,61 & Loser & Big|Medium|Loser & $6,98 \%$ & $0,59 \%$ & $7,66 \%$ & $10,74 \%$ & $3,32 \%$ & $8,19 \%$ & $-13,04 \%$ & $4,38 \%$ & $9,26 \%$ & $-1,56 \%$ & $-11,70 \%$ & $-5,64 \%$ \\
\hline USIM5 & Usiminas PNA & 1,17 & Medium & 20.498.459.927 & Big & 0,61 & Loser & Big|Medium|Loser & $6,42 \%$ & $0,47 \%$ & $5,44 \%$ & $-1,52 \%$ & $11,30 \%$ & $-2,25 \%$ & $0,43 \%$ & $3,47 \%$ & $19,03 \%$ & \begin{tabular}{|c|}
$-7,90 \%$ \\
\end{tabular} & $-18,20 \%$ & $4,81 \%$ \\
\hline BRKM3 & Braskem ON & 1,31 & Medium & \begin{tabular}{|l|l|}
3.690 .547 .736 \\
\end{tabular} & Big & 0,57 & Loser & Big|Medium|Loser & $5,16 \%$ & $28,61 \%$ & $15,47 \%$ & $6,70 \%$ & $-5,93 \%$ & $13,71 \%$ & $0,32 \%$ & $-0,32 \%$ & $-5,95 \%$ & $-6,15 \%$ & $-16,94 \%$ & $18,09 \%$ \\
\hline RAPT3 & Randon Part ON & 0,81 & Medium & 1.427.208.960 & Big & 0,54 & Loser & Big|Medium|Loser & $26,67 \%$ & $11,23 \%$ & $-0,45 \%$ & $8,14 \%$ & $13,44 \%$ & $1,40 \%$ & $1,11 \%$ & $-1,17 \%$ & $-1,78 \%$ & $-0,59 \%$ & $-2,75 \%$ & $-0,50 \%$ \\
\hline SUZB5 & Suzano & 1,02 & Medium & 46.782 .560 & Big & 0,54 & Loser & \begin{tabular}{|l} 
Big|Medium/Loser \\
\end{tabular} & $17,08 \%$ & $0,28 \%$ & $5,06 \%$ & $-17,56 \%$ & $22,55 \%$ & $12,85 \%$ & $-0,93 \%$ & $-8,42 \%$ & $30,65 \%$ & $-8,77 \%$ & $-9,73 \%$ & $-4,94 \%$ \\
\hline BRKM5 & Braskem PNA & 1,31 & Medium & 3.690 .547 .736 & Big & 0,53 & Loser & \begin{tabular}{|l|} 
Big|Medium|Loser \\
\end{tabular} & $15,74 \%$ & $25,87 \%$ & $7,65 \%$ & $3,91 \%$ & $-1,54 \%$ & $22,22 \%$ & $-5,82 \%$ & $-3,62 \%$ & $2,43 \%$ & $-3,97 \%$ & $-14,16 \%$ & $16,13 \%$ \\
\hline RAPT4 & Randon Part PN & 0,81 & Medium & 1.427.208.960 & Big & 0,53 & Loser & Big|Medium|Loser & $25,53 \%$ & $-1,68 \%$ & $14,02 \%$ & $0,45 \%$ & $11,79 \%$ & $4,70 \%$ & $-1,80 \%$ & $-1,70 \%$ & $-8,84 \%$ & \begin{tabular}{l|l}
$5,91 \%$ \\
\end{tabular} & $-0,83 \%$ & $8,99 \%$ \\
\hline CYRE3 & Cyrela Realty ON & 0,65 & Medium & 2.950 & Big & 50 & Loser & Big|Medium|Loser & $29,63 \%$ & $23,06 \%$ & $-2,70 \%$ & $-2,39 \%$ & $9,78 \%$ & $-0,81 \%$ & $-11,67 \%$ & $4,21 \%$ & $-6,61 \%$ & $-0,28 \%$ & $-3,80 \%$ & $-1,22 \%$ \\
\hline GFSA3 & Gafisa ON & 1,18 & Medium & 36.239 .820 & Big & 0,48 & Loser & \begin{tabular}{|l|} 
Big|Medium|Loser \\
\end{tabular} & $45,21 \%$ & $14,75 \%$ & $-2,31 \%$ & $-2,02 \%$ & $11,09 \%$ & $-2,75 \%$ & $-13,70 \%$ & $12,43 \%$ & $-10,29 \%$ & $-2,67 \%$ & $-7,09 \%$ & $-1,82 \%$ \\
\hline BRAP3 & Bradespar ON & 0,75 & Mediu & D10.600 & Big & 0,47 & Loser & Big|Medium|Loser & $11,13 \%$ & $4,15 \%$ & $11,93 \%$ & $12,50 \%$ & $11,42 \%$ & $1,04 \%$ & $0,00 \%$ & $2,50 \%$ & $0,00 \%$ & $-5,20 \%$ & $-6,52 \%$ & $-6,69 \%$ \\
\hline AEDU11 & Anhanguera UNT N2 & 0,66 & Medium & $\begin{array}{l}0.822 .943 \\
\end{array}$ & Big & 0,47 & Loser & Big|Medium|Loser & $3,93 \%$ & $8,92 \%$ & $0,25 \%$ & $20,54 \%$ & $-0,25 \%$ & $2,39 \%$ & $4,54 \%$ & $1,77 \%$ & $-2,53 \%$ & $5,47 \%$ & $-3,66 \%$ & $4,16 \%$ \\
\hline \begin{tabular}{|l|l|} 
MRVE3 & \\
\end{tabular} & MRV ON & 1,17 & Medium & 83.374 .050 & Big & 0,46 & Loser & g|Medium|Loser & $16,94 \%$ & $7,53 \%$ & $-0,41 \%$ & $-3,59 \%$ & $16,08 \%$ & $11,17 \%$ & $-13,83 \%$ & $7,82 \%$ & $-5,27 \%$ & \begin{tabular}{l|l}
$-0,89 \%$ \\
\end{tabular} & $-2,26 \%$ & $7,53 \%$ \\
\hline OHLB3 & OHL Brasil ON & 0,94 & Medium & 01.091.310 & Big & 0,45 & Loser & Big|Medium|Loser & $-7,76 \%$ & $18,26 \%$ & $6,86 \%$ & $10,24 \%$ & $21,96 \%$ & $-0,44 \%$ & $4,41 \%$ & $6,85 \%$ & $8,09 \%$ & $-0,02 \%$ & $-0,97 \%$ & $4,75 \%$ \\
\hline BRAP4 & Bradespar PN & 0,75 & Medium & 8.840 .010 .600 & Big & 0,43 & Loser & Big|Medium|Loser & $9,96 \%$ & $3,91 \%$ & $11,45 \%$ & $11,81 \%$ & $7,69 \%$ & $-0,44 \%$ & $0,75 \%$ & $1,57 \%$ & $11,46 \%$ & $-8,83 \%$ & $-6,47 \%$ & $-11,38 \%$ \\
\hline VALE3 & Vale ON & 0,70 & Medium & 6.900 & Big & 43 & Lose & Im/Loser & $7,39 \%$ & $-1,00 \%$ & $12,30 \%$ & $9,95 \%$ & $9,42 \%$ & $0,98 \%$ & $-1,19 \%$ & $3,15 \%$ & $13,28 \%$ & $-6,43 \%$ & $-5,84 \%$ & $-12,70 \%$ \\
\hline VALES & Vale PNA & 0,70 & Medium & 6.900 & Big & 0,41 & Loser & \begin{tabular}{|l|l|l|} 
Big|Mdium|Loser \\
\end{tabular} & $8,54 \%$ & $1,54 \%$ & $11,25 \%$ & $9,11 \%$ & $7,40 \%$ & $-0,40 \%$ & $-0,14 \%$ & $5,48 \%$ & $11,47 \%$ & $-5,32 \%$ & $-7,84 \%$ & $11,59 \%$ \\
\hline EMBR3 & Embraer ON & 0,95 & Medium & 5.897.870.109 & Big & 0,41 & Loser & Big|Medium|Loser & $11,90 \%$ & $10,96 \%$ & $1,28 \%$ & $-12,78 \%$ & $-2,24 \%$ & $11,66 \%$ & $5,05 \%$ & $-1,80 \%$ & $7,24 \%$ & $-2,33 \%$ & $-4,41 \%$ & $-4,36 \%$ \\
\hline BRFS3 & BRF Foods ON & 0,67 & Medium & .785.675 & Big & 39 & se & Big|Medium|Loser & $10,40 \%$ & $1,45 \%$ & $12,38 \%$ & $-9,53 \%$ & $-3,96 \%$ & $11,20 \%$ & $-0,48 \%$ & $-2,33 \%$ & $8,62 \%$ & $-5,22 \%$ & $2,64 \%$ & $1,96 \%$ \\
\hline JBSS3 & JBS ON & 0,89 & Medium & 601.170 & Big & 0,38 & Winner & Big|Medium|Winner & $5,41 \%$ & $5,53 \%$ & $17,90 \%$ & $5,97 \%$ & $-1,74 \%$ & $-2,92 \%$ & $0,21 \%$ & $-2,78 \%$ & $-12,44 \%$ & $2,77 \%$ & $-10,97 \%$ & $5,38 \%$ \\
\hline TMAR3 & Telemar N L ON & 0,74 & Medium & 14.062.939.500 & Big & 0,35 & Winner & Big|Medium/Winner & $-1,99 \%$ & $-8,33 \%$ & $11,91 \%$ & $0,73 \%$ & $12,90 \%$ & $2,84 \%$ & $-1,40 \%$ & $-2,10 \%$ & $-20,56 \%$ & \begin{tabular}{|c|}
$-9,44 \%$ \\
\end{tabular} & $9,78 \%$ & $9,35 \%$ \\
\hline PETR3 & Petrobras ON & 0,64 & Medium & \begin{tabular}{|l|}
323.479 .137 .281 \\
\end{tabular} & $\mathrm{Big}$ & 0,33 & $\begin{array}{l}\text { Winner } \\
\end{array}$ & Big|Medium/Winner & $-3,07 \%$ & $-2,65 \%$ & $8,85 \%$ | & $-0,37 \%$ & $8,91 \%$ & $-5,12 \%$ & $-8,24 \%$ & $1,26 \%$ & $2,58 \%$ & $-6,30 \%$ & $-7,18 \% \mid$ & $-9,04 \%$ \\
\hline CNFB4 & Confab P & 0,92 & Mediur & & Big & 0,31 & Winn & Winner & $23,11 \%$ & $-11,30 \%$ & & $-7,59 \%$ & $1,28 \%$ & $0,98 \%$ & $-3,70 \%$ & $-3,04 \%$ & $-1,25 \%$ & $-2,80 \%$ & $-5,63 \%$ & $16,23 \%$ \\
\hline CLSC6 & Celesc PNB & 1,06 & Medium & 1.339.965.280 & Big & 0,30 & Winner & Big|Medium|Winner & $7,75 \%$ & $-0,09 \%$ & $-0,44 \%$ & $4,19 \%$ & $-1,07 \%$ & $-0,31 \%$ & $3,70 \%$ & $-0,96 \%$ & $2,05 \%$ & $-2,96 \%$ & $-2,37 \%$ & $1,03 \%$ \\
\hline VIVO3 & Vivo ON & 0,81 & Medium & \begin{tabular}{|l|l}
13.796 .234 .370 \\
\end{tabular} & Big & 0,25 & Winner & Big|Medium/Winner & $15,54 \%$ & $2,36 \%$ & $-1,26 \%$ & $5,98 \%$ & $9,36 \%$ & $9,76 \%$ & $-2,32 \%$ & $-4,74 \%$ & $0,68 \%$ & $-4,56 \%$ & $57,70 \%$ & $17,81 \%$ \\
\hline TMAR5 & & & & & Big & & & & & & & & $15,63 \%$ & & & & & $-7,20 \%$ & & $-5,59 \%$ \\
\hline IGTA3 & Iguatemi ON & 1,12 & Medium & 1.219 .274 .000 & Big & 0,25 & Winner & Big|Medium|Winner & $19,10 \%$ & $3,53 \%$ & $19,93 \%$ ] & $-3,96 \%$ | & $8,16 \%$ & $19,24 \%$ & $-16,21 \%$ & $0,39 \%$ & $4,72 \%$ & $-2,66 \%$ & $3,70 \%[$ & $5,77 \%$ \\
\hline TCSL4 & Tim Part S/A PN & 0,92 & Medium & 10.748.354.060 & Big & 0,23 & Winner & Big|Medium|Winner & $19,54 \%$ & $-4,81 \%$ & $11,36 \%$ & $-5,90 \%$ & $12,05 \%$ & $10,11 \%$ & $-3,32 \%$ & $3,84 \%$ & $-3,31 \%$ & $-6,41 \%$ & $9,07 \%$ & $-1,62 \%$ \\
\hline PDGR3 & DDG Re & 0,91 & Medium & 3.281.065.770 & & 0,23 & Ninner & Big|Medium/Winner & $24,4 / \%$ & $53 \%[]$ & & & 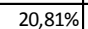 & & & & & $2 \pi$ & $4,0 / \% \mid$ & $-0,46 \%$ \\
\hline
\end{tabular}


Anexo 1 - Retorno mensal e classificação das ações

\begin{tabular}{|c|c|c|c|c|c|c|c|c|c|c|c|c|c|c|c|c|c|c|c|c|}
\hline Código & $2009-2010$ & $\begin{array}{l}\text { Índice } B / M \\
\text { de dez/2008 }\end{array}$ & $\begin{array}{c}\text { Grupo com } \\
\text { base no } \\
\text { indice } B / M\end{array}$ & $\begin{array}{c}\text { Valor de Mercado } \\
\text { em jun/2009 }\end{array}$ & $\begin{array}{c}\text { Grupo com } \\
\text { base no } \\
\text { tamanho }\end{array}$ & $\begin{array}{c}\text { Retorno } \\
\text { acumulado } \\
\text { de jun/2009 }\end{array}$ & $\begin{array}{l}\text { Grupo com } \\
\text { base no } \\
\text { retorno } \\
\text { acumulado }\end{array}$ & Carteiras & $\mathrm{jul} / 09$ & ago/09 & set/09 & out/09 & nov/09 & dez/09 & $\mathrm{jan} / 10$ & fev/10 & $\mathrm{mar} / 10$ & $\mathrm{abr} / 10$ & $\mathrm{mai} / 10$ & jun/10 \\
\hline CMIG3 & Cemig ON & 0,65 & Medium & 14.768 .654 .550 & Big & 0,19 & Winner & Big|Medium|Winner & $1,70 \%$ & $0,91 \%$ & $3,60 \%$ & $2,01 \%$ & $9,91 \%$ & $-0,41 \%$ & $-1,64 \%$ & $-4,67 \%$ & \begin{tabular}{l|l|}
$-0,79 \%$ \\
\end{tabular} & $10,97 \%$ & $-8,88 \%$ & $-0,71 \%$ \\
\hline \begin{tabular}{|l|l|} 
VIVO4 \\
\end{tabular} & Vivo PN & 0,81 & Medium & 13.796.234.370 & Big & 0,19 & Winner & Big|Medium|Winner & $13,88 \%$ & $1,76 \%$ & $3,35 \%$ & $-3,36 \%$ & $21,60 \%$ & $3,71 \%$ & $-1,35 \%$ & $-8,21 \%$ & $2,17 \%$ & $-4,35 \%$ & $8,16 \%$ & $-7,14 \%$ \\
\hline CPLE3 & Copel ON & 1,28 & Medium & 7.282 .251 .334 & Big & 0,17 & Winner & Big|Medium|Winner & $3,81 \%$ & $5,04 \%$ & $6,14 \%$ & $1,36 \%$ & $14,95 \%$ & $6,10 \%$ & $5,48 \%$ & $-6,10 \%$ & $2,90 \%$ & $-4,34 \%$ & $-10,76 \%$ & $8,70 \%$ \\
\hline BRML3 & BR Malls Par ON & 1,12 & Medium & 2.526 .801 .600 & Big & 0,16 & Winner & Big|Medium|Winner & $30,20 \%$ & $-1,03 \%$ & $8,85 \%$ & $-6,70 \%$ & $23,08 \%$ & $-10,42 \%$ & $-4,65 \%$ & $14,63 \%$ & $-10,64 \%$ & $5,43 \%$ & $5,93 \%$ & $1,29 \%$ \\
\hline HYPE3 & Hypermarcas ON & 0,72 & Medium & 4.826 .004 .300 & Big & 0,15 & Winner & Big|Medium|Winner & $11,85 \%$ & $10,30 \%$ & $15,71 \%$ & $3,98 \%$ & $3,41 \%$ & $7,24 \%$ & $8,55 \%$ & $-0,64 \%$ & $0,83 \%$ & $10,34 \%$ & $2,50 \%$ & $-5,77 \%$ \\
\hline ELPL4 & Eletropaulo PN & 0,83 & Medium & 5.669 .514 .604 & Big & 0,13 & Winner & Big|Medium|Winner & $0,20 \%$ & $6,39 \%$ & $3,66 \%$ & $-9,10 \%$ & $3,19 \%$ & $2,76 \%$ & $4,06 \%$ & $4,51 \%$ & \begin{tabular}{l|l}
$3,92 \%$ \\
\end{tabular} & $-1,51 \%$ & $-9,80 \%$ & $16,75 \%$ \\
\hline MULT3 & Multiplan ON & 1,06 & Medium & 2.919.696.932 & Big & 0,13 & Winner & Big|Medium|Winner & $20,86 \%$ & $6,56 \%$ & $8,82 \%$ & $-2,70 \%$ & $25,89 \%$ & $-4,53 \%$ & $-7,55 \%$ & $4,13 \%$ & $-5,70 \%$ & $1,49 \%$ & $14,18 \%$ & $-2,19 \%$ \\
\hline ENBR3 & Energias BR ON & 1,13 & Medium & 3.868 .826 .250 & Big & 0,11 & Winner & Big|Medium|Winner & $1,33 \%$ & $3,25 \%$ & $3,18 \%$ & $-2,40 \%$ & $8,77 \%$ & $8,23 \%$ & $5,37 \%$ & $-0,28 \%$ & $-2,98 \%$ & $3,15 \%$ & $0,15 \%$ & $7,19 \%$ \\
\hline PCAR4 & P.Acucar-Cbd PN & 0,74 & Medium & 9.011 .966 .000 & Big & 0,10 & Winner & Big|Medium|Winner & $13,39 \%$ & $7,33 \%$ & $8,44 \%$ & $6,60 \%$ & $3,88 \%$ & $17,58 \%$ & $-2,72 \%$ & $-2,92 \%$ & $-3,47 \%$ & $1,03 \%$ & $-1,51 \%$ & $7,68 \%$ \\
\hline GRND3 & Grendene ON & 0,99 & Medium & 1.800 .000 .000 & Big & 0,09 & Winner & Big|Medium|Winner & $15,28 \%$ & $22,84 \%$ & $-0,52 \%$ & $-5,51 \%$ & $14,95 \%$ & $10,68 \%$ & $-11,96 \%$ & $5,59 \%$ & $-1,62 \%$ & $-10,77 \%$ & $-6,68 \%$ & $4,73 \%$ \\
\hline CMIG4 & Cemig PN & 0,65 & Medium & 14.768.654.550 & Big & 0,07 & Winner & Big|Medium|Winner & $2,66 \%$ & $2,59 \%$ & $-2,70 \%$ & $1,89 \%$ & $9,41 \%$ & $4,98 \%$ & $-0,79 \%$ & $-5,23 \%$ & \begin{tabular}{l|l}
$-0,64 \%$ \\
\end{tabular} & 7,79\% & $-5,66 \%$ & $0,65 \%$ \\
\hline CPLE6 & Copel PNB & 1,28 & Medium & 7.282.251.334 & Big & 0,06 & Winner & Big|Medium|Winner & $4,40 \%$ & $2,91 \%$ & $6,89 \%$ & $-2,23 \%$ & $12,62 \%$ & $9,49 \%$ & $4,05 \%$ & $-4,51 \%$ & $-1,06 \%$ & $-1,91 \%$ & $-5,08 \%$ & $10,71 \%$ \\
\hline EQTL3 & Equatorial ON & 1,04 & Medium & 1.667.279.250 & Big & 0,05 & Winner & Big|Medium|Winner & $8,25 \%$ & $-5,04 \%$ & $8,09 \%$ & $-2,86 \%$ & $-0,53 \%$ & $7,47 \%$ & $-6,08 \%$ & $3,35 \%$ & $-10,98 \%$ & $2,33 \%$ & $-1,92 \%$ & $6,21 \%$ \\
\hline TNLP3 & Telemar ON & 0,75 & Medium & 12.697 .054 .400 & Big & 0,04 & Winner & Big|Medium|Winner & $-1,49 \%$ & $2,65 \%$ & $13,28 \%$ & $1,25 \%$ & $8,64 \%$ & $1,59 \%$ & $-10,76 \%$ & $-5,99 \%$ & $1,87 \%$ & $-10,60 \%$ & $14,35 \%$ & $5,34 \%$ \\
\hline \begin{tabular}{|l|} 
UGPA4 \\
\end{tabular} & Ultrapar PN & 0,69 & Medium & 8.319 .800 .320 & Big & 0,03 & Winner & Big|Medium|Winner & $2,03 \%$ & $10,24 \%$ & $3,58 \%$ & $7,16 \%$ & $3,24 \%$ & $1,41 \%$ & $3,48 \%$ & $-2,77 \%$ & $7,61 \%$ & $-4,09 \%$ & $-0,26 \%$ & $5,62 \%$ \\
\hline TNLP4 & Telemar PN & 0,75 & Medium & 12.697.054.400 & Big & 0,01 & Winner & Big|Medium|Winner & $-1,13 \%$ & $4,53 \%$ & $10,93 \%$ & $0,60 \%$ & $9,50 \%$ & $0,54 \%$ & $-9,43 \%$ & $-6,85 \%$ & \begin{tabular}{l|l}
$0,67 \%$ \\
\end{tabular} & $-7,84 \%$ & 13,45\% & $-9,30 \%$ \\
\hline ELPL5 & Eletropaulo $\mathrm{P}$ & 0,83 & Medium & 5.669 .514 .604 & Big & 0,13 & Winner & Big|Medium|Winner & $1,56 \%$ & $-1,54 \%$ & $2,66 \%$ & $1,46 \%$ & $0,81 \%$ & $2,51 \%$ & $0,00 \%$ & $2,94 \%$ & $8,57 \%$ & $1,05 \%$ & $-10,88 \%$ & $18,50 \%$ \\
\hline EBTP3 & Embratel Part ON & 0,99 & Medium & 9.297 .543 .793 & Big & 0,15 & Winner & Big|Medium|Winner & $21,67 \%$ & $-8,68 \%$ & $7,50 \%$ & $21,30 \%$ & $4,69 \%$ & $10,21 \%$ & $0,00 \%$ & $-6,67 \%$ & $-2,14 \%$ & $-26,05 \%$ & $22,95 \%$ & $0,42 \%$ \\
\hline EBTP4 & Embratel Part PN & 0,99 & Medium & 9.297 .543 .793 & Big & 0,15 & Winner & Big|Medium|Winner & $19,57 \%$ & $-7,27 \%$ & $7,84 \%$ & $18,59 \%$ & $15,23 \%$ & $0,47 \%$ & $-0,33 \%$ & $-5,33 \%$ & $-2,82 \%$ & $-24,60 \%$ & \begin{tabular}{|l|}
$19,78 \%$ \\
\end{tabular} & $-4,09 \%$ \\
\hline \begin{tabular}{|l|l|} 
TRNA11 & \\
\end{tabular} & Taesa UNT N2 & 0,76 & Medium & 3.333.261.174 & Big & 0,23 & Winner & Big |Medium/Winner & $1,84 \%$ | & $-0,34 \%$ & $3,19 \%$ | & $1,05 \%$ & $0,95 \%$ & $0,84 \%$ | & $0,64 \%$ & $0,43 \%$ & $1,59 \% \mid$ & $0,63 \%$ & $-26,48 \%$ & $-5,57 \%$ \\
\hline AELP3 & AES Elpa ON & 0,87 & Medium & 3.507 .750 .900 & Big & 0,42 & Winner & Big|Medium|Winner & $13,82 \%$ & $-9,52 \%$ & $11,84 \%$ & $1,18 \%$ & $-0,02 \%$ & $2,89 \%$ & $5,71 \%$ & $2,04 \%$ & $5,06 \%$ & $-3,11 \%$ & $12,50 \%$ & $-1,96 \%$ \\
\hline BBRK3 & BR Brokers ON & 1,36 & High & 463.706 .700 & Small & 0,84 & Loser & Small|High| Loser & $82,62 \%$ & $0,97 \%$ & $16,15 \%$ & $0,99 \%$ & $-5,25 \%$ & $12,11 \%$ & $22,22 \%$ & $3,54 \%$ & $-5,49 \%$ & $3,55 \%$ & $-25,32 \%$ & $-1,36 \%$ \\
\hline ECOD3 & Ecodiesel ON & 1,38 & High & 197.915 .040 & Small & 0,83 & Loser & Small|High|Loser & $2,78 \%$ & $12,16 \%$ & $0,00 \%$ & $21,69 \%$ & $8,91 \%$ & $-0,91 \%$ & $22,94 \%$ & $0,75 \%$ & $-14,07 \%$ & $-0,86 \%$ & $-27,83 \%$ & $1,20 \%$ \\
\hline FHER3 & Fer Heringer OI & 1,37 & High & 388.737 .420 & Small & 0,80 & Loser & Small|High|Loser & $23,57 \%$ & $16,75 \%$ & $3,72 \%$ & $-16,67 \%$ & $4,00 \%$ & $2,88 \%$ & $3,36 \%$ & $3,53 \%$ & $-11,44 \%$ & $-14,20 \%$ & $-8,62 \%$ & $-6,16 \%$ \\
\hline SGPS3 & Springs ON & 2,97 & High & 565.969 .180 & Small & 0,79 & Loser & Small|High|Loser & $2,79 \%$ & $0,99 \%$ & $27,87 \%$ & $-2,49 \%$ & $-7,84 \%$ & $1,06 \%$ & $5,47 \%$ & $21,76 \%$ & $-6,72 \%$ & $-16,70 \%$ & $-11,99 \%$ & $4,88 \%$ \\
\hline BEEF3 & Minerva ON & 2,17 & High & 242.416 .800 & Small & 0,76 & Loser & Small|High|Loser & $43,52 \%$ & $22,58 \%$ & $13,90 \%$ & $7,63 \%$ & $-7,56 \%$ & $-0,68 \%$ & $18,18 \%$ & $-4,21 \%$ & $16,29 \%$ & $-1,84 \%$ & $-12,20 \%$ & $4,73 \%$ \\
\hline TPIS3 & Triunfo P & 5,25 & High & 401.909 .760 & Small & 0,74 & Loser & Small|High|Loser & $20,75 \%$ & $11,83 \%$ & $35,77 \%$ & $-1,44 \%$ & $3,58 \%$ & $3,83 \%$ & $14,04 \%$ & $-3,85 \%$ & $-9,65 \%$ & $-8,21 \%$ & $-5,84 \%$ & $11,36 \%$ \\
\hline GSHP3 & Generalshopp ON & 3,26 & High & \begin{tabular}{|l|l|}
199.398 .370 \\
\end{tabular} & Small & 0,74 & Loser & Small|High|Loser & $30,38 \%$ & $9,51 \%$ & $24,11 \%$ & $1,71 \%$ & $13,76 \%$ & $5,56 \%$ & $15,67 \%$ & $-0,71 \%$ & $-11,51 \%$ & $-3,91 \%$ & $-14,37 \%$ & $14,55 \%$ \\
\hline IBDU3 & J B Duarte C & 4,86 & High & \begin{tabular}{|l|l|}
14.262 .920 \\
\end{tabular} & Small & 0,73 & Loser & Small|High|Loser & $0,00 \%$ & 0,00 & $14,29 \%$ & $0,00 \%$ & $0,00 \%$ & $-12,50 \%$ & $114,29 \%$ & $-6,67 \%$ & $-21,43 \%$ & $-18,18 \%$ & $-11,11 \%$ & $0,00 \%$ \\
\hline VIVR3 & Viver ON & 3,95 & High & 514.303 .400 & Small & 0,73 & Loser & Small|High|Loser & $21,54 \%$ & $0,00 \%$ & $32,91 \%$ & $-11,19 \%$ & $-3,75 \%$ & $-3,06 \%$ & $1,15 \%$ & $-11,93 \%$ & $2,90 \%$ & $-11,29 \%$ & $-1,06 \%$ & $-1,79 \%$ \\
\hline \begin{tabular}{|l|} 
PFRM3 \\
\end{tabular} & \begin{tabular}{|l|} 
Profarma ON \\
\end{tabular} & 2,46 & High & 084.900 & Small & 0,72 & Loser & Small|High|Loser & $31,07 \%$ & $14,81 \%$ & $3,23 \%$ & $-0,19 \%$ & $9,64 \%$ & $-5,48 \%$ & $7,85 \%$ & $-0,06 \%$ & $4,26 \%$ & \begin{tabular}{l|l|}
$-5,91 \%$ \\
\end{tabular} & $-9,27 \%$ & $1,66 \%$ \\
\hline EVEN3 & Even ON & 1,47 & High & 600.532 .800 & Small & 0,69 & Loser & Small|High|Loser & $71,73 \%$ & $18,20 \%$ & $-0,29 \%$ & $-9,41 \%$ & $26,62 \%$ & $9,49 \%$ & $-11,59 \%$ & $-0,66 \%$ & $-12,00 \%$ & $-5,85 \%$ & $8,91 \%$ & $1,67 \%$ \\
\hline SGEN4 & Sergen PN & 1,32 & High & 28.159 .037 & Small & 0,68 & Loser & Small|High|Loser & $25,00 \%$ & $2,76 \%$ & $-9,40 \%$ & $21,48 \%$ & $-7,32 \%$ & $7,89 \%$ & $7,32 \%$ & $33,52 \%$ & $-15,32 \%$ & $-7,04 \%$ & $-5,41 \%$ & $-14,86 \%$ \\
\hline INEP4 & Inepar P & 1,66 & High & 329.480 & Smal & 67 & Loser & Small|High|Loser & $11,82 \%$ & $-3,29 \%$ & $14,30 \%$ & $28,72 \%$ & $10,55 \%$ & $4,46 \%$ & $24,37 \%$ & $-8,40 \%$ & \begin{tabular}{l|l}
$0,00 \%$ \\
\end{tabular} & $-17,50 \%$ & $-10,77 \%$ & $-13,21 \%$ \\
\hline CCIM3 & CC Des Imob ON & 2,28 & High & 550.000 & Small & 0,66 & Loser & Small|High | Loser & $55,32 \%$ & $-5,52 \%$ & $-3,72 \%$ & $3,86 \%$ & $0,88 \%$ & $-4,39 \%$ & $3,49 \%$ & $0,00 \%$ & $-0,31 \%$ & $5,45 \%$ & $-3,97 \%$ & $-8,44 \%$ \\
\hline INEP3 & Inepar ON & 1,66 & High & 169.329 .480 & Small & 0,66 & Los & Small|High|Loser & $10,35 \%$ & $-6,88 \%$ & $16,25 \%$ & $28,71 \%$ & $10,52 \%$ & $8,56 \%$ & $17,98 \%$ & $-11,50 \%$ & $2,11 \%$ & $-15,24 \%$ & $-14,31 \%$ & $-7,74 \%$ \\
\hline JBDU4 & J B Duarte PI & 4,86 & High & \begin{tabular}{|l|l|}
14.262 .920 \\
\end{tabular} & Small & 0,64 & Loser & nall|High|Loser & $-14,29 \%$ & $33,33 \%$ & $-12,50 \%$ & $14,29 \%$ & $0,00 \%$ & $0,00 \%$ & $100,00 \%$ & $6,25 \%$ & $29,41 \%$ & $-16,67 \%$ & $-10,00 \%$ & $-7,69 \%$ \\
\hline TRIS3 & Trisul ON & 2,26 & High & 289.388 .770 & Small & 0,64 & Loser & Small|High|Loser & $15,68 \%$ & $13,33 \%$ & $-10,78 \%$ & $10,55 \%$ & $13,32 \%$ & $10,53 \%$ & $9,52 \%$ & $-9,42 \%$ & $6,40 \%$ & $9,15 \%$ & $-4,40 \%$ & $-6,51 \%$ \\
\hline ECPR4 & Encorpar PN & 2,96 & High & \begin{tabular}{|l|l|}
26.118 .920 \\
\end{tabular} & Small & 0,63 & Loser & Small|High|Loser & $41,66 \%$ & $-4,65 \%$ & $20,16 \%$ & $-13,89 \%$ & $20,71 \%$ & $-16,89 \%$ & $9,32 \%$ & $0,00 \%$ & $5,76 \%$ & $-5,51 \%$ & $-1,51 \%$ & $3,11 \%$ \\
\hline FESA4 & Ferbasa PN & 1,41 & High & 762.990 .000 & Small & 0,61 & Loser & Small|High/Loser & $20,12 \%$ & $25,39 \%$ & $6,56 \%$ | & $-7,69 \%$ & $-1,25 \%$ & $-0,33 \%$ & $-0,60 \%$ & $1,46 \%$ & $6,95 \%$ | & $-0,17 \%$ & $-10,72 \%$ & $-7,92 \%$ \\
\hline UNIP3 & Unipar O & 1,49 & High & 0.554 .869 & Small & 0,60 & Loser & nall|High|Loser & $6,87 \%$ & $65,04 \%$ & $-0,43 \%$ & $3,06 \%$ & $-5,51 \%$ & $-1,35 \%$ & $-15,91 \%$ & $-16,22 \%$ & $\begin{array}{ll}-17,42 \% \\
\end{array}$ & $-4,69 \%$ & $-28,69 \%$ & $11,49 \%$ \\
\hline \begin{tabular}{|l|} 
MGEL4 \\
\end{tabular} & Mangels Indl PN & 2,36 & High & \begin{tabular}{l|}
105.832 .792 \\
\end{tabular} & Small & 0,57 & Loser & Small|High|Loser & $14,59 \%$ & $32,33 \%$ & $27,03 \%$ & $-1,87 \%$ & $12,06 \%$ & $12,23 \%$ & $-13,79 \%$ & $-6,40 \%$ & $-11,54 \%$ & $-9,08 \%$ & $-14,71 \%$ & $-9,09 \%$ \\
\hline \begin{tabular}{l|l|} 
CTNM3 \\
\end{tabular} & Coteminas ON & 3,43 & High & 547.154 .990 & Small & 0,57 & Loser & Small|High|Loser & $11,54 \%$ & $4,06 \%$ & $2,34 \% \mid$ & $\mid 13,33 \%$ | & $-11,76 \%$ & $-0,19 \%$ & $2,86 \%$ | & $14,66 \%$ & $-1,29 \%$ | $>$ & $-6,56 \%$ & $-20,93 \%$ & $2,00 \%$ \\
\hline \begin{tabular}{|l|l|} 
UNIP6 \\
\end{tabular} & Unipa & & $\mathrm{Hi}$ & & $\overline{S m a}$ & 0.57 & Los & & & & & 8,6 & & & 107 & $3,85 \%$ & & $-7,79 \%$ & 14,0 & $-4,92 \%$ \\
\hline PMAM3 & Paranapanema & 1,47 & High & 954.831 .320 & Small & 0,56 & Loser & Small|High|Loser & $34,21 \%$ | & $15,20 \%$ & $53,19 \%$ & $-4,31 \%$ & $5,22 \%$ & $-7,86 \%$ & $-0,30 \%$ & $23,87 \%$ & $-18,79 \%$ _ & $-14,78 \%$ & $-9,11 \%$ & $-2,50 \%$ \\
\hline TIBR6 & Millennium PNB & 3,43 & High & 180.505 .517 & Small & 0,56 & Loser & Small|High|Loser & $-14,29 \%$ & $50,00 \%$ & $11,11 \%$ & $0,00 \%$ & $10,00 \%$ & $18,18 \%$ & $15,38 \%$ & $-6,67 \%$ & $-21,43 \%$ & \begin{tabular}{l|l|}
$0,00 \%$ \\
\end{tabular} & $0,48 \%$ & $0,00 \%$ \\
\hline HBOR3 & lbor ON & 2,50 & High & 325.575 .430 & mall & 0,55 & Loser & Small|High|Loser & (20) & $7,83 \%$ & (2) & $34 \%$ & 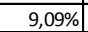 & r 00 t & 43\% & $02 \%$ & (2) & $27 \pi$ & $-0,83 \%$ & $8,74 \%$ \\
\hline
\end{tabular}


Anexo 1 - Retorno mensal e classificação das ações

\begin{tabular}{|c|c|c|c|c|c|c|c|c|c|c|c|c|c|c|c|c|c|c|c|c|}
\hline Código & 2009 - 2010 & $\begin{array}{l}\text { Índice } B / M \\
\text { de dez/2008 }\end{array}$ & $\begin{array}{c}\text { Grupo com } \\
\text { base no } \\
\text { indice } B / M\end{array}$ & $\begin{array}{c}\text { Valor de Mercado } \\
\text { em jun/2009 }\end{array}$ & $\begin{array}{c}\text { Grupo com } \\
\text { base no } \\
\text { tamanho }\end{array}$ & $\begin{array}{c}\text { Retorno } \\
\text { acumulado } \\
\text { de jun/2009 }\end{array}$ & \begin{tabular}{|c|} 
Grupo com \\
base no \\
retorno \\
acumulado
\end{tabular} & Carteiras & $\mathrm{jul} / 09$ & ago/09 & set/09 & out/09 & nov/09 & dez/09 & jan/10 & fev/10 & $\mathrm{mar} / 10$ & $\mathrm{abr} / 10$ & $\mathrm{mai} / 10$ & jun/10 \\
\hline CRDE3 & Cr2ON & 2,49 & High & 209.918 .800 & Small & 0,55 & Loser & Small|High|Loser & $47,25 \%$ & $-2,24 \%$ & $3,66 \%$ & $2,06 \%$ & $2,60 \%$ & $-12,66 \%$ & $-11,27 \%$ & $0,73 \%$ & $-1,62 \%$ & $-4,76 \%$ & $3,47 \%$ & $-2,83 \%$ \\
\hline \begin{tabular}{|l|l|} 
HBTS5 \\
\end{tabular} & Habitasul PNA & 2,77 & High & 45.759 .772 & Small & 0,51 & Loser & Small|High|Loser & $9,78 \%$ & $-9,09 \%$ & $-16,00 \%$ & $30,95 \%$ & $-3,64 \%$ & $9,43 \%$ & $28,79 \%$ & $5,09 \%$ & $13,38 \%$ & $-10,11 \%$ & $-12,63 \%$ & $4,43 \%$ \\
\hline FRAS4 & Fras-Le PN & 1,34 & High & 190.630 .440 & Small & 0,50 & Loser & Small|High|Loser & $17,13 \%$ & $15,52 \%$ & $3,36 \%$ & $2,50 \%$ & $2,68 \%$ & $1,49 \%$ & $-0,72 \%$ & $0,48 \%$ & $13,73 \%$ & $12,71 \%$ & $-5,71 \%$ & $8,19 \%$ \\
\hline CEBR6 & Ceb PNB & 2,62 & High & 265.836 .784 & Small & 0,50 & Loser & Small|High|Loser & $7,22 \%$ & $-1,21 \%$ & $-9,09 \%$ & $12,27 \%$ & $6,20 \%$ & $-16,77 \%$ & $-2,71 \%$ & $3,59 \%$ & $11,31 \%$ & $-10,16 \%$ & $1,89 \%$ & $6,59 \%$ \\
\hline \begin{tabular}{|l|} 
CTNM4 \\
\end{tabular} & Coteminas PN & 3,43 & High & 547.154 .990 & Small & 0,49 & Loser & Small|High|Loser & $0,41 \%$ & $3,70 \%$ & $16,63 \%$ & $-1,53 \%$ & $-1,90 \%$ & $-5,98 \%$ & $5,05 \%$ & $16,37 \%$ & $-11,62 \%$ & $-7,79 \%$ & $-17,50 \%$ & $6,38 \%$ \\
\hline TIBR5 & Millennium PNA & 3,43 & High & 180.505 .517 & Small & 0,45 & Loser & Small|High|Loser & $-12,50 \%$ & $42,86 \%$ & $10,00 \%$ & $9,09 \%$ & $0,00 \%$ & $8,33 \%$ & $15,38 \%$ & $0,00 \%$ & $-13,33 \%$ & $3,34 \%$ & $\begin{array}{ll}-7,69 \% \\
\end{array}$ & $0,00 \%$ \\
\hline CEBR5 & Ceb PNA & 2,62 & High & 265.836 .784 & Small & 0,44 & Loser & Small|High|Loser & $6,63 \%$ & $3,16 \%$ & $1,52 \%$ & $4,45 \%$ & $8,60 \%$ & $-13,16 \%$ & $-9,09 \%$ & $15,00 \%$ & $1,62 \%$ & $2,11 \%$ & \begin{tabular}{|l|l|}
$2,88 \%$ \\
\end{tabular} & $12,12 \%$ \\
\hline \begin{tabular}{|l|l|} 
MNDL4 \\
\end{tabular} & Mundial PN & 2,72 & High & 62.719 .320 & Small & 0,44 & Loser & Small|High|Loser & $10,48 \%$ & $-5,11 \%$ & $3,85 \%$ & $-5,19 \%$ & $-1,56 \%$ & $-1,59 \%$ & $12,10 \%$ & $1,44 \%$ & $-9,22 \%$ & $-4,69 \%$ & $9,02 \%$ & $-6,77 \%$ \\
\hline EUCA4 & Eucatex PN & 1,99 & High & 300.407 .250 & Small & 0,43 & $\begin{array}{l}\text { Loser } \\
\end{array}$ & Small|High|Loser & $-1,54 \%$ & $1,56 \%$ & $4,31 \%$ & $48,08 \%$ & $5,38 \%$ & $-4,91 \%$ & $0,80 \%$ & $0,79 \%$ & $13,11 \%$ & $-3,11 \%$ & $3,04 \%$ & $0,52 \%$ \\
\hline SAPR4 & Sanepar PN & 3,08 & High & 853.009 .295 & Small & 0,42 & Loser & Small|High|Loser & $3,00 \%$ & $8,78 \%$ & $-1,35 \%$ & $5,00 \%$ & $1,30 \%$ & $12,39 \%$ & $-5,74 \%$ & $17,96 \%$ & $-1,38 \%$ & $-2,11 \%$ & $-10,39 \%$ & $-2,00 \%$ \\
\hline TCSA3 & Tecnisa ON & 1,61 & High & 811.527 .300 & Small & 0,41 & Loser & Small|High|Loser & $33,51 \%$ & $16,64 \%$ & $6,90 \%$ & $6,46 \%$ & $0,10 \%$ & $5,05 \%$ & $-9,13 \%$ & $-0,63 \%$ & $1,70 \%$ & $-8,49 \%$ & $-12,85 \%$ & $15,28 \%$ \\
\hline PNOR5 & Pronor PNA & 2,70 & High & 82.510 .050 & Small & 0,40 & Loser & Small|High|Loser & $17,32 \%$ & $10,00 \%$ & $3,90 \%$ & $12,50 \%$ & $7,41 \%$ & $13,45 \%$ & $13,98 \%$ & $-1,87 \%$ & $-4,35 \%$ & $3,69 \%$ & $-34,25 \%$ & $-2,08 \%$ \\
\hline BHGR3 & BHG ON & 1,48 & High & 382.830 .000 & Small & 0,39 & Loser & Small|High|Loser & $0,00 \%$ & $14,29 \%$ & $-0,01 \%$ & $18,34 \%$ & $-3,17 \%$ & $3,64 \%$ & $22,11 \%$ & $-2,36 \%$ & $1,24 \%$ & $-2,62 \%$ & $-1,85 \%$ & $-12,47 \%$ \\
\hline RDNI3 & Rodobensim & 1,58 & High & 869.492 .500 & Small & 0,39 & Winner & Small|High|Winner & $-0,56 \%$ & $1,12 \%$ & $-0,11 \%$ & $2,34 \%$ & $-7,07 \%$ & $5,09 \%$ & $-6,01 \%$ & $-11,78 \%$ & $-16,11 \%$ & $1,09 \%$ & $-4,80 \%$ & $-1,26 \%$ \\
\hline LOGN3 & Log-In ON & 1,39 & High & 726.894.774 & Small & 0,34 & Winner & Small| |High | Winner & $-3,30 \%$ & $1,10 \%$ & $8,67 \%$ & $-2,55 \%$ & $-4,66 \%$ & $1,43 \%$ & $1,18 \%$ & $-5,23 \%$ & $1,10 \%$ & $-5,70 \%$ & $-18,15 \%$ & $5,35 \%$ \\
\hline EZTC3 & Eztec ON & 2,34 & High & 651.935 .521 & Small & 0,33 & Winner & Small|High|Winner & $31,65 \%$ & $18,03 \%$ & $5,94 \%$ & $-4,41 \%$ & $12,99 \%$ & $5,07 \%$ & $-4,12 \%$ & $2,09 \%$ & $-2,04 \%$ & $3,97 \%$ & $-2,68 \%$ & $3,76 \%$ \\
\hline PRVI3 & Providenci & 1,75 & High & 433.021 .810 & Small & 0,31 & Winner & Small|High|Winner & $-2,40 \%$ & $16,29 \%$ & $-2,28 \%$ & $-5,83 \%$ & $27,71 \%$ & $12,45 \%$ & $-0,63 \%$ & $-0,51 \%$ & $-7,38 \%$ & $-3,85 \%$ & $-9,03 \%$ & $-3,88 \%$ \\
\hline MEND6 & Mendes Jr PNB & 7,38 & High & 394.815 .658 & Small & 0,31 & Winner & Small|High|Winner & $8,29 \%$ & $18,60 \%$ & $12,75 \%$ & $-2,61 \%$ & $-3,57 \%$ & $3,70 \%$ & $-5,36 \%$ & $-3,77 \%$ & $-3,92 \%$ & $-1,02 \%$ & $6,58 \%$ & $-7,07 \%$ \\
\hline EMAE4 & Emae PN & 3,46 & High & 413.806 .400 & Small & 0,29 & Winner & Small|High|Winner & $-0,89 \%$ & $0,81 \%$ & $-8,04 \%$ & $17,59 \%$ & $-0,83 \%$ & $16,67 \%$ & $-0,79 \%$ & $-16,49 \%$ & $-13,79 \%$ & $-6,60 \%$ & $-18,14 \%$ & $-0,26 \%$ \\
\hline LIXC4 & Lix da Cunha PN & 1,66 & High & 38.913 .220 & Small & 0,29 & Winner & Small|High|Winner & $-2,68 \%$ & $18,97 \%$ & $5,80 \%$ & $7,95 \%$ & $5,33 \%$ & $-3,86 \%$ & $4,01 \%$ & $-4,82 \%$ & $-0,25 \%$ & $0,81 \%$ & $-4,48 \%$ & $-6,25 \%$ \\
\hline MEND5 & Mendes Jr PNA & 7,38 & High & 44.815.658 & Small & 0,28 & Winner & Small|High|Winner & $11,82 \%$ & $38,86 \%$ & $1,69 \%$ & $0,00 \%$ & $-5,00 \%$ & $-0,88 \%$ & $0,88 \%$ & $-7,02 \%$ & $-2,83 \%$ & $-7,18 \%$ & $17,24 \%$ & $2,98 \%$ \\
\hline IENG3 & Ienergia ON & 4,76 & High & 112.705 .270 & Small & 0,27 & Winner & Small|High|Winner & $2,86 \%$ & $-8,33 \%$ & $3,03 \%$ & $23,53 \%$ & $4,76 \%$ & $-2,27 \%$ & $65,12 \%$ & $-2,82 \%$ & $4,35 \%$ & $-12,50 \%$ & $-15,87 \%$ & $7,55 \%$ \\
\hline IENG5 & lenergia PNA & 4,76 & High & 112.705 .270 & Small & 0,27 & Winner & Small|High|Winner & $0,00 \%$ & $3,23 \%$ & $-3,13 \%$ & $12,90 \%$ & $-2,86 \%$ & $2,94 \%$ & $57,14 \%$ & $7,27 \%$ & $-11,86 \%$ & $-21,15 \%$ & $-12,20 \%$ & $0,00 \%$ \\
\hline CMGR3 & Cemat O & 1,78 & High & 817.940 .860 & Small & 0,25 & Winner & Small|High|Winner & $13,14 \%$ & $5,34 \%$ & $-5,07 \%$ & $-5,87 \%$ & $-2,13 \%$ & $1,45 \%$ & $11,43 \%$ & $-0,64 \%$ & \begin{tabular}{|l|}
$3,02 \%$ \\
\end{tabular} & $-1,65 \%$ & $-3,05 \%$ & $6,26 \%$ \\
\hline \begin{tabular}{|l|} 
MLFT4 \\
\end{tabular} & $\begin{array}{l}\text { Jereissati PN } \\
\end{array}$ & 1,70 & High & 1.074 .617 .400 & Small & 0,24 & Winner & Small| |High | Winner & $5,88 \%$ & $0,00 \%$ & $11,11 \%$ & $-3,75 \%$ & $1,30 \%$ & $32,05 \%$ & $0,97 \%$ & $46,15 \%$ & $-14,47 \%$ & $-12,31 \%$ & $12,10 \%$ & $-7,94 \%$ \\
\hline SULT4 & Sultepa PN & 5,10 & High & 72.004.800 & Small & 0,15 & Winner & Small|High|Winner & $-0,83 \%$ & $-0,84 \%$ & $-0,85 \%$ & $-4,96 \%$ & $0,36 \%$ & $-0,18 \%$ & $-4,85 \%$ & $5,28 \%$ & $-4,30 \%$ & $3,00 \%$ & \begin{tabular}{l|l|l|}
$-0,10 \%$ \\
\end{tabular} & $-2,70 \%$ \\
\hline MRSL4 & Marisol PN & 1,80 & High & 263.796 .900 & Small & 0,11 & Winner & Small|High|Winner & $0,75 \%$ & $6,41 \%$ & $0,80 \%$ & $-6,37 \%$ & $-1,70 \%$ & $21,65 \%$ & $4,98 \%$ & $3,39 \%$ & $13,91 \%$ & $-5,88 \%$ & $-9,69 \%$ & $-3,11 \%$ \\
\hline \begin{tabular}{|l|l|} 
SGAS4 \\
\end{tabular} & WIm Ind Com PN & 1,57 & High & 3.760 .302 & Small & 0,06 & Winner & Small|High | Winner & $9,75 \%$ & $4,44 \%$ & $6,73 \%$ & $4,22 \%$ & $-3,80 \%$ & $10,53 \%$ & $4,76 \%$ & $6,36 \%$ & $-0,02 \%$ & $-2,76 \%$ & $3,13 \%$ & $0,02 \%$ \\
\hline BRGE12 & Alfa Consorc PNF & 1,55 & High & 869.190 & Small & 0,04 & Winner & Small|High|Winner & $20,60 \%$ & $1,32 \%$ & $0,16 \%$ & $-0,16 \%$ & $0,16 \%$ & $1,31 \%$ & $-0,97 \%$ & $-8,56 \%$ & $-0,18 \%$ & $3,97 \%$ & $-3,82 \%$ & $-7,22 \%$ \\
\hline $\begin{array}{ll}\text { CTSA4 } \\
\end{array}$ & Santanense PN & 2,25 & High & 128.900 .720 & Small & 0,51 & Winner & Small|High|Winner & $5,79 \%$ & $-3,46 \%$ & $5,97 \%$ & $-1,41 \%$ & $-10,00 \%$ & $11,70 \%$ & $-4,62 \%$ & $1,52 \%$ & $2,99 \%$ & $-15,94 \%$ & $-4,83 \%$ & $1,48 \%$ \\
\hline $\begin{array}{ll}\text { CTSA3 } \\
\end{array}$ & Santanense ON & 2,25 & High & 128.900 .720 & Small & 0,70 & Winner & Small|High|Winner & $4,88 \%$ & $-1,16 \%$ & $2,94 \%$ & $6,86 \%$ & $-15,51 \%$ & $12,19 \%$ & $-8,31 \%$ & $2,19 \%$ & \begin{tabular}{l|l|l|}
$10,09 \%$ \\
\end{tabular} & $-19,44 \%$ & $-5,02 \%$ & $2,59 \%$ \\
\hline$B \Pi L 4$ & Battistella PN & 0,20 & Low & 84.819 .080 & Small & 0,79 & Loser & Small|Low|Loser & $3,70 \%$ & $3,57 \%$ & $0,00 \%$ & $18,97 \%$ & $18,84 \%$ & $-14,63 \%$ & $61,43 \%$ & $6,19 \%$ & $-1,67 \%$ & $-20,34 \%$ & $-18,09 \%$ & $0,00 \%$ \\
\hline LPSB3 & Lopes Brasil ON & 0,00 & Low & 526.621 .200 & Small & 0,77 & Loser & Small|Low|Loser & $16,43 \%$ & $11,29 \%$ & $33,12 \%$ & $2,89 \%$ & $-2,33 \%$ & $32,18 \%$ & $-8,20 \%$ & $16,07 \%$ & $-1,15 \%$ & $-9,20 \%$ & $-1,33 \%$ & $3,51 \%$ \\
\hline \begin{tabular}{|l|l|} 
LUPA3 \\
\end{tabular} & Lupatech ON & 0,17 & Low & 501.280 & Small & 0,57 & Loser & Small|Low|Loser & $-13,03 \%$ & $6,05 \%$ & $13,51 \%$ & $4,95 \%$ & $-7,22 \%$ & $7,74 \%$ & $7,18 \%$ & $-7,56 \%$ & $-10,41 \%$ & $-1,04 \%$ & $-12,49 \%$ & $0,62 \%$ \\
\hline SHUL4 & Schulz PN & 0,47 & Low & 159.537 .500 & Small & 0,56 & Loser & Small|Low|Loser & $8,80 \%$ & $22,06 \%$ & $7,23 \%$ & $15,11 \%$ & $27,79 \%$ & $-0,38 \%$ & $11,97 \%$ & $13,79 \%$ & $-1,58 \%$ & $1,57 \%$ & $-8,39 \%$ & $10,85 \%$ \\
\hline TCNO4 & Tecnosolo PN & 0,46 & Low & 49.280 .000 & Small & 0,55 & Loser & Small|Low|Loser & $3,85 \%$ & $0,00 \%$ & $-1,85 \%$ & $26,42 \%$ & $-4,48 \%$ & $4,69 \%$ & $31,34 \%$ & $25,00 \%$ & $-10,00 \%$ & $-14,14 \%$ & \begin{tabular}{l|l|}
$-9,79 \%$ \\
\end{tabular} & $-2,63 \%$ \\
\hline BAUH4 & Excelsior PN & 0,56 & Low & 0.015 .900 & Small & 0,49 & Loser & Small|Low|Loser & $24,64 \%$ & $4,42 \%$ & $-16,26 \%$ & $-6,65 \%$ & $13,11 \%$ & $0,50 \%$ & $-5,76 \%$ & $6,38 \%$ & $-3,50 \%$ & $0,26 \%$ & $-6,98 \%$ & $0,00 \%$ \\
\hline PTBL3 & Portobello ON & 0,03 & Low & 181.270.260 & Small & 0,48 & Loser & Small|Low|Loser & $5,26 \%$ & $-3,33 \%$ & $7,76 \%$ & $12,00 \%$ & $-3,57 \%$ & $6,67 \%$ & $19,44 \%$ & $8,14 \%$ & $-3,23 \%$ & $-17,22 \%$ & $-6,04 \%$ & $14,29 \%$ \\
\hline RHDS3 & MG Poliest ON & 0,35 & Low & 802.496 .000 & Small & 0,47 & Loser & Small|Low|Loser & $0,00 \%$ & $20,00 \%$ & $8,33 \%$ & $7,69 \%$ & $-7,14 \%$ & $7,69 \%$ & $50,00 \%$ & $9,52 \%$ & $-8,70 \%$ & $-19,05 \%$ & $-35,29 \%$ & $18,18 \%$ \\
\hline \begin{tabular}{ll|} 
CTKA4 \\
\end{tabular} & Karsten PN & 0,48 & Low & 73.678.350 & Small & 0,37 & Winner & Small|Low|Winner & $-13,64 \%$ & $-5,20 \%$ & $-6,33 \%$ & $-3,83 \%$ & $0,23 \%$ & $2,73 \%$ & $-4,19 \%$ & $0,24 \%$ & $18,64 \%$ & $-4,08 \%$ & $-14,89 \%$ & $3,50 \%$ \\
\hline \begin{tabular}{|l|} 
MTIG4 \\
\end{tabular} & Metal I乏 & 0,35 & Low & & Small & 0,36 & Winner & Small|Low|Winner & $5,26 \%$ & $-2,50 \%$ & $-2,56 \%$ & $15,79 \%$ & $-13,64 \%$ & $-2,63 \%$ & $56,76 \%$ & $5,17 \%$ & $-8,20 \%$ & $-30,36 \%$ & $-15,38 \%$ & $6,06 \%$ \\
\hline ODPV3 & Odontoprev ON & 0,42 & Low & 728.186 .650 & Small & 0,33 & Winner & Small|Low|Winner & $3,92 \%$ & $7,12 \%$ & $12,34 \%$ & $40,47 \%$ & $12,87 \%$ & $17,79 \%$ & $-9,38 \%$ & $14,40 \%$ & $-0,10 \%$ & $-8,02 \%$ & $7,40 \%$ & $13,54 \%$ \\
\hline RNAR3 & Renar ON & 0,52 & Low & 112.800 .000 & Small & 0,32 & Winner & Small|Low|Winner & $-23,49 \%$ & $-11,02 \%$ & $-7,96 \%$ & $-6,73 \%$ & $3,09 \%$ & $2,00 \%$ & $19,61 \%$ & $-3,28 \%$ & $-6,78 \%$ & $-8,18 \%$ & $-12,87 \%$ & $0,00 \%$ \\
\hline VLID3 & Jar & & Low & & Sma & 0,29 & Win & -2 & & & 12,7 & & $-2,33 \%$ & 9,9 & & $-7,09 \%$ & & $\begin{array}{ll}-0,83 \% \\
\end{array}$ & & $-0,67 \%$ \\
\hline RSIP4 & Rasip Agro PN & 0,53 & Low & $84.831 .3 / 0$ & Small & 0,22 & Winner & Small|Low|Winner & 4,88\% & $0,00 \%$ & $0,00 \%$ ] & $6,98 \%$ | & $-2,17 \%$ & $-3,46 \%$ & $16,67 \%$ & $8,16 \%$ & $-9,43 \%$ & $-22,92 \%$ & $-4,23 \%$ & $-5,71 \%$ \\
\hline HGTX3 & Cia Hering ON & 0,57 & Low & 657.909 .400 & Small & 0,18 & Winner & Small|Low|Winner & $28,25 \%$ & $19,28 \%$ & $11,69 \%$ & $3,91 \%$ & $23,76 \%$ & $12,13 \%$ & $4,94 \%$ & $5,52 \%$ & $7,69 \%$ & $12,21 \%$ & $5,91 \%$ & $14,08 \%$ \\
\hline MTSA4 & Metisa PN & 0,48 & Low & 219.505 .578 & nall & 0,12 & Ninner & Small|Low|Winner & $10,59 \%$ & $40 \%$ & 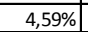 & $70 \% \mid$ & $000 \mathrm{~s}$ & $85 \%$ & & renct & 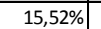 & 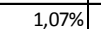 & 2 & $-7,11 \%$ \\
\hline
\end{tabular}


Anexo 1 - Retorno mensal e classificação das ações

\begin{tabular}{|c|c|c|c|c|c|c|c|c|c|c|c|c|c|c|c|c|c|c|c|c|}
\hline Código & $2009-2010$ & $\begin{array}{l}\text { Índice } B / M \\
\text { de dez/2008 }\end{array}$ & $\begin{array}{c}\text { Grupo com } \\
\text { base no } \\
\text { indice } B / M\end{array}$ & $\begin{array}{c}\text { Valor de Mercado } \\
\text { em jun/2009 }\end{array}$ & $\begin{array}{c}\text { Grupo com } \\
\text { base no } \\
\text { tamanho }\end{array}$ & $\begin{array}{c}\text { Retorno } \\
\text { acumulado } \\
\text { de jun/2009 }\end{array}$ & \begin{tabular}{|c|} 
Grupo com \\
base no \\
retorno \\
acumulado
\end{tabular} & Carteiras & jul/09 & ago/09 & set/09 & out/09 & nov/09 & dez/09 & $\mathrm{jan} / 10$ & fev/10 & $\mathrm{mar} / 10$ & $a b r / 10$ & $\mathrm{mai} / 10$ & jun/10 \\
\hline \begin{tabular}{|l|} 
DROG3 \\
\end{tabular} & Drogasil ON & 0,60 & Low & 1.111 .675 .540 & Small & 0,08 & Winner & Small|Low|Winner & $6,72 \%$ & $5,00 \%$ & $7,57 \%$ & $14,44 \%$ & $-5,05 \%$ & $14,94 \%$ & $-3,57 \%$ & $2,96 \%$ & $3,18 \%$ & $5,00 \%$ & $-1,34 \%$ & $17,09 \%$ \\
\hline CTAX3 & Contax ON & 0,47 & Low & 795.940 .600 & Small & 0,05 & Winner & Small|Low|Winner & $22,22 \%$ & $19,70 \%$ & $10,13 \%$ & $-4,02 \%$ & $15,45 \%$ & $11,49 \%$ & $7,89 \%$ & $-0,28 \%$ & $7,54 \%$ & $-14,31 \%$ & $5,11 \%$ & $10,86 \%$ \\
\hline CTAX4 & Contax PN & 0,47 & Low & 795.940 .600 & Small & 0,01 & Winner & Small|Low|Winner & $18,97 \%$ & $16,43 \%$ & $7,37 \%$ & $-1,23 \%$ & $13,29 \%$ & $11,73 \%$ & $-0,80 \%$ & $0,81 \%$ & $-1,60 \%$ & $-12,20 \%$ & $3,70 \%$ & $3,20 \%$ \\
\hline LIPR3 & Eletropar ON & 0,27 & Low & 431.185.000 & Small & 0,03 & Winner & Small|Low|Winner & $4,34 \%$ & $0,00 \%$ & $1,62 \%$ & $1,14 \%$ & $0,90 \%$ & $1,11 \%$ & $-0,02 \%$ & $0,09 \%$ & $-0,07 \%$ & $0,14 \%$ & $2,42 \%$ & $-2,15 \%$ \\
\hline RSIP3 & Rasip Agro ON & 0,53 & Low & 84.831 .370 & Small & 0,14 & Winner & Small | Low |Winner & $0,00 \%$ & $-2,22 \%$ & $-4,55 \%$ & $16,67 \%$ & $-8,16 \%$ & $-5,84 \%$ & $21,95 \%$ & $20,00 \%$ & $-18,33 \%$ & $-10,20 \%$ & $-8,23 \%$ & $2,50 \%$ \\
\hline TELB4 & Telebras PN & 0,02 & Low & 448.593 .698 & Small & 0,45 & Winner & Small|Low|Winner & $6,25 \%$ & $8,82 \%$ & $8,11 \%$ & $110,00 \%$ & $-2,38 \%$ & $-8,54 \%$ & $140,00 \%$ & $32,22 \%$ & $-39,92 \%$ & $39,86 \%$ & $-19,00 \%$ & $10,49 \%$ \\
\hline TELB3 & Telebras ON & 0,02 & Low & 448.593 .698 & Small & 0,62 & Winner & Small|Low|Winner & $25,58 \%$ & $14,81 \%$ & $11,29 \%$ & $14,49 \%$ & $0,00 \%$ & $0,00 \%$ & $127,85 \%$ & $29,44 \%$ & $-42,06 \%$ & $48,15 \%$ & $-5,50 \%$ & $-6,35 \%$ \\
\hline FRIO3 & Metalfrio ON & 0,95 & Medium & 147.764 .780 & Small & 0,80 & Loser & Small|Medium|Loser & $41,71 \%$ & $17,54 \%$ & $63,35 \%$ & $3,35 \%$ & $13,22 \%$ & $-11,69 \%$ & $25,38 \%$ & $-7,04 \%$ & $-6,28 \%$ & $-9,09 \%$ & $-0,06 \%$ & $2,26 \%$ \\
\hline JHSF3 & JHSF Part ON & 1,24 & Medium & 784.427.558 & Small & 0,79 & Loser & Small|Medium|Loser & $43,48 \%$ & $26,89 \%$ & $17,01 \%$ & $-9,18 \%$ & $-0,56 \%$ & $9,56 \%$ & $-8,00 \%$ & $-2,90 \%$ & $-2,69 \%$ & $-12,27 \%$ & $-13,25 \%$ & $7,44 \%$ \\
\hline GLOB3 & Globex ON & 1,19 & Medium & 953.290 .800 & Small & 0,68 & Loser & Small|Medium|Loser & $7,14 \%$ & $-4,85 \%$ & $2,68 \%$ & $-0,12 \%$ & $18,01 \%$ & $62,11 \%$ & $-13,64 \%$ & $-17,29 \%$ & $21,73 \%$ & $-5,15 \%$ & $3,15 \%$ & $-2,29 \%$ \\
\hline IDNT3 & Ideiasnet ON & 0,76 & Medium & 338.819 .000 & Small & 0,66 & Loser & Small|Medium | Loser & $6,46 \%$ & $2,89 \%$ & $9,55 \%$ & $35,90 \%$ & $0,38 \%$ & $2,26 \%$ & $-9,74 \%$ & $-10,39 \%$ & $-9,32 \%$ & $-9,93 \%$ & $-15,04 \%$ & $-2,62 \%$ \\
\hline FBMC4 & Fibam PN & 0,89 & Medium & 32.452 .200 & Small & 0,65 & Loser & Small|Medium|Loser & $11,63 \%$ & $2,20 \%$ & $26,47 \%$ & $-0,02 \%$ & $16,30 \%$ & $19,99 \%$ & $-5,55 \%$ & $1,16 \%$ & $6,99 \%$ & $-2,68 \%$ & $-13,78 \%$ & $2,39 \%$ \\
\hline TGMA3 & Tegma ON & 1,09 & Medium & 494.535.000 & Small & 0,65 & Loser & Small| |Medium|Loser & $26,67 \%$ & $25,00 \%$ & $4,49 \% \mid$ & $2,85 \%$ & $6,10 \%$ & $18,87 \%$ | & $3,23 \%$ & $-9,00 \%$ | $>2$ & $6,18 \%$ | & $0,91 \%$ & $-14,32 \%$ & $17,64 \%$ \\
\hline MEDI3 & Medial S. & 1,01 & Medium & 5.550 & Small & 0,63 & Loser & Small|Medium|Loser & $-1,17 \%$ & $11,24 \%$ & $15,43 \%$ & $31,80 \%$ & $16,08 \%$ & $4,82 \%$ & $-8,05 \%$ & $-6,19 \%$ & $-0,07 \%$ & $-3,33 \%$ & $-10,00 \%$ & $-11,49 \%$ \\
\hline TEMP3 & Tempo Part ON & 0,69 & Medium & 494.363.876 & Small & 0,62 & Loser & Small|Medium|Loser & $11,11 \%$ & $-20,29 \%$ & $9,32 \%$ & $10,82 \%$ & $13,02 \%$ & $-1,83 \%$ & $-1,33 \%$ & $1,35 \%$ & $-12,80 \%$ & $-6,73 \%$ & $1,31 \%$ & $6,80 \%$ \\
\hline GPCP3 & GPC Part ON & 1,13 & Medium & 66.832.000 & Small & 0,62 & Loser & Small|Medium|Loser & $10,94 \%$ & $-7,04 \%$ & $1,52 \%$ & $17,91 \%$ & $16,46 \%$ & $8,70 \%$ & $17,00 \%$ & $5,13 \%$ & $-14,63 \%$ & $-9,52 \%$ & 0,00\% & $-4,21 \%$ \\
\hline MYPK3 & lochp-Maxion & 1,07 & Medium & 676.854 .640 & Small & 0,60 & Loser & Small|Medium|Loser & $27,68 \%$ & $5,38 \%$ & $23,18 \%$ & $-4,06 \%$ & $11,24 \%$ & $0,83 \%$ & $17,09 \%$ & $-7,38 \%$ & $2,07 \%$ & $15,68 \%$ & $-1,62 \%$ & $8,30 \%$ \\
\hline KEPL3 & Kepler Weber ON & 0,89 & Medium & 208.209.280 & Small & 0,60 & Loser & Small|Medium|Loser & $-6,25 \%$ & $6,67 \%$ & $87,50 \%$ & $10,00 \%$ & $15,15 \%$ & $-5,26 \%$ & $55,56 \%$ & $14,29 \%$ & $-17,19 \%$ & $-15,09 \%$ & $-26,67 \%$ & $3,03 \%$ \\
\hline CGRA3 & Grazziotin ON & 1,13 & Medium & 5.514 .969 & Small & 0,59 & Loser & Small|Medium|Loser & $5,52 \%$ & $4,71 \%$ & $23,00 \%$ & $-2,44 \%$ & $0,00 \%$ & $12,14 \%$ & $-3,69 \%$ & $4,23 \%$ & $6,90 \%$ & $8,09 \%$ & $-18,92 \%$ & $8,33 \%$ \\
\hline ROMI3 & Inds Romi ON & 1,17 & Medium & 0.400 & Small & 0,59 & Loser & Small|Medium | Loser & $22,73 \%$ & $11,48 \%$ & $-4,65 \%$ & $8,45 \%$ | & $2,81 \%$ & $-7,28 \% \mid$ & $20,20 \%$ & $-4,26 \%$ & $-6,53 \%$ & $-2,08 \%$ & $-7,27 \%$ & $0,10 \%$ \\
\hline \begin{tabular}{|l|l|} 
KROT11 \\
\end{tabular} & Kroton UNT N2 & 1,20 & Medium & 771 & Small & 0,58 & Loser & Small|Medium|Loser & $28,64 \%$ & $6,01 \%$ & $-12,28 \%$ & $18,94 \%$ & $-4,69 \%$ & $0,56 \%$ & $6,11 \%$ & $-2,62 \%$ & $-10,75 \%$ & $-1,51 \%$ & $-8,87 \%$ & $10,40 \%$ \\
\hline DTEX3 & Duratex ON & 1,27 & Medium & 39.279 .100 & Small & 0,56 & Loser & Small|Medium | Loser & $23,19 \%$ & $10,16 \%$ & $-0,18 \%$ & $9,73 \%$ & $27,85 \%$ & $5,26 \%$ & $-0,06 \%$ & $6,25 \%$ & $-10,76 \%$ & $3,58 \%$ & $-1,89 \%$ & $5,13 \%$ \\
\hline PLAS3 & Plascar Part ON & 1,23 & Medium & 817.400 & Small & 0,54 & Loser & Small|Medium|Loser & $6,88 \%$ & $1,29 \%$ & $-0,42 \%$ & $-10,21 \%$ & $8,06 \%$ & $6,58 \%$ & $50,21 \%$ & $6,85 \%$ & $-13,08 \%$ & $6,19 \%$ & $-11,94 \%$ & $13,56 \%$ \\
\hline JFEN3 & Joao Fo & 0,69 & Medium & & Small & 0,51 & Lose & Small|Mec & $25,00 \%$ & $18,80 \%$ & $10,27 \%$ & $5,95 \%$ & $21,04 \%$ & $-4,76 \%$ & $0,00 \%$ & $3,75 \%$ & $8,43 \%$ & $10,56 \%$ & $12,56 \%$ & $8,93 \%$ \\
\hline LLS3 & Le Lis Blanc ON & 0,77 & Medium & 0.337 .500 & Small & 0,50 & Loser & Small| |Medium|Loser & $26,67 \%$ & $1,00 \%$ & $0,25 \%$ & $1,49 \%$ & $41,04 \%$ & $14,44 \%$ & $-4,62 \%$ & $-0,81 \%$ & $15,45 \%$ & $1,41 \%$ & $-1,90 \%$ & 7,71\% \\
\hline ITEC3 & Itautec ON & 1,30 & Medium & 466.040 .000 & Small & 0,47 & Loser & Small|Medium|Loser & $0,00 \%$ & $0,76 \%$ & $0,00 \%$ & $-7,50 \%$ & $25,68 \%$ & $7,53 \%$ & $-4,00 \%$ & $-4,55 \%$ & $0,00 \%$ & $-2,22 \%$ & $2,27 \%$ & $1,22 \%$ \\
\hline POSI3 & Positi & 0,96 & Medium & 901.018 .000 & Small & 0,47 & Loser & Small|Medium|Loser & $31,68 \%$ & $9,35 \%$ & $10,93 \%$ & $22,46 \%$ & $-0,98 \%$ & $10,00 \%$ & $-9,67 \%$ & $-1,78 \%$ & $-10,20 \%$ & $8,40 \%$ & $-10,70 \%$ & $1,62 \%$ \\
\hline \begin{tabular}{|l|} 
PTNT4 \\
\end{tabular} & Pettenati PN & 0,89 & Medium & 82.519 .811 & Small & 0,46 & Loser & Small|Medium|Loser & $22,90 \%$ & $7,67 \%$ & $-14,57 \%$ & $2,36 \%$ & $1,32 \%$ & $-4,30 \%$ & $5,99 \%$ & $-1,16 \%$ & $-7,02 \%$ & $-2,38 \%$ & $-9,74 \%$ & $-9,52 \%$ \\
\hline LEVE4 & Metal Leve PN & 0,89 & Medic & & Small & 0,45 & Loser & Small|Medium|Loser & $14,54 \%$ & $20,07 \%$ & $6,62 \%$ & $-4,2$ & $18,88 \%$ & $2,57 \%$ & $-0,04 \%$ & $-0,76 \%$ & $8,06 \%$ & $-0,75 \%$ & & $8,82 \%$ \\
\hline ELEK4 & Elekeirc & 0,90 & Mediu & 401.293 .700 & Small & 0,45 & Loser & Small|Medium|Loser & $16,36 \%$ & $-13,71 \%$ & $13,50 \% \mid$ & $-12,98 \%$ & $1,67 \%$ & $18,03 \%$ & $-11,14 \%$ & $9,73 \%$ & $3,65 \%$ & $-4,83 \%$ | & $-7,32 \%$ & $-8,05 \%$ \\
\hline SEBB11 & Seb UNT N2 & 0,75 & Medium & 2.857 & Small & 0,45 & Loser & nall|Medium|Loser & $-0,69 \%$ & $-3,28 \%$ & $17,61 \%$ & $-3,39 \%$ & $19,59 \%$ & $13,59 \%$ & $-0,99 \%$ & $0,00 \%$ & $4,35 \%$ & $-2,87 \%$ & $-8,66 \%$ & $.15,71 \%$ \\
\hline TKNO4 & Tekno PN & 1,10 & Medium & 59.550 & Small & 0,43 & Loser & Small|Medium|Loser & $3,88 \%$ & $2,04 \%$ & $2,00 \%$ & $9,80 \%$ & $1,19 \%$ & $-2,85 \%$ & $-0,68 \%$ & $0,00 \%$ & $5,00 \%$ & $4,76 \%$ & $-10,61 \%$ & $0,00 \%$ \\
\hline \begin{tabular}{|l|l|} 
CGRA4 & \\
\end{tabular} & Grazziotin PN & 1,13 & Medium & 514.969 & Small & 0,43 & Loser & Small|Medium|Loser & $12,61 \%$ & $10,00 \%$ & $18,18 \%$ & $-5,38 \%$ & $-2,28 \%$ & $13,37 \%$ & $0,08 \%$ & $-1,29 \%$ & $28,74 \%$ & $-9,19 \%$ & $-13,33 \%$ & $7,69 \%$ \\
\hline REDE4 & Rede En & 0,68 & dium & & Smal & 2 & Los & |Loser & $8,33 \%$ & $-1,79 \%$ & $14,88 \%$ & $1,82 \%$ & $60,71 \%$ & $-16,67 \%$ & $9,17 \%$ & $-10,53 \%$ & $38,74 \%$ & $61,62 \%$ & $6,54 \%$ & $-12,14 \%$ \\
\hline FJTA4 & Forjas T & 0,94 & Medium & 0.700 & Small & 0,41 & Los & Small| |Medium|Loser & $27,27 \%$ & $8,60 \%$ & $3,76 \%$ & $-10,22 \%$ & $-7,70 \%$ & $1,12 \%$ & $-5,36 \%$ & $-2,17 \%$ & $-2,04 \%$ & $-0,17 \%$ & $-9,45 \%$ & $15,47 \%$ \\
\hline BDLL4 & Bardella PN & 1,01 & Medium & 000.000 & Small & 0,39 & Winner & Small|Medium|Winner & $-10,59 \%$ & $12,24 \%$ & $10,98 \%$ & $5,14 \%$ & $-8,91 \%$ & $4,40 \%$ & $-1,40 \%$ & $12,86 \%$ & $-4,43 \%$ & $-3,34 \%$ & $-8,57 \%$ & $24,92 \%$ \\
\hline CREM3 & Cremer ON & 1,04 & Medium & 664.000 & Small & 77 & Winne & Small|Medium|Winner & $-6,10 \%$ & $31,77 \%$ & $14,42 \%$ & $10,40 \%$ & $3,53 \%$ & $3,91 \%$ & $5,29 \%$ & $-3,97 \%$ & $13,82 \%$ & $8,51 \%$ & $2,29 \%$ & $6,67 \%$ \\
\hline SLED4 & Saraiva Livr PN & 0,68 & Mediur & 862.840 & Small & & Winne & Small|Medium|Winner & $21,41 \%$ & $0,54 \%$ & $12,58 \%$ & $-5,35 \%$ & $7,73 \%$ & $7,97 \%$ & $1,47 \%$ & $1,74 \%$ & $0,85 \%$ & $10,73 \%$ & $-10,71 \%$ & $6,57 \%$ \\
\hline $\begin{array}{ll}\text { PNVL3 } \\
\end{array}$ & Dimed ON & 0,94 & Medium & .720 .400 & Small & 0,35 & Winner & Small|Medium|Winner & $26,62 \%$ & $11,84 \%$ & $4,67 \%$ & $18,08 \%$ & $9,26 \%$ & $5,83 \%$ & $16,65 \%$ & $0,70 \%$ & $3,58 \%$ & $-0,34 \%$ & $-5,29 \%$ & $-4,21 \%$ \\
\hline BEMA3 & Bematech ON & 1,26 & Medium & 331.522 .380 & Small & 0,33 & Winner & Small|Medium|Winner & $3,58 \%$ & $22,11 \%$ & $-3,94 \%$ & $6,41 \%$ & $2,05 \%$ & $0,00 \%$ & $11,57 \%$ & $-1,90 \%$ & $-2,05 \%$ & $2,73 \%$ & $-3,44 \%$ & $-0,46 \%$ \\
\hline TUPY3 & Tupy & 1,24 & Mediu & & Sma & 0,32 & Winr & all $\mid \mathrm{Me}$ & 0, & $-300 \%$ & 11, & $0,36 \%$ & $4,77 \%$ & $0,90 \%$ & 15,5 & $4,47 \%$ & $4,03 \%$ & $15,35 \%$ & $5,16 \%$ & 0,7 \\
\hline POMO4 & Marcopolo PN & 1,00 & Medium & 985.082 .780 & Small & 0,32 & Winner & Small|Medium|Winner & $21,35 \%$ & $4,44 \%$ & $9,30 \%$ & $2,46 \%$ & $1,60 \%$ & $10,80 \%$ & $12,44 \%$ & $7,11 \%$ & $-0,94 \%$ & $4,50 \%$ & $1,20 \%$ & $12,69 \%$ \\
\hline \begin{tabular}{|l|l|} 
DXTG4 \\
\end{tabular} & Dixie Toga PN & 1,28 & Medium & 480.212 .250 & Small & 0,31 & Winner & Small|Medium|Winner & $2,29 \%$ & $-3,91 \%$ & $6,40 \%$ & $-1,64 \%$ & $3,33 \%$ & $-1,61 \%$ & $13,11 \%$ & $0,48 \%$ & $7,69 \%$ & $2,23 \%$ & $7,39 \%$ & $0,42 \%$ \\
\hline REDE3 & Rede Energia $\mathrm{O}$ & & & & $\overline{S m}=2 x_{1}$ & & & & & & & & & $-14,2$ & & & . & 5 & & $\%$ \\
\hline UOLL4 & Uol PN & 0,84 & Medium & 59.248 & Small & 0,28 & Winner & Small|Medium|Winner & 10,07\% & $-1,63 \% \mid$ & 7,01\% & $27,74 \%$ & $-12,49 \%$ & $0,11 \%$ & $-2,13 \%$ & $8,04 \%$ & $4,63 \%$ & $-3,93 \%$ & $6,91 \%[$ & $-1,08 \%$ \\
\hline POMO3 & Marcopolo ON & 1,00 & Medium & 985.082 .780 & Small & 0,25 & Winner & Small|Medium|Winner & $15,01 \%$ & $-3,61 \%$ & $16,03 \%$ & $-7,45 \%$ & $6,09 \%$ & $15,64 \%$ & $9,24 \%$ & $3,69 \%$ & $-1,45 \%$ & $10,02 \%$ & $0,69 \%$ & $-1,38 \%$ \\
\hline [CCPR3 & re Co & 0,64 & Medium & 750.358 .600 & nall & & Winner & Small|Medium $\mid \mathrm{W}$ & & $4 \% 0$ & & & & & & & & 20 & 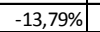 & $-0,80 \%]$ \\
\hline
\end{tabular}


Anexo 1 - Retorno mensal e classificação das ações

\begin{tabular}{|c|c|c|c|c|c|c|c|c|c|c|c|c|c|c|c|c|c|c|c|c|}
\hline Código & $2009-2010$ & $\begin{array}{l}\text { Índice } B / M \\
\text { de dez/2008 }\end{array}$ & $\begin{array}{c}\text { Grupo com } \\
\text { base no } \\
\text { índice } B / M\end{array}$ & $\begin{array}{c}\text { Valor de Mercado } \\
\text { em jun/2009 }\end{array}$ & $\begin{array}{c}\text { Grupo com } \\
\text { base no } \\
\text { tamanho }\end{array}$ & $\begin{array}{c}\text { Retorno } \\
\text { acumulado } \\
\text { de jun/2009 }\end{array}$ & $\begin{array}{l}\text { Grupo com } \\
\text { base no } \\
\text { retorno } \\
\text { acumulado }\end{array}$ & Carteiras & $\mathrm{jul} / 09$ & ago/09 & set/09 & out/09 & nov/09 & dez/09 & $\mathrm{jan} / 10$ & fev/10 & $\mathrm{mar} / 10$ & $\mathrm{abr} / 10$ & mai/10 & jun/10 \\
\hline ETER3 & Eternit ON & 0,68 & $\mathrm{um}$ & pt & Small & 0,17 & Winner & $r$ & +4 & $-1,64 \%$ & $2,48 \%$ & 16,6 & 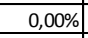 & & & & & $0,25 \%$ & $\%$ & $5,09 \%$ \\
\hline AMAR3 & Lojas Marisa ON & 1,01 & Medium & 1.700 & Small & 0,14 & Winner & Small|Medium|Winner & $46,53 \%$ & $10,31 \%$ & $4,80 \%$ & $7,11 \%$ & $11,47 \%$ & $12,00 \%$ & $13,64 \%$ & $14,40 \%$ & $10,49 \%$ & $9,92 \%$ & $5,68 \%$ & $14,70 \%$ \\
\hline RPAD3 & Alfa Holding ON & 1,27 & Medium & 210.927 & Small & 0,13 & Winner & Small|Medium|Winner & $10,69 \%$ & $-1,47 \%$ & $11,35 \%$ & $-7,84 \%$ & $2,13 \%$ & $13,96 \%$ & $-10,79 \%$ & $-0,37 \%$ & $23,35 \%$ & $-16,25 \%$ & $-1,00 \%$ & $5,45 \%$ \\
\hline CARD3 & Csu Card & 1,14 & $\mathrm{~m}$ & 334.350 & Small & 04 & Winner & all|Medium|Wi & $-2,80 \%$ & $14,60 \%$ & $15,83 \%$ & $-1,83 \%$ & $37,52 \%$ & 4,44 & $0,47 \%$ & $-2,47$ & $-3,74 \%$ & $12,16 \%$ & $12,28 \%$ & $7,69 \%$ \\
\hline RPAD5 & Alfa Holding PNA & 1,27 & Medium & 3.210.927 & Small & 0,04 & Winner & Small|Medium|Winner & $1,74 \%$ & $1,24 \%$ & $0,44 \%$ & $0,43 \%$ & $0,87 \%$ & $-0,21 \%$ & $0,00 \%$ & $8,79 \%$ & $11,41 \%$ & $-9,32 \%$ & $0,20 \%$ & $-0,20 \%$ \\
\hline RPAD6 & Alfa Holding PN & 1,27 & Medium & 363.210 .927 & Small & 0,04 & Winner & Small|Medium|Winner & $7,29 \%$ & $-0,37 \%$ & $-0,66 \%$ & $2,22 \%$ & $-0,43 \%$ & $1,53 \%$ & $-2,80 \%$ & $5,43 \%$ & \begin{tabular}{l|l}
$15,40 \%$ \\
\end{tabular} & $-9,51 \%$ & $-7,07 \%$ & $0,22 \%$ \\
\hline CAR3 & Sao Carlos ON & 0,89 & Medium & 876.248 .100 & Small & $\begin{array}{l}0,06 \\
\end{array}$ & Winner & Small|Medium/Winner & $1,25 \%$ & $2,68 \%$ & $4,52 \%$ & $1,85 \%$ & $3,03 \%$ & $-8,53 \%$; $>2$, & $5,21 \%$ & $5,20 \%$ & $-1,88 \%$ - & $9,00 \%$ & $13,02 \%$ & $8,69 \%$ \\
\hline
\end{tabular}

\begin{tabular}{|c|c|c|c|c|c|c|c|c|c|c|c|c|c|c|c|c|c|c|c|c|}
\hline Código & 2010 - 2011 & $\begin{array}{l}\text { Índice } B / M \\
\text { de dez/2009 }\end{array}$ & $\begin{array}{c}\text { Grupo com } \\
\text { base no } \\
\text { indice } B / M\end{array}$ & \begin{tabular}{|c|} 
Valor de Mercado \\
em jun/2010
\end{tabular} & $\begin{array}{c}\text { Grupo com } \\
\text { base no } \\
\text { tamanho }\end{array}$ & $\begin{array}{c}\text { Retorno } \\
\text { acumulado } \\
\text { de jun/2010 }\end{array}$ & \begin{tabular}{c|} 
Grupo com \\
base no \\
retorno \\
acumulado
\end{tabular} & Carteiras & $\mathrm{jul} / 10$ & ago/10 & set/10 & out $/ 10$ & nov/10 & $\operatorname{dez} / 10$ & $\mathrm{jan} / 11$ & fev/11 & $\operatorname{mar} / 11$ & $\mathrm{abr} / 11$ & mai/11 & jun/11 \\
\hline BRTO3 & Brasil Telec ON & 0,92 & High & 7.945.251.798 & Big & 0,76 & Loser & Big|High|Loser & $-1,00 \%$ & $-4,48 \%$ & $-0,86 \%$ & $6,20 \%$ & $-9,79 \%$ & $11,29 \%$ & $12,71 \%$ & $-5,44 \%$ & $8,01 \%$ & $-2,76 \%$ & $3,08 \%$ & $-1,96 \%$ \\
\hline BRTO4 & Brasil Telec PN & 0,92 & High & \begin{tabular}{|l|l|}
7.945 .251 .798 \\
\end{tabular} & Big & 0,20 & Loser & Big|High|Loser & $-4,45 \%$ & $-4,22 \%$ & $0,36 \%$ & $12,91 \%$ & $-4,61 \%$ & $5,10 \%$ & $\begin{array}{ll}7,92 \% \\
\end{array}$ & $-3,09 \%$ & $16,02 \%$ & $2,30 \%$ & $8,84 \%$ & $-5,60 \%$ \\
\hline CSMG3 & Copasa ON & 0,98 & High & 2.873 .225 .000 & Big & \begin{tabular}{l|l|l}
0,03 \\
\end{tabular} & Loser & Big|High|Loser & $3,24 \%$ & $-2,21 \%$ & $4,89 \%$ & $2,54 \%$ & $4,98 \%$ & $4,74 \%$ & $-4,70 \%$ & $6,03 \%$ & $-3,05 \%$ & $5,68 \%$ & \begin{tabular}{|l|l|}
$10,10 \%$ \\
\end{tabular} & $-0,95 \%$ \\
\hline SBSP3 & Sabesp ON & 1,34 & High & 8.543 .850 .000 & Big & 0,12 & Loser & Big|High|Loser & $-6,21 \%$ & $-5,00 \%$ & $13,44 \%$ & $0,66 \%$ & $-0,42 \%$ & $17,39 \%$ & $-4,20 \%$ & $-0,07 \%$ & $15,28 \%$ & $-3,04 \%$ & $5,97 \%$ & $-3,75 \%$ \\
\hline ELET6 & Eletrobras PNB & 1,90 & High & 28.006 .397 .832 & Big & 0,20 & Loser & Big|High|Loser & $-3,37 \%$ & $-6,94 \%$ & $0,16 \%$ & $8,23 \%$ & $-4,33 \%$ & $1,71 \%$ & $0,88 \%$ & $12,28 \%$ & $1,19 \%$ & $-6,56 \%$ & $-1,08 \%$ & $-0,77 \%$ \\
\hline JBSS3 & JBS ON & 0,77 & High & \begin{tabular}{|l|}
19.279 .394 .840 \\
\end{tabular} & Big & 0,21 & Loser & Big|High|Loser & $12,57 \%$ & $-13,37 \%$ & $-1,88 \%$ & $-10,53 \%$ & $0,15 \%$ & $9,47 \%$ & $-12,13 \%$ & $-0,95 \%$ & $-6,09 \%$ & $-8,36 \%$ & $5,40 \%$ & $-4,95 \%$ \\
\hline CESP3 & Cesp ON & 1,15 & High & 7.446 .577 .020 & Big & \begin{tabular}{l|l}
0,27 & \\
\end{tabular} & Loser & Big|High|Loser & $2,58 \%$ & $2,58 \%$ & $-2,71 \%$ & $8,47 \%$ & $2,29 \%$ & $2,34 \%$ & $0,46 \%$ & $6,36 \%$ & $8,46 \%$ & $1,65 \%$ & $0,63 \%$ & $1,89 \%$ \\
\hline ENBR3 & Energias BR ON & 0,80 & High & 5.675 .195 .000 & Big & 0,28 & Loser & Big|High|Loser & $0,28 \%$ & $4,43 \%$ & $-2,37 \%$ & $1,91 \%$ & $-1,88 \%$ & $7,68 \%$ & $-3,25 \%$ & $-0,53 \%$ & $6,58 \%$ & $2,21 \%$ & $-2,56 \%$ & $-1,05 \%$ \\
\hline ELET3 & Eletrobras ON & 1,90 & High & 28.006 .397 .832 & Big & 0,28 & Loser & Big|High|Loser & $-4,44 \%$ & $-6,27 \%$ & 0,89\% & $8,53 \%$ & $-3,89 \%$ & $-1,11 \%$ & $\begin{array}{ll}0,75 \% \\
\end{array}$ & $4,91 \%$ & $4,98 \%$ & $-7,17 \%$ & $-2,18 \%$ & $-2,77 \%$ \\
\hline $\begin{array}{l}\text { CPLE6 } \\
\end{array}$ & Copel PNB & 0,88 & High & 9.750 .687 .953 & Big & 0,29 & Loser & Big|High|Loser & $2,42 \%$ & $1,74 \%$ & $-3,12 \%$ & $7,33 \%$ & $6,30 \%$ & $-2,35 \%$ & $2,41 \%$ & $-1,65 \%$ & $6,34 \%$ & $-1,54 \%$ & $-4,65 \%$ & $1,22 \%$ \\
\hline BRML3 & BR Malls Par ON & 1,16 & High & 4.738 .798 .500 & Big & 0,31 & Loser & Big|High|Loser & $11,45 \%$ & $5,00 \%$ & $2,84 \%$ & $14,92 \%$ & $4,00 \%$ & $1,18 \%$ & $-11,11 \%$ & $4,28 \%$ & $7,26 \%$ & $-2,59 \%$ & $11,38 \%$ & $-2,25 \%$ \\
\hline CPLE3 & Copel ON & $\begin{array}{ll}0,88 \\
\end{array}$ & High & 9.750 .687 .953 & Big & 0,45 & Winner & Big|High|Winner & $2,95 \%$ & $2,10 \%$ & $-5,04 \%$ & $4,13 \%$ & $8,47 \%$ & $-0,76 \%$ & $2,63 \%$ & $-2,59 \%$ & $3,95 \%$ & $0,01 \%$ & $-0,90 \%$ & $-1,17 \%$ \\
\hline CESP6 & Cesp PNB & 1,15 & High & 7.446 .577 .020 & Big & 0,47 & Winner & Big|High|Winner & $10,24 \%$ & $-5,57 \%$ & $-0,90 \%$ & $6,92 \%$ & $6,47 \%$ & $-5,99 \%$ & $5,44 \%$ & $-4,11 \%$ & $13,92 \%$ & $-2,12 \%$ & $2,39 \%$ & $0,16 \%$ \\
\hline CESP5 & Cesp PNA & 1,15 & High & 7.446 .577 .020 & Big & \begin{tabular}{l|l}
0,65 \\
\end{tabular} & Winner & Big|High|Winner & $-1,61 \%$ & $0,41 \%$ & $-6,30 \%$ & $1,91 \%$ & $2,17 \%$ & $0,42 \%$ & $-0,41 \%$ & $6,63 \%$ & $5,51 \%$ & $2,33 \%$ & $10,13 \%$ & $-0,11 \%$ \\
\hline \begin{tabular}{|l|} 
ILMD4 \\
\end{tabular} & Yara Brasil PN & 0,25 & Low & 1.760 .176 .500 & Big & \begin{tabular}{l|l|}
0,17 \\
\end{tabular} & Loser & Big|Low|Loser & $-15,59 \%$ & $-0,92 \%$ & $-3,89 \%$ & $7,55 \%$ & $9,33 \%$ & $-6,74 \%$ & $3,85 \%$ & $-0,04 \%$ & $-16,60 \%$ & $-2,04 \%$ & $-2,38 \%$ & $2,29 \%$ \\
\hline BTOW3 & B2W Varejo ON & 0,05 & Low & 3.314 .635 .520 & Big & \begin{tabular}{l|l|l}
0,07 & \\
\end{tabular} & Loser & Big|Low|Loser & $12,37 \%$ & $-17,16 \%$ & \begin{tabular}{|l|l|}
$11,79 \%$ \\
\end{tabular} & $-0,64 \%$ & $-1,93 \%$ & $3,28 \%$ & $-10,32 \%$ & $-9,42 \%$ & $-11,56 \%$ & $-3,36 \%$ & $2,08 \%$ & $-13,61 \%$ \\
\hline FFTL4 & Valefert PN & 0,24 & Low & 5.697 .311 .418 & Big & \begin{tabular}{l|l}
0,02 \\
\end{tabular} & Loser & Big|Low|Loser & $14,07 \%$ & $9,94 \%$ & 5,14\% & $8,15 \%$ & $-4,42 \%$ & $3,21 \%$ & $0,32 \%$ & $-6,93 \%$ & $-10,04 \%$ & $3,16 \%$ & $8,87 \%$ & $32,72 \%$ \\
\hline CGAS5 & Comgas PNA & 0,34 & Low & 3.767 .318 .700 & Big & 0,04 & Loser & Big|Low|Loser & $4,95 \%$ & $-2,09 \%$ & $3,08 \%$ & $0,96 \%$ & $4,96 \%$ & $6,50 \%$ & $11,61 \%$ & $-2,85 \%$ & $2,85 \%$ & $7,03 \%$ & $1,90 \%$ & $-3,19 \%$ \\
\hline CIEL3 & Cielo ON & 0,04 & Low & 20.672 .972 .800 & Big & 0,05 & Loser & Big|Low|Loser & $3,95 \%$ & $-5,06 \%$ & $2,03 \%$ & $-0,68 \%$ & $1,85 \%$ & $-9,73 \%$ & $-8,03 \%$ & $6,14 \%$ & $10,10 \%$ & $5,13 \%$ & $8,04 \%$ & $-0,76 \%$ \\
\hline ENGI3 & Energisa ON & 0,36 & Low & 1.928 .983 .720 & Big & \begin{tabular}{l|l}
0,06 \\
\end{tabular} & Loser & Big|Low|Loser & $\begin{array}{ll}9,94 \% \\
\end{array}$ & $6,38 \%$ & $-2,33 \%$ & $10,00 \%$ & $-8,13 \%$ & $-0,52 \%$ & $-0,52 \%$ & $-4,74 \%$ & $2,97 \%$ & $3,83 \%$ & $0,00 \%$ & $45,26 \%$ \\
\hline ENGI4 & Energisa PN & 0,36 & Low & \begin{tabular}{|l|}
1.928 .983 .720 \\
\end{tabular} & Big & \begin{tabular}{l|l}
0,06 & \\
\end{tabular} & Loser & Big|Low|Loser & $-4,97 \%$ & 11,63\% & \begin{tabular}{l|l}
$4,95 \%$ \\
\end{tabular} & $-1,02 \%$ & $-3,09 \%$ & $-3,19 \%$ & $-2,20 \%$ & $2,81 \%$ & $4,06 \%$ & $-1,07 \%$ & $4,86 \%$ & $18,04 \%$ \\
\hline RDCD3 & Redecard ON & 0,04 & Low & $\begin{array}{l}17.155 .405 .500 \\
\end{array}$ & Big & \begin{tabular}{l|l|l|l|l|l}
0,07 \\
\end{tabular} & Loser & Big|Low|Loser & $4,16 \%$ & $-6,15 \%$ & $9,38 \%$ & $-16,19 \%$ & $1,59 \%$ & $-5,64 \%$ & $-2,14 \%$ & $4,37 \%$ & $11,86 \%$ & $-1,66 \%$ & $4,62 \%$ & $-1,00 \%$ \\
\hline GET13 & AES Tiete ON & 0,07 & Low & 7.338 .362 .850 & Big & 0,12 & Loser & Big|Low|Loser & $5,21 \%$ & $-1,53 \%$ & $2,71 \%$ & $6,74 \%$ & $\begin{array}{l}9,56 \% \\
\end{array}$ & $2,17 \%$ & $-3,53 \%$ & $2,89 \%$ & $6,61 \%$ & $3,16 \%$ & $0,32 \%$ & $-0,31 \%$ \\
\hline GETI4 & AES Tiete PN & 0,07 & Low & 7.338 .362 .850 & Big & \begin{tabular}{l|l}
0,12 \\
\end{tabular} & Loser & Big|Low|Loser & $6,51 \%$ & $-1,38 \%$ & $5,96 \%$ & $3,81 \%$ & $2,79 \%$ & $2,43 \%$ & $-2,17 \%$ & $-2,04 \%$ & $7,83 \%$ & $5,24 \%$ & \begin{tabular}{l|l}
$-0,74 \%$ \\
\end{tabular} & $2,14 \%$ \\
\hline \begin{tabular}{|l|} 
CGAS3 \\
\end{tabular} & Comgas ON & 0,34 & Low & 3.767 .318 .700 & Big & 0,14 & Loser & Big|Low|Loser & $12,48 \%$ & $-1,54 \%$ & $-1,74 \%$ & $3,61 \%$ & $4,48 \%$ & $6,22 \%$ & $13,61 \%$ & $-1,47 \%$ & $1,08 \%$ & $5,97 \%$ & $0,44 \%$ & $-1,05 \%$ \\
\hline WEGE3 & Weg ON & 0,21 & Low & 10.369 .113 .984 & Big & \begin{tabular}{l|l|l|l|l|}
0,14 & \\
\end{tabular} & Loser & Big|Low|Loser & \begin{tabular}{l|l}
$9,89 \%$ \\
\end{tabular} & $-6,80 \%$ & \begin{tabular}{l|l}
$9,18 \%$ \\
\end{tabular} & $18,76 \%$ & $2,73 \%$ & $-3,16 \%$ & \begin{tabular}{l|l|}
$-8,90 \%$ \\
\end{tabular} & $1,75 \%$ & $7,59 \%$ & $-8,37 \%$ & \begin{tabular}{l|l|}
$-8,63 \%$ \\
\end{tabular} & $-0,67 \%$ \\
\hline CPFE3 & CPFL Energia ON & 0,30 & Low & \begin{tabular}{|l|}
18.961 .614 .293 \\
\end{tabular} & Big & 0,20 & Loser & Big|Low|Loser & $3,02 \%$ & $3,67 \%$ & $-4,56 \%$ & $3,07 \%$ & $-0,48 \%$ & $3,78 \%$ & $-0,39 \%$ & $5,43 \%$ & $7,21 \%$ & $0,27 \%$ & $-0,46 \%$ & $-1,57 \%$ \\
\hline WHRL4 & Whirlpool PN & 0,31 & Low & 4.989 .067 .500 & Big & 0,21 & Loser & Big|Low|Loser & $-2,23 \%$ & $2,86 \%$ & $-1,39 \%$ & $8,67 \%$ & $5,59 \%$ & $4,74 \%$ & $1,33 \%$ & $-2,62 \%$ & $-0,27 \%$ & $2,70 \%$ & $3,68 \%$ & $-6,09 \%$ \\
\hline BMTO4 & Brasmotor PN & 0,33 & Low & 2.681 .779 .400 & Big & \begin{tabular}{l|l}
0,25 \\
\end{tabular} & Loser & Big|Low|Loser & $0,00 \%$ & $14,74 \%$ & $-2,75 \%$ & $-0,62 \%$ & $3,16 \%$ & $1,02 \%$ & $-3,03 \%$ & $0,00 \%$ & $-3,12 \%$ & $-4,30 \%$ & $2,25 \%$ & $-3,30 \%$ \\
\hline TBLE3 & Tractebel ON & 0,26 & Low & 13.831 .607 .048 & Big & \begin{tabular}{l|l}
0,26 & \\
\end{tabular} & Loser & Big|Low|Loser & $7,83 \%$ & $1,66 \%$ & $9,00 \%$ & $4,09 \%$ & $5,91 \%$ & $1,37 \%$ & $-6,01 \%$ & $0,78 \%$ & $6,15 \%$ | & $-0,14 \%$ & $-2,08 \%$ & $2,80 \%$ \\
\hline
\end{tabular}


Anexo 1 - Retorno mensal e classificação das ações

\begin{tabular}{|c|c|c|c|c|c|c|c|c|c|c|c|c|c|c|c|c|c|c|c|c|}
\hline Código & 2010 - 2011 & $\begin{array}{l}\text { Índice } B / M \\
\text { de dez/2009 }\end{array}$ & $\begin{array}{c}\text { Grupo com } \\
\text { base no } \\
\text { índice } B / M\end{array}$ & \begin{tabular}{|c|} 
Valor de Mercado \\
em jun/2010
\end{tabular} & $\begin{array}{l}\text { Grupo com } \\
\text { base no } \\
\text { tamanho }\end{array}$ & $\begin{array}{c}\text { Retorno } \\
\text { acumulado } \\
\text { de jun/2010 }\end{array}$ & $\begin{array}{l}\text { Grupo com } \\
\text { base no } \\
\text { retorno } \\
\text { acumulado }\end{array}$ & Carteiras & $\mathrm{jul} / 10$ & ago/10 & set/10 & out $/ 10$ & nov/10 & dez/10 & $\mathrm{jan} / 11$ & fev/11 & $\operatorname{mar} / 11$ & $\mathrm{abr} / 11$ & $\mathrm{mai} / 11$ & jun/11 \\
\hline CEEB3 & Coelba ON & 0,29 & Low & 6.680 .283 .500 & Big & 0,29 & Loser & g|Low|Loser & $-3,85 \%$ & $-2,94 \%$ & $6,06 \%$ & $-7,52 \%$ & $2,75 \%$ & $16,54 \%$ & $-3,40 \%$ & $1,10 \%$ & $6,97 \%$ & $5,53 \%$ & $2,77 \%$ & $7,69 \%$ \\
\hline CSNA3 3 & Sid Nacional ON & 0,14 & Low & 38.344 .611 .000 & Big & 0,34 & Loser & Big|Low|Loser & $11,18 \%$ & $-8,00 \%$ & $9,03 \%$ & $-3,68 \%$ & $\begin{array}{ll}-7,58 \% \\
\end{array}$ & $2,14 \%$ & $3,86 \%$ & $-3,79 \%$ & $0,11 \%$ & $-8,32 \%$ & $-4,94 \%$ & $-12,93 \%$ \\
\hline \begin{tabular}{|l|l|} 
CCRO3 \\
\end{tabular} & CCR SA ON & 0,16 & Low & \begin{tabular}{|l|}
6.499 .412 .384 \\
\end{tabular} & Big & 0,36 & Loser & Big|Low|Loser & $7,17 \%$ & $0,60 \%$ & $12,80 \%$ & $5,38 \%$ & $1,63 \%$ & $0,32 \%$ & $-1,86 \%$ & $0,80 \%$ & $2,16 \%$ & $3,87 \%$ & $0,80 \%$ & $-5,95 \%$ \\
\hline MRVE3 & MRV ON & 0,35 & Low & 6.131 .265 .870 & Big & 0,36 & Loser & Big|Low|Loser & $24,08 \%$ & $-7,10 \%$ & $9,62 \%$ & $3,36 \%$ & $2,11 \%$ & $-7,00 \%$ & $-9,67 \%$ & $-6,31 \%$ & $-1,14 \%$ & $4,13 \%$ & $8,30 \%$ & $10,93 \%$ \\
\hline AMBV4 & Ambev PN & 0,20 & Low & \begin{tabular}{|l|}
103.059 .437 .730 \\
\end{tabular} & Big & 0,37 & Winner & Big|Low|Winner & \begin{tabular}{|l|l|}
$5,82 \%$ \\
\end{tabular} & $1,63 \%$ & $7,71 \%$ & $15,33 \%$ & $-2,53 \%$ & $11,23 \%$ & $-11,34 \%$ & $-1,32 \%$ & $4,23 \%$ & $10,23 \%$ & $-2,75 \%$ & $5,40 \%$ \\
\hline \begin{tabular}{|l|l|} 
LAME4 \\
\end{tabular} & Lojas Americ PN & 0,04 & Low & 8.680 .076 .940 & Big & 0,38 & Winner & Big|Low|Winner & $14,68 \%$ & $-1,40 \%$ & $4,67 \%$ & $18,31 \%$ & $-11,15 \%$ & $-5,78 \%$ & $-12,48 \%$ & $0,07 \%$ & $1,99 \%$ & $2,94 \%$ & $13,93 \%$ & $-3,19 \%$ \\
\hline CYRE3 & Cyrela Realty ON & 0,37 & Low & 8.250 .993 .610 & Big & 0,39 & Winner & Big|Low|Winner & $27,06 \%$ & $-11,94 \%$ & $9,71 \%$ & $-1,88 \%$ & $-7,66 \%$ & $0,69 \%$ & $-15,74 \%$ & $-10,10 \%$ & $-6,47 \%$ & $6,65 \%$ & $4,50 \%$ & $12,01 \%$ \\
\hline CRUZ3 & Souza Cruz ON & 0,12 & Low & 20.786 .920 .000 & Big & 0,40 & Winner & Big|Low|Winner & $18,82 \%$ & $2,50 \%$ & $4,57 \%$ & $3,37 \%$ & $-1,46 \%$ & $5,06 \%$ & $-11,92 \%$ & $0,23 \%$ & $9,69 \%$ & $4,06 \%$ & $11,98 \%$ & $0,34 \%$ \\
\hline BRAP4 & Bradespar PN & 0,37 & Low & 11.548 .670 .250 & Big & 0,41 & Winner & Big|Low|Winner & $12,60 \%$ & $-0,87 \%$ & $10,66 \%$ & $7,58 \%$ & $-1,54 \%$ & $2,17 \%$ & $5,54 \%$ & $-5,56 \%$ & $-0,88 \%$ & $-2,66 \%$ & $-0,49 \%$ & $-2,22 \%$ \\
\hline BRAP3 & Bradespar ON & 0,37 & Low & 11.548 .670 .250 & Big & 0,41 & Winner & Big|Low|Winner & $10,42 \%$ & $-0,51 \%$ & $11,39 \%$ & $6,12 \%$ & $0,49 \%$ & $1,71 \%$ & 7,52\% & $-5,94 \%$ & $-1,55 \%$ & $0,19 \%$ & $0,86 \%$ & $-2,28 \%$ \\
\hline ALLL3 & All Amer Lat ON & 0,29 & Low & 10.446 .518 .800 & Big & 0,42 & Winner & Big|Low|Winner & $6,05 \%$ & $-11,41 \%$ & $0,84 \%$ & $-10,11 \%$ & $-1,42 \%$ & $-5,96 \%$ & $-6,13 \%$ & $-2,06 \%$ & $-2,83 \%$ & $-2,99 \%$ & $1,84 \%$ & $-0,15 \%$ \\
\hline AMBV3 & Ambev ON & 0,20 & Low & \begin{tabular}{|l|}
103.059 .437 .730 \\
\end{tabular} & Big & 0,43 & Winner & Big|Low/Winner & \begin{tabular}{ll|}
$4,63 \%$ \\
\end{tabular} & $2,31 \%$ & $5,43 \%$ & $11,69 \%$ & $2,99 \%$ & $10,77 \%$ & $-12,51 \%$ & $-1,37 \%$ & $5,11 \%$ & $8,71 \%$ & $-2,47 \%$ & $4,57 \%$ \\
\hline LAME3 & Lojas Americ ON & 0,04 & Low & 8.680 .076 .940 & Big & 0,45 & Winner & Big|Low|Winner & $10,89 \%$ & $4,46 \%$ & $9,15 \%$ | & $11,38 \%$ & $-5,28 \%$ & $-7,81 \%$ | & $-4,85 \%$ & $-0,08 \%$ & $0,56 \%$ & $3,57 \%$ & $14,03 \%$ | & $-4,10 \%$ \\
\hline EKTR4 & Elektro PN & 0,31 & Low & 4.650 .222 .360 & Big & 0,46 & Winner & Big|Low|Winner & $20,21 \%$ & $3,43 \%$ & $-11,11 \%$ & $0,59 \%$ & $-6,80 \%$ & $7,86 \%$ & $-12,86 \%$ & $-18,99 \%$ & $7,22 \%$ & $-1,55 \%$ & $13,41 \%$ & $0,39 \%$ \\
\hline \begin{tabular}{|l|} 
NATUZ3 \\
\end{tabular} & Natura ON & 0,07 & Low & 17.222 .240 .000 & \begin{tabular}{|l|} 
Big \\
\end{tabular} & 0,49 & Winner & Big|Low/Winner & $16,07 \%$ & $-7,44 \%$ & $7,57 \%$ & $7,03 \%$ & $-5,38 \%$ & $3,49 \%$ & $-10,46 \%$ & $-1,15 \%$ & $11,61 \%$ & $-3,70 \%$ & $-4,51 \%$ & $-7,80 \%$ \\
\hline AMIL3 & Amil ON & 0,26 & Low & 5.232.174.250 & Big & 0,55 & Winner & Big|Low|Winner & $3,75 \%$ & $6,05 \%$ & $0,93 \%$ & $6,33 \%$ & $-3,18 \%$ & $6,27 \%$ & $-9,61 \%$ & $5,66 \%$ & $13,56 \%$ & $0,83 \%$ & $2,12 \%$ & $-7,14 \%$ \\
\hline RENT3 & Localiza ON & 0,16 & Low & 37.247.900 & Big & 0,60 & Winner & Big|Low|Winner & $16,36 \%$ | & $0,74 \%$ ] & $16,12 \%$ & $-0,87 \%$ [ & $0,04 \%$ & $-4,47 \%$ ] & $-6,53 \%$ & $-6,19 \%$ & $11,49 \%$ & $3,28 \%$ ] & $-2,16 \%$ ] $>$ & $6,08 \%$ ] \\
\hline RAPT4 & Randon Part PN & 0,37 & Low & 2.320 .506 .810 & Big & 0,61 & Winner & Big|Low|Winner & $13,70 \%$ & $-4,10 \%$ & $6,06 \%$ & $19,92 \%$ & $-3,29 \%$ & $-10,13 \%$ & $-6,02 \%$ & $-2,60 \%$ & $-0,89 \%$ & $6,03 \%$ & $6,23 \%$ & $0,71 \%$ \\
\hline AELP3 & AES Elpa ON & 0,34 & Low & 4.753 .050 .000 & Big & 0,62 & Winner & Big|Low|Winner & $-8,04 \%$ & $1,88 \%$ & $-2,17 \%$ & $1,78 \%$ & $-3,93 \%$ & $5,17 \%$ & $-2,61 \%$ & $-2,21 \%$ & $-1,85 \%$ & $10,49 \%$ & $3,77 \%$ & $-2,03 \%$ \\
\hline MDIA3 & M. Diasbranco ON & 0,31 & Low & 23.731 .000 & Big & 0,74 & Winner & Big|Low|Winner & $2,05 \%$ & $3,02 \%$ & $1,20 \%$ & $3,64 \%$ & $-2,33 \%$ & $-5,95 \%$ & \begin{tabular}{l|l|}
$-6,58 \%$ \\
\end{tabular} & $-2,44 \%$ & $8,33 \%$ & $6,96 \%$ & $5,13 \%$ & $-3,49 \%$ \\
\hline RAPT3 & Randon Part ON & 0,37 & Low & 20.506 .810 & Big & 0,76 & Winner & Big|Low|Winner & $16,79 \%$ & $0,62 \%$ & $5,10 \%$ & $1,07 \%$ & $4,71 \%$ & $-11,89 \%$ & $-2,63 \%$ & $-1,62 \%$ & $9,34 \%$ & $-0,88 \%$ & $3,49 \%$ & $-1,57 \%$ \\
\hline TOTS3 & Totvs ON & 0,14 & Low & \begin{tabular}{|l|l|l|} 
\\
\end{tabular} & Big & 0,76 & Winner & Big|Low|Winner & $-3,76 \%$ & $0,85 \%$ & $-0,08 \%$ & $20,86 \%$ & $8,51 \%$ & $-0,30 \%$ & $-4,14 \%$ & $-3,12 \%$ & $1,03 \%$ & $-4,31 \%$ & $5,00 \%$ & $-8,57 \%$ \\
\hline OGXP3 & OGX Petroleo ON & 0,17 & Low & 54.046 .122 .592 & Big & 0,79 & Winner & Big|Low|Winner & $11,18 \%$ & $12,32 \%$ & $5,60 \%$ & $1,22 \%$ & $-10,84 \%$ & $0,50 \%$ & $-13,95 \%$ & $13,02 \%$ & $1,03 \%$ & $-14,05 \%$ & $-4,91 \%$ & $-9,15 \%$ \\
\hline DASA3 & Dasa ON & 0,16 & Low & 3.893 .309 .470 & Big & 0,80 & Winner & Big|Low|Winner & $-0,47 \%$ & $8,81 \%$ & $10,87 \%$ & $2,94 \%$ & $4,76 \%$ & $2,88 \%$ & $-10,00 \%$ & $-0,74 \%$ & $4,48 \%$ & $0,24 \%$ & $6,41 \%$ & $-6,25 \%$ \\
\hline TAMM4 & Tam S/A PN & 0,29 & Low & 3.758 .600 .000 & Big & 0,84 & Winner & Big|Low/Winner & $17,64 \%$ & $16,49 \%$ & $11,82 \%$ & $8,33 \%$ & $-2,53 \%$ & $-3,68 \%$ & $-6,03 \%$ & $-4,26 \%$ & $-10,13 \%$ & $6,39 \%$ & $6,41 \%$ & $-2,53 \%$ \\
\hline CBEE3 & Ampla Energ ON & 0,26 & Low & 5.766 .098 .399 & Big & 0,87 & Winner & Big|Low|Winner & \begin{tabular}{|l|l|l}
$14,97 \%$ \\
\end{tabular} & $-5,33 \%$ & $0,00 \%$ & $-12,50 \%$ & \begin{tabular}{|l|l|}
$-0,71 \%$ \\
\end{tabular} & $-2,16 \%$ & \begin{tabular}{ll|}
$-7,35 \%$ \\
\end{tabular} & $-1,59 \%$ & $-4,84 \%$ & $4,24 \%$ & $-0,57 \%$ & $6,61 \%$ \\
\hline \begin{tabular}{|l|} 
DROG3 \\
\end{tabular} & Drogasil ON & 0,25 & Low & 2.049 .507 .000 & Big & 0,94 & Winner & Big|Low|Winner & $6,09 \%$ & $1,07 \%$ & $17,09 \%$ & $-0,39 \%$ & $-2,44 \%$ & $-3,25 \%$ & $-11,11 \%$ & $5,83 \%$ & $0,83 \%$ & $-11,32 \%$ & $-0,88 \%$ & $-4,50 \%$ \\
\hline $\begin{array}{ll}\text { LREN3 } \\
\end{array}$ & Lojas Renner ON & 0,16 & Low & 5.973 .149 .000 & Big & 1,04 & Winner & Big|Low|Winner & $20,33 \%$ & $-3,83 \%$ & $2,28 \%$ & $15,88 \%$ & $-10,67 \%$ & $-5,06 \%$ & $-14,18 \%$ & $5,37 \%$ & $4,00 \%$ & $12,47 \%$ & $3,10 \%$ & $-0,32 \%$ \\
\hline ODPV3 & Odontoprev ON & 0,28 & Low & 87.500 & Big & 1,04 & Winner & Big|Low|Winner & $4,93 \%$ & $13,27 \%$ & $6,42 \%$ & $25,69 \%$ & $3,86 \%$ & $-1,22 \%$ & $-10,32 \%$ & $-0,44 \%$ & $19,11 \%$ & $-4,50 \%$ & $12,20 \%$ & $-8,77 \%$ \\
\hline HYPE3 & Hypermarcas ON & 0,36 & Low & \begin{tabular}{|c|}
12.541 .793 .980 \\
\end{tabular} & Big & 1,16 & Winner & Big|Low|Winner & $-1,21 \%$ & $1,00 \%$ & $13,66 \%$ & $6,50 \%$ & $-3,11 \%$ & $-16,96 \%$ & $-11,94 \%$ & $-4,23 \%$ & $13,68 \%$ & $-2,31 \%$ & $-29,22 \%$ & $-1,01 \%$ \\
\hline LXXL3 & LIx Log ON & 0,14 & Low & 5.097 .263 .680 & Big & 1,35 & Winner & Big|Low|Winner & $20,92 \%$ & $0,00 \%$ & $4,04 \%$ & $1,30 \%$ & $-9,38 \%$ & $-41,24 \%$ & $-15,43 \%$ & $13,50 \%$ & $10,79 \%$ & $-9,54 \%$ & $5,05 \%$ & $0,42 \%$ \\
\hline DTEX3 & Duratex ON & 0,32 & Low & 7.508 .461 .200 & Big & 2,27 & Winner & Big|Low|Winner & $12,50 \%$ & $-2,77 \%$ & $3,09 \%$ & $6,81 \%$ & \begin{tabular}{l|l}
$0,00 \%$ \\
\end{tabular} & $-8,19 \%$ & $-10,36 \%$ & $4,75 \%$ & $3,29 \%$ & $-5,74 \%$ & $-5,24 \%$ & $2,88 \%$ \\
\hline AMAR3 & Lojas Marisa ON & 0,35 & Low & 31.278 .760 & Big & 2,57 & Winner & Big|Low|Winner & $6,89 \%$ & $5,35 \%$ & $4,27 \%$ & $13,27 \%$ & $-4,51 \%$ & $-3,42 \%$ & $-13,16 \%$ & $0,69 \%$ & $15,64 \%$ & $17,43 \%$ & $-9,83 \%$ & $-11,19 \%$ \\
\hline HGTX3 & Cia Hering ON & 0,20 & Low & 2.549 .327 .000 & Big & 2,59 & Winner & Big|Low|Winner & $26,63 \%$ & $14,31 \%$ & $8,01 \%$ & $15,04 \%$ & $8,14 \%$ & $-9,97 \%$ & $-5,19 \%$ & $-3,01 \%$ & $20,82 \%$ & $14,06 \%$ & $5,87 \%$ & $-0,15 \%$ \\
\hline TMAR3 & Telemar N L ON & 0,59 & Medium & 12.859 .922 .630 & Big & 0,19 & Loser & \begin{tabular}{|l|l|} 
Big|Medium|Loser \\
\end{tabular} & $4,97 \%$ & $-7,92 \%$ & $3,26 \%$ & $1,85 \%$ & $1,30 \%$ & $-6,62 \%$ & $12,09 \%$ & $4,26 \%$ & $4,56 \%$ & $8,68 \%$ & $-7,69 \%$ & $-6,57 \%$ \\
\hline TNLP3 & Telemar ON & 0,54 & Medium & 11.696 .287 .700 & Big & 0,16 & Loser & Big|Medium|Loser & $-11,67 \%$ & $-8,56 \%$ & $3,28 \%$ & $8,59 \%$ & $-10,28 \%$ & $5,42 \%$ & $12,63 \%$ & $-0,36 \%$ & $2,90 \%$ & $-7,21 \%$ & $-4,09 \%$ & $-16,74 \%$ \\
\hline TMAR5 & Telemar N L PNA & 0,59 & Medium & .922 .630 & Big & 0,13 & Loser & Big|Medium|Loser & $-5,71 \%$ & $-3,66 \%$ & $0,88 \%$ & $7,37 \%$ & $-0,44 \%$ & $1,27 \%$ & $5,44 \%$ & $-3,85 \%$ & $14,83 \%$ & $-0,15 \%$ & $7,52 \%$ & $-11,43 \%$ \\
\hline PETR3 & Petrobras ON & 0,47 & Medium & 337.940 & Big & 0,12 & Loser & Big|Medium|Loser & $3,35 \%$ & $-7,07 \%$ & $2,74 \%$ & $-6,09 \%$ & $-3,67 \%$ & $12,41 \%$ & $-1,64 \%$ & $8,49 \%$ & $0,54 \%$ & $-11,05 \%$ & $-6,44 \%$ & $-2,16 \%$ \\
\hline TNLP4 & Telemar PN & 0,54 & Medium & 11.696.287.700 & Big & 0,11 & Loser & Big|Medium/Loser & $-4,63 \%$ & $-7,18 \%$ & $1,26 \%$ & $7,64 \%$ & $-8,25 \%$ & $1,63 \%$ & $9,43 \%$ & $-2,37 \%$ & $8,29 \%$ & $-3,66 \%$ & $5,25 \%$ & $-13,38 \%$ \\
\hline EBTP4 & Embratel Part PI & 0,60 & Medium & 12.380 .320 .293 & Big & 0,04 & Loser & Big|Medium|Loser & $-1,04 \%$ & $-4,22 \%$ & $-3,67 \%$ & $3,33 \%$ & $-8,68 \%$ & $-1,01 \%$ & $-4,90 \%$ & $-3,11 \%$ & $-9,19 \%$ & $8,91 \%$ & $0,58 \%$ & $9,83 \%$ \\
\hline PETR4 & Petrob & 0,47 & Medit & 7.940 & Big & 0,02 & Loser & Big|Medium|Loser & $3,69 \%$ & $-5,75 \%$ & $4,72 \%$ & $-5,28 \%$ & $-4,37 \%$ & $11,85 \%$ & $-0,73 \%$ & $5,50 \%$ & $0,30 \%$ & $-9,77 \%$ & $-5,11 \%$ & $-1,54 \%$ \\
\hline EBTP3 & Embratel Part ON & 0,60 & Medium & 12.380.320.293 & Big & 0,02 & Loser & Big|Medium|Loser & $-5,48 \%$ & $-3,95 \%$ & $-4,02 \%$ & $3,71 \%$ & $-11,76 \%$ & $2,19 \%$ & $-3,16 \%$ & $-6,32 \%$ & $-7,87 \%$ & $8,10 \%$ & $3,45 \%$ & $5,56 \%$ \\
\hline NETC4 & Net PN & 0,44 & Medium & 5.962 .017 .000 & Big & 0,03 & Loser & Big|Medium|Loser & $11,29 \%$ & $17,76 \%$ & $-0,81 \%$ & $3,53 \%$ & $-0,35 \%$ & $-0,83 \%$ & $-24,81 \%$ & $6,41 \%$ & $-20,73 \%$ & $1,53 \%$ & $9,20 \%$ & $3,77 \%$ \\
\hline LIGT3 & Light S/A & 0,55 & & & Big & & Lose & & $4,66 \%$ & & 6,7 & & & $15,70 \%$ & & & & 0,0 & & \\
\hline CNFB4 & Confab PN & 0,59 & Medium & 1.992 .511 .800 & Big & 年, & Loser & Big|Medium|Loser & $5,95 \%$ & $16,05 \%$ & $3,36 \%$ & $0,00 \%$ [ & $0,75 \%$ & $-0,16 \%$ & $-5,25 \%$ & $13,67 \%$ & $-11,82 \%$ & $0,70 \%$ & $4,39 \%$ & $-5,49 \%$ \\
\hline EMBR3 & Embraer ON & 0,74 & Medium & 6.715 .611 .200 & Big & 0,09 & Loser & Big|Medium|Loser & $23,81 \%$ & $-6,01 \%$ & $9,62 \%$ & $2,54 \%$ & $2,31 \%$ & $-3,17 \%$ & $14,58 \%$ & $3,62 \%$ & $-3,21 \%$ & $-8,44 \%$ & $1,21 \%$ & $-4,10 \%$ \\
\hline TRPL4 & ran Paulist PN & 0,53 & Medium & 7.155.840.000 & & 0,10 & Loser & Big|Medium|Loser & $5,96 \%$ & $2,89 \%$ | $<>$ & i, 32\% & 4, /4\%] & $00 \%$ & $96 \%$ [ & $49 \%$ & , & $\Rightarrow+\frac{1}{2}$ & , & 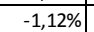 & 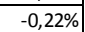 \\
\hline
\end{tabular}


Anexo 1 - Retorno mensal e classificação das ações

\begin{tabular}{|c|c|c|c|c|c|c|c|c|c|c|c|c|c|c|c|c|c|c|c|c|}
\hline Código & 2010 - 2011 & $\begin{array}{l}\text { Índice } B / M \\
\text { de dez/2009 }\end{array}$ & $\begin{array}{c}\text { Grupo com } \\
\text { base no } \\
\text { índice } B / M\end{array}$ & $\begin{array}{c}\text { Valor de Mercado } \\
\text { em jun/2010 }\end{array}$ & $\begin{array}{c}\text { Grupo com } \\
\text { base no } \\
\text { tamanho }\end{array}$ & $\begin{array}{c}\text { Retorno } \\
\text { acumulado } \\
\text { de jun/2010 }\end{array}$ & \begin{tabular}{c|} 
Grupo com \\
base no \\
retorno \\
acumulado
\end{tabular} & Carteiras & $\mathrm{jul} / 10$ & ago/10 & set/10 & out $/ 10$ & nov/10 & $\operatorname{dez} / 10$ & jan/11 & $\mathrm{fev} / 11$ & $\operatorname{mar} / 11$ & $\mathrm{abr} / 11$ & mai/11 & jun/11 \\
\hline EQTL3 & Equatorial ON & 0,60 & Medium & 1.762 .816 .250 & Big & 0,11 & Loser & Big|Medium|Loser & $2,46 \%$ & $-3,79 \%$ & $-8,07 \%$ & $14,83 \%$ & $2,72 \%$ & $-5,71 \%$ & $1,58 \%$ & $1,90 \%$ & $7,71 \%$ & $5,43 \%$ & $0,86 \%$ & $1,71 \%$ \\
\hline TRPL3 & Tran Paulist ON & 0,53 & Medium & \begin{tabular}{|l|l}
7.155 .840 .000 \\
\end{tabular} & Big & 0,13 & Loser & Big|Medium|Loser & $6,01 \%$ & $-1,00 \%$ & $6,06 \%$ & $7,54 \%$ & $2,73 \%$ & $8,14 \%$ & $0,12 \%$ & $0,00 \%$ & $0,33 \%$ & $0,73 \%$ & $0,32 \%$ & $-4,24 \%$ \\
\hline TRNA11 & Taesa UNT N2 & 0,57 & Medium & 2.353 .923 .569 & Big & \begin{tabular}{l|l|}
0,13 \\
\end{tabular} & Loser & Big|Medium/Loser & $7,84 \%$ & $10,76 \%$ & $3,81 \%$ & $2,29 \%$ & $-3,83 \%$ & $-3,11 \%$ & $1,61 \%$ & $0,35 \%$ & $12,50 \%$ & $24,85 \%$ & $0,00 \%$ & $2,94 \%$ \\
\hline VIVO3 & Vivo ON & 0,47 & Medium & 23.976 .874 .800 & Big & 0,15 & Loser & Big|Medium|Loser & $27,90 \%$ & $-0,26 \%$ & $4,38 \%$ & $1,30 \%$ & $-3,90 \%$ & $-2,22 \%$ & $5,86 \%$ & $1,79 \%$ & $-43,95 \%$ & $-0,56 \%$ & $7,46 \%$ & $2,21 \%$ \\
\hline \begin{tabular}{|l|l|} 
BRFS3 \\
\end{tabular} & BRF Foods ON & 0,67 & Medium & 20.623 .381 .277 & Big & \begin{tabular}{l|l|l|l|l|}
0,16 \\
\end{tabular} & Loser & \begin{tabular}{|l|} 
Big|Medium|Loser \\
\end{tabular} & $4,26 \%$ & $-4,69 \%$ & $9,34 \%$ & $-4,16 \%$ & $3,32 \%$ & $8,16 \%$ & $0,04 \%$ & $5,67 \%$ & $6,68 \%$ & $2,27 \%$ & $-7,14 \%$ & $-8,34 \%$ \\
\hline TCSL4 & Tim Part S/A PN & 0,58 & Medium & 14.073.353.200 & Big & 0,17 & Loser & Big|Medium/Loser & $4,12 \%$ & $-1,78 \%$ & $9,88 \%$ & $2,20 \%$ & $-0,72 \%$ & $-0,36 \%$ & $11,80 \%$ & $2,44 \%$ & \begin{tabular}{|l|l|}
$11,09 \%$ & \\
\end{tabular} & $5,99 \%$ & $5,12 \%$ & $-0,53 \%$ \\
\hline |ITSA3 & Itausa ON & 0,45 & Medium & 48.008.309.460 & Big & 0,18 & Loser & Big|Medium|Loser & $12,72 \%$ | & $-2,72 \%$ & $3,66 \%$ ] & $4,82 \%$ ] & $-2,52 \%$ | $>2>$ & $10,23 \%[$ & $-16,76 \%$ ] & $-0,67 \%$ | & $5,24 \%$ & $1,70 \%$ ] & $-6,52 \%$ & $4,65 \%$ ] \\
\hline CMIG4 & Cemig PN & 0,58 & Medium & \begin{tabular}{|l|}
15.842 .972 .140 \\
\end{tabular} & Big & 0,20 & Loser & Big|Medium/Loser & $0,54 \%$ & $6,46 \%$ & $-1,96 \%$ & $9,07 \%$ & $-4,81 \%$ & $-1,84 \%$ & $2,58 \%$ & $0,91 \%$ & $12,80 \%$ & $3,24 \%$ & $-2,79 \%$ & $6,99 \%$ \\
\hline VIV04 & Vivo PN & 0,47 & Medium & 23.976 .874 .800 & Big & 0,21 & Loser & Big|Medium|Loser & $1,40 \%$ & $-10,31 \%$ & $9,48 \%$ & $6,06 \%$ & $0,65 \%$ & $8,07 \%$ & $6,16 \%$ & $6,61 \%$ & $8,21 \%$ & $7,19 \%$ & \begin{tabular}{|c|}
$9,75 \%$ \\
\end{tabular} & $2,87 \%$ \\
\hline COCE5 & Coelce PNA & 0,42 & Medium & 2.093 .049 .176 & Big & 0,23 & Loser & Big|Medium|Loser & $6,53 \%$ & $7,57 \%$ & $-11,10 \%$ & $5,59 \%$ & $0,39 \%$ & $-0,07 \%$ & $3,54 \%$ & $4,51 \%$ & $9,91 \%$ & $2,68 \%$ & $2,56 \%$ & $3,87 \%$ \\
\hline CMIG3 & Cemig ON & 0,58 & Medium & 15.842.972.140 & Big & 0,26 & Loser & Big|Medium|Loser & $1,23 \%$ & $7,77 \%$ & $-5,28 \%$ & $11,94 \%$ & $-4,00 \%$ & $2,05 \%$ & $2,99 \%$ & $0,61 \%$ & $12,79 \%$ & $4,95 \%$ & $0,38 \%$ & $7,19 \%$ \\
\hline MRFG3 & Marfrig ON & 0,63 & Medium & 5.849 .653 .537 & Big & 0,29 & Loser & Big|Medium|Loser & $4,86 \%$ & $-3,95 \%$ & $1,41 \%$ & $-10,79 \%$ & $-15,15 \%$ & $18,77 \%$ & $-12,47 \%$ & $7,64 \%$ & $0,55 \%$ & $11,03 \%$ & $-11,65 \%$ & $7,69 \%$ \\
\hline UGPA4 & Ultrapar PN & 0,45 & Medium & 11.572 .026 .890 & $\mathrm{Big}$ & 0,31 | & Loser & Big|Medium/Loser & $4,29 \%$ & $8,57 \%$. & $5,49 \%$ & $1,47 \%$ & $-1,16 \%$ & $2,94 \% \mid$ & $0,10 \%$ & $-0,42 \% \mid$ & $5,08 \%$ & $1,55 \%$ & $0,66 \%$ & $0,07 \%$ \\
\hline GOAU4 & Gerdau Met & 0,58 & Medium & 5.300 & Big & \begin{tabular}{l|l}
0,32 \\
\end{tabular} & Loser & Big|Medium|Loser & $6,13 \%$ & $-8,46 \%$ & $-3,02 \%$ & $-4,14 \%$ & $-10,60 \%$ & $15,27 \%$ & $-4,89 \%$ & $1,37 \%$ & $-5,40 \%$ & $-5,87 \%$ & $-4,64 \%$ & $-8,09 \%$ \\
\hline \begin{tabular}{|l|} 
COCE 3 \\
\end{tabular} & Coelce ON & 0,42 & Medium & 2.093 .049 .176 & Big & \begin{tabular}{|l|l|}
0,33 \\
0
\end{tabular} & Loser & \begin{tabular}{|l|} 
Big|Medium|Loser \\
\end{tabular} & $1,72 \%$ & $7,12 \%$ & $-8,63 \%$ & $1,03 \%$ & $1,82 \%$ & $1,14 \%$ & $-2,12 \%$ & $9,64 \%$ & $11,26 \%$ & $2,57 \%$ & $-0,12 \%$ & $1,81 \%$ \\
\hline ELPL4 & Eletropaulo PN & 0,58 & Medium & 6.017 .927 .175 & Big & 0,34 & Loser & Big|Medium|Loser & $2,89 \%$ & $-0,37 \%$ & $-8,48 \%$ & $-1,66 \%$ & $4,31 \%$ & $5,13 \%$ & $1,21 \%$ & $-1,23 \%$ & $12,46 \%$ & $6,09 \%$ & $5,54 \%$ & $-2,98 \%$ \\
\hline GFSA3 & Gafisa ON & 0,49 & Medium & 8.400 & Big & 0,34 & Loser & $\mathrm{m} \mid$ Loser & $22,22 \%$ & $-8,33 \%$ & $7,85 \%$ & $8,05 \%$ & $-15,39 \%$ & $0,92 \%$ & $-15,20 \%$ & $0,29 \%$ & $0,78 \%$ & $-6,69 \%$ & $-7,46 \%$ & $14,60 \%$ \\
\hline GGBR3 & Gerdau ON & 0,44 & Medium & 30.409 .372 .130 & Big & \begin{tabular}{l|l|l|l|l|}
0,37 \\
\end{tabular} & Winner & Big $\mid$ Medium $\mid$ Winner & $6,96 \%$ & $-5,84 \%$ & $-0,17 \%$ & $-2,59 \%$ & $-11,25 \%$ & $12,63 \%$ & $-2,80 \%$ & $4,60 \%$ & $-7,00 \%$ & $-2,91 \%$ & $-3,10 \%$ & $-3,51 \%$ \\
\hline ITSA4 & Itausa PN & 0,45 & Medium & 48.008.309.460 & Big & 0,38 & Winner & Big|Medium|Winner & $22,13 \%$ & $-5,43 \%$ & $5,16 \%$ & $4,41 \%$ & $-3,93 \%$ & $1,96 \%$ & $-10,09 \%$ & $2,97 \%$ & $6,96 \%$ & $-5,08 \%$ & $-2,64 \%$ & $1,64 \%$ \\
\hline SUZB5 & Suzano & 0,70 & Medium & 1.020 & Big & \begin{tabular}{l|l}
0,39 \\
\end{tabular} & Winner & um|Winner & $10,45 \%$ & $-4,10 \%$ & $0,56 \%$ & $1,56 \%$ & $-7,98 \%$ & $1,32 \%$ & $-1,89 \%$ & $-2,00 \%$ & $5,91 \%[$ & $2,26 \%$ & $-4,92 \%$ & $22,67 \%$ \\
\hline GGBR4 & Gerdau PN & 0,44 & Medium & 30.409 .372 .130 & Big & 0,39 & Winner & Big $\mid$ Medium $\mid$ Winner & $7,67 \%$ & $-7,51 \%$ & $-2,83 \%$ & $-3,08 \%$ & $-10,86 \%$ & $16,26 \%$ & $-5,82 \%$ & $3,00 \%$ & $-7,93 \%$ & $-6,39 \%$ & $-8,08 \%$ & $-5,83 \%$ \\
\hline CSAN3 & Cosan ON & 0,47 & Medium & 9.172 .383 .879 & Big & \begin{tabular}{l|l}
0,39 \\
\end{tabular} & Winner & Big|Medium|Winner & $10,72 \%$ & $-6,60 \%$ & $9,83 \%$ & $6,80 \%$ & $-2,23 \%$ & $5,18 \%$ & $-5,72 \%$ & $-0,15 \%$ & $-2,27 \%$ & $-4,72 \%$ & $-0,21 \%$ & $1,86 \%$ \\
\hline VALE3 & Vale ON & 0,39 & Medium & 19.020 .269 .280 & Big & \begin{tabular}{l|l}
0,42 & \\
\end{tabular} & Winner & Big|Medium|Winner & $11,23 \%$ & $-3,44 \%$ & $11,56 \%$ & $3,56 \%$ & $-0,07 \%$ & $3,30 \%$ & $3,72 \%$ & $-1,37 \%$ & $-5,24 \%$ & $-1,76 \%$ & $-2,97 \%$ & $-1,51 \%$ \\
\hline GOAU3 & Gerdau Met ON & 0,58 & Medium & 11.120 .245 .300 & Big & 0,42 & Winner & Big|Medium/Winner & 6,95\% & $-2,70 \%$ & $0,41 \%$ & $-6,71 \%$ & $-6,88 \%$ & $11,32 \%$ & $-6,44 \%$ & $-0,59 \%$ & $-3,02 \%$ & $-3,92 \%$ & $-2,57 \%$ & $-7,35 \%$ \\
\hline PDGR3 & PDG Realt ON & 0,43 & Medium & 8.400 .882 .360 & Big & 0,44 & Winner & Big|Medium|Winner & $22,83 \%$ & $-3,63 \%$ & $11,70 \%$ & $5,56 \%$ & $-2,30 \%$ & $-2,21 \%$ & $-9,25 \%$ & $-1,41 \%$ & $0,77 \%$ & $2,65 \%$ & $7,14 \%$ & $-11,21 \%$ \\
\hline USIM5 & Usiminas PNA & 0,62 & Medium & 68.737 .969 & Big & \begin{tabular}{l|l|l}
0,45 \\
\end{tabular} & Winner & Big $\mid$ Medium $\mid$ Winner & $2,85 \%$ & $-11,01 \%$ & $3,11 \%$ & $-5,40 \%$ & $-11,92 \%$ & $3,50 \%$ & $1,41 \%$ & $-2,21 \%$ & $4,71 \%$ & $-18,23 \%$ & $-6,19 \%$ & $-9,57 \%$ \\
\hline \begin{tabular}{|l|l} 
VALE5 \\
\end{tabular} & Vale PNA & 0,39 & Medium & 219.020 .269 .280 & Big & \begin{tabular}{l|l}
0,46 \\
\end{tabular} & Winner & Big|Medium |Winner & $12,56 \%$ & $-2,91 \%$ & $11,75 \%$ & $4,34 \%$ & $0,52 \%$ & $1,04 \%$ & $5,78 \%$ & $-2,73 \%$ & $-4,46 \%$ & $-1,48 \%$ & $-2,67 \%$ & $-0,45 \%$ \\
\hline CEPE5 & Celpe PNA & 0,42 & Medium & 3.432 .152 .000 & Big & 0,46 & Winner & Big|Medium $\mid$ Winner & $0,62 \%$ & $0,00 \%$ & $-2,17 \%$ & $4,18 \%$ & $0,00 \%$ & $-2,22 \%$ & $-1,41 \%$ & $-0,23 \%$ & $4,65 \%$ & $2,22 \%$ & $-1,82 \%$ & $2,29 \%$ \\
\hline USIM3 & Usiminas oN & 0,62 & Medium & $\begin{array}{l}3.737 .969 \\
\end{array}$ & Big & \begin{tabular}{l|l}
0,47 \\
\end{tabular} & Winner & Big|Medium|Winner & $7,59 \%$ & $-9,53 \%$ & $11,70 \%$ & $-2,89 \%$ & $-12,34 \%$ & $-0,99 \%$ & $17,05 \%$ & $7,32 \%$ & $\begin{array}{l}4,88 \% \\
\end{array}$ & $-7,86 \%$ & $-9,88 \%$ & $0,99 \%$ \\
\hline MPXE3 & MPX Ene & 0,62 & Medium & 2.100 & Big & \begin{tabular}{l|l}
0,51 \\
\end{tabular} & Winner & Big|Medium|Winner & $5,58 \%$ & $39,09 \%$ & $-4,25 \%$ & $2,49 \%$ & $-6,62 \%$ & $-0,64 \%$ & $4,86 \%$ & $29,62 \%$ & $11,59 \%$ & $-6,93 \%$ & $14,15 \%$ & $-1,05 \%$ \\
\hline MULT3 & Multiplan ON & 0,49 & Medium & 0.834 .243 & Big & \begin{tabular}{l|l|l}
0,52 \\
\end{tabular} & Winner & Big $\mid$ Medium $\mid$ Winner & $-0,36 \%$ & $1,25 \%$ & $7,81 \%$ & $8,64 \%$ & $-2,56 \%$ & $-2,89 \%$ & $-13,31 \%$ & $1,47 \%$ & $3,97 \%$ & $-2,96 \%$ & $11,99 \%$ & $-5,36 \%$ \\
\hline IGTA3 & Iguatemi ON & 0,52 & Medium & 12.383 .500 & Big & \begin{tabular}{l|l}
0,53 & \\
\end{tabular} & Winner & Big|Medium|Winner & $10,28 \%$ & $-3,32 \%$ & $12,43 \%$ & $4,47 \%$ & $8,11 \%$ & $-2,35 \%$ & $-13,25 \%$ & $0,08 \%$ & \begin{tabular}{l|l|l|l|l}
$10,74 \%$ \\
\end{tabular} & $2,27 \%$ & $0,00 \%$ & $-5,31 \%$ \\
\hline MAGG3 & Magnesita SA OI & 0,60 & Medium & & Big & 0,56 & Winner & ium /Winner & $14,42 \%$ & $-8,57 \%$ & $5,70 \%$ & $-3,39 \%$ & $-4,77 \%$ & $-3,59 \%$ & $-6,18 \%$ & $-13,38 \%$ & $3,74 \%$ & $-3,02 \%$ & $-10,07 \%$ & $1,33 \%$ \\
\hline ALPA4 & Alpargatas PN & 0,51 & Medium & 850 & Big & 0,56 & Winner & Big|Medium|Winner & $2,45 \%$ & $7,63 \%$ & $11,76 \%$ & $10,53 \%$ & $-5,74 \%$ & $9,54 \%$ & $-0,83 \%$ & $-0,56 \%$ & $6,55 \%$ & $2,50 \%$ & $7,72 \%$ & $-1,63 \%$ \\
\hline BRKM3 & Braskem ON & 0,68 & Medium & 9.195 .557 .340 & Big & 0,58 & Winner & Big|Medium/Winner & $2,51 \%$ & $24,91 \%$ & $1,52 \%$ & $10,57 \%$ & $0,78 \%$ & $14,10 \%$ & $-3,37 \%$ & $-4,42 \%$ & $5,23 \%$ & $5,09 \%$ & $6,36 \%$ & $-0,81 \%$ \\
\hline RSID3 & Rossi Resid ON & 0,56 & Medium & 3.462 .248 .365 & Big & 0,59 & Winner & Big|Medium|Winner & $21,68 \%$ & $-4,23 \%$ & $6,86 \%$ & $2,84 \%$ & $-9,06 \%$ & $-2,38 \%$ & $-11,36 \%$ & $-1,60 \%$ & $5,50 \%$ & $8,38 \%$ & $-3,04 \%$ & $-8,86 \%$ \\
\hline PCAR4 & P.Acucar-Cbd PN & 0,40 & Medium & 16.199 .778 .580 & Big & 0,59 & Winner & Big|Medium $\mid$ Winner & $-8,57 \%$ & $7,65 \%$ & $-5,74 \%$ & $14,14 \%$ & $6,61 \%$ & $-2,28 \%$ & $-9,41 \%$ & $-1,56 \%$ & $8,61 \%$ & $5,05 \%$ & $9,58 \%$ & $14,14 \%$ \\
\hline GRND3 & Grendene ON & 0,48 & Mediun & 2.330 .580 .000 & Big & \begin{tabular}{l|l|}
0,60 \\
\end{tabular} & Winner & Big|Medium|Winner & $3,87 \%$ & $-5,47 \%$ & $13,47 \%$ & $3,38 \%$ & $7,22 \%$ & $-0,85 \%$ & $-1,50 \%$ & $2,40 \%$ & $2,13 \%$ & $-0,34 \%$ & $-4,78 \%$ & $2,27 \%$ \\
\hline KLBN4 & Klabin S/A PN & 0,50 & Medium & 4.722 .485 .630 & Big & 0,68 & Winner & Big|Medium|Winner & $3,57 \%$ & $-4,30 \%$ & $-2,45 \%$ & $0,85 \%$ & $3,38 \%$ & $19,39 \%$ & $-2,91 \%$ & $8,45 \%$ & $7,14 \%$ & $-6,11 \%$ & $-1,80 \%$ & $-3,49 \%$ \\
\hline POMO3 & Marcopolo ON & 0,51 & Medium & 27.380 & Big & 0,70 & Winner & Big|Medium /Winner & $10,49 \%$ & \begin{tabular}{l|l|}
$1,90 \%$ \\
\end{tabular} & $14,91 \%$ & $21.52 \%$ & $8,23 \%$ & $4,40 \%$ & $-3,15 \%$ & $-7,18 \%$ & $13,99 \%$ & $10,06 \%$ & $2,51 \%$ & $-2.45 \%$ \\
\hline STBP11 & Santos Brp UNT N2 & 0,50 & Medium & 1.967 .328 .000 & Big & \begin{tabular}{|l|l|}
0,70 \\
0
\end{tabular} & Winner & Big|Medium $\mid$ Winner & $11,80 \%$ & $-0,42 \%$ & $9,52 \%$ & $25,70 \%$ & $3,74 \%$ & $-1,53 \%$ & $7,61 \%$ & $-0,71 \%$ & $8,52 \%$ & $13,86 \%$ & $-0,50 \%$ & $-6,17 \%$ \\
\hline BRKM5 & Braskem PNA & 0,68 & Medium & 9.195.557.340 & Big & 0,76 & Winner & Big|Medium /Winner & $5,43 \%$ & $17,18 \%$ & $10,98 \%$ & $1,51 \%$ & $4,30 \%$ & $11,98 \%$ & $2,95 \%$ & $-3,29 \%$ & $6,71 \%$ & $5,82 \%$ & $11,93 \%$ & $-9,76 \%$ \\
\hline POMO4 & Marce & 0,51 & Mdiv & & Big & ( & Winner & Big $\mid$ & $6,33 \%$ & & $2,27 \%$ & $22,50 \%$ & $4,96 \%$ & $1,09 \%$ & $1400 \%$ & $-5,16 \%$ & $20,52 \%$ & 2,92 & $5,40 \%$ & $-5,27 \%$ \\
\hline BISA3 & Brookfield ON & 0,71 & Medium & 856.455 & Big & 0,95 | & Winner & Big|Medium|Winner & $18,25 \%$ & $-1,52 \%$ ] & $0,33 \%$ & $1,87 \%$ & $-12,10 \%$ & $6,27 \%$ & $-11,21 \%$ & $0,78 \%$ & $9,56 \%$ & $3,18 \%$ & $-2,45 \%$ & $-8,09 \%$ \\
\hline ALPA3 & Alpargatas ON & 0,51 & Medium & 2.727 .041 .850 & Big & 1,11 & Winner & Big|Medium|Winner & \begin{tabular}{l|l}
$5,06 \%$ \\
\end{tabular} & $20,98 \%$ & $5,60 \%$ & $10,80 \%$ & $-5,17 \%$ & $-5,88 \%$ & $20,10 \%$ & $-18,49 \%$ & $10,20 \%$ & $-1,80 \%$ & $6,47 \%$ & $8,23 \%$ \\
\hline UAR4 & 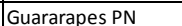 & 0,40 & dium & 00 & Big & \begin{tabular}{l|l|l|l|l|}
1,13 &
\end{tabular} & Winner & dium/Winner & 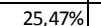 & t & $8,73 \%$ | & $4,13 \%$ | & $1,14 \%$ & $-0,63 \%$ & $-1,02 \%$ & $-2,81 \%$ | $>$ & $4,21 \%$ & $11,69 \%$ & $-2,51 \%$ & $-5,33 \%$ \\
\hline HLB3 & HCB & 0,40 & edium & 2.885 .760 .210 & & 1,18 & Winner & Big|Medium/Winner &, $5 \% \% \mid$ & & & $8,96 \%$ & , 32\% & $2,53 \%$ & 3,58\% & 4,104 & & $9,56 \%$ & J,/5\% &,$/ 15 \%$ \\
\hline
\end{tabular}


Anexo 1 - Retorno mensal e classificação das ações

\begin{tabular}{|c|c|c|c|c|c|c|c|c|c|c|c|c|c|c|c|c|c|c|c|c|}
\hline Código & $2010-2011$ & $\begin{array}{l}\text { Índice } B / M \\
\text { de dez/2009 }\end{array}$ & $\begin{array}{c}\text { Grupo com } \\
\text { base no } \\
\text { indice } B / M\end{array}$ & $\begin{array}{c}\text { Valor de Mercado } \\
\text { em jun/2010 }\end{array}$ & $\begin{array}{l}\text { Grupo com } \\
\text { base no } \\
\text { tamanho }\end{array}$ & $\begin{array}{c}\text { Retorno } \\
\text { acumulado } \\
\text { de jun/2010 }\end{array}$ & $\begin{array}{l}\text { Grupo com } \\
\text { base no } \\
\text { retorno } \\
\text { acumulado }\end{array}$ & Carteiras & $\mathrm{jul} / 10$ & ago/10 & set/10 & out $/ 10$ & nov/10 & dez/10 & $\mathrm{jan} / 11$ & $\mathrm{fev} / 11$ & $\operatorname{mar} / 11$ & $\mathrm{abr} / 11$ & $\mathrm{mai} / 11$ & jun/11 \\
\hline GUAR3 & Guararapes ON & 0,40 & Medium & 3.706 .248 .000 & Big & 1,52 & Winner & Big|Medium /Winner & $18,56 \%$ & $3,08 \%$ & $8,40 \%$ & $3,12 \%$ & $-3,53 \%$ & $-6,92 \%$ & $-0,37 \%$ & $-0,51 \%$ & $7,39 \%$ & $1,11 \%$ & $3,67 \%$ & $-2,14 \%$ \\
\hline GOLL4 & Gol PN & 0,41 & Medium & 5.767 .832 .260 & Big & \begin{tabular}{l|l}
1,79 \\
\end{tabular} & Winner & Big|Medium /Winner & $14,59 \%$ & $-7,35 \%$ & $14,32 \%$ & $13,10 \%$ & $-6,47 \%$ & $-8,56 \%$ & $-5,14 \%$ & $-7,52 \%$ & $-0,82 \%$ & $-0,18 \%$ & $-7,72 \%$ & $-6,57 \%$ \\
\hline \begin{tabular}{|l|l|} 
REDE4 \\
\end{tabular} & Rede Energia PN & 0,53 & Medium & 3.452 .859 .100 & Big & \begin{tabular}{|l|l|}
2,33 \\
\end{tabular} & Winner & Big $\mid$ Medium $\mid$ Winner & $8,94 \%$ & $0,09 \%$ & $-45,18 \%$ & $3,84 \%$ & $-10,02 \%$ & $5,82 \%$ & $-3,88 \%$ & $-14,48 \%$ & $-10,24 \%$ & $7,46 \%$ & $-2,04 \%$ & $-10,63 \%$ \\
\hline EMAE4 & Emae PN & 1,59 & High & 280.797 .200 & Small & 0,21 & Loser & Small|High|Loser & $-6,71 \%$ & $-4,80 \%$ & $-3,70 \%$ & $13,08 \%$ & \begin{tabular}{|l|l|l}
$5,99 \%$ \\
\end{tabular} & $-0,13 \%$ & $1,41 \%$ & $-15,08 \%$ & $6,72 \%$ & $13,43 \%$ & $-3,27 \%$ & $6,31 \%$ \\
\hline CTKA4 & Karsten PN & 1,00 & High & 59.640 .840 & Small & 0,20 & Loser & Small|High|Loser & $0,97 \%$ & $-2,87 \%$ & $-2,46 \%$ & $9,85 \%$ & $32,18 \%$ & $11,63 \%$ & $3,25 \%$ & $2,20 \%$ & $0,00 \%$ & $-0,77 \%$ & $-3,44 \%$ & $-8,43 \%$ \\
\hline CTSA4 & Santanense PN & 1,35 & High & 108.820 .520 & Small & 0,09 & Loser & Small|High|Loser & $4,01 \%$ & $1,40 \%$ & $4,84 \%$ & $3,96 \%$ & $-11,11 \%$ & $-3,58 \%$ & $-5,66 \%$ & $0,40 \%$ & $11,95 \%$ & $3,91 \%$ & $15,36 \%$ & $-1,84 \%$ \\
\hline CTSA3 & Santanense ON & 1,35 & High & 108.820 .520 & Small & \begin{tabular}{l|l}
0,07 \\
\end{tabular} & Loser & Small|High|Loser & $3,61 \%$ & $-2,44 \%$ & $-3,57 \%$ & $2,96 \%$ & $5,04 \%$ & $-8,46 \%$ & $-8,37 \%$ & $4,98 \%$ & $18,58 \%$ & $1,00 \%$ & $12,08 \%$ & $0,00 \%$ \\
\hline SMTO3 & Sao Martinho ON & 0,85 & High & 1.574 .410 .950 & Small & \begin{tabular}{l|l|}
0,07 \\
\end{tabular} & Loser & Small|High|Loser & $16,13 \%$ & $7,07 \%$ & $4,53 \%$ & $19,58 \%$ & \begin{tabular}{l|l}
$9,77 \%$ \\
\end{tabular} & $13,10 \%$ & \begin{tabular}{l|l|}
$-9,43 \%$ \\
\end{tabular} & $-4,29 \%$ & $11,41 \%$ & $-5,43 \%$ & \begin{tabular}{l|l}
$0,83 \%$ \\
\end{tabular} & $-1,23 \%$ \\
\hline MNDL3 & Mundial ON & 2,01 & High & 59.270 .000 & Small & 0,06 & Loser & Small|High|Loser & $26,19 \%$ & $15,09 \%$ & $1,09 \%$ & $-14,05 \%$ & $-13,84 \%$ & $7,30 \%$ & \begin{tabular}{|l|l|}
$0,68 \%$ \\
\end{tabular} & $4,73 \%$ & $-8,39 \%$ & $86,62 \%$ & $58,38 \%$ & $411,59 \%$ \\
\hline CEBR6 & Ceb PNB & 1,15 & High & 286.159 .889 & Small & 0,04 & Loser & Small|High|Loser & $-7,24 \%$ & $1,92 \%$ & $-26,89 \%$ & $-2,63 \%$ & $\begin{array}{ll}9,73 \% \\
\end{array}$ & $3,45 \%$ & $28,10 \%$ & $0,37 \%$ & $0,00 \%$ & $0,00 \%$ & $-7,41 \%$ & $-12,40 \%$ \\
\hline MNDL4 & Mundial PN & 2,01 & High & 59.270 .000 & Small & 0,02 & Loser & Small|High|Loser & $49,19 \%$ & $-1,62 \%$ & $-1,65 \%$ & $-3,35 \%$ & $-17,92 \%$ & $24,65 \%$ & $3,39 \%$ & $0,00 \%$ & $4,92 \%$ & $66,15 \%$ & $38,86 \%$ & $160,27 \%$ \\
\hline LOGN3 & Log-In ON & 0,81 & High & 573.638.985 & Small & \begin{tabular}{l|l|l}
0,00 \\
\end{tabular} & Loser & Small|High|Loser & $9,70 \%$ & $17,28 \%$ & $5,45 \%$ & $4,07 \%$ & $4,65 \%$ & $5,05 \%$ & $-8,65 \%$ & $-4,53 \%$ & $-7,39 \%$ & $-1,90 \%$ & $-3,52 \%$ & $-6,92 \%$ \\
\hline CRDE3 3 & $\mathrm{Cr} 2 \mathrm{ON}$ & 1,33 & High & 237.600 .400 & Small & 0,02 & Loser & Small|High|Loser & $1,94 \%$ & $7,43 \%$ & $9,04 \%$ & $7,97 \%$ & $-6,95 \%$ & $28,45 \%$ & $-2,15 \%$ & $-16,32 \%$ & $9,84 \%$ & $0,00 \%$ & $11,09 \%$ & $0,87 \%$ \\
\hline VIVR3 & Viver ON & 1,15 & High & 784.599 .750 & Small & \begin{tabular}{l|l}
0,07 \\
\end{tabular} & Loser & Small|High|Loser & $19,27 \%$ & $-9,15 \%$ & $4,36 \%$ & $6,11 \%$ & $-0,91 \%$ & $5,50 \%$ & $-6,38 \%$ & $-5,26 \%$ & $1,31 \%$ & $-3,87 \%$ & $-6,38 \%$ & $-7,89 \%$ \\
\hline CLSC6 & Celesc PNB & 1,28 & $\begin{array}{ll}\text { High } \\
\end{array}$ & 1.565 .607 .000 & Small & \begin{tabular}{l|l|l|l|l|l|}
0,08 \\
\end{tabular} & Loser & Small|High|Loser & $-0,50 \%$ & $0,21 \%$ & $2,93 \%$ & $-0,57 \%$ & $-1,43 \%$ & $16,11 \%$ & $2,90 \%$ & $4,85 \%$ & $5,18 \%$ & $-1,67 \%$ & $-0,33 \%$ & $-2,292 \%$ \\
\hline TUPY3 & Tupy ON & 1,13 & High & 796.496.283 & Small & 0,10 & Loser & Small|High|Loser & $1,79 \%$ & $42,25 \%$ & $5,89 \%$ & $13,14 \%$ & $11,53 \%$ & $-5,52 \%$ & $-2,00 \%$ & $4,04 \%$ & $-0,19 \%$ & $1,54 \%$ & $11,05 \%$ & $4,64 \%$ \\
\hline BDLL4 & Bardella PN & 0,99 & High & 274.110 .700 & Small & 0,11 & Loser & Small|High|Loser & \begin{tabular}{l|l}
$0,06 \%$ \\
\end{tabular} & $8,13 \%$ & $-5,20 \%$ & $-1,83 \%$ & $3,73 \%$ & $-15,57 \%$ & \begin{tabular}{l|l}
$0,71 \%$ \\
\end{tabular} & $1,41 \%$ & $6,60 \%$ & $0,33 \%$ & \begin{tabular}{|l|l|}
$-6,11 \%$ \\
\end{tabular} & $0,78 \%$ \\
\hline CMGR4 & Cemat PN & 1,57 & High & 907.876 .470 & Small & 0,13 & Loser & Small|High|Loser & $-9,60 \%$ & $-0,15 \%$ & $-14,18 \%$ & $-5,92 \%$ & $-2,29 \%$ & $7,42 \%$ & $2,79 \%$ & $-5,36 \%$ & $-0,75 \%$ & $-4,75 \%$ & $0,80 \%$ & $-0,99 \%$ \\
\hline LIXC4 & Lix da Cunha PN & 1,19 & High & 39.580 .360 & Small & \begin{tabular}{l|l}
0,13 \\
\end{tabular} & Loser & Small|High|Loser & $16,33 \%$ & $-11,46 \%$ & $0,00 \%$ & $-2,27 \%$ & $-0,66 \%$ & $-6,00 \%$ & $-9,57 \%$ & $-3,53 \%$ & $-11,38 \%$ & $-5,50 \%$ & $-10,68 \%$ & $-17,39 \%$ \\
\hline ELEK4 & \begin{tabular}{|l|l|} 
Elekeiroz PN \\
\end{tabular} & 0,96 & High & $\begin{array}{l}444.046 .495 \\
\end{array}$ & Small & \begin{tabular}{l|l}
0,14 & \\
\end{tabular} & Loser & Small/High/Loser & $-5,13 \%$ & $2,27 \%$ & $-0,44 \%$ & $-1,88 \%$ & $7,28 \%$ | & $8,99 \%$ & $1,98 \%$ & $-3,88 \%$ & $-3,23 \%$ & $-0,83 \%$ & $-4,54 \%$ & $8,27 \%$ \\
\hline PTNT4 & \begin{tabular}{|l|} 
Pettenati PN \\
\end{tabular} & 1,16 & High & 74.873.015 & Small & 0,14 & Loser & Small|High|Loser & $0,00 \%$ & $-10,53 \%$ & $12,75 \%$ & $9,91 \%$ & $-14,65 \%$ & $11,11 \%$ & $-4,00 \%$ & $-9,85 \%$ & $5,88 \%$ & $-0,79 \%$ & $4,00 \%$ & $-4,62 \%$ \\
\hline DXTG4 & Dixie Toga PN & 1,10 & High & 661.320 .870 & Small & 0,16 & Loser & Small|High|Loser & $0,83 \%$ & $1,23 \%$ & $4,47 \%$ & $-2,72 \%$ & $-0,40 \%$ & $1,61 \%$ & $1,58 \%$ & $29,96 \%$ & $2,99 \%$ & $2,62 \%$ & $1,32 \%$ & $4,01 \%$ \\
\hline \begin{tabular}{|l|l|} 
SULT4 \\
\end{tabular} & Sultepa PN & 3,55 & High & 63.630 .000 & Small & \begin{tabular}{l|l}
0,16 \\
\end{tabular} & Loser & Small||High|Loser & $-0,99 \%$ & $6,00 \%$ & $-1,89 \%$ & $-6,73 \%$ & $-3,30 \%$ & $-6,18 \%$ & $5,23 \%$ & $-1,30 \%$ & $5,91 \%$ & $13,64 \%$ & $24,55 \%$ & $-11,43 \%$ \\
\hline BRGE12 & Alfa Consorc & 1,39 & High & 427.889 .560 & Small & \begin{tabular}{l|l}
0,17 & \\
\end{tabular} & Loser & Small|High|Loser & $3,31 \%$ & $-0,17 \%$ & $-22,31 \%$ & $36,25 \%$ & $-12,50 \%$ & $-7,14 \%$ & \begin{tabular}{l|l}
$0,00 \%$ \\
\end{tabular} & $-0,48 \%$ & $-11,11 \%$ & $2,50 \%$ & $-7,32 \%$ & $-5,26 \%$ \\
\hline ECPR4 & Encorpar PN & 2,83 & High & 31.540 .000 & Small & \begin{tabular}{l|l|l|l|}
0,17 \\
\end{tabular} & Loser & Small|High|Loser & $2,35 \%$ & $0,06 \%$ & $5,29 \%$ & $14,53 \%$ & $-12,20 \%$ & $-0,11 \%$ & $-0,17 \%$ & $5,68 \%$ & $-0,74 \%$ & $8,82 \%$ & $51,68 \%$ & $37,24 \%$ \\
\hline DOHL4 & Dohler PN & 1,97 & High & 141.204 .000 & Small & 0,18 & Loser & Small|High|Loser & $7,11 \%$ & $1,37 \%$ & $13,49 \%$ & $6,93 \%$ & $0,27 \%$ & $5,17 \%$ & $-1,33 \%$ & $1,32 \%$ & $-0,24 \%$ & $1,04 \%$ & $-14,79 \%$ & $-0,62 \%$ \\
\hline GPCP3 & GPC Part ON & 0,91 & High & 95.026 .750 & Small & 0,19 & Loser & Small|High|Loser & $-3,30 \%$ & $3,41 \%$ & $-2,20 \%$ & $-3,37 \%$ & $-4,65 \%$ & $-1,22 \%$ & \begin{tabular}{|l|l|}
$-7,41 \%$ \\
\end{tabular} & $-10,67 \%$ & $-4,48 \%$ & $6,25 \%$ & $4,41 \%$ & $-1,41 \%$ \\
\hline CTNM4 & Coteminas PN & 2,43 & High & 541.389 .690 & Small & 0,21 & Loser & Small|High|Loser & $2,78 \%$ & $-9,38 \%$ & $-3,91 \%$ & $5,02 \%$ & $2,51 \%$ & $20,00 \%$ & $-4,63 \%$ & $-4,85 \%$ & $-4,08 \%$ & $-3,62 \%$ & $1,68 \%$ & $-7,61 \%$ \\
\hline RPAD6 & Alfa Holding PNB & 1,29 & High & 61.110 & Small & \begin{tabular}{l|l}
0,25 \\
\end{tabular} & Loser & Small|High|Loser & 0,00\% & $-7,52 \%$ & $19,72 \%$ & $-6,86 \%$ & $1,05 \%$ & $-9,17 \%$ & $-0,23 \%$ & $-8,01 \%$ & $0,00 \%$ & $0,50 \%$ & $-17,16 \%$ & $1,20 \%$ \\
\hline CEBR5 & Ceb PNA & 1,15 & High & 286.159 .889 & Small & 0,28 & Loser & Small|High|Loser & \begin{tabular}{|l|l|}
$-5,68 \%$ \\
\end{tabular} & $-5,10 \%$ & $-13,95 \%$ & $-7,02 \%$ & \begin{tabular}{l|l}
$9,43 \%$ \\
\end{tabular} & $13,79 \%$ & $-5,76 \%$ & $4,53 \%$ & $7,66 \%$ & $7,06 \%$ & \begin{tabular}{l|l|}
$-0,64 \%$ \\
\end{tabular} & $-11,36 \%$ \\
\hline JBDU3 & J B Duarte ON & 1,99 & High & 30.970 .960 & Small & 0,29 & Loser & Small|High|Loser & $0,00 \%$ & $-12,50 \%$ & $0,00 \%$ & $0,00 \%$ & $0,00 \%$ & $-14,29 \%$ & $0,00 \%$ & $16,67 \%$ & $20,00 \%$ & $0,00 \%$ & $0,00 \%$ & $0,00 \%$ \\
\hline MEND5 & Mendes Jr PNA & 5,24 & High & 281.946 & Small & 0,29 & Loser & Small|High|Loser & $-12,26 \%$ & $9,97 \%$ & $-11,34 \%$ & $5,10 \%$ & $-8,54 \%$ & $-3,71 \%$ & $-3,07 \%$ & $8,57 \%$ & $-7,63 \%$ & $33,90 \%$ & $56,85 \%$ & $13,91 \%$ \\
\hline RPAD3 & Alfa Holding ON & 1,29 & High & 461.110 & Small & 0,30 & Loser & Small/High|Loser & $-6,70 \%$ & $2,53 \%$ & $0,60 \%$ & $19,32 \%$ & $-2,34 \%$ & $-11,62 \%$ & $-2,67 \%$ & $-0,60 \%$ & $-19,60 \%$ & $10,70 \%$ & $-0,22 \%$ & $-1,80 \%$ \\
\hline SGPS3 & Springs ON & 2,48 & High & 682.100 & Small & 0,30 & Loser & Small|High|Loser & $2,33 \%$ & $-7,27 \%$ & $-1,96 \%$ & $4,25 \%$ & $13,43 \%$ & $14,16 \%$ & $-2,41 \%$ & $-5,12 \%$ & $-3,00 \%$ & $-5,15 \%$ & $-1,09 \%$ & $-9,89 \%$ \\
\hline $\begin{array}{l}\text { PATI4 } \\
\end{array}$ & Panatlantica PN & 1,18 & High & 73.100 & Small & 0,30 & Loser & Small|High|Loser & $-2,54 \%$ & $9,83 \%$ & $4,21 \%$ & $0,51 \%$ & $18,09 \%$ & $-0,51 \%$ & $2,65 \%$ & $-4,17 \%$ & $-10,00 \%$ & $0,72 \%$ & $-14,67 \%$ & $-1,84 \%$ \\
\hline RPAD5 & Alfa Holding PNA & 1,29 & High & 461.110 & Small & 0,32 & Loser & Small|High|Loser & $0,20 \%$ & $-2,74 \%$ & $11,06 \%$ & $9,20 \%$ & $-0,53 \%$ & $-0,53 \%$ & $0,35 \%$ & $10,11 \%$ & $0,33 \%$ & $0,83 \%$ & $1,48 \%$ & $0,00 \%$ \\
\hline IENG5 & Ienergia PNA & 0,83 & High & 17.760 & Small & 0,32 & Loser & Small|High|Loser & $5,56 \%$ & $0,00 \%$ & $-10,53 \%$ & $-2,94 \%$ & $3,03 \%$ & $-2,94 \%$ & $-12,12 \%$ & $-10,34 \%$ & $-7,69 \%$ & $0,00 \%$ & $-4,17 \%$ & $-4,35 \%$ \\
\hline \begin{tabular}{|l|} 
MGELL4 \\
\end{tabular} & Mangels Indl PP & 0,86 & High & 32.430 & Small & \begin{tabular}{l|l|l|}
0,33 \\
\end{tabular} & Loser & Small|High|Loser & $12,96 \%$ & $-0,25 \%$ & $21,25 \%$ & $14,43 \%$ & $2,70 \%$ & $-5,26 \%$ & $-7,87 \%$ & $-5,03 \%$ & $2,12 \%$ & $-3,83 \%$ & $0,50 \%$ & $0,00 \%$ \\
\hline MEND6 & Mendes Jr PNB & 5,24 & High & 404.281.946 & Small & 0,34 & Loser & Small|High|Loser & $8,92 \%$ & $-8,43 \%$ & $2,63 \%$ & $-3,85 \%$ & $-5,33 \%$ & $-4,08 \%$ & $-0,09 \%$ & $6,44 \%$ & $-6,05 \%$ & $27,81 \%$ & $44,77 \%$ & $0,00 \%$ \\
\hline CTNM3 & Coteminas ON & 2,43 & High & 541.389 .690 & Small & 0,39 & Winner & Small|High|Winner & $0,22 \%$ & $-2,17 \%$ & $5,56 \%$ & $-0,21 \%$ & $-2,53 \%$ & $16,23 \%$ & $21,04 \%$ & $20,15 \%$ & $-5,59 \%$ & $1,63 \%$ & $-3,50 \%$ & $-8,12 \%$ \\
\hline PRVI3 & Provide & 0,80 & High & 3.950 & Small & 0,39 & Winner & Small|High|Winner & $16,30 \%$ & $7,66 \%$ & $-6,04 \%$ & 3,57 & $-0,10 \%$ & $4,23 \%$ & $-0,68 \%$ & $-4,76 \%$ & $-11,57 \%$ & $4,20 \%$ & $-4,82 \%$ & $2,56 \%$ \\
\hline MRSL4 & Marisol PN & 0,82 & High & 314.311 .200 & Small & 0,40 & Winner & Small|High|Winner & $10,36 \%$ & $-7,77 \%$ & $5,96 \%$ & $-3,97 \%$ & $-5,17 \%$ & $8,00 \%$ & $-5,72 \%$ & $-9,66 \%$ & $13,47 \%$ & \begin{tabular}{l|l|l}
$3,60 \%$ & \\
\end{tabular} & \begin{tabular}{l|l}
$0,69 \%$ \\
\end{tabular} & $2,76 \%$ \\
\hline JBDU4 & J B Duarte PN & 1,99 & High & 30.970 .960 & Small & 0,43 & Winner & Small|High|Winner & $12,50 \%$ & $-11,11 \%$ & $-12,50 \%$ & $0,00 \%$ & $0,00 \%$ & $0,00 \%$ & $-28,57 \%$ & $0,00 \%$ & $0,00 \%$ & $0,00 \%$ & $0,00 \%$ & $-20,00 \%$ \\
\hline TKNO4 & Tekn & 0,90 & High & & smat & & Wing & & & & & & -29 & $5,26 \%$ & & & & 0,5 & $8,31 \%$ & 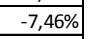 \\
\hline CCIM3 & CC Des Imob ON & 1,10 & High & 576.249 .000 & Small & 0,51 & Winner & Small| High | Winner & 11,76\% & $5,26 \%$ | & $6,67 \%$ & $30,16 \%$ & $-11,40 \%$ & $7,86 \%$ & $-6,78 \%$ & $-3,64 \%$ | & $-5,84 \%$ & $0,62 \%$ & - $13,08 \%$ & $-10,09 \%$ \\
\hline ROMI3 & Inds Romi ON & 0,78 & High & 839.532 .340 & Small & 0,58 & Winner & Small|High|Winner & $13,98 \%$ & $-0,78 \%$ & $2,45 \%$ & $11,33 \%$ & $1,05 \%$ & $0,97 \%$ & $-16,21 \%$ & $-9,55 \%$ & $3,57 \%$ & $-11,91 \%$ & $-12,41 \%$ & $-19,32 \%$ \\
\hline BHGR3 & $\mathrm{AG} \mathrm{ON}$ & 1,24 & gh & 511.046 .460 & nall & 0,58 & Ninner & Small|High/Winner & $15,22 \%$ & +2 & 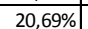 & $25 \%$ & 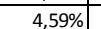 & & $0,06 \%$ & 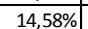 & 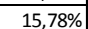 & 0,0 & $0,47 \pi$ & $\%$ \\
\hline
\end{tabular}


Anexo 1 - Retorno mensal e classificação das ações

\begin{tabular}{|c|c|c|c|c|c|c|c|c|c|c|c|c|c|c|c|c|c|c|c|c|}
\hline Código & 2010 - 2011 & $\begin{array}{l}\text { Índice } B / M \\
\text { de dez/2009 }\end{array}$ & $\begin{array}{c}\text { Grupo com } \\
\text { base no } \\
\text { indice } B / M\end{array}$ & \begin{tabular}{|c|} 
Valor de Mercado \\
em jun/2010
\end{tabular} & $\begin{array}{l}\text { Grupo com } \\
\text { base no } \\
\text { tamanho }\end{array}$ & $\begin{array}{c}\text { Retorno } \\
\text { acumulado } \\
\text { de jun/2010 }\end{array}$ & \begin{tabular}{c|} 
Grupo com \\
base no \\
retorno \\
acumulado
\end{tabular} & Carteiras & $\mathrm{jul} / 10$ & ago/10 & set/10 & out $/ 10$ & nov/10 & dez/10 & $\mathrm{jan} / 11$ & $\mathrm{fev} / 11$ & $\operatorname{mar} / 11$ & $\mathrm{abr} / 11$ & $\mathrm{mai} / 11$ & jun/11 \\
\hline ITEC3 & Itautec ON & 0,85 & High & 530.703 .050 & Small & 0,61 & Winner & Small|High|Winner & $-0,55 \%$ & $13,92 \%$ & $-5,88 \%$ & $-1,56 \%$ & $-0,42 \%$ & $-5,38 \%$ & $-7,91 \%$ & $0,02 \%$ & $-2,46 \%$ & $-5,00 \%$ & $-7,87 \%$ & $0,00 \%$ \\
\hline BEMA3 & Bematech ON & 0,86 & High & $\begin{array}{l}447.094 .560 \\
\end{array}$ & Small & 0,61 & Winner & Small|High|Winner & $5,54 \%$ & $-5,79 \%$ & $6,73 \%$ & $9,78 \%$ & $-10,01 \%$ & $-3,89 \%$ & $-0,69 \%$ & $-8,92 \%$ & $-6,42 \%$ & $11,48 \%$ & $-13,94 \%$ & $-8,62 \%$ \\
\hline SAPR4 & Sanepar PN & 1,89 & High & 1.014 .501 .346 & Small & 0,62 & Winner & Small|High|Winner & $15,23 \%$ & $5,11 \%$ & $-5,21 \%$ & $6,23 \%$ & $1,38 \%$ & $-0,68 \%$ & $8,42 \%$ & $32,48 \%$ & $-0,96 \%$ & $-3,64 \%$ & $2,02 \%$ & $3,21 \%$ \\
\hline TIBR5 & Millennium PNA & 1,25 & High & 338.379.277 & Small & 0,68 & Winner & Small|High|Winner & $0,00 \%$ & $8,33 \%$ & $0,00 \%$ & $-7,69 \%$ & $0,00 \%$ & $0,00 \%$ & $0,00 \%$ & $0,00 \%$ & $0,00 \%$ & $3,63 \%$ & $-8,33 \%$ & $9,09 \%$ \\
\hline IENG3 & lenergia ON & 0,83 & High & 155.417 .760 & Small & 0,70 & Winner & Small|High|Winner & $-1,75 \%$ & $-10,71 \%$ & $-4,00 \%$ & $-2,08 \%$ & $0,00 \%$ & $-6,38 \%$ & $-2,27 \%$ & $-6,98 \%$ & $-20,00 \%$ & $-28,13 \%$ & $0,00 \%$ & $8,70 \%$ \\
\hline FESA4 & Ferbasa PN & 0,84 & High & 958.386 .000 & Small & 0,71 & Winner & Small|High|Winner & $16,91 \%$ & $-0,91 \%$ & $4,50 \%$ & $4,85 \%$ & $8,62 \%$ & $-3,86 \%$ & 0,00\% & $-10,71 \%$ & $7,00 \%$ & $-4,21 \%$ & $0,75 \%$ & $11,06 \%$ \\
\hline EUCA4 & Eucatex PN & 1,71 & High & 552.052 .980 & Small & 0,73 & Winner & Small|High|Winner & $18,79 \%$ & $-15,82 \%$ & $-3,62 \%$ & $16,46 \%$ & $9,06 \%$ & $5,66 \%$ & $4,17 \%$ & $9,33 \%$ & $9,27 \%$ & $-1,79 \%$ & $-11,30 \%$ & $-0,51 \%$ \\
\hline PFRM3 & Profarma ON & 0,89 & High & 527.307 .600 & Small & 0,82 & Winner & Small|High|Winner & $0,63 \%$ & $-12,50 \%$ & $16,07 \%$ & $2,15 \%$ & $-11,14 \%$ & $5,08 \%$ & $-6,45 \%$ & $4,48 \%$ & $1,32 \%$ & $0,98 \%$ & $-3,05 \%$ & $0,00 \%$ \\
\hline TIBR6 & Millennium PNB & 1,25 & High & 338.379 .277 & Small & 0,83 & Winner & Small|High|Winner & $0,00 \%$ & $0,00 \%$ & $9,09 \%$ & $-16,67 \%$ & $0,00 \%$ & $0,00 \%$ & $0,00 \%$ & $-10,00 \%$ & $11,11 \%$ & $0,00 \%$ & $-10,00 \%$ & $22,22 \%$ \\
\hline FRAS4 & Fras-Le PN & 0,86 & High & 348.933 .690 & Small & 0,91 & Winner & Small|High|Winner & $16,62 \%$ & $3,19 \%$ & $2,62 \%$ & $2,09 \%$ & $-10,00 \%$ & $4,00 \%$ & $-4,70 \%$ & $-5,71 \%$ & $-2,20 \%$ & $-1,47 \%$ & $-3,75 \%$ & $1,15 \%$ \\
\hline SGEN4 & Sergen PN & 2,63 & High & .169 .798 & Small & 1,06 & Winner & Small|High|Winner & $\begin{array}{l}17,45 \% \\
\end{array}$ & $-5,14 \%$ & $26,51 \%$ & $-30,95 \%$ & \begin{tabular}{l|l|}
$-0,69 \%$ \\
\end{tabular} & $-2,78 \%$ & 7,14\% & $-1,33 \%$ & $-10,14 \%$ & $3,76 \%$ & $-4,35 \%$ & $6,06 \%$ \\
\hline GSHP3 & Generalshopp & 0,92 & High & \begin{tabular}{|l|l|}
413.436 .114 \\
\end{tabular} & Small & 1,09 & Winner & Small|High|Winner & $10,74 \%$ & $4,08 \%$ & $5,93 \%$ & $25,80 \%$ & $1,27 \%$ & $2,75 \%$ & $-8,33 \%$ & $-10,00 \%$ & $1,67 \%$ & $13,75 \%$ & $-1,52 \%$ & $8,94 \%$ \\
\hline INEP3 & Inepar ON & 0,77 & High & 314.494 .100 & Small & 1,10 & Winner & Small|High|Winner & $12,32 \%$ & $-4,25 \%$ & $-1,69 \%$ & $13,55 \%$ & $1,14 \%$ & $4,87 \%$ & $-10,71 \%$ & $7,40 \%$ & $1,86 \%$ & $-6,03 \%$ & $-13,61 \%$ & $8,97 \%$ \\
\hline TRIS3 & Trisul ON & 0,99 & High & 1.796 .110 & Small & 1,25 & Winner & Small|High|Winner & $9,34 \%$ & $3,88 \%$ & $0,15 \%$ & $19,25 \%$ & $-4,26 \%$ & $-7,84 \%$ & $-11,49 \%$ & $-4,97 \%$ & $-25,46 \%$ & $-3,85 \%$ & $1,54 \%$ & $-5,71 \%$ \\
\hline BEEF3 & Minerva ON & 0,86 & High & \begin{tabular}{|l|}
723.709 .420 \\
\end{tabular} & Small & 1,25 & Winner & Small|High | Winner & $0,00 \%$ & $-0,15 \%$ & $-0,29 \%$ & $-11,27 \%$ & $7,92 \%$ & $6,73 \%$ & $-6,16 \%$ & $-1,68 \%$ & $0,16 \%$ & $3,72 \%$ & $-19,28 \%$ & $-9,44 \%$ \\
\hline HBTS5 & Habitasul PNA & 1,94 & High & \begin{tabular}{l|l|l|}
66.675 .915 \\
\end{tabular} & Small & 1,29 & Winner & Small|High|Winner & $-4,93 \%$ & $-13,54 \%$ & $-9,17 \%$ & $-13,94 \%$ & $2,35 \%$ & $-2,08 \%$ & $-2,13 \%$ & $-8,70 \%$ & $47,62 \%$ & $72,58 \%$ & $26,53 \%$ & $-11,63 \%$ \\
\hline TPIS3 & Triunfo Part ON & 1,04 & High & 786.940 .000 & Small & 1,51 & Winner & Small|High|Winner & $15,58 \%$ & $4,67 \%$ & $4,63 \%$ & $19,73 \%$ & $8,61 \%$ & $12,07 \%$ & $-5,13 \%$ & $-7,46 \%$ & $5,51 \%$ & $0,67 \%$ & $1,77 \%$ & $-0,11 \%$ \\
\hline RCSL4 & Recrusul PN & 0,02 & Low & 61.896 .820 & Small & 0,15 & Loser & Small|Low|Loser & $1,14 \%$ & $-13,48 \%$ & $14,29 \%$ & $-7,95 \%$ & $4,94 \%$ & $3,53 \%$ & $-9,09 \%$ & $-15,00 \%$ & $-17,65 \%$ & $-16,07 \%$ & $2,13 \%$ & $-2,08 \%$ \\
\hline UNIP6 & Unipar PNB & 0,27 & Low & 551.200 .553 & Small & 0,15 & Loser & Small|Low|Loser & $1,72 \%$ & $6,78 \%$ & $0,00 \%$ & $4,76 \%$ & $-7,58 \%$ & $-4,92 \%$ & $-1,72 \%$ & $-12,28 \%$ & $-10,00 \%$ & $0,00 \%$ & $-13,33 \%$ & $7,69 \%$ \\
\hline $\begin{array}{ll}\text { LUPA3 } \\
\end{array}$ & Lupatech ON & 0,15 & Low & 1.002.477.000 & Small & 0,11 & Loser & Small|Low|Loser & $2,95 \%$ & $-5,41 \%$ & $9,29 \%$ & $-4,47 \%$ & $-11,01 \%$ & $1,47 \%$ & $-9,23 \%$ & $-6,06 \%$ & $-14,90 \%$ & $\begin{array}{l}-15,87 \% \\
\end{array}$ & $-4,59 \%$ & $5,97 \%$ \\
\hline UNIP3 & Unipar ON & 0,27 & Low & & Small & 0,07 & Loser & Small|Low|Loser & $-5,19 \%$ & $8,22 \%$ & $-5,06 \%$ & $1,33 \%$ & $-11,84 \%$ & $4,48 \%$ & $-10,00 \%$ & $-11,11 \%$ & $-7,14 \%$ & $1,92 \%$ & $-3,77 \%$ & $-1,96 \%$ \\
\hline ESTC3 & Estacio Part ON & 0,24 & Low & 1.582 .674 .000 & Small & 0,02 & Loser & Small|Low|Loser & $4,43 \%$ & $-10,53 \%$ & $3,35 \%$ & $30,91 \%$ & $6,85 \%$ & $-0,55 \%$ & $-11,11 \%$ & $1,25 \%$ & $9,05 \%$ & $-11,44 \%$ & $0,87 \%$ & $13,79 \%$ \\
\hline MTIG4 & Metal Iguacu PN & 0,27 & Low & 134.275 .850 & Small & 0,03 & Loser & Small|Low|Loser & $8,57 \%$ & $-2,63 \%$ & $5,41 \%$ & $-10,26 \%$ & $-2,86 \%$ & $-5,88 \%$ & $-3,13 \%$ & $-9,68 \%$ & $-3,57 \%$ & $-7,41 \%$ & $-4,00 \%$ & $0,00 \%$ \\
\hline UCOP4 & Usin CP & 0,21 & Low & 1.501. & Small & 0,13 & Loser & Small|L & $0,00 \%$ & $-37,38 \%$ & $4,17 \%$ & $0,20 \%$ & $5,79 \%$ & $10,75 \%$ & $2,21 \%$ & $0,00 \%$ & $-0,50 \%$ & $0,50 \%$ & $-0,17 \%$ & $-1,17 \%$ \\
\hline \begin{tabular}{|l|l|} 
RCSL3 \\
\end{tabular} & $\begin{array}{l}\text { Recrusul ON } \\
\end{array}$ & 0,02 & Low & 61.896 .820 & Small & 0,14 & Loser & Small|Low|Loser & $11,73 \%$ & $-5,00 \%$ & $-15,79 \%$ & $-5,63 \%$ & $15,21 \%$ & $-8,75 \%$ & $-4,11 \%$ & $-10,00 \%$ & $-20,63 \%$ & $0,00 \%$ & $-10,00 \%$ & $1,11 \%$ \\
\hline TOYB3 & Tectoy ON & 0,05 & Low & 82.954 .144 & Small & 0,17 & Loser & Small|Low|Loser & $0,00 \%$ & $-12,50 \%$ & $-14,29 \%$ & $16,67 \%$ & $0,00 \%$ & $7,12 \%$ & $-14,29 \%$ & $-16,67 \%$ & $0,00 \%$ & $\begin{array}{l}-20,00 \% \\
\end{array}$ & $0,00 \%$ & $0,00 \%$ \\
\hline \begin{tabular}{|l|l|} 
VULC3 \\
\end{tabular} & Vulcabr & 0,24 & Low & 1.435 .000 .000 & Small & 0,23 & Loser & Small|Low|Loser & $4,63 \%$ & $4,90 \%$ & $-13,24 \%$ & $-3,18 \%$ & $8,47 \%$ & $39,02 \%$ & $-1,75 \%$ & $-12,71 \%$ & $-7,53 \%$ & $0,81 \%$ & $-14,13 \%$ & $1,04 \%$ \\
\hline IDNT3 & Ideiasnet ON & 0,23 & Low & 299.803 .824 & Small & 0,23 & Loser & Small|Low|Loser & $4,04 \%$ & $8,41 \%$ & $4,48 \%$ & $8,57 \%$ & $-1,58 \%$ & $2,14 \%$ & $2,36 \%$ & $-3,07 \%$ & $-7,65 \%$ & $-0,86 \%$ & $-5,19 \%$ & $11,85 \%$ \\
\hline CSRN3 & Cosern & 0,36 & Low & 55.500 & Small & 0,27 & Loser & Small|Low|Loser & $0,52 \%$ & 4,08 & $-1,86 \%$ & $13,80 \%$ & $-7,74 \%$ & $15,88 \%$ & \begin{tabular}{l|l|}
$12,56 \%$ \\
\end{tabular} & $3,85 \%$ & $-0,07 \%$ & $6,65 \%$ & $-2,17 \%$ & $-2,96 \%$ \\
\hline BTL3 & Battistella ON & 0,02 & Low & \begin{tabular}{|c|}
116.250 .300 \\
\end{tabular} & Small & 0,29 & Loser & Small|Low|Loser & $8,86 \%$ & $-1,16 \%$ & $5,88 \%$ & $21,11 \%$ & $-7,34 \%$ & $15,84 \%$ & $11,11 \%$ & $1,54 \%$ & $-4,55 \%$ & $-2,38 \%$ & $-0,81 \%$ & $2,46 \%$ \\
\hline TOYB4 & Tectoy PN & 0,05 & Low & \begin{tabular}{|l|l|}
82.954 .144 \\
\end{tabular} & Small & 0,29 & Loser & Small|Low|Loser & $0,00 \%$ & $-12,50 \%$ & $-14,29 \%$ & $16,67 \%$ & $0,00 \%$ & $6,66 \%$ & $-28,57 \%$ & $0,00 \%$ & $20,00 \%$ & $33,33 \%$ & $0,00 \%$ & $25,00 \%$ \\
\hline PTBL3 & Portobello ON & 0,13 & Low & \begin{tabular}{l|l|}
.414 .400 \\
\end{tabular} & Small & 0,32 & Loser & Small|Low|Loser & $4,38 \%$ & $7,78 \%$ & $-3,33 \%$ & $-2,30 \%$ & $17,06 \%$ & $2,01 \%$ & $-5,91 \%$ & $-2,62 \%$ & $-6,99 \%$ & $18,50 \%$ & $-11,71 \%$ & $-14,36 \%$ \\
\hline BTL4 & Battistella PN & 0,02 & Low & 116.250 .300 & Small & 0,40 & Winner & Small|Low|Winner & $16,88 \%$ & $-1,11 \%$ & $16,85 \%$ & $12,50 \%$ & $-9,40 \%$ & $10,38 \%$ & $1,71 \%$ & $3,36 \%$ & $-4,07 \%$ & $-2,54 \%$ & $-0,87 \%$ & $20,18 \%$ \\
\hline GLOB3 & Globex ON & 0,34 & Low & .584 .691 .200 & Small & 0,41 & Winner & Small|Low|Winner & $19,92 \%$ & $-2,28 \%$ & $1,33 \%$ & $-1,97 \%$ & $27,52 \%$ & $2,68 \%$ & $12,76 \%$ & $24,55 \%$ & $-1,46 \%$ & $-3,70 \%$ & $1,92 \%$ & $-9,43 \%$ \\
\hline \begin{tabular}{|l|} 
CTAX4 \\
\end{tabular} & Contax PN & 0,23 & Low & 845.600 & Small & 0,66 & Winner & Small | Low |Winner & $7,27 \%$ & $9,80 \%$ & $8,29 \%$ & $7,66 \%$ & $5,87 \%$ & $1,88 \%$ & $-9,07 \%$ & $-3,40 \%$ & $-11,74 \%$ & $-3,83 \%$ & $-2,73 \%$ & $1,29 \%$ \\
\hline RHDS3 & M G Poliest ON & 0,17 & Low & 244.800 & Small & 0,70 & Winner & Small|Low|Winner & $30,77 \%$ & $-5,88 \%$ & $0,00 \%$ & $-6,25 \%$ & $0,00 \%$ & $-6,67 \%$ & $0,00 \%$ & $-14,29 \%$ & $-8,33 \%$ & \begin{tabular}{l|l|l}
$9,09 \%$ \\
\end{tabular} & $0,00 \%$ & $16,67 \%$ \\
\hline TGMA3 & Tegma $\mathrm{O}$ & 0,33 & Low & 73.260 & Small & 1,01 & Winner & Small|Low|Winner & $-2,75 \%$ & $23,02 \%$ & $11,80 \%$ & $4,93 \%$ & $20,30 \%$ & $1,48 \%$ & $-15,68 \%$ & $9,46 \%$ & $8,26 \%$ & $7,90 \%$ & $-6,19 \%$ & $-0,20 \%$ \\
\hline CTAX3 & Contax C & 0,23 & Low & 45.600 & Small & 1,01 & Winner & Small|Low|Winner & $1,02 \%$ & $8,72 \%$ & $0,31 \%$ & $-1,54 \%$ & $1,56 \%$ & $-1,54 \%$ & $-8,75 \%$ & $-3,08 \%$ & $-11,66 \%$ & $6,00 \%$ & $-9,43 \%$ & $5,00 \%$ \\
\hline CARD3 & Csu Cardsystem ON & 0,32 & Low & 401.301 .600 & Small & 1,02 & Winner & Small|Low|Winner & $5,95 \%$ & $-8,88 \%$ & $-0,12 \%$ & $-13,58 \%$ & $-0,86 \%$ & $-0,23 \%$ & $-11,24 \%$ & $-16,67 \%$ & $-2,40 \%$ & $-2,37 \%$ & $0,22 \%$ & $-0,22 \%$ \\
\hline POSI3 & Positivo Inf ON & 0,33 & Low & 1.460 .149 .710 & Small & 1,08 & Winner & Small|Low|Winner & $6,54 \%$ & $-1,55 \%$ & $-4,49 \%$ & $-6,12 \%$ & $31,02 \%$ & $-11,44 \%$ & $-2,87 \%$ & $4,96 \%$ & $-19,92 \%$ & $-10,18 \%$ & $3,03 \%$ & $1,41 \%$ \\
\hline JFEN3 & Joao Fo & 0,30 & Low & 0000.000 & Small & 1,65 & Winner & Small|Low|Winner & $-3,28 \%$ & $10,17 \%$ & $-1,54 \%$ & $-2,34 \%$ & $-4,00 \%$ & $-1,75 \%$ & $-3,31 \%$ & $4,82 \%$ & $0,00 \%$ & $-2,85 \%$ & $-3,33 \%$ & $-5,77 \%$ \\
\hline KEPL3 & Kepler Weber ON & 0,36 & Low & 444.895 .100 & Small & 1,65 & Winner & Small|Low|Winner & $2,94 \%$ & $2,86 \%$ & $0,00 \%$ & $2,78 \%$ & $-5,41 \%$ & $0,00 \%$ & $-2,86 \%$ & $-2,94 \%$ & $-6,06 \%$ & $-12,90 \%$ & $-11,11 \%$ & $8,33 \%$ \\
\hline LPSB3 & Lopes Brasil ON & 0,01 & Low & 1.137 .670 .860 & Small & 2,00 & Winner & Small|Low|Winner & $18,36 \%$ & $6,62 \%$ & $5,00 \%$ & $21,51 \%$ & $7,43 \%$ & $-1,89 \%$ & $-7,44 \%$ & $4,16 \%$ & $1,86 \%$ & $11,23 \%$ & $-6,02 \%$ & $-4,04 \%$ \\
\hline RNAR3 & Renar & 0,69 & & & 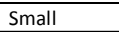 & & & & & & & & 111 & & & & & & & \\
\hline RDNI3 & Rodobensimob ON & 0,71 & Medium & 570.756 .250 & Small & 0,24 & Loser & Small|Medium|Loser & $18,21 \%$ & $7,99 \%$ | & $16,00 \%$ & $1,15 \%$ & $-4,03 \%$ | & $-1,18 \%$ & $0,90 \%$ & $-14,25 \%$ & $-13,43 \%$ & $10,77 \%$ & $11,28 \%$ & $10,67 \%$ \\
\hline RSIP3 & Rasip Agro ON & 0,67 & Medium & 71.625.010 & Small & 0,20 & Loser & Small|Medium|Loser & $0,00 \%$ & $0,00 \%$ & $7,32 \%$ & $0,00 \%$ & $-4,55 \%$ & $-4,76 \%$ & $5,00 \%$ & $-4,76 \%$ & $-2,50 \%$ & $-12,82 \%$ & $-2,94 \%$ & $6,06 \%$ \\
\hline RSIP4 & sip Agro PN & 0,67 & edium & 71.625.010 & mall & 0,07 & oser & Small|Medi & $2,12 \%$ & & $2,56 \%$ & $2,63 \%$ & $2,56 \%$ & $-2,50 \%$ & $13 \%$ &, $10 \%$ & 4,10 & 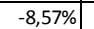 & $3,13 \%$ & 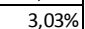 \\
\hline
\end{tabular}


Anexo 1 - Retorno mensal e classificação das ações

\begin{tabular}{|c|c|c|c|c|c|c|c|c|c|c|c|c|c|c|c|c|c|c|c|c|}
\hline Código & $2010-2011$ & $\begin{array}{l}\text { Índice } B / M \\
\text { de dez/2009 }\end{array}$ & $\begin{array}{c}\text { Grupo com } \\
\text { base no } \\
\text { índice } B / M\end{array}$ & $\begin{array}{c}\text { Valor de Mercado } \\
\text { em jun/2010 }\end{array}$ & $\begin{array}{c}\text { Grupo com } \\
\text { base no } \\
\text { tamanho }\end{array}$ & $\begin{array}{c}\text { Retorno } \\
\text { acumulado } \\
\text { de jun/2010 }\end{array}$ & \begin{tabular}{c|} 
Grupo com \\
base no \\
retorno \\
acumulado
\end{tabular} & Carteiras & $\mathrm{jul} / 10$ & ago/10 & set $/ 10$ & out $/ 10$ & nov/10 & $\operatorname{dez} / 10$ & $\mathrm{jan} / 11$ & $\mathrm{fev} / 11$ & $\mathrm{mar} / 11$ & $\mathrm{abr} / 11$ & $\mathrm{mai} / 11$ & jun/11 \\
\hline TEMP3 & Tempo Part ON & 0,49 & Medium & 492.802 .200 & Small & 0,05 & Loser & Small|Medium|Loser & $15,45 \%$ & $4,99 \%$ & $27,25 \%$ & $12,97 \%$ & $-4,52 \%$ & $-6,56 \%$ & $-17,35 \%$ & $-2,12 \%$ & $-5,78 \%$ & $5,37 \%$ & $-2,43 \%$ & $-6,72 \%$ \\
\hline SLCE3 & SLC Agricola ON & 0,51 & Medium & 1.308 .128 .100 & Small & \begin{tabular}{l|l|l}
0,05 & \\
\end{tabular} & Loser & Small|Medium | Loser & $12,31 \%$ & $6,31 \%$ & $16,63 \%$ & $17,90 \%$ & $-14,73 \%$ & $17,27 \%$ & $-10,05 \%$ & $9,35 \%$ & $6,01 \%$ & $-13,00 \%$ & $2,88 \%$ & $-9,23 \%$ \\
\hline \begin{tabular}{|l|} 
FTTA4 \\
\end{tabular} & \begin{tabular}{|l|} 
Forjas Taurus PN \\
\end{tabular} & 0,54 & Medium & \begin{tabular}{|l|l|}
653.993 .500 \\
\end{tabular} & Small & \begin{tabular}{|l|l|}
0,08 \\
\end{tabular} & Loser & Small|Medium|Loser & $5,27 \%$ & $-10,60 \%$ & $0,00 \%$ & $-2,80 \%$ & $-9,48 \%$ & $2,76 \%$ & $-1,71 \%$ & $4,22 \%$ & $-0,48 \%$ & $-2,15 \%$ & $-9,86 \%$ & $1,49 \%$ \\
\hline SCAR3 & Sao Carlos ON & 0,67 & Medium & 960.133.050 & Small & 0,14 & Loser & Small|Medium|Loser & 8,24\% & $-2,78 \%$ ] $>$ & $0,00 \%$ & 1,94\% ] & $28,76 \%$ | & $1,22 \%$ ] & $-8,60 \%$ & $-0,28 \%$ | & $6,18 \%$ & $-2,22 \%$ ] & $-0,18 \%$ & $-0,73 \%$ \\
\hline KROT11 & \begin{tabular}{|l|} 
Kroton UNT N2 \\
\end{tabular} & 0,74 & Medium & \begin{tabular}{|l|}
816.108 .386 \\
\end{tabular} & Small & $0,0,15$ & Loser & Small|Medium|Loser & $6,14 \%$ & $0,21 \%$ & $5,56 \%$ & $17,01 \%$ & $7,53 \%$ & $15,85 \%$ & $6,09 \%$ & $-13,72 \%$ & $5,20 \%$ & $-1,38 \%$ & $0,19 \%$ & $-2,60 \%$ \\
\hline VLID3 & Valid ON & 0,40 & Medium & 760.421 .500 & Small & 0,19 & Loser & Small|Medium|Loser & $4,32 \%$ & $13,57 \%$ & $3,49 \%$ & $7,14 \%$ & $2,34 \%$ & \begin{tabular}{l|l|}
$3,47 \%$ \\
\end{tabular} & $2,81 \%$ & $-5,86 \%$ & $1,79 \%$ & $8,86 \%$ & $2,33 \%$ & $4,80 \%$ \\
\hline FHER3 & Fer Heringer ON & 0,57 & Medium & 361.593 .660 & Small & 0,24 & Loser & Small|Medium|Loser & $5,63 \%$ & $-5,84 \%$ & $-3,37 \%$ & $32,78 \%$ & $-3,99 \%$ & $1,42 \%$ & $-16,50 \%$ & $33,07 \%$ & $-2,91 \%$ & $6,30 \%$ & $-11,10 \%$ & $4,23 \%$ \\
\hline PTPA4 & Petropar PN & 0,54 & Medium & 541.266 .000 & Small & 0,28 & Loser & Small|Medium|Loser & $12,12 \%$ & $-5,43 \%$ & $-12,83 \%$ & $-1,64 \%$ & $11,00 \%$ & $22,72 \%$ & $-5,00 \%$ & $-1,00 \%$ & $-0,08 \%$ & $11,85 \%$ & $-4,74 \%$ & $1,23 \%$ \\
\hline ETER3 & Eternit ON & 0,60 & Medium & 756.924 .660 & Small & 0,30 & Loser & Small|Medium|Loser & $1,30 \%$ & $11,95 \%$ & $-0,11 \%$ & $9,28 \%$ & $4,87 \%$ & $14,50 \%$ & $-6,17 \%$ & $-1,60 \%$ & $2,99 \%$ & $-3,40 \%$ & $-8,66 \%$ & $-0,52 \%$ \\
\hline ENMA3B & Cemar ON & 0,40 & Medium & 1.329 .890 .400 & Small & 0,34 & Loser & Small|Medium|Loser & $10,00 \%$ & $4,94 \%$ & $-1,71 \%$ & $-4,79 \%$ & $-0,57 \%$ & $1,15 \%$ & $-0,57 \%$ & $2,29 \%$ & $7,82 \%$ & $4,15 \%$ & $3,04 \%$ & $0,99 \%$ \\
\hline UOLL4 & Uol PN & 0,77 & Medium & & Small & \begin{tabular}{l|l}
0,38 & \\
\end{tabular} & Winner & Small|Medium|Winner & \begin{tabular}{l|l|}
$-0,54 \%$ \\
\end{tabular} & $6,02 \%$ & $0,10 \%$ & $5,15 \%$ & $7,25 \%$ & $21,30 \%$ & \begin{tabular}{l|l}
$9,27 \%$ \\
\end{tabular} & 7,93 & $0,26 \%$ & $12,17 \%$ & $-7,63 \%$ & $0,00 \%$ \\
\hline \begin{tabular}{|l|l|} 
MTSA4 \\
\end{tabular} & Metisa PN & 0,42 & Medium & 253.876 .558 & Small & \begin{tabular}{l|l|l|l|l|l|l|l|}
0,40 \\
\end{tabular} & Winner & Small|Medium|Winner & $10,77 \%$ & $-2,81 \%$ & $-3,18 \%$ & $-8,82 \%$ & $-4,90 \%$ & $15,30 \%$ & $6,46 \%$ & $-2,50 \%$ & $5,13 \%$ & $1,05 \%$ & $2,31 \%$ & $-3,05 \%$ \\
\hline CCPR3 & Cyre Com-Ccp ON & 0,38 & Medium & 857.742 .720 & Small & 0,47 & Winner & Small|Medium|Winner & $9,98 \%$ & $19,07 \%$ & $-1,54 \%$ & $5,55 \%$ & $8,07 \%$ & $-0,62 \%$ & $-2,83 \%$ & $2,84 \%$ & $-4,07 \%$ & $2,39 \%$ & $-3,08 \%$ & $3,25 \%$ \\
\hline ECOD3 & Ecodies & 0,53 & Medium & .208 .320 & Small & 0,48 & Winner & Small|Medium|Winner & $5,95 \%$ & $-2,25 \%$ & $11,49 \%$ & $9,28 \%$ & $-6,60 \%$ & $1,01 \%$ & $-9,00 \%$ & $-8,79 \%$ & $1,20 \%$ & $-1,19 \%$ & $-16,87 \%$ & $1,45 \%$ \\
\hline TCNO4 & Tecnosolo PN & 0,48 & Medium & $\begin{array}{l}75.520 .000 \\
\end{array}$ & Small & \begin{tabular}{l|l|}
0,57 \\
0,5
\end{tabular} & Winner & Small|Medium|Winner & $10,81 \%$ & $-9,76 \%$ & $-4,05 \%$ & $0,00 \%$ & $-9,86 \%$ & $-1,56 \%$ & $4,76 \%$ & $-6,06 \%$ & $-1,61 \%$ & $-11,48 \%$ & $3,70 \%$ & $1,79 \%$ \\
\hline PLAS3 & Plascar Part ON & 0,73 & Medium & 599.148 .000 & Small & 0,58 & Winner & Small|Medium|Winner & $-4,72 \%$ & $2,04 \%$ & $0,86 \%$ & $8,50 \%$ & $-6,01 \%$ & $1,39 \%$ & $-9,59 \%$ & $-16,36 \%$ & $-6,88 \%$ & $-5,06 \%$ & $8,61 \%$ & $-7,17 \%$ \\
\hline JHSF3 & JHSF Pa & 0,58 & Medium & 88.170.245 & Small & \begin{tabular}{l|l}
0,58 & \\
\end{tabular} & Winner & Small|Medium|Winner & $16,15 \%$ & $-0,99 \%$ & $3,68 \%$ & $3,95 \%$ & $3,86 \%$ & $8,36 \%$ & $-7,43 \%$ & $-0,93 \%$ & $29,28 \%$ & $3,13 \%$ & $16,18 \%$ & $1,06 \%$ \\
\hline TCSA3 & Tecnisa ON & 0,58 & Medium & 1.250.199.200 & Small & 0,68 & Winner & Small|Medium|Winner & $11,63 \%$ & $1,56 \%$ & $-2,36 \%$ & $9,24 \%$ & $4,33 \%$ & $2,12 \%$ & $-9,75 \%$ & $-3,60 \%$ & $23,13 \%$ & $6,19 \%$ & $5,35 \%$ & $0,38 \%$ \\
\hline PMAM3 & Paranapanema ON & 0,66 & Medium & 1.614.914.180 & Small & 0,70 & Winner & Small|Medium|Winner & $23,12 \%$ & $-1,28 \%$ & $-5,85 \%$ & $-7,60 \%$ & $-10,65 \%$ & $4,81 \%$ & $2,99 \%$ & $0,78 \%$ & $1,73 \%$ & $-0,95 \%$ & $-7,97 \%$ & $9,09 \%$ \\
\hline MLFT4 & Jereiss: & 0,73 & Medium & 845.460 & Small & \begin{tabular}{l|l}
0,78 \\
\end{tabular} & Winner & Small|Medium|Winner & $24,14 \%$ & $-1,39 \%$ & $-1,41 \%$ & $7,14 \%$ & \begin{tabular}{l|l}
$-0,67 \%$ \\
\end{tabular} & $14,09 \%$ & $-7,65 \%$ & $0,64 \%$ & $3,16 \%$ & $-2,45 \%$ & $-13,21 \%$ & $2,90 \%$ \\
\hline SLED4 & Saraiva Livr PN & 0,43 & Medium & 1.006 .271 .900 & Small & \begin{tabular}{l|l}
0,80 \\
\end{tabular} & Winner & Small|Medium|Winner & \begin{tabular}{c|c|}
$-9,38 \%$ \\
\end{tabular} & $9,44 \%$ & $-1,35 \%$ & $1,95 \%$ & \begin{tabular}{l|l}
$9,68 \%$ \\
\end{tabular} & $10,03 \%$ & $-6,06 \%$ & $10,02 \%$ & $1,48 \%$ & $3,44 \%$ & $-12,58 \%$ & $10,71 \%$ \\
\hline EVEN3 & Even ON & 0,56 & Medium & 1.565 .396 .030 & Small & \begin{tabular}{l|l|l|}
0,89 \\
\end{tabular} & Winner & Small|Medium|Winner & $22,06 \%$ & $0,61 \%$ & $7,04 \%$ & $9,75 \%$ & $-7,44 \%$ & $-4,02 \%$ & $-8,14 \%$ & $-5,06 \%$ & $12,27 \%$ & $2,73 \%$ & $2,47 \%$ & $-8,37 \%$ \\
\hline \begin{tabular}{|l|l|} 
CGRA4 & \\
\end{tabular} & Grazziotin PN & 0,60 & Medium & 294.671.525 & Small & 0,89 & Winner & Small|Medium|Winner & $-4,43 \%$ & $2,77 \%$ & $-4,00 \%$ & $11,36 \%$ & $2,11 \%$ & $9,84 \%$ & $-6,00 \%$ & $-8,24 \%$ & $8,55 \%$ & $2,88 \%$ & $-3,68 \%$ & $-5,14 \%$ \\
\hline EZTC3 & Eztec ON & 0,75 & Medium & 1.186.379.365 & Small & \begin{tabular}{l|l|l}
0,97 & \\
\end{tabular} & Winner & Small|Medium|Winner & $14,01 \%$ & $13,45 \%$ & $6,44 \%$ & $5,88 \%$ & $7,79 \%$ & $7,84 \%$ & $-3,99 \%$ & $0,82 \%$ & $3,09 \%$ & $17,65 \%$ & $5,29 \%$ & $0,30 \%$ \\
\hline INEP4 & Inepar PN & 0,77 & Medium & 314.494 .100 & Small & \begin{tabular}{l|l|l|}
1,08 \\
\end{tabular} & Winner & Small|Medium|Winner & $15,73 \%$ & $-8,91 \%$ & $-3,40 \%$ & $11,01 \%$ & $0,00 \%$ & $10,32 \%$ & $-10,43 \%$ & 7, & $-0,19 \%$ & $-5,62 \%$ & $-10,27 \%$ & $-2,71 \%$ \\
\hline TCNO3 & Tecnosolo ON & 0,48 & Medium & 75.520 .000 & Small & \begin{tabular}{l|l}
1,19 \\
\end{tabular} & Winner & Small|Medium|Winner & $31,82 \%$ & $-8,62 \%$ & $-5,66 \%$ & $-2,00 \%$ & $-8,16 \%$ & $2,22 \%$ & $-10,87 \%$ & \begin{tabular}{l|l}
$-14,63 \%$ \\
\end{tabular} & $-12,86 \%$ & $8,20 \%$ & $7,58 \%$ & $-8,45 \%$ \\
\hline PNVL3 & Dimed ON & 0,55 & Medium & 6.566 .500 & Small & 1,29 & Winner & Small|Medium|Winner & $2,18 \%$ & $4,26 \%$ & $-1,45 \%$ & $9,48 \%$ & $3,69 \%$ & $19,84 \%$ & $-0,54 \%$ & $-2,21 \%$ & $4,92 \%$ & $0,61 \%$ & $-6,84 \%$ & $5,13 \%$ \\
\hline LLIS3 & Le Lis Blanc ON & 0,41 & Medium & 0.850 .680 & Small & 1,30 & Winner & Small|Medium|Winner & $32,63 \%$ & $14,14 \%$ & $18,63 \%$ & $4,64 \%$ & $2,57 \%$ & $21,79 \%$ & $-1,17 \%$ & $-2,37 \%$ & $4,24 \%$ & $8,37 \%$ & $13,79 \%$ & $-5,70 \%$ \\
\hline CREM3 & Cremer ON & 0,42 & Medium & 565.160 .000 & Small & \begin{tabular}{l|l}
1,33 \\
\end{tabular} & Winner & Small|Medium|Winner & $2,76 \%$ & $-1,99 \%$ & $3,77 \%$ & $-0,61 \%$ & \begin{tabular}{l|l}
$-0,09 \%$ \\
\end{tabular} & $-1,11 \%$ & $-5,95 \%$ & $-1,28 \%$ & $-7,76 \%$ & \begin{tabular}{l|l}
$0,07 \%$ \\
\end{tabular} & $8,07 \%$ & $-5,19 \%$ \\
\hline \begin{tabular}{|l|l|} 
MYPK3 & \\
\end{tabular} & Iochp-Maxion ON & 0,40 & Medium & \begin{tabular}{|l|l|}
1.622 .157 .300 \\
\end{tabular} & Small & \begin{tabular}{l|l}
1,33 \\
\end{tabular} & Winner & Small|Medium|Winner & \begin{tabular}{|l|l|}
$13,98 \%$ \\
\end{tabular} & $0,56 \%$ & $8,16 \%$ & $16,75 \%$ & $1,70 \%$ & $-4,25 \%$ & $-16,60 \%$ & $2,29 \%$ & $9,10 \%$ & $2,81 \%$ & $4,08 \%$ & $-8,19 \%$ \\
\hline FRIO3 & Metalfrio 0 & 0,67 & Medium & 393.670.500 & Small & 1,47 & Winner & Small|Medium|Winner & $5,16 \%$ & $9,91 \%$ & $1,82 \%$ & $11,63 \%$ & $7,69 \%$ & $4,09 \%$ & $-7,79 \%$ & $17,05 \%$ & $4,67 \%$ & $11,10 \%$ & $3,09 \%$ & $-0,97 \%$ \\
\hline HBOR3 & Helbor ON & 0,63 & Medium & 842.355 .180 & Small & \begin{tabular}{l|l}
1,47 & \\
\end{tabular} & Winner & Small|Medium|Winner & $8,19 \%$ & $18,21 \%$ & $12,39 \%$ & $3,76 \%$ & 5,39\% & $3,20 \%$ & $-7,10 \%$ & $-2,56 \%$ & $2,26 \%$ & $10,82 \%$ & $6,14 \%$ & $0,59 \%$ \\
\hline SHUL4 & Schulz PN & 0,39 & Medium & 418.626 .400 & Small & 1,56 & Winner & Small|Medium|Winner & \begin{tabular}{l|l}
$0,30 \%$ \\
\end{tabular} & $-2,74 \%$ & $1,87 \%$ & $1,20 \%$ & $16,62 \%$ & $19,08 \%$ & $1,33 \%$ & $-0,44 \%$ & $-0,33 \%$ & \begin{tabular}{l|l}
$0,59 \%$ \\
\end{tabular} & $-17,13 \%$ & $10,67 \%$ \\
\hline CAMB4 & $\mathrm{Camb}$ & 0,40 & Medi & 000 & Small & 1,89 & Winner & Small|N & $26,41 \%$ & 23,979 & $1,93 \%$ & $7,59 \%$ & $-4,28 \%$ & $0,00 \%$ & $-8,42 \%$ & $-2,59 \%$ & $-7,08 \%$ & $-3,17 \%$ & $-4,92 \%$ & $9,66 \%$ \\
\hline \begin{tabular}{|l|} 
BBRK3 \\
\end{tabular} & BR Brokers ON & o, 0 & Medium & \begin{tabular}{|l|l|l}
973.825 .680 \\
\end{tabular} & Small & \begin{tabular}{l|l|l|l|l|l|}
2,03 & \\
\end{tabular} & Winner & Small|Medium|Winner & $19,07 \%$ & $-4,62 \%$ & $13,46 \%$ & $25,20 \%$ & $0,11 \%$ & $1,60 \%$ & $-15,18 \%$ & $-4,32 \%$ & $9,68 \%$ & $3,95 \%$ & $-2,89 \%$ & $-8,93 \%$ \\
\hline
\end{tabular}


Anexo 2 - Retorno mensal das carteiras

\begin{tabular}{|c|c|c|c|c|c|c|c|c|c|c|c|c|}
\hline Carteiras & jul/96 & ago/96 & set/96 & out/96 & nov/96 & dez/96 & jan/97 & fev/97 & mar/97 & $a b r / 97$ & mai/97 & jun/97 \\
\hline Big|High|Loser & $-9,80 \%$ & $3,92 \%$ & $4,03 \%$ & $20,82 \%$ & $-2,99 \%$ & $8,24 \%$ & $18,92 \%$ & $15,87 \%$ & $-2,20 \%$ & $-2,40 \%$ & $1,57 \%$ & $11,47 \%$ \\
\hline Big|High|Winner & $-1,03 \%$ & $-3,89 \%$ & $-2,10 \%$ & $16,69 \%$ & $2,58 \%$ & $12,07 \%$ & $15,68 \%$ & $7,31 \%$ & $-5,66 \%$ & $9,45 \%$ & $3,60 \%$ & $16,79 \%$ \\
\hline Big|Low|Loser & $-10,53 \%$ & $1,97 \%$ & $9,07 \%$ & $-3,99 \%$ & $-0,17 \%$ & $4,15 \%$ & $2,31 \%$ & $12,09 \%$ & $-4,39 \%$ & $-1,98 \%$ & $-7,04 \%$ & $-7,51 \%$ \\
\hline Big|Low|Winner & $-2,87 \%$ & $-0,27 \%$ & $-0,44 \%$ & $-0,53 \%$ & $-3,11 \%$ & $2,89 \%$ & $4,29 \%$ & $9,06 \%$ & $-2,03 \%$ & $4,45 \%$ & $-1,09 \%$ & $3,44 \%$ \\
\hline Big|Medium |Loser & $-8,78 \%$ & $-6,82 \%$ & $-1,41 \%$ & $1,57 \%$ & $-0,92 \%$ & $1,19 \%$ & $5,63 \%$ & $12,87 \%$ & $-2,28 \%$ & $4,92 \%$ & $-4,88 \%$ & $4,68 \%$ \\
\hline Big|Medium/Winner & $0,01 \%$ & $3,59 \%$ & $1,70 \%$ & $2,13 \%$ & $2,84 \%$ & $8,10 \%$ & $14,80 \%$ & $9,86 \%$ & $2,91 \%$ & $7,79 \%$ & $15,40 \%$ & $8,87 \%$ \\
\hline Small|High|Loser & $-5,90 \%$ & $1,22 \%$ & $8,03 \%$ & $7,01 \%$ & $2,13 \%$ & $0,35 \%$ & $5,00 \%$ & $12,70 \%$ & $7,37 \%$ & $7,74 \%$ & $3,17 \%$ & $11,86 \%$ \\
\hline Small|High |Winner & $9,55 \%$ & $1,45 \%$ & $0,76 \%$ & $14,55 \%$ & $-3,18 \%$ & $-2,51 \%$ & $22,43 \%$ & $1,19 \%$ & $-1,23 \%$ & $-2,53 \%$ & $6,05 \%$ & $20,19 \%$ \\
\hline Small|Low|Loser & $-8,12 \%$ & $-3,12 \%$ & $-0,56 \%$ & $0,71 \%$ & $-8,28 \%$ & $-2,81 \%$ & $14,09 \%$ & $8,49 \%$ & $6,10 \%$ & $-2,56 \%$ & $17,60 \%$ & $6,29 \%$ \\
\hline Small|Low|Winner & $4,39 \%$ & $-2,07 \%$ & $10,27 \%$ & $-9,65 \%$ & $-7,87 \%$ & $0,72 \%$ & $7,80 \%$ & $7,69 \%$ & $5,28 \%$ & $-14,48 \%$ & $15,44 \%$ & $-9,52 \%$ \\
\hline Small|Medium|Loser & $-8,78 \%$ & $-3,90 \%$ & $3,64 \%$ & $0,19 \%$ & $7,23 \%$ & $-0,79 \%$ & $11,36 \%$ & $20,77 \%$ & $-1,11 \%$ & $-0,91 \%$ & $2,88 \%$ & $19,66 \%$ \\
\hline Small|Medium/Winner & $1,50 \%$ & $-1,50 \%$ & $2,02 \%$ & $-1,53 \%$ & $4,02 \%$ & $-0,05 \%$ & $-0,64 \%$ & $3,84 \%$ & $-1,51 \%$ & $0,33 \%$ & $-2,49 \%$ & $-1,23 \%$ \\
\hline
\end{tabular}

\begin{tabular}{|c|c|c|c|c|c|c|c|c|c|c|c|c|}
\hline Carteiras & jul/97 & ago/97 & set/97 & out/97 & nov/97 & dez/97 & jan/98 & $\mathrm{fev} / 98$ & $\mathrm{mar} / 98$ & $a b r / 98$ & mai/98 & jun/98 \\
\hline Big|High|Loser & $10,60 \%$ & $-8,68 \%$ & $-4,66 \%$ & $-20,58 \%$ & $-21,18 \%$ & $8,47 \%$ & $-16,30 \%$ & $-0,85 \%$ & $18,66 \%$ & $-2,61 \%$ & $-19,15 \%$ & $-12,49 \%$ \\
\hline Big|High | Winner & $-0,47 \%$ & $-19,35 \%$ & $21,75 \%$ & $-23,69 \%$ & $9,18 \%$ & $3,92 \%$ & $-16,65 \%$ & $5,11 \%$ & $4,57 \%$ & $-6,31 \%$ & $-20,63 \%$ & $-7,67 \%$ \\
\hline Big|Low|Loser & $2,03 \%$ & $-8,20 \%$ & $5,66 \%$ & $-18,65 \%$ & $-4,24 \%$ & $1,97 \%$ & $-7,32 \%$ & $7,72 \%$ & $12,03 \%$ & $-5,33 \%$ & $-10,34 \%$ & $-5,50 \%$ \\
\hline Big|Low|Winner & $0,98 \%$ & $-14,29 \%$ & $3,47 \%$ & $-20,69 \%$ & $-5,02 \%$ & $1,19 \%$ & $-8,63 \%$ & $6,32 \%$ & $9,56 \%$ & $-0,71 \%$ & $-17,22 \%$ & $-11,01 \%$ \\
\hline Big|Medium|Loser & $9,98 \%$ & $-9,38 \%$ & $0,57 \%$ & $-19,16 \%$ & $-9,17 \%$ & $-0,37 \%$ & $-3,12 \%$ & $5,36 \%$ & $13,06 \%$ & $-2,70 \%$ & $-14,83 \%$ & $-7,62 \%$ \\
\hline Big|Medium/Winner & $4,01 \%$ & $-19,75 \%$ & $10,14 \%$ & $-25,82 \%$ & $4,85 \%$ & $4,94 \%$ & $-7,70 \%$ & $6,50 \%$ & $7,86 \%$ & $-0,83 \%$ & $-17,54 \%$ & $-4,36 \%$ \\
\hline Small|High|Loser & $3,13 \%$ & $-5,13 \%$ & $-3,23 \%$ & $-13,62 \%$ & $-17,50 \%$ & $-5,79 \%$ & $-3,66 \%$ & $1,97 \%$ & $16,41 \%$ & $11,18 \%$ & $-13,51 \%$ & $-6,61 \%$ \\
\hline Small|High/Winner & $0,39 \%$ & $-0,35 \%$ & $0,99 \%$ & $-12,47 \%$ & $-23,57 \%$ & $5,34 \%$ & $-10,81 \%$ & $-0,57 \%$ & $37,57 \%$ & $8,64 \%$ & $-15,46 \%$ & $-4,22 \%$ \\
\hline Small|Low|Loser & $-4,17 \%$ & $-7,16 \%$ & $7,75 \%$ & $-6,63 \%$ & $-19,46 \%$ & $24,83 \%$ & $-11,97 \%$ & $2,40 \%$ & $6,04 \%$ & $23,50 \%$ & $-14,41 \%$ & $1,68 \%$ \\
\hline Small|Low|Winner & $1,93 \%$ & $-19,26 \%$ & $-13,57 \%$ & $0,84 \%$ & $-13,56 \%$ & $-11,08 \%$ & $-14,87 \%$ & $6,59 \%$ & $-0,32 \%$ & $26,35 \%$ & $-17,76 \%$ & $-19,96 \%$ \\
\hline Small|Medium|Loser & $12,54 \%$ & $-7,81 \%$ & $1,89 \%$ & $-9,82 \%$ & $-17,70 \%$ & $-8,85 \%$ & $-8,69 \%$ & $4,45 \%$ & $16,68 \%$ & $11,29 \%$ & $-11,35 \%$ & $-4,60 \%$ \\
\hline Small|Medium|Winner & $6,11 \%$ & $-6,57 \%$ & $3,43 \%$ & $-14,18 \%$ & $-21,00 \%$ & $-8,63 \%$ & $-14,79 \%$ & $13,87 \%$ & $25,89 \%$ & $16,52 \%$ & $-10,72 \%$ & $-10,64 \%$ \\
\hline
\end{tabular}


Anexo 2 - Retorno mensal das carteiras

\begin{tabular}{|c|c|c|c|c|c|c|c|c|c|c|c|c|}
\hline Carteiras & jul/98 & ago/98 & set/98 & out/98 & nov/98 & dez/98 & jan/99 & fev/99 & mar/99 & abr/99 & mai/99 & jun/99 \\
\hline Big|High|Loser & $8,37 \%$ & $-43,34 \%$ & $-5,32 \%$ & $2,19 \%$ & $58,58 \%$ & $-13,25 \%$ & $-10,70 \%$ & $14,70 \%$ & $53,26 \%$ & $5,54 \%$ & $-13,41 \%$ & $18,31 \%$ \\
\hline Big|High|Winner & $3,32 \%$ & $-30,34 \%$ & $-15,20 \%$ & $4,81 \%$ & $-6,35 \%$ & $-4,22 \%$ & $23,00 \%$ & $28,49 \%$ & $25,84 \%$ & $18,35 \%$ & $12,60 \%$ & $5,74 \%$ \\
\hline Big|Low|Loser & $11,87 \%$ & $-32,34 \%$ & $-17,02 \%$ & $-0,60 \%$ & $26,48 \%$ & $-14,73 \%$ & $-2,82 \%$ & $11,40 \%$ & $21,31 \%$ & $0,67 \%$ & $5,03 \%$ & $1,63 \%$ \\
\hline Big|Low|Winner & $10,73 \%$ & $-44,37 \%$ & $-6,56 \%$ & $14,45 \%$ & $14,10 \%$ & $-16,40 \%$ & $2,32 \%$ & $12,29 \%$ & $58,98 \%$ & $4,69 \%$ & $-0,96 \%$ & $5,82 \%$ \\
\hline Big|Medium|Loser & $2,78 \%$ & $-46,24 \%$ & $29,13 \%$ & $2,88 \%$ & $17,38 \%$ & $-24,96 \%$ & $18,22 \%$ & $3,54 \%$ & $23,45 \%$ & $4,48 \%$ & $3,54 \%$ & $-2,67 \%$ \\
\hline Big|Medium/Winner & $7,66 \%$ & $-37,91 \%$ & $2,53 \%$ & $7,23 \%$ & $15,19 \%$ & $-17,04 \%$ & $30,44 \%$ & $-0,10 \%$ & $21,57 \%$ & $16,30 \%$ & $-0,49 \%$ & $7,09 \%$ \\
\hline Small|High|Loser & $-3,48 \%$ & $-31,02 \%$ & $-10,82 \%$ & $-18,12 \%$ & $6,95 \%$ & $-3,10 \%$ & $21,86 \%$ & $2,60 \%$ & $32,01 \%$ & $5,92 \%$ & $-4,88 \%$ & $5,86 \%$ \\
\hline Small|High|Winner & $-5,39 \%$ & $-13,20 \%$ & $-4,52 \%$ & $-5,14 \%$ & $20,48 \%$ & $7,30 \%$ & $10,08 \%$ & $-5,77 \%$ & $-3,45 \%$ & $8,57 \%$ & $0,46 \%$ & $5,97 \%$ \\
\hline Small|Low|Loser & $-16,71 \%$ & $-4,50 \%$ & $-30,98 \%$ & $-25,38 \%$ & $-10,23 \%$ & $23,18 \%$ & $15,53 \%$ & $4,19 \%$ & $34,70 \%$ & $-14,69 \%$ & $10,08 \%$ & $-2,29 \%$ \\
\hline Small|Low|Winner & $-21,15 \%$ & $-20,25 \%$ & $-8,50 \%$ & $-10,70 \%$ & $34,38 \%$ & $18,49 \%$ & $15,32 \%$ & $-4,31 \%$ & $14,39 \%$ & $-7,64 \%$ & $-5,71 \%$ & $33,72 \%$ \\
\hline Small|Medium|Loser & $-0,49 \%$ & $-13,44 \%$ & $-19,45 \%$ & $4,37 \%$ & $-1,98 \%$ & $-2,77 \%$ & $-3,15 \%$ & $-6,35 \%$ & $16,07 \%$ & $0,32 \%$ & $0,04 \%$ & $4,39 \%$ \\
\hline Small|Medium|Winner & $3,93 \%$ & $-22,64 \%$ & $-15,67 \%$ & $-5,02 \%$ & $9,10 \%$ & $-0,19 \%$ & $7,25 \%$ & $6,00 \%$ & $14,78 \%$ & $0,27 \%$ & $5,56 \%$ & $14,79 \%$ \\
\hline
\end{tabular}

\begin{tabular}{|c|c|c|c|c|c|c|c|c|c|c|c|c|}
\hline Carteiras & jul/99 & go/99 & set/99 & out/99 & nov/99 & dez/99 & jan/00 & fev/00 & $\mathrm{mar} / 00$ & $\mathrm{abr} / 00$ & mai/00 & un/00 \\
\hline Big|High|Loser & $-5,74 \%$ & $7,91 \%$ & $7,31 \%$ & $12,44 \%$ & $31,23 \%$ & $16,64 \%$ & $3,92 \%$ & $-3,38 \%$ & $-3,48 \%$ & $-7,89 \%$ & $1,93 \%$ & $-0,28 \%$ \\
\hline Big|High/Winner & $-13,49 \%$ & $1,78 \%$ & $5,44 \%$ & $3,85 \%$ & $17,47 \%$ & & $-15,82 \%$ & & & & & $24,81 \%$ \\
\hline Big|Low|Loser & $2,21 \%$ & $-5,27 \%$ & $13,82 \%$ & $11,29 \%$ & $7,75 \%$ & $19,63 \%$ & & $0,26 \%$ & $4,72 \%$ & $-0,84 \%$ & $-4,77 \%$ & $14,56 \%$ \\
\hline Big|Low/Winner & $-0,72 \%$ & $-0,86 \%$ & $7,10 \%$ & $2,00 \%$ & $9,61 \%$ & $11,53 \%$ & $-5,84 \%$ & $-7,42 \%$ & $8,32 \%$ & $-3,54 \%$ & $1,07 \%$ & $13,38 \%$ \\
\hline Big|Medium |Loser & $-6,97 \%$ & $-3,84 \%$ & $3,01 \%$ & $3,08 \%$ & $35,85 \%$ & $15,66 \%$ & $-3,61 \%$ & $-1,24 \%$ & $1,19 \%$ & $-8,53 \%$ & $-10,95 \%$ & $11,42 \%$ \\
\hline Big|Medium |Winner & $-5,60 \%$ & $5,07 \%$ & $7,84 \%$ & $4,96 \%$ & $22,05 \%$ & $17,71 \%$ & $-9,44 \%$ & $5,29 \%$ & $1,80 \%$ & $-8,31 \%$ & $0,24 \%$ & $04 \%$ \\
\hline Small|High|Loser & $3,79 \%$ & $-2,81 \%$ & $7,06 \%$ & $0 \%$ & $24,52 \%$ & & $13,12 \%$ & $-3,65 \%$ & $2 \%$ & $-0,69 \%$ & $7,74 \%$ & $38 \%$ \\
\hline Small|High/Winne & $-3,46 \%$ & $-8,59 \%$ & $-0,16 \%$ & $12,41 \%$ & $37,39 \%$ & $18,52 \%$ & $-6,66 \%$ & $27,11 \%$ & $-0,83 \%$ & $-11,25 \%$ & $-6,24 \%$ & $12,90 \%$ \\
\hline Small|Low|Loser & $-11,28 \%$ & $-8,26 \%$ & $4,82 \%$ & $15,98 \%$ & $16,74 \%$ & $70,52 \%$ & $1,81 \%$ & $3,28 \%$ & $11,25 \%$ & $-11,69 \%$ & $-17,07 \%$ & $8,69 \%$ \\
\hline Small|Low/Winner & $-16,11 \%$ & $2,07 \%$ & $-6,70 \%$ & $12,66 \%$ & $-5,19 \%$ & $17,20 \%$ & $-1,32 \%$ & $9,62 \%$ & $3,84 \%$ & $1,41 \%$ & $-3,00 \%$ & $11,54 \%$ \\
\hline Small|Medium|Loser & $-3,37 \%$ & $-2,63 \%$ & $7,14 \%$ & $13,28 \%$ & $9,42 \%$ & $19,64 \%$ & $-1,76 \%$ & $-1,12 \%$ & $-3,70 \%$ & $-2,95 \%$ & $-6,99 \%$ & $9,36 \%$ \\
\hline Small|Medium|Winner & $0,14 \%$ & $-2,31 \%$ & $10,13 \%$ & $9,26 \%$ & $21,31 \%$ & $11,51 \%$ & $5,73 \%$ & $-0,89 \%$ & $1,86 \%$ & $-1,61 \%$ & $-2,92 \%$ & 8,10 \\
\hline
\end{tabular}


Anexo 2 - Retorno mensal das carteiras

\begin{tabular}{|c|c|c|c|c|c|c|c|c|c|c|c|c|}
\hline Carteiras & jul/00 & ago/00 & set/00 & out/00 & nov/00 & dez/00 & jan/01 & fev/01 & $\mathrm{mar} / 01$ & $\mathrm{abr} / 01$ & mai/01 & jun/01 \\
\hline Big|High|Loser & $7,92 \%$ & $-11,01 \%$ & $3,30 \%$ & $-6,55 \%$ & $-4,16 \%$ & $7,43 \%$ & $19,52 \%$ & $-5,28 \%$ & $3,70 \%$ & $-9,17 \%$ & $-18,84 \%$ & $-0,63 \%$ \\
\hline Big|High|Winner & $9,87 \%$ & $11,68 \%$ & $-3,80 \%$ & $-8,46 \%$ & $-14,85 \%$ & $1,67 \%$ & $25,23 \%$ & $-6,64 \%$ & $-8,89 \%$ & $-2,36 \%$ & $-18,42 \%$ & $2,96 \%$ \\
\hline Big|Low|Loser & $0,91 \%$ & $2,29 \%$ & $-6,63 \%$ & $-1,89 \%$ & $-11,88 \%$ & $17,72 \%$ & $15,88 \%$ & $-11,03 \%$ & $-6,36 \%$ & $4,25 \%$ & $2,86 \%$ & $-3,88 \%$ \\
\hline Big|Low|Winner & $-10,22 \%$ & $13,92 \%$ & $-7,63 \%$ & $-3,71 \%$ & $-11,62 \%$ & $7,66 \%$ & $14,89 \%$ & $-3,99 \%$ & $-8,69 \%$ & $10,38 \%$ & $8,00 \%$ & $-7,07 \%$ \\
\hline Big|Medium |Loser & $4,98 \%$ & $8,15 \%$ & $-5,39 \%$ & $-3,69 \%$ & $-9,53 \%$ & $12,05 \%$ & $21,64 \%$ & $-7,50 \%$ & $-12,40 \%$ & $0,30 \%$ & $-5,50 \%$ & $5,71 \%$ \\
\hline Big|Medium/Winner & $1,84 \%$ & $5,29 \%$ & $-9,81 \%$ & $-4,46 \%$ & $-10,79 \%$ & $21,72 \%$ & $14,79 \%$ & $-12,91 \%$ & $-11,16 \%$ & $5,09 \%$ & $-5,40 \%$ & $3,57 \%$ \\
\hline Small|High|Loser & $77 \%$ & $5,56 \%$ & $3,48 \%$ & $-6,97 \%$ & $-9,65 \%$ & $10,78 \%$ & $33,34 \%$ & $4,06 \%$ & $-8,53 \%$ & $-6,26 \%$ & $-5,63 \%$ & $4,56 \%$ \\
\hline Small|High |Winner & $11,36 \%$ & $1,68 \%$ & $-5,66 \%$ & $-6,99 \%$ & $-5,61 \%$ & $4,15 \%$ & $12,13 \%$ & $-4,64 \%$ & $-6,98 \%$ & $1,39 \%$ & $-12,53 \%$ & $9,45 \%$ \\
\hline Small|Low|Loser & $12,51 \%$ & $-2,25 \%$ & $4,08 \%$ & $-5,94 \%$ & $-12,18 \%$ & $8,03 \%$ & $7,09 \%$ & $-4,70 \%$ & $-7,07 \%$ & $1,69 \%$ & $-13,34 \%$ & $0,32 \%$ \\
\hline Small|Low|Winner & $12,51 \%$ & $-2,25 \%$ & $4,08 \%$ & $-5,94 \%$ & $-12,18 \%$ & $8,03 \%$ & $7,09 \%$ & $-4,70 \%$ & $-7,07 \%$ & $1,69 \%$ & $-13,34 \%$ & $0,32 \%$ \\
\hline Small|Medium|Loser & $6,42 \%$ & $6,45 \%$ & $-3,79 \%$ & $-4,64 \%$ & $-1,02 \%$ & $4,98 \%$ & $11,31 \%$ & $-6,34 \%$ & $-1,56 \%$ & $-2,63 \%$ & $-3,22 \%$ & $3,33 \%$ \\
\hline Small|Medium/Winner & $4,59 \%$ & $0,96 \%$ & $-4,04 \%$ & $-3,69 \%$ & $-0,89 \%$ & $\begin{array}{ll}4,65 \% \\
\end{array}$ & $7,26 \%$ & $-2,76 \%$ & $-1,43 \%$ & $-2,56 \%$ & $-2,86 \%$ & $0,13 \%$ \\
\hline
\end{tabular}

\begin{tabular}{|c|c|c|c|c|c|c|c|c|c|c|c|c|}
\hline Carteiras & $\mathrm{jul} / 01$ & ago/01 & set/01 & out/01 & nov/01 & dez/01 & jan/02 & $\mathrm{fev} / 02$ & $\mathrm{mar} / 02$ & $a b r / 02$ & mai/02 & jun/02 \\
\hline Big|High|Loser & $-4,61 \%$ & $-1,36 \%$ & $-14,80 \%$ & $5,22 \%$ & $18,26 \%$ & $8,81 \%$ & $9,15 \%$ & $4,42 \%$ & $-2,83 \%$ & $6,35 \%$ & $-4,03 \%$ & $-6,03 \%$ \\
\hline Big|High | Winner & $14,77 \%$ & $0,23 \%$ & $-14,06 \%$ & $12,17 \%$ & $-4,41 \%$ & $3,28 \%$ & $9,46 \%$ & $13,43 \%$ & $-5,13 \%$ & $-6,06 \%$ & $-8,85 \%$ & $-9,08 \%$ \\
\hline Big|Low|Loser & $-11,43 \%$ & $-10,84 \%$ & $-26,20 \%$ & $5,03 \%$ & $22,61 \%$ & $3,50 \%$ & $-10,08 \%$ & $5,54 \%$ & $-13,97 \%$ & $-3,00 \%$ & $-4,14 \%$ & $-19,17 \%$ \\
\hline Big|Low|Winner & $-2,33 \%$ & $-4,71 \%$ & $-13,09 \%$ & $5,87 \%$ & $-0,24 \%$ & $4,67 \%$ & $-3,72 \%$ & $10,52 \%$ & $3,42 \%$ & $-0,51 \%$ & $2,04 \%$ & $-6,32 \%$ \\
\hline Big|Medium|Loser & $-7,28 \%$ & $-8,12 \%$ & $-6,93 \%$ & $5,85 \%$ & $16,85 \%$ & $-0,81 \%$ & $-3,11 \%$ & $9,82 \%$ & $-2,67 \%$ & $1,07 \%$ & $-2,60 \%$ & $-7,41 \%$ \\
\hline Big|Medium/Winner & $0,53 \%$ & $-0,60 \%$ & $-22,15 \%$ & $4,13 \%$ & $9,58 \%$ & $6,24 \%$ & $-0,71 \%$ & $8,02 \%$ & $-2,08 \%$ & $7,80 \%$ & $-7,19 \%$ & $-7,93 \%$ \\
\hline Small|High|Loser & $0,85 \%$ & $-2,97 \%$ & $-11,68 \%$ & $9,15 \%$ & $11,58 \%$ & $3,13 \%$ & $0,96 \%$ & $6,44 \%$ & $2,17 \%$ & $-6,16 \%$ & $-1,03 \%$ & $-2,57 \%$ \\
\hline Small|High/Winner & $-1,35 \%$ & $2,02 \%$ & $-10,27 \%$ & $6,44 \%$ & $12,14 \%$ & $0,93 \%$ & $1,31 \%$ & $2,12 \%$ & $-0,82 \%$ & $-3,09 \%$ & $-4,24 \%$ & $-6,18 \%$ \\
\hline Small|Low|Loser & $3,38 \%$ & $-0,51 \%$ & $-18,41 \%$ & $2,52 \%$ & $11,20 \%$ & $14,54 \%$ & $8,00 \%$ & $2,04 \%$ & $-7,56 \%$ & $-3,35 \%$ & $-15,31 \%$ & $-24,16 \%$ \\
\hline Small|Low|Winner & $3,38 \%$ & $-0,51 \%$ & $-18,41 \%$ & $2,52 \%$ & $11,20 \%$ & $14,54 \%$ & $8,00 \%$ & $2,04 \%$ & $-7,56 \%$ & $-3,35 \%$ & $-15,31 \%$ & $-24,16 \%$ \\
\hline Small|Medium|Loser & $31,07 \%$ & $-3,52 \%$ & $-13,63 \%$ & $3,08 \%$ & $11,68 \%$ & $3,12 \%$ & $-4,14 \%$ & $4,41 \%$ & $3,89 \%$ & $-5,12 \%$ & $-4,71 \%$ & $-2,17 \%$ \\
\hline Small|Medium|Winner & $-2,25 \%$ & $5,85 \%$ & $-8,97 \%$ & $8,63 \%$ & $6,01 \%$ & $-1,90 \%$ & $-2,79 \%$ & $5,11 \%$ & $1,00 \%$ & $5,20 \%$ & $-6,51 \%$ & $-6,64 \%$ \\
\hline
\end{tabular}


Anexo 2 - Retorno mensal das carteiras

\begin{tabular}{|c|c|c|c|c|c|c|c|c|c|c|c|c|}
\hline Carteiras & jul/02 & ago/02 & set/02 & out/02 & nov/02 & $\mathrm{dez} / 02$ & $\mathrm{jan} / 03$ & fev/03 & $\mathrm{mar} / 03$ & $\mathrm{abr} / 03$ & mai/03 & jun/03 \\
\hline Big|High|Loser & $-20,04 \%$ & $6,22 \%$ & $-10,60 \%$ & $9,27 \%$ & $-4,14 \%$ & $8,20 \%$ & $-6,64 \%$ & $-12,16 \%$ & $3,68 \%$ & $26,41 \%$ & $5,77 \%$ & $-5,85 \%$ \\
\hline Big|High/Winner & $-22,12 \%$ & $2,95 \%$ & $-26,07 \%$ & $28,34 \%$ & $-0,92 \%$ & $15,98 \%$ & $-13,73 \%$ & $-9,62 \%$ & $6,72 \%$ & $19,37 \%$ & $6,43 \%$ & $-10,94 \%$ \\
\hline Big|Low|Loser & $-12,16 \%$ & $3,27 \%$ & $-12,79 \%$ & $18,68 \%$ & $0,92 \%$ & $3,84 \%$ & $-3,13 \%$ & $-10,60 \%$ & $10,23 \%$ & $5,52 \%$ & $5,18 \%$ & $-2,21 \%$ \\
\hline Big|Low|Winner & $2,27 \%$ & $-5,31 \%$ & $8,83 \%$ & $9,86 \%$ & $3,52 \%$ & $2,69 \%$ & $-4,12 \%$ & $4,23 \%$ & $-6,14 \%$ & $-6,03 \%$ & $5,51 \%$ & $-2,22 \%$ \\
\hline Big|Medium|Loser & $-5,69 \%$ & $8,27 \%$ & $-8,06 \%$ & $15,73 \%$ & $-4,15 \%$ & $1,79 \%$ & $-4,79 \%$ & $0,52 \%$ & $3,80 \%$ & $13,58 \%$ & $4,78 \%$ & $-2,14 \%$ \\
\hline Big|Medium|Winner & $-5,50 \%$ & $-0,56 \%$ & $-11,87 \%$ & $9,39 \%$ & $-0,48 \%$ & $9,50 \%$ & $-1,47 \%$ & $-4,51 \%$ & $4,30 \%$ & $10,20 \%$ & $4,36 \%$ & $2,55 \%$ \\
\hline Small|High|Loser & $-6,55 \%$ & $3,39 \%$ & $-2,09 \%$ & $-2,24 \%$ & $5,58 \%$ & $-0,81 \%$ & $1,41 \%$ & $-13,04 \%$ & $0,85 \%$ & $5,81 \%$ & $1,12 \%$ & $-7,92 \%$ \\
\hline Small|High/Winner & $3,45 \%$ & $6,91 \%$ & $-8,89 \%$ & $11,02 \%$ & $-2,02 \%$ & $8,78 \%$ & $-1,83 \%$ & $6,00 \%$ & $7,11 \%$ & $7,43 \%$ & $5,77 \%$ & $1,57 \%$ \\
\hline Small|Low|Loser & $-17,86 \%$ & $0,50 \%$ & $-17,92 \%$ & $-4,51 \%$ & $7,47 \%$ & $2,47 \%$ & $-0,15 \%$ & $-8,67 \%$ & $-6,61 \%$ & $25,31 \%$ & $-1,20 \%$ & $-7,85 \%$ \\
\hline Small|Low|Winner & $-17,86 \%$ & $0,50 \%$ & $-17,92 \%$ & $-4,51 \%$ & $7,47 \%$ & $2,47 \%$ & $-0,15 \%$ & $-8,67 \%$ & $-6,61 \%$ & $25,31 \%$ & $-1,20 \%$ & $-7,85 \%$ \\
\hline Small|Medium|Loser & $-3,59 \%$ & $2,21 \%$ & $-11,17 \%$ & $4,13 \%$ & $6,24 \%$ & $6,31 \%$ & $5,98 \%$ & $-3,62 \%$ & $0,22 \%$ & $-4,00 \%$ & $7,60 \%$ & $-5,13 \%$ \\
\hline Small|Medium|Winner & $-1,86 \%$ & $0,68 \%$ & $-1,67 \%$ & $2,40 \%$ & $6,97 \%$ & $5,47 \%$ & $-5,99 \%$ & $-3,38 \%$ & $2,92 \%$ & $10,62 \%$ & $7,11 \%$ & $8,51 \%$ \\
\hline
\end{tabular}

\begin{tabular}{|c|c|c|c|c|c|c|c|c|c|c|c|c|}
\hline Carteiras & $\mathrm{ul} / 03$ & ago/03 & set/03 & out/03 & nov/03 & dez/03 & jan/04 & fev/04 & $\mathrm{mar} / 04$ & $\mathrm{abr} / 04$ & mai/04 & jun/04 \\
\hline Big|High|Loser & $1,00 \%$ & $10,32 \%$ & $8,07 \%$ & $30,98 \%$ & $15,79 \%$ & $13,84 \%$ & $-20,87 \%$ & $-2,67 \%$ & $5,84 \%$ & $-12,45 \%$ & $-7,75 \%$ & $9,02 \%$ \\
\hline Big|High|Winner & $6,61 \%$ & $15,59 \%$ & $8 \%$ & $45 \%$ & $38 \%$ & $1 \%$ & $-6,00 \%$ & $1,56 \%$ & $56 \%$ & $-18,62 \%$ & $2,09 \%$ & $86 \%$ \\
\hline Big|Low|Loser & $6,55 \%$ & $7,79 \%$ & $0,95 \%$ & $5,90 \%$ & $9,54 \%$ & $15,53 \%$ & $0,67 \%$ & $3,19 \%$ & $6,62 \%$ & $-14,07 \%$ & $-2,66 \%$ & $7,35 \%$ \\
\hline Big|Low/Winner & $9,24 \%$ & $8,98 \%$ & $2,49 \%$ & $5,29 \%$ & $2,66 \%$ & $17,00 \%$ & $-4,78 \%$ & $5,87 \%$ & $-1,76 \%$ & $-10,61 \%$ & $10,92 \%$ & $0,09 \%$ \\
\hline Big|Medium |Loser & $-0,06 \%$ & $10,63 \%$ & $7,28 \%$ & $12,59 \%$ & $2,50 \%$ & $7,50 \%$ & $8,03 \%$ & $-5,77 \%$ & $-1,58 \%$ & $-5,24 \%$ & $-4,26 \%$ & $8,59 \%$ \\
\hline Big|Medium |Winner & $0,55 \%$ & $15,19 \%$ & $1,12 \%$ & $3,56 \%$ & $7,47 \%$ & $11,09 \%$ & $6,56 \%$ & $-4,27 \%$ & $-1,04 \%$ & $-8,86 \%$ & $-2,16 \%$ & $9,97 \%$ \\
\hline Small|High|Loser & $0,57 \%$ & $33 \%$ & $15,33 \%$ & $1 \%$ & $12,63 \%$ & $5,71 \%$ & $6,67 \%$ & $-1,06 \%$ & $1,47 \%$ & $-2,67 \%$ & $-12,46 \%$ & $5,93 \%$ \\
\hline Small|High/Winner & $8,52 \%$ & $6,29 \%$ & $10,11 \%$ & $0,99 \%$ & $12,75 \%$ & $10,05 \%$ & $4,50 \%$ & $1,21 \%$ & $-0,55 \%$ & $0,64 \%$ & $-4,78 \%$ & $10,81 \%$ \\
\hline Small|Low|Loser & $-4,57 \%$ & $13,47 \%$ & $30,35 \%$ & $12,90 \%$ & $32,72 \%$ & $1,90 \%$ & $-7,89 \%$ & $-1,03 \%$ & $-1,36 \%$ & $-7,59 \%$ & $-4,39 \%$ & $2,55 \%$ \\
\hline Small|Low/Winner & $-4,57 \%$ & $13,47 \%$ & $30,35 \%$ & $12,90 \%$ & $32,72 \%$ & $1,90 \%$ & $-7,89 \%$ & $-1,03 \%$ & $-1,36 \%$ & $-7,59 \%$ & $-4,39 \%$ & $2,55 \%$ \\
\hline Small|Medium|Loser & $0,24 \%$ & $6,62 \%$ & $21,19 \%$ & $-1,02 \%$ & $8,39 \%$ & $25,81 \%$ & $1,10 \%$ & $-2,85 \%$ & $0,94 \%$ & $-2,66 \%$ & $-3,97 \%$ & $4,20 \%$ \\
\hline Small|Medium|Winner & $0,84 \%$ & $11,07 \%$ & $4,87 \%$ & $-0,18 \%$ & $1,61 \%$ & $10,44 \%$ & $4,06 \%$ & $0,97 \%$ & $2,54 \%$ & $-7,11 \%$ & $-1,14 \%$ & $3,12 \%$ \\
\hline
\end{tabular}


Anexo 2 - Retorno mensal das carteiras

\begin{tabular}{|c|c|c|c|c|c|c|c|c|c|c|c|c|}
\hline Carteiras & jul/04 & ago/04 & set/04 & out/04 & nov/04 & dez/04 & jan/05 & fev/05 & mar/05 & $\mathrm{abr} / 05$ & mai/05 & jun/05 \\
\hline Big|High|Loser & $27,05 \%$ & $-3,21 \%$ & $8,29 \%$ & $-4,85 \%$ & $6,72 \%$ & $-7,11 \%$ & $-9,61 \%$ & $14,03 \%$ & $-9,35 \%$ & $-5,40 \%$ & $11,82 \%$ & $-5,41 \%$ \\
\hline Big|High|Winner & $-6,02 \%$ & $-1,48 \%$ & $-6,87 \%$ & $-7,40 \%$ & $10,98 \%$ & $-21,15 \%$ & $-23,62 \%$ & $21,58 \%$ & $0,01 \%$ & $-11,74 \%$ & $9,94 \%$ & $-7,53 \%$ \\
\hline Big|Low|Loser & $2,05 \%$ & $4,39 \%$ & $9,38 \%$ & $1,07 \%$ & $2,18 \%$ & $5,18 \%$ & $-4,01 \%$ & $15,01 \%$ & $-6,44 \%$ & $-8,38 \%$ & $1,61 \%$ & $4,31 \%$ \\
\hline Big|Low|Winner & $4,18 \%$ & $3,62 \%$ & $2,84 \%$ & $0,94 \%$ & $6,36 \%$ & $7,14 \%$ & $-4,40 \%$ & $8,21 \%$ & $-6,93 \%$ & $-17,11 \%$ & $0,95 \%$ & $-0,69 \%$ \\
\hline Big|Medium|Loser & $3,29 \%$ & $0,15 \%$ & $1,74 \%$ & $1,40 \%$ & $10,58 \%$ & $7,94 \%$ & $-8,16 \%$ & $8,78 \%$ & $-4,12 \%$ & $-4,48 \%$ & $1,70 \%$ & $3,96 \%$ \\
\hline Big|Medium/Winner & $18,17 \%$ & $8,79 \%$ & $1,40 \%$ & $-4,04 \%$ & $14,95 \%$ & $3,66 \%$ & $-3,65 \%$ & $19,43 \%$ & $-7,67 \%$ & $-9,72 \%$ & $-3,91 \%$ & $-9,16 \%$ \\
\hline Small|High|Loser & $3,51 \%$ & $5,36 \%$ & $15,38 \%$ & $-0,77 \%$ & $3,09 \%$ & $0,46 \%$ & $-6,35 \%$ & $10,19 \%$ & $-5,35 \%$ & $-8,90 \%$ & $3,46 \%$ & $-3,71 \%$ \\
\hline Small|High|Winner & $4,98 \%$ & $9,38 \%$ & $5,51 \%$ & $2,51 \%$ & $6,05 \%$ & $16,50 \%$ & $2,57 \%$ & $8,23 \%$ & $-4,99 \%$ & $2,00 \%$ & $-5,90 \%$ & $-6,48 \%$ \\
\hline Small|Low|Loser & $-0,06 \%$ & $47,39 \%$ & $-0,33 \%$ & $-11,00 \%$ & $-2,49 \%$ & $8,81 \%$ & $-8,89 \%$ & $2,62 \%$ & $-3,50 \%$ & $-2,89 \%$ & $0,31 \%$ & $-9,69 \%$ \\
\hline Small|Low|Winner & $-0,06 \%$ & $47,39 \%$ & $-0,33 \%$ & $-11,00 \%$ & $-2,49 \%$ & $8,81 \%$ & $-8,89 \%$ & $2,62 \%$ & $-3,50 \%$ & $-2,89 \%$ & $0,31 \%$ & $-9,69 \%$ \\
\hline Small|Medium|Loser & $7,60 \%$ & $7,84 \%$ & $7,25 \%$ & $-2,20 \%$ & $2,07 \%$ & $6,40 \%$ & $-8,26 \%$ & $11,64 \%$ & $-3,27 \%$ & $-5,90 \%$ & $-1,88 \%$ & $-1,91 \%$ \\
\hline Small|Medium|Winner & $12,20 \%$ & $11,44 \%$ & $7,56 \%$ & $3,69 \%$ & $7,65 \%$ & $4,36 \%$ & $-6,91 \%$ & $12,42 \%$ & $-2,64 \%$ & $-0,63 \%$ & $-1,59 \%$ & $-0,14 \%$ \\
\hline
\end{tabular}

\begin{tabular}{|c|c|c|c|c|c|c|c|c|c|c|c|c|}
\hline Carteiras & $\mathrm{jul} / 05$ & ago/05 & set/05 & out/05 & nov/05 & dez/05 & jan/06 & $\mathrm{fev} / 06$ & $\mathrm{mar} / 06$ & $a b r / 06$ & mai/06 & jun/06 \\
\hline Big|High|Loser & $-0,34 \%$ & $-0,24 \%$ & $27,05 \%$ & $-9,15 \%$ & $2,21 \%$ & $0,79 \%$ & $4,06 \%$ & $6,55 \%$ & $4,86 \%$ & $19,28 \%$ & $-18,37 \%$ & $7,16 \%$ \\
\hline Big|High | Winner & $-6,95 \%$ & $7,23 \%$ & $19,60 \%$ & $-3,77 \%$ & $8,00 \%$ & $4,40 \%$ & $6,73 \%$ & $2,60 \%$ & $-3,06 \%$ & $0,10 \%$ & $-13,04 \%$ & $9,91 \%$ \\
\hline Big|Low|Loser & $5,61 \%$ & $2,98 \%$ & $12,90 \%$ & $-5,04 \%$ & $4,41 \%$ & $3,24 \%$ & $10,24 \%$ & $-1,88 \%$ & $0,00 \%$ & $3,51 \%$ & $-5,25 \%$ & $-1,29 \%$ \\
\hline Big|Low|Winner & $5,35 \%$ & $-0,48 \%$ & $10,59 \%$ & $-3,83 \%$ & $5,41 \%$ & $4,59 \%$ & $7,91 \%$ & $1,69 \%$ & $0,61 \%$ & $-1,40 \%$ & $-6,50 \%$ & $-1,51 \%$ \\
\hline Big|Medium|Loser & $2,59 \%$ & $13,50 \%$ & $8,72 \%$ & $-8,26 \%$ & $5,26 \%$ & $6,59 \%$ & $20,53 \%$ & $-3,19 \%$ & $-4,69 \%$ & $8,16 \%$ & $-7,64 \%$ & $-2,30 \%$ \\
\hline Big|Medium/Winner & $3,84 \%$ & $6,63 \%$ & $8,41 \%$ & $-3,50 \%$ & $6,61 \%$ & $4,63 \%$ & $17,63 \%$ & $2,86 \%$ & $-0,53 \%$ & $18,69 \%$ & $-9,34 \%$ & $-1,80 \%$ \\
\hline Small|High|Loser & $-0,46 \%$ & $2,21 \%$ & $14,64 \%$ & $-4,99 \%$ & $3,20 \%$ & $5,28 \%$ & $17,90 \%$ & $15,65 \%$ & $-0,16 \%$ & $3,99 \%$ & $-8,21 \%$ & $-2,51 \%$ \\
\hline Small|High/Winner & $-3,96 \%$ & $-1,24 \%$ & $13,60 \%$ & $11,12 \%$ & $11,23 \%$ & $13,31 \%$ & $4,21 \%$ & $6,69 \%$ & $0,19 \%$ & $6,69 \%$ & $-7,54 \%$ & $2,77 \%$ \\
\hline Small|Low|Loser & $-4,90 \%$ & $1,41 \%$ & $2,84 \%$ & $-5,66 \%$ & $3,57 \%$ & $-7,77 \%$ & $-6,14 \%$ & $-0,80 \%$ & $-5,69 \%$ & $-3,44 \%$ & $-17,97 \%$ & $-6,14 \%$ \\
\hline Small|Low|Winner & $-4,90 \%$ & $1,41 \%$ & $2,84 \%$ & $-5,66 \%$ & $3,57 \%$ & $-7,77 \%$ & $-6,14 \%$ & $-0,80 \%$ & $-5,69 \%$ & $-3,44 \%$ & $-17,97 \%$ & $-6,14 \%$ \\
\hline Small|Medium|Loser & $-1,94 \%$ & $-2,83 \%$ & $10,97 \%$ & $-8,88 \%$ & $-0,56 \%$ & $9,48 \%$ & $3,50 \%$ & $-0,65 \%$ & $7,28 \%$ & $6,62 \%$ & $-4,37 \%$ & $-0,45 \%$ \\
\hline Small|Medium|Winner & $-3,25 \%$ & $2,67 \%$ & $3,96 \%$ & $-4,24 \%$ & $2,12 \%$ & $15,85 \%$ & $7,20 \%$ & $0,31 \%$ & $-4,16 \%$ & $4,66 \%$ & $3,00 \%$ & $0,25 \%$ \\
\hline
\end{tabular}


Anexo 2 - Retorno mensal das carteiras

\begin{tabular}{|c|c|c|c|c|c|c|c|c|c|c|c|c|}
\hline Carteiras & jul/06 & ago/06 & set/06 & out/06 & nov/06 & dez/06 & jan/07 & fev/07 & mar/07 & $\mathrm{abr} / 07$ & mai/07 & jun/07 \\
\hline Big|High|Loser & $0,88 \%$ & $-0,89 \%$ & $1,58 \%$ & $0,74 \%$ & $0,34 \%$ & $-0,52 \%$ & $-0,41 \%$ & $-20,24 \%$ & $4,72 \%$ & $20,71 \%$ & $-0,25 \%$ & $3,02 \%$ \\
\hline Big|High|Winner & $-0,89 \%$ & $2,17 \%$ & $3,55 \%$ & $-4,63 \%$ & $8,22 \%$ & $2,81 \%$ & $-2,71 \%$ & $-7,04 \%$ & $0,96 \%$ & $2,05 \%$ & $12,32 \%$ & $12,09 \%$ \\
\hline Big|Low|Loser & $-0,58 \%$ & $5,15 \%$ & $2,24 \%$ & $4,90 \%$ & $8,49 \%$ & $0,34 \%$ & $-2,68 \%$ & $3,18 \%$ & $1,01 \%$ & $6,77 \%$ & $1,32 \%$ & $2,49 \%$ \\
\hline Big|Low|Winner & $0,14 \%$ & $-1,98 \%$ & $-2,04 \%$ & $5,65 \%$ & $7,63 \%$ & $5,90 \%$ & $1,06 \%$ & $-4,24 \%$ & $5,18 \%$ & $4,07 \%$ & $4,34 \%$ & $6,00 \%$ \\
\hline Big|Medium|Loser & $-3,58 \%$ & $6,64 \%$ & $2,65 \%$ & $6,72 \%$ & $10,48 \%$ & $3,25 \%$ & $-2,75 \%$ & $-1,68 \%$ & $6,97 \%$ & $11,80 \%$ & $2,20 \%$ & $1,65 \%$ \\
\hline Big|Medium/Winner & $0,46 \%$ & $-5,12 \%$ & $-0,07 \%$ & $6,68 \%$ & $6,14 \%$ & $4,23 \%$ & $2,13 \%$ & $4,85 \%$ & $5,29 \%$ & $6,38 \%$ & $5,71 \%$ & $6,39 \%$ \\
\hline Small|High|Loser & $-2,35 \%$ & $1,68 \%$ & $-1,06 \%$ & $6,01 \%$ & $7,57 \%$ & $9,46 \%$ & $5,12 \%$ & $11,05 \%$ & $3,64 \%$ & $16,37 \%$ & $20,24 \%$ & $1,76 \%$ \\
\hline Small|High|Winner & $-3,69 \%$ & $1,91 \%$ & $-3,86 \%$ & $2,49 \%$ & $5,41 \%$ & $0,88 \%$ & $6,40 \%$ & $5,37 \%$ & $2,58 \%$ & $20,70 \%$ & $12,87 \%$ & $5,43 \%$ \\
\hline Small|Low|Loser & $-3,57 \%$ & $2,34 \%$ & $-1,59 \%$ & $2,66 \%$ & $9,30 \%$ & $8,64 \%$ & $8,75 \%$ & $7,23 \%$ & $9,57 \%$ & $4,49 \%$ & $4,45 \%$ & $5,64 \%$ \\
\hline Small|Low|Winner & $-3,57 \%$ & $2,34 \%$ & $-1,59 \%$ & $2,66 \%$ & $9,30 \%$ & $8,64 \%$ & $8,75 \%$ & $7,23 \%$ & $9,57 \%$ & $4,49 \%$ & $4,45 \%$ & $5,64 \%$ \\
\hline Small|Medium|Loser & $-1,34 \%$ & $4,69 \%$ & $1,00 \%$ & $1,38 \%$ & $12,42 \%$ & $1,92 \%$ & $5,06 \%$ & $1,17 \%$ & $16,88 \%$ & $8,10 \%$ & $12,57 \%$ & $0,55 \%$ \\
\hline Small|Medium|Winner & $4,50 \%$ & $-2,39 \%$ & $0,38 \%$ & $3,60 \%$ & $8,28 \%$ & $11,41 \%$ & $6,20 \%$ & $1,86 \%$ & $4,52 \%$ & $6,54 \%$ & $1,75 \%$ & $4,75 \%$ \\
\hline
\end{tabular}

\begin{tabular}{|c|c|c|c|c|c|c|c|c|c|c|c|c|}
\hline Carteiras & $\mathrm{ul} / 07$ & go/07 & set/07 & out/07 & nov/07 & dez/07 & jan/08 & $\mathrm{fev} / 08$ & mar/08 & $\mathrm{abr} / 08$ & mai/08 & jun/08 \\
\hline Big|High|Loser & $-7,95 \%$ & $0,80 \%$ & $1,56 \%$ & $0,27 \%$ & $-6,13 \%$ & $-2,54 \%$ & $-6,50 \%$ & $9,57 \%$ & $0,65 \%$ & $0,20 \%$ & $10,67 \%$ & $5,35 \%$ \\
\hline Big|High|Winner & $12,33 \%$ & $-4,53 \%$ & $-0,50 \%$ & $09 \%$ & $-5,34 \%$ & $3 \%$ & $5 \%$ & $0,10 \%$ & & $16 \%$ & $41 \%$ & $3,60 \%$ \\
\hline Big|Low|Loser & $-4,97 \%$ & & $3,95 \%$ & $4,83 \%$ & $-6,59 \%$ & $-2,96 \%$ & $-6,29 \%$ & $8,49 \%$ & $-5,17 \%$ & $4,77 \%$ & $-2,90 \%$ & $-12,20 \%$ \\
\hline Big|Low/Winner & $5,13 \%$ & $0,56 \%$ & $20,00 \%$ & $3,97 \%$ & $-5,16 \%$ & $-4,84 \%$ & $-12,10 \%$ & $8,91 \%$ & $-1,00 \%$ & $7,96 \%$ & $3,01 \%$ & $-12,16 \%$ \\
\hline Big|Medium |Loser & $0,86 \%$ & $-0,03 \%$ & $8,33 \%$ & $14,20 \%$ & $-0,66 \%$ & $13,07 \%$ & $-5,24 \%$ & $4,42 \%$ & $-5,92 \%$ & $12,09 \%$ & $12,47 \%$ & $-5,59 \%$ \\
\hline Big|Medium |Winner & $-4,32 \%$ & $0,60 \%$ & $4,40 \%$ & $2,77 \%$ & $-5,76 \%$ & $-5,30 \%$ & $-11,65 \%$ & $10,15 \%$ & $-4,31 \%$ & $12,78 \%$ & $1,72 \%$ & $-7,57 \%$ \\
\hline Small|High|Loser & $4,72 \%$ & $10,33 \%$ & $1,51 \%$ & $1 \%$ & $-3,41 \%$ & $0,68 \%$ & $-8,29 \%$ & $5,11 \%$ & $0,89 \%$ & $4,78 \%$ & $8,85 \%$ & $-4,34 \%$ \\
\hline Small|High|Winner & $-5,59 \%$ & $2,35 \%$ & $3,39 \%$ & $4,16 \%$ & $-12,78 \%$ & $-2,08 \%$ & $-11,60 \%$ & $2,85 \%$ & $-6,94 \%$ & $-1,57 \%$ & $6,83 \%$ & $-2,78 \%$ \\
\hline Small|Low|Loser & $1,82 \%$ & $-6,70 \%$ & $-0,11 \%$ & $-1,24 \%$ & $-11,13 \%$ & $-1,30 \%$ & $-15,98 \%$ & $7,44 \%$ & $-1,40 \%$ & $5,09 \%$ & $13,21 \%$ & $-4,71 \%$ \\
\hline Small|Low/Winner & $1,82 \%$ & $-6,70 \%$ & $-0,11 \%$ & $-1,24 \%$ & $-11,13 \%$ & $-1,30 \%$ & $-15,98 \%$ & $7,44 \%$ & $-1,40 \%$ & $5,09 \%$ & $13,21 \%$ & $-4,71 \%$ \\
\hline Small|Medium|Loser & $2,61 \%$ & $2,85 \%$ & $1,19 \%$ & $2,69 \%$ & $-1,22 \%$ & $-2,91 \%$ & $-5,96 \%$ & $0,49 \%$ & $-4,20 \%$ & $-0,09 \%$ & $2,13 \%$ & $-5,13 \%$ \\
\hline Small|Medium|Winner & $1,09 \%$ & $-0,89 \%$ & $0,40 \%$ & $4,40 \%$ & $-8,53 \%$ & $-0,19 \%$ & $-7,40 \%$ & $2,65 \%$ & $-6,68 \%$ & $4,58 \%$ & $7,01 \%$ & $-5,81 \%$ \\
\hline
\end{tabular}


Anexo 2 - Retorno mensal das carteiras

\begin{tabular}{|c|c|c|c|c|c|c|c|c|c|c|c|c|}
\hline Carteiras & jul/08 & ago/08 & set/08 & out/08 & nov/08 & dez/08 & jan/09 & fev/09 & mar/09 & $a b r / 09$ & mai/09 & jun/09 \\
\hline Big|High|Loser & $-1,67 \%$ & $-7,59 \%$ & $-11,77 \%$ & $-15,63 \%$ & $5,15 \%$ & $-1,69 \%$ & $-2,25 \%$ & $2,30 \%$ & $-2,98 \%$ & $14,53 \%$ & 4,49\% & $3,04 \%$ \\
\hline Big|High|Winner & $0,84 \%$ & $-7,14 \%$ & $-10,45 \%$ & $-17,11 \%$ & $9,75 \%$ & $-1,38 \%$ & $-7,33 \%$ & $3,17 \%$ & $7,08 \%$ & $7,89 \%$ & $6,19 \%$ & $-4,97 \%$ \\
\hline Big|Low|Loser & $-5,46 \%$ & $0,57 \%$ & $-4,71 \%$ & $-16,81 \%$ & $2,25 \%$ & $2,87 \%$ & $-2,48 \%$ & $0,51 \%$ & $6,91 \%$ & $15,43 \%$ & $6,67 \%$ & $1,38 \%$ \\
\hline Big|Low|Winner & $-18,03 \%$ & $-5,69 \%$ & $-9,13 \%$ & $-28,10 \%$ & $-10,14 \%$ & $9,16 \%$ & $11,49 \%$ & $0,23 \%$ & $4,70 \%$ & $11,83 \%$ & $11,80 \%$ & $-7,33 \%$ \\
\hline Big|Medium |Loser & $-5,29 \%$ & $-5,03 \%$ & $-7,44 \%$ & $-20,78 \%$ & $4,41 \%$ & $-4,61 \%$ & $3,12 \%$ & $1,31 \%$ & $0,18 \%$ & $16,01 \%$ & 7,16\% & $-3,78 \%$ \\
\hline Big|Medium/Winner & $-6,49 \%$ & $-10,29 \%$ & $-20,43 \%$ & $-26,48 \%$ & $0,23 \%$ & $3,61 \%$ & $4,60 \%$ & $-6,85 \%$ & $4,45 \%$ & $17,70 \%$ & $15,83 \%$ & $-2,86 \%$ \\
\hline Small|High|Loser & $-9,51 \%$ & $-7,51 \%$ & $-21,94 \%$ & $-25,34 \%$ & $-3,43 \%$ & $2,77 \%$ & $-3,91 \%$ & $2,67 \%$ & $-2,23 \%$ & $24,92 \%$ & $10,87 \%$ & $6,61 \%$ \\
\hline Small|High |Winner & $-4,96 \%$ & $-4,02 \%$ & $-10,62 \%$ & $-19,29 \%$ & $-6,36 \%$ & $1,05 \%$ & $-1,62 \%$ & $-5,81 \%$ & $-4,15 \%$ & $10,76 \%$ & $8,31 \%$ & $3,43 \%$ \\
\hline Small|Low|Loser & $-10,48 \%$ & $-10,79 \%$ & $-24,64 \%$ & $-21,44 \%$ & $-6,94 \%$ & $3,03 \%$ & $-3,27 \%$ & $-0,13 \%$ & $6,03 \%$ & $35,41 \%$ & $5,07 \%$ & $2,22 \%$ \\
\hline Small|Low|Winner & $-10,48 \%$ & $-10,79 \%$ & $-24,64 \%$ & $-21,44 \%$ & $-6,94 \%$ & $3,03 \%$ & $-3,27 \%$ & $-0,13 \%$ & $6,03 \%$ & $35,41 \%$ & $5,07 \%$ & $2,22 \%$ \\
\hline Small|Medium|Loser & $-6,41 \%$ & $-8,68 \%$ & $-20,40 \%$ & $-31,11 \%$ & $2,64 \%$ & $7,87 \%$ & $-1,64 \%$ & $-1,30 \%$ & $-1,62 \%$ & $31,36 \%$ & $9,23 \%$ & $5,30 \%$ \\
\hline Small|Medium/Winner & $-12,14 \%$ & $-3,05 \%$ & $-22,83 \%$ & $-31,41 \%$ & $-5,12 \%$ & $-8,55 \%$ & $2,30 \%$ & $-5,12 \%$ & $3,07 \%$ & $36,38 \%$ & $18,25 \%$ & $5,85 \%$ \\
\hline
\end{tabular}

\begin{tabular}{|c|c|c|c|c|c|c|c|c|c|c|c|c|}
\hline Carteiras & $\mathrm{jul} / 09$ & ago/09 & set/09 & out/09 & nov/09 & dez/09 & jan/10 & $\mathrm{fev} / 10$ & mar/10 & $a b r / 10$ & mai/10 & jun/10 \\
\hline Big|High|Loser & $12,37 \%$ & $7,03 \%$ & $6,63 \%$ & $1,87 \%$ & $7,20 \%$ & $4,77 \%$ & $3,71 \%$ & $-2,67 \%$ & $-1,94 \%$ & $-4,10 \%$ & $-7,00 \%$ & $1,48 \%$ \\
\hline Big|High | Winner & $0,95 \%$ & $-0,38 \%$ & $-0,64 \%$ & $-7,66 \%$ & $10,95 \%$ & $20,96 \%$ & $4,02 \%$ & $-14,62 \%$ & $9,33 \%$ & $-3,96 \%$ & $-5,16 \%$ & $5,43 \%$ \\
\hline Big|Low|Loser & $9,78 \%$ & $4,91 \%$ & $6,01 \%$ & $2,00 \%$ & $7,73 \%$ & $-0,19 \%$ & $-3,40 \%$ & $4,19 \%$ & $9,95 \%$ & $-5,54 \%$ & $-10,66 \%$ & $-3,64 \%$ \\
\hline Big|Low|Winner & $1,51 \%$ & $0,92 \%$ & $8,07 \%$ & $0,98 \%$ & $6,24 \%$ & $2,56 \%$ & $-4,60 \%$ & $-0,19 \%$ & $0,96 \%$ & $-1,74 \%$ & $-4,56 \%$ & $-1,59 \%$ \\
\hline Big|Medium|Loser & $8,50 \%$ & $1,25 \%$ & $9,22 \%$ & $6,30 \%$ & $7,53 \%$ & $1,96 \%$ & $-3,18 \%$ & $2,97 \%$ & $10,77 \%$ & $-6,00 \%$ & $-8,27 \%$ & $-8,71 \%$ \\
\hline Big|Medium/Winner & $0,78 \%$ & $-1,43 \%$ & $7,96 \%$ & $-0,03 \%$ & $8,77 \%$ & $-2,27 \%$ & $-6,39 \%$ & $-0,77 \%$ & $0,03 \%$ & $-5,50 \%$ & $-2,83 \%$ & $-5,32 \%$ \\
\hline Small|High|Loser & $25,11 \%$ & $12,35 \%$ & $12,01 \%$ & $2,16 \%$ & $1,90 \%$ & $1,06 \%$ & $2,39 \%$ & $1,58 \%$ & $-5,55 \%$ & $-6,01 \%$ & $-9,54 \%$ & $-0,55 \%$ \\
\hline Small|High/Winner & $5,76 \%$ & $5,71 \%$ & $2,31 \%$ & $-0,89 \%$ & $1,23 \%$ & $8,06 \%$ & $0,06 \%$ & $-0,28 \%$ & $-5,31 \%$ & $-3,88 \%$ & $-6,44 \%$ & $-0,33 \%$ \\
\hline Small|Low|Loser & $-2,12 \%$ & $10,17 \%$ & $14,06 \%$ & $6,08 \%$ & $-4,88 \%$ & $10,88 \%$ & $17,96 \%$ & $3,36 \%$ & $-7,87 \%$ & $-9,52 \%$ & $-16,85 \%$ & $6,62 \%$ \\
\hline Small|Low|Winner & $-2,12 \%$ & $10,17 \%$ & $14,06 \%$ & $6,08 \%$ & $-4,88 \%$ & $10,88 \%$ & $17,96 \%$ & $3,36 \%$ & $-7,87 \%$ & $-9,52 \%$ & $-16,85 \%$ & $6,62 \%$ \\
\hline Small|Medium|Loser & $18,22 \%$ & $6,80 \%$ & $9,61 \%$ & $4,84 \%$ & $12,34 \%$ & $8,69 \%$ & $1,40 \%$ & $-3,71 \%$ & $0,13 \%$ & $1,34 \%$ & $-5,87 \%$ & $2,79 \%$ \\
\hline Small|Medium|Winner & $10,39 \%$ & $6,10 \%$ & $6,79 \%$ & $5,71 \%$ & $7,46 \%$ & $2,05 \%$ & $2,04 \%$ & $3,17 \%$ & $4,13 \%$ & $6,78 \%$ & $-3,36 \%$ & $4,46 \%$ \\
\hline
\end{tabular}


Anexo 2 - Retorno mensal das carteiras

\begin{tabular}{|c|c|c|c|c|c|c|c|c|c|c|c|c|}
\hline Carteiras & $\mathrm{jul} / 10$ & ago/10 & set/10 & out/10 & nov/10 & $\mathrm{dez} / 10$ & jan/11 & $\mathrm{fev} / 11$ & $\mathrm{mar} / 11$ & $a b r / 11$ & mai/11 & jun/11 \\
\hline Big|High|Loser & $0,94 \%$ & $-6,04 \%$ & $0,48 \%$ & $2,53 \%$ & $-1,80 \%$ & $4,58 \%$ & $-3,45 \%$ & $1,47 \%$ & $3,46 \%$ & $-5,03 \%$ & $1,76 \%$ & $-3,44 \%$ \\
\hline Big|High | Winner & $5,91 \%$ & $-2,35 \%$ & $-3,60 \%$ & $4,89 \%$ & $6,84 \%$ & $-3,96 \%$ & $3,41 \%$ & $-3,77 \%$ & $8,37 \%$ & $-1,63 \%$ & $0,34 \%$ & $-1,13 \%$ \\
\hline Big|Low|Loser & $6,87 \%$ & $-3,68 \%$ & $5,62 \%$ & $-0,23 \%$ & $-0,66 \%$ & $-0,99 \%$ & $-2,62 \%$ & $-0,01 \%$ & $3,81 \%$ & $-1,57 \%$ & $-0,27 \%$ & $-3,82 \%$ \\
\hline Big|Low/Winner & $9,05 \%$ & $2,03 \%$ & $5,53 \%$ & $6,91 \%$ & $-3,70 \%$ & $1,65 \%$ & $-11,43 \%$ & $0,61 \%$ & $4,09 \%$ & $0,77 \%$ & $-1,92 \%$ & $-1,93 \%$ \\
\hline Big|Medium|Loser & $3,94 \%$ & $-5,34 \%$ & $2,80 \%$ & $-2,79 \%$ & $-4,00 \%$ & $8,34 \%$ & $-1,41 \%$ & $4,35 \%$ & $0,10 \%$ & $-5,99 \%$ & $-4,25 \%$ & $-2,21 \%$ \\
\hline Big|Medium/Winner & $10,47 \%$ & $-3,36 \%$ & $7,70 \%$ & $2,79 \%$ & $-2,62 \%$ & $2,71 \%$ & $0,15 \%$ & $-1,23 \%$ & $-2,16 \%$ & $-2,83 \%$ & $-3,28 \%$ & $-2,46 \%$ \\
\hline Small|High|Loser & $4,78 \%$ & $4,49 \%$ & $0,55 \%$ & $6,39 \%$ & $3,59 \%$ & $6,02 \%$ & $-3,99 \%$ & $-1,92 \%$ & $0,76 \%$ & $-1,33 \%$ & $0,99 \%$ & $-1,29 \%$ \\
\hline Small|High |Winner & $9,29 \%$ & $-0,31 \%$ & $2,86 \%$ & $8,26 \%$ & $-0,13 \%$ & $1,29 \%$ & $-5,93 \%$ & $-2,95 \%$ & $-0,46 \%$ & $-0,70 \%$ & $-6,64 \%$ & $-5,15 \%$ \\
\hline Small|Low|Loser & $2,07 \%$ & $-5,92 \%$ & $-1,11 \%$ & $7,60 \%$ & $0,42 \%$ & $11,03 \%$ & $-2,75 \%$ & $-4,18 \%$ & $-3,42 \%$ & $-3,55 \%$ & $-5,41 \%$ & $-2,79 \%$ \\
\hline Small|Low|Winner & $2,07 \%$ & $-5,92 \%$ & $-1,11 \%$ & $7,60 \%$ & $0,42 \%$ & $11,03 \%$ & $-2,75 \%$ & $-4,18 \%$ & $-3,42 \%$ & $-3,55 \%$ & $-5,41 \%$ & $-2,79 \%$ \\
\hline Small|Medium|Loser & $8,54 \%$ & $3,48 \%$ & $4,58 \%$ & $5,96 \%$ & $0,33 \%$ & $5,30 \%$ & $-6,16 \%$ & $0,97 \%$ & $1,44 \%$ & $0,02 \%$ & $-0,91 \%$ & $-2,68 \%$ \\
\hline Small|Medium/Winner & $12,13 \%$ & $3,10 \%$ & $3,02 \%$ & $6,45 \%$ & $0,39 \%$ & $3,89 \%$ & $-7,04 \%$ & $-2,97 \%$ & $6,09 \%$ & $3,32 \%$ & $-0,46 \%$ & $-2,28 \%$ \\
\hline
\end{tabular}


Anexo 3 - Prêmio mensal dos fatores de risco

\begin{tabular}{|c|c|c|c|c|c|c|c|c|c|c|c|c|}
\hline Carteiras & $\mathrm{jul} / 96$ & ago/96 & set/96 & out/96 & nov/96 & dez/96 & jan/97 & fev/97 & $\mathrm{mar} / 97$ & $\mathrm{abr} / 97$ & mai/97 & jun/97 \\
\hline $\begin{array}{c}\text { Retorno real da carteira de } \\
\text { mercado }\end{array}$ & $-1,21 \%$ & $1,84 \%$ & $2,11 \%$ & $5,09 \%$ & $2,03 \%$ & $7,72 \%$ & $12,17 \%$ & $11,06 \%$ & $0,36 \%$ & $7,01 \%$ & $7,17 \%$ & $8,75 \%$ \\
\hline $\begin{array}{c}\text { Retorno real do ativo livre } \\
\text { de risco (poupança) }\end{array}$ & $1,06 \%$ & $1,13 \%$ & $1,10 \%$ & $1,21 \%$ & $1,37 \%$ & $1,11 \%$ & $1,37 \%$ & $1,42 \%$ & $1,10 \%$ & $1,10 \%$ & $1,15 \%$ & $1,13 \%$ \\
\hline $\begin{array}{l}\text { Prêmio da carteira de } \\
\text { mercado }\end{array}$ & $-2,28 \%$ & $0,71 \%$ & $1,01 \%$ & $3,88 \%$ & $0,66 \%$ & $6,61 \%$ & $10,80 \%$ & $9,64 \%$ & $-0,75 \%$ & $5,91 \%$ & $6,02 \%$ & $7,62 \%$ \\
\hline $\begin{array}{c}\text { Prêmio do fator tamanho } \\
\text { (SMB) } \\
\end{array}$ & $4,27 \%$ & $-1,07 \%$ & $2,22 \%$ & $-4,23 \%$ & $-0,70 \%$ & $-6,96 \%$ & $-0,26 \%$ & $-2,06 \%$ & $4,76 \%$ & $-5,77 \%$ & $5,85 \%$ & $1,59 \%$ \\
\hline $\begin{array}{c}\text { Prêmio do fator índice } \mathrm{B} / \mathrm{M} \\
(H M L)\end{array}$ & $2,49 \%$ & $1,55 \%$ & $-1,90 \%$ & $18,13 \%$ & $4,50 \%$ & $3,30 \%$ & $8,39 \%$ & $-0,07 \%$ & $-1,67 \%$ & $6,71 \%$ & $-2,63 \%$ & $16,90 \%$ \\
\hline $\begin{array}{c}\text { Prêmio do fator momento } \\
\text { (WinMLos) }\end{array}$ & $10,58 \%$ & $0,67 \%$ & $-1,76 \%$ & $-0,78 \%$ & $-0,29 \%$ & $1,82 \%$ & $1,17 \%$ & $-7,31 \%$ & $-0,95 \%$ & $0,03 \%$ & $3,93 \%$ & $-1,32 \%$ \\
\hline
\end{tabular}

\begin{tabular}{|c|c|c|c|c|c|c|c|c|c|c|c|c|}
\hline Carteiras & jul/97 & ago/97 & set/97 & out/97 & nov/97 & dez/97 & jan/98 & $\mathrm{fev} / 98$ & $\mathrm{mar} / 98$ & $\mathrm{abr} / 98$ & mai/98 & jun/98 \\
\hline $\begin{array}{c}\text { Retorno real da carteira de } \\
\text { mercado }\end{array}$ & $4,11 \%$ & $-15,76 \%$ & $11,28 \%$ & $-22,12 \%$ & $3,27 \%$ & $5,25 \%$ & $-7,74 \%$ & $7,71 \%$ & $9,99 \%$ & $-1,03 \%$ & $-16,29 \%$ & $-5,56 \%$ \\
\hline $\begin{array}{c}\text { Retorno real do ativo livre } \\
\text { de risco (poupança) }\end{array}$ & $1,13 \%$ & $1,24 \%$ & $1,08 \%$ & $1,13 \%$ & $1,36 \%$ & $1,91 \%$ & $1,74 \%$ & $1,56 \%$ & $1,30 \%$ & $0,91 \%$ & $1,06 \%$ & $0,93 \%$ \\
\hline $\begin{array}{c}\text { Prêmio da carteira de } \\
\text { mercado }\end{array}$ & $2,98 \%$ & $-17,00 \%$ & $10,20 \%$ & $-23,25 \%$ & $1,91 \%$ & $3,34 \%$ & $-9,47 \%$ & $6,15 \%$ & $8,69 \%$ & $-1,93 \%$ & $-17,35 \%$ & $-6,49 \%$ \\
\hline $\begin{array}{c}\text { Prêmio do fator tamanho } \\
\text { (SMB) }\end{array}$ & $-1,20 \%$ & $5,56 \%$ & $-6,61 \%$ & $12,12 \%$ & $-14,54 \%$ & $-4,05 \%$ & $-0,84 \%$ & $-0,24 \%$ & $6,09 \%$ & $19,33 \%$ & $2,75 \%$ & $0,72 \%$ \\
\hline $\begin{array}{l}\text { Prêmio do fator índice } \mathrm{B} / \mathrm{M} \\
(H M L)\end{array}$ & $3,22 \%$ & $3,85 \%$ & $2,88 \%$ & $-6,31 \%$ & $-2,70 \%$ & $-1,24 \%$ & $-1,16 \%$ & $-4,34 \%$ & $12,48 \%$ & $-8,23 \%$ & $-2,25 \%$ & $0,95 \%$ \\
\hline $\begin{array}{l}\text { Prêmio do fator momento } \\
\text { (WinMLos) }\end{array}$ & $-3,53 \%$ & $-5,54 \%$ & $3,04 \%$ & $-1,26 \%$ & $6,69 \%$ & $-4,09 \%$ & $-3,73 \%$ & $2,79 \%$ & $0,38 \%$ & $1,39 \%$ & $-2,63 \%$ & $-3,79 \%$ \\
\hline
\end{tabular}


Anexo 3 - Prêmio mensal dos fatores de risco

\begin{tabular}{|c|c|c|c|c|c|c|c|c|c|c|c|c|}
\hline Carteiras & $\mathrm{jul} / 98$ & ago/98 & set/98 & out/98 & nov/98 & dez/98 & jan/99 & fev/99 & mar/99 & $\mathrm{abr} / 99$ & mai/99 & jun/99 \\
\hline $\begin{array}{c}\text { Retorno real da carteira de } \\
\text { mercado }\end{array}$ & $8,53 \%$ & $-39,27 \%$ & $2,69 \%$ & $8,43 \%$ & $18,95 \%$ & $-16,19 \%$ & $13,22 \%$ & $8,73 \%$ & $35,76 \%$ & $7,99 \%$ & $1,90 \%$ & $4,85 \%$ \\
\hline $\begin{array}{c}\text { Retorno real do ativo livre } \\
\text { de risco (poupança) }\end{array}$ & $0,98 \%$ & $0,84 \%$ & $1,04 \%$ & $1,88 \%$ & $1,31 \%$ & $0,81 \%$ & $1,28 \%$ & $1,67 \%$ & $1,54 \%$ & $1,06 \%$ & $0,98 \%$ & $0,64 \%$ \\
\hline $\begin{array}{c}\text { Prêmio da carteira de } \\
\text { mercado }\end{array}$ & $7,55 \%$ & $-40,11 \%$ & $1,65 \%$ & $6,55 \%$ & $17,64 \%$ & $-17,00 \%$ & $11,94 \%$ & $7,06 \%$ & $34,22 \%$ & $6,92 \%$ & $0,92 \%$ & $4,20 \%$ \\
\hline $\begin{array}{c}\text { Prêmio do fator tamanho } \\
\text { (SMB) } \\
\end{array}$ & $-14,67 \%$ & $21,58 \%$ & $-12,92 \%$ & $-15,16 \%$ & $-11,11 \%$ & $22,25 \%$ & $1,07 \%$ & $-12,33 \%$ & $-15,98 \%$ & $-9,55 \%$ & $-0,13 \%$ & $4,42 \%$ \\
\hline $\begin{array}{l}\text { Prêmio do fator índice } \mathrm{B} / \mathrm{M} \\
(H M L)\end{array}$ & $4,52 \%$ & $-4,11 \%$ & $6,80 \%$ & $1,49 \%$ & $3,73 \%$ & $-5,95 \%$ & $3,47 \%$ & $4,11 \%$ & $-5,43 \%$ & $13,84 \%$ & $-3,42 \%$ & $-0,75 \%$ \\
\hline $\begin{array}{c}\text { Prêmio do fator momento } \\
\text { (WinMLos) }\end{array}$ & $-0,54 \%$ & $0,36 \%$ & $1,09 \%$ & $6,71 \%$ & $-1,71 \%$ & $3,93 \%$ & $8,24 \%$ & $1,09 \%$ & $-8,11 \%$ & $6,38 \%$ & $1,84 \%$ & $7,98 \%$ \\
\hline
\end{tabular}

\begin{tabular}{|c|c|c|c|c|c|c|c|c|c|c|c|c|}
\hline Carteiras & jul/99 & ago/99 & set/99 & out/99 & nov/99 & dez/99 & jan/00 & $\mathrm{fev} / 00$ & mar/00 & $\mathrm{abr} / 00$ & mai/00 & jun/00 \\
\hline $\begin{array}{c}\text { Retorno real da carteira de } \\
\text { mercado }\end{array}$ & $-5,12 \%$ & $2,51 \%$ & $7,79 \%$ & $5,70 \%$ & $20,24 \%$ & $15,11 \%$ & $-7,45 \%$ & $1,39 \%$ & $3,18 \%$ & $-7,17 \%$ & $1,48 \%$ & $18,32 \%$ \\
\hline $\begin{array}{c}\text { Retorno real do ativo livre } \\
\text { de risco (poupança) }\end{array}$ & $0,82 \%$ & $0,76 \%$ & $0,80 \%$ & $0,74 \%$ & $0,66 \%$ & $0,78 \%$ & $0,72 \%$ & $0,73 \%$ & $0,69 \%$ & $0,73 \%$ & $0,71 \%$ & $0,76 \%$ \\
\hline $\begin{array}{l}\text { Prêmio da carteira de } \\
\text { mercado }\end{array}$ & $-5,94 \%$ & $1,76 \%$ & $6,99 \%$ & $4,97 \%$ & $19,58 \%$ & $14,33 \%$ & $-8,16 \%$ & $0,66 \%$ & $2,49 \%$ & $-7,89 \%$ & $0,76 \%$ & $17,56 \%$ \\
\hline $\begin{array}{l}\text { Prêmio do fator tamanho } \\
\qquad(S M B)\end{array}$ & $0,00 \%$ & $-4,55 \%$ & $-3,70 \%$ & $6,48 \%$ & $-3,29 \%$ & $11,71 \%$ & $6,88 \%$ & $7,20 \%$ & $-0,76 \%$ & $2,62 \%$ & $-4,33 \%$ & $-1,83 \%$ \\
\hline $\begin{array}{l}\text { Prêmio do fator índice } \mathrm{B} / \mathrm{M} \\
(H M L)\end{array}$ & $1,75 \%$ & $2,65 \%$ & $0,15 \%$ & $-0,09 \%$ & $20,42 \%$ & $-15,37 \%$ & $-0,13 \%$ & $2,99 \%$ & $-9,12 \%$ & $-4,63 \%$ & $9,29 \%$ & $2,66 \%$ \\
\hline $\begin{array}{l}\text { Prêmio do fator momento } \\
\text { (WinMLos) }\end{array}$ & $-2,98 \%$ & $2,01 \%$ & $-3,25 \%$ & $-3,97 \%$ & $-3,81 \%$ & $-13,28 \%$ & $-7,88 \%$ & $6,20 \%$ & $1,57 \%$ & $-0,68 \%$ & $4,87 \%$ & $4,11 \%$ \\
\hline
\end{tabular}


Anexo 3 - Prêmio mensal dos fatores de risco

\begin{tabular}{|c|c|c|c|c|c|c|c|c|c|c|c|c|}
\hline Carteiras & jul/00 & ago/00 & set/00 & out/00 & nov/00 & dez/00 & jan/01 & $\mathrm{fev} / 01$ & mar/01 & $a b r / 01$ & mai/01 & jun/01 \\
\hline $\begin{array}{c}\text { Retorno real da carteira de } \\
\text { mercado }\end{array}$ & $-1,60 \%$ & $8,12 \%$ & $-5,35 \%$ & $-3,27 \%$ & $-9,72 \%$ & $11,74 \%$ & $17,22 \%$ & $-6,08 \%$ & $-7,11 \%$ & $5,43 \%$ & $1,02 \%$ & $-1,79 \%$ \\
\hline $\begin{array}{c}\text { Retorno real do ativo livre } \\
\text { de risco (poupança) }\end{array}$ & $0,63 \%$ & $0,71 \%$ & $0,66 \%$ & $0,60 \%$ & $0,66 \%$ & $0,64 \%$ & $0,61 \%$ & $0,60 \%$ & $0,64 \%$ & $0,66 \%$ & $0,65 \%$ & $0,70 \%$ \\
\hline $\begin{array}{c}\text { Prêmio da carteira de } \\
\text { mercado }\end{array}$ & $-2,22 \%$ & $7,41 \%$ & $-6,00 \%$ & $-3,88 \%$ & $-10,37 \%$ & $11,11 \%$ & $16,61 \%$ & $-6,68 \%$ & $-7,75 \%$ & $4,77 \%$ & $0,36 \%$ & $-2,49 \%$ \\
\hline $\begin{array}{l}\text { Prêmio do fator tamanho } \\
\qquad(S M B)\end{array}$ & $7,31 \%$ & $-3,36 \%$ & $4,69 \%$ & $-0,90 \%$ & $3,55 \%$ & $-4,61 \%$ & $-5,62 \%$ & $4,71 \%$ & $1,86 \%$ & $-2,53 \%$ & $-2,27 \%$ & $2,91 \%$ \\
\hline $\begin{array}{l}\text { Prêmio do fator índice } \mathrm{B} / \mathrm{M} \\
(H M L)\end{array}$ & $6,30 \%$ & $-0,95 \%$ & $0,85 \%$ & $-2,87 \%$ & $3,39 \%$ & $-4,35 \%$ & $11,32 \%$ & $2,98 \%$ & $2,12 \%$ & $-8,60 \%$ & $-9,90 \%$ & $6,66 \%$ \\
\hline $\begin{array}{l}\text { Prêmio do fator momento } \\
\text { (WinMLos) }\end{array}$ & $-2,42 \%$ & $3,68 \%$ & $-3,65 \%$ & $-0,59 \%$ & $-1,25 \%$ & $-2,19 \%$ & $-4,57 \%$ & $-0,81 \%$ & $-2,00 \%$ & $4,24 \%$ & $-0,15 \%$ & $-0,01 \%$ \\
\hline
\end{tabular}

\begin{tabular}{|c|c|c|c|c|c|c|c|c|c|c|c|c|}
\hline Carteiras & $\mathrm{jul} / 01$ & ago/01 & set/01 & out/01 & nov/01 & $\mathrm{dez} / 01$ & jan/02 & $\mathrm{fev} / 02$ & mar/02 & $a b r / 02$ & mai/02 & jun/02 \\
\hline $\begin{array}{c}\text { Retorno real da carteira de } \\
\text { mercado }\end{array}$ & $-1,57 \%$ & $-4,12 \%$ & $-14,88 \%$ & $6,78 \%$ & $7,12 \%$ & $4,79 \%$ & $-2,21 \%$ & $9,99 \%$ & $-0,70 \%$ & $0,43 \%$ & $-0,89 \%$ & $-8,16 \%$ \\
\hline $\begin{array}{c}\text { Retorno real do ativo livre } \\
\text { de risco (poupança) }\end{array}$ & $0,71 \%$ & $0,83 \%$ & $0,78 \%$ & $0,76 \%$ & $0,75 \%$ & $0,72 \%$ & $0,76 \%$ & $0,73 \%$ & $0,69 \%$ & $0,70 \%$ & $0,68 \%$ & $0,74 \%$ \\
\hline $\begin{array}{l}\text { Prêmio da carteira de } \\
\text { mercado }\end{array}$ & $-2,28 \%$ & $-4,94 \%$ & $-15,66 \%$ & $6,01 \%$ & $6,37 \%$ & $4,07 \%$ & $-2,97 \%$ & $9,26 \%$ & $-1,39 \%$ & $-0,27 \%$ & $-1,56 \%$ & $-8,90 \%$ \\
\hline $\begin{array}{l}\text { Prêmio do fator tamanho } \\
\qquad(S M B)\end{array}$ & $7,57 \%$ & $4,30 \%$ & $2,64 \%$ & $-0,99 \%$ & $0,19 \%$ & $1,45 \%$ & $1,72 \%$ & $-4,93 \%$ & $2,40 \%$ & $-3,59 \%$ & $-3,72 \%$ & $-1,66 \%$ \\
\hline $\begin{array}{l}\text { Prêmio do fator índice } \mathrm{B} / \mathrm{M} \\
(H M L)\end{array}$ & $4,17 \%$ & $3,62 \%$ & $6,33 \%$ & $4,26 \%$ & $-1,80 \%$ & $-5,27 \%$ & $4,67 \%$ & $1,57 \%$ & $4,77 \%$ & $0,31 \%$ & $3,64 \%$ & $12,49 \%$ \\
\hline $\begin{array}{l}\text { Prêmio do fator momento } \\
\text { (WinMLos) }\end{array}$ & $0,13 \%$ & $4,93 \%$ & $0,78 \%$ & $1,48 \%$ & $-9,65 \%$ & $-0,75 \%$ & $1,80 \%$ & $1,43 \%$ & $1,63 \%$ & $1,70 \%$ & $-1,37 \%$ & $0,20 \%$ \\
\hline
\end{tabular}


Anexo 3 - Prêmio mensal dos fatores de risco

\begin{tabular}{|c|c|c|c|c|c|c|c|c|c|c|c|c|}
\hline Carteiras & $\mathrm{jul} / 02$ & ago/02 & set/02 & out/02 & nov/02 & $\mathrm{dez} / 02$ & jan/03 & $\mathrm{fev} / 03$ & $\mathrm{mar} / 03$ & $\mathrm{abr} / 03$ & mai/03 & jun/03 \\
\hline $\begin{array}{c}\text { Retorno real da carteira de } \\
\text { mercado }\end{array}$ & $-7,66 \%$ & $1,98 \%$ & $-7,84 \%$ & $16,03 \%$ & $1,82 \%$ & $6,13 \%$ & $-3,12 \%$ & $-4,53 \%$ & $5,57 \%$ & $6,80 \%$ & $6,10 \%$ & $-1,27 \%$ \\
\hline $\begin{array}{c}\text { Retorno real do ativo livre } \\
\text { de risco (poupança) }\end{array}$ & $0,73 \%$ & $0,80 \%$ & $0,69 \%$ & $0,74 \%$ & $0,85 \%$ & $0,77 \%$ & $0,98 \%$ & $1,01 \%$ & $0,83 \%$ & $0,92 \%$ & $0,98 \%$ & $0,93 \%$ \\
\hline $\begin{array}{c}\text { Prêmio da carteira de } \\
\text { mercado }\end{array}$ & $-8,39 \%$ & $1,17 \%$ & $-8,53 \%$ & $15,29 \%$ & $0,97 \%$ & $5,35 \%$ & $-4,10 \%$ & $-5,54 \%$ & $4,74 \%$ & $5,88 \%$ & $5,13 \%$ & $-2,20 \%$ \\
\hline $\begin{array}{c}\text { Prêmio do fator tamanho } \\
\text { (SMB) } \\
\end{array}$ & $3,16 \%$ & $-0,11 \%$ & $0,15 \%$ & $-14,16 \%$ & $6,16 \%$ & $-2,89 \%$ & $5,53 \%$ & $0,13 \%$ & $-4,12 \%$ & $0,24 \%$ & $-2,14 \%$ & $0,36 \%$ \\
\hline $\begin{array}{l}\text { Prêmio do fator índice } \mathrm{B} / \mathrm{M} \\
(H M L)\end{array}$ & $0,09 \%$ & $5,13 \%$ & $-1,97 \%$ & $6,72 \%$ & $-5,22 \%$ & $5,17 \%$ & $-3,31 \%$ & $-1,28 \%$ & $6,87 \%$ & $2,22 \%$ & $2,70 \%$ & $-0,76 \%$ \\
\hline $\begin{array}{c}\text { Prêmio do fator momento } \\
\text { (WinMLos) }\end{array}$ & $4,04 \%$ & $-3,11 \%$ & $0,84 \%$ & $2,57 \%$ & $0,44 \%$ & $3,85 \%$ & $-3,33 \%$ & $5,27 \%$ & $-0,65 \%$ & $-0,96 \%$ & 0,79\% & $3,79 \%$ \\
\hline
\end{tabular}

\begin{tabular}{|c|c|c|c|c|c|c|c|c|c|c|c|c|}
\hline Carteiras & $\mathrm{jul} / 03$ & ago/03 & set/03 & out/03 & nov/03 & dez/03 & jan/04 & $\mathrm{fev} / 04$ & mar/04 & $a b r / 04$ & mai/04 & jun/04 \\
\hline $\begin{array}{c}\text { Retorno real da carteira de } \\
\text { mercado }\end{array}$ & $6,32 \%$ & $11,13 \%$ & $3,88 \%$ & $8,20 \%$ & $7,99 \%$ & $15,05 \%$ & $-0,13 \%$ & $2,01 \%$ & $2,43 \%$ & $-10,32 \%$ & $1,70 \%$ & $6,45 \%$ \\
\hline $\begin{array}{c}\text { Retorno real do ativo livre } \\
\text { de risco (poupança) }\end{array}$ & $1,01 \%$ & $1,00 \%$ & $0,81 \%$ & $0,78 \%$ & $0,80 \%$ & $0,63 \%$ & $0,67 \%$ & $0,64 \%$ & $0,65 \%$ & $0,63 \%$ & $0,63 \%$ & $0,67 \%$ \\
\hline $\begin{array}{l}\text { Prêmio da carteira de } \\
\text { mercado }\end{array}$ & $5,31 \%$ & $10,13 \%$ & $3,08 \%$ & $7,41 \%$ & $7,19 \%$ & $14,42 \%$ & $-0,80 \%$ & $1,37 \%$ & $1,78 \%$ & $-10,95 \%$ & $1,07 \%$ & $5,78 \%$ \\
\hline $\begin{array}{l}\text { Prêmio do fator tamanho } \\
\qquad(S M B)\end{array}$ & $-5,48 \%$ & $-1,96 \%$ & $13,99 \%$ & $-7,55 \%$ & $7,75 \%$ & $-5,36 \%$ & $2,83 \%$ & $-0,28 \%$ & $-2,49 \%$ & $7,14 \%$ & $-4,55 \%$ & $-2,45 \%$ \\
\hline $\begin{array}{l}\text { Prêmio do fator índice } \mathrm{B} / \mathrm{M} \\
(H M L)\end{array}$ & $5,01 \%$ & $-1,42 \%$ & $-5,56 \%$ & $3,34 \%$ & $-5,02 \%$ & $4,07 \%$ & $1,05 \%$ & $-1,99 \%$ & $3,29 \%$ & $1,69 \%$ & $-5,59 \%$ & $5,52 \%$ \\
\hline $\begin{array}{l}\text { Prêmio do fator momento } \\
\text { (WinMLos) }\end{array}$ & $4,58 \%$ & $2,66 \%$ & $-4,31 \%$ & $-4,37 \%$ & $-1,33 \%$ & $0,53 \%$ & $1,46 \%$ & $2,41 \%$ & $-0,92 \%$ & $-1,25 \%$ & $6,00 \%$ & $-0,37 \%$ \\
\hline
\end{tabular}


Anexo 3 - Prêmio mensal dos fatores de risco

\begin{tabular}{|c|c|c|c|c|c|c|c|c|c|c|c|c|}
\hline Carteiras & $\mathrm{jul} / 04$ & ago/04 & set/04 & out/04 & nov/04 & $\mathrm{dez} / 04$ & jan/05 & $\mathrm{fev} / 05$ & mar/05 & $\mathrm{abr} / 05$ & mai/05 & jun/05 \\
\hline \begin{tabular}{|c|} 
Retorno real da carteira de \\
mercado
\end{tabular} & $6,74 \%$ & $4,58 \%$ & $6,29 \%$ & $0,72 \%$ & $6,56 \%$ & $5,65 \%$ & $-4,40 \%$ & $13,10 \%$ & $-5,73 \%$ & $-9,69 \%$ & $2,17 \%$ & $1,32 \%$ \\
\hline \begin{tabular}{|c|} 
Retorno real do ativo livre \\
de risco (poupança)
\end{tabular} & $0,71 \%$ & $0,67 \%$ & $0,70 \%$ & $0,64 \%$ & $0,59 \%$ & $0,71 \%$ & $0,69 \%$ & $0,63 \%$ & $0,73 \%$ & $0,78 \%$ & $0,71 \%$ & $0,84 \%$ \\
\hline $\begin{array}{c}\text { Prêmio da carteira de } \\
\text { mercado }\end{array}$ & $6,03 \%$ & $3,90 \%$ & $5,59 \%$ & $0,08 \%$ & $5,97 \%$ & $4,94 \%$ & $-5,09 \%$ & $12,47 \%$ & $-6,46 \%$ & $-10,48 \%$ & $1,45 \%$ & $0,48 \%$ \\
\hline $\begin{array}{c}\text { Prêmio do fator tamanho } \\
(S M B) \\
\end{array}$ & $-3,43 \%$ & $19,42 \%$ & $3,04 \%$ & $-0,98 \%$ & $-6,32 \%$ & $8,28 \%$ & $2,79 \%$ & $-6,55 \%$ & $1,87 \%$ & $6,27 \%$ & $-4,56 \%$ & $-2,85 \%$ \\
\hline $\begin{array}{c}\text { Prêmio do fator índice } \mathrm{B} / \mathrm{M} \\
(H M L)\end{array}$ & $5,86 \%$ & $-23,19 \%$ & $2,68 \%$ & $2,37 \%$ & $5,82 \%$ & $-10,31 \%$ & $-2,70 \%$ & $6,39 \%$ & $0,17 \%$ & $1,81 \%$ & $4,03 \%$ & $-1,85 \%$ \\
\hline \begin{tabular}{|c|} 
Prêmio do fator momento \\
(WinMLos)
\end{tabular} & $-1,66 \%$ & $2,87 \%$ & $-5,27 \%$ & $0,18 \%$ & $3,56 \%$ & $-0,39 \%$ & $0,07 \%$ & $1,70 \%$ & $1,05 \%$ & $-0,69 \%$ & $-2,87 \%$ & $-3,54 \%$ \\
\hline
\end{tabular}

\begin{tabular}{|c|c|c|c|c|c|c|c|c|c|c|c|c|}
\hline Carteiras & jul/05 & ago/05 & set/05 & out/05 & nov/05 & dez/05 & jan/06 & $\mathrm{fev} / 06$ & mar/06 & $a b r / 06$ & mai/06 & jun/06 \\
\hline $\begin{array}{c}\text { Retorno real da carteira de } \\
\text { mercado }\end{array}$ & $4,42 \%$ & $7,35 \%$ & $12,15 \%$ & $-5,31 \%$ & $5,62 \%$ & $5,51 \%$ & $14,83 \%$ & $0,04 \%$ & $-0,75 \%$ & $8,00 \%$ & $-6,75 \%$ & $-0,36 \%$ \\
\hline $\begin{array}{c}\text { Retorno real do ativo livre } \\
\text { de risco (poupança) }\end{array}$ & $0,81 \%$ & $0,80 \%$ & $0,80 \%$ & $0,67 \%$ & $0,69 \%$ & $0,74 \%$ & $0,70 \%$ & $0,75 \%$ & $0,68 \%$ & $0,63 \%$ & $0,66 \%$ & $0,73 \%$ \\
\hline $\begin{array}{l}\text { Prêmio da carteira de } \\
\text { mercado }\end{array}$ & $3,60 \%$ & $6,55 \%$ & $11,34 \%$ & $-5,99 \%$ & 4,93\% & $4,76 \%$ & $14,13 \%$ & $-0,71 \%$ & $-1,43 \%$ & $7,37 \%$ & $-7,41 \%$ & $-1,08 \%$ \\
\hline $\begin{array}{l}\text { Prêmio do fator tamanho } \\
\qquad(S M B)\end{array}$ & $-4,92 \%$ & $-4,33 \%$ & $-6,41 \%$ & $2,54 \%$ & $-1,46 \%$ & $0,69 \%$ & $-7,76 \%$ & $1,96 \%$ & $-0,90 \%$ & $-5,54 \%$ & $1,18 \%$ & $-3,73 \%$ \\
\hline $\begin{array}{l}\text { Prêmio do fator índice } \mathrm{B} / \mathrm{M} \\
(H M L)\end{array}$ & $-3,22 \%$ & $0,66 \%$ & $11,43 \%$ & $3,35 \%$ & $1,92 \%$ & $7,87 \%$ & $6,76 \%$ & $8,32 \%$ & $3,15 \%$ & $8,71 \%$ & $0,13 \%$ & $8,10 \%$ \\
\hline $\begin{array}{l}\text { Prêmio do fator momento } \\
\text { (WinMLos) }\end{array}$ & $-1,74 \%$ & $-0,14 \%$ & $-3,02 \%$ & $5,35 \%$ & $3,14 \%$ & $2,90 \%$ & $-2,09 \%$ & $-0,39 \%$ & $-2,37 \%$ & $-2,14 \%$ & $1,74 \%$ & $1,50 \%$ \\
\hline
\end{tabular}


Anexo 3 - Prêmio mensal dos fatores de risco

\begin{tabular}{|c|c|c|c|c|c|c|c|c|c|c|c|c|}
\hline Carteiras & jul/06 & ago/06 & set/06 & out/06 & nov/06 & dez/06 & jan/07 & fev/07 & mar/07 & $\mathrm{abr} / 07$ & mai/07 & jun/07 \\
\hline $\begin{array}{c}\text { Retorno real da carteira de } \\
\text { mercado }\end{array}$ & $0,46 \%$ & $-0,62 \%$ & $-0,15 \%$ & $5,89 \%$ & $8,24 \%$ & $5,64 \%$ & $1,49 \%$ & $-1,45 \%$ & $5,64 \%$ & $5,88 \%$ & $5,49 \%$ & $6,53 \%$ \\
\hline $\begin{array}{c}\text { Retorno real do ativo livre } \\
\text { de risco (poupança) }\end{array}$ & $0,64 \%$ & $0,73 \%$ & $0,73 \%$ & $0,65 \%$ & $0,67 \%$ & $0,67 \%$ & $0,69 \%$ & $0,63 \%$ & $0,65 \%$ & $0,63 \%$ & $0,64 \%$ & $0,67 \%$ \\
\hline $\begin{array}{c}\text { Prêmio da carteira de } \\
\text { mercado }\end{array}$ & $-0,18 \%$ & $-1,35 \%$ & $-0,88 \%$ & $5,24 \%$ & $7,56 \%$ & $4,98 \%$ & $0,80 \%$ & $-2,09 \%$ & 4,99\% & $5,26 \%$ & $4,85 \%$ & $5,86 \%$ \\
\hline $\begin{array}{l}\text { Prêmio do fator tamanho } \\
\qquad(S M B)\end{array}$ & $-1,08 \%$ & $0,76 \%$ & $-2,44 \%$ & $-0,21 \%$ & $1,83 \%$ & $4,16 \%$ & $7,61 \%$ & $9,85 \%$ & $3,77 \%$ & $1,48 \%$ & $5,11 \%$ & $-1,31$ \\
\hline $\begin{array}{c}\text { Prêmio do fator índice } \mathrm{B} / \mathrm{M} \\
(H M L)\end{array}$ & $0,38 \%$ & $-0,74 \%$ & $0,80 \%$ & $-2,81 \%$ & $-3,29 \%$ & $-2,73 \%$ & $-1,87 \%$ & $-6,06 \%$ & $-3,36 \%$ & $10,00 \%$ & $7,66 \%$ & $0,63 \%$ \\
\hline $\begin{array}{l}\text { Prêmio do fator momento } \\
\text { (WinMLos) }\end{array}$ & $1,25 \%$ & $-3,78 \%$ & $-1,41 \%$ & $-0,99 \%$ & $-0,60 \%$ & $1,80 \%$ & $1,46 \%$ & $1,22 \%$ & $-2,45 \%$ & $-4,00 \%$ & $0,15 \%$ & $4,20 \%$ \\
\hline
\end{tabular}

\begin{tabular}{|c|c|c|c|c|c|c|c|c|c|c|c|c|}
\hline Carteiras & jul/07 & ago/07 & set/07 & out/07 & nov/07 & dez/07 & jan/08 & $\mathrm{fev} / 08$ & mar/08 & $a b r / 08$ & mai/08 & jun/08 \\
\hline $\begin{array}{c}\text { Retorno real da carteira de } \\
\text { mercado }\end{array}$ & $0,52 \%$ & $0,82 \%$ & $9,94 \%$ & $7,65 \%$ & $-3,55 \%$ & $2,24 \%$ & $-7,59 \%$ & $7,78 \%$ & $-3,30 \%$ & $9,14 \%$ & $5,93 \%$ & $-7,53 \%$ \\
\hline $\begin{array}{c}\text { Retorno real do ativo livre } \\
\text { de risco (poupança) }\end{array}$ & $0,61 \%$ & $0,65 \%$ & $0,61 \%$ & $0,58 \%$ & $0,59 \%$ & $0,57 \%$ & $0,61 \%$ & $0,57 \%$ & $0,52 \%$ & $0,59 \%$ & $0,59 \%$ & $0,62 \%$ \\
\hline $\begin{array}{l}\text { Prêmio da carteira de } \\
\text { mercado }\end{array}$ & $-0,10 \%$ & $0,17 \%$ & $9,33 \%$ & $7,06 \%$ & $-4,14 \%$ & $1,67 \%$ & $-8,20 \%$ & $7,21 \%$ & $-3,82 \%$ & $8,56 \%$ & $5,34 \%$ & $-8,15 \%$ \\
\hline $\begin{array}{l}\text { Prêmio do fator tamanho } \\
\qquad(S M B)\end{array}$ & $0,90 \%$ & $0,66 \%$ & $-5,25 \%$ & $-2,06 \%$ & $-3,09 \%$ & $-0,92 \%$ & $-3,25 \%$ & $-2,61 \%$ & $-0,80 \%$ & $-4,35 \%$ & $3,81 \%$ & $0,18 \%$ \\
\hline $\begin{array}{l}\text { Prêmio do fator índice } \mathrm{B} / \mathrm{M} \\
(H M L)\end{array}$ & $-0,08 \%$ & $5,47 \%$ & $-4,44 \%$ & $0,21 \%$ & $1,59 \%$ & $1,87 \%$ & $5,00 \%$ & $-3,67 \%$ & $1,10 \%$ & $-3,34 \%$ & $0,81 \%$ & $8,91 \%$ \\
\hline $\begin{array}{c}\text { Prêmio do fator momento } \\
\text { (WinMLos) }\end{array}$ & $2,23 \%$ & $-2,62 \%$ & $1,86 \%$ & $-1,93 \%$ & $-3,26 \%$ & $-2,79 \%$ & $-2,40 \%$ & $-0,57 \%$ & $-0,73 \%$ & $1,36 \%$ & $-1,54 \%$ & $-0,47 \%$ \\
\hline
\end{tabular}


Anexo 3 - Prêmio mensal dos fatores de risco

\begin{tabular}{|c|c|c|c|c|c|c|c|c|c|c|c|c|}
\hline Carteiras & $\mathrm{jul} / 08$ & ago/08 & set/08 & out/08 & nov/08 & $\mathrm{dez} / 08$ & jan/09 & fev/09 & mar/09 & $\mathrm{abr} / 09$ & mai/09 & jun/09 \\
\hline $\begin{array}{c}\text { Retorno real da carteira de } \\
\text { mercado }\end{array}$ & $-11,93 \%$ & $-5,54 \%$ & $-10,67 \%$ & $-24,89 \%$ & $-4,14 \%$ & $6,57 \%$ & $7,58 \%$ & $-0,09 \%$ & $4,89 \%$ & $14,44 \%$ & $11,82 \%$ & $-4,20 \%$ \\
\hline \begin{tabular}{|c|} 
Retorno real do ativo livre \\
de risco (poupança)
\end{tabular} & $0,67 \%$ & $0,73 \%$ & $0,68 \%$ & $0,72 \%$ & $0,73 \%$ & $0,65 \%$ & $0,72 \%$ & $0,67 \%$ & $0,62 \%$ & $0,59 \%$ & $0,55 \%$ & $0,55 \%$ \\
\hline $\begin{array}{c}\text { Prêmio da carteira de } \\
\text { mercado }\end{array}$ & $-12,60 \%$ & $-6,27 \%$ & $-11,35 \%$ & $-25,61 \%$ & $-4,87 \%$ & $5,92 \%$ & $6,86 \%$ & $-0,75 \%$ & $4,26 \%$ & $13,85 \%$ & $11,27 \%$ & $-4,75 \%$ \\
\hline $\begin{array}{c}\text { Prêmio do fator tamanho } \\
(S M B) \\
\end{array}$ & $-2,70 \%$ & $-1,61 \%$ & $-10,19 \%$ & $-4,19 \%$ & $-6,30 \%$ & $0,21 \%$ & $-3,09 \%$ & $-1,75 \%$ & $-2,20 \%$ & $15,14 \%$ & $0,78 \%$ & $6,69 \%$ \\
\hline $\begin{array}{c}\text { Prêmio do fator índice } \mathrm{B} / \mathrm{M} \\
(H M L) \\
\end{array}$ & $6,87 \%$ & $0,11 \%$ & $2,08 \%$ & $2,61 \%$ & $6,72 \%$ & $-4,33 \%$ & $-4,40 \%$ & $0,46 \%$ & $-6,49 \%$ & $-9,99 \%$ & $0,31 \%$ & $2,40 \%$ \\
\hline $\begin{array}{c}\text { Prêmio do fator momento } \\
\text { (WinMLos) }\end{array}$ & $-2,35 \%$ & $-0,32 \%$ & $-1,20 \%$ & $-2,12 \%$ & $-3,78 \%$ & $-0,55 \%$ & $2,77 \%$ & $-3,31 \%$ & $2,48 \%$ & $-2,95 \%$ & $3,66 \%$ & $-3,07 \%$ \\
\hline
\end{tabular}

\begin{tabular}{|c|c|c|c|c|c|c|c|c|c|c|c|c|}
\hline Carteiras & jul/09 & ago/09 & set/09 & out/09 & nov/09 & dez/09 & jan/10 & fev/10 & $\mathrm{mar} / 10$ & $a b r / 10$ & mai/10 & jun/10 \\
\hline $\begin{array}{c}\text { Retorno real da carteira de } \\
\text { mercado }\end{array}$ & $4,55 \%$ & $1,41 \%$ & $8,41 \%$ & $2,31 \%$ & $7,95 \%$ & $2,24 \%$ & $-3,43 \%$ & $0,62 \%$ & $4,08 \%$ & $-3,50 \%$ & $-4,87 \%$ & $-3,32 \%$ \\
\hline $\begin{array}{c}\text { Retorno real do ativo livre } \\
\text { de risco (poupança) }\end{array}$ & $0,58 \%$ & $0,52 \%$ & $0,52 \%$ & $0,50 \%$ & $0,50 \%$ & $0,52 \%$ & $0,54 \%$ & $0,52 \%$ & $0,56 \%$ & $0,52 \%$ & $0,52 \%$ & $0,57 \%$ \\
\hline $\begin{array}{c}\text { Prêmio da carteira de } \\
\text { mercado }\end{array}$ & $3,97 \%$ & $0,89 \%$ & $7,90 \%$ & $1,81 \%$ & $7,45 \%$ & $1,72 \%$ & $-3,97 \%$ & $0,10 \%$ & $3,53 \%$ & $-4,02 \%$ & $-5,39 \%$ & $-3,88 \%$ \\
\hline $\begin{array}{l}\text { Prêmio do fator tamanho } \\
\qquad(S M B)\end{array}$ & $3,56 \%$ & $6,50 \%$ & $3,60 \%$ & $3,42 \%$ & $-5,88 \%$ & $2,30 \%$ & $8,61 \%$ & $3,10 \%$ & $-8,57 \%$ & $1,00 \%$ & $-3,40 \%$ & $5,33 \%$ \\
\hline $\begin{array}{c}\text { Prêmio do fator índice } \mathrm{B} / \mathrm{M} \\
(H M L)\end{array}$ & $9,28 \%$ & $-0,37 \%$ & $-5,47 \%$ & $-4,92 \%$ & $4,27 \%$ & $2,68 \%$ & $-4,44 \%$ & $-6,68 \%$ & $0,34 \%$ & $2,10 \%$ & $5,20 \%$ & $-0,49 \%$ \\
\hline $\begin{array}{l}\text { Prêmio do fator momento } \\
\text { (WinMLos) }\end{array}$ & $-9,10 \%$ & $-3,57 \%$ & $-3,16 \%$ & $-3,18 \%$ & $-0,34 \%$ & $2,51 \%$ & $-0,96 \%$ & $-2,51 \%$ & $-0,70 \%$ & $2,00 \%$ & $3,16 \%$ & $1,88 \%$ \\
\hline
\end{tabular}


Anexo 3 - Prêmio mensal dos fatores de risco

\begin{tabular}{|c|c|c|c|c|c|c|c|c|c|c|c|c|}
\hline Carteiras & $\mathrm{jul} / 10$ & ago/10 & set/10 & out/10 & nov/10 & dez/10 & jan/11 & $\mathrm{fev} / 11$ & $\mathrm{mar} / 11$ & $a b r / 11$ & mai/11 & jun/11 \\
\hline $\begin{array}{c}\text { Retorno real da carteira de } \\
\text { mercado }\end{array}$ & $7,73 \%$ & $-2,21 \%$ & $5,40 \%$ & $2,35 \%$ & $-2,27 \%$ & $4,46 \%$ & $-2,94 \%$ & $1,71 \%$ & $1,65 \%$ & $-2,25 \%$ & $-1,95 \%$ & $-1,86 \%$ \\
\hline $\begin{array}{c}\text { Retorno real do ativo livre } \\
\text { de risco (poupança) }\end{array}$ & $0,60 \%$ & $0,57 \%$ & $0,61 \%$ & $0,59 \%$ & $0,51 \%$ & $0,61 \%$ & $0,57 \%$ & $0,60 \%$ & $0,60 \%$ & $0,62 \%$ & $0,62 \%$ & $0,64 \%$ \\
\hline $\begin{array}{c}\text { Prêmio da carteira de } \\
\text { mercado }\end{array}$ & $7,12 \%$ & $-2,78 \%$ & $4,80 \%$ & $1,76 \%$ & $-2,77 \%$ & $3,85 \%$ & $-3,51 \%$ & $1,11 \%$ & $1,05 \%$ & $-2,86 \%$ & $-2,57 \%$ & $-2,50 \%$ \\
\hline $\begin{array}{c}\text { Prêmio do fator tamanho } \\
(S M B)\end{array}$ & $0,28 \%$ & $2,94 \%$ & $-1,62 \%$ & $4,69 \%$ & $1,82 \%$ & $4,37 \%$ & $-2,21 \%$ & $-2,77 \%$ & $-2,78 \%$ & $1,75 \%$ & $-1,70 \%$ & $-0,33 \%$ \\
\hline $\begin{array}{l}\text { Prêmio do fator índice } \mathrm{B} / \mathrm{M} \\
(H M L)\end{array}$ & $0,21 \%$ & $2,32 \%$ & $-2,16 \%$ & $0,05 \%$ & $3,01 \%$ & $-3,70 \%$ & $2,40 \%$ & $0,15 \%$ & $2,76 \%$ & $-0,20 \%$ & $2,36 \%$ & $0,08 \%$ \\
\hline $\begin{array}{l}\text { Prêmio do fator momento } \\
\text { (WinMLos) }\end{array}$ & $3,63 \%$ & $1,04 \%$ & $0,24 \%$ & $2,91 \%$ & $0,55 \%$ & $-2,95 \%$ & $-0,54 \%$ & $-2,53 \%$ & $1,06 \%$ & $2,14 \%$ & $-1,55 \%$ & $0,08 \%$ \\
\hline
\end{tabular}

